\title{
Mediação \\ Comunicacional \\ das Marcas na Cultura \\ Alimentar Infantil
}

Cinira Baader

São Paulo

2021 
UNIVERSIDADE DE SÃO PAULO

ESCOLA DE COMUNICAÇÕES E ARTES

CINIRA BAADER

Mediação comunicacional das marcas

na cultura alimentar infantil

São Paulo

2021 
CINIRA BAADER

\section{Mediação comunicacional das marcas \\ na cultura alimentar infantil}

Versão corrigida (versão original disponível na Biblioteca da ECA/USP)

Tese apresentada ao Programa de Pós-graduação em Ciências da Comunicação da Escola de Comunicações e Artes da Universidade de São Paulo, como requisito parcial para a obtenção do título de doutora em Comunicação.

Área de concentração: Ciências da Comunicação

Linha de pesquisa: Processos comunicacionais: Tecnologias, Produção e Consumos

Orientador: Prof. Dr. Eneus Trindade Barreto Filho

São Paulo 
Autorizo a reprodução e divulgação total ou parcial deste trabalho, por qualquer meio convencional ou eletrônico, para fins de estudo e pesquisa, desde que citada a fonte.

Catalogação na Publicação

Serviço de Biblioteca e Documentação

Escola de Comunicações e Artes da Universidade de São Paulo

Dados inseridos pelo(a) autor(a)

Cinira, Baader

Mediação comunicacional das marcas na cultura alimentar

infantil / Baader Cinira ; orientador, Eneus Trindade

Barreto filho. -- São Paulo, 2021.

$629 \mathrm{p}$ : il.

Tese (Doutorado) - Programa de Pós-Graduação em Ciências da

Comunicação - Escola de Comunicações e Artes / Universidade

de São Paulo.

Bibliografia

Versão corrigida

1. Comunicação 2. Consumo 3. Marcas 4. Crianças 5.

Alimentação I. Trindade Barreto filho, Eneus II. Título.

CDD 21.ed. - 302.2 


\section{ERRATA}

BAADER, C. Mediação comunicacional das marcas na cultura alimentar infantil. 2021. Tese (Doutorado em Comunicação) - Escola de Comunicações e Artes, Universidade de São Paulo, São Paulo, 2021.

Em coerência com a perspectiva ética de preservação da identidade dos sujeitos da pesquisa, conforme explicitado nos Termos de Consentimento Livre e Esclarecido assinados pelas famílias pesquisadas, a banca observou que a versão corrigida, deve preservar a imagem dos sujeitos das famílias (adultos e crianças) e deve-se trocar os seus nomes por pseudônimos no corpo da tese e nos Apêndices, bem como qualquer outra informação que possibilite a identificação de tais sujeitos.

Esta versão cumpre a orientação da Banca Examinadora. 
BAADER, C. Mediação comunicacional das marcas na cultura alimentar infantil. 2021. Tese (Doutorado em Comunicação) - Escola de Comunicações e Artes, Universidade de São Paulo, São Paulo, 2021.

Aprovado em:

\section{Banca Examinadora}

Prof.(a) Dr.(a)

Instituição:

Julgamento:

Prof.(a) Dr.(a)

Instituição:

Julgamento:

Prof.(a) Dr.(a)

Instituição:

Julgamento:

Prof.(a) Dr.(a)

Instituição:

Julgamento:

Prof.(a) Dr.(a)

Instituição:

Julgamento: 


\section{DEDICATÓRIA}

Dedico este trabalho à minha mãe, à memória de meu pai, e à minha irmã: presenças essenciais em minha vida. Sempre. 


\section{AGRADECIMENTOS}

No complexo, desafiador e surpreendente percurso da experiência acadêmica no desenvolvimento deste estudo, minha gratidão se estende em diferentes direções, mas com um mesmo sentido: gratidão a pessoas especiais e essenciais em meus processos de convivência, de experiência, de aprendizado, de formação, de estudos, de pesquisa e de vida:

Agradeço primeiramente a Deus, por todas as graças e bênçãos concedidas, pela coragem de ousar, pela força de sempre recomeçar e pela persistência de nunca desistir.

À minha mãe, Dulcira Baader, e à memória de meu pai, Bruno Mário Baader, pelo amor, presença, apoio e incentivo, essenciais e incondicionais ao longo deste percurso acadêmico e na minha história de vida.

À minha irmã, Eliane Baader de Lima, pelo amor, presença, apoio, incentivo e parceria em todos os momentos, dos maiores desafios às maiores superações.

Aos meus familiares e amigos, pelo acompanhamento, apoio e compreensão nos momentos de dificuldade e pela alegria compartilhada nos momentos de conquistas.

No contexto acadêmico, agradeço muito especialmente ao meu orientador, Prof. Dr. Eneus Trindade Barreto Filho, pelos desafios propostos, pela orientação desenvolvida, pela presença constante, pelos ensinamentos e esclarecimentos concedidos, pelas correções necessárias ao longo do processo, e por todo apoio e inspiração em momentos essenciais.

A todos os professores com os quais tive o prazer de conviver e a oportunidade de aprender ao longo do meu processo acadêmico de pós-graduação, desde o mestrado até o doutorado: Eneus Trindade, Leandro Leonardo Batista, Clotilde Perez, Mayra Rodrigues Gomes, Norma Discini, Sônia Buongermino de Souza, Sérgio Bairon, Arlete Petry, Pedro Hélin, Maria Ogécia Drigo, Isabel Orofino, Vitor Blotta, Claudemir Viana, Danilo Paiva Ramos, Fernando Lefevre. Fontes constantes de sabedoria, conhecimento, experiência e inspiração em meu percurso na academia.

Aos meus amigos no curso do mestrado e doutorado, pela presença, companheirismo, amizade, incentivo, inspiração, apoio, participação, parceria, alegria e bom humor em muitos momentos, no ambiente acadêmico e no dia-a-dia. Presenças inspiradoras e muito especiais.

À Maria Lourdes e Otávio, amigos especiais e presenças essenciais em meu percurso acadêmico no doutorado e em minha história de vida em São Paulo.

À Denise e ao Hector, companheiros da moradia estudantil e presenças especiais nos processos acadêmicos e experiências de vida.

À Elaine Gardinali, por toda a atenção, carinho, competência e dedicação nos momentos em que me auxiliou, desde os primeiros dias na ECA, o acompanhamento no curso do mestrado e doutorado, até o momento da revisão textual da tese. Muito grata.

No contexto institucional, agradeço ao PPGCOM e à Maria, sempre presente nos momentos de dissolver as dúvidas e desvendar os processos e procedimentos, procurando manter ativo o processo de comunicação entre o Programa de Pós-Graduação e seus discentes. 
Às bibliotecas da ECA, FE, FFLCH, FEA e FSP (USP) e à biblioteca da Universidade Regional de Blumenau (FURB), pela atenção especial e apoio em todos os momentos de buscas de informações e pesquisas de materiais.

Ao departamento de informática e às salas de pesquisa da ECA, pela estrutura, apoio e auxílio disponibilizados sempre que necessário.

À Guarda Universitária, por todo apoio e dedicação no transporte dos alunos com necessidades especiais no campus da universidade.

Ao SAS, especialmente à Neusa, pela atenção e compreensão desde os momentos iniciais de adaptação às instalações e ao sistema de moradia coletiva na residência estudantil até o final da minha permanência no condomínio residencial da universidade.

No contexto do desenvolvimento da pesquisa, agradeço especialmente às famílias participantes do processo de investigação, na figura dos pais e das crianças. Gratidão a essas famílias, que abriram as portas de seus lares para compartilhar comigo suas experiências, conhecimentos e saberes sobre a cultura alimentar infantil. E muito especialmente, gratidão a essas crianças, sempre presentes e dispostas a participar, na construção de um conhecimento partilhado sobre a mediação comunicacional das marcas na cultura contemporânea de consumo alimentar infantil na perspectiva da ciência e dos saberes infantis.

Agradeço também à Manoela e Priscila, que muito me auxiliaram nos registros em fotografia e vídeo nas atividades em campo nos contextos familiares pesquisados.

E finalmente, agradeço ao Francesco. Felino elegante, charmoso, exigente, fofo, sensível e companheiro nos momentos de estudo, diversão e inspiração. 
“Ah!... Eu achei bem legal!

Tipo... Porque geralmente, né... Éh...

Pra pesquisa... Essas coisas mais sérias... Éh... Levam muito mais em consideração a opinião de pessoas mais velhas, por experiência, e tal.

Acho bem legal porque agora, tipo, a gente, né - que é criança, ou pré-adolescente tem mais... Tipo... Pode falar o que acha, o que prefere, a opinião mesmo. Éh... É isso. Haha!"

(Luana, 11 anos) 


\section{RESUMO}

BAADER, C. Mediação comunicacional das marcas na cultura alimentar infantil. 2021. Tese (Doutorado em Comunicação) - Escola de Comunicações e Artes, Universidade de São Paulo, São Paulo, 2021.

Uma investigação sobre a mediação comunicacional das marcas na cultura contemporânea de consumo alimentar infantil, desenvolvida com a participação das crianças no campo da comunicação. Assim se caracteriza o estudo desenvolvido, situado no contexto dos estudos comunicacionais e dos estudos da infância, explorando sua temática de investigação na interface comunicação, consumo, infância e cultura alimentar. Interface de estudos que demarca o interesse e preocupação social, política, institucional, acadêmica e de saúde pública no âmbito das questões de saúde e alimentação das crianças, do consumo alimentar infantil, da publicidade de alimentos, e da comunicação dirigida ao público infantil, caracterizados em um amplo e emaranhado contexto de discussão e debate social em que se coloca o desenvolvimento deste estudo. Nessa perspectiva, na delineação do objeto de investigação, propôs-se o estudo da recepção infantil de marcas de alimentos no âmbito das práticas e rituais de consumo alimentar das crianças em contextos familiares na cidade de São Paulo, explorando os modos de presença e mediação comunicacional das marcas na construção da cultura alimentar infantil e considerando os vínculos de sentidos entre marcas/produtos e crianças, na interface com as mediações culturais e comunicacionais presentes na modulação do consumo alimentar infantil no âmbito familiar. No campo dos estudos comunicacionais, em um contexto de raras pesquisas acadêmicas situadas na interface comunicação, consumo, infância e cultura alimentar, destacase o desenvolvimento deste estudo, pois que, para além de uma investigação sobre a mediação comunicacional das marcas na cultura contemporânea de consumo alimentar infantil, este estudo dedicou-se ao desenvolvimento da pesquisa com crianças em campo em seus contextos familiares, tomando as crianças como informantes, participantes e copesquisadores no processo de investigação. Perspectiva que torna este estudo original e relevante pela raridade da sua proposta e temática no contexto dos estudos comunicacionais e pelos investimentos filosóficoteórico-metodológicos de uma investigação de inspiração etnográfica desenvolvida com crianças no campo da comunicação.

Palavras-chave: Comunicação; Consumo; Marcas; Crianças; Infância; Alimentação; Cultura Alimentar; Mediações. 


\begin{abstract}
BAADER, C. Communication mediation of brands in children's food culture. 2021. Tese (Doutorado em Comunicação) - Escola de Comunicações e Artes, Universidade de São Paulo, São Paulo, 2021.

An investigation into the communicational mediation of brands in the contemporary culture of infant food consumption developed with the participation of children in the field of communication, thus, characterizes this study developed situated in the context of communicational and childhood studies, exploring the research theme in the communication, consumption, childhood and food culture interface. The study interface that outlines social, political, institutional, academic and public health interest and concern in the area of children's health and nutrition, children's food consumption, food advertising and communication aimed at children is characterized in a wide and tangled context of discussion and social debate the development of this study. In this perspective, in delineating the object of investigation, proposed a study on children's reception of food brands within the scope of food consumption practices and rituals in family contexts in the city of São Paulo, exploring the ways of presence and mediation of brands in the construction of children's food culture, considering the sense links between brands/products and children at the interface with cultural and communicational mediations present in the modulation of children's food consumption in the family context. In the field of communicational studies, in a context of rare academic research located at the interface of communication, consumption, childhood and food culture, the development of this study stands out in addition to an investigation into the communicational mediation of brands in the contemporary culture of infant food consumption. This study was dedicated to the development of research with children, in the field in their family contexts, as informants, participants and co-researchers in the research process. The perspective that makes this study original and relevant is the rarity of its proposal and thematic in the context of communicational studies and the philosophical-theoretical-methodological investments of an ethnographicinspired investigation developed with children in the field of communication.
\end{abstract}

Keywords: Communication; Consumption; Brands; Kids; Childhood; Food; Food Culture; Mediations. 


\section{LISTA DE QUADROS}

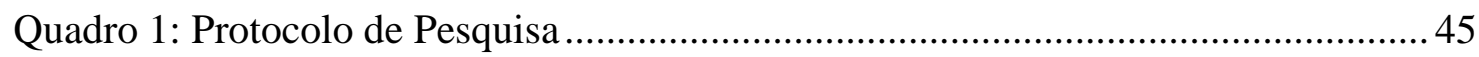

Quadro 2: Encontros com as Famílias: Atividades da Pesquisa................................... 50

Quadro 3: Brincadeira de comer: Jogo de Cards: Alimentos ....................................223

Quadro 4: Brincadeira de Comer: Jogo de Cards: Marcas ........................................2231

Quadro 5: Brincadeira de Comer: Desenhos: Consumo Alimentar.............................2236

Quadro 6: Brincadeira de Comer: Desenhos: Marcas e Personagens...........................241

Quadro 7: Sobre a Brincadeira de Comer ..................................................................243

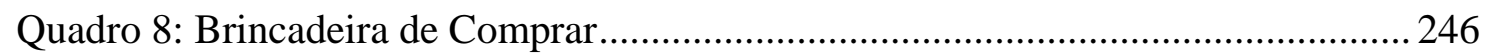

Quadro 9: Experiência Lúdica The Kids: Kids by Kids I..........................................2253

Quadro 10: Experiência Lúdica The Kids: Kids by Kids II .....................................2259

Quadro 11: Experiência Lúdica The Kids: Kids by Kids III ....................................2266

Quadro 12: Experiência Lúdica The Kids: Kids by Kids IV ......................................268

Quadro 13: Experiência Lúdica The Kids: My Foods ............................................. 271 


\section{LISTA DE FIGURAS}

Figura 1: Mapa Mediações Comunicativas da Cultura................................................ 75

Figura 2: Mapa Mediação Comunicacional das Marcas na Cultura Alimentar Infantil.. 76

Figura 3: My Family: Retratos Primeira Família …................................................ 273

Figura 4: My Family: Retratos Segunda Família .................................................... 273

Figura 5: My Family: Retratos Terceira Família ..................................................... 273

Figura 6: Marcas Favoritas das Crianças ................................................................. 275 


\section{SUMÁRIO}

INTRODUÇÃO 17

PRIMEIRO CAPÍTULO:

APRESENTAÇÃO CONTEXTUALIZAÇÃO E FUNDAMENTAÇÃO DO ESTUDO. 21

1 APRESENTAÇÃO E CONTEXTUALIZAÇÃO DO ESTUDO. .23

2 FUNDAMENTAÇÃO FILOSÓFICO-TEÓRICO-METODOLÓGICA DO ESTUDO 65

\section{SEGUNDO CAPÍTULO:}

MEDIAÇÃO COMUNICACIONAL DAS MARCAS NA CULTURA ALIMENTAR INFANTIL

1 COM AS CRIANÇAS EM CAMPO EM SEUS CONTEXTOS FAMILIARES: BREVE RELATO DA EXPERIÊNCIA E PROCESSO DE INVESTIGAÇÃO 129

2 PRESENÇA E MEDIAÇÃO COMUNICACIONAL DAS MARCAS NA CULTURA ALIMENTAR INFANTIL: MARCAS E PRODUTOS NO CONTEXTO FAMILIAR 158

TERCEIRO CAPÍTULO:

RECEPÇÃO INFANTIL E PERSPECTIVAS DAS CRIANÇAS: UM ESTUDO DE INSPIRAÇÃO ETNOGRÁFICA COM CRIANÇAS EM COMUNICAÇÃO 214

CONCLUSÃO 280

REFERÊNCIAS

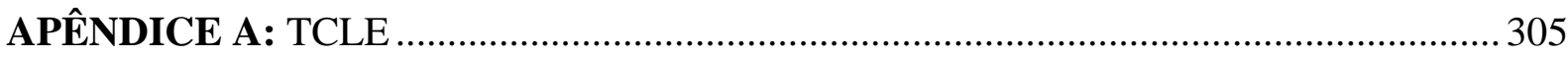

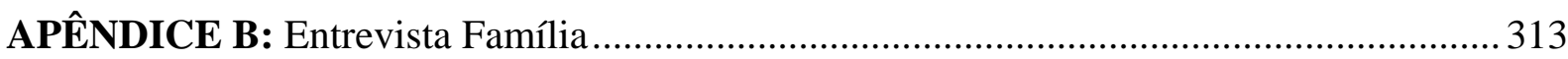

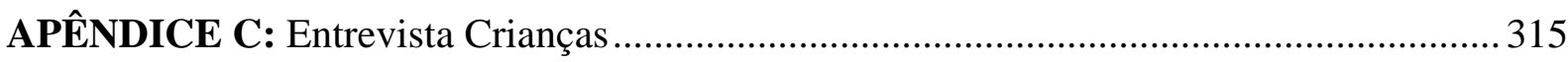

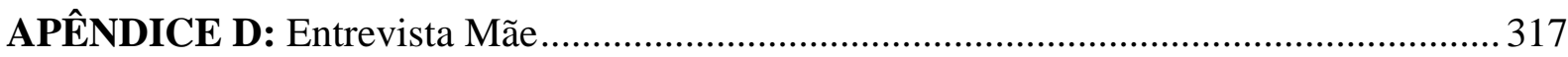

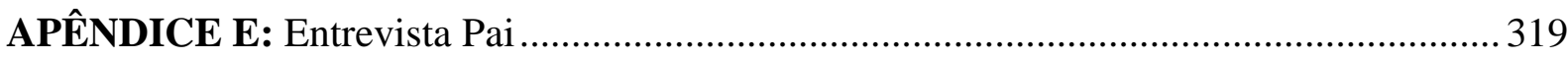

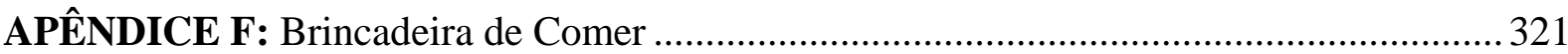

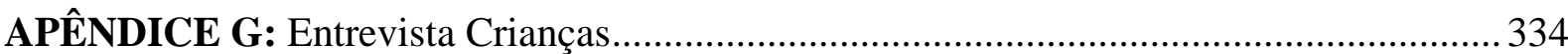


APÊNDICE H: Brincadeira de Comprar 336

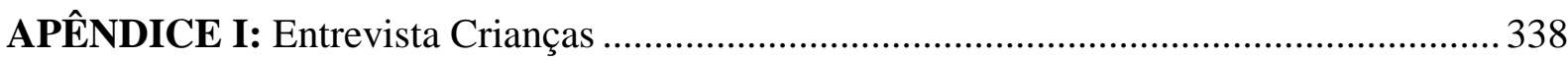

APÊNDICE J: Experiência Lúdica The Kids: Kids by Kids .............................................. 340

APÊNDICE K: Experiência Lúdica The Kids: My Foods .................................................. 343

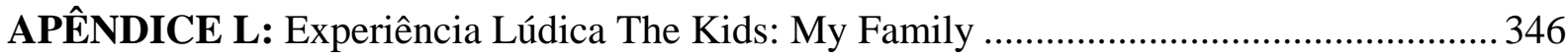

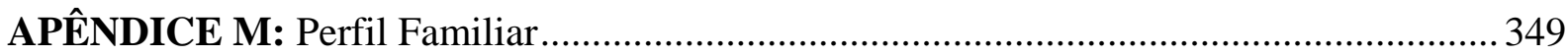

APÊNDICE N: Marcas e Produtos no Contexto Familiar: Primeira Família ......................... 353

APÊNDICE O: Marcas e Produtos no Contexto Familiar: Segunda Família....................... 414

APÊNDICE P: Marcas e Produtos no Contexto Familiar: Terceira Família..........................476

APÊNDICE Q: Marcas de Alimentos no Contexto Familiar: Primeira Família .................. 529

APÊNDICE R: Marcas de Alimentos no Contexto Familiar: Segunda Família .................. 553

APÊNDICE S: Marcas de Alimentos no Contexto Familiar: Terceira Família.....................577

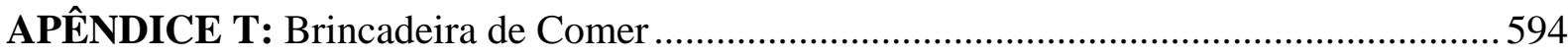

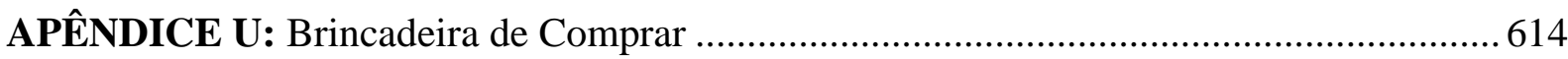

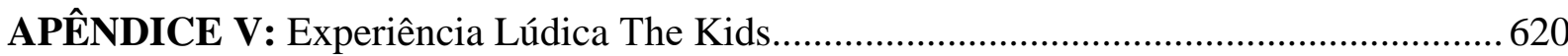




\section{INTRODUÇÃO}

As crianças falam e têm voz. Sempre prontas a compartilhar e participar, como sujeitos que são, na cultura, na sociedade, e nos processos de investigação. É no contexto das agências das crianças e das perspectivas e subjetividades infantis, que se faz possível conhecer as crianças e as culturas da infância. Conhecer as crianças e sua cultura de consumo alimentar infantil.

Temáticas de estudo e objetos de investigação, situados na perspectiva das crianças tomadas como sujeitos, consumidores e cidadãos, no contexto dos estudos da infância e no campo da comunicação, inspiram e demarcam o conjunto dos principais estudos desenvolvidos por mim enquanto pesquisadora no percurso da academia. Inicialmente, em nível de graduação e especialização, com estudos desenvolvidos sobre os processos de comunicação e marketing para marcas e produtos dirigidos ao público infantil; estudos sobre produtos marcas e personagens para o consumo das crianças nos campos da moda, brinquedos e papelaria; e estudos desenvolvidos sobre crianças, televisão e publicidade. Mais adiante, em nível de mestrado, com o desenvolvimento de um estudo sobre a publicidade contemporânea de alimentos infantis, na combinação alimentação-diversão, e suas possibilidades de sentidos para as práticas de consumo alimentar das crianças. E finalmente, em nível de doutorado, com o estudo desenvolvido sobre os modos de presença e mediação comunicacional das marcas na cultura contemporânea de consumo alimentar das crianças em contexto familiar, e que aqui se apresenta na composição da tese.

Uma investigação sobre a mediação comunicacional das marcas na cultura contemporânea de consumo alimentar infantil, desenvolvida com a participação das crianças, no campo da comunicação: assim se caracteriza o estudo desenvolvido, situado no contexto dos estudos comunicacionais e dos estudos da infância, explorando sua temática de investigação a partir da interface comunicação, consumo, infância e cultura alimentar.

As temáticas situadas no contexto dos estudos sobre comunicação, consumo, infância e cultura alimentar demarcam o interesse e preocupação social, política, institucional, acadêmica e de saúde pública no âmbito das questões de saúde e alimentação das crianças, do consumo alimentar infantil, da publicidade de alimentos, e da comunicação dirigida ao público infantil no mundo contemporâneo, caracterizados em um amplo e emaranhado contexto de discussão e debate social, contexto em que se coloca a temática e o desenvolvimento deste estudo. 
O estudo desenvolvido, caracterizado enquanto estudo de inspiração etnográfica, desenvolvido com crianças, em seus contextos familiares, para uma investigação sobre os modos de presença e mediação comunicacional das marcas na cultura alimentar das crianças, a partir dos processos de recepção infantil de marcas de alimentos, foi estruturado e desenvolvido na perspectiva das crianças tomadas como sujeitos e atores sociais, no processo de pesquisa e nos cotidianos da sua cultura alimentar; assim, tomadas como sujeitos que são, com direito à participação e voz no processo de investigação. E tomando-se as perspectivas e subjetividades infantis e agências das crianças, em seus processos de recepção infantil de marcas de alimentos, como importante mediação, no conjunto das diversas mediações culturais e comunicacionais presentes na modulação do consumo alimentar das crianças em contexto familiar e dos diferentes modos de presença e mediação comunicacional das marcas nos cotidianos da cultura alimentar infantil.

Nessa perspectiva, coloca-se na sequência a descrição da estrutura e organização da tese para apresentação e exploração do estudo desenvolvido, desde a caracterização e estruturação do projeto; a elaboração da pesquisa teórica para fundamentação do estudo; e o desenvolvimento da pesquisa empírica para realização das investigações em campo; até a apresentação, interpretação e análise dos dados; e as reflexões propostas a partir dos resultados do estudo, destacando-se a estrutura filosófico-teórico-metodológica e as perspectivas comunicacionais e socioculturais que orientaram as bases do estudo e deram forma ao processo de investigação.

O primeiro capítulo é dedicado à apresentação da estrutura, delimitação e caracterização do estudo - contemplando-se a temática e problemática que compõem o contexto da investigação desenvolvida, os eixos de abordagem teórica e empírica propostos para orientação do processo de investigação e o conjunto das especificações necessárias para caracterização, estruturação e orientação do estudo; à contextualização do estudo no quadro atual de pesquisas acadêmicas desenvolvidas sobre o tema no Brasil - contemplando-se o quadro contemporâneo dos estudos e pesquisas acadêmicas desenvolvidas sobre o tema no campo da comunicação e no campo dos estudos em saúde pública e nutrição, além de uma breve perspectiva histórica sobre os estudos comunicacionais de recepção infantil nas últimas décadas; e à apresentação da arquitetura filosófico-teórico-metodológica proposta para fundamentação do estudo contemplando-se o quadro filosófico-teórico-metodológico de referência para fundamentação do estudo, na perspectiva de um estudo interdisciplinar, e o conjunto das principais noções, conceitos e teorizações presentes no âmbito de uma interface da comunicação com os estudos culturais (estudos culturais latino-americanos), a antropologia (antropologia da cultura, do 
consumo, e da criança), e a sociologia (sociologia da infância) no contexto do estudo desenvolvido.

O segundo capítulo é dedicado à apresentação, análise e conclusão da pesquisa de campo, contemplando-se o relato das principais atividades desenvolvidas e experiências vivenciadas com as crianças em campo em seus contextos familiares - com atenção aos processos de entrada em campo em cada contexto familiar; às atividades realizadas com as crianças e com os pais nos encontros com as famílias para o desenvolvimento da pesquisa; e ao constante envolvimento e participação das crianças e dos pais no processo de investigação -; a interpretação e análise dos dados e avaliação dos resultados da pesquisa a partir dos eixos de abordagem teórica e empírica propostos para orientação da investigação - com atenção às interpretações e análises dos dados e avaliação dos resultados, elaboradas à luz da perspectiva das mediações comunicativas da cultura, com inspiração na proposta de Martin-Barbero, e tomadas a partir do enfoque da cultura alimentar infantil e as mediações culturais e comunicacionais na modulação do consumo alimentar das crianças no contexto familiar; da mediação comunicacional das marcas na cultura alimentar infantil e as marcas e produtos alimentícios no contexto familiar; e da recepção infantil de marcas de alimentos e os vínculos de sentidos entre marcas/produtos e crianças no contexto familiar -; e as reflexões propostas a partir dos resultados da pesquisa para uma perspectiva de conclusão do estudo - com atenção às possibilidades de reflexões na composição de uma perspectiva de conclusão deste estudo desenvolvido sobre a mediação comunicacional das marcas na cultura contemporânea de consumo alimentar infantil, e de uma sinalização de perspectivas para estudos futuros sobre a temática proposta, situados na interface comunicação, consumo, infância e cultura alimentar.

O terceiro capítulo é dedicado a uma abordagem sobre a experiência de investigação enquanto experiência de um estudo de inspiração etnográfica desenvolvido com crianças no campo da comunicação, com atenção às perspectivas infantis e agências das crianças nos processos de recepção infantil de marcas de alimentos e de consumo alimentar das crianças. E contemplando-se a apresentação e exploração das perspectivas e subjetividades infantis e agências das crianças participantes do estudo sobre sua cultura alimentar e sobre as marcas e produtos alimentícios em seu contexto familiar e nas preferências do seu consumo alimentar, presentes no conjunto das principais atividades desenvolvidas e experiências vivenciadas com as crianças em campo nos contextos familiares pesquisados. Especialmente nas atividades lúdicas e momentos de conversação desenvolvidos exclusivamente com as crianças no processo de investigação, na forma dos relatos infantis, entrevistas com as crianças, jogos e brincadeiras, e produção infantil de fotografias e vídeos, em que as perspectivas infantis e agências das 
crianças se fizeram presentes de modo mais intenso, dinâmico e autoral no desenvolvimento do estudo. Na perspectiva de uma complementação, enriquecimento e conclusão para o estudo desenvolvido sobre a mediação comunicacional das marcas na cultura contemporânea de consumo alimentar infantil, e de uma construção de conhecimentos e saberes a partir da presença, participação e voz das crianças no processo de investigação. Uma construção partilhada de conhecimentos a partir da ciência e dos saberes infantis.

Assim se desenha a estrutura e organização proposta para apresentação e exploração do estudo na composição da tese, no sentido de se buscar a melhor forma para a exposição do estudo desenvolvido e para o compartilhamento da experiência de investigação. E destacandose, na medida do possível, toda a riqueza, profundidade e diversidade do processo acadêmico de pesquisa vivenciado.

No campo dos estudos comunicacionais, em um contexto de raras pesquisas acadêmicas situadas na interface comunicação, consumo, infância e cultura alimentar, destaca-se o desenvolvimento deste estudo. Pois que, para além de uma investigação sobre a mediação comunicacional das marcas na cultura contemporânea de consumo alimentar infantil, este estudo dedicou-se ao desenvolvimento da pesquisa com crianças em campo em seus contextos familiares, tomando as crianças como informantes, participantes e copesquisadores no processo de investigação. Perspectiva que torna este estudo original e relevante não somente pela raridade da sua perspectiva e temática no contexto dos estudos comunicacionais, mas especialmente pelos investimentos filosófico-teórico-metodológicos de uma investigação de inspiração etnográfica desenvolvida com a participação das crianças no campo da comunicação. 
PRIMEIRO CAPÍTULO

APRESENTAÇÃO, CONTEXTUALIZAÇÃO E FUNDAMENTAÇÃO DO ESTUDO 
O primeiro capítulo desta pesquisa - uma investigação científica no campo da comunicação sobre a mediação comunicacional das marcas na cultura contemporânea de consumo alimentar infantil - é dedicado à apresentação da estrutura, delimitação e caracterização do estudo; sua contextualização no quadro atual de pesquisas acadêmicas desenvolvidas sobre o tema no Brasil e apresentação da arquitetura filosófico-teóricometodológica proposta para fundamentação do estudo.

A apresentação do estudo caracteriza-se pela exploração da temática e problemática que compõem o contexto da investigação desenvolvida e pela exposição dos eixos de abordagem teórica e empírica propostos para orientação do processo de investigação, bem como, pela abordagem de algumas especificações importantes para caracterização, estruturação e orientação do estudo: o objeto de estudo e corpus de investigação; o problema de pesquisa e pressupostos de investigação; os objetivos gerais e específicos do estudo; a justificativa para a investigação; o resumo do quadro filosófico-teórico-metodológico para fundamentação do estudo; os procedimentos metodológicos para a pesquisa teórica e pesquisa empírica; o protocolo de pesquisa; os métodos, técnicas e atividades desenvolvidas para a pesquisa de campo com as crianças.

A contextualização do estudo é caracterizada pela exploração do quadro contemporâneo dos estudos e pesquisas acadêmicos, em nível de dissertação de mestrado e tese de doutorado, desenvolvidos sobre o tema no Brasil, do campo da comunicação ao campo dos estudos em saúde pública e nutrição, bem como, uma breve perspectiva histórica sobre os estudos comunicacionais de recepção infantil no Brasil nas últimas décadas.

A apresentação do quadro filosófico-teórico-metodológico proposto para fundamentação do estudo, em sua concepção de estudo interdisciplinar, caracteriza-se pela exploração de noções, conceitos e teorizações específicas nos campos das disciplinas que compõem a proposta de interface da comunicação com os estudos culturais (estudos culturais latino-americanos), a antropologia (antropologia da cultura, do consumo, e da criança), e a sociologia (sociologia da infância) no contexto e temática do estudo desenvolvido. 


\section{APRESENTAÇÃO E CONTEXTUALIZAÇÃO DO ESTUDO}

Obesidade infantil e consumo alimentar das crianças: uma problemática de saúde pública no Brasil e no mundo. - "Infância na balança: mudanças nos hábitos alimentares e a redução constante de atividades físicas estariam levando a população mundial ao sobrepeso e à obesidade, a começar pelas crianças" (UFSC, 2013). "Obesidade infantil: um problema de saúde pública" (SÍRIO-LIBANÊS, 2016). "Obesidade entre crianças e adolescentes aumentou dez vezes em quatro décadas, revela novo estudo do Imperial College London e da OMS" (OPAS BRASIL, 2017). “A Organização Mundial da Saúde aponta a obesidade como um dos maiores problemas de saúde pública no mundo" (SENADO FEDERAL, 2017; ABESO, 2017). "OMS lança novas diretrizes de combate à obesidade infantil no mundo: estima-se que 41 milhões de crianças menores de 5 anos sejam obesas ou estejam acima do peso no mundo" (ONU BRASIL, 2017). "Segundo dados, 7,3\% das crianças menores de 5 anos encontram-se acima do peso no Brasil: segundo a Pesquisa de Orçamento Familiar (IBGE) uma em cada três crianças brasileiras com idade entre 5 e 9 anos estão com o peso acima do recomendado pela OMS" (TERRA, 2017). "Brasil terá 11,3 milhões de crianças obesas em 2025, estima organização: a população mundial está ganhando peso rapidamente, principalmente crianças e adolescentes" (BBC BRASIL, 2017). "Uma a cada três crianças brasileiras está com sobrepeso: cerca de $80 \%$ das crianças obesas se tornam adultos também obesos, diz especialista" (JORNAL DA USP, 2018). “O número de crianças com sobrepeso e obesidade pode chegar a 75 milhões caso nada seja feito: incluindo 427 mil crianças com pré-diabetes, 1 milhão com hipertensão arterial e 1,4 milhão com aumento do acúmulo de gordura no fígado” (EXAME, 2018). “Obesidade infantil: um desafio de peso" (SAÚDE ABRIL, 2018). “Obesidade infantil: a culpa é de quem? Hábitos alimentares dos pais e fácil acesso a alimentos ultraprocessados estão entre os responsáveis pelo problema. No Brasil, 33\% dos pequeninos estão acima do peso, segundo o Ministério da Saúde" (ESTADÃO, 2018; GAZETA, 2018; DIÁRIO DE PERNAMBUCO, 2018). "Obesidade infantil desafia pais e gestores: levantamento do IBGE aponta que uma em cada três crianças está acima do peso no Brasil. Endocrinologista associa obesidade na infância à mudança dos hábitos alimentares e à diminuição da atividade física” (SAÚDE. GOIÁS, 2019). "A obesidade infantil é um problema sério e traz riscos para a saúde adulta: a obesidade na infância está associada à mudança de hábitos alimentares e à diminuição da atividade física. $\mathrm{A}$ OMS estima que, em 2025, crianças obesas no planeta chegarão a 75 milhões" (MINISTÉRIO DA SAÚDE, 2019). "Brasil lança primeira campanha para prevenir obesidade infantil: novo guia alimentar ajuda pais a escolherem melhores alimentos e ensina que hora da alimentação 
deve ser um momento de afeto" (GOVERNO DO BRASIL, 2019). "O Ministério da Saúde lançou a campanha '1, 2, 3 e já! Vamos prevenir a obesidade infantil!' A ideia é incentivar as crianças a seguirem três passos simples para evitar o sobrepeso: alimentação saudável, atividade física e brincadeiras longe das telas..." (A TARDE UOL, 2019). "Dados do ministério apontam que três a cada dez crianças de 5 a 9 anos atendidas pelo SUS estão acima do peso (4,4 milhões). Do total de crianças, $16 \%$ (2,4 milhões) estão com sobrepeso, 8\% (1,2 milhão) com obesidade e 5\% (755 mil) com obesidade grave. Abaixo de 5 anos, são 15,9\% com excesso de peso" (AGÊNCIA BRASIL, 2019). "Saúde alerta sobre riscos da obesidade infantil: segundo a Organização Mundial da Saúde, este é considerado um dos principais desafios para o século XXI" (GOVERNO DO ESTADO DO PARANÁ, 2020). "Médicos alertam sobre obesidade infantil: segundo dados (Organização Internacional World Obesity) atualmente cerca de 158 milhões de crianças e adolescentes entre 5 e 19 anos convivem com o excesso de peso e esse número deve aumentar para 254 milhões em 2030 em todo o mundo" (AGÊNCIA BRASIL, 2020). "Especialistas alertam para a obesidade infantil: desafio para mudança de hábitos pode ser maior durante o isolamento social” (SAÚDE DEBATE, 2020). "Filhos 'se espelham' nos pais, afirma médico sobre combate à obesidade infantil" (CBN, 2020). "Obesidade infantil: estilo de vida dos pais pode ser a resposta para a mudança" (FOLHA VITÓRIA, 2020). "IBGE: Obesidade mais do que dobra na população com mais de 20 anos: Resultados são da Pesquisa Nacional de Saúde 2019: Entre 2003 e 2019, a proporção de obesos na população com 20 anos ou mais de idade do país mais que dobrou, passando de 12,2\% para 26,8\%" (AGÊNCIA BRASIL, 2020).

Saúde e alimentação das crianças: uma importante questão médica, nutricional, educacional, familiar, social, política e institucional. - "Projetos de educação alimentar nas escolas buscam mudar hábitos familiares: para garantir que crianças e adolescentes se alimentem de maneira saudável, poder público e instituições de ensino vêm adotando medidas que restringem a entrada de alimentos [...] nocivos à saúde no ambiente escolar" (EDUCAÇÃO, 2017). “A importância de uma alimentação saudável na infância: quando se trata de alimentação na infância os cuidados devem ser redobrados" (ESTADÃO, 2018). "Alimentação e Saúde Infantil: nutrição consciente desde a infância” (ALIMENTO SAÚDE INFANTIL, 2019). “A importância da comida de verdade para o desenvolvimento das crianças: uma alimentação adequada e saudável contribui para a saúde infantil e deve ter como base a "comida de verdade"” (UOL, 2019). "Nutrição infantil: como tornar a alimentação das crianças mais saudável." (PRODIET, 2019) "Má alimentação prejudica a saúde de milhões de crianças em todo o mundo: uma em cada três crianças está desnutrida ou com sobrepeso no mundo; na América Latina e 
no Caribe uma em cada cinco crianças é afetada pela má nutrição; no Brasil aumento do sobrepeso é particularmente importante" (UNICEF BRASIL, 2019; ESTADÃO, 2019). "Os desafios para a alimentação das crianças: especialistas apontam quais são os aliados da alimentação saudável para crianças e quais são os principais desafios enfrentados pela família quando o assunto é comida de verdade" (MINISTÉRIO DA SAÚDE, 2019). "Ministério da Saúde orienta alimentação saudável e atividade física para combater a obesidade infantil: a cada dez crianças brasileiras na faixa etária entre 5 e 9 anos, três estão acima do peso de acordo com dados do Ministério da Saúde" (GOVERNO DO BRASIL, 2019). "Ministério da Saúde lança guia de nutrição infantil: a inclusão de açúcar e alimentos ultraprocessados na dieta de crianças até 2 anos é contraindicada" (JORNAL USP, 2019). "A importância da alimentação saudável para a criança: a alimentação para a criança não é apenas uma necessidade biológica para o seu desenvolvimento, mas também um momento de afeto e vínculo com a família" (PASTORAL DA CRIANÇA, 2020). “Alimentação das crianças: dicas para seu filho comer melhor durante a quarentena" (CANGURU NEWS, 2020). “Alimentação saudável previne a obesidade infantil e o câncer" (VEJA ABRIL, 2020). “Alimentação infantil: uma oportunidade para a família buscar mais saúde. Bons hábitos alimentares começam na infância: veja como a família toda pode se beneficiar com isso" (UNIMED, 2020).

Publicidade infantil e publicidade de alimentos para crianças: um extenso e intenso debate social, político e institucional no mundo contemporâneo. - "Obesidade infantil aquece debate sobre publicidade para crianças: a obesidade infantil está no centro de um debate: de um lado, a indústria de alimentos e suas guloseimas, do outro, organizações de direito do consumidor e sociedades médicas. Causa da discórdia: a publicidade de alimentos para crianças no Brasil”" (ASBRAN, 2012). "Publicidade Infantil é obstáculo para alimentação saudável: novo guia alimentar para a população brasileira, do Ministério da Saúde, traz informações e dados sobre as consequências da comunicação mercadológica dirigida às crianças" (CRIANÇA E CONSUMO, 2014). "Publicidade e obesidade andam juntos: dados indicam relação entre aumento do peso corporal em 13 países da América Latina e o consumo de alimentos de baixo valor nutricional" (CRIANÇA E CONSUMO, 2015). "Mercado infantil é a bola da vez" (NIELSEN, 2015). "Mercado de alimentação saudável chega à festas infantis" (EMPREENDEDOR, 2015). "Publicidade de alimentos e obesidade infantil: uma reflexão necessária" (PLANALTO, 2015; ÉPOCA, 2015). "Obesidade infantil: precisamos falar sobre a publicidade de alimentos" (HUFFPOST BRASIL, 2018). "Cresce mercado diferenciado para crianças" (JORNAL DO COMERCIO, 2018). "Mercado infantil exige diferencial e foco" (ESTADÃO, 2018). "Publicidade infantil: marcas fazem balanço de revisão de normas: 
compromisso pela publicidade responsável para crianças restringiu anúncios de alimentos que não atinjam critérios nutritivos suficientes" (MEIO E MENSAGEM, 2018). "Publicidade infantil aumenta o nível de obesidade: a publicidade infantil incentiva hábitos não saudáveis nas crianças, aumentando os níveis de doenças crônicas não transmissíveis como a obesidade" (CRIANÇA E CONSUMO, 2019. “Cresce participação do consumo infantil no varejo alimentar: pesquisa da Kantar Worldpanel aponta crescimento do consumo infantil de alimentos no Brasil" (CONSUMIDOR MODERNO, 2019). "Alimentação Infantil: mercado exige criatividade e responsabilidade: sabemos a dificuldade que pais e educadores têm quando o assunto é oferecer uma alimentação saudável e de qualidade para as crianças; os desafios também se expandem para quem empreende no setor de alimentação infantil" (SEBRAE SC, 2019). "Publicidade infantil e a responsabilidade das marcas: a regulamentação da publicidade infantil ainda é muito delicada no Brasil" (PORTAL COMUNIQUE-SE, 2019). "Publicidade infantil: a porta de entrada para produtos ultraprocessados" (FIOCRUZ, 2020). "Mídias sociais influenciam crianças a consumirem mais alimentos calóricos: as mídias sociais também influenciam os pequenos, principalmente quando o assunto é alimentação" (UOL, 2019). "Mídias sociais: atenção à publicidade infantil na internet" (INSTITUTO PENSI, 2020). "Ainda sobre publicidade infantil: parecia que o marketing já tinha superado essa discussão" (MEIO E MENSAGEM, 2020). "Entenda mais sobre a publicidade infantil em alimentos: o que torna a publicidade infantil abusiva? Quais as reais consequências da publicidade infantil na vida das crianças? (ECONOMIA IG, 2020).

Regulação e regulamentação da publicidade infantil no Brasil: um longo e amplo processo de discussão e debate social, político e institucional, mas que ainda carece de maturidade, representatividade e reflexividade. - "A regulação da publicidade é necessária para proteger a saúde das crianças: o estímulo ao consumo excessivo e habitual de produtos alimentícios ultraprocessados constitui uma das causas - ainda que não a única - da transição nutricional e aumento de peso da população" (GAZETA DO POVO, 2016). "Países que regulam publicidade infantil: o Superior Tribunal de Justiça determinou que é abusivo o uso de comunicação dirigida às crianças: veja como outros mercados lidam com o tema" (MEIO E MENSAGEM, 2016). "Publicidade infantil: entenda o debate e saiba como a questão é regulamentada" (AGENCIA BRASIL, 2017). "Seis marcas de alimentos para bebês têm fabricação, venda e uso proibidos pela Agência Nacional de Vigilância Sanitária” (METRO1, 2017). "Nove denúncias de oferta abusiva de produtos alimentícios com brinquedo: saiba quais empresas já foram questionadas pela prática abusiva de venda de brinquedo com produtos alimentícios, com foco nas crianças" (CRIANÇA E CONSUMO, 2018). "Reino Unido avança 
contra publicidade de junk food para crianças" (CRIANÇA E CONSUMO, 2018). "Alemanha pede o fim da publicidade infantil de produtos alimentícios" (CRIANÇA E CONSUMO, 2018). "Decisão histórica condenou propaganda de alimentos dirigida ao público infantil (no Brasil)" (SUPERIOR TRIBUNAL DE JUSTIÇA, 2019). "Proibição da publicidade infantil não é fake news: dirigir mensagens comerciais a um público menor de 12 anos é prática regulada e até proibida em muitos países, que entendem ser antiético explorar a ingenuidade infantil em vez de dirigir-se aos pais" (MEIO E MENSAGEM, 2019). "Publicidade e crianças: o mundo não é uma bolha. No Brasil, não é proibido anunciar produtos e serviços de consumo infantil e adolescente, e é importante que continue assim” (MEIO E MENSAGEM, 2019). "Governo abre consulta pública sobre lei que deve reger publicidade infantil: apesar de não contar com lei explícita, propaganda voltada às crianças já é considerada ilegal por entidades e chama a atenção dos anunciantes" (O CONSUMERISTA, 2020). "Entidades questionam no Ministério da Justiça a flexibilização da publicidade infantil: manifesto defende que proposta da Secretaria Nacional do Consumidor pode enfraquecer a proteção das crianças” (MIGALHAS, 2020). "A minuta de portaria da Secretaria Nacional do Consumidor sobre publicidade infantil precisa ser mais discutida: consulta pública sobre minuta de portaria regulamentadora da publicidade infantil objetivando harmonizar a proteção constitucional da criança e do adolescente com o direito constitucional da livre iniciativa dos fornecedores" (CONSULTOR JURÍDICO, 2020).

Participação infantil e a voz das crianças: uma reflexão importante e necessária no contexto das problemáticas sociais infantis e políticas públicas para crianças: questão ainda ausente no debate contemporâneo sobre saúde e alimentação das crianças e a publicidade de alimentos infantis - "Ouvir as crianças faz toda a diferença.” (ESTADÃO, 2015). "Participação infantil: opinar também é direito das crianças" (LUNETAS, 2016). "Documentário 'A Voz das Crianças' registra diversidade de expressões infantis de cinco países” (PRIMEIRA INFÂNCIA, 2017). "Ideias pipocam: a voz das crianças no planejamento da educação infantil: explorar o direito de participação e a autonomia das crianças; evidenciar seus desejos por meio da expressão oral, do registro escrito e dos desenhos; estimular a auto-organização, expressa no planejamento das ações cotidianas" (MINISTÉRIO DA EDUCAÇÃO, 2017). "Seminário Internacional Infâncias Sul-Americanas: crianças nas cidades, políticas e participação: a ciência e experiências afetivas sobre a infância compartilhadas [...]. Vamos aprender outras formas de ouvir as crianças!” (CECIP, 2017) "O que é protagonismo infantil e como incentivá-lo?” (DENTRO DA HISTÓRIA, 2018). "Por que é preciso escutar as crianças? Em que consiste a escuta das crianças e como esse conceito se concretiza na prática?" (CRIANÇA E NATUREZA, 2019). "Por que é tão importante dar voz e vez às crianças?” (G1, 2019). "CECIP 
participa da X Conferência do Conselho Estadual da Criança e do Adolescente: conversas e atividades com os pequenos sobre as habilidades e qualidades que um porta-voz das crianças deveria ter para representá-las..." (CECIP, 2019). "Sentimentos de crianças: campanha lançada pelo Fundo das Nações Unidas para a Infância: crianças de todo o país são convidadas a registrar, por meio de desenhos, suas emoções em relação ao isolamento social" (CORREIO BRAZILIENSE, 2020). "Mais do que nunca, precisamos ouvir as crianças: estar em casa é uma oportunidade para estreitar as relações e ouvir de fato o que as crianças estão dizendo" (LUNETAS, 2020). "Sujeitos do presente e do futuro: crianças e adolescentes” (UOL, 2020).

Assim se desenha o importante e complexo contexto social contemporâneo de discussão sobre crianças, publicidade e consumo alimentar no Brasil e no mundo. Um debate acalorado envolvendo a sociedade civil, governos, organizações não governamentais de proteção às crianças e defesa dos consumidores, indústrias de alimentos, empresas de mídia, agências de publicidade, imprensa, profissionais da saúde e educação infantil, e a academia. Entretanto, ainda não contempla a participação infantil e a voz das crianças nos processos de discussão e reflexão.

O debate apresenta-se essencialmente caracterizado pela oposição entre as estratégias da indústria alimentícia e da publicidade de alimentos - marcadas pela combinação alimentação-diversão, notadamente presente na composição dos produtos alimentícios e na elaboração estética das mensagens publicitárias e outros dispositivos promocionais para comunicação das marcas no mercado de alimentos para crianças - e as reivindicações da sociedade civil, profissionais da saúde e educação infantil, e organizações não governamentais de proteção às crianças e adolescentes - materializadas a partir da crescente preocupação social com a saúde e alimentação infantil, em face à grande quantidade de produtos alimentícios não saudáveis produzidos pela indústria e divulgados pela publicidade dirigida ao público infantil, e aos altos índices de obesidade entre crianças e adolescentes, dados por um consumo em excesso de alimentos ultraprocessados, hipercalóricos e de baixo valor nutricional. Este movimento tem demarcado presença crescente de manifestações sociais e ações políticas pela regulamentação da publicidade dirigida às crianças, especialmente a publicidade de alimentos. (BAADER, 2013:186-196)

No entanto, é importante destacar que o contexto atual de discussão sobre crianças, publicidade e consumo alimentar, apesar de toda a legitimidade social e política do debate, encontra-se extremamente polarizado. De um lado, os discursos da indústria de alimentos, veículos de comunicação e profissionais de publicidade - tomando as crianças como especialmente autônomas, dinâmicas e inteligentes, diante de uma publicidade de alimentos 
dada como possibilidade de informação, conhecimento e entretenimento para as crianças. De outro, os discursos da sociedade civil, agências de saúde, organizações não-governamentais de proteção à infância e adolescência, entidades de defesa do consumidor, profissionais da saúde e educação infantil - tomando as crianças como consideravelmente frágeis, vulneráveis e indefesas, diante de uma publicidade de alimentos dada como principal influência para o comportamento alimentar das crianças e jovens na contemporaneidade, marcado pelo consumo em excesso de alimentos não saudáveis (ricos em açúcares, sódio, gorduras e conservantes). (BAADER, 2013:186-196)

Trata-se da mesma polaridade discursiva destacada por Buckingham, ao propor uma análise dos discursos sociais, institucionais e acadêmicos sobre o conceito de infância e a relação das crianças com as mídias, a publicidade e o consumo no mundo contemporâneo: ou a "morte da infância"; ou "geração eletrônica / digital". De um lado, o ponto de vista dos que acreditam na "morte da infância": no desaparecer da infância bela e inocente e no precoce despertar das crianças para a vida adulta; na perda do encantamento, da fantasia, das brincadeiras, de tudo o que antes caracterizava e protegia o mundo das crianças. E aí as mídias são colocadas como a causa principal de tal fenômeno, pelo excesso de conteúdos impróprios veiculados para as crianças. De outro, a perspectiva dos que celebram a liberdade e autonomia das crianças em face aos adultos; o nascer de uma "geração eletrônica / digital"; o pleno domínio das crianças sobre as tecnologias e as mídias, seu poder de escolha e decisão nas experiências de consumo. E aí as mídias são tomadas como fonte contínua de comunicação, informação, conhecimento e entretenimento para as crianças. (BUCKINGHAM, 2007a:18-19; BUCKINGHAM, 2012a:49)

No entanto, como observa o autor em sua proposta de reflexão sobre a temática da obesidade infantil, é preciso ir além da dualidade essencial que caracteriza o debate contemporâneo, procurando atentar para o contexto mais amplo em que se coloca a questão, para além de uma visão focada exclusivamente na relação de tal fenômeno com a publicidade de alimentos. (BUCKINGHAM, 2012a:64-65)

Nessa ordem, e no momento em que questões como a saúde infantil, o consumo alimentar das crianças, a publicidade de alimentos e a regulação das comunicações para o público infantil se colocam em pauta, faz-se essencial a presença de estudos e pesquisas acadêmicas no contexto social de discussão sobre comunicação, consumo, infância e cultura alimentar, no sentido de se experimentar perspectivas mais amplas e plurais no tratamento da questão, para além das polaridades que caracterizam o debate na contemporaneidade. 
Partindo de novos aportes filosófico-teórico-metodológicos, este estudo foi delineado na proposta de uma continuidade e aprofundamento para a temática da pesquisa desenvolvida no curso do mestrado (BAADER, 2013) - dedicada ao estudo da publicidade de alimentos infantis e suas possibilidades de sentidos para as práticas de consumo alimentar das crianças.

No estudo desenvolvido, foi possível observar que a publicidade de alimentos dirigida ao público infantil, assim como outros dispositivos promocionais dirigidos a este público no mercado de alimentos, apresenta-se essencialmente caracterizada pela estética da diversão - a partir da tendência do eatertainment: combinação alimentação-diversão - buscando promover entre as crianças a ética da brincadeira, da diversão e interação com os produtos alimentícios, as marcas e seus dispositivos promocionais, no sentido da promoção de uma lógica quase que exclusiva da diversão, que se sobrepõe à lógica da nutrição, para criação dos vínculos entre marcas/produtos e crianças e para modulação e construção da cultura contemporânea de consumo alimentar infantil. (BAADER, 2013:317-325)

Os resultados do estudo, bem como sua proposta de reflexão, instigaram o interesse no desenvolvimento de nova investigação, em continuidade e aprofundamento da temática, para explorações no campo da recepção infantil de marcas de alimentos e das práticas de consumo das crianças nos cotidianos da sua cultura alimentar.

Nesse contexto, e a partir dos resultados obtidos na pesquisa, foi então delineada a proposta deste estudo - dada em uma perspectiva que contempla os fenômenos das mediações culturais e comunicacionais na cultura alimentar infantil, para exploração da presença mediática de marcas e produtos alimentícios, em suas lógicas e sentidos, no contexto dos usos e consumos das crianças nas práticas sociais da cultura alimentar em âmbito familiar.

O tema proposto para o estudo apresenta-se em um contexto amplo e abrangente, marcado pela diversidade de tendências e movimentos que caracterizam a contemporaneidade: os fenômenos das mediações culturais e comunicacionais no mundo em que hoje vivemos; a presença das mídias e novas mídias e as tecnologias da informação e da comunicação; os contextos da midiatização; os sistemas da moda, a publicidade e a publicização; os atuais fenômenos do consumo; as diversidades sociais e novas composições familiares; a pluralidade de crianças e infâncias nas culturas e sociedades; as diversas representações de infância nas mídias e na publicidade; a criança no status de consumidor; a multiplicidade de conteúdos para o público infantil nas diversas plataformas midiáticas e a interatividade das crianças com as mídias; a diversidade de marcas e produtos para crianças no mercado e o contexto das marcas e produtos alimentícios infantis; as marcas de alimentos como dispositivos midiáticos promocionais; a presença das marcas na construção e modulação da cultura alimentar infantil; 
as tendências mundiais do consumo alimentar e a tendência do eatertainment; as lógicas da diversão e as lógicas da nutrição; a preocupação social com a saúde e alimentação das crianças; a presença de alimentos não saudáveis nos cotidianos da cultura alimentar infantil; os altos índices de obesidade infantil e outros distúrbios de saúde causados pelo consumo em excesso de produtos alimentícios ultraprocessados e hipercalóricos; o excesso de publicidade de alimentos não saudáveis dirigida às crianças; os movimentos sociais e políticos pela regulamentação e proibição da publicidade infantil. Fenômenos diversos e plurais na composição do heterogêneo e contemporâneo contexto sociocultural no qual se destaca a temática deste estudo.

Com atenção à temática e à proposta de investigação, é importante observar que o objeto do estudo é composto a partir de uma articulação entre eixos específicos de abordagem teórica e empírica: a cultura alimentar infantil e as mediações culturais e comunicacionais na modulação do consumo alimentar das crianças no contexto familiar (compreendendo a cultura alimentar familiar e a cultura alimentar infantil no contexto familiar, as práticas e rituais de consumo alimentar das crianças, as mediações culturais e comunicacionais presentes na modulação do consumo alimentar infantil no contexto familiar); a mediação comunicacional das marcas na cultura alimentar infantil e as marcas e produtos alimentícios no contexto familiar (considerando os modos de presença e mediação comunicacional das marcas na construção da cultura alimentar infantil, as marcas e produtos alimentícios presentes no contexto familiar, os vínculos de sentidos que se estabelecem entre as marcas/produtos e as famílias/crianças); a recepção infantil de marcas de alimentos e os vínculos de sentidos entre marcas/produtos e crianças no contexto familiar (compreendendo os processos de recepção infantil de marcas de alimentos tomadas como dispositivos midiáticos promocionais e os vínculos de sentidos dados entre marcas/produtos e crianças nos cotidianos dos contextos familiares).

É a partir da complexa articulação entre estes eixos de abordagem e seus desdobramentos, que se propôs esta investigação sobre a mediação comunicacional das marcas na cultura alimentar infantil. Perspectivas importantes de abordagem teórica e empírica para fundamentação e orientação das bases da investigação: desde o recorte do objeto de estudo, quadro filosófico-teórico-metodológico de referência para a investigação, procedimentos metodológicos da pesquisa, até as interpretações e análises dos dados e avaliação dos resultados, considerando os processos de observação, descrição e interpretação realizados durante as investigações em campo.

Nesse sentido, na delineação do objeto de investigação, propôs-se o estudo da recepção infantil de marcas de alimentos, como dispositivos midiáticos promocionais, no âmbito das 
práticas e rituais de consumo alimentar das crianças em contextos familiares na cidade de São Paulo, explorando os modos de presença e mediação comunicacional das marcas na construção da cultura alimentar infantil e considerando os vínculos de sentidos entre marcas/produtos e crianças, na interface com as mediações culturais e comunicacionais presentes na modulação do consumo alimentar infantil no contexto familiar.

Com atenção aos principais elementos conceituais que compõem o objeto de investigação proposto, faz-se importante considerar: a recepção infantil de marcas de alimentos é aqui considerada enquanto os diversos processos socioculturais a partir dos quais as crianças têm contato com marcas e produtos alimentícios nos cotidianos da sua cultura alimentar; tomando-se as marcas de alimentos como dispositivos midiáticos promocionais: as marcas tomadas como mídia no contexto promocional do mercado de alimentos e nos cotidianos das práticas de consumo alimentar das crianças - em suas diversas formas de presença e expressividade, consideradas para além dos formatos tradicionais de publicidade, ou ainda para além da forma publicidade; tomando-se os modos de presença e expressividade das marcas e produtos alimentícios, em sua dimensão de presença material e presença simbólica, enquanto importante mediação comunicacional, em um contexto de diversas mediações culturais e comunicacionais, nos processos de construção da cultura alimentar infantil no âmbito familiar; tomando-se os vínculos de sentidos entre marcas/produtos e crianças enquanto os laços de afeto, representação e significação criados entre as marcas e produtos alimentícios e as crianças nos contextos familiares pesquisados; e especialmente, tomando-se as crianças como sujeitos no desenvolvimento do estudo: as crianças tomadas como informantes e participantes no processo de investigação.

Considerando-se o recorte e perspectiva conceitual propostos no objeto, o estudo se coloca em um lugar privilegiado no campo dos estudos comunicacionais de recepção e práticas de consumo, pois, na proposta de uma investigação sobre os processos de recepção infantil de marcas de alimentos nos cotidianos da cultura alimentar das crianças em seus contextos familiares, este estudo marca presença entre as pesquisas acadêmicas que contemplam as experiências, perspectivas, saberes e afetos infantis no contexto dos estudos sobre comunicação consumo e infância, contribuindo com novas explorações para a construção e ampliação dos seus referenciais filosófico-teórico-metodológicos de investigação.

A partir da temática proposta e delineação do objeto de estudo, colocou-se o problema de pesquisa para orientação da investigação: Como se dá a recepção infantil de marcas de alimentos, como dispositivos midiáticos promocionais, no âmbito das práticas e rituais de consumo alimentar das crianças no contexto familiar, considerando os vínculos de sentidos 
entre marcas/produtos e crianças? E como se dão os modos de presença e mediação comunicacional das marcas na construção da cultura alimentar infantil, na interface com as mediações culturais e comunicacionais presentes na modulação do consumo alimentar das crianças no contexto familiar?

Questões importantes na composição da problemática da relação criança-marcaconsumo alimentar no contexto familiar, no sentido de contribuir com novas perspectivas de investigação e reflexão, no campo dos estudos comunicacionais, para a arena do debate contemporâneo que se estabelece sobre comunicação, consumo, infância e cultura alimentar.

Os questionamentos que envolvem e compõem a problemática trouxeram à luz alguns pressupostos de investigação para orientação inicial do estudo, no caminho de se tentar buscar respostas ao problema de pesquisa proposto:

1. A cultura alimentar infantil contemporânea apresenta-se notadamente marcada pela presença de diferentes e diversas mediações culturais e comunicacionais na modulação do consumo alimentar das crianças no contexto familiar.

2. Os diversos modos de presença e mediação comunicacional das marcas no contexto familiar participam e contribuem nos processos de construção da cultura contemporânea de consumo alimentar das crianças.

3. A recepção infantil de marcas de alimentos, como dispositivos midiáticos promocionais, dáse em um contexto especialmente marcado pela presença dos vínculos de sentidos dados entre marcas/produtos e crianças no âmbito familiar.

A proposta deste estudo foi motivada a partir do crescente interesse da sociedade e comunidade acadêmica nas temáticas que envolvem a saúde infantil, o consumo alimentar das crianças e a publicidade de alimentos - um importante e complexo encontro de contextos que caracteriza os estudos contemporâneos sobre comunicação, consumo, infância e cultura alimentar.

Entende-se a originalidade e relevância do tema em face à rara literatura científica no campo da comunicação dedicada ao estudo da mediação comunicacional das marcas na cultura alimentar infantil - especialmente estudos que contemplam os processos de recepção infantil e práticas de consumo de crianças em contextos familiares, tomando as crianças como informantes e participantes no processo de investigação - no sentido de trazer possíveis contribuições às questões sociais e acadêmicas que se apresentam sobre a temática da saúde e alimentação das crianças e a publicidade de alimentos. Temas esses com expressiva presença em debates contemporâneos nos campos da comunicação, educação, sociologia, direito, saúde, saúde pública e nutrição. 
Este estudo traz contribuição significativa para a produção científica no campo da comunicação, pois, ao realizar a exploração e investigação do seu objeto, buscou compreender o fenômeno contemporâneo da mediação comunicacional das marcas na cultura alimentar infantil e suas possibilidades de alinhamento às práticas desejáveis de consumo alimentar das crianças em perspectivas de saudabilidade. Com isso, talvez seja possível encontrar, no processo de regulação de sentidos dos discursos das marcas de alimentos, caminhos que melhor se afinem com o contexto das práticas de consumo das crianças, as necessidades presentes nos cotidianos da sua cultura alimentar, e a regulação e regulamentação do setor alimentar e de suas comunicações para o público infantil.

Dentro dessa visão, e partindo do problema de pesquisa proposto para orientação da investigação, foram definidos os objetivos para o estudo, na tentativa de buscar respostas às questões que caracterizam a problemática e promover reflexões importantes sobre a temática em que o estudo se apresenta:

Como objetivo geral teórico, o estudo buscou propor um percurso e contribuição teórico-metodológica para o estudo da recepção infantil de marcas de alimentos, nos cotidianos das práticas culturais de consumo alimentar das crianças em contextos familiares, tomando as crianças como informantes e participantes no processo de investigação, procurando dar voz às crianças e atentando para a importância da presença de perspectivas infantis na produção dos estudos contemporâneos sobre comunicação consumo infância e cultura alimentar.

Como objetivo geral empírico, o estudo visou compreender como se dá a recepção infantil de marcas de alimentos, como dispositivos midiáticos promocionais, no âmbito das práticas e rituais de consumo alimentar das crianças em contextos familiares, explorando os modos de presença e mediação comunicacional das marcas na construção da cultura alimentar infantil e considerando os vínculos de sentidos entre marcas/produtos e crianças, na interface com as mediações culturais e comunicacionais presentes na modulação do consumo alimentar infantil no contexto familiar.

E a partir dos objetivos gerais, com base nos eixos de abordagem propostos para orientação do estudo e nos pressupostos iniciais de investigação, foram definidos os objetivos específicos, sugeridos para orientação dos procedimentos metodológicos da pesquisa:

1. Observar como se caracterizam as práticas e rituais de consumo na cultura alimentar infantil, a partir dos contextos familiares pesquisados, explorando os cotidianos das interações infantis e atentando para as mediações culturais e comunicacionais que participam na modulação do consumo alimentar das crianças no âmbito familiar. 
2. Explorar e identificar os modos de presença e mediação comunicacional das marcas na construção da cultura alimentar infantil, a partir dos contextos familiares pesquisados, atentando para as marcas e produtos alimentícios presentes no âmbito familiar e os vínculos de sentidos que se estabelecem entre as marcas/produtos e as famílias/crianças.

3. Explorar e observar, na proposta de um percurso de estudo, como se dá a recepção infantil de marcas de alimentos, como dispositivos midiáticos promocionais, considerando os vínculos de sentidos dados entre marcas/produtos e crianças nos cotidianos dos contextos familiares pesquisados.

Com atenção aos procedimentos metodológicos de investigação, faz-se importante observar que esta pesquisa é caracterizada enquanto estudo exploratório de natureza qualitativa, especialmente por seu caráter exploratório em um contexto de construção filosófico-teóricometodológica de investigação sobre recepção infantil de marcas de alimentos e práticas de consumo das crianças na cultura contemporânea de consumo alimentar. Nesse contexto, o estudo foi desenvolvido na forma de pesquisa teórica e pesquisa empírica.

No formato de pesquisa teórica, o estudo desenvolveu-se como pesquisa bibliográfica ao proceder à revisão de literatura científica nos campos de conhecimento que compõem, em seu caráter interdisciplinar de investigação, o quadro filosófico-teórico-metodológico de referência para sua contextualização e fundamentação.

No formato de pesquisa empírica, o estudo desenvolveu-se como pesquisa de campo ao proceder às observações, descrições, interpretações e análises para exploração dos modos de presença e mediação comunicacional das marcas na cultura alimentar das crianças, no estudo da recepção infantil de marcas de alimentos e da relação criança-marca-consumo alimentar nos contextos familiares pesquisados.

Colocando-se em uma perspectiva interdisciplinar de investigação, o estudo foi delineado na interface da comunicação com os estudos culturais, a antropologia e a sociologia - considerando também algumas contribuições nos campos da educação, psicologia, direito, saúde pública e nutrição, demarcando presença, desse modo, no contexto de interdisciplinaridade que marca os estudos contemporâneos sobre comunicação, consumo, infância e cultura alimentar.

Numa síntese do quadro filosófico-teórico-metodológico do estudo, é possível destacar seu caráter interdisciplinar no campo da comunicação a partir do seguinte desenho de investigação: um estudo de recepção em perspectiva de abordagem sociocultural, dado a partir do enfoque da comunicação - na vertente dos estudos das mediações culturais e comunicacionais; dos estudos de midiatização; dos estudos sobre marca; e dos estudos sobre 
mídia, publicidade, consumo e infância. Estudo delineado a partir de uma interface da comunicação com os estudos culturais - na vertente dos estudos culturais latino-americanos; com a antropologia - considerando os estudos antropológicos sobre cultura, consumo e infância, e no aporte dos principais métodos e técnicas sugeridos pelos estudos etnográficos; e com a sociologia - na vertente dos estudos da sociologia da infância.

Nesse contexto plural de investigação, e partindo dos eixos de abordagem teórica e empírica propostos para orientação do estudo, o trabalho desenvolvido contou com o apoio da perspectiva das mediações para realização das interpretações e análises dos dados e avaliação dos resultados da pesquisa, orientados a partir de uma proposta de articulação entre os eixos de abordagem sugeridos para orientação da investigação e o mapa das mediações (na perspectiva das mediações comunicativas da cultura) proposto por Martin-Barbero (2009). Tal articulação teórica será apresentada e explorada mais adiante, no momento da fundamentação filosóficoteórico-metodológica do estudo.

Como investigação interdisciplinar no campo da Comunicação, o estudo pretendeu-se em uma base comunicacional de interface antropo-sociocultural, ao visar compreender o fenômeno da mediação comunicacional das marcas na cultura alimentar infantil, tanto na dimensão das marcas tomadas como dispositivos midiáticos promocionais, em suas lógicas e sentidos, para construção da cultura alimentar infantil, quanto na dimensão das práticas culturais de consumo alimentar das crianças, em suas perspectivas e saberes infantis, como sujeitos-receptores-consumidores em suas apropriações desses dispositivos, na interface com as diversas mediações culturais e comunicacionais que participam na modulação do seu consumo alimentar no contexto familiar.

Para tanto, enquanto proposta de um estudo sobre a relação criança-marca-consumo alimentar no contexto familiar, procurou-se desenvolver a pesquisa com a participação das crianças em seus contextos familiares, nos cotidianos das suas práticas de consumo alimentar, demarcando, assim, no campo da comunicação, presença entre os estudos que contemplam as experiências, perspectivas e saberes das crianças na exploração das culturas infantis, e tomandoas como informantes e participantes no processo de investigação - apesar das incertezas e desafios que um processo partilhado de pesquisa pode representar nos trabalhos desenvolvidos com crianças em campo.

$\mathrm{O}$ interesse e persistência na proposta de se tomar as crianças como informantes e participantes no processo de investigação fundamentou-se a partir da visão que as compreende como sujeitos plenos, atores sociais e produtores de cultura, para além de objetos de pesquisa a serem cuidadosamente investigados. Perspectiva que busca transcender a estática dualidade 
estabelecida entre adultos e crianças nas esferas sociais, políticas e institucionais do mundo contemporâneo. E nesse sentido, entende-se aqui o processo de participação infantil no trabalho científico em uma dimensão mais ampla: desde uma instância primeira da participação das crianças na produção dos dados em campo, com atenção às expressividades e saberes infantis; até a instância mais refinada de um incentivo à participação das crianças nos processos de seleção, observação e coleta dos dados em campo, valorizando as suas percepções e dando ênfase às vozes infantis, bem como, de uma valorização da possível participação das crianças em eventuais reelaborações no recorte do objeto e nos procedimentos metodológicos da pesquisa, compartilhando com as crianças o olhar sobre o que é pesquisado e tornando possível a produção de um conhecimento partilhado, com especial inspiração nas reflexões propostas e trabalhos desenvolvidos por pesquisadores como: Corsaro $(2011 ; 2005$; 1992; 1990); Prout (2011; 2010a; 2010b); Christensen e Prout (2002); Sarmento (2011; 2008a; 2008b; 2007; 2005a; 2005b); Ferreira e Sarmento (2008); Soares e Sarmento (2005); Sirota (2001); Qvortrup (2010a; 2010b); Cohn (2005).

Nessa perspectiva, faz-se importante observar que se trata do desenvolvimento de uma investigação de inspiração etnográfica no campo da comunicação. E que, ao se lançar ao desenvolvimento do trabalho de campo com as crianças em seus contextos familiares, nos cotidianos da cultura de consumo alimentar, este estudo experimentou a possibilidade da construção de um saber teórico construído a partir do campo, em que os dados da observação, descrição e interpretação de um saber empírico encontraram a interpretação, análise e fundamentação de um saber teórico.

No entanto, faz-se igualmente importante observar, trata-se de um estudo que, conhecendo as suas características estruturais e as delimitações próprias do campo, não se pretendeu enquanto estudo etnográfico ou etnografia, mas sim, enquanto estudo de inspiração etnográfica desenvolvido com crianças no campo da comunicação. Pois que, em sua proposta de trabalho com as crianças em campo, e ainda que se lançando ao desenvolvimento do trabalho destas em seus contextos familiares, nos cotidianos da cultura de consumo alimentar, esta investigação não pode ser caracterizada como estudo etnográfico, uma vez que o trabalho de campo não apresenta as dimensões de abrangência e profundidade que caracterizariam em essência uma etnografia.

Enquanto investigação de inspiração etnográfica - na interface entre comunicação e antropologia - o estudo propôs desenvolver a pesquisa a partir do trabalho de campo com as crianças em seus contextos familiares, inspirado na dimensão primeira que a experiência em campo assume na caracterização dos estudos etnográficos, pois que as práticas culturais (a 
cultura de consumo alimentar das crianças) somente podem ser apreendidas no interior de seus contextos (os contextos familiares), a partir do olhar daqueles que vivenciam a cultura (as crianças), mais do que daqueles que observam, em uma contínua interação e negociação entre observadores e observados. (RIBERO, 2003:63,67)

E a partir daí, na forma de um estudo de inspiração etnográfica desenvolvido com crianças, compreendeu-se a necessidade de uma combinação especial de métodos e técnicas para possibilitar o incentivo às expressividades infantis, à expressão das experiências, perspectivas, saberes e afetos das crianças no contexto da sua cultura de consumo alimentar, possibilitando e incentivando a presença das vozes infantis, e a participação ativa das crianças no processo de investigação - crianças tomadas enquanto sujeitos plenos, atores sociais e produtores de cultura que são. (COHN, 2005:21,27-28,33-35,45-47)

Com base em um trabalho de campo dado a partir de constante observação, participação, interação, negociação, troca de experiências e partilha de conhecimentos entre pesquisador e sujeitos pesquisados (coparticipantes no processo de pesquisa), o estudo pretendeu-se, na sua dimensão de inspiração etnográfica, em uma perspectiva antropológica de abordagem exploratória, partindo do desenvolvimento progressivo do trabalho de campo (exploração da cultura alimentar infantil no contexto familiar) à gradativa construção teórica do conhecimento (saberes sobre a mediação comunicacional das marcas na cultura alimentar infantil). (RIBEIRO, 2003:125,145-146) Desde a materialidade primeira das observações e descrições em campo, passando pelas primeiras sínteses e interpretações, até as abstrações maiores de um saber teórico construído a partir das interpretações, análises e fundamentações. O objeto comunicacional tomado a partir de sua dimensão empírica à dimensão teórica, em perspectiva etnográfica, etnológica e antropológica. (RIBEIRO, 2003:227-229)

Entretanto, como o conceito de etnografia é amplo e abrangente, envolvendo práticas e reflexões que podem ir além do campo, constituindo também o produto escrito dado a partir das experiências, observações e descrições realizadas no trabalho empírico, este estudo pretendeu-se como inspiração etnográfica também no momento da construção de sua escrita, no sentido de um ensaio ou tentativa para a produção de uma escrita etnográfica, dada a partir do campo, a escrita do olhar, "escrita da cultura", como que pela transformação do olhar em linguagem, na tradução do que é visível ao que se torna dizível e legível. (LAPLANTINE apud RIBEIRO, 2003:230) Atividade que requer atenção, vigilância, criatividade e, sobretudo, reflexividade do pesquisador, desde as observações em campo até a produção escrita, interpretando o que vê, mas também refletindo sobre sua participação naquilo que vê, todo o contexto e a própria relação que estabelece com aqueles que observa. Produção escrita que 
contempla o percurso de um conhecimento construído, desde a descrição etnográfica em campo, e a interpretação etnológica, até o nível teórico de um saber antropológico (comunicacional), na transformação e organização textual da experiência visual, transformando o olhar em escrita. (RIBEIRO, 2003:226-233)

Partindo da configuração interdisciplinar e perspectiva etnográfica do estudo, e após as definições apresentadas sobre natureza, objeto e formato da pesquisa, pode-se dar início à descrição dos procedimentos metodológicos da pesquisa de campo, caracterizando-se as delimitações propostas para a investigação, as atividades desenvolvidas no processo de pesquisa, e os métodos e técnicas empregados para sua realização.

Tomando-se o objeto de estudo e sua perspectiva de recorte para a pesquisa - enquanto estudo de recepção infantil de marcas de alimentos no âmbito das práticas de consumo alimentar de crianças em contextos familiares - delineou-se, a partir daí, o seu corpus de investigação, tomando-se como locus para o desenvolvimento da pesquisa a cultura alimentar infantil em contextos e ambientes cotidianos de algumas famílias na cidade de São Paulo: famílias residentes na cidade de São Paulo - SP (três grupos familiares); pertencentes a diferentes classes socioeconômicas (classes A B e C); com uma ou mais crianças em sua composição familiar; crianças de ambos os sexos e diferentes idades (na faixa etária entre quatro e doze anos); para explorações sobre a mediação comunicacional das marcas na cultura alimentar infantil em contextos familiares; e considerando-se as práticas e rituais de consumo alimentar das crianças tanto em ambientes domésticos quanto em espaços públicos.

A opção por realizar a pesquisa com crianças em contextos familiares, compreendendo a família como mediação cultural de base, na interface com outras mediações culturais e comunicacionais presentes na modulação do consumo alimentar das crianças, deu-se pela concepção de que a família representa o primeiro e um dos principais espaços de socialização infantil, especialmente no contexto da cultura alimentar - e tomando-se a família como importante lugar de estudo e unidade de observação no âmbito das investigações sobre cultura alimentar, como tratado em Hernández (2005:179-180) e Trindade (2012:83-85).

A escolha da cidade de São Paulo - SP como delimitação geográfica para o desenvolvimento do estudo deu-se por tratar-se de uma das maiores regiões metropolitanas do país, e com relativa diversidade cultural, econômica e social da população. E ainda por tratarse da cidade sede da Universidade de São Paulo (instituição responsável pelo acompanhamento do estudo desenvolvido).

A definição do número de famílias pesquisadas (três grupos familiares) deu-se pelo fato de tratar-se de um estudo exploratório de natureza qualitativa, sem a pretensão de estabelecer 
relações quantitativas em perspectivas de generalizações no processo desta investigação, mas vislumbrando-se a possibilidade de estudos futuros de natureza quantitativa para contextualização e complementação do conhecimento produzido no estudo desenvolvido.

A diversidade de classes socioeconômicas para as composições familiares foi sugerida com o intuito de realizar-se uma investigação de modo abrangente, procurando contemplar parte da diversidade socioeconômica que caracteriza a sociedade brasileira, mas sem a pretensão de estabelecer comparativos específicos e detalhados de ordem social ou econômica para além da perspectiva sociocultural das mediações. Nesse sentido, a classificação da estratificação socioeconômica das famílias participantes da pesquisa (famílias das classes A1, B1 e C1) foi definida com base no Critério Brasil, com atenção especial à estimativa de renda média domiciliar (ABEP BRASIL, 2018; 2019), combinado às proposições de modelagem para estratificação socioeconômica da sociedade brasileira sugeridas em Mazzon e Kamakura. (KAMAKURA; MAZZON, 2013)

A sugestão do recorte da faixa etária das crianças pesquisadas (crianças entre quatro e doze anos) deu-se pela concepção de que nesta faixa etária as crianças já se mostram mais socializadas e comunicativas, demonstrando-se capazes de falar por si, com maior domínio da linguagem verbal, e expressando com mais espontaneidade suas perspectivas, interesses e preferências, seus afetos e desafetos - especialmente por conta do seu contínuo e dinâmico processo de desenvolvimento biológico, cognitivo, psicológico e de socialização, e das experiências vivenciadas por elas no contexto da família, da escola e outros grupos sociais, como destaca Montigneaux (2003: 32-54) em uma interessante e abrangente proposta de abordagem do desenvolvimento infantil com base nos estudos de Piaget, Freud, Winnicott, Leontiev e Vigotsky.

A intenção de explorar o contexto das práticas e rituais de consumo alimentar das crianças nos cotidianos familiares, considerando-se tanto os limites do âmbito doméstico quanto a presença familiar em espaços públicos, deu-se pela concepção de que o consumo alimentar infantil em contexto familiar acontece não somente no espaço privado dos ambientes domésticos, mas também no espaço público dos ambientes comerciais e de entretenimento.

O objetivo de observar e interagir também com os pais no desenvolvimento da pesquisa - ainda que tomando-se as crianças como principais informantes e participantes e os pais como informantes em complementação - colocou-se pela crença de que grande parte das vivências e experiências infantis, principalmente no âmbito do consumo alimentar, são mediadas pela família (especialmente pela presença dos pais), mas observando-se também a interface com 
outras mediações culturais e comunicacionais presentes na modulação do consumo alimentar infantil no contexto familiar.

E finalmente, a proposta de se desenvolver a pesquisa com a participação das crianças, a partir da expressão das experiências e perspectivas infantis, ouvindo o que as crianças têm a dizer, e dando voz as vozes infantis, por meio de observação, participação, interação, produção de vídeos e realização de jogos e brincadeiras, colocou-se com base na visão de que as crianças são sujeitos plenos, atores sociais e produtores de cultura, justificando-se, a partir daí, a necessidade da combinação e utilização de formas dinâmicas, lúdicas e diversas de interação com estes sujeitos na exploração e estudo das culturas infantis, estimulando e incentivando a participação ativa das crianças no processo de investigação. (COHN, 2005)

Assim, de modo amplo e abrangente, colocaram-se os critérios de inclusão/exclusão para a seleção das famílias participantes da pesquisa, procurando-se contemplar a diversidade e pluralidade que caracterizam os contextos das crianças e o conceito de infância, e atentar para a possibilidade de expressão e participação ativa das crianças neste processo de investigação.

Nesse sentido, vale observar que o processo de seleção e escolha das famílias pesquisadas deu-se a partir de indicações e contatos informais para identificação dos perfis familiares, respeitando-se os critérios estabelecidos na delineação do corpus de investigação.

Antes de dar início ao estudo proposto com as crianças em seus contextos familiares, no entanto, e com o objetivo de explorar o panorama contemporâneo dos principais formatos e expressões promocionais das marcas e produtos para crianças no mercado de alimentos, foi realizada pesquisa informal de observação em pontos de venda (supermercado e praça de alimentação) a fim de conhecer e explorar, ainda que de modo breve, restrito e superficial, o contexto promocional contemporâneo do consumo alimentar infantil na cidade de São Paulo. Pesquisa informal de observação realizada no Supermercado Carrefour e praça de alimentação do Shopping Eldorado (São Paulo - SP).

A partir daí, após a seleção das famílias participantes da pesquisa, foram iniciados os procedimentos da pesquisa de campo com as crianças em seus contextos familiares, para exploração dos cotidianos da cultura contemporânea de consumo alimentar infantil.

Inicialmente, foram realizados os primeiros contatos com cada uma das famílias participantes da pesquisa para o registro de alguns dados sobre os perfis familiares, apresentação do trabalho a ser desenvolvido no processo de investigação, leitura e assinatura do termo de consentimento livre e esclarecido (TCLE), e agendamento e programação dos encontros e atividades a serem realizadas. Em anexo encontra-se o modelo do termo de consentimento livre e esclarecido apresentado às famílias participantes do estudo para 
esclarecimentos sobre a pesquisa e autorização para participação das crianças nas atividades desenvolvidas durante o processo de investigação e para registros de imagens das crianças em fotografia e vídeo. (APÊNDICE A)

Na sequência, em momentos distintos dentro do processo de investigação, deu-se início ao desenvolvimento da pesquisa de campo com as crianças em seus contextos familiares, a partir da realização de encontros com cada uma das famílias participantes do estudo. Para o desenvolvimento do trabalho de campo, foram realizados o total de seis encontros com cada uma das famílias, para exploração das mediações culturais e comunicacionais presentes na modulação do consumo alimentar das crianças, atentando para os modos de presença e mediação comunicacional das marcas na cultura alimentar infantil, nos cotidianos dos contextos familiares pesquisados. Cada encontro foi formatado a partir de um objetivo ou motivação especial para sua orientação:

O primeiro encontro - no formato de visita à família - foi realizado para conhecer o ambiente doméstico e explorar o contexto, rotina e composição familiar em seu cotidiano, a fim de observar e investigar sobre a cultura alimentar infantil e as mediações culturais e comunicacionais presentes na modulação do consumo alimentar das crianças no contexto familiar.

O segundo encontro - igualmente no formato de visita à família - foi realizado com a finalidade de observar e participar de um ritual de alimentação da família, com a presença das crianças, no ambiente doméstico, atentando para a cultura alimentar infantil e as mediações culturais e comunicacionais presentes na modulação do consumo alimentar das crianças no contexto familiar; e para os modos de presença e mediação comunicacional das marcas na cultura alimentar infantil e as marcas e produtos alimentícios presentes no contexto familiar.

O terceiro encontro - no formato de visita / passeio com a família - foi realizado para observação e participação em um ritual alimentar da família, com a presença das crianças, em espaço público, ou lanche especial com as crianças em casa, atentando igualmente para a cultura alimentar infantil e as mediações culturais e comunicacionais presentes na modulação do consumo alimentar das crianças no contexto familiar; e para os modos de presença e mediação comunicacional das marcas na cultura alimentar infantil e as marcas e produtos alimentícios presentes no contexto familiar.

O quarto encontro - no formato de atividade lúdica com as crianças - foi realizado no ambiente doméstico, para desenvolver uma atividade lúdica com as crianças sobre marcas e produtos alimentícios e o consumo alimentar infantil, com o objetivo de conhecer as experiências, perspectivas, saberes e afetos infantis quanto ao consumo alimentar e quanto às 
marcas e produtos alimentícios e o contexto promocional das marcas e produtos no mercado de alimentos, buscando compreender os processos de recepção infantil de marcas de alimentos e os vínculos de sentidos entre marcas/produtos e crianças no contexto familiar.

O quinto encontro - igualmente no formato de atividade lúdica com as crianças - foi realizado na forma de visita ao supermercado para desenvolver uma atividade lúdica de simulação de compra e consumo de produtos alimentícios com as crianças, igualmente com o objetivo de conhecer as experiências, perspectivas, saberes e afetos infantis quanto ao consumo alimentar e quanto às marcas e produtos alimentícios e o contexto promocional das marcas e produtos no mercado de alimentos, buscando compreender os processos de recepção infantil de marcas de alimentos e os vínculos de sentidos entre marcas/produtos e crianças no contexto familiar.

E finalmente, o sexto encontro - no formato de atividades lúdicas / experimentação metodológica - realizado com as crianças no ambiente doméstico para uma experimentação metodológica da pesquisa com a participação das crianças na produção, organização, apresentação e registro dos dados e informações em campo. Novamente aqui, com o objetivo de conhecer as experiências, perspectivas, saberes e afetos infantis quanto ao consumo alimentar e quanto às marcas e produtos alimentícios e o contexto promocional das marcas e produtos no mercado de alimentos, buscando compreender os processos de recepção infantil de marcas de alimentos e os vínculos de sentidos entre marcas/produtos e crianças no contexto familiar. Mas, nesse momento, procurando tomar as crianças como informantes, participantes e copesquisadoras no processo de investigação. - Uma proposta de experimentação metodológica para além dos procedimentos metodológicos propostos para a investigação.

Para tanto, com base nas perspectivas e delimitações propostas a partir do objeto, pressupostos iniciais e objetivos do estudo, o trabalho de campo contou com a proposição de eixos específicos de abordagem teórica e empírica para orientação da investigação, como especificado inicialmente na apresentação das características e delimitações do estudo:

- A cultura alimentar infantil e as mediações culturais e comunicacionais na modulação do consumo alimentar das crianças no contexto familiar.

- A mediação comunicacional das marcas na cultura alimentar infantil e as marcas e produtos alimentícios no contexto familiar.

- A recepção infantil de marcas de alimentos e os vínculos de sentidos entre marcas/produtos e crianças no contexto familiar.

Eixos de abordagem teórica e empírica que caracterizaram as bases para o desenvolvimento do estudo em seu todo, especialmente quanto à orientação dos procedimentos 
metodológicos da investigação e formatação do protocolo de pesquisa, orientando os processos de observação, descrição, interpretação e análise, desde as investigações empíricas até os procedimentos de análise dos dados e avaliação dos resultados. Nesse intuito, em todo o processo de desenvolvimento da pesquisa - desde os encontros realizados nos ambientes familiares; as observações e participações no âmbito das práticas e rituais de consumo alimentar das crianças; as interações e participações experimentadas com as crianças e os pais; as conversações e entrevistas realizadas com as crianças e os pais; as atividades lúdicas, brincadeiras e jogos propostos às crianças; as fotografias e vídeos coproduzidos pelas crianças; as imagens registradas em fotografia e vídeo; até as anotações e registros dados em diários de campo - procurou-se contemplar, nos processos de observação, descrição, interpretação e análise, cada um dos eixos de abordagem teórica e empírica propostos para orientação do estudo e formatação do protocolo de pesquisa.

A formatação do protocolo de pesquisa teve como base os aspectos sugeridos para orientação das observações, descrições, interpretações e análises dadas no processo de investigação com as crianças em campo, nos contextos familiares pesquisados, e fundamentouse a partir dos eixos de abordagem teórica e empírica propostos para o estudo. No entanto, ainda que tais elementos estivessem na base para formatação do protocolo e orientação da investigação, procurou-se tomar o trabalho em uma linha abrangente e flexível de abordagem, considerando-se também outros aspectos, informações ou eventos dados em campo que pudessem enriquecer a experiência da pesquisa em seu todo. O protocolo de pesquisa elaborado para orientação da investigação com as crianças em campo apresenta-se detalhadamente na sequência: (QUADRO 1) 
Quadro 1 - Protocolo de Pesquisa

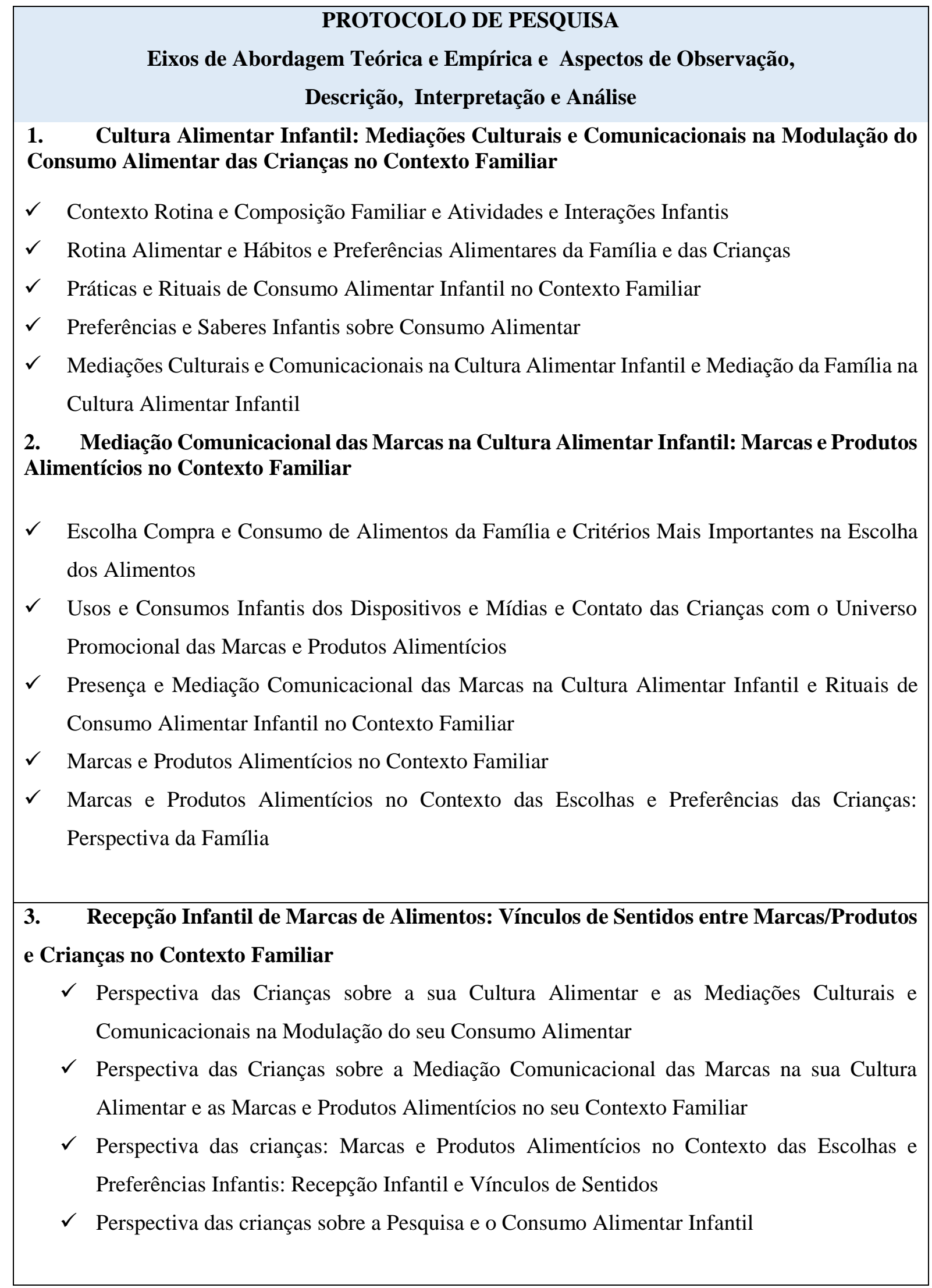

Fonte: Elaborado pela autora. 
Nesse sentido, partindo do que se apresenta nos eixos de abordagem teórica e empírica e aspectos de observação, descrição, interpretação e análise, tomados como base para orientação e formatação do protocolo de pesquisa, foram desenvolvidas as atividades propostas para a investigação com as crianças em campo, nos cotidianos dos contextos familiares pesquisados, por meio de observação, participação e interação com as crianças e com os pais, na combinação e utilização de métodos e técnicas inspirados no que caracteriza os investimentos metodológicos dos estudos etnográficos:

- Observação (inspirada na observação implicada e observação participante).

- Interação / Participação (inspiradas na interação e participação dadas a partir da observação participante).

- Entrevista Individual / Entrevista de Grupo (inspiradas na entrevista semiestruturada que caracteriza uma das formas da entrevista etnográfica).

- Atividades Lúdicas (inspiradas nas atividades lúdicas desenvolvidas com crianças nos estudos etnográficos da antropologia da criança: como brincadeiras, jogos, desenhos, representações de imagens e dramatizações).

- Produção e coprodução de Fotografias / Vídeos (inspiradas na perspectiva de participação e coparticipação das crianças no processo de investigação).

- Registros em Fotografia e Vídeo (inspirados no que caracteriza os registros de imagem efetuados em campo nos estudos etnográficos).

- Notas de Campo / Relatos de Campo (inspirados no que caracteriza os registros de dados e informações efetuados em campo nos estudos etnográficos).

Métodos e técnicas identificados e selecionados para a pesquisa de campo com base nas especificações e sugestões dadas em Ribeiro (2003) e Cohn (2005), que se apresentam detalhadamente a seguir: 


\section{Observação:}

A utilização da técnica da observação na pesquisa de campo foi inspirada a partir do que caracteriza a observação implicada e observação participante no contexto dos estudos etnográficos. Especialmente no que se coloca na dimensão da importância do olhar na etnografia: um olhar atento, preparado, inquieto e interrogador, que sabe ir em busca das significações, variações e inconstâncias do que vê. Nessa direção, o objeto de observação se constitui a partir da relação observador-observado e de todo contexto implicado nessa relação, as percepções, interações e interpretações que caracterizam e se inscrevem nesse encontro. Observação em campo que se constitui tanto na forma primeira do contato, da troca, da experiência, quanto na forma aprofundada do acesso às dimensões interiores dos processos socioculturais. E partindo da ideia de que o mais importante em um processo de pesquisa é a natureza, as circunstâncias e a qualidade da observação, vale destacar a importância de uma observação reflexiva, sensível ao todo que se observa, mas também sensível à própria natureza da observação e participação do pesquisador em campo. (RIBEIRO, 2003:198-199, 212, 219)

\section{Interação / Participação:}

A interação e participação, inspiradas na interação e participação dadas a partir da observação participante no contexto dos estudos etnográficos, foi utilizada na pesquisa enquanto técnica que torna possível ao pesquisador em campo participar do que é observado, tomando parte no próprio objeto de investigação. Participação que torna a observação exterior em implicada e participante, permitindo a observação e exploração de informações, comportamentos e acontecimentos dados em campo de forma mais aberta, aprofundada e significativa. E assim transforma-se a relação entre observador e observado, em continua interação, dialética, onde a participação transforma a observação e a observação transforma a participação. (RIBEIRO, 2003:217,219)

\section{Entrevista Individual / Entrevista de Grupo:}

A técnica da entrevista (individual e de grupo), inspirada na entrevista semiestruturada que caracteriza uma das formas de entrevista realizadas no contexto dos estudos etnográficos, foi empregada na pesquisa enquanto possibilidade de familiarização com as práticas socioculturais dos atores e apreensão dos sentidos atribuídos por eles às suas práticas, permitindo o aprofundamento das observações, descrições e interpretações das dimensões em análise na pesquisa. Uma forma qualitativa de entrevista que tornou possível, ao mesmo tempo, elaborar uma preparação previa da temática e semiestruturação das questões, e manter a 
liberdade de estilo, expressão e construção do discurso dos entrevistados. (RIBEIRO, 2003:261-263)

\section{Atividades Lúdicas:}

As atividades lúdicas desenvolvidas com as crianças durante a pesquisa em campo inspiradas desenvolvidas com crianças nos estudos etnográficos da antropologia da criança, como: brincadeiras, jogos, desenhos, representações de imagens e dramatizações - foram combinadas e utilizadas neste processo de investigação enquanto técnicas que possibilitam a expressividade das experiências, perspectivas, saberes e afetos infantis no contexto da cultura em estudo (a cultura alimentar infantil) permitindo que as crianças falem por si, sobre si, e sobre o mundo em que vivem, tomando as crianças enquanto sujeitos plenos, atores sociais e produtores de cultura. (COHN, 2005:21,27-28,33-35,45-47) Diferentemente da possibilidade de utilização de tais técnicas pelos estudos realizados com crianças no campo da educação ou da psicologia, em que, para além de atividades lúdicas dadas para possibilitar e incentivar a expressividade e participação infantil nos processos de investigação, tais atividades seriam também utilizadas como formas de projeção, o que não se aplica no caso dos objetivos propostos para este estudo.

\section{Produção e coprodução de Fotografias e Vídeos:}

A produção e coprodução de fotografias e vídeos - enquanto técnica inspirada na perspectiva de participação e coparticipação das crianças no processo de investigação - foi empregada na pesquisa de campo, em combinação com outras técnicas, como forma lúdica de incentivar a expressão e participação das crianças em determinadas atividades no processo de investigação, incentivando sua espontaneidade e facilitando sua expressividade em momentos específicos de produção, organização, apresentação e registro de dados, informações e eventos, uma vez que as crianças costumam ser ativas e participativas por natureza, e muitas vezes se mostram familiarizadas com a proposta e linguagem das tecnologias e mídias digitais nos cotidianos dos seus usos e consumos midiáticos. As crianças tomadas como sujeitos plenos, atores sociais e produtores de cultura que são no processo de investigação. (COHN, 2005)

\section{Registros em Fotografia e Vídeo / Notas de Campo / Relatos de Campo:}

E finalmente, as técnicas de registros em fotografia e vídeo, notas de campo e relatos de campo - inspiradas no que caracteriza os registros efetuados em campo no contexto dos estudos etnográficos - foram empregadas na pesquisa como forma de tentar ao máximo captar e registrar 
a riqueza das experiências vivenciadas, ações desenvolvidas, observações realizadas, impressões obtidas e informações coletadas em campo, contribuindo para melhor apreensão, descrição e interpretação do contexto e da cultura em estudo. Técnicas essas selecionadas a partir de especificações e sugestões apreendidas em Ribeiro (2003).

Quanto às atividades desenvolvidas na investigação com as crianças em campo, nos cotidianos dos contextos familiares pesquisados, colocam-se na sequência a apresentação e descrição das especificações, formato e dinâmica dos encontros propostos para a pesquisa de campo e das atividades desenvolvidas com as crianças e com os pais em cada um dos encontros realizados com as famílias no processo de investigação.

\section{Encontros com as Famílias:}

Como especificado, para o desenvolvimento do trabalho de campo foram realizados o total de seis encontros com cada uma das famílias participantes da pesquisa, para exploração das mediações culturais e comunicacionais presentes na modulação do consumo alimentar das crianças, atentando para os modos de presença e mediação comunicacional das marcas na cultura alimentar infantil, nos cotidianos dos contextos familiares pesquisados. Na sequência, apresenta-se a descrição detalhada do formato, objetivo, dinâmica, atividades desenvolvidas, e procedimentos metodológicos e técnicas empregados para a realização de cada um dos encontros e atividades propostos no processo de investigação com as crianças em seus contextos familiares: (QUADRO 2) 
Quadro 2 - Encontros com as Famílias: Atividades da Pesquisa

\begin{tabular}{|c|c|c|c|c|c|c|}
\hline \multicolumn{7}{|c|}{ PRIMEIRO ENCONTRO } \\
\hline FORMATO & LOCAL & OBJETIVO & DINÂMICA & $\begin{array}{l}\text { ATIVIDADES DESENVOLVIDAS } \\
\text { EM CAMPO }\end{array}$ & $\begin{array}{l}\text { PROCEDIMENTOS } \\
\text { METODOLÓGICOS/TÉCNICAS }\end{array}$ & $\begin{array}{l}\text { ASPECTOS DE OBSERVAÇ̃̃O / DESCRIÇÃO / } \\
\text { INTERPRETAÇÃO / ANÁLISE: }\end{array}$ \\
\hline Visita à família & Ambiente doméstico & $\begin{array}{l}\text { Conhecer o ambiente doméstico } \\
\text { e explorar o contexto, rotina e } \\
\text { composição familiar em seu } \\
\text { cotidiano, a fim de observar e } \\
\text { investigar sobre a cultura } \\
\text { alimentar infantil e as mediações } \\
\text { culturais e comunicacionais } \\
\text { presentes na modulação do } \\
\text { consumo alimentar das crianças } \\
\text { no contexto familiar. }\end{array}$ & $\begin{array}{l}\text { Visita à família e } \\
\text { conversação com os } \\
\text { pais e com as } \\
\text { crianças. }\end{array}$ & $\begin{array}{l}\text { Entrevista em grupo com a família na } \\
\text { forma de conversação com os pais e } \\
\text { com as crianças. / Produção de } \\
\text { fotografias e vídeos para registro da } \\
\text { entrevista em grupo realizada com a } \\
\text { família. }\end{array}$ & $\begin{array}{l}\text { Observação (implicada / participante) / } \\
\text { Interação e participação (observação } \\
\text { participante) / Entrevista de grapo } \\
\text { (semiestruturada) / Produção e coprodução de } \\
\text { fotografias e vídeos / Registros em fotografia } \\
\text { e vídeo / Notas de campo / Relatos de campo. }\end{array}$ & $\begin{array}{l}\text { Foram realizadas observações, descrições e interpretações } \\
\text { em campo, atentando para os seguintes aspectos: A cultura } \\
\text { alimentar infantil e as mediações culturais e } \\
\text { comunicacionais na modulação do consumo alimentar das } \\
\text { crianças no contexto familiar: contexto rotina e composição } \\
\text { familiar e atividades e interações infantis; rotina alimentar e } \\
\text { hábitos e preferências alimentares da família e das crianças; } \\
\text { práticas e rituais de consumo alimentar infantil no contexto } \\
\text { familiar (cultura alimentar); mediações culturais e } \\
\text { comunicacionais na cultura alimentar infantil; mediação da } \\
\text { família na cultura alimentar infantil. }\end{array}$ \\
\hline
\end{tabular}

\section{DESCRIÇÃO DAS PRINCIPAIS ATIVIDADES DESENVOLVIDAS}

\section{Entrevista em grupo com a família:}

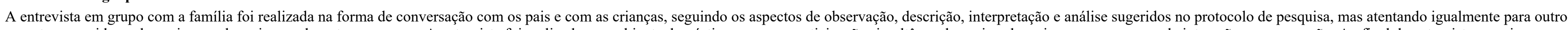

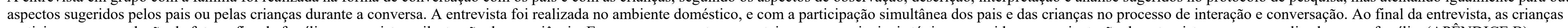

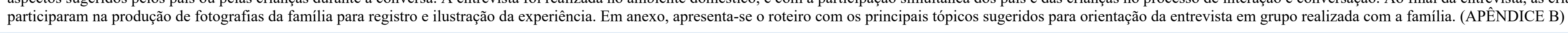

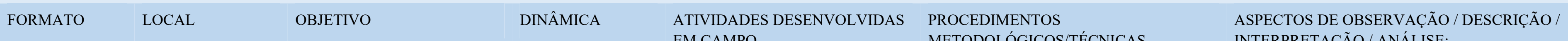

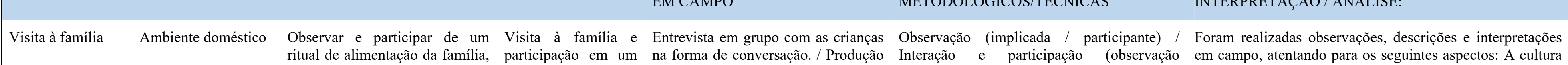
com a presença das crianças, no ritual de alimentação de fotografias e vídeos para registro participante) / Entrevista individual alimentar infantil e as mediações culturais e ambiente doméstico, atentando da família, com a da entrevista em grupo realizada com (semiestruturada) / Entrevista de grupo comunicacionais na modulação do consumo alimentar das para a cultura alimentar infantil e presença das as crianças. / Conversa informal com (semiestruturada) / Produção e coprodução de crianças no contexto familiar: contexto rotina e composição as mediações culturais e crianças, no ambiente os pais sobre marcas e produtos fotografias e vídeos / Registros em fotografia familiar e atividades e interações infantis; rotina alimentar e comunicacionais presentes na doméstico. alimentícios no contexto das escolhas e vídeo / Notas de campo / Relatos de campo. hábitos e preferências alimentares da família e das crianças; modulação do consumo $\quad$ e preferências da família e das $\begin{array}{ll}\text { modulação do consumo } & \text { e preferências da familia e das } \\ \text { alimentar das crianças no } & \text { crianças. / Registros em fotografias }\end{array}$ contexto familiar; e para os $\quad$ crianças. / marcas e produtos alimentícios modos de presença e mediação presentes no ambiente doméstico. 1 comunicacional das marcas na $\quad$ Observação e participação em um cultura alimentar infantil e as ritual de alimentação da familia, com a presença das crianças, no ambiente presentes no contexto familiar. doméstico. / Registros em fotografias e vídeos sobre o ritual de alimentação da família e das crianças. / Registros em fotografias das marcas e produtos alimentícios presentes na composição da refeição. / Entrevista individual com a mãe na forma de conversação. / Registros em fotografias e vídeos sobre a entrevista realizada com a mãe. práticas e rituais de consumo alimentar infantil no contexto comur (cultura alinena); mediações culturais e cóliaciação da camilia comunicaciontar infantil e as marcas e produtos alinenticios nóticas (maras e ramiliar (marcas e produtos allim de alimentos da familia e criterios mais importantes na escolha dos alimentos; preferencias e saberes infantis sobre consumo alimentar; usos e consumos infantis das tecnologias e mídias e contato das crianças com o universo promocional das marcas e produtos alimentícios; presença e mediação comunicacional das marcas na cultura alimentar infantil; marcas e produtos alimentícios no contexto familiar; marcas e produtos alimentícios no contexto das escolhas e preferências das crianças (perspectiva da família). 


\section{Entrevista em grupo com as crianças:}

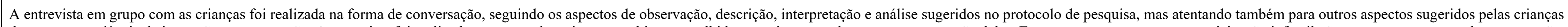

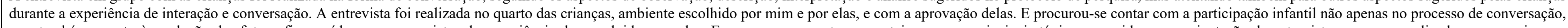

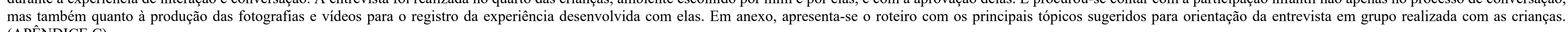
(APÊNDICE C)

\section{Registros em fotografias: marcas e produtos alimentícios no ambiente doméstico:}

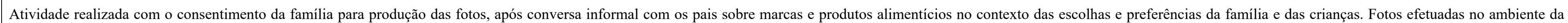
cozinha da residência da família (bancadas / armários / geladeira) para o registro das marcas e produtos alimentícios presentes no ambiente doméstico.

\section{Observação e participação: ritual de alimentação da família no ambiente doméstico:}

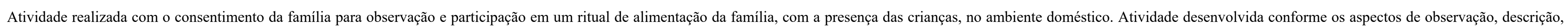

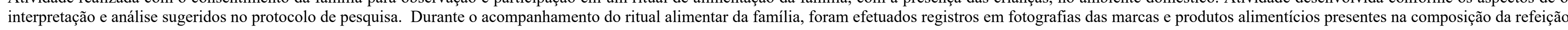

\section{Entrevista individual com a mãe:}

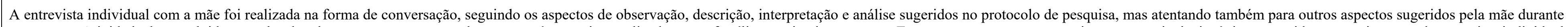

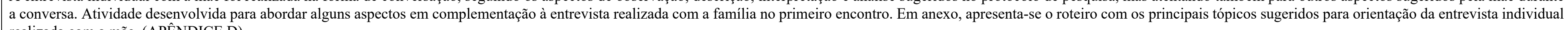
realizada com a mãe. (APÊNDICE D)

\begin{tabular}{|c|c|c|c|c|}
\hline FORMATO & LOCAL & OBJETIVO & DINÂMICA & $\begin{array}{l}\text { ATIVIDADES DESENVOLVIDAS } \\
\text { EM CAMPO }\end{array}$ \\
\hline $\begin{array}{l}\text { Visita / Passeio } \\
\text { com a família. }\end{array}$ & $\begin{array}{l}\text { Ambiente doméstico } \\
\text { / Espaço público. }\end{array}$ & $\begin{array}{l}\text { Observação e participação em } \\
\text { um ritual alimentar da família, } \\
\text { com a presença das crianças, em } \\
\text { espaço público, ou lanche } \\
\text { especial com as crianças em casa, } \\
\text { atentando igualmente para a } \\
\text { cultura alimentar infantil e as } \\
\text { mediações culturais e } \\
\text { comunicacionais presentes na } \\
\text { modulação do consumo } \\
\text { alimentar das crianças no } \\
\text { contexto familiar; e para os } \\
\text { modos de presença e mediação } \\
\text { comunicacional das marcas na } \\
\text { cultura alimentar infantil e as } \\
\text { marcas e produtos alimentícios }\end{array}$ & $\begin{array}{l}\text { Visita à família e } \\
\text { participação em um } \\
\text { ritual alimentar da } \\
\text { família, com a } \\
\text { presença } \\
\text { crianças, em espaço } \\
\text { público, ou lanche } \\
\text { especial com as } \\
\text { crianças em casa. }\end{array}$ & $\begin{array}{l}\text { Registros em fotografias das marcas e } \\
\text { produtos alimentícios presentes no } \\
\text { ambiente doméstico. / Observação e } \\
\text { participação em um ritual alimentar } \\
\text { da família, com a presença das } \\
\text { crianças, em espaço público, ou } \\
\text { lanche especial com as crianças em } \\
\text { cassa. / Registros em fotografias e } \\
\text { vídeos sobre o ritual alimentar da } \\
\text { família e das crianças. / Registros em } \\
\text { fotografias das marcas e produtos } \\
\text { alimentícios presentes na composição } \\
\text { da refeição. / Entrevista individual } \\
\text { com o pai na forma de conversação. / } \\
\text { Registros em fotografias e vídeos } \\
\text { sobre a entrevista realizada com o pai. }\end{array}$ \\
\hline
\end{tabular}

$\begin{array}{ll}\text { PROCEDIMENTOS } & \text { ASPECTOS DE OBSERVAÇÃO / DESCRIÇÃO / } \\ \text { METODOLÓGICOS/TÉCNICAS } & \text { INTERPRETAÇÃO / ANÁLISE: }\end{array}$

Observação (implicada / participante) / Foram realizadas observações, descrições e interpretações Interação e participação (observação em campo, atentando para os seguintes aspectos: A cultura participante) Entrevista individual alimentar infantil e as mediações culturais e (sén crianças no contexto famillar. contexto rotina e composição familiar e atividades e interações infantis; rotina alimentar e hábitos e preferências alimentares da família e das crianças; práticas e rituais de consumo alimentar infantil no contexto familiar (cultura alimentar); mediações culturais e comunicacionais na cultura alimentar infantil; mediação da família na cultura alimentar infantil. E a mediação comunicacional das marcas na cultura alimentar infantil e as marcas e produtos alimentícios no contexto familiar: práticas e rituais de consumo alimentar infantil no contexto familiar (marcas e produtos alimentícios); escolha compra e consumo de alimentos da família e critérios mais importantes na escolha dos alimentos; preferências e saberes infantis sobre consumo alimentar; usos e consumos infantis das tecnologias e mídias e contato das crianças com o universo promocional das marcas e produtos alimentícios; presença e mediação comunicacional das marcas na cultura alimentar infantil; marcas e produtos alimentícios no contexto familiar: marcas e produtos alimentícios no contexto das familis, mas 
Registros em fotografias: marcas e produtos alimentícios no ambiente doméstico:

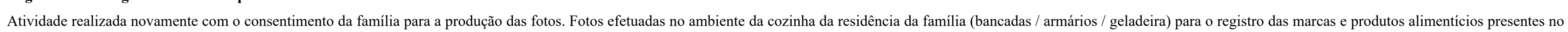
ambiente doméstico. Atividade desenvolvida em complementação à mesma atividade realizada no encontro anterior, na ocasião da primeira produção de fotos.

\section{Observação e participação: ritual de alimentação da família em espaço público:}

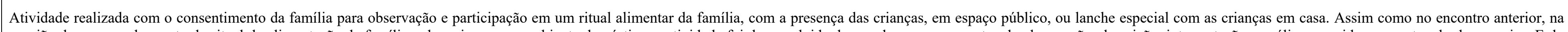

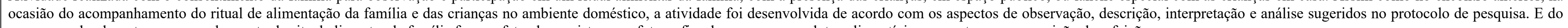
mesmo modo, durante o acompanhamento do ritual alimentar da família foram efetuados registros em fotografias das marcas e produtos alimentícios presentes na composição da refeição.

\section{Entrevista individual com o pai}

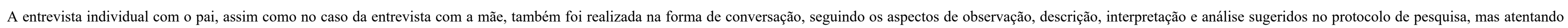

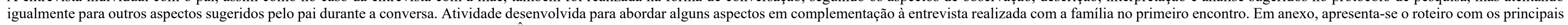
tópicos sugeridos para orientação da entrevista individual realizada com o pai. (APÊNDICE E)

QUARTO ENCONTRO

\begin{tabular}{l|ll} 
FORMATO LOCAL OBJETIVO & DINÂMICA & ATIVIDADES DESENVOLVIDAS
\end{tabular}
$\begin{array}{lll}\begin{array}{l}\text { Atividade lúdica } \\ \text { com as crianças. }\end{array} & \text { Ambiente doméstico. } & \begin{array}{l}\text { Desenvolver uma atividade } \\ \text { lúdica com as crianças na forma as crianças na forma com }\end{array} \\ \text { a }\end{array}$

$\begin{array}{ll}\text { Desenvolver uma atividade } & \text { Atividade lúdica com } \\ \text { lúdica com as crianças na forma } & \text { as criança na forma } \\ \text { de jogo e desenho - atividade } & \text { de jogo e desenho }\end{array}$

de jogo e desenho - atividade

lúdica sobre marcas e produtos

alimentícios e o consumo

objetivo de conhecer as

objetivo de conhecer as

experiências, perspectivas,

saberes e afetos infantis quant

ao consumo alimentar e quanto

às marcas e produto

alimentícios $\mathrm{e} \quad \mathrm{o}$ contexto

promocional das marcas e

produtos no mercado de

alimentos, buscando

compreender os processos de

recepção infantil de marcas de

alimentos e os vínculos de

sentidos entre marcas/produtos ATIVIDADES DESENVOLVIDAS
EM CAMPO

\section{PROCEDIMENTOS}

METODOLÓGICOS/TÉCNICAS

ASPECTOS DE OBSERVAÇÃO / DESCRIÇÃO /

INTERPRETAÇÃO / ANÁLISE:

\section{Atividade lúdica com as crianças na Observação (implicada / participante) /}

forma de jogo e desenho. / Registros Interação e participação (observação em fotografias e vídeos sobre a participante) / Entrevista individual

Foram realizadas observações, descrições e interpretações atividade lúdica desenvolvida com as (semiestruturada) / Entrevista de grupo entre marcas/produtos e crianças no contexto familiar: crianças. / Entrevista individual com (semiestruturada) / Atividades lúdicas (jogos cultura alimentar infantil e mediações culturais e as crianças na forma de conversação. e desenhos) / Produção e coprodução de comunicacionais na modulação do consumo alimentar das para registro da entrevista individual e vídeo / Notas de campo / Relatos de campo. comunicacional das marcas na cultura alimentar infantil e com as crianças. / Entrevista em grupo - comunicacional das marcas nácultura alimentar infantil e com as criançs nata forma com as crianças na forma de conversação. / Produção de fotografus e vídeos para registro marcas e produtos alimenticios no contexto familiar (peripectiva dín chlanças), reçęão infantil de marcas de alines (perpectiva das criancas); marcas e produtos crianças (pectivas alimenticios no con consumo alimentar infantil (perspectiva das crianças).
conchas (perspectiva as riancas); sobre a pesquisa e

\section{DESCRIÇÃO DAS PRINCIPAIS ATIVIDADES DESENVOLVIDAS}

\section{Atividade lúdica: jogo e desenho: Brincadeira de Comer:}

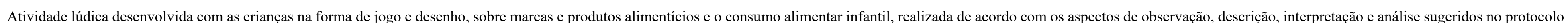

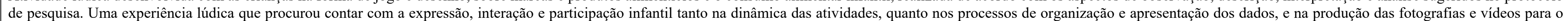
registro das atividades realizadas. Na sequência, apresenta-se a descrição da dinâmica da atividade lúdica desenvolvida com as crianças: Brincadeira de Comer. 
PRIMEIRA PARTE: Jogo de Cards

\section{Sobre consumo alimentar:}

Jogo de cards apresentado às crianças com imagens de alimentos / produtos alimentícios diversos (alimentos / bebidas guloseimas / produtos industrializados / alimentos in natura).

Cada criança recebeu um baralho completo com os cards.

O jogo teve início quando as crianças foram solicitadas a organizar os cards sobre a mesa, livremente, de acordo com suas perspectivas e critérios de organização.

Em seguida, após a organização dos cards, as crianças foram solicitadas a compor algumas combinações de alimentos produtos alimentícios para simulação de consumo alimentar. De acordo com suas perspectivas, experiências, saberes, preferências e afetos. Independentemente das suas escolhas serem ou não representativas do seu consumo alimentar no cotidiano. Foram solicitadas às crianças combinações alimentares para composição do café da manhã / almoço / jantar / lanch da escola / lanche com amigos.

Após cada composição de produtos alimentícios para simulação de consumo alimentar, as crianças foram convidadas a falar sobre suas composições, destacando os alimentos ou produtos alimentícios escolhidos. Explicando o porquê de cada escolha, falando sobre as marcas e produtos alimentícios da sua preferência, e expressando as preferências e saberes infantis sobre o consumo alimentar.

Durante o jogo, cada solicitação feita às crianças era denominada como desafio.

O jogo foi finalizado quando as crianças concluíram todas as composições alimentares solicitadas na forma de desafios.

\section{SEGUNDA PARTE: Desenhos}

\section{Sobre consumo alimentar:}

Desenhos elaborados pelas crianças sobre seus gostos e preferências no consumo alimentar (o que gostam e o que não gostam de comer).

Cada criança recebeu uma folha de papel em branco. E na folha, as crianças foram solicitadas a fazer uma dobradura para dividir o papel em quatro partes iguais, numerando cada uma das partes em sequência (1-2-3-4).

Em seguida, as crianças foram solicitadas a fazer os desenhos, em cada uma das partes do papel, seguindo a ordem indicada, de acordo com a sequência das solicitações para os desenhos:

1 - Que mais gosta de comer.

2 - Que não gosta de comer.

3- Que gosta de comer e é saudável.

4 - Que gosta de comer e não é saudável.

Ao final, após a conclusão dos desenhos, as crianças foram convidadas a falar sobre o que desenharam, destacando os alimentos / produtos alimentícios que gostam de comer, que não gostam de comer, que são saudáveis, e que não são saudáveis. Explicando o porquê de cada escolha, falando sobre os alimentos / produtos alimentícios, e expressando as preferências e saberes infantis sobre o consumo alimentar.

Durante a atividade, cada solicitação feita às crianças era denominada como desafio

A atividade foi finalizada quando as crianças concluíram todos os desenhos solicitados na forma de desafios.

\section{Sobre marcas de produtos alimentícios:}

Jogo de cards apresentado às crianças com imagens de marcas de produtos alimentícios diversos, incluindo imagens de marcas representadas por personagens e mascotes.

Cada criança recebeu um baralho completo com os cards.

O jogo teve início quando as crianças foram solicitadas a organizar os cards sobre a mesa, livremente, de acordo com suas perspectivas e critérios de organização.

Em seguida, após a organização dos cards, as crianças foram solicitadas a escolher algumas marcas de produtos alimentícios de que gostam, ou que gostam mais, e algumas marcas de produtos alimentícios de que não gostam, ou que gostam menos (marcas de produtos alimentícios ou earcas represt marcas para cada grupo de marcas escolhidas. De acordo com suas perspectivas, experiências, saberes, preferências e afetos. Após as suas composições, dentre as diversas marcas de produtos alimentícios e personagens e mascotes, as crianças foram convidadas a falar sobre suas escolhas, destacando as marcas de produtos alimentícios escolhidas. Explicando o porquê de cada escolha, falando sobre as marcas ou personagens e mascotes de que gostam e de que não gostam, e expressando os saberes e afetos infantis no contexto promocional das marcas e produtos alimentícios.

Durante o jogo, cada solicitação feita às crianças era denominada como desafio.

O jogo foi finalizado quando as crianças concluíram as escolhas e composições de marcas solicitadas na forma de desafios.

Em anexo, encontra-se a apresentação do roteiro e dinâmica do jogo, e das imagens sobre consumo alimentar (alimentos / produtos alimentícios) e sobre marcas (marcas de produtos alimentícios / marcas representadas por personagens e mascotes), propostos para composição e formatação da atividade lúdica desenvolvida com as crianças na forma de jogo. (APÊNDICE F)

\section{Sobre marcas de produtos alimentícios:}

Desenhos elaborados pelas crianças sobre marcas de produtos alimentícios e marcas representadas por personagens e mascotes (marcas e personagens que as crianças conhecem / que as crianças gostam).

Cada criança recebeu uma folha de papel em branco. E na folha, as crianças foram solicitadas a fazer uma dobradura para dividir o papel em duas partes iguais, numerando cada uma das partes em sequência (1-2).

Em seguida, as crianças foram solicitadas a fazer os desenhos, em cada uma das partes do papel, seguindo a ordem indicada, de acordo com a sequência das solicitações para os desenhos:

1 - Marca de produto alimentício que conhece / que gosta.

2 - Personagem ou mascote que conhece / que gosta.

Ao final, após a conclusão dos desenhos, as crianças foram convidadas a falar sobre o que desenharam, destacando as marcas de produtos alimentícios que conhecem / que gostam e os personagens e mascotes que conhecem / que gostam. Explicando o porque de cada escolha, falando sobre as marcas e personagens, e expressando os saberes e afetos infantis no contexto promocional das marcas e produtos alimentícios.

Durante a atividade, cada solicitação feita às crianças era denominada como desafio.

A atividade foi finalizada quando as crianças concluíram todos os desenhos solicitados na forma de desafios.

Em anexo, encontra-se a apresentação do roteiro e dinâmica propostos para composição e formatação da atividade lúdica desenvolvida com as crianças na forma de desenho. (APÊNDICE F)

\section{Entrevista individual / Entrevista em grupo com as crianças:}

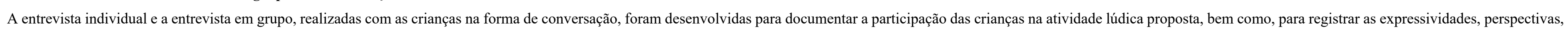

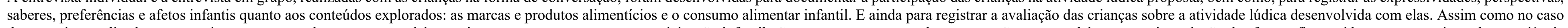

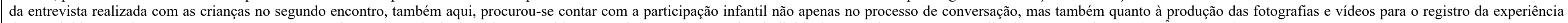
desenvolvida com elas. Em anexo, apresenta-se o roteiro com os principais tópicos sugeridos para orientação da entrevista individual e entrevista em grupo, realizadas com as crianças. (APÊNDICE G) 


\begin{tabular}{|c|c|c|c|c|c|c|}
\hline FORMATO & LOCAL & OBJETIVO & DINÂMICA & $\begin{array}{l}\text { ATIVIDADES DESENVOLVIDAS } \\
\text { EM CAMPO }\end{array}$ & $\begin{array}{l}\text { PROCEDIMENTOS } \\
\text { METODOLÓGICOS/TÉCNICAS }\end{array}$ & $\begin{array}{l}\text { ASPECTOS DE OBSERVAÇÃO / DESCRIÇÃO / } \\
\text { INTERPRETAÇÃO / ANÁLISE: }\end{array}$ \\
\hline $\begin{array}{l}\text { Atividade lúdica com } \\
\text { as crianças. }\end{array}$ & $\begin{array}{l}\text { Espaço público } \\
\text { (supermercado). }\end{array}$ & $\begin{array}{l}\text { Desenvolver uma atividade } \\
\text { lúdica com as crianças na forma } \\
\text { de jogo e dramatização - } \\
\text { atividade lúdica de simulação de } \\
\text { compra e consumo de produtos } \\
\text { alimentícios com as crianças no } \\
\text { supermercado - igualmente com } \\
\text { o objetivo de conhecer as } \\
\text { experiências, perspectivas, } \\
\text { saberes e afetos infantis quanto } \\
\text { ao consumo alimentar e quanto } \\
\text { às marcas e produtos } \\
\text { alimentícios e o contexto } \\
\text { promocional das marcas e } \\
\text { produtos no mercado de } \\
\text { alimentos, } \\
\text { compreender os processos de } \\
\text { recepção infantil de marcas de } \\
\text { alimentos e os vínculos de } \\
\text { sentidos entre marcas/produtos e } \\
\text { crianças no contexto familiar. }\end{array}$ & $\begin{array}{l}\text { Atividade lúdica com } \\
\text { as crianças na forma } \\
\text { de jogo e e } \\
\text { dramatização. }\end{array}$ & $\begin{array}{l}\text { Atividade lúdica com as crianças na } \\
\text { forma de jogo e dramatização / } \\
\text { Produção de fotografias para registro } \\
\text { da atividade lúdica desenvolvida com } \\
\text { as crianças. / Entrevista individual } \\
\text { com as crianças na forma de } \\
\text { conversação. / Notas de campo para } \\
\text { registro da entrevista individual com } \\
\text { as crianças. }\end{array}$ & $\begin{array}{l}\text { Observação (implicada / participante) / } \\
\text { Interação e participação (observação } \\
\text { participante) / Entrevista individual (semi- } \\
\text { estruturada) / Atividades lúdicas (jogos e } \\
\text { dramatizações) / Produção e coprodução de } \\
\text { fotografias / Registros em fotografia / Notas } \\
\text { de campo / Relatos de campo. }\end{array}$ & $\begin{array}{l}\text { Foram realizadas observações, descrições e } \\
\text { interpretações em campo, atentando para os seguintes } \\
\text { aspectos: A recepção infantil de marcas de alimentos e os } \\
\text { vínculos de sentidos entre marcas/produtos e crianças no } \\
\text { contexto familiar: cultura alimentar infantil e mediações } \\
\text { culturais e comunicacionais na modulação do consumo } \\
\text { alimentar das crianças (perspectiva das crianças); } \\
\text { mediação comunicacional das marcas na cultura } \\
\text { alimentar infantil e marcas e produtos alimentícios no } \\
\text { contexto familiar (perspectiva das crianças); recepção } \\
\text { infantil de marcas de alimentos e vínculos de sentidos } \\
\text { entre marcas/produtos e crianças (perspectiva das } \\
\text { crianças); marcas e produtos alimentícios no contexto das } \\
\text { escolhas e preferências das crianças (perspectiva das } \\
\text { crianças); sobre a pesquisa e o consumo alimentar infantil } \\
\text { (perspectiva das crianças). }\end{array}$ \\
\hline
\end{tabular}

\section{DESCRIÇÃO DAS PRINCIPAIS ATIVIDADES DESENVOLVIDAS}

\section{Atividade lúdica: jogo e dramatização: Brincadeira de Comprar:}

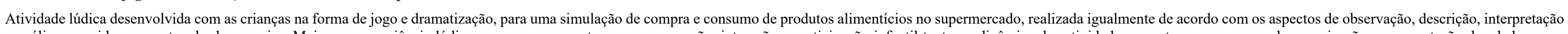

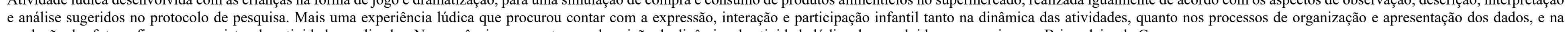
produção das fotografias para o registro das atividades realizadas. Na sequência, apresenta-se a descrição da dinâmica da atividade lúdica desenvolvida com as crianças: Brincadeira de Comprar.

\section{Brincadeira de Comprar: Sobre marcas e produtos alimentícios:}

Jogo-dramatização proposto para uma atividade lúdica de simulação de compra e consumo de alimentos com as crianças no supermercado.

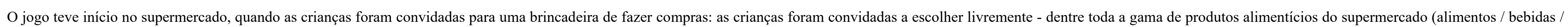
guloseimas / produtos industrializados / alimentos in natura) - alguns produtos alimentícios para colocar no carrinho em uma experiência lúdica de simulação de compra e consumo.

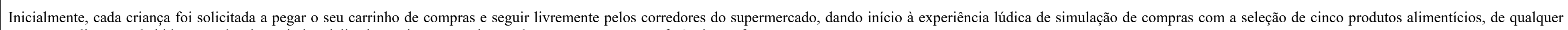
natureza - alimentos, bebidas ou guloseimas, industrializados ou in natura - de acordo com seus gostos, preferências e afetos.

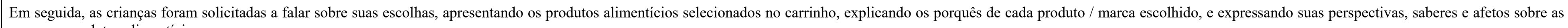
marcas e produtos alimentícios.

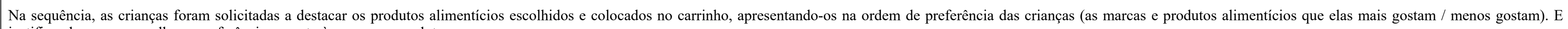
justificando as suas escolhas e preferências quanto às marcas e produtos.

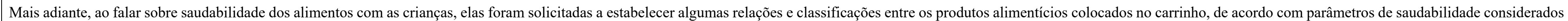
por elas (alimentos mais saudáveis / menos saudáveis). E justificando as suas elaborações e classificações quanto à saudabilidade dos produtos alimentícios escolhidos.

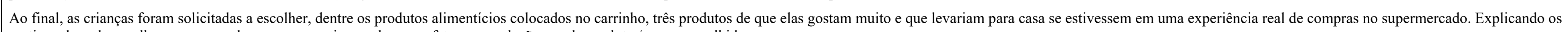
motivos de cada escolha e expressando suas perspectivas, saberes e afetos com relação a cada produto / marca escolhido.

O jogo foi finalizado quando as crianças concluíram todas as solicitações efetuadas sobre as marcas e produtos alimentícios escolhidos e apresentados no carrinho de compras.

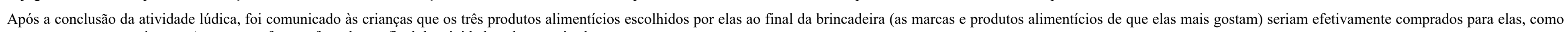
um presente para as crianças. As compras foram efetuadas ao final da atividade pela pesquisadora em campo.

Em anexo, encontra-se a apresentação do roteiro e dinâmica propostos para composição e formatação da atividade lúdica desenvolvida com as crianças na forma de jogo e dramatização. (APÊNDICE H) 


\section{Entrevista individual com as crianças:}

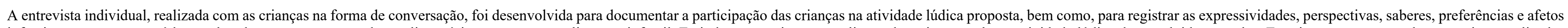

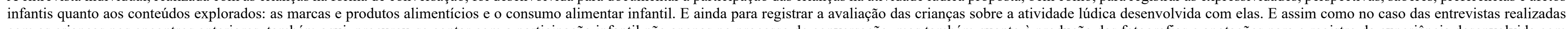

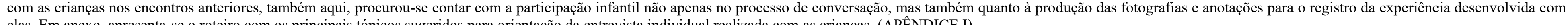
elas. Em anexo, apresenta-se o roteiro com os principais tópicos sugeridos para orientação da entrevista individual realizada com as crianças. (APÊNDICE I)

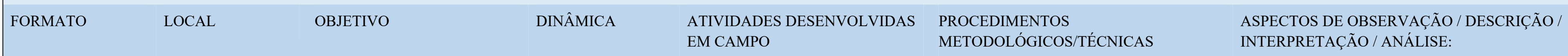

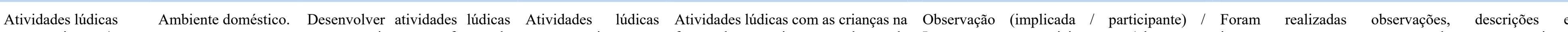
com as crianças / com as crianças na forma de com as crianças na forma de entrevista e produção de Interação e participação (observação interpretações em campo, atentando para os seguintes entrevista e produção de forma de entrevista e fotografias e vídeos com a participante) / Entrevista de grupo aspectos: A recepção infantil de marcas de alimentos e os fotografias e vídeos com a produção de coparticipação infantil. / Registros em (semiestruturada) / Atividades lúdicas vínculos de sentidos entre marcas/produtos e crianças no coparticipação infantil - fotografias e vídeos fotografias e vídeos sobre as (entrevista e produção infantil de fotografias e contexto familiar: cultura alimentar infantil e mediações atividades lúdicas para uma com a coparticipação atividades lúdicas desenvolvidas com vídeos) / Produção e coprodução de culturais e comunicacionais na modulação do consumo experimentação metodológica da infantil. $\quad$ as crianças. / Entrevista em grupo com fotografias e vídeos / Registros em fotografia alimentar das crianças (perspectiva das crianças); $\begin{array}{lll}\text { pesquisa com a participação das } & \text { as crianças na forma de conversação. e vídeo / Notas de campo / Relatos de campo. mediação comunicacional das marcas na cultura } \\ \text { crianças al alimentar infantil e marcas e produtos alimentícios no }\end{array}$ crianças na produção, registro dos dados e informações rem campo. Novamente aqui, com o objetivo de con experiências, do conhecer as experiências, perspectivas, saberes e afetos infantis quanto ao consumo alimentar e quanto às marcas e produto alimentícios $e \mathrm{o}$ contexto promocional das marcas e produtos no mercado de alimentos, buscando compreender os processos de recepção infantil de marcas de alimentos e os vínculos de sentidos entre marcas/produtos e crianças no contexto familiar. Mas, nesse momento, procurando tomar as crianças como informantes, participantes e copesquisadoras no processo de investigação. - Uma proposta de experimentação metodológica para além dos procedimentos metodológicos propostos para investigação.

DESCRIÇÃO DAS PRINCIPAIS ATIVIDADES DESENVOLVIDAS

\section{Atividades lúdicas: experimentação metodológica: Experiência The Kids:}

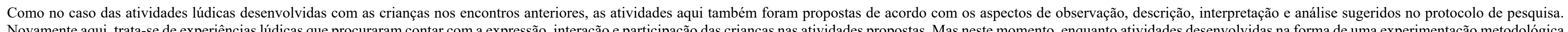

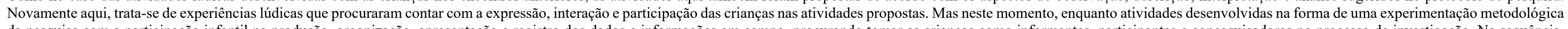

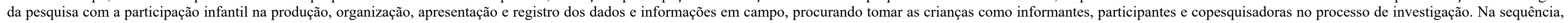
apresenta-se a descrição das atividades lúdicas desenvolvidas com as crianças: Experiência The Kids. 


\section{Atividade lúdica: entrevista em grupo com as crianças / produção infantil de vídeos para registro da entrevista em grupo com as crianças: Kids by Kids:}

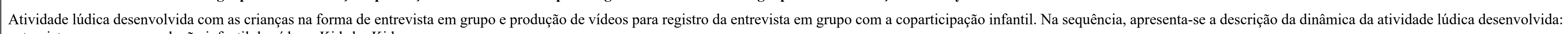
entrevista em grupo e produção infantil de vídeos: Kids by Kids.

\section{Kids by Kids:}

\section{A voz das crianças: mediação comunicacional das marcas na cultura alimentar infantil:}

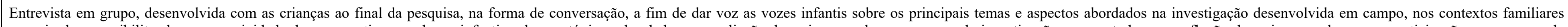

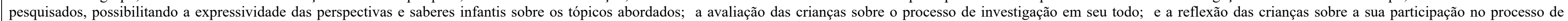
investigação. A entrevista em grupo desenvolvida com as crianças foi gravada em vídeo (em selfie) pelas próprias crianças (as crianças mais velhas).

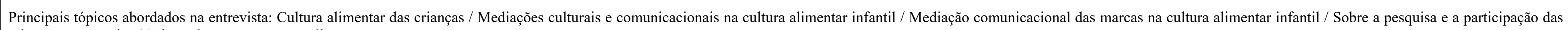
crianças na pesquisa / Sobre crianças e consumo alimentar.

Atividade proposta às crianças com a denominação: Kids by Kids.

Realizada com a coparticipação das crianças sob a coordenação das crianças mais velhas.

Atividade desenvolvida na forma de uma experimentação metodológica da pesquisa com a coparticipação das crianças na produção infantil de vídeos.

Em anexo, encontra-se a apresentação do roteiro sugerido para orientação da entrevista em grupo realizada com as crianças na atividade lúdica proposta. (APÊNDICE J)

\section{Atividade lúdica: composição de marcas e produtos alimentícios / produção infantil de fotografias para registro da composição de marcas e produtos alimentícios: My Foods:}

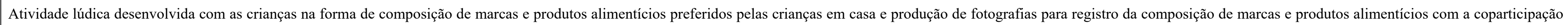
infantil. Na sequência, apresenta-se a descrição da dinâmica da atividade lúdica desenvolvida: composição de marcas e produtos alimentícios e produção infantil de fotografias: My Foods.

\section{My Foods:}

Proposta apresentada às crianças:

- Elaborar uma composição com os alimentos / produtos alimentícios que as crianças mais gostam (alimentos / produtos alimentícios disponíveis em casa no momento do desenvolvimento da atividade).

- Elaborar a produção fotográfica da composição elaborada por elas com os alimentos / produtos alimentícios de que mais gostam.

Atividade lúdica proposta às crianças com a denominação: My Foods.

Realizada com a coparticipação das crianças sob a coordenação das crianças mais velhas.

Atividade desenvolvida na forma de uma experimentação metodológica da pesquisa com a coparticipação das crianças na produção infantil de fotografias.

Em anexo, apresenta-se o roteiro sugerido para orientação da produção fotográfica elaborada pelas crianças na atividade lúdica proposta. (APÊNDICE K)

\section{Atividade lúdica: retrato das crianças e da família / produção infantil de fotografias para retrato das crianças e da família: My Family:}

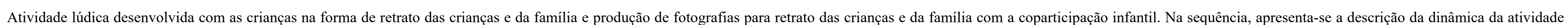
lúdica desenvolvida: retrato das crianças e da família e produção infantil de fotografias: My Family.

\section{My Family:}

Proposta apresentada às crianças:

- Produção infantil de fotografias (em selfie) para o retrato das crianças e da família. Com escolha e preparação do cenário e produção e direção de fotografia.

Atividade lúdica proposta às crianças com a denominação: My Family.

Realizada com a coparticipação das crianças sob a coordenação das crianças mais velhas.

Atividade desenvolvida na forma de uma experimentação metodológica da pesquisa com a coparticipação das crianças na produção infantil de fotografias.

Em anexo, apresenta-se o roteiro sugerido para orientação da produção fotográfica elaborada pelas crianças na atividade lúdica proposta, (APÊNDICE L). 
Finalmente, concluídas as atividades propostas para a pesquisa de campo, e após os registros das observações, descrições e interpretações a partir das experiências vivenciadas na investigação realizada com as crianças nos contextos familiares pesquisados, deu-se início aos procedimentos de interpretação e análise dos dados e avaliação dos resultados da pesquisa, com base no protocolo estabelecido em função dos objetivos do estudo e dos eixos de abordagem teórica e empírica propostos, combinados em uma articulação teórica apoiada na perspectiva das mediações comunicativas da cultura (MARTIN-BARBERO, 2009). Leituras, análises e avaliações dadas a partir da orientação filosófico-teórico-metodológica proposta na configuração interdisciplinar do estudo - na interface da comunicação com os estudos culturais, a antropologia e a sociologia - para proposição de uma perspectiva plural, crítica e abrangente para melhor compreensão do fenômeno da mediação comunicacional das marcas na cultura contemporânea de consumo alimentar infantil.

Na perspectiva e desenvolvimento desta investigação, conforme sinalizado inicialmente na apresentação da justificativa do estudo, é caracterizada sua motivação primeira a partir do crescente interesse da sociedade e comunidade acadêmica nas temáticas sobre saúde infantil, consumo alimentar das crianças e publicidade de alimentos. Temáticas plurais que se encontram e se combinam na caracterização dos estudos contemporâneos sobre comunicação, consumo, infância e cultura alimentar.

E nesse sentido, destaca-se a originalidade e relevância do tema proposto para o estudo desenvolvido: no contexto de uma rara literatura científica no campo da comunicação dedicada ao estudo da mediação comunicacional das marcas na cultura alimentar infantil, contemplando os processos de recepção infantil e práticas de consumo das crianças em contextos familiares, e tomando as crianças como informantes e participantes no processo de investigação.

Uma investigação acadêmica no campo da comunicação desenvolvida para trazer contribuições importantes ao conhecimento científico e ao debate social contemporâneo que se apresenta sobre saúde e alimentação das crianças e a publicidade de alimentos, uma vez que a temática em debate, apesar de ainda relativamente rara no campo dos estudos comunicacionais, já se faz consideravelmente presente no contexto dos estudos desenvolvidos nos campos da educação, psicologia, sociologia, direito, ciências da saúde, saúde pública e nutrição.

No entanto, tomando-se em consideração o contexto mais amplo dos estudos sobre comunicação, mídia, consumo e infância, para além da temática da cultura alimentar infantil, é possível observar que tais estudos têm maior presença no campo da comunicação. Entre 1990 e 2000 somente 21 pesquisas em um conjunto de 1.769 trabalhos acadêmicos defendidos no campo da comunicação nesse período, e dentre as quais, somente seis pesquisas se dedicavam 
à investigação da problemática da infância no sentido dos estudos de recepção. (JACKS; MENEZES; PIEDRAS, 2008:155)

No início da década de 2000 (no período entre 2000 e 2005) ainda eram poucos os trabalhos acadêmicos no campo da comunicação dedicados a investigações sobre crianças e adolescentes na perspectiva dos estudos de recepção: somente duas pesquisas desenvolvidas em um conjunto de sete estudos comunicacionais na direção da recepção midiática e de publicidade. (JACKS; PIEDRAS et al., 2010:15-16)

Aos poucos, no entanto, a temática da infância ganhou espaço entre os estudos acadêmicos no campo da comunicação, tanto na perspectiva dos estudos de recepção, quanto na dos estudos de mídia, de publicidade, das práticas de consumo, entre outras abordagens comunicacionais, no estudo do complexo fenômeno contemporâneo da relação entre comunicação, mídia, consumo e infância.

Nesse contexto mais amplo de estudos, alguns autores e pesquisadores importantes se destacam em suas investigações desenvolvidas sobre a relação comunicação-mídiapublicidade-consumo-infância, em diferentes campos de estudo, mas, em algum momento e em diferentes modos, explorando a temática em perspectiva comunicacional: David Buckingham (em seus estudos sobre as crianças e as mídias, a publicidade e o consumo); Sonia Livingstone (em seus estudos sobre as crianças e os jovens, e as mídias e a literacia midiática); Gilka Girardello, Monica Fantim e Isabel Orofino (em seus estudos sobre as crianças, as mídias e a educação); Inês Vitorino (em seus estudos sobre as crianças, as mídias e a comunicação); Elisa Piedras (em seus estudos sobre as crianças, a recepção infantil e a publicidade); Pâmela Craveiro e Luciana Correa (em seus estudos sobre as crianças, as mídias digitais, a publicidade e o YouTube); Juliana Doretto (em seus estudos sobre crianças, mídias e jornalismo).

Mas ao considerar-se o contexto específico dos estudos sobre comunicação, consumo, infância e cultura alimentar, é importante destacar que tais estudos se fazem mais presentes no campo das ciências da saúde, especialmente saúde pública e nutrição, do que no campo da comunicação, onde a temática ainda se apresenta com raridade no contexto das pesquisas acadêmicas e literatura científica.

De acordo com levantamento recente realizado junto à plataforma Catálogo de Teses e Dissertações da CAPES, a partir da expressão de busca "crianças - publicidade - alimentação", considerando-se os estudos desenvolvidos no Brasil, no período entre 2000 e 2020, e com foco específico no campo da comunicação, foram encontrados pouquíssimos trabalhos publicados no contexto da pesquisa acadêmica sobre cultura e consumo alimentar infantil no sentido comunicacional. Apenas três trabalhos podem ser destacados, e todos apresentados na categoria 
de dissertações. Não foram encontradas teses publicadas sobre a temática específica da relação comunicação, consumo, infância e cultura alimentar. (CAPES, 2020) (levantamento realizado em fevereiro / 2020). - Com eventuais ressalvas aqui com relação a possíveis imprecisões observadas na interpretação e seleção dos temas propostos nos trabalhos publicados ou com relação a possíveis limitações de abrangência dadas a partir da expressão de busca utilizada.

Dentre as publicações encontradas, como publicação mais recente, apresenta-se a pesquisa desenvolvida por mim (Cinira Baader), em nível de mestrado, no Programa de PósGraduação em Ciências da Comunicação da Universidade de São Paulo - USP (São Paulo SP), publicada no ano de 2013, sob o título: Alimentação ou diversão? A publicidade contemporânea de alimentos infantis e suas possibilidades de sentidos para as práticas de consumo e hábitos alimentares das crianças. - Um estudo sobre a midiatização publicitária contemporânea de alimentos infantis, considerando as diferentes manifestações midiáticas e expressividades de marcas materializadas a partir da tendência do eatertainment, por meio da análise semiótica e fenomenológica dos principais elementos sígnicos presentes nos processos de midiatização publicitária de alimentos e suas possibilidades de sentidos para as práticas de consumo e hábitos alimentares das crianças em seus cotidianos.

No mesmo conjunto de pesquisas acadêmicas publicadas, foram encontrados ainda outros dois trabalhos publicados anteriormente, também na categoria de dissertações: A pesquisa desenvolvida por Fernanda Cintra de Paula, em nível de mestrado, no Programa de Pós-Graduação em Comunicação e Práticas de Consumo da Escola Superior de Propaganda e Marketing - ESPM (São Paulo - SP), publicada no ano de 2013, sob o título: Muito antes da marca: relações entre a recepção de publicidade e o consumo de alimentos por crianças de classes populares. - Um estudo de recepção com crianças, em caráter etnográfico, sobre as relações entre a recepção de publicidade e o consumo de alimentos por crianças de classes populares, a fim de analisar os processos de significação elaborados pelas crianças a partir dos apelos midiáticos da publicidade para o consumo de produtos alimentícios, bem como, de refletir sobre a questão da regulamentação da publicidade para o público infantil. E a pesquisa desenvolvida por Ana Cristina Nogueira de Carvalho, também em nível de mestrado, no Programa de Pós-Graduação em Comunicação da Universidade Paulista - UNIP (São Paulo SP), publicada no ano de 2003 sob o título: A comunicação visual nas embalagens para produtos infantis. - Um estudo sobre embalagens de produtos alimentícios infantis para identificar a potencialidade comunicativa das embalagens e os elementos gráficos que possibilitam a leitura visual de produtos alimentícios para crianças pequenas (de três a seis anos), considerando as tendências culturais, os aspectos mercadológicos, as cores e elementos gráficos, e os desenhos 
e personagens presentes nas embalagens, e atentando para os processos de percepção e alfabetismo visual das crianças, bem como, para a influência do público infantil sobre o universo dos conteúdos das embalagens.

Observando-se as pesquisas acadêmicas publicadas mais recentemente no campo da comunicação, especialmente as publicadas a partir de 2015 - ainda de acordo com o levantamento realizado - é possível notar que são muito presentes as propostas de investigação sobre a relação entre as crianças e as mídias digitais, redes sociais, plataformas de vídeo e a publicidade (especialmente no contexto do YouTube / youtubers). Entretanto, nenhuma delas se dedica ao estudo de tal temática no contexto do consumo alimentar infantil.

Outra observação importante no que se refere aos estudos comunicacionais - tanto para os estudos com temáticas abrangentes sobre a relação comunicação, mídia, consumo e infância, quanto aqueles com temáticas específicas sobre a relação comunicação, consumo, infância e cultura alimentar - trata da perspectiva e investimento metodológico no desenvolvimento de pesquisas com crianças em campo, tomando as crianças como informantes e participantes no processo de investigação. Pois que, grande parte das pesquisas referidas se dedicam a estudos sobre crianças, mas não desenvolvem suas investigações em campo com a participação das crianças.

Ao se buscar um comparativo e complementação entre os campos da comunicação e da saúde, no que se refere ao contexto específico dos estudos sobre comunicação, consumo, infância e cultura alimentar, foi realizado novamente um levantamento sobre os trabalhos acadêmicos publicados junto à plataforma Catalogo de Teses e Dissertações da CAPES. Considerando-se igualmente a expressão de busca "crianças - publicidade - alimentação", para os estudos desenvolvidos no Brasil, no período entre 2000 e 2020, mas desta vez, com foco nos trabalhos publicados no campo das ciências da saúde, especialmente saúde pública e nutrição. Este contexto revelou um número bem mais expressivo de pesquisas acadêmicas publicadas no período e, dentre as quais, muitas delas caracterizadas enquanto investimentos metodológicos que visam explorar as culturas infantis com a participação das crianças no processo de investigação (CAPES, 2020). Levantamento também realizado em fevereiro / 2020, e novamente aqui, com eventuais ressalvas quanto a possíveis imprecisões dadas na interpretação e seleção dos temas propostos nos trabalhos publicados ou a possíveis limitações de abrangência dadas a partir da expressão de busca utilizada.

Em meio às principais e mais recentes publicações encontradas no campo das ciências da saúde (saúde pública e nutrição), é possível destacar 12 pesquisas acadêmicas que abordam 
o tema da cultura e consumo alimentar infantil no âmbito comunicacional, sendo todas na categoria de dissertações, não contendo nenhuma tese.

Dentre os trabalhos acadêmicos destacados: pesquisa desenvolvida por Mariana Rodrigues Barreiros da Silva, em nível de mestrado, no Programa de Pós-Graduação em Informação e Comunicação em Saúde da Fundação Oswaldo Cruz - FIOCRUZ (Rio de Janeiro - RJ), publicada no ano de 2018, sob o título: Do ver ao comer: o papel mediador da publicidade de alimentos ultraprocessados na produção social de sentidos sobre alimentação infantil; pesquisa desenvolvida por Hermano Pinheiro de Rezende, em nível de mestrado profissional, no Programa de Pós-Graduação em Nutrição: do Nascimento à Adolescência do Centro Universitário São Camilo (São Paulo - SP), publicada no ano de 2017, sob o título: Escolhas alimentares na infância: podem as personagens infantis interferir nesta decisão?; pesquisa desenvolvida por Camila Peternella Veltrini, em nível de mestrado, no Programa de PósGraduação em Bioética da Pontifícia Universidade Católica do Paraná - PUC PR (Curitiba PR), publicada no ano de 2017, sob o título: Publicidade, obesidade infantil e violação do direito humano à alimentação adequada: uma análise à luz da bioética; pesquisa desenvolvida por Lana Angelica Braudes Silva, em nível de mestrado, no Programa de Pós-Graduação em Nutrição e Saúde da Universidade Federal de Goiás - UFG (Goiânia - GO), publicada no ano de 2015, sob o título: Consumo de refrigerantes e salgadinhos de pacote por crianças de 12 a 59 meses e fatores associados; pesquisa desenvolvida por Natalia Durigon Zucchi, em nível de mestrado, no Programa de Pós-Graduação em Nutrição da Universidade Federal de Santa Catarina UFSC (Florianópolis - SC), publicada no ano de 2015, sob o título: Alimentos ultraprocessados direcionados a crianças: disponibilidade, informação nutricional complementar e opinião de consumidores infantis; pesquisa desenvolvida por Soraya da Rocha Britto Mazzei, em nível de mestrado profissional, no Programa de Pós-Graduação em Nutrição: do Nascimento à Adolescência do Centro Universitário São Camilo (São Paulo - SP), publicada no ano de 2015, sob o título: Análise das propagandas de alimentos veiculadas em canais de televisão fechada direcionada ao público infantil segundo o guia alimentar para a população brasileira e legislação vigente; pesquisa desenvolvida por Ana Maria Spaniol, em nível de mestrado, no Programa de Pós-Graduação em Nutrição Humana da Universidade de Brasília - UNB (Brasília - DF), publicada no ano de 2014, sob o título: Influência da publicidade de alimentos sobre a escolha alimentar de crianças e adolescentes de escolas públicas do distrito federal; pesquisa desenvolvida por Fabiane de Almeida Leite, em nível de mestrado, no Programa de PósGraduação em Saúde Pública da Universidade de São Paulo - USP (São Paulo - SP), publicada no ano de 2013, sob o título: A notícia e o discurso: o caso da regulamentação da publicidade 
de alimentos infantis ultraprocessados no Brasil; pesquisa desenvolvida por Ana Claudia Mazzoneto, em nível de mestrado, no Programa de Pós-Graduação em Nutrição da Universidade Federal de Santa Catarina - UFSC (Florianópolis - SC), publicada no ano de 2012, sob o título: Escolhas alimentares e comportamento de consumo: percepções de escolares da rede pública de ensino de Florianópolis, SC; pesquisa desenvolvida por Jussara Santos de Sousa, em nível de mestrado, no Programa de Pós-Graduação em Nutrição Humana da Universidade de Brasília - UNB (Brasília - DF), publicada no ano de 2012, sob o título: Estratégias de persuasão para o público infantil utilizadas em embalagens de alimentos; pesquisa desenvolvida por Márcia Hiroko Ueda, em nível de mestrado, no Programa de PósGraduação em Ciências do Comportamento da Universidade de Brasília - UNB (Brasília - DF), publicada no ano de 2010, sob o título: O efeito da publicidade de alimentos saudáveis e não saudáveis sobre as escolhas alimentares das crianças; pesquisa desenvolvida por Andréa Siliveste Brasil Villagelim Bizerra, em nível de mestrado, no Programa de Pós Graduação em Alimentação Nutrição e Saúde da Universidade do Estado do Rio de Janeiro - UERJ (Rio de Janeiro - RJ), publicada no ano de 2009, sob o título: A vida não pode ser feita só de sonhos: reflexões sobre alimentação saudável a partir da publicidade de uma linha de biscoitos industrializados.

Assim, em um contexto de raras pesquisas acadêmicas no campo dos estudos comunicacionais, dedicadas a investigar a relação comunicação, consumo, infância e cultura alimentar - e em que tais pesquisas se fazem mais presentes no campo das ciências da saúde do que no campo da comunicação - apresenta-se o desenvolvimento desta tese: um estudo que, para além de uma investigação sobre a mediação comunicacional das marcas na cultura alimentar infantil, dedicou-se ao desenvolvimento da pesquisa com crianças em seus contextos familiares, tomando-as como informantes e participantes no processo de investigação. O que demarca a relevância e originalidade do estudo desenvolvido pela raridade da sua perspectiva e temática e pelo investimento metodológico de uma pesquisa desenvolvida com a participação das crianças em campo no contexto dos estudos comunicacionais. 


\section{FUNDAMENTAÇÃO FILOSÓFICO-TEÓRICO-METODOLÓGICA DO ESTUDO}

Enquanto estudo comunicacional de recepção infantil de marcas de alimentos no contexto das práticas sociais e culturais de consumo alimentar das crianças - caracterizado na proposta de uma investigação de inspiração etnográfica no campo da comunicação - o estudo desenvolvido delineou-se em uma base interdisciplinar dada na interface da comunicação com os estudos culturais, a antropologia e a sociologia.

Nesse sentido de investigação apresenta-se a seguir - como sinalizado em síntese inicialmente - a exploração do quadro filosófico-teórico-metodológico proposto para fundamentação do estudo, e em que se fundamentam as principais noções, conceitos e teorizações que caracterizam e compõem os eixos de abordagem teórica e empírica propostos para orientação da investigação.

Considerando-se a arquitetura filosófico-teórico-metodológica proposta para o estudo, foi delineada a seguinte estrutura de investigação para formatação, orientação e fundamentação do processo de pesquisa teórica e empírica desenvolvido: um estudo de recepção em perspectiva de abordagem sociocultural (JACKS; PIEDRAS et al., 2010; JACKS; MENEZES; PIEDRAS, 2008; JACKS; PIEDRAS; VILELA, 2006; JACKS; ESCOSTEGUY, 2005; PIEDRAS, 2006) dado a partir do enfoque da comunicação - com atenção aos estudos das mediações culturais e comunicacionais (MARTIN-BARBERO, 2009; 2004a; 2004b; GARCIA CANCLINI, 2013; 2010; OROZCO GOMEZ, 2014; 1991a; 1991b); aos estudos de midiatização (HJARVARD, 2014a; 2014b; 2012; COULDRY, 2012; COULDRY; HEPP, 2013); aos estudos sobre marcas (PEREZ, 2011; PEREZ; TRINDADE, 2011; TRINDADE; PEREZ, 2019; 2014; 2013); e aos estudos sobre mídia, publicidade, consumo e infância (BUCKINGHAM, 2012a; 2012b; 2012c; 2007a; 2007b; 2003; LIVINGSTONE, 2012; 2011; 2002; COULDRY; LIVIINGSTONE, 2010; FANTIM; GIRARDELLO, 2008; GIRARDELLO, 2005; GIRARDELLO; OROFINO, 2012; 2002; OROFINO, 2013; 2011; 2008; PIEDRAS, 2013; CRAVEIRO, 2018; 2016; CORREA, 2016; DORETTO, 2017; 2016). Delineado na interface da comunicação com os estudos culturais - considerando os estudos culturais latino-americanos (MARTINBARBERO, 2009; 2004a; 2004b; GARCIA CANCLINI, 2013; 2010; OROZCO GOMEZ, 2014; 1991a; 1991b); com a antropologia - considerando os estudos antropológicos sobre culturas (GEERTZ, 2013; CERTEAU, 2012a; 2012b; PEIRANO, 2003; 1995; 1991), sobre consumo (MCCRACKEN, 2003; DOUGLAS; ISHERWOOD, 2013; MILLER, 2007), sobre antropologia da criança (COHN, 2005), e na perspectiva dos métodos e técnicas dos estudos etnográficos (RIBEIRO, 2003; CLIFFORD, 2014); e com a sociologia - considerando os 
estudos da sociologia da infância (CORSARO, 2011; 2005; 1992; 1990; PROUT, 2011; 2010a; 2010b; CHRISTENSEN; PROUT, 2002; SARMENTO, 2011; 2008a; 2008b; 2007; 2005a; 2005b; FERREIRA; SARMENTO, 2008; SOARES; SARMENTO, 2005; SIROTA, 2001; QVORTRUP, 2010a; 2010b).

$\mathrm{Na}$ forma de uma investigação interdisciplinar no campo da comunicação, esta pesquisa coloca-se na corrente dos estudos de recepção, tomado na visão latino-americana do uso social dos meios proposta por Martin-Barbero - conforme especificações e interpretações apresentadas em Jacks; Escosteguy (2005:65-68) e orientado em uma perspectiva de abordagem sociocultural para a investigação - a partir de pressupostos dados em Geertz, Bourdieu e Thoompson, apresentados e interpretados em Jacks; Menezes; Piedras (2008:25-29).

No sentido do uso social dos meios, proposta por Martin-Barbero (2009) a partir do estudo das mediações, a comunicação é tomada como prática social em que o receptor se coloca de forma ativa, enquanto produtor de sentidos. E a partir daí, tomando-se a comunicação a partir da cultura, no entendimento da relação entre as práticas da comunicação (os meios e as mensagens) e as práticas sociais e culturais dos sujeitos (os receptores produtores de sentidos), o cotidiano se torna, então, o lugar da pesquisa em comunicação. (JACKS; ESCOSTEGUY 2005:65-68)

Entendendo-se, desse modo, no contexto do estudo desenvolvido: as práticas sociais da comunicação, enquanto os processos de mediação comunicacional das marcas e produtos alimentícios na cultura alimentar infantil; as práticas sociais e culturais dos sujeitos, receptores e consumidores, enquanto as práticas de recepção infantil das marcas de alimentos e práticas de consumo alimentar das crianças em seus contextos familiares; os sujeitos, receptores e consumidores, produtores de sentidos, representados aqui pelas crianças como atores sociais, cidadãos, sujeitos em comunicação e participantes ativos no processo de investigação; e o lugar da pesquisa em comunicação, enquanto os cotidianos da cultura alimentar infantil no contexto familiar.

$\mathrm{Na}$ proposta de uma abordagem sociocultural, o estudo desenvolvido coloca-se enquanto possibilidade de uma confluência entre comunicação e cultura. Entendendo-se a comunicação (os modos de presença e expressividade das marcas e produtos alimentícios na cultura alimentar infantil) como parte da cultura (a cultura alimentar infantil e as mediações culturais e comunicacionais na modulação do consumo alimentar das crianças em contexto familiar) para um entendimento mais amplo, contextualizado e aprofundado do complexo fenômeno contemporâneo da mediação comunicacional das marcas na cultura alimentar infantil. 
Nessa direção, no contexto do estudo desenvolvido, a recepção infantil de marcas de alimentos é tomada enquanto os diversos processos socioculturais a partir dos quais as crianças têm contato com marcas e produtos alimentícios nos cotidianos da sua cultura alimentar; a noção de recepção publicitária é tomada em sua forma conceitual mais alargada, expandida, considerando os diversos modos de presença e expressividade das marcas e produtos como "lugar de manifestação do sistema publicitário" na vida dos sujeitos (receptores, consumidores, produtores de sentidos) em seus cotidianos. Como tratado em Trindade e Perez (2013:248).

E nesse sentido, como sinalizado inicialmente, as marcas de alimentos são aqui tomadas como dispositivos midiáticos promocionais: as marcas tomadas como mídia no contexto promocional do mercado de alimentos e nos cotidianos das práticas de consumo alimentar das crianças - em suas diversas formas de presença e expressividade, consideradas para além dos formatos tradicionais de publicidade, ou ainda para além da forma publicidade, em um contexto de lógicas e processos do consumo midiatizado pelas marcas nos cotidianos dos sujeitos dados a partir das mensagens publicitárias e diferentes modos de presença e expressividade das marcas. Assim, desde a compra e consumo dos produtos, até a criação de vínculos afetivos com as marcas, em uma "lógica de presença da marca midiatizada" na vida cotidiana. (TRINDADE; PEREZ, 2013:248;253) Perspectiva na qual os autores propõem o entendimento de que:

[...] o consumo das marcas é um tipo de recepção e que o dispositivo marca, mesmo tendo um papel de sujeito institucional mediador, é também dispositivo sócio-técnicodiscursivo comunicacional e que modula relações e modos de interação com receptores que também são consumidores de mídias e de mercadorias midiatizadas, a marca é mídia... (TRINDADE; PEREZ, 2019:8)

Como destacado pelos autores, é possível observar que as marcas estão muito presentes nos cotidianos da cultura alimentar, desde o consumo alimentar nos ambientes domésticos familiares até as experiências de alimentação em espaços públicos. E nesse sentido, partilhando de uma visão contemporânea sobre marcas, os autores sinalizam para "o entendimento de que marcas são fenômenos sígnicos construídos dialogicamente com o objetivo de dar sentido às ofertas materiais e simbólicas e servir de expressão identitária para as pessoas..." O que torna possível compreender a multiplicidade dos modos de presença e expressividade das marcas nos cotidianos da contemporaneidade. (PEREZ; TRINDADE, 2011:13)

A partir daí, os diferentes e diversos modos de presença e expressividade das marcas e produtos alimentícios nos cotidianos da cultura alimentar das crianças - em sua dimensão de presença material: marcas e produtos materialmente presentes no contexto de consumo alimentar da família e das crianças, no ambiente doméstico e espaço público, durante o desenvolvimento da pesquisa; e presença simbólica: marcas e produtos simbolicamente 
presentes no contexto de consumo alimentar da família e das crianças, na forma de relatos, observações e citações, durante o desenvolvimento da pesquisa - são tomados neste estudo enquanto importante mediação comunicacional, em um contexto de diversas mediações culturais e comunicacionais presentes nos processos de construção da cultura alimentar infantil no contexto familiar. - Entendendo-se, no âmbito do estudo desenvolvido, que a mediação comunicacional das marcas na cultura alimentar das crianças pode se dar tanto em uma dimensão material quanto simbólica de presença das marcas e produtos alimentícios nos cotidianos infantis.

Contexto em que se dão os vínculos de sentidos entre marcas/produtos e crianças, tomados neste estudo enquanto os laços de afeto, representação e significação criados entre as marcas e produtos alimentícios e as crianças nos contextos familiares pesquisados. Vínculos de sentidos dados na combinação entre a publicidade e os diferentes modos de presença e expressividade das marcas, seus processos de recepção nos diversos contextos da vida social cotidiana, e suas implicações nas práticas de consumo dos sujeitos dadas a partir daí, como sinalizado em Perez e Trindade (2011:2).

Os vínculos de sentidos entre marcas e consumidores, como destacam os autores, podem se dar de formas diferentes: em um contexto material, na forma de uma influência direta ou indireta da publicidade ou outros modos de presença e expressividade das marcas junto aos receptores e consumidores, orientando a partir daí suas escolhas e práticas de consumo (vínculo sígnico-material); em uma perspectiva simbólica, na forma de uma influência mais abstrata ou menos concreta da publicidade ou outros modos de presença e expressividade das marcas junto aos sujeitos, caracterizada mais pela orientação das suas ideias, valores, afetos, visão de mundo e estilo de vida, e que, a partir daí - de modos diversos nos diferentes contextos sociais, experiências culturais e subjetividades individuais - passam a orientar também seus comportamentos e hábitos de vida e de consumo (vínculo sígnico-simbólico). (PEREZ; TRINDADE, 2011:4; TRINDADE; PEREZ, 2013:247-248)

É importante observar que as práticas e rituais de consumo alimentar das crianças em contextos familiares, tanto em ambientes domésticos quanto em espaços públicos, são tomados neste estudo enquanto "dispositivos midiáticos articuladores de vínculos de sentidos entre marcas e consumidores", compreendidos aqui como importantes mediadores nos processos de construção dos vínculos de sentidos entre as marcas (as marcas de alimentos e os produtos alimentícios em geral) e os consumidores (as crianças e as famílias) a partir da publicidade e dos diferentes modos de presença e expressividade das marcas na vivência cotidiana dessas 
práticas e rituais de consumo alimentar (o consumo alimentar infantil em contexto familiar), conforme abordagem proposta em Trindade e Perez (2014:157).

A perspectiva de uma abordagem antropológica e comunicacional dos rituais de consumo, como proposta por Trindade e Perez, especialmente com base em Peirano (2003) e McCracken (2003) - e igualmente compartilhada neste estudo - torna possível uma articulação entre a dimensão antropológica das vivências e representações dos rituais e a dimensão comunicacional das experiências e significações do consumo. E a partir daí, o consumo é assim tomado como dispositivo midiático de mediação entre produtos, marcas e consumidores. (TRINDADE; PEREZ, 2014:166-167) Perspectiva na qual:

[...] pensar o consumidor midiatizado e os processos de midiatização do consumo consiste em perceber o consumo como mediação cultural, atrelado a outras mediações que sejam identificadas como potencializadoras da moldagem da mediação comunicativa das marcas com seus consumidores, em um dado contexto cultural. (TRINDADE; PEREZ, 2019:11)

Finalmente, faz-se importante sinalizar ainda que o estudo desenvolvido - do mesmo modo como o estudo desenvolvido anteriormente (BAADER, 2013) - embora ainda situado em um contexto de uso corrente dos termos receptores e consumidores, entende tais significados para além das possibilidades de recepção e consumo: em uma concepção de recepção dada em contextos diversos e dinâmicos de circulação e fluxos de marcas e dispositivos do sistema publicitário nos cotidianos das práticas sociais e culturais dos sujeitos - como as reflexões propostas em Piedras (2009; 2006); e em uma concepção de crianças tomadas como sujeitos comunicantes, pessoas em comunicação, participantes ativos em seus processos de ação, interação, inter-relação, experimentação, e em suas experiências comunicacionais e de produção de sentidos - como a reflexão proposta em Maldonado (2013:87-100) ao pensar os processos sociocomunicacionais em recepção numa perspectiva de transformação para as pesquisas em comunicação. E assim, as crianças tomadas como sujeitos em comunicação, informantes e participantes no processo de investigação.

Enquanto pesquisa de recepção dado no sentido do uso social dos meios e orientado a partir de uma proposta de abordagem sociocultural, o estudo desenvolvido é caracterizado enquanto objeto comunicacional de investigação. E nesse sentido, a partir do enfoque da comunicação, a fundamentação filosófico-teórico-metodológica proposta apresenta suas bases primeiras em abordagens desenvolvidas sobre as mediações culturais e comunicacionais, sobre midiatização, sobre marcas (como abordado há pouco na visão dos estudos de recepção e consumo), e sobre a relação entre mídias, publicidade, consumo e infância. - Em uma proposta interdisciplinar de investigação que, como já sinalizado, é materializada na interface da 
comunicação com os estudos culturais (estudos culturais latino-americanos), a antropologia (antropologia da cultura, do consumo e da criança) e a sociologia (sociologia da infância).

Os estudos culturais, enquanto proposta de um campo interdisciplinar de investigação, tomam como objeto de estudo as culturas vividas, em suas subjetividades, códigos culturais e processos sociais de produção de sentido. E nesse contexto, a comunicação - enquanto circuito de produção, circulação e consumo da cultura midiática - é então percebida e considerada como uma prática cotidiana da vida social que, no contexto de outras práticas sociais, se coloca a partir de tais processos socioculturais de produção de sentido, com seus textos e contextos dados em um universo de práticas simbólicas e estruturas de poder. (JACKS; ESCOSTEGUY, 2005:37-41)

Assim, a corrente dos estudos culturais latino-americanos traz para esse campo interdisciplinar de investigação a dimensão da presença das mediações culturais nos processos e contextos sociais. Especialmente a partir das contribuições das teorias das mediações - cujos principais colaboradores são Jesus Martin-Barbero, explorando a presença das mediações culturais no contexto das mídias e da comunicação de massa (MARTIN-BARBERO, 2009; 2004a; 2004b) e Nestor Garcia Canclini, tomando os processos de mediações culturais a partir das relações entre consumo e cidadania (GARCIA CANCLINI, 2013; 2010). Considerando-se também as contribuições de Guilhermo Orozco, em seus estudos sobre mídias, recepção midiática e mediações culturais (OROZCO GOMEZ, 2014; 1991a; 1991b).

$\mathrm{Na}$ perspectiva latino-americana das mediações culturais, partindo de uma visão do contexto macro-cultural da América Latina, destaca-se a presença de diversas categorias culturais para a formulação das práticas sociais na família, na escola, no trabalho, na economia, na política, na religião, na arte, nas línguas, nas mídias, no consumo, e em todas as dimensões da vida social, considerando seus processos de subjetividades, conflitos, valores, costumes, institucionalizações, para o entendimento das manifestações da cultura a partir das interações e mediações culturais dos sujeitos, pois que os sentidos da cultura se revelam nas práticas culturais mediadas, como abordado em Trindade e Moreira (2010:68-70).

Nesse contexto plural de interdisciplinaridade e de diferentes enfoques e conceitos comunicacionais, o estudo desenvolvido, ainda que estruturado a partir da perspectiva maior das mediações (MARTIN-BARBERO, 2009) - assinalando-se a interface da comunicação com os estudos culturais latino-americanos na proposta filosófico-teórico-metodológica delineada para fundamentação da investigação - reconhece também a perspectiva da midiatização. Toma como pano de fundo para o contexto contemporâneo das mediações culturais e comunicacionais os processos de midiatização da cultura e da sociedade, conforme reflexões propostas na 
abordagem social construtivista (COULDRY, 2012; COULDRY; HEPP, 2013) e na abordagem institucionalista (HJARVARD, 2014a; 2014b; 2012).

O conceito de midiatização é tomado neste estudo enquanto o fenômeno crescente e dinâmico da presença das mídias e tecnologias nos cotidianos das práticas culturais e sociais dos sujeitos e suas marcas no contexto de mudanças e transformações das culturas e sociedades. (COULDRY, 2012; COULDRY; HEPP, 2013) Considerando-se também a presença das mídias no mundo contemporâneo enquanto instituição midiática e enquanto mediação das tecnologias e das mídias na cultura e sociedade; lógicas midiatizadas, em suas formas diretas e indiretas de midiatização, implicadas nas lógicas de interações dos sujeitos em seus cotidianos. (HJARVARD, 2014a; 2014b; 2012)

A perspectiva da midiatização é tomada em consideração neste estudo, ainda que demarcada como perspectiva de contexto, por conta da sua proposta de leitura ampla e abrangente sobre a presença das mídias na cultura e sociedade, tomando as mídias e tecnologias como parte do tecido sociocultural; como instituição social e como processo e prática cultural em interação com outras instituições sociais e processos e práticas culturais. Proposta de leitura que, em perspectivas diferentes, apresenta-se tanto na abordagem social construtivista desenvolvida em Couldry (2012); Couldry; Hepp (2013) quanto na abordagem institucionalista apresentada em Hjarvard (2012; 2014a; 2014b).

Desta forma, considerando-se a cultura contemporânea de consumo alimentar infantil enquanto um conjunto de processos e práticas socioculturais atravessados por mediações culturais e comunicacionais diversas, e em que a mediação comunicacional das marcas de alimentos se faz tão presente na construção da cultura alimentar das crianças desde o contexto familiar, a presença das mídias, das marcas, da publicidade de alimentos, em suas diversas formas e dispositivos midiáticos promocionais, poderia ser entendida como contexto para uma forma de consumo alimentar infantil midiatizado.

E a partir daí, seria possível destacar a presença das mídias, das marcas, da publicidade de alimentos na construção da cultura alimentar das crianças sob o ponto de vista de uma forma indireta de midiatização, como apresentada em Hjarvard (2014b: 40-42).

Ao considerar as formas diretas e indiretas de midiatização na cultura e sociedade - e em uma aproximação com a temática e perspectiva deste estudo - o autor toma como exemplo de midiatização indireta o contexto contemporâneo dos restaurantes de fastfood (no caso específico dos hambúrgueres) destacando o quanto o universo promocional das mídias, da publicidade e dos personagens, em seus signos e representações, está presente na caracterização 
das experiências de consumo alimentar vivenciadas em tais espaços, especialmente no caso do público mais jovem (crianças e adolescentes):

\begin{abstract}
Uma visita ao Burger King ou ao McDonald's deixou de ser uma simples experiência de alimentação; implica agora uma considerável exposição a filmes e animações. Tanto quanto a oportunidade de comer um hambúrguer, uma visita a um desses restaurantes pode significar - especialmente para os clientes mais jovens - a possibilidade de adquirir bonecos colecionais representando os personagens dos filmes exibidos. Claro que ainda podemos apenas comer nossa refeição sem nos expormos ao entretenimento midiático oferecido, mas o contexto cultural que envolve o hambúrguer, grande parte da atração de visitar o restaurante, etc., tem a ver com a presença dos meios de comunicação, tanto em termos simbólicos quanto em termos econômicos. (HJARVARD, 2014b: 41)
\end{abstract}

Perspectiva que se faz bastante aproximada à temática e ao enfoque propostos neste estudo, especialmente no contexto das marcas e produtos alimentícios que se utilizam de personagens e mascotes, ou mesmo de outros códigos característicos do contexto midiático infanto-juvenil, em seu universo simbólico de comunicação com o público infantil, como no caso dos restaurantes de fastfood e outros produtos alimentícios destinados às crianças e adolescentes na cultura contemporânea de consumo alimentar.

Mas como sinalizado, a perspectiva da midiatização é tomada no âmbito do estudo desenvolvido enquanto contexto, como pano de fundo para a exploração do fenômeno contemporâneo da mediação comunicacional das marcas na cultura alimentar infantil a partir do olhar maior das mediações, como apresentada em Martin-Barbero (2009). - abordagem que assinala a interdisciplinaridade entre a comunicação e os estudos culturais latino-americanos no contexto desta investigação.

No âmbito das mediações, proposta por Martin-Barbero, a comunicação é vista a partir da cultura (e a cultura é vista a partir da comunicação). Os processos comunicacionais são tomados enquanto práticas sociais em que os receptores se tornam sujeitos produtores de sentidos. E a partir daí, o lugar da pesquisa em comunicação passa a ser o cotidiano, o lugar da experiência cultural, o contexto das práticas culturais e sociais onde acontecem os processos de produção, reprodução, organização, reorganização, reelaboração e ressignificação dos sentidos - o lugar das mediações (culturais e comunicacionais). (MARTIN-BARBERO, 2009:280-304; JACKS; ESCOSTEGUY, 2005:65-68)

Como destaca Martin-Barbero (2009:287), tal sentido implica em uma mudança de paradigma sobre os processos comunicacionais, pois que: "pensar os processos de comunicação nesse sentido, a partir da cultura, significa deixar de pensá-los a partir das disciplinas e dos meios. Significa romper com a segurança proporcionada pela redução da problemática da comunicação à das tecnologias.” 
E nesse sentido, na proposta de uma nova visão conceitual de cultura e comunicação, o autor observa o quão fundamental se torna a percepção da "natureza comunicativa da cultura", enquanto processo de produção de significações, para muito além da circulação de informações. (MARTIN-BARBERO, 2009:289)

A partir da perspectiva das mediações, Martin-Barbero propõe o entendimento da relação entre receptores e meios, entre consumidores e produtores, partindo do entendimento mais amplo das relações e articulações entre as práticas e processos comunicacionais e as experiências culturais e movimentos sociais, considerando a diversidade e pluralidade das temporalidades sociais e matrizes culturais. (MARTIN-BARBERO, 2009:280-304; JACKS; ESCOSTEGUY, 2005:65-68)

O estudo das mediações propõe que o olhar da investigação se volte para as experiências culturais, no lugar onde elas acontecem, tornando possível um melhor entendimento das múltiplas interações entre meios e audiências, entre produtores e receptores, entre produção e consumo. E é no contexto das mediações (culturais e comunicacionais) que essas interações tomam forma, na produção e reprodução dos significados sociais; na estruturação, organização e reorganização da realidade cultural e social em sua percepção e valor. (MARTIN-BARBERO, 2009:280-304; JACKS; ESCOSTEGUY, 2005:65-68)

Nas palavras do autor: "propomos partir das mediações, isto é, dos lugares de onde provem as construções que delimitam e configuram a materialidade social e a expressividade cultural... [dos meios]". (MARTIN-BARBERO, 2009: 294) E assim, "o eixo do debate deve se deslocar dos meios para as mediações, isto é, para as articulações entre práticas de comunicação e movimentos sociais, para as diferentes temporalidades e para a multiplicidade de matrizes culturais.” (MARTIN-BARBERO, 2009: 261)

Para o estudo dos fenômenos comunicacionais a partir da perspectiva das mediações, Martin-Barbero propõe atenção a três tipos especiais de mediação: a cotidianidade familiar; a temporalidade social e a competência cultural. É a partir daí que se faz a entrada no lugar da experiência cultural, no contexto das práticas culturais e sociais (em suas dimensões de socialidade, institucionalidade, tecnicidade e ritualidade). (MARTIN-BARBERO, 2009:295301)

Na perspectiva das mediações, a cotidianidade familiar é descrita pelo autor como importante mediação social, a ser especialmente considerada e cuidadosamente investigada no contexto dos estudos sobre processos comunicacionais, uma vez que a família representa a "situação primordial de reconhecimento" para os indivíduos, constituindo-se enquanto "lugar social de uma interpelação fundamental". Um espaço de conflitos e tensões, mas também o 
lugar de manifestação das emoções, ansiedades e frustrações. (MARTIN-BARBERO, 2009:295)

Nesse sentido, é possível fundamentar a proposta deste estudo ao tomar a família como mediação cultural de base no âmbito da cultura alimentar infantil - em um contexto de interação com diversas mediações culturais e comunicacionais - para o estudo da presença e mediação comunicacional das marcas na construção da cultura alimentar das crianças, uma vez que a cotidianidade familiar constitui a principal mediação social no contexto das práticas culturais de consumo alimentar das crianças e, ao mesmo tempo, um importante espaço de interações e conflitos entre mediações diversas, na construção, produção e reprodução das culturas infantis.

A temporalidade social, na perspectiva das mediações, é descrita pelo autor como o tempo da cotidianidade. O tempo da repetição e do fragmento; do ritual e da rotina. "[...] um tempo repetitivo, que começa e acaba para recomeçar...” E ao propor uma relação entre a temporalidade social da cotidianidade e os tempos da televisão em sua programação, o autor remete à possibilidade de uma "estética da repetição" que materializa a um só tempo a "variação de um idêntico" e a "identidade de vários diversos", na forma de uma mediação entre o "tempo de capital" e o "tempo da cotidianidade". (MARTIN-BARBERO, 2009:297-298)

Tal visão pode ser válida também na proposta de uma relação entre a temporalidade social da cotidianidade das crianças em seus contextos familiares e culturas infantis e os tempos midiáticos da televisão e mídias digitais, em sua programação, conteúdos e comunicação publicitária para o público infantil, bem como, os tempos do universo promocional das marcas e produtos para crianças (considerando-se especialmente o contexto promocional das marcas e produtos alimentícios), em sua presença e mediação comunicacional na construção das culturas infantis (tomando-se em especial atenção o âmbito da cultura de consumo alimentar das crianças).

E finalmente, ao abordar a questão da competência cultural na perspectiva das mediações, Martin-Barbero observa o quanto o culturalismo ofusca "o sentido social das diferenças culturais", desqualificando o massivo em sua essência de matriz cultural. O que acontece em todas as esferas da cultura e sociedade, mas que aparece de modo muito claro na relação entre comunicação e cultura ou, na proposta de reflexão apresentada pelo autor, na relação televisão-cultura. Em que aí, a partir de noções fundadas no culturalismo: "a televisão não seria assunto de cultura, só de comunicação". Mas o autor destaca que, para além de um debate superficial que tenta definir se a televisão e suas produções podem ou não ser consideradas como cultura, uma reflexão mais contextualizada e aprofundada permitiria compreender que "é a própria noção de cultura, sua significação social, o que está sendo 
transformado pelo que a televisão produz em seu modo de reprodução.” (MARTINBARBERO, 2009:299-300)

E nesse contexto, a especificidade cultural do massivo, como o autor observa em sua análise sobre a televisão, se torna legítima enquanto matriz cultural, e se faz materializada não mais a partir das obras de arte, mas a partir dos gêneros, que passam a figurar como as unidades básicas de conteúdo nos processos de comunicação de massa. Em síntese, a dinâmica cultural da televisão é marcada por seus gêneros. "A partir deles, ela ativa a competência cultural e a seu modo dá conta das diferenças sociais que a atravessam. Os gêneros [...] constituem uma mediação fundamental entre as lógicas do sistema produtivo e as do sistema de consumo...”. (MARTIN-BARBERO, 2009:300-301) Especialmente no caso da televisão, conforme a análise proposta pelo autor, mas que seria igualmente válido para todo o contexto contemporâneo da produção midiática (com especial atenção ao caso das mídias digitais).

Em uma conexão com a temática deste estudo, quanto à mediação da competência cultural, seria interessante arriscar que o mesmo movimento de desqualificação da especificidade cultural muitas vezes acontece no contexto das culturas infantis. Desde os diversos gêneros e conteúdos produzidos para crianças e pelas crianças na televisão, nas mídias digitais, nas redes sociais, e na publicidade, até as apropriações, reelaborações e ressignificações que as crianças fazem dessa multiplicidade de conteúdos e experiências culturais na produção das culturas infantis. E talvez o próprio termo "culturas infantis" já traga em si, de algum modo, essa desqualificação da especificidade cultural daquilo que vem das crianças, como que na proposição de uma cultura à parte para o universo infantil.

No processo contínuo e dinâmico de revisão e atualização da sua obra, Martin-Barbero sugere, adiante, uma abordagem mais abrangente, contextualizada e aprofundada dos processos comunicacionais, a partir da proposição da relação mais ampla entre comunicação, cultura e política, e de uma atenção especial à questão das tecnologias da comunicação, como forma e possibilidade de se compreender e assumir "a complexidade social e perceptiva que hoje reveste as tecnologias comunicacionais, seus modos transversais de presença na cotidianidade, desde o trabalho até o jogo, suas intricadas formas de mediação tanto do conhecimento como da política..." sem ceder, no entanto, aos encantamentos discursivos do fascínio tecnológico ou do domínio mercadológico. Contexto que se apresenta como uma complexa e emaranhada arena de percepções, possibilidades e interesses, e que "exige continuar o esforço por desentranhar a cada dia mais complexa trama de mediações que a relação comunicação-cultura-política articula.” (MARTIN-BARBERO, 2009:12) 
Ao pensar sobre a emergência dos processos e tecnologias comunicacionais na contemporaneidade e o "lugar estratégico que passou a ocupar a comunicação na configuração dos novos modelos de sociedade" - agora em uma visão que, para além da comunicação vista a partir da cultura, visa compreender também a cultura a partir da comunicação: a perspectiva das mediações comunicativas da cultura - o autor aponta para a necessidade de se pensar a comunicação de um modo mais crítico e abrangente, tomada enquanto "a emergência de uma razão comunicacional, cujos dispositivos - a fragmentação que desloca e descentra, o fluxo que globaliza e comprime, a conexão que desmaterializa e hibridiza - agenciam as mudanças do mercado da sociedade.” (MARTIN-BARBERO, 2009:13)

E nesse sentido, talvez seria possível vislumbrar certa conexão ou paralelo entre as perspectivas de midiatização, apresentadas por Couldry, Hepp e Hjarvard, e a das mediações (mediações comunicativas da cultura), proposta por Martin-Barbero. Uma vez que, apesar de suas diferentes posições de abordagem, elas tomam em consideração o lugar estratégico de destaque que as tecnologias da comunicação e os processos comunicacionais passam a ocupar nas sociedades da contemporaneidade. Fenômeno que, em uma proposta mais contextualizada e crítica de reflexão, tomando a cultura a partir da comunicação, Martin-Barbero descreve enquanto "a hegemonia comunicacional do mercado na sociedade." (MARTIN-BARBERO, 2009:13)

No sentido mais amplo da cultura vista a partir da comunicação, e na proposta de uma nova orientação para o estudo das mediações, considerando as muitas e diversas complexidades que se apresentam nas "relações constitutivas entre comunicação, cultura e política", o autor propõe, na abordagem das mediações comunicativas da cultura, uma nova configuração de investigação (MARTIN-BARBERO, 2009:16): 
Figura 1 - Mapa: Mediações Comunicativas da Cultura

MEDIAÇÕES COMUNICATIVAS DA CULTURA

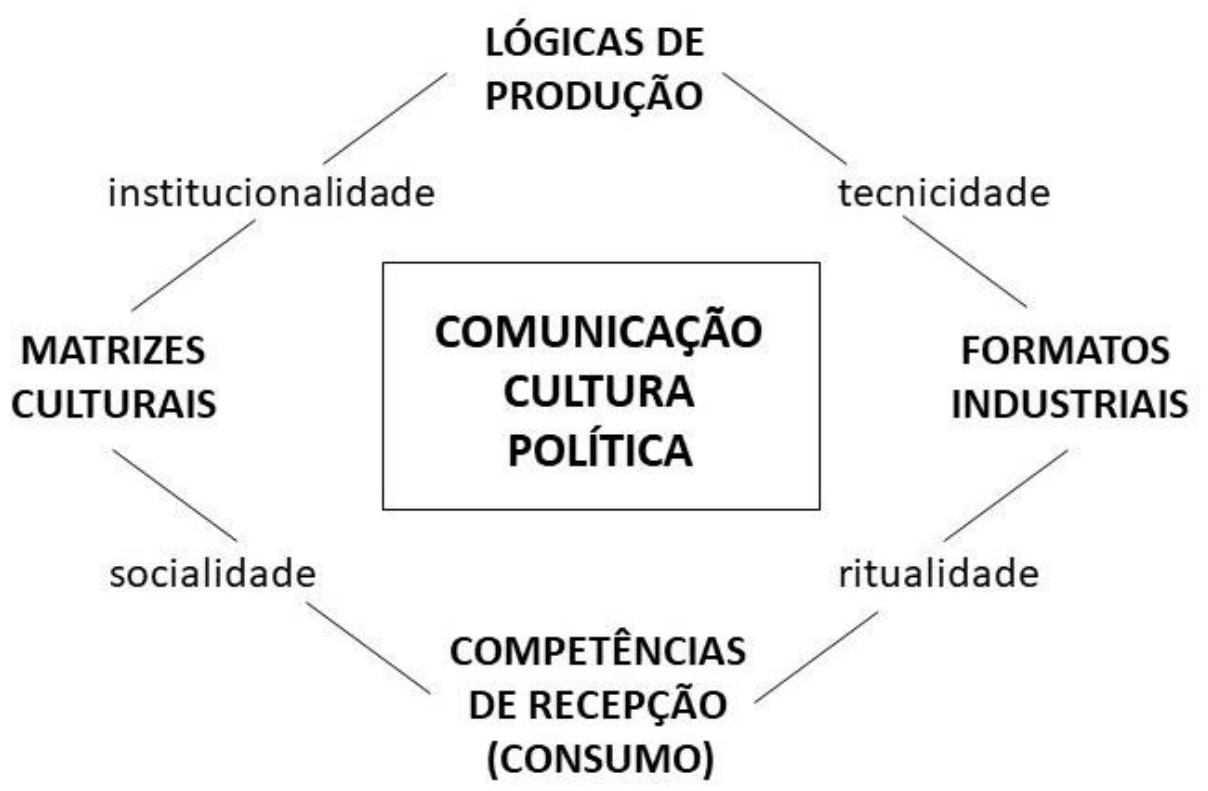

Fonte: elaborado pela autora, com base em Martin-Barbero (2009:16).

Na configuração dada a partir das mediações comunicativas da cultura, no contexto da problemática da relação comunicação-cultura-política, o autor propõe uma leitura em dois eixos: o eixo das mediações entre as matrizes culturais e os formatos industriais e o eixo das mediações entre as lógicas de produção e as competências de recepção ou consumo. Um complexo contexto de relações mediado por diferentes e diversas formas de institucionalidade (na mediação entre as matrizes culturais e as lógicas de produção); de socialidade (na mediação entre as matrizes culturais e as competências de recepção ou consumo); de tecnicidade (na mediação entre as lógicas de produção e os formatos industriais); e de ritualidade (na mediação entre os formatos industriais e as competências de recepção ou consumo). (MARTINBARBERO, 2009:16)

O que busco com esse mapa é reconhecer que os meios de comunicação constituem hoje espaço-chave de condensação e intersecção de múltiplas redes de poder e de produção cultural, mas também alertar, ao mesmo tempo, contra o pensamento único que legitima a ideia de que a tecnologia é hoje o "grande mediador" entre as pessoas e o mundo, quando o que a tecnologia medeia hoje, de modo mais intenso e acelerado, é a transformação da sociedade em mercado, e deste em principal agenciador da mundialização. (MARTIN-BARBERO, 2009:20)

Com o aporte da perspectiva das mediações, como sinalizado inicialmente, e no sentido da proposição de um paralelo para reflexão sobre a temática explorada nesta investigação - 
partindo da nova orientação sugerida para o estudo das mediações na perspectiva da cultura compreendida a partir da comunicação - delineou-se uma configuração específica para a realização das interpretações e análises dos dados e avaliação dos resultados da pesquisa no estudo da mediação comunicacional das marcas na cultura alimentar infantil, com base em uma proposta de articulação entre os eixos de abordagem teórica e empírica definidos para orientação da investigação e a perspectiva das mediações comunicativas da cultura apresentada por Martin-Barbero (MARTIN-BARBERO, 2009:16).

Figura 2 - Mapa: Mediação Comunicacional das Marcas na Cultura Alimentar Infantil

MEDIAÇÃO COMUNICACIONAL DAS MARCAS NA CULTURA ALIMENTAR INFANTIL NA PERSPECTIVA DAS MEDIAÇÕES COMUNICATIVAS DA CULTURA

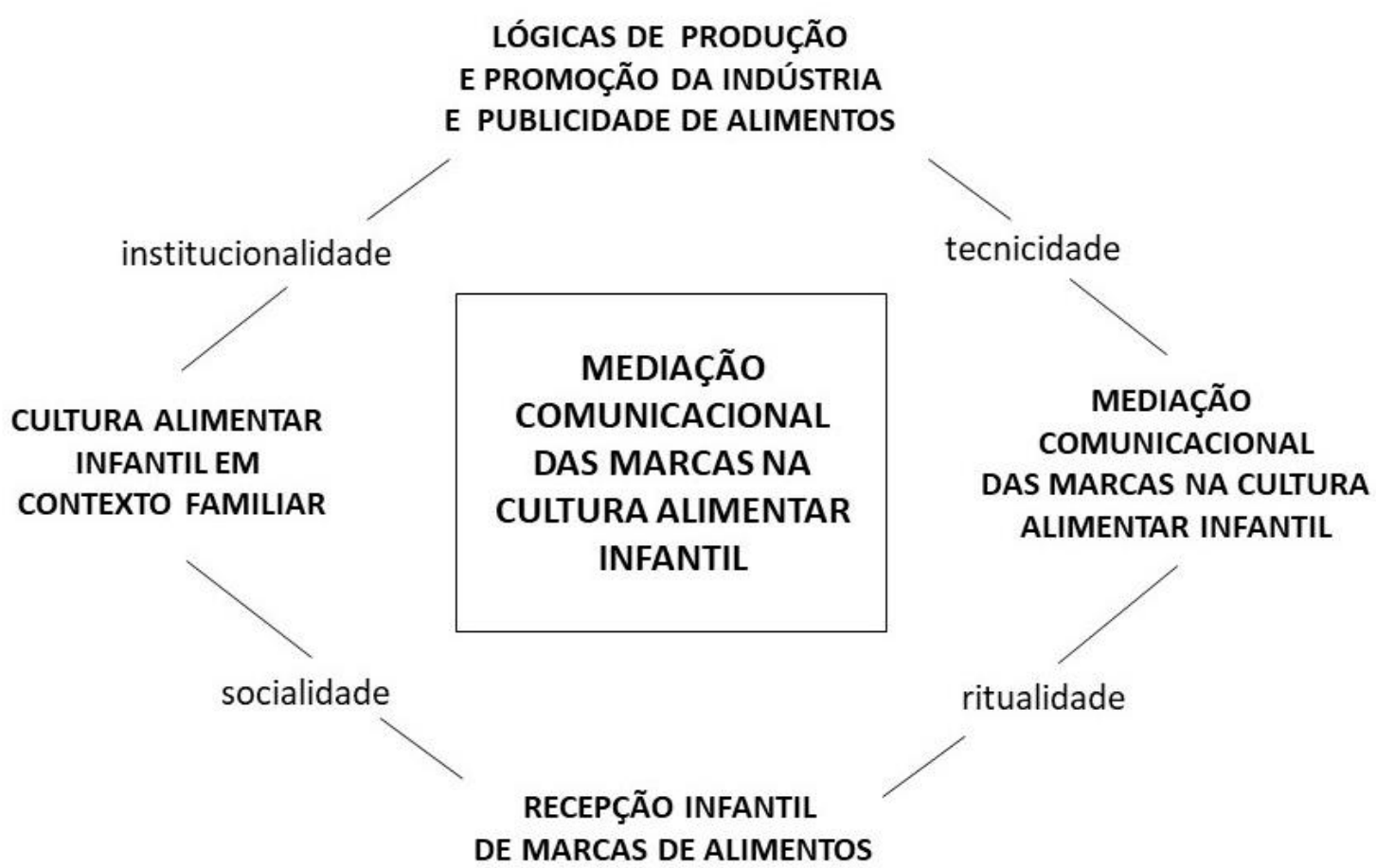

Fonte: elaborado pela autora, com base em Martin-Barbero (2009:16).

Nessa proposta de configuração, no centro do mapa colocou-se a problemática da relação comunicação-cultura-política explorada neste estudo: a mediação comunicacional das marcas na cultura alimentar infantil. E a partir daí, com base nos eixos de abordagem teórica e empírica propostos para orientação da investigação, propôs-se igualmente uma leitura em dois eixos: o eixo das mediações entre as competências de recepção ou consumo e as lógicas de produção e o eixo das mediações entre as matrizes culturais e os formatos industriais. 
No entanto, em uma proposta de exploração do mapa das mediações comunicativas da cultura, como apresentado por Martin-Barbero, de acordo com a perspectiva e recorte deste estudo, faz-se importante observar que a parte superior do mapa - que contempla as lógicas de produção e as mediações entre as lógicas de produção e os formatos industriais (tecnicidade) e entre as lógicas de produção e as matrizes culturais (institucionalidade) - foi explorada no processo de investigação enquanto problemática para contextualização e reflexão a partir do tema de pesquisa proposto. O estudo desenvolvido, tanto nas proposições da pesquisa teórica quanto nas investigações da pesquisa empírica, concentrou-se em explorações dadas a partir da parte inferior do mapa - que contempla as competências de recepção ou consumo e as mediações entre as competências de recepção ou consumo e as matrizes culturais (socialidade) e entre as competências de recepção ou consumo e os formatos industriais (ritualidade).

Nessa direção, as reflexões, interpretações e análises realizadas no processo de investigação concentraram-se em três dos quatro tópicos de observação e análise sugeridos pelo autor, no mapa das mediações comunicativas da cultura:

- $\quad$ As matrizes culturais - que no estudo desenvolvido se apresentam na forma do primeiro eixo de abordagem proposto para orientação da investigação: a cultura alimentar infantil e as mediações culturais e comunicacionais na modulação do consumo alimentar das crianças no contexto familiar.

- Os formatos industriais - que no estudo desenvolvido se apresentam na forma do segundo eixo de abordagem proposto para orientação da investigação: a mediação comunicacional das marcas na cultura alimentar infantil e as marcas e produtos alimentícios no contexto familiar.

- $\quad$ E as competências de recepção ou consumo - que no estudo desenvolvido se apresentam na forma do terceiro eixo de abordagem proposto para orientação da investigação: a recepção infantil de marcas de alimentos e os vínculos de sentidos entre marcas/produtos e crianças no contexto familiar.

O quarto tópico de observação e análise sugerido pelo autor - as lógicas de produção embora não estivessem sinalizadas neste estudo enquanto perspectiva de interpretação e análise, aqui se colocaram enquanto proposta de reflexão no contexto da temática explorada na investigação, tomadas na forma das lógicas contemporâneas de produção e promoção da indústria e publicidade de alimentos no contexto promocional das marcas e produtos alimentícios infantis.

A configuração delineada para o estudo da mediação comunicacional das marcas na cultura alimentar infantil, a partir da proposta de articulação entre os eixos de abordagem teórica 
e empírica definidos para orientação da investigação e o aporte teórico da perspectiva das mediações (no sentido das mediações comunicativas da cultura), será explorada no capítulo seguinte, no momento da interpretação e análise dos dados observados com as crianças em campo nos contextos familiares pesquisados e avaliação dos resultados da pesquisa desenvolvida para exploração da cultura contemporânea de consumo alimentar infantil.

A partir do exposto sobre a perspectiva das mediações proposta por Martin-Barbero que no contexto do estudo desenvolvido, ainda que tomada enquanto visão filosófico-teóricometodológica de base, pretendeu-se em conexão e debate com as perspectivas de midiatização propostas por Couldry, Hepp e Hjarvard - faz-se interessante mencionar a reflexão proposta por Lopes em sua abordagem sobre os estudos comunicacionais latino-americanos na interface com os estudos comunicacionais europeus, sinalizando para a importância e necessidade de uma maior integração entre as diferentes abordagens no debate contemporâneo sobre comunicação:

[...] a perspectiva da mediação tem se imposto no campo da comunicação na América Latina. Com esta definição, devemos explorar e integrar os debates com as recentes tendências europeias sobre a mediação e a midiatização. Vivemos em uma cultura midiatizada que [...] pode ser melhor compreendida através da mediação comunicativa da cultura. É nesta concepção de mediação onde podemos enxergar proximidade com a noção de midiatização. (LOPES, 2014:78)

Perspectiva também compartilhada por Trindade e Perez, ao propor uma reflexão sobre as possibilidades de compreensão do sujeito consumidor no contexto dos estudos sobre comunicação e consumo, considerando-se os diferentes modos de entendimento e abordagem entre o olhar latino-americano das mediações (mediações comunicativas da cultura) e o aspecto nórdico-europeu da midiatização, no sentido de uma possível e rentável interface teórica para o campo dos estudos comunicacionais:

A combinação entre estas abordagens teóricas busca a possibilidade de complementaridade teórico-metodológica para compreender o lugar do sujeito consumidor nos estudos de comunicação e consumo em suas dimensões midiatizadas pelos processos de interação, materializados nas lógicas da criação, da participação, do engajamento de criação e da circulação, dados nas relações e vínculos constituídos entre marcas e consumidores. (TRINDADE;PEREZ,2019:2-3)

Ainda no âmbito da interdisciplinaridade entre a comunicação e os estudos culturais (estudos culturais latino-americanos) e permanecendo no enfoque da perspectiva das mediações, faz-se importante sinalizar, no que tange à fundamentação filosófico-teóricometodológica do estudo desenvolvido, para algumas abordagens propostas sobre consumo e sujeitos consumidores.

Na perspectiva das mediações, o consumo é visto para muito além da simples posse dos objetos, alcançando uma dimensão de uso e forma social, experiência cultural e produção de 
sentidos. Como descreve Martin-Barbero, o consumo não é somente reprodução de forças, "mas também produção de sentidos: lugar de uma luta que não se restringe à posse dos objetos, pois passa ainda mais decisivamente pelos usos que lhes dão forma social e nos quais se inscrevem demandas e dispositivos de ação provenientes de diversas competências culturais.” (MARTINBARBERO, 2009: 292)

Nesse sentido do consumo tomado enquanto experiência cultural e prática social, e que vai além da posse dos objetos, colocam-se também as contribuições de Garcia Canclini que, igualmente na perspectiva das mediações, propõe tomar o consumo em sua dimensão de cidadania.

$\mathrm{O}$ autor observa que o consumo pode ser visto como um processo mais amplo e complexo, para além de uma "relação entre meios manipuladores e dóceis audiências." Pois que, tanto nas relações entre consumidores e produtores, quanto nas relações entre indivíduos e meios, há que se considerar processos de mediação. Como o autor destaca, em muitos dos estudos contemporâneos sobre comunicação de massa tem se mostrado que "a hegemonia cultural não se realiza mediante ações verticais, nas quais os dominadores capturariam os receptores", uma vez que, entre uns e outros, se reconhece a presença de mediadores. E assim, se faz possível não mais "conceber os vínculos entre aqueles que emitem as mensagens e aqueles que as recebem como relações, unicamente, de dominação". (GARCIA CANCLINI, 2010:59-60)

Se, em uma primeira instância, o encantamento dos receptores ou consumidores pode se dar a partir dos apelos emocionais das superproduções criativas da publicidade, em um contexto de consumidores-cidadãos, a publicidade, a comunicação se coloca para além de tal movimento de sedução em seus processos de interação entre produtores e receptores, pois que, como observa o autor: "a comunicação não é eficaz se não inclui também interações de colaboração e transação entre uns e outros." No sentido de que o contexto das mídias, da comunicação, da publicidade e do consumo no mundo contemporâneo já não representa mais um espaço de orientação unilateral, mas sim, "um espaço de interação no qual os produtores e emissores não só devem seduzir os destinatários, mas também justificar-se racionalmente”. (GARCIA CANCLINI, 2010:60-62)

Na proposta de uma relação entre consumo e cidadania, o autor observa que a dimensão de um consumo cidadão começa no momento em que este ultrapassa sua dimensão primeira de irracionalidade, impulso emocional dos desejos, ansiedade por novidades, na direção de algo maior, que vai além, na busca da qualidade, do bem estar, da solidariedade, para uma mudança, transformação - na esfera do individual e do social. A partir daí o consumo ganha nova 
dimensão, uma vez que, reconhecendo-se "que ao consumir também se pensa, se escolhe e reelabora o sentido social, é preciso se analisar como esta área de apropriação de bens e signos intervém em formas mais ativas de participação do que aquelas que habitualmente recebem o rótulo de consumo". O consumo conquista assim, em sua versão de cidadania, uma dimensão reflexiva em seus contextos, suas práticas e finalidades, dando especial sentido à reflexão proposta pelo autor ao sugerir que "devemos nos perguntar se ao consumir não estamos fazendo algo que sustenta, nutre e, até certo ponto, constitui uma nova maneira de sermos cidadãos”. (GARCIA CANCLINI, 2010:42)

No contexto multicultural da comunicação e do consumo no mundo contemporâneo, o autor propõe a reflexão de que se experimenta hoje um cenário de fraturas, segmentações e heterogeneidade, ao mesmo tempo em que fluem múltiplas comunicações e identificações entre indivíduos e grupos a partir de códigos universais da comunicação, da informação, da moda, do conhecimento. Como o autor observa, indivíduos e grupos encontram códigos que lhes unem e lhes permitem mútuo entendimento e comunicação, como que na forma de "pactos móveis de leitura dos bens e das mensagens." (GARCIA CANCLINI, 2010:67)

Nesse mesmo contexto da multiculturalidade, heterogeneidade e universalidade, no entanto, como destaca o autor, é importante observar que os processos de decisão sobre o que consumir, como, quando e onde consumir, e ainda, quem poderá ou não consumir, nem sempre dependem diretamente das necessidades, desejos, escolhas ou decisões dos indivíduos ou grupos de consumidores, uma vez que o planejamento e logística, nos processos de distribuição de bens, quase sempre dependem das grandes estruturas de administração do capital. E nesse sentido, como observa o autor, independentemente de se estar ou não de acordo com os movimentos de seleção de consumos e consumidores, é importante considerar que "as ofertas de bens e a indução publicitária de sua compra não são atos arbitrários”. (GARCIA CANCLINI, 2010:61)

Mas no sentido de um processo contínuo da busca de novas regulações para o mundo contemporâneo, o autor observa que também no contex to do consumo, e especialmente a partir da participação ativa e reflexiva de consumidores-cidadãos, podem se criar e tomar forma tais processos regulatórios. Pois que, "é neste jogo entre desejos e estruturas que as mercadorias e o consumo servem também para ordenar politicamente cada sociedade. O consumo é um processo em que os desejos se transformam em demandas e em atos socialmente regulados." (GARCIA CANCLINI, 2010:65)

A perspectiva das mediações traz importantes abordagens sobre o consumo a partir das contribuições de Martin-Barbero e Garcia Canclini, no sentido de propor compreender o 
consumo em sua dimensão de experiência cultural e prática social, de produção de sentidos, e de cidadania. Tal aspecto se revelou muito importante no processo de investigação desenvolvido com as crianças neste estudo, no sentido de se tomar as crianças não apenas enquanto consumidores, mas também, e especialmente, como sujeitos, produtores de sentidos, consumidores-cidadãos nos cotidianos da cultura contemporânea de consumo alimentar.

Ainda em uma perspectiva de abordagem conceitual sobre o consumo, mas agora sinalizando-se a interdisciplinaridade entre a comunicação e a antropologia no contexto do estudo desenvolvido, a partir da fundamentação filosófico-teórico-metodológica sugerida para orientação da investigação, faz-se importante estabelecer aqui um paralelo com a abordagem antropológica proposta por McCracken, ao tomar o consumo na dimensão de significação cultural.

Assim, McCracken propõe a compreensão de que tudo o que caracteriza o universo do consumo está essencialmente relacionado ao universo da cultura: "Os bens de consumo nos quais o consumidor desperdiça tempo, atenção e renda são carregados de significado cultural.” Os consumidores, como o autor observa, a partir dos usos que fazem dos significados dos bens de consumo, expressam categorias e princípios culturais, cultivam ideias e ideais, criam ou reforçam estilos de vida, constroem noções e significações de si, promovem mudanças sociais, ou ainda, sobrevivem a elas. (MCCRACKEN,2003:11)

Os significados que envolvem os bens de consumo, como observa o autor, encontramse em constante movimento e transformação no mundo cultural, de onde partem tais significados, movendo-se do universo da cultura para o mundo material dos bens de consumo. E destes, são extraídos pelos consumidores em suas práticas e rituais de consumo para a construção e significação de seus mundos individuais e coletivos. (MCCRACKEN, 2003:15)

E nessa perspectiva de uma nova relação entre os indivíduos, o consumo e os objetos materiais no mundo contemporâneo, proposta por McCracken em sua abordagem cultural do consumo, "os bens de consumo têm uma significação que vai além de seu caráter utilitário e de seu valor comercial”. (MCCRACKEN, 2003:99)

Assim, o autor destaca a publicidade como importante canal por meio do qual "o significado está constantemente fluindo, em seu movimento do mundo culturalmente constituído para os bens de consumo". É por meio dos anúncios, das peças e campanhas publicitárias, das diversas estratégias da comunicação e do marketing, que "bens antigos e novos estão constantemente destituindo-se de velhos significados e assimilando outros". (MCCRACKEN, 2003:109) 
Ao mesmo tempo, como destaca o autor, os consumidores se colocam como participantes ativos nesse processo, como presenças essenciais nos movimentos de transferência dos significados dos bens de consumo, originados no mundo culturalmente constituído e dados aí pela ação da publicidade, para os seus universos culturais, individuais e coletivos, nos cotidianos da sua experiência cultural. Somente os consumidores, receptores, são capazes de efetivar essas transferências de significados a partir de suas leituras e de suas práticas e rituais de consumo. E a publicidade se colocaria então para os consumidores como uma espécie de "léxico dos significados culturais correntes". (MCCRACKEN, 2003:109)

E nesse sentido, considerando-se a participação essencial dos consumidores nos movimentos de transferência dos significados dos bens de consumo para o seu universo cultural, como trata McCracken, seria possível estabelecer aqui certa conexão com a abordagem proposta por Garcia Canclini, ao destacar a interação e colaboração necessárias nas dinâmicas e processos de intersecção entre a publicidade e os consumidores, entre os produtores e os receptores, tomados como participantes ativos em um contexto contemporâneo de consumo e cidadania.

Ao considerar a presença marcante do consumo nos movimentos contemporâneos de novas regulações, mudanças e transformações socioculturais, McCracken destaca a importante participação e significado dos bens de consumo nos principais movimentos de transformação da sociedade. Nessa direção, como observa o autor, os bens de consumo, e toda sua carga de significados, "são objetos notórios no processo de autotransformação com o qual o Ocidente está comprometido. São importantes e ubíquos agentes da mudança e da continuidade.” (MCCRACKEN, 2003:164)

Desta forma, os bens de consumo podem protagonizar histórias de mudança, servindo aos indivíduos e grupos engajados como instrumentos-chave, como oportunidades para a contemplação, o debate, a reflexão e a comunicação social de ideais de mudanças e transformações. E assim os bens passam a funcionar, na expressão do autor, como linguagem e discurso entre grupos e sociedade: "o grupo anuncia para um público muito mais genérico sua insatisfação com as convenções existentes e indica, na linguagem dos bens, exatamente quais ideias e valores alternativos pretende defender". (MCCRACKEN, 2003:170-172)

E tomando-se o consumo como possibilidade e participação no contexto de mudanças e transformações das sociedades na contemporaneidade, como propõe McCracken, seria possível, novamente aqui, estabelecer conexão com a abordagem proposta por Garcia Canclini, na perspectiva do consumo tomado como espaço para o exercício da cidadania, pela 
participação ativa e reflexiva de consumidores-cidadãos nos processos socioculturais de novas regulações, mudanças e transformações.

$\mathrm{Na}$ mesma visão antropológica do consumo tomado a partir da cultura e da sociedade, coloca-se a abordagem proposta por Douglas e Isherwood, destacando a necessidade e importância de se "devolver o consumo ao processo social" nas reflexões propostas sobre o consumo no mundo contemporâneo. "A teoria do consumo tem de ser uma teoria da cultura e uma teoria da vida social." (DOUGLAS; ISHERWOOD, 2013:39-41)

Como observam os autores, os bens são codificados para os processos de comunicação, possibilitando que os consumidores se envolvam entre si em uma série de trocas de bens e significações. E no contexto social dos rituais de consumo, os bens se apresentam como formas de marcação, de significação. "O que chamamos de rituais de consumo são as marcas normais da amizade. O fluxo padronizado dos bens de consumo mostra um mapa da integração social.” (DOUGLAS; ISHERWOOD, 2013:39-40)

Tomando o consumo a partir da cultura, em sua essência cultural e social, a abordagem antropológica entende que o valor dos bens só pode ser tomado a partir da captura de todo o “espaço de significação" dos objetos em seus usos e consumos pelos indivíduos em suas comunidades. Nesse sentido, tomando a realidade como dada e acreditando que ela é sempre socialmente construída, a investigação antropológica reconhece que no processo continuo e dinâmico de significação e valoração dos bens, "a construção está em andamento, e as maneiras de construir se tornam canais padronizados de pensamento e atribuem valor a um conjunto padrão de objetos." E que, em outras palavras: "tudo depende de qual maneira as pessoas são organizadas, a comunidade como um todo sendo a caixa de sinais." (DOUGLAS; ISHERWOOD, 2013:41-43)

Como destacam os autores, em uma abordagem cultural e social do consumo, é preciso manter vivo o interesse pelos modos como os consumidores percebem, significam, valorizam e materializam seus usos e consumos dos bens em suas comunidades. Como organizam e justificam suas escolhas em sociedade, nos movimentos e cotidianos da cultura e sociedade. Assim, a cultura é "essencialmente um conjunto de princípios justificadores para reunir apoio e solidariedade, e um conjunto de sinais de 'entrada proibida'. A cultura não depende simplesmente da organização, ela é parte da organização, e fornece as justificativas para limites e controles.” (DOUGLAS; ISHERWOOD, 2013:44)

A perspectiva de abordagem cultural do consumo, proposta por McCrackern, assim como a abordagem do consumo tomada a partir da cultura e sociedade, proposta por Douglas e Isherwood, trouxeram importantes contribuições ao estudo desenvolvido com as crianças, 
possibilitando a observação, descrição, interpretação e análise dos processos de recepção infantil das marcas de alimentos no contexto do consumo alimentar a partir do contexto das significações culturais e práticas sociais de consumo das crianças nos cotidianos de seus contextos familiares.

Ainda em uma visão antropológica de abordagem sobre o consumo, mas agora tomandoo em sua dimensão de cultura material, coloca-se a abordagem proposta por Miller (2007). O autor traz importantes contribuições na proposta de uma abordagem sobre o consumo dada a partir da cultura material e tenta demonstrar a importância de uma perspectiva material de cultura para o estudo do consumo e atenta para a necessidade de se reconhecer "o quanto várias outras abordagens do consumo são fundadas sobre um peculiar preconceito antimaterial." (MILLER, 2007:34)

A maioria dos estudos acadêmicos desenvolvidos no âmbito de uma teorização sobre o consumo, como observa o autor, parecem reduzir a vasta escala e o materialismo que o caracterizam a uma simples percepção do consumo de massa. A partir daí, o consumo passa a ser percebido como uma espécie de mal, como um perigo para a sociedade moderna e contemporânea, deixando-se de lado a percepção de que a presença do consumo poderia representar também uma tentativa de se abolir a pobreza e conquistar o desenvolvimento econômico e social.

\footnotetext{
A razão pela qual os estudos do consumo adotaram esse aspecto inusitadamente moral ou normativo comparado com o estudo da maioria dos outros fenômenos modernos, no entanto, não é necessariamente resultado de algum atributo do próprio consumo de massa. A percepção do consumo como uma atividade maligna ou anti-social é bem mais profunda e existia muito antes do consumo de massa moderno. O próprio termo "consumo" sugere que o problema é um tanto intrínseco à atividade. Consumir algo é usar algo, na realidade, destruir a própria cultura material. (MILLER, 2007:34)
}

Nesse sentido, pode-se observar que, em grande parte da literatura acadêmica sobre o consumo, há uma noção de que a cultura das mercadorias veio contaminar as relações sociais entre indivíduos antes considerados puros, como se um apego aos objetos viesse tomar o lugar do apego às pessoas. E um dos principais problemas que se colocam a partir de tal postura acadêmica tomada como representação do consumo, como ressalta o autor, é o fato de aí não haver o reconhecimento de que: "nós vivemos num tempo no qual a maior parte do sofrimento humano é ainda o resultado direto da falta de bens. Há continentes inteiros, tal como a África, onde a vasta maioria das pessoas desesperadamente precisa de mais consumo." Uma perspectiva negativa de crítica ao consumo que o autor destaca até mesmo como uma forma de negação da condição de pobreza enquanto uma das importantes causas do sofrimento humano.

(MILLER, 2007:38) 
Complementando sua reflexão, no entanto, o autor propõe que, na prática, seria possível uma conciliação entre as diferentes visões teóricas sobre o consumo. Pois que, "o desejo de dar crédito à maneira como os consumidores consomem e à autenticidade de alguns de seus desejos por bens não precisa diminuir o valor da crítica acadêmica da maneira como as companhias tentam vender bens e serviços, ou explorar os trabalhadores ao fazê-lo." E nesse sentido, como ressalta o autor, “é bem possível adotar uma aceitação dos bens como potencialmente um aspecto integral da humanidade moderna sem na verdade contradizer as doutrinas de alguns dos mais estridentes críticos.” (MILLER, 2007:38-39)

Na contrapartida das teorizações de base moralista e antimaterialista, Miller propõe uma abordagem antropológica do consumo a partir da cultura material. "Estudos de cultura material trabalham através da especificidade de objetos materiais para, em última instância, criar uma compreensão mais profunda da especificidade de uma humanidade inseparável de sua materialidade.” (MILLER, 2007:47)

Enquanto o consumo era tomado como expressão maior do capitalismo, como o ponto final no processo de exploração iniciado na produção de bens para venda e lucro, Miller propôs uma leitura diferente, sugerindo que o consumo poderia ser percebido também como uma forma de negação da produção capitalista, argumentando que "o consumo retornava os bens para a criação da especificidade e das relações depois de extraí-los das condições anônimas e alienadas de sua produção.” E o autor observa que essa teorização se colocaria sobre um pano de fundo datado em que "a antropologia era dominada por uma versão particular do marxismo que havia levado a um foco exclusivo na produção e nos bens como expressões do capitalismo.” (MILLER, 2007:47)

Nesse sentido, segundo o autor, todos os esforços paralelos de se tentar teorizar o consumo para além do moralismo e antimaterialismo contribuíram para liberá-lo da obrigação de ser caracterizado tão somente como expressão do capitalismo, permitindo-o retomar a sua especificidade, o que, em muitos aspectos, significou também "uma volta à sua materialidade", uma vez que, como destaca o autor, "se a teoria deveria ter algum uso substantivo, este sugeria que havia muitas maneiras diferentes pelas quais o consumo poderia se manifestar enquanto produção de grupos sociais, e que esses tinham de ser examinados cada um de seu jeito.” (MILLER, 2007:48)

O autor observa que, dentre os diferentes modos de se pesquisar e teorizar o consumo a partir dessa nova visão, destaca-se a contribuição dos estudos dados a partir da cultura material, especialmente aqueles desenvolvidos sobre categorias específicas de objetos em seus usos e consumos (como a casa, o vestuário, a mídia, o carro). Trabalhos que em muito têm contribuído 
para um referencial teórico mais amplo sobre o consumo na contemporaneidade. (MILLER, 2007:48)

Nesse sentido, Miller argumenta que muitos dos trabalhos mais recentes e importantes sobre o consumo na perspectiva da cultura material tem se preocupado, acima de tudo, com questões teóricas e analíticas que podem ser aplicadas a qualquer tipo de "sujeito materializado" ou “objeto personalizado." (MILLER, 2007:51)

Os estudos mais recentes sobre consumo e cultura material têm suas bases dadas a partir de duas tendências principais de investigação: por um lado, as abordagens que visam reconciliar as relações entre produção e consumo; por outro, as abordagens que valorizam as cadeias de mercadorias e suas possibilidades de relações. (MILLER, 2007:51-52)

E nessa direção, o autor atenta para a importância de se considerar a conexão essencial entre essas abordagens, especialmente para os novos estudos desenvolvidos sobre o consumo a partir da perspectiva da cultura material, uma vez que o consumo traz em si, intrinsecamente, essas diversas dimensões (produção e consumo, objetos e pessoas, mercadorias e relações, materialidade e humanidade). Novas abordagens que se colocam "na vanguarda de tais estudos da cultura material, em parte porque rearticulam a ligação com a produção e a troca e em parte porque levam a repensar a materialidade de volta a uma consideração sobre a natureza da humanidade dentro de uma sociedade consumidora.” (MILLER, 2007:48)

Finalizando sua proposta de reflexão, o autor observa que tais estudos vem demonstrar o quanto "uma abordagem genuína de cultura material ao consumo começa e termina com uma compreensão intensificada e não reduzida da humanidade, ao reconhecer também a sua materialidade intrínseca.” (MILLER, 2007:53)

As importantes reflexões propostas por Miller também trouxeram contribuições significativas para o desenvolvimento deste estudo, especialmente ao propor uma abordagem antropológica do consumo a partir de uma perspectiva da cultura material. Este aspecto possibilitou uma abordagem do consumo alimentar infantil que não mantenha suas bases em uma crítica moralista sobre a mediação comunicacional das marcas e produtos alimentícios nos cotidianos da cultura alimentar das crianças, mas sim, uma leitura atenta e reflexiva sobre as dimensões materiais e humanas intrínsecas aos contextos, cotidianos e significações da cultura de consumo alimentar infantil no mundo contemporâneo.

$\mathrm{Na}$ interface da comunicação com a antropologia, como proposto no percurso filosóficoteórico-metodológico sugerido para a orientação da investigação - desde a perspectiva da antropologia da cultura, na abordagem interpretativa das culturas proposta por Geertz (2013), à perspectiva da etnografia e dos métodos e técnicas dos estudos etnográficos, como tratado em 
Ribeiro (2003), considerando-se as abordagens antropológicas sobre consumo, cultura e sociedade propostas em McCracken (2003) e Douglas e Isherwood (2013) e a abordagem proposta por Miller (2007) sobre consumo e cultura material (como aqui apresentadas no contexto comparativo entre abordagens sobre o consumo), e ainda a perspectiva de abordagem da antropologia da criança, como proposta por Cohn (2005) - é importante observar que os investimentos teórico-metodológicos da antropologia possibilitaram significativas contribuições para o desenvolvimento deste estudo.

Especialmente no desenho de uma investigação desenvolvida junto aos sujeitosreceptores-consumidores (as crianças) nos cotidianos das suas experiências culturais e práticas sociais (a cultura de consumo alimentar infantil no contexto familiar), permitindo, a partir da proposta de um estudo de inspiração etnográfica no campo da comunicação, dado no sentido de uma descrição densa para interpretação das culturas (GEERTZ, 2013:3-21), a observação, descrição, interpretação e análise dos processos de recepção infantil de marcas de alimentos na cultura contemporânea de consumo alimentar das crianças.

No contexto da interpretação das culturas, como apresentado por Geertz, a cultura é tomada em sua dimensão de significação, a emaranhada rede dos significados culturalmente e socialmente construídos por indivíduos e coletividades. E assim, como destaca o autor, uma proposta antropológica de abordagem para interpretação das culturas se colocaria "não como uma ciência experimental em busca de leis, mas como uma ciência interpretativa, à procura do significado." (GEERTZ, 2013:4)

Nesse sentido da cultura tomada enquanto processo contínuo de significação (e ressignificação) o autor atenta para a importância de se buscar uma interpretação da cultura como contexto, em toda sua pluralidade de experiências culturais e práticas sociais em suas múltiplas significações:

Como sistemas entrelaçados de signos interpretáveis (...), a cultura não é um poder, algo ao qual podem ser atribuídos casualmente os acontecimentos sociais, os comportamentos, as instituições ou os processos; ela é um contexto, algo dentro do qual eles podem ser descritos de forma inteligível - isto é, descritos com densidade. (GEERTZ, 2013:10)

Como assinala o autor, se a proposta de uma interpretação antropológica da cultura é construir uma leitura do que acontece na cultura, é essencial que esta leitura seja dada no lugar, no momento, no acontecimento. De outro modo, a leitura se torna vazia, pois que: "uma boa interpretação de qualquer coisa - um poema, uma pessoa, uma estória, um ritual, uma instituição, uma sociedade - leva-nos ao cerne do que nos propomos interpretar." (GEERTZ, 2013:13) 
No entanto, como o autor também observa, uma abordagem interpretativa da cultura dada nos movimentos contínuos e dinâmicos das culturas e sociedades - é sempre, por essência, imprecisa e incompleta. "A antropologia, ou pelo menos a antropologia interpretativa, é uma ciência cujo progresso é marcado menos por uma perfeição de consenso do que por um refinamento de debate." (GEERTZ, 2013:20)

Nesse contexto de incertezas e incompletudes da antropologia, em uma clara exposição sobre a importância da etnografia no âmbito dos estudos antropológicos, o autor destaca que para que se possa compreender a antropologia enquanto ciência, faz-se essencial que o olhar se volte para os praticantes desta ciência: os pesquisadores em campo no exercício da etnografia. Pois que, somente a partir de um olhar atento às práticas da etnografia, "é que se pode começar a entender o que representa a análise antropológica como forma de conhecimento." (GEERTZ, 2013:4)

Como descreve o autor ao caracterizar a etnografia, ele a define como uma "descrição densa" para interpretação das culturas, o que requer do pesquisador em campo um certo investimento de sensibilidade e intelectualidade no seu fazer etnográfico. Desta forma, em campo, em sua construção de uma leitura sobre o que acontece na cultura, o etnógrafo tem de enfrentar "uma multiplicidade de estruturas conceptuais complexas, muitas delas sobrepostas ou amarradas umas às outras, que são simultaneamente estranhas, irregulares e inexplícitas, e que ele tem de, de alguma forma, primeiro apreender e depois apresentar.” (GEERTZ, 2013:7)

O fazer etnográfico, assim, se propõe a uma descrição densa da cultura, elaborada a partir do olhar, da construção de uma leitura sobre o que acontece na cultura, ainda que tudo seja estranho ao próprio olhar. "Fazer a etnografia é como tentar ler (...) um manuscrito estranho, desbotado, cheio de elipses, incoerências, emendas suspeitas e comentários tendenciosos, escritos não com os sinais convencionais do som, mas com exemplos transitórios de comportamento modelado.” (GEERTZ, 2013:7)

Ao caracterizar a etnografia enquanto materialização da prática da ciência da antropologia, o autor destaca a imprescindibilidade e importância do trabalho de campo no contexto dos estudos antropológicos, especialmente em se tratando das propostas de abordagem interpretativa das culturas. Somente em campo, no lugar onde a cultura acontece, é que se faz possível a construção de uma leitura sobre a cultura, na proposta de uma densa descrição para sua interpretação. (GEERTZ, 2013:3-21)

Nesse sentido, enquanto proposta de uma abordagem de inspiração etnográfica para exploração da mediação comunicacional das marcas na cultura alimentar infantil, a perspectiva filosófico-teórico-metodológica delineada para orientação deste estudo - especialmente na 
interface da comunicação com a antropologia - se aproxima consideravelmente da perspectiva antropológica interpretativa da cultura, como apresentada por Geertz. Pois que, a partir daí, pode-se dizer que o estudo desenvolvido se propôs à construção de uma leitura e densa descrição para interpretação dos processos de recepção infantil de marcas de alimentos no contexto da cultura contemporânea de consumo alimentar das crianças.

Como investigação de inspiração etnográfica no campo da comunicação, e tomando-se a dimensão primeira que constitui a experiência em campo na caracterização dos estudos etnográficos, o estudo desenvolvido procurou dar forma à pesquisa a partir do trabalho de campo com as crianças em seus contextos familiares, nos cotidianos da sua cultura de consumo alimentar - como sinalizado na apresentação dos procedimentos metodológicos do estudo, uma vez que, a apreensão das práticas culturais dá-se verdadeiramente no interior de seus contextos, pelo olhar daqueles que vivenciam a cultura, mais do que pelo olhar daqueles que observam, em contínua interação e negociação entre observadores e observados. Assim, como proposto por Ribeiro $(2003: 63,67)$. - Ou ainda, no lugar onde a cultura acontece, como poderia se dizer em um paralelo com a abordagem interpretativa da cultura proposta por Geertz (2013).

$\mathrm{Na}$ visão antropológica de uma abordagem exploratória, partindo do desenvolvimento progressivo do trabalho de campo à gradativa construção teórica do conhecimento - no contexto do estudo desenvolvido enquanto investigação de inspiração etnográfica no campo da comunicação - o objeto comunicacional foi assim tomado de sua dimensão empírica à dimensão teórica, em perspectiva etnográfica, etnológica e antropológica de interpretação e análise como também sinalizado na apresentação dos procedimentos metodológicos do estudo. Assim, desde a materialidade primeira das observações e descrições em campo, seguindo-se às primeiras sínteses e interpretações, até alcançar as abstrações maiores de um saber teórico construído a partir das interpretações, análises e fundamentações. (RIBEIRO, 2003:125,145146,227-229).

Considerando-se a dimensão da escrita, a composição dos textos antropológicos no sentido da abordagem interpretativa da cultura, o texto antropológico constitui em si mesmo uma forma secundária de interpretação. Pois que, as leituras construídas pelos pesquisadores em campo, em seus fazeres etnográficos, serão sempre leituras sobre a cultura. Cultura que somente pode ser vivida pelos que integram os significados e cotidianos dessa cultura. (GEERTZ, 2013:11)

Como destaca o autor, a descrição etnográfica caracteriza-se especialmente como a inscrição de uma interpretação do fluxo do discurso social, na tentativa de salvá-lo da sua possibilidade de extinção e fixá-lo em formas e estruturas próprias para seu registro e pesquisa. 
"O etnógrafo inscreve o discurso social: ele o anota. Ao fazê-lo, ele o transforma de acontecimento passado, que existe apenas em seu próprio momento de ocorrência, em um relato, que existe em sua inscrição e que pode ser consultado novamente." (GEERTZ, 2013: 14-15)

Nesse sentido, considerando-se toda a amplitude e abrangência conceitual da etnografia, em suas múltiplas possibilidades de práticas e reflexões, desde as vivências e experiências em campo até os registros e relatos escritos, elaborados a partir das observações, descrições e interpretações dadas em campo, vale destacar - como igualmente sinalizado na apresentação dos procedimentos metodológicos do estudo - que a perspectiva de inspiração etnográfica da investigação procurou se fazer presente também no momento da construção de sua escrita, na proposta de um ensaio ou tentativa para a produção de uma escrita etnográfica. Uma escrita a partir do campo, a escrita do olhar, a "escrita da cultura". Na transformação do olhar em linguagem e na tradução do que é visível ao que pode se tornar dizível e legível. (LAPLANTINE apud RIBEIRO, 2003:230)

No entanto, tal investimento metodológico exige toda atenção, vigilância, criatividade e reflexividade do pesquisador, desde as observações e interpretações em campo até a produção escrita. Na interpretação do que vê, mas também na reflexão sobre sua participação naquilo que vê, tomando-se o contexto da pesquisa como um todo e a relação que o pesquisador estabelece com aqueles que observa. Na produção de uma escrita para contemplação e registro do percurso de um conhecimento construído, desde a descrição etnográfica em campo, e a interpretação etnológica, até o nível teórico de um saber antropológico. A transformação e organização textual da experiência visual. A tradução do olhar em escrita. (RIBEIRO, 2003:226-233)

$\mathrm{Na}$ interface da comunicação com a antropologia, especialmente na perspectiva da etnografia, é importante sinalizar que contribuições significativas para o desenvolvimento deste estudo foram dadas a partir das abordagens propostas por Geertz e Ribeiro. Tanto na dimensão conceitual de uma proposta de interpretação das culturas infantis no âmbito da cultura contemporânea de consumo alimentar das crianças quanto na dimensão metodológica dos trabalhos etnográficos desenvolvidos com as crianças em campo, nos contextos familiares pesquisados, e ainda na tentativa de produção de uma escrita etnográfica para relato e documentação do estudo.

Na perspectiva da etnografia, especialmente em se tratando de uma investigação de inspiração etnográfica desenvolvida com crianças, nos cotidianos das práticas de consumo alimentar infantil no contexto familiar, faz-se importante sinalizar, novamente aqui, que o 
estudo desenvolvido foi realizado com a participação das crianças em campo, tomando as crianças como informantes e participantes no processo de investigação.

Nesse sentido - ainda na interface proposta entre comunicação e antropologia contribuição importante para este estudo deu-se a partir das reflexões propostas por Clarice Cohn, com base em seus estudos desenvolvidos sobre o que a autora propõe como uma "antropologia da criança":

\begin{abstract}
Precisamos nos fazer capazes de entender a criança e seu mundo a partir do seu próprio ponto de vista. E é por isso que uma antropologia da criança é importante. Ela não é a única disciplina científica que elege esse objeto de estudo [...] Mas é aquela que, desde seu nascimento, se dedica a entender o ponto de vista daqueles sobre quem e com quem fala, seus objetos de estudo. (COHN, 2005:08)
\end{abstract}

A antropologia da criança é uma proposta de abordagem antropológica que procura tomar as crianças como participantes no processo de investigação, como sujeitos ativos e participativos, capazes de expressar por si suas experiências, perspectivas, saberes e afetos, suas vivências cotidianas como sujeitos que tomam parte na cultura e sociedade. As crianças tomadas como sujeitos plenos, atores sociais e produtores de cultura. (COHN, 2005)

Como explica Cohn, a antropologia da criança pode se dedicar tanto ao estudo de crianças de diferentes culturas e sociedades quanto a estudos sobre crianças em contextos urbanos da contemporaneidade, procurando sempre conhecê-las de perto, observá-las e perceber seu ponto de vista sobre o mundo. "Fazer antropologia é tentar entender um fenômeno em seu contexto social e cultural. É tentar entendê-lo em seus próprios termos." (COHN, 2005:09)

Para além de possibilitar um modelo analítico que permite investigar e conhecer as crianças por si mesmas, a antropologia oferece aos pesquisadores uma metodologia que torna possível a coleta de dados sobre as crianças em seus contextos culturais, especialmente a partir da etnografia: "entendendo ser esse o melhor meio de entendê-las em seus próprios termos porque permite uma observação direta, delas e de seus afazeres, e uma compreensão de seu ponto de vista sobre o mundo em que se inserem". Pois que, como complementa a autora em sua reflexão, "usando-se da etnografia, um estudioso das crianças pode observar diretamente o que elas fazem e ouvir delas o que têm a dizer sobre o mundo. (COHN, 2005:09-10)

Uma questão importante no contexto dos estudos desenvolvidos na temática da infância, e que também se faz presente no conjunto das principais dificuldades encontradas pela antropologia no estudo das crianças, trata do desafio proposto ao se tentar "reconhecer na criança um objeto legítimo de estudo". Como observa Cohn, no campo dos estudos científicos sobre crianças, ainda se faz presente o entendimento de que elas são "seres incompletos" 
carentes de formação e socialização. (COHN, 2005:10) Somente nas últimas décadas é que as crianças começaram a ganhar espaço e legitimidade em estudos acadêmicos e científicos sobre temáticas relacionadas a elas. E a partir daí, "algo que não é menos importante: começou-se a perceber na criança um sujeito social." (COHN, 2005:10-11)

Começa então a surgir uma nova linha de investigação, destacada pela autora como uma "nova antropologia da criança", (COHN, 2005:18-20) que se dá a partir do engajamento da antropologia na avaliação e revisão de conceitos centrais em seus processos de investigação, tais como os conceitos de cultura, sociedade e agência, que passam a ser percebidos como fenômenos mais amplos, dinâmicos, em constante movimento, e considerando-se neles a participação ativa dos sujeitos em ação. Uma revisão de conceitos-chave da antropologia que permite e possibilita uma nova visão sobre as crianças: "ao contrário de seres incompletos, treinando para a vida adulta, encenando papéis sociais enquanto são socializados ou adquirindo competências e formando sua personalidade social, passam a ter um papel ativo na definição de sua própria condição." As crianças tomadas como "seres sociais plenos" e que assim conquistam sua "legitimidade como sujeitos" nos estudos desenvolvidos sobre elas. (COHN, 2005:21)

Outra questão fundamental para as pesquisas desenvolvidas com crianças, ou sobre crianças, trata da definição dos conceitos de criança e de infância, uma vez que são conceitos plurais, em constante movimento, e que resultam de processos históricos e socioculturais de construção. E nesse sentido, Cohn atenta para a importância dos conceitos de criança e de infância para a antropologia: "Falamos aqui de uma antropologia da criança e não da infância. Isso porque a infância é um modo particular, e não universal, de pensar a criança.” (COHN, 2005:21) Em uma visão plural sobre crianças e infâncias, como destaca a autora em sua proposta de reflexão, é importante considerar que a ideia ou conceito de infância, em outras culturas e sociedades, pode ser diferente, ou mesmo inexistente. "O que é ser criança, ou quando acaba a infância, pode ser pensado de maneira muito diversa em diferentes contextos socioculturais, e uma antropologia da criança deve ser capaz de apreender essas diferenças." (COHN, 2005:22)

Mesmo nas sociedades ocidentais contemporâneas, é importante ressaltar, as noções de criança e de infância estão sempre em movimento, em processos contínuos de construção e reconstrução histórica e sociocultural: "Portanto, mesmo uma antropologia da criança que seja feita em uma realidade sociocultural muito próxima à do antropólogo não pode prescindir de uma reflexão sobre o que é ser criança nesse contexto, e de que infância se está falando.” (COHN, 2005: 26) E nesse sentido, faz-se essencial considerar: "embora se possa pensar que 
haja uma tradição ocidental definidora da infância, seu estatuto pode ser um debate contemporâneo e às vezes acirrado.” (COHN, 2005:27)

Nesse sentido, duas concepções são especialmente importantes na abordagem de uma antropologia da criança, como apresenta a autora: a criança atuante e a criança como produtora de cultura. A criança atuante tem papel ativo "na constituição das relações sociais em que se engaja”. E nesse sentido:

Reconhecê-lo é assumir que ela não é um 'adulto em miniatura', ou alguém que treina para a vida adulta. É entender que, onde quer que esteja, ela interage ativamente com os adultos e as outras crianças, com o mundo, sendo parte importante na consolidação dos papéis que assume e de suas relações. (COHN, 2005:27-28)

A criança como produtora de cultura é uma noção que passa a tomar forma a partir do momento em que a cultura passa a ser entendida como um sistema simbólico de significações e sentidos. Para além das questões sobre como e quando uma cultura é transmitida, uma perspectiva que toma a criança como produtora de cultura está atenta a questionar de que modo a criança formula um sentido para o mundo. E a partir daí: "a diferença entre as crianças e os adultos não é quantitativa, mas qualitativa; a criança não sabe menos, sabe outra coisa." Nesse sentido, questão importante para a antropologia "não é saber em que condição cognitiva a criança elabora sentidos e significados, e sim a partir de que sistema simbólico o faz". (COHN, 2005:33-34)

A partir daí, as crianças deixam de ser percebidas apenas como passivamente produzidas pela cultura e passam a ser percebidas também como ativamente produtoras de cultura. Mas as crianças tomadas em um mesmo contexto em que se colocam os adultos e a sociedade da qual fazem parte, como ressalta Cohn, e não em uma cultura infantil à parte:

Elas elaboram sentidos para o mundo e suas experiências compartilhando plenamente de uma cultura. Esses sentidos tem uma particularidade, e não se confundem e nem podem ser reduzidos àqueles elaborados pelos adultos; as crianças tem autonomia cultural em relação ao adulto. Essa autonomia deve ser reconhecida, mas também relativizada. (COHN, 2005:35)

E aprofundando sua perspectiva de reflexão, a autora observa que a autonomia cultural das crianças, ainda que legítima e reconhecida, deve ser interpretada como "uma relativa autonomia cultural". Pois que na verdade, "os sentidos que elaboram partem de um sistema simbólico compartilhado com os adultos. Negá-lo seria ir de um extremo ao outro; seria afirmar a particularidade da experiência infantil sob o custo de cunhar uma nova, e dessa vez irredutível, cisão entre os mundos." Ou em síntese: "seria tornar esses mundos incomunicáveis." (COHN, 2005:35) 
Desse modo, no processo de se perceber as crianças como produtoras de cultura, é importante atentar para o cuidado em não se passar a percebê-las como produtoras de uma cultura à parte da cultura, como que se vivessem em um mundo separado do mundo dos adultos. "Falar de culturas infantis, portanto, é mais adequado; mas devemos, ainda assim, fazê-lo com cuidado, para não incompatibilizar o que as crianças fazem e pensam com aquilo que outros, que compartilham com ela uma cultura mas não são crianças, fazem e pensam." (COHN, 2005:36)

Em suas reflexões propostas sobre a antropologia da criança, Cohn destaca que crianças e infâncias têm se tornado objeto de estudo em diversos campos do conhecimento - como no caso desta investigação de inspiração etnográfica desenvolvida com crianças no campo da comunicação - e atenta para a importância de que constantemente sejam exploradas possibilidades de diálogo entre a antropologia e essas diferentes áreas de investigação. (COHN, 2005:41) Assim, nessa interface, tanto a antropologia como os demais campos do conhecimento são beneficiados: "como recentemente a própria antropologia ganhou, com o reconhecimento da criança como sujeito social ativo e atuante, produtor mais que receptor de cultura." (COHN, 2005:42)

Como sinalizado, a antropologia da criança não tem se dedicado somente ao estudo de crianças de outras culturas e sociedades, ou de outros tempos ou historicidades, mas também ao estudo de crianças de contextos socioculturais contemporâneos, bem próximos das realidades vividas por seus pesquisadores. E nesse sentido, como ressalta a autora, é importante observar que ambos os contextos de pesquisa representam desafios para os seus pesquisadores: "para um, tudo é estranho e deve ser aprendido e apreendido de modo amplo para começar a fazer sentido; para outro, tudo parece normal e conhecido, e ele deve ser capaz de rever e reaprender o que lhe parece tão natural." (COHN, 2005:49)

E na proposta de uma antropologia da criança, seria interessante finalizar a exposição do pensamento da autora com uma última reflexão acerca da importância do olhar do pesquisador sobre o contexto sociocultural em que se colocam as crianças em suas culturas infantis: "porque não há imagem produzida sobre a criança e a infância, ou pela criança, que não seja, de algum modo, produto de um contexto sociocultural e histórico específico, do qual o antropólogo deve dar conta." (COHN, 2005:50)

No aspecto dos estudos etnográficos com crianças, Cohn trouxe contribuições importantes para o contexto deste estudo, especialmente no enfoque antropológico específico proposto, na perspectiva de uma antropologia da criança. Uma vez que o estudo desenvolvido propôs-se a uma investigação sobre os processos de recepção infantil de marcas de alimentos 
no âmbito das práticas de consumo alimentar das crianças em seus contextos familiares, tomando as crianças como informantes e participantes no processo de investigação.

Na mesma visão, em que as crianças são tomadas como sujeitos plenos, atores sociais e produtores de cultura - e agora sinalizando-se a interface da comunicação com a sociologia (sociologia da infância) no contexto do desenvolvimento deste estudo - colocam-se propostas de abordagem marcadas pela perspectiva da construção histórica e sociocultural dos conceitos de criança e de infância; da relação das crianças com as tecnologias e mídias, a publicidade e o consumo; e da noção de infância como cidadania e participação ativa das crianças na cultura e sociedade. Perspectivas sociológicas sobre crianças e infâncias, abordadas aqui com base em algumas das explorações teóricas realizadas para fundamentação do estudo desenvolvido anteriormente (BAADER, 2013), somadas às novas explorações filosófico-teóricometodológicas desenvolvidas para o aprofundamento e refinamento do estudo neste processo de investigação.

Nesse sentido, no percurso filosófico-teórico-metodológico sugerido para orientação da investigação, outra importante contribuição para este estudo deu-se a partir das propostas de abordagem da sociologia da infância - especialmente no sentido de uma nova sociologia da infância (CORSARO, 2011; 2005; PROUT, 2010a; 2010b; SARMENTO, 2008a; 2008b), uma vez que a sociologia da infância trata da constituição de um enfoque específico no campo da sociologia para o estudo da infância, em seus diferentes e diversos contextos sociais, a partir de perspectivas históricas e culturais de investigação, considerando-se as crianças em suas culturas infantis, nos contextos familiares, na cultura de pares (ou em suas relações com as tecnologias, as mídias, a publicidade, o consumo), no complexo contexto das mudanças e transformações da cultura e sociedade. E considerando-se aí as problemáticas sociais e políticas públicas para as crianças e a infância na contemporaneidade. (CORSARO, 2011:09-12)

Perspectiva sociológica de investigação sobre a infância que busca tomar em conta as especificidades e desafios que caracterizam os estudos etnográficos com crianças em campo, na proposta de se desenvolver pesquisas com crianças e não apenas sobre crianças. (CORSARO, 2005:443-446) E ainda, atentando para a necessidade de se lançar em investigações mais abertas e atentas aos movimentos, instabilidades, hibridismos, mobilidades, mediações, mudanças e transformações da sociedade e da infância enquanto fenômeno social contemporâneo. (PROUT, 2010b:729-730)

A sociologia da infância, constituindo-se como campo específico de aplicação da sociologia para o estudo da infância, tomando as crianças como objeto de estudo e colocando a infância no centro das reflexões e investigações das ciências sociais, compõe-se na estruturação 
do campo interdisciplinar dos estudos da infância, na proposta de um espaço teórico e empírico de diálogo com as ciências que tomam por objeto a investigação e o conhecimento dos mundos sociais e culturais das crianças, a exploração das culturas infantis. (SARMENTO, 2008b:3233)

Na perspectiva sociológica da construção histórica e sociocultural dos conceitos de criança e de infância, é importante considerar que tais definições ou representações materializam conceitos ou ideias em movimento, construção e contínua transformação, ressignificação. Como sinaliza Buckingham, para muito além de uma definição ou conceito fechado em si mesmo, a noção de infância não pode ser tomada enquanto absoluta ou universal, mas como relativa e diversa, assumindo formas diferentes em contextos diferentes. (BUCKINGHAM, 2007a:08; 2012b:98)

Nesse sentido, como observa o autor, faz-se importante atentar para a premissa de que o ser criança não é em si a representação de uma categoria natural, universal ou puramente biológica, em um formato e sentido fixos, sobre o qual seja possível tecer observações, generalizações, ou ainda reivindicações. Para muito além daí, a noção de infância é em essência movimento, na história, cultura e sociedade. "As crianças são vistas - e vêem a si mesmas - de formas muito diversas em diferentes períodos históricos, em diferentes culturas e em diferentes grupos sociais.” (BUCKINGHAM, 2007a:19)

E nesse processo de construção histórica e sociocultural das noções de infância e do ser criança, vale observar, como destaca o autor, que nem mesmo tais definições históricosocioculturalmente constituídas podem ser tomadas como fixas ou estáticas, uma vez que o significado de infância dá-se em um processo contínuo e dinâmico de negociação, tanto na esfera pública dos discursos políticos, midiáticos e sociais quanto na esfera privada das relações pessoais dos indivíduos em seus cotidianos. (BUCKINGHAM, 2007a:19; 2012b:98) A noção de infância e do ser criança são tomadas em processos contínuos de significação e ressignificação, e cujos conceitos e definições se dão em movimento e relatividade, em constante negociação social. (BUCKINGHAM, 2012b:114)

Em uma visão histórica de leitura sobre os processos de construção sociocultural das noções e significações sobre crianças e infâncias, é possível destacar a proposta de abordagem apresentada por Ariès - um dos primeiros estudiosos a dar atenção ao processo de construção conceitual de infância ao longo da história, desde os últimos séculos, em uma visão históricosociocultural. Mas devem ser consideradas também as possíveis limitações de suas leituras, limitadas às manifestações e expressões artísticas de cada período para representação histórica da imagem da criança, da infância e do universo infantil. Buscar-se aí um paralelo com as 
contribuições de Corsaro, a partir da perspectiva da sociologia da infância, no sentido de se experimentar uma leitura contextualizada e plural sobre a construção histórica cultural e social do conceito de infância.

A análise proposta por Ariès tem início na era medieval, a partir das representações da infância expressas nas principais manifestações e expressões artísticas do período. Segundo o autor, na sociedade medieval o sentimento da infância era inexistente - no sentido de um sentimento da infância tomado enquanto a "consciência da particularidade infantil, essa particularidade que distingue essencialmente a criança do adulto, mesmo jovem". Tão logo as crianças apresentavam-se em condições de sobreviver sem os cuidados de suas mães ou amas, como observa o autor, elas passavam a integrar a sociedade dos adultos, dos quais não mais se distinguiam. E nessa mistura, a questão das idades de crianças ou adultos não mais se fazia importante. Uma indeterminação das idades estendida às diversas dimensões da atividade social da época. (ARIÈS, 2012:99)

No entanto, seria importante atentar aqui, como sinalizam alguns historiadores e sociólogos da infância destacados por Corsaro, para algumas possíveis limitações da análise proposta por Ariès: quanto à sua abrangência, concentrada em alguns dos principais países da Europa medieval e moderna; quanto ao contexto social analisado, orientado para as camadas socioeconomicamente superiores da sociedade da época; e quanto às eventuais impossibilidades de comprovação histórica para suas leituras e análises, dadas a partir de manifestações e expressões artísticas e literárias do período. (CORSARO, 2011:80-83)

Ao final da era medieval, e no início da era moderna, na medida em que a criança ganhava atenção especial, materializada na forma de representação artística da imagem da infância, a partir do século XIV, nota-se a expressão de uma personalidade infantil, uma personalidade que se acreditava pertencer às crianças, em um sentido poético e familiar que passava a figurar na forma de uma particularidade da infância. Assim, especialmente nos ambientes familiares das camadas superiores da sociedade dos séculos XVI e XVII, como destaca Ariès, as crianças (os meninos pequenos) ganhavam um traje especial para que fossem distinguidas dos adultos. Uma nova atitude social com relação às crianças, a partir da especialização do traje infantil, especialmente em uma época em que as convenções e formas exteriores representavam grande importância e valor social. (ARIÈS, 2012:100)

Dois sentimentos da infância ganhavam forma nesse novo contexto sociocultural, como sinalizado pelo autor: o sentimento de "paparicação" e o sentimento de "moralização". Primeiramente, surgia o sentimento descrito como "paparicação" - quando as crianças, a partir daí olhadas com carinho e atenção especial, despertavam nos adultos sentimentos de alegria, 
diversão e encantamento: "Um novo sentimento da infância havia surgido, em que a criança, por sua ingenuidade, gentileza e graça, se tornava uma fonte de distração e de relaxamento para o adulto..." Sentimentos que os adultos não mais precisavam conter ou deixar de expressar. "De agora em diante [...] as pessoas não hesitariam mais em admitir o prazer provocado pelas maneiras das crianças pequenas, o prazer que sentiam em 'paparicá-las'.” (ARIÈS, 2012:100101)

Ao mesmo tempo, mais expressivamente a partir do século XVII, na forma de uma reação ao primeiro sentimento da infância, surgia um sentimento diferente: o sentimento de "moralização", de aversão ou exasperação quanto ao excesso de mimos e paparicos expressados diante das crianças, especialmente nos contextos familiares. E a partir daí, como destaca o autor, diversas restrições sociais passavam a se colocar com relação às crianças, no sentido de não mais se considerar agradável ou desejável tê-las misturadas aos adultos em determinadas ocasiões ou rituais coletivos da sociedade, como no caso das refeições à mesa, pois que isso estimularia o excesso de mimos e maus modos das crianças. (ARIÈS, 2012:103)

Vale destacar que o sentimento de "moralização", em sua preocupação com a separação das crianças do mundo dos adultos, representava igualmente uma forma de preocupação com a infância e de sensibilidade à presença infantil, ainda que em um sentido oposto ao sentimento de "paparicação". Ambos, sentimentos novos, estranhos e contrários àquele sentimento anterior, da indiferença das idades nas sociedades medievais. (ARIÈS, 2012:103) Como observa o autor, dava-se aí, a partir do sentimento de moralização da infância, a materialização de um maior interesse na disciplina e moral das crianças do que no universo gracioso e lúdico infantil:

É entre os moralistas e os educadores do século XVII que vemos formar-se esse outro sentimento da infância [...] e que inspirou toda a educação até o século XX, tanto na cidade como no campo, na burguesia como no povo. $\mathrm{O}$ apego à infância e à sua particularidade não se exprimia mais por meio da distração e da brincadeira, mas por meio do interesse psicológico e da preocupação moral. (ARIÈS, 2012:104)

Assim, como o autor apresenta, ao final do século XVIII, o contexto social da época expressava esses dois sentimentos acerca da infância, diferentes e opostos, mas que materializavam, cada um a seu modo, um olhar atento às crianças e às particularidades da infância. E aliando-se aí uma preocupação especial: os cuidados com a higiene e saúde destas, não apenas quanto ao tratamento de doenças (preocupação já existente desde os tempos antigos) mas especialmente quanto à proteção, prevenção e saudabilidade infantil. "Tudo o que se referia às crianças e à família tornara-se um assunto sério e digno de atenção. Não apenas o futuro da 
criança, mas também sua simples presença e existência eram dignas de preocupação...” (ARIÈS, 2012:105)

É importante observar que o sentimento de moralização da infância, enquanto necessidade de disciplina e educação das crianças, instituiu ao contexto social da época a noção de uma infância mais longa - ao contrário da noção de uma infância curta, com atenção às criancinhas, que marcava o sentimento de paparicação. Como descreve o autor:

\footnotetext{
A infância foi prolongada além dos anos em que o garotinho ainda andava com o auxílio de 'guias' ou falava seu 'jargão', quando uma etapa intermediária, antes rara e daí em diante cada vez mais comum, foi introduzida entre a época da túnica com gola e a época do adulto reconhecido: a etapa da escola, do colégio. (ARIÈS, 2012:123)
}

A partir daí, a atenção e preocupação da família e da sociedade com a educação infantil, especialmente materializada na preocupação dos moralistas e educadores do século XVII com a separação, o disciplinamento e a escolarização das crianças, instituiu as bases para todo o processo da educação escolar, da instituição moderna da escola, desde a modernidade até a contemporaneidade. (ARIÈS, 2012:123) Assim, estabeleceu-se aí o marco essencial da concepção moderna de infância, e que se faz presente ainda hoje na sociedade contemporânea.

No sentido de uma infância que toma crescente atenção e cuidado no contexto da família e da sociedade, e na medida em que o mundo manifesta cada vez maior interesse quanto aos problemas físicos, morais, educacionais, sociais e sexuais das crianças, diversas ciências contemporâneas como a psicanálise, a psicologia, a pedagogia, a sociologia, a pediatria, as ciências da saúde, o direito apresentam dedicação especial em seus estudos às temáticas e problemáticas da infância. (ARIÈS, 2012:193-194) Questões e preocupações que, para além da educação das crianças, tornam-se cada vez mais presentes, aquecendo e enriquecendo os debates sociais, políticos e acadêmicos contemporâneos sobre a infância. - A exemplo do debate contemporâneo sobre mídias, consumo e infância, ou ainda mais especialmente, sobre saúde e alimentação das crianças e a publicidade de alimentos infantis (debate que concentra a temática deste estudo).

Na perspectiva plural da construção histórico-sociocultural da noção de infância e da preocupação com as crianças, a família, a escola, a ciência, a igreja, a sociedade, compõem o complexo conjunto das instituições que colocam as crianças no centro das atenções e preocupações sociais, políticas e acadêmicas contemporâneas, ao mesmo tempo em que, na contrapartida, relegam-nas à periferia dos acontecimentos do mundo. E nesse sentido, como observa o autor ao avaliar o processo histórico, social e cultural de atenção e preocupação com as crianças, dado igualmente enquanto um processo de separação das crianças do convívio 
social: "A família e a escola retiraram juntas a criança da sociedade dos adultos. [...] Mas esse rigor traduzia um sentimento muito diferente da antiga indiferença: um amor obsessivo que deveria dominar a sociedade a partir do século XVIII.” (ARIÈS, 2012:195)

A partir da perspectiva histórica apresentada, é importante considerar que o entendimento de que o conceito de infância é dinâmico - em um processo contínuo de construção histórico-sociocultural e na circularidade que o coloca em movimento na história, nas culturas e sociedades - é essencial para o próprio entendimento do ser criança na contemporaneidade. No entanto, é igualmente importante considerar que as noções e definições de infância, construídas ao longo da história, como sinalizado por Buckingham, foram elaboradas a partir dos adultos. O olhar do adulto sobre a experiência infantil. A imagem que faz o adulto do ser criança. Significações e ressignificações adultocêntricas da infância. Os sentimentos e conflitos dos adultos sobre a infância e as crianças nos diferentes períodos, culturas e sociedades. Desde as imagens da criança pecadora e corrompida, às imagens da criança pura e inocente, às imagens da criança livre e natural. Todas, representações de um olhar adulto sobre o mundo infantil, sustentando as retóricas da infância na história e na contemporaneidade. (BUCKINGHAM, 2007a:55-56)

E nesse sentido, trata-se aí de uma sinalização importante a se considerar no âmbito dos estudos sobre crianças e infâncias na contemporaneidade: o reconhecimento da presença de perspectivas adultocêntricas sobre a infância e o entendimento da necessidade de perspectivas infantis no estudo e exploração das culturas das crianças.

Os estudos históricos e sociológicos orientados para as temáticas e problemáticas da infância, para além das suas possíveis limitações, representam importantes avanços para os estudos sobre crianças e infâncias, tanto em termos da exploração de diferentes objetos de estudo quanto em termos da experimentação de diferentes metodologias. Especialmente os estudos que, procurando ir além da visão do adulto sobre a criança, tentam dar atenção às vozes infantis em seus processos de pesquisa e reflexão:

As narrativas históricas de todos esses estudos dão vida às crianças e mostram que
elas eram atores influentes nas sociedades passadas. A importância desses estudos vai
além da documentação histórica das contribuições das crianças, contudo. Eles também
foram de vital importância para que as crianças pudessem ser vistas como
contribuintes ativas na produção e na mudança social enquanto criam,
simultaneamente, suas próprias culturas infantis. (CORSARO, 2011:97)

O contexto histórico-sociocultural apresentado para o entendimento dos conceitos de criança e de infância como um processo contínuo de construção, faz-se igualmente importante para o entendimento do movimento e relatividade de tais conceitos na contemporaneidade. É 
importante observar que o entendimento que se tem do significado da infância ou do ser criança na contemporaneidade é resultante desse processo de construção e, por sua vez, limitado às perspectivas e experiências ocidentais das sociedades da industrialização. Como observa Buckingham, a noção contemporânea de infância - que tem suas bases a partir da definição moderna de infância ocorrida mais expressivamente a partir da segunda metade do século XIX - é ainda recente, se comparada ao longo e dinâmico processo histórico-sociocultural de construção de tal noção, e especialmente restrita ao contexto das sociedades ocidentais industrializadas. (BUCKINGHAM, 2007a:25)

A partir daí, e tomando-se neste estudo a noção contemporânea de infância verificada a partir da visão das sociedades ocidentais industrializadas, é possível observar, como sinaliza o autor, que a contemporaneidade expressa momentos de tensão e ansiedade quanto à concepção de infância e do ser criança, tanto na esfera privada do ambiente familiar quanto na esfera pública do contexto social e político e especialmente com atenção à relação das crianças com o universo das mídias, das tecnologias, da publicidade e do consumo. Trata-se de um conceito em crise, uma vez que quase todas as certezas sobre o significado da infância têm sido abaladas, num sentido em que parece não mais se saber ao certo como definir ou onde encontrar a infância. (BUCKINGHAM, 2007a:15-16) E assim, desfazendo-se as construções conceituais estabelecidas sobre a infância, "as crianças reais, de alguma maneira, evadem-se automaticamente e inevitavelmente destas construções". (BUCKINGHAM, 2012b:114)

Tal entendimento é também destacado por Prout, ao observar que as complexas e contraditórias transformações sociais das últimas décadas têm provocado significativas mudanças nas condições da infância e nas experiências das crianças, e provocam uma diferença cada vez mais significativa entre as formas convencionais de representação social e cultural da infância e as novas realidades vividas e experimentadas por elas. Como observa o autor, se na perspectiva da modernidade a infância se apresentava como um fenômeno que podia ser facilmente modelado e compreendido a partir do conhecimento racional e da vontade humana, na expressão dos seus domínios sobre a natureza e a sociedade, "a emergência de novas formas da infância na modernidade tardia exige a revisão do que seria um novo século da infância". (PROUT, 2010a:22;31-32)

As noções e representações contemporâneas sobre as crianças e a infância, a partir desse contexto de incertezas, tensões e transformações, como destaca Buckingham, apresentam-se marcadas por duas perspectivas de interpretação, diferentes e opostas. De um lado, a perspectiva da "morte da infância": o desaparecer da infância viva, bela e inocente; o precoce despertar das crianças para a vida adulta; a perda do encantamento, da fantasia, das brincadeiras infantis; o 
desaparecer de tudo o que antes caracterizava e protegia o mundo das crianças; enquanto as mídias e tecnologias são tomadas como a causa principal da problemática pelo excesso de conteúdos impróprios apresentados às crianças. De outro, a perspectiva da "geração eletrônica / digital": a celebração da liberdade e autonomia das crianças; seu domínio sobre as tecnologias e as mídias; seu poder de escolha e decisão nas experiências de consumo; a independência e especial inteligência das crianças; a inata habilidade infantil para a inovação, a transformação; enquanto as mídias e tecnologias se apresentam como importantes fontes de informação, conhecimento e entretenimento para as crianças. (BUCKINGHAM, 2007a:18-19; 2012a:49)

É importante considerar, no entanto, que ambas as perspectivas são marcadas por uma visão essencialista da infância e uma interpretação determinista do papel das mídias e tecnologias em sua relação com as crianças, uma vez que, apoiadas em versões sentimentalistas da infância, acabam por não reconhecer a diversidade das experiências dessa fase da vida e a complexidade da relação que as crianças estabelecem com as mídias e tecnologias em seus cotidianos. Como observado pelo autor em sua proposta de reflexão, nesses contextos de tão significativas mudanças e transformações que caracterizam a contemporaneidade, é essencial que se possa compreender a complexidade e contraditoriedade que caracteriza a noção contemporânea de infância e a relação das crianças com as mídias, as tecnologias, a publicidade e o consumo. "Simplesmente culpar ou festejar as mídias é superestimar seu poder e subestimar as diversas maneiras como as crianças criam seus próprios significados e prazeres." (BUCKINGHAM, 2007a:87)

A mesma dualidade de perspectivas é também destacada por Prout, quanto às representações sociais e culturais da noção de infância e da imagem das crianças na contemporaneidade, sinalizada no contraste estabelecido entre a imagem da "criança em perigo" e a imagem da "criança perigosa". Imagens que, como observa o autor, são extremamente diferentes, mas igualmente problemáticas. A imagem da "criança em perigo" toma como base a ideia da criança frágil, dependente, inocente, indefesa e vulnerável, marcada por uma visão sentimentalista e nostálgica da infância. A imagem da "criança perigosa" toma as crianças como ameaça à sociedade, como a possível personificação da criminalidade, da imoralidade, do consumismo, e de outros males do mundo contemporâneo. No entanto, como ressalta o autor, nenhuma dentre as representações da infância apresentadas se mostra capaz de compreender a complexidade da presença e do papel das crianças na atual sociedade, enquanto indivíduos sociais, ativos e participativos em seus contextos socioculturais. (PROUT, 2010a:23-24) 
Para além das simetrias ou oposições entre as perspectivas contemporâneas sobre a infância, como observa Buckingham, é importante notar que todas tomam em conta o contexto de mudanças e transformações das culturas e sociedades que marcam a contemporaneidade, tentando interpretar, a partir daí, cada uma a seu modo, o contexto de complexidades e contraditoriedades de uma infância em mudança. No entanto, como observa o autor em complemento, as mudanças nas experiências vividas pelas crianças em seus cotidianos, marcadas também pela crescente presença das mídias e tecnologias, bem como, as mudanças no conceito de infância, que colocam as noções estabelecidas sobre crianças e infâncias em constante relatividade, revelam o permanente caráter transitório de tais conceitos e proposições na história e na contemporaneidade, e assinalam que é preciso "avançar para além do essencialismo e reconhecer a natureza provisória e diversificada da infância contemporânea". (BUCKINGHAM, 2007a:91-92)

No fenômeno contemporâneo de uma infância em mudança, transitória e no plural, Buckingham assim descreve a experiência das crianças nos cotidianos da contemporaneidade:

\begin{abstract}
A infância, portanto, está certamente mudando. A vida das crianças é mais institucionalizada e privatizada, e menos estável e segura do que era trinta anos atrás. As fronteiras entre crianças e adultos tornaram-se menos visíveis em algumas áreas, mas foram reforçadas e expandidas em outras. As crianças adquiriram poder, tanto político quanto econômico, mas também estão sujeitas a mais controle e vigilância por parte dos adultos. E a desigualdade entre crianças ricas e pobres cresceu exponencialmente. (BUCKINGHAM, 2007a:116)
\end{abstract}

Reflexão que traz à luz a necessidade de uma nova percepção da infância, mais heterogênea, menos definitiva, mais contextualizada, transitória e relativa. Uma infância em movimento. Uma infância no plural. Perspectiva conceitual que inspirou o desenvolvimento deste estudo, da fundamentação teórica à experimentação empírica com as crianças em campo nos contextos familiares pesquisados.

E no universo heterogêneo e transitório de uma infância em movimento e no plural, fazse interessante assinalar algumas observações sobre o contexto da família nessa complexa e emaranhada trama das vivências e experiências das crianças no mundo contemporâneo de uma infância em constante transformação.

O lugar que as crianças hoje ocupam enquanto sujeitos de uma infância em mudança é marcado especialmente nas relações interacionais infantis dadas no contexto da família, como também da escola e dos espaços de lazer. É no âmbito da família, além da escola e do lazer, enquanto instituição em transformação, que são dadas as interações das crianças com os pais, com outras crianças, e com o mundo a sua volta. E especialmente, as interações das crianças 
com as tecnologias, as mídias, a publicidade, o consumo, e todas as experiências e vivências infantis implicadas a partir daí. (BUCKINGHAM, 2007a: 91-116; 117-148; 209-241)

Tal reflexão é compartilhada por Corsaro, ao destacar a família como importante espaço das interações infantis no contexto contemporâneo das transformações socioculturais em que se apresentam as crianças de uma infância em mudança. (CORSARO, 2011:09-12)

Esta visão, de certo modo, também se coloca na reflexão proposta por Trindade sobre “a compreensão do lar como lugar de estudo da cultura alimentar". Buscar conhecer e compreender, a partir do contexto familiar, os vínculos de sentidos dados nos cotidianos das famílias (as crianças e seus familiares) com relação às marcas, produtos e ao consumo de alimentos, uma vez que as transformações culturais e sociais da contemporaneidade tem se manifestado também, e de modo especial, nos contextos do lar e nas dinâmicas da sua cultura alimentar. (TRINDADE, 2012:83-85)

Os pontos de reflexão e propostas de abordagem apresentados fundamentaram o entendimento e a definição da família como importante contexto e lócus para o desenvolvimento deste estudo. De forma especial ao se propor, a partir de uma interação e participação infantil no processo de investigação, a exploração dos cotidianos da cultura alimentar das crianças em seus contextos familiares. Pois que é no contexto familiar, e nas diversas possibilidades de mediações verificadas a partir daí, que se dão as práticas e rituais de consumo alimentar das crianças, os processos de recepção infantil de marcas de alimentos, e os vínculos de sentidos entre as marcas/produtos e as famílias/crianças.

$\mathrm{Na}$ perspectiva sociológica da relação das crianças com as tecnologias e mídias, a publicidade e o consumo, é importante notar que se trata de uma relação bem mais complexa do que o que se apresenta nos debates contemporâneos sobre o tema, como sinalizado por Buckingham, um dos principais autores a dar atenção à temática e problemática da relação entre crianças, mídias, publicidade e consumo no mundo contemporâneo.

$\mathrm{Na}$ proposta de compreender o fenômeno da atualidade de uma infância em mudança em sua relação com o fenômeno das tecnologias e mídias na contemporaneidade, o autor observa que o contexto das novas experiências da infância é também o das relações e interações das crianças com as tecnologias, as mídias, a publicidade e o consumo em seus cotidianos, no âmbito mais amplo dos movimentos, mudanças e transformações na história e nas culturas e sociedades da contemporaneidade. A reflexão proposta por Buckingham contempla a pluralidade da infância e juventude em sua conexão com as inovações e transformações nos ambientes midiáticos, que os posiciona na vanguarda de tais movimentos e processos das mídias. (BUCKINGHAM, 2007a:116-117) 
O debate sobre as tecnologias e mídias é igualmente marcado pelas dúvidas, incertezas, preocupações e paradoxos que se apresentam nos debates sociais sobre a infância em mudança na contemporaneidade. Como observa o autor, também no universo da relação entre crianças e mídias as fronteiras de conceitos e conhecimentos se mostram difusas e relativas, uma vez que as novas mídias vislumbram possibilidades e realidades mais dinâmicas, efêmeras e difíceis de se prever, compreender ou controlar.

Assim como no debate sobre a infância, também na discussão sobre as tecnologias e mídias na contemporaneidade colocam-se interpretações opostas. E no que tange à relação das crianças com as mídias, Buckingham propõe que o debate estaria excessivamente polarizado: “Considerar que as crianças sejam ou vítimas passivas da mídia ou consumidoras ativas significa efetivamente vê-las como isoladas dos processos de mudança social e cultural mais amplos.” (BUCKINGHAM, 2007a:118-119) E significa negligenciar o importante fato de que as crianças, para além de vulneráveis ou soberanas, precisam saber mais sobre as mídias e os contextos e processos midiáticos. (BUCKINGHAM, 2012b:105)

Tomando em conta os processos de mudanças sociais e culturais mais amplos hoje vistos, bem como, o atual contexto das tecnologias e das mídias nas culturas e sociedades, o autor observa que o debate que se vê sobre a relação das crianças com as mídias confere às tecnologias um poder determinante, superestimando o seu papel nos processos de produção de mudanças e desconsiderando os movimentos mais amplos a partir dos quais as tecnologias e mídias são utilizadas. No entanto, quando as novas tecnologias são consideradas em combinação com outras mudanças socioculturais, é possível perceber que tais movimentos contribuem significativamente para o que o autor destaca como uma revolução nos processos das indústrias midiáticas, nos campos da produção, distribuição, e recepção. (BUCKINGHAM, 2007a:119-120)

Tecnologias e mídias diversas colocam-se à disposição dos indivíduos nas sociedades atuais - ainda que nem todos tenham acesso ao mesmo tempo ou em um mesmo nível de acessibilidade. Tecnologias e mídias que - em suas diferentes medidas de acesso - colocam-se especialmente ao alcance das crianças e jovens, uma vez que é para esses públicos que muitas das novas formas culturais dadas a partir dos processos e produções tecnológicas e midiáticas são orientadas. Como destaca o autor, a facilidade de acesso às novas tecnologias e mídias possibilita às crianças e aos jovens uma série de experimentações que os coloca não apenas na posição de consumidores, mas também de produtores de conteúdos midiáticos, uma vez que facilmente aprendem e manipulam as novas linguagens e recursos tecnológicos para explorar e expressar sua criatividade e interatividade. (BUCKINGHAM, 2007a:122) 
Por outro lado, no entanto, coloca-se um cenário de dúvidas, incertezas e preocupações com as crianças, diante da possibilidade de uma exposição infantil a conteúdos que até então circulavam apenas no domínio dos adultos - como conteúdos relacionados à violência, à sexualidade, ou ao consumismo. (BUCKINGHAM, 2007a:123)

E nesse sentido, estariam dadas aí as mesmas oposições de interpretação apresentadas nos debates contemporâneos sobre a infância: a visão das crianças tomadas como vulneráveis, vítimas passivas das tecnologias e mídias versus a visão das crianças tomadas como inteligentes e autônomas, soberanas para lidar com as tecnologias e mídias em todo seu potencial.

Com atenção ao contexto da internet e mídias digitais, Livingstone - uma das principais autoras dedicadas ao estudo da relação entre crianças e jovens e as mídias digitais na contemporaneidade - destaca que são muitas as possibilidades que se apresentam para as crianças e os jovens a partir das relações de interface e interação com as novas mídias e tecnologias, em seu especial potencial de vinculação a conteúdos de informação, educação, entretenimento, participação interativa em atividades on-line, comunidades de interesses e redes sociais. (LIVINGSTONE, 2011:12)

As redes sociais, como observa a autora, têm se tornado muito populares entre crianças e jovens, em suas múltiplas e diversas plataformas de conteúdos, atividades, interfaces e interações, que se apresentam em convergência, combinadas em um mesmo ambiente, proporcionando a essas crianças e jovens a exploração, experimentação e expressão da sua criatividade e liberdade no contato cotidiano com as pessoas e com o mundo. (LIVINGSTONE, 2012:93)

No entanto, nesse universo de possibilidades, conteúdos, atividades, interfaces e interações que se apresentam a partir das tecnologias e mídias digitais, a autora atenta para as experiências concretas que as crianças e os jovens vivenciam na interação com as tecnologias midiáticas digitais e com a internet. Conforme destaca Livingstone a partir de pesquisas desenvolvidas com adolescentes na interface com a internet, muitas vezes esses usuários não sabem explorar as possibilidades e recursos tecnológicos que as novas mídias oferecem, e não demonstram maior habilidade de leitura crítica e de criatividade para uma melhor exploração dos conteúdos, informações, conhecimentos e possibilidades de participação que as mídias digitais podem proporcionar. (LIVINGSTONE, 2011:12;14-19)

E nessa direção, a autora destaca a necessidade de se estabelecer um conceito e uma prática efetiva de literacia na internet. Uma noção ou definição do que se poderia considerar como os conhecimentos e habilidades necessários para uma plena exploração e domínio das tecnologias e mídias digitais nas experiências on-line, especialmente no caso das crianças e dos 
jovens, nascidos na contemporaneidade dos contextos midiáticos digitais interativos e convergentes. Literacia que seja entendida como o conjunto de habilidades individuais, práticas sociais, e conhecimentos formais e informais necessários às experiências da interface e interação on-line, pois que a internet provoca e requer demandas novas e específicas para o conhecimento e a compreensão dos seus usuários, sejam crianças, jovens ou adultos. O domínio das tecnologias digitais e interativas, como destaca a autora, para além de um perfeito manejar de hardwares e softwares, requer o conhecimento e a exploração do potencial que a internet oferece e pode oferecer a esses usuários: "uma definição ambiciosa de literacidade dadas as expectativas sociais, econômicas, culturais e políticas que a sociedade reserva [...] para a chamada geração internet”. (LIVINGSTONE, 2011:13)

Tomando-se em conta os textos midiáticos na perspectiva das novas tecnologias e mídias - especialmente aqueles dirigidos às crianças e jovens - conforme reflexão proposta por Buckingham, tais textos se apresentam em transformação de suas características essenciais, sendo dificilmente tomados em seu sentido original, como objetos completos em sua significação. (BUCKINGHAM, 2007a:128-129)

Este fenômeno pode ser resultado dos processos de convergência tecnológica e econômica que caracterizam o contexto atual das mídias, tornando mais difusas as definições e delimitações entre as mídias e entre os textos midiáticos. A partir daí, é importante notar que as especificações ou diferenciações entre os diversos textos midiáticos talvez tenham se tornado um tanto desnecessárias, na medida em que, na visão do merchandising, eles se transformam em mídias para a promoção de outros textos midiáticos, além dos produtos e marcas para consumo. (BUCKINGHAM, 2007a:129)

Muitos dos textos midiáticos criados e produzidos para crianças e jovens - como os personagens do cinema, dos desenhos animados, dos videogames, ou as celebridades da música, do cinema ou da televisão - apresentam-se como textos midiáticos que se colocam em outros textos midiáticos, ao mesmo tempo em que se lançam ao universo das mercadorias. Textos midiáticos diversos, dados em uma mesma dimensão e cenário dos textos midiáticos “originais". (BUCKINGHAM, 2007a:131; 2012a:53-54) Nesse sentido, como destaca o autor: "a cultura midiática infantil cada vez mais atravessa as fronteiras entre textos e entre formas midiáticas tradicionais". E nesse processo, como observa o autor em complemento: “a identidade do texto 'original' está longe de ser clara: as mercadorias são empacotadas e comercializadas como um fenômeno integrado...”. (BUCKINGHAM, 2007a:131)

Nesse sentido, duas características se apresentam como marcantes no contexto das tecnologias e mídias na contemporaneidade: a intertextualidade e a interatividade. 
Intertextualidade: em que textos diversos se apropriam de estilos diversos, misturam e combinam diferentes elementos, de períodos históricos, gêneros e contextos socioculturais diferentes, remetendo-se a outros textos, brincando com as regras ou convenções, criando novas representações e significações - dirigindo-se aos receptores como consumidores. Interatividade: em que os novos textos midiáticos são criados e produzidos de forma mais livre e aberta, para a interação e a participação dos leitores ou receptores nos processos de criação, produção e experimentação desses mesmos textos em seus cotidianos - dirigindo-se aos receptores como consumidores e como produtores ou coprodutores. (BUCKINGHAM, 2007a:129)

Fenômenos midiáticos que tomam forma a partir das mudanças e inovações tecnológicas, mas que, ao mesmo tempo, também se orientam a partir das lógicas econômicas e comerciais do mundo contemporâneo. E assim as mídias passam a se dirigir às crianças e jovens enquanto grupos de consumidores ativos, participativos e conhecedores das diversas estruturas e linguagens midiáticas da atualidade - o que, para Buckingham, como já sinalizado, representa uma questão bem mais complexa. (BUCKINGHAM, 2007a:133-134)

Trata-se aí de um conjunto convergente de lógicas tecnológicas e econômicas que se misturam e se combinam na apropriação das tecnologias, das mídias, dos textos midiáticos para a composição do complexo, interativo e intertextual contexto midiático da atualidade, especialmente na criação e produção dos textos midiáticos dirigidos às crianças e jovens. Como observa o autor em sua perspectiva de reflexão, muitos dos conteúdos e linguagens das novas formas culturais direcionadas ao público em geral, nasceram antes como textos midiáticos orientados para crianças e jovens - como no contexto dos desenhos animados, das histórias em quadrinhos, dos personagens do cinema e da televisão, das músicas e videoclipes, dos jogos de videogame ou de computador. Todos, textos midiáticos repletos de referências a outros textos, misturando e combinando conteúdos, estruturas, estilos, linguagens, e elementos diversos de diferentes culturas, sociedades e historicidades. Estas convidam as crianças e jovens a uma contínua interação e participação. (BUCKINGHAM, 2007a:130-131)

Nesse sentido, do mesmo modo que se dá no contexto das tecnologias e mídias e da internet - como sugerido por Livingstone $(2011$; 2012) quanto às experiências das crianças e jovens on-line - também no universo das mídias e seus textos midiáticos vale a mesma reflexão: se de um lado tem-se a diversidade e a multiplicidade das produções midiáticas para crianças e jovens e todas as possibilidades que se apresentam a eles a partir daí, de outro, tem-se a necessidade essencial de que as crianças e os jovens tenham domínio das habilidades e conhecimentos necessários para uma plena experiência das mídias e leitura crítica dos textos midiáticos. 
Como a autora observa, as iniciativas para a literacia das crianças e jovens na internet e nas mídias, para além de necessárias, devem ser criticamente avaliadas e entendidas como parte de um processo mais amplo de mudanças, envolvendo desde as políticas públicas do estado para regulação das indústrias, das mídias e da comunicação orientadas para o público infantil e juvenil, e as políticas de internacionalização do discurso social sobre os direitos das crianças, até uma conscientização social, educacional e familiar nos processos de acompanhamento das crianças e jovens em suas experiências midiáticas on-line. Assim, a literacia midiática se constituiria em formas concretas de empoderamento para as crianças e jovens em um mundo continuamente mediado. (LIVINGSTONE, 2011:35-37)

No contexto contemporâneo de uma infância em mudança e no plural, as tecnologias e mídias se apresentam para as crianças e jovens como novas oportunidades para a criatividade e a democracia, especialmente ao oferecer-lhes possibilidades concretas de tornarem-se, para além de receptores ou consumidores, também produtores de mídia. "As novas tecnologias trazem ao alcance das crianças meios de comunicação e de expressão cultural que lhes eram até então inacessíveis, e que podem fazer suas visões e perspectivas serem muito mais amplamente reconhecidas." (BUCKINGHAM, 2007a:148)

E tomando-se a internet como uma das principais arenas em que muitas das novas possibilidades de interface, interação, criatividade, informação, conhecimento, comunicação e participação acontecem para crianças e jovens em seus cotidianos midiáticos, como se destaca em Livingstone, as crianças e os jovens tomam a internet, as redes sociais e outras formas de interação on-line como um espaço livre para a sua expressão: um espaço para explorar, experimentar, criar, produzir; combinar, trocar, compartilhar, se divertir; conectar, acessar, comunicar, descobrir; participar, interagir, escolher, decidir. (LIVINGSTONE, 2011:37; 2012:96-97)

No que tange à relação das crianças com a publicidade e o consumo - no cenário contemporâneo das tecnologias e mídias e no contexto mais amplo de uma infância em mudança e no plural - o debate social é marcado pelas mesmas oposições que caracterizam as discussões sobre a relação das crianças e jovens com as tecnologias e mídias: de um lado, a criança tomada como frágil, indefesa e incapaz, extremamente vulnerável às estratégias da publicidade e às demandas do consumismo; de outro, a criança tomada como inteligente, autônoma, independente e hedonista, suficientemente preparada para lidar com o universo da publicidade e as experiências do consumo.

Como observa Buckingham, do mesmo modo como na arena do debate sobre as tecnologias e mídias, também nos debates sociais sobre a publicidade e o consumo, as maiores 
preocupações concentram-se na necessidade de proteção às crianças e de regulamentação das mídias e da publicidade. No entanto, o autor atenta para a importância e necessidade de uma abordagem mais contextualizada e crítica ao se tratar a problemática nos debates sociais, políticos e acadêmicos, considerando-se tanto as políticas midiáticas contemporâneas quanto as políticas públicas e educacionais. Pois que, em tais contextos de discussão, a preocupação com a relação entre as crianças e a cultura de consumo parece dada ainda em um nível de significação demasiadamente simbólico. (BUCKINGHAM, 2007a:209-210)

Tomando-se a história recente das sociedades ocidentais industrializadas, como observado em Buckingham com base em Jordanova, é possível destacar que, no que tange à abrangência e à escala das atividades de consumo, houve mudanças significativas: ampliação da produção e oferta de produtos e serviços no mercado; diversificação dos canais de vendas e modalidades de compras; universalização das compras e do consumo como experiências de lazer - o que marca a intensa e abrangente presença do consumo no contexto sociocultural contemporâneo. Nessa direção, e na constante busca de novos mercados do capitalismo, as crianças e jovens ganham atenção especial nas ações da indústria, varejo e publicidade. Ao mesmo tempo em que o valor e significado da infância na família e sociedade se tornam cada vez maiores, possibilitando às crianças mais voz na expressão dos seus desejos de consumo e participação nas decisões de compra em seus ambientes familiares. Momento a partir do qual as crianças são tomadas como consumidores. (BUCKINGHAM, 2007a:211-212; 2012a:45)

Como observa o autor, o ambiente global das mídias, em sua convergência com o universo do consumo, passa assim a ser orquestrado, para além das lógicas tecnológicas e midiáticas, por lógicas econômicas e comerciais. Contexto em que as mídias dirigidas ao público infantil, como no caso da televisão e internet, são caracterizadas por uma programação orientada às crianças e pelas mensagens publicitárias, comerciais ou promocionais, dirigidas ao público infantil, muitas vezes, misturadas ou embutidas na programação ou nos conteúdos. E no caso da internet, onde é cada vez maior a presença de plataformas que combinam conteúdos educativos e de entretenimento infantil a mensagens promocionais dirigidas às crianças, a questão é mais complexa, na medida em que é mais difícil para as crianças perceber as diferenças entre conteúdos e propagandas. As fronteiras aí se tornam híbridas e mais difusas. (BUCKINGHAM, 2007a:212-213; 2012a:55-56) Neste sentido, como destaca Buckingham: “a convergência da mídia e do marketing integrado leva a uma situação na qual todos os textos das mídias podem ser considerados propagandas para outros textos das mídias." (BUCKINGHAM, 2007a:213) 
Nessa proposta mais ampla de reflexão, como sugere o autor, a complexa relação que se delineia entre o cotidiano das crianças, o universo das mídias e da publicidade e a cultura de consumo infantil não pode ser reduzida a uma simples questão de vulnerabilidade ou soberania das crianças, pois que não se trata aí de uma questão de consumo emocional versus consumo racional. Nem crianças, nem adultos, poderiam ser tomados unicamente como consumidores racionais, "porque os objetos materiais estão inevitavelmente revestidos de valores simbólicos dos quais não podem ser separados”, (BUCKINGHAM, 2007a:222) como também sinalizado em McCracken (2003).

E nessa linha de pensamento, igualmente limitada e reducionista seria uma proposta de análise focada exclusivamente na publicidade, como isolada da cultura contemporânea de consumo em nível mais amplo, especialmente no momento em que emergem novos formatos promocionais, para além da publicidade tradicional, em que textos midiáticos se transformam em produtos, em mercadorias. (BUCKINGHAM, 2007a:223; 2012a:54)

Tomando-se a cultura contemporânea de consumo como uma arena na qual as necessidades sociais e culturais dos indivíduos são expressadas, definidas, articuladas e experimentadas, Buckingham propõe que a infância contemporânea está essencialmente vinculada e inegavelmente entrelaçada à cultura de consumo. E nessa perspectiva, o autor observa que é a partir da relação que as crianças estabelecem com as mercadorias materiais e com os textos midiáticos promocionais entrelaçados aos seus cotidianos que se expressam e definem as suas necessidades sociais e culturais. Como destaca o autor em sua proposta de reflexão sobre as crianças e o consumo no mundo contemporâneo: "as crianças já são consumidoras, mesmo que muitas das compras em nome delas sejam feitas por seus pais". (BUCKINGHAM, 2007a:237;239)

Tal visão é de certo modo compartilhada por Gunter e Furnham, ao observarem que a criança pode ser tomada como um consumidor, embora ainda em um processo de socialização e aprendizado das competências essenciais para uma plena experiência de tal status. Processo de socialização do consumidor em que as crianças experimentam e desenvolvem as competências, os conhecimentos e as atitudes necessárias para uma experiência plena no contexto sociocultural contemporâneo do consumo. (GUNTER; FURNHAM, 2001:25)

Ao se tomar em consenso o status reconhecido das crianças enquanto consumidores, no entanto, traz-se à luz a necessidade de uma nova formulação e fundamentação para as políticas sociais e institucionais sobre a relação entre infância, mídias, publicidade e consumo. Como observa Buckingham, as tentativas correntes para a criação de espaços especiais e seguros para as crianças, tentando protegê-las das influências persuasivas das mídias e do mercado - como 
no caso dos movimentos contemporâneos para proibição da publicidade para crianças em diferentes países do mundo - apresentam-se como uma proposta de refúgio das crianças em um mundo à parte. $\mathrm{O}$ que, em verdade, seria impossível de se sustentar em face aos dinamismos e efemeridades da contemporaneidade, assim "em vez de buscarmos proteger as crianças do mercado, precisamos encontrar modos de prepará-las para lidar com ele." (BUCKINGHAM, 2007a:239-240)

E no sentido das novas políticas sociais e institucionais para a cultura contemporânea de consumo e o contexto das crianças-consumidoras, destaca-se a necessidade de visões e processos plurais, envolvendo diversos fatores, propostas de ação e perspectivas de reflexão: para uma educação reflexiva para o consumo; para a criação de políticas públicas para a criançaconsumidora; para definição das necessidades sociais e culturais das crianças. Perspectivas e processos, no entanto, que não podem ser baseados somente em definições dadas pelos adultos sobre as necessidades das crianças. Como destaca Buckingham, trata-se aí de uma problemática que somente poderia ser alcançada no diálogo com as crianças. A partir das suas vozes. (BUCKINGHAM, 2007a:240)

O mundo contemporâneo é significativamente marcado pela presença das tecnologias e mídias e pelas experiências do consumo. E as crianças, como sujeitos, cidadãos, participantes ativos nas culturas e sociedades na atualidade, precisam e devem ser olhadas com atenção, ouvidas no que dizem suas vozes infantis, preparadas e incentivadas para agir e refletir no mundo.

\footnotetext{
Não podemos trazer as crianças de volta ao jardim secreto da infância ou encontrar a chave mágica que as manterá para sempre presas entre seus muros. As crianças estão escapando para o grande mundo adulto - um mundo de perigos e oportunidades onde as mídias eletrônicas desempenham um papel cada vez mais importante. Está acabando a era em que podíamos esperar proteger as crianças desse mundo. Precisamos ter a coragem de prepará-las para lidar com ele, compreendê-lo e nele tornar-se participantes ativas, por direito próprio. (BUCKINGHAM, 2007a:295)
}

No tão diverso, dinâmico e enigmático universo das tecnologias e mídias e do consumo que se desvela às crianças no mundo contemporâneo, é importante considerar com especial atenção o crescente movimento de acesso, consumo midiático e participação das crianças brasileiras na internet nos últimos anos. Especialmente nos ambientes de jogos on-line, plataformas de vídeo e redes sociais. E com presença cada vez mais significativa de crianças menores em atividades on-line. (NIC.BR - CETIC.BR, 2017; 2018; 2019)

No Brasil, em comparação a outros países da Europa, a presença de crianças e adolescentes nas redes sociais é bastante significativa - como mostra o estudo comparativo sobre acesso e usos da internet por crianças e jovens no Brasil e Europa (Children and Internet 
Use: A comparative analysis of Brazil and seven European countries). Conforme os dados apresentados no relatório, dentre as crianças e adolescentes brasileiros usuários de Internet, $78 \%$ possuem perfil próprio em redes sociais. Percentual este superior a países como Portugal (76\%), Bélgica (66\%) e Itália (64\%), entre outros, ficando abaixo apenas da Dinamarca (81\%). O estudo destaca que no Brasil há o maior percentual de crianças entre 9 e 10 anos presentes nas redes sociais (52\%), seguido pelos demais países pesquisados: Romênia (50\%), Dinamarca (41\%), Portugal (26\%), Bélgica (22\%), Reino Unido (19\%), Itália (15\%) e Irlanda (14\%). Outro dado importante destacado no relatório traz a informação de que mais da metade do total de crianças e adolescentes usuários de internet no Brasil têm acesso à rede por dispositivos móveis (52\%). E dentre as atividades on-line mais citadas pelas crianças e adolescentes brasileiros de 11 a 16 anos está a preferência por redes sociais, vídeos e jogos on-line. Trata-se das mesmas preferências demonstradas por crianças e jovens em suas atividades on-line nos demais países pesquisados. (NIC.BR - CETIC.BR, 2015)

Um estudo sobre consumo e participação infantil no YouTube Brasil, desenvolvido a partir do projeto Família e Tecnologias do ESPM Mídia Lab (Escola Superior de Propaganda e Marketing - ESPM - SP), destaca que o Brasil é o segundo maior consumidor de vídeos no YouTube no mundo, e que, dentre os canais infantis consumidos por crianças ou produzidos para ou por crianças no YouTube Brasil, muitos figuram na lista geral dos canais mais acessados na plataforma (ranking do YouTube Brasil), concentrando bilhões de views junto ao público infantil. Dentre os 176 canais infantis investigados no estudo, durante os dez primeiros anos de existência do YouTube no Brasil (2005-2015), 41 deles se apresentam entre os canais de maior acesso e audiência no país, totalizando 30 bilhões de views entre crianças de 0 a 12 anos no período no YouTube Brasil. (CORREA, 2016:1331-1332)

As categorias de canais infantis de maior interesse e acesso pelas crianças no YouTube Brasil durante o período pesquisado, conforme destacado no estudo, são os canais que promovem vídeos de unboxing, e os canais com conteúdos produzidos por YouTubers mirins. A partir daí, tais categorias de canais na plataforma, especialmente os mais populares entre as crianças - do mesmo modo como muitos dos conteúdos produzidos para crianças no YouTube Brasil em diferentes categorias de canais - passam a ser explorados pela comunicação mercadológica orientada para o público infantil, nos diversos formatos e linguagens da publicidade no contexto das mídias digitais. Isso ocorre desde uma publicidade independente ou paralela, até a publicidade que passa a tomar parte na composição dos conteúdos, muitas vezes, se confundindo à programação dos canais infantis. (CORREA, 2016:1333) 
Uma forma de hibridização entre publicidade e entretenimento é o que acontece no contexto da comunicação mercadológica orientada para o público infantil nas diferentes plataformas e conteúdos produzidos para crianças na internet, como destacado por Craveiro. Tem-se aí - tanto no contexto do YouTube como em outras plataformas que desenvolvem conteúdos para crianças - uma forma híbrida de comunicação que promove maior proximidade e envolvimento com as crianças, que possibilita e incentiva a participação infantil como expectadores e consumidores nos ambientes on-line. Mas que, ao mesmo tempo, provoca uma espécie de embaçamento das fronteiras entre o que caracteriza um conteúdo de entretenimento e uma publicidade para crianças nas diferentes plataformas acessadas pelo público infantil na internet. (CRAVEIRO, 2016:30)

Nessa direção, faz-se presente a necessidade de um processo contínuo de discussão e reflexão sobre ética na publicidade orientada para crianças, especialmente no caso dos novos formatos e linguagens da publicidade dirigida ao público infantil, que promovem a hibridização entre publicidade e entretenimento infantil nos ambientes on-line. Espaços ainda carentes de processos de investigação, regulação e regulamentação no Brasil. Perspectiva compartilhada por Craveiro (2016:30) e por Correa (2016:1333-1335;1341-1342)

Na mesma medida - como já destacado por Livingstone $(2011 ; 2012)$ e compartilhado também por Craveiro (2018:172;181) e Correa (2016:1341-1342) - faz-se essencial o desenvolvimento de processos de literacia midiática e de consumo para crianças e adolescentes. Especialmente no contexto das novas tecnologias e mídias digitais e ambientes on-line. Uma literacia midiática crítica, que possibilite às crianças e adolescentes - importantes consumidores, usuários e produtores de conteúdo em mídias digitais no nosso país - maior conhecimento, experiência, reflexividade e consciência em suas atividades e experimentações nos ambientes midiáticos e contextos do consumo no mundo contemporâneo.

As reflexões propostas sobre a relação das crianças com as tecnologias, as mídias, a publicidade e o consumo no mundo contemporâneo foram significativamente importantes no âmbito do estudo desenvolvido. Especialmente a partir da visão de uma infância em mudança e no plural. Uma vez que o trabalho realizado com as crianças em campo em seus contextos familiares - trabalho atento ao olhar e às experiências das crianças, procurando dar voz às vozes infantis - foi continuamente atravessado pela presença das tecnologias, das mídias, da publicidade e do consumo nos cotidianos infantis, especialmente no que se refere ao contexto das mídias digitais e plataformas de conteúdo e interatividade on-line, delineando-se assim os diferentes modos de presença e mediação comunicacional das marcas na diversidade da cultura 
alimentar das crianças e na pluralidade de uma infância em constante movimento e transformação.

E finalmente, na perspectiva sociológica da noção de infância como cidadania e participação ativa das crianças na cultura e sociedade, é importante considerar que se trata de um processo histórico-sociocultural complexo e contínuo de reconhecimento das crianças como sujeitos, cidadãos, produtores de cultura e atores sociais, com direito à plena participação e voz nas culturas e sociedades da contemporaneidade.

Como sinalizado em Buckingham, ao mesmo tempo em que as crianças têm conquistado maior espaço no contexto sociocultural contemporâneo - no âmbito da família, da escola, da sociedade, das mídias e do mercado - e mesmo com todas as políticas, atenções e cuidados dedicados às crianças, e toda a estrutura midiática e mercadológica orientada para elas, as crianças ainda não são de fato percebidas e reconhecidas enquanto consumidores, cidadãos, sujeitos ativos e participativos na cultura e sociedade. Na verdade, as vozes infantis ainda não se fazem ouvir. (BUCKINGHAM, 2007a:147)

Este entendimento, de certo modo, é compartilhado por Sarmento, ao sinalizar para o processo histórico de exclusão das crianças nas diferentes esferas de participação social e política da sociedade, promovendo o que o autor destaca como "o afastamento do mundo da infância do mundo dos adultos". A infância se torna um espaço confinado, condicionado e controlado pelos adultos, em que as crianças são privadas dos seus diretos de cidadania e participação, marcando assim a invisibilidade e exclusão da infância na política e sociedade. “A invisibilidade é, no caso, homóloga da exclusão [...]. Não é, por isso, sem consequência, que a exclusão das crianças da acção política directa caminha a par do efeito simbólico da sua invisibilização política.” (SARMENTO; FERNANDES; TOMÁS, 2007:184-185)

No entanto, ainda que se trate de um processo complexo e contínuo de construção sociocultural para o reconhecimento dos direitos de cidadania e participação das crianças, como observa Prout, nos debates sociais, políticos e institucionais contemporâneos, aos poucos, começa a se fazer presente a perspectiva de se tentar dar voz às vozes infantis, buscando-se uma participação ativa, embora ainda limitada, das crianças nos processos sociais e políticos que direta ou indiretamente envolvem interesses infantis. (PROUT, 2010a:25-30)

Conforme a reflexão proposta por Prout, é a partir do final do século XX que a percepção da criança como indivíduo social ativo e participativo começa a ser considerada nos diferentes contextos socioculturais, políticos e institucionais da contemporaneidade, como retratado no texto da Convenção das Nações Unidas sobre os Direitos das Crianças. No entanto, como observa o autor, mesmo com uma maior abertura conceitual com relação à temática da 
participação das crianças na cultura, na sociedade e na política, a questão da cidadania infantil se apresenta ainda como um espaço de discussão marcado por dúvidas, incertezas e controvérsias:

\begin{abstract}
Ainda temos muito a aprender sobre formas de permitir que as crianças falem por si próprias e de sua maneira. Com muita frequência exige-se que as crianças se ajustem às formas de participação dos adultos, quando o que é necessário são mudanças institucionais e organizacionais que facilitem e encorajem as vozes das crianças. (PROUT, 2010a:35)
\end{abstract}

Nesse sentido, também se coloca a reflexão proposta por Qvortrup ao sinalizar as perspectivas de proteção, provisão e participação infantil apresentadas na Convenção das Nações Unidas sobre os Direitos das Crianças, destacando o desafio que ainda representa a possibilidade de uma participação infantil efetiva na política e na sociedade, especialmente a partir da polaridade que se apresenta no contexto sociocultural e político contemporâneo sobre os direitos de participação infantil versus a necessidade de proteção das crianças. (QVORTRUP, 2010a:778-780) O autor reconhece a necessidade de proteção às crianças, mas atenta para a importância essencial da participação infantil: "É óbvio que infância e política estão inerentemente ligadas. É igualmente óbvio que todos desejamos proteger as crianças dos piores efeitos da política e da economia. Contudo, manter as crianças fora da economia e da política é irrealista." (QVORTRUP, 2010a:790)

Esta reflexão é complementada em Sarmento, quando o autor igualmente destaca a importância da participação infantil em um contexto de cidadania da infância e participação política das crianças, observando que é no equilíbrio entre a proteção e a participação que se colocam os interesses e necessidades das crianças: "não apenas a visibilização das crianças como destinatários das políticas públicas, mas a sua assunção plena como sujeitos políticos peculiares.” (SARMENTO; FERNANDES; TOMÁS, 2007:189-190)

Prout sinaliza para a importância e imprescindibilidade do reconhecimento social e político da cidadania das crianças, como também o faz Buckingham em sua proposta de reflexão. As crianças tomadas como atores sociais, sujeitos ativos e participativos na cultura e sociedade - cidadãos de direito e de fato. Prout observa que, em um contexto de mudanças sociais e culturais que transformam as condições da infância e as experiências das crianças no mundo contemporâneo, estas se colocam como indivíduos sociais que precisam e requerem cidadania. E para se construir uma noção social e política renovada sobre uma infância cívica - em que a sociedade seja capaz de garantir às crianças uma igualdade no tratamento das suas necessidades e interesses, atentando para as diferenças entre as crianças, os diferentes e diversos grupos sociais infantis e seus cotidianos; com instituições públicas engajadas na sua 
representação política para a defesa dos interesses e necessidades infantis, e buscando dar voz e participação às crianças em tais processos; e em um contexto sociocultural e político aberto às novas concepções sobre cidadania, reconhecendo, incentivando e garantindo a participação das crianças e jovens nos processos sociais e políticos da sociedade - é preciso reconhecer e estabelecer um compromisso entre a sociedade e as crianças, para além dos laços estabelecidos em seus ambientes familiares, em que se possa de fato desenvolver e manter as condições de uma cidadania da infância. (PROUT, 2010a:32-34)

No mesmo sentido da necessidade e importância do reconhecimento de uma cidadania plena para a infância, e novamente atentando para o processo histórico-sociocultural de exclusão das crianças nas principais esferas sociais e políticas da contemporaneidade, Sarmento observa que as crianças são tomadas como seres em desenvolvimento, cidadãos em formação para o exercício de uma cidadania que, de forma plena, somente poderá ser expressa no futuro, uma vez que "uma concepção clássica de cidadania recusa o estatuto político às crianças". (SARMENTO; FERNANDES; TOMÁS, 2007:187-188)

Mas o autor também observa que é nesse mesmo contexto de uma cidadania infantil que ainda não se reconhece plena, que as crianças desenvolvem uma espécie de "cidadania periférica", nas culturas infantis, onde são capazes de expressar suas ideias, interesses e sentimentos, revelando suas competências políticas, como atores políticos que são, ainda que suas vozes nem sempre se possa fazer ouvir. (SARMENTO; FERNANDES; TOMÁS, 2007:191-202) Os autores ainda destacam que em um processo de comprometimento social e político para o reconhecimento de uma cidadania plena da infância, ouvir a voz das crianças se faz essencial:

\footnotetext{
A imaginação de formas de auscultação de opinião e de processos de tomada de decisão é absolutamente indispensável para fazer da voz das crianças (essa voz que nunca deixou de ecoar, mesmo baixinho, nos espaços intersticiais onde a deixam exprimir) uma voz verdadeiramente ouvida. (SARMENTO; FERNANDES; TOMÁS, 2007:203-204)
}

Na perspectiva da cidadania e participação ativa das crianças na cultura e na sociedade, novamente aqui se observa que estas são reflexões essenciais e importantes no contexto do estudo desenvolvido. De forma especial, para a compreensão de quanto o reconhecimento das crianças como atores sociais, produtores de cultura e participantes ativos na sociedade, com competências sociais e políticas, e com direito à plena cidadania, participação e voz, se faz essencial no âmbito de qualquer investigação que se proponha a uma exploração e conhecimento consistente, aprofundado e abrangente sobre crianças e infâncias no mundo contemporâneo. 
É nessa direção que o presente estudo orientou suas bases de investigação e reflexão sobre a mediação comunicacional das marcas na cultura alimentar infantil: procurando tomar as crianças, para além de consumidores, como sujeitos, cidadãos, atores sociais, como informantes e participantes no processo de pesquisa, procurando criar meios para que elas se expressem e sejam ouvidas, para uma produção partilhada do conhecimento e do saber.

Uma produção de conhecimentos sobre a infância e as crianças, dada a partir da perspectiva e da participação infantil - como observam autores e pesquisadores nos campos da sociologia da infância e antropologia da criança - sugere uma renovação em nível filosófico, epistemológico e metodológico. E nesse sentido, como destaca Sarmento, é importante o recurso a metodologias etnográficas e participativas na pesquisa com crianças, combinadas a procedimentos estatísticos "devidamente depurados dos enviesamentos adultocêntricos." Uma vez que um conhecimento sólido, relevante e significativo sobre a infância precisa considerar as subjetividades infantis e deve ser construído com a participação das crianças, envolvidas em processos de pesquisa onde suas falas, para além de testemunhos sobre os cotidianos da infância, se tornem verdadeiramente "a condição da produção de informação relevante para o conhecimento das sociedades contemporâneas.” (FERREIRA; SARMENTO, 2008:61-62;8586)

Na proposta de uma construção de percursos de investigação etnográfica e participativa com crianças, é imprescindível atentar para questões éticas e aspectos metodológicos que se fazem essenciais em processos de pesquisa com a participação infantil, como observa Sarmento ao destacar a importância de orientações e escolhas metodológicas atentas à diversidade e multiplicidade de interesses, experiências e interações infantis ao longo do processo de investigação. Perspectivas e escolhas metodológicas que tomem com atenção e prioridade a visibilidade e voz das crianças no processo de investigação e o conhecimento e consentimento informado das crianças para participação na pesquisa; a combinação de estratégias e dispositivos metodológicos plurais e a utilização de métodos, técnicas e materiais diversos para o estímulo à participação das crianças; a participação infantil na avaliação do processo de investigação e a partilha, com elas, dos resultados da pesquisa na finalização do estudo. (FERREIRA; SARMENTO, 2008:81-83)

Entretanto, como ressalta o autor, é importante observar que as possibilidades de investigação orientadas para a participação infantil nos processos de pesquisa, tomando as crianças como sujeitos e atores sociais com visibilidade e voz, tomam forma, em essência, a partir de suas orientações filosóficas e concepções epistemológicas, políticas e éticas, mais do 
que por suas composições metodológicas ou elaborações técnicas. "É de poderes, mais do que de 'modus faciendi', que se trata." (SOARES; SARMENTO; TOMÁS, 2005:57)

Ao assumir a perspectiva da participação infantil e da visibilidade e voz das crianças como atores sociais nos processos de investigação, a sociologia da infância - como também a antropologia da criança - propõe um entendimento das crianças como sujeitos do conhecimento, a partir da escuta efetiva das crianças, e uma reflexividade epistemológica e metodológica, a partir da escolha e utilização de métodos e técnicas participativos, para que assim seja possível tomar as crianças, para além de informantes, como participantes e parceiros na pesquisa e composição do estudo. "O que se recupera com as metodologias participativas é a presença da criança-parceira no trabalho interpretativo, mobilizando para tal um discurso polifónico e cromático, que resulta da voz e acção da criança em todo o processo." (SOARES; SARMENTO; TOMÁS, 2005:53-55)

Processos de investigação orientados para o recurso a metodologias etnográficas e participativas, apesar das complexidades e desafios, trazem à luz a importância da participação infantil, a visibilidade e escuta das crianças, a construção e a partilha do conhecimento e do saber:

Ao contrário do que preconiza muita da 'ciência oficial', a existência de outras visões
e outras vozes sobre o mundo não é sinónimo de desordem, superficialidade, ou caos
metodológico, senão uma última e legítima expressão da própria complexidade e
multidimensionalidade do que nos rodeia. (FERREIRA; SARMENTO, 2008:84)

A perspectiva da participação infantil na investigação transforma os processos de pesquisa com crianças em espaços de participação social e cidadania da infância. Espaços onde a presença, a voz e a agência das crianças fazem a diferença no processo de investigação e produção de um conhecimento partilhado, buscando sempre um equilíbrio possível entre participação, autonomia, cooperação e hierarquia entre os participantes no desenvolvimento da pesquisa. Trata-se aí da dimensão social e política da investigação participativa com crianças, tomando-se "o processo de investigação como uma realidade participada e partilhada" onde o pesquisado torna-se também um pesquisador. E ao privilegiar uma parceria entre adultos e crianças, tais processos de investigação permitem e valorizam uma coparticipação infantil na construção das dinâmicas e ferramentas metodológicas da pesquisa. "As crianças passam desta forma a ser consideradas parceiras presentes na agenda de investigação, não de uma forma manipulada ou decorativa [...] mas sim de uma forma genuína e efectiva." (SOARES; SARMENTO; TOMÁS, 2005:56-57) 
Como sinalizado, essa visão orientou o desenvolvimento deste estudo em seu todo, ao incentivar a participação infantil nos diferentes momentos e atividades do processo de investigação e valorizar a presença, a voz e a agência das crianças para a produção de um conhecimento partilhado.

Faz-se importante considerar, no entanto, que os processos de investigação tomados na direção da participação infantil trazem à discussão uma série de preocupações e reflexões sobre ética na pesquisa com crianças. Como observa Sarmento, é preciso atenção especial às questões éticas nos trabalhos desenvolvidos com crianças em campo, tomando-se em conta a singularidade infantil, respeitando-se a liberdade, autonomia e privacidade delas, e atentandose para a necessidade de um constante acompanhamento e capacitação das crianças para uma legítima e significativa participação infantil nos processos de investigação. (SOARES; SARMENTO; TOMÁS, 2005:56)

A criança ou a infância como temática de investigação social no mundo contemporâneo constitui um amplo e diverso campo interdisciplinar de estudos. Nesse contexto, como observa Prout, na medida em que novas perspectivas teóricas vão tomando forma na pesquisa com crianças, especialmente os investimentos de pesquisa orientados na visão destas tomadas como atores sociais, novas propostas de experimentações empíricas também começam a se destacar no contexto de tais estudos, trazendo ao campo interdisciplinar de investigação sobre crianças e infância a necessidade constante de discussões e reflexões sobre aspectos metodológicos e questões éticas. Possibilidades teóricas e experiências empíricas inovadoras, que enriquecem o campo de estudos com novas propostas metodológicas - especialmente no contexto das metodologias etnográficas e participativas - mas com menor atenção às questões éticas que as inovações epistemológicas e metodológicas na pesquisa com crianças trazem ao campo de estudos para necessária e contínua reflexão. (CHRISTENSEN; PROUT, 2002:477-478)

A perspectiva das crianças tomadas como atores sociais no contexto dos estudos e pesquisas sobre crianças e infâncias - atores como as crianças o são na cultura e sociedade demanda novas e diversas questões éticas para reflexão. Uma série de questões que precisam ser cuidadosamente observadas e consideradas entre os pesquisadores do campo, pois que, no momento que as crianças são tomadas como atores sociais, novas propostas de experimentações metodológicas emergem, trazendo com elas novos dilemas éticos a partir do trabalho desenvolvido com as crianças em campo, e novos desafios e responsabilidades aos pesquisadores, tanto em nível individual (no contexto do desenvolvimento de cada pesquisa) quanto em nível coletivo (no campo interdisciplinar dos estudos da infância). (CHRISTENSEN; PROUT, 2002:478) 
Dessa forma, o autor assinala para a necessidade e importância de uma constante discussão e reflexão sobre ética na pesquisa com crianças. Não no sentido de uma busca ou estabelecimento de padrões e condutas éticas gerais a serem consideradas nos trabalhos desenvolvidos com crianças, mas no sentido de uma partilha e avaliação em grupo de experiências individuais de pesquisa com crianças em campo, para uma construção coletiva dos principais valores éticos a serem observados e considerados nos estudos contemporâneos sobre crianças e infâncias, na proposta de uma combinação entre códigos e valores gerais de ética sobre a infância e as experiências e responsabilidades individuais de cada pesquisador em suas atividades de pesquisa com as crianças. Processos de discussão e reflexão que, de modo presente e constante no campo de estudos sobre crianças e infâncias, devem envolver todos os pesquisadores. E ainda para além daí, como assinada Prout, um diálogo constante com as crianças sobre os processos de investigação também se faz essencial, e pode em muito contribuir para o contexto das discussões e reflexões sobre ética nos estudos da infância. (CHRISTENSEN; PROUT, 2002:478)

O campo interdisciplinar de estudos sobre crianças e infâncias na contemporaneidade, como destacado em Prout, é caracterizado por diferentes perspectivas de olhar sobre as crianças: desde a criança tomada como objeto de investigação, passando pela criança tomada como sujeito na pesquisa - caracterizando-se os estudos desenvolvidos sobre crianças - até a visão da criança considerada como ator social e, mais recentemente, da criança considerada como participante e copesquisadora - caracterizando-se os estudos desenvolvidos com crianças. Possibilidades diversas, mas que coexistem e, algumas vezes, até se misturam ou se combinam nesse amplo e diverso campo de estudos, especialmente nos momentos ou situações em que questões ou dilemas éticos ainda não conseguem ser claramente assimilados ou completamente superados no contexto das novas perspectivas de investigação. (CHRISTENSEN; PROUT, 2002:480)

No contexto dos estudos desenvolvidos com crianças, o autor destaca a visão da criança tomada como ator social - a criança com sua agência, suas próprias experiências e entendimentos, que toma parte ao mudar e ser mudado pelo mundo cultural e social em que vive; e a visão da criança tomada como participante e copesquisadora - a criança como participante ativa no processo de pesquisa, como ela o é na cultura e sociedade, considerada e respeitada como ser humano, ator social e cidadão, com seus direitos de participação, atuando na pesquisa como informante, participante e parceira de investigação. (CHRISTENSEN; PROUT, 2002:481) 
Nesse sentido, é importante observar que o presente estudo procurou orientar suas bases epistemológicas e metodológicas a partir da visão das crianças tomadas como atores sociais e, em momentos específicos do processo de pesquisa, experimentando a perspectiva das crianças tomadas como participantes e copesquisadores - apesar dos desafios metodológicos e dilemas éticos implicados em tais situações e escolhas nos processos de investigação com crianças em campo - no intento de contribuir com novas visões, explorações, experimentações e reflexões no campo dos estudos contemporâneos sobre comunicação, consumo e infância.

Como destacado em Prout, as novas perspectivas nos estudos desenvolvidos com crianças representam experiências de pesquisa que trazem inovação e diversidade ao campo de investigação sobre crianças e infância, ao mesmo tempo em que trazem questões e dilemas éticos que precisam ser observados, considerados e continuamente avaliados pelos pesquisadores do campo. Concepções epistemológicas e metodológicas sobre a infância sempre representam implicações práticas na pesquisa com crianças, formatando desde a escolha dos métodos e técnicas, até a interpretação dos dados e avaliação dos resultados, passando pelas perspectivas, questões e dilemas éticos envolvidos em todo o processo de investigação. (CHRISTENSEN; PROUT, 2002:481)

A emergência das crianças como atores sociais, assim como participantes e copesquisadores nos processos de investigação, transforma significativamente sua posição no campo científico da pesquisa social e cultural. O entendimento de que as crianças têm voz no contexto das problemáticas sociais e culturais em que estão inseridas, traz um novo ator - a criança - aos processos de investigação. Mas não o faz sem um conjunto de novas complexidades, desafios e incertezas que passam a caracterizar tais processos de pesquisa com crianças em campo. (CHRISTENSEN; PROUT, 2002:482) Ao campo de estudos, novas questões e dilemas éticos para reflexão. Aos pesquisadores, novas responsabilidades e desafios para superação. Às crianças, o reconhecimento do seu direito à voz e à participação.

Complexidades e desafios para os quais, no sentido das crianças tomadas como atores sociais, participantes e copesquisadores nos processos de investigação, o autor propõe a concepção de uma "simetria ética" entre crianças e adultos nos processos de pesquisa com a participação infantil. Simetria ética que entende perceber adultos e crianças com a mesma sensibilidade, atenção, respeito e consideração nos diversos momentos e atividades do processo de investigação, uma vez que, como observa Prout, a relação ética entre pesquisador e pesquisado deve ter a mesma natureza, valores e princípios, independentemente de se tratar da faixa etárea. E assim, as eventuais particularidades ou diferenças no trabalho desenvolvido com crianças nos processos de investigação devem ser percebidas e consideradas nos momentos em 
que elas aparecem, nos trabalhos em campo, de modo concreto, sem que a ideia conceitual de uma separação ou diferenciação entre adultos e crianças tenha que ser assimilada ou assumida como algo dado a priori, no momento da fundamentação epistemológica ou formatação metodológica da pesquisa. Questão que requer ampla e contínua discussão, avaliação e reflexão entre os pesquisadores do campo, considerando-se tanto os contextos individuais de suas pesquisas, quanto o contexto mais amplo do campo de estudos, na tentativa de se alinhar valores gerais de ética a circunstâncias específicas na pesquisa com crianças em campo. (CHRISTENSEN; PROUT, 2002:478;482)

Tal entendimento, no entanto, não assinala a inexistência de particularidades ou diferenças entre adultos e crianças, mas que estas não precisam ser tomadas a priori, em nível conceitual, com base em estereótipos sobre crianças e adultos, antes que se façam presentes de modo concreto, nos cotidianos dos processos de investigação. Como destaca Prout, nos processos de investigação desenvolvidos com crianças, os pesquisadores não deveriam se preocupar em lançar mão de métodos e técnicas especiais, com base em valores éticos diferenciais. Devem antes, certificar-se de que os métodos, técnicas e atividades envolvidos na pesquisa estejam alinhados às experiências, interesses, entendimentos, valores e cotidianos das crianças, participantes e copesquisadores no processo de investigação. Pesquisadores com crianças em campo precisam conhecer e se engajar nas culturas infantis pesquisadas, percebendo as ações e relações entre as crianças, as semelhanças e diferenças entre elas, as particularidades de seus contextos, a comunicação e linguagens que utilizam, as perspectivas e significações a partir das quais percebem o mundo. Deve haver uma aproximação concreta e diálogo constante entre pesquisadores e crianças, atentando para os contextos e relações socioculturais nos quais as crianças tomam parte em seus cotidianos como atores sociais. (CHRISTENSEN; PROUT, 2002:478-483)

E faz-se importante notar, como bem ressalta o autor, que a concepção de uma "simetria ética" entre adultos e crianças não pressupõe a ideia de uma "simetria social" nas relações de poder entre adultos e crianças, ou mesmo entre crianças. Pois que as relações de pesquisa não podem ser vistas à parte das relações sociais e contextos culturais nos quais se inserem. "Research relationships always take place within social relations and cultural contexts that fundamentally form the character of the research process and its results." (CHRISTENSEN; PROUT, 2002:478-484)

Questões éticas na pesquisa com crianças são importantes e essenciais para observação, discussão e constante reflexão, especialmente nos processos de investigação tomados na perspectiva da participação infantil - como no caso das metodologias etnográficas e 
participativas, onde os pesquisadores têm maior aproximação com as crianças nos cotidianos dos contextos socioculturais explorados. Como observa Prout, quanto maior a aproximação ou mais intensa a relação entre pesquisadores e crianças, mais presentes se tornam as questões e dilemas éticos envolvidos no processo de investigação. CHRISTENSEN; PROUT, 2002:485)

E nesse contexto, como destaca o autor, faz-se essencial que as discussões e reflexões sobre ética na pesquisa com crianças sejam dadas coletivamente, de modo mais amplo, contemplando-se todos os pesquisadores do campo, mas, a partir da partilha das experiências individuais de pesquisa com crianças, dos dilemas éticos encontrados, das angústias e incertezas vivenciadas, das decisões e soluções experimentadas. Somente aí será possível uma documentação qualificada e consistente das experiências e conhecimentos sobre questões éticas na pesquisa com crianças a partir das práticas individuais de cada pesquisador no campo dos estudos da infância. CHRISTENSEN; PROUT, 2002:489-491)

No contexto dos estudos contemporâneos sobre crianças e infâncias, o engajamento no processo de discussão e reflexão sobre ética na pesquisa com crianças deve representar, assim, um esforço individual e coletivo, envolvendo as experiências singulares e práticas reflexivas de cada pesquisador em campo e as experiências partilhadas e conhecimentos plurais do campo de estudos em seu todo. Engajamento baseado mais na troca de experiências para a produção de um conhecimento plural, do que na busca de regras gerais para condução de pesquisas individuais ou solução de dilemas pontuais. Pois que:

Rules are in their very nature poor at dealing with new, unforeseen situations, they
can be inflexible, too easily become a routine, and at worst they act as a fig leaf for
the instrumental determination to get the research done at any cost. In short, they can
become a substitute for the active engagement of individual researchers and the social
science community as a whole with ethical issues. CHRISTENSEN; PROUT,
2002:491)

E aliando-se ao engajamento individual e coletivo dos pesquisadores na discussão e reflexão sobre ética nos estudos da infância, como sugere o autor, faz-se essencial a experiência de ouvir as crianças sobre os processos de investigação nos quais elas participam como atores sociais, participantes e copesquisadores. A voz das crianças representa importante e imprescindível contribuição para assa reflexão. CHRISTENSEN; PROUT, 2002:494)

Diante do exposto sobre participação infantil e ética na pesquisa com crianças, faz-se importante destacar que o presente estudo, desde a estruturação inicial de sua arquitetura filosófico-teórico-metodológica até o trabalho final de análise e interpretação dos dados e avaliação dos resultados, passando pelo desenvolvimento da pesquisa de campo, procurou ter sempre presente a preocupação com as questões éticas. Especialmente por tratar-se de um 
estudo desenvolvido com crianças - não somente com crianças, mas com adultos e crianças nos cotidianos de seus contextos familiares. E exatamente por acreditar que todo trabalho de pesquisa desenvolvido com pessoas, sejam elas adultos ou crianças - mas especialmente no caso das crianças - demanda atenção, cuidado e dedicação quanto às questões éticas, que devem estar presentes tanto na perspectiva e estruturação do estudo quanto no desenvolvimento de suas atividades em campo.

E nesse sentido, ainda que o estudo não tenha sido previamente submetido a comitês de ética em pesquisa - uma vez que a submissão ainda não se faz obrigatória para estudos e pesquisas desenvolvidos no campo da comunicação - toda atenção, cuidado e dedicação quanto às questões éticas, entendidos como essenciais ao contexto deste estudo, se fizeram presentes no processo de investigação, com base tanto no âmbito da epistemologia e formatação metodológica propostas para o estudo, quanto na Resolução 196/96 do Conselho Nacional de Saúde - que orienta as bases dos comitês de ética em pesquisa para estudos desenvolvidos com seres humanos. Especialmente por caracterizar-se como um estudo desenvolvido no sentido das crianças serem tomadas como atores sociais. Crianças que, para além de informantes, se fizeram também presentes como participantes e importantes parceiras neste processo de investigação.

A partir daí, no âmbito da participação infantil, deu-se início ao desenvolvimento da pesquisa com as crianças em campo, ainda que tendo-se em vista os desafios que tal empreitada representaria ao estudo proposto. Desafios presentes, mas não maiores que a riqueza proporcionada pela participação e voz das crianças no contexto do estudo e processo da investigação.

Como sinaliza Corsaro, a partir de suas próprias experiências de pesquisa, a entrada em campo é um momento crucial nos estudos etnográficos com crianças, na tentativa de se estabelecer ao pesquisador, no contexto sociocultural infantil estudado, "o status de membro e uma perspectiva ou ponto de vista de dentro". Nesse aspecto, especialmente por conta das marcantes diferenças entre adultos e crianças - diferenças biológicas, cognitivas e sociais como o autor observa: "a aceitação no mundo das crianças é particularmente desafiadora". (CORSARO, 2005:444)

Processo desafiador e enriquecedor - o autor atenta para a importância de uma detalhada e cuidadosa documentação da experiência de entrada em campo com as crianças, em seus diferentes níveis ou momentos de aceitação e participação do pesquisador. A documentação das experiências em campo pode trazer significativas contribuições teóricas e metodológicas ao campo dos estudos etnográficos - especialmente os estudos etnográficos com crianças. (CORSARO, 2005:445) 
Ainda que desafiadora e limitada, a experiência de conhecer e tomar parte nas culturas infantis pesquisadas é essencial e extremamente enriquecedora para os estudos da infância. Tal experiência que só pode ser vivenciada por pesquisadores com crianças em campo, a partir de metodologias etnográficas e participativas, permitindo maior aproximação com as crianças em seus cotidianos. E eis que aí se faz essencial atentar para a importância da sensibilidade, do cuidado, da empatia e do respeito às crianças e às singularidades da infância na exploração e estudo das culturas infantis. (CORSARO, 2005:446-464)

No sentido de um processo de investigação que, para além de um estudo sobre crianças, caracteriza-se como um estudo desenvolvido com crianças, e no exercício constante de um conhecimento e engajamento nas culturas infantis, dá-se na sequência a apresentação da pesquisa desenvolvida com as crianças em campo, em seus contextos familiares, com relato e descrição das principais atividades realizadas, exploração, interpretação e análise dos dados observados no processo de investigação, e avaliação e reflexão a partir dos resultados do estudo desenvolvido com a participação das crianças para exploração dos modos de presença e mediação comunicacional das marcas na cultura contemporânea de consumo alimentar infantil. 
SEGUNDO CAPÍTULO

MEDIAÇÃo COMUNiCACIONAL DAS MARCAS NA CULTURA ALIMENTAR INFANTIL 
O segundo capítulo do estudo é dedicado à apresentação, análise e conclusão da pesquisa de campo, contemplando o relato das principais atividades desenvolvidas e experiências vivenciadas com as crianças e as famílias em campo; a interpretação e análise dos dados e avaliação dos resultados a partir dos eixos específicos de abordagem teórica e empírica propostos para orientação da investigação; e as reflexões propostas a partir dos resultados da pesquisa para uma perspectiva de conclusão do estudo desenvolvido.

Inicialmente, um breve relato das experiências vivenciadas com as crianças em seus contextos familiares, atentando para os processos de entrada em campo em cada contexto familiar; as atividades realizadas com as crianças e com os pais ao longo dos encontros promovidos com as famílias para o desenvolvimento da pesquisa; e o envolvimento e participação das crianças e dos pais no processo de investigação.

$\mathrm{Na}$ sequência, as interpretações e análises dos dados e avaliação dos resultados da pesquisa de campo a partir do enfoque dos eixos de abordagem teórica e empírica propostos para orientação da investigação: a cultura alimentar infantil e as mediações culturais e comunicacionais na modulação do consumo alimentar das crianças no contexto familiar; a mediação comunicacional das marcas na cultura alimentar infantil e as marcas e produtos alimentícios no contexto familiar; a recepção infantil de marcas de alimentos e os vínculos de sentidos entre marcas/produtos e crianças no contexto familiar. Interpretações e análises elaboradas à luz da perspectiva das mediações comunicativas da cultura (como proposto por Martin-Barbero).

E finalmente, as reflexões propostas a partir dos resultados da pesquisa para composição de uma perspectiva de conclusão deste estudo desenvolvido sobre a mediação comunicacional das marcas na cultura contemporânea de consumo alimentar infantil, bem como, para sinalização de propostas para o desenvolvimento de estudos futuros na temática da combinação comunicação, consumo, infância e cultura alimentar. 


\section{COM AS CRIANÇAS EM CAMPO EM SEUS CONTEXTOS FAMILIARES: BREVE RELATO DA EXPERIÊNCIA E PROCESSO DE INVESTIGAÇÃO}

Como sinalizado no capítulo anterior, no momento da apresentação da estrutura, características e delimitações do estudo - e tomando-se o objeto de estudo e sua perspectiva de recorte para a pesquisa enquanto estudo de recepção infantil de marcas de alimentos no âmbito das práticas de consumo alimentar de crianças em contextos familiares - delineou-se, a partir daí, o seu corpus de investigação, tomando-se como locus para o desenvolvimento da pesquisa a cultura alimentar infantil em contextos e ambientes cotidianos de algumas famílias na cidade de São Paulo.

Nessa perspectiva, a pesquisa de campo foi desenvolvida em três contextos familiares: famílias residentes na cidade de São Paulo - SP; pertencentes a diferentes estratificações socioeconômicas (classes A1 B1 e C1); com uma ou mais crianças em sua composição familiar; crianças de ambos os sexos e diferentes idades (na faixa etária entre quatro e doze anos); para explorações sobre a mediação comunicacional das marcas na cultura alimentar infantil em contextos familiares; e considerando-se as práticas e rituais de consumo alimentar das crianças em ambientes domésticos e espaços públicos.

Na sequência, uma breve apresentação das famílias participantes do estudo para, em seguida, dar-se início ao relato das experiências vivenciadas com as crianças em campo em seus contextos familiares, atentando para os processos de entrada em campo em cada contexto familiar; as atividades realizadas com as crianças e com os pais ao longo dos encontros promovidos com as famílias para o desenvolvimento da pesquisa; e o envolvimento e participação das crianças e dos pais no processo de investigação.

\section{Primeira Família}

A primeira família participante do estudo é composta pelo pai, a mãe e duas crianças: uma menina e um menino. O pai: Carlos, 44 anos, natural de Cuiabá - MT. Com pós-graduação em nível de doutorado em comunicação. É professor universitário e consultor de projetos e pesquisa de mercado. A mãe: Carolina, 39 anos, natural de Sorriso - MS. Com pós-graduação em nível de mestrado em comunicação. É professora universitária também. A menina: Rose, 9 anos, natural de São Paulo - SP. É estudante no nível do ensino fundamental I. O menino: João, 
7 anos, natural de São Paulo - SP. Igualmente, é estudante no nível do ensino fundamental I. Ambos, estudantes em colégio da rede particular de ensino na cidade de São Paulo ${ }^{1}$.

No início do processo de pesquisa, a família era residente no bairro Vila São Francisco, na cidade de São Paulo. Apartamento com $128 \mathrm{~m}^{2}$ e 16 cômodos no total. Espaço bem amplo, iluminado e arejado. Ambiente com bastante espaço e conforto para a família e as crianças. E ao final do processo de pesquisa, a família passou a residir no bairro Higienópolis, também na cidade de São Paulo. Apartamento com $146 \mathrm{~m}^{2}$ e 12 cômodos no total. Espaço ainda mais amplo, iluminado e arejado. E igualmente, ambiente com bastante espaço e conforto para a família e as crianças.

A família possui dois carros, um para o pai e outro para a mãe. E conforme declaração dos pais, a família possui renda média mensal familiar de $\mathrm{R} \$ 30.000,00$. Faixa de renda que permite a classificação da família na estratificação socioeconômica da Classe A1. (ABEP BRASIL, 2018; 2019; KAMAKURA; MAZZON, 2013)

Os pais moravam em Cuiabá - MT e vieram para São Paulo - SP para concluir os estudos e dar sequência à carreira acadêmica. As crianças nasceram na cidade de São Paulo. Os pais contam que a rotina da família se tornou muito diferente na cidade grande. Muitas atividades profissionais e acadêmicas. E menos tempo para estar com a família e as crianças (especialmente no caso do pai).

O pai faz carreira acadêmica. É professor universitário na rede pública e privada de ensino superior na cidade de São Paulo. E possui uma empresa de consultoria em projetos e pesquisa de mercado. Trabalha nos três períodos (de manhã, à tarde e à noite). Trabalha durante o dia na sua empresa e dá aula à noite (três vezes por semana). E toca violão, às vezes, como lazer.

A mãe, igualmente, faz carreira acadêmica. Está cursando o doutorado e também é professora universitária. Trabalha no período da noite. Dá aula à noite (uma vez por semana). No período da manhã e, às vezes, à noite, a mãe fica com as crianças. Acompanha toda a rotina de atividades das crianças. Tanto as atividades escolares quanto as demais atividades (esportivas e artísticas) em que as crianças estão envolvidas. À tarde, se dedica às atividades do doutorado e faz academia.

As crianças cursam o ensino fundamental I. A menina, cursando o $3^{\circ}$ ano. E o menino, cursando o $2^{\circ}$ ano. Eles estudam no período vespertino. E na parte da manhã e à noite, as

\footnotetext{
${ }^{1}$ Os nomes atribuídos às crianças e aos pais foram escolhidos pelas crianças para preservação da identidade das crianças e dos pais enquanto participantes da pesquisa.
} 
crianças participam de atividades esportivas, artísticas e de estudo de línguas.

A menina faz balé, toca piano, e estuda inglês. E nos dias livres ou horas de folga, além da obrigação diária de fazer a lição de casa, ela costuma ver televisão, brincar no tablet (IPad), fazer atividades lúdicas no Matific (game de matemática da escola), brincar com as amigas, e tocar piano.

O menino faz natação, luta judô, toca bateria e pratica o jogo de xadrez. E nos dias livres ou horas de folga, além da obrigação diária de fazer a lição de casa, ele costuma ver televisão, jogar no tablet (IPad), brincar com os amigos, brincar no piano da irmã, e andar de bicicleta.

A família conta com o apoio de uma empregada e uma babá (todos os dias) e de uma faxineira (uma vez por semana). A babá está com as crianças desde que elas nasceram.

E na composição da família também há pets: três gatos que também são parte da família. Um gato siamês (o Pudim) e dois gatos persas (o Guri e a Pucca). As crianças gostam muito dos gatos e costumam brincar com eles todos os dias.

Família adorável, acolhedora e muito participativa. E que, com todo interesse, atenção e dedicação, teve ativa participação no processo de investigação. Pesquisa realizada com a família no período de dezembro / 2016 a agosto / 2019.

\section{Segunda Família}

A segunda família participante do estudo, assim como a primeira, é composta pelo pai, a mãe e duas crianças: uma menina e um menino. O pai: Daniel, 40 anos, natural de Osasco SP. Possui graduação em letras e é professor de língua portuguesa. A mãe: Paula, 35 anos, natural de São Paulo - SP. Possui graduação em matemática e é professora de matemática e física. A menina: Luana, 11 anos, natural de São Paulo - SP. É estudante no nível do ensino fundamental II. O menino: Rafael, 6 anos, natural de São Paulo - SP. É estudante no nível do ensino fundamental I. Ambos, estudantes em colégio da rede particular de ensino na cidade de São Paulo².

A família é residente no bairro Vila Lageado, na cidade de São Paulo. Casa com 276m² e 14 cômodos no total. Espaço igualmente amplo, iluminado e arejado. Ambiente com bastante espaço e conforto para a família e as crianças.

A família possui dois carros, um para o pai e outro para a mãe. E conforme declaração dos pais, a família possui renda média mensal familiar de $\mathrm{R} \$ 10.000,00$. Faixa de renda que

\footnotetext{
${ }^{2}$ Os nomes atribuídos às crianças e aos pais foram escolhidos pelas crianças para preservação da identidade das crianças e dos pais enquanto participantes da pesquisa.
} 
permite a classificação da família na estratificação socioeconômica da Classe B1. (ABEP BRASIL, 2018; 2019; KAMAKURA; MAZZON, 2013)

O pai é sansei (neto de imigrantes japoneses). É professor de língua portuguesa na rede pública estadual e municipal de ensino de São Paulo. Trabalha no período da manhã e da tarde e faz formação pedagógica à noite. E toca violão, às vezes como lazer.

A mãe é professora de matemática e física na rede pública estadual de ensino de São Paulo. Trabalha no período da manhã. E também costura e faz trabalhos artesanais em casa sob encomenda. Fica com as crianças no período da tarde e à noite. A mãe administra as atividades e a rotina da casa e acompanha toda a rotina de atividades das crianças. Tanto as atividades escolares quanto as demais atividades em que as crianças estão envolvidas, e ainda as tarefas domésticas das quais as crianças participam para ajudar na rotina da casa. E algumas vezes por semana a mãe faz academia no horário do almoço.

As crianças cursam o ensino fundamental. A menina, cursando o $6^{\circ}$ ano do ensino fundamental II e o menino, cursando o $2^{\circ}$ ano do ensino fundamental I. Eles estudam no período matutino. E na parte da tarde, a menina participa de atividades esportivas e de estudos. $\mathrm{O}$ menino ainda não participa de atividades além da escola.

No período da tarde, na escola, a menina pratica voleibol (duas vezes por semana) e faz aprofundamento de estudos em matemática (uma vez por semana). E nos dias livres ou horas de folga, além das obrigações diárias de fazer a lição de casa e participar nas tarefas domésticas para ajudar na rotina da casa, a menina costuma fazer desenhos em papel e pinturas em tela, ler livros, e ficar brincando no celular (vídeos / séries / músicas / redes sociais).

O menino, nos dias livres ou horas de folga, além das obrigações diárias de fazer a lição de casa e participar nas tarefas domésticas para ajudar na rotina da casa, costuma ler revistas de mangá e jogar videogame.

A família não conta com o apoio de empregada ou faxineira. A mãe e as crianças são responsáveis pelas tarefas domésticas da casa; o pai também ajuda nos fins de semana.

E na composição da família há também um pet: um cachorro ShihTzu (o Cheetos), que também é parte da família. As crianças gostam muito do cachorro e costumam brincar com ele todos os dias, também são responsáveis para ajudar a cuidar do cachorro (alimentação e limpeza), especialmente a menina.

Como a primeira família, esta também é uma família adorável, acolhedora e muito participativa. E que, com todo interesse, atenção e dedicação, teve ativa participação no processo de investigação. Pesquisa realizada com a família no período de abril / 2019 a agosto / 2019. 


\section{Terceira Família}

A terceira família participante do estudo é composta pelo pai, a mãe e três crianças: duas meninas e um bebê (também menina). O pai: Luís, 37 anos, natural de São Paulo - SP. Com ensino médio completo, é profissional da área de TI (analista de suporte técnico). A mãe: Zélia, 34 anos, natural de São Paulo - SP. Igualmente com ensino médio completo, é agente comunitária de saúde. A menina mais velha: Celina, 9 anos, natural de São Paulo - SP. É estudante no nível do ensino fundamental I em colégio da rede particular de ensino na cidade de São Paulo, onde estuda como aluna bolsista. A menina mais nova: Teresinha, 4 anos, natural de São Paulo - SP. É estudante no nível da educação infantil em creche da rede particular de ensino na cidade de São Paulo. Como a irmã mais velha, ela frequenta a creche também como aluna bolsista. E a bebê: Paulina, 1 ano, natural de São Paulo - SP frequenta uma creche da rede pública na cidade de São Paulo no nível do berçário ${ }^{3}$.

A família é residente na comunidade de Paraisópolis, na cidade de São Paulo. Apartamento com $54 \mathrm{~m}^{2}$ e sete cômodos no total. Espaço pequeno, mas bem planejado e organizado. Ambiente arejado, iluminado e confortável para a família e as crianças.

A família possui um carro. E conforme declaração dos pais, a família possui renda média mensal familiar de R 3.000,00. Faixa de renda que permite a classificação da família na estratificação socioeconômica da Classe C1. (ABEP BRASIL, 2018; 2019; KAMAKURA; MAZZON, 2013)

Os pais nasceram na cidade de São Paulo. Mas as famílias de ambos são do nordeste (Paraíba). O pai mora na comunidade da cidade desde que nasceu. A mãe morava em outra região de São Paulo, mas veio para onde moram hoje ainda criança. As meninas também moram na comunidade desde que nasceram.

O pai trabalha na área de TI, como analista de suporte técnico. Ele trabalha com computadores e impressões. Já trabalha nessa área há 10 anos e gosta muito da área de TI. No entanto, no momento do desenvolvimento da pesquisa, estava desempregado, recebendo somente o seguro desemprego. Mas assim que possível, ele pretendia conseguir uma nova colocação no mercado, e de preferência, mantendo um emprego na mesma área de trabalho. De acordo com o pai, no entanto, o fato do desemprego não altera muito a faixa de renda média da família, pois, como as crianças são pequenas, quando o pai trabalha, a mãe fica em casa com as crianças. Ou vice versa. Nesse período, dificilmente os dois conseguem trabalhar ao mesmo

\footnotetext{
${ }^{3}$ Os nomes atribuídos às crianças e aos pais foram escolhidos pelas crianças para preservação da identidade das crianças e dos pais enquanto participantes da pesquisa.
} 
tempo. Somente se for em turnos alternados. Quando não está trabalhando, é o pai que fica em casa com as crianças. Prepara as refeições, organiza as atividades e a rotina da casa, faz as compras, e encaminha as crianças para a escola e para a creche (leva e busca as crianças de carro). O pai toca violão toda semana na igreja (ministério de música). E, às vezes, também toca violão em casa, como lazer.

A mãe trabalha como agente comunitária de saúde. Ela trabalha em um posto de saúde da rede pública municipal de saúde da cidade de São Paulo no período da manhã e da tarde. Em horário integral. Ela havia iniciado no emprego a pouco tempo e estava gostando muito da experiência, pois, segundo ela, o trabalho consiste em fazer a ponte ou vínculo entre o posto de saúde e as famílias ou a comunidade. Uma experiência nova de trabalho e que ela estava achando muito interessante. Mas antes, quando o pai estava trabalhando e a mãe estava desempregada, ela ficava em casa com as crianças. Acompanhando a rotina das crianças e administrando a rotina da casa.

A menina mais velha está cursando o $4^{\circ}$ ano do ensino fundamental I. Ela estuda no período vespertino. E ainda não participa de atividades esportivas, artísticas ou de estudo de línguas em modalidades extracurriculares na escola. Atividades oferecidas às crianças somente a partir do ensino fundamental II. No entanto, no momento do desenvolvimento da pesquisa, a menina havia sido aprovada no processo seletivo de uma escola de idiomas para estudar inglês como aluna bolsista. As aulas iniciariam no semestre seguinte. No período da manhã a menina fica em casa com o pai. Período em que ela tem algumas obrigações diárias como fazer a lição de casa e participar nas tarefas domésticas para ajudar na rotina da casa. Nos dias livres ou horas de folga, a menina costuma brincar no celular (vídeos, jogos, e comunicação por mensagens), ou ver televisão, ou ler algum livro da biblioteca da escola, ou brincar com a irmã mais nova e a bebê. A menina, às vezes, também ajuda a cuidar da bebê, quando os pais estão envolvidos em algumas tarefas da casa (especialmente a noite, quando estão todos juntos em casa). E aos sábados de manhã a menina faz catequese.

A menina mais nova e a bebê ficam na creche em período integral. E lá fazem todas as atividades (educativas / artísticas / recreativas). Assim como as principais refeições do dia (café da manhã / lanche / almoço /lanche da tarde / jantar).

A família não conta com o apoio de empregada ou faxineira. O pai, a mãe e as crianças são responsáveis pelas tarefas domésticas da casa. Todos contribuem em alguma medida. O pai e a mãe ficam com a maior parte do trabalho. E as meninas contribuem com pequenas tarefas diárias. Especialmente a menina mais velha. A menina mais nova ainda não participa diretamente nas tarefas domésticas, mas em a obrigação diária de guardar os seus brinquedos. 
Como a primeira e a segunda família, também esta é uma família adorável, acolhedora e muito participativa. E que, com todo interesse, atenção e dedicação, teve ativa participação no processo de investigação. Pesquisa realizada com a família no período de junho / 2019 a agosto / 2019.

Em anexo, tabelas com resumo descritivo das famílias: alguns dados sobre as composições familiares, perfil de consumo e estratificação socioeconômica das famílias. (APÊNDICE M)

O processo de entrada em campo para o desenvolvimento da pesquisa com as crianças em seus contextos familiares foi bastante tranquilo e extremamente enriquecedor. A disponibilidade, acolhimento, envolvimento e participação ativa dos pais e das crianças foi algo muito presente em todos os momentos e etapas do trabalho desenvolvido em campo. Desde os primeiros contatos com as famílias, até o momento da realização efetiva das atividades propostas nos encontros promovidos com as famílias para o desenvolvimento da investigação.

Como apresentado no capítulo anterior, no momento da apresentação da estrutura, características e delimitações do estudo, inicialmente foram realizados os primeiros contatos com as famílias participantes do estudo para o registro de alguns dados sobre os perfis familiares, apresentação do trabalho a ser desenvolvido no processo de investigação, leitura e assinatura do termo de consentimento livre e esclarecido, e agendamento e programação dos encontros e atividades a serem realizadas. Em anexo encontra-se o modelo do termo de consentimento livre e esclarecido apresentado às famílias para esclarecimentos sobre a pesquisa e do termo assinado pelos pais e pelas crianças para autorização para participação das crianças nas atividades desenvolvidas no processo de investigação e para registros de imagens das crianças em fotografia e vídeo. (APÊNDICE A)

Ainda como apresentado no capítulo anterior, na sequência, em momentos distintos no processo de investigação, deu-se início à pesquisa de campo com as crianças em seus contextos familiares, com a realização de encontros e atividades com cada uma das famílias participantes do estudo. Para o desenvolvimento do trabalho de campo, foram realizados o total de seis encontros com as famílias, para explorações sobre os modos de presença e mediação comunicacional das marcas na cultura alimentar infantil nos cotidianos dos contextos familiares pesquisados.

O primeiro encontro - no formato de visita à família - foi realizado para conhecer o ambiente doméstico e explorar o contexto, rotina e composição familiar em seu cotidiano a fim de observar e investigar sobre a cultura alimentar infantil e as mediações culturais e comunicacionais presentes na modulação do consumo alimentar das crianças no contexto 
familiar. Como apresentado detalhadamente no capítulo anterior, a principal atividade desenvolvida no primeiro encontro: uma entrevista em grupo com a família na forma de conversação com os pais e com as crianças.

Logo no primeiro encontro promovido no processo de investigação, fomos muito bem recebidas pelas famílias e pelas crianças participantes do estudo (eu e a assistente de fotografia e vídeo que me auxiliou no registro das principais atividades da pesquisa). Em cada contexto familiar, os pais e as crianças se mostraram extremamente receptivos, acolhedores e participativos.

No encontro com a primeira família participante do estudo, fomos recebidas com toda atenção e carinho pela mãe (Carolina) e pelo pai (Carlos). Os pais são meus amigos, o que foi muito importante para o trabalho de campo, uma vez que já havia um processo de aproximação com a família e as crianças. Eles nos receberam muito bem.

Tomamos um café e ficamos aguardando um pouco para o início das atividades. Era uma manhã de sexta-feira (29/9/2017). Chegamos à residência da família às 9:30h e saímos às 14:30h.

O pai tomou café da manhã e, em seguida, saiu para o trabalho. A mãe e as crianças já haviam tomado café da manhã. As crianças (Maria Luíza e João) estavam um pouco tímidas e ainda com sono. Haviam acordado a pouco tempo, tomado café da manhã, e estavam concluindo a lição de casa. O trabalho demorou um pouco a começar. Mas enquanto aguardávamos, foi possível observar e sentir um pouco a rotina do lar.

Em seguida, deu-se início à entrevista em grupo com a família na forma de conversação com a mãe e com as crianças. Entrevista gravada em vídeo e formatada a partir dos objetivos propostos para o primeiro encontro. Mas antes de iniciar a entrevista, fiz uma breve apresentação dos objetivos da pesquisa para a mãe e as crianças. Para que as crianças pudessem compreender o trabalho a ser desenvolvido e o quanto elas poderiam contribuir.

A entrevista com a mãe e as crianças foi realizada na sala de estar. E durante a entrevista, as crianças se mostraram bem à vontade. E pareciam não se importar muito com o fato da nossa presença (presença eventualmente estranha ao cotidiano da casa) e nem com o fato de estarmos gravando a conversa em vídeo.

É verdade que as crianças já me conheciam, pois eu já tinha algum convívio com a família, uma vez que os pais são meus amigos. Mas, de qualquer modo, a assistente de fotografia e vídeo era uma pessoa estranha para elas, assim como estranho para elas era o fato de eu estar naquele momento exercendo um papel diferente: o papel de pesquisadora. Ainda assim, no entanto, as crianças se mostraram muito espontâneas durante toda a entrevista. 
Conversei bastante com a mãe e com as crianças. E as crianças estavam bem atentas, participando de tudo e comentando sobre todos os tópicos propostos. Participação ativa das crianças na conversação. Tanto a menina quanto o menino falavam o tempo todo, enriquecendo em muito a entrevista com os relatos, comentários e respostas que traziam para contribuir com o estudo.

No entanto, depois de certo tempo, como a entrevista estava se alongando, a atividade se tornou um pouco cansativa para as crianças. Ao final, já estavam um pouco impacientes. Queriam sair para brincar. Mas ainda assim, e com alguns pedidos da mãe, as crianças participaram ativamente da nossa conversa até o final. A atividade teve a duração aproximada de 35 minutos.

Ao final, agradeci a participação da mãe e, muito especialmente, a participação das crianças na entrevista. A conversa com a mãe e as crianças foi muito produtiva e extremamente enriquecedora para o processo de investigação. E trouxe muitas informações importantes para o desenvolvimento da pesquisa.

Após a entrevista, fizemos algumas fotos da família produzidas pelas crianças. As crianças escolheram o local e organizaram as cenas para as fotos. Foi muito interessante e as crianças gostaram muito de participar.

Nas fotos da família, as crianças escolheram o sofá da sala como cenário. E o menino quis incluir a sua bicicleta na foto (a bicicleta nova que ele havia ganhado). Então, fizeram a foto da família com a mãe, as crianças e a bicicleta.

$\mathrm{Na}$ sequência, as crianças foram se preparar para o almoço, pois logo em seguida, elas teriam que sair para a escola. Fomos convidadas para almoçar com a família e aceitamos o convite.

Durante o almoço, segui conversando com a mãe e com as crianças. E, ainda que não estivesse previsto para o primeiro encontro o acompanhamento de um ritual alimentar da família, foi uma excelente oportunidade para observar e coletar informações importantes para o desenvolvimento da pesquisa. Após o almoço, as crianças logo saíram para a escola.

Em seguida, tomarmos mais um café. E eu então realizei uma entrevista individual complementar com a mãe (gravada em áudio). Do mesmo modo, uma entrevista formatada a partir dos objetivos propostos para o primeiro encontro.

A conversa com a mãe também foi muito produtiva e trouxe muitas informações importantes para o desenvolvimento da pesquisa. A atividade teve a duração aproximada de 1 hora e 20 minutos. 
Ao final, agradeci a atenção e participação da família (especialmente da mãe e das crianças) no primeiro encontro da pesquisa. E agendamos os próximos encontros.

No encontro com a segunda família participante do estudo, fomos muito bem recebidas pela mãe (Paula) e pelo pai (Daniel). Eu e os pais temos um amigo em comum, que estava presente no primeiro encontro para fazer as apresentações. O que foi muito importante no processo de aproximação com a família.

Era uma manhã de sábado (6/4/2019). Chegamos à residência da família às $9 \mathrm{~h}$ e saímos às 12:30h. A mãe havia feito um bolo para nos receber. Um bolo delicioso de chocolate e ninho. Tomamos um café e comemos o bolo.

Durante o café, começamos a conversar. Então, me apresentei à família e eles também se apresentaram para mim (os pais e as crianças). E como no encontro com a primeira família, fiz uma breve apresentação dos objetivos da pesquisa para os pais e as crianças. Para que as crianças pudessem compreender o trabalho a ser desenvolvido e o quanto elas poderiam contribuir.

Em seguida, como no encontro com a primeira família, deu-se início à entrevista em grupo com a família na forma de conversação com os pais e com as crianças. Entrevista gravada em vídeo e igualmente formatada a partir dos objetivos propostos para o primeiro encontro.

A entrevista com os pais e as crianças foi realizada ali mesmo, na cozinha. Estávamos todos sentados à mesa e então, ali mesmo, começamos a conversar sobre os tópicos propostos para a pesquisa.

A mãe conduziu a maior parte dos relatos, em resposta aos tópicos propostos na entrevista. Mas, de modo geral, houve a participação de toda a família (a mãe, o pai e as crianças). Todos pareciam muito interessados e empenhados em participar da pesquisa e contribuir para o estudo.

As crianças (Luana e Rafael) também participaram bastante e trouxeram contribuições importantes. Especialmente a menina. Ela estava bastante concentrada na conversação e contribuiu com relatos, comentários e respostas muito interessantes para o estudo. O menino teve participação menor. Talvez por ser mais novo e ainda um pouco tímido para conversar. Respondia sempre que perguntado diretamente. Às vezes sozinho, outras vezes, com o incentivo ou auxilio da mãe. Mas, do seu modo, ele também trouxe relatos, comentários e respostas muito interessantes para o estudo durante a conversação.

No entanto, assim como no encontro com a primeira família, depois de certo tempo, e como a entrevista estava se alongando muito, a atividade se tornou um pouco cansativa para as crianças. Especialmente para o menino. Ao final, ele já estava um pouco impaciente. Queria 
sair para brincar. E também estava com fome. Mas ainda assim, e com alguns pedidos da mãe, o menino participou da nossa conversa até o final. A atividade teve a duração aproximada de 1 hora e 40 minutos.

A entrevista em grupo com a segunda família teve duração maior que a primeira porque, por conta de reformulações metodológicas no processo de pesquisa, tomou-se como mais importante a participação das crianças em todos os tópicos propostos. Excluindo-se, assim, a necessidade de entrevista complementar mais extensa com a mãe ou com o pai.

Ao final da entrevista, agradeci a participação da família e, muito especialmente, a participação das crianças. Foi muito interessante esse primeiro contato com a família, pois se mostraram muito receptivos e participativos. Como no encontro com a primeira família, a conversa com a família foi igualmente muito produtiva e extremamente enriquecedora para o processo de investigação, trazendo informações e contribuições muito importantes para o desenvolvimento da pesquisa.

Após a entrevista, como no encontro com a primeira família, também aqui fizemos algumas fotos da família produzidas pelas crianças. As crianças escolheram o local e organizaram as cenas para as fotos. Foi muito interessante e as crianças gostaram muito de participar.

Nas fotos da família, as crianças escolheram o quintal da casa como cenário. E incluíram o cachorro (o Cheetos) na foto da família. Porque ele também faz parte da família. Em uma das fotos, a menina escolheu mostrar um dos quadros que pintou. Um dos que ela mais gosta (Abacaxi). Ela fez a foto segurando o quadro. Em outra foto, o menino escolheu mostrar um bonequinho de pano que ele gosta muito (Amigurumi). Foi a mãe quem fez para ele. Ele fez a foto segurando o seu Amigurumi.

Ao final, agradeci a atenção e participação da família e das crianças no primeiro encontro da pesquisa. E agendamos os próximos encontros.

No encontro com a terceira família participante do estudo, fomos recebidas com muito carinho pela mãe (Zélia) que nos recebeu na portaria do condomínio. E quando chegamos ao apartamento, fomos recebidas por toda a família: a mãe, o pai (Helio), e as meninas (Celina e Teresinha). A bebê (Paulina) estava dormindo.

Eu e os pais temos uma amiga em comum. O que foi muito importante no processo de aproximação com a família. Ainda que ela não estivesse presente no primeiro encontro para fazer as apresentações.

Era uma tarde de sábado (29/6/2019). Chegamos à residência da família às 14:30h e saímos às 16:30h. A família já estava nos aguardando e todos nos receberam com muito carinho. 
Nos sentamos com a família na sala e começamos a conversar. Então, me apresentei à família e eles também se apresentaram para mim (os pais e as meninas). E como no encontro com a primeira e a segunda família, fiz uma breve apresentação dos objetivos da pesquisa para os pais e as crianças. Para que as crianças pudessem compreender o trabalho a ser desenvolvido e o quanto elas poderiam contribuir.

Em seguida, como no encontro com a primeira e a segunda família, deu-se início à entrevista em grupo com a família na forma de conversação com os pais e com as crianças. Entrevista gravada em vídeo e formatada igualmente a partir dos objetivos propostos para o primeiro encontro.

A entrevista com a família foi realizada no sofá da sala. A conversa com os pais e as crianças foi muito agradável. Os pais foram extremamente receptivos e participativos. Com todo interesse e atenção em participar da pesquisa e contribuir para o estudo. Respondendo prontamente as questões apresentadas e comentando sobre os tópicos propostos. Relatos e comentários muito valiosos para o desenvolvimento da pesquisa.

As crianças também tiveram importante participação na entrevista. Especialmente a menina mais velha (Celina). Ela participou da conversa com a família com muita atenção e interesse, do início ao final da entrevista. E mesmo com alguma timidez, ela respondeu todas as questões solicitadas e fez comentários e relatos muito interessantes e valiosos para o estudo.

A menina mais nova (Teresinha) falou pouco. Talvez por ser ainda muito nova e bastante tímida. Ela quase não falou conosco. Mas esteve presente conosco na sala, prestando atenção a nossa conversa, até o final da entrevista. Ela somente respondia a alguma questão, quando insistíamos para ela falar. Às vezes, ela falava, outras vezes, apenas sinalizava com a cabeça. Os pais comentaram que ela é uma criança que costuma falar pouco. Mas, do seu modo, ela também trouxe contribuições importantes para o estudo.

No entanto, assim como no encontro com a primeira e a segunda família, depois de certo tempo, e como a entrevista estava se alongando muito, a atividade se tornou um pouco cansativa para as crianças, especialmente para a menina mais nova. Ao final, ela já estava um pouco impaciente. Queria brincar. Mas ainda assim, a menina acompanhou a nossa conversa até o final. A atividade teve a duração aproximada de 1 hora e 30 minutos.

A entrevista em grupo com a terceira família, assim como no caso da segunda família, teve duração maior que a primeira porque, por conta de reformulações metodológicas no processo de pesquisa, tomou-se como mais importante a participação das crianças em todos os tópicos propostos, excluindo-se, assim, a necessidade de entrevista complementar mais extensa com a mãe ou com o pai. 
Ao final da entrevista, agradeci a participação da família e, muito especialmente, a participação das crianças. Foi muito interessante o primeiro contato com a família, pois se mostraram muito atenciosos, receptivos e participativos. E foi muito agradável estar com eles. Como no encontro com a primeira e a segunda família, a conversa foi igualmente muito produtiva e extremamente enriquecedora para o processo de investigação, trazendo informações e contribuições muito importantes para o desenvolvimento da pesquisa.

Após a entrevista, como no encontro com a primeira e a segunda família, fizemos também algumas fotos da família produzidas pelas crianças. As crianças escolheram o local e organizaram as cenas para as fotos. Foi muito interessante e as crianças gostaram muito de participar.

As meninas escolheram fazer as fotos com a família no sofá da sala. E escolheram incluir nas fotos o sapo de pelúcia da menina mais nova (o Djodje). Então, fizeram as fotos da família com a mãe, o pai, as meninas, a bebê e o sapo de pelúcia.

Ao final, agradeci a atenção e participação da família e das crianças no primeiro encontro da pesquisa. E agendamos os próximos encontros.

Como sinalizado no capítulo anterior, em anexo apresenta-se roteiro com os principais tópicos sugeridos para orientação da entrevista em grupo realizada com as famílias participantes do estudo no primeiro encontro. (APÊNDICE B)

Nos períodos seguintes ao primeiro encontro com as famílias - o que demarcou o processo de entrada em campo nos contextos familiares pesquisados - seguiram-se os demais encontros propostos para o desenvolvimento da pesquisa com as crianças em campo em seus contextos familiares. Cada encontro, formatado a partir de objetivos e atividades específicas para o desenvolvimento da pesquisa, com base nos eixos de abordagem teórica e empírica propostos para orientação da investigação - como especificado detalhadamente no capítulo anterior, no memento da apresentação da estrutura, características e delimitações do estudo. Em cada encontro realizado e para cada atividade desenvolvida, a disponibilidade, acolhimento, envolvimento e participação ativa das famílias (as crianças e os pais) no processo de investigação.

O segundo encontro - igualmente no formato de visita à família - foi realizado com a finalidade de observar e participar de um ritual de alimentação da família, com a presença das crianças, no ambiente doméstico. Atentando para a cultura alimentar infantil e as mediações culturais e comunicacionais presentes na modulação do consumo alimentar das crianças no contexto familiar; e para os modos de presença e mediação comunicacional das marcas na cultura alimentar infantil e as marcas e produtos alimentícios presentes no contexto familiar. 
Como apresentado detalhadamente no capítulo anterior, as principais atividades desenvolvidas no segundo encontro: entrevista em grupo com as crianças na forma de conversação; registros em fotografias das marcas e produtos alimentícios presentes no ambiente doméstico; observação e participação em um ritual de alimentação da família, com a presença das crianças, no ambiente doméstico; entrevista individual com a mãe na forma de conversação.

Com a primeira família, o encontro foi bastante produtivo, com envolvimento e participação ativa da mãe e das crianças em todas as atividades propostas. O encontro foi realizado, novamente, numa sexta-feira de manhã (6/10/2017). Chegamos à residência da família às 10:30h e saímos às $14: 30 \mathrm{~h}$.

Inicialmente, foi realizada entrevista com as crianças na forma de conversação, gravada em vídeo coproduzido e dirigido por elas, para falar sobre o seu consumo alimentar. Gravamos um vídeo sobre o consumo alimentar da menina e um vídeo sobre o consumo alimentar do menino. O ambiente escolhido pelas crianças para as gravações foi o quarto da menina e o quarto do menino. As crianças prepararam os cenários com brinquedos favoritos e se expressaram com muita espontaneidade nos vídeos. Elas gostaram muito de participar da atividade. A atividade teve a duração aproximada de 10 minutos.

$\mathrm{Na}$ sequência, observamos e participamos de um ritual alimentar da família, com a presença das crianças, no ambiente doméstico: um almoço com a família e as crianças em casa. Almoçamos com a mãe e as crianças. O pai estava trabalhando. A empregada havia preparado a refeição. E a mãe preparou a mesa. Durante o almoço, conversei bastante com a mãe e com as crianças. E foi possível observar detalhes e coletar informações importantes para o desenvolvimento da pesquisa e melhor conhecimento das crianças e da sua cultura alimentar no contexto familiar. O ritual teve a duração aproximada de 40 minutos. Em anexo, tabela com descrição do cardápio da refeição e da composição do prato de cada criança. (APÊNDICE N)

Após o almoço, foi realizada entrevista individual com a mãe na forma de conversação, gravada em vídeo, e proposta em complementação aos tópicos abordados na entrevista em grupo realizada com a família no primeiro encontro. A entrevista foi breve e a participação da mãe foi muito importante para a complementação de informações sobre as crianças, o contexto familiar, e a cultura alimentar infantil no contexto familiar. A atividade teve a duração aproximada de 20 minutos.

Finalmente, com o consentimento e auxílio da mãe, efetuamos registros em fotografias das marcas e produtos alimentícios presentes no ambiente doméstico. Na cozinha da residência da família, fotografamos marcas e produtos presentes nas bancadas, armários e geladeira. Atividade realizada após conversa informal com a mãe sobre marcas e produtos alimentícios 
no contexto das escolhas e preferências da família e das crianças. As primeiras fotos para o registro de marcas e produtos alimentícios no ambiente doméstico já havíamos efetuado no primeiro encontro com a família. Em anexo, tabela com descrição das marcas e produtos alimentícios presentes no ambiente doméstico da família. (APÊNDICE N)

Com a segunda família, o encontro foi igualmente muito produtivo. E como no caso da primeira família, com todo envolvimento e participação ativa da mãe e das crianças nas atividades propostas. O encontro foi realizado, novamente, numa manhã de sábado (13/4/2019). Chegamos à residência da família às 10:30h e saímos às $14 \mathrm{~h}$.

Inicialmente, como realizado com a primeira família, e com o consentimento e auxílio da mãe, efetuamos registros em fotografias das marcas e produtos alimentícios presentes no ambiente doméstico. Na cozinha da residência da família, fotografamos marcas e produtos presentes nas bancadas, armários e geladeira. Atividade realizada após conversa informal com a mãe sobre marcas e produtos alimentícios no contexto das escolhas e preferências da família e das crianças. Em anexo, tabela com descrição das marcas e produtos alimentícios presentes no ambiente doméstico da família. (APÊNDICE O)

Em seguida, foi realizada entrevista em grupo com as crianças na forma de conversação, gravada em vídeo coproduzido por elas, para falar sobre o seu consumo alimentar, contexto familiar, marcas e publicidade de alimentos, mídias e tecnologias, e outros tópicos propostos para a pesquisa. O ambiente escolhido pelas crianças para as gravações foi o quarto da menina e o quarto do menino. Realizamos então a entrevista com as crianças. Primeiramente, usando o quarto da menina como cenário (onde foi gravada a maior parte da entrevista). E ao final, usando como cenário o quarto do menino (onde foi gravada a finalização da entrevista). As crianças participaram com atenção e dedicação da atividade proposta. Atividade com duração aproximada de 40 minutos.

Na sequência, observamos e participamos de um ritual alimentar da família, com a presença das crianças, no ambiente doméstico: um almoço com a família e as crianças em casa. Almoçamos com a mãe, o pai e as crianças. E um amigo da família também estava presente (amigo que tenho em comum com os pais). Com dedicação, a mãe havia preparado a refeição para todos nós. Ela preparou a mesa também. Durante o almoço, conversei bastante com os pais e com as crianças. E assim como no caso da primeira família, foi possível observar detalhes e coletar informações importantes para o desenvolvimento da pesquisa e melhor conhecimento das crianças e da sua cultura alimentar no contexto familiar. O ritual teve duração aproximada de 50 minutos. Em anexo, tabela com descrição do cardápio da refeição e da composição do prato de cada criança. (APÊNDICE O) 
Finalmente, após o almoço, foi realizada entrevista individual com a mãe na forma de conversação, gravada em vídeo, e proposta em complementação aos tópicos abordados na entrevista em grupo realizada com a família no primeiro encontro. Como no caso da primeira família, a entrevista foi breve e a participação da mãe foi muito importante para a complementação de informações sobre as crianças, o contexto familiar, e a cultura alimentar infantil no contexto familiar. Atividade com duração aproximada de 30 minutos.

Com a terceira família, o encontro também foi bastante produtivo. E muito agradável também. E como no caso da primeira e da segunda família, com extremo acolhimento, envolvimento e participação ativa dos pais e das crianças nas atividades propostas. O encontro foi realizado em um dia de feriado em São Paulo (9/7/2019). Chegamos à residência da família às $12: 30 \mathrm{~h}$ e saímos às $16: 30 \mathrm{~h}$.

Inicialmente, como realizado com a primeira e a segunda família, e com o consentimento e auxílio do pai e da mãe, efetuamos registros em fotografias das marcas e produtos alimentícios presentes no ambiente doméstico. Na cozinha da residência da família, fotografamos marcas e produtos presentes nas bancadas, armários e geladeira. Atividade realizada após conversa informal com os pais sobre marcas e produtos alimentícios no contexto das escolhas e preferências da família e das crianças. Em anexo, tabela com descrição das marcas e produtos alimentícios presentes no ambiente doméstico da família. (APÊNDICE P)

Em seguida, foi realizada entrevista em grupo com as crianças na forma de conversação, gravada em vídeo coproduzido por elas, para falar sobre o seu consumo alimentar, contexto familiar, marcas e publicidade de alimentos, mídias e tecnologias, e outros tópicos propostos para a pesquisa. O ambiente escolhido pelas crianças para as gravações foi o quarto das meninas, que mostraram o quarto e, em seguida, foram entrevistadas. As meninas participaram com atenção e dedicação da atividade proposta, especialmente a menina mais velha, que comentou atentamente todos os tópicos abordados. A menina mais nova falou pouco, mas esteve presente ao lado da irmã até o final da atividade. Atividade com duração aproximada de 35 minutos.

Na sequência, observamos e participamos de um ritual alimentar da família, com a presença das crianças, no ambiente doméstico: um almoço com a família e as crianças em casa. Almoçamos com o pai, a mãe e as crianças. Com carinho e dedicação, a mãe e o pai haviam preparado a refeição para nós. Eles prepararam a mesa também. Antes do almoço, pudemos acompanhar um pouco do ritual de preparação da refeição, quando o pai e a mãe estavam trabalhando juntos na cozinha. Durante o almoço, conversei bastante com os pais e com as crianças. E assim como no caso da primeira e da segunda família, foi possível observar detalhes 
e coletar informações importantes para o desenvolvimento da pesquisa e melhor conhecimento das crianças e da sua cultura alimentar no contexto familiar. O ritual teve duração aproximada de 45 minutos. Em anexo, tabela com descrição do cardápio da refeição e da composição do prato de cada criança. (APÊNDICE P)

Finalmente, após o almoço, foi realizada entrevista com os pais na forma de conversação, gravada em vídeo, e proposta em complementação aos tópicos abordados na entrevista em grupo realizada com a família no primeiro encontro. A entrevista foi breve e a participação do pai e da mãe foi muito importante para a complementação de informações sobre as crianças, o contexto familiar, e a cultura alimentar infantil no contexto familiar. E diferentemente do caso da primeira e da segunda família, na terceira família a entrevista foi realizada não somente com a mãe, mas com a mãe e o pai juntos. A atividade teve duração aproximada de 15 minutos.

Como sinalizado no capítulo anterior, em anexo apresenta-se roteiro com os principais tópicos sugeridos para orientação da entrevista em grupo realizada com as crianças e para orientação da entrevista individual realizada com as mães no segundo encontro com as famílias participantes do estudo. (APÊNDICE C; APÊNDICE D)

O terceiro encontro - no formato de visita / passeio com a família - foi realizado para observação e participação em um ritual alimentar da família, com a presença das crianças, em espaço público, ou lanche especial com as crianças em casa. Atentando igualmente para a cultura alimentar infantil e as mediações culturais e comunicacionais presentes na modulação do consumo alimentar das crianças no contexto familiar; e para os modos de presença e mediação comunicacional das marcas na cultura alimentar infantil e as marcas e produtos alimentícios presentes no contexto familiar. Como apresentado detalhadamente no capítulo anterior, as principais atividades desenvolvidas no terceiro encontro: registros em fotografias das marcas e produtos alimentícios presentes no ambiente doméstico; observação e participação em um ritual alimentar da família, com a presença das crianças, em espaço público, ou lanche especial com as crianças em casa; entrevista individual com o pai na forma de conversação.

O encontro com a primeira família foi bastante rentável. E muito dinâmico também. Com todo envolvimento e participação ativa dos pais e, especialmente, das crianças nas atividades propostas. O encontro foi realizado em um feriado (12/10/2017), dia das crianças. Cheguei à residência da família às $11: 30 \mathrm{~h}$ e saí às 18:30h. Nessa ocasião eu estava sozinha, sem a presença da assistente de fotografia e vídeo.

Inicialmente, foi realizada entrevista individual com o pai na forma de conversação, gravada em vídeo, e proposta em complementação aos tópicos abordados na entrevista em 
grupo realizada com a família no primeiro encontro. A entrevista foi um pouco mais extensa e, como no caso da entrevista realizada com a mãe no encontro anterior, a participação do pai também foi muito importante para a complementação de informações sobre as crianças, a história da família e o contexto familiar, e a cultura alimentar infantil no contexto familiar. A atividade teve a duração aproximada de 45 minutos.

Os registros em fotografias das marcas e produtos alimentícios presentes no ambiente doméstico, embora previstos também para o terceiro encontro, já haviam sido efetuados no primeiro e no segundo encontro com a família. Em anexo, tabela com descrição das marcas e produtos alimentícios presentes no ambiente doméstico da família. (APÊNDICE N)

$\mathrm{Na}$ sequência, a preparação para observação e participação em um ritual alimentar da família, com a presença das crianças, em espaço público: um almoço especial com a família e as crianças em comemoração ao dia das crianças. Antes de sairmos, pude registrar em vídeo a reunião feita entre as crianças (a menina e o menino) para a escolha do restaurante e da sorveteria. Nesse dia as crianças estavam livres para escolher. Para o almoço, escolheram o Restaurante América. E para a sobremesa, o sorvete do McDonald's. Durante o almoço com a família e as crianças, pude observar diversas situações e experiências e coletar informações muito importantes sobre o consumo alimentar das crianças para o desenvolvimento da pesquisa. O ritual teve a duração aproximada de 1 hora (para o almoço) e 15 minutos (para o sorvete). Em anexo, tabela com descrição dos pedidos das crianças e dos pais no restaurante e dos pedidos das crianças na sorveteria. (APÊNDICE N)

O encontro com a segunda família também foi muito rentável e dinâmico. Com envolvimento e participação ativa da família nas atividades propostas. Especialmente a mãe e as crianças. Mais uma vez, o encontro foi realizado em uma manhã de sábado (27/4/2019). Chegamos à residência da família às $11 \mathrm{~h}$ e saímos às $14 \mathrm{~h}$.

Inicialmente, com o consentimento e auxílio da mãe, efetuamos novos registros em fotografias das marcas e produtos alimentícios presentes no ambiente doméstico. Como da primeira vez, na cozinha da residência da família, fotografamos marcas e produtos presentes nas bancadas, armários e geladeira. Em anexo, tabela com descrição das marcas e produtos alimentícios presentes no ambiente doméstico da família. (APÊNDICE O)

Na sequência, a preparação para observação e participação em um ritual alimentar da família, com a presença das crianças, em espaço público, ou lanche especial com as crianças em casa. Que no caso específico da segunda família, foi organizado na forma de um lanche especial com a família e as crianças em casa: o dia da pastelaria. Para se manter fiel à rotina da família, a mãe propôs, como lanche especial, fazer pastéis para as crianças. Uma vez que, por 
questões de custo e de gosto, a família não costuma sair para comer fora com as crianças. E por isso, a mãe sempre prepara lanches especiais para as crianças nos fins de semana. Como no caso da primeira família, durante o lanche com a família e as crianças, pude observar situações e experiências diversas e coletar informações importantes sobre o consumo alimentar das crianças para o desenvolvimento da pesquisa. O ritual teve a duração aproximada de 45 minutos. Em anexo, tabela com descrição do cardápio dos pasteis preparados pela mãe para a família e as crianças no dia da pastelaria. (APÊNDICE O)

A entrevista individual com o pai na forma de conversação, programada para o terceiro encontro, por questões de tempo, e em acordo com o pai, entendemos como melhor transferi-la para o próximo encontro. A entrevista com o pai foi então realizada no encontro seguinte com a família. Realizada igualmente na forma de conversação, gravada em vídeo, e proposta em complementação aos tópicos abordados na entrevista em grupo realizada com a família no primeiro encontro. Como no caso da primeira família, a entrevista com o pai também foi um pouco mais extensa e, assim como a entrevista realizada com a mãe no encontro anterior, a participação do pai também foi muito importante para a complementação de informações sobre as crianças, a história da família e o contexto familiar, e a cultura alimentar infantil no contexto familiar. Atividade com duração aproximada de 30 minutos.

O encontro com a terceira família foi igualmente rentável e bastante dinâmico. Novamente aqui, com extremo acolhimento, envolvimento e participação ativa dos pais e das crianças nas atividades propostas. O encontro foi realizado em um domingo à tarde (14/7/2019). Cheguei à residência da família às $12: 30$ h e saí às 16 h. Nessa ocasião eu estava sozinha, sem a presença da assistente de fotografia e vídeo.

Inicialmente, com o consentimento e auxílio do pai e da mãe, efetuamos novos registros em fotografias das marcas e produtos alimentícios presentes no ambiente doméstico. Como da primeira vez, na cozinha da residência da família, fotografamos marcas e produtos presentes nas bancadas, armários e geladeira. Em anexo, tabela com descrição das marcas e produtos alimentícios presentes no ambiente doméstico da família. (APÊNDICE P)

Na sequência, a preparação para observação e participação em um ritual alimentar da família, com a presença das crianças, em espaço público: um lanche especial com a família e as crianças no McDonald's. Antes de sairmos, pude observar o quanto a família estava feliz por compartilhar esse momento. Especialmente as crianças. Com certeza, um momento especial para os pais e para as crianças. Ainda que a família tenha o hábito de ir ao McDonald's com as crianças uma ou duas vezes ao mês. Como no caso da primeira e da segunda família, durante o lanche com a família e as crianças, pude observar situações e experiências diversas e coletar 
informações importantes sobre o consumo alimentar das crianças para o desenvolvimento da pesquisa. O ritual teve a duração aproximada de 1 hora. Em anexo, tabela com descrição dos pedidos das crianças e dos pais no restaurante e sorveteria. (APÊNDICE P)

A entrevista com o pai na forma de conversação, programada para o terceiro encontro e que no contexto da terceira família seria desenvolvida com o pai e a mãe juntos - como no caso da segunda família, entendemos como melhor transferi-la para o próximo encontro. A entrevista com os pais foi então realizada no encontro seguinte com a família. Realizada igualmente na forma de conversação, gravada em vídeo, e proposta em complementação aos tópicos abordados na entrevista em grupo realizada com a família no primeiro encontro. E assim como a entrevista realizada com os pais no encontro anterior, também aqui a entrevista foi breve e a participação do pai e da mãe também foi muito importante para a complementação de informações sobre as crianças, o contexto familiar, e a cultura alimentar infantil no contexto familiar. Mais uma vez, diferentemente do caso da primeira e da segunda família, na terceira família a entrevista foi realizada não somente com o pai, mas com o pai e a mãe juntos. Atividade com duração aproximada de 15 minutos.

Como sinalizado no capítulo anterior, em anexo apresenta-se roteiro com os principais tópicos sugeridos para orientação da entrevista individual realizada com os pais no terceiro encontro com as famílias participantes do estudo. (APÊNDICE E)

O quarto encontro - no formato de atividade lúdica com as crianças - foi realizado para desenvolver uma atividade lúdica com as crianças, na forma de jogo e desenho, sobre marcas e produtos alimentícios e o consumo alimentar infantil. Com o objetivo de conhecer as experiências, perspectivas, saberes e afetos infantis quanto ao consumo alimentar e quanto às marcas e produtos alimentícios e o contexto promocional das marcas e produtos no mercado de alimentos. Buscando compreender os processos de recepção infantil de marcas de alimentos e os vínculos de sentidos entre marcas/produtos e crianças no contexto familiar. Como apresentado de modo detalhado no capítulo anterior, as principais atividades desenvolvidas no quarto encontro: atividade lúdica com as crianças na forma de jogo e desenho; entrevista individual e entrevista em grupo com as crianças na forma de conversação.

No contexto das três famílias participantes do estudo, o encontro foi extremamente produtivo e enriquecedor para o desenvolvimento da pesquisa. As atividades foram desenvolvidas exclusivamente com as crianças. Sem a participação direta dos pais. Com envolvimento, entusiasmo e participação ativa das crianças em todas as atividades propostas. As crianças gostaram muito de participar. 
Inicialmente, foi desenvolvida com as crianças a atividade lúdica proposta para o encontro: Brincadeira de Comer. Atividade desenvolvida com as crianças na forma de desenho e na forma de jogo (jogos de cards). Com diversos temas, imagens, proposições e desafios sobre marcas e produtos alimentícios e sobre o consumo alimentar infantil. As crianças participaram da atividade com entusiasmo, atenção e dedicação. E foi possível perceber toda expressividade das crianças nas diversas formas da atividade lúdica proposta.

Finalmente, foram realizadas entrevistas individuais e em grupo com as crianças, na forma de conversação, para documentar a participação das crianças na atividade lúdica proposta; para registrar as expressividades, perspectivas, saberes, preferências e afetos infantis quanto às marcas e produtos alimentícios e o consumo alimentar infantil; e para possibilitar a avaliação das crianças sobre a atividade lúdica desenvolvida com elas.

Com a primeira família, o encontro foi realizado em uma manhã de sexta-feira (13/10/2017). Chegamos à residência da família às $10 \mathrm{~h}$ e saímos às $14 \mathrm{~h}$. A atividade foi desenvolvida com a presença da menina (Rose) e do menino (João) e teve duração aproximada de 1 hora e 30 minutos. No início as crianças estavam mais quietas. Pareciam estar com sono e sem muito interesse em participar. Mas, na medida em que foram se desenvolvendo as atividades, as crianças logo começaram a participar de tudo com entusiasmo, atenção e dedicação. As crianças falavam o tempo todo. Com relatos, citações e observações extremamente valiosas para o desenvolvimento do estudo.

Com a segunda família, o encontro foi realizado em um feriado (1/5/2019). Chegamos à residência da família às 9:30h e saímos às 12:30h. A atividade foi desenvolvida com a presença da menina (Luana) e do menino (Rafael) e teve duração aproximada de 1 hora e 45 minutos. No início as crianças estavam um tanto quietas. E talvez um pouco tímidas. Mas, como no contexto da primeira família, na medida em que as atividades foram se desenvolvendo, as crianças começaram a participar com mais entusiasmo e muita atenção e dedicação. A menina não falava muito. O menino falava o tempo todo. Mas cada um a seu modo, com relatos, citações e observações igualmente valiosas para o desenvolvimento do estudo.

Com a terceira família, o encontro foi realizado em uma tarde de sábado (20/7/2019). Chegamos à residência da família às $15 \mathrm{~h}$ e saímos às $18 \mathrm{~h}$. A atividade foi desenvolvida com a presença da menina mais velha (Celina) e da menina mais nova (Teresinha) e teve duração aproximada de 2 horas e 15 minutos. No início as crianças estavam caladas e um pouco tímidas. Mas, como no contexto da primeira e da segunda família, na medida em que as atividades foram sendo desenvolvidas, as crianças começaram a participar com entusiasmo, atenção e dedicação. A menina mais velha falava mais e participou de todas as fases das atividades propostas. A 
menina mais nova falava pouco e não participou de todas as fases das atividades desenvolvidas. Mas ambas, cada uma a seu modo, com relatos, citações e observações, ou mesmo contribuições, igualmente valiosas para o desenvolvimento do estudo.

Desenvolver a atividade lúdica proposta - Brincadeira de Comer - com a participação das crianças nos diferentes contextos familiares representou uma experiência extremamente importante no contexto deste estudo. Tanto para o enriquecimento do processo de investigação, quanto para o aprofundamento e diversidade empírica no desenvolvimento da pesquisa.

Como sinalizado no capítulo anterior, em anexo apresenta-se o roteiro e dinâmica do jogo e as imagens sobre consumo alimentar (alimentos e produtos alimentícios) e sobre marcas (marcas e personagens), propostos para composição e formatação da atividade lúdica desenvolvida com as crianças na forma de jogo (jogos de cards); e o roteiro e dinâmica propostos para composição e formatação da atividade lúdica desenvolvida com as crianças na forma de desenho. Atividades lúdicas propostas na composição da Brincadeira de Comer, desenvolvida com as crianças no quarto encontro no contexto das famílias participantes do estudo. (APÊNDICE F) Também em anexo, apresenta-se roteiro com os principais tópicos sugeridos para orientação da entrevista individual e entrevista em grupo, realizadas com as crianças após a atividade lúdica desenvolvida com elas nos contextos familiares pesquisados. (APÊNDICE G)

O quinto encontro - igualmente no formato de atividade lúdica com as crianças - foi realizado para desenvolver uma atividade lúdica de simulação de compra e consumo de produtos alimentícios com as crianças no supermercado, na forma de jogo e dramatização. Igualmente, com o objetivo de conhecer as experiências, perspectivas, saberes e afetos infantis quanto ao consumo alimentar e quanto às marcas e produtos alimentícios e o contexto promocional das marcas e produtos no mercado de alimentos. Buscando compreender os processos de recepção infantil de marcas de alimentos e os vínculos de sentidos entre marcas/produtos e crianças no contexto familiar. Como apresentado de modo detalhado no capítulo anterior, as principais atividades desenvolvidas no quinto encontro: atividade lúdica com as crianças na forma de jogo e dramatização; entrevista individual com as crianças na forma de conversação.

No contexto de cada uma das famílias participantes do estudo, como na atividade lúdica desenvolvida com as crianças anteriormente, o encontro foi muito produtivo e bastante enriquecedor para o processo de pesquisa. Também aqui, as atividades foram desenvolvidas exclusivamente com as crianças. Sem a participação direta dos pais. Com todo envolvimento e 
participação ativa das crianças nas atividades propostas. E mais uma vez, as crianças gostaram muito de participar.

Primeiramente, foi desenvolvida com as crianças a atividade lúdica proposta para o encontro: Brincadeira de Comprar. Atividade lúdica de simulação de compra e consumo de produtos alimentícios com as crianças no supermercado, na forma de jogo e dramatização. As crianças participaram da atividade com muito entusiasmo e toda disposição. E assim como na atividade realizada no encontro anterior, foi possível perceber as diversas formas de expressividade das crianças ao longo de toda a atividade lúdica desenvolvida com elas no supermercado.

Ao final, foi realizada entrevista individual com as crianças na forma de conversação. E do mesmo modo, como as entrevistas realizadas com as crianças na atividade lúdica anterior, também aqui a entrevista foi realizada para documentar a participação das crianças na atividade lúdica proposta; para registrar as expressividades, perspectivas, saberes, preferências e afetos infantis quanto às marcas e produtos alimentícios e o consumo alimentar infantil; e para possibilitar a avaliação das crianças sobre a atividade lúdica desenvolvida com elas no supermercado.

Com a primeira família, o encontro foi realizado em uma manhã de sexta-feira (16/12/2016). Cheguei à residência da família às 11 h e saí as 14 h. Logo no início, saímos com as crianças para o desenvolvimento da atividade. A atividade foi realizada em um supermercado próximo à residência da família (Supermercado Jaguaré) com a presença da menina (Rose) e do menino (João). E teve duração aproximada de 1 hora. A mãe (Carolina) também estava presente conosco no supermercado. Ao final da atividade, retornamos à residência da família para conversar com as crianças. No caso específico da primeira família, a atividade lúdica desenvolvida com as crianças no supermercado foi a primeira atividade realizada no processo de pesquisa com a família. Desde o início da atividade no supermercado, as crianças participaram com muito entusiasmo e disposição. Escolhendo os produtos alimentícios e falando sobre os produtos e marcas escolhidos por elas e sobre seus gostos e preferências no consumo alimentar. Com relatos, citações e observações muito valiosas para o contexto do estudo desenvolvido.

Com a segunda família, o encontro foi realizado novamente em uma manhã de sábado (4/5/2019). Chegamos à residência da família às 9:30h e saímos às 11:30h. Logo no início, saímos com as crianças para o desenvolvimento da atividade. Como no caso da primeira família, a atividade foi realizada em um supermercado próximo à residência da família (Supermercado Jaguaré) com a presença da menina (Luana) e do menino (Rafael). Igualmente, 
com duração aproximada de 1 hora. A mãe (Paula) estava presente conosco no supermercado também. Ao final da atividade, retornamos à residência da família para conversar com as crianças. Como na atividade desenvolvida no contexto da primeira família, desde o início da atividade no supermercado, as crianças participaram com muito entusiasmo e disposição. Escolhendo os produtos alimentícios e falando sobre os produtos e marcas escolhidos por elas e sobre seus gostos e preferências no consumo alimentar. E como na atividade lúdica desenvolvida com as crianças no encontro anterior, também aqui, elas trouxeram relatos, citações e observações muito valiosas para o contexto do estudo.

Com a terceira família, o encontro foi realizado, mais uma vez, numa tarde de sábado (28/7/2019). Chegamos à residência da família às $14 \mathrm{~h}$ e saímos às $19 \mathrm{~h}$. Depois de um tempo conversando com as crianças e com os pais, saímos com as crianças para o desenvolvimento da atividade. Assim como no caso da primeira e da segunda família, a atividade foi realizada em um supermercado próximo à residência da família (Supermercado Extra) com a presença da menina mais velha (Celina) e da menina mais nova (Teresinha). Do mesmo modo, com duração aproximada de 1 hora. O pai (Helio) estava também presente conosco no supermercado. Ao final da atividade, retornamos à residência da família para conversar com as meninas. Como na atividade desenvolvida no contexto da primeira e da segunda família, desde o início da atividade no supermercado, as crianças participaram com muito entusiasmo e disposição. Escolhendo os produtos alimentícios e falando sobre os produtos e marcas escolhidos por elas e sobre seus gostos e preferências no consumo alimentar. A menina mais velha falou bastante conosco sobre suas escolhas e preferências. A menina mais nova quase não falou, mas escolheu os produtos alimentícios e marcas de que mais gosta. E como na atividade lúdica desenvolvida com as crianças no encontro anterior, elas trouxeram relatos, citações e observações igualmente importantes e valiosas para o contexto do estudo.

Novamente aqui, o desenvolvimento da atividade lúdica proposta - Brincadeira de Comprar - com a participação das crianças nos diferentes contextos familiares - do mesmo modo como a atividade desenvolvida no encontro anterior - representou uma experiência igualmente importante e valiosa no contexto do estudo. Enriquecendo o processo de investigação e promovendo o aprofundamento e a diversidade empírica no desenvolvimento da pesquisa.

Como sinalizado no capítulo anterior, em anexo apresenta-se o roteiro e dinâmica propostos para composição e formatação da atividade lúdica desenvolvida com as crianças na forma de jogo e dramatização. Atividade lúdica proposta na composição da Brincadeira de Comprar, desenvolvida com as crianças no quinto encontro no contexto das famílias 
participantes do estudo. (APÊNDICE H) Também em anexo, apresenta-se roteiro com os principais tópicos sugeridos para orientação da entrevista individual realizada com as crianças após a atividade lúdica desenvolvida com elas nos contextos familiares pesquisados. (APÊNDICE I)

E finalmente o sexto encontro - novamente no formato de atividade lúdica com as crianças - realizado no ambiente doméstico para uma experimentação metodológica da pesquisa com a participação das crianças na produção, organização, apresentação e registro dos dados e informações em campo. Mais uma vez, com o objetivo de conhecer as experiências, perspectivas, saberes e afetos infantis quanto ao consumo alimentar e quanto às marcas e produtos alimentícios e o contexto promocional das marcas e produtos no mercado de alimentos. Buscando compreender os processos de recepção infantil de marcas de alimentos e os vínculos de sentidos entre marcas/produtos e crianças no contexto familiar. Mas nesse momento, procurando tomar as crianças como informantes, participantes e copesquisadoras no processo de investigação. Como apresentado de modo detalhado no capítulo anterior, as principais atividades desenvolvidas no sexto encontro: entrevista em grupo com as crianças na forma de conversação e produção infantil de vídeos para registro da entrevista em grupo com as crianças; composição de marcas e produtos alimentícios preferidos pelas crianças em casa e produção infantil de fotografias para registro das marcas e produtos alimentícios preferidos pelas crianças; retrato das crianças e da família e produção infantil de fotografias para retrato das crianças e da família.

No contexto das três famílias participantes do estudo, a proposta do sexto encontro Experiência The Kids: uma experiência lúdica de participação infantil - foi extremamente enriquecedora para o processo de investigação. Uma experimentação metodológica da pesquisa com a participação das crianças na produção, organização, apresentação e registro dos dados e informações em campo. As atividades propostas foram desenvolvidas exclusivamente com as crianças, tomadas como informantes, participantes e copesquisadoras no processo de investigação. As crianças participaram com empenho, entusiasmo, atenção e dedicação de todas as atividades propostas, uma vez que estavam presentes não apenas como informantes, mas também como participantes ativas no desenvolvimento e produção da pesquisa.

A primeira atividade proposta foi a realização de uma entrevista em grupo com as crianças, na forma de conversação, com produção infantil de vídeos para registro da entrevista com a coparticipação das crianças. Como descrito detalhadamente no capítulo anterior, trata-se de uma entrevista em grupo, desenvolvida com as crianças ao final da pesquisa, a fim de dar voz às vozes infantis sobre os principais temas e aspectos abordados na investigação 
desenvolvida em campo, nos contextos familiares pesquisados, possibilitando a expressividade das perspectivas e saberes infantis sobre os tópicos abordados; a avaliação das crianças sobre o processo de investigação em seu todo; e a reflexão das crianças sobre a sua participação no processo de investigação. Atividade lúdica desenvolvida com as crianças sob a denominação Kids by Kids, como parte do conjunto de atividades propostas para composição da Experiência The Kids: uma experiência lúdica de participação infantil. Em anexo, apresenta-se o roteiro sugerido para orientação da entrevista em grupo realizada com as crianças na atividade lúdica proposta, desenvolvida com as crianças em cada contexto familiar: entrevista em grupo com as crianças sobre o seu consumo alimentar com a coparticipação infantil. (APÊNDICE J)

A segunda atividade proposta foi a criação de uma composição de marcas e produtos alimentícios preferidos pelas crianças em casa, com produção infantil de fotografias para registro da composição de marcas e produtos com a coparticipação das crianças. Como descrito de modo detalhado no capítulo anterior, trata-se da criação e elaboração, efetuada pelas crianças, de uma composição de marcas e produtos alimentícios preferidos por elas (com escolha de produtos e marcas a partir dos alimentos ou produtos alimentícios disponíveis em casa no momento do desenvolvimento da atividade) e da produção fotográfica, igualmente elaborada pelas crianças, para o registro da composição de marcas e produtos alimentícios de que elas mais gostam em casa. Atividade lúdica desenvolvida com as crianças sob a denominação My Foods, como parte do conjunto de atividades propostas para composição da Experiência The Kids: uma experiência lúdica de participação infantil. Em anexo, apresenta-se o roteiro sugerido para orientação da produção fotográfica elaborada pelas crianças na atividade lúdica proposta, desenvolvida com as crianças em cada contexto familiar: registro das marcas e produtos alimentícios preferidos pelas crianças em casa. (APÊNDICE K)

A terceira atividade proposta foi a elaboração de uma composição de retratos das crianças e da família, com a coparticipação infantil na produção e direção de fotografia para composição dos retratos da família e das crianças. Como descrito detalhadamente no capítulo anterior, trata-se de uma produção infantil de fotografias para o retrato das crianças e da família, com a participação das crianças na escolha e preparação do cenário, produção fotográfica e direção de fotografia. Atividade lúdica desenvolvida com as crianças sob a denominação My Family, como parte do conjunto de atividades propostas para composição da Experiência The Kids: uma experiência lúdica de participação infantil. Em anexo, apresenta-se o roteiro sugerido para orientação da produção fotográfica elaborada pelas crianças na atividade lúdica proposta, desenvolvida com as crianças em cada contexto familiar: o retrato das crianças e da família com a coprodução infantil. (APÊNDICE L) 
No contexto da primeira família participante do estudo, as atividades foram desenvolvidas com as crianças (Maria Luisa e Julio) em momentos distintos no processo de investigação. A entrevista em grupo com as crianças (Kids by Kids) foi realizada em dezembro de 2018 (8/12/2018). O local escolhido pelas crianças para a produção do vídeo para registro da entrevista foi o quarto da menina. A menina (Maria Luisa) fez a produção e direção do vídeo para registro da entrevista realizada com ela e o irmão (vídeo gravado em selfie pela menina). A composição de marcas e produtos alimentícios preferidos pelas crianças em casa (My Foods) foi realizada em agosto de 2019 (2/8/2019). O local escolhido pelas crianças para a produção das fotografias para registro das composições de marcas e produtos foi a bancada da cozinha. A menina (Maria Luisa) fez a produção fotográfica das marcas e produtos alimentícios preferidos por ela. E o menino (Julio) fez a produção fotográfica das marcas e produtos alimentícios preferidos por ele. A composição dos retratos das crianças e da família (My Family) foi realizada igualmente em agosto de 2019 (2/8/2019). O local escolhido pelas crianças para a composição dos retratos foi a sala (os diferentes ambientes da sala). A menina (Maria Luisa) fez a produção fotográfica e direção de fotografia para os retratos da família e das crianças (fotos registradas em selfie pela menina). As crianças participaram das atividades com empenho, entusiasmo, atenção e dedicação. E gostaram muito de participar da experiência.

No contexto da segunda família participante do estudo, as atividades foram desenvolvidas com as crianças (Luana e Rafael) em um mesmo momento no processo de investigação. A entrevista em grupo com as crianças (Kids by Kids) foi realizada em agosto de 2019 (2/8/2019). O local escolhido pelas crianças para a produção do vídeo para registro da entrevista foi a sala (o sofá da sala) A menina (Luana) fez a produção e direção do vídeo para registro da entrevista realizada com ela e o irmão (vídeo gravado em selfie pela menina). A composição de marcas e produtos alimentícios preferidos pelas crianças em casa (My Foods) foi também realizada em agosto de 2019 (2/8/2019). O local escolhido pelas crianças para a produção das fotografias para registro das composições de marcas e produtos foi a mesa da cozinha. A menina (Luana) fez a produção fotográfica das marcas e produtos alimentícios preferidos por ela. E o menino (Rafael) fez a produção fotográfica das marcas e produtos alimentícios preferidos por ele. A composição dos retratos das crianças e da família (My Family) foi realizada igualmente em agosto de 2019 (2/8/2019). O local escolhido pelas crianças para a composição dos retratos foi a sala (os diferentes ambientes da sala). A menina (Luana) fez a produção fotográfica e direção de fotografia para os retratos da família e das crianças (fotos registradas em selfie pela menina). Como no contexto da primeira família, as 
crianças participaram das atividades com empenho, entusiasmo, atenção e dedicação. Elas também gostaram muito de participar da experiência.

No contexto da terceira família participante do estudo, as atividades foram desenvolvidas com as crianças (Celina e Teresinha) igualmente em um único momento no processo de investigação. A entrevista em grupo com as crianças (Kids by Kids) foi realizada em agosto de 2019 (4/8/2019). O local escolhido pelas crianças para a produção do vídeo para registro da entrevista foi o quarto das meninas. A menina mais velha (Celina) fez a produção e direção do vídeo para registro da entrevista realizada com ela e a irmã (vídeo gravado em selfie pela menina). A composição de marcas e produtos alimentícios preferidos pelas crianças em casa (My Foods) foi também realizada em agosto de 2019 (4/8/2019). O local escolhido pelas crianças para a produção das fotografias para registro das composições de marcas e produtos foi a mesa da sala. A menina mais velha (Celina) fez a produção fotográfica das marcas e produtos alimentícios preferidos por ela. E a menina mais nova (Teresinha) fez a produção fotográfica das marcas e produtos alimentícios preferidos por ela. A composição dos retratos das crianças e da família (My Family) foi realizada igualmente em agosto de 2019 (4/8/2019). O local escolhido pelas crianças para a composição dos retratos foi a sala (o sofá da sala). A menina mais velha (Celina) fez a produção fotográfica e direção de fotografia para os retratos da família e das crianças (fotos registradas em selfie pela menina). Como no contexto da primeira e da segunda família, as crianças participaram das atividades com empenho, entusiasmo, atenção e dedicação. E também elas, gostaram muito de participar da experiência.

O desenvolvimento da experimentação metodológica com as atividades lúdicas propostas - The Kids: uma experiência lúdica de participação infantil - com a participação ativa e efetiva das crianças nos diferentes contextos familiares representou uma experiência extremamente valiosa e enriquecedora para o processo de investigação e desenvolvimento do estudo. E a presença e participação das crianças foi essencial em todo o processo.

O processo de pesquisa em campo, em seu todo, foi marcado pelo expressivo envolvimento e participação ativa dos pais e das crianças. Desde a receptividade e acolhimento das famílias nos primeiros contatos realizados, encontros promovidos, e atividades desenvolvidas, até a participação ativa e todo empenho e dedicação dos pais e das crianças ao logo dos demais encontros e atividades propostos para o desenvolvimento da pesquisa em campo nos contextos familiares pesquisados.

Envolvimento e participação dos pais e das crianças, tanto nas atividades realizadas com a família, onde a participação das crianças e dos pais acontecia de modo conjunto, quanto nas atividades desenvolvidas exclusivamente com as crianças, onde as crianças participavam mais 
ativamente, e os pais participavam de modo indireto, promovendo todo apoio necessário para o desenvolvimento das atividades com as crianças. E considerando-se ainda o apoio e auxílio dos pais para possibilitar e facilitar os registros em fotografia e vídeo das atividades desenvolvidas com a família e as crianças.

E mesmo depois de concluídas as atividades desenvolvidas e finalizados os trabalhos em campo com as famílias, ainda assim se manteve a disponibilidade e envolvimento dos pais e das crianças para a provisão de dados e informações complementares ou a realização de atividades adicionais, eventualmente necessárias para complementação e conclusão do estudo.

Em anexo, apresentam-se as transcrições completas dos principais contextos explorados, situações e eventos observados, experiências vivenciadas, e atividades desenvolvidas ao longo da pesquisa em campo nos contextos familiares pesquisados, contemplando o conjunto dos encontros promovidos e atividades realizadas com as famílias e as crianças, a partir do enfoque dos eixos de abordagem teórica e empírica propostos para orientação da investigação e consolidação do estudo. 
2 PRESENÇA E MEDIAÇÃO COMUNICACIONAL DAS MARCAS NA CULTURA ALIMENTAR INFANTIL: MARCAS E PRODUTOS NO CONTEXTO FAMILIAR

Após o relato das principais atividades desenvolvidas e experiências vivenciadas com as crianças em campo em seus contextos familiares, apresentam-se as interpretações e análises dos dados e avaliação dos resultados da pesquisa, a partir do enfoque dos eixos de abordagem teórica e empírica propostos para orientação da investigação: a cultura alimentar infantil e as mediações culturais e comunicacionais na modulação do consumo alimentar das crianças no contexto familiar; a mediação comunicacional das marcas na cultura alimentar infantil e as marcas e produtos alimentícios no contexto familiar; a recepção infantil de marcas de alimentos e os vínculos de sentidos entre marcas/produtos e crianças no contexto familiar. Interpretações e análises elaboradas à luz da perspectiva das mediações comunicativas da cultura. (MARTINBARBERO, 2009)

Para as interpretações e análises, é importante sinalizar que os contextos explorados, situações e eventos observados, experiências vivenciadas, e atividades desenvolvidas com as crianças em seus contextos familiares foram tomados em conjunto, no todo da experiência em campo, a partir do enfoque dos eixos de abordagem propostos para orientação da investigação. Independentemente dos formatos ou momentos específicos em que tenham se dado tais contextos, situações, eventos, experiências e atividades ao logo do processo de pesquisa. Uma vez que a formatação dos encontros e atividades propostos, para além de caracterizar e organizar a estrutura e sequência da pesquisa de campo, teve o objetivo maior de plenamente promover a exploração dos contextos, a observação das situações e eventos, a vivência das experiências e o desenvolvimento das atividades, possibilitando e enriquecendo a coleta de dados, a leitura de informações, e a produção de conhecimentos em resposta aos eixos de abordagem propostos para orientação e desenvolvimento da investigação.

E partindo do todo da experiência em campo, é importante sinalizar também que, para as interpretações e análises, foram considerados com especial atenção os principais contextos explorados, situações e eventos observados, experiências vivenciadas, e atividades desenvolvidas com as crianças em seus contextos familiares, priorizando os dados e informações diretamente relacionados à temática e problemática do estudo desenvolvido sobre a presença e mediação comunicacional das marcas na cultura alimentar das crianças. Permanecendo o conjunto dos dados e informações da investigação desenvolvida em campo, em anexo, para conhecimentos e explorações adicionais para o enriquecimento contextual deste 
estudo, ou para o desenvolvimento de estudos futuros na temática da combinação comunicação, consumo, infância e cultura alimentar. ${ }^{4}$

Em uma perspectiva interdisciplinar de investigação - como apresentado de modo detalhado no capítulo anterior, no momento da apresentação e fundamentação do estudo - a investigação desenvolvida apresenta-se como um estudo de recepção em perspectiva de abordagem sociocultural, delineado na interface da comunicação com os estudos culturais, a antropologia e a sociologia (sociologia da infância). O que demarca a presença do estudo no contexto de interdisciplinaridade que caracteriza os estudos contemporâneos sobre comunicação, consumo, infância e cultura alimentar.

Nesse contexto plural de investigação - como igualmente detalhado no capítulo anterior - e partindo dos eixos de abordagem teórica e empírica propostos para orientação do estudo, o trabalho desenvolvido contou com o apoio da perspectiva das mediações (no enfoque da cultura compreendida a partir da comunicação) para realização das interpretações e análises dos dados e avaliação dos resultados da pesquisa, orientados a partir de uma proposta de articulação entre os eixos de abordagem sugeridos para orientação da investigação e o mapa das mediações (mediações comunicativas da cultura) como proposto por Martin-Barbero (2009).

$\mathrm{Na}$ perspectiva de uma articulação teórico-empírica entre o mapa das mediações comunicativas da cultura (MARTIN-BARBERO, 2009) e os eixos de abordagem teórica e empírica propostos para orientação da investigação - como apresentado detalhadamente no capítulo anterior, mas entendendo-se igualmente importante e producente destacar novamente aqui - foi elaborada proposta específica de configuração para as interpretações e análises dos dados e avaliação dos resultados da pesquisa na composição e consolidação do estudo: a proposição de um mapa para o estudo da mediação comunicacional das marcas na cultura alimentar infantil na perspectiva da cultura compreendida a partir da comunicação.

$\mathrm{Na}$ configuração proposta, é colocada no centro do mapa a problemática da relação comunicação-cultura-política explorada neste estudo: a mediação comunicacional das marcas na cultura alimentar infantil. E com base nos eixos de abordagem propostos para orientação da investigação, foi proposta igualmente uma leitura em dois eixos: o eixo das mediações entre as competências de recepção ou consumo e as lógicas de produção e o eixo das mediações entre as matrizes culturais e os formatos industriais.

\footnotetext{
$\overline{4}$ O conteúdo disponibilizado em link temporário para avaliação da Banca Examinadora encontra-se disponível em pen-drive na versão da Tese para a Biblioteca da ECA/USP.
} 
Faz-se importante observar, no entanto, em uma proposta de exploração do mapa das mediações comunicativas da cultura, de Martin-Barbero, de acordo com a perspectiva e recorte deste estudo, que a parte superior do mapa - contemplando as lógicas de produção e as mediações entre as lógicas de produção e os formatos industriais (tecnicidade) e entre as lógicas de produção e as matrizes culturais (institucionalidade) - foi explorada no processo de investigação como problemática para contextualizações e reflexões a partir do tema de pesquisa proposto. O estudo desenvolvido, desde as proposições da pesquisa teórica até as investigações da pesquisa empírica, concentrou-se em explorações dadas na parte inferior do mapa contemplando as competências de recepção ou consumo e as mediações entre as competências de recepção ou consumo e as matrizes culturais (socialidade) e entre as competências de recepção ou consumo e os formatos industriais (ritualidade).

Perspectiva em que as reflexões, interpretações e análises realizadas no processo de investigação concentraram-se em três dos quatro tópicos de observação e análise sugeridos pelo autor no mapa das mediações comunicativas da cultura:

- $\quad$ As matrizes culturais - apresentadas na forma do primeiro eixo de abordagem proposto para orientação da investigação: a cultura alimentar infantil e as mediações culturais e comunicacionais na modulação do consumo alimentar das crianças no contexto familiar.

- Os formatos industriais - apresentados na forma do segundo eixo de abordagem proposto para orientação da investigação: a mediação comunicacional das marcas na cultura alimentar infantil e as marcas e produtos alimentícios no contexto familiar.

- $\quad$ E as competências de recepção ou consumo - apresentadas na forma do terceiro eixo de abordagem proposto para orientação da investigação: a recepção infantil de marcas de alimentos e os vínculos de sentidos entre marcas/produtos e crianças no contexto familiar.

As lógicas de produção - o quarto tópico de observação e análise sugerido pelo autor ainda que elas não figurassem neste estudo enquanto perspectiva de interpretação e análise, elas se caracterizaram enquanto proposta de reflexão e contextualização para a temática explorada na investigação, tomadas na forma das lógicas contemporâneas de produção e promoção da indústria e publicidade de alimentos no contexto promocional das marcas e produtos alimentícios infantis.

Quanto às múltiplas mediações dadas na relação entre os eixos de observação propostos no mapa das mediações comunicativas da cultura, adaptado à perspectiva de reflexão, interpretação e análise proposta a partir da temática explorada neste estudo, e aos eixos de abordagem teórica e empírica definidos para orientação da investigação, também aqui elas se 
apresentaram na forma de diferentes e diversos modos de socialidade, ritualidade, tecnicidade e institucionalidade.

$\mathrm{Na}$ mediação entre as competências de recepção ou consumo (a recepção infantil de marcas de alimentos e os vínculos de sentidos entre marcas/produtos e crianças no contexto familiar) e as matrizes culturais (a cultura alimentar infantil e as mediações culturais e comunicacionais na modulação do consumo alimentar das crianças no contexto familiar) apresentaram-se para reflexão, interpretação e análise diferentes e diversas formas de socialidade: contexto rotina e composição familiar e atividades e interações infantis; rotina alimentar e hábitos e preferências alimentares da família e das crianças; práticas e rituais de consumo alimentar infantil no contexto familiar; preferências e saberes infantis sobre consumo alimentar; mediações culturais e comunicacionais na cultura alimentar infantil e mediação da família na cultura alimentar infantil.

$\mathrm{Na}$ mediação entre as competências de recepção ou consumo (a recepção infantil de marcas de alimentos e os vínculos de sentidos entre marcas/produtos e crianças no contexto familiar) e os formatos industriais (a mediação comunicacional das marcas na cultura alimentar infantil e as marcas e produtos alimentícios no contexto familiar) apresentaram-se para reflexão, interpretação e análise diferentes e diversas formas de ritualidade: escolha compra e consumo de alimentos da família e critérios mais importantes na escolha dos alimentos; usos e consumos infantis dos dispositivos e mídias e contato das crianças com o universo promocional das marcas e produtos alimentícios; presença e mediação comunicacional das marcas na cultura alimentar infantil e rituais de consumo alimentar infantil no contexto familiar; marcas e produtos alimentícios no contexto familiar; marcas e produtos alimentícios no contexto das escolhas e preferências das crianças: perspectiva da família (os pais e as crianças).

E com especial atenção às competências de recepção ou consumo (a recepção infantil de marcas de alimentos e os vínculos de sentidos entre marcas/produtos e crianças no contexto familiar) foram propostas reflexões, interpretações e análises contemplando as perspectivas infantis: perspectiva das crianças sobre a sua cultura alimentar e as mediações culturais e comunicacionais na modulação do seu consumo alimentar; perspectiva das crianças sobre a mediação comunicacional das marcas na sua cultura alimentar e as marcas e produtos alimentícios no seu contexto familiar; marcas e produtos alimentícios no contexto das escolhas e preferências das crianças: perspectiva das crianças: recepção infantil e vínculos de sentidos.

Quanto à mediação entre as lógicas de produção (as lógicas contemporâneas de produção e promoção da indústria e publicidade de alimentos no contexto promocional das marcas e produtos alimentícios infantis) e os formatos industriais (a mediação comunicacional 
das marcas na cultura alimentar infantil e as marcas e produtos alimentícios no contexto familiar) foram propostas reflexões contextuais sobre algumas formas de tecnicidade: o contexto promocional das marcas e produtos no mercado de alimentos infantis; as estratégias e técnicas de produção e promoção de marcas e produtos na indústria e publicidade de alimentos para crianças; as normas, padrões e procedimentos para produção e promoção de marcas e produtos na indústria e publicidade de alimentos para crianças.

E quanto à mediação entre as lógicas de produção (as lógicas contemporâneas de produção e promoção da indústria e publicidade de alimentos no contexto promocional das marcas e produtos alimentícios infantis) e as matrizes culturais (a cultura alimentar infantil e as mediações culturais e comunicacionais na modulação do consumo alimentar das crianças no contexto familiar) foram propostas reflexões contextuais sobre algumas formas de institucionalidade: o debate social, político e acadêmico sobre saúde e alimentação infantil e a publicidade de alimentos para crianças; os índices nacionais e internacionais sobre obesidade infantil e sobrepeso das crianças e adolescentes e as políticas de saúde pública para acompanhamento e controle da saúde e alimentação infantil; os processos de regulação e regulamentação para produção e promoção de marcas e produtos na indústria e publicidade de alimentos infantis.

Reflexões sobre as lógicas contemporâneas de produção e promoção da indústria e publicidade de alimentos no contexto promocional das marcas e produtos alimentícios infantis propostas para problematização e contextualização do estudo ao longo do processo de investigação. Mas que não tomaram parte direta, como sinalizado, no desenvolvimento da pesquisa e consolidação das interpretações e análises elaboradas para o estudo proposto sobre a mediação comunicacional das marcas na cultura alimentar infantil.

A proposição de um mapa para o estudo da mediação comunicacional das marcas na cultura alimentar infantil na perspectiva das mediações comunicativas da cultura, colocou-se, desse modo, como proposta de orientação e fundamentação para as interpretações e análises dos dados e avaliação dos resultados da pesquisa na consolidação deste estudo.

$\mathrm{Na}$ sequência, apresentam-se as explorações, interpretações e análises dos dados e avaliação dos resultados da pesquisa desenvolvida em campo com as crianças em seus contextos familiares - no enfoque dos eixos de abordagem teórica e empírica sugeridos para orientação da investigação - e a proposição de algumas reflexões para consolidação e conclusão do estudo desenvolvido sobre a mediação comunicacional das marcas na cultura contemporânea de consumo alimentar das crianças em uma perspectiva da cultura compreendida a partir da comunicação. 


\section{Recepção Infantil de Marcas de Alimentos e Cultura Alimentar das Crianças}

A partir do trabalho desenvolvido com as crianças em campo em seus contextos familiares, e com atenção aos processos de mediação entre as competências de recepção ou consumo das crianças (a recepção infantil de marcas de alimentos e os vínculos de sentidos entre marcas/produtos e crianças no contexto familiar) e as matrizes culturais em seus contextos familiares (a cultura alimentar infantil e as mediações culturais e comunicacionais na modulação do consumo alimentar das crianças no contexto familiar) - a mediação entre o terceiro e o primeiro eixo de abordagem, propostos para orientação do estudo, na perspectiva das mediações comunicativas da cultura - apresentam-se para interpretação, análise e reflexão diferentes e diversas formas de socialidade.

Socialidades diversas, observadas, participadas e vivenciadas em campo com as famílias e com as crianças no processo de investigação, envolvendo o contexto rotina e composição familiar e as atividades e interações infantis; a rotina alimentar e os hábitos e preferências alimentares da família e das crianças; as práticas e rituais de consumo alimentar infantil no contexto familiar; as preferências e saberes infantis sobre consumo alimentar; e as mediações culturais e comunicacionais na cultura alimentar infantil e a mediação da família na cultura alimentar infantil.

E em seu conjunto, esses diferentes e diversos modos de socialidade dão forma e possibilitam compreender os processos de mediação entre as crianças, em seus contextos e processos cotidianos de recepção infantil de marcas de alimentos, e os cotidianos da sua cultura alimentar em âmbito familiar, com atenção às mediações culturais e comunicacionais presentes na modulação do consumo alimentar infantil.

Nessa perspectiva, considerando-se as socialidades e mediações presentes na forma do contexto rotina e composição familiar e das atividades e interações infantis - e tomando-se em atenção os cotidianos dos contextos familiares pesquisados - é possível destacar alguns pontos importantes para interpretação, análise e reflexão, em nível contextual, para melhor conhecimento das famílias e das crianças participantes do estudo, bem como, das diversas formas de mediação presentes nos contextos familiares pesquisados.

As três famílias participantes do estudo são estruturadas de modo bastante semelhante: com o pai, a mãe e as crianças na composição familiar. A primeira e a segunda família, com duas crianças: uma menina e um menino. E a terceira família, com três crianças: duas meninas e uma bebê. O que demarca a presença das interações e mediações infantis entre irmãos nos cotidianos das três famílias pesquisadas. Interações e mediações entre irmãos que, 
continuamente presentes no dia a dia das crianças, aparecem de modo igualmente frequente nos processos de modulação do consumo alimentar infantil no contexto familiar. Especialmente na modulação das escolhas e preferências infantis quanto às marcas e produtos alimentícios no contexto familiar para o consumo das crianças. O que foi possível notar entre as crianças nos três contextos familiares pesquisados, especialmente na primeira família, onde há pouca diferença de idade entre a menina e o menino.

Nessa perspectiva, um aspecto interessante a ser observado se refere ao convívio entre as crianças. A relação entre irmãos em cada contexto familiar estudado. Na primeira família, as crianças (a menina e o menino) têm uma relação de extrema empatia e cumplicidade. Uma cumplicidade no agir, no brincar, e até mesmo no pensar. Gostam muito um do outro. Gostam de estar juntos e costumam fazer quase tudo juntos. Na segunda família, a relação entre as crianças (a menina e o menino), ainda que afetuosa, parece de menor proximidade e cumplicidade. Talvez pelo fato de haver maior diferença de idade entre a menina e o irmão mais novo. Mas ainda assim, há cumplicidade, empatia e respeito entre os irmãos. E na terceira família, as crianças (as duas meninas e a bebê) são extremamente afetuosas. Elas se gostam muito. Gostam de estar sempre juntas. Gostam de brincar juntas. Mesmo com as diferenças de idade entre elas. Há muito carinho entre as meninas. E nesse sentido, as dinâmicas das relações e interações entre as crianças, presentes nos diferentes contextos familiares pesquisados, se fizeram igualmente presente ao longo das atividades desenvolvidas com as crianças no processo de investigação, trazendo à luz um pouco da dinâmica dos processos de mediação entre irmãos que acontecem no cotidiano de cada família participante do estudo.

Quanto à história e cotidiano das famílias, como destacado inicialmente, no momento da apresentação das famílias participantes do estudo, em meio às muitas diferenças, é possível destacar algumas semelhanças entre as famílias pesquisadas no processo de investigação.

No contexto da primeira família, o pai faz carreira acadêmica, é professor universitário na rede pública e privada de ensino superior na cidade de São Paulo, e possui uma empresa de consultoria em projetos e pesquisa de mercado. Trabalha nos três períodos (de manhã, à tarde e à noite). Trabalha durante o dia na sua empresa e dá aula à noite (três vezes por semana). $\mathrm{E}$ toca violão, às vezes, como lazer. A mãe, igualmente, faz carreira acadêmica. Está cursando o doutorado e também é professora universitária. Trabalha no período da noite. Dá aula à noite (uma vez por semana). No período da manhã e, às vezes, à noite, a mãe fica com as crianças. Acompanha toda a rotina de atividades das crianças. Tanto as atividades escolares quanto as demais atividades esportivas e artísticas em que as crianças estão envolvidas. À tarde, se dedica às atividades do doutorado e faz academia. 
No contexto da segunda família, o pai é professor de língua portuguesa na rede pública estadual e municipal de ensino de São Paulo. Trabalha no período da manhã e da tarde e faz formação pedagógica à noite. E toca violão, às vezes, como lazer. A mãe é professora de matemática e física na rede pública estadual de ensino de São Paulo. Trabalha no período da manhã. E também costura e faz trabalhos artesanais em casa sob encomenda. Fica com as crianças no período da tarde e à noite. A mãe administra as atividades e a rotina da casa e acompanha toda a rotina de atividades das crianças. Tanto as atividades escolares quanto as demais atividades em que as crianças estão envolvidas, e ainda as tarefas domésticas das quais as crianças participam para ajudar na rotina da casa. E algumas vezes por semana a mãe faz academia no horário do almoço.

E no contexto da terceira família, o pai trabalha na área de TI, como analista de suporte técnico. No entanto, no momento do desenvolvimento da pesquisa, estava desempregado, recebendo somente o seguro desemprego. Quando não está trabalhando, é o pai que fica em casa com as crianças. Prepara as refeições, organiza as atividades e a rotina da casa, faz as compras, e encaminha as crianças para a escola e para a creche. O pai toca violão toda semana na igreja (ministério de música). E, às vezes, também toca violão em casa, como lazer. A mãe trabalha como agente comunitária de saúde. Ela trabalha em um posto de saúde nas proximidades de sua residência. Trabalha no período da manhã e da tarde. Em horário integral. Mas antes, quando o pai estava trabalhando e a mãe estava desempregada, ela ficava em casa com as crianças. Acompanhava as atividades das crianças e organizava as atividades e a rotina da casa.

Interessante observar que no contexto das três famílias pesquisadas os pais trabalham, mas tentam, de algum modo, acompanhar a rotina das crianças em algum período do dia. No caso da primeira e da segunda família, os pais trabalham em período integral, enquanto as mães trabalham em período menor. E a missão de acompanhar a rotina das crianças fica a cargo das mães. Já no caso da terceira família, à época da realização da pesquisa, a situação era inversa. A mãe trabalhava em período integral enquanto o pai estava desempregado. E a missão de acompanhar a rotina das crianças estava então a cargo do pai. E nesse sentido, nos três contextos familiares pesquisados, a presença da mãe ou do pai no acompanhamento diário da rotina dos filhos pode oportunizar maior atenção e cuidado às crianças, especialmente no que tange ao desenvolvimento infantil e cuidados com a saúde e alimentação das crianças.

Quanto às crianças e suas rotinas de atividades, na escola e fora da escola, no contexto das famílias participantes do estudo - e considerando-se a época do desenvolvimento da pesquisa - é possível notar que há diferenças significativas entre os cotidianos infantis de cada 
família pesquisada, resultando em diferentes níveis de riqueza e diversidade de experiências vivenciadas e atividades experimentadas pelas crianças.

No contexto da primeira família, as crianças cursam o ensino fundamental I. A menina (Rose, 9 anos) cursando o $3^{\circ}$ ano. E o menino (João, 7 anos) cursando o $2^{\circ}$ ano. Eles estudam no período vespertino. E na parte da manhã e à noite, as crianças participam de atividades esportivas, artísticas e de estudo de línguas. A menina faz balé, toca piano, e estuda inglês. E nos dias livres ou horas de folga, além da obrigação diária de fazer a lição de casa da escola, ela costuma ver televisão, brincar no tablet (IPad), fazer atividades lúdicas em game de matemática da escola, brincar com as amigas, e tocar piano. O menino faz natação, luta judô, toca bateria e pratica o jogo de xadrez. E nos dias livres ou horas de folga, além da obrigação diária de fazer a lição de casa da escola, ele costuma ver televisão, jogar no tablet (IPad), brincar com os amigos, brincar no piano da irmã, e andar de bicicleta.

No contexto da segunda família, as crianças cursam o ensino fundamental. A menina (Luana, 11 anos) cursando o $6^{\circ}$ ano do ensino fundamental II. E o menino (Rafael, 6 anos) cursando o $2^{\circ}$ ano do ensino fundamental I. Eles estudam no período matutino. E na parte da tarde, a menina participa de atividades esportivas e de estudos. O menino ainda não participa de atividades além da escola. No período da tarde, na escola, a menina treina voleibol e faz aprofundamento de estudos em matemática. E nos dias livres ou horas de folga, além das obrigações diárias de fazer a lição de casa da escola e participar nas tarefas domésticas para ajudar na rotina da casa, a menina costuma fazer desenhos em papel e pinturas em tela, ler livros, e ficar brincando no celular (vídeos / séries / músicas / redes sociais). O menino, nos dias livres ou horas de folga, além das obrigações diárias de fazer a lição de casa da escola e participar nas tarefas domésticas para ajudar na rotina da casa, ele costuma ler revistas de mangá e jogar videogame. O menino não participa de atividades esportivas. Fazia natação com a mãe na academia no ano anterior e iria retomar a natação no ano seguinte.

E no contexto da terceira família, a menina mais velha (Celina, 9 anos) cursa o $4^{\circ}$ ano do ensino fundamental I. Ela estuda no período vespertino. E ainda não participa de atividades esportivas, artísticas ou de estudo de línguas em modalidades extracurriculares na escola. Atividades oferecidas às crianças somente a partir do ensino fundamentar II. No entanto, no momento do desenvolvimento da pesquisa, a menina havia sido aprovada em um processo seletivo de uma escola de idiomas para estudar inglês como aluna bolsista. As aulas iniciariam no semestre seguinte. No período da manhã a menina fica em casa com o pai. Período em que ela tem algumas obrigações diárias como fazer a lição de casa e participar nas tarefas domésticas para ajudar na rotina da casa. Nos dias livres ou horas de folga, a menina costuma brincar no 
celular (vídeos, jogos, e comunicação por mensagens), ou ver televisão, ou ler algum livro da biblioteca da escola, ou brincar com a irmã mais nova e a bebê. A menina, às vezes, também ajuda a cuidar da bebê, quando os pais estão envolvidos em algumas tarefas da casa (especialmente a noite, quando estão todos juntos em casa). E aos sábados de manhã a menina faz catequese. A menina mais nova (Teresinha, 4 anos) e a bebê (Paulina, 1 ano) ficam na creche em período integral. E lá fazem todas as atividades (educativas / artísticas / recreativas). Assim como as principais refeições do dia (café da manhã / lanche / almoço /lanche da tarde / jantar).

É importante observar que as famílias participantes do estudo classificam-se em estratificações socioeconômicas diferentes: a primeira família, na classe A1 - com renda média mensal familiar declarada de R \$30.000,00; a segunda família, na classe B1 - com renda média mensal familiar declarada de R \$10.000,00; e a terceira família, na classe C1 - com renda média mensal familiar declarada de R\$ 3.000,00. (ABEP BRASIL, 2018; 2019; KAMAKURA; MAZZON, 2013) O que demarca diferenças significativas entre os contextos familiares pesquisados, desde a localização e caracterização dos espaços de moradia, até a composição das experiências cotidianas de consumo das famílias, incluindo o consumo alimentar dos pais e das crianças em contexto familiar. Especialmente no que tange à frequência, quantidade e diversidade de alimentos e de marcas e produtos alimentícios disponíveis no âmbito familiar para o consumo alimentar das crianças e dos pais. Em anexo, tabelas com resumo descritivo das famílias: alguns dados sobre as composições familiares, perfil de consumo e estratificação socioeconômica das famílias. (APÊNDICE M)

Quanto à moradia, há consideráveis diferenças entre os três contextos familiares pesquisados. Como apresentado inicialmente, no momento da apresentação das famílias participantes do estudo, cada família caracteriza um contexto bem diferente na composição da casa e do lar.

A primeira família, no início do processo de pesquisa, era residente em bairro elegante da cidade de São Paulo. Apartamento com $128 \mathrm{~m}^{2}$ e 16 cômodos no total. Espaço bem amplo, iluminado e arejado. Ambiente com bastante espaço e conforto para a família e as crianças. Cada criança com o seu quarto (suíte). O quarto da menina: espaço muito bonito e bem delicado, decorado em tons de rosa, rose e roxo. Com muitos bichinhos de pelúcia, mini bonecas e objetos de decoração para a menina. O quarto do menino: espaço igualmente bonito e mais colorido, decorado em tons de verde, azul e amarelo. Com muitos bichinhos de pelúcia, mini bonecos e objetos de decoração para o menino. Ambos os quartos com televisão, espaço para brincar, e espaço para as atividades de estudos das crianças. E ao final do processo de pesquisa, a família passou a residir em outro bairro nobre na cidade de São Paulo. Apartamento com $146 \mathrm{~m}^{2}$ e 12 
cômodos no total. Espaço ainda mais amplo, iluminado e arejado. E igualmente, ambiente com bastante espaço e conforto para a família e as crianças.

A segunda família é residente em bairro de classe média da cidade de São Paulo. Casa com $276 \mathrm{~m}^{2}$ e 14 cômodos no total. Espaço igualmente amplo, iluminado e arejado. Ambiente com bastante espaço e conforto para a família e as crianças. Cada criança tem o seu quarto. E dividem o mesmo banheiro (banheiro das crianças). O quarto da menina: espaço amplo, bonito e muito organizado, decorado em tons de rosa, rose e branco. Com painel de fotos, decorações e recados, lousa para anotações, alguns livros, e objetos de decoração para a menina. Com televisão, espaço para suas atividades artísticas (desenho em papel e pintura em tela), para leitura, e para as atividades de estudos. Há uma decoração com o nome da menina na porta do quarto. O quarto do menino: espaço um pouco menor, mas também muito bonito e organizado, decorado em tons de azul e verde. Com bichinhos de pelúcia, coleção de carrinhos, revistas de mangá, lousa para anotações, e muitos painéis decorativos com temas de games. Com televisão, espaço para brincar e espaço para as atividades de estudos. Há uma decoração com o nome do menino na porta do quarto.

E a terceira família reside em uma das comunidades da periferia da cidade de São Paulo. Apartamento com $54 \mathrm{~m}^{2}$ e sete cômodos no total. Espaço pequeno, mas bem planejado e organizado. Ambiente arejado, iluminado e confortável para a família e as crianças. No quarto das meninas, dormem a menina mais velha e a menina mais nova. Elas dividem o mesmo quarto. Quarto pequeno, mas muito bonito e bem organizado. Decorado em branco e rosa. Com muitas pelúcias e alguns objetos de decoração para as meninas. Com televisão, espaço para brincar, e espaço para as atividades de estudos (para a menina mais velha). Como o espaço é pequeno, há uma bicama para as meninas. E quando a bebê crescer e passar a ocupar o quarto junto com as irmãs, haverá uma triliche, para que as meninas possam dormir todas juntas. Enquanto bebê, ela ainda dorme no quarto dos pais. Na porta do quarto, há uma decoração para representar as meninas: duas bonequinhas com os nomes das meninas (a menina mais velha e a menina mais nova).

Em um comparativo entre as famílias pesquisadas, é possível notar que são famílias residentes em bairros bem diferentes: enquanto a primeira família reside em um bairro nobre da cidade, e a segunda família reside em um bairro residencial de classe média, a terceira família é residente em uma comunidade na periferia da cidade. E a mesma diferenciação pode ser observada quanto às residências das famílias: enquanto no contexto da primeira e da segunda família as residências são bem amplas, com bastante espaço e conforto para as famílias, no 
contexto da terceira família a residência é pequena, com espaço bem menor, mas ainda assim, com organização e conforto para a família.

No que se refere à estrutura e organização doméstica no contexto das famílias pesquisadas, algumas diferenças marcantes se destacam para interpretação e análise. No primeiro contexto familiar pesquisado, a família conta diariamente com o apoio de uma empregada e de uma babá (babá que está com as crianças desde que elas nasceram), e ainda com o apoio de uma faxineira (uma vez por semana). Enquanto no segundo contexto familiar pesquisado, a família não conta com o apoio de empregada ou faxineira, sendo a mãe e as crianças responsáveis pelas tarefas domésticas da casa e com a ajuda do pai nos fins de semana. E onde as crianças participam inclusive de atividades culinárias, auxiliando a mãe no preparo de pratos especiais (quando a mãe prepara algo especial para as crianças). O que também acontece no terceiro contexto familiar pesquisado, onde a família também não conta com o apoio de empregada ou faxineira, sendo o pai, a mãe e as crianças (especialmente a menina mais velha) responsáveis pelas tarefas domésticas da casa, em que todos contribuem em alguma medida (inclusive a menina mais nova que, mesmo ainda não contribuindo diretamente nas tarefas domésticas, ela tem a obrigação diária de guardar os seus brinquedos).

E nesse sentido, vale observar que tais configurações de estrutura e organização doméstica se refletem de modos diferentes no cotidiano das crianças em cada contexto familiar pesquisado: enquanto no caso da primeira família, as crianças não são envolvidas nas tarefas domésticas da rotina da casa, ficando suas obrigações diárias restritas às atividades escolares (lição de casa da escola); no caso da segunda e da terceira família, o cotidiano das crianças é diferente, incluindo, para além das obrigações diárias das atividades escolares (lição de casa da escola), também a participação diária das crianças nas atividades domesticas para contribuir na rotina da casa.

Finalmente, no contexto das mídias e tecnologias - mais um aspecto interessante a se observar em um comparativo contextual entre as famílias participantes do estúdio - à época do desenvolvimento da pesquisa, as três famílias pesquisadas apresentavam um perfil de consumo bastante semelhante: com televisão, computador ou notebook, tablet, smartphone e videogame em casa. Dispositivos disponíveis para o acesso dos pais e das crianças (com controle e acompanhamento dos pais). E com acesso à internet e tv a cabo no caso das três famílias. Perfil de consumo midiático bastante semelhante para as três famílias pesquisadas, salvaguardadas algumas diferenças quanto à marcas e modelos de dispositivos, ou à quantidade de dispositivos disponíveis, ou diferentes pacotes de acesso à internet e tv a cabo. De acordo com a estratificação socioeconômica e disponibilidade financeira de cada família. As únicas 
diferenças significativas observadas com relação ao consumo midiático das famílias pesquisadas diz respeito ao acesso a plataformas de conteúdo online por assinatura, como o NetFlix e Apple Music (disponíveis para o acesso dos pais e das crianças no contexto da primeira família), e o NetFlix e o Spotify (disponíveis para o acesso dos pais e das crianças no contexto da segunda família); e ao acesso à revistas por assinatura, como no caso da revista da Turma da Mônica, assinada pelos pais no contexto da primeira e da segunda família, para leitura das crianças. No contexto da terceira família, quando realizada a pesquisa, não havia acesso a plataformas de conteúdo online via assinatura para os pais ou para as crianças, nem assinatura de revistas infantis para leitura das crianças.

As interpretações, análises e reflexões propostas sobre o contexto rotina e composição familiar e as atividades e interações infantis, nos diferentes contextos familiares pesquisados, para além de possibilitar melhor conhecimento das famílias e das crianças participantes do estudo, se fazem importantes para uma compreensão das primeiras mediações de contexto no âmbito do estudo proposto sobre a mediação comunicacional das marcas na cultura alimentar infantil. Mediações que também se fazem presentes, ainda que de modo indireto, na modulação do consumo alimentar das crianças em contexto familiar.

Com atenção às socialidades e mediações presentes na forma da rotina alimentar e dos hábitos e preferências alimentares da família e das crianças; das práticas e rituais de consumo alimentar infantil no contexto familiar; e das preferências e saberes infantis sobre consumo alimentar - tomando-se igualmente em atenção os cotidianos dos contextos familiares pesquisados e, a partir de agora, em maior aproximação com a temática do estudo desenvolvido - é possível destacar aspectos importantes para interpretação, análise e reflexão, no sentido de um conhecimento e compreensão da cultura alimentar infantil no âmbito das famílias participantes do estudo, bem como, das principais mediações presentes na cultura alimentar das crianças em seus contextos familiares.

Inicialmente, considerando-se a rotina, hábitos, preferências, práticas e rituais alimentares das famílias e das crianças, faz-se interessante apresentar um breve resumo da experiência cotidiana de cada família pesquisada, para que algumas interpretações, análises e reflexões propostas sejam dadas em conjunto.

No contexto da primeira família participante do estudo, de acordo com relatos dos pais e das crianças, a rotina alimentar da família, durante a semana e nos fins de semana, geralmente acontece de modo bastante organizado e com tranquilidade e bem estar.

Durante a semana, a mãe costuma acordar mais cedo. Ela organiza algumas coisas e, em seguida, ela acorda o pai e depois as crianças. Os pais e as crianças têm uma rotina densa de 
atividades nos dias de semana. Após o café da manhã, o pai logo sai de casa para o trabalho. As crianças estudam no período vespertino e fazem atividades diversas pela manhã. E a mãe tem suas atividades acadêmicas e profissionais e acompanha a rotina de atividades das crianças. Mas, de modo geral, há tempo para as atividades cotidianas do lar e para os rituais de alimentação familiar.

As refeições da família são feitas em casa - especialmente no caso da mãe e das crianças. Com horários bem definidos, e muito controle e atenção para a escolha dos alimentos e composição dos cardápios.

Os cardápios das refeições são bem variados e balanceados, com qualidade, quantidade e diversidade de alimentos. E há controle e acompanhamento dos pais, especialmente da mãe, na composição dos cardápios e preparo dos alimentos. Em perspectivas de qualidade, saudabilidade, sensorialidade e prazer para o consumo alimentar da família e das crianças.

As refeições são preparadas diariamente pela empregada da casa, de acordo com as orientações da mãe para a composição dos cardápios, O que caracteriza um consumo alimentar diário de comida caseira e fresca pela família. E os momentos de refeição, o café da manhã, o almoço e o jantar, acontecem em horários definidos, com calma e com tempo, e com todos sentados à mesa para os rituais de alimentação.

Nos dias de semana, a mãe está quase sempre com as crianças, na maior parte das refeições. E costumam partilhar juntos os rituais de alimentação. Poucas vezes, no entanto, o pai consegue estar presente com a família para as refeições nos dias de semana.

Mas nos finais de semana, a rotina da família é diferente, eles conseguem estar todos juntos: o pai, a mãe e as crianças. Para os momentos de refeição e de lazer. Tanto em casa como fora de casa. E o pai tem mais tempo para estar com as crianças.

No sábado e no domingo, todos dormem mais tarde e acordam mais tarde. Os horários das refeições também são mais flexíveis. E há mais liberdade para os cardápios das refeições. Podem comer as coisas de que mais gostam. E as crianças têm mais liberdade para comer guloseimas, ainda que com moderação no consumo.

Aos sábados, especialmente à noite, a mãe costuma cozinhar para a família. E o cardápio é sempre especial: macarronada ou risoto. Aos domingos - após o café da manhã da família: momento especial que os pais compartilham com as crianças, todos os domingos, e com cardápio diferenciado e personalizado - a família costuma almoçar fora com as crianças. E sempre em bons restaurantes, tanto para refeições como para lanches, procurando manter, no espaço público, as mesmas perspectivas de qualidade, saudabilidade, sensorialidade e prazer, presentes na orientação das escolhas alimentares da família no ambiente doméstico. Embora, 
algumas vezes, os pais também cedam aos gostos e preferências das crianças para a escolha dos restaurantes ou lanchonetes e sorveterias, ainda que as escolhas infantis se deem muito mais por perspectivas de sensorialidade e prazer do que por qualidade e saudabilidade. E nos domingos à noite, a família costuma pedir pizza em delivery, ou a mãe prepara um lanche especial, ou saem para comer um lanche fora com as crianças.

Destaque especial para o café da manhã de domingo da família: um momento especial para os pais e para as crianças, Onde todos podem comer o que mais gostam, com variedade e diversidade no cardápio. E a mãe costuma preparar o que cada um quer comer. E todos à mesa, então, compartilham juntos o ritual do café da manhã de domingo, com tempo, com prazer, e sem pressa.

O conjunto da composição de alimentos e cardápios para o consumo alimentar da família e das crianças no cotidiano, bem como, a descrição das marcas e produtos alimentícios no contexto das escolhas e preferências da família e das crianças em contexto familiar, considerando a presença material e simbólica de marcas e produtos alimentícios no contexto da primeira família participante do estudo, encontram-se em anexo. (APÊNDICE N; APÊNDICE Q)

No contexto da segunda família participante do estudo, igualmente de acordo com relatos dos pais e das crianças, a rotina alimentar da família, durante a semana e nos fins de semana, também acontece de modo organizado, porém com certa tensão e muita correria. Especialmente nos dias de semana.

Durante a semana, a família tem uma rotina bem densa de atividades. Com horários apertados. Incluindo as atividades dos pais e das crianças. O pai acorda bem cedo e, em seguida, a mãe acorda também. Depois, a mãe acorda as crianças. A família não toma café da manhã. Cada um come alguma coisa com pressa, pois não há tempo para o ritual de alimentação matinal. Em seguida, a mãe logo sai de casa com as crianças, deixa as crianças na escola, pois elas estudam no período matutino, e vai para o trabalho. E o pai, na sequência, sai de casa para o trabalho também.

Como no contexto da primeira família, as refeições da família são feitas em casa especialmente no caso da mãe e das crianças. Com horários bem definidos, mas com menor controle e atenção para a escolha dos alimentos e composição dos cardápios, por conta da correria e falta de tempo para o preparo das refeições nos dias de semana.

Os cardápios das refeições são variados, com qualidade, quantidade e diversidade de alimentos. E assim como no caso da primeira família, há controle e acompanhamento dos pais, especialmente da mãe, na composição dos cardápios e preparo dos alimentos. Em perspectivas 
de qualidade, sensorialidade e prazer para o consumo alimentar da família e das crianças. Porém, tais perspectivas são combinadas a outras, igualmente importantes e presentes no contexto do consumo alimentar da família, como praticidade e preço dos alimentos. E a perspectiva de saudabilidade não é tão presente na cultura alimentar familiar.

As refeições são preparadas pela mãe. Mas, por causa da falta de tempo, esta cozinha somente algumas vezes por semana, em maior quantidade, reservando e congelando os alimentos para as refeições dos dias seguintes, o que caracteriza um consumo alimentar diário de comida caseira pela família, porém, não de comida fresca. E os momentos de refeição, o café da manhã, o almoço e o jantar, por conta da correria e densidade da rotina familiar, acontecem em horários definidos, mas nem sempre com calma e com tempo. Muitas vezes, há certa tensão ou pressa nos rituais de alimentação da família, ainda que todos costumem estar sempre sentados à mesa para as refeições.

Como no contexto da primeira família, nos dias de semana, a mãe está quase sempre com as crianças, na maior parte das refeições. E, salvo algumas exceções, a mãe e as crianças costumam partilhar juntos os rituais de alimentação. No entanto, o pai poucas vezes consegue estar presente com a família para as refeições nos dias de semana.

Já nos finais de semana, a rotina da família é diferente. Conseguem estar todos juntos em casa no fim de semana: o pai, a mãe e as crianças. Especialmente aos domingos. E o pai tem mais tempo para estar com a família e as crianças nos momentos das refeições.

No sábado e no domingo, assim como no caso da primeira família, há mais flexibilidade nos horários das refeições. E há mais liberdade também na composição dos cardápios para as refeições e lanches. Os pais e as crianças podem comer as coisas de que mais gostam. E as crianças têm ainda mais liberdade para comer guloseimas (incluindo as "besteiras").

Os cardápios das refeições ou lanches nos fins de semana, tanto os preparados pela mãe em casa, quanto os pedidos em delivery, são mais variados e diversificados. E diferentemente do contexto do consumo alimentar da família durante a semana, no final de semana há bem menos controle e acompanhamento dos pais na composição dos cardápios, em perspectivas de qualidade e saudabilidade. Destacando-se mais as perspectivas de sensorialidade e prazer para o consumo alimentar da família e das crianças no fim de semana.

Na sexta ou no sábado à noite, geralmente a mãe prepara algo especial para as crianças: lanche (hambúrguer + batata frita), ou pastel, ou cachorro quente. Outras vezes, pedem pizza em delivery. Ou compram algo na rua para comer em casa (pizza / lanche / esfiha). Mas é raro, por causa do preço. Costumam comer em casa. Algo especial, preparado pela mãe. Porque é mais gostoso e mais barato. Aos domingos, geralmente a mãe prepara um almoço especial para 
a família. Comida caseira. Comida fresca. A mãe gosta de cozinhar para a família no domingo porque tem mais tempo e todos podem comer juntos. É o único dia em que almoçam todos juntos em casa: o pai, a mãe e as crianças. E no domingo à noite, geralmente comem macarrão instantâneo. Porque é mais fácil e mais rápido para preparar.

Destaque especial para o almoço de domingo da família: um momento muito especial para os pais e para as crianças. Pois é o único dia na semana em que a família consegue se reunir para o almoço. Todos à mesa, compartilhando juntos o ritual do almoço de domingo com tempo, com prazer, e sem pressa.

O conjunto da composição de alimentos e cardápios para o consumo alimentar da família e das crianças no cotidiano, bem como, a descrição das marcas e produtos alimentícios no contexto das escolhas e preferências da família e das crianças em contexto familiar, considerando a presença material e simbólica de marcas e produtos alimentícios no contexto da segunda família participante do estudo, encontram-se em anexo. (APÊNDICE O; APÊNDICE R)

No contexto da terceira família participante do estudo, também de acordo com relatos dos pais e das crianças, a rotina alimentar da família, durante a semana e nos fins de semana, acontece igualmente de modo organizado, e com tranquilidade e prazer. Porém, com eventuais restrições de quantidade e variedade de alimentos, possivelmente por conta da limitação financeira da família.

Durante a semana, a rotina da família é bastante corrida. Pois são três crianças em casa, e todas em fase de escola ou creche. Os pais acordam cedo e logo saem de casa para levar a menina mais nova e a bebê para as creches. A menina mais velha fica em casa dormindo. Depois, quando retornam, os pais tomam café da manhã e a mãe sai de casa para o trabalho. A menina mais velha toma café da manhã mais tarde. Ela estuda no período vespertino. E o pai, como está desempregado, cuida das atividades da casa e da rotina do lar.

Como no contexto da primeira e da segunda família, as refeições da família são feitas em casa - especialmente no caso do pai, da mãe e da menina mais velha, pois a menina mais nova e a bebê fazem as principais refeições do dia na creche. Refeições com horários definidos, mas com menor controle e atenção para a escolha dos alimentos e composição dos cardápios, possivelmente por conta da limitação financeira da família.

Os cardápios das refeições são variados, com qualidade e quantidade, mas com pouca diversidade de alimentos. E assim como no caso da primeira e da segunda família, há controle e acompanhamento dos pais, do pai e da mãe, na composição dos cardápios e preparo dos alimentos. Em perspectivas de qualidade, sensorialidade e prazer para o consumo alimentar da 
família e das crianças. Porém, como no contexto da segunda família, tais perspectivas são combinadas a outras, igualmente importantes e presentes no contexto do consumo alimentar da família, como praticidade e preço dos alimentos. E a perspectiva de saudabilidade também não é tão presente na cultura alimentar familiar.

Diferentemente do contexto da primeira e da segunda família, na terceira família as refeições são preparadas pelo pai. Mas, por causa da falta de tempo, o pai cozinha somente algumas vezes por semana, em maior quantidade, reservando os alimentos para as refeições dos dias seguintes. O que caracteriza um consumo alimentar diário de comida caseira pela família, porém, não de comida fresca. E os momentos de refeição, o café da manhã, o almoço e o jantar, apesar da correria e tensão da rotina familiar, acontecem em horários definidos, e quase sempre com calma e tranquilidade. E com todos sentados à mesa para as refeições. Pois a família faz questão de estar à mesa nos rituais de alimentação.

Nos dias de semana, o pai, a mãe e a menina mais velha estão quase sempre juntos, na maior parte das refeições. E costumam partilhar juntos os rituais de alimentação. A menina mais nova e a bebê, somente estão com a família à noite e nos fins de semana para as refeições. Pois ficam na creche em período integral.

Nos finais de semana, no entanto, a rotina da família é diferente. Pois estão todos juntos em casa: os pais e as crianças. E podem partilhar todos juntos os momentos de refeição e rituais de alimentação. Mas a rotina da casa se torna ainda mais corrida, pois como as crianças estão em casa, o pai e a mãe precisam dividir um pouco as tarefas, entre os preparos dos alimentos, as atividades da casa e os cuidados com as crianças.

No sábado e no domingo, assim como no caso da primeira e da segunda família, há mais flexibilidade nos horários das refeições. E há mais liberdade também na composição dos cardápios para as refeições e lanches. Os pais e as crianças podem comer coisas de que mais gostam. E as crianças têm mais liberdade para comer guloseimas. Mas dependendo da disponibilidade e diversidade de alimentos e guloseimas que a família tiver em casa. O que às vezes é restrito por conta da limitação financeira da família.

Os cardápios das refeições ou lanches nos fins de semana, tanto os preparados em casa, quanto os pedidos em delivery, ou eventualmente consumidos em restaurantes ou lanchonetes, são variados e diversificados, na medida da disponibilidade ou limitação financeira da família. E no final de semana há menos controle e acompanhamento dos pais na composição dos cardápios, em perspectivas de qualidade e saudabilidade. Destacando-se as perspectivas de sensorialidade e prazer para o consumo alimentar da família e das crianças no fim de semana. Novamente aqui, dependendo da disponibilidade ou limitação financeira da família. 
No sábado, a família costuma tomar o café da manhã, todos juntos em casa. E no sábado à noite, muitas vezes, a família pede pizza em delivery. Quando não pedem pizza, as crianças geralmente comem macarrão instantâneo. Aos domingos de manhã, a família costuma fazer um café da manhã especial, com todos juntos à mesa e um cardápio especial (com itens que a os pais compram na padaria especialmente para o café da manhã de domingo da família). E para o almoço de domingo, a família costuma sair de casa, pois quase sempre há alguma programação ou convite especial da família ou de amigos para o almoço. E quando não há programação especial, a família geralmente vai ao McDonald's com as crianças aos domingos para fazer um lanche. As crianças gostam muito!

Destaque especial para o café da manhã de domingo da família: um momento especial para os pais e para as crianças. Onde a família está reunida, todos juntos à mesa, saboreando um cardápio especial: os itens que os pais compram na padaria especialmente para o café da manhã de domingo. E assim, partilham juntos o ritual do café da manhã de domingo da família, com tempo, com prazer, e sem pressa.

O conjunto da composição de alimentos e cardápios para o consumo alimentar da família e das crianças no cotidiano, bem como, a descrição das marcas e produtos alimentícios no contexto das escolhas e preferências da família e das crianças em contexto familiar, considerando a presença material e simbólica de marcas e produtos alimentícios no contexto da terceira família participante do estudo, encontram-se em anexo. (APÊNDICE P; APÊNDICE S)

Nos três contextos familiares pesquisados, a rotina alimentar das famílias parece se dar de modo bastante organizado. Com horários definidos e rituais estabelecidos para os momentos de refeição das famílias e das crianças. Apesar das diferenças que marcam as dinâmicas e rotinas do lar no cotidiano de cada família participante do estudo.

As diferenças se mostram especialmente na questão do tempo e dinâmica dos rituais de alimentação familiar. Enquanto no contexto da primeira família, há mais tempo para os preparos e rituais de alimentação, onde as refeições podem ser feitas com tranquilidade, bem estar e prazer; no contexto da segunda família, há significativamente menos tempo para os preparos e rituais alimentares, onde as refeições, muitas vezes, acabam se dando em um contexto de tensão e pressa. E no contexto da terceira família, ainda que a questão da falta de tempo para os preparos e rituais alimentares não interfira tanto nos momentos das refeições, que quase sempre acontecem com calma e tranquilidade, as diferenças se mostram na questão da limitação financeira da família, o que eventualmente demarca restrições de quantidade e diversidade de 
alimentos no contexto do consumo alimentar familiar, tanto na alimentação dos pais quanto na alimentação das crianças.

No contexto das três famílias participantes do estudo, durante a semana a rotina de atividades dos pais e das crianças é mais densa e corrida, com menos tempo para as refeições e sem a presença de todos para os rituais de alimentação. Enquanto nos finais de semana, os momentos de refeição se dão com mais tempo e os rituais de alimentação acontecem com a presença de toda a família: as crianças e os pais.

Característica comum no contexto das três famílias pesquisadas, trata da presença diária da comida caseira na rotina alimentar familiar, em que o preparo e o consumo das principais refeições do dia acontecem em casa e com rituais estabelecidos para os momentos de refeição. Ainda que nem sempre seja possível consumir comida fresca no cardápio diário das refeições da família (como no caso da segunda e da terceira família em estudo).

Outra característica presente no contexto das três famílias participantes do estudo, trata da atenção e acompanhamento dos pais na escolha dos alimentos, composição dos cardápios e preparo das refeições da família. O que, no contexto da primeira família, acontece com inspiração em perspectivas de qualidade, saudabilidade, sensorialidade e prazer para o consumo alimentar da família e das crianças. Enquanto no contexto da segunda e da terceira família, as perspectivas de qualidade, sensorialidade e prazer para o consumo alimentar da família e das crianças são combinadas às perspectivas de praticidade e preço dos alimentos, em detrimento da perspectiva de saudabilidade, cuja presença é menos marcante nesses contextos familiares.

Quanto às refeições em casa, nos três contextos familiares pesquisados as crianças costumam se alimentar bem, com cardápios balanceados, considerando o consumo diário de carnes, proteínas, carboidratos e legumes - salvaguardadas algumas diferenças de qualidade, quantidade e diversidade de alimentos disponíveis em cada contexto familiar, bem como, algumas diferenças quanto às perspectivas familiares de saudabilidade, e quanto aos modos de acompanhamento e controle dos pais sobre a alimentação das crianças. E ainda a questão dos gostos e preferências das crianças por determinados alimentos, em detrimento de outros, os quais elas não gostam de comer.

Quanto ao consumo de frutas, legumes e verduras pelas crianças, é interessante destacar que no contexto da primeira família há maior variedade e diversidade de itens à disposição das crianças, para o consumo diário da família e das crianças. E há constante incentivo dos pais para o consumo de tais alimentos. E especialmente no caso das frutas, no contexto da primeira família, as crianças são apaixonadas por frutas e consomem com prazer uma grande diversidade delas. Enquanto no contexto da segunda família, há menor diversidade de frutas, verduras e 
legumes à disposição das crianças, pois elas têm gostos bastante restritos e comem somente as frutas, legumes e verduras de que mais gostam. Independentemente do eventual incentivo dos pais para o consumo. Mas ainda assim, as crianças têm um consumo diário e diversificado de frutas, legumes e verduras. Já no contexto da terceira família, há pouca diversidade de frutas, legumes e verduras à disposição das crianças. Há certa variedade de frutas semanalmente em casa, especialmente para o consumo das crianças. Mas os legumes e verduras não costumam fazer parte do cardápio diário da família em seu cotidiano. E não há um incentivo mais intenso dos pais para o consumo de frutas, legumes e verduras por parte das crianças. Sempre que há frutas, legumes ou verduras em casa, os pais costumam deixar à disposição para que as crianças, a seu tempo, despertem o gosto para o consumo.

Interessante observar que no contexto das três famílias em estudo, nos finais de semana, há mais flexibilidade nos horários das refeições e composição dos cardápios. Os pais e as crianças podem comer o que mais gostam e as crianças ficam mais livres para o consumo de guloseimas - o que durante a semana acontece de modo mais regrado ou controlado no contexto das famílias pesquisadas. E as escolhas alimentares das famílias, nos finais de semana, são inspiradas quase que exclusivamente em perspectivas de sensorialidade e prazer. Em detrimento das perspectivas de qualidade e saudabilidade. Especialmente no contexto da segunda e da terceira família participante do estudo.

No entanto, faz-se importante sinalizar que tais perspectivas, presentes nas escolhas alimentares das famílias em seus cotidianos, no caso da terceira família, elas se fazem também marcadas pela limitação financeira da família, o que pode demarcar eventuais restrições na quantidade e diversidade de alimentos disponíveis, ou na escolha de marcas e produtos alimentícios para o consumo da família e das crianças.

Quanto ao consumo de guloseimas, é interessante destacar que, no contexto da primeira família - onde há maior acompanhamento e controle dos pais sobre o consumo de guloseimas por parte das crianças, especialmente nos dias de semana - a família não costuma armazenar itens de guloseima em casa (como doces, chocolates, salgadinhos) e as compras eventuais de guloseimas se restringem aos finais de semana, e somente com produtos para o consumo imediato das crianças. Enquanto no contexto da segunda família - onde não há tamanho acompanhamento e controle dos pais sobre o consumo de guloseimas por parte das crianças, mas há regras bem definidas para moderação no consumo - a família costuma ter uma grande diversidade de itens de guloseima em estoque em casa, para um consumo diário e moderado das crianças. Já no contexto da terceira família - onde igualmente o controle e acompanhamento dos pais sobre o consumo de guloseimas por parte das crianças é eventual, mas com regras 
definidas para moderação no consumo - a família não costuma ter itens de guloseima em estoque em casa, mas especialmente por questões de limitação financeira familiar, o que não possibilita a compra constante de tais itens para o consumo das crianças, concentrando-se as compras de guloseimas nos momentos em que a família faz as compras de alimentos da semana ou do mês.

Outro aspecto interessante a ser observado se refere ao hábito de fazer refeições fora de casa com as crianças, em restaurantes ou lanchonetes, ou ao consumo de refeições em delivery. O que se mostra presente no contexto das três famílias pesquisadas, marcando especialmente a rotina alimentar das famílias nos finais de semana. Especialmente no caso da primeira família, que costuma frequentar restaurantes, lanchonetes e sorveterias diversas nos finais de semana para refeições e lanches com as crianças, além do consumo semanal de alimentação em delivery. No contexto da segunda família, no entanto, o hábito de frequentar restaurantes ou lanchonetes e sorveterias é pouco presente, pois raramente a família sai de casa com as crianças para refeições ou lanches. Especialmente por conta dos custos. Mas os pedidos de alimentação em delivery, assim como no contexto da primeira família, acontecem em uma média de frequência semanal. $\mathrm{O}$ que igualmente acontece no contexto da terceira família, que tem o hábito de consumir alimentos em delivery semanalmente também. Além de uma frequência quinzenal ou mensal da família em lanchonetes (do McDonald's) para fazer lanche coma as crianças.

Aspecto interessante se mostra também quanto aos eventuais gostos diferentes ou paladar diferenciado das crianças nos contextos familiares pesquisados, especialmente no contexto da primeira e da segunda família. No caso da primeira família, destaca-se o gosto das crianças por grande diversidade de frutas, a preferência delas por suco natural de frutas à refrigerante, e ainda o gosto das crianças por tempero na salada; destaca-se também o gosto do menino por iogurte natural, suco de frutas mais densas, chocolate amargo, isotônico, aceto balsâmico no tempero da salada, e por comer frutas junto com a salada nas refeições; e destacase ainda o gosto da menina por suco ou água no acompanhamento das refeições, por não gostar de refrigerante, e pela preferência dela em não comer carne nas refeições. No caso da segunda família, destaca-se o gosto das crianças por alguns itens da culinária japonesa, e ainda o gosto expressivo das crianças por tomate; e destaca-se também o gosto da menina por queijo parmesão fresco ralado sobre o macarrão, o gosto dela por diversos itens da culinária japonesa, o gosto da menina por cebola crua, e ainda a preferência dela por tempero na salada, especialmente o molho agridoce (que ela já sabe preparar). 
E ainda um aspecto interessante observado, quanto à rotina alimentar das famílias pesquisadas, se refere à importância das refeições em família, com a presença dos pais e das crianças nos rituais de alimentação familiar. No contexto das três famílias pesquisadas, a possibilidade das refeições em família parece algo muito importante, e que acontece somente aos finais de semana, quando estão todos juntos em casa. Os rituais de alimentação com a presença dos pais e das crianças representam os momentos mais especiais de refeição para as famílias participantes do estudo. No caso da primeira família: o café da manhã de domingo, que a mãe prepara com carinho para a família; e o almoço de domingo, quando os pais e as crianças vão juntos aos restaurantes. No caso da segunda família: o almoço de domingo, que a mãe faz questão de preparar para a família com carinho e dedicação. E no caso da terceira família: o café da manhã de domingo, quando os pais compram na padaria produtos especiais para o café da manhã em família; e o almoço de domingo, quando os pais vão ao McDonald's com as crianças para fazer um lanche.

Considerando-se as práticas e rituais de consumo alimentar das crianças, nos diferentes contextos familiares pesquisados, no que se refere às refeições em casa, às refeições fora de casa, às guloseimas e ao lanche da escola, é interessante sinalizar algumas semelhanças e diferenças marcantes sobre o consumo alimentar infantil em cada contexto familiar:

Quanto às refeições em casa: No contexto da primeira e da segunda família, as crianças dispõem diariamente de comida caseira, um cardápio balanceado, e grande diversidade de alimentos. As crianças gostam de comer e costumam se alimentar bem nos horários das refeições. No contexto da terceira família, as crianças também dispõem todos os dias de comida caseira e um cardápio balanceado, ainda que com menor diversidade de alimentos. Mas a menina mais velha nem sempre se alimenta bem, pois não gosta muito de comer nas refeições. Prefere fazer lanches.

Quanto às refeições ou lanches fora de casa: No contexto da primeira família, as crianças vivenciam com frequência experiências gastronômicas diversas, experimentando diferentes pratos, ingredientes e sabores, em diferentes restaurantes e lanchonetes (Rascal, América, Pirajá, The Fifties, McDonald's). Assim como experimentam diferentes tipos e sabores de sorvetes em diferentes sorveterias (Bacio di Latte, Haagen Dazs, McDonald's). As crianças gostam muito de ir a lanchonetes e restaurantes com os pais, o que torna mais rico seu consumo alimentar em contexto familiar. Já no contexto da segunda família, o ritual de sair com as crianças para refeições e lanches fora de casa é muito raro. Especialmente por conta dos custos. Mas quando saem para comer fora, costumam frequentar uma pastelaria tradicional no bairro da Liberdade (Pastelaria Yoka) que os pais e as crianças gostam muito. Ou vão com as crianças 
ao McDonald's para fazer um lanche. O que as crianças também gostam muito, pois é o lanche favorito delas. E no contexto da terceira família, as experiências de consumo alimentar das crianças e dos pais fora de casa acontecem sempre nas lanchonetes do McDonald's. Quase sempre aos domingos, quando os pais saem com as crianças para fazer um lanche e tomar sorvete. Os pais gostam muito e as crianças gostam muito também. Pois é o lanche de que elas mais gostam.

Quanto ao consumo de guloseimas: No contexto da primeira família, as crianças consomem guloseimas, mas sempre com moderação e somente nos finais de semana. Geralmente não há guloseimas em casa à disposição das crianças, especialmente nos dias de semana. Mas no sábado e no domingo elas têm mais liberdade para consumir guloseimas, especialmente nos momentos em que saem de casa com os pais para refeições ou lanches. A guloseima preferida das crianças é sorvete. Já no contexto da segunda família, as crianças têm mais liberdade para o consumo de guloseimas, tanto nos dias de semana quanto nos finais de semana. Mas o consumo deve ser com moderação. E há sempre guloseimas em estoque em casa, à disposição das crianças. Elas podem escolher o que querem comer, desde que o consumo seja em horários definidos e sempre com moderação. A guloseima preferida das crianças é chocolate. E no contexto da terceira família, ainda que as crianças também tenham mais liberdade para o consumo de guloseimas, tanto nos dias de semana quanto nos finais de semana, desde que o consumo seja sempre com moderação, geralmente não há guloseimas em estoque em casa para o consumo das crianças. E quando há guloseimas, é sempre em pouca quantidade e com menor diversidade. Especialmente pela questão da limitação financeira da família que, muitas vezes, restringe a frequência das compras e a diversidade de marcas e produtos disponíveis. A guloseima favorita das crianças é chocolate.

Quanto ao lanche da escola: No contexto da primeira família a composição do lanche da escola para as crianças é sempre definida pela mãe. E o lanche é composto com produtos naturais, integrais, evitando a presença de guloseimas na composição do lanche. Destaque para a presença das frutas, biscoitos doces e salgadinhos integrais, amendoim e castanhas, sanduíche natural, e suco integral em caixinha. Mas uma vez por semana, na sexta-feira, as crianças podem comprar o lanche na cantina da escola. E nesse momento, ficam livres para escolher o que querem comprar para o lanche. Desde que o valor não ultrapasse o limite estabelecido pelos pais. E geralmente as crianças compram salgados, pão de queijo, suco, chocolate quente, chocolate, cookie, sorvete. No contexto da segunda família, a composição do lanche da escola é definida pelas crianças, que são livres para escolher o que querem levar no lanche a cada dia, entre produtos alimentícios e marcas diversas. Mas devem seguir uma estrutura de composição 
definida pela mãe: um doce, um salgado e um suco. O lanche da escola para as crianças é composto por guloseimas diversas, e os itens para o lanche são comprados em estoque pela mãe e armazenados em casa para as escolhas diárias das crianças na composição do lanche. Destaque para a presença dos bolinhos, biscoito doce recheado, wafer, barra de cereais, bisnaguinha com requeijão e mortadela, queijo processado, sanduíche natural, suco em caixinha. salgadinhos, refrigerante. E uma vez por semana a menina pode comprar o lanche na cantina da escola. Ela pode escolher o que quer comprar para o lanche, mas não pode ultrapassar o valor estabelecido pelos pais. E no contexto da terceira família, o lanche das crianças é fornecido pela escola, no caso da menina mais velha, e pela creche, no caso da menina mais nova e da bebê. E as crianças não podem levar lanche de casa. Para a menina mais velha, o lanche da escola é composto por sanduíche natural (com queijo branco e pão integral), biscoito doce, wafer, frutas e suco em caixinha. Mas a menina não gosta muito do lanche da escola, especialmente do sanduíche natural. Ela prefere os doces. E geralmente consome somente os biscoitos ou wafer, as frutas e o suco.

Com atenção aos rituais de alimentação das famílias participantes do estudo, tanto em ambiente doméstico quanto em espaço público, e especialmente com base no acompanhamento dos rituais alimentares das famílias durante o processo de investigação, é possível assinalar alguns aspectos importantes para o estudo desenvolvido.

Quanto ao acompanhamento de rituais alimentares das famílias com a presença das crianças em ambiente doméstico, com atenção aos três contextos familiares pesquisados, foi possível observar que as famílias costumam fazer as principais refeições à mesa com as crianças, com comida caseira, e vivenciando os formatos e estruturas convencionais dos rituais de alimentação em família. Ainda que nem sempre haja tempo suficiente para vivenciar com calma ou sem pressa tais rituais, e que nem sempre seja possível ter a presença da família toda nos momentos das refeições. Mas no contexto das famílias pesquisadas, os momentos de refeição em família, com a presença de todos, ainda que nem sempre sejam possíveis, são sempre muito especiais para as crianças e para os pais.

E quanto ao acompanhamento de rituais alimentares das famílias com a presença das crianças em espaço público, igualmente com atenção aos três contextos familiares pesquisados, foi possível observar que nas famílias, ainda que com frequências e experiências diferentes, e cada uma a seu modo, de acordo com suas possibilidades, os pais costumam sair com as crianças para refeições e lanches fora de casa - com bastante frequência no contexto da primeira família; com frequência um pouco menor no contexto da terceira família; e com rara frequência no contexto da segunda família. E que quando as famílias o fazem, é sempre com muito prazer dos 
pais em partilhar esses momentos de alimentação e lazer com as crianças. E as crianças ficam muito felizes.

A variedade e diversidade de alimentos e experiências gastronômicas presentes nos cotidianos do consumo alimentar das famílias participantes do estudo, tanto durante a semana quanto nos finais de semana, tanto em ambiente doméstico quanto em espaços públicos, demarcam a presença de marcas e produtos alimentícios diversos na cultura alimentar das famílias e das crianças. Cultura alimentar familiar marcada por perspectivas de qualidade, saudabilidade, sensorialidade, prazer, praticidade e preço - em diferentes pesos e medidas para cada contexto familiar - presentes na escolha, preparo e consumo dos alimentos no ambiente doméstico ou em espaços públicos. Perspectivas que, em seu conjunto, orientam as escolhas das marcas e produtos alimentícios para a composição do consumo alimentar de cada família, e dão base aos vínculos de sentidos entre as marcas/produtos e os pais/crianças em cada contexto familiar.

No que se refere às socialidades presentes na forma das mediações culturais e comunicacionais na cultura alimentar infantil e na forma da mediação da família na cultura de consumo alimentar das crianças - e tomando-se novamente em atenção os contextos familiares pesquisados em seus cotidianos - é possível destacar aspectos importantes para interpretação, análise e reflexão, para melhor conhecimento e compreensão das principais mediações da cultura, da comunicação e da família, presentes nos cotidianos da cultura de consumo alimentar infantil em contexto familiar no âmbito de cada família participante do estudo.

Nessa perspectiva, uma mediação importante e presente no contexto da cultura alimentar das crianças, considerando-se os contextos familiares pesquisados, trata das tradições familiares na alimentação.

Tradições familiares que, no contexto da primeira família, são bastante presentes na cultura alimentar dos pais e das crianças, especialmente no que tange ao gosto e carinho pelas frutas, em uma grande diversidade delas; ao consumo diário de saladas; e ao preparo e consumo de diversos tipos de carnes - tradições herdadas dos avós paternos e maternos das crianças.

Enquanto no contexto da segunda família, as tradições familiares na cultura alimentar fazem-se presentes especialmente no gosto e consumo familiar de alguns pratos da culinária japonesa, principalmente no caso do pai e das crianças - tradição herdada dos avós paternos das crianças; e também no gosto e hábito da mãe por cozinhar para a família, no preparo da comida caseira e a culinária de modo geral - tradição herdada da avó materna das crianças.

E no contexto da terceira família, ainda que não sejam tão presentes, as tradições familiares na cultura alimentar se mostram nos momentos em que a mãe se inspira em receitas 
da mãe dela para o preparo de pratos especiais para a família; e ainda, no gosto e carinho do pai por cozinhar para a família no dia a dia, um hábito bastante presente entre os homens da família da mãe e do pai, especialmente nas festas e reuniões de família - tradição herdada do avô paterno e do avô materno das crianças.

Não se observou, no entanto, nos contextos familiares pesquisados, a presença de tradições familiares enquanto mediação nas preferências e escolhas por produtos alimentícios ou marcas específicas na composição da cultura de consumo alimentar da família e das crianças.

Outra mediação importante, e consideravelmente presente nos cotidianos da cultura alimentar das crianças no âmbito das famílias participantes do estudo, trata da presença e interação com os amigos. Especialmente os amigos das crianças no contexto da escola, mas também os amigos de modo geral. No contexto das três famílias pesquisadas, a presença e interação com os amigos trazem muitas influências para o consumo alimentar das crianças, especialmente quanto ao conhecimento e experimentação de novas marcas e produtos alimentícios na categoria de guloseimas ou produtos alimentícios especiais. E segundo relatos das crianças e dos pais, a influência dos amigos para o consumo alimentar das crianças é consideravelmente maior do que a influência da publicidade ou outros formatos promocionais das marcas e produtos no mercado de alimentos. É no contato e interação diária das crianças com os amigos que elas fazem trocas, experimentações, e descobrem novas marcas e produtos alimentícios para o enriquecimento do seu paladar e diversidade da sua cultura alimentar.

Quanto à mediação da escola na cultura alimentar das crianças, considerando-se os três contextos familiares em estudo, conforme relatos das crianças e dos pais, não há influência ou interferência direta da escola nos cotidianos das práticas e hábitos de consumo alimentar infantil em contexto familiar. A escola não interfere diretamente na cultura alimentar das crianças, restringindo sua possível participação aos conteúdos trabalhados em sala de aula com as crianças sobre saúde e alimentação. A única forma de uma interferência, ainda que de modo indireto, acontece na escola da menina mais velha, no contexto da terceira família, quando a escola fornece o lanche para as crianças e não permite que as crianças levem o lanche de casa.

A saúde das crianças é outra mediação presente nos cotidianos da cultura alimentar infantil em contexto familiar, tomando-se em atenção as famílias participantes do estudo. A preocupação dos pais com a saúde e alimentação das crianças se faz presente nos três contextos familiares pesquisados, ainda que em perspectivas e intensidades diferentes. Sendo uma preocupação mais expressiva no contexto da primeira família, e menos expressiva no contexto da segunda e da terceira família. E quanto a eventuais problemas de saúde infantil que demandam restrições alimentares às crianças, há algumas situações específicas observadas no 
processo de investigação: No contexto da primeira família, o menino tem alergia a produtos alimentícios com corantes vermelhos, como o ketchup, e a menina apresenta índices iniciais de possibilidade para sobrepeso; No contexto da segunda família, a menina apresenta intolerância à lactose; E no contexto da terceira família, a menina mais velha apresenta alterações nos níveis de colesterol. O que demanda alguns cuidados e restrições alimentares dos pais para as crianças.

Quanto à mediação da religião na cultura alimentar da família e das crianças, considerando-se os três contextos familiares pesquisados, os pais relatam que não há uma influência ou interferência das crenças e práticas religiosas familiares na cultura cotidiana de consumo alimentar dos pais e das crianças. As únicas exceções se dão no contexto da primeira e da terceira família, praticantes da religião católica. Na primeira família, os pais e as crianças não comem carne na Sexta-Feira Santa. E na terceira família, os pais e as crianças também não comem carne na Sexta-Feira Santa, mas os pais mantém o mesmo jejum da carne para todas as sextas-feiras do ano. Somente os pais. As crianças não precisam participar.

A questão do tempo também se faz muito presente enquanto mediação no âmbito da cultura alimentar da família e das crianças, considerando-se os cotidianos das contextos familiares pesquisados. Especialmente, no que tange à falta de tempo para que toda a família possa estar presente à mesa nos momentos das refeições, onde os pais e as crianças possam partilhar juntos as experiências cotidianas da alimentação. Um relato bastante presente no discurso dos pais no processo de investigação em cada contexto familiar pesquisado. E ainda, no que tange à falta de tempo para o preparo diário das refeições da família, com comida caseira e fresca todos os dias. O que aparece com destaque nos relatos dos pais no contexto da segunda e da terceira família em estudo.

A classificação socioeconômica das famílias participantes do estudo caracteriza outra mediação importante e consideravelmente presente, talvez uma entre as mais marcantes, na cultura alimentar dos pais e das crianças em contexto familiar.

Tanto na forma de uma situação econômica mais confortável, que permite com tranquilidade o acesso frequente da família à experiências gastronômicas diversas no ambiente doméstico e em espaços públicos, bem como, o acesso à uma grande diversidade de marcas e produtos alimentícios para o consumo alimentar dos pais e das crianças no cotidiano, em perspectivas de qualidade, saudabilidade, sensorialidade e prazer - como no contexto da primeira família;

Como na forma de uma situação econômica mais tensa e limitada que, para possibilitar o eventual acesso da família à experiências gastronômicas diversas no ambiente doméstico ou em espaços públicos, bem como, o acesso à uma considerável diversidade de marcas e produtos 
alimentícios para o consumo alimentar dos pais e das crianças no cotidiano, em perspectivas de qualidade, sensorialidade e prazer, combinadas às perspectivas de praticidade e preço, necessita constantemente de revisão de orçamento, controle de gastos, avaliação de custos e comparativos de preços - como no contexto da segunda família;

Ou ainda, na forma de uma situação econômica de significativa limitação financeira, com a necessidade constante ou eventual de restrições quanto às possibilidades de acesso da família à algumas experiências gastronômicas diversas no ambiente doméstico ou em espaços públicos, bem como, de acesso a alguma diversidade de marcas e produtos alimentícios, ainda que em menor quantidade e variedade, para o consumo alimentar dos pais e das crianças no cotidiano, em perspectivas de qualidade, sensorialidade e prazer, quando possível, mas muitas vezes priorizando as perspectivas de praticidade e preço - como no contexto da terceira família.

Trata-se assim de diferentes e diversas formas de mediação da classe socioeconômica na cultura alimentar das famílias e das crianças em contexto familiar. E que significativamente parecem dar forma à composição das experiências gastronômicas e ao conjunto das marcas e produtos alimentícios presentes no contexto do consumo alimentar infantil em cada ambiente familiar em estudo.

No entanto, para além das diferenças marcantes da classificação socioeconômica, curiosamente, é possível observar também algumas semelhanças nos contextos familiares pesquisados. Especialmente quanto aos momentos especiais de fruição do consumo alimentar em família no ambiente doméstico ou em espaços públicos. Como o que foi possível observar no caso da primeira e da terceira família, onde, apesar das consideráveis diferenças materiais quanto à caracterização das experiências gastronômicas e diversidade de marcas e produtos alimentícios para o consumo alimentar familiar, há semelhança simbólica no que tange aos momentos especiais de fruição do consumo alimentar em família: sejam essas experiências de consumo alimentar vivenciadas entre os pais e as crianças no restaurante Rascal ou restaurante América, ou saboreando um sorvete Bacio di Latte ou Haagen Dazs, ou ainda comendo trufas de chocolate Lindt ou Kopenhagen (como no contexto da primeira família); sejam tais experiências de consumo alimentar vivenciadas entre os pais e as crianças no restaurante e sorveteria do McDonald's, ou comendo uma barra de chocolate Hershey's ou Lacta (como no contexto da terceira família). Em ambos os contextos, apesar das diferenças marcantes, a alegria e o prazer das crianças e dos pais na fruição do consumo alimentar em família nos momentos especiais é muito semelhante. O que acontece de modo diferente no contexto da segunda família, onde as limitações e desafios da classificação socioeconômica familiar levam a um 
constante estado de tensão e atenção dos pais, ainda que em momentos e vivências especiais do consumo alimentar em contexto familiar.

Os dispositivos e mídias, outra forma de mediação presente na cultura de consumo alimentar das crianças nos contextos familiares pesquisados, elas se fazem mediação na medida em que possibilitam o acesso constante das crianças ao universo promocional das marcas e produtos alimentícios, tanto as marcas e produtos dirigidos ao consumo alimentar infantil quanto as marcas e produtos no mercado de alimentos de modo geral. E no contexto das famílias participantes do estudo, foi possível observar que as crianças têm acesso constante e diário aos dispositivos, às mídias e a internet em seus cotidianos, ainda que com acompanhamento e controle dos pais quanto aos tempos de uso dos dispositivos e conteúdos acessados nas mídias. Sendo o acompanhamento e controle dos pais mais rigoroso no contexto da primeira família, e menos rigoroso no contexto da segunda e da terceira família.

No que tange à mediação da publicidade de alimentos e outros formatos promocionais no universo das marcas e produtos alimentícios dirigidos ao consumo alimentar da família e, especialmente, das crianças em contexto familiar - e tomando-se em atenção o âmbito das três famílias participantes do estudo - conforme relatos das crianças e dos pais, trata-se sim de uma mediação presente na cultura alimentar infantil, mas com menor expressividade nos cotidianos das crianças, se comparada à expressiva mediação da presença e interação das crianças com os amigos, enquanto mediação presente e marcante nos cotidianos da cultura alimentar infantil em contexto familiar. Pois como já sinalizado, para além da publicidade ou outros formatos promocionais, as trocas, experimentações e descobertas de novas marcas e produtos alimentícios pelas crianças se dão mais expressivamente na presença e interação cotidiana com os amigos. Em suas trocas constantes de experiências e saberes infantis. E nessa perspectiva, a mediação comunicacional das marcas nos cotidianos da cultura alimentar infantil, para além da publicidade ou outros formatos promocionais, é especialmente materializada nos diferentes e diversos modos de presença das marcas e produtos alimentícios nos cotidianos infantis da cultura alimentar em contexto familiar.

E finalmente, a mediação da família, especialmente dos pais, na modulação da cultura de consumo alimentar infantil em contexto familiar que, no âmbito das famílias participantes do estudo, aparece como a principal, a mais presente e marcante mediação nos cotidianos das rotinas, dos hábitos, das preferências, das práticas e dos rituais de consumo alimentar das crianças em contexto familiar. O constante e continuo acompanhamento e controle dos pais sobre os alimentos e a alimentação das crianças, as refeições e lanches, as guloseimas, sobre a modulação dos gostos e preferências infantis, e sobre o conjunto das marcas e produtos 
alimentícios que compõem os cotidianos do consumo alimentar das crianças em contexto familiar, demarcam a presença e importância da mediação da família na cultura alimentar infantil nos contextos familiares pesquisados. E nessa perspectiva é possível observar: é como se a presença e mediação dos pais perpassasse de modo transversal diversas outras formas de mediação presentes nos cotidianos da cultura alimentar das crianças. O que foi possível observar com igual intensidade e expressividade nos cotidianos das três famílias participantes do estudo.

E nesse mesmo contexto da mediação familiar, ainda que com menor expressão que a mediação dos pais na modulação da cultura de consumo alimentar das crianças, coloca-se a mediação entre irmãos. Nessa perspectiva, são muito presentes as trocas de experiências, conhecimentos e descobertas entre os irmãos nos cotidianos da cultura alimentar infantil em contexto familiar, especialmente sobre novas marcas e produtos alimentícios com que as crianças têm contato a partir das interações com os amigos, e ainda sobre seus gostos e preferências no consumo alimentar. O que igualmente foi possível observar nos cotidianos das três famílias participantes do estudo, ainda que com maior intensidade no contexto da primeira e da terceira família e com menor intensidade no contexto da segunda família.

Especialmente combinada a outras formas expressivas de mediação - como a mediação da classe socioeconômica familiar, a mediação da interação cotidiana das crianças com os amigos, e a presença e mediação das marcas e produtos alimentícios no contexto familiar - a mediação da família (mediação dos pais e mediação entre irmãos) compõe, com estas, o conjunto das principais mediações culturais presentes nos cotidianos da cultura de consumo alimentar das crianças no âmbito das famílias participantes do estudo. Mediações culturais que se apresentam perpassadas, entrelaçadas e combinadas às mediações comunicacionais, especialmente materializadas nos diferentes e diversos modos de presença e mediação comunicacional das marcas e produtos alimentícios nos cotidianos da cultura de consumo alimentar infantil em contexto familiar. A presença material e simbólica das marcas e produtos alimentícios no contexto das escolhas e preferências e do consumo alimentar das crianças no âmbito familiar.

Finalmente, é importante sinalizar que as interpretações, análises e reflexões propostas sobre o conjunto das socialidades observadas e exploradas nos cotidianos das famílias participantes do estudo, no trabalho desenvolvido com as crianças em campo em seus contextos familiares, possibilitaram melhor compreensão dos processos de mediação entre as competências de recepção ou consumo das crianças (a recepção infantil de marcas de alimentos e os vínculos de sentidos entre marcas/produtos e crianças no contexto familiar) e as matrizes 
culturais em seus contextos familiares (a cultura alimentar infantil e as mediações culturais e comunicacionais na modulação do consumo alimentar das crianças no contexto familiar), trazendo significativas contribuições para o estudo desenvolvido sobre a mediação comunicacional das marcas na cultura alimentar infantil em uma perspectiva das mediações comunicativas da cultura.

Nesse sentido, faz-se importante destacar o quanto as mediações culturais e comunicacionais presentes na cultura alimentar das crianças em contexto familiar participam, ainda que em nível contextual, na modulação dos processos de recepção e consumo das crianças quanto às marcas e produtos alimentícios presentes na composição da sua cultura alimentar e na criação dos vínculos de sentido e de afeto entre as crianças, as marcas e os produtos nos cotidianos do consumo alimentar infantil.

E somadas a essas contribuições, apresenta-se na sequência a proposição de interpretações, análises e reflexões sobre o conjunto das ritualidades presentes nos processos de mediação entre as competências de recepção ou consumo das crianças (a recepção infantil de marcas de alimentos e os vínculos de sentidos entre marcas/produtos e crianças no contexto familiar) e os formatos industriais e promocionais das marcas e produtos alimentícios (a mediação comunicacional das marcas na cultura alimentar infantil e as marcas e produtos alimentícios no contexto familiar).

Em anexo, apresenta-se transcrição completa dos dados, informações, atividades, eventos e situações observados em campo com as famílias e com as crianças no processo de investigação, referentes às socialidades e mediações presentes nos processos de mediação entre a recepção infantil de marcas de alimentos e a cultura alimentar das crianças. - Vide Parte I:1.11.5; Parte II:1.1-1.5; Parte III:1.1-1.5) ${ }^{5}$

\section{Recepção Infantil de Marcas de Alimentos e Mediação Comunicacional das Marcas}

Com atenção aos processos de mediação entre as competências de recepção ou consumo das crianças (a recepção infantil de marcas de alimentos e os vínculos de sentidos entre marcas/produtos e crianças no contexto familiar) e os formatos industriais e promocionais das marcas e produtos alimentícios (a mediação comunicacional das marcas na cultura alimentar infantil e as marcas e produtos alimentícios no contexto familiar) - a mediação entre o terceiro e o segundo eixo de abordagem, propostos para orientação do estudo, na perspectiva das

\footnotetext{
${ }^{5} \mathrm{O}$ conteúdo disponibilizado em link temporário para avaliação da Banca Examinadora encontra-se disponível em pen-drive na versão da Tese para a Biblioteca da ECA/USP.
} 
mediações comunicativas da cultura - colocam-se para interpretação, análise e reflexão diferentes e diversas formas de ritualidade.

Ritualidades igualmente observadas, participadas e vivenciadas em campo com as famílias e com as crianças no processo de investigação, compreendendo a escolha compra e consumo de alimentos da família e os critérios mais importantes na escolha dos alimentos; os usos e consumos infantis dos dispositivos e mídias e o contato das crianças com o universo promocional das marcas e produtos alimentícios; a presença e mediação comunicacional das marcas na cultura alimentar infantil e os rituais de consumo alimentar infantil no contexto familiar; as marcas e produtos alimentícios no contexto familiar; e as marcas e produtos alimentícios no contexto das escolhas e preferências das crianças: perspectiva da família (os pais e as crianças).

Diferentes e diversas formas de ritualidade que, em seu conjunto, formatam e possibilitam compreender os processos de mediação entre os contextos e processos cotidianos da recepção infantil de marcas de alimentos, e os modos de presença e mediação comunicacional das marcas na cultura alimentar das crianças em contexto familiar.

Nessa perspectiva, considerando-se as ritualidades e mediações presentes na forma dos processos de escolha compra e consumo de alimentos da família e dos critérios mais importantes na escolha dos alimentos - com atenção aos contextos familiares pesquisados em seus cotidianos - apresentam-se alguns tópicos importantes para interpretação, análise e reflexão, na perspectiva de uma compreensão em nível contextual sobre a mediação das marcas e produtos alimentícios na cultura alimentar das famílias participantes do estudo.

Quanto às compras de alimentos da família, nos três contextos familiares pesquisados as compras costumam ser realizadas em periodicidade mensal e semanal. Em supermercados maiores e atacados, para as compras mensais, e em supermercados menores, para as compras semanais. No caso da primeira família, a mãe é responsável pelas compras de alimentos, e as compras geralmente são realizadas no Supermercado Assaí, Supermercado Extra e Supermercado Jaguaré, além das compras semanais no açougue e na feira. No caso da segunda família, é também a mãe a responsável pelas compras de alimentos, que geralmente acontecem no Supermercado Assaí, Supermercado Carrefour e Supermercado Jaguaré, além das compras semanais no açougue e, raramente, na feira. Já no caso da terceira família, as compras de alimentos ficam a cargo do pai, e as compras geralmente são realizadas no Supermercado Assaí e Supermercado Catanduva, além das compras semanais no mercadinho, na padaria e, eventualmente, na feira (sacolão). Interessante observar que o hábito de fazer compras mensais em supermercados da rede de atacado é comum no contexto das três famílias pesquisadas, 
enquanto as compras semanais na feira acontecem com frequência maior e constante no contexto da primeira família, e com frequência menor e eventual no contexto da segunda e da terceira família.

As perspectivas que inspiram as compras e o consumo de alimentos no âmbito das famílias participantes do estudo são, em essência, as mesmas. O que muda, no entanto, são as prioridades de cada família quanto às escolhas de marcas e produtos, as compras de alimentos e o consumo alimentar.

No contexto da primeira família - onde a escolha, compra e consumo de alimentos fazse inspirada primeiramente em perspectivas de qualidade, saudabilidade, e sensorialidade e prazer, permanecendo em um segundo plano as perspectivas de praticidade e preço - o conjunto das marcas e produtos disponíveis para o consumo alimentar dos pais e das crianças, tanto no ambiente doméstico quanto em espaços públicos, é bastante diversificado, privilegiando a presença de marcas e produtos de melhor qualidade, confiabilidade e preços mais elevados, e em que a maior parte das escolhas de produtos alimentícios ou restaurantes se dá por conta das marcas.

Enquanto no contexto da segunda família - onde a escolha, compra e consumo de alimentos acontece com principal inspiração em perspectivas de preço, praticidade, sensorialidade e prazer, e qualidade, permanecendo em um segundo plano a perspectiva de saudabilidade - o conjunto das marcas e produtos disponíveis para o consumo alimentar dos pais e das crianças, tanto no ambiente doméstico quanto em espaços públicos, é igualmente bastante diversificado, mas privilegiando, no entanto, a presença de marcas e produtos de menor preço, ou melhor custo-benefício, em um comparativo entre preço, praticidade, sensorialidade e qualidade, e em que a maior parte das escolhas de produtos alimentícios ou restaurantes se dá por conta dos preços.

E no contexto da terceira família - onde a escolha, compra e consumo de alimentos se dá igualmente inspirada em perspectivas de preço, praticidade, sensorialidade e prazer, e qualidade, permanecendo em um segundo plano a perspectiva de saudabilidade (como no contexto da segunda família) - o conjunto das marcas e produtos disponíveis para o consumo alimentar dos pais e das crianças, tanto no ambiente doméstico quanto em espaços públicos, é pouco diversificado, privilegiando a presença de marcas e produtos de menor preço, e em que a maior parte das escolhas de produtos alimentícios ou restaurantes, bem como a frequência de consumo, se dá por conta dos preços.

Quanto à presença das crianças nas compras de alimentos da família no supermercado, de acordo com relatos dos pais e das crianças - considerando-se os três contextos familiares 
pesquisados - na maioria das vezes as crianças não acompanham os pais nos momentos das compras. Mas, nas poucas vezes em que estão presentes com os pais no supermercado, as crianças sempre podem escolher algo de que gostam para comprar. E elas sempre escolhem as guloseimas. No entanto, ainda que raramente estejam fisicamente presentes nos momentos das compras, as crianças de algum modo se fazem presentes, quando os pais escolhem e compram determinadas marcas ou produtos alimentícios especialmente por conta dos gostos e preferências das crianças. $\mathrm{O}$ que acontece com frequência nas compras de alimentos no contexto das três famílias participantes do estudo. E no contexto da segunda família, as crianças se fazem ainda mais presentes nas compras de alimentos da família quando participam na elaboração da lista de compras da casa, compondo, juntamente com os pais, a lista de tudo o que necessita ser comprado durante o mês.

E no que tange às perspectivas que inspiram as crianças na escolha das marcas e produtos alimentícios de que mais gostam, tomando-se em atenção as crianças dos três contextos familiares pesquisados, é possível observar que as escolhas infantis são unanimemente inspiradas em perspectivas de sensorialidade e prazer, quando as crianças relatam escolher os produtos de que mais gostam sempre pelo sabor, ou no caso de novas marcas e produtos, pela curiosidade ou vontade de experimentar.

Para conhecimento das principais marcas e produtos alimentícios presentes nos cotidianos da cultura de consumo alimentar das famílias e das crianças participantes do estudo, bem como, das principais marcas e produtos alimentícios presentes no contexto das escolhas e preferências das crianças, apresenta-se em anexo tabelas com registros detalhados da presença material e simbólica das marcas e produtos na cultura alimentar da família e das crianças em cada contexto familiar. (APÊNDICE N; Q; APÊNDICE O; R; APÊNDICE P; S)

Na perspectiva de uma compreensão contextual sobre a mediação das marcas e produtos alimentícios na cultura alimentar das famílias e das crianças participantes do estudo, as interpretações, análises e reflexões propostas sobre os processos de escolha compra e consumo de alimentos das famílias e os critérios mais importantes na escolha dos alimentos para os pais e para as crianças nos contextos familiares pesquisados trazem importantes contribuições para o estudo desenvolvido, na medida em que possibilitam compreender os modos de presença e mediação das marcas e produtos alimentícios na inspiração das perspectivas e composição dos rituais de escolha, compra e consumo alimentar das famílias e das crianças em seus cotidianos.

Tomando-se em atenção as ritualidades e mediações presentes na forma dos usos e consumos infantis dos dispositivos e mídias e do contato das crianças com o universo promocional das marcas e produtos alimentícios - considerando-se o âmbito das famílias 
participantes do estudo - faz-se possível destacar pontos importantes para interpretação, análise e reflexão, no sentido de uma melhor compreensão dos processos de mediação dos dispositivos e mídias e das marcas e produtos nos cotidianos da cultura de consumo alimentar das crianças nos contextos familiares pesquisados.

Os usos e consumos infantis dos dispositivos e mídias no âmbito das famílias participantes do estudo são especialmente marcados pela presença do celular. Citado pelas crianças como sua tela favorita para o acesso à diversas mídias, conteúdos e jogos no seu tempo livre ou momentos de lazer, o celular é muito presente nas rotinas e cotidianos infantis nos três contextos familiares pesquisados. Especialmente para o acesso a vídeos e conteúdos diversos no YouTube - a plataforma mais acessada pelas crianças no celular, de acordo com os relatos das crianças participantes do estudo - e também para jogos de diferentes modalidades em plataformas diversas.

Outras plataformas e redes acessadas pelas crianças no celular, nos contextos familiares pesquisados, principalmente as crianças mais velhas, e conforme relatos das próprias crianças, são o NetFlix, o TikTok, o Instagram, o WhatsApp e o Spotify. Especialmente para o consumo ou produção de vídeos, o acompanhamento de séries, além do consumo de músicas, participação em redes sociais e o contato cotidiano com os amigos.

Somente no caso das crianças menores, especificamente os dois meninos, no contexto da primeira e da segunda família, as crianças preferem o videogame, tablet ou computador ao celular, mas especificamente para o acesso a plataformas de jogos. Uma vez que os dois meninos são apaixonados por jogos e tudo o que se refere ao universo dos games.

Entre os demais dispositivos citados pelas crianças participantes do estudo, como preferências em seus usos e consumos midiáticos no cotidiano, estão a televisão, o tablet, o computador e o videogame. No entanto, especialmente no caso da televisão e do tablet, são quase sempre utilizados pelas crianças para o acesso a conteúdos disponíveis em plataformas online, como o YouTube e o NetFlix, onde as crianças acessam vídeos diversos e acompanham séries, principalmente as crianças mais velhas. Mas há também o consumo cotidiano da programação de televisão entre as crianças - como no caso de alguns canais citados pelas crianças em especial: Cartoon Network, Gloob, Nickelodeon, Disney Channel e Discovery Kids, e especialmente para o consumo de desenhos, séries e filmes - ainda que com menor frequência que o consumo de conteúdos disponíveis em plataformas online. Somente no caso da menina mais nova, no contexto da terceira família, é que o uso do celular e da televisão se dão em um mesmo nível de preferência e consumo. 
Quanto ao acompanhamento e controle dos pais nos usos e consumos infantis dos dispositivos e mídias, no que tange aos cotidianos das crianças nos contextos familiares pesquisados, é possível observar que, de modo geral, os pais se fazem presentes no acompanhamento e controle dos tempos de uso dos dispositivos pelas crianças, quando estabelecem regras com horários específicos e limitação diária ou semanal para os usos e consumos infantis do celular, tablet, televisão, computador ou videogame. Acompanhamento e controle que se fazem presentes no contexto das três famílias participantes do estudo, sendo de um modo mais intenso no contexto da primeira família e de um modo menos intenso no contexto da segunda e da terceira família.

Já quanto aos conteúdos acessados pelas crianças nos dispositivos e mídias, o acompanhamento e controle dos pais se fazem presentes de modo mais intenso no contexto da primeira família, onde os pais se utilizam de filtros específicos para conteúdos infantis nas diferentes plataformas acessadas pelas crianças, além de um acompanhamento constante dos pais quanto aos conteúdos acessados e atividades realizadas pelas crianças nos dispositivos, mídias e plataformas online. Enquanto no contexto da segunda e da terceira família, o acompanhamento e controle dos pais quanto aos conteúdos acessados pelas crianças nos dispositivos e plataformas diversas se dão de modo menos intenso, sem a utilização de filtros específicos para conteúdos infantis, tentando conversar com as crianças e buscando acompanhar os conteúdos acessados e atividades realizadas pelas crianças nos diferentes dispositivos e plataformas.

Partindo do exposto, e como já sinalizado, é importante destacar que os usos e consumos infantis dos dispositivos e mídias se fazem ritualidade e mediação no contexto da cultura de consumo alimentar infantil na medida e que, assim como no caso dos diversos conteúdos acessados pelas crianças nas diferentes plataformas ou canais, os dispositivos e mídias também possibilitam e promovem o acesso das crianças ao universo promocional das marcas e produtos alimentícios infantis, no contato cotidiano das crianças com as marcas, a publicidade, e outros formatos promocionais no mercado de alimentos. Tanto o mercado de alimentos para o consumo alimentar infantil quanto o mercado de alimentos de modo geral.

E nessa perspectiva, considerando-se os três contextos familiares em estudo, é possível observar que as crianças têm contato com o universo promocional das marcas e produtos alimentícios em seus cotidianos, especialmente a partir do acesso a plataformas de conteúdo online e canais de televisão. Ainda que, como já sinalizado, o contato constante das crianças com novas marcas e produtos alimentícios, segundo relatos dos pais e das crianças, se dê mais 
expressivamente na interação cotidiana das crianças com os amigos do que no contato com a publicidade de alimentos.

A partir das investigações desenvolvidas em campo com as crianças em seus contextos familiares, é possível observar que as crianças têm contato com diversas marcas e produtos no universo promocional do mercado de alimentos. Marcas e produtos alimentícios diversos que se fazem mediação constante na cultura alimentar das crianças em contexto familiar.

O contato cotidiano das crianças com as marcas, a publicidade, e outros formatos promocionais no mercado de alimentos, segundo relatos das próprias crianças, se dá principalmente por meio das plataformas online acessadas pelas crianças nos diferentes dispositivos. Principalmente o YouTube - plataforma mais acessada pelas crianças participantes do estudo e na qual elas têm contato constante com o universo promocional de marcas e produtos diversos, incluindo marcas e produtos no mercado de alimentos.

Especialmente no contexto de fastfood (lanches e hambúrgueres), onde as crianças citam com unanimidade as marcas McDonald's e Burger King como as mais presentes no contexto promocional da publicidade de alimentos nas plataformas online às quais elas têm acesso (YouTube e Instagram). A Nutella também é citada por uma das crianças como exemplo de publicidade de alimentos presente nas plataformas online. E os chocolates Twix e KitKat, que são citados pelas crianças como exemplos de marcas com ações promocionais inseridas em conteúdos de canais de youtubers.

E quanto ao contato das crianças com as marcas, a publicidade, e outros formatos promocionais no mercado de alimentos por meio da televisão, nos contextos familiares pesquisados, as crianças relatam com unanimidade que é pouco e eventual o contato que elas têm com a publicidade de alimentos por meio da televisão, especialmente se comparado ao contato cotidiano das crianças com o universo promocional das marcas e produtos alimentícios nas plataformas online. Uma vez que, como destacado, na maior parte do tempo as crianças preferem o celular ou tablet, com acesso às diversas plataformas de conteúdo online, do que a televisão, com sua programação convencional. A única exceção se dá no contexto da terceira família, especialmente no caso da menina mais nova, que gosta muito de televisão, tanto quanto ela gosta do celular. E nesse contexto, os pais citam a marca McDonald's como a principal marca presente no contexto promocional da publicidade de alimentos na televisão.

Quanto aos personagens e mascotes no contexto promocional das marcas e produtos alimentícios, considerando-se os relatos das crianças participantes do estudo, é possível destacar que as crianças não demonstram muito interesse por personagens ou mascotes, ainda que tenham afeto por alguns personagens em especial. E que, na maioria das vezes, a presença 
de personagens ou mascotes nos produtos alimentícios não funcionam para elas como critério de escolha. Elas se dizem escolher sempre pelo sabor, a sensorialidade e prazer, a curiosidade, a vontade de consumir ou experimentar. Especialmente no caso das crianças mais velhas. A única exceção se dá no caso da menina mais nova, no contexto da terceira família. A única criança, no contexto da pesquisa desenvolvida, que demonstra interesse e afeto incondicional por personagens, especialmente aqueles que ela já conhece da televisão ou do cinema. E nesse caso, as escolhas da menina, sempre que possível, são por produtos alimentícios com a presença de personagens ou mascotes.

No contexto das ritualidades e mediações presentes na forma dos usos e consumos infantis dos dispositivos e mídias e do contato das crianças com o universo promocional das marcas e produtos alimentícios, é interessante observar o quanto as crianças fazem uso de uma diversidade de dispositivos, com acesso a diversas mídias, canais e plataformas online. E o quanto as crianças têm contato com as marcas, a publicidade, e outros formatos promocionais no mercado de alimentos em seus cotidianos, especialmente no que tange aos usos e consumos midiáticos infantis, ainda que em menor expressividade que as interações cotidianas das crianças com os amigos. E ainda, o quão presentes se fazem essas mediações nos cotidianos da cultura alimentar das crianças em contexto familiar.

Nessa perspectiva, com atenção aos modos de presença e mediação comunicacional das marcas na cultura alimentar infantil em contexto familiar, especialmente no que tange aos conhecimentos e saberes das crianças sobre os principais conceitos que envolvem o contexto promocional das marcas e produtos alimentícios - como produto, marca, publicidade, embalagem, personagem ou mascote - e ainda os conceitos que envolvem as perspectivas de alimentação-diversão e saudabilidade no âmbito do consumo alimentar infantil, é interessante observar o quanto as crianças conhecem, sabem e são capazes de expressar sobre as marcas e produtos alimentícios presentes nos cotidianos da sua cultura de consumo alimentar.

De modo geral, as crianças participantes do estudo demonstram muitos conhecimentos sobre os conceitos de produto alimentício, marca, publicidade, embalagem, personagem ou mascote, e sabem explicar com clareza as relações e diferenças entre eles. Expressando com objetividade, criatividade e espontaneidade seus saberes infantis sobre o universo promocional das marcas e produtos no contexto do consumo alimentar infantil.

Nessa perspectiva, as crianças explicam produto alimentício, como o alimento que é produzido por uma fábrica ou fabricante. Explicam marca, como o nome do produto, para diferenciá-lo dos demais produtos, e também para identificar o fabricante. Explicam publicidade, como a ação promocional para divulgar o produto, torná-lo mais conhecido, tentar 
convencer ou influenciar os consumidores, e vender mais. E explicam personagem ou mascote, como estratégias das marcas para chamar a atenção das crianças pequenas.

E as crianças citam marcas e produtos alimentícios diversos, presentes no contexto dos seus gostos e preferências infantis e nos cotidianos da sua cultura de consumo alimentar em contexto familiar. Especialmente na categoria de guloseimas (chocolates, salgadinhos, biscoitos, e balas e chicletes); doces e sobremesas (sorvete e gelatina); laticínios (iogurte, iogurte grego, e petit suisse); bebidas (sucos e refrigerantes); e fastfood (hambúrgueres) categorias em que as crianças citam o maior número de marcas e produtos alimentícios e relatam suas principais experiências de consumo alimentar.

Interessante observar, no entanto, que ainda que as crianças tenham certa clareza quanto aos conceitos de marca e produto, elas muitas vezes parecem perceber as marcas como se fossem os produtos em si. Especialmente no caso das guloseimas, onde, por exemplo, cada marca de chocolate citada pelas crianças parece representar para elas o próprio chocolate.

Para conhecimento das principais marcas e produtos alimentícios presentes no contexto das escolhas e preferências infantis e nos cotidianos da cultura de consumo alimentar das crianças participantes do estudo, apresenta-se em anexo tabelas com registros detalhados da presença material e simbólica das marcas e produtos na cultura alimentar das crianças em cada contexto familiar. (APÊNDICE Q; APÊNDICE R; APÊNDICE S)

Quanto aos conceitos de alimentação-diversão e saudabilidade - muito presentes entre as perspectivas que orientam a cultura contemporânea de consumo alimentar infantil - as crianças também demonstram conhecimentos e saberes em suas expressividades infantis. Para as crianças, alimentação-diversão se explica como elementos de prazer e diversão presentes na composição dos produtos alimentícios ou nas experiências de alimentação. E elas citam como principais exemplos os doces e guloseimas, os personagens e mascotes, e o McLanche Feliz do McDonald's. E o conceito de saudabilidade, as crianças explicam como a alimentação que faz bem para a saúde, citando como principais exemplos as frutas, as saladas, e as composições das refeições.

No entanto, para além dos conceitos, as crianças participantes do estudo, em unanimidade, destacam a importância de haver um equilíbrio entre alimentação e diversão. Entre os alimentos e as guloseimas. Entre o que é saudável e o que é divertido e agradável. Priorizando a saudabilidade, mas também a sensorialidade e o prazer no seu consumo alimentar em contexto familiar. As crianças concordam que a sua alimentação deve ser saudável, mas acreditam que comer doces e guloseimas também é essencial, para a alegria e o prazer na alimentação. 
No que tange às ritualidades e mediações presentes na forma dos diversos modos de presença e mediação comunicacional das marcas na cultura alimentar infantil e os rituais de consumo alimentar infantil no contexto familiar; considerando-se as marcas e produtos alimentícios no contexto familiar e as marcas e produtos alimentícios no contexto das escolhas e preferências das crianças na perspectiva da família (os pais e as crianças) - com atenção aos três contextos familiares pesquisados - é possível sinalizar aspectos importantes para interpretação, análise e reflexão, na perspectiva de um conhecimento e compreensão das formas de presença e processos de mediação das marcas e produtos nos cotidianos da cultura de consumo alimentar das crianças no âmbito das famílias participantes do estudo.

Observando-se a presença das marcas e produtos alimentícios nas rotinas, nos hábitos, nas práticas e nos rituais de consumo alimentar das famílias e das crianças em estudo, é interessante notar algumas particularidades e similaridades nos modos de presença e mediação das marcas e produtos na cultura alimentar familiar e, especialmente, na cultura alimentar infantil em contexto familiar.

No café da manhã das três famílias em estudo, apesar das muitas diferenças na composição dos cardápios e formatação dos rituais, é interessante observar a presença marcante do achocolatado em pó com leite para o consumo matinal diário das crianças. No contexto da primeira família, com a marca Toddy; e no contexto da segunda e da terceira família, com a marca Nescau. Nesse sentido, o consumo diário do achocolatado com leite pelas crianças pode ser a representação de uma prática cultural contemporânea para o consumo alimentar infantil em contexto familiar, marcada especialmente pela necessidade de praticidade para a família e sensorialidade e prazer para as crianças.

E é interessante observar ainda que a marca Nescau se faz presente no discurso das crianças das três famílias pesquisadas, ao referenciar o produto achocolatado em pó, ao longo das diversas atividades da pesquisa. Incluindo as crianças da primeira família, onde o consumo do achocolatado em pó se dá com a marca Toddy. O que pode sinalizar uma maior presença midiática e comunicacional da marca Nescau nos cotidianos infantis das crianças participantes do estudo.

Outra presença marcante no café da manhã das famílias pesquisadas, especialmente para o consumo das crianças, é o pão de forma, no caso da primeira família, e o pão de forma e a bisnaguinha, no caso da segunda família. E apesar de as famílias relatarem o consumo de diferentes marcas para os pães, há que se destacar a presença constante da marca Pullman nas citações dos pais e, especialmente, das crianças durante as atividades desenvolvidas ao longo da pesquisa. E no contexto da terceira família, ainda que o consumo diário de pães seja dado na 
forma do pão francês (ou pão de sal), são também expressivas as citações da marca Pullman pela menina mais velha, ao longo das atividades desenvolvidas na pesquisa, ao fazer referência à bisnaguinha como consumo eventual para o café da manhã ou lanchinho. O que, assim como no caso da marca Nescau, pode sinalizar uma presença midiática e comunicacional mais intensa da marca Pullman nos cotidianos das famílias e das crianças participantes do estudo.

Um destaque interessante no contexto do café da manhã das famílias em estudo se dá com a presença, ou ausência, do creme de avelã e cacau. Especialmente com a marca Nutella. Nesse contexto, ainda que a Nutella seja unanimidade entre as preferências das crianças participantes do estudo, tanto o produto quanto a marca Nutella aparecem de modo bastante distinto em cada ambiente familiar pesquisado. No contexto da primeira família, a Nutella aparece como um item cotidiano do café da manhã, disponível para o consumo das crianças (especialmente para a menina que gosta muito de Nutella). E especialmente no café da manhã nos finais de semana. Já no contexto da segunda família, a Nutella aparece com um produto de consumo menos frequente, consumido pelas crianças no lanche da escola (especialmente para a menina que é apaixonada por Nutella). E cujo consumo cotidiano, na maioria das vezes, se dá na forma de marcas similares, como Nutry Cream e Carrefour. Marcas similares que a família consome por questões de limitação de gastos. E que a menina ajuda a escolher ao fazer constantes comparativos de sabor e textura entre Nutella e seus similares. E no contexto da terceira família, possivelmente por questões de limitação financeira familiar, a Nutella aparece como um produto de consumo bastante raro. E que não está assimilado ao café da manhã ou lanche da escola. Aparece como um item de guloseima, quando a menina mais velha, que é apaixonada por Nutella, classifica o produto como um chocolate.

Interessante observar que, independentemente das possibilidades de frequência de consumo, as crianças (especialmente as meninas) das três famílias em estudo destacam o produto e a marca Nutella como uma preferência especial de consumo. O que pode ser a sinalização de uma presença midiática e comunicacional expressiva da marca Nutella nos cotidianos das crianças em estudo, assim como no caso das marcas Nescau e Pullman.

Para o consumo de laticínios, relativamente comum entre as crianças no contexto das três famílias participantes do estudo, destacam-se marcas semelhantes, mas com categorias de produtos diferentes para as crianças de cada família pesquisada. Na primeira família, as crianças costumam consumir com frequência iogurte grego, o preferido delas, especialmente das marcas Danone e Vigor. E também iogurte em garrafinha das marcas Fazenda e Vigor. Tanto a menina quanto o menino gostam muito de iogurte. E o menino gosta inclusive de iogurte natural, como da marca Fazenda, o que não é muito comum no contexto dos gostos e preferências das crianças, 
e nem na caracterização comum do paladar infantil. Na segunda família, as crianças também consomem iogurte, mas com menor frequência. A menina não gosta de iogurte, mas o menino gosta bastante. O menino consome iogurte grego, o preferido dele, especialmente das marcas Danone e Vigor. E também iogurte em bandeja ou garrafinha de marcas diversas, como Danone, Danoninho, Vigor, Elegê. Ele gosta de comer iogurte com cereais (Nescau Ball). Mas há um iogurte em especial, que é consumido pelo menino e também pela menina (o único iogurte que a menina consome) que é um iogurte da marca Vigor (Minions) que vem com cereais e confeitos. As crianças gostam muito. E na terceira família, por sua vez, possivelmente pela limitação financeira familiar, o consumo de iogurte pelas crianças é pouco frequente. Dandose eventualmente na forma de petit suisse das marcas Danoninho e Chambinho, mas especialmente para o consumo da bebê. O que as crianças consomem com mais frequência, ainda que não com a mesma constância que nos demais contextos familiares pesquisados, é o leite fermentado, especialmente das marcas Vigor (Minions) e Elegê (Bob Esponja). Porque a menina mais nova gosta muito do produto e também dos personagens.

Interessante notar que Danone e Vigor são as marcas mais citadas pelas crianças ao longo das atividades da pesquisa, no contexto das três famílias em estudo, mas especialmente no contexto da primeira e da segunda família, ao referenciar o produto iogurte. E fazendo referência especial ao iogurte grego. O que pode denotar a sinalização de uma maior presença midiática e comunicacional das marcas Danone e Vigor, especialmente na categoria do iogurte grego, nos cotidianos infantis das famílias pesquisadas. Como no caso das marcas Nescau, Pullman e Nutella.

Nos três contextos familiares pesquisados, de modo geral, no almoço e no jantar, as crianças se alimentam fazendo refeições. Mas às vezes, nos finais de semana, ou quando não há tempo para o preparo das refeições, há o preparo de lanches ou alimentos instantâneos para as crianças, como sanduíche, cachorro-quente, hambúrguer, nuggets, ou macarrão instantâneo.

Nessa perspectiva, presença marcante a se observar, no âmbito das três famílias pesquisadas, é o macarrão instantâneo para o consumo alimentar das crianças. Especialmente no jantar, nos finais de semana, quando não há tempo para preparar uma refeição ou lanche mais elaborado. Sendo que, no contexto da primeira família, o consumo de macarrão instantâneo pelas crianças se dá de modo mais eventual, e especialmente com a marca Miojo (Turma da Mônica). Enquanto no contexto da segunda e da terceira família, o consumo de macarrão instantâneo pelas crianças se dá com mais constância. Na segunda família, com marcas diversas: Miojo, Miojo (Turma da Mônica), Qualitá, Predilecta, Carrefour, Renata. E na terceira família, com as marcas Miojo e Miojo (Turma da Mônica). E nesse sentido, o 
consumo de macarrão instantâneo pelas crianças pode ser igualmente a representação de uma prática cultural contemporânea para o consumo alimentar infantil em contexto familiar, marcado especialmente pela necessidade de praticidade para a família e sensorialidade e prazer para as crianças.

Interessante observar ainda que a marca Miojo tem presença com destaque entre as citações das crianças para fazer referência ao macarrão instantâneo durante as atividades da pesquisa, nos três contextos familiares em estudo. O que, mais uma vez, pode ser a sinalização de uma maior presença midiática e comunicacional da marca Miojo nos cotidianos das crianças participantes do estudo. Como no caso das marcas Nescau, Pullman, Nutella, Danone e Vigor.

Quanto à presença dos lanches para o consumo alimentar das crianças no âmbito das famílias em estudo, geralmente nos finais de semana, no jantar, quando não há tempo para o preparo das refeições, vale destacar a preferência especial das crianças pelo cachorro-quente e pelo hambúrguer, independentemente da frequência com que tais alimentos sejam oferecidos a elas em seus contextos familiares. Sendo um consumo menos comum no contexto da primeira família, e mais assíduo no contexto da segunda e da terceira família.

Nesse sentido, faz-se interessante observar o quanto as crianças destacam suas preferências por produtos como salsicha e hambúrguer em seus relatos durante as atividades da pesquisa, no contexto das três famílias participantes do estudo, destacando especialmente as marcas Sadia e Seara em suas citações, ainda que nem sempre as famílias tenham por hábito o consumo exclusivo ou constante de tais marcas. Como no caso da segunda família, que consome marcas diversas: Kidelli, Frimesa, Aurora, Lar, Sadia. Ou no caso da terceira família, que também consome marcas diversas: Perdigão, Aurora, Seara. O que, também aqui, pode indicar a sinalização de uma presença midiática mais intensa das marcas Sadia e Seara nos cotidianos infantis no contexto das famílias pesquisadas, como no caso das marcas Nescau, Pullman, Nutella, Danone, Vigor e Miojo.

Vale destacar ainda, no contexto dos lanches, o consumo de produtos para acompanhamento ou tempero, como no caso da maionese, do ketchup e da mostarda, também bastante consumidos pelas crianças, nos três contextos familiares pesquisados, principalmente a maionese e o ketchup. E nessa categoria de produtos, é possível observar que as famílias consomem marcas bastante distintas, com exceção da maionese Hellmann's, presente nos três contextos familiares pesquisados. No contexto da primeira família, com a presença das marcas Hellmann's e Heinz. No contexto da segunda família, com a presença das marcas Hellmann's, Kraft, Heinz, Ekma e Quero. E no contexto da terceira família, com a presença das marcas Hellmann's, Kissabor, Farri e Predilecta. 
Para os lanchinhos preparados com frequência para as crianças, especialmente nos finais de semana, considerando-se os três ambientes familiares em estudo, vale destacar a presença marcante da pipoca. Tanto o milho para pipoca, presente nos três contextos familiares, quanto a pipoca de micro-ondas, presente no contexto da primeira família (na forma de pipoca salgada e pipoca doce) e no contexto da segunda família (na forma de pipoca salgada saborizada), sendo que nos três contextos familiares é unânime a presença da marca Yoki.

Outra presença marcante no lanchinho das crianças, nos três ambientes familiares pesquisados, é o pão de queijo. No contexto da primeira família, com a marca Forno de Minas. No contexto da segunda família, com as marcas Estrela Mineira e Duduxo. E no contexto da terceira família, com a marca Seara (Turma da Mônica).

Interessante destacar a constante presença da marca Yoki no contexto das três famílias participantes do estudo, em diversas categorias de produtos. O que pode denotar a sinalização de uma maior presença midiática e comunicacional da marca Yoki, além de estratégias promocionais da marca, nos cotidianos das famílias, em diferentes contextos socioeconômicos.

Para o acompanhamento das refeições ou lanches no almoço e no jantar, no contexto das três famílias pesquisadas, é possível observar a presença diária do suco. As crianças gostam muito de suco e fazem questão do suco para o acompanhamento de todas as refeições. No caso da primeira família, o suco é quase sempre natural, feito com frutas. E nas poucas vezes em que o suco é industrializado, é quase sempre um suco integral, especialmente das marcas Prat's, Natural One, Aurora e Casa de Bento, ou suco em caixa da marca Fazenda. No contexto da segunda e da terceira família, no entanto, quase não há a presença do suco natural de frutas. Onde o consumo diário de suco pelas crianças é intensamente marcado pela presença do suco em pó. Especialmente das marcas Tang, Mid, Fit e Clight (no caso da segunda família) e das marcas Tang e Mid (no caso da terceira família). E no caso da segunda família, nas poucas vezes em que as crianças não consomem o suco em pó, há o suco de soja com frutas em caixa da marca SuFresh (Soyos), ou ainda, mas raramente, o suco integral da marca Prat's. E nessa perspectiva, o consumo diário do suco pelas crianças para o acompanhamento das refeições pode ser também a representação de uma prática cultural contemporânea para o consumo alimentar infantil em contexto familiar. E, no caso do suco em pó, assim como no caso do achocolatado em pó e do macarrão instantâneo, pode se tratar de um consumo marcado especialmente pela necessidade de praticidade para a família e sensorialidade e prazer para as crianças.

Destaque especial para a marca Tang, que se faz bastante presente nas citações das crianças ao longo das atividades desenvolvidas na pesquisa, para fazer referência ao suco para 
o acompanhamento das refeições e lanches. Incluindo as crianças da primeira família, onde não há o consumo de suco em pó pelas crianças. O que pode sinalizar uma presença midiática e comunicacional mais expressiva da marca Tang nos cotidianos das crianças nos contextos familiares pesquisados. Como no caso das marcas Nescau, Pullman, Nutella, Danone, Vigor, Miojo, Sadia, Seara, Hellmann's e Yoki.

Quanto à presença de refrigerantes no contexto das famílias participantes do estudo, vale observar que os refrigerantes estão presentes para o consumo dos pais e das crianças no âmbito das três famílias pesquisadas, embora em quantidade, diversidade e frequência de consumo diferentes. No primeiro contexto familiar, o refrigerante está presente somente às vezes, nos finais de semana, para o consumo dos pais e das crianças, especialmente do menino. E com marcas específicas: Coca-Cola, Pepsi, Fanta, Antarctica, Kuat, Guaraná Jesus. Enquanto no segundo contexto familiar, a presença do refrigerante é quase diária, especialmente para o consumo da mãe, mas também para as crianças, especialmente o menino. A marca é sempre Coca-Cola. Mas o menino também gosta de refrigerantes de outras marcas, além da Coca-Cola: Pepsi, Sprite, Fanta, Antarctica, Kuat, Schweppes. E no contexto da terceira família, também há a presença constante do refrigerante para o consumo dos pais e das crianças, mas a constância do consumo depende da disponibilidade ou limitação financeira da família, além de uma certa preocupação dos pais com a saudabilidade, especialmente no caso das crianças. A marca é sempre Coca-Cola ou Itubaína. Mas a menina mais velha também gosta do refrigerante da marca Fanta.

Interessante observar que algumas crianças relatam não gostar muito de refrigerante, como as meninas da primeira e da segunda família. Elas preferem suco ou água para o acompanhamento das refeições. Mas costumam beber refrigerante quando comem lanches. $\mathrm{O}$ que pode ser a representação de uma prática cultural contemporânea, ou mesmo de um estilo de vida e de consumo para as crianças e jovens no universo fastfood, onde há sempre o acompanhamento de um refrigerante para o lanche.

Interessante observar também que as marcas Coca-Cola e Fanta estão presentes nas citações das crianças ao logo de todas as atividades da pesquisa ao referenciarem o produto refrigerante na categoria refrigerante favorito. Incluindo as crianças que não gostam muito de refrigerante (as meninas da primeira e da segunda família). O que pode, mais uma vez, representar a sinalização de uma presença midiática intensa das marcas Coca-Cola e Fanta nos cotidianos das crianças participantes do estudo. Como no caso das marcas Nescau, Pullman, Nutella, Danone, Vigor, Miojo, Sadia, Seara, Hellmann's, Yoki e Tang. 
A presença de doces e sobremesas também é bastante marcante no contexto das famílias participantes do estudo. Especialmente nos finais de semana, e para o consumo das crianças. Embora os pais também acompanhem as crianças no consumo de doces e sobremesas.

Nessa perspectiva, o sorvete parece unanimidade, entre as preferências das crianças e dos pais, no consumo de doces e sobremesas, considerando-se os três ambientes familiares pesquisados. Tanto no contexto das refeições feitas em casa, quanto fora de casa. No caso da primeira família, o sorvete aparece especialmente com a marca Kibon, para o consumo em ambiente doméstico, e com as marcas Bacio di Latte e McDonald's, para o consumo em espaços públicos. No contexto da segunda família, o sorvete aparece com marcas diversas: Kibon, Oggi, Carrefour. Mas somente para o consumo em ambiente doméstico, pois a família não tem o hábito de sair com as crianças para refeições ou lanches fora de casa. E no contexto da terceira família, o sorvete raramente se faz presente para o consumo da família e das crianças em ambiente doméstico. E nas raras vezes em que compram sorvete, é com marcas diversas. $\mathrm{O}$ sorvete do McDonald's, no entanto, está bastante presente no contexto da família quando fazem lanche com as crianças nas lanchonetes da rede McDonald's.

Importante destacar que o sorvete do McDonald's, em suas diversas linhas e sabores, é preferência unânime entre as crianças participantes do estudo, nos três contextos familiares pesquisados. Sendo que a marca McDonald's é citada por todas as crianças em diversos momentos ao longo das atividades desenvolvidas na pesquisa. O que com certeza sinaliza a intensa e expressiva presença midiática e comunicacional da marca McDonald's nos cotidianos infantis, nos diferentes contextos socioeconômicos. Mas caracteriza também a representação de uma prática cultural contemporânea, um estilo de vida e de consumo para as crianças e jovens no universo fastfood.

Sobre a presença das guloseimas, no contexto das famílias participantes do estudo, há maior controle no consumo de guloseimas para as crianças durante a semana, onde as crianças não podem comer guloseimas nos dias de semana, como no contexto da primeira família, ou somente podem comer guloseimas nos dias de semana com moderação, como no contexto da segunda e da terceira família. Nos finais de semana, no entanto, nos três contextos familiares pesquisados, as crianças têm mais liberdade para o consumo de guloseimas, e ficam mais livres para comer o que mais gostam.

As marcas e produtos para o consumo de guloseimas são bastante diversificados em cada contexto familiar, dependendo do perfil de consumo da família, dos gostos e preferências das crianças, e da disponibilidade financeira familiar. Interessante notar, no entanto, que apesar das diferenças marcantes no perfil de consumo das famílias em estudo, algumas semelhanças 
se mantém na escolha de marcas e produtos pelas crianças para o consumo de guloseimas, assim como algumas marcas e produtos se apresentam como singularidades do consumo infantil de guloseimas em cada contexto familiar.

E nessa perspectiva, considerando-se tanto a presença material quanto simbólica das marcas no universo infantil do consumo de guloseimas, nos diferentes contextos familiares pesquisados, é possível destacar diversas marcas citadas pelas crianças em categorias especificas de guloseimas. Dentre as quais, faz-se interessante destacar as categorias chocolate, balas e chicletes, cookie wafer e biscoito doce recheado, e salgadinhos.

Os chocolates representam a categoria de guloseimas com a maior quantidade e diversidade de citações de marcas pelas crianças ao longo das atividades da pesquisa. Nesse contexto, quanto às similaridades de marcas e produtos no consumo infantil de chocolates, é interessante destacar as marcas Kinder Ovo, KitKat, Twix, Bis, Tortuguita, Hershey's, Lacta, bastante presentes nas citações de consumo das crianças nos três contextos familiares pesquisados; E também as marcas Milka, Laka, Diamante Negro e Baton, presentes nas citações de consumo das crianças no contexto da primeira e da segunda família; E a marca Nestlé, presente nas citações de consumo das crianças no contexto da primeira e da terceira família. Faz-se interessante destacar também, no entanto, algumas singularidades de cada família no consumo infantil de chocolates. Como as marcas Lindt, Kopenhagen, Kinder Bueno, Garoto, Alpino, Sensação, It Coco, presentes somente nas citações de consumo das crianças no contexto da primeira família; As marcas Kinder, Arcor, Top Cau, Glauci, Chokito, Sonho de Valsa, presentes somente nas citações de consumo das crianças no contexto da segunda família; E as marcas Lollo e Nutella, presentes somente nas citações de consumo das crianças no contexto da terceira família.

As balas e chicletes representam também uma categoria de guloseimas com diversidade de citações de marcas pelas crianças durante as atividades da pesquisa. Nesse contexto, considerando-se as similaridades de marcas e produtos no consumo infantil de balas e chicletes, vale destaque especial para as marcas M\&M's, Fini e 7 Belo, bastante presentes nas citações de consumo das crianças nos três contextos familiares pesquisados. E tomando-se em atenção as singularidades de marcas e produtos no consumo de balas e chicletes por parte das crianças em cada contexto familiar, é interessante destacar as marcas Fazendinha Rio Pardo e Tachão (bananinha sem açúcar), presentes somente nas citações de consumo das crianças no contexto da primeira família; A marca Dadinho (caramelo), presente somente nas citações de consumo das crianças no contexto da segunda família; E a marca Cherry Pop (pirulito), presente somente nas citações de consumo das crianças no contexto da terceira família. 
Outra categoria de guloseimas com diversidade de citações de marcas pelas crianças ao longo das atividades da pesquisa é a de cookie wafer e biscoito doce recheado. Nesse contexto, com referência às similaridades de marcas e produtos no consumo das crianças em tal categoria de guloseimas, vale destacar especialmente as marcas Bauducco e Passa Tempo, muito presentes nas citações de consumo das crianças nos três contextos familiares pesquisados; E a marca Oreo, presente nas citações de consumo das crianças no contexto da primeira e da segunda família. E quanto às singularidades de marcas e produtos no consumo infantil de cookie wafer e biscoito doce recheado, no contexto de cada família pesquisada, é interessante destacar a marca Bono, presente somente nas citações de consumo das crianças no contexto da primeira família; As marcas Coala, Tortuguita e Amandita, presentes somente nas citações de consumo das crianças no contexto da segunda família; E as marcas Moça e Adria (Minions), presentes somente nas citações de consumo das crianças no contexto da terceira família.

E finalmente, os salgadinhos, que representam uma categoria de guloseimas com expressiva quantidade e diversidade de citações de marcas pelas crianças durante as atividades da pesquisa. Nesse contexto, tomando-se as similaridades de marcas e produtos no consumo de salgadinhos pelas crianças, vale destaque especial para a marca Cheetos, com presença marcante entre as citações de consumo das crianças nos três contextos familiares pesquisados; As marcas Doritos e Cebolitos, bastante presentes nas citações de consumo das crianças no contexto da primeira e da segunda família; E a marca Ruffles, muito presente nas citações de consumo das crianças no contexto da segunda e da terceira família. E com atenção às singularidades de marcas e produtos no consumo infantil de salgadinhos em cada contexto familiar, é interessante destacar as marcas Pringles, Lays, Mãe Terra (Ceboloko) e EQlibri, presentes somente nas citações de consumo das crianças no contexto da primeira família; E a marca Fofura, presente somente nas citações de consumo das crianças no contexto da segunda família.

Considerando-se o contexto das guloseimas em seu todo, seria interessante destacar algumas marcas em especial. As marcas com presença mais expressiva nas citações das crianças durante a pesquisa desenvolvida nos três contextos familiares. E nesse sentido, partindo das categorias de guloseimas apresentadas, vale destaque especial para as marcas Kinder Ovo, KitKat, e Twix (na categoria chocolate); As marcas M\&M's e Fini (na categoria balas e chicletes); A marca Bauducco (na categoria cookie wafer e biscoito doce recheado); E a marca Cheetos (na categoria salgadinhos). Marcas muito presentes nas citações das crianças para o consumo de guloseimas ao longo das atividades da pesquisa, o que pode sinalizar uma presença 
midiática e comunicacional mais intensa das marcas Kinder Ovo, KitKat, Twix, M\&M's, Fini, Bauducco e Cheetos nos cotidianos das crianças nos diferentes contextos familiares em estudo.

No contexto do lanche da escola, as composições de marcas e produtos alimentícios são bastante distintas, considerando-se as crianças dos três ambientes familiares pesquisados. Para as crianças da primeira família, o lanche da escola é composto por produtos integrais, naturais, ou com menor composição de sódio, açúcar e gorduras. Especialmente das marcas Mãe Terra, Mãe Terra (Ceboloko), EQlibri, Camil, Cassini, Panco, Mabel, Shelly Senbei, Lianyougang (Okazu Noi), Fazenda, Maguary, Do Bem, Danone, Vigor. Enquanto para as crianças da segunda família, o lanche da escola é composto por guloseimas e lanchinhos, sem tanta preocupação ou controle quanto à saudabilidade dos alimentos. E se compõe de marcas diversas como: Pullman, Pullman (Bisnaguito), WickBold, WickBold (Scooby Doo), Seven Boys, Panco, Danone, Tirolez, Seara (Turma da Mônica), Sadia, Polenguinho, Polenghi, Nutella, Nutry Cream, Carrefour, Ades, Yoki, Ana Maria, Bauducco, Santa Edwiges, Oreo, Passa Tempo, Tortuguita, Hershey's, Cheetos, Cebolitos, Doritos, Rufles, Fofura, Coca-Cola, Pepsi, Sprite, Fanta, Antarctica, Kuat, Schweppes. E no contexto da terceira família, no caso da menina mais velha, o lanche da escola é fornecido pela escola para as crianças, e é composto por sanduíche natural (integral), biscoito doce, frutas e suco em caixinha. Com marcas diversas como: Bauducco, Ades, SuFresh, entre outras.

Sobre as refeições e lanches com as crianças fora de casa, independentemente da frequência com que cada família costuma sair de casa com as crianças para refeições ou lanches, é interessante observar algumas semelhanças e diferenças, entre os contextos familiares pesquisados, quanto às marcas que caracterizam tais experiências de consumo alimentar das famílias e das crianças em espaço público.

Na perspectiva das semelhanças ou coincidências de consumo, vale destaque expressivo para a marca McDonald's, presente no contexto do consumo alimentar das crianças em espaço público no âmbito das três famílias pesquisadas. Com menor frequência no contexto da primeira família; com frequência rara no contexto da segunda família; com frequência maior no contexto da terceira família. No entanto, independentemente da constância de consumo, a marca McDonald's aparece com muito destaque no discurso das crianças ao fazerem citações sobre hambúrguer e sorvete ao longo das atividades da pesquisa. As crianças parecem apaixonadas pela marca! Apaixonadas pelo hambúrguer, pelo sorvete, pela marca, e por tudo o que caracteriza o universo McDonald's! E como já sinalizado, isso pode representar, a um só tempo: uma prática cultural contemporânea para o consumo alimentar das crianças com base em um estilo de vida e de consumo formatado a partir da linguagem juvenil contemporânea do universo 
fastfood; e a sinalização de uma presença expressiva da marca McDonald's nos cotidianos infantis em âmbito familiar nos diferentes contextos socioeconômicos.

Tal fato acontece também com a marca Burguer King, igualmente presente nas citações das crianças durante a pesquisa, nos três contextos familiares pesquisados, mas é claro, no entanto, que com menor assiduidade e intensidade bem menor, figurando como uma espécie de segunda opção das crianças para o consumo de hambúrguer na categoria fastfood.

E na perspectiva das diferenças ou singularidades de consumo, vale destacar algumas marcas em especial, como Restaurante Rascal, Restaurante América, e Sorveteria Bacio di Latte (caracterizando as principais experiências de consumo alimentar em espaço público da família e das crianças no primeiro contexto familiar pesquisado); e como Pastelaria Yoka e Restaurante Habib's (caracterizando as principais experiências de consumo alimentar em espaço público ou em delivery da família e das crianças no segundo contexto familiar pesquisado). No contexto da terceira família participante do estudo, os pais e as crianças frequentam somente o McDonald's para as suas experiências de consumo alimentar em espaço público.

Nessa perspectiva, as interpretações, análises e reflexões propostas sobre os modos de presença das marcas e produtos alimentícios nas rotinas, nos hábitos, nas práticas e nos rituais de consumo alimentar das famílias e das crianças nos contextos familiares pesquisados possibilitam compreender algumas das principais singularidades e similaridades que marcam os processos de mediação comunicacional das marcas e produtos na cultura alimentar familiar e na cultura alimentar infantil em contexto familiar.

Presença e mediação das marcas e produtos na cultura alimentar infantil que se faz marcada tanto na forma de presença material (marcas e produtos alimentícios no contexto familiar) quanto simbólica (marcas e produtos alimentícios no contexto das escolhas e preferências da família e das crianças). Tomando-se, nos contextos familiares pesquisados, a cultura alimentar das famílias e, especialmente, a cultura alimentar das crianças em contexto familiar; tanto em ambiente doméstico quanto em espaços públicos; a partir dos relatos, observações, cotações e expressividades das crianças e dos pais no processo de investigação.

Para conhecimento das principais marcas e produtos alimentícios presentes no contexto das escolhas e preferências infantis e nos cotidianos da cultura de consumo alimentar das crianças participantes do estudo, como já sinalizado, apresenta-se em anexo tabelas com registros detalhados da presença material e simbólica das marcas e produtos na cultura alimentar das crianças em cada contexto familiar. (APÊNDICE Q; APÊNDICE R; APÊNDICE S) 
E igualmente em anexo, apresenta-se transcrição completa dos dados, informações, atividades, eventos e situações observados em campo com as famílias e com as crianças no processo de investigação, referentes às ritualidades e mediações presentes nos processos de mediação entre a recepção infantil de marcas de alimentos e a mediação comunicacional das marcas na cultura alimentar infantil. - Vide Parte I:2.1-2.5; Parte II:2.1-2.5; Parte III:2.1-2.5) ${ }^{6}$

\section{Recepção Infantil de Marcas de Alimentos e Perspectivas das Crianças}

A recepção infantil de marcas de alimentos - tomada no contexto deste estudo enquanto os diversos processos socioculturais a partir dos quais as crianças têm contato com marcas e produtos alimentícios nos cotidianos da sua cultura de consumo alimentar em contexto familiar - coloca-se no mapa proposto sobre a mediação comunicacional das marcas na cultura alimentar infantil na perspectiva das mediações comunicativas da cultura (MARTIN-BARBERO, 2009) como um processo complexo que se compõe a partir das diversas formas de socialidade e ritualidade dadas na mediação entre as competências de recepção ou consumo das crianças e as matrizes culturais em sua cultura cotidiana de consumo alimentar infantil em contexto familiar, e entre as competências de recepção ou consumo das crianças e os formatos industriais e promocionais nos modos de presença e mediação comunicacional das marcas e produtos alimentícios na cultura alimentar infantil.

Nessa perspectiva, com atenção aos contextos familiares pesquisados, é possível observar que os processos de recepção infantil de marcas de alimentos e de consumo alimentar das crianças participantes do estudo são especialmente marcados pelas diversas mediações presentes na cultura alimentar familiar e na cultura alimentar infantil em contexto familiar, bem como, pelos diferentes e diversos modos de presença e mediação comunicacional das marcas na cultura alimentar das crianças em seus cotidianos.

Tais processos de recepção e consumo, no entanto, são igualmente marcados pelas singularidades que caracterizam as perspectivas infantis sobre sua cultura alimentar e sobre as marcas e produtos alimentícios presentes em seu âmbito familiar e no contexto dos seus gostos e preferências infantis para o consumo alimentar.

O reconhecimento da importância e valor das perspectivas infantis sobre as experiências e processos que caracterizam os cotidianos das crianças é essencial para que seja possível compreender tais experiências e processos que marcam as vivências da infância no mundo

\footnotetext{
${ }^{6}$ O conteúdo disponibilizado em link temporário para avaliação da Banca Examinadora encontra-se disponível em pen-drive na versão da Tese para a Biblioteca da ECA/USP.
} 
contemporâneo. E dentre tais vivências e experiências, destaca-se a cultura cotidiana de consumo alimentar das crianças em contexto familiar.

Perspectiva que orientou o desenvolvimentos deste estudo em seu todo, especialmente no processo de investigação desenvolvido com as crianças em campo, em seus contextos familiares. Não somente no sentido de uma percepção, reconhecimento e valorização das perspectivas infantis, mas no reconhecimento de uma legitima cidadania e participação ativa das crianças na cultura e sociedade e, por extensão, em qualquer processo de investigação sobre crianças e infâncias na contemporaneidade.

Para que seja possível compreender os processos de recepção infantil de marcas de alimentos, bem como, os cotidianos do consumo alimentar das crianças em contexto familiar, as perspectivas infantis e a participação ativa das crianças se fazem essenciais nos processos de investigação. Como fizeram-se essenciais as perspectivas infantis e a participação ativa das crianças no contexto deste estudo. Tanto nas atividades desenvolvidas em campo com as famílias (os pais e as crianças), quanto nas atividades lúdicas desenvolvidas exclusivamente com as crianças, as perspectivas, a participação e as vozes infantis estiveram sempre presentes. Nos diversos temas abordados, contextos explorados, informações e dados coletados, experiências vivenciadas, reflexões propostas e conhecimentos elaborados.

A presença, a participação e a voz das crianças foram marcantes em todos os momentos e atividades no processo de investigação. Em que as perspectivas infantis se tornaram parte essencial na construção de um conhecimento e compreensão dos diversos modos de presença e mediação comunicacional das marcas na cultura alimentar infantil.

E nessa perspectiva, para complementação e conclusão do estudo desenvolvido sobre a mediação comunicacional das marcas na cultura alimentar infantil - com atenção aos processos de recepção infantil de marcas de alimentos e ao consumo alimentar das crianças nos contextos familiares pesquisados - propõe-se a apresentação e exploração das perspectivas das crianças participantes do estudo no contexto dos principais temas abordados, atividades desenvolvidas e experiências vivenciadas em campo no processo de investigação, na construção de conhecimentos e saberes que somente se fizeram possíveis com a presença, a participação e as vozes infantis. Proposta que será apresentada e explorada no capítulo seguinte, no momento da abordagem sobre a experiência de um estudo de inspiração etnográfica desenvolvido com crianças no campo da comunicação. 


\section{Reflexões Sobre a Mediação Comunicacional das Marcas na Cultura Contemporânea de Consumo Alimentar Infantil}

As interpretações, análises e reflexões propostas sobre os processos de recepção infantil de marcas de alimentos em sua relação com a cultura alimentar das crianças em contexto familiar e com a presença e mediação das marcas e produtos alimentícios no âmbito familiar, tomando-se em atenção os contextos familiares pesquisados e as crianças participantes do estudo, possibilitam um melhor conhecimento e compreensão da temática em estudo no processo de investigação, sobre a mediação comunicacional das marcas na cultura contemporânea de consumo alimentar das crianças.

A proposição de um mapa para o estudo da mediação comunicacional das marcas na cultura alimentar infantil na perspectiva das mediações comunicativas da cultura (MARTINBARBERO, 2009), tornou possível a orientação e desenvolvimento das interpretações e análises dos dados e avaliação dos resultados da pesquisa - no enfoque dos eixos de abordagem sugeridos para orientação da investigação - em uma perspectiva da cultura compreendida a partir da comunicação.

Nessa perspectiva, os diferentes e diversos modos de presença e mediação comunicacional das marcas e produtos alimentícios se fazem contínua e consideravelmente presentes nos cotidianos da cultura alimentar infantil em contexto familiar, em combinação com diversas outras mediações culturais e comunicacionais presentes na modulação do consumo alimentar das crianças. E os processos de recepção infantil de marcas de alimentos, bem como, os vínculos de sentidos que se estabelecem entre as marcas/produtos e as crianças, se compõem na mediação entre as perspectivas infantis e agências das crianças, em suas competências de recepção e consumo, e a cultura alimentar infantil em contexto familiar, e a mediação comunicacional das marcas na cultura alimentar infantil, considerando-se as diversas formas de socialidade e ritualidade que caracterizam tais processos de mediação.

Perspectivas e conhecimentos sobre a presença e mediação comunicacional das marcas e produtos alimentícios na cultura alimentar das crianças e os processos de recepção infantil de marcas de alimentos que trazem à luz reflexões e respostas à problemática proposta neste estudo, ao encontro dos pressupostos iniciais de investigação.

Nesse complexo contexto de mediações que caracteriza a cultura contemporânea de consumo alimentar das crianças - com atenção aos eixos de abordagem sugeridos para orientação da investigação, presentes no mapa proposto para o estudo da mediação comunicacional das marcas na cultura alimentar infantil na perspectiva da cultura 
compreendida a partir da comunicação - faz-se interessante destacar alguns aspectos conclusivos para reflexão e consolidação do estudo desenvolvido.

A cultura alimentar infantil contemporânea apresenta-se notadamente marcada pelas diversas mediações culturais e comunicacionais presentes na modulação do consumo alimentar das crianças em contexto familiar. Especialmente a presença e mediação dos pais e interação das crianças com os irmãos, a interação cotidiana das crianças com os amigos, o contato das crianças com o universo promocional das marcas e produtos alimentícios, e a classificação socioeconômica familiar.

A presença e mediação dos pais e dos irmãos, as interações das crianças com os amigos, e a classificação socioeconômica familiar constituem as principais formas de mediação que, em combinação com a importante mediação do contato das crianças com o universo promocional das marcas e produtos alimentícios em seus cotidianos, marcam e modulam a cultura de consumo alimentar infantil em contexto familiar.

Os diversos modos de presença e mediação comunicacional das marcas no contexto familiar participam e contribuem nos processos de construção da cultura contemporânea de consumo alimentar das crianças. Ainda que a presença e mediação comunicacional das marcas e produtos alimentícios tomem diferentes formas nos cotidianos infantis da cultura alimentar, para além dos formatos tradicionais da publicidade ou ainda para além da própria publicidade.

Presença e mediação comunicacional das marcas e produtos alimentícios materializada, cada vez mais expressivamente, em diferentes e diversos formatos, especialmente no contato cotidiano das crianças com o universo promocional de marcas e produtos nas plataformas online, em seus usos e consumos infantis dos dispositivos e mídias e da internet.

Os processos de recepção infantil de marcas de alimentos se compõem na mediação entre a cultura alimentar das crianças em contexto familiar e a presença e mediação comunicacional das marcas na cultura alimentar infantil. Em um contexto especialmente marcado pelas perspectivas e agências infantis, em suas competências de recepção e consumo, e pelos vínculos de sentidos que se estabelecem entre as marcas/produtos e as crianças.

Perspectivas e agências infantis que dão singularidade, forma e cor aos processos de recepção infantil de marcas de alimentos e aos vínculos de sentidos criados entre marcas/produtos e crianças nos diferentes e diversos cotidianos da cultura alimentar infantil em contexto familiar.

No que tange à importância e valor das perspectivas infantis, como destacado anteriormente, para melhor compreender os processos de recepção infantil de marcas de alimentos e os cotidianos do consumo alimentar das crianças em contexto familiar, faz-se 
essencial que a presença, participação ativa e voz das crianças tomem parte no processo de investigação. E nesse sentido, como igualmente já sinalizado, em uma perspectiva de complementação e conclusão para este estudo desenvolvido sobre a mediação comunicacional das marcas na cultura alimentar infantil, atentando para os processos de recepção infantil de marcas de alimentos e o consumo alimentar das crianças nos contextos familiares pesquisados, propõe-se a extensão e complementação das reflexões aqui propostas para o capítulo seguinte, dedicado à abordagem sobre a experiência de um estudo de inspiração etnográfica desenvolvido com crianças no campo da comunicação. Em que as perspectivas das crianças participantes do estudo se fizeram presentes em todo o processo de investigação, para a construção de conhecimentos e saberes que não seriam possíveis sem a presença, a participação e as vozes infantis. 
TERCEIRO CAPÍTULO

RECEPÇÃO INFANTIL E PERSPECTIVAS DAS CRIANÇAS: UM ESTUDO DE INSPIRAÇÃO ETNOGRÁFICA COM CRIANÇAS EM COMUNICAÇÃO 
O terceiro e último capítulo deste estudo é dedicado a uma abordagem sobre esta investigação: a experiência de um estudo de inspiração etnográfica desenvolvido com crianças no campo da comunicação. E com especial atenção às perspectivas infantis e agências das crianças nos processos de recepção infantil de marcas de alimentos e de consumo alimentar das crianças nos contextos familiares pesquisados. Na perspectiva de uma complementação, enriquecimento e conclusão para o estudo desenvolvido sobre a mediação comunicacional das marcas na cultura contemporânea de consumo alimentar infantil, e de uma construção de conhecimentos e saberes a partir da presença, da participação e das vozes infantis no processo de investigação.

Tanto quanto os processos de recepção infantil de marcas de alimentos e de consumo alimentar das crianças - tomando-se em atenção os contextos familiares pesquisados e as crianças participantes do estudo - sejam marcados pelas diversas mediações presentes na cultura alimentar familiar e na cultura alimentar infantil em contexto familiar, bem como, pelos diferentes e diversos modos de presença e mediação comunicacional das marcas na cultura alimentar das crianças, eles se fazem igualmente marcados pelas singularidades e subjetividades que caracterizam as perspectivas infantis sobre sua cultura alimentar e sobre as marcas e produtos alimentícios em seu âmbito familiar e no contexto dos seus gostos e preferências infantis para o consumo alimentar.

Nesse sentido, para melhor compreender os processos de recepção infantil de marcas de alimentos e os cotidianos do consumo alimentar das crianças em contexto familiar, especialmente no que tange à importância e valor do ponto de vista infantil, a presença, participação ativa e voz das crianças se tornam parte essencial no processo de investigação.

Sentido em que se propõe, neste capítulo, a apresentação e exploração das perspectivas infantis e agências das crianças participantes do estudo sobre sua cultura alimentar e sobre as marcas e produtos alimentícios no seu contexto familiar e nas preferências do seu consumo alimentar, que se fizeram presentes no âmbito dos principais temas abordados, atividades desenvolvidas e experiências vivenciadas com as crianças em campo nos contextos familiares pesquisados no desenvolvimento desta investigação.

Tomando as crianças como sujeitos e atores sociais, com participação ativa na cultura e sociedade, e com direito à cidadania, participação e voz, este estudo compreende os conceitos de criança e de infância como dinâmicos, resultantes de processos históricos e socioculturais de construção. Assim como compreende a importância da participação das crianças, a essencialidade das vozes infantis, e a imprescindibilidade da ética nas pesquisas com crianças em campo em qualquer processo de investigação. Reconhecendo que a perspectiva das crianças 
tomadas como sujeitos ativos e participativos, como participantes e copesquisadores no processo de investigação, é antes uma visão filosófica, política e social sobre a infância e as crianças no contexto do estudo, para além dos investimentos e especificações exclusivamente metodológicas no desenvolvimento das atividades de pesquisa com as crianças em campo, como tratado no contexto de estudos e pesquisas desenvolvidos com crianças nos campos da antropologia da criança e sociologia da infância. (COHN, 2005; CORSARO, 2011; 2005; 1992; 1990; PROUT, 2011; 2010a; 2010b; CHRISTENSEN; PROUT, 2002; SARMENTO, 2011; 2008a; 2008b; 2007; 2005a; 2005b; FERREIRA; SARMENTO, 2008; SOARES; SARMENTO, 2005; SIROTA, 2001; QVORTRUP, 2010a; 2010b).

Tais aspectos orientaram as bases deste estudo em seu todo, desde os investimentos filosófico-teórico-metodológicos para sua fundamentação até os procedimentos de pesquisa para a investigação com as crianças em campo em seus contextos familiares, caracterizando-se, desse modo, os investimentos de um estudo de inspiração etnográfica desenvolvido com crianças no campo da comunicação, em um processo de investigação dado com a presença e a participação das crianças, nos cotidianos das culturas infantis, no contexto das práticas e rituais de consumo alimentar das crianças e dos processos de recepção infantil de marcas de alimentos, para o estudo da mediação comunicacional das marcas e produtos alimentícios no âmbito do seu consumo alimentar em contexto familiar. Aqui, a importância e valor das perspectivas infantis e agências das crianças, o direito das crianças à presença, participação e voz em um processo de investigação sobre sua cultura de consumo alimentar em contexto familiar, fez-se presente de modo estrutural e essencial.

Desde o início do trabalho desenvolvido com as crianças em campo, em cada contexto familiar, fez-se presente no processo de investigação o ponto de vista das crianças tomadas como sujeitos e atores sociais, com direito à presença, participação e voz no desenvolvimento do estudo. Desde o primeiro momento em que, enquanto pesquisadora, fiz questão de apresentar às crianças os objetivos da pesquisa a ser desenvolvida com elas e com suas famílias, acordando com as próprias crianças que elas estariam presentes em todos os momentos da pesquisa, participando ativamente das atividades propostas, e procurando deixar claro para elas o quanto a sua participação e contribuição seriam essenciais para o desenvolvimento do estudo.

Nessa direção, é interessante observar o quanto as crianças compreendem, e o quanto são capazes de compreender no momento em que há a disposição de se falar diretamente com elas. Com clareza, sinceridade, e sem ressalvas ou receios. Como sujeitos que são no processo de investigação. 
Experiência marcante no reconhecimento da cidadania e participação das crianças no processo deste estudo deu-se, igualmente, no momento em que, juntamente com as assinaturas dos pais, as crianças também participaram na assinatura do termo de consentimento livre e esclarecido para sua participação nas atividades da pesquisa. As crianças participaram com entusiasmo, atenção e dedicação, como legitimas participantes no processo de investigação.

E assim, com as crianças tomadas como sujeitos e atores sociais, deu-se continuidade ao desenvolvimento do estudo, com a presença e participação ativa das crianças em todos os momentos e atividades propostas, dando voz às vozes infantis, e no intuito de compreender as perspectivas infantis e agências das crianças nos processos de recepção infantil de marcas de alimentos e de consumo alimentar das crianças em contexto familiar nos cotidianos da sua cultura alimentar.

Tanto no contexto das atividades desenvolvidas com as famílias (os pais e as crianças) quanto nas atividades lúdicas desenvolvidas exclusivamente com as crianças, elas tiveram participação ativa em todos os momentos e atividades propostas. Especialmente durante os relatos, entrevistas, jogos e brincadeiras, e produção de fotografias e vídeos, houve grande envolvimento, não somente com suas muitas informações e riquíssimas contribuições para o estudo, mas também, auxiliando na organização e preparação das atividades, ou na organização e apresentação dos dados, sempre que solicitadas ou quando entendiam ser necessário. Relatos, entrevistas, jogos, brincadeiras, fotografias e vídeos marcados tanto pelos pontos de vista e saberes infantis quanto pelas agências das crianças, enquanto participantes e copesquisadores no processo de investigação.

Especialmente no contexto das atividades lúdicas desenvolvidas exclusivamente com as crianças no processo de investigação, com temáticas sobre o consumo alimentar infantil e as marcas e produtos alimentícios no contexto dos gostos e preferências das crianças para o consumo alimentar, em que a presença, a participação e a voz das crianças no processo de investigação se deram de modo intenso, dinâmico e autoral, marcando a presença das perspectivas infantis e agências das crianças no desenvolvimento do estudo e na construção partilhada de conhecimentos sobre a cultura contemporânea de consumo alimentar infantil sob o âmbito da ciência e das crianças.

Ao final do estudo desenvolvido, mais uma vez, e como não poderia deixar de ser, fezse presente a perspectiva das crianças tomadas como sujeitos e atores sociais, com presença, participação e voz no processo de investigação: no especial momento em que as crianças foram convidadas por mim a fazer uma avaliação sobre a pesquisa e sua participação no processo de investigação e sobre a temática contemporânea do consumo alimentar infantil. Expressar 
livremente suas opiniões e sinalizar suas observações - as crianças acolheram a proposta com entusiasmo, interesse e dedicação, mostrando o quanto são capazes de compreender e o quanto têm a nos dizer sobre sua cultura alimentar, sobre as marcas e produtos alimentícios nas preferências do seu consumo alimentar, e sobre a experiência da pesquisa e sua oportunidade de participar.

Coloca-se a seguir a apresentação e exploração das perspectivas infantis e agências das crianças participantes do estudo sobre sua cultura alimentar e sobre as marcas e produtos alimentícios em seu contexto familiar e nas preferências do seu consumo alimentar, presentes no conjunto das principais atividades desenvolvidas e experiências vivenciadas com as crianças em campo nos contextos familiares pesquisados, concentrando-se atenção às atividades lúdicas e momentos de conversação desenvolvidos exclusivamente com elas no processo de investigação. Na forma de relatos infantis, entrevistas, jogos e brincadeiras, e produção infantil de fotografias e vídeos, as perspectivas infantis e agências das crianças se fizeram presentes de modo bastante especial no desenvolvimento do estudo e marcaram a construção de conhecimentos e saberes sobre a mediação comunicacional das marcas na cultura contemporânea de consumo alimentar infantil a partir da presença, participação e voz das crianças no processo de investigação.

\section{Perspectivas das Crianças Sobre sua Cultura de Consumo Alimentar e as Marcas Produtos Alimentícios no Contexto das Escolhas e Preferências Infantis}

Destaca-se aqui a apresentação e exploração de alguns dos principais relatos e expressividades das crianças, ao longo do processo de investigação, ao compartilharem suas experiências, perspectivas e saberes infantis sobre sua cultura alimentar e as marcas e produtos alimentícios no seu contexto familiar e no contexto dos seus gostos e preferências para o consumo alimentar.

Desde o início do processo de pesquisa, na investigação em campo com as crianças em seus contextos familiares, estas se mostraram acolhedoras e abertas a participar, ainda que, inicialmente, com um pouco de timidez. Entretanto, sempre se mostraram prontas a participar das atividades propostas e contribuir para o desenvolvimento do estudo com suas experiências, perspectivas e saberes infantis.

Nesse sentido, é interessante observar a disponibilidade e espontaneidade das crianças ao falarem sobre si e sobre os seus cotidianos, sinalizando o quanto são dispostas a participar e contribuir nos processos de investigação, desde que tenham oportunidade de se fazerem presentes, com direito à participação e voz. 
No contexto da presente pesquisa, as perspectivas infantis e agências das crianças no processo de investigação se apresentaram de modo bastante dinâmico, com toda espontaneidade, expressividade e disponibilidade em contribuir para o desenvolvimento do estudo, ao compartilharem suas experiências e saberes infantis, seus gostos e preferências para o consumo alimentar, e as marcas e produtos alimentícios presentes na sua cultura alimentar. Perspectivas infantis e agências das crianças que dão forma aos processos de recepção infantil de marcas de alimentos e de consumo alimentar das crianças nos cotidianos da sua cultura alimentar em contexto familiar.

Nesse sentido, vale observar o quanto os alimentos, as marcas e produtos alimentícios se fazem presentes no imaginário e no discurso das crianças ao falarem sobre sua cultura alimentar e sobre seus gostos e preferências para o consumo alimentar. E o quanto os gostos e preferências infantis por alimentos, marcas e produtos alimentícios têm especial participação na composição da cultura alimentar das crianças no contexto das famílias participantes do estudo, demarcando a presença das marcas e produtos alimentícios como elemento marcante e importante mediação na composição das experiências e vivências das crianças nos cotidianos infantis da cultura alimentar em contexto familiar.

Outro aspecto importante a se observar nos relatos e expressividades das crianças é o quanto, no contexto dos gostos e preferências infantis para o consumo alimentar, as marcas de alimentos parecem se confundir com os próprios produtos alimentícios. Muitas vezes, ao se referirem às marcas de alimentos, as crianças parecem estar se referindo aos produtos alimentícios em si, em suas diferentes e diversas dimensões de sensorialidade e prazer para o consumo alimentar infantil.

Importante observar ainda que as marcas e produtos alimentícios que caracterizam os gostos e preferências infantis, presentes nos relatos, observações, citações e expressividades das crianças durante o processo de investigação, especialmente no contexto das atividades lúdicas desenvolvidas exclusivamente com as crianças, caracterizam-se não somente enquanto presença material nos cotidianos da sua cultura alimentar em contexto familiar (marcas e produtos alimentícios que as crianças consomem), mas também enquanto presença simbólica no contexto dos gostos e preferências infantis para o consumo alimentar (marcas e produtos alimentícios que as crianças gostariam de consumir).

Como destacado inicialmente, as atividades lúdicas desenvolvidas exclusivamente com as crianças neste processo de investigação, merecem atenção especial no contexto do estudo desenvolvido: a Brincadeira de Comer - atividade lúdica desenvolvida com as crianças na forma de jogos de cards e de desenhos; a Brincadeira de Comprar - atividade lúdica 
desenvolvida com as crianças na forma de dramatização para simulação de compra e consumo de produtos alimentícios no supermercado; e a Experiência The Kids - conjunto de atividades lúdicas para composição de uma experiência lúdica de participação infantil, desenvolvida com as crianças na forma de uma experimentação metodológica da pesquisa com a participação e coprodução infantil na realização de entrevistas e na produção de fotografias e vídeos sobre o seu consumo alimentar em contexto familiar, e com a participação das crianças na produção, organização, apresentação e registro dos dados e informações em campo.

Atividades lúdicas que merecem destaque especial, pois que, é no contexto de tais atividades que a presença, participação e voz das crianças no processo de investigação se deram de modo mais intenso e marcante, demarcando a presença das perspectivas infantis e agências das crianças no desenvolvimento do estudo e na construção de conhecimentos e saberes sobre a cultura de consumo alimentar infantil a partir da voz e do olhar das crianças.

Por tal motivo, neste capítulo, fez-se a escolha e recorte para a apresentação e exploração das perspectivas infantis e agências das crianças no processo de investigação a partir da presença e participação das crianças no contexto específico das atividades lúdicas propostas na pesquisa. Reconhecendo-se, no entanto, que a presença, participação e voz das crianças se fizeram marcantes no processo de investigação em seu todo, em todos os momentos e atividades da pesquisa para o desenvolvimento do estudo.

A Brincadeira de Comer, a Brincadeira de Comprar, e a Experiência The Kids constituem o conjunto das principais atividades lúdicas desenvolvidas com as crianças no processo de investigação, realizadas com o objetivo de conhecer as experiências, perspectivas, saberes e afetos infantis quanto ao consumo alimentar das crianças e quanto às marcas e produtos alimentícios no contexto das escolhas e preferências infantis, onde buscou-se compreender os processos de recepção infantil de marcas de alimentos e os vínculos de sentidos entre marcas/produtos e crianças no contexto familiar, como especificado detalhadamente no primeiro capítulo (no momento da apresentação da estrutura e caracterização do estudo) e no segundo capitulo (no momento do relato das atividades desenvolvidas com as crianças em campo em seus contextos familiares).

O desenvolvimento das atividades lúdicas propostas com a presença e participação ativa das crianças nos diferentes contextos familiares pesquisados caracterizou-se enquanto experiência de extrema importância no contexto deste estudo, tanto para o enriquecimento do processo de investigação quanto para o aprofundamento e diversidade empírica no desenvolvimento da pesquisa. 
Na sequência, a materialização da presença, participação e voz das crianças no processo de investigação, a partir da apresentação e exploração das perspectivas infantis e agências das crianças presentes no desenvolvimento das atividades lúdicas propostas sobre os processos de recepção infantil de marcas de alimentos e sobre o consumo alimentar das crianças em contexto familiar que, na forma de dados e informações, se fizeram presentes no capítulo anterior, no momento da análise dos dados e avaliação dos resultados da pesquisa, mas que, neste momento, se colocam de modo concreto, enquanto retrato das subjetividades infantis e da presença, participação e voz das crianças no processo de investigação para o estudo da mediação comunicacional das marcas na cultura contemporânea de consumo alimentar das crianças em uma perspectiva da ciência e dos saberes infantis.

As crianças participaram das atividades com interesse, entusiasmo, atenção e dedicação, demonstrando toda expressividade dos saberes infantis nas diversas formas das atividades lúdicas propostas. E no âmbito da participação ativa das crianças, apresentam-se, a seguir, os principais relatos, observações, citações e expressividades infantis presentes nas atividades lúdicas desenvolvidas no processo de pesquisa, demarcando a presença singular e enriquecedora das perspectivas infantis e agências das crianças no processo de investigação e no contexto do estudo.

\section{BRINCADEIRA DE COMER}

\section{JOGO DE CARDS: ALIMENTOS}

Jogo de cards apresentado às crianças com imagens de alimentos / produtos alimentícios diversos (alimentos / bebidas / guloseimas / produtos industrializados / alimentos in natura), em que cada criança recebeu um baralho completo com os cards.

O jogo teve início quando as crianças foram solicitadas a organizar os cards sobre a mesa, livremente, de acordo com suas perspectivas e critérios de organização.

Em seguida, após a organização dos cards, foram solicitadas a compor algumas combinações de alimentos / produtos alimentícios para simulação de consumo alimentar (refeições e lanches), de acordo com suas perspectivas, experiências, saberes, preferências e afetos, independentemente das suas escolhas serem ou não representativas do seu consumo alimentar no cotidiano. Foram solicitadas às crianças combinações alimentares para composição do café da manhã / almoço / jantar / lanche da escola / lanche com amigos. 
Após cada composição de produtos alimentícios para simulação de consumo alimentar, as crianças foram convidadas a falar sobre suas composições, destacando os alimentos ou produtos alimentícios escolhidos. Explicando o porquê de cada escolha, falando sobre as marcas e produtos alimentícios da sua preferência, e expressando as preferências e saberes infantis sobre o consumo alimentar.

Durante o jogo, cada solicitação feita às crianças era denominada como desafio.

O jogo foi finalizado quando as crianças concluíram todas as composições alimentares solicitadas na forma de desafios.

O Quadro 3 contempla o registro da participação das crianças na atividade lúdica proposta, demarcando as perspectivas e subjetividades infantis e agências das crianças no desenvolvimento da Brincadeira de Comer: Jogo de Cards: Alimentos. 
Quadro 3 - Brincadeira de Comer: Jogo de Cards: Alimentos

ORGANIZAÇÃO DOS CARDS (ALIMENTOS QUE CONHECE / GOSTA / GOSTA MAIS)

FAMÍLIA

MENINO

FAMÍLIA 2

MENINA

Chocolate: Twix

Hambúrger: McDonald's

Hambúrger: Burger King

Creme de avelã e cacau: Nutella

Observação: Citações espontâneas da menina durante a organização dos Pastel cards.

Suco (caixinha): Ades

Pizza: Pizza Hut

Gelatina: Roy

Refrigerante (laranja): Fanta

Biscoito doce (maisena): Piraquê

Confeitos de chocolate: M\&M's

Chiclete: Bubbalo

Wafer: Toddy

Refrigerante (guaraná): Kua

Balas: 7 Belo

Biscoito doce / salgado (?): Bauducco

(Cereale)

Balas de gelatina: Haribo

Iogurte petit suisse: Vigor (Minions)

Iogurte (garrafinha): Ninho

Leite (integral / garrafa): Parmalat

Iogurte grego: Danone

Suco (caixinha): Do Bem

Salgadinho: Doritos

Chocolate: KitKat

Sorvete (picolé): Kibon

Salgadinho: Cheetos

Sorvete: Bacio di Latte

Salgadinho (integral): EQlibri

Chocolate: Ditemante EQlib

Salgadinho (integral): Mãe Terra

(Ceboloko)

Salgadinho: Cebolitos

Chocolate: Twix

Sorvete: McDonald's

Suco natural (goiaba)

Suco natural (uva)

Agua mineral: BonaFont

Água de coco: Do Bem

Batata

Macarrão instantâneo: Miojo (Turma

da Mônica)

Peixe

Arroz (branco)

Cebola

Rabanete

FAMÍLIA 3

MENINA MAIS VELHA

MENINA MAIS NOVA

$\begin{array}{ll}\text { Chocolate: Twix } & \text { Doces (diversos): Marcas (?) } \\ \text { Hambúrguer: Burger King } & \text { Creme de avelã e cacau: Nutella }\end{array}$

Hambúrguer: Burger King

Macarrão instantâneo: Miojo (Turma da $\quad$ Brigadeiro

Mônica)

Pão de queijo

Bisnaguinha: Pullman (Bisnaguito)

Cereais (sucrilhos / bolinhas): Nescau

Refrigerante: Coca-Cola

Refrigerante (laranja): Fanta

Cachorro-Quente

Macarrão

Creme de avelã e cacau: Nutella

Salgadinho: Cheetos
Hambúrguer: McDonald's

Observação: Citações espontâneas menino durante a organização dos cards.

Mônica)

Suco (caixinha): Ades

Suco (caixinha): Del Valle (Kapo)

Suco natural (uva)

Suco natural (laranja)

Suco natural (goiaba)

Água mineral (garrafinha): BonaFont

Água mineral (garrafinha): Marcas

diversas

Iogurte petit suisse: Elegê (Bob Esponja)

Iogurte petit suisse: Vigor (Minions)

Iogurte petit suisse: Danoninho

Iogurte (garrafinha): Ninho

Iogurte (garrafinha): Vigor (Minions)

Iogurte (garrafinha): Danoninho

Melancia

Pêra

Morango

Abacaxi

Macarrão instantâneo: Miojo (Turma da

Mônica)

Hambúrguer: McDonald's

Arroz (branco)

Feijão (preto)

Batata

Sorvete (casquinha): McDonald's

Gelatina: Dr Oetker

Confeitos de chocolate: M\&M's

Balas (chiclete)
Balas: 7 Belo

Balas (diversas): Marcas (?)

Chocolate: Kinder Ovo

Chocolate: Tortuguita

Observação: Citações espontâneas da menina durante a organização dos cards.
Goina

Frutas (diversas)

Observação: Citações espontâneas da menina durante a organização dos cards.

Suco (em pó): Tang

Água de coco: Kero Coco

Suco natural (uva)

Agua mineral: BonaFont 
Água de coco: Do Bem

Salgadinho (integral): EQlibri

Sorvete: Bacio di Latte

Salgadinho (integral): Mãe Terra

(Ceboloko)

Pipoca salgada / doce (micro-ondas)

(?): Yok

Peixe

Arroz (branco)

Arroz (integral)

Sorvete: McDonald's

Observação: Citações espontâneas da

menina durante a organização dos cards.
Observação: Citações espontâneas do

menino durante a organização dos cards.

ORGANiZAÇÃo dOS CARDS (ALIMENTOS QUE NÃO CONHECE / NÃO GOSTA / GOSTA MENOS)

FAMÍLIA 1

MENINA
FAMÍLIA 2

MENINO

MENINA

MENINO

MENINA MAIS VELHA

FAMÍLIA 3

Achocolatado (caixinha): ChocoLeco Balas de gelatina: Haribo

Achocolatado (caixinha): ChocoLeco Banan Cereais (Sucrilhos) Achocolatado (caixinha): Danone

Observação: Citações espontâneas da (Dori)

menina durante a organização dos Bolo (seco)

cards.

Requeijão cremoso: Polengh

Biscoito salgado (gergelim): Piraquê

Queijo processado: Polenguinho

Observação: Citações espontâneas do

menino durante a organização dos

cards.

$\begin{array}{ll}\text { Banana } & \text { Frutas } \\ & \text { Legumes } \\ \text { Observacão: Citações espontâneas da } & \text { Verduras } \\ \text { menina durante a organização dos } & \text { Café }\end{array}$

menina durante a organização dos

cards.

egumes

Café

Observação: Citações espontâneas da

menina durante a organização dos cards.
Suco (caixinha): Do Bem

Arroz (integral)

Observação: Citações espontâneas da

menina durante a organização dos cards.

\section{PARA O CAFÉ DA MANHã}

FAMÍLIA 1

MENINA

Leite (integral / garrafa) - Shefa Achocolatado (em pó) - Nescau Pão francês - -

Margarina - Doriana

Suco natural (uva) - --- Para ela é

suco de amora.

Sorvete - Bacio di Latte
Leite (integral / garrafa) - Parmalat Suco (caixinha) - Ades

Melancia - --

Banana - ---

Sorvete - Bacio di Latte

Sorvete (picolé) - Kibon

[Bisnaguinha] - [Pullman

(Bisnaguito)] - Ele escolheu. Mas

desistiu.

[Pizza] - [Pizza Hut] - Ele escolheu.

Mas desistiu.

\section{FAMÍLIA}

MENINA
MENINO

Bolo de chocolate - ---

Bisnaguinha - Pullman
Água mineral - Crystal

Iogurte petit suisse (mo

Cereais (sucrilhos) - -

Leite (integral/garrafa) - Shefa

Salgadinho - Cheetos

logutte (morango /garrafinha) - Ninho

Salsicha - Sadia
Café (em pó / torrado) - Pil̃o

Laranja - ---
FAMÍLIA 3

MENINA MAIS VELHA

MENINA MAIS NOVA
Pão francês - --- - A menina chama de pão Pão francês - --- - A menina mais velha de sal.

Margarina - Doriana

Leite (integral / garrafa) - Shefa

Achocolatado (em pó) - Nescau

Bisnaguinha - Pullman (Bisnaguito)

Pão de queijo - ---

[Margarina] - [Qualy] - Ela ia escolher.

Mas desistiu - Trocou por Margarina

Dorian chama de pão de sal.

Margarina - Doriana

Leite (integral / garrafa) - Shef

Café (em pó / torrado) - Pilão

Maçã - ---

Leite fermentado - Vigor (Minions)

Cenoura - -

Cachorro-Quente - --- 
"Eu tenho o pãozinho francês... Eu tenho a manteiga..."

"Eu tenho a manteiga... O pão francês... O leite... O Nescau... O suco de amora... E um sorvete."

"Sim! (Gosto de tudo)."

"Eu acho que ta gostoso. E só não ta tão saudável por causa do Nescau. E do sorvete."
"O meu café... Um super leite!... Suco de soja... E banana.

Sorvete... A marca desse sorvete é

Bacio di Latte. A marca desse sorvete é Fruttare.

E uma melançona pra mim comer!'

"Banana... Melancia... Suco de soja. Leite... Sorvete do Bacio di Latte.. Sorvete da Fruttare."

"Tá mais pra gostoso. E mais pra saudável também. Porque tem uma melançona e uma banana."
"No meu... Haha!... Eu quero: Bolo de "Bisnaguinha... Água... Danone... Éh... chocolate com cobertura!

Éh... Uma bisnaguinha com Nutella!... Café... Laranja... E morango."

“Ái... É porque, assim... Eu não aguentaria comer tudo.

Mas eu gosto tanto de doce quanto dessas frutas - que são umas das únicas que eu gosto.

E café também, né."

"E mistura tudo... Dá um café da manhã muito bom! Éh!"
"Bisnaguinha... Agua... Danone... É...,

"Éh... Como é que é o nome disso aqui?...

"Salsicha... E macarrão."

"Porque eu gosto. Éh."

"Macarrão de manhã?"

"Aham. Éh." Acho que é Danoninho..."
"Em

Éh...

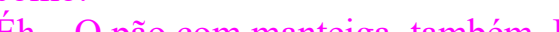
leite com Nescau."

\section{"E o que você gostaria?"}

"E... Esse aqui... Não é bem o que eu gostaria. Mas é que... Geralmente, eu como (às vezes).

Que é bisnaguinha e o pão de queijo."

"E você gosta, né?"

"Gosto!"
Os que ela escolheu, é mais o que ela gosta Não o que ela come no café da manhã.

Como a maçã Éh... Esse Yakult. E a cenoura. E o cachorro-quente,"

\section{"São coisas que ela gosta?"}

"Éh!... Mas..."

“Mas não no café da manhã, né?”

"Éh."

"E eu escolhi o que ela geralmente come no café da manhã. Que é pão com manteiga esquentado. E leite com café."

\section{PARA O ALMOÇO}

FAMÍLIA 1

MENINA

MENINO

MENINA

Hambúrguer - McDonald's

Refrigera

Sorvete (casquinha) - McDonald'

[Refrigerante / laranja] - [Fanta] - Ele

escolheu. Mas desistiu. Trocou por

Coca-Cola.

McDonald's

desistiu. Mudou o cardápio para

lanche.

[Feijão (preto)] - --- - Ela escolheu.

Mas desistiu. Mudou o cardápio par lanche.

[Arroz (branco)] - --- - Ela escolheu. Mas desistiu. Mudou o cardápio par lanche.

Tá. O meu é: Hambúrguer do Mc.. Suco de amora... E sorvete de sobremesa. De chocolate."

"Hambúrguer do McDonald's.. CocaCola... E sorvete do McDonald's."

\section{FAMÍLIA 2}

MENINO

Tomate - ---
Pepino - ---
Ovos - --
Macarrão - ---
Carne - ---
Batata - ---
Arroz (branco) - ---
Feijão (preto) - ---
Água mineral - BonaFont
Chocolate - Twix - Sobremesa.

"De salada... Só tomate e pepino."

"Éh... E agora, no almoço mesmo.. Ovo frito... Macarrão.... Éh... Carne. Batata... Arroz... E feijão."

"E água como bebida."

"E de sobremesa... Um Twix!"

"Bom... Também é por causa das coisas saudáveis e não saudáveis. Mas... Também, porque eu gosto da maioria das coisas que tem aí. Tipo. Ovo, eu gosto demais! Carne, também Éh E Twix né! De sobrem

Porque é um dos meus doces

favoritos!"

Salsicha - Sadia
Arroz (integral) - --- Para ele é arroz
branco e feijão.
Feijão (preto) - ---
Refrigerante (laranja) - Fanta
Pepino - ---
Tomate - ---
Sorvete (picolé) - Kibon - Sobremesa.
[Brócolis] - --- Ele escolheu. Mas desistiu.
Trocou por tomate.

Trocou por tomate.

\section{“Éh... Sorvete! De sobremesa!”}

“A salsicha... O arroz e o feijão... Éh... Bebida... Éh... Pepino... Brócolis... E de sobremesa... O sorvete!"

"Porque... Éh... Porque tem que ter coisas saudáveis e coisas não saudáveis no almoço."

"E o que é saudável aí?"

"Tomate e pepino."

"E o que não é saudável aí?"

"Salsicha. Sorvete."

"Não é saudável (sorvete)."

FAMÍLIA 3

MENINA MAIS VELHA

MENINA MAIS NOVA

Arroz (branco) - ---

Feijão (preto) - ---

Carne - ---

Ovos - ---

Tomate - ---

Suco (em pó) - Tang

Coca-Cola - Às vezes. No lugar do suco

Creme de avelã e cacau - Nutella -

Sobremesa

Salgadinho - Cheetos - Sobremesa

"Eu escolhi o que eu geralmente como: Arroz... Feijão... A carne..

O ovo... Éh... Âs vezes, no lugar da carn

Éh... E o tomate."

"E às vezes eu também tomo Coca-Cola no lugar do suco."

"Mas a maioria das vezes é suco ou Coc Cola?"

"Éh... A maioria das vezes é suco."

"O Tang né?"

"Éh "

"E sobremesa... Eu gostaria de um salgadinho Cheetos e Nutella."
Arroz (branco)- ---

Feijão (preto) - --

Carne -

Batata - --- A menina gosta muito de

batata! Suco (em pó) - Tang

Laranja - ---

Bolinho (chocolate) - Panco

(Bebezinho)

Banana - --

[Suco (caixinha)] - [Ades] - Escolheu. Mas desistiu quando a irmã mostrou Suco Tang.

[Agrião] - --- Ela escolheu. Mas não gosta. Escolheu pela cor e desenho.

"O que eu escolhi, de novo, é o que ela... a gente geralmente come. Que é o arroz... O feijão... A carne... E a batata."

"E a batata é o que ela gosta. E que a gente também comeu hoje."

"E o suco... Éh... A gente geralmente... Eh... Usa a marca Tang."

"E as outras coisas que ela gosta?"

"Éh... E aqui é o que ela gosta. Que é laranja... Esse bolinho aqui com recheio dentro... E a banana." 
"Você gosta de água? Que bom!" "Éh!"

"Eu também gosto. Mas eu nem coloquei."

"Você gosta de água para acompanhar a comida?"
"Legal! Isso não é sempre... Mas é o que vocề gosta, né?"

"Éh!"

"Aham."

\section{PARA O JANTAR:}

FAMÍLIA 1

\section{MENINA}

MENINO

Hambúrguer - McDonald's

Pizza - Pizza Hut

Suco natural (laranja) - --

Suco natural (laranja) - --

Morango - ---

Gelatina - Royal

Achocolatado (caixinha) - Toddynho

Eu já falei. Eu já falei."

"Suco de laranja... Ovo... Banana... E gelatina Royal."

"Arroz... Fe Fejă

"Morango (o mais saudável)."

"Toddynho (o menos saudável)."
MENINA

\section{FAMÍLIA 2}

MENINO

Salgadinho - Cebolitos

Hambúrguer - Burger King

Salgadinho - Doritos

Chocolate - Kinder Ovo - Sobremesa.

Chocolate - Kinder Ovo -Sobremesa.

- Bolo de Chocolate - --- - Sobremesa.

Balas de gelatina - Haribo - So

Chocolate - Twix - Sobremesa.

Chocolate - Diamante Negro - Sobremesa.

Chocolate - KitKat - Sobremesa.

Confeitos de chocolate - M\&M's

Sobremesa.

"Na minha... Como tem... Tipo... No dia a dia tem, assim... Tem uma regra que a minha mãe criou: Que tem que ter pelo menos uma refeição... Tipo. De arroz e feijão. Uma coisa mais saudável. E na outra, até pode ser alguma coisa menos saudável."

"Não nesse caso... Mas... Enfim Haha!"

“Éh... Um hambúrguer do

McDonald's... Uma pizza ...

Suco de laranja natural - que é o único

tipo de suco de laranja que eu gosto.

E um Kinder Ovo de sobremesa!"

\section{"Kinder Ovo!"}

"Não. Mas tudo isso aqui é sobremesa!"

"Esse salgadinho... Hambúrguer... Éh... E esse aqui... Um outro salgadinho."

"E tudo isso aqui é sobremesa!"

"Kinder Ovo... Bolo..."

"Éh... Como é que o nome disso aqui?..."

"Haribo"

"Ham?"

"Haribo"

"Haribo!"

"É uma bala? Ele gosta?"

\section{FAMÍLIA 3}

MENINA MAIS VELHA

MENINA MAIS NOVA

Arroz (branco) - ---

Feijão (preto) - ---

Carne - -.-

Suco (em pó) - Tang

Pizza - Pizza Hut

Refrigerante - Coca-Cola - Às vezes

Coca-Cola - Preferência da menina

Refrigerante (tubaína) - Itubaína - À

vezes ITubaína - Preferencia Às

Cereais (sucillos / boling / familia.

Cereais (sucrilhos/boring / chocolate)

Cacho-Quente -

Cacho (banilha) - An

Bolinho (bau
Sobremesa.
Arroz (branco) - ---

Feijão (preto) - --

Carne - --.

Suco (em pó) - Tang - A menina mais

velha lembrou do suco depois.

Pizza - Pizza Hut

Refrigerante - Coca-Cola - Quando não

tem ITubaína (Delivery).

Refrigerante (tubaína) - Itubaína -

Preferência da família (Delivery)

Cachorro-Quente - --- - Às vezes tem

cachorro-quente. (Citação do pai)
"O que é... Que a gente geralmente come é a comida: Arroz... Feijão... Carne. Ou outra coisa."

"A pizza. Às vezes a pizza, com Tubaína ou Coca-Cola."

"E... Se tivesse, eu ia comer o sucrilhos. Ou cachorro-quente. E...

"E o que também geralmente a gente bebe é o suco."

"E sobremesa O bolinho Ana Maria!"
"Hum... Essa vez a gente... A gente sô pegou o que a gente geralmente come. Que é a pizza com refrigerante. Geralmente, Tubaina. Mas... Mas aí.. Às vezes também Coca-Cola."

"E às vezes a gente também come comida: Arroz... Feijão... Carne. Também, geralmente, a comida do almoço."

"Suco?... Tem. Suco de..."

"Suco do... Do almoç, que sobra assim."

"Ou, se não tem, faz." 
"Twix... Tortuguita... Diamante Negro.. KitKat... E M\&M's."

"Porque eu gosto desses negócios que estão aí."

"Você vai comer tudo isso de sobremesa?"

"Éh!"

"Mas a mamãe deixaria comer tudo isso de sobremesa?"

"Não. Como isso... Isso... Isso...

Não. Como uma coisa... E só."

"Haha!"

\section{PARA O LANCHE DA ESCOLA:}

FAMÍLIA 1

MENINA

\section{Cachorro-Quente - -.-}

Água mineral - Crystal

Banana - -.-

Iogurte grego (morango) - Danone

Biscoito doce (leite) - Marilan - Para
ele é biscoito doce (maisena).
Iogurte petit suisse (morango) - Vigor
(Minions)

Iogurte petit suisse (morango) - Vigor

Banana -

Suco (caixinha) - Del Valle (Kapo)

\section{FAMÍLIA}

MENINA

MENINO

Wafer (chocolate) - Bauducco Pão de queijo - ---

Queijo processado - Polenguinho Suco (laranja / caixinha)-Ades - Ela só gosta do sabor laranja.

\section{Iogurte (morango / garrafinha) - Danoninho \\ Sorvete (casquinha) - McDonald' \\ Hambúrguer - McDonald's \\ Gelatina - Royal}

\section{FAMÍLIA 3}

MENINA MAIS VELHA

MENINA MAIS NOVA
"O meu é: Banana... Cachorro quente... Água... Iogurte grego de frutas vermelhas."

“Ah... Ta os dois. O mais saudável é a água. E o menos saudável é o cachorro quente."

\author{
"Eu pus um lanche normal." \\ "Banana... Suco..." \\ "O Júlio tem uma banana?" \\ "Tenho" \\ "No meu... Eu quero: Esse... Essa \\ bolachinha wafer da Bauducco... Um \\ pão de queijo... E o Polenguinho. \\ E o suco de laranja da Ades." \\ "Que também... Eu só gosto de suco \\ natural de laranja e o da Ades. Só \\ esses dois tipos de suco."
}

Suco (caixinha) - Ades - No lanche da escola tem suco de diversas marcas. Wafer (chocolate) - Bauducco Maçã - --

Pêra - ---

Pão francês - --- - No lanche da escol tem pãozinho integral.

Bisnaguinha - Pullman (Bisnaguito) Sobremesa.

Bolinho (baunilha) - Ana Maria -

Sobremesa.

Creme de avelã e cacau - Nutella -

Sobremesa.

[Suco (caixinha)] - [SuFresh (Turma da

Mônica)] - Ela estava em dúvida entre o

suco (caixinha) Ades e SuFresh.

[Suco (caixinha)] - [Marcas diversas] -

Tem suco (caixinha) de diversas marcas

no lanche da escola.

"Danoninho... Sorvete... Hambúrguer... E gelatina.'

"Porque eu queria comer..."

"Tirando esse picles que ta aqui. Porque en não gosto. Aqui, oh! Coisinha verdinha... Aqui, oh!”
"Na escola tem... Suco de caixinha. E de sobremesa, às vezes, tem bolacha ou fruta."

"Truta." (aqui) o pão que geralmente eles dão. Então 
"Eu pus banana... Suco... é... Iogurte. E bolacha maisena Só que de leite. Pronto."

"Ta os dois. Eu acho. (gostoso saudável)."
"Ah.. Eu escolhi porque é rápido. Não "Com ketchup!" é tão grande as coisas.

E também porque não é tão fora d realidade. Assim... Que dá pra eu

"E você escolheu o wafer Bauducco. Você gosta desse em específico?"

"Desse em específico. Tem outros que eu gosto. Mas eu prefiro esse."
"E porque eu gosto desse lanche."

“E o resto é a sobremesa do lanche?" "Aham."

“Éh... Eu não sei muito. É que nem o pão... O pão de sal. Que nem aquele. Mas... um pouquinho diferente. Éh... É um pão inteiro. Éh. É que nem esse aqui. Só que um pouquinho menor e diferente."

"Esse é o lanche da escola, né?"

"Éh."

"E o que mais você gostaria de lanche?"

"O que eu gostaria era mais... É mais pra sobremesa mesmo. Que é... Éh... A bisnaguinha e a Ana Maria. E...

"Ah! Eu achei que você tinha escolhido a Nutella também!”

"Que... A Nutella tá... Tá bem aqui! Hahaha!"

O card com Nutella havia caído no chão.

\section{PARA O LANCHE COM AMIGOS/AMIGAS}

\begin{tabular}{|c|c|c|c|c|c|}
\hline \multicolumn{2}{|c|}{ FAMÍLIA 1} & \multicolumn{2}{|c|}{ FAMÍLIA 2} & \multicolumn{2}{|c|}{ FAMÍLIA 3} \\
\hline MENINA & MENINO & MENINA & MENINO & MENINA MAIS VELHA & MENINA MAIS NOVA \\
\hline $\begin{array}{l}\text { Hambúrguer - McDonald's } \\
\text { Sorvete (casquinha / chocolate) - } \\
\text { McDonald's } \\
\text { Brigadeiro - --- } \\
\text { Balas - } 7 \text { Belo } \\
\text { Macarrão instantâneo - Miojo (Turma } \\
\text { da Mônica) }\end{array}$ & $\begin{array}{l}\text { Pão francês - --- } \\
\text { Margarina - Doriana } \\
\text { Achocolatado (caixinha) - Toddynho } \\
\text { Suco natural (goiaba) - --- } \\
\text { Brigadeiro - --- } \\
\text { Balas - } 7 \text { Belo }\end{array}$ & $\begin{array}{l}\text { Pera - --- } \\
\text { Melancia - --- } \\
\text { Hambúrguer - Burger King } \\
\text { Sorvete (casquinha) - McDonald's } \\
\text { Chocolate - KitKat } \\
\text { Chocolate - Tortuguita } \\
\text { Confeitos de chocolate - M\&M's } \\
\text { Suco (em pó / laranja) - Tang }\end{array}$ & $\begin{array}{l}\text { Pão francês - --- } \\
\text { Presunto - Seara } \\
\text { Requeijão cremoso - Polenghi } \\
\text { Creme de avelã e cacau - Nutella } \\
\text { Margarina - Doriana } \\
\text { Água mineral - BonaFont } \\
\text { Bolinho (chocolate) - Bauducco (Bob } \\
\text { Esponja) } \\
\text { Pizza - Pizza Hut } \\
\text { Pastel - --- } \\
\text { Cachorro- Quente - --- } \\
\text { Hambúrguer - Bob's } \\
\text { Brigadeiro - --- } \\
\text { Pão de queijo - --- } \\
\text { Macarrão instantâneo - Miojo (Turma da } \\
\text { Mônica) }\end{array}$ & $\begin{array}{l}\text { Salgadinho - Cheetos } \\
\text { Refrigerante (laranja) - Fanta } \\
\text { Hamburguer - McDonald's } \\
\text { Confeitos de chocolate - M\&M's } \\
\text { Refrigerante - Coca-Cola - A menina } \\
\text { gosta de Fanta e Coca-Cola. As amigas } \\
\text { também. }\end{array}$ & \\
\hline
\end{tabular}


"Ta bom... Brigadeiro... Sorvete do Mc... Hambúrguer do Mc...7 Belo... E Miojo."

“Não. Não. (nada saudável).”

"Minha mãe sempre diz que Miojo não é saudável. Eu ia falar Miojo. Mas não é."

“Toddynho... Brigadeiro... Pão Francês... Suco de goiaba... 7 Belo...E..."

"Como que é o nome disso?... Peraí.. Margarina."

“Tem! Suco de goiaba e pão. (que é saudável)."

"Cadê o pão Francês?"
"Bom... No meu... Haha!... Vou começar com fruta: Pêra e melancia."

"Aí... Depois, tem um lanche... Hambúrguer, né."

"Depois vai ter: Sorvete... KitKat.. Tortuguita... E M\&M's.

"E pra acompanhar... Qualquer um... Suco. De pozinho... Haha!'

"Ah... Eu escolhi (as frutas)... Eu escolhi porque eu gosto. Eu gosto bastante de melancia e pera."
"Éh... Esses aqui são os primeiros. Pra.. Com pão. Junto com esse."

"Se alguém... Se alguém quiser o presunto, coloca no pão. Se alguém quiser... Éh..

$\begin{array}{ll}\text { Requeijão, coloca no pão. Nutella, no pão. } & \text { "E o que eu sei que todas as minhas } \\ \text { Ou Doriana, no pão." } & \text { amigas gostam: É o McDonald’s... E }\end{array}$

“Tem água... Tem bolinho... Tem pizza..

Depois, pastel... Depois, Hotdog... Depois, hambúrguer...

Depois, brigadeiro... Depois... Éh... Pão de queijo..."

"E depois... Como que é o nome disso, mesmo?... Miojo!"

"Porque todas essas coisas... A maioria dessas coisas aqui... Na verdade são todas que eu gosto. É por isso."

"Éh... Os meus amigos, eles gostam de alguma coisa que ta aqui,"

"Nossa! E se bater uma fome no final, ainda tem um Miojo?"
"Eu peguei o que eu sei que uma das minhas amigas gosta, que nem eu:

Que é... Éh... Salgadinho... A Fanta... E. M\&M's."

"Éh. Então eu peguei."

\section{Fonte: elaborado pela pesquisadora}

\section{Legenda:}

Falas da criança mais velha

Falas da criança mais nova

Falas do pai

Falas da mãe

Falas da pesquisadora 


\section{JOGO DE CARDS: MARCAS / PERSONAGENS}

Jogo de cards apresentado às crianças com imagens de marcas de produtos alimentícios diversos, incluindo imagens de marcas representadas por personagens e mascotes.

Cada criança recebeu um baralho completo com os cards.

O jogo teve início quando as crianças foram solicitadas a organizar os cards sobre a mesa, livremente, de acordo com suas perspectivas e critérios de organização.

Em seguida, após a organização dos cards, foram solicitadas a escolher algumas marcas de produtos alimentícios de que gostam, ou que gostam mais, e algumas marcas de produtos alimentícios de que não gostam, ou que gostam menos (marcas de produtos alimentícios ou marcas representadas por personagens e mascotes), devendo escolher entre três e cinco marcas para cada grupo de marcas escolhidas, de acordo com sua visão, experiências, saberes, preferências e afetos.

Após as suas composições, dentre as diversas marcas de produtos alimentícios e personagens e mascotes, as crianças foram convidadas a falar sobre suas escolhas, destacando as marcas de produtos alimentícios escolhidas, explicando o porquê de cada escolha, falando sobre as marcas ou personagens e mascotes de que gostam e de que não gostam, e expressando os saberes e afetos infantis no contexto promocional das marcas e produtos alimentícios.

Durante o jogo, cada solicitação feita às crianças era denominada como desafio.

O jogo foi finalizado quando as crianças concluíram as escolhas e composições de marcas solicitadas na forma de desafios.

O Quadro 4 contempla o registro da participação das crianças na atividade lúdica proposta, demarcando as perspectivas e subjetividades infantis e agências das crianças no desenvolvimento da Brincadeira de Comer: Jogo de Cards: Marcas. 
ORGANIZAÇÃO DOS CARDS (MARCAS QUE CONHECE/GOSTA/ GOSTA MAIS)

\begin{tabular}{|c|c|c|c|c|c|}
\hline \multicolumn{2}{|c|}{ FAMÍLIA 1} & \multicolumn{2}{|c|}{ FAMÍLIA 2} & \multicolumn{2}{|c|}{ FAMÍLIA 3} \\
\hline MENINA & MENINO & MENINA & MENINO & MENINA MAIS VELHA & MENINA MAIS NOVA \\
\hline Obrigado & SuFresh & Nutella & Nutella & McDonald's & Fini \\
\hline 3 Corações & BonaFont & & Fini & Os Minions & Kinder Ovo \\
\hline BonaFont & Cheetos & Observação: Citações espontâneas da & Sadia & Os Vingadores & McDonald's \\
\hline Do Bem & Cebolitos & cards. & Danone & & lacta \\
\hline Pilão & Kibon & & Ninho & Observação: Citações espontâneas da & Elma Chips \\
\hline Danone & Twix & & Vigor & & Turma da Mônica \\
\hline $\begin{array}{l}\text { Turolez } \\
\text { Ninho }\end{array}$ & Fini & & Leco & & Mickey \\
\hline Parmalat & Kinder Ovo & & Italac & & Minnie \\
\hline Shefa & Diamante Negro & & Italakinho & & Os Minions \\
\hline Fanta & Forno de Minas & & Itambé & & Mônica \\
\hline Paulista & Bauducco & & Shefa & & Cebolinha \\
\hline Nescau & Pullman & & Paulista & & Homem Aranha \\
\hline Crioulo & Ana Maria & & Nescau & & Frozen \\
\hline Hershey's & Polenguinho & & Toddy & & \\
\hline Twix & Doritos & & Toddynho & & Observação: Citações espontâneas da \\
\hline Habib's & Ninho & & Royal & & menina durante a organização dos cards. \\
\hline Pizza Hut & Do Bem & & Dr Oetker & & \\
\hline Burger King & Avengers & & Kibon & & \\
\hline Ades & Peppa Pig & & Coca-Cola & & \\
\hline Giraffas & Mãe Terra & & Fanta & & \\
\hline América & Cmil & & Kuat & & \\
\hline Peppa Pig & Nestlé & & Pepsi & & \\
\hline Cebolinha & Homem Aranha & & Guaraná & & \\
\hline Avengers & Minions & & Antarctica & & \\
\hline $\begin{array}{l}\text { Mãe Terra } \\
\text { Bauducco }\end{array}$ & & & Tang & & \\
\hline McDonald's & Observação: Citações espontâneas do & & Ades & & \\
\hline Elma Chips & menino durante a organização dos & & Do Bem & & \\
\hline Doritos & cards. & & Kero Coco & & \\
\hline Dr Oetker & & & Obrigado & & \\
\hline Cebolitos & & & BonaFont & & \\
\hline Garoto & & & Bubbaloo & & \\
\hline Cheetos & & & M\&M’s & & \\
\hline Lacta & & & Mentos & & \\
\hline Bubbaloo & & & Halls & & \\
\hline M\&M’s & & & Hershey's & & \\
\hline Fini & & & Arcor & & \\
\hline Passa Tempo & & & KitKat & & \\
\hline Ana Maria & & & Kinder Ovo & & \\
\hline Pullman & & & Tortuguita & & \\
\hline Minions & & & Twix & & \\
\hline $\begin{array}{l}\text { Nutella } \\
\text { FOlibri }\end{array}$ & & & Baton & & \\
\hline $\begin{array}{l}\text { EQ11bri } \\
\text { Qualy }\end{array}$ & & & Chokito & & \\
\hline
\end{tabular}




$\begin{array}{ll}\text { Minnie } & \text { Elma Chips } \\ \text { Turma da } & \text { Cheetos } \\ \text { Mônica } & \text { Cebolitos } \\ \text { Mônica } & \text { Doritos } \\ \text { Frozen } & \text { Panco } \\ \text { Mickey } & \text { Yoki } \\ \text { Seara } & \text { Adria } \\ \text { Sadia } & \text { Pizza Hut } \\ \text { Chamyto } & \text { Turma da Mônica } \\ & \text { Mickey } \\ \text { Observação: Citações espontâneas da } & \text { Nintendo } \\ \text { menina durante a organização dos } & \\ \text { cards. } & \text { Observação: Citações espontâneas do } \\ & \text { menino durante a organização dos cards }\end{array}$

\section{ORGANIZAÇ̃̃o DOS CARDS (MARCAS QUE NÃO CONHECE / NÃO GOSTA / GOSTA MENOS)}

\begin{tabular}{|c|c|c|c|c|c|}
\hline \multicolumn{2}{|c|}{ FAMÍLIA 1} & \multicolumn{2}{|c|}{ FAMÍLIA 2} & \multicolumn{2}{|c|}{ FAMÍLIA 3} \\
\hline MENINA & MENINO & MENINA & MENINO & MENINA MAIS VELHA & MENINA MAIS NOVA \\
\hline $\begin{array}{l}\text { Haribo } \\
\text { Batavo } \\
\text { Aurora } \\
\text { Perdigão } \\
\text { Ádria } \\
\text { Trakinas } \\
\text { Observação: Citações espontâneas da } \\
\text { menina durante a organização dos } \\
\text { cards. }\end{array}$ & $\begin{array}{l}\text { Hershey's } \\
\text { Marilan } \\
\text { Haribo } \\
\text { Observação: Citações espontâneas do } \\
\text { menino durante a organização dos } \\
\text { cards. }\end{array}$ & & $\begin{array}{l}\text { Elegê } \\
\text { Batavo } \\
\text { Fazenda } \\
\text { Parmalat } \\
\text { Pilão } \\
3 \text { Corações } \\
\text { Nescafé } \\
\text { Bacio di Latte } \\
\text { Mãe Terra } \\
\text { Observação: Citações espontâneas do } \\
\text { menino durante a organização dos cards. }\end{array}$ & & $\begin{array}{l}\text { Os Vingadores } \\
\text { Observação: Citações espontâneas da } \\
\text { menina durante a organização dos cards. }\end{array}$ \\
\hline \multicolumn{6}{|c|}{ MARCAS QUE GOSTA / GOSTA MAIS } \\
\hline \multicolumn{2}{|c|}{ FAMÍLIA 1} & \multicolumn{2}{|c|}{ FAMÍLIA 2} & \multicolumn{2}{|c|}{ FAMÍLIA 3} \\
\hline MENINA & MENINO & MENINA & MENINO & MENINA MAIS VELHA & MENINA MAIS NOVA \\
\hline $\begin{array}{l}\text { Cheetos } \\
\text { Mc Donald's } \\
\text { Kibon }\end{array}$ & $\begin{array}{l}\text { Baton } \\
\text { Cheetos } \\
\text { KitKat }\end{array}$ & $\begin{array}{l}\text { Polenguinho } \\
\text { Ades } \\
\text { Kinder Ovo } \\
\text { McDonald's } \\
\text { Nutella }\end{array}$ & $\begin{array}{l}\text { McDonald's } \\
\text { Cheetos } \\
\text { Kinder Ovo } \\
\text { Sadia } \\
\text { Polenguinho } \\
\text { [Ana Maria] } \\
\text { Escolheu. Mas desistiu. Trocou por } \\
\text { Polenguinho. }\end{array}$ & $\begin{array}{l}\text { Fini } \\
\text { KitKat } \\
\text { McDonald's } \\
\text { Nutella } \\
\text { Marcas de chocolate que mais gosta } \\
\text { KitKat } \\
\text { Nutella } \\
\text { M\&M's } \\
\text { Twix } \\
\text { Kinder Ovo }\end{array}$ & \\
\hline
\end{tabular}


"Essas aqui são as marcas que eu osto: Cheetos. McDonald's. E Kibon."

"Eu gosto do Cheetos porque ele é gostoso!"

"Eu gosto do McDonal's porque lá eles servem bem os hambúrgueres.

Na hora. Quentinho. E bom!'

"Eu gosto do Kibon porque o sorvete

ele é muito gostoso!

E dá vontade de comer toda hora na

praia."
"Essas aqui são as que eu gosto: Baton Cheetos. E KitKat."

"Porque é muito gostoso!"

"Baton e KiKat eu gosto porque é docinho."

"E Cheetos eu gosto porque salgadinho."
"Bom... Marcas que eu gosto: Que Polenguinho - Porque tem aquele queijinho que eu gosto.

Ades - Porque é um dos únicos sucos de laranja que eu tomo.

Kinder Ovo - Porque é um chocolate muito gostoso! Por mais que seja car McDonald's - É um lanche que eu gosto. É o McChicken!

E Nutella - Porque é doce. (E porque é Nutella) Éh! Haha!"
"McDonald's - Porque vem com brinquedo no lanche. Cheetos - Porque é gostoso. Kinder Ovo - Porque é gostoso. Sadia - Porque tem o presunto. E Polenguinho - Porque é gostoso." "Polenguinho... Éh. O normal... Sem ser o de sabor cheddar."

"Tem... Só a Nutella!"

“Gosto. Mas não muito. (Kinder Ovo)"

\section{"Fini!... Fini!... Aquela das gominhas!"}

"O KitKat!... Que é a marca de chocolate!"

\section{"Hum... O McDonald's!"}

\section{MARCAS QUE NÃO GOSTA / GOSTA MENOS}

FAMÍLIA

MENINA

MENINO

MENINA

FAMÍLIA 2

MENINO

\section{FAMÍLIA 3}

MENINA MAIS VELHA
MENINA MAIS NOVA

$\begin{array}{ll}\text { Pizza Hut } & \text { Bob's } \\ \text { Peppa Pig } & \text { Haribo } \\ \text { Giraffa's } & \text { Piraquê } \\ & \text { [Chamyto] - Ele escolheu. Mas } \\ & \text { desistiu. Porque é da Nestlé. Trocou } \\ & \text { por Piraquê. }\end{array}$

"Essas são as que eu não gosto. Gosto menos: Pizza Hut. Peppa Pig! E Giraffas."

"A Pizza Hut... Mesmo ela sendo... é... uma coisa gostosa... toda... Ela faz uma maior meleira. Por isso eu não gosto."

“A Peppa Pig... É porque ela fica roncando toda hora. Crr... Crr... Crr... Peppa Pig!"

“A Giraffas... Eu já comi lá uma vez. É muito ruim. Os pratos não são bons. Os pratos são frios. Não tem sabor. É tudo muito ruim!"
“As marcas desse lado, que eu to apontando esse negócio brilhando, são as que eu não gosto: Bob's. Piraquê. Haribo."

"Eu não gosto... por causa... Não. Eu gosto menos." "Bob's... Porque..."

"Porque o hambúrguer..."

"Porque o hambúrguer, ele não vem. Eu não gosto tanto."

"Piraquê... É porque..."

"Tu não sabe porque."

"Eu não sei porque. Eu gosto menos de Piraquê. Mas eu gosto."

"Haribo eu não gosto porque é uma cópia de Fini."

$\begin{array}{ll}\text { SuFresh } & \text { Nescafé } \\ \text { Cheetos } & 3 \text { Corações } \\ \text { Danoninho } & \text { Pilão }\end{array}$

Mãe Terrra

"As que eu não gosto: suco muito azedo e forte.

Cheetos - Porque o cheiro é muito ruim! Me dá vontade de vomitar.

Danoninho - Porque eu não gosto de danone... Assim. Só aqueles que vem com... Tipo... Granulado, sabe? Que você põe dentro.

Polenguinho

Habib's

Italakinho

Mãe Terra - Porque as coisas... são coisas saudáveis demais. Que vem com muito grãozinho. Eu não gosto. Não."

"Eu não gosto do Danoninho em potinho... Eu não gosto de nenhum tipo de danone.

Só o que você põe o granulado."

"Desculpa Cheetos. Mas eu não gosto."

"Porque são marcas de café. Que eu não gosto."

"Os três de café. Os três de café, porque

eu não gosto de café. É ruim.

"Que eu não gosto..."

"Polenguinho."

"Hum... Habib's. Eu gosto um pouquinho

só. Éh."

"O que você não gosta são todas marcas

de café?"

"Éh! Porque café é ruim!"

"Mas e se a marca é boa?"

"Não. Essa marca é ruim." 
“Ah! Ela não gosta! Ela não gosta de

Cheetos! Ah! Ela não... Como ela não

gosta de Cheetos!"

"Ah!.. Ela não gosta de Danoninho!..

Cheetos!..."

MARCAS / PERSONAGENS

MENINA
FAMÍLIA 1

MENINO
FAMÍLIA 2

MENINA
FAMÍLIA 3

MENINO

MENINA MAIS VELHA

MENINA MAIS NOVA

Minions

A menina também não gosta de nenhum

tipo de personagem ou mascote.

Gosta somente dos Minions.

"Pra mim... Não. Porque a maioria... A maioria das marcas que tem personagem assim, famoso...

Tipo os Minions...

Éh... A maioria é de danone ou de Miojo.

E eu não gosto muito de danone (iogurte).

E de Miojo, eu até gosto. Só que eu tenho preferência por outros sabores. Outras

marcas. Éh.”

"Mas de sabor. Tino de., De comida

Da Turma da Mônica, do Miojo, ex

gosto."
Mario - Personagem de videogame. Pokémon - Personagem de videogame. Sonic - Personagem de videogame. Kirby - Personagem de videogame.

ersonagem ou mascote.

Gosta somente dos personagens de games.

"Éh... Porque eu não gosto de nenhum. Eu

acho todos..."

"E quais os personagens de que você mais gosta?"

"Éh! Mário!... Pokémon!... Sonic!...Éh... E

Kirby!"

"E como chama aquele verde?

"Luigi!... Yoshi!..."

"Tem o Yoshi... Que ele é verde."

"E aquele que sai correndo / voando?"

"Sonic! Eu já tinha falado."
Os Vingadores

Turma da Mônica

Homem Aranha

Minions

\section{Mais personagen \\ Hotel Transilvânia \\ Pets}

Princesas

"Que eu gosto... São os Vingadores!... A

Turma da Mônica!... E . O Homem Aranha!"

"Hum... Eu também gosto bastante dos

Minions!"

"Hum... Gosto de desenho também... Gosto, tipo, de desenhos assim..."

"Hum... Da Transilvânia!... Os Pets!... E..

Éh... As Princesas!"
Pegando os cards com personagens:

Turma da Mônica - Mickey - Minnie Ursinho (Pullman) - Ela escolheu. Mas

desistiu.

Frozen - Homem Aranha

Os Vingadores - Mônica - Cebolinha

Escolhendo os personagens:

Minions - Peppa Pig - Bob Esponja -

Mônica - Cebolinha - Homem Aranha -

Frozen - Os Vingadores - Mickey -

Turma da Mônica - Minnie

Personagens que mais gosta:

Mônica - Minnie - Turma da Mônica

Minions - Bob Esponja -

Mais personagens:

Pets - Rei Leão -

Meu Malvado Favorito (Gru)

Moana - Princesas

Fonte: Elaborado pela autora

Legenda:

Falas da criança mais velh

Falas da criança mais nova

Falas do pai

Falas da mãe

Falas da pesquisadora 


\section{DESENHOS: CONSUMO ALIMENTAR}

Desenhos elaborados pelas crianças sobre seus gostos e preferências no consumo alimentar (o que gostam e o que não gostam de comer).

Cada criança recebeu uma folha de papel em branco. E na folha, as crianças foram solicitadas a fazer uma dobradura para dividir o papel em quatro partes iguais, numerando cada uma das partes em sequência (1-2-3-4).

Em seguida, as crianças foram solicitadas a fazer os desenhos, em cada uma das partes do papel, seguindo a ordem indicada, de acordo com a sequência das solicitações para os desenhos:

1 - Que gosta de comer.

2 - Que não gosta de comer.

3 - Que gosta de comer e é saudável.

4 - Que gosta de comer e não é saudável.

Ao final, após a conclusão dos desenhos, as crianças foram convidadas a falar sobre o que desenharam, destacando os alimentos / produtos alimentícios que gostam de comer, que não gostam de comer, que gostam de comer e são saudáveis, e que gostam de comer mas não são saudáveis. Explicando o porquê de cada escolha, falando sobre os alimentos / produtos alimentícios, e expressando as preferências e saberes infantis sobre o consumo alimentar.

Durante a atividade, cada solicitação feita às crianças era denominada como desafio.

A atividade foi finalizada quando as crianças concluíram todos os desenhos solicitados na forma de desafios.

O Quadro 5 contempla o registro da participação das crianças na atividade lúdica proposta, demarcando as perspectivas e subjetividades infantis e agências das crianças no desenvolvimento da Brincadeira de Comer: Desenhos: Consumo Alimentar. 


\section{CONSUMO ALIMENTAR}

\section{FAMÍLIA 1}

MENINA

MENINO

\section{Creme de avelã e cacau - Nutella - Que gosta de comer.}

Tangerina - --- - Que não gosta de comer.

Banana - --- - Que gosta de comer e é saudável.

Chiclete - --- - Que gosta de comer, mas não é saudável.

"Nutella!"

"Eu gosto de Nutella porque... porque ela... Porque ela tem um gosto de chocolate muito bom!"

"Mexerica!"

"Eu só gosto do suco de tangerina."

"Porque... assim.. Não é só por causa da semente.

É por causa do... do gosto e daquela palhinha que tem em volta."

"Eu não gosto de mexerica."

"Banana!"

"Banana é uma fruta. E por isso que ela é saudável."

"Bem gostosa!"

"E ela é gostosa. Porque ela tem um doce muito bom!"

"Chiclete!"

"Não é saudável, mas é gostoso."

"Ele tem um gosto bom. Mas ele não faz bem pra gente."

"Porque ele tem muito açúcar.

"Eaí os dentes. Você vai perdendo os dentes. Aí não faz bem."

"E aí se você engolir... Pode acontecer um monte de coisa. Aí não faz bem."

\section{Chocolate - Twix - Que gosta de comer.}

Tomate - --- - Que não gosta de comer.

Água de coco - --- - Que gosta de comer e é saudável.

Balinhas - --- - Que gosta de comer, mas não é saudável.

[Água] - --- - Ele escolheu água. Mas desistiu. - Trocou por água de coco.

[Cerveja] - --- - Ele queria escolher cerveja. - Mas mudou de ideia. Escolheu balinhas.

"Twix!"

"É chocolate, caramelo e biscoito!"

"Porque é docinho. Tem biscoito... Tem caramelo.. E é muito bom! Pronto."

"Tomate!"

"Quem gosta de suco de tomate?"

"Eu nunca tomei."

"Eu também não."

"Eu também nunca."

"Hummm! Agora veio um cheiro de molho de tomate!"

"Verdade!

"Eu não sei por que eu não gosto de tomate, mas gosto do molho de tomate."

"Talvez o molho de tomate nem tenha tomate."

"Verdade! Pode ser feito de ketchup. Mas ketchup é feito de tomate!"

"É!"

"Eu não gosto da coisa gelatinosa e da semente. É o que eu menos gosto, na verdade,"

"Porque eu não gosto daquela coisa gelatinosa e da semente."

"Água!"

"Não. Éágua de coco. É água de cocol"

Ele mudou de ideia.

"Eu escrevi errado. Não é água. É água de coco. É água de coco!"

"Porque é muito gostoso!

E também.. É saudável porque é a água de uma fruta!"

"Cerveja!"

"Eu vou escrever cerveja."

"Mas tem que ser gostoso."

"É! É!!

Depois ele mudou de ideia

"É uma coisa óbvia.."

"Balinha!"

"Qualquer balinha não é saudável."

"Ela é gostosa porque é docinha. E eu adoro coisa doce!"

"(Não é saudável) Porque ela gruda nos dentes e faz mal."

"E ela é muito doce." 
Hambúrguer - McDonald's - Que gosta de comer.

Alface - --- - Que não gosta de comer.

Melancia - --- - Que gosta de comer e é saudável.

Chocolate - --- - Que gosta de comer, mas não é saudável.

"Ah... Eu desenhei um hambúrguer. Éh."

"Ah... Pode ser qualquer um. Mas... Se for o do McDonald's... Eu vou ficar mais feliz! Hahaha! Éh!"

"Mais feliz ainda! Éh!... Porque o do McDonald’s é a melhor coisa!... Do mundo!"

"Melhor alface do mundo! Haha!"

"Melancia!"

"Uma melancia-Magali!"

"Éh... Haha!"

"Uma melancia."

"Chocolate! Chocolate de barra, assim. Que eu vou comendo de fileirinha em fileirinha."

"Uma fileirinha por semana, né?"

"Por dia! Haha!"
Salgadinho - Cebolitos - Que gosta de comer.

Alface - --- - Que não gosta de comer.

Tomate - - Que gosta de comer e é saudável.

Pizza - -.- - Que gosta de comer, mas não é saudável.

"Um salgadinho que é... Que é feito de cebola... Que é o Cebolitos!"

"Eu achava que você gostava mais do Cheetos.?

"Sim. Eu até... Eu gosto!

Então comecei a falar sobre o próximo desafio:

"Bom... Eu não vou escolher salgadinho de novo. Que eu não sou fã de todos os salgadinhos do mundo."

"Um alface. Eu não gosto de alface."

"Um tomate!"

"Uma pizza! Sim... Com catupiry. Não parece... Mas é." 
Creme de avelã e cacau - Nutella - Que gosta de comer.

Queijo processado - Polenguinho - Que não gosta de comer.

Manga - --- - Que gosta de comer e é saudável.

Hambúrguer - McDonald's - Que gosta de comer, mas não é saudável.

Cenoura - --- - Que não gosta de comer, mas é saudável.

Pudim - Que não gosta de comer e ñó é saúvén.

"Que eu gosto: Nutella!"

"O meu, eu escolhi pelo que eu gosto mesmo. Porque... A Nutella eu não como muito. Mas eu gosto!"

"A Nutella! Porque eu gosto muito de chocolate! E ela é muito doce!"

"E o que eu não gosto... Não gosto mesmo: Éh... Polenguinho."

"E o Polenguinho, eu não gosto não. Eu já tentei comer na escola... Que dá. Mas eu não gosto."

"O Polenguinho. Porque... Éh... Eu não gosto muito do gosto.

E é que nem requeijão. E eu não... Éh. Éh... E eu não gosto muito de requeijão,"

"E você já tentou comer e não gostou né?"

"Não. Não gostei."

"Manga!"

"E manga é saudável?"

"Éh. Porque é uma fruta."

"Eu vou de manga!"

"Eu escolhi a manga. Que é uma fruta que eu gosto muito! E eu sei que é saudável. Porque é uma fruta."

"Hambúrguer!"

"Qual é o hambúrguer?"

"Eu to tentando farer. do McDonald's. Só que eu não lembro muito o que vem."

"O Hambúrguer. Porque ele tem muita gordura."

"Hum... Cenoura."

"Eh... Cenoura. Eu acho o gosto meio ruim."

"E porque ela é saudável?"

"Hum... Porque ela faz parte dos legumes."

"Hum... Pudim. Pudim!"”

"Pudim você não gosta e também não é saudável?

"Éh. Eu não gosto"”

"O pudim. Éh. Porque ele é uma guloseima."

"E por que você não gosta?"

"Eu não gosto muito do gosto dele. Éh."
Chocolate - Bis - Que gosta de comer.

Maçã - --- - Que gosta de comer.

Salgadinho - Cheetos - Que gosta de comer.

Alface - --- - Que não gosta de comer.

Mamão - --- - Que não gosta de comer.

"Os que ela gosta, eu escolhi pelo que... Pelo que ela mais come. Que é: O salgadinho Cheetos e o Bis. E a maçã, que ela escolheu." "E tem o desenho que a Livia fez né!"

"Parece uma maçã."

"Vem cá Livia! O que você desenhou aqui? É maçã? É uma maçã?" "Sim." (com a cabeça)

"O que ela não gosta, eu não sei muito. Quem falou foi o meu pai.

E aí... Eu desenhei... Eu desenhei: O mamão. E o alface. Éh."

\section{Fonte: elaborado pela pesquisadora}

Legenda:

Falas da criança mais velha

Falas da criança mais nova

Falas do pai

Falas da mãe

Falas da pesquisadora 


\section{DESENHOS: MARCAS / PERSONAGENS}

Desenhos elaborados pelas crianças sobre marcas de produtos alimentícios e marcas representadas por personagens e mascotes (marcas e personagens que as crianças conhecem / que as crianças gostam).

Cada criança recebeu uma folha de papel em branco. E na folha, as crianças foram solicitadas a fazer uma dobradura para dividir o papel em duas partes iguais, numerando cada uma das partes em sequência (1-2).

Em seguida, as crianças foram solicitadas a fazer os desenhos, em cada uma das partes do papel, seguindo a ordem indicada, de acordo com a sequência das solicitações para os desenhos:

1 - Marca de produto alimentício que conhece / que gosta.

2 - Personagem ou mascote que conhece / que gosta.

Ao final, após a conclusão dos desenhos, as crianças foram convidadas a falar sobre o que desenharam, destacando as marcas de produtos alimentícios que conhecem / que gostam e os personagens e mascotes que conhecem / que gostam. Explicando o porquê de cada escolha, falando sobre as marcas e personagens, e expressando os saberes e afetos infantis no contexto promocional das marcas e produtos alimentícios.

Durante a atividade, cada solicitação feita às crianças era denominada como desafio.

A atividade foi finalizada quando as crianças concluíram todos os desenhos solicitados na forma de desafios.

O Quadro 6 contempla o registro da participação das crianças na atividade lúdica proposta, demarcando as perspectivas e subjetividades infantis e agências das crianças no desenvolvimento da Brincadeira de Comer: Desenhos: Marcas e Personagens.

O Quadro 7 contempla o registro da participação das crianças na avaliação da atividade lúdica proposta, demarcando as perspectivas e subjetividades infantis sobre a Brincadeira de Comer e o consumo alimentar das crianças.

Em anexo apresenta-se o roteiro e dinâmica do jogo e as imagens sobre consumo alimentar (alimentos e produtos alimentícios) e sobre marcas (marcas e personagens), propostos para composição e formatação da atividade lúdica desenvolvida com as crianças na forma de jogo (jogos de cards); e o roteiro e dinâmica propostos para composição e formatação da atividade lúdica desenvolvida com as crianças na forma de desenho. Atividades lúdicas propostas na composição da Brincadeira de Comer, desenvolvida com as crianças no quarto encontro no contexto das famílias participantes do estudo. (APÊNDICE F) Também em anexo, 
apresentam-se imagens documentando a participação das crianças na Brincadeira de Comer em cada contexto familiar; imagens das composições alimentares e composições de marcas elaboradas pelas crianças nos jogos de cards; e imagens dos desenhos elaborados pelas crianças na atividade lúdica proposta. (APÊNDICE T) 


\section{MARCAS E PERSONAGENS}

\section{FAMÍLIA}

\section{MENINA}

MENINO

Pullman - Marca que conhece / gosta

Magali - Personagem que conhece / gosta.

"Que eu gosto... (?)"

"Pullman!"

Inspirada na resposta do menino.

"Eu to desenhando o mascote da Pullman (ursinho)."

"Eu gosto (da marca)."

"A Magali!"

"Mas ela ta feia."

"(Eu já vi ela) numa melancia."
Pullman - Marca que conhece / gosta.

Cebolinha - Personagem que conhece / gosta.

"Pullman!"

"É uma marca de pão bolinho. Eé muito gostoso!"

Respondeu logo e inspirou a menina.

O menino fala também sobre a marca Nutella:

"Nutella! Nutella não é Nutella. É creme de avelã!"

"Cebolinha!"

Inspirado na resposta da menina.

"Eu vou fazer o Cebolinha!"

"Porque eu já vi cle numa marca de Miojo!"

"E cebola! Parece uma cebola a cabeça dele! 1234 .

Desenhando e contando os fios do cabelo do Cebolinha.

\section{FAMÍLIA 2}

MENINA

MENINO

Nutella - Marca que conhece / gosta.

Minions - Personagem que conhece / gosta.

"Nutella! Haha!"

"Todo mundo já sabe essa!"

"E qual a cor da marca Nutella?"

"Éh... Eu acho que é só vermelho."

"Nutella! (Porque é Nutella!) Éh! Haha!"

"Os Minions!"

"O único tipo de danone que eu gosto. Que é o danone com granulado."

"E esse danone que tu gosta é dos Minions?"

"Éh!... Os Mínions!"

"Os Minios! (Porque estão no único tipo de danone que eu gosto. Com granulado.)

Éh! Isso! Haha! Isso!"
Cheetos - Marca que conhece / gosta.

Leopardo (Cheetos) - Personagem que conhece / gosta.

"Cheetos!"

"Cheetos é com 2Es. Eu sei."

"E qual é a cor da marca Cheetos?"

"Amarelo!"

"Cheetos é com 2Os? Ou só com 2Es?"

"Só com 2Es."

"Ah!... Então ta!"

"Cheetos! (Porque é Cheetos!) Sim. Porque eu gosto!"

"Ah. Como é que eu vou desenhar o Cheetos?"

"O Cheetos tem personagem / mascote?"

"O Che "To

"É um tigrinho!"

"Leopardo!"

"Éh! Isso!"

"Leopardo! (Porque é do Cheetos!) Éh! Porque é do Cheetos!" 
FAMÍLIA 3

MENINA MAIS VELHA

MENINA MAIS NOVA

KitKat - Marca que conhece / gosta.

Lady Bug - Personagem que conhece / gosta

"A marca, eu coloquei o KitKat!

Que eu gosto bastante!"

"Porque. Por dentro ele é como se fosse uma bolacha. Então... Eu... Eu gosto porque é crocante. Éh!"

"E... O personagem, eu fiz a Lady Bug!

Que é um personagem que eu gosto muito!"

"Lady Bug!. Eu mais gosto porque.. Ela é uma joaninha. Ela é uma joaninh.

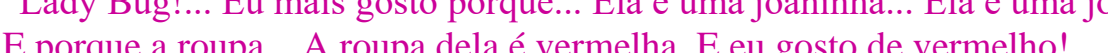

E porque a roupa... A roupa dela é vert

"Passa em a

"Passa em algum cana

"No Gloob. Éh."

"Ácho que na Globo também passava."

"É filme ou desenho?"

"É desenho... É uma serie, assim."

"Éh... Éh... É tipo uma série."

Fonte: elaborado pela pesquisadora

Legenda:

Falas da criança mais velh

Falas da criança mais nova

Falas do pai

Falas da mãe

Falas da pesquisadora
Minions - Personagem que gosta.

"Você fez os Minions?"

"Você fez o que?"

“Tem Minions aí? Então mostra! Cadê os Minions?”

"Mostra!"

"Onde ta os Minions?"

E a menina mais nova, então mostrou o seu desenho no vídeo.

"Ah! Olha lá! Tem os Minions aí! Que bonito o seu desenho!" 


\section{AVALIAÇÃO DAS CRIANÇAS}

\section{FAMÍLIA 1}

\section{MENINA}

FAMÍLIA 2

\section{MENINA}

"Eu achei... Eu achei essa brincadeira bem legal!

Assim... De escolher as marcas... Escolher os produtos... Eu achei... Montar as refeições.

Achei bem legal essa brincadeira!"
MENINO

MENINO

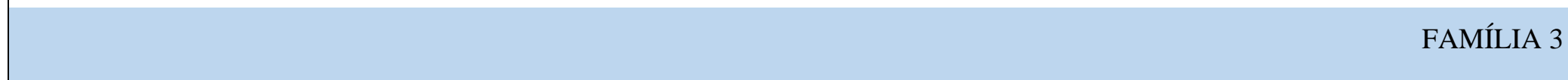

MENINA MAIS VELHA

"Éh... Eu gostei!

E... Eu gostei porque eu pude escolher o que eu mais gosto, assim, de comer. Que é mais guloseima!"

"Porque eu pude escolher o que eu gosto. Ou o que eu queria comer... Éh... Nas refeições.

Que é mais guloseimas!"

“Éh... Eu gostei!

E... Porque... Tem vários personagens que eu gosto!

E... Várias marcas também de chocolate! Que eu também gosto muito! Éh!”

"Eu gostei! (das atividades)"

"Mas eu preferi mais o desenho. Porque eu gosto muito de desenhar!"

"Eu... Eu quero até, quando eu crescer, me tornar uma desenhista!"

“Ah! Que legal! E o que você achou mais legal em cada atividade?"

"Éh... No de cards... Eu pude escolher o que eu mais gosto."

"E o de desenho... Eu pude fazer o que eu mais gosto, também. Que é desenhar!"
Fonte: elaborado pela pesquisadora
Legenda:
Falas da criança mais velha
Falas da criança mais nova
Falas do pai
Falas da mãe
Falas da pesquisadora

"Também achei legal!" 


\section{BRINCADEIRA DE COMPRAR}

\section{JOGO / DRAMATIZAÇÃO: SIMULAÇÃO DE COMPRAS}

Jogo-dramatização proposto para uma atividade lúdica de simulação de compra e consumo de alimentos com as crianças no supermercado.

O jogo teve início no supermercado, quando as crianças foram convidadas para uma brincadeira de fazer compras: as crianças foram convidadas a escolher livremente - dentre toda a gama de produtos alimentícios do supermercado (alimentos / bebidas / guloseimas / produtos industrializados / alimentos in natura) - alguns produtos alimentícios para colocar no carrinho em uma experiência lúdica de simulação de compra e consumo.

Inicialmente, cada criança foi solicitada a pegar o seu carrinho de compras e seguir livremente pelos corredores do supermercado, dando início à experiência lúdica de simulação de compras com a seleção de cinco produtos alimentícios, de qualquer natureza - alimentos, bebidas ou guloseimas, industrializados ou in natura - de acordo com seus gostos, preferências e afetos.

Em seguida, as crianças foram solicitadas a falar sobre suas escolhas, apresentando os produtos alimentícios selecionados no carrinho, explicando os porquês de cada produto / marca escolhida, e expressando suas perspectivas, saberes e afetos sobre as marcas e produtos alimentícios.

$\mathrm{Na}$ sequência, as crianças foram solicitadas a destacar os produtos alimentícios escolhidos e colocados no carrinho, apresentando-os na ordem de preferência das crianças (as marcas e produtos alimentícios que elas mais gostam / menos gostam) e justificando as suas escolhas e preferências quanto às marcas e produtos.

Mais adiante, ao falar sobre saudabilidade dos alimentos com as crianças, elas foram solicitadas a estabelecer algumas relações e classificações entre os produtos alimentícios colocados no carrinho, de acordo com parâmetros de saudabilidade considerados por elas (alimentos mais saudáveis / menos saudáveis) e justificando as suas elaborações e classificações quanto à saudabilidade dos produtos alimentícios escolhidos.

Ao final, as crianças foram solicitadas a escolher, dentre os produtos alimentícios colocados no carrinho, três produtos de que elas gostam muito e que levariam para casa se estivessem em uma experiência real de compras no supermercado, explicando os motivos de cada escolha e expressando suas perspectivas, saberes e afetos com relação a cada produto / marca escolhido. 
O jogo foi finalizado quando as crianças concluíram todas as solicitações efetuadas sobre as marcas e produtos alimentícios escolhidos e apresentados no carrinho de compras.

Após a conclusão da atividade lúdica, foi comunicado às crianças que os três produtos alimentícios escolhidos por elas ao final da brincadeira (as marcas e produtos alimentícios de que elas mais gostam) seriam efetivamente comprados para elas, como um presente. As compras foram efetuadas ao final da atividade pela pesquisadora em campo.

O Quadro 8 contempla o registro da participação das crianças na atividade lúdica proposta, demarcando as perspectivas e subjetividades infantis e agências das crianças no desenvolvimento da Brincadeira de Comprar. Incluindo a avaliação das crianças sobre a Brincadeira de Comprar e o consumo alimentar infantil.

Em anexo apresenta-se o roteiro e dinâmica propostos para composição e formatação da atividade lúdica desenvolvida com as crianças na forma de jogo e dramatização. Atividade lúdica proposta na composição da Brincadeira de Comprar, desenvolvida com as crianças no quinto encontro no contexto das famílias participantes do estudo (APÊNDICE H). Também em anexo, apresentam-se imagens documentando a participação das crianças na Brincadeira de Comprar em cada contexto familiar; e imagens das composições de marcas e produtos alimentícios escolhidos pelas crianças na simulação de compras no supermercado na atividade lúdica proposta. (APÊNDICE U) 
MARCAS E PRODUTOS NO CARRINHO:

\begin{tabular}{|c|c|c|c|c|c|}
\hline \multicolumn{6}{|c|}{ MARCAS E PRODUTOS NO CARRINHO: } \\
\hline \multicolumn{2}{|c|}{ FAMÍLIA 1} & \multicolumn{2}{|c|}{ FAMÍLIA 2} & \multicolumn{2}{|c|}{ FAMÍLIA 3} \\
\hline MENINA & MENINO & MENINA & MENINO & MENINA MAIS VELHA & MENINA MAIS NOVA \\
\hline $\begin{array}{l}\text { Sobremesa (chocolate) - Danette } \\
\text { Achocolatado (em pó) - Nescau } \\
\text { Balas de gelatina (melancia) - Fini } \\
\text { Chips (batata frita) - Lays } \\
\text { Leite (semidesnatado / garrafa) - } \\
\text { Shefa } \\
\text { [Chocotone] - [Bauducco] - Trocou } \\
\text { por Balas de gelatina (melancia): } \\
\text { Fini. }\end{array}$ & $\begin{array}{l}\text { Suco (morango / caixinha) - Vigor } \\
\text { (Minions) } \\
\text { Manga - -- } \\
\text { Banana - --- } \\
\text { Cereais (sucrilhos) - Kellogg's (Star } \\
\text { Wars) } \\
\text { Balas de gelatina (melancia) - Fini }\end{array}$ & $\begin{array}{l}\text { Chocolate branco (barra) - Laka } \\
\text { Chocolate (barra) - Milka (Oreo) } \\
\text { Bolinho (gotas de chocolate) - Ana } \\
\text { Maria } \\
\text { Suco (laranja / caixinha) - Ades } \\
\text { Chocolate - Kinder Ovo }\end{array}$ & $\begin{array}{l}\text { Melancia (em cubos) - --- - Ele queria } \\
\text { pegar a fruta inteira. Mas a mãe sugeriu } \\
\text { em cubos. } \\
\text { Refrigerante (citrus) - Schweppes } \\
\text { Balas de gelatina - Fini (Emoji) } \\
\text { Coxinha de frango - Supermercado } \\
\text { Jaguaré } \\
\text { Pão de forma - Seven Boys }\end{array}$ & $\begin{array}{l}\text { Cookie (gotas de chocolate) - Bauducco } \\
\text { Chocolate - KitKat } \\
\text { Creme de avelã e cacau - Nutella } \\
\text { Salgadinho - Ruffles } \\
\text { Balas de gelatina (tubes / morango) - Fini }\end{array}$ & $\begin{array}{l}\text { Cookie (chocolate) - Bauducco - } \\
\text { (Choco Biscuit) } \\
\text { Chocolate branco - Bis } \\
\text { Biscoito salgado - Club Social } \\
\text { Salgadinho - Ruffles } \\
\text { Confeitos de chocolate - M\&M's } \\
\text { Balas de gelatina (tubes / banana+tutti- } \\
\text { frutti) - Fini (Minions) }\end{array}$ \\
\hline \multicolumn{6}{|c|}{ APRESENTAÇÃO DAS MARCAS E PRODUTOS: } \\
\hline \multicolumn{2}{|c|}{ FAMÍLIA 1} & \multicolumn{2}{|c|}{ FAMÍLIA 2} & \multicolumn{2}{|c|}{ FAMÍLIA 3} \\
\hline MENINA & MENINO & MENINA & MENINO & MENINA MAIS VELHA & MENINA MAIS NOVA \\
\hline $\begin{array}{l}\text { Sobremesa (chocolate) - Danette } \\
\text { Balas de gelatina (melancia) - Fini } \\
\text { Chips (batata frita) - Lays } \\
\text { Leite (semi-desnatado / garrafa) - } \\
\text { Shefa } \\
\text { Achocolatado (em pó) - Nescau } \\
\text { "Danette: Porque é de chocolate ao } \\
\text { leite. Delicioso!" } \\
\text { "Balas Fini: Porque começa azedo e } \\
\text { depois fica doce. Super delicioso!" } \\
\text { "Batata Lay's: Porque tem gosto } \\
\text { bom... E é de batata." } \\
\text { "Leite Shefa: Porque o leite é } \\
\text { branquinho... Vem da vaca... E é } \\
\text { super bom!"” } \\
\text { "Nescau: É um pozinho de } \\
\text { chocolate... E é super bom!" }\end{array}$ & $\begin{array}{l}\text { "Banana: Porque é gostoso!” } \\
\text { "Manga: Porque é molinha... E } \\
\text { gostosa... E docinha!" } \\
\text { "Kellogg's: Porque é durinho e } \\
\text { crocante. E chocolate é gostoso!" } \\
\text { "Balas Fini: Porque começa } \\
\text { azedinho... E depois fica doce!” } \\
\text { "Suco Minions: Porque é doce... E } \\
\text { fofinho (o personagem)." }\end{array}$ & $\begin{array}{l}\text { "Chocolate Laka: Porque prefiro } \\
\text { chocolate branco. E porque to mais } \\
\text { acostumada a comer mais chocolate } \\
\text { desse tipo, como o Laka, do que o } \\
\text { Milka. Por causa do preço, } \\
\text { principalmente." } \\
\text { "Chocolate Milka (Oreo): Escolhi esse } \\
\text { segundo, porque gosto tanto da bolacha } \\
\text { Oreo! Quanto do chocolate Milka!" } \\
\text { "Chocolate Kinder Ovo: Porque é raro } \\
\text { comer ele, por causa do preço também. } \\
\text { E também porque eu gosto muito do } \\
\text { gosto dele!" }\end{array}$ & $\begin{array}{l}\text { "Melancia: Porque eu gosto dela! E eu } \\
\text { acho saudável.” } \\
\text { "Refrigerante Schweppes (citrus): } \\
\text { Porque é o refrigerante que, quando foi a } \\
\text { primeira vez que eu bebi ele, eu gostei!" } \\
\text { "Balas de gelatina Fini (Emoji): Porque } \\
\text { ele é mole. E ele é gostoso!" } \\
\text { "Pão de forma Seven Boys: Porque tava } \\
\text { faltando em casa.” } \\
\text { "Coxinha de frango: Eu escolhi porque é } \\
\text { bem de vez em quando, quando a gente } \\
\text { compra. E aí é uma coisa que a gente } \\
\text { compra e aí acaba rápido. Porque eu e a } \\
\text { Sayuri, a gente come muito rápido!" }\end{array}$ & $\begin{array}{l}\text { Cookie (gotas de chocolate) - Bauducco } \\
\text { Chocolate - KitKat } \\
\text { Creme de avelã e cacau - Nutella } \\
\text { Salgadinho - Ruffles } \\
\text { Balas de gelatina (tubes / morango) - Fini } \\
\text { "Cookie Bauducco: Porque eu gosto } \\
\text { muito! E eu como muito também!" } \\
\text { "KitKat: Porque ele, por dentro, parece } \\
\text { que ele tem uma bolacha. E por causa do } \\
\text { chocolate também. Que eu acho bem } \\
\text { gostoso!" } \\
\text { "Nutella: Porque ela tem muito açúcar. E } \\
\text { eu gosto! E eu gosto de chocolate com } \\
\text { bastante açúcar!" } \\
\text { "Ruffles: Porque eu gosto muito! Porque } \\
\text { toda vez que o meu pai vinha no Extra, } \\
\text { ele comprava pra mim. E eu gosto muito } \\
\text { de todos os tipos de batata: frita, } \\
\text { cozida..." }\end{array}$ & \\
\hline
\end{tabular}


"Suco Ades (laranja): Eu escolhi porque ele é um dos poucos sucos de laranja de caixinha que eu gosto."

"Bolinho Ana Maria (gotas de

chocolate): Eu escolhi ele porque eu

gosto bastante do bolinho Ana Maria! E

principalmente do com gotas de

chocolate!"
“Fini: Porque, não sempre, mas às vezes, quando a gente vai no mercado, meu pai compra um pacotinho pequeno de Fini pra mim. Porque é de morango! E minha fruta preferida é morango!"

\section{QUE MAIS GOSTA:}

FAMÍLIA 1

MENINA

\section{FAMÍLIA 2}

MENINA
MENINO

MENINA MAIS VELHA
FAMÍLIA 3

MENINA MAIS NOVA
Chocolate (barra) - Milka (Oreo)

Chocolate - Kinder Ovo

Chocolate branco (barra) - Lak

Suco (laranja / caixinha) - Ades

Bolinho (gotas de chocolate) - Ana Maria

"Chocolate Milka (Oreo): Porque é raro

ter em casa. E é muito bom!"

"Chocolate Kinder Ovo: Porque o

chocolate dele é bem docinho. É

gostoso!"

"Chocolate Laka: Porque o meu

chocolate favorito é o branco! E porque

ele rende bastante."

"Suco Ades (laranja): Porque ele é o

único suco de laranja que eu considero

bom."

"Bolinho Ana Maria (gotas de

chocolate): Porque ele é um bolinho de

chocolate. E é muito bom as gotas de

chocolate também. Eu adoro as gotas de

chocolate!"

\section{Coxinha de frango - Supermercado \\ Jaguaré \\ Balas de gelatina - Fini (Emoji) \\ Melancia (em cubos) - --- \\ Refrigerante (citrus) - Schweppes Pão de forma - Seven Boys}

"Coxinha de frango: Porque ela é

gostosa!"

"Balas de gelatina Fini (Emoji): Porque

tinha carinhas!"

"Melancia: Porque ela é saudável.

Porque ela é boa!"

"Refrigerante Schweppes (citrus):

Porque é um refrigerante. Ele é gostoso!" "Pão de forma Seven Boys: Porque ele é gostoso! Porque tava acabando (en casa)."

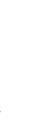




\begin{tabular}{|c|c|c|c|c|c|}
\hline \multicolumn{6}{|c|}{ QUE É MAIS SAUDÁVEL / MENOS SAUDÁVEL: } \\
\hline \multicolumn{2}{|c|}{ FAMÍLIA 1} & \multicolumn{2}{|c|}{ FAMÍLIA 2} & \multicolumn{2}{|c|}{ FAMÍLIA 3} \\
\hline MENINA & MENINO & MENINA & MENINO & MENINA MAIS VELHA & MENINA MAIS NOVA \\
\hline $\begin{array}{l}\text { Leite (semidesnatado / garrafa) - } \\
\text { Shefa } \\
\text { Chips (batata frita) - Lays } \\
\text { Balas de gelatina (melancia) - Fini } \\
\text { Sobremesa (chocolate) - Danette } \\
\text { Achocolatado (em pó) - Nescau }\end{array}$ & $\begin{array}{l}\text { Banana - --- } \\
\text { Manga - --- } \\
\text { Suco (morango / caixinha) - Vigor } \\
\text { (Minions) } \\
\text { Balas de gelatina (melancia) - Fini } \\
\text { Cereais (sucrilhos) - Kellogg's (Star } \\
\text { Wars) }\end{array}$ & $\begin{array}{l}\text { Suco (laranja / caixinha) - Ades } \\
\text { Bolinho (gotas de chocolate) - Ana } \\
\text { Maria } \\
\text { Chocolate - Kinder Ovo } \\
\text { Chocolate branco (barra) - Laka } \\
\text { Chocolate (barra) - Milka (Oreo) }\end{array}$ & $\begin{array}{l}\text { Melancia (em cubos) - --- } \\
\text { Pão de forma - Seven Boys } \\
\text { Refrigerante (citrus) - Schweppes } \\
\text { Balas de gelatina - Fini (Emoji) } \\
\text { Coxinha de frango - Supermercado } \\
\text { Jaguaré }\end{array}$ & $\begin{array}{l}\text { Salgadinho - Ruffles } \\
\text { Balas de gelatina (tubes / morango) - Fini } \\
\text { Chocolate - KitKat } \\
\text { Cookie (gotas de chocolate) - Bauducco } \\
\text { Creme de avelã e cacau - Nutella }\end{array}$ & \\
\hline $\begin{array}{l}\text { Mais saudável: } \\
\text { "Leite Shefa: Porque a vaca é um } \\
\text { bicho... E veio da vaca." } \\
\text { "O leite é bom para os ossos." } \\
\text { "Batata Lay’s: Porque batata é um } \\
\text { vegetal... E é feito de batata." } \\
\text { "Balas Fini: É como se um chiclete } \\
\text { tivesse várias fatias de melancia!" } \\
\text { Menos saudável: } \\
\text { "Danette: Porque tem chocolate... } \\
\text { Chocolate é doce... E doce não é } \\
\text { saudável." } \\
\text { "Nescau: Porque é um pozinho de } \\
\text { chocolate doce." }\end{array}$ & $\begin{array}{l}\text { Mais saudável: } \\
\text { "Banana: Porque é banana... Porque é } \\
\text { fruta." } \\
\text { "Manga: Porque também é fruta." } \\
\text { "Suco Minions: Porque é feito de } \\
\text { morango... E é uma fruta... E porque } \\
\text { morango tem vitamina." } \\
\text { Menos saudável: } \\
\text { "Balas Fini: É mais ou menos } \\
\text { saudável. Porque é de melancia, que é } \\
\text { saudável... E é chiclete, que é doce. } \\
\text { Imagina várias fatiazinhas de melancia } \\
\text { em um só chiclete!" } \\
\text { "Kellogg’s: É mais ou menos } \\
\text { saudável. Saudável porque tem } \\
\text { nutrientes... E tem chocolate, que é } \\
\text { doce. Porque come com leite... } \\
\text { Chocolate é doce." }\end{array}$ & $\begin{array}{l}\text { "Suco Ades (laranja): Porque ele é um } \\
\text { suco de laranja. E então, deve ter um } \\
\text { pouco de laranja." } \\
\text { "Bolinho Ana Maria (gotas de } \\
\text { chocolate): Porque ele é um bolinho e } \\
\text { tem massa. E deve ter trigo na massa." } \\
\text { "Chocolate Kinder Ovo: Porque ele só } \\
\text { tem chocolate na casca. Não tem nada de } \\
\text { chocolate dentro. - E isso é muito triste. } \\
\text { Não ter chocolate dentro. - E porque } \\
\text { também, de acordo com a embalagem, } \\
\text { deve ter leite." } \\
\text { "Chocolate Laka: Porque se ele é } \\
\text { branco, deve ter mais leite do que o } \\
\text { chocolate preto. Eu acho." } \\
\text { "Chocolate Milka (Oreo): Que é o } \\
\text { menos saudável de todos. Porque além } \\
\text { do chocolate, tem o Oreo do recheio } \\
\text { (bolacha doce e recheada)." }\end{array}$ & $\begin{array}{l}\text { "Melancia: Porque tem semente." } \\
\text { "Pão de forma Seven Boys: Porque ele é } \\
\text { feito de trigo." } \\
\text { "Refrigerante Schweppes (citrus): } \\
\text { Porque ele é gostoso." } \\
\text { "Balas de gelatina Fini (Emoji): Porque } \\
\text { ela é mais doce." } \\
\text { "Coxinha de frango: Porque ela é mais } \\
\text { salgada." }\end{array}$ & $\begin{array}{l}\text { "Ruffles: Não é que ele é menos } \\
\text { guloseima. Mas é que ele é mais salgado } \\
\text { que doce." } \\
\text { "Fini: Porque ele não tem tanto gosto. } \\
\text { Mas tem um pouquinho de gosto de } \\
\text { morango. Que é uma fruta. E frutas são } \\
\text { saudáveis." } \\
\text { "KitKat: Porque dentro dele tem uma } \\
\text { bolacha. E algumas bolachas são } \\
\text { saudáveis (como a bolacha de água e } \\
\text { sal)." } \\
\text { "Cookie Bauducco: Porque ele também é } \\
\text { uma bolacha. E ele tem gotas de } \\
\text { chocolate. E pra mim essas gotas de } \\
\text { chocolate não é tão doce." } \\
\text { "Nutella: Ela é a última porque o } \\
\text { chocolate dela tem muito açúcar." }\end{array}$ & \\
\hline \multicolumn{6}{|c|}{ PRODUTOS MAIS SAUDÁVEIS: } \\
\hline \multicolumn{2}{|c|}{ FAMÍLIA 1} & \multicolumn{2}{|c|}{ FAMÍLIA 2} & \multicolumn{2}{|c|}{ FAMÍLIA 3} \\
\hline MENINA & MENINO & MENINA & MENINO & MENINA MAIS VELHA & MENINA MAIS NOVA \\
\hline $\begin{array}{l}\text { Laranja - --- } \\
\text { Água mineral - Crystal }\end{array}$ & $\begin{array}{l}\text { Cenoura - --- } \\
\text { Morango - --- }\end{array}$ & & & & \\
\hline Iogurte grego (morango) - Vigor & Melancia - --- & & & & \\
\hline
\end{tabular}


"Laranja: Porque é boa... E é uma fruta."

"Laranja tem vitamina C."

"Água: Porque é boa e saudável." "Iogurte grego: Porque é de frutas vermelhas, que é fruta... E dentro do iogurte tem uma bactéria que é boa. Minha mãe que me explicou."
"Cenoura: Porque deixa você sem usar óculos."

"Morango: Por causa que é bom... E é uma fruta."

"Melancia: Mesma coisa que o

morango. Porque é bom... E é uma

fruta."

PARA LEVAR PARA CASA:

FAMÍLIA 1

\section{MENINA}

Balas de gelatina (melancia) - Fini Chips (batata frita) - Lays

Sobremesa (chocolate) - Danette

Leite (semidesnatado / garrafa) -

Shefa

[Água mineral] - [Crystal] - Pensou

em levar água. Mas desistiu. Pois

água tem em casa.

\section{Pra levar pra casa:}

"Balas Fini: Porque chiclete é bom!..

E eu adoro!"

"Batata Lay's: Porque eu adoro!... E

é batata!"

"Danette: Porque é chocolate!"

E mais um. Saudável:

"Leite Shefa: Porque vem da vaca...

Eé bom!"
FAMÍLIA 2

MENINA

MENINO

Chocolate (barra) - Milka (Oreo)

Melancia - ---

$\begin{array}{ll}\text { Bolas de gelatina (melancia) - Fini } & \text { Bolinho (gotas de chocolate) - Ana }\end{array}$

Banana - --Maria

Coxinha de frango - Supermercado

Jaguaré

Balas de gelatina - Fini (Emoji)

Pra levar pra casa:

"Melancia: Porque eu gosto muito!

"Morango: Porque eu adoro!"

\section{E mais um. Saudável:}

"Banana: Porque banana é vida!" O chato é ficar tirando as sementes dela." gostosa! $\mathrm{E}$ as únicas que tinham er
"Chocolate Milka (Oreo): Porque ele é mais carinho. E mais raro de eu comer. aí eu aproveitei a oportunidade. E também porque ele era o favorito dos que eu peguei!"

"Chocolate Kinder Ovo: Porque não sei explicar. Ele vem pouco, mas é muito bom! E fazia tempo que eu não comia. $\mathrm{E}$ eu tava com muita vontade de comer!" "Bolinho Ana Maria (gotas de chocolate): Eu escolhi ele pra não ficar, tipo, só chocolate em si. Aí tem um pouco de massa."

Ela escolheu os três produtos. Mas levou pra casa os demais produtos também.
FAMÍLIA 3

MENINA MAIS VELHA

Creme de avelã e cacau - Nutella Salgadinho - Ruffles

Balas de gelatina (tubes / morango) - Fin

Chocolate - KitKat

Cookie (gotas de chocolate) - Bauducco

Melancia: Porque eu gosto de melancia!

"Coxinha de frango: Foi porque ela era daquele sabor de frango. E eu não lembro mais do que que tinha."

"Balas Fini (Emoji): O Fini... Porque ele era... Ele tinha formato de Emoji! E era gostoso!"

Ele escolheu os três produtos. Mas levou pra casa os demais produtos também.

"Nutella: Porque faz muito tempo que eu não como ela. E eu to com vontade!" "Ruffles: Porque também faz tempo que eu não como ele. Porque também esse Ruffles é uma batata assada. E eu gosto dela!"

"Fini: Porque eu gosto do gosto dela. Que é morango! E é minha fruta favorita! E também por causa do creme que tem dentro dela."

Ela escolheu os três produtos. Mas levou pra casa os demais produtos também.

\section{MENINA MAIS NOVA}

Confeitos de chocolate - M\&M's Salgadinho - Ruffles

Biscoito salgado - Club Social

Cookie (chocolate) - Bauducco

Balas de gelatina (tubes / banana+tutti-

frutti) - Fini (Minions)

Chocolate branco - Bis

Observação: A menina escolheu todos os produtos para levar pra casa. 
SOBRE A BRINCADEIRA DE COMPRAR:

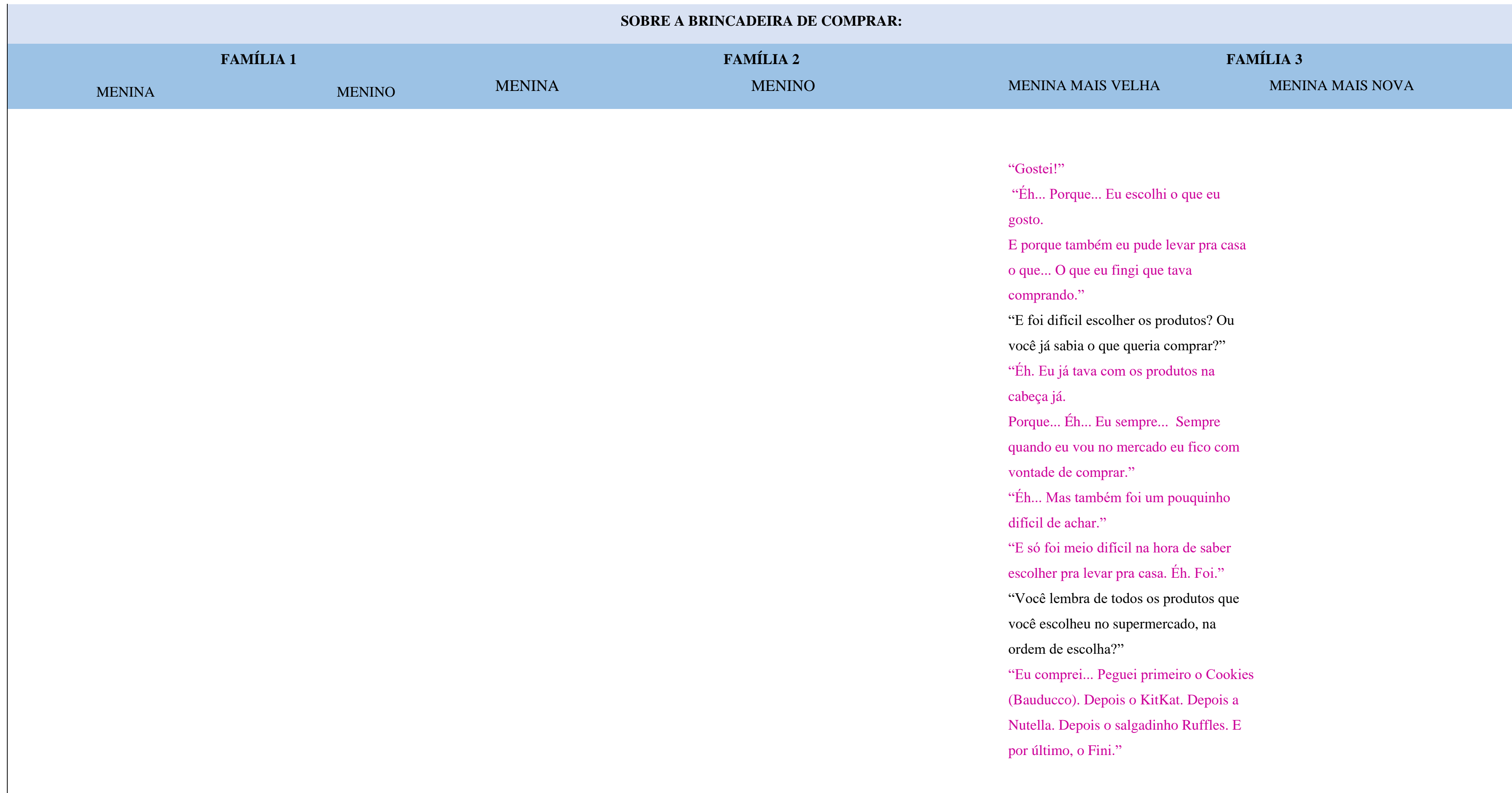

Fonte: elaborado pela pesquisadora genda:

Falas da criança mais velha

Falas da criança mais nova

Falas do pai

Falas da mãe

Falas da pesquisadora 


\section{EXPERIÊNCIA THE KIDS: UMA EXPERIÊNCIA LÚDICA DE PARTICIPAÇÃO INFANTIL}

\section{ENTREVISTA COM AS CRIANÇAS: KIDS BY KIDS}

Trata-se de atividade lúdica desenvolvida com as crianças na forma de entrevista em grupo e produção infantil de vídeos para registro da entrevista em grupo com a coparticipação das crianças.

A entrevista em grupo foi desenvolvida com as crianças ao final da pesquisa, na forma de conversação, a fim de dar voz às vozes infantis sobre os principais temas e aspectos abordados na investigação desenvolvida em campo, nos contextos familiares pesquisados, possibilitando a expressividade das perspectivas e saberes infantis sobre os tópicos abordados; a avaliação das crianças sobre o processo de investigação em seu todo e a reflexão das crianças sobre a sua participação no processo de investigação.

A entrevista em grupo desenvolvida com as crianças foi gravada em vídeo (em selfie) pelas próprias crianças (as crianças mais velhas). E os principais tópicos abordados na entrevista foram os seguintes:

- Cultura alimentar das crianças

- Mediações culturais e comunicacionais na cultura alimentar infantil

- Mediação comunicacional das marcas na cultura alimentar infantil

- Marcas e produtos alimentícios no contexto das escolhas e preferências infantis.

- Sobre a pesquisa e a participação das crianças na pesquisa

- Sobre crianças e consumo alimentar.

A atividade foi proposta às crianças com a denominação Kids by Kids, como parte do conjunto de atividades propostas para a composição da Experiência Lúdica The Kids. E foi realizada com a coparticipação das crianças sob a coordenação das crianças mais velhas.

Essa atividade foi desenvolvida na forma de uma experimentação metodológica da pesquisa com a coparticipação das crianças na produção infantil de vídeos.

Os Quadros 9, 10, 11 e 12 contemplam o registro da participação das crianças na atividade lúdica proposta, demarcando as perspectivas e subjetividades infantis e agências das crianças na realização da entrevista e produção infantil de vídeo para a experiência lúdica The Kids: Kids by Kids. 
Em anexo, apresenta-se o roteiro sugerido para orientação da entrevista em grupo realizada com as crianças na atividade lúdica proposta, desenvolvida com as crianças em cada contexto familiar:

Em anexo, apresenta-se o roteiro sugerido para orientação da entrevista em grupo realizada com as crianças na atividade lúdica proposta, desenvolvida com as crianças em cada contexto familiar: entrevista em grupo com as crianças sobre o seu consumo alimentar com a coparticipação infantil. Atividade lúdica desenvolvida com as crianças ao final da pesquisa sob a denominação Kids by Kids, como parte do conjunto de atividades propostas para composição da Experiência Lúdica The Kids. (APÊNDICE J) Também em anexo, apresentam-se imagens documentando a participação das crianças e a produção infantil de vídeos na entrevista Kids by Kids em cada contexto familiar para o desenvolvimento da atividade lúdica proposta. (APÊNDICE V) 
AS CRIANÇAS E SUA CULTURA DE CONSUMO ALIMENTAR EM CONTEXTO FAMILIAR

O QUE MAIS GOSTA DE COMER:

FAMÍLIA 1

FAMÍLIA 2

FAMÍLIA 3

MENINA

MENINO

MENINA

MENINO

MENINA MAIS VELHA

MENINA MAIS NOVA

Vídeo da menina sobre o seu consumo alimentar:

Abertura:

"Pode começar. Gravando..."

Que mais gosta de comer

"Eu mais gosto de comer...

Hambúrguer! Porque ele..."

"É gostoso!"

"Porque ele é gostoso... E dá pra

saborear muito... E ele é muito

suculentinho...

Muito bom! Principalmente o do

Mc!"

"Macarrão... Panqueca... Macarrão e panqueca!"

"Porque... O macarrão, ele é

fininho... e ele..

$\mathrm{O}$ espaguete com molho ao sugo.

Ele é muito gostoso!

Aí... ele faz... Ele é muito bom pra mim!"

"E panqueca... Porque tem aquele recheio de carne moída.

Eu gosto de primeiro comer a massa e depois a carne moíd

Aí fica muito bom!"

$O$ que é mais importante quando

escolhe algo pra comer:

"Eu acho mais importante a salada.

E depois a comida."

"Ah... o que é importante ter na

comida pra mim?"

"Arroz... feijão... salada."

"Não João! Para!"

“É importante ter na comida... é... É

tempero."

Quando escolhe um lanchinho /

guloseima:

"Eu compro... Eu escolho..."

"Hambúrguer!"

Eu cito como exemplo: biscoito /

"Cheetos! Porque o Cheetos é muito

bom! Ele é muito bom! Ele é muito

gostoso!"

"Hum... Bala Fini! Bala Fini..

Porque ela é gostosa!"
Vídeo do menino sobre o seu consumo Com o meu smartphone em mãos, a

alimentar:

Abertura:

"Gravando..."

Que mais gosta de comer:

"Posso falar 3 (coisas)?"

"Eu gosto mais... Chocolate!

Hambúrguer! E Batata frita!"

"Porque... E... Chocolate... E

docinho."

"Hambúrguer... Tem carne... Muito

gostosa!

E porque o hambúrguer Pode coloca

maionese, ketchup, mostarda, cheddar,

barbecue... Hummm!"

"Batata frita... Porque batata frita

muito gostosa! Com sal, e molho

barbecue, e maionese, e ketchup!"

Quando escolhe um lanchinho

guloseima:

"Eu vou... Posso falar sem se

biscoito?"

"Eu gosto de comer de lanche... É... É

um pão... Com manteiga... Muito

gostoso! Com leite."

E doce... Que eu gosto de comer... "Na rua eu costumo comer mais... Se eu

o Twix! Que eu já falei.

Porque o Twix tem caramelo e é muito

gostoso.

E caramelo é o meu doce preferido!"

Fechamento:

"Quero falar! Bye! Bye!"

(n)

as crianças:

"Vai!"

"Oi gente! Estamos aqui agora pra

conversar com a [menina] e o

E esse vídeo vai ser produzido pela

[menina]!”

"O que você mais gosta de comer em

casa / na rua / na escola / de

guloseimas?"

"Bom... Na escola eu gosto bastante de

comer... Tipo..

Eu gosto de comer lanche, tipo,

bisnaguinha com requeijão. Essas

coisas."

Em Casa.

chocolate! Hahaha!

Mas aí eu como só de sobremesa. E vou maneirando."

Na rua:

to fora, eu costumo comer mais comida

de fast food.

Tipo, hambúrguer, ou algum hot dog.

Essas coisas."

"De guloseima... Éh... Éh! Chocolate!

Haha! É isso."

E quando não tem chocolate, aí é

chocolate!

"Éh! Mais chocolate! Haha!"
"O que você mais gosta de comer em

casa / na rua / na escola / de

guloseimas?"

.

Hot dog.

Mas é bem de vez em quando, quando e

como."

"Hambúrguer... Batata frita... Essas

coisas."

Na escola:

bisnaguinha."

Guloseimas:

"Bombom! Sonho de Valsa! Éh."

"Ele gosta?"

"Gosta!"
Com o meu smartphone em mãos, a

menina fez a gravação da entrevista com

as crianças:

"Vai!"

"Oi gente! Estamos aqui agora pra

conversar com a [menina mais velha] e a

E esse vídeo vai ser produzido pela

[menina mais velha]!"

"Uhum!"

"Então vamos lá! Ta com você [menina

mais velha]!"

"O que você mais gosta de comer em casa

/ na rua / na escola / de guloseimas?"

Em casa:

"Em casa: Comida, assim... Eu gosto de

comer mais salsicha, assim . Ou ovo."

Na rua:

"Na rua: Hum... Qualquer tipo de comida.

Mas eu prefiro mesmo... Hum..

Guloseimas.

Ou outras coisas, assim. Tipo cachorro-

quente... Ou pastel... Essas coisas."

Na escola:

"Na escola: Éh... Mais o lanche. Que..

Mas o que eu gosto mais no lanche é

sempre a sobremesa.

Que é: Frutas... Outras... Hum... Algum

tipo de... de guloseimas. Isso aí."

Guloseimas:

"Guloseimas: Chocolate! Éh! Hum... A

Nutella! Éh... O KitKat!” 


\section{"Tubes!"}

"E principalmente da tubes

daquelas de chiclete de melancia!"

Fechamento:

"Quero falar! A Cinira é legal!'

"Eu quero falar mais uma cois

também!

Quero falar mais uma coisa!"

"Tá bom. Você vai fazer o seu

(vídeo)."

ESCOLHENDO O RESTAURANTE:

FAMÍLIA 1
SOBRE O LANCHE DA ESCOLA:

FAMÍLIA 1
SAUDÁVEL X GULOSEIMAS:

FAMÍLIA 1

MENINA E MENINO

MENINO

MENINA
No dia do lanche livre: O que mais gosta "Pergunta!"

as crianças:

"Oi gente! Estamos aqui agora pra

conversar com a [menina] o [menino]

E esse vídeo vai ser produzido penin

[menina]!"

No lanche da escola:

"Eu não escolho. Eu não compro."

No dia do lanche livre:

"Ah.... Lu compro o lanche e como."

Trocas de lanche com amigos:

"De vez em quando."

"Comigo."

Valor do lanche:

"Sim. (R\$15,00)"

"Acho que sim."

"Só que a minha mãe abaixou pra R\$

1,00 (o valor)." (trolando)

"Que R \$ 1,00 o que ! Ela baixou nada

João!"

O que mais gosta de comprar no lanche:

"O que eu mais gosto de comprar

"Suco."

"Pra comer... Sorvete!"

chocolatinho e um suco." de comprar no lanche:

"Ta. Depende muito.

Às vezes tem... Tipo... Pão de queijo...

Hamburgão... Tem várias coisas!

Qual e a comida mais saudável que voce

ja comeu na vida João?"

ce. Não. Agua. Agua e alface!"

"E a coisa mais guloseima?"

pizza... Ou coxinha... Aí eu compro um

Trocas de lanche com amigos:

"Cada uma compra o seu. $\mathrm{E}$ às vezes a

gente troca.

Âs vezes... Tipo... Às vezes eu trago

lanche. Aí minha amiga não quer mais

comer a coxinha...

Ela me dá a coxinha... E eu dou uma

coisa do meu lanche pra ela."
MENINA

A comida mais saudável que eu já comi em toda a minha vida foi: tomate com água.

Eu não gostei. Mas é saudável."

"E a coisa mais guloseima?"

"Era um... Um Triplo Quarterão com Milk-Shake do McDonald's!

E era um Milk-Shake de chocolate da Kopenhagen!"

"Eu recon!" Porque é muito bom!"

"América."

"McDonald's"

"Rascal.",

"Burger king."

"A gente vai esco

Votação:

"Tá. Quem vota em América levanta a mão!"

(a menina votou / o menino votou) (?)

"Ouem vota em McDonald's!"

(o menino votou) 
(a menina votou)

(o menino votou)

"E um voto para o América!"

"Eu votei."

"Eu votei."

Resultado:

Ah! América nós dois votamos!

"É!"

"Vai ser América!"

\section{SOBRE OS AMIGOS / AMIGAS:}

FAMÍLIA 1

\section{SOBRE FAMÍLIA / AMIGOS / ESCOLA / PUBLICIDADE:}

\section{FAMÍLIA 2}

SOBRE A FAMÍLIA / OS AMIGOS / A ESCOLA

\section{FAMÍLIA 3}

MENINO

MENINA MAIS VELHA

MENINA MAIS NOVA
Trocas de ideias com os amigos sobre Trocas de ideias com os amigos sobre coisas de comer:

"E aí João!"

"Não. Nenhum. Nada."

Ideia de algum amigo (pra comer)

"Eu já dei pra algum amigo (uma

ideia).

De água. De comprar água."

"Ele só comprava Toddynho."

(trolando)

"Porque ele não achava... Ele ś comprava Toddynho... E nunca achava água." (trolando) Alguma ideia ruim:

"Do meu amigo! Eu lembro! Ele pediu pra mim comprar un hamburgão só de tomate.

Eu comprei. E não gostei."

(trolando) uh!

Aí... Aí a minha amiga... Ela chegou
Ideia de alguma amiga (pra comer)/ Ideia para alguma amiga (de comer): comprar um hamburgão. falo

'Rose! O hamburgão daqui não vale pena. Acho melhor você comprar um esfiha.

Aí eu comprei uma esfiha."

"E um dia... Ela foi comprar pão de queijo. Porque não tinha quase nada. Só tinha pão de queijo e torta de palmito.

Eu falei: 'A torta de palmito, Gi, é

melhor.'

Aí ela pegou torta de palmito. E agora ela ama torta de palmito!"

Alguma ideia ruim:

"A minha ideia ruim foi quando A

"A minha ideia ruim for quando... A

minha... A minha amiga... Ela falou

'Ah!... Compra aquela torta de frango.

Vale mais a pena do que comprar uma coxinha.'

Eu comprei. Não vale não. É muito ruim!"

"Éh!... Á́... Tipo... Eu fiquei: ‘Come. Come.

Daí ela: 'Não. Não. Não gosto.'

Daí eu falei: 'Então porque você ped

pra mim comprar? Porque eu ia

comprar a última coxinha!"
"De onde vem as maiores referências/ influências pra você com relação à comida / coisas de comer?"

Ěn... Pra mim, né... Eu... Tipo... Eu sou bastante influenciada, na parte de comida... Acho que mais por... Não sei. Acho que por propaganda de... Provavelmente de rede social. Essas coisas."

"Mas quando não é por isso, é por alguma amiga minha, que fala de algun comida.

E eu fico com vontade de comer. Ou de algum lugar pra comer. Essas coisas."

"De que redes sociais você está falando? E como aparecem as propagandas?"

"É tipo... Instagram.

Quando você ta descendo o feed, aí voce

acha alguma propaganda ali no meio.

De alguma comida. Alguma coisa "assim. E á eu fico com vontade! Haha!"

"Geralmente é de hambúrguer! Ou de "Geuma coisa do OutBack! Haha!" "Éh Burger King en vejo baste propaganda. McDonald's.

mais coisa de hambúrouer que eu vejo

"Então, as referências / influências pra você vem mais a partir da publicidade ou através de alguma amiga né?"

"Éh. Principalmente isso."

"E sobre o papai e a mamãe.

Como são as referências / influências

que vem deles sobre comida / coisas de comer?"
"De onde vem as maiores referências influências pra você com relação à comida / coisas de comer?"

"Sim. Sobre comida / coisas de comer."

"Sím. Sobre comida / coisas de com propaganda de TV." "De vez em quando eu também vejo o meus amigos bebendo ou comendo

coisas.

Tipo... Éh... Não lembro. Mas teve um negócio que eu comprei.

E era uma bebida. E eu gostei."

"Que voce viu um amigo bebendo?"

Aham."

quais propagandas você costuma ver na TV?"

"Hambúrouer do McDonalds! Essas

coisas."

"E sobre o papai e a mamãe.

Como são as referências / influências

que vem deles sobre comida / coisas de

"Nossa!. To pensando!.."

"Eu acho que, de vez em quando, eles falam pra eu comer menos. Menos "Esteira"

"Eles falam pra você?"

"E na escola, eles falam sobre

alimentação / coisas de comer?"

"Mas... Eu acho... Se eu não me engano,

ele teve aula de sustentabilidade. Eu não

lembro..."

"Você teve alguma aula sobre

alimentação na escola Rafael??"
"Tem alguma influência ou interferência dos pais ou dos amigos ou da escola na sua alimentação?"

\section{Os pais:}

"Éh... Com os meus pais a gente come.. Geralmente, o que a gente come bastante. Ou o que a gente sabe que todo mundo gosta."

"Com os pais... Geralmente, o que todos sabem que... que gosta.

Éh... Como a pizza: Eu gosto, a

Terezinha, os meus pais gostam.

Então, é como se fosse a comida que todo Éh."

"E com relação à comida, que sugestão os pais dão a vocês na hora de comer:"

"Comer a comida É . Toda a comida.

E E Comer alguns legumes, se tiver.

Én.".

"Eles pedem pra você comer?"

"Éh."

"E o que eles pedem pra você comer, quando tem?"

"Geralmente, tem beterraba. E aí eles sempre pedem pra mim experimentar. Éh"

Amigos:

"E com os amigos também... Que..."

"Eu acho que as minhas amigas... A gente

vai mais, talvez, pelos votos, assim.

Geralmente, quando a gente vai come 
“Também influencia. Mas aí, geralmente, é mais por... Tipo. Por exemplo: salada. Se... Eles ficam Pra eu comer algum tomate, po

exenplo. Eu gosto de tomate.

exemplo: falando que é melhor eu

comer. Essas coisas."

"Eh... Ou falando, por exemplo,

principalmente por... Pelo negócio do

preço.

Eles ficam falando... Tipo... Que tem

marcas que são mais baratas.

Se eu gosto de alguma coisa que é um

pouco mais cara, eles falam que tem

coisas que são muito parecidas,

que são de umas marcas com preço um

pouco mais acessível,"

"E eles falam pra você maneirar no

chocolate? haha!'

"Hahaha! Éh... Porque eu... Por mais que

eu goste bastante, eu consigo... Éh

Comer só nos horários de sobremesa

Essas coisas. Horários que eu possa

mesmo. Mais certinho."

"E na escola, eles falam sobre

"Ah... Geralmente eles falam... Tipo...

"Áh... Coralme assim?te Os amigos?"

"Nh... Como assim? Os amigos?"

"Não. A escola. Os professores. Os

conteúdos. A escola como instituição."

momentos de Ciências, fala sobre

alimentação.

Principalmente quando fala sobre o

corpo humano, fala sobre alimentação."

"Mas... Eu acho... Se eu não me engano,

lembro..." influenciando, falando... Tipo... Sei 1 .

Mas eles ficam influenciando. Por

ele teve aula de sustentabilidade. Eu não

"Não. Mas teve um cartaz que botaram perto da minha sala que era sobre comida

De coisas saudáveis e coisas não

saudáveis."

"E você lembra o que havia no cartaz?"

"Eu não lembro. Mas tinha coisa escrita.

Que eu não parei pra ler pra não perder aula."

(2)

OBRE OS DISPOSITIVOS / MÍDIAS / YOUTUBE / NETFLIX / PUBLICIDADE / INSTAGRAM:

FAMÍLIA 1

FAMÍLIA 2

MENINO

MENINA

MENINA

MENINO
"Como é o seu uso das mídias

Primeira tela: celular

"Como é o seu uso das mídias e

Segunda tela: TV (YouTube / NetFlix

Terceira tela: computador (jogos

YouTube)

NetFlix: Jovens Titãs / Ursos sem

Curso / O Incrível Mundo de Gumball

\section{Mídias / Telas:}

tecnologias?

Quais as telas que você mais usa? O que

você mais gosta de fazer?"

"Éh... Antes, quando eu era menor, eu

costumava assistir, com certeza,
"Aham... Sim.... Eh.... Sim..." entre aspas, né, que geralmente é só na escola que a gente ta junta-

Éh... A gente... Se tiver muitas coisas que

"Mue mais gente quiser."

"Na escola. Porque..."

pra escola?"

Que... Que não pode comer o lanche da

escola.

Mas quem pode, não... não precisa levar o

lanche."

"Mas então como é esse negócio de

votar? Não entendi..."

"Eh... Se a gente saísse, assim. E aí, se

tivesse muita coisa que muita

gente...Cada um quer isso..."

"Ah!

"Em outro lugar,"

"Ém."

"Se um queresse uma coisa Ou muitos quisessem uma coisa, e outros quisessem outra...

Aí a gente fazia ... Fazia um voto pra saber qual que a gente conpra, assim.

"Dais ou menos. É isso."

"Dá um exemplo:"

"Exemplo... Hum... Éh... Guloseimas,

assim. Guloseima como: Salgadinho..
Chocolate..."

\section{Escola:}

"Os professores falam sobre alimentação?

Vocês aprendem sobre isso na escola?"

"Não. Eles... Éh... Esse ano só... Sobre

alimentação... Eu só aprendi mesmo como

é feita, assim, a comida.

Mas sobre dicas, assim, de como... De

alimentação, não." todo mundo gosta, a gente vota o mais..

"Mas isso na escola? Ou fora da escola?"

"Mas é dos lanches que as crianças levan

Ëh... Tem gente que leva. Que... Éh...
JailBreak / Mine Craft

Jogo favorito: Beyond (Naruto)
Super Power Training Sinuto/

"E jogar videogame. E assistir

MENINA MAIS VELHA

\section{Mídias / Telas:}

tecnologias?

Quais as telas que você mais usa? O que

você mais gosta de fazer?"

"Eh... A minha p

"Como é o seu uso das mídias e tecnologias? Como você usa as telas?

Quais as telas que você mais usa? E o que

"Mais videogame! Com certeza!"

FAMÍLIA 3

MENINA MAIS NOVA

Conversando com a menina mais velha sobre o uso que a menin mais nova faz do celular:

Celular:

"E o que a [menina mais nova] faz no celular?" 
NetFlix: Jovens Titãs / Ursos sem Curso / O Incrível Mundo de Gumball

TV: Clarêncio / Hora de Aventura / Esquadrão Bizarro

Canais YouTube / Youtubers: Gato Galáctico / Felipe Neto / Authentic Games / ProSidu / vídeos (parkour)

\section{Primeira tela:}

"Tá. Vai João!"

"Computador!"

"Computador. Eu gosto."

“Computador!'

"Éh... O notebook. (?)"

“Éh... Não. Não é notebook. É... E

um computador de gamer."

"Éh... Notebook (?)"

"Notebook. (?")

\section{$\mathrm{O}$ que mais gosta de fazer no}

computador:

"Jogar!"

“Jogar que jogo?"

"Jogar que jogo?... Bá... Bá... Bá...”

Jogar Roblox. Que jogo do

Roblox?"

"Beyond!"

"Beyon.... Que é muito bom!"

"Beyond e Super Power Training

Simulator!"

"Super Power Training Simulator

Bayond.

Bayond é do Naruto... Que eu

conheço muito bem!"

"E... No último... Jailbreak!"

"Jailbreak. Você tem que fugir da

prisão... e... sei lá... Assaltar banco...

Em uma base secreta... (?)"

$\mathrm{O}$ jogo mais legal:

"Beyond!"

"Beyond! Porque eu gosto muito de anime!"

Quanto tempo ficaria jogando se

possível:

"Um dia inteiro!"

\section{Segunda tela:}

"TV"

O que mais gosta de fazer na TV:

"Assistir NetFlix."

"Qualquer coisa,"

"Jovens Titãs!"

"Jovens Titãs! Joven

"Ele assiste comigo."
"E o Incrível Mundo de Gumball!

Porque é muito engraçado!"
TV: Clarêncio / Hora de Aventura / Esquadrão Bizarro

Canais YouTube / Youtubers: Gato Galáctico / Felipe Neto / Authentic Games / ProSidu / vídeos (parkour) Jogos: Roblox / Beyond (Naruto) /

Jimulator

Jogo favorito: Bubble Gum Simulato

\section{Primeira tela:}

"Celular!"

"A primeira tela é o celular!"

"Eu tenho um celular. IPhone 5."

O que mais gosta de fazer no celular:

"Olha... Eu gosto... Eu gosto de

assistir... éh... vídeos..."

"Assistir (?)!" "Assistir (?)!"

"Para João!"

"Eu gosto de assistir vídeos... Eu gosto

"Tik Tok é um aplicativo que ante se chamava Musical Ly. Que você grava vídeos. Você dubla.. Faz mégic vídeos... Você dubla..

"Eu gosto de coisa!" " Faz méries

"Eu gosto de fazer séries de anime com um aplicativo... Um aplicativo

"Ele... Esse aplicativo dá pra fazer

séries de anime. E eu gosto de fazer!"

Algo mais no celula

"É verdade! Eu escuto música no

celular!"

E no tablet:

"Sim. Essas mesmas coisas eu faço no

IPad."

\section{Segunda tela:}

"Não. (Não é o IPad)"

"A minha segunda tela e a TV."

“Não. É a minha TV!"

Não. Éh! A TV do meu irmão. Mas uma TV!"

O que mais gosta de fazer na TV:

"A gente gosta de assistir vídeos

"Também a gente gosta de fazer... A gente também gosta de fazer... éh... A gente também gosta de assistir

"A gente também gosta de assistir vídeos... Às vezes vídeos do Felipe Neto... Às vezes vídeos de... sei lá. Authentic Games... Que é un youtuber que joga Minecraft."

Prosidu"

"ProSidu! É o que eu mais assisto!"
Que eu ainda não tinha celular. Essas coisas

Mas aí, com o tempo, eu fui mexendo mais, tipo, em celular, computador. Essas coisas."

\section{Publicidade:}

"E aí as propagandas foram aparecendo, nos lugares que eu mais uso

Tipo, celular. Como o Instagram e o

YouTube - que eu uso tambem bastante.

Mas antes, na TV, também aparecia

bastante. So eu não lembro do que que

Mas na maioria das vezes é sempre de hambúrguer. Sim."

"E quando você vê propaganda no

YouTube você assiste? Ou você pula os

anúncios?"

"Geralmente, eu pulo os anúncios.

Mas se eu vejo algum que chama muito

a atenção, assim, nos primeiros

segundos,

antes de aparecer pra pular, eu assisto.

Pra ver sobre o que que é.

Mas geralmente, de comida, eu não faço isso. Eu pulo.

Porque aí eu já sei que é alguma coisa de hambúrguer. Ou de promoção."

"E aí você vai direto para os vídeos que você quer assistir?"

\section{YouTube:}

"O que você gosta de fazer no

YouTube?"

"No YouTube, eu costumo assistir mais vídeos de maquiagem, papelaria... Essas coisas."

"E tem algum / alguma youtuber que você gosta / segue?"

"Tem. Uma que se chama Jana Taffarel. Eu gosto bastante dela. Haha!"

"Ela fala sobre maquiagem. E ela faz vídeo de ideias de unhas decoradas.

Essas coisas.

Antes, ela fazia de... Éh... Do it yourself.

Mas agora ela parou."

"Ela fala mais sobre maquiagem, ne?"

"Éh. Sim."

"E você segue algum / algum

instagramer no Instagram?"

No Instagram eu sigo uma que se

chama Mari Maria.
"E quais os jogos que você mais gosta no Que geralmente, eu fico mais no videogame? no momento?"

"Eu to jogando mais... É que... Sei lá.

Os jogos são muito difíceis pra

completar. E a maioria deles, eu não

consigo

Mas... De vez em quando eu até consige completar um jogo."

"E qual é o jogo que você mais gosta no

videogame?"

gente chegou, você tava no

"E tem mais jogos que você gosta, ne?" canal da Bibi Tatto né?"

"Mario!"

"E o menos que eu to jogando agora é o Sonic."

"Então o Sonic ficou descansando um pouco, ne?"

"Aham."

(1)

"Assistir duas youtubers. Que é: a Bib Tatto e a Júlia Mine Girl. E.

A Bibi Tatto e Júlia Mine Girl."

"A Bibi Tatto, ela tem dois canais: Um canal de games - que é jogos. E outro

canal, que é pra fazer qualquer coisa. Que

Girl, ela tem um canal de

"Éh."

"E o que você tava vendo?"

"Eh... Eu tava... Não era um vídeo. Era

um post que ela tinha postado no

YouTube."

"Sobre uma pergunta... Sobre heróis..

Heróis da Marvel.Éh."

"Ah... Aí você vê o post e dá pra ver o

que as pessoas vão respondendo né?"

"Éh.

Celular: Jogos

"E o que mais você faz no celular além do

"Éh... Eu fico jogando. Como um jogo.. Éh... chamado Roblox."

"Roblox. E o Gacha Life. Éh."

"Esses são os jogos que você mais joga?" "Éh"

Celular: Instagram / Faceboo

"E você usa o Instagram no celular?"

"Não. Minha mãe ainda não deixa eu

usar. Não."

"Ah. Então você não usa o Instagram nem o FaceBook?"

"Não."

"Éh."

\section{Celular: WhatsApp}

"Você tem um chip com o seu número no

celular?"

"E você usa o WhatsApp no celular?"

Evocê conversa com quem no

WhatsApp?"

"Com as minhas amigas da escola."

"E elas mandam mensagens pra você?

Vídeos? O que vocês fazem no

"Éh... Algumas. Vídeos não.

“Éh... Ela tem um jogo lá - que ela instalou, não sei como. Aí ela fica jogando."

"Ou ela entra no YouTube, assim, né. Que tem no celular dela.

E... Aí ela fica assistindo... Vídeo assim, de criancinha."

"Éh."

"Mas o YouTube dela é o YouTube

Kids?"

"Não. É o YouTube normal."

"Ela procura os vídeos sozinha?'

"Eh."

"E ela já sabe acessar os vídeos que ela mais gosta?"

Não. Ela... Quando ela vai... Aperta no botão de pesquisar...

Ela fica apertando em várias letras,

assim, aleatórias."

"E você ajuda ela a acessar os vídeos

que ela gosta?"

"Éh... Assim... Só quando ela pede."

"E os jogos, ela sabe acessar sozinha?" "Éh. Éh."

"O celular da [menina mais nova] é só dela? é só pra [menina mais nova]?"

"Éh.. Todo mundo usa o celular de todo mundo aqui em casa."

"Mas cada um tem um chip com o seu "umero no celular né?"

"Só que a [menina mais nova] ainda não né?"

"Não."

Enquanto conversávamos, a menina mais nova entrou no quarto trazendo o

seu celular.

Acho que ela queria mostrar o celular. Provavelmente estava prestando atenção à nossa conversa.

"Mostra sua irmã lá [menina mais velha]!"

"Mostra a [menina mais nova] no

vídeo!"

A menina mais velha, então, posicionou a câmera na direção da irmã mais nova. "Olha só quem chegou de novo!"

"E ela ta trazendo o que? O celular!"

"O que que a [menina mais velha] ta fazendo no celular?"

A menina mais nova estava jogando um 


\begin{tabular}{|c|c|c|}
\hline $\begin{array}{l}\text { YouTube: } \\
\text { Sobre o You } \\
\text { "Não." } \\
\text { "Ele assiste.' } \\
\text { Sobre o You } \\
\text { "Aham... De } \\
\text { sim." } \\
\text { "Eu assisto Y } \\
\text { "De vez em } \\
\text { O que mais g } \\
\text { YouTube: } \\
\text { "Gato Galáct } \\
\text { "É youtuber! } \\
\text { "É youtuber! }\end{array}$ & 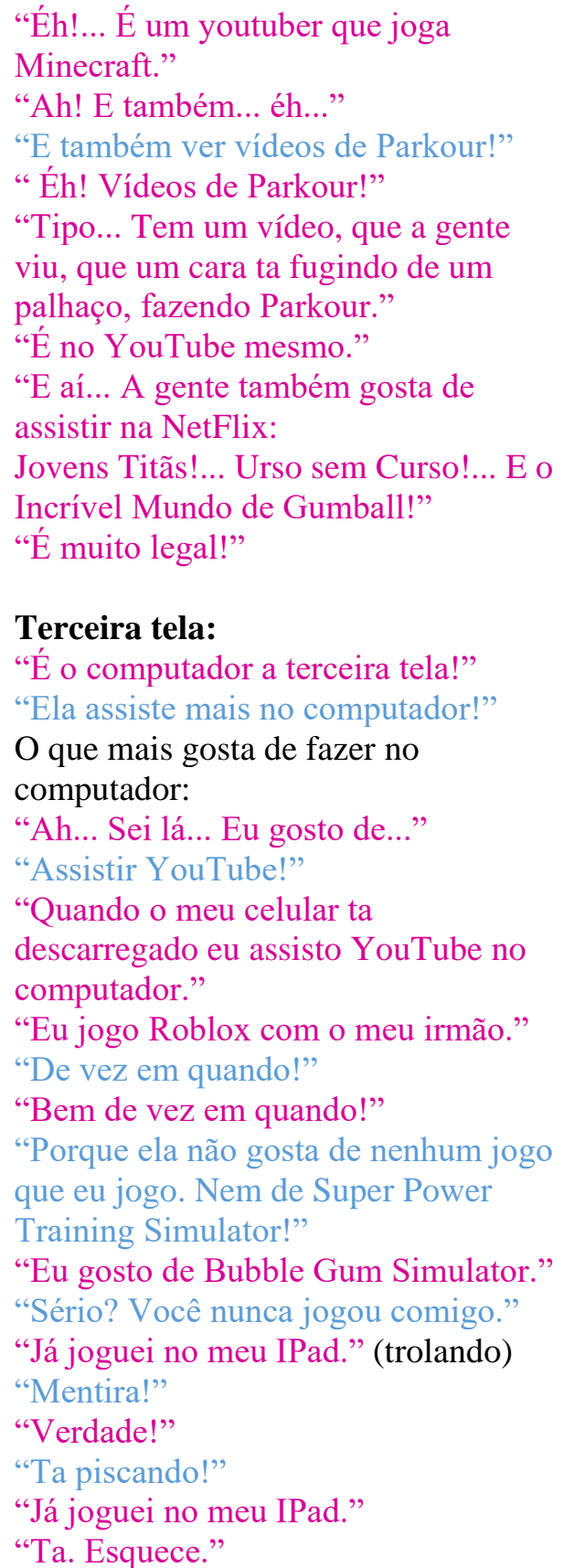 & $\begin{array}{l}\text { YouTube / Instagram: } \\
\text { "Tem mais algum / alguma youtuber que } \\
\text { você segue no YouTube? } \\
\text { Ou instagramer que você segue no } \\
\text { Instagram?". } \\
\text { "Tem... Éh. São mais essas duas que eu } \\
\text { vejo. Mas também tem uns outros que eu } \\
\text { assisto. } \\
\text { Tipo... Tem um canal que se chama } \\
\text { Você Sabia? Que bastante gente } \\
\text { acompanha. } \\
\text { Que fala mais de curiosidades. Essas } \\
\text { coisas. Daí eu assisto também. Éh. No } \\
\text { YouTube." } \\
\text { "No Insta eu costumo seguir mais } \\
\text { blogueira. Eu não sigo muito... Éh... } \\
\text { Outros tipos de perfis. } \\
\text { Mas eu também sigo alguns que falam } \\
\text { sobre papelaria. } \\
\text { Que recentemente, eu tenho tentado } \\
\text { treinar lettering. Essas coisas de escrita. } \\
\text { Haha!" } \\
\text { "Lettering - Que é tipo uma escrita toda } \\
\text { bonitinha! Cheia de detalhezinhos! Essas } \\
\text { coisas." } \\
\text { "E esse conteúdo está nos canais sobre } \\
\text { papelaria?"” } \\
\text { "Éh. Sim." }\end{array}$ \\
\hline
\end{tabular}

A gente só conversa, às vezes, sobre algumas coisas da escola. Ou outras coisas."

"E vocês usam mais mensagem escrita, mensagem de áudio, ou chamadas de vídeo no WhatsApp?

"Com uma amiga minha... Éh... a gente se conversa mais sobre chamada de vídeo." "Ah. Com chamada de vídeo." "Éh."

"E em outras situações, vocês usam mensagem de texto?"

"Éh. Uhum."

\section{Televisão:}

"Qual a sua segunda tela?"

"A televisão."

"Na tv..."

"Quando nós chegamos, você estava na

televisão e no celular né?

Ou era a [menina mais nova] que tava

vendo televis̃̃o e você tava qú

celular?"

"Éh. A Terezinha Vamos dizer que

tava no celular e a Terezinha, na ty.

tava no celular e a Terezinha, na tv. tv, assim, pra assistir."

"Você sabe o que tava passando na televisão?"

"elevisão?"

"Sim. O Hotel Transilvânia.'

"O que você gosta de ver na televisão?"

"Éh... Algumas séries de um canal.

Umas séries no... Num canal que se

chama Nickelodeon."

"E uma das séries que eu gosto é Game

Shakers!"

"Game Shakers. Éh. No Nickelodeon."

"Você assiste o Gloob também né?"

"Sim."

"E o que você gosta de assistir no

Gloob?"

"Éh... Lady Bug! Éh!"

"Que é a sua personagem favorita né?" "Sim! Uhum!"

"Ah! Ela é uma joaninha e mora em..."

"Paris!"
"O que você tá fazendo?"

"O que que ce tá fazendo?"

A menina mais nova não fal

E contina sorindo pra nós.

Econtinuava jogando e mostrando o se joguinho no celular.

É um joguinho? É [menina mai

nova]?"

"O que ela ta fazendo [menina mais

velha]?"

"Ela ta jogando."

"E qual é o joguinho?"

"Voce consegue mostrar no vídeo o que ela tá jogando?"

"Sim. Ėh... Não muito. Mas dá pra mostrar um pouco."

A menina mais velha, então, mostrou no vídeo o joguinho no celular da menina mais nova.

E a menina mais nova continuava

jogando pra mostrar o seu joguinho no

"Oh! O joguinho que a [menina mais noval ta jogando!"

Fonte: elaborado pela pesquisadora
Legenda:

Falas da criança mais velha

Falas da criança mais nova

Falas do pai

Falas da mãe

Falas da pesquisadora 


\begin{tabular}{|c|c|c|c|}
\hline \multicolumn{2}{|c|}{ SOBRE AS MARCAS: } & SOBRE A PUBLICIDADE: & SOBRE O YOUTUBE / YOUTUBERS: \\
\hline \multicolumn{2}{|c|}{ FAMÍLIA 1} & FAMÍLIA 1 & FAMÍLIA 1 \\
\hline MENINO & MENINA & MENINA E MENINO & MENINA E MENINO \\
\hline $\begin{array}{l}\text { O que é marca: } \\
\text { "Marcas?" } \\
\text { "Vai João!" } \\
\text { "Marca?"" } \\
\text { Marca de chocolate / etc.: } \\
\text { "Nutella!" } \\
\text { "(Que é) Creme de avelã!"” } \\
\text { "Lacta!" } \\
\text { O que é marca: } \\
\text { "Marca... É o logotipo da empresa." } \\
\text { "Oh! Arrasou hein!" } \\
\text { "Porque existe marca: } \\
\text { "Pra saberem em qual empresa foi } \\
\text { "Peito." } \\
\text { "Pra ver se não é cópia. Se a outra } \\
\text { empresa não ta copiando essa." } \\
\text { "Eh... Mas na verdade qualquer } \\
\text { empresa pode fazer um creme de } \\
\text { avelã." } \\
\text { "Éh!" } \\
\text { "Ne há diferença / Qual a diferença: } \\
\text { "Pode. Fica bem diferente." umas que ficam mais com } \\
\text { gosto de sorvete de creme." } \\
\text { "Não. É o gosto. (a diferença)" } \\
\text { "Menino (a marca é pra saber quem fez)" } \\
\text { "João! Para!" se mexendo muito. }\end{array}$ & 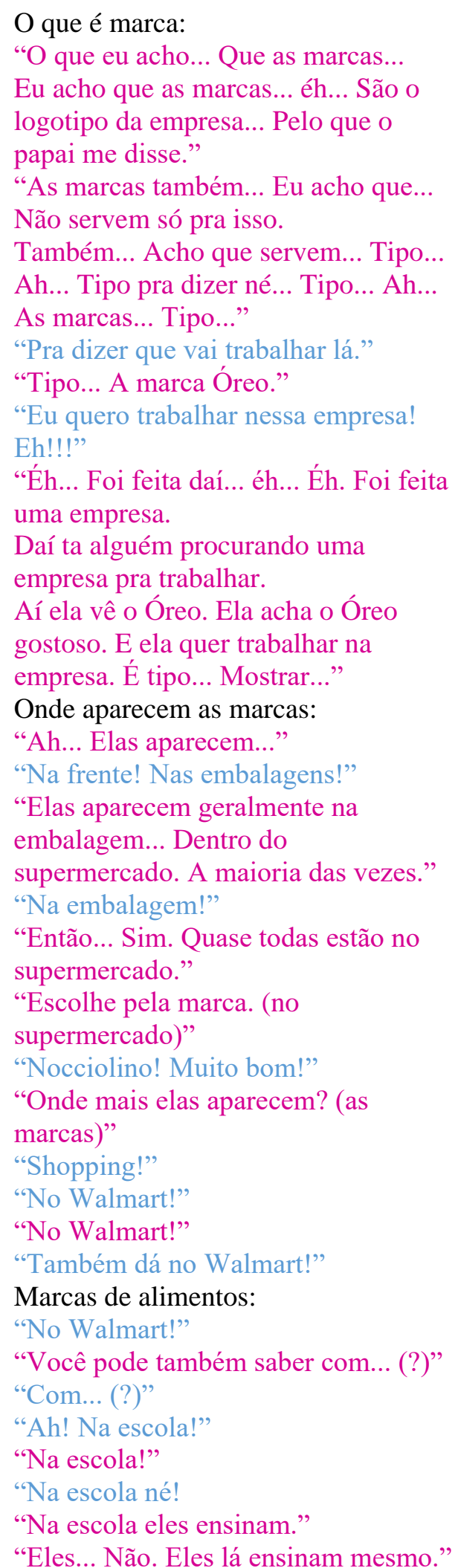 & 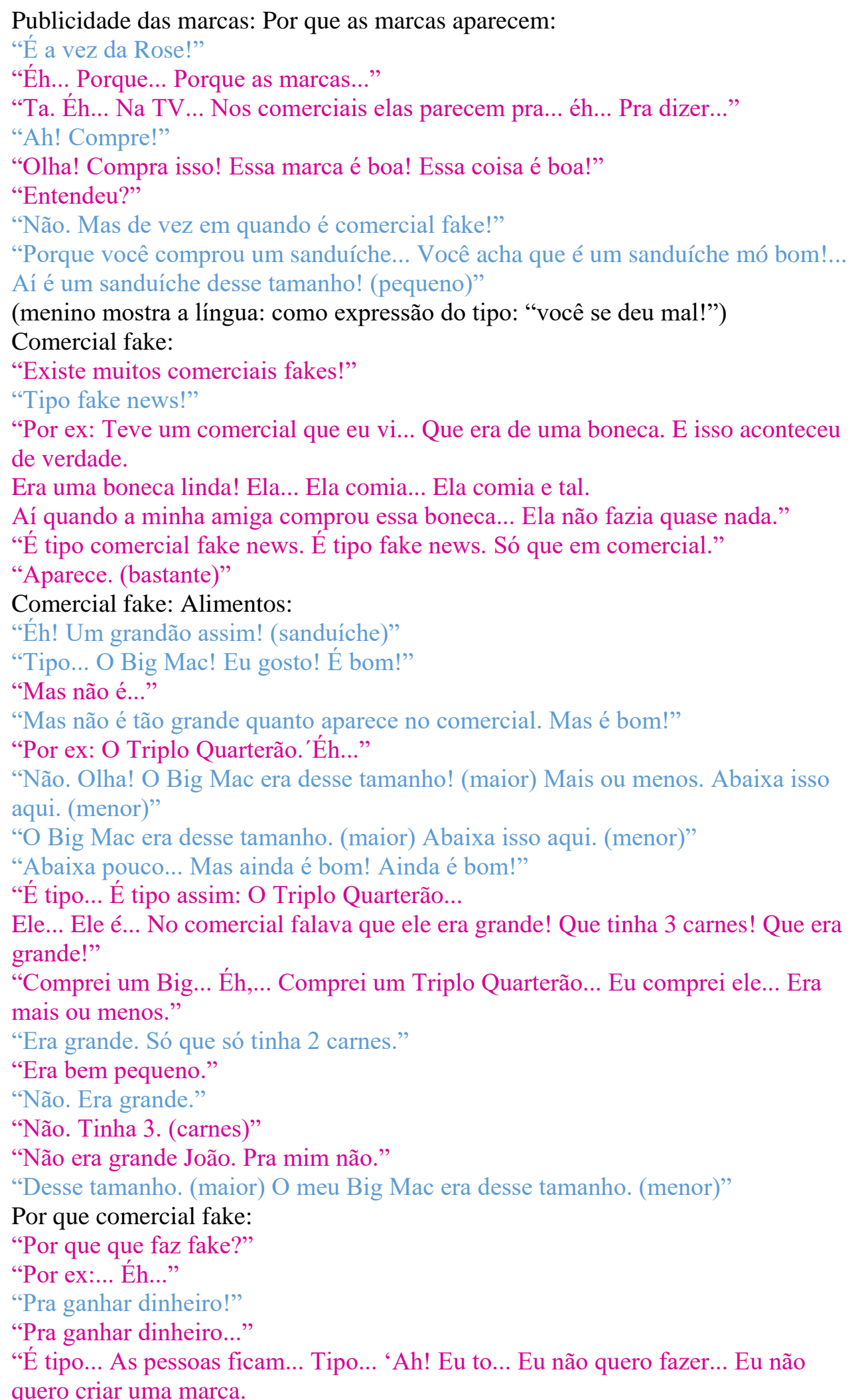 & 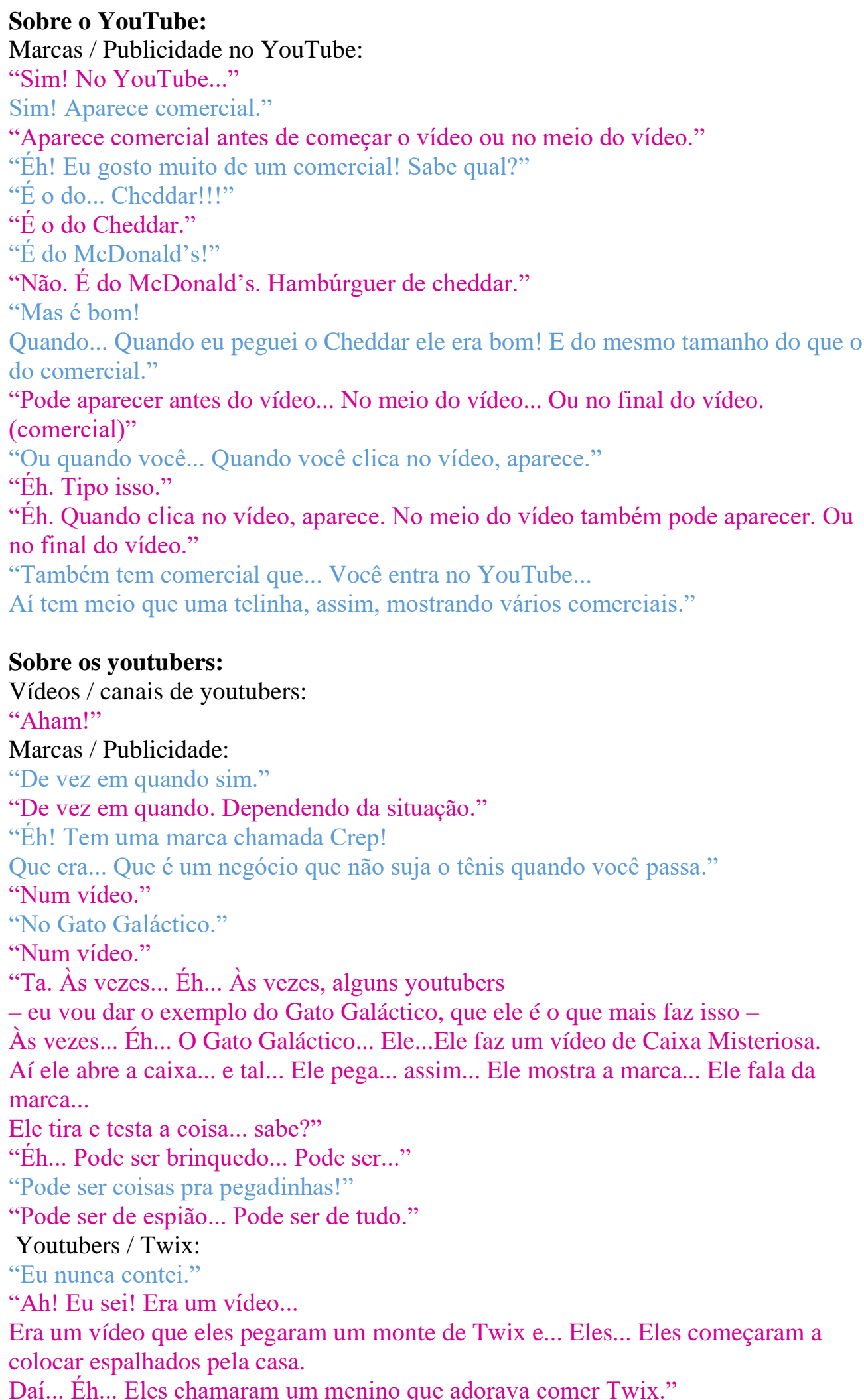 \\
\hline
\end{tabular}


"Aprendem. Na escola."

Menino estava se mexendo muito. "Para João! Caramba! Você ta se mexendo demais!'

"Mall!"

"Mall é shopping!"

"Shopping Mall.."

E nas telas:

"Celular?"

"Mercado livre!"

"Aham. (na internet)"

"Sim. (na internet)"

"Aham. (na TV)"

"Aham. (na TV)"

"Na TV! Na TV!"

"Eh! Comerciais!"

"No cinema!"

Na publicidade

"Éh!"
Ah! Aquela marca ali é muito boa. Ah! Eu vou pegar essa ."

Sobre pirataria:

"É tipo o que aconteceu com LQL. Éh... LOL. Éh... O que aconteceu com a LOL. "A LOL é uma boneca que vem dentro de uma bola. Ela é super fofinha! Bonitinha!

Ela começou a fazer muito!... Mas muito sucesso!'

"Muitas marcas começaram a fazer bola também.

Tipo... Shopkins agora vem dentro de uma bola. Hatchimals! Nossa! Vem a Sister! Vem a Baby!

Vem igualzinho. Vem igualzinho a LOL o Hatchimals! Só o que muda... É um bichinho de pelúcia!"

"Aí aconteceu da LQL. Eles... Éh... Umas pessoas foram lá... Ficaram com inveja da LOL...

Não conseguiam fazer nada igual da LOL... Aí... Aí eles falaram:

'Quer saber? Vamos comprar as LOLs!

Por que? Ah! Porque assim a gente pode escolher como é que a gente vai fazer a nossa LOL."”

"Compraram a LOL... e tal. Fizeram muito falso a LOL! A LQL não presta!"

"As LOLs tem que custar, mais ou menos, de $\mathrm{R} \$ 50,00$ pra cima.

Se ela custa de R\$ 50,00 pra baixo, é uma LQL."

"Não. Eu já vi..."

"Na embalagem dessas LOLs falsas vem LQL Não vem LOL"

"Não. Eu já vi uma de menos... Éh... de... Eu já vi uma de menos de... de... de R\$

$50,00$.

Só que era tipo $\$ 7,00$ (dólares)"

"É porque era lá nos Estados Unidos né João! 7X4 (R\$ 4,00) é muito!"

"Éh! 7 X4 (R\$ 4,00) da 28 (R \$28,00)!"

"É porque é Estados Unidos né!"

"Éh! (valor diferente)"

"Éh! E se você trabalhar nos Estados Unidos... Só é tipo... R\$ 7,00."
"Não. Sem ser o meu irmão."

"Eu não gosto mais tanto. Eu gosto mais de sorvete."

"Éh... Um cara que adorava comer Twix. Que ficava na casa dele.

Aí... Eles foram lá... E ele foi achando pistas pra encontrar o maior Twix do universo!

Não... O Twix maior que eles fizeram mesmo!" (trolando)

"Éh! Mas não era tão grande quanto..." (?

Youtubers / Sorvete

"Mahomenos. Dependendo..."

"De vez em quando."

"Um cara já fez um sorvete gigante!"

"Já fez mesmo."

"Não. Eles fazem."

"Eles fazem o sorvete."

Youtubers / Chocolate:

Oh!... Tipo... Tipo tem o chocolate KitKat.

Quando eles fazem um gigante, eles meio que imprimem. Só que fica gigante!

"Fica (bem parecido)",

"Fica do mesmo jeito."
SOBRE PRODUTO / MARCA / PERSONAGEM EMBALAGEM / PUBLICIDADE:

FAMÍLIA 2

MENINA E MENINO
SOBRE MARCAS / PUBLICIDADE / SUPERMERCADO:

FAMÍLIA 2

MENINA E MENINO
O QUE É MAIS IMPORTANTE: PRODUTO / MARCA / PERSONAGEM/ EMBALAGEM

FAMÍLIA 2

MENINA E MENINO
"Podem falar o que vocês sabem sobre isso. Sobre essa combinação. Pra que serve? Se vocês gostam ou não?"

\section{Publicidade:}

"Éh... Bom... Eu acho que as marcas, né... A maioria das marcas precisam de publicidade.

Principalmente marcas menores, né. Pras pessoas conhecerem a marca. E eu acho que, principalmente se for propaganda de vídeo de YouTube, tem que ter alguma coisa

que chame a atenção nos primeiros cinco segundos. Antes da pessoa pular." "E quanto às propagandas de marcas de alimentos / comida / coisas de comer?" "De marca de comida... Eu acho que... Éh... Tem muita coisa, tipo, de hambúrguer. Essas coisas.

Eu não sei muito sobre propaganda de comida. Mas... Éh... Não tem muita.

E principalmente, elas não me chamam muito a atenção. São sempre do mesmo E princip

"As propagandas de hambúrguer / fastfood né?"

"As prop

"E o que mais vocês podem falar sobre a publicidade?"

\section{Marcas / Publicidade:}

"Como a publicidade chega até vocês? Em quais mídias / formatos ela aparece?"

"Bom... Essas... Publicidade chega pra mim, né, por causa da internet.

Principalmente."

"Pro Rafael, acho que chega mais por conta da TV, não é?"

"Éh."

"E aí eu... Se eu..."

E sem perceber, eu acabei interrompendo a fala da menina.

"E aparece mais publicidade em geral? Ou mais publicidade de alimentos?"

"Pra mim... Como eu... Eu não sei se tem alguma classificacão pra anúncio,

mas eu sinto que pra mim não aparece muito de comida. Aparece mais de outros assuntos."

"Tipo, maquiagem! Haha!"

"Éh!... hahaha!"

E então eu expliquei a ela que com certeza existem filtros para a publicidade na

internet.

"E pra você? Aparece mais propaganda de que? Tem propaganda no videogame?"

"Mas na TV tem, né?"
Produto / Marca: Personagem / Embalagem:

"O que é mais importante nessa combinação?"

"Eu acho que é o preço."

"O preço pode ser muito importante. Mas vamos imaginar que aqui, nesse momento, o preço não seria considerado. Então, fora o preço, ou depois do preço, o que é mais importante pra vocês?"

"Pra mim, se é algum... Éh... Se é alguma coisa que eu já conheço, que eu já provei, eu vou mais pelo gosto. Pelo que eu acho melhor. Sim."

"Então aí o mais importante é o produto, né?"

"Éh. Sim."

"Mas quando é alguma coisa que eu nunca comi... Éh... Que eu vou provar... Novo... Geralmente, eu procuro embalagens que sejam pequenas. E alguma coisa que seja. Tipo...

Além de mais barato... Seja, sei lá... Pareça ser mais... Ah. .

Que a embalagem seja mais bonitinha Que. A embalagem que me chame mais a atenção."

"E pra você o que é mais importante? Além do preço, que você já falou."

"Eu acho que é o gosto."

"Então, é o produto, ne? Porque o gosto faz parte do produto, né?" 
"Publicidade é mais... Eu acho que é mais chamar a atenção. Porque eu acho que as propagandas são sempre as mesmas, sabe? Acho que falta inovação na área da publicidade. Haha!'

“Éh. De comida, principalmente. Mas as outras, eu acho que... Éh. (também)" "Chamar mais a atenção nos cinco segundos. Depois, pode dar uma relaxada. Mas... Tipo... Nos primeiros cinco tem que chamar a atenção!" "Senão pula o vídeo?"

"Éh!"

"Quando fala da publicidade, você ta falando mais de propaganda na internet do que de propaganda na TV né?"

"Éh. Sim. Eu não costumo assistir muita TV. Agora."

"Principalmente no YouTube. Eu vejo mais."

\section{Marca:}

"Marca serve pra você conseguir, não só diferenciar pelo sabor, essas coisas, mas ter um nome específico pra você dividir, né, as marcas. Quer dizer, os produtos em marcas. Sim."

\section{Embalagem:}

"

"Calma aî...

"Sobre embalagem. Pra que serve? Se vocês gostam ou não?"

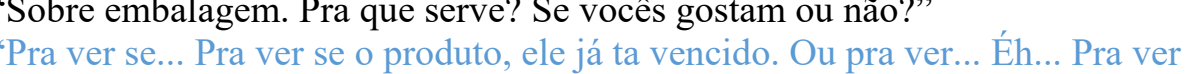
cle é um...

menino parou de falar e ficou pensando em como poderia continuar a resposta. E aí ele travou

Pedi que a menina, então, tentasse ajudar o irmão na resposta.

"Haha!... Éh... Tipo... A embalagem.

Como é que a pessoa sabe qual a marca do produto, se não tem nada escrito, no produto em si?"

"Ah ta!... Pelo... Sabendo pelo nome que ta na embalagem."

"E a embalagem deve ser bonita? Ou isso não tem importância?"

"Eu acho que, principalmente pra criança pequena, essa coisa de embalagem colorida, bonitinha,

que chama a atenção, ajuda bastante na venda. Haha! Com criança pequena." "Mas acho que sim, né. Dá mais vontade de comprar quando a coisa é mais

fofinha, bonitinha. Essas coisas."

Personagem / Mascote:

"Ah!... Eu sei! No Sprite, tem aquele limão lá!"

"De personagem."

"Éh... Não. Mas tipo... Tipo, o Cheetos. Por exemplo: o Tigre do Cheetos!"

Comentei que o menino estava certo. Porque há mesmo um limão que fala em

algumas propagandas do Sprite.

"Ah!... É verdade!"

Mas foi engano. As propagandas com limões são da Pepsi Twist.

"E pra que serve essa coisa de personagem / mascote?"

"Serve pra chamar mais a atenção das crianças. Principalmente."

"E pra você, os personagens / mascotes chamam a atenção?"

"Acho que sim."

"Mas uma vez você me contou que você gosta de outro tipo de personagem, lembra?"

"Ah! Personagem de videogame!"

"E se fosse um personagem de videogame na comida? Aí sim, né!"
"Éh.

"E aparece mais propaganda de que na TV?"

"De hambúrguer! Aparece muita propaganda de hambúrguer!

"Én."

“Tipo, do McLanche Feliz / das promoções / dos personagens / brinquedos?’ "Na verdade, ta aparecendo mais... Hambúrguer de... Tipo.

Tirando o McLanche Feliz. Ta aparecendo os outros."

“Ah. Sim. As promoções e os lançamentos dos outros lanches, né?"

"Aham."

Marcas / Supermercado

"E como acontece o contato de vocês com as marcas / produtos alimentícios no supermercado?"

"Geralmente, quando tem alguma propaganda que chama mais a atenção, que sej de comida...

Eh... Se eu vejo no mercado, eu lembro na hora da propaganda. Haha!"

"E se for alguma coisa que eu sei que eu goste... Tipo... Nutella, por exemplo.

Eu... Eu já vi algumas vezes a propaganda da Nutella.

Aí, quando eu vejo no mercado, eu fico com vontade de comprar. Haha!"

"Mas mesmo quando não há propaganda. Ou quando você não lembra da

propaganda. Como acontece o seu contato com as marcas / produtos alimentícios no supermercado? As marcas chamam a sua atenção?"

"Éh... Eu... Geralmente, quando eu vejo alguma marca que eu gosto mais... Que

Não que eu uso mais, né. Porque as marcas que eu gosto são um pouco mais caras. Haah!

Mas... As que eu costumo utilizar mais, né... Não... Não me chamam tanto atenção, assim.

Que eu já to acostumada a ver. Essas coisas.

Mas as que eu gosto mais, mas que eu não posso comer todo dia.

Éh... Me chamam mais a atenção, sim. Que dá mais vontade."

"Você pode dar o exemplo de três dessas marcas que você gosta mais e que são

mais caras?"

"Milka! Haha! Milka!"

"Lindt - que é um chocolate caro pra caramba! Haha!"

"Você gosta?"

"Eu gosto! Só acho que eu comi (poucas vezes). Da pra contar em uma mão quantas vezes eu já comi um Lindt."

"E a terceira marca?"

"Éh... Eu não consigo, assim, identificar uma marca que seja realmente cara, de comida (hambúrguer)

Mas... O McDonald's. Que é um pouquinho mais caro, assim, do que... Éh."

"Falando de fastfood / hambúrguer, né?"

"Éh. Sim. Aham."

"E pra você? Como acontece o contato com as marcas / produtos alimentícios no supermercado?"

"Ás vezes, quando eu vejo uma... Uma coisa que eu ainda não conheço,

e pode ser de uma coisa, de um ingrediente que eu gosto... Às vezes eu tenho

vontade de comprar."

"Pra experimentar?"

"Aham."

"Lembra de algum exemplo?"

"Não."

“Mas acontece, né?"

"Aham."

"E no supermercado você também encontra as marcas / produtos que você mai gosta e que já conhece?’
.
"Éh."

Preço:

"E vocês sempre pensam no preço dos produtos quando vocês estão no supermercado?"

"Sim." Haha!"

"E porque vocês pensam no preço?"

"Porque, basicamente, tudo ta caro hoje em dia. Haha!

E aí eu sei que a gente não tem dinheiro pra caramba.

Aí eu tento ajudar a dar uma economizada na hora de escolher as coisas."

"A Luana tem uma estratégia boa, né? Que é procurar produtos similares!"

"Éh. Que sejam mais baratos. Que sejam... Tipo uma... Éh. Similares."

"Uma imitação bem perfeita!"

"Sim! Éh! Hahaah!"

"Conta pra gente a história da Nutella."

"Éh... É NutryCream o nome? É ne?"

"Éh. Sim. Sim."

E a menina, então, contou a história da Nutella:

"Éh. Tem a Nutella! Que eu gosto bastante, né! Eu gosto bastante de doce!

Mas... Pra passar em pão, essas coisas, tipo, a bisnaguinha, eu gosto bastante de

passar Nutella.

Pra lanche, principalmente. Só que a Nutella é bastante cara.

Então eu procurei produtos, né, que sejam similares.

Eu até achei alguns produtos que parecem. Mas o gosto não é tão bom quanto o da Nutella.

Mas eu achei um que é bem, bem parecido mesmo, o gosto, com a Nutella. Só que ele é bem mais barato.

E aí... Éh... Tem dois, na verdade: um que vende no Carrefour - que é do próprio Carrefour;

e um outro, que se chama NutryCream - que eu acho que só vende em mercado... É isso. Mercado atacado.'

"E aí funcionou a estratégia, né! Para o cover da Nutella!"

"Sim! Funcionou! Haha!" 
"Me diz um personagem de videogame que poderia estar no salgadinho?" "O Pikachu!

"E o Pikachu ta em algum alimento?"

"Acho... Acho que até ta. Num chiclete. Éh."

"Chiclete japonês com a licenç

"Essa eu não sabia! Haha!"
"Aham

"Você pode dar um exemplo?"

"No mercado, às vezes, eu encontro rolinho de salsicha. Eu fico com vontade de comprar."

"Mas aí é pelo produto ou pela marca que você escolhe?"

"Pelo produto mesmo. Porque eu gosto."

\section{SOBRE PRODUTO / MARCA / PERSONAGEM / EMBALAGEM / PUBLICIDADE:}

\section{FAMÍLIA 3}

MENINA MAIS VELHA

\section{SOBRE MARCAS / PUBLICIDADE: SUPERMERCADO / TELEVISÃO / INTERNET / JOGOS}

\section{FAMÍLIA 3}

MENINA MAIS VELHA
"O que é produto / marca / personagem / embalagem / publicidade?"

\section{Produto:}

"Produto é a comida."

Marca:

"E a marca é como se fosse o nome da fábrica que criou essa... essa comida."

"E por que existem as marcas? Por que existem marcas diferentes? Para que servem as marcas?"

"Éh... Pra diferenciar. Porque, às vezes, tem produtos que tem o mesmo nome, mas de gostos diferentes."

"E pra gente saber quem criou, assim.

O original, vamos dizer, e o outro, assim, que que copia Én. Én. Parecido"

\section{Personagem / Mascote:}

"Personagem é mais pra as criancinhas, né.

Que... Como a Terezinha, ela escolhe mais pelos personagens."

"Ah! A gente viu lá no supermercado, né. Que a Terezinha foi logo escolher... Qual era o produto?"

"Dos Minions."

"As balas Fini (Minions)."

"Éh."

"Gosta dos Minions né Terezinha?"

A menina mais nova não respondeu. Mas sorriu.

"E... Éh. E os personagens é mais pra isso mesmo. (...) Pras crianças."

"E os mascotes?"

"Mascotes?... Eu não sei..."

"Mascotes são aqueles personagens que são das marcas. Que não são da televisão ou do cinema, como os Minions. Mas são das marcas, como o leopardo do Cheetos..."

"Éh."

"Tem também aquele do Danoninho... É um dinossauro?"

“Éh. O Dino!"

"Esses são os mascotes das marcas."

"E para que servem os mascotes?"

"Éh... Eu acho... Hum... Eu não sei muito bem.

Mas eu acho que esses, como o Dino de Danoninho... Essas coisas, assim... É mais também pras crianças."

"E tem também, vamos dizer... A Seara tem aquele, tipo um frango.

Éh... Eu não sei muito pra que que é. Mas... Éh... Eu acho que é pra... pra chamar mais atenção, assim.

Que também... Ou pra... falar, assim, que... Essa... Éh...

(Provavelmente a menina estava se referindo ao mascote da marca Sadia.)

\section{Embalagem:}

"Pra proteger os produtos."

"A embalagem é só pra proteger os produtos? Ou você acha que pode ter mais alguma função a embalagem?"

"Hum... Acho que é só pra proteger mesmo. Éh."

\section{Supermercado:}

"Quando você vai ao supermercado, como aparecem as marcas pra você? Onde as marcas aparecem?

E como você escolhe as marcas e produtos no supermercado?"

"Hum... Hum... Eh... Geralmente, assim, sem ser propaganda... Pelos meus amigos.

Eles me falam, assim, desse produto. Aí eles falam o nome. Aí... Se eu ver esse nome... Aí eu... Aí eu já sei."

"Ai você vai ver pela embalagem né? Pra saber qual e o produto ou a marca?"

"Sim. Sim."

"Ou também quando você já conhece o produto e a marca, né?

Como aquele dia que nós fomos ao supermercado e você escolheu alguns produtos / marcas

que você já conhece."

"Sim."

"Você já tinha na cabeça os produtos / marcas que você queria escolher né?"

"Sim."

"E aí você também visualizou pelas embalagens

(1)

"Era saber."

"Então... Mais uma função da embalagem: mostrar os produtos e as marcas pra gente saber."

"Éh."

\section{Televisão / Internet / Jogos}

"Para além das propagandas e vídeos, há algum outro formato em que as marcas aparecem pra você na televisão ou na internet?"

"Acho que só... só na tv mesmo. Éh. Nas propagandas."

Na internet:

Pra mim... Acho que... Tem num jogo. Num jogo, que é o Gacha Life, que eu jogo.

Ele também tem algumas propagandas. Então..."

"Dentro do jogo?"

"Sim."

"Tem propaganda de alimentos também?"

"Tem. Tem de todo tipo de propaganda. Éh."

"E você pode pular as propagandas? Ou tem que assistir pra passar pra próxima fase?"

"Éh... Éh... Não é bem assistir. É mais só uma foto, assim, vamos dizer."

"Ah. Não é vídeo."

"Não."

"É só uma tela que aparece, assim, dentro do jogo."

"Éh. Sim."

"Aí aparece. Some. Depois aparece de novo, né?"

"Éh Á́, às vezes, demora um pouco . Às vezes, demora mais Pra aparecer Éh" 
"E as embalagens são bonitas? São diferentes umas das outras?"

"Sim. Elas... Tem algumas bonitas... Outras que são só pra embalagem mesmo.

"Sim. Elas... Tem algumas bonitas.,

"E você escolhe os produtos pela embalagem? Ou você vai mais pelo que você mais gosta?"

"Hum... Geralmente eu vou mais pelo que eu mais gosto."

"Porque aí você já sabe qual é o produto e a marca né?"

"E quando você não conhece. Mas quer experimentar.

A embalagem chama a atenção? Você escolhe pela embalagem?"

"Não. Eu... Eu só compro mesmo se eu ficar com curiosidade. Pra saber o gosto. Éh."

"Ah. Só se você estiver querendo experimentar aquele produto?"

"Éh."

\section{Publicidade:}

"Como é o seu contato com a publicidade / as propagandas de alimentos?

Como chega essa publicidade pra você?"

"Pra mim chega mais pelo YouTube. Éh."

"E quais vídeos de propagandas de alimentos aparecem mais pra você no YouTube?"

"Hum... Tanto faz. Mas... Éh... Aparece mais o do McDonald's!"

"E acho que só."

"Mas você comentou comigo uma vez que aparece também outra marca além do McDonald's né?"

"Ah! O Burger King!"

"E geralmente você pula os vídeos né?"

"Éh. Éh."

"E propagandas de outras coisas aparecem também pra você no YouTube?"

"Hum... Não. Éh... Também... Ah!... Propagandas de aplicativos! Aplicativos como jogos, assim... Éh."

"Ah. Porque você se interessa por conteúdos de jogos né. Aí aparece pra você."

"Sim"

"As propagandas aparecem pra você mais pelo YouTube. Mas você vê propagandas também na televisão?"

"Éh. Consigo. Mas é mais pelo YouTube mesmo."

\section{ALIMENTAÇÃO X DIVERSÃO}

\section{FAMÍLIA 1}

\section{FAMÍLIA 2}

MENINA
MENINO

\section{FAMÍLIA 3}

MENINA MAIS VELHA

MENINA MAIS NOVA

\section{Mais saudável:}

- Alface

- Água

"Qual é a comida mais saudável que

você já comeu na vida João?’”

"Alface. Não. Água. Água e alface!"

\section{Mais guloseima:}

- Sorvete: McDonald's

"E a coisa mais guloseima?"

"Sorvete do Mc!

\section{Mais saudável:}

- Tomate

Águ

A comida mais saudável que eu já

comi em toda a minha vida foi: tomate

com água.

Mais guloseima:

- Hambúrguer (Triplo Quarterão):

McDonald's

- Milk-Shake (chocolate): McDonal

(Kopenhagen)

"E a coisa mais guloseima?"

"Era um... Um Triplo Quarterão com

Milk-Shake do McDonald's!

E era um Milk-Shake de chocolate da

Kopenhagen!"
Como a menina estava responsável pela "O que vai ter nas suas cestas Rafael?" gravaç̃o do vídeo, ela controlava o "Na cesta."

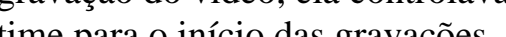

$$
\text { "Aí! Vai!" }
$$

Na cesta da alimentação:

Tomate

"Imaginem que vocês têm duas cestas: - Purê de batata

uma cesta com coisas que vocês gostam - Salsicha

e que são saudáveis;

- Laranja

gostam e que são guloseimas.

A cesta da alimentação e a cesta de

diversão."

"O que vocês vão colocar em cada

cesta?"

"Vamos começar!"

"Aham."

"Aham."
- Tangerina

"Tomate, purê de bata e salsicha.'

"Mas a cesta da alimentação é a cesta

das coisas saudáveis."

"Ah! Então ta!"

"A salsicha pode ficar? Será? Você decide ta?"

"Éh... Não. Acho que não."

E o menino ficou pensando em outro da salsicha. alimento pra colocar na cesta, no lugar
"Vamos imaginar que você tem duas cestas:

una cesta com coisas que você gosta e que são saudáveis;

e uma cesta com coisas que você gosta

que são guloseimas.

A cesta da alimentação e a cesta de

diversão."

"O que você vai colocar em cada cesta?"

"Vamos começar!"

"Tá!"

Na cesta da alimentação:

Manga / Morango / Tomate

"Éh... Alimentação?... Que eu gosto..."

"Coisas saudáveis que você gosta."

"Éh... Alimentaç̃o saudável: A manga ..

Hum... O morango.. Éh... O tomate." 
"Eu recomendo vocês comerem muito! "O que vai ter nas suas cestas Luana?" Porque é muito bom!"

"O que vai ter nas suas cestas Luana?" "Quantos você quiser colocar." "Acho que dois ou três, né?... Éh." "Pode ser."

Na cesta da alimentação:
- Tomate
- Morango
- Batata
- Purê de batata
"De coisa... Éh... Da alimentação:
Eu acho que, tomate! Que eu gosto
bastante de tomate. Como que nem
maçã. Haha!...
É... Deixa eu ver... Morango! Tomate
e morango eu gosto bastante!
Éh... E de comida mesmo, tipo, pra
comer junto com arroz e feijão, é purê
de batata."
"Então, na cesta da alimentação você
tem: tomate; morango; e purê de
batata."
"Éh. Pode ser batata também. Haha!
Pode ser uma batata. Hahaha!"
(Imaginando, talvez, que seria difícil
colocar o purê de batata em uma cesta.
"Mas pode ser o purê de batata. Olha só
que combinação gourmet: tomate,
morango e purê de batata!”
"Hahaha!"
"Mas você gosta? Você curte tudo o
que ta na cesta?"
"Sim! Bastante!"

\section{Na cesta da diversão:}

- Chocolate (barra / caramelo): Milka - Creme de avelã e cacau: Nutella - Creme de avelã e cacau: NutryCream - Chocolate: Kinder Ovo

"Éh... Milka! Com caramelo!

Hahaha!... Éh... Deixa eu ver... Éh..." "Olha só, gente! Ela ta pensando, não porque ela não tem ideia.

Mas porque é difícil escolher entre as tantas ideias que ela tem. Haha!"

"Haha! Sim!"

"Éh... Nutella! Quer dizer, o cover da Nutella, né. O NutryCream!"

"Mas esta é a sua cesta. Você escolhe que quer colocar. Você quer colocar a cover ou a Nutella?"

"Pra mim é igual o sabor. Nem pelo preço, mesmo. Pelo sabor, tanto faz Então..."

"Mas então você escolhe."

"Éh... Então Nutella mesmo."

"E o que mais?"
"Então..."

"Procurando informação... Procurando formação... Loading..."

"Haha!"

Laranja! Não. Mexerica!"

"Ele gosta de mexerica?

"Acho que... Éh."

"Você gosta de laranja ou de mexerica?

"Acho que mexerica."

"Aquela que vai tirando os gominhos, né?"

"Isso."

"Aham."

"La no sul a gente chama de tangerina." "Então, na cesta da alimentação você

tem: tomate..."

"Purê de batata e tangerina. Não

Tangerina, não. Mexerica."

\section{Na cesta da diversão:}

Chocolate. Kinder Ovo

(Chocolate (bara): : Son

"Kinder Ovo!... Éh..."

$\mathrm{O}$ menino parou de falar e ficou

pensando por alguns segundos. E ele

ravou.

"Ta faltando opção de guloseimas? Ou ão muitas ideias? Haha!"

"Hahaha! Olha só! Se quiser eu tenh

um dicionário de (guloseimas)!

"Imagina que você está lá no

supermercado pra escolher."

"De doce... Bumbom! Sonho de Valsa!"

"E falta só mais um na cesta."

"Barra de chocolate! Tipo..."

"Qual chocolate?"

O menino fica pensando. E a irmã tenta

ajudá-lo:

Qual o chocolate que, de vez em

quando, a gente pede pra mamãe

comprar? Aquele de barra."

"Lacta?"

"Pode ser."

"Lacta de chocolate! Pode ser."

"Você gosta?"

"Pode colocar na cesta?"

"Pode."

"Então, na cesta da diversão vocêtem: barra de chocolate Lacta.."

"O Kinder Ovo..."

E o bombom Sonho de Valsa."

Agora revisando as cestas:

Na cesta da alimentação:

\section{"E porque essas coisas são mais pra}

"Éh... São mais pra alimentação porque é que eu como bastante.

c... Menos o morango. Mas... Éh... São "Mmidas que eu como bastante."

"Mas por que?"

"Por que elas são mais saudáveis. Éh."

\section{a cesta da diversão:}

Danoninho / Bolacha (Minions) / Nutella

/ KitKat / Pipoca / Fini

"Hum... Eh... Comidas com personagem."

"Comidas com personagem, como o

Danoninho."

"Você gosta de Danoninho?"

"Gosto!"

"Éh... A... Uma bolacha - que agora eu não lembro muito o nome. Só que eu... Eu lembro que tem uma que

"Mas pode ser também sem peronagem.

"Só tem que ser guloseimas que você

"Então:

"Anão: O Danoninho..."

"A bolacha..."

Minions, né?"

"Éh... Que... Ah! Mais a Nutella também!

E pode colocar mais duas coisas na cesta da diversão. Se você quiser ta?"

"Ê... O KitKat! E... A pipoca!"

"Pipoca doce ou salgada?"

Hum... Tanto faz. Mas eu como mais a

pipoca salgada! Uhum!"

Tentando lembrar o que tem em cada

cesta:

Cesta da alimentação:

A manga. O morango. E o tomate."

Cesta da diversão:

"A Nutella..."

"O biscoito..."

"Dos Minions."

"O Danoninho... E..."

"O chocolate..."

"Não. O chocolate..."

"Ah! O KitKat!"

"E. Hum O último eu nunca lembro .."

"O KitKat e o... Acho que o Fini."

"Não sei se era o Fini."

"Eu não tinha falado ainda."

"Não. Eu tinha falado só mais um."

"Eh... Você tinha falado: O Danoninho...

"A biscoito dos Minions..." 
"Éh... E o Kinder Ovo!"

"Então, na cesta da diversão você tem:

Milka; Nutella; e Kinder Ovo."

Milka de caramelo?"

de caramelo."

Agora revisando as cestas:

Na cesta da alimentação:

"Foi: morango, batata e tomate."

Na cesta da diversão:

"Foi: Milka (com caramelo), Nutella e

Kinder Ovo."
"Éh... Purê de batata, tomate... E qual que era o outro?... Mexerica."

Na cesta da diversão:

Or... Bara de chocolate Lacta, e Kind

De repente o cachorro das crianças

entrou na sala.

o Cheetos ta bem aqui

Olha só, gente! O Cheetos! Ele quer

participar da entrevista!

"Ah!... Fugiu na hora de filmar!"
"Mas eu acho que você tinha falado outra

"Eu não tinha falado ainda. Não."

"Qualquer dúvida, depois é só olhar no

vídeo né! Haha!"

A menina esqueceu da pipoca!

Fonte: elaborado pela pesquisadora Legenda:

Falas da criança mais velha

Falas da criança mais nova

Falas do pai

Falas da mãe

Falas da pesquisadora 
Quadro 11 - Experiência Lúdica The Kids: Kids by Kids III

AS CRIANÇAS E AS MARCAS E PRODUTOS ALIMENTÍCIOS NAS ESCOLHAS E PREFERÊNCIAS INFANTIS

\section{MARCAS QUE CONHECEM / RECONHECEM:}

\section{PERSONAGENS OU MASCOTES QUE CONHECEM / RECONHECEM:}

\section{FAMÍLIA 1}

MENINA E MENINO

"Vocês conhecem marcas de coisas de comer?"

"Sim!" "Não!"

"Sim ou não? Fiquei confusa. Haha!"

"Sim ou n no? "Eu sim!"

"Que marcas você conhece?"

"Twix. KitKat. ItCoco."

"Ham?"

"Posso falar?"

"ItCoco? O que é isso?"

"É um chocolate. De coco."

"E que outras marcas você conhece?"

"Éh..."

"Posso falar um monte?"

"Kinder Bueno. Kinder Ovo,"

"Só chocolate!"

"Eu também conheco mais um que ninguém (conhece)..."

"Sensação."

"E tambem tem mais um que eu não me lembro o nome."

"Eu conheço as marcas de comida São: ,"

"Ah! Eu conheço..."

"São :... Eu conheco.... Kinder Ovo. Alpino. Sensaç̃o. Nestlé. Laka. Diamante Negro. Nutella. KitKat. Twix."

"Brigadeiro."

"Brigadeiro é uma marca?"

"Tem uma marca de brigadeiro."

"Eu sei mais uma coisa! Eu sei... Vigor!"

"Toddy!"

"Peraí! Deixa eu ver aqui na mesa..."

(Procurando na mesa do café da manhã)

"Vigor Grego!... De gordice."

"McDonald's! E uma marca de comida."

“Já sei! (...) Eu sei mais uma coisa que a Rose ainda não falou!"

"É daquele ursinho."

"Ursinho?"

"Ursinho do pão!"

"Ah! É o Pullman!"

"Pullman."

E quando a mãe cita algumas marcas que ela escolhe para o consumo da família as crianças comentam:

"Camil!"

"Feijão Camil!... É bom!... Eu comi muito arroz e feijão para chegar... (..)"

(Ele faz uma brincadeira. Como se estivesse fazendo propaganda da marca.)

"Hellmann’s! Hellmann's! Hellmann's mãe!"

"Éh! Heinz! Heinz! Heinz!"

\section{FAMÍLIA 1}

MENINA E MENINO

"Vocês conhecem personagem / mascote que tem nas marcas de coisas de comer?"

"Eu sei!'

"Pullman (o ursinho)."

"Ursinho."

"O ursinho da Pullman."

"Jacaré."

"Da onde é o jacaré?"

(A menina ficou pensando. Não lembrava da marca. Mas depois lembrou.)

"É do América."

"Jacaré do América! Ursinho do Pullman!"

(E a menina continuou pensando.)

"Qual que era?... Ah! Era dois cisnes... Acho que era de uma marca... né?"

(Provavelmente se referindo à marca Perdigão)

"Tinha mais alguma marca?..."

"Ái! Era um gato."

(O menino quase caiu da bicicleta.)

"Cuidado gente! Cuidado!"

"Só isso que eu me lembro."

"Eu lembro mais de um... Um super hiper mega gatinho!"

"Ham?"

"Um gatinho."

"Um gatinho? Da onde?"

"Um gatinho."

"Onde que tem gatinho? Você lembra?"

"Não."

Hahaha!"

"Was tem a marca de um gatinho. Mas não me lembro o nome da marce."

(Provavelmente se referindo à marca Língua de Gato - Kopenhagen) 
FAMÍLIA 2

MENINO

MENINA

MENINA MAIS VELHA

FAMÍLIA 3

"Um produto / marca que vocês gostam. E um personagem / Produtos / Marcas / Personagens:

mascote que vocês gostam."

"Você quer falar alguma coisa primeiro?"

Produtos / Marcas / Personagens:

- Salgadinho: Cheetos

- Personagem: Leopardo (Cheetos)

- Personagem: Pikachu (Pokémon)

"De personagem, que eu gosto, é o Cheetos!"

"O personagem do Cheetos? O Leopardo?"

"Aham."

"E um produto / marca que você gosta?"

"Salgadinho! Cheetos!"

"E se ao invés do Leopardo, o mascote do Cheetos fosse

Pikachu?"

"Ah... Eu... Eu preferia mesmo assim."

"Mas você ia preferir com o Pikachu?"

"Muito mais!"

"Mais do que o Leopardo?"

"Éh!"

"Ele é mesmo um videogamer gente!" "Hahaha!"
- Chocolate branco: Laka

- Chocolate (barra / caramelo): Milka

- Chocolate (barra): Milka (Oreo)

- Personagem: Minions

"Pra mim... Personagem são Os Minions. Do danone. Que tem uns danones que vem com... Éh... Esqueci o nome... Que é docinho, pra você jogar dentro do danone e comer."

"Éh... Mas de marca, de produto, mesmo. Que eu goste, sem ser pelo personagem, não é esse.

Que eu não curto muito danone."

"Qual seria?"

"Éh... Agora eu não vou lembrar, gente!... Tanta marca na cabeça!...

Éh... Não sei. Eu acho que... Chocolate também! Haha! Éh... E acho que é Laka. Que é uma opção..."

"Mais que Milka? Haha!"

"Éh! Milka! Milka! Tinha deletado da cabeça. Milka!" "E qual Milka é o seu amor do momento?"

"Sempre foi, na verdade. Haha! Que é o Milka com

"Éh. O Milka Oreo ta competindo. Haha!"
"Alguns produtos / marcas que você gosta. E alguns personagens / mascotes que você gosta."

Produtos / Marcas:

"Hum... Produtos é mais... Que eu gosto muito é da Nutella."

"Depois vem o salgadinho Ruffles."

"E depois vem o KitKat."

"Você gosta de muitas coisas né?"

"Sim."

"Mas esses três são alguns dos que você mais gosta. Certo?" "Éh."

"E tem mais algum produto / marca que você gosta? Além desses que você já falou?

Se você quiser pode falar,"

"Hum... Acho que... Acho que só esses mesmo."

"Aum!... Acho que... Acho que só esses men Não. O Cookies! Da Bauducco!"

"Ah! Que você gosta bastante. E come bastante também né?"

"Sim."

"E a balinha? Haha!"

"Éh... A Fini também. Mas não muito não."

"Você gosta mais dos outros que você escolheu né?"

"Voce go

\section{Personagens:}

"Personagem... A Lady Bug!"

"Éh... O Hotel Transilvânia! Que eu gosto bastante!"

"Éh... Éh... Os Minions!"

Fonte: elaborado pela pesquisadora

Fenda:

Falas da criança mais velha

Falas da criança mais nova

Falas do pai

Falas da mãe

Falas da pesquisadora 
AS CRIANÇAS, A PESQUISA E O CONSUMO ALIMENTAR INFANTIL

SOBRE CONSUMO ALIMENTAR INFANTIL:

\section{FAMÍLIA 2}

MENINA

MENINO

MENINA MAIS VELHA

FAMÍLIA 3

"O quê? Eu não sei."

"Que eu não gosto de alface. Eu não gosto de alface." "E criança tem que comer alface?"

"Não. Dá tomate ou pepino."
"Éh... Muita criança, mesmo. Tipo... A minha amiga, por exemplo:

A mãe dela controla muito a alimentação dela. - Ela faz

faculdade de nutricionismo... Uma coisa assim.

E tipo... Ela sempre manda... Sempre uma fruta... E alguma.

$\mathrm{E}$ às vezes, ela manda bisnaguinha.

Só que o recheio é sempre alguma coisa muito natural.

E ela sempre acaba dando pra... (mim?)

Pras outras pessoas.

E acaba comendo muito pouco."

"Então... Tipo... Sei lá... Sabe?

Tem que ter... Tem que ta saudável. Mas também tem que te algum agrado.

Pra pessoa comer, pelo menos."

"Ou ela não come nada... Ou ela vai... Ela vai distribuindo, assim...

Ela vai dando pras pessoas. "Você quer? Você não quer?’”

"Às vezes a gente fica com dó... E dá um pedacinho do nosso lanche pra ela.

Porque a coitada não come doce!

Aí ela fica só com vontade! Éh!... Ela... Ela fica olhando!'

"Aí... A mãe dela também não deixa ela comprar... Tipo, nunca na cantina.

Porque tem salgado... Às vezes, essas coisas muito

Porque tem salge

Então... Tipo... Quando ela consegue, ela fica... Ela come mesmo!"

“Éh. Então... Tipo... Tem que controlar. Mas tem que saber..

Éh... Tipo...
Éh... Ser saudável. E também... Éh... Agradável. Sabe?" "Saudável e agradável"

"Éh... Tipo aquela frase que eu usei da última vez.

Mas... Éh. Eu acho que... É isso mesmo.

Aquela frase de: Você tem que comer coisa saudável.

Aquela frase de: Voce ten que coner coisa saudável...

Mas tem que saber colocar... Achar um meio-termo entre

e coisa que... Sabe?... Que te sirva bem. Que te deixa feliz quando você come."

Sobre ser "Saudável e Agradável":

"Éh.. Tipo... As crianças, né... Elas tem que comer coisa

saudável, né... Pra ficar com uma saúde boa.
“Éh... Comer... Comer só... Éh... Mais coisas saudáveis. Como salada, legumes. Que eu falei.

Éh... Hum... Éh... E maneirar um pouquinho na... Nas guloseimas. Comer só de vez em quando.

Éh É É isso. Éh. Tchau!"

"Hum... Comer mais coisa saudável mesmo.

Que eu... Eu sempre falo, assim, sobre alimentação: Comer mais coisas saudáveis

Ou comer só coisas não saudáveis na sobremesa. Ou quando os pais deixarem."

"Eh. Tem que ter um controle. Tem que comer coisas

saudáveis.

E quando pode... Ou na hora, que nem na sobremesa, pode comer as guloseimas."

"Não... Hum... Não sei.

É porque eu... Eu não sei muito sobre alimentacão.

Então, geralmente (...).

O conselho que eu dou é comer mais coisa saudável. Como os legumes e as frutas.

E... Ėh... Comer... Geralmente... Éh... Tem gente que come sobremesa.

Então... Comer as guloseimas mais na sobremesa.

E pelo menos uma coisa saudável no almoço... Ou no café da manhã ... Ou no jantar. Éh.”

"Hum... Éh... As crianças tem que comer mais coisas saudáveis. Pra quando crescer, ser mais...

Ser um... Hum... Mais forte... Entre aspas, assim. E mais audável!!"

"E as guloseimas?"

"Comer só de vez em quando. E também quando os pais deixarem. Éh."

"Mas é importante comer as guloseimas também?"

"Sim!... É pra... É porque se não comer, também...

Se comer só muita coisa saudável pode ficar, talvez, muito

magra, ou magro.

E aí... Pode aí, acabar, né... Ficar sem... Éh... Eu não sei

muito. Éh."

"Mas é divertido comer as coisas que a gente gosta né?" "Éh!"

"Você acha que uma criança deve comer só coisa saudável? Só guloseima? Ou as duas coisas?"

"Tem que comer os dois. O saudável... Pra... Éh... Ser mais saudável.

E a guloseima... Pra... Porque, né, às vezes, você tem que comer coisas que você gosta." 
Mas eu acho que se elas não comem doce - que é uma coisa que quase toda criança come, né

A menos que não goste.

Que... Eth... Eu acho que... Tipo... Tem festas... Tem vários lugares...

Se você fala pra uma criança... Por exemplo: Pro seu filho

não comer...

Ela não... É uma... Éh... Doce, né... Entra como... Pra mim,

como uma classificação pra diversão.

Então... É uma forma de se divertir, quando você come um

doce. Sabe?

É mais uma coisa extra. Tipo um brinde. Você fez uma coisa

boa... Você se comportou... Ganha um docinho.

Eu acho que... Pode ser também... Éh... Uma forma de

educação, por exemplo. Sabe?"

"Você acha importante ter as duas coisas? O "saudável" e o

"agradável"?"

SOBRE A PESQUISA:

FAMÍLIA 2

MENINA

"Fala aí [menina]!"

"Haha!... Éh... Sobre (?)"

"Sobre a pesquisa."

"Ah!... Eu achei bem legal! Tipo... Porque geralmente, né..

Pra pesquisa... Essas coisas mais sérias...Éh...

Levam muito mais em consideração a opinião de pessoas mais velhas, por experiência, e tal.

Acho bem legal porque agora, tipo, a gente, né - que é

criança, ou pré-adolescente -

tem mais... Tipo... Pode falar o que acha, o que prefere, a

opinião mesmo.

Éh... É isso. Haha! Ah... Acho que só mesmo."

FAMÍLIA 3

MENINA MAIS VELHA

MENINA MAIS NOVA

\section{"Fala aí [menino]! Sobre a pesquisa."}

A menina estava se aproximando do menino com a câmera

"Que é isso Luana! Ta botando mais perto? Haha!"

"Haha! Pra focar em você!"

"Eu gostei da... Nossa! Esqueci o nome."

"Pesquisa."

"Isso!"

"Você gostou?"

"Aham."

"O que você mais gostou?"

"De falar sobre as comidas!"

"E dos jogos que a gente fez, você gostou?"

"Como assim?... Gostei!"

"E algum recado sobre alimentação pras outras crianças?"

"Não. Não sei."

"Só isso?"

"Aham."

\section{"Você gostou de participar da pesquisa?"}

"Hum... Gostei! Éh. Eu gostei bastante!"

"Porque alimentação é uma coisa que eu gosto muito.

Ainda mais, a alimentação das guloseimas. Éh. Da parte das

guloseimas!"

"Éh... Foi bem legal! Que teve... Teve atividades. Foi muito

legais! As brincadeiras!"

\section{Fonte: elaborado pela pesquisadora}

Legenda:

Falas da criança mais velha

Falas da criança mais nova

Falas do pai

Falas da mãe

Falas da pesquisadora 


\section{COMPOSIÇÃO DE MARCAS E PRODUTOS ALIMENTÍCIOS: MY FOODS}

Atividade lúdica desenvolvida com as crianças na forma de composição de marcas e produtos alimentícios preferidos pelas crianças em casa e produção infantil de fotografias para registro da composição de marcas e produtos alimentícios com a coparticipação das crianças.

A seguir, a proposta apresentada às crianças:

- Criação e elaboração de uma composição com os alimentos, marcas e produtos alimentícios de que as crianças mais gostam (alimentos / produtos alimentícios disponíveis em casa no momento do desenvolvimento da atividade).

- Elaboração da produção fotográfica para registro da composição elaborada pelas crianças com os alimentos, marcas e produtos alimentícios de que mais gostam em casa.

A atividade lúdica proposta às crianças com a denominação My Foods, como parte do conjunto de atividades propostas para composição da Experiência Lúdica The Kids, sendo realizada com a coparticipação das crianças sob a coordenação das crianças mais velhas.

Essa atividade foi desenvolvida na forma de uma experimentação metodológica da pesquisa com a coparticipação das crianças na produção infantil de fotografias.

O Quadro 13 contempla o registro da participação das crianças na atividade lúdica proposta, demarcando as perspectivas e subjetividades infantis e agências das crianças na elaboração da composição de marcas e produtos alimentícios e produção infantil de fotografia para a experiência lúdica The Kids: My Foods.

Em anexo, apresenta-se o roteiro sugerido para orientação da produção fotográfica elaborada pelas crianças na atividade lúdica proposta, desenvolvida em cada contexto familiar: registro das marcas e produtos alimentícios preferidos pelas crianças em casa. Atividade lúdica desenvolvida com as crianças ao final da pesquisa sob a denominação My Foods, como parte do conjunto de atividades propostas para composição da Experiência Lúdica The Kids. (APENDICE K) Também em anexo, apresentam-se imagens documentando a participação das crianças e a produção infantil de fotografias na composição My Foods em cada contexto familiar para o desenvolvimento da atividade lúdica proposta. (APENDICE V) 
Quadro 13 - Experiência Lúdica The Kids: My Foods

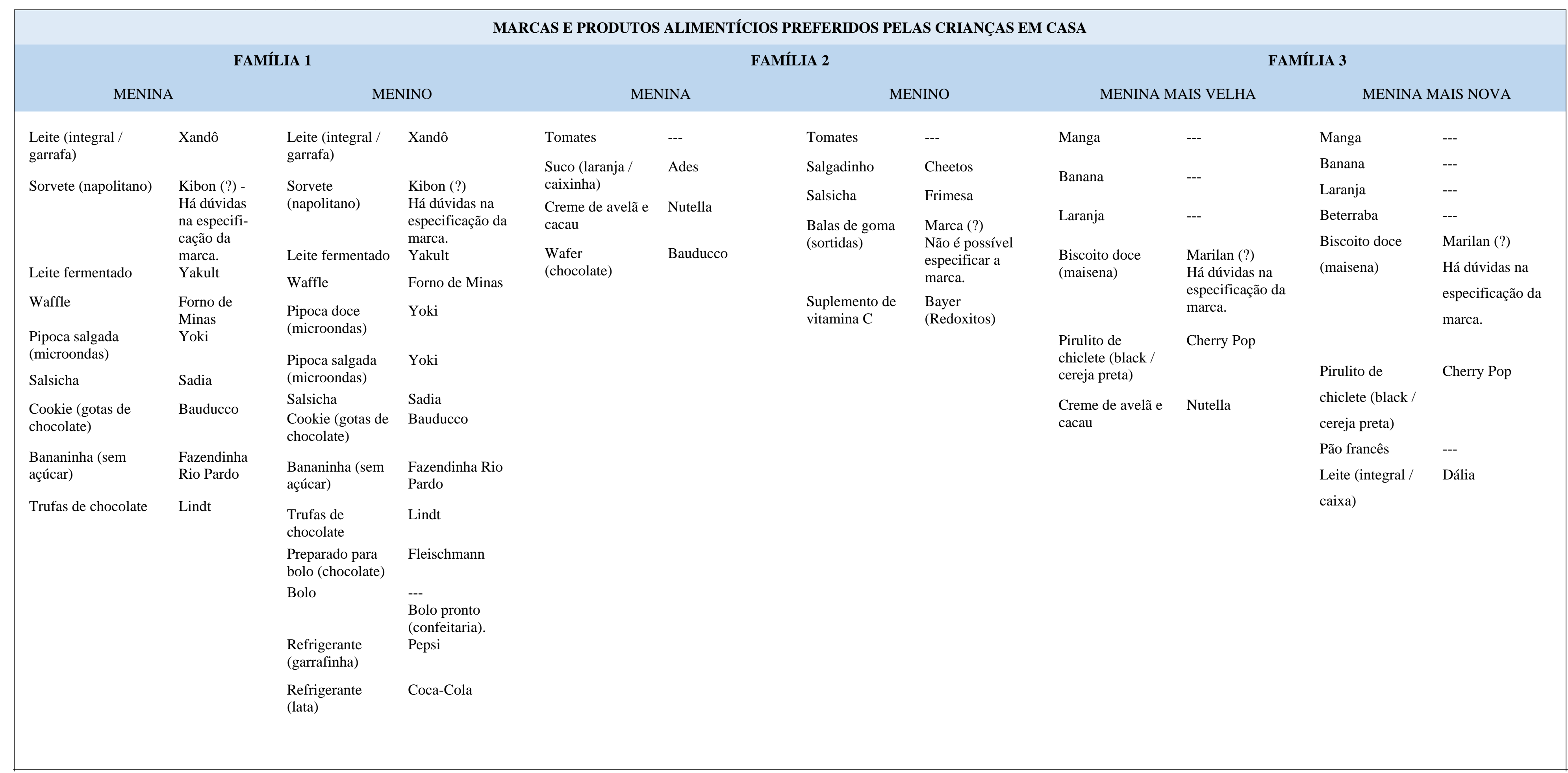

Fonte: elaborado pela pesquisadora

Falas da criança mais velha

Falas da criança mais nova

Falas do pai

Falas da mãe

Falas da pesquisadora 


\section{RETRATO DA FAMÍLIA E DAS CRIANÇAS: MY FAMILY}

A atividade lúdica foi desenvolvida com as crianças na forma de composição de retratos das crianças e da família, e produção infantil de fotografias para retrato das crianças e da família com a coparticipação das crianças.

A proposta apresentada às crianças foi a seguinte:

- Produção infantil de fotografias (em selfie) para o retrato das crianças e da família, com escolha e preparação do cenário, produção fotográfica e direção de fotografia.

A atividade lúdica proposta às crianças com a denominação My Family, como parte do conjunto de atividades propostas para composição da Experiência Lúdica The Kids e realizada com a coparticipação das crianças sob a coordenação das crianças mais velhas.

A atividade foi desenvolvida na forma de uma experimentação metodológica da pesquisa com a coparticipação das crianças na produção infantil de fotografias.

Em anexo, apresenta-se o roteiro sugerido para orientação da produção fotográfica elaborada pelas crianças na atividade lúdica proposta, desenvolvida com as crianças em cada contexto familiar: o retrato das crianças e da família com a coprodução infantil. Atividade lúdica desenvolvida com as crianças ao final da pesquisa sob a denominação My Family, como parte do conjunto de atividades propostas para composição da Experiência Lúdica The Kids. (APÊNDICE L) Também em anexo, apresentam-se imagens documentando a participação das crianças e a produção infantil de fotografias na composição My Family em cada contexto familiar para o desenvolvimento da atividade lúdica proposta. (APÊNDICE V) 
My Family: retratos das crianças e das famílias

Figura 3 -My Family: Retratos da Primeira Família

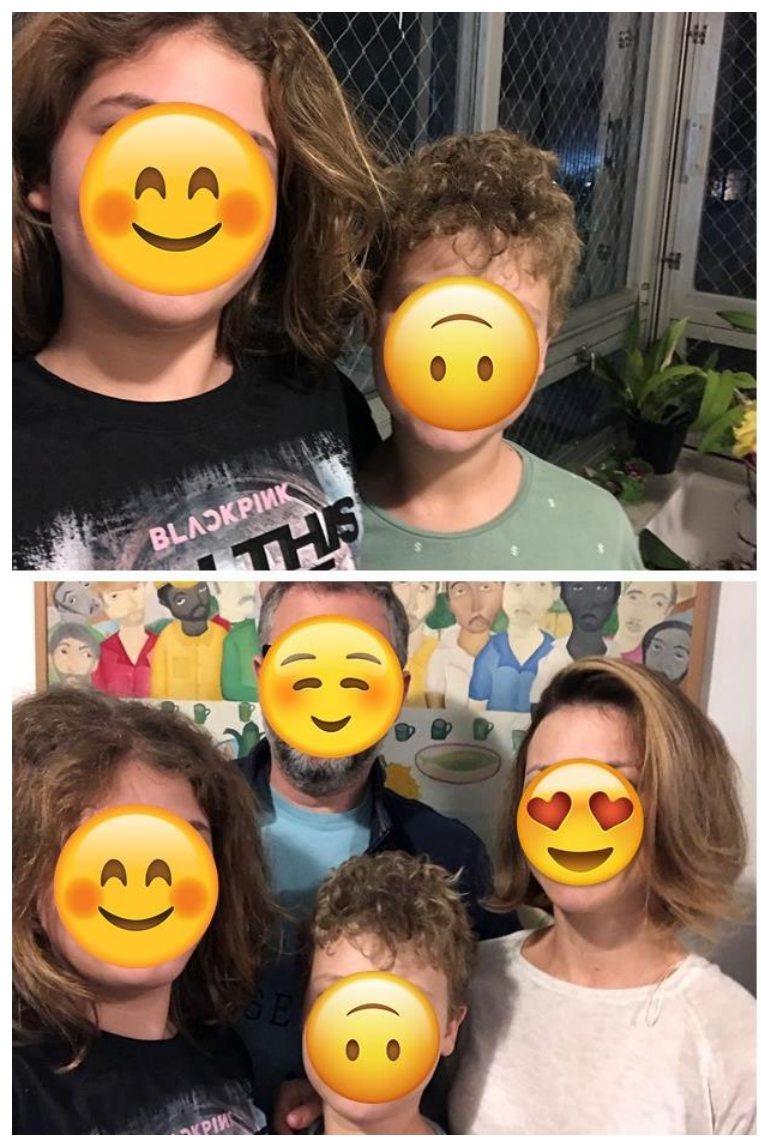

Fonte: Arquivo da autora
Figura 3 -My Family: Retratos da Segunda Família
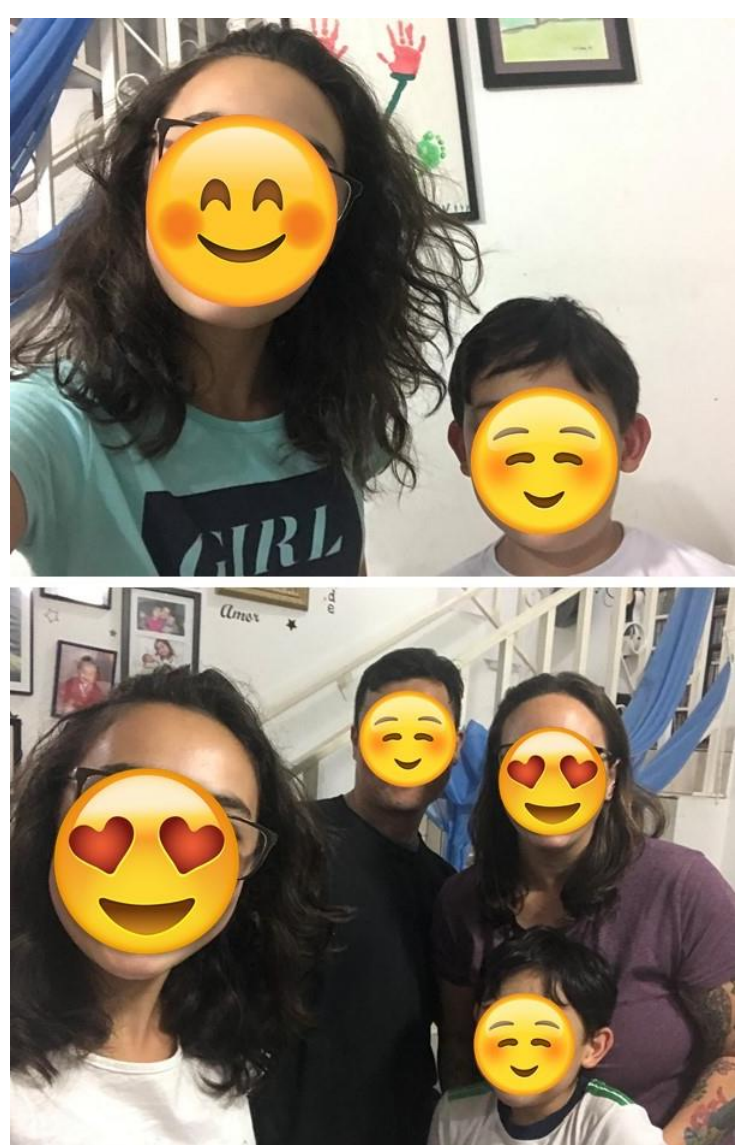

Fonte: Arquivo da autora
Figura 3-My Family: Retratos da Terceira Família

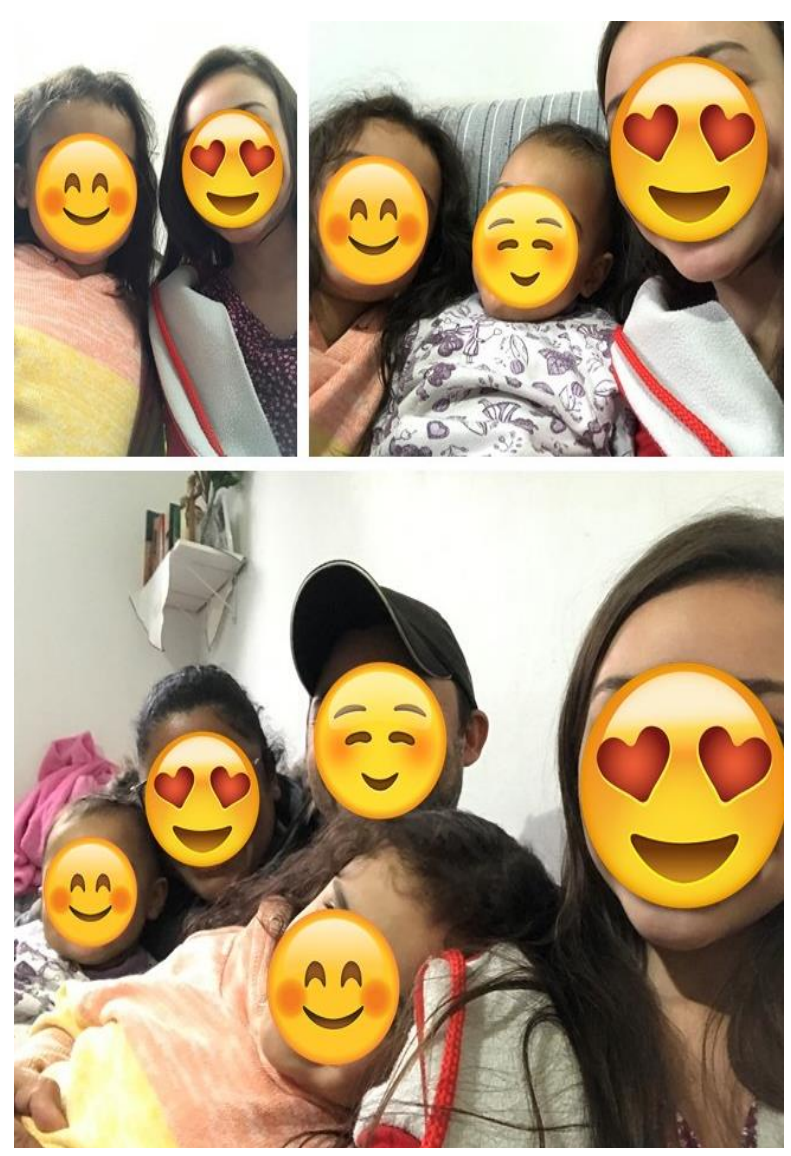

Fonte: Arquivo da autora 


\section{MARCAS E PRODUTOS ALIMENTÍCIOS NO CONTEXTO DAS ESCOLHAS E PREFERÊNCIAS INFANTIS}

PRODUTOS MARCAS PERSONAGENS EM DESTAQUE

Destaque das principais marcas e produtos alimentícios no contexto das escolhas e preferências infantis para o consumo alimentar, presentes na forma dos relatos, citações, observações e expressividades das crianças nas diversas experiências vivenciadas e atividades desenvolvidas no processo de investigação, especialmente no contexto das atividades lúdicas desenvolvidas exclusivamente com as crianças, considerando-se os três contextos familiares pesquisados e as marcas e produtos alimentícios mais citados pelas crianças nas atividades da pesquisa. Aqui, tomando-se as marcas e produtos alimentícios enquanto presença material nos cotidianos da cultura alimentar das crianças em contexto familiar (marcas e produtos alimentícios que as crianças consomem) e enquanto presença simbólica no contexto dos gostos e preferências infantis para o consumo alimentar (marcas e produtos alimentícios que as crianças gostariam de consumir). 
Marcas e personagens favoritos das crianças nos três contextos familiares:

Figura 6 - Marcas Favoritas das Crianças

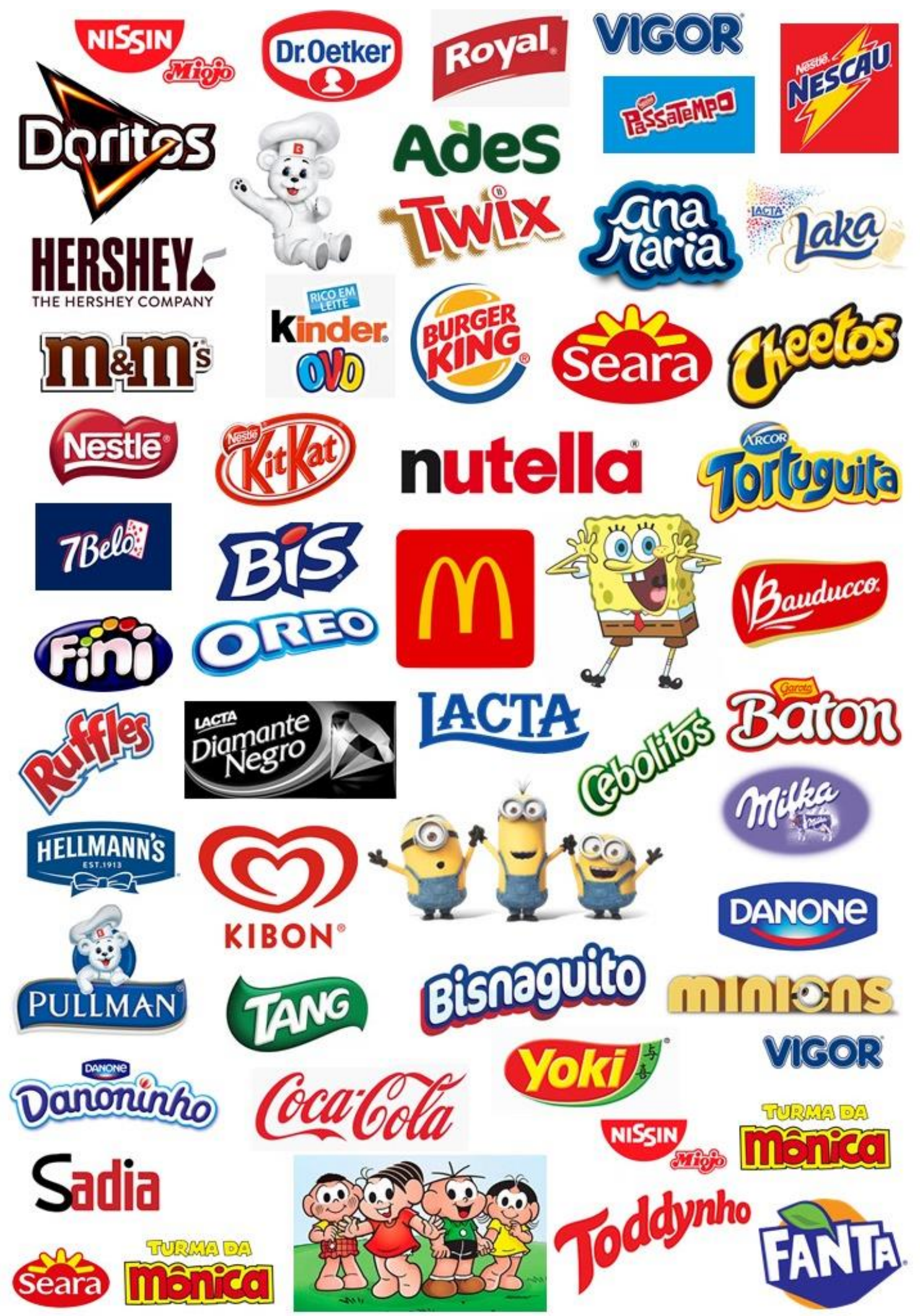

Fonte: Elaborado pela autora 
Para conhecimento das marcas e produtos alimentícios presentes no contexto das escolhas e preferências infantis e nos cotidianos da cultura de consumo alimentar das crianças participantes do estudo, como já sinalizado, apresenta-se em anexo tabelas com registros detalhados da presença material e simbólica das marcas e produtos na cultura alimentar das crianças em cada contexto familiar. (APÊNDICE Q; APÊNDICE R; APÊNDICE S)

Igualmente em anexo, apresenta-se transcrição completa dos dados, informações, atividades, eventos e situações observadas em campo, no contexto das atividades lúdicas desenvolvidas com as crianças no processo de investigação, bem como, dos relatos, observações e expressividades das crianças que caracterizam as perspectivas e agências infantis no processo de investigação e dão forma aos processos de recepção infantil de marcas de alimentos na cultura de consumo alimentar das crianças nos contextos familiares pesquisados. Vide Parte I:3.1-3.3; Parte II:3.1-3.3; Parte III:3.1-3.3) ${ }^{7}$

\section{Reflexões Sobre Recepção Infantil de Marcas de Alimentos e as Perspectivas e Agências das Crianças no Processo de Investigação}

As perspectivas, agências e subjetividades infantis, presentes na forma dos relatos, observações, citações e expressividades das crianças manifestadas no contexto das atividades lúdicas propostas no processo de investigação, demarcam as perspectivas, agências e subjetividades das crianças nos processos de recepção infantil de marcas de alimentos e de consumo alimentar das crianças em seus cotidianos.

E nesse sentido, como sinalizado inicialmente, na mesma medida em que os processos de recepção infantil de marcas de alimentos e de consumo alimentar das crianças - com atenção aos contextos familiares pesquisados e às crianças participantes do estudo - são marcados pelas diversas mediações presentes na cultura alimentar familiar e na cultura alimentar infantil em contexto familiar, assim como pelos diferentes e diversos modos de presença e mediação comunicacional das marcas na cultura alimentar das crianças, eles se fazem também marcados pelas singularidades e subjetividades que caracterizam as perspectivas e agências infantis sobre sua cultura alimentar e sobre as marcas e produtos alimentícios em seu âmbito familiar e no contexto dos seus gostos e preferências para o consumo alimentar. Estes aspectos, aqui apresentados, destacam a presença e participação das crianças, com suas subjetividades, perspectivas, agências, saberes e afetos infantis, como importante mediação no contexto das

\footnotetext{
${ }^{7}$ O conteúdo disponibilizado em link temporário para avaliação da Banca Examinadora encontra-se disponível em pen-drive na versão da Tese para a Biblioteca da ECA/USP.
} 
diversas mediações que caracterizam e compõem a cultura contemporânea de consumo alimentar infantil em contexto familiar.

Nesse sentido, se faz essencial a presença, participação ativa e voz das crianças nos processos de investigação que se proponham a um melhor conhecimento e compreensão sobre os processos de recepção infantil de marcas de alimentos e os cotidianos do consumo alimentar das crianças em contexto familiar, especialmente no que tange à importância e valor das perspectivas e subjetividades infantis, o que caracteriza o desenvolvimento deste estudo enquanto proposta de uma investigação de inspiração etnográfica desenvolvida com crianças no campo da comunicação. Assim, a presença e participação ativa das crianças, o espaço das vozes infantis, se fez presente de modo estrutural e essencial em todas as atividades desenvolvidas e experiências vivenciadas com as crianças em campo no processo de investigação.

Ao longo de todo o processo de pesquisa as crianças se fizeram presentes com participação e voz, tomadas como sujeitos que são no processo de investigação. Desde as primeiras atividades desenvolvidas em campo, no momento da apresentação dos objetivos da pesquisa e realização dos primeiros encontros e atividades com as famílias, até o desenvolvimento do conjunto das atividades lúdicas realizadas exclusivamente com as crianças, se fizeram presentes as perspectivas infantis e agências das crianças no processo de investigação e desenvolvimento do estudo.

No contexto das atividades lúdicas propostas, desenvolvidas com as crianças no processo de investigação - a Brincadeira de Comer: atividade lúdica desenvolvida com as crianças na forma de jogos de cards e de desenhos sobre o consumo alimentar das crianças e as marcas e produtos alimentícios no contexto das escolhas e preferências infantis; a Brincadeira de Comprar: atividade lúdica desenvolvida com as crianças na forma de dramatização para simulação de compra e consumo de produtos alimentícios com as crianças no supermercado; e a Experiência The Kids: conjunto de atividades lúdicas para composição de uma experiência lúdica de participação infantil, desenvolvida com as crianças na forma de entrevista e na forma de produção infantil de fotografias e vídeos sobre o consumo alimentar infantil em contexto familiar (Kids by Kids - My Foods - My Family) - a presença, a participação ativa e a voz das crianças se fizeram presentes de modo bastante intenso, dinâmico e autoral. Podemos dizer, de forma especial, ao fazerem relatos sobre os cotidianos do seu consumo alimentar em contexto familiar, ao expressarem as escolhas das marcas e produtos alimentícios de que mais gostam, ao expressarem seus conhecimentos sobre a publicidade e o contexto promocional das marcas e produtos alimentícios, e ao fazerem reflexões sobre a pesquisa e a temática do consumo 
alimentar infantil, como foi possível observar a partir da apresentação e exploração das perspectivas, agências e subjetividades infantis presentes na forma dos relatos, observações citações e expressividades das crianças, manifestadas ao longo das atividades lúdicas propostas.

No contexto do estudo desenvolvido, a presença e participação ativa das crianças e as vozes infantis no processo de investigação, trouxeram importantes contribuições e possibilidades de reflexões sobre a temática e problemática da pesquisa, ou ainda, para além daí. Assim, desde as reflexões propostas no que tange às mediações entre os processos de recepção infantil de marcas de alimentos e a cultura alimentar das crianças em contexto familiar e a mediação comunicacional das marcas na cultura alimentar infantil (conforme interpretações, análises e reflexões dadas a partir do âmbito das mediações comunicativas da cultura) até as possibilidades de reflexões dadas em um contexto mais amplo, considerando-se a mediação das perspectivas e subjetividades infantis e agências das crianças nos processos de recepção infantil de marcas de alimentos e de consumo alimentar das crianças em contexto familiar vê-se a sua relevância enriquecendo o estudo desenvolvido e o processo de pesquisa para além dos pressupostos iniciais de investigação.

Estas reflexões se colocam especialmente na forma de uma presença marcante da mediação subjetiva das crianças na cultura contemporânea de consumo alimentar infantil, para além das mediações culturais e comunicacionais presentes na modulação do consumo alimentar das crianças em contexto familiar e dos modos de presença e mediação comunicacional das marcas na cultura alimentar infantil, pois que, nos contextos familiares pesquisados, a mediação subjetiva das crianças se faz presente na cultura alimentar infantil somada às demais formas de mediação e, ao mesmo tempo, em constante mediação com essas mediações.

A mediação subjetiva das crianças na cultura alimentar infantil é assim tomada no contexto do estudo desenvolvido como importante descoberta que somente se tornou possível a partir da presença, participação ativa e voz das crianças no processo de investigação em que as agências das crianças e as perspectivas e subjetividades infantis - concebidas neste estudo enquanto presença essencial para um conhecimento consistente e melhor compreensão sobre os processos de recepção infantil de marcas de alimentos e de consumo alimentar das crianças em contexto familiar - possibilitaram interpretações, análises e reflexões que agregam para além da temática e problemática do estudo, tornando mais rico o processo de investigação.

Ao mesmo tempo, as perspectivas e subjetividades infantis demarcam diferentes e diversas possibilidades de ação subjetiva das crianças, em seus processos de recepção infantil de marcas de alimentos, em face a sua cultura de consumo alimentar em contexto familiar e aos modos de presença e mediação comunicacional das marcas e produtos alimentícios na cultura 
alimentar infantil. Delineiam-se, a partir daí, perspectivas e possibilidades para o desenvolvimento de estudos futuros no campo das pesquisas sobre comunicação, consumo, infância e cultura alimentar, no sentido da presença, participação ativa e voz das crianças no processo de investigação, e da mediação subjetiva das crianças na cultura alimentar infantil.

A experiência de uma investigação de inspiração etnográfica desenvolvida com crianças no campo da comunicação trouxe desafios e superações ao processo de investigação. Desafios, na medida em que um trabalho desenvolvido com crianças em campo, e com a participação ativa das crianças no processo de investigação, é marcado por situações, eventos e acontecimentos que nem sempre podem ser previstos ou controlados. E superações, na medida em que tais situações, eventos e acontecimentos imprevisíveis e incontroláveis que as crianças trazem ao processo de investigação, muitas vezes se colocam no contexto do estudo como oportunidades e possibilidades para novas reflexões e conhecimentos para o enriquecimento das temáticas e problemáticas de pesquisa.

Desafios e superações que tornaram o desenvolvimento deste estudo uma experiência mais ampla, diversificada, surpreendente e consistente de investigação e construção de conhecimentos sobre a cultura contemporânea de consumo alimentar infantil em contexto familiar - a partir da voz das crianças no processo de investigação - e na proposta de uma construção partilhada de conhecimentos no âmbito da ciência e dos saberes infantis. 


\section{CONCLUSÃO}

No complexo contexto de mediações que caracteriza a cultura contemporânea de consumo alimentar infantil, e na perspectiva da cultura compreendida a partir da comunicação, o estudo desenvolvido trouxe importantes contribuições e possibilidades de reflexões a partir da problemática de pesquisa proposta. Conhecimentos e saberes sobre os modos de presença e mediação comunicacional das marcas e produtos alimentícios na cultura alimentar das crianças e os processos de recepção infantil de marcas de alimentos que, trazendo à luz reflexões e respostas à problemática proposta neste estudo, colocam-se ao encontro dos pressupostos iniciais de investigação, ao mesmo tempo em que perpassam e vão além das possibilidades iniciais de interpretação e reflexão sobre a temática do estudo, sinalizando perspectivas e possibilidades para o desenvolvimento de estudos futuros na interface comunicação, consumo, infância e cultura alimentar.

O processo de investigação em seu todo, partindo das interpretações, análises e reflexões propostas sobre os processos de recepção infantil de marcas de alimentos, em sua relação com a cultura de consumo alimentar das crianças e com a mediação das marcas e produtos alimentícios na cultura alimentar infantil, e considerando-se os contextos familiares pesquisados e as crianças participantes do estudo, tornou possível um melhor conhecimento e compreensão sobre os modos de presença e mediação comunicacional das marcas na cultura contemporânea de consumo alimentar infantil.

Perspectiva em que algumas sinalizações se fazem essenciais, a partir das interpretações, análises e reflexões propostas no processo de investigação, como apresentado ao final do estudo, enquanto aspectos conclusivos e possibilidades de reflexão para consolidação do estudo desenvolvido:

A cultura alimentar infantil contemporânea apresenta-se notadamente marcada pelas diversas mediações culturais e comunicacionais presentes na modulação do consumo alimentar das crianças em contexto familiar. Especialmente a presença e mediação dos pais e interação das crianças com os irmãos, a interação cotidiana das crianças com os amigos, o contato das crianças com o universo promocional das marcas e produtos alimentícios, e a classificação socioeconômica familiar. E nessa perspectiva, a presença e mediação da família, as interações com os amigos, e a classificação socioeconômica constituem as principais formas de mediação que, em combinação com a importante mediação do contato das crianças com o ambiente promocional das marcas e produtos alimentícios em seu dia a dia, marcam e modulam a cultura de consumo alimentar infantil em contexto familiar. 
Os modos de presença e mediação comunicacional das marcas no contexto familiar participam e contribuem nos processos de construção da cultura contemporânea de consumo alimentar das crianças. Ainda que a presença e mediação comunicacional das marcas e produtos alimentícios tomem diferentes e diversas formas nos cotidianos infantis da cultura alimentar, para além dos formatos tradicionais da publicidade, ou ainda para além da própria forma publicidade. Modos de presença e mediação comunicacional das marcas materializados de forma cada vez mais expressiva, em diferentes e diversos formatos, especialmente no contato cotidiano das crianças com o universo promocional de marcas e produtos nas plataformas online, em seus usos e consumos infantis dos dispositivos e mídias e da internet.

Os processos de recepção infantil de marcas de alimentos se compõem na mediação entre a cultura alimentar das crianças em contexto familiar e a presença e mediação comunicacional das marcas na cultura alimentar infantil, em uma conjuntura especialmente marcada pelas perspectivas e agências infantis, em suas competências de recepção e consumo, e pelos vínculos de sentidos que se estabelecem entre as marcas/produtos e as crianças. Perspectivas, subjetividades e agências infantis que dão singularidades e formas aos processos de recepção infantil de marcas de alimentos e aos vínculos de sentidos criados entre marcas/produtos e crianças nos diferentes e diversos cotidianos da cultura alimentar infantil em contexto familiar.

Dessa forma, se os processos de recepção infantil de marcas de alimentos e de consumo alimentar das crianças se fazem marcados pelas diversas mediações presentes na cultura alimentar familiar e na cultura alimentar infantil em contexto familiar, e pelos diferentes e diversos modos de presença e mediação comunicacional das marcas na cultura alimentar das crianças, eles se fazem igualmente marcados pelas singularidades e subjetividades que caracterizam as perspectivas e agências infantis sobre sua cultura alimentar e sobre as marcas e produtos alimentícios em seu âmbito familiar e no contexto dos seus gostos e preferências para o consumo alimentar. Perspectiva em que a presença e participação das crianças, as subjetividades, perspectivas, agências, saberes e afetos infantis, se apresentam como importante mediação no contexto das mediações que caracterizam e compõem a cultura contemporânea de consumo alimentar infantil em contexto familiar.

É neste ponto que as interpretações, análises e reflexões propostas no processo de investigação se colocam enquanto possibilidades de entendimentos para além dos pressupostos iniciais de investigação, enriquecendo a problemática de pesquisa proposta no estudo, no momento em que as perspectivas e subjetividades infantis e agências das crianças, as mediações subjetivas das crianças, tomadas neste estudo como mediação essencial no processo de 
investigação, se revelam também como mediação essencial nos processos de recepção infantil de marcas de alimentos e nos cotidianos do consumo alimentar das crianças em seus contextos familiares.

Nos contextos familiares pesquisados, a mediação subjetiva das crianças na cultura alimentar infantil se faz presente nos cotidianos do consumo alimentar das crianças para além e em constante mediação com as mediações culturais e comunicacionais presentes na modulação do consumo alimentar das crianças e com os diferentes e diversos modos de presença e mediação comunicacional das marcas na cultura alimentar infantil, na composição do complexo conjunto de mediações que caracterizam a cultura contemporânea de consumo alimentar das crianças em contexto familiar. Demarcando-se, no contexto das perspectivas e subjetividades infantis, diferentes e diversas possibilidades de ação subjetiva das crianças, em seus processos de recepção infantil de marcas de alimentos, no âmbito da sua cultura alimentar em contexto familiar e em face aos modos de presença e mediação comunicacional das marcas e produtos alimentícios nos cotidianos do seu consumo alimentar.

No âmbito do estudo desenvolvido, a mediação subjetiva das crianças na cultura alimentar infantil é tomada na forma de uma importante descoberta, que se tornou possível especialmente a partir da presença, participação e voz das crianças no processo de investigação, e que trouxe significativa contribuição ao desenvolvimento da pesquisa, ampliando, aprofundando e enriquecendo a problemática do estudo. No entanto, especificamente por conta das delimitações de recorte do objeto e de tempo para o desenvolvimento do estudo, entendese a necessidade de maior exploração em estudos futuros da temática e problemática proposta, no âmbito das ações subjetivas das crianças, da mediação subjetiva das crianças na cultura alimentar infantil.

Novas perspectivas e possibilidades podem então ser delineadas, a partir daí, para o desenvolvimento de estudos futuros no campo dos estudos comunicacionais, na interface comunicação, consumo, infância e cultura alimentar, tomando-se em conta as perspectivas e subjetividades infantis e agências das crianças nos cotidianos da sua cultura alimentar; as ações subjetivas das crianças nos cotidianos do seu consumo alimentar em contexto familiar; as perspectivas e ações subjetivas das crianças no contato com as marcas e produtos alimentícios em seus cotidianos; a mediação subjetiva das crianças no universo promocional das marcas e produtos alimentícios; a mediação subjetiva das crianças na cultura alimentar infantil. E considerando-se a premissa da participação das crianças no processo de investigação, pois que a presença, participação e voz das crianças, especialmente no que tange à importância e valor das perspectivas e subjetividades infantis, se fazem essenciais nos processos de investigação 
que se proponham a um melhor conhecimento e compreensão sobre os processos de recepção infantil de marcas de alimentos e os cotidianos do consumo alimentar das crianças em contexto familiar, a partir da voz e do olhar das crianças.

Enquanto experiência de uma investigação de inspiração etnográfica desenvolvida com crianças no campo da comunicação, este estudo marca presença no contexto dos estudos da infância que buscam uma construção partilhada do conhecimento e do saber a partir das perspectivas e subjetividades infantis. Da mediação subjetiva das crianças no processo de investigação. Com todos os desafios e superações que caracterizam os trabalhos desenvolvidos com crianças em campo, elaborados na perspectiva da participação das crianças e das vozes infantis. E que tornaram o desenvolvimento deste estudo uma experiência maior e melhor de investigação, no sentido de uma construção partilhada de conhecimentos sobre a cultura contemporânea de consumo alimentar infantil no âmbito dos conhecimentos da ciência e dos saberes das crianças.

As crianças falam e tem voz. Sempre prontas a compartilhar e participar. Como sujeitos que são, na cultura, na sociedade, e nos processos de investigação. É no contexto das agências das crianças e das perspectivas e subjetividades infantis, que se faz possível conhecer as crianças e as culturas da infância. Conhecer as crianças e sua cultura de consumo alimentar infantil. 


\section{REFERÊNCIAS}

ABEP - Associação Brasileira das Empresas de Pesquisa. Critério Brasil 2018. 2018. Disponível em: http://www.abep.org/criterio-brasil . Acesso em: 10 jun. 2018.

. Associação Brasileira das Empresas de Pesquisa. Critério Brasil 2019. 2019.

Disponível em: http://www.abep.org/criterio-brasil . Acesso em: 10 jun. 2019.

ARIÈS, Philippe. História social da criança e da família. 2.ed. Rio de Janeiro: LTC, 2012.

BAADER, Cinira. Alimentação ou Diversão?: A Publicidade Contemporânea de Alimentos Infantis e suas Possibilidades de Sentidos para as Práticas de Consumo e Hábitos Alimentares das Crianças. São Paulo: ECA/USP, 2013. Dissertação (Mestrado) - Programa de PósGraduação em Ciências da Comunicação, ECA/USP, São Paulo, 2013.

BECK, Ulrich; GIDDENS, Anthony; LASH, Scott. Modernização reflexiva: política, tradição e estética na ordem social moderna. 2.ed. São Paulo: Ed. UNESP, 2012.

BELLONI, Maria Luiza. O que é sociologia da infância. Campinas: Autores Associados, 2009.

BENJAMIN, Walter. Reflexões sobre a criança, o brinquedo e a educação. São Paulo: Duas Cidades / Editora 34, 2002.

BRAGA, José Luiz. Interação como contexto da comunicação. Matrizes, São Paulo, v.6, n.1, p.25-42, jul./dez., 2012.

Sobre "mediatização" como processo interacional de referência. 2006. Trabalho apresentado no 15. Encontro Nacional da Compós, Bauru, 2006.

BRANDINI, Valéria. Por uma etnografia das práticas de consumo. Comunicação Mídia e Consumo, São Paulo, v.4, n.9, p.153-169, mar., 2007.

BRAUDEL, Fernand. Civilização material, economia e capitalismo: séculos XV-XVIII: As estruturas do cotidiano. v.1. São Paulo: Martins Fontes, 1995.

BUCKINGHAM, David. Repensando a criança-consumidora: novas práticas, novos paradigmas. Comunicação Mídia e Consumo. São Paulo, v.9, n.25, p.43-72, ago., 2012a.

As crianças e a mídia: uma abordagem sob a ótica dos Estudos Culturais. Matrizes. São Paulo, v.5, n.2, p.93-121, jan./jul., 2012 b.

Precisamos realmente de educação para os meios?. Comunicação \& Educação. São Paulo, v.17, n.2, p.41-60, jul./dez., 2012c. 
Crescer na era das mídias eletrônicas. Tradução de Gilka Girardello, Isabel Orofino. São Paulo: Edições Loyola, 2007a.

Digital Media Literacies: rethinking media education in the age of the Internet.

Research in Comparative and International Education. Paderborn, v.2, n.1, p.43-55, 2007b.

Media Education and the End of the Critical Consumer. Harvard Educational Review. Harvard, v.73, n.3, p.309-327, 2003.

CAPES - Coordenação de Aperfeiçoamento de Pessoal de Nível Superior. Catálogo de Teses e Dissertações. 2020. Disponível em: http://catalogodeteses.capes.gov.br/catalogo-teses/\#!/ . Acesso em: 15 fev. 2020.

CARNEIRO, Henrique. Comida e sociedade: uma história da alimentação. Rio de Janeiro: Campus, 2003.

CASAQUI, Vander. Por uma teoria da publicização: transformações no processo publicitário. Significação - revista de cultura audiovisual. São Paulo, v.38, n.36, p.131-151, 2011.

CERTEAU, Michel de. A invenção do cotidiano: 1 . Artes de fazer. 18.ed. Petrópolis: Vozes, 2012a.

A cultura no plural. 7.ed. Campinas: Papirus, 2012b.

CHRISTENSEN, Pia.; PROUT, Alan. Working with ethical symmetry in social research with children. Childhood. Londres, v.9, n.4, p.477-497, 2002.

CLIFFORD, James. A experiência etnográfica: antropologia e literatura no século XX. Rio de Janeiro: Editora UFRJ, 2014.

COHN, Clarice. Antropologia da criança. Rio de Janeiro: Jorge Zahar, 2005.

CORREA, Luciana. O que tem dentro da caixa? Crianças hipnotizadas pelo Youtube Brasil. As fronteiras entre entretenimento, conteúdo proprietário e publicidade. Anais 7. Pro-Pesq. Rio de Janeiro: PROPESQ, 2016.

CORSARO, William A. Sociologia da infância. Porto Alegre: Artmed, 2011.

. Entrada no campo, aceitação e natureza da participação nos estudos etnográficos com crianças pequenas. Educação e Sociedade. Campinas, v.26, n.91, p.443-464, mai./ago., 2005.

Interpretive Reproduction in Children's Peer Cultures. Social Psychology Quarterly. Columbia, v.55, n.2, p.160-177, jun., 1992. 
.; EDER, Donna. Children's Peer Cultures. Annual Review of Sociology. Stanford: v.16, p.197-220, 1990.

COULDRY, Nick; HEPP, Andreas. Conceptualizing mediatization: contexts, traditions, arguments. Communication Theory. v.23, n.3, p.191-202, ago., 2013.

Midia, society, world. Cambridge: Polity Press, 2012.

; LIVINGSTONE, Sonia. et al. Midia consumption and public engagement: beyond the presumption of attention. London: Palgrave Macmillan, 2010.

CRAVEIRO, Pâmela. Publicidade e infância: relato de uma experiência de literacia publicitária com crianças. Comunicação \& Educação. São Paulo, v.23, n.1, p.171-183, jan./jun., 2018.

. Publicidade e infância: estratégias persuasivas direcionadas para crianças na internet. Culturas Midiáticas. João Pessoa, v.9, n.16, p.16-32, jan./jun., 2016.

CRUZ, Silvia Helena Vieira. (Org.). A criança fala: a escuta de crianças em pesquisa. São Paulo: Cortez, 2008.

DORETO, Juliana. Fã número 1: as mensagens enviadas pelas crianças ao jornalismo infantojuvenil. Anais 26. Compós. São Paulo: COMPÓS, 2017.

Fala conosco: o jornalismo infantil e a participação das crianças, em Portugal e no Brasil. Anais 25. Compós. Goiânia: COMPÓs, 2016.

DOUGLAS, Mary; ISHERWOOD, Baron. O mundo dos bens: para uma antropologia do consumo. Rio de Janeiro: Editora UFRJ, 2013.

ESCOSTEGUY, Ana Carolina. (et al). O que é, afinal, estudos culturais?. Belo Horizonte: Autentica, 2006.

FANTIN, Mônica; GIRARDELLO, Gilka. (Orgs.). Liga, roda, clica: estudos em mídia, cultura e infância. Campinas: Papirus, 2008.

FAUSTO NETO, Antônio. As bordas da circulação. ALCEU, Rio de Janeiro, v.10, n.20, p.55-69, jan./jun. 2010.

FERREIRA, Manuela.; SARMENTO, Manuel. J. Subjectividade e bem-estar das crianças: (in)visibilidade e voz. Revista Eletrônica de Educação. São Carlos, v.2, n.2, p.60-91, Nov., 2008 .

FISCHLER, Claude. A McDonaldização dos costumes. In: FLANDRIN, Jean-Louis; MONTANARI, Massimo. (Orgs.). História da alimentação. São Paulo: Estação Liberdade, 1998. 
FLANDRIN, Jean-Louis; MONTANARI, Massimo. (Orgs.). História da alimentação. São Paulo: Estação Liberdade, 1998.

GALINDO, Daniel; ASSOLINI, Pablo José. Eatertainment: a divertida publicidade que alimenta o público infantil. Anais 11. Congresso Latinoamericano de Investigadores de la Comunicación. Cidade do México: ALAIC, 2008.

GARCIA CANCLINI, N. Culturas híbridas: estratégias para entrar e sair da modernidade.São Paulo: Ed. USP, 2013.

Consumidores e cidadãos: conflitos multiculturais da globalização. 8.ed. Rio de Janeiro: Ed. UFRJ, 2010.

. Los estudios sobre comunicación y consumo: El trabajo interdisciplinario en tiempos neoconsevadores. Revista Diálogos de La comunicación - FELAFACS, Lima, n.74, p.1-9, mai./ago., 2007.

GARVEY, Hugh; YEOMANS, Matthew. Gastrokid: alimentando uma família gourmet no mundo do fast-food. São Paulo: Gaia, 2011.

GASKINS, Suzanne.; MILLER, Peggy.; CORSARO, William. Theoretical and Methodological Perspectives in the Interpretive Study of Children. New Directions for Child and Adolescent Development. New Haven, n.58, p.5-23, 1992.

GEERTZ, Clifford. A interpretação das culturas. Rio de Janeiro: LTC, 2013.

GIDDENS, Anthony. As consequências da modernidade. São Paulo: Ed. UNESP, 1991.

GIRARDELLO, Gilka; OROFINO, Isabel. Crianças, cultura e participação: um olhar sobre a mídiaeducação no Brasil. Comunicação Mídia e Consumo. São Paulo, v.9, n.25, p.73-90, ago., 2012.

Produção cultural infantil diante da tela: da tv à internet. Revista Teias. Rio de Janeiro, v.6, n.11-12, jan./dez., 2005.

OROFINO, Isabel. A pesquisa de recepção com crianças: mídia, cultura e cotidiano.

Anais 11. Compós. Rio de Janeiro: COMPÓS, 2002.

GUNTER, Barrie; FURNHAM, Adrian. As crianças como consumidoras: uma análise psicológica do mercado juvenil. Lisboa: Instituto Piaget, 2001.

HENRIQUES, Isabella; VIVARTA, Veet. (Orgs.). Publicidade de Alimentos e Crianças: Regulação no Brasil e no Mundo. São Paulo: Saraiva, 2013.

HERNÁNDEZ, Jesus C.; ARNÁIZ, Mabel G. Alimentación y cultura: perspectivas antropológicas. Barcelona: Ariel, 2005. 
HJARVARD, Stig. Midiatização: Conceituando a mudança social e cultural. In: Matrizes. Revista do Programa de Pós-Graduação em Ciências da Comunicação da USP. São Paulo, v.8, n.1, p.21-44, jan./jun., 2014a.

. A midiatização da cultura e da sociedade. São Leopoldo: Ed. UNISINOS, 2014b.

. Midiatização: teorizando a mídia como agente de mudança social e cultural.

Matrizes, São Paulo, v.5, n.2, p.53-91, Jan./Jun., 2012.

HUIZINGA, Johan. Homo ludens: o jogo como elemento da cultura.6.ed. São Paulo: Perspectiva, 2010.

JACKS, N.; PIEDRAS, E.R. et al. A publicidade "vista" entre 2000 e 2005: pesquisas com foco na recepção. Revista Eco-Pós, Rio de Janeiro, v.13, n.1, p.14-28, 2010.

; MENEZES, D.; PIEDRAS, E.R. Meios e Audiências: A emergência dos estudos de recepção no Brasil. Porto Alegre: Sulina, 2008.

; PIEDRAS, E.R.; VILELA, R.S. (Orgs.). O que sabemos sobre audiências?. Porto

Alegre: Armazém Digital, 2006.

; ESCOSTEGUY, A.C. Comunicação e recepção. São Paulo: Hacker, 2005.

KAMAKURA, W.A.; MAZZON, J.A. Estratificação socioeconômica e consumo no Brasil. São Paulo: Blucher, 2013.

LA PASTINA, Antonio. Etnografia de audiência: uma estratégia de envolvimento. In: JACKS, Nilda. (et al). O que sabemos sobre as audiências?. Porto Alegre: Armazém Digital, 2006.

LEWIN, Zaida G. A criança, os comerciais de televisão e a cultura alimentar: uma análise critica. Educação e Sociedade, Campinas: Papirus, v.3, n.43, p.504-523, dez. 1992.

LIPOVETSKY, Gilles. A cultura-mundo: Resposta a uma sociedade desorientada.São Paulo: Cia das Letras, 2011.

O império do efêmero: a moda e seu destino nas sociedades modernas. São Paulo: Cia das Letras, 2009.

A felicidade paradoxal: ensaio sobre a sociedade de hiperconsumo. São Paulo: Cia das Letras, 2007.

Os tempos hipermodernos. São Paulo: Barcarolla, 2004. 
LIVINGSTONE, Sonia. Tomando oportunidades arriscadas na criação de conteúdo jovem: o uso pelos adolescentes de sites de redes sociais para intimidade privacidade e expressão própria. Comunicação Mídia e Consumo, São Paulo, v.9, n.25, p.91-118, ago., 2012.

. Internet literacy: a negociação dos jovens com as novas oportunidades on-line. Matrizes, São Paulo, v.4, n.2, p.11-42, jan./jun., 2011.

. As crianças e o ambiente da mídia em mudança: panorama de um estudo comparativo europeu. In: CARLSSON, Ulla.; FEILITZEN, Cecilia Von. A criança e a mídia: imagem, educação, participação. São Paulo: Cortez Editora, 2002.

LLANO LINARES, Nicolas; TRINDADE, Eneus. Processos de movimentos de significados simbólicos no consumo alimentar. Pensamento \& Realidade, São Paulo, v.26, n.2, p.46-64, 2011.

LOPES, M.I.V. Mediação e recepção: algumas conexões teóricas e metodológicas nos estudos latino-americanos de comunicação. Matrizes. São Paulo: PPGCOM/USP, v.8, n.1, p.65-80, 2014.

MADI, Luis; PRADO, Antonio C.; REGO, Raul A. Brasil food trends 2020. São Paulo: Ed. FIESP-ITAL, 2010.

MALDONADO, A.E. Pensar os processos sociocomunicacionais em recepção na conjuntura latinoamericana de transformação civilizadora. In: BONIN, J.A.; ROSÁRIO, N.M.

Processualidades metodológicas: configurações transformadoras em comunicação.

Florianópolis: Insular, 2013.

MARTIN-BARBERO, Jesús. Dos meios às mediações: comunicação, cultura e hegemonia. 6.ed. Rio de Janeiro: Ed. UFRJ, 2009.

2004a.

Os exercícios do ver: hegemonia audiovisual e ficção televisiva. São Paulo: SENAC,

Ofício de cartógrafo: travessias latino-americanas da comunicação e da cultura. São Paulo: Edições Loyola, 2004b.

MATTOS, Maria Ângela; JANOTTI JUNIOR, Jeder; JACKS, Nilda. Mediação \& Midiatização. Salvador: EDUFBA / Brasília: Compós, 2012.

MCCRACKEN, Grant. Cultura \& consumo: novas abordagens ao caráter simbólico dos bens e das atividades de consumo.Rio de Janeiro: Mauad, 2003.

MILLER, Daniel. Consumo como cultura material. Horizontes Antropológicos, Porto Alegre, v.13, n.28, p.33-63, jul./dez. 2007. 
MONTIGNEAUX, Nicolas. Público-alvo: crianças: a força dos personagens e do marketing para falar com o consumidor infantil. São Paulo: Negócio, 2003.

MONTÚFAR, Fernando Checa. De la "recepción” al "consumo": una necesaria reflexión conceptual. In: JACKS, N. (Org.). Análisis de recepción en America Latina: un recuento histórico con perspectivas al futuro. Quito: Ciespal, 2011.

MÜLLER, Fernanda. (Org.). Infância em perspectiva: políticas, pesquisas e instituições. São Paulo: Cortez, 2010.

NIC.BR - CETIC.BR. Children and internet use: a comparative analysis of Brazil and seven European countries. EuKids Online, 2015. Disponível em:

https://www.cetic.br/publicacao/children-and-internet-use-a-comparative-analysis-of-braziland-seven-european-countries/ . Acesso em: 10 jul. 2020.

Tic kids online Brasil. 2017. Disponível em: https://cetic.br/pesquisa/kids-online/. Acesso em: 1 jun. 2020.

. Tic kids online Brasil. 2018. Disponível em: https://cetic.br/pesquisa/kids-online/. Acesso em: 1 jun. 2020.

Tic kids online Brasil. 2019. Disponível em: https://cetic.br/pesquisa/kids-online/. Acesso em: 1 jun. 2020.

OROFINO, Maria Isabel. Crianças, televisão, cotidianidade: reflexões sobre a qualidade da programação de tv aberta no Brasil. Anais 3. Comunicon. São Paulo: COMUNICON, 2013.

. Crianças, recepção e imaginários do consumo. Anais 20. Compós. Porto Alegre: COMPÓS, 2011.

. Ciranda de sentidos: crianças, consumo cultural e mediações. In: FANTIN, Mônica; GIRARDELLO, Gilka. (Orgs.). Liga, roda, clica: estudos em mídia, cultura e infância. Campinas: Papirus, 2008.

OROZCO GÓMEZ, Guilhermo. Educomunicação: recepção midiática, aprendizagens e cidadania. Paulinas, 2014.

Recepción televisiva y mediaciones: La construción de estrategias por la audiência. Mexico: UniversidadIberoamericana, 1993.

. Mediaciones familiares y escolares em La recepción televisiva de los niños: algunos hallazgos recientes. Comunicación y Sociedad, n.13, p.113-129, dez., 1991a.

. La mediación em juego: televisión, cultura y audiências. Comunicación y Sociedad, n.10-11, p.107-128, abr., 1991 . 
PASSARELLI, Brasilina; JUNQUEIRA, Antonio H. Gerações interativas Brasil: crianças e adolescentes diante das telas. São Paulo: Escola do Futuro/USP, 2012.

PEDROCCO, Giorgio. A indústria alimentar e as novas técnicas de conservação. In: FLANDRIN, Jean-Louis; MONTANARI, Massimo. (Orgs.). História da alimentação. São Paulo: Estação Liberdade, 1998.

PEIRANO, Marisa. Rituais ontem e hoje. Rio de Janeiro: Jorge Zahar, 2003.

A favor da etnografia. Rio de Janeiro: Relume Dumará, 1995.

Uma antropologia no plural. Brasília: UNB, 1991.

PENN, Mark J.; ZALESNE, E.K. Microtendências: as pequenas forças por trás das grandes mudanças de amanhã. Rio de Janeiro: Best Seller, 2008.

PEREIRA, Rita Marisa Ribes. Infância, televisão e publicidade: uma metodologia de pesquisa em construção. Cadernos de pesquisa. n.116, p.81-105, jul., 2002.

PEREZ, Clotilde. Mascotes:semiótica da vida imaginária. São Paulo: Cengage Learning, 2011.

; TRINDADE, Eneus. Marcas e publicidade de alimentos: vínculos de sentidos no consumo da vida doméstica e nos ambientes públicos de São Paulo. Anais 34. Intercom. Recife: INTERCOM, 2011.

Signos da marca:expressividade e sensorialidade. São Paulo: Thomson, 2004.

PIEDRAS, Elisa R. Vulnerabilidade ou resistência? Um panorama da questão do consumo infantil de alimentos permeado pelo marketing e a mídia. Comunicação Mídia e Consumo. São Paulo, v.10, n.29, p.143-159, set./dez, 2013.

Fluxo Publicitario: anúncios, produtores e receptores. Porto Alegre, Sulina, 2009.

. As práticas de recepção da publicidade como fluxo: apontamentos teóricometodológicos. In: JACKS, N; PIEDRAS, E.R.; VILELA, R. (orgs.). O que sabemos sobre as audiências?. Porto Alegre: Armazém Digital, 2006.

PIRES, Jorge Miguel. Padrões de utilização do brand entertainment. Lisboa: IPL, 2011. Dissertação (mestrado) - Mestrado em Publicidade e Marketing, Escola Superior de Comunicação Social, Instituto Politécnico de Lisboa, Lisboa, 2011.

PITAS, Alexander Marcellus C.S. Propagandas de Alimentos e Bebidas na TV: percepção de crianças e mães. São Paulo: FSP/USP, 2010. Dissertação (mestrado) - Programa de PósGraduação em Saúde Pública, FSP/USP, São Paulo, 2010. 
PITTE, Jean-Robert. Nascimento e Expansão dos restaurantes. In: FLANDRIN, Jean-Louis; MONTANARI, Massimo. (Orgs.). História da alimentação. São Paulo: Estação Liberdade, 1998.

PROUT, Alan. Taking a Step Away from Modernity: reconsidering the new sociology of childhood. Global Studies of Childhood. Austrália, v.1, n.1, p.4-14, 2011.

Participação, políticas e as condições da infância em mudança. In: MÜLLER, Fernanda. (Org.). Infância em perspectiva: políticas, pesquisas e instituições. São Paulo: Cortez, 2010a.

. Reconsiderando a Nova Sociologia da Infância. Cadernos de Pesquisa. São Paulo, v.40, n.141, p.729-750, set./dez., 2010 b.

QVORTRUP, Jens. Infância e política. Cadernos de Pesquisa. São Paulo, v.40, n.141, p.777792, set./dez., 2010a.

. A infância enquanto categoria estrutural. Educação e Pesquisa. São Paulo, v.36, n.2, p.631-643, mai./ago., 2010 b.

RIBEIRO, J. S. Métodos e técnicas de investigação antropológica. Lisboa: Universidade Aberta de Lisboa. 2003.

SALGADO, Raquel G.; PEREIRA, Rita M.R.; SOUZA, Solange J. Pela tela, pela janela: questões teóricas e práticas sobre infância e televisão. Cad. Cedes. Campinas, v.25, n.65, p.924, jan./abr., 2005.

SAMPAIO, Inês S. Vitorino; CAVALCANTE, Andréia P. Paiva; ALCÂNTARA, Alessandra C. Mídia de Chocolate: estudos sobre a relação infância, adolescência e comunicação. Rio de Janeiro: E-Papers, 2006.

. Criança, televisão e propaganda. São Paulo: Annablume, 2004.

SARMENTO, Manuel. J. A reinvenção do ofício de criança e de aluno. Atos de Pesquisa em Educação. Blumenau, v.6, n.3, p.581-602, set./dez., 2011.

; GOUVEA, Maria Cristina Soares. (Orgs.). Estudos da infância: educação e práticas sociais. Petrópolis: Vozes, 2008a.

Sociologia da Infância: correntes e confluências. In: SARMENTO, Manuel Jacinto; GOUVEA, Maria Cristina Soares. (Orgs.). Estudos da Infância: educação e práticas sociais. Petrópolis: Vozes, 2008b.

; FERNANDES, Natália; TOMÁS, Catarina. Políticas públicas e participação infantil . Educação Sociedade \& Culturas. Porto, n.25, p.183-206, 2007. 
. Gerações e alteridade: interrogações a partir da sociologia da infância. Educação \& Sociedade. Campinas, v.26, n.91, p.361-378, mai./ago., 2005a.

Crianças: educação, culturas e cidadania activa. Refletindo em torno de uma proposta

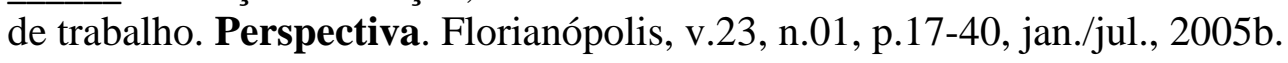

SIROTA, Règine. Emergência de uma Sociologia da Infância: evolução do objeto e do olhar. Cadernos de Pesquisa. São Paulo, n.112, p.7-31, mar., 2001.

SOARES, Natália. F.; SARMENTO, Manuel. J.; TOMÁS, Catarina. A. Investigação da infância e crianças como investigadoras: metodologias participativas dos mundos sociais das crianças. Nuances / UNESP. Presidente Prudente, ano 11, v.12, n.13, p.49-64, jan./dez., 2005 .

SOBRAL, Jacqueline; OROFINO, Isabel. Estudos de recepção com crianças: trajetórias, aportes e metodologias. Interin. Curitiba, v.15, n.1, p.97-106, jan./jun., 2013.

SORCINELLI, Paolo. Alimentação e saúde. In: FLANDRIN, Jean-Louis; MONTANARI, Massimo. (Orgs.). História da alimentação. São Paulo: Estação Liberdade, 1998.

STEINBERG, Shirley R; KINCHELOE, Joe L. Sem segredos: cultura infantil, saturação de informação e infância pós-moderna. In: STEINBERG, Shirley R; KINCHELOE, Joe L.

(Orgs.). Cultura infantil: a construção corporativa da infância. Rio de Janeiro: Civilização Brasileira, 2001.

TOALDO, Mariângela M.; JACKS, Nilda. Consumo midiático: uma especificidade do consumo cultural: uma antessala para os estudos de recepção. Anais 22. Compós. Salvador: COMPÓS, 2013.

TRINDADE, Eneus; PEREZ, Clotilde. O consumidor entre mediações e midiatização. FAMECOS. v.26, n.2, p.2-18, dez., 2019.

; PEREZ, Clotilde. Consumo midiático e consumo midiatizado: aproximações e diferenças. Uma contribuição teórico-metodológica. In. LUVIZOTTO, Caroline K.; LOSNACK, Celio J. et al. Mídia e sociedade em transformação. São Paulo: Cultura Acadêmica, 2016.

; PEREZ, Clotilde. Os rituais de consumo como dispositivos midiáticos para a construção de vínculos entre marcas e consumidores. ALCEU. Rio de Janeiro, v.15, n.29, p.157-171, jul./dez., 2014.

; PEREZ, Clotilde. Dimensões do consumo midiatizado. Anais 2. Confibercom. Braga: CONFIBERCOM, 2014. 
; PEREZ, Clotilde. Aspectos dos vínculos de sentidos do consumo alimentar em ão Paulo: difusão publicitária e megatendências. Revista Brasileira de Ciências da Comunicação - INTERCOM, São Paulo, v.36, n.2, p.245-266, jul./dez., 2013.

; PEREZ, Clotilde. Rituais de Consumo: dispositivos midiáticos de articulação de vínculos de sentidos entre marcas e consumidores. Anais 9. Seminário Internacional Imagens da Cultura. Cultura das Imagens. São Paulo: ICCI, 2013 b.

; PEREZ, Clotilde. Mediatização em Processos Promocionais de Ativação das Marcas: Perspectivas da Publicidade. Anais 15. Intercom Nordeste. Mossoró: INTERCOM, 2013c.

Um olhar exploratório sobre o consumo e a midiatização das marcas de alimentos nas vidas de algumas famílias. Matrizes. São Paulo, v.6, n.1, p.77-96, jul./dez., 2012.

; PEREZ, Clotilde. Vínculos de sentidos do consumo alimentar em São Paulo: publicidade e práticas de consumo. Anais 21. Compós. Juiz de Fora: COMPÓS, 2012.

; MOREIRA, Rafael A. L. Aspectos da recepção publicitária e das práticas de consumo em três famílias paulistanas. Revista Eco-Pós, Rio de Janeiro, v.13, n.1, p.63-79, 2010.

Em busca da produção de sentido da recepção publicitária e das práticas de consumo: testando possibilidades. Extraprensa - USP, v.1, n.1, p.47-60, 2010.

Da etnografia à produção de sentido da recepção publicitária e das práticas de consumo na vida social. Animus - Revista Interamericana de Comunicação Midiática, Santa Maria, v.8, n.15, p.123-144, 2009.

Diretrizes para uma teoria da Enunciação da Recepção Publicitária. Revista Brasileira de Ciências da Comunicação - INTERCOM. São Paulo: Intercom, v.31, n.2, p.35-54, 2008a.

. Recepção publicitária e práticas de consumo. Revista Fronteiras. Estudos midiáticos. São Leopoldo: Unisinos, v.10, n.2, p.73-80, mai.-ago., 2008 b.

VIANA, Victor; SANTOS, Pedro L.; GUIMARÃES, Maria J. Comportamentos e hábitos alimentares em crianças e jovens: uma revisão da literatura. Psicologia Saúde \& Doenças, Lisboa, v.9, n.2, p.209-231, 2008.

VIGOTSKY, L. S.; COLE, M. A formação social da mente: o desenvolvimento dos processos psicológicos superiores. 7. ed. São Paulo: Martins Fontes, 2007.

. Pensamento e Linguagem. 2.ed. São Paulo: Martins Fontes, 1998.

WILLIAMS, Raymond. Televisão: tecnologia e forma cultural. Belo Horizonte: PUC Minas, 2016.

WINNICOTT, Donald W. A criança e o seu mundo. 6.ed. Rio de Janeiro: LTC, 2012. 


\section{REFERÊNCIAS DIGITAIS SOBRE A TEMÁTICA}

A TARDE UOL. 2019. O Ministério da Saúde lançou a campanha 1, 2, 3 e já! Vamos prevenir a obesidade infantil. A ideia é incentivar as crianças a seguirem três passos simples para evitar o sobrepeso: alimentação saudável, atividade física e brincadeiras longe das telas da TV, celular e jogos eletrônicos. Disponível em:

https://atarde.uol.com.br/saude/noticias/2108572-ministerio-da-saude-lanca-campanha-paraprevenir-a-obesidade-infantil.

ABESO. 2017. Mapa da obesidade. Disponível em: https://abeso.org.br/obesidade-e-sindromemetabolica/mapa-da-obesidade/

AGÊNCIA BRASIL, 2020. IBGE: Obesidade mais do que dobra na população com mais de 20 anos: Resultados são da Pesquisa Nacional de Saúde 2019: Entre 2003 e 2019, a proporção de obesos na população com 20 anos ou mais de idade do país mais que dobrou, passando de 12,2\% para 26,8\%. Disponível em: https://agenciabrasil.ebc.com.br/saude/noticia/202010/ibge-obesidade-mais-do-que-dobra-na-populacao-com-mais-de-20-anos

AGENCIA BRASIL. 2017. Publicidade infantil: entenda o debate e saiba como a ques.tão é regulamentada. Disponível em: https://agenciabrasil.ebc.com.br/geral/noticia/2017-

07/publicidade-infantil-entenda-o-debate-e-saiba-como-questao-e-regulamentada.

AGÊNCIA BRASIL. 2019. Dados do ministério apontam que três de cada 10 crianças de 5 a 9 anos atendidas pelo Sistema Único de Saúde (SUS) estão acima do peso, um total de 4,4 milhões. Do total de crianças, $16 \%$ (2,4 milhões) estão com sobrepeso, $8 \%$ (1,2 milhão) com obesidade e $5 \%$ (755 mil) com obesidade grave. Abaixo de 5 anos, são 15,9\% com excesso de peso. Disponível em: https://agenciabrasil.ebc.com.br/saude/noticia/2019-11/saude-lancacampanha-para-prevenir-obesidade-infantil.

AGÊNCIA BRASIL. 2020. Médicos alertam sobre obesidade infantil: segundo dados divulgados pela Organização Internacional World Obesity, atualmente cerca de 158 milhões de crianças e adolescentes entre 5 e 19 anos convivem com o excesso de peso, e esse número deve aumentar para 254 milhões em 2030 em todo o mundo. Disponível em: https://agenciabrasil.ebc.com.br/saude/noticia/2020-06/em-dia-de-conscientizacao-medicosalertam-sobre-obesidade-infantil

ALIMENTO SAÚDE INFANTIL. 2019. Alimentação e Saúde Infantil: nutrição consciente desde a infância. Disponível em: https://alimentosaudeinfantil.wordpress.com/.

ASBRAN. 2012. A obesidade infantil aquece debate sobre publicidade para crianças: a obesidade infantil está no centro de um debate que coloca, de um lado, a indústria de alimentos e suas guloseimas e, do outro, as organizações de direito do consumidor e sociedades médicas. A causa da discórdia é a publicidade de alimentos para crianças no Brasil. Disponível em: https://www.asbran.org.br/noticias/a-obesidade-infantil-aquece-debatesobre-publicidade-para-criancas. 
BBC BRASIL. 2017. Brasil terá 11,3 milhões de crianças obesas em 2025, estima organização: a população mundial está ganhando peso rapidamente, principalmente crianças e adolescentes. Disponível em: https://www.bbc.com/portuguese/geral-41588686.

CANGURU NEWS, 2020. Alimentação das crianças: dicas para seu filho comer melhor durante a quarentena.Disponível em: https://cangurunews.com.br/alimentacao-das-criancas/.

CBN. 2020. Filhos 'se espelham' nos pais, afirma médico sobre combate à obesidade infantil. Disponível em: https://www.nsctotal.com.br/noticias/filhos-se-espelham-nos-pais-afirmamedico-sobre-combate-a-obesidade-infantil.

CECIP. 2017. Seminário Internacional Infâncias Sul-Americanas: crianças nas cidades, políticas e participação: a ciência e experiências afetivas sobre a infância compartilhadas em mesas, oficinas, minicursos e visitas guiadas. Vamos aprender outras formas de ouvir as crianças! Disponível em: http://www.cecip.org.br/site/seminario-internacional-infancias-sulamericanas-criancas-nas-cidades-politicas-e-participacao/.

CECIP. 2019. CECIP participa da x conferência do Conselho Estadual da Criança e do Adolescente: conversas e atividades com os pequenos sobre as habilidades e qualidades que um porta-voz das crianças deveria ter para representá-las... Disponível em: http://www.cecip.org.br/site/cecip-participa-da-X-conferencia-do-conselho-estadual-dacrianca-e-do-adolescente-cedca/.

CONSULTOR JURÍDICO. 2020. A minuta de portaria da Senacon sobre publicidade infantil precisa ser mais discutida: a Secretaria Nacional do Consumidor (Senacon), vinculada ao Ministério da Justiça, realizou, em inícios do corrente ano, consulta pública sobre minuta de Portaria regulamentadora da publicidade infantil, objetivando harmonizar a proteção constitucional da criança e do adolescente, com o direito, também constitucional, da livre iniciativa dos fornecedores. Disponível em: https://www.conjur.com.br/2020-mar-26/olhareconomico-portaria-senacon-publicidade-infantil-discutida.

CONSUMIDOR MODERNO. 2019. Cresce participação do consumo infantil no varejo alimentar: pesquisa da Kantar Worldpanel aponta crescimento do consumo infantil de alimentos no Brasil. Disponível em: https://www.consumidormoderno.com.br/2019/02/18/cresce-participacao-consumo-infantilvarejo-alimentar/.

CORREIO BRAZILIENSE. 2020. Sentimentos de crianças: campanha lançada pelo Fundo das Nações Unidas para a Infância: crianças de todo o país são convidadas a registrar, por meio de desenhos, suas emoções em relação ao isolamento social. Disponível em: https://www.correiobraziliense.com.br/app/noticia/opiniao/2020/05/16/internas_opiniao,8554 46/artigo-sentimentos-de-criancas.shtml.

CRIANÇA E CONSUMO. 2014. Publicidade Infantil é obstáculo para alimentação saudável: novo Guia Alimentar para a População Brasileira, do Ministério da Saúde, traz informações e dados sobre as consequências da comunicação mercadológica dirigida às crianças. Disponível em:https://criancaeconsumo.org.br/noticias/publicidade-infantil-e-obstaculo-paraalimentacao-saudavel/\#: :text=para\%20alimenta\%C3\%A7\%C3\%A3o\%20saud\%C3\%A1vel- 
,Publicidade\%20Infanti1\%20\%C3\%A9\%20obst\%C3\%A1culo\%20para\%20alimenta\%C3\%A7 $\% \mathrm{C} 3 \% \mathrm{~A} 3 \mathrm{o} \% 20$ saud\%C3\%A1vel,comunica\%C3\%A7\%C3\%A3o\%20mercadol\%C3\%B3gica $\% 20$ dirigida $\% 20 \% \mathrm{C} 3 \% \mathrm{~A} 0 \mathrm{~s} \% 20 \mathrm{crian} \% \mathrm{C} 3 \% \mathrm{~A} 7$ as.

CRIANÇA E CONSUMO. 2015. Publicidade e obesidade andam juntos: dados indicam relação entre aumento do peso corporal em 13 países da América Latina e o consumo de alimentos de baixo valor nutricional. Disponível em: https://criancaeconsumo.org.br/noticias/publicidade-eobesidade-andam-juntos/\#: :text=obesidade $\% 20$ andam $\% 20$ juntos-

,Publicidade $\% 20 \mathrm{e} \% 20 \mathrm{obesidade} \% 20$ andam $\% 20$ juntos,alimentos $\% 20 \mathrm{de} \% 20$ baixo $\% 20$ valor $\%$ 20nutricional.

CRIANÇA E CONSUMO. 2018. Alemanha pede o fim da publicidade infantil de produtos alimentícios. Disponível em: https://criancaeconsumo.org.br/noticias/alemanha-pede-o-fimda-publicidade-infantil-de-produtos-alimenticios/.

CRIANÇA E CONSUMO. 2018. Nove denúncias de oferta abusiva de produtos alimentícios com brinquedo: saiba quais empresas já foram questionadas pela prática abusiva de venda de brinquedo com produtos alimentícios, com foco nas crianças. Disponível em: https://criancaeconsumo.org.br/noticias/denuncia-de-oferta-abusiva-de-brinquedo-comcomida/.

CRIANÇA E CONSUMO. 2018. Reino Unido avança contra publicidade de junk food para crianças. Disponível em: https://criancaeconsumo.org.br/noticias/reino-unido-publicidadecriancas/.

CRIANÇA E CONSUMO. 2019. Publicidade infantil aumenta o nível de obesidade: a publicidade infantil incentiva hábitos não saudáveis nas crianças, aumentando os níveis de doenças crônicas não transmissíveis como a obesidade. Disponível em: https://criancaeconsumo.org.br/noticias/idec-lanca-observatorio-de-publicidade-de-alimentos/.

CRIANÇA E NATUREZA. 2019. Por que é preciso escutar as crianças? Em que consiste a escuta das crianças e como esse conceito se concretiza na prática? Disponível em: https://criancaenatureza.org.br/entrevistas/a-vez-e-a-voz-das-criancas/.

DENTRO DA HISTÓRIA. 2018. O que é protagonismo infantil e como incentivá-lo? Disponível em: https://www.dentrodahistoria.com.br/blog/educacao/o-que-e-protagonismoinfantil/.

DIÁRIO DE PERNAMBUCO. 2018. Obesidade infantil: a culpa é de quem. Disponível em:https://www.diariodepernambuco.com.br/noticia/cienciaesaude/2018/08/obesidadeinfantil-a-culpa-e-de-quem.html.

ECONOMIA ESTADÃO. 2018. Mercado infantil exige diferencial e foco. Disponível em: https://economia.estadao.com.br/blogs/sua-oportunidade/mercado-infantil-exige-diferencial-efoco/. 
ECONOMIA IG. 2020. Entenda mais sobre a publicidade infantil em alimentos: o que torna a publicidade infantil abusiva? Quais são as reais consequências da publicidade infantil na vida das crianças? Disponível em: https://economia.ig.com.br/colunas/defesa-doconsumidor/2020-07-07/entenda-mais-sobre-a-publicidade-infantil-em-alimentos.html.

EDUCAÇÃO. 2017. Projetos de educação alimentar nas escolas buscam mudar hábitos familiares: para garantir que crianças e adolescentes se alimentem de maneira mais saudável, poder público e instituições de ensino vêm adotando medidas que restringem a entrada de alimentos que podem ser nocivos à saúde no ambiente escolar. Disponível em: https://revistaeducacao.com.br/2017/03/16/projetos-de-educacao-alimentar-nas-escolasbuscam-mudar-habitos-familiares/.

EMPREENDEDOR. 2015. Mercado de alimentação saudável chega à festas infantis. Disponível em: https://empreendedor.com.br/noticia/mercado-de-alimentacao-saudavelchega-a-festas-infantis/.

ÉPOCA. 2015. Publicidade de alimentos e obesidade infantil: uma reflexão necessária. Disponível em: https://epoca.globo.com/vida/noticia/2015/03/publicidade-de-alimentos-eobesidade-infantil-buma-reflexao-necessariab.html.

ESTADÃO, 2015. Ouvir as crianças faz toda a diferença. Disponível em:

https://educacao.estadao.com.br/blogs/villare/ouvir-as-criancas-faz-toda-a-diferenca/.

ESTADÃO, 2018. A importância de uma alimentação saudável na infância: quando se trata de alimentação na infância os cuidados devem ser redobrados. Disponível em: https://educacao.estadao.com.br/blogs/blog-dos-colegios-bis/a-importancia-de-umaalimentacao-saudavel-na-infancia/.

ESTADÃO. 2019. Má alimentação prejudica a saúde de milhões de crianças em todo o mundo. https://emais.estadao.com.br/blogs/comida-de-verdade/ma-alimentacao-prejudica-asaude-de-milhoes-de-criancas-em-todo-o-mundo/.

ESTADÃO. 2018. Obesidade infantil: a culpa é de quem? Hábitos alimentares dos pais e fácil acesso a alimentos ultraprocessados estão entre os responsáveis pelo problema. No Brasil, 33\% dos pequeninos estão acima do peso, segundo o Ministério da Saúde. Disponível em: https://emais.estadao.com.br/noticias/bem-estar,obesidade-infantil-a-culpa-e-dequem,70002471424.

EXAME. 2018. O número de crianças com sobrepeso e obesidade pode chegar a 75 milhões caso nada seja feito: incluindo 427 mil crianças com pré-diabetes, 1 milhão com hipertensão arterial e 1,4 milhão com aumento do acúmulo de gordura no fígado. Disponível em: https://exame.com/ciencia/um-em-cada-8-adultos-no-mundo-e-obeso-diz-oms-no-diamundial-da-obesidade/.

FOLHA VITÓRIA. 2020. Obesidade infantil: estilo de vida dos pais pode ser a resposta para a mudança. Disponível em: https://www.folhavitoria.com.br/saude/noticia/01/2020/obesidade-infantil-estilo-de-vida-dospais-pode-ser-a-resposta-para-a-mudanca. 
GAZETA DO POVO. 2016.A regulação da publicidade é necessária para proteger a saúde das crianças: o estímulo ao consumo excessivo e habitual de produtos alimentícios ultraprocessados constitui uma das causas - ainda que não a única - da transição nutricional e do aumento de peso da população. Disponível em: https://www.gazetadopovo.com.br/vidapublica/justica-e-direito/artigos/a-regulacao-da-publicidade-e-necessaria-para-proteger-asaude-das-criancas-8sslrrpojns7t1ge25ljjlk28/.

GI. 2019. Por que é tão importante dar voz e vez às crianças? Disponível em: https://g1.globo.com/ba/bahia/especial-publicitario/escola-nossainfancia/noticia/2019/11/18/por-que-e-tao-importante-dar-voz-e-vez-as-criancas.ghtml.

GAZETA. 2018. Obesidade infantil: a culpa é de quem. Disponível em: https://www.agazeta.com.br/revista-ag/vida/obesidade-infantil-a-culpa-e-de-quem-0818

GOVERNO DO BRASIL. 2019. Brasil lança primeira campanha para prevenir obesidade infantil: novo Guia Alimentar ajuda pais a escolherem melhores alimentos e ensina que hora da alimentação deve ser um momento de afeto. Disponível em: https://www.gov.br/ptbr/noticias/saude-e-vigilancia-sanitaria/2019/11/brasil-lanca-primeira-campanha-paraprevenir-obesidadeinfantil\#: :text=Para\%20garantir\%20a\%20sa\%C3\%BAde\%20das,Brasileiras\%20Menores\%2 0de $\% 202 \% 20$ Anos.

GOVERNO DO BRASIL. 2019. Ministério da Saúde orienta alimentação saudável e atividade física para combater a obesidade infantil: a cada dez crianças brasileiras na faixa etária entre cinco e nove anos, três estão acima do peso de acordo com dados do Ministério da Saúde. Disponível em: https://www.gov.br/pt-br/noticias/saude-e-vigilanciasanitaria/2019/11/ministerio-da-saude-orienta-alimentacao-saudavel-e-atividade-fisica-paracombater-a-obesidade-infantil.

GOVERNO DO ESTADO DO PARANÁ. 2020. Saúde alerta sobre riscos da obesidade infantil: segundo a Organização Mundial da Saúde, este é considerado um dos principais desafios para o século XXI. Disponível em:

http://www.aen.pr.gov.br/modules/noticias/article.php?storyid=107303\&tit=Saude-alertasobre-riscos-da-obesidade-infantil

HUFFPOST BRASIL. 2018. Obesidade infantil: precisamos falar sobre a publicidade de alimentos. Disponível em: https://www.huffpostbrasil.com/alianca-pela-alimentacaoadequada-e-saudavel/obesidade-infantil-precisamos-falar-sobre-a-publicidade-dealimentos_a_23409516/.

INSTITUTO PENSI. 2020. Mídias sociais: atenção à publicidade infantil na internet. Disponível em: https://institutopensi.org.br/midias-sociais-atencao-a-publicidade-na-internet/.

JORNAL DA USP. 2018. Uma a cada três crianças brasileiras está com sobrepeso: cerca de $80 \%$ das crianças obesas se tornam adultos também obesos, diz especialista. Disponível em: https://jornal.usp.br/atualidades/obesidade-atinge-35-das-criancas-brasileiras/. 
JORNAL DO COMERCIO. 2018. Cresce mercado diferenciado para crianças.Disponível em: https://www.jornaldocomercio.com/_conteudo/economia/2018/07/639481-crescemercado-diferenciado-para-criancas.html.

JORNAL USP. 2019. Ministério da Saúde lança guia de nutrição infantil: a inclusão de açúcar e alimentos ultraprocessados na dieta de crianças até dois anos é contraindicada.Disponível em: https://jornal.usp.br/atualidades/ministerio-da-saude-lanca-guia-de-nutricao-infantil/.

LUNETAS. 2016. Participação infantil: opinar também é direito das crianças. Disponível em:https://lunetas.com.br/participacao-infantil-opinar-tambem-e-direito-das-criancas/.

LUNETAS. 2020. Mais do que nunca, precisamos ouvir as crianças: estar em casa é uma oportunidade para estreitar as relações e ouvir de fato o que as crianças estão dizendo. Disponível em: https://lunetas.com.br/ouvir-as-criancas/.

MEIO E MENSAGEM. 2016. Países que regulam publicidade infantil: o Superior Tribunal de Justiça determinou que é abusivo o uso de comunicação dirigida às crianças: veja como outros mercados lidam com o tema. Disponível em:

https://www.meioemensagem.com.br/home/comunicacao/2016/03/11/paises-que-regulampublicidade-infantil.html.

MEIO E MENSAGEM. 2018. Publicidade infantil: marcas fazem balanço de revisão de normas: compromisso pela publicidade responsável para crianças restringiu anúncios de alimentos que não atinjam critérios nutritivos suficientes. Disponível em:

https://www.meioemensagem.com.br/home/marketing/2018/03/20/publicidade-infantilmarcas-fazem-balanco-de-revisao-de-normas.html.

MEIO E MENSAGEM. 2019. Proibição da publicidade infantil não é fake news: dirigir mensagens comerciais a um público menor de 12 anos é prática regulada e até proibida em muitos países, que entendem ser antiético explorar a ingenuidade infantil em vez de dirigir-se aos pais e mães. Disponível em:

https://www.meioemensagem.com.br/home/opiniao/2019/07/30/proibicao-da-publicidadeinfantil-nao-e-fake-

news.html\#: :text=\%C3\%89\%20anti\%C3\%A9tico\%20explorar\%20a\%20ingenuidade,de\%20 vendas $\% 20 \mathrm{em} \% 20$ suas $\% 20 \mathrm{fam} \% \mathrm{C} 3 \%$ ADlias.

MEIO E MENSAGEM. 2019. Publicidade e crianças: o mundo não é uma bolha. No Brasil, não é proibido anunciar produtos e serviços de consumo infantil e adolescente, e é importante que continue assim. Disponível em:

https://www.meioemensagem.com.br/home/opiniao/2019/08/12/publicidade-e-criancas-omundo-nao-e-uma-bolha.html

MEIO E MENSAGEM. 2020. Ainda sobre publicidade infantil: parecia que o marketing já tinha superado essa discussão. Disponível em:

https://www.meioemensagem.com.br/home/opiniao/2020/05/08/ainda-sobre-publicidadeinfantil.html. 
METRO1. 2017. Seis marcas de alimentos para bebês têm fabricação, venda e uso proibidos pela Agência Nacional de Vigilância Sanitária. Disponível em:

https://www.metro1.com.br/noticias/saude/37343, seis-marcas-de-alimentos-para-bebes-temfabricacao-venda-e-uso-proibidos-pela-anvisa.

MIGALHAS. 2020. Entidades questionam no MJ a flexibilização da publicidade infantil: manifesto defende que proposta da Secretaria Nacional do Consumidor pode enfraquecer a proteção das crianças. Disponível em:

https://www.migalhas.com.br/quentes/321337/entidades-questionam-no-mj-a-flexibilizacaoda-publicidade-infantil

MINISTÉRIO DA EDUCAÇÃO. 2017. Ideias pipocam: a voz das crianças no planejamento da Educação Infantil: explorar o direito de participação e a autonomia das crianças, evidenciar seus desejos por meio da expressão oral, do registro escrito e dos desenhos; e estimular a auto-organização, expressa no planejamento das ações cotidianas Disponível em: http://basenacionalcomum.mec.gov.br/implementacao/praticas/caderno-de-praticas/educacaoinfantil/190-ideias-pipocam-a-voz-das-crianc-as-no-planejamento-da-educacao-infantil.

MINISTÉRIO DA SAÚDE, 2019. A obesidade infantil é um problema sério e traz riscos para a saúde adulta: a obesidade na infância está associada à mudança de hábitos alimentares e à diminuição da atividade física. Os números sobre a obesidade infantil são tão preocupantes que a Organização Mundial da Saúde estima que, em 2025, crianças obesas no planeta chegarão a 75 milhões. Disponível em: http://www.blog.saude.gov.br/index.php/promocaoda-saude/54034-a-obesidade-infantil-e-um-problema-serio-e-traz-riscos-para-a-saude-adulta

MINISTÉRIO DA SAÚDE. 2019. Os desafios para a alimentação das crianças: especialistas apontam quais são os aliados da alimentação saudável para crianças e quais são os principais desafios enfrentados pela família quando o assunto é comida de verdade. Disponível em: https://www.saude.gov.br/noticias/agencia-saude/45981-como-garantir-alimentacao-saudaveldas-criancas.

NIELSEN. 2015. Mercado infantil é a bola da vez. Disponível em: https://www.nielsen.com/br/pt/insights/article/2015/infografico-mercado-infantil-e-a-bola-davez-vendas-de-comida-para-bebes-crescem-37porcento-na-america-latina/.

O CONSUMERISTA. 2020. Governo abre consulta pública sobre lei que deve reger publicidade infantil: apesar de não contar com lei explícita, propaganda voltada às crianças já é considerada ilegal por entidades e chama a atenção dos anunciantes. Disponível em: https://www.oconsumerista.com.br/2020/01/governo-consulta-lei-publicidade-infantil/

OBHAFIOCRUZ. 2020. Publicidade infantil: a porta de entrada para produtos ultraprocessados. Disponível em: https://obha.fiocruz.br/?p=463.

ONU BRASIL. 2017. OMS lança novas diretrizes de combate à obesidade infantil no mundo: estima-se que 41 milhões de crianças menores de 5 anos sejam obesas ou estejam acima do peso no mundo. Disponível em: https://nacoesunidas.org/oms-lanca-novas-diretrizes-decombate-a-obesidade-infantil-nomundo/\#: :text=OMS\%20lan\%C3\%A7a\%20novas\%20diretrizes\%20de\%20combate $\% 20 \% \mathrm{C}$ 
3\%A0\%20obesidade\%20infantil\%20no\%20mundo,-

Desenvolvimento\%20Sustent\%C3\%A1vel\&text=Estima\%2Dse\%20que\%2041\%20milh\%C3

$\%$ B5es,acima\%20do\%20peso\%20no\%20mundo.

OPAS BRASIL. 2017. Obesidade entre crianças e adolescentes aumentou dez vezes em quatro décadas, revela novo estudo do Imperial College London e da OMS. Disponível em: https://www.paho.org/bra/index.php?option=com_content\&view=article\&id=5527:obesidadeentre-criancas-e-adolescentes-aumentou-dez-vezes-em-quatro-decadas-revela-novo-estudodo-imperial-college-london-e-da-oms $\&$ Itemid $=820$.

PASTORAL DA CRIANÇA, 2020. A importância da alimentação saudável para a criança: a alimentação para a criança não é apenas uma necessidade biológica para o seu desenvolvimento, mas também um momento de afeto e vínculo com a família. Disponível em: https://www.pastoraldacrianca.org.br/alimentacao-da-crianca/a-importancia-da-alimentacaosaudavel-para-a-crianca.

PLANALTO. 2015. Publicidade de alimentos e obesidade infantil: uma reflexão necessária. Disponível em: http://www4.planalto.gov.br/consea/comunicacao/artigos/2015/publicidadede-alimentos-e-obesidade-infantil-uma-reflexao-necessaria

PORTAL COMUNIQUE-SE. 2019. Publicidade infantil e a responsabilidade das marcas: a regulamentação da publicidade infantil ainda é muito delicada no Brasil. Disponível em: https://portal.comunique-se.com.br/publicidade-infantil-e-a-responsabilidade-das-marcas/.

PRIMEIRA INFÂNCIA. 2017. Documentário 'A Voz das Crianças’ registra diversidade de expressões infantis de cinco países. Disponível em:

http://primeirainfancia.org.br/documentario-a-voz-das-criancas-registra-diversidade-deexpressoes-infantis-de-cinco-paises/.

PRODIET, 2019. Nutrição infantil: como tornar a alimentação das crianças mais saudável. Disponível em: http://prodiet.com.br/blog/2019/02/18/nutricao-infantil-como-tornar-aalimentacao-das-criancas-mais-saudavel/.

SAÚDE DEBATE. 2020. Especialistas alertam para a obesidade infantil: desafio para mudança de hábitos pode ser maior ainda durante o isolamento social. Disponível em:https://saudedebate.com.br/noticias/especialistas-alertam-para-a-obesidade-infantil

SAÚDE. ABRIL. 2018. Obesidade infantil: um desafio de peso. Disponível em https://saude.abril.com.br/blog/com-a-palavra/obesidade-infantil-um-desafio-de-peso/

SAÚDE. GOIÁS. 2019. Obesidade infantil desafia pais e gestores: levantamento do IBGE aponta que uma em cada três crianças está acima do peso no Brasil; endocrinologista associa obesidade na infância à mudança dos hábitos alimentares e à diminuição da atividade física. Disponível em: https://www.saude.go.gov.br/noticias/81-obesidade-infantil-desafia-pais-egestores 
SEBRAE-SC. 2019. Alimentação Infantil: mercado exige criatividade e responsabilidade: sabemos a dificuldade que pais e educadores têm quando o assunto é oferecer uma alimentação saudável e de qualidade para as crianças; e os desafios também se expandem para quem empreende no setor de alimentação infantil. Disponível em: https://blog.sebraesc.com.br/alimentacao-infantil-mercado-exige-criatividade-e-responsabilidade/.

SENADO FEDERAL. 2017. A Organização Mundial de Saúde aponta a obesidade como um dos maiores problemas de saúde pública no mundo. Disponível em: https://www12.senado.leg.br/ecidadania/visualizacaoideia?id=63854

SÍRIO-LIBANÊS. 2016. Obesidade infantil: um problema de saúde pública. Disponível em:https://hospitalsiriolibanes.org.br/imprensa/noticias/Paginas/Obesidade-infantil-umproblema-de-sa\%C3\%BAde-p\%C3\%BAblica.aspx.

STJ. 2019. Decisão histórica condenou propaganda de alimentos dirigida ao público infantil. Disponível em: http://www.stj.jus.br/sites/portalp/Paginas/Comunicacao/Noticiasantigas/2019/2019-03-17_06-50_Decisao-historica-condenou-propaganda-de-alimentosdirigida-ao-publico-infantil.aspx

TERRA. 2017. Segundo dados, 7,3\% das crianças menores de cinco anos encontram-se acima do peso no Brasil: o aumento da obesidade infantil no Brasil é preocupante. Segundo a Pesquisa de Orçamento Familiar realizada pelo IBGE, uma em cada três crianças brasileiras com idade entre cinco e nove anos estão com o peso acima do recomendado pela Organização Mundial de Saúde. Disponível em: https://www.terra.com.br/noticias/dino/segundo-dados-73-dascriancas-menores-de-cinco-anos-encontram-se-acima-do-peso-nobrasil,f657afca7e30b62960c12400b2ff900fn7mfn0nh.html.

UFSC. 2013. Infância na balança: mudanças nos hábitos alimentares e a redução constante de atividades físicas estariam levando a população mundial ao sobrepeso e à obesidade, a começar pelas crianças. Disponível;em: https://noticias.ufsc.br/2013/09/ufsc-na-midiainfancia-na-balanca/.

UNICEF BRASIL. 2019. Má alimentação prejudica a saúde de milhões de crianças em todo o mundo: uma em cada três crianças está desnutrida ou com sobrepeso no mundo; na América Latina e no Caribe, uma em cada cinco crianças é afetada pela má nutrição; no Brasil, aumento do sobrepeso é particularmente importante." https://www.unicef.org/brazil/comunicados-de-imprensa/ma-alimentacao-prejudica-saudedas-criancas-em-todo-o-mundo-alerta-o-unicef.

UNIMED. 2020. Alimentação infantil: uma oportunidade para a família buscar mais saúde. Bons hábitos alimentares começam na infância: veja como a família toda pode se beneficiar com isso. Disponívl em: https://www.centralnacionalunimed.com.br/viverbem/alimentacao/alimentacao-infantil-uma-oportunidade-para-a-familia-buscar-mais-saude.

UOL. 2019. A importância da comida de verdade para o desenvolvimento das crianças: uma alimentação adequada e saudável contribui para a saúde infantil e deve ter como base a 'comida de verdade'. Disponível em: 
https://www.uol.com.br/vivabem/noticias/redacao/2019/12/06/a-importancia-da-comida-deverdade-para-o-desenvolvimento-das-criancas.htm.

UOL. 2019. Mídias sociais influenciam crianças a consumirem mais alimentos calóricos: as mídias sociais também influenciam os pequenos, principalmente quando o assunto é alimentação. Disponível em:

https://www.uol.com.br/vivabem/noticias/redacao/2019/03/07/midias-sociais-influenciamcriancas-a-consumirem-mais-alimentos-caloricos.htm.

UOL. 2020. Sujeitos do presente e do futuro: crianças e adolescentes. Disponível em: https://www.uol.com.br/ecoa/colunas/opiniao/2020/07/13/sujeitos-do-presente-e-futurocriancas-e-adolescentes.htm

VEJA, 2020. Alimentação saudável previne a obesidade infantil e o câncer. Disponível em: https://veja.abril.com.br/saude/alimentacao-saudavel-previne-a-obesidade-infantil-e-ocancer/. 


\section{APÊNDICE A}

\section{PESQUISA DE CAMPO \\ TERMO DE CONSENTIMENTO LIVRE E ESCLARECIDO}

Modelo do Termo de Consentimento Livre e Esclarecido.

Autorizações assinadas pelos pais e pelas crianças participantes do estudo. 
UNIVERSIDADE DE SÃO PAULO

ESCOLA DE COMUNICAÇÕES E ARTES

PROGRAMA DE PÓS-GRADUAÇÃO EM CIÊNCIAS DA COMUNICAÇÃO

ÁREA DE CONCENTRAÇÃO: CIÊNCIAS DA COMUNICAÇÃo

LINHA DE PESQUISA: PROCESSOS COMUNICACIONAIS: TECNOLOGIAS PRODUÇÃO E CONSUMOS

ORIENTADOR: Prof. Dr. ENEUS TRINDADE BARRETO FILHO

CINIRA BAADER

MEDIAÇÃO COMUNICACIONAL DAS MARCAS

NA CULTURA ALIMENTAR INFANTIL

Projeto: Doutorado

São Paulo

Março/2016 - Março/2021 


\section{TERMO DE CONSENTIMENTO LIVRE E ESCLARECIDO \\ PARA PARTICIPAÇÃO NA PESQUISA}

\section{SOBRE A PESQUISA}

Título: Mediação Comunicacional das Marcas na Cultura Alimentar Infantil: um Estudo Sobre a Relação Criança-Marca-Consumo Alimentar no Contexto Familiar

Objeto de Estudo: O projeto propõe o estudo da recepção infantil de marcas de alimentos, como dispositivos midiáticos promocionais, no âmbito das práticas e rituais de consumo alimentar das crianças em contextos familiares na cidade de São Paulo, explorando os modos de presença e mediação comunicacional das marcas na construção da cultura alimentar infantil e considerando os vínculos de sentidos entre marcas/produtos e crianças, na interface com as mediações culturais e comunicacionais presentes na modulação do consumo alimentar infantil no contexto familiar.

Problema de Pesquisa: Como se dá a recepção infantil de marcas de alimentos, como dispositivos midiáticos promocionais, no âmbito das práticas e rituais de consumo alimentar das crianças no contexto familiar, considerando os vínculos de sentidos entre marcas/produtos e crianças? E como se dão os modos de presença e mediação comunicacional das marcas na construção da cultura alimentar infantil, na interface com as mediações culturais e comunicacionais presentes na modulação do consumo alimentar das crianças no contexto familiar?

Objetivo Teórico: Propor um percurso e contribuição teórico-metodológica para o estudo da recepção infantil de marcas de alimentos, nos cotidianos da cultura de consumo alimentar de crianças em contextos familiares, procurando dar voz às crianças no processo de investigação e atentando para a importância da presença de perspectivas infantis na elaboração dos estudos contemporâneos sobre comunicação consumo e infância.

Objetivo Empírico: Compreender como se dá a recepção infantil de marcas de alimentos, como dispositivos midiáticos promocionais, no âmbito das práticas e rituais de consumo alimentar das crianças em contextos familiares, explorando os modos de presença e mediação comunicacional das marcas na construção da cultura alimentar infantil e considerando os vínculos de sentidos entre marcas/produtos e crianças, na interface com as mediações culturais e comunicacionais presentes na modulação do consumo alimentar infantil no contexto familiar..

\section{Procedimentos Metodológicos:}

\section{Sobre o Estudo:}

Um estudo exploratório de natureza qualitativa. Estudo de recepção em perspectiva de abordagem sociocultural. Uma proposta de estudo interdisciplinar. 
Estudo de inspiração etnográfica no campo da comunicação. Um estudo etnográfico com crianças. Na perspectiva de dar voz às crianças.

Estudo de recepção infantil de marcas de alimentos (como dispositivos midiáticos promocionais). Para explorar os modos de presença e mediação comunicacional das marcas na construção da cultura alimentar infantil.

Tomando-se o lar, o contexto familiar como lugar de estudo. Tomando-se a família como mediação cultural de base, na interface com outras mediações culturais e comunicacionais presentes na modulação do consumo alimentar infantil no contexto familiar.

E tomando-se as crianças como principais informantes e co-participantes no processo de pesquisa. E os pais e familiares como informantes em complementação.

Numa proposta de construção de conhecimento: do saber empírico ao saber teórico.

\section{Sobre o Corpus de Investigação:}

Famílias residentes na cidade de São Paulo - SP.

Famílias de diferentes classes socioeconômicas.

Com uma ou mais crianças em sua composição familiar.

Crianças de ambos os sexos e diferentes idades (faixa etária entre 4 e 12 anos).

\section{Sobre os Métodos e Técnicas:}

Observação / Observação Participante

Interação / Participação

Entrevista / Entrevista de Grupo

Jogos / Brincadeiras

Produção / Co-Produção de Fotos e Vídeos

Registros em Fotografia / Vídeo

Notas de Campo / Relatos de Campo

\section{Sobre as Atividades da Pesquisa:}

Visitas às Famílias

- Primeira Visita - Família / Crianças / Cultura Alimentar / Marcas e Produtos

- Segunda Visita - Ritual de Alimentação em Casa

- Terceira Visita - Ritual de Alimentação em Espaço Público

Jogos e Brincadeiras

- Primeiro Jogo - Brincadeira de Comer (cards)

- Segundo Jogo - Brincadeira der Comprar (supermercado) 


\section{Eixos de Abordagem Empírica:}

1. Cultura Alimentar Infantil: Mediações Culturais e Comunicacionais na Modulação do Consumo Alimentar das Crianças

Cultura alimentar familiar / Cultura alimentar infantil no contexto familiar / Práticas e rituais de consumo alimentar das crianças / Mediações culturais e comunicacionais presentes na modulação do consumo alimentar infantil no contexto familiar.

2. Mediação Comunicacional das Marcas na Cultura Alimentar Infantil: Marcas e Produtos no Contexto Familiar Modos de presença e mediação comunicacional das marcas na construção da cultura alimentar infantil / A presença dos vínculos de sentidos que se estabelecem entre as marcas/produtos e as famílias/crianças.

3. Recepção Infantil de Marcas de Alimentos: Vínculos de Sentidos entre Marcas/Produtos e Crianças

Recepção infantil de marcas de alimentos como dispositivos midiáticos promocionais / Os vínculos de sentidos dados entre marcas/produtos e crianças nos cotidianos dos contextos familiares. 


\section{SOBRE A PARTICIPAÇÃo NA PESQUISA E EM PRODUTOS DE DIVULGAÇÃo CIENTÍFICA}

A pesquisa será realizada com as crianças e, em algumas atividades, também com os pais. Mas as atividades a serem desenvolvidas exclusivamente com as crianças poderão ser acompanhadas pelos pais.

A participação das crianças na pesquisa se dará com o consentimento e autorização dos pais, e durante todas as atividades as crianças deverão estar acompanhadas pelos pais ou responsáveis.

A pesquisa não causará nenhum tipo de constrangimento moral e nem riscos de qualquer natureza aos seus integrantes e participantes.

Os dados da pesquisa e suas publicações científicas impressas e/ou audiovisuais não terão caráter comercial, pois só poderão ser utilizados com fins de divulgação científica, preservando a identidade dos participantes da pesquisa.

A pesquisa prevê a criação de um vídeo ou documentário, também sem fins comerciais, cuja participação será dada com a concordância dos participantes (pais e crianças).

Todo participante pode solicitar sua saída da pesquisa durante qualquer fase da coleta de dados da pesquisa. 


\section{AUTORIZAÇÃo}

A partir do exposto, se estiver de acordo, solicitamos que assine o termo de concordância em participar da pesquisa, autorizando também a participação de seus filhos, manifestando a modalidade de participação:

Aceito participar da pesquisa e autorizo a participação da criança (meu filho/a) na seguinte modalidade de participação:

1 - ( ) Os esclarecimentos oferecidos são suficientes e declaro ter ciência de que: a pesquisa será realizada com as crianças (meus filhos) e, em algumas atividades, também com a participação dos pais, e as atividades a serem desenvolvidas exclusivamente com as crianças poderão ser acompanhadas pelos pais; a participação das crianças na pesquisa se dará com meu consentimento e autorização, e durante todas as atividades as crianças deverão estar acompanhadas pelos pais ou responsáveis; a pesquisa não causará nenhum tipo de constrangimento moral e nem riscos de qualquer natureza a minha pessoa, aos meus filhos, ou familiares; os dados da pesquisa e suas publicações científicas impressas e/ou audiovisuais não terão caráter comercial e só poderão ser utilizados com fins de divulgação científica, preservando a minha identidade e a identidade das crianças. $\mathrm{O}$ uso de imagens fotográficas com a minha presença, ou com a presença das crianças, deverá ocultar os rostos para preservar nossa identidade. Também concordo em participar da criação de documentário acadêmico sobre Mediação Comunicacional das Marcas na Cultura Alimentar Infantil, autorizando o uso da minha imagem e da imagem das crianças. Por fim, estou ciente de que posso solicitar a saída da pesquisa, de minha parte e da parte das crianças, bem como a exclusão dos dados informados ao pesquisador, durante qualquer fase da coleta de dados da pesquisa.

Assim sendo, aceito participar da pesquisa e autorizo a participação da criança (meu filho/a).

2 - ( ) Os esclarecimentos oferecidos são suficientes e declaro ter ciência de que: a pesquisa será realizada com as crianças (meus filhos) e, em algumas atividades, também com a participação dos pais, e as atividades a serem desenvolvidas exclusivamente com as crianças poderão ser acompanhadas pelos pais; a participação das crianças na pesquisa se dará com meu consentimento e autorização, e durante todas as atividades as crianças deverão estar acompanhadas pelos pais ou responsáveis; a pesquisa não causará nenhum tipo de constrangimento moral e nem riscos de qualquer natureza a minha pessoa, aos meus filhos, ou familiares; os dados da pesquisa e suas publicações científicas impressas e/ou audiovisuais não terão caráter comercial e só poderão ser utilizados com fins de divulgação científica, preservando a minha identidade e a identidade das crianças. O uso de imagens fotográficas com a minha presença, ou com a presença das crianças, deverá ocultar os rostos para preservar nossa identidade. Não concordo em participar da criação de documentário acadêmico sobre Mediação Comunicacional das Marcas na Cultura Alimentar Infantil, não autorizando o uso da minha imagem e da imagem das crianças para tal finalidade. Por fim, estou ciente de que posso solicitar a saída da pesquisa, de minha parte e da parte das crianças, bem como a exclusão dos dados informados ao pesquisador, durante qualquer fase da coleta de dados da pesquisa.

Assim sendo, aceito participar da pesquisa e autorizo a participação da criança (meu filho/a).

3 - ( ) Não aceito participar da pesquisa e não autorizo a participação da criança (meu filho/a). 
Nome Completo:

Pai ( ) Mãe ( ) Responsável ( )

RG:

CPF:

Data de Nascimento I

Endereço Residencial:

Telefone: Celular:

E-mail:

Nome da criança (filho/filha):

Assinatura do Pai:

Assinatura da Mãe:

Assinatura da Criança:

São Paulo, 


\section{APÊNDICE B}

\section{PESQUISA DE CAMPO ENTREVISTA FAMÍLIA}

Roteiro sugerido para orientação da entrevista em grupo realizada com as famílias no primeiro encontro da pesquisa de campo. 


\section{ENTREVISTA EM GRUPO COM A FAMÍLIA}

\section{SUGESTÃO DE ROTEIRO}

\section{Cultura Alimentar Infantil: Mediações Culturais e Comunicacionais na Modulação do Consumo} Alimentar das Crianças no Contexto Familiar

○ Contexto Rotina e Composição Familiar e Atividades e Interações Infantis

○ Rotina Alimentar e Hábitos e Preferências Alimentares da Família e das Crianças

○ Práticas e Rituais de Consumo Alimentar Infantil no Contexto Familiar

- Preferências e Saberes Infantis sobre Consumo Alimentar

- Mediações Culturais e Comunicacionais na Cultura Alimentar Infantil e Mediação da Família na Cultura Alimentar Infantil

Mediação Comunicacional das Marcas na Cultura Alimentar Infantil: Marcas e Produtos Alimentícios no Contexto Familiar

- Escolha Compra e Consumo de Alimentos da Família e Critérios Mais Importantes na Escolha dos Alimentos

- Usos e Consumos Infantis dos Dispositivos e Mídias e Contato das Crianças com o Universo Promocional das Marcas e Produtos Alimentícios

- Presença e Mediação Comunicacional das Marcas na Cultura Alimentar Infantil e Rituais de Consumo Alimentar Infantil no Contexto Familiar

- Marcas e Produtos Alimentícios no Contexto Familiar

- Marcas e Produtos Alimentícios no Contexto das Escolhas e Preferências das Crianças: Perspectiva da Família 


\section{APÊNDICE C}

\section{PESQUISA DE CAMPO ENTREVISTA CRIANÇAS}

Roteiro sugerido para orientação da entrevista em grupo realizada com as crianças no segundo encontro da pesquisa de campo. 


\section{ENTREVISTA EM GRUPO COM AS CRIANÇAS \\ SUGESTÃO DE ROTEIRO}

Recepção Infantil de Marcas de Alimentos: Vínculos de Sentidos entre Marcas/Produtos e Crianças no Contexto Familiar

- Perspectiva das Crianças sobre a sua Cultura Alimentar e as Mediações Culturais e Comunicacionais na Modulação do seu Consumo Alimentar

- Perspectiva das Crianças sobre a Mediação Comunicacional das Marcas na sua Cultura Alimentar e as Marcas e Produtos Alimentícios no seu Contexto Familiar

- Perspectiva das crianças: Marcas e Produtos Alimentícios no Contexto das Escolhas e Preferências Infantis: Recepção Infantil e Vínculos de Sentidos

- Perspectiva das crianças sobre a Pesquisa e o Consumo Alimentar Infantil 


\section{APENNDICE D}

\section{PESQUISA DE CAMPO \\ ENTREVISTA MÃE}

Roteiro sugerido para orientação da entrevista individual realizada com as mães no segundo encontro da pesquisa de campo. 


\section{ENTREVISTA INDIVIDUAL COM A MÃE}

SUGESTÃO DE ROTEIRO

Cultura Alimentar Infantil: Mediações Culturais e Comunicacionais na Modulação do Consumo Alimentar das Crianças no Contexto Familiar

- Contexto Rotina e Composição Familiar e Atividades e Interações Infantis

○ Rotina Alimentar e Hábitos e Preferências Alimentares da Família e das Crianças

- Práticas e Rituais de Consumo Alimentar Infantil no Contexto Familiar

- Preferências e Saberes Infantis sobre Consumo Alimentar

- Mediações Culturais e Comunicacionais na Cultura Alimentar Infantil e Mediação da Família na Cultura Alimentar Infantil

Mediação Comunicacional das Marcas na Cultura Alimentar Infantil: Marcas e Produtos Alimentícios no Contexto Familiar

- Escolha Compra e Consumo de Alimentos da Família e Critérios Mais Importantes na Escolha dos Alimentos

- Usos e Consumos Infantis dos Dispositivos e Mídias e Contato das Crianças com o Universo Promocional das Marcas e Produtos Alimentícios

- Presença e Mediação Comunicacional das Marcas na Cultura Alimentar Infantil e Rituais de Consumo Alimentar Infantil no Contexto Familiar

- Marcas e Produtos Alimentícios no Contexto Familiar

- Marcas e Produtos Alimentícios no Contexto das Escolhas e Preferências das Crianças: Perspectiva da Família 


\section{APÊNDICE E}

\section{PESQUISA DE CAMPO \\ ENTREVISTA PAI}

Roteiro sugerido para orientação da entrevista individual realizada com os pais no terceiro encontro da pesquisa de campo. 


\section{ENTREVISTA INDIVIDUAL COM O PAI}

SUGESTÃO DE ROTEIRO

Cultura Alimentar Infantil: Mediações Culturais e Comunicacionais na Modulação do Consumo Alimentar das Crianças no Contexto Familiar

○ Contexto Rotina e Composição Familiar e Atividades e Interações Infantis

○ Rotina Alimentar e Hábitos e Preferências Alimentares da Família e das Crianças

- Práticas e Rituais de Consumo Alimentar Infantil no Contexto Familiar

○ Preferências e Saberes Infantis sobre Consumo Alimentar

- Mediações Culturais e Comunicacionais na Cultura Alimentar Infantil e Mediação da Família na Cultura Alimentar Infantil

\section{Mediação Comunicacional das Marcas na Cultura Alimentar Infantil: Marcas e Produtos Alimentícios no} Contexto Familiar

- Escolha Compra e Consumo de Alimentos da Família e Critérios Mais Importantes na Escolha dos Alimentos

- Usos e Consumos Infantis dos Dispositivos e Mídias e Contato das Crianças com o Universo Promocional das Marcas e Produtos Alimentícios

○ Presença e Mediação Comunicacional das Marcas na Cultura Alimentar Infantil e Rituais de Consumo Alimentar Infantil no Contexto Familiar

- Marcas e Produtos Alimentícios no Contexto Familiar

- Marcas e Produtos Alimentícios no Contexto das Escolhas e Preferências das Crianças: Perspectiva da Família 


\section{APÊNDICE F}

\section{PESQUISA DE CAMPO \\ BRINCADEIRA DE COMER}

Roteiro e dinâmica da atividade lúdica proposta.

Imagens dos alimentos, produtos alimentícios, marcas e personagens presentes na composição dos cards para a atividade lúdica desenvolvida com as crianças no quarto encontro da pesquisa de campo. 


\section{BRINCADEIRA DE COMER \\ ROTEIRO / DINÂMICA / IMAGENS}

\section{JOGO CARDS ALIMENTOS}

Sobre consumo alimentar:

Jogo de cards apresentado às crianças com imagens de alimentos / produtos alimentícios diversos (alimentos / bebidas / guloseimas / produtos industrializados / alimentos in natura).

Cada criança recebeu um baralho completo com os cards.

O jogo teve início quando as crianças foram solicitadas a organizar os cards sobre a mesa, livremente, de acordo com suas perspectivas e critérios de organização.

Em seguida, após a organização dos cards, as crianças foram solicitadas a compor algumas combinações de alimentos / produtos alimentícios para simulação de consumo alimentar. De acordo com suas perspectivas, experiências, saberes, preferências e afetos. Independentemente das suas escolhas serem ou não representativas do seu consumo alimentar no cotidiano. Foram solicitadas às crianças combinações alimentares para composição do café da manhã / almoço / jantar / lanche da escola / lanche com amigos.

Após cada composição de produtos alimentícios para simulação de consumo alimentar, as crianças foram convidadas a falar sobre suas composições, destacando os alimentos ou produtos alimentícios escolhidos. Explicando o porquê de cada escolha, falando sobre as marcas e produtos alimentícios da sua preferência, e expressando as preferências e saberes infantis sobre o consumo alimentar.

Durante o jogo, cada solicitação feita às crianças era denominada como desafio.

O jogo foi finalizado quando as crianças concluíram todas as composições alimentares solicitadas na forma de desafios.

\section{JOGO CARDS MARCAS}

Sobre marcas de produtos alimentícios:

Jogo de cards apresentado às crianças com imagens de marcas de produtos alimentícios diversos, incluindo imagens de marcas representadas por personagens e mascotes.

Cada criança recebeu um baralho completo com os cards.

O jogo teve início quando as crianças foram solicitadas a organizar os cards sobre a mesa, livremente, de acordo com suas perspectivas e critérios de organização.

Em seguida, após a organização dos cards, as crianças foram solicitadas a escolher algumas marcas de produtos alimentícios de que gostam, ou que gostam mais, e algumas marcas de produtos alimentícios de que não gostam, ou que gostam menos (marcas de produtos alimentícios ou marcas representadas por personagens e mascotes). 
Devendo escolher entre três e cinco marcas para cada grupo de marcas escolhidas. De acordo com suas perspectivas, experiências, saberes, preferências e afetos.

Após as suas composições, dentre as diversas marcas de produtos alimentícios e personagens e mascotes, as crianças foram convidadas a falar sobre suas escolhas, destacando as marcas de produtos alimentícios escolhidas. Explicando o porquê de cada escolha, falando sobre as marcas ou personagens e mascotes de que gostam e de que não gostam, e expressando os saberes e afetos infantis no contexto promocional das marcas e produtos alimentícios.

Durante o jogo, cada solicitação feita às crianças era denominada como desafio.

O jogo foi finalizado quando as crianças concluíram as escolhas e composições de marcas solicitadas na forma de desafios.

\section{DESENHOS CONSUMO ALIMENTAR}

Sobre consumo alimentar:

Desenhos elaborados pelas crianças sobre seus gostos e preferências no consumo alimentar (o que gostam e o que não gostam de comer).

Cada criança recebeu uma folha de papel em branco. E na folha, as crianças foram solicitadas a fazer uma dobradura para dividir o papel em quatro partes iguais, numerando cada uma das partes em sequência (1-2-3-4).

Em seguida, as crianças foram solicitadas a fazer os desenhos, em cada uma das partes do papel, seguindo a ordem indicada, de acordo com a sequência das solicitações para os desenhos:

1 - Que mais gosta de comer.

2 - Que não gosta de comer.

3- Que gosta de comer e é saudável.

4 - Que gosta de comer e não é saudável.

Ao final, após a conclusão dos desenhos, as crianças foram convidadas a falar sobre o que desenharam, destacando os alimentos / produtos alimentícios que gostam de comer, que não gostam de comer, que são saudáveis, e que não são saudáveis. Explicando o porquê de cada escolha, falando sobre os alimentos / produtos alimentícios, e expressando as preferências e saberes infantis sobre o consumo alimentar.

Durante a atividade, cada solicitação feita às crianças era denominada como desafio.

A atividade foi finalizada quando as crianças concluíram todos os desenhos solicitados na forma de desafios.

\section{DESENHOS MARCAS E PERSONAGENS}

Sobre marcas de produtos alimentícios: 
Desenhos elaborados pelas crianças sobre marcas de produtos alimentícios e marcas representadas por personagens e mascotes (marcas e personagens que as crianças conhecem / que as crianças gostam).

Cada criança recebeu uma folha de papel em branco. E na folha, as crianças foram solicitadas a fazer uma dobradura para dividir o papel em duas partes iguais, numerando cada uma das partes em sequência (1-2).

Em seguida, as crianças foram solicitadas a fazer os desenhos, em cada uma das partes do papel, seguindo a ordem indicada, de acordo com a sequência das solicitações para os desenhos:

1 - Marca de produto alimentício que conhece / que gosta.

2 - Personagem ou mascote que conhece / que gosta.

Ao final, após a conclusão dos desenhos, as crianças foram convidadas a falar sobre o que desenharam, destacando as marcas de produtos alimentícios que conhecem / que gostam e os personagens e mascotes que conhecem / que gostam. Explicando o porquê de cada escolha, falando sobre as marcas e personagens, e expressando os saberes e afetos infantis no contexto promocional das marcas e produtos alimentícios.

Durante a atividade, cada solicitação feita às crianças era denominada como desafio.

A atividade foi finalizada quando as crianças concluíram todos os desenhos solicitados na forma de desafios. 

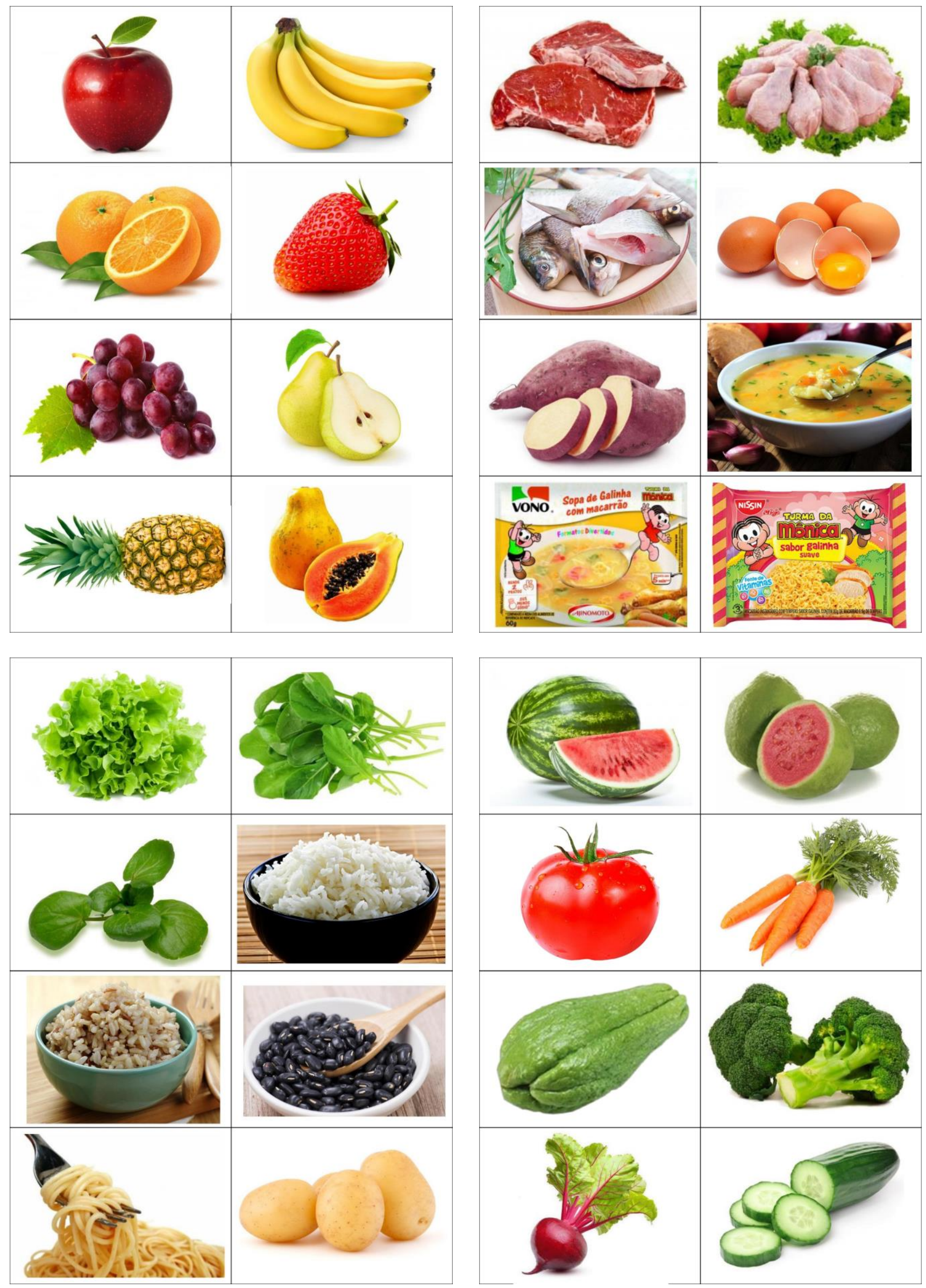


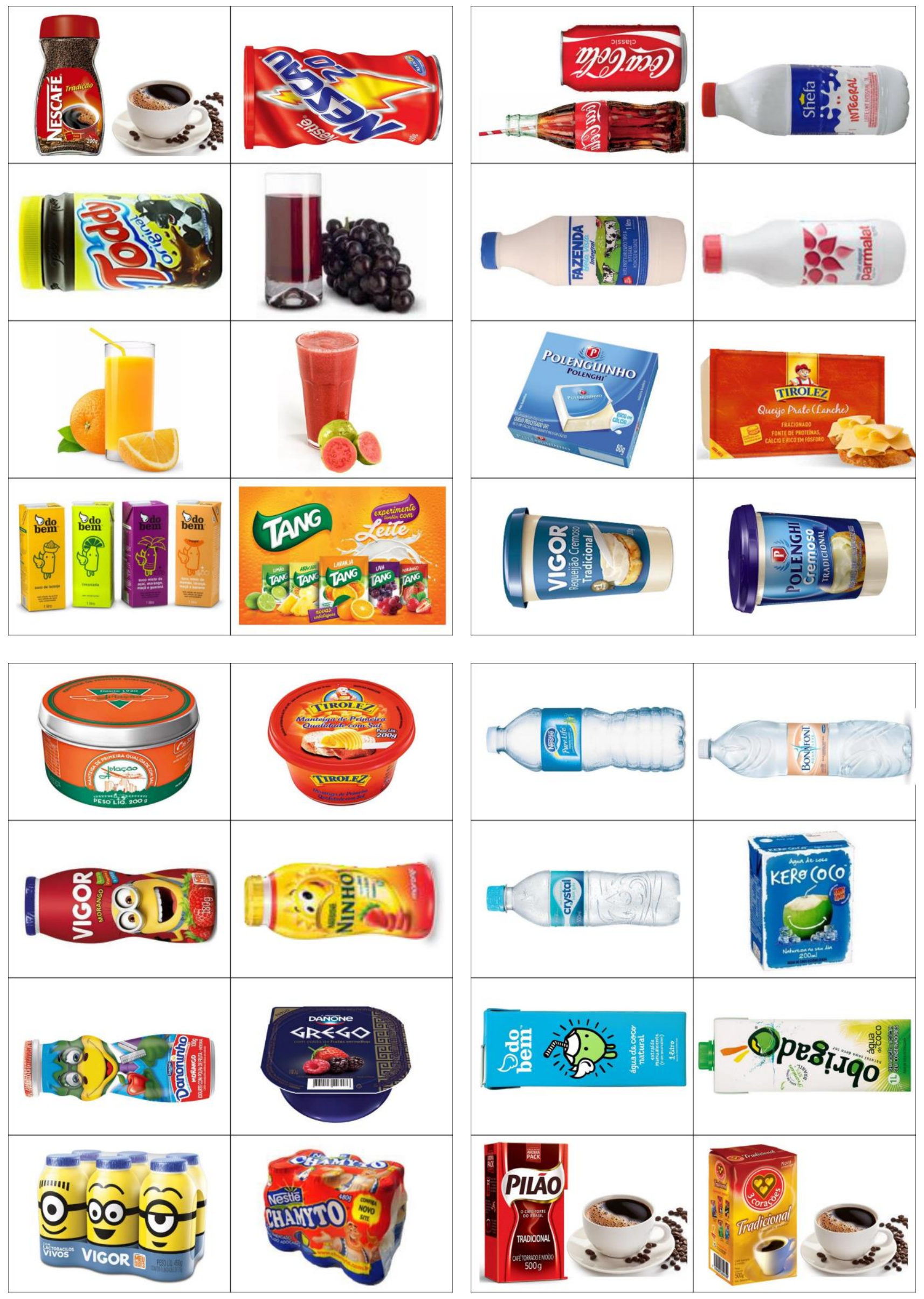



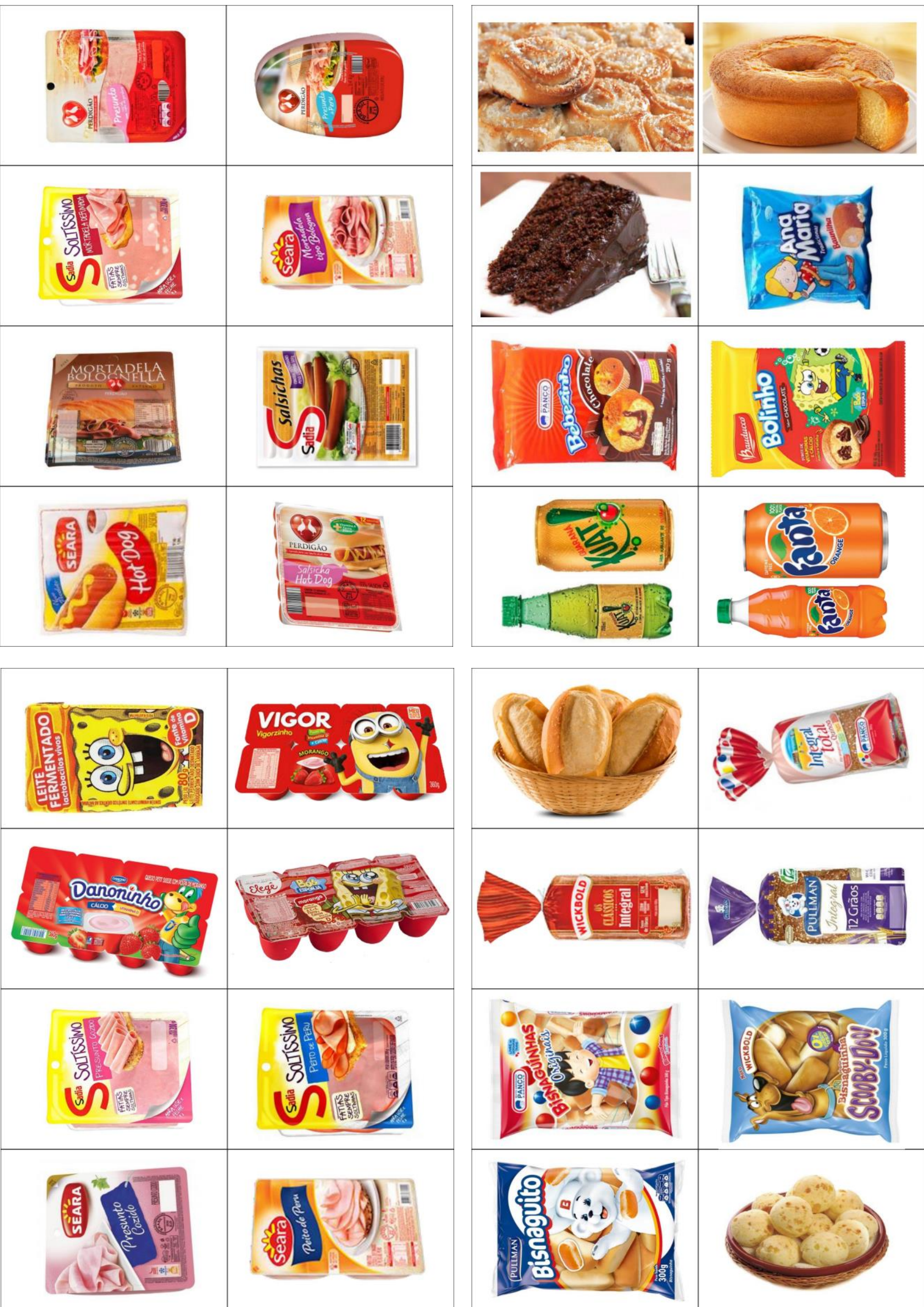

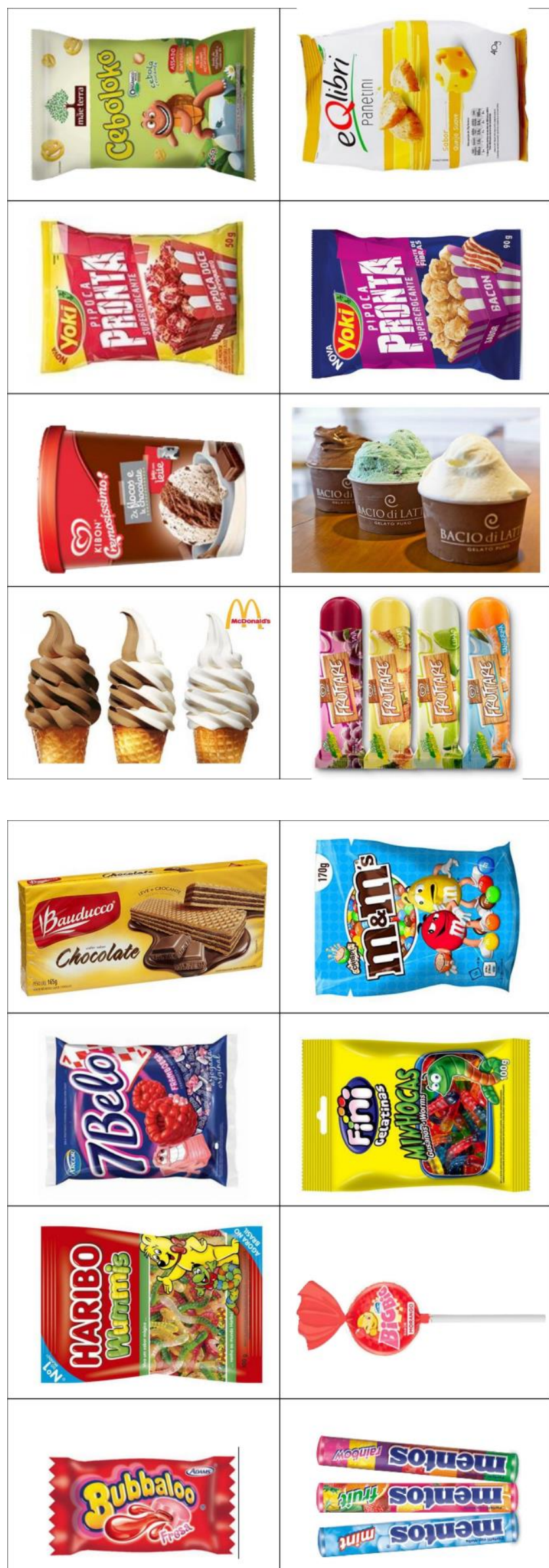
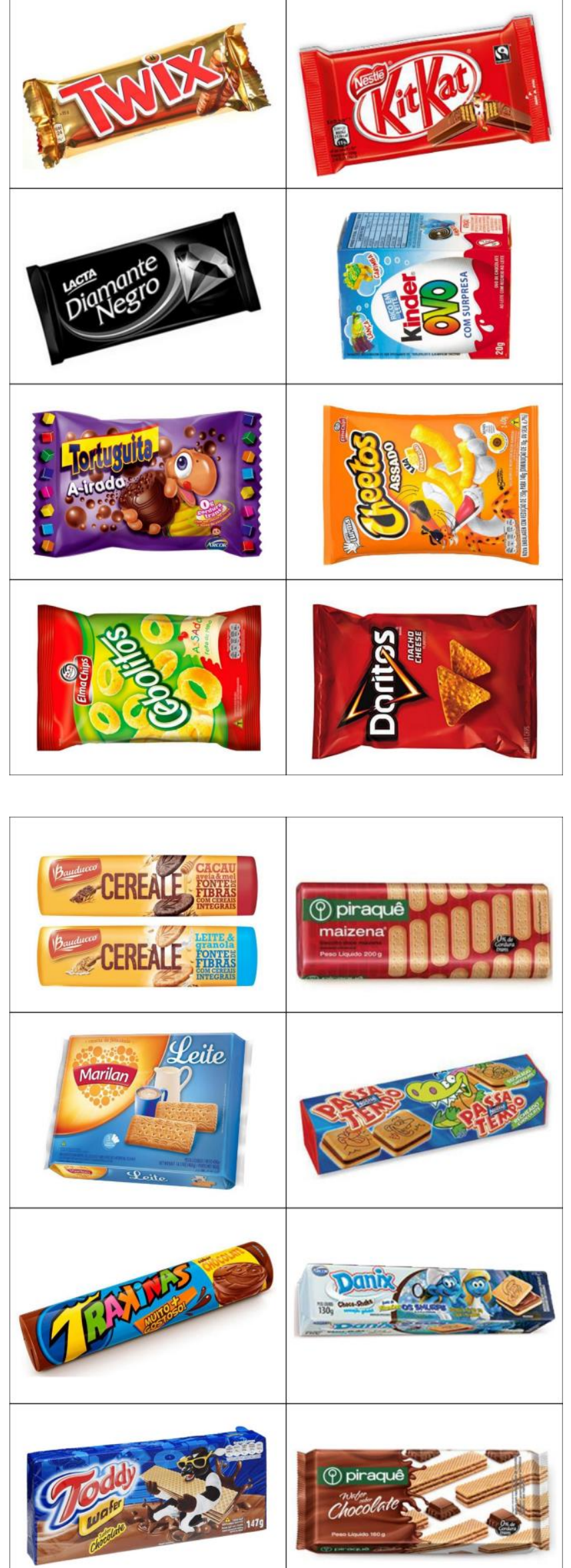


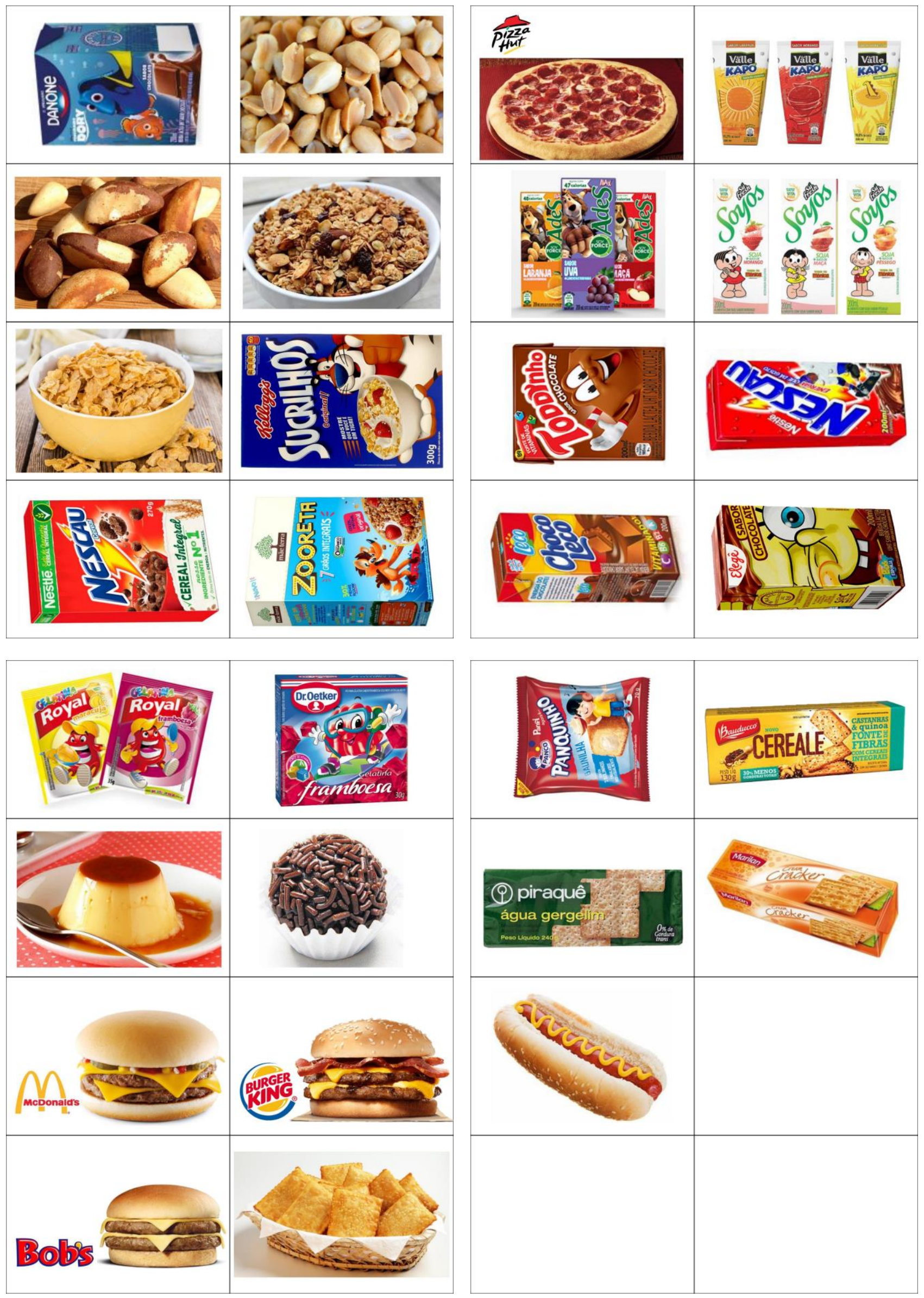



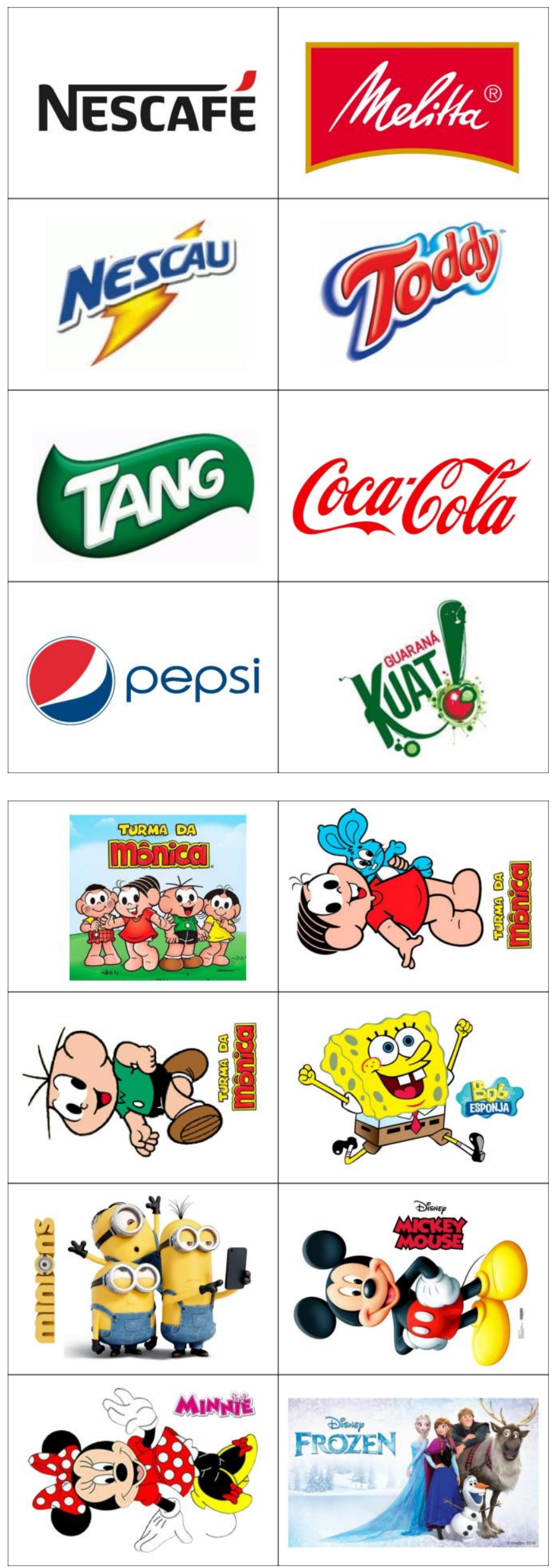
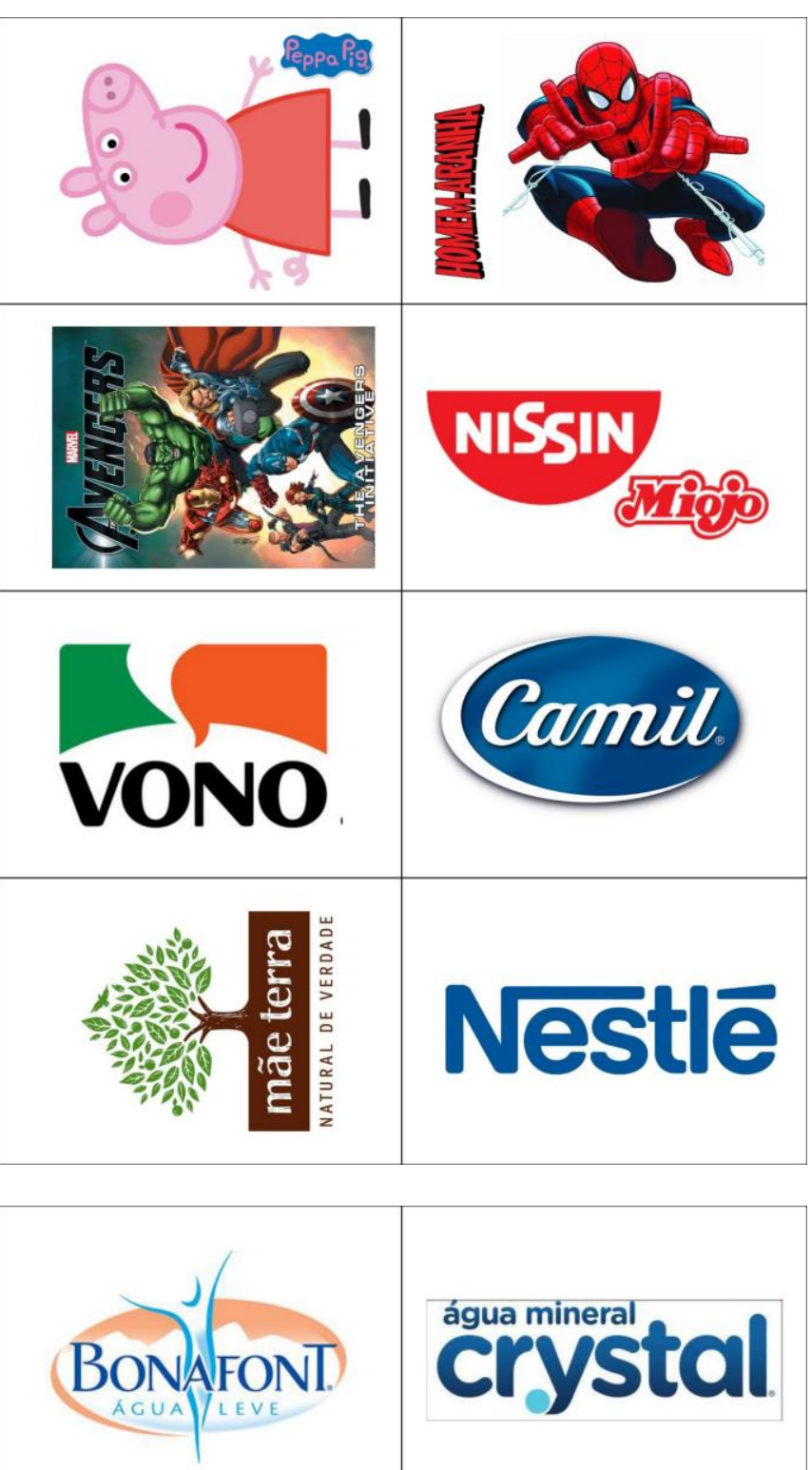

cryystal

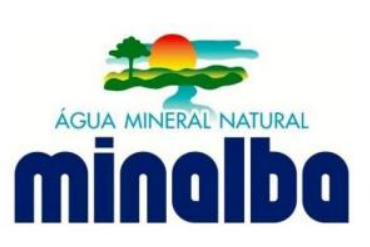

KER $\sigma$ C 0

\section{obrigad $(\theta$}

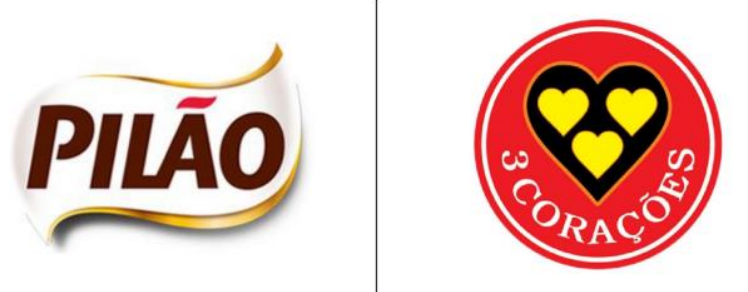



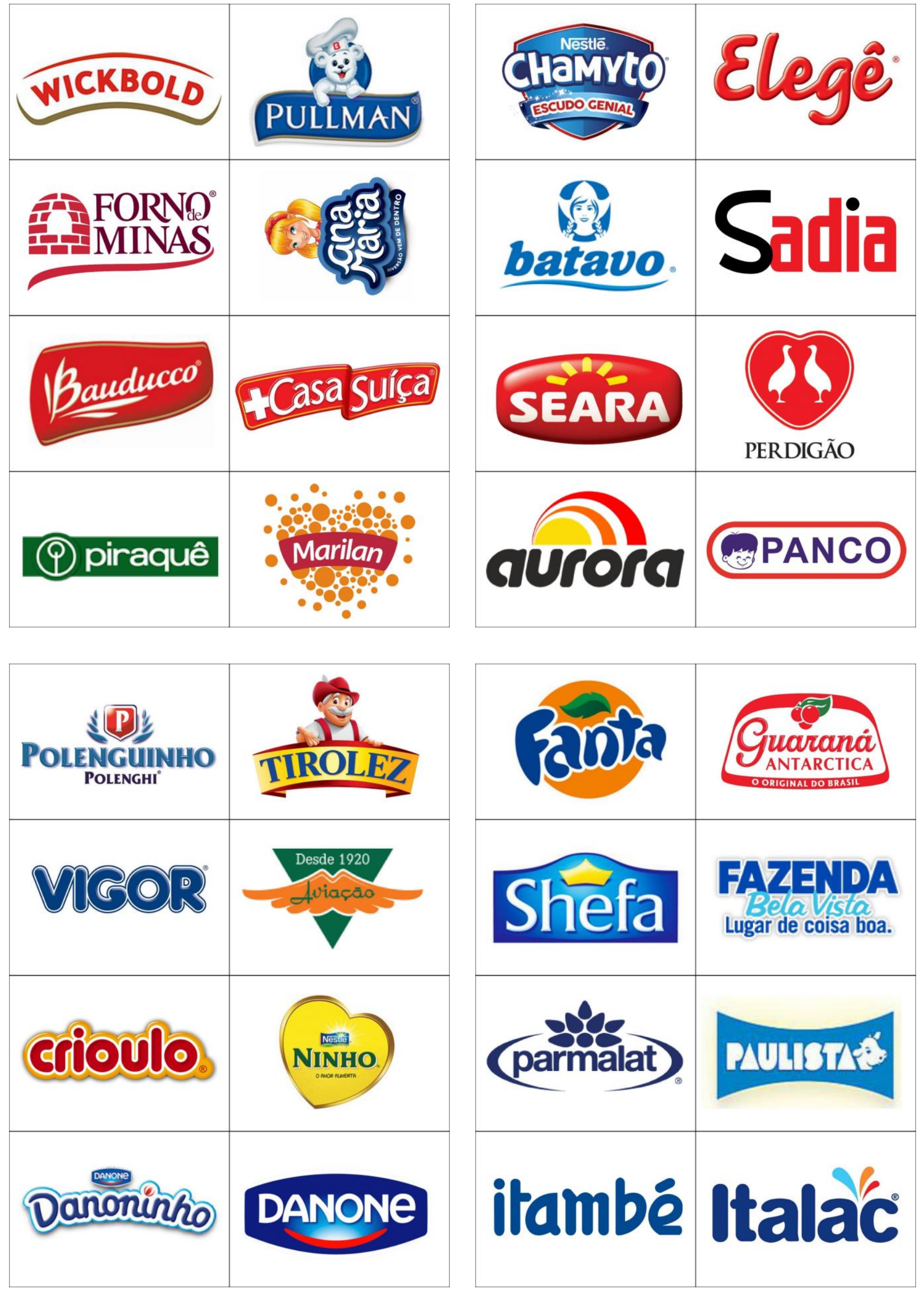


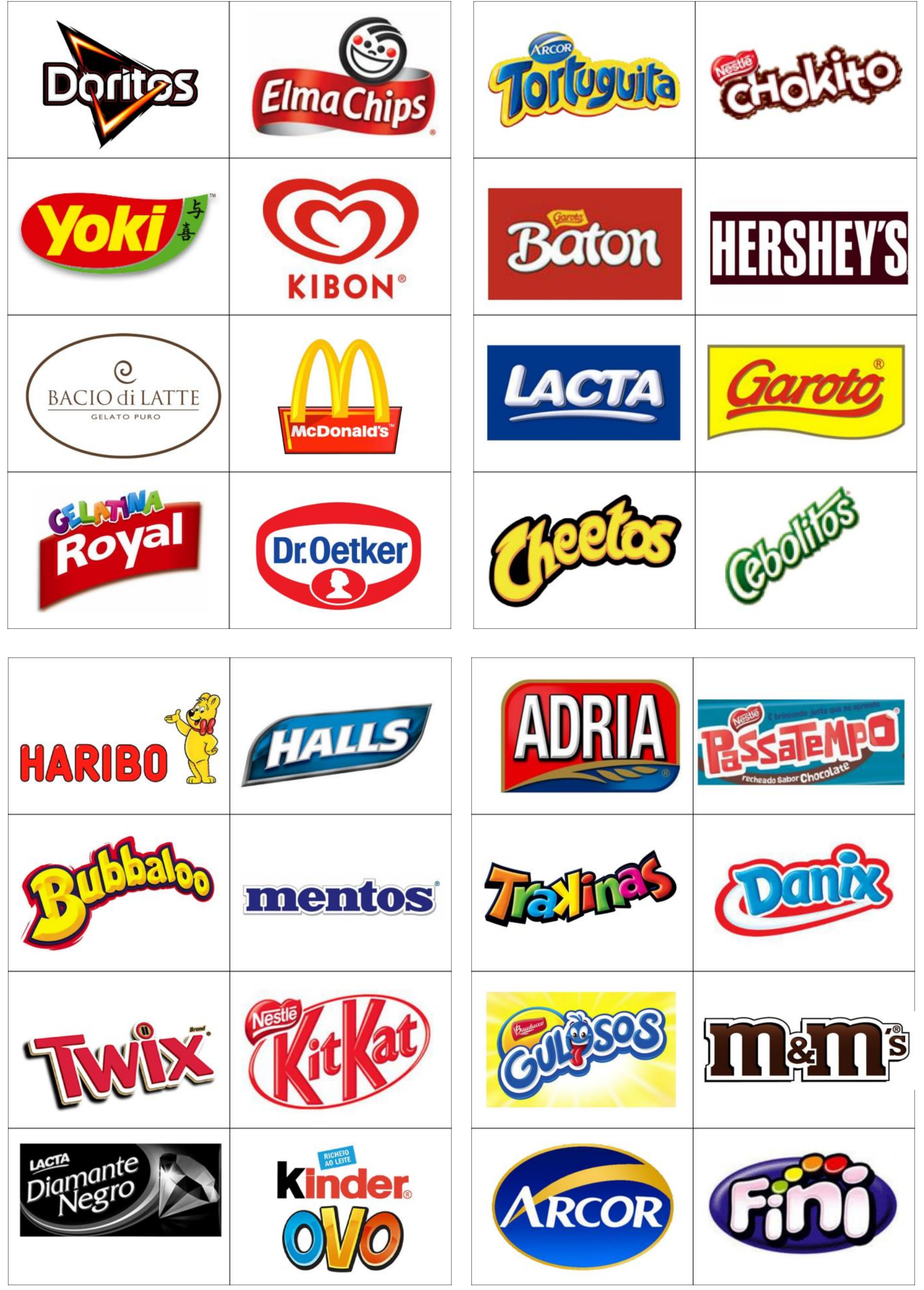




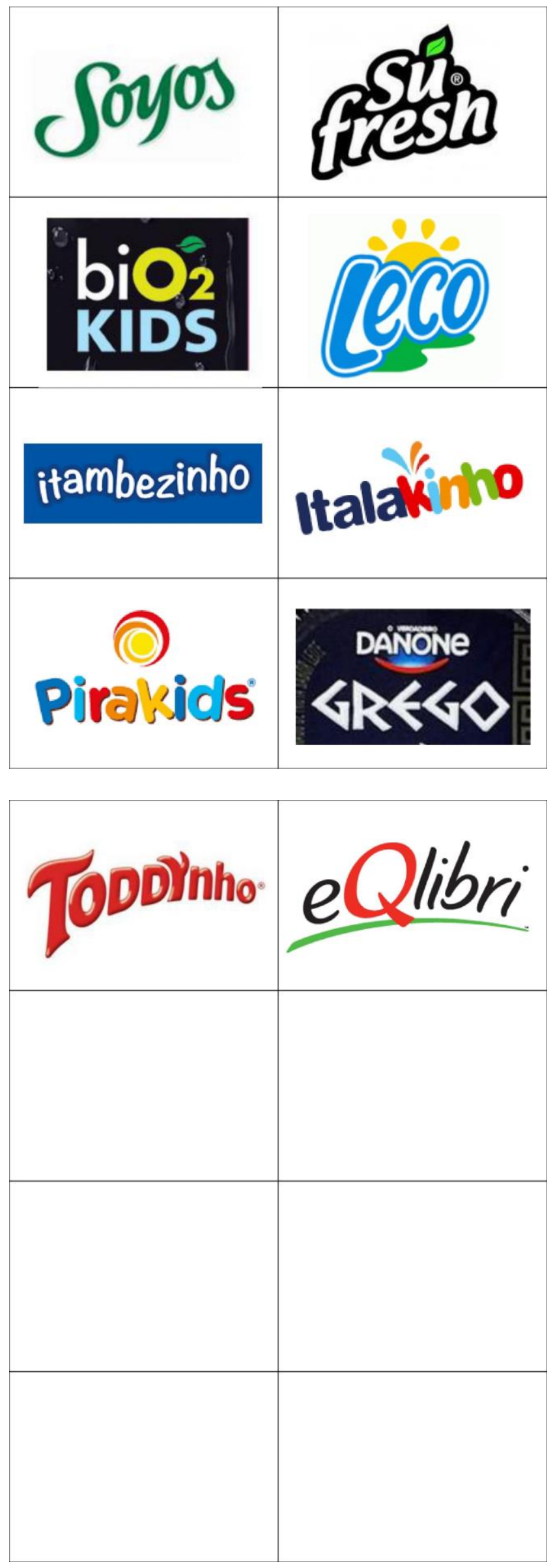

(1)




\section{APÊNDICE G}

\section{PESQUISA DE CAMPO \\ ENTREVISTA CRIANÇAS}

Roteiro sugerido para orientação da entrevista individual / em grupo realizada com as crianças sobre a Brincadeira de Comer e o consumo alimentar infantil

no quarto encontro da pesquisa de campo. 
ENTREVISTA INDIVIDUAL / EM GRUPO COM AS CRIANÇAS

SUGESTÃO DE ROTEIRO

Recepção Infantil de Marcas de Alimentos: Vínculos de Sentidos entre Marcas/Produtos e Crianças no Contexto Familiar

- Perspectiva das Crianças sobre a sua Cultura Alimentar e as Mediações Culturais e Comunicacionais na Modulação do seu Consumo Alimentar

- Perspectiva das Crianças sobre a Mediação Comunicacional das Marcas na sua Cultura Alimentar e as Marcas e Produtos Alimentícios no seu Contexto Familiar

- Perspectiva das crianças: Marcas e Produtos Alimentícios no Contexto das Escolhas e Preferências Infantis: Recepção Infantil e Vínculos de Sentidos

- Perspectiva das crianças sobre a Pesquisa e o Consumo Alimentar Infantil

- Apresentação das composições elaboradas pelas crianças durante a atividade lúdica proposta.

- Perspectiva das crianças sobre a atividade lúdica proposta. 


\title{
APÊNDICE H
}

\author{
PESQUISA DE CAMPO \\ BRINCADEIRA DE COMPRAR
}

Roteiro e dinâmica da atividade lúdica proposta

desenvolvida com as crianças no quinto encontro da pesquisa de campo. 


\section{BRINCADEIRA DE COMPRAR \\ ROTEIRO / DINÂMICA}

\section{SIMULAÇÃO DE COMPRAS NO SUPERMERCADO COM AS CRIANÇAS}

Sobre marcas e produtos alimentícios:

Jogo-dramatização proposto para uma atividade lúdica de simulação de compra e consumo de alimentos com as crianças no supermercado.

O jogo teve início no supermercado, quando as crianças foram convidadas para uma brincadeira de fazer compras: as crianças foram convidadas a escolher livremente - dentre toda a gama de produtos alimentícios do supermercado (alimentos / bebidas / guloseimas / produtos industrializados / alimentos in natura) - alguns produtos alimentícios para colocar no carrinho em uma experiência lúdica de simulação de compra e consumo.

Inicialmente, cada criança foi solicitada a pegar o seu carrinho de compras e seguir livremente pelos corredores do supermercado, dando início à experiência lúdica de simulação de compras com a seleção de cinco produtos alimentícios, de qualquer natureza - alimentos, bebidas ou guloseimas, industrializados ou in natura - de acordo com seus gostos, preferências e afetos.

Em seguida, as crianças foram solicitadas a falar sobre suas escolhas, apresentando os produtos alimentícios selecionados no carrinho, explicando os porquês de cada produto / marca escolhido, e expressando suas perspectivas, saberes e afetos sobre as marcas e produtos alimentícios.

$\mathrm{Na}$ sequência, as crianças foram solicitadas a destacar os produtos alimentícios escolhidos e colocados no carrinho, apresentando-os na ordem de preferência das crianças (as marcas e produtos alimentícios que elas mais gostam / menos gostam). E justificando as suas escolhas e preferências quanto às marcas e produtos.

Mais adiante, ao falar sobre saudabilidade dos alimentos com as crianças, elas foram solicitadas a estabelecer algumas relações e classificações entre os produtos alimentícios colocados no carrinho, de acordo com parâmetros de saudabilidade considerados por elas (alimentos mais saudáveis / menos saudáveis). E justificando as suas elaborações e classificações quanto à saudabilidade dos produtos alimentícios escolhidos.

Ao final, as crianças foram solicitadas a escolher, dentre os produtos alimentícios colocados no carrinho, três produtos de que elas gostam muito e que levariam para casa se estivessem em uma experiência real de compras no supermercado. Explicando os motivos de cada escolha e expressando suas perspectivas, saberes e afetos com relação a cada produto / marca escolhido.

O jogo foi finalizado quando as crianças concluíram todas as solicitações efetuadas sobre as marcas e produtos alimentícios escolhidos e apresentados no carrinho de compras.

Após a conclusão da atividade lúdica, foi comunicado às crianças que os três produtos alimentícios escolhidos por elas ao final da brincadeira (as marcas e produtos alimentícios de que elas mais gostam) seriam efetivamente comprados para elas, como um presente para as crianças. As compras foram efetuadas ao final da atividade pela pesquisadora em campo. 


\section{APÊNDICE I}

\section{PESQUISA DE CAMPO \\ ENTREVISTA CRIANÇAS}

Roteiro sugerido para orientação da entrevista individual / em grupo realizada com as crianças sobre a Brincadeira de Comprar e o consumo alimentar infantil

no quinto encontro da pesquisa de campo. 


\section{ENTREVISTA INDIVIDUAL / EM GRUPO COM AS CRIANÇAS}

\section{SUGESTÃO DE ROTEIRO}

Recepção Infantil de Marcas de Alimentos: Vínculos de Sentidos entre Marcas/Produtos e Crianças no Contexto Familiar

- Perspectiva das Crianças sobre a sua Cultura Alimentar e as Mediações Culturais e Comunicacionais na Modulação do seu Consumo Alimentar

- Perspectiva das Crianças sobre a Mediação Comunicacional das Marcas na sua Cultura Alimentar e as Marcas e Produtos Alimentícios no seu Contexto Familiar

- Perspectiva das crianças: Marcas e Produtos Alimentícios no Contexto das Escolhas e Preferências Infantis: Recepção Infantil e Vínculos de Sentidos

- Perspectiva das crianças sobre a Pesquisa e o Consumo Alimentar Infantil

- Apresentação das composições elaboradas pelas crianças durante a atividade lúdica proposta.

- Perspectiva das crianças sobre a atividade lúdica proposta. 


\section{APÊNDICE J}

\section{PESQUISA DE CAMPO \\ EXPERIÊNCIA LÚDICA THE KIDS ENTREVISTA KIDS BY KIDS}

Roteiro e dinâmica da atividade lúdica proposta

desenvolvida com as crianças no último encontro da pesquisa de campo. 


\section{KIDS BY KIDS}

\section{ROTEIRO / DINÂMICA}

\section{ENTREVISTA KIDS BY KIDS}

A voz das crianças: mediação comunicacional das marcas ma cultura alimentar infantil:

Entrevista em grupo, desenvolvida com as crianças ao final da pesquisa, na forma de conversação, a fim de dar voz as vozes infantis sobre os principais temas e aspectos abordados na investigação desenvolvida em campo, nos contextos familiares pesquisados, possibilitando a expressividade das perspectivas e saberes infantis sobre os tópicos abordados; a avaliação das crianças sobre o processo de investigação em seu todo; e a reflexão das crianças sobre a sua participação no processo de investigação. A entrevista em grupo desenvolvida com as crianças foi gravada em vídeo (em selfie) pelas próprias crianças (as crianças mais velhas).

Principais tópicos abordados na entrevista: Cultura alimentar das crianças / Mediações culturais e comunicacionais na cultura alimentar infantil / Mediação comunicacional das marcas na cultura alimentar infantil / Sobre a pesquisa e a participação das crianças na pesquisa / Sobre crianças e consumo alimentar.

Atividade proposta às crianças com a denominação: Kids by Kids.

Realizada com a co-participação das crianças sob a coordenação das crianças mais velhas.

Atividade desenvolvida na forma de uma experimentação metodológica da pesquisa com a co-participação das crianças na produção infantil de vídeos. 


\section{ENTREVISTA EM GRUPO COM AS CRIANÇAS E PRODUÇÃO INFANTIL DE VÍDEO SUGESTÃO DE ROTEIRO}

Recepção Infantil de Marcas de Alimentos: Vínculos de Sentidos entre Marcas/Produtos e Crianças no Contexto Familiar

- Perspectiva das Crianças sobre a sua Cultura Alimentar e as Mediações Culturais e Comunicacionais na Modulação do seu Consumo Alimentar

- Perspectiva das Crianças sobre a Mediação Comunicacional das Marcas na sua Cultura Alimentar e as Marcas e Produtos Alimentícios no seu Contexto Familiar

- Perspectiva das crianças: Marcas e Produtos Alimentícios no Contexto das Escolhas e Preferências Infantis: Recepção Infantil e Vínculos de Sentidos

- Perspectiva das crianças sobre a Pesquisa e o Consumo Alimentar Infantil 


\title{
APÊNDICE K
}

\author{
PESQUISA DE CAMPO \\ EXPERIÊNCIA LÚDICA THE KIDS \\ PRODUÇÃO FOTOGRÁFICA MY FOODS
}

Roteiro e dinâmica da atividade lúdica proposta

desenvolvida com as crianças no último encontro da pesquisa de campo. 


\section{MY FOODS}

\section{ROTEIRO / DINÂMICA}

\section{PRODUÇÃO FOTOGRÁFICA MY FOODS}

Proposta apresentada às crianças:

- Elaborar uma composição com os alimentos / produtos alimentícios que as crianças mais gostam (alimentos / produtos alimentícios disponíveis em casa no momento do desenvolvimento da atividade).

- Elaborar a produção fotográfica da composição elaborada por elas com os alimentos / produtos alimentícios de que mais gostam.

Atividade lúdica proposta às crianças com a denominação: My Foods.

Realizada com a co-participação das crianças sob a coordenação das crianças mais velhas.

Atividade desenvolvida na forma de uma experimentação metodológica da pesquisa com a co-participação das crianças na produção infantil de fotografias. 
PRODUÇÃO FOTOGRÁFICA INFANTIL

SUGESTÃO DE ROTEIRO

Elaboração da produção fotográfica de uma composição com os alimentos / produtos alimentícios de que as crianças mais gostam em casa:

- Selecionar os alimentos / produtos alimentícios de que as crianças mais gostam em casa (alimentos / produtos alimentícios disponíveis em casa no momento da realização da atividade lúdica).

○ Elaborar uma composição com os alimentos / produtos alimentícios escolhidos.

- Realizar a produção fotográfica da composição elaborada com os alimentos / produtos alimentícios de que as crianças mais gostam em casa. 


\title{
APÊNDICE L
}

\author{
PESQUISA DE CAMPO \\ EXPERIÊNCIA LÚDICA THE KIDS \\ PRODUÇÃO FOTOGRÁFICA MY FAMILY
}

Roteiro e dinâmica da atividade lúdica proposta

desenvolvida com as crianças no último encontro da pesquisa de campo. 
MY FAMILY

ROTEIRO / DINÂMICA

\section{PRODUÇÃO FOTOGRÁFICA MY FAMILY}

Proposta apresentada às crianças:

- Produção infantil de fotografias (em selfie) para o retrato das crianças e da família. Com escolha e preparação do cenário e produção e direção de fotografia.

Atividade lúdica proposta às crianças com a denominação: My Family.

Realizada com a co-participação das crianças sob a coordenação das crianças mais velhas.

Atividade desenvolvida na forma de uma experimentação metodológica da pesquisa com a co-participação das crianças na produção infantil de fotografias. 


\section{PRODUÇ̃̃O FOTOGRÁFICA INFANTIL}

\section{SUGESTÃO DE ROTEIRO}

Produção infantil de fotografias para o retrato das crianças e da família. Com escolha e preparação do cenário e produção e direção de fotografia.

- Escolher e preparar o cenário para a elaboração da produção fotográfica.

- Organizar e posicionar a família e as crianças para a elaboração dos retratos.

- Realizar a produção fotográfica para elaboração dos retratos da família e das crianças. 


\section{APÊNDICE M}

\section{PESQUISA DE CAMPO}

\section{PERFIL FAMILIAR}

Alguns dados sobre o perfil familiar:

composição da família; perfil de consumo da família; estratificação socioeconômica familiar. 
PERFIL FAMILIAR: PRIMEIRA FAMÍLIA

\begin{tabular}{|c|c|c|c|c|}
\hline \multicolumn{5}{|c|}{ COMPOSIÇÃO DA FAMÍLIA } \\
\hline & ESPECIFICAÇÃO & IDADE & PROFISSÃO & INSTRUÇÃO \\
\hline PAI & $\begin{array}{ll}---- \\
\end{array}$ & 44 anos & Professor & Pós-graduação \\
\hline MÃE & $\begin{array}{c}---- \\
\end{array}$ & 39 anos & Professora & Pós-graduação \\
\hline \multirow[t]{3}{*}{ FILHOS } & Menina & 9 anos & ----- & E. Fundamental 1 \\
\hline & Menino & 7 anos & $\begin{array}{l}---- \\
\end{array}$ & E. Fundamental 1 \\
\hline & & & ----- & \\
\hline \multicolumn{5}{|l|}{ OUTROS } \\
\hline \multicolumn{5}{|c|}{ BENS / SERVIÇOS / ATIVIDADES } \\
\hline \multirow[b]{2}{*}{ A CASA } & ESPECIFICAÇÃO & ÁREA TOTAL & CôMODOS & LOCALIZAÇÃO \\
\hline & Apartamento & $128 m^{2}$ & 16 & Vila São Francisco \\
\hline \multirow[b]{2}{*}{ CARRO } & ESPECIFICAÇÃO & ESPECIFICAÇÃO & ESPECIFICAÇÃO & TOTAL \\
\hline & BMW (2013) & Dodge Journey (2014) & ---- & 2 \\
\hline \multirow{7}{*}{ ELETRÔNICOS } & ESPECIFICAÇÃO & SIM & NÃO & QTD \\
\hline & TV & $\mathbf{X}$ & & 2 \\
\hline & Computador & $\mathbf{X}$ & & 1 \\
\hline & Notebook & $\mathbf{X}$ & & 3 \\
\hline & Tablet & $\mathbf{X}$ & & 3 \\
\hline & Smartphone / Celular & $\mathbf{X}$ & & 2 \\
\hline & Videogame & $\mathbf{X}$ & & 1 \\
\hline \multirow{11}{*}{$\begin{array}{c}\text { MÍDIA / } \\
\text { EDUCAÇÃO / } \\
\text { SAÚDE }\end{array}$} & ESPECIFICAÇÃO & SIM & NÃO & QUAL \\
\hline & Tv a Cabo & $\mathbf{X}$ & & Vivo \\
\hline & Internet & $\mathbf{X}$ & & Vivo \\
\hline & $\begin{array}{l}\text { Conteúdo Online: } \\
\text { Filmes e Séries }\end{array}$ & $\mathbf{X}$ & & Netflix \\
\hline & $\begin{array}{l}\text { Conteúdo Online: } \\
\text { Músicas }\end{array}$ & $\mathbf{X}$ & & Apple Music \\
\hline & Jornais e Revistas & $\mathbf{X}$ & & Turma da Mônica \\
\hline & $\begin{array}{ll}\text { Escola } & \text { Particular } \\
\text { (crianças) } & \end{array}$ & $\mathbf{X}$ & & $\begin{array}{c}\text { Colégio particular em } \\
\text { São Paulo }\end{array}$ \\
\hline & Esportes (crianças) & $\mathbf{X}$ & & $\begin{array}{c}\text { Balé (menina) } \\
\text { Natação (menino) }\end{array}$ \\
\hline & Línguas (crianças) & $\mathbf{X}$ & & Inglês \\
\hline & Artes (crianças) & $\mathbf{X}$ & & $\begin{array}{c}\text { Piano (menina) } \\
\text { Bateria (menino) }\end{array}$ \\
\hline & $\begin{array}{ll}\text { Plano de } & \text { Saúde } \\
\text { (crianças) } & \end{array}$ & $\mathbf{X}$ & & Sulamérica \\
\hline RENDA FA & ILIAR & VALOR (R\$) & & ERVAÇÃO \\
\hline (total / médi & nensal) & $30.000,00$ & & ----- \\
\hline
\end{tabular}


PERFIL FAMILIAR: SEGUNDA FAMÍLIA

\begin{tabular}{|c|c|c|c|c|}
\hline \multicolumn{5}{|c|}{ COMPOSIÇÃO DA FAMÍLIA } \\
\hline & ESPECIFICAÇÃO & IDADE & PROFISSÃO & INSTRUÇÃO \\
\hline PAI & ---- & 40 anos & Professor & Graduação \\
\hline MÃE & ----- & 35 anos & Professora & Graduação \\
\hline \multirow[t]{3}{*}{ FILHOS } & Menina & 11 anos & $\begin{array}{c}---- \\
\end{array}$ & E. Fundamental 2 \\
\hline & \multirow[t]{2}{*}{ Menino } & 6 anos & ----- & E. Fundamental 1 \\
\hline & & & ----- & \\
\hline \multicolumn{5}{|l|}{ OUTROS } \\
\hline \multicolumn{5}{|c|}{ BENS / SERVIÇOS / ATIVIDADES } \\
\hline \multirow[b]{2}{*}{ A CASA } & ESPECIFICAÇÃO & ÁREA TOTAL & CôMODOS & LOCALIZAÇÃO \\
\hline & Casa & $276 \mathrm{~m}^{2}$ & 14 & Vila Lageado \\
\hline \multirow[b]{2}{*}{ CARRO } & ESPECIFICAÇÃO & ESPECIFICAÇÃO & ESPECIFICAÇÃO & TOTAL \\
\hline & Uno (2010) & Corsa Classic (2004) & $-\cdots--$ & 2 \\
\hline \multirow{7}{*}{ ELETRÔNICOS } & ESPECIFICAÇÃO & SIM & NÃO & QTD \\
\hline & TV & $\mathbf{X}$ & & 4 \\
\hline & Computador & & $\mathbf{X}$ & \\
\hline & Notebook & $\mathbf{X}$ & & 2 \\
\hline & Tablet & $\mathbf{X}$ & & 2 \\
\hline & Smartphone / Celular & $\mathbf{X}$ & & 3 \\
\hline & Videogame & $\mathbf{X}$ & & 10 \\
\hline \multirow{11}{*}{$\begin{array}{c}\text { MÍDIA / } \\
\text { EDUCAÇÃO / } \\
\text { SAÚDE }\end{array}$} & ESPECIFICAÇÃO & SIM & NÃO & QUAL \\
\hline & Tv a Cabo & $\mathbf{X}$ & & Net \\
\hline & Internet & $\mathbf{X}$ & & Net \\
\hline & $\begin{array}{l}\text { Conteúdo Online: } \\
\text { Filmes e Séries }\end{array}$ & $\mathbf{X}$ & & Netflix \\
\hline & $\begin{array}{l}\text { Conteúdo Online: } \\
\text { Músicas }\end{array}$ & $\mathbf{X}$ & & $\begin{array}{c}\text { Colégio particular em } \\
\text { São Paulo }\end{array}$ \\
\hline & Jornais e Revistas & $\mathbf{X}$ & & \\
\hline & $\begin{array}{ll}\text { Escola } & \text { Particular } \\
\text { (crianças) } & \end{array}$ & $\mathbf{X}$ & & \\
\hline & Esportes (crianças) & $\mathbf{X}$ & & Voleibol (menina) \\
\hline & Línguas (crianças) & $\mathbf{X}$ & & Inglês \\
\hline & Artes (crianças) & & $\mathbf{X}$ & \\
\hline & $\begin{array}{l}\text { Plano de Saúde } \\
\text { (crianças) }\end{array}$ & $\mathbf{X}$ & & $\begin{array}{c}\text { Plano dos servidores } \\
\text { públicos }\end{array}$ \\
\hline \multirow{2}{*}{\multicolumn{2}{|c|}{$\begin{array}{l}\text { RENDA FAMILIAR } \\
\text { (total / média mensal) }\end{array}$}} & VALOR (R\$) & \multicolumn{2}{|c|}{ OBSERVAÇÃO } \\
\hline & & $10.000,00$ & & $-\cdots--$ \\
\hline
\end{tabular}


PERFIL FAMILIAR: TERCEIRA FAMÍLIA

\begin{tabular}{|c|c|c|c|c|}
\hline \multicolumn{5}{|c|}{ COMPOSIÇÃO DA FAMÍLIA } \\
\hline & ESPECIFICAÇÃO & IDADE & PROFISSÃO & INSTRUÇÃO \\
\hline PAI & ----- & 37 anos & $\begin{array}{c}\text { Analista de suporte } \\
\text { técnico }\end{array}$ & Ensino médio \\
\hline $\mathbf{M} \tilde{\mathbf{A E}}$ & $\begin{array}{l}---- \\
\end{array}$ & 34 anos & $\begin{array}{c}\text { Agente comunitária } \\
\text { de saúde }\end{array}$ & Ensino médio \\
\hline \multirow[t]{3}{*}{ FILHOS } & Menina & 9 anos & ----- & E. Fundamental 1 \\
\hline & Menina & 4 anos & ----- & Educação Infantil \\
\hline & Menina & 1 ano & ----- & Educação Infantil \\
\hline \multicolumn{5}{|l|}{ OUTROS } \\
\hline \multicolumn{5}{|c|}{ BENS / SERVIÇOS / ATIVIDADES } \\
\hline \multirow[b]{2}{*}{ A CASA } & ESPECIFICAÇÃO & ÁREA TOTAL & CôMODOS & LOCALIZAÇÃO \\
\hline & Apartamento & $54 m^{2}$ & 7 & Paraisópolis \\
\hline \multirow[b]{2}{*}{ CARRO } & ESPECIFICAÇÃO & ESPECIFICAÇÃO & ESPECIFICAÇÃO & TOTAL \\
\hline & Spin (2013) & $\begin{array}{l}---- \\
\end{array}$ & ---- & 1 \\
\hline \multirow{7}{*}{ ELETRÔNICOS } & ESPECIFICAÇÃO & SIM & NÃO & QTD \\
\hline & TV & $\mathbf{X}$ & & 2 \\
\hline & Computador & $\mathbf{X}$ & & 1 \\
\hline & Notebook & $\mathbf{X}$ & & 1 \\
\hline & Tablet & & $\mathbf{X}$ & \\
\hline & Smartphone / Celular & $\mathbf{X}$ & & 4 \\
\hline & Videogame & $\mathbf{X}$ & & 1 \\
\hline \multirow{11}{*}{$\begin{array}{c}\text { MÍDIA / } \\
\text { EDUCAÇÃO / } \\
\text { SAÚDE }\end{array}$} & ESPECIFICAÇÃO & SIM & NÃO & QUAL \\
\hline & Tv a Cabo & $\mathbf{X}$ & & Sky \\
\hline & Internet & $\mathbf{X}$ & & Vivo \\
\hline & $\begin{array}{l}\text { Conteúdo Online: } \\
\text { Filmes e Séries }\end{array}$ & & $\mathbf{X}$ & \\
\hline & $\begin{array}{l}\text { Conteúdo Online: } \\
\text { Músicas }\end{array}$ & & $\mathbf{X}$ & \\
\hline & Jornais e Revistas & & $\mathbf{X}$ & \\
\hline & $\begin{array}{ll}\text { Escola } & \text { Particular } \\
\text { (crianças) } & \end{array}$ & $\mathbf{X}$ & & $\begin{array}{l}\text { Colégio particular em } \\
\text { São Paulo (bolsista) }\end{array}$ \\
\hline & Esportes (crianças) & & $\mathbf{X}$ & \\
\hline & Línguas (crianças) & & $\mathbf{X}$ & \\
\hline & Artes (crianças) & & $\mathbf{X}$ & \\
\hline & $\begin{array}{l}\text { Plano de Saúde } \\
\text { (crianças) }\end{array}$ & & $\mathbf{X}$ & \\
\hline RENDA FA & LIAR & VALOR (R\$) & & ERVAÇÃO \\
\hline (total / médi & iensal) & $3.000,00$ & & ---- \\
\hline
\end{tabular}




\section{APÊNDICE N}

PESQUISA DE CAMPO

MARCAS E PRODUTOS NO CONTEXTO FAMILIAR

\section{FAMÍLIA I}

MARCAS E PRODUTOS: PRESENÇA MATERIAL E SIMBÓLICA 


\section{F A M Í L I A}

MARCAS E PRODUTOS ALIMENTÍCIOS NO AMBIENTE DOMÉSTICO E ESPAÇO PÚBLICO (RELATOS / OBSERVAÇÕES / CITAÇÕES / EXPRESSIVIDADES)

\begin{tabular}{|c|c|c|c|c|c|c|}
\hline \multicolumn{2}{|r|}{ NATUREZA } & ALIMENTO / PRODUTO & MARCA / PERSONAGEM & $\mathbf{F}$ & $\mathbf{C}$ & OBSERVAÇÃO \\
\hline \multirow{3}{*}{$\mathbf{C}$} & \multirow{6}{*}{$\begin{array}{c}\text { CONSUMO } \\
\text { POR MARCAS } \\
- \\
\text { DESEJO DE } \\
\text { CONSUMO POR } \\
\text { MARCAS }\end{array}$} & Arroz (branco / integral) & Tio João & & & \\
\hline & & Arroz (branco / integral) & Camil & & & \\
\hline & & Feijão (preto / carioca) & Camil & & & \\
\hline \multirow{2}{*}{$\begin{array}{l}\mathbf{N} \\
\mathbf{S}\end{array}$} & & Macarrão & Barilla & & & \\
\hline & & Macarrão & Renata & & & \\
\hline \multirow{2}{*}{$\begin{array}{l}\mathbf{U} \\
\mathbf{M}\end{array}$} & & Farinha de trigo & Sol & & & \\
\hline & & Sal (refinado) & Cisne & & & \\
\hline \multirow[t]{2}{*}{$\mathbf{O}$} & & & & & & \\
\hline & & Óleo de soja & Liza & & & \\
\hline $\mathbf{A}$ & & & & & & \\
\hline \multirow{2}{*}{$\begin{array}{l}\mathbf{L} \\
\mathbf{I}\end{array}$} & & Molho de tomate & Pomarola & & & \\
\hline & & Molho de tomate & Salsaretti & & & \\
\hline \multirow{2}{*}{$\begin{array}{l}\text { M } \\
\text { E }\end{array}$} & & Cogumelo (champignon) & Kenko & & & \\
\hline & & & & & & \\
\hline \multirow{2}{*}{$\mathbf{N}$} & & Azeite de oliva & Andorinha & & & \\
\hline & & Azeite de oliva & Borges & & & \\
\hline \multirow{2}{*}{$\begin{array}{l}\mathbf{A} \\
\mathbf{R}\end{array}$} & & Aceto balsâmico & Gallo & & & \\
\hline & & Molho de pimenta (tabasco) & McllhennyCo. & & & \\
\hline
\end{tabular}




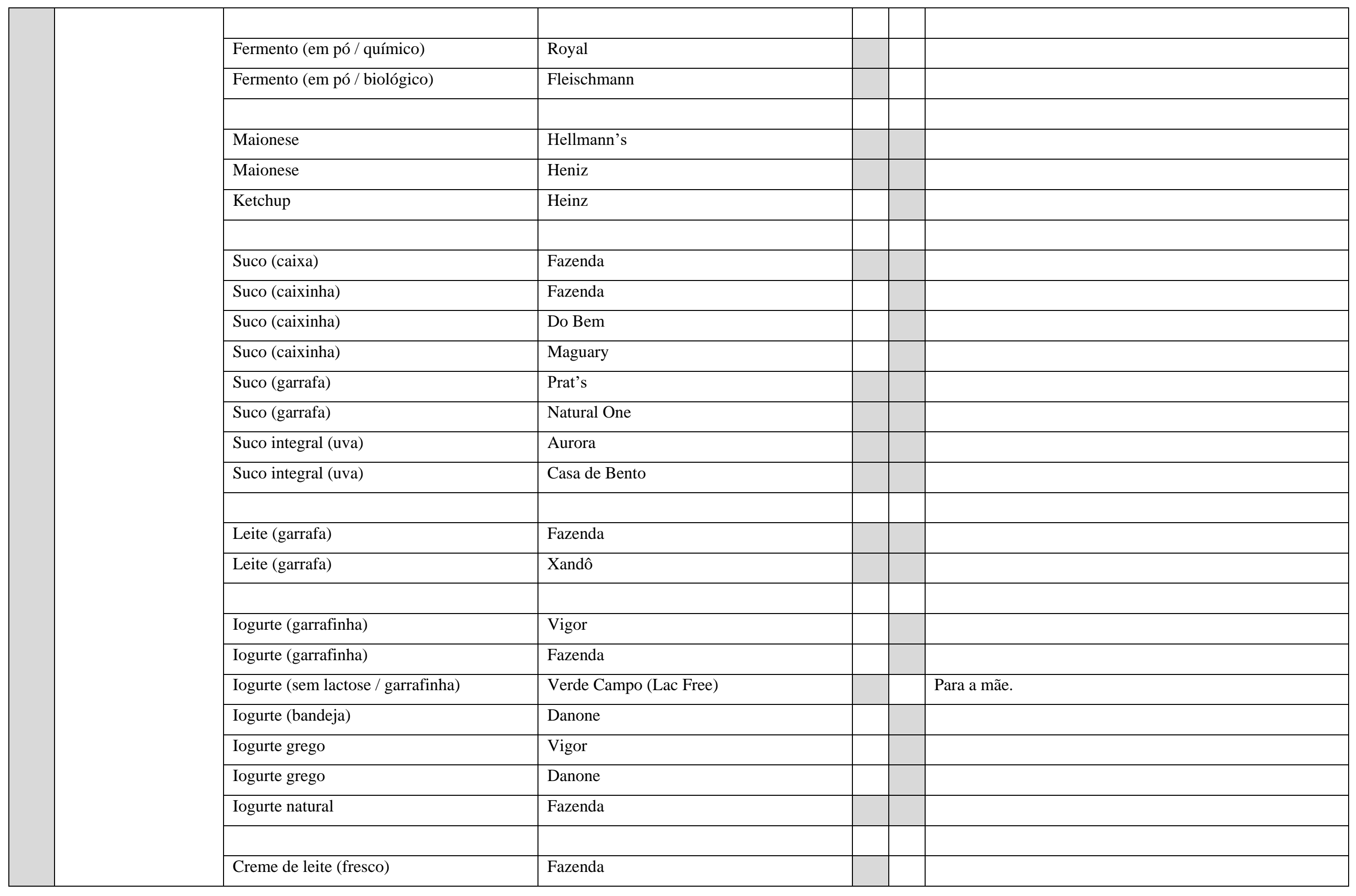




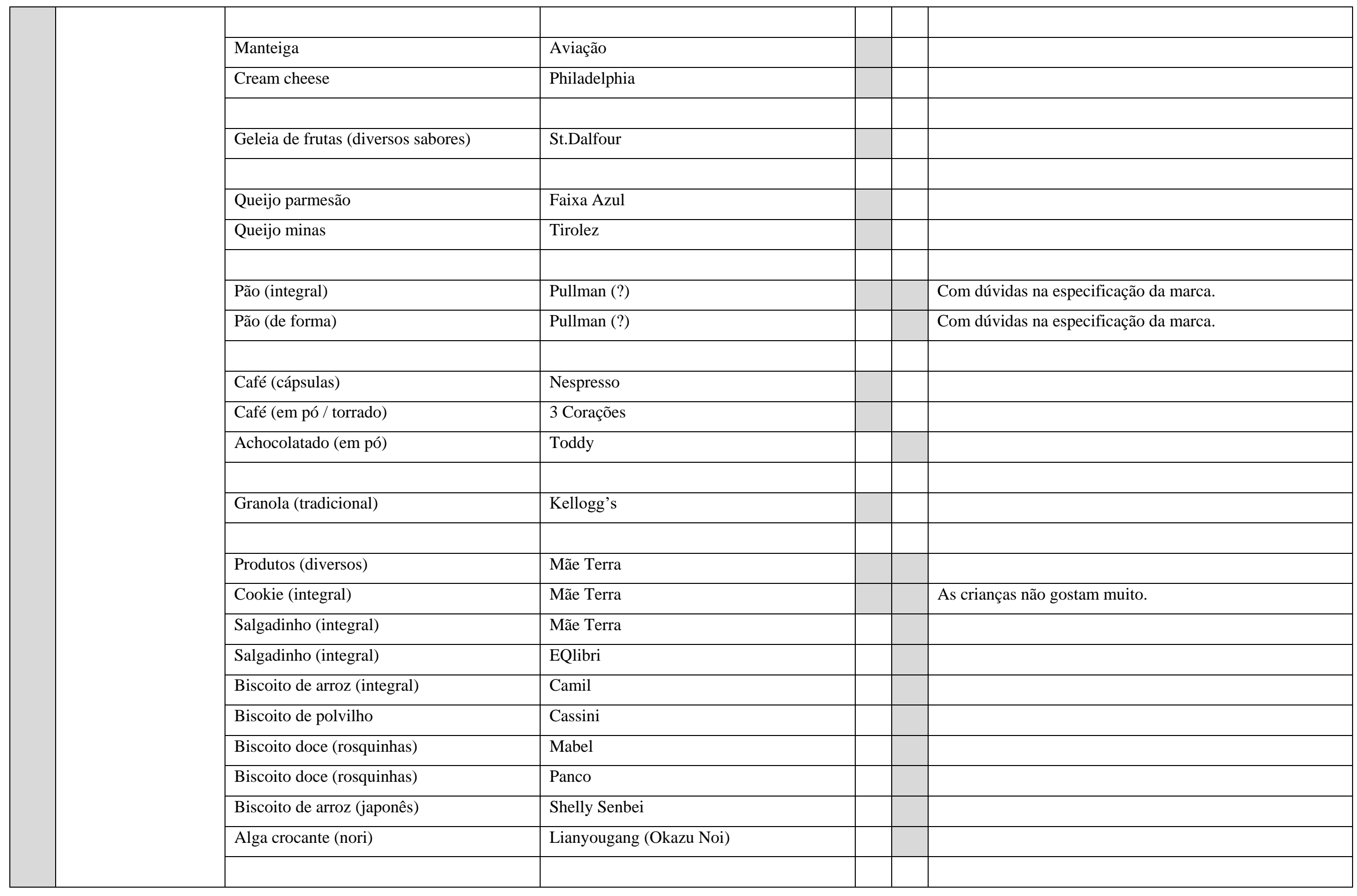




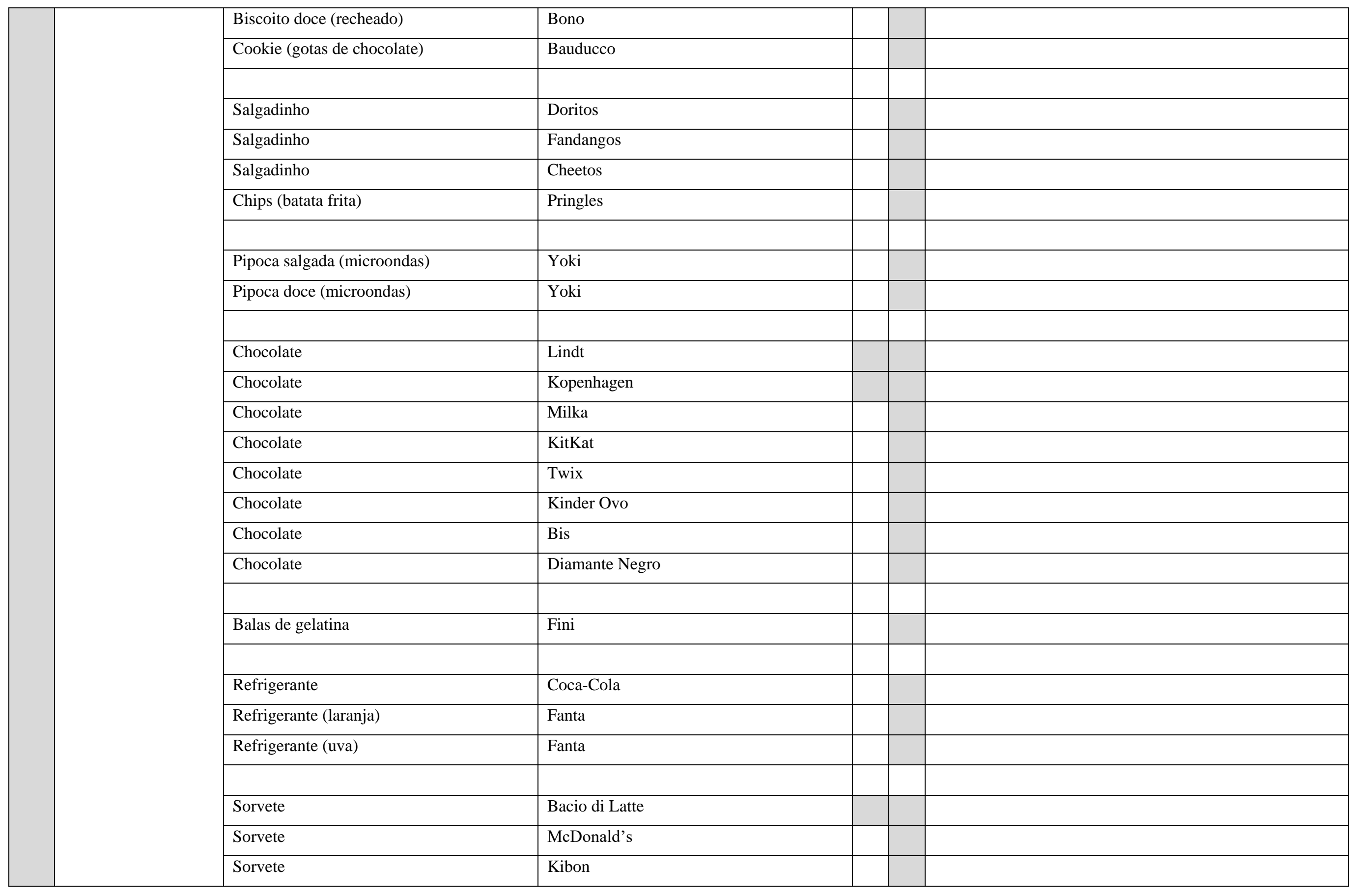




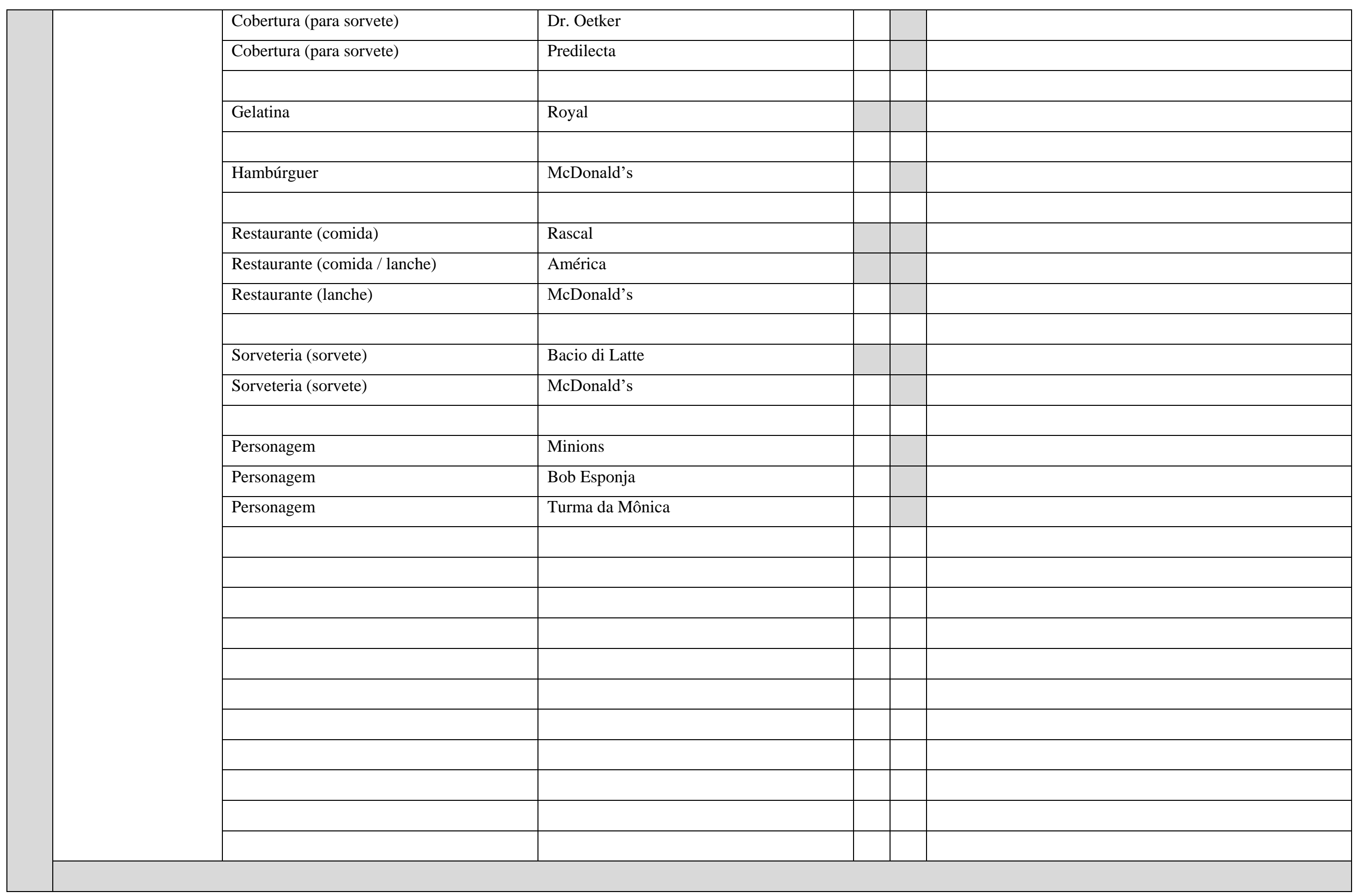




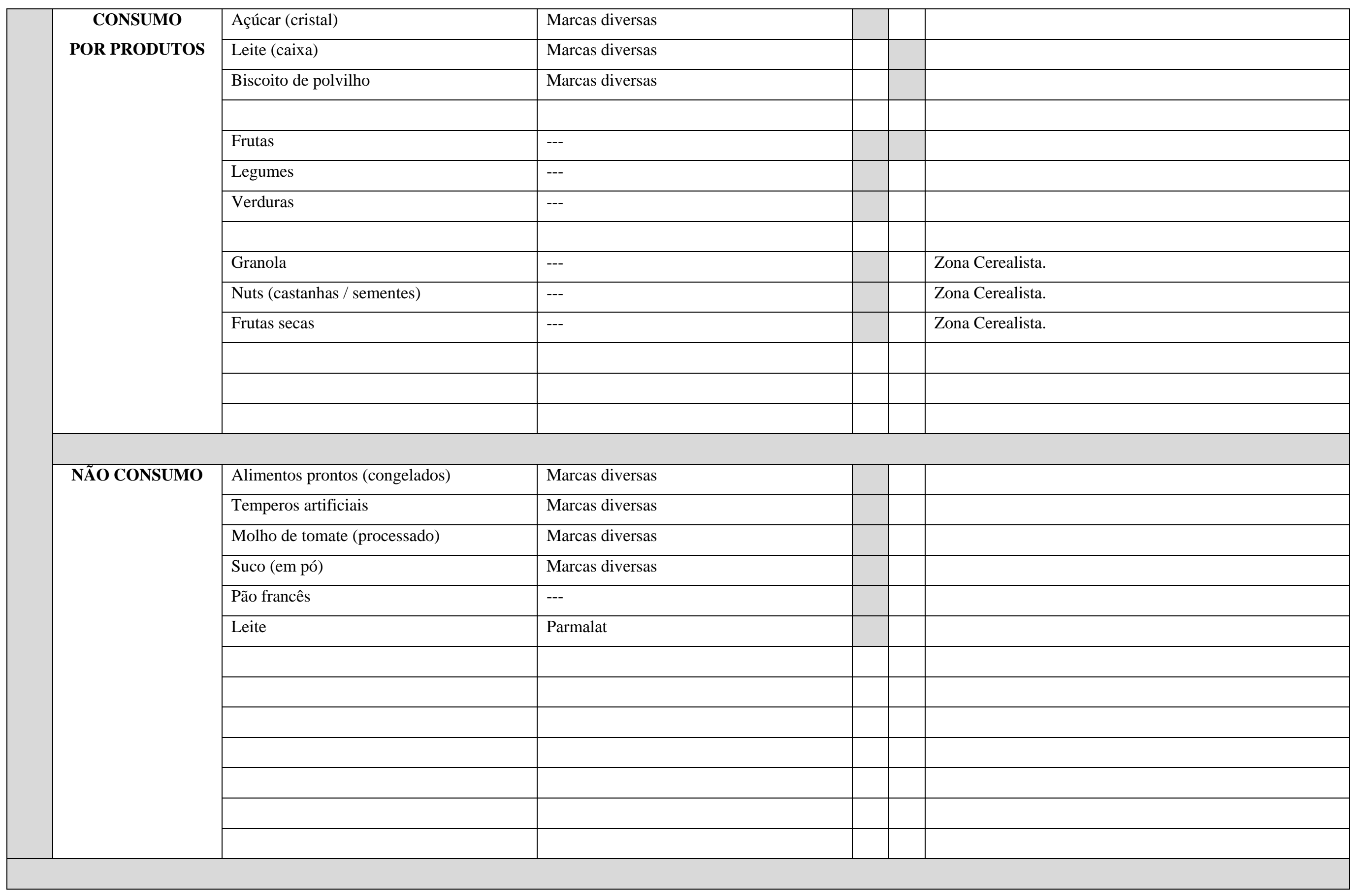


MARCAS E PRODUTOS ALIMENTÍCIOS NO ESPAÇO PÚBLICO

(RELATOS / OBSERVAÇÕES / CITAÇÕES / EXPRESSIVIDADES)

\begin{tabular}{|c|c|c|c|c|c|c|}
\hline \multirow{3}{*}{$\mathbf{C}$} & NATUREZA & CATEGORIA / ALIMENTO & MARCA / PERSONAGEM & $\mathbf{F}$ & $\mathbf{C}$ & OBSERVAÇÃO \\
\hline & \multirow{2}{*}{$\begin{array}{l}\text { CONSUMO } \\
\text { MAIS }\end{array}$} & Restaurante (comida) & Rascal & & & Quase sempre. Aos domingos. \\
\hline & & & & & & \\
\hline \multirow[t]{2}{*}{$\mathbf{O}$} & FREQUENTE & Sorveteria (sorvete) & Baccio di Latte & & & Quase sempre. Aos domingos. \\
\hline & \multirow{4}{*}{$\begin{array}{c}\text { SEMPRE / } \\
\text { QUASE SEMPRE }\end{array}$} & & & & & \\
\hline \multirow[t]{2}{*}{$\mathbf{S}$} & & & & & & \\
\hline & & & & & & \\
\hline \multirow{3}{*}{$\begin{array}{l}\text { M } \\
\text { O }\end{array}$} & & & & & & \\
\hline & & & & & & \\
\hline & \multirow{2}{*}{$\begin{array}{l}\text { CONSUMO } \\
\text { MENOS }\end{array}$} & Restaurante (comida / lanche) & América & & & Às vezes. Aos domingos. \\
\hline A & & & & & & \\
\hline \multirow{2}{*}{$\begin{array}{l}\mathbf{L} \\
\mathbf{I}\end{array}$} & \multirow{5}{*}{$\begin{array}{c}\text { FREQUENTE } \\
- \\
\text { ÀS VEZES }\end{array}$} & Sorveteria (sorvete) & McDonald's & & & Às vezes. Nos fins de semana. \\
\hline & & & & & & \\
\hline \multirow{3}{*}{$\begin{array}{c}\text { M } \\
\text { E } \\
\mathbf{N} \\
\mathbf{T}\end{array}$} & & & & & & \\
\hline & & & & & & \\
\hline & & & & & & \\
\hline \multicolumn{7}{|c|}{$\mathbf{T}$} \\
\hline \multirow{6}{*}{$\mathbf{R}$} & \multirow{6}{*}{$\begin{array}{c}\text { CONSUMO } \\
\text { EVENTUAL } \\
- \\
\text { RARAMENTE }\end{array}$} & Restaurante (comida) & Pirajá & & & Raramente. Nos fins de semana. \\
\hline & & Restaurante (lanche) & McDonald's & & & Raramente. Nos fins de semana. \\
\hline & & & & & & \\
\hline & & Sorveteria (sorvete) & Gelateria Parmalat & & & Raramente. Nos fins de semana. \\
\hline & & Sorveteria (sorvete) & Haagen Dazs & & & Raramente. Nos fins de semana. \\
\hline & & & & & & \\
\hline
\end{tabular}




\section{PRIMEIRO ENCONTRO: CONVERSA COM A FAMÍLIA E AS CRIANÇAS}

\section{MARCAS E PRODUTOS ALIMENTÍCIOS NO AMBIENTE DOMÉSTICO \\ (FOTOS / VÍDEOS / OBSERVAÇÃO)}

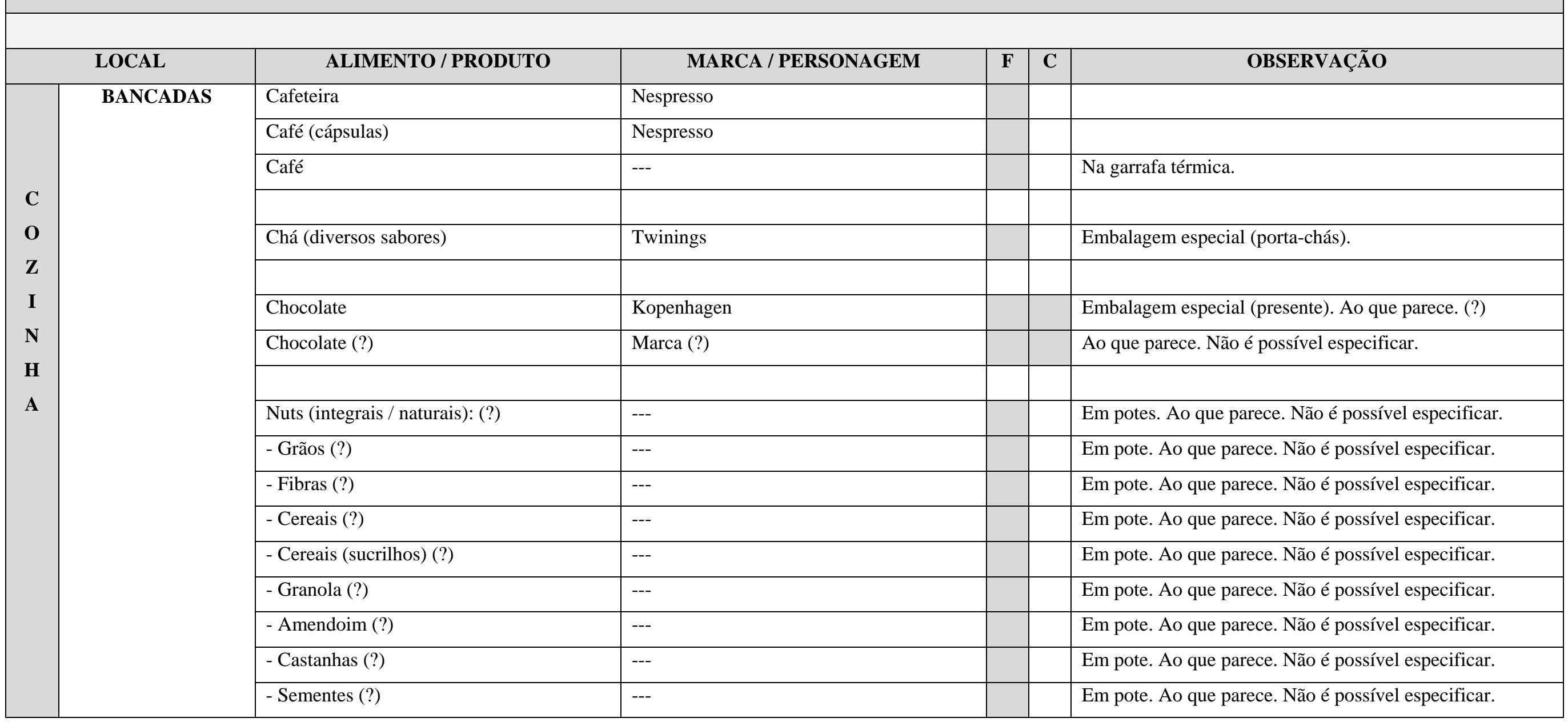




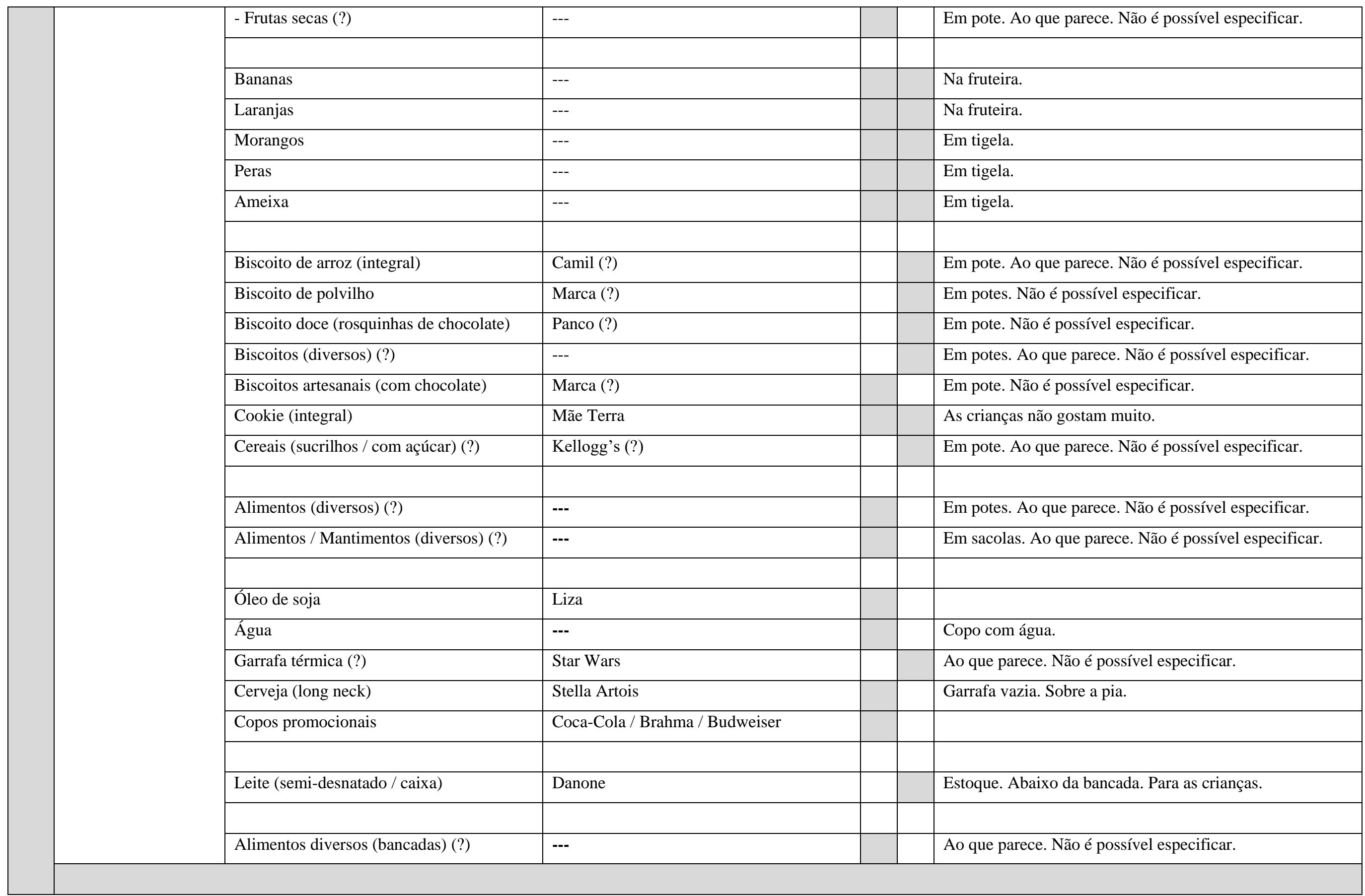




\begin{tabular}{|c|c|c|c|}
\hline \multirow[t]{27}{*}{ ARMÁRIOS } & Macarrão (espaguete) & Barilla & Estoque. \\
\hline & Macarrão & Renata & Estoque. \\
\hline & Macarrão & Petybon & Estoque. \\
\hline & Macarrão instantâneo (tomate) (?) & Miojo (Turma da Mônica) (?) & Ao que parece. Não é possível especificar. \\
\hline & Arroz (branco) (?) & Camil (?) & Ao que parece. Não é possível especificar. \\
\hline & Lentilha & Yoki & \\
\hline & Trigo (para kibe) & Yoki & \\
\hline & Milho (para pipoca) (?) & Yoki (?) & Ao que parece. Não é possível especificar. \\
\hline & Açúcar (cristal) (?) & União (?) & Ao que parece. Não é possível especificar. \\
\hline & Açúcar (cristal) (?) & Colombo & Ao que parece. Não é possível especificar. \\
\hline & Café (em pó / torrado) & 3 Corações & \\
\hline & Alimentos (diversos) (?) & --- & Nas embalagens.Ao que parece.Não é possível especificar. \\
\hline & Alimentos / Mantimentos diversos: (?) & --- & Em potes. Ao que parece. Não é possível especificar. \\
\hline & - Arroz (integral) (?) & --- & Em pote. Ao que parece. Não é possível especificar. \\
\hline & - Arroz (branco) (?) & --- & Em pote. Ao que parece. Não é possível especificar. \\
\hline & - Feijão (preto) (?) & --- & Em pote. Ao que parece. Não é possível especificar. \\
\hline & - Feijão (carioca) (?) & --- & Em pote. Ao que parece. Não é possível especificar. \\
\hline & - Farinha de trigo (?) & --- & Em pote. Ao que parece. Não é possível especificar. \\
\hline & - Farinha de mandioca (?) & --- & Em pote. Ao que parece. Não é possível especificar. \\
\hline & - Farinha de milho (?) & --- & Em pote. Ao que parece. Não é possível especificar. \\
\hline & - Açúcar (cristal) (?) & --- & Em pote. Ao que parece. Não é possível especificar. \\
\hline & Manteiga & Aviação & \\
\hline & Achocolatado (em pó) & Toddy & \\
\hline & Café (em pó / torrado) & --- & Em pote. Ao que parece. Não é possível especificar. \\
\hline & Pipoca doce (microondas) & Yoki & \\
\hline & Pipoca salgada (microondas) (?) & Yoki (?) & Ao que parece. Não é possível especificar. \\
\hline & Calda (para sorvete) & Predilecta (?) & Ao que parece. Não é possível especificar. \\
\hline
\end{tabular}




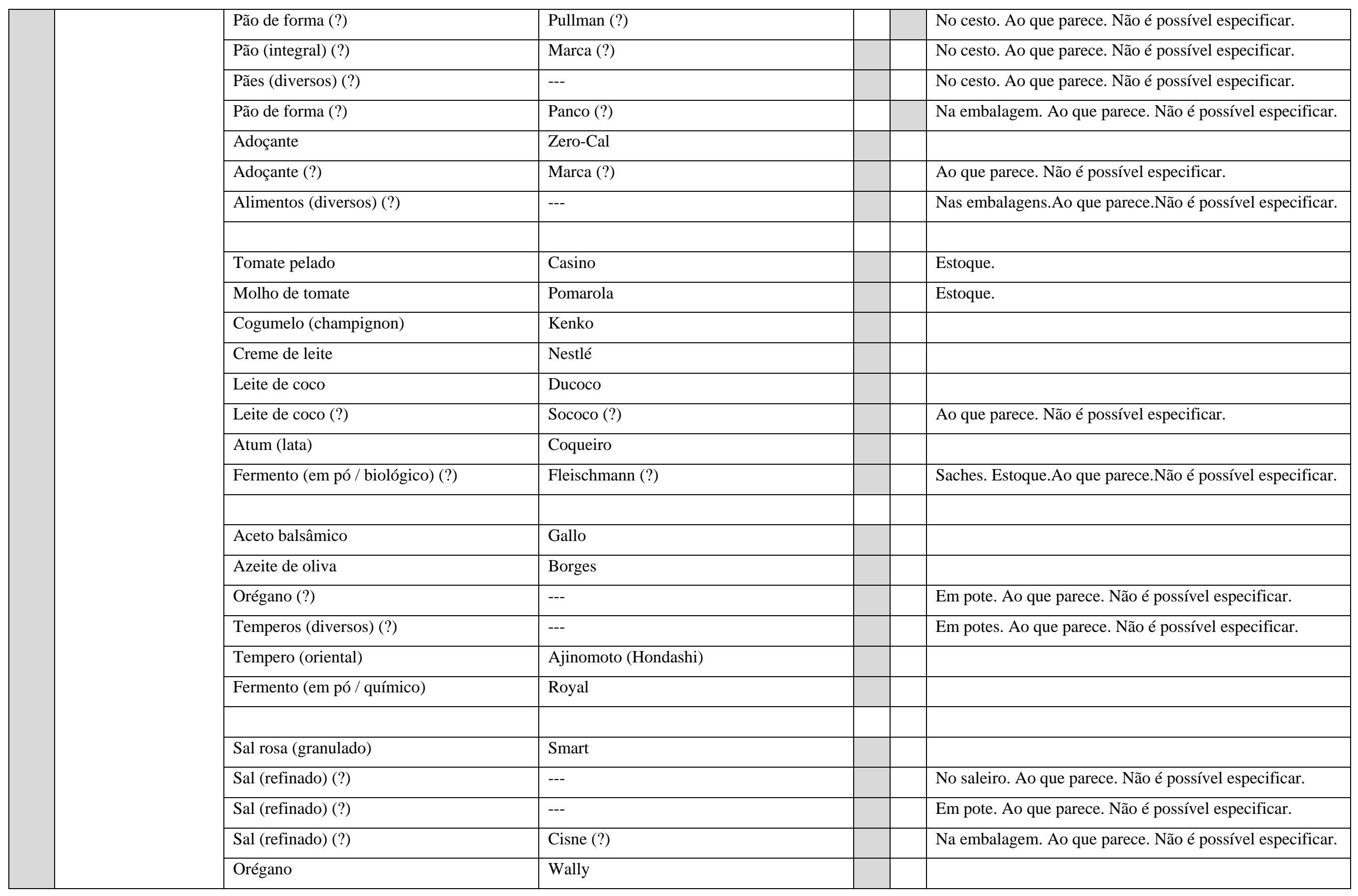




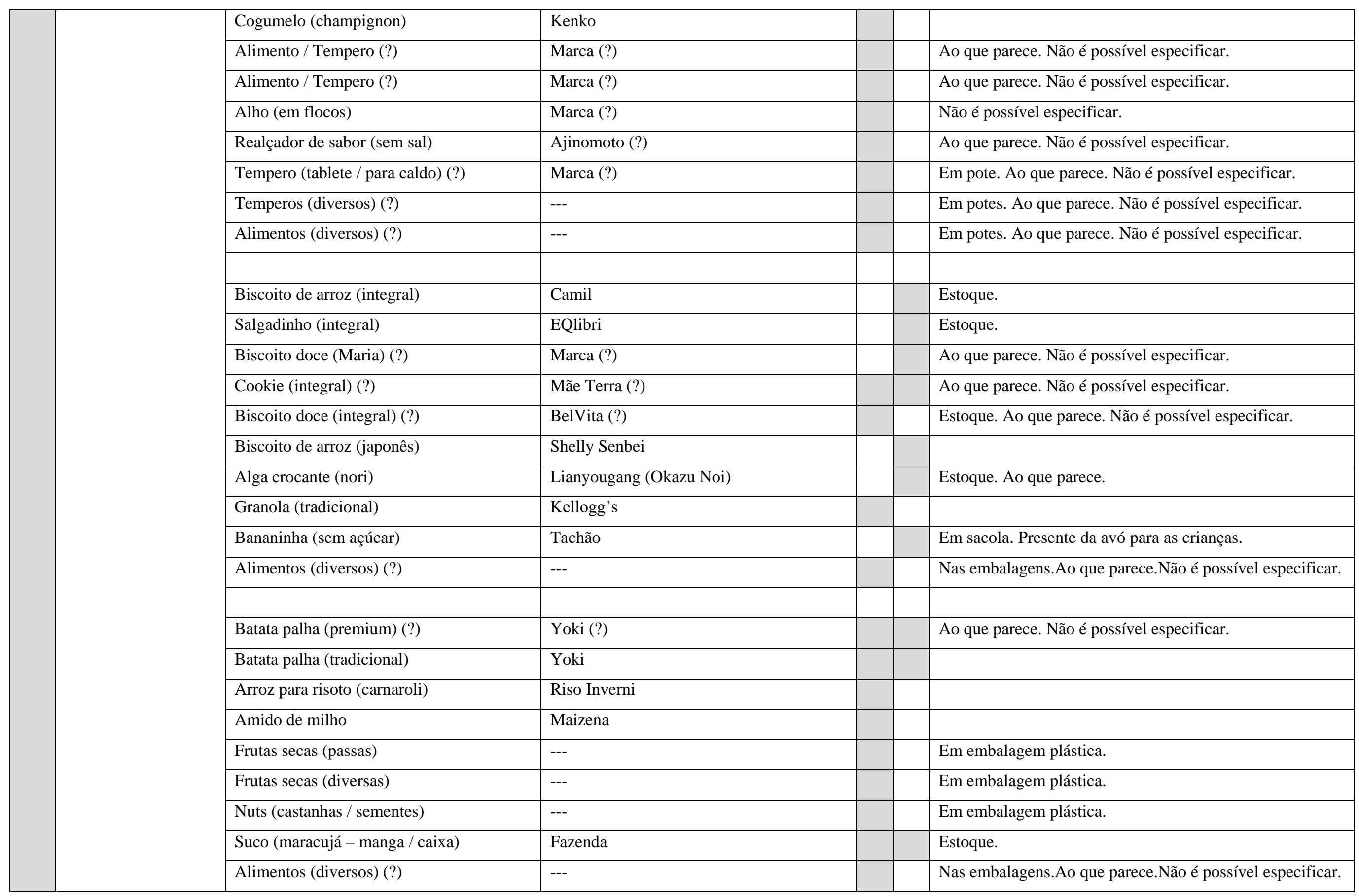




\begin{tabular}{|c|c|c|c|}
\hline & & & \\
\hline & Cereais (sucrilhos / com açúcar) & Kellogg's & Estoque. Embalagem maior. \\
\hline & Suplemento alimentar (?) & Marca (?) & Ao que parece. Não é possível especificar. \\
\hline & Temperos (diversos) & --- & Em potes (porta-temperos). \\
\hline & & & \\
\hline & & & \\
\hline & & & \\
\hline & Alimentos diversos (armários) (?) & --- & Ao que parece. Não é possível especificar. \\
\hline GELADEIRA & Suco (diversos sabores / caixinha) & Fazenda & Estoque. \\
\hline & Suco (diversos sabores / caixinha) & Maguary & Estoque. \\
\hline & Cerveja (long neck) & Stella Artois & Estoque. \\
\hline & Queijo (fatiado) (?) & --- & Ao que parece. Não é possível especificar. \\
\hline & Presunto (fatiado) (?) & --- & Ao que parece. Não é possível especificar. \\
\hline & Peito de peru (fatiado) (?) & --- & Ao que parece. Não é possível especificar. \\
\hline & Frios (diversos / fatiados) (?) & --- & Ao que parece. Não é possível especificar. \\
\hline & Manteiga & Aviação & Embalagem com alimento. Ao que parece. (?) \\
\hline & Alimentos (diversos) (?) & --- & Em potes. Ao que parece. Não é possível especificar. \\
\hline & Margarina & Qualy & \\
\hline & Alimentos (diversos) (?) & --- & Nas embalagens.Ao que parece.Não é possível especificar. \\
\hline & Alimentos (diversos) (?) & --- & Em potes. Ao que parece. Não é possível especificar. \\
\hline & Ovos (caipira) & Marca (?) & Não é possível especificar. \\
\hline & Ovos de codorna & Marca (?) & Não é possível especificar. \\
\hline & Alimentos (diversos) (?) & --- & Em embalagens.Ao que parece.Não é possível especificar. \\
\hline
\end{tabular}




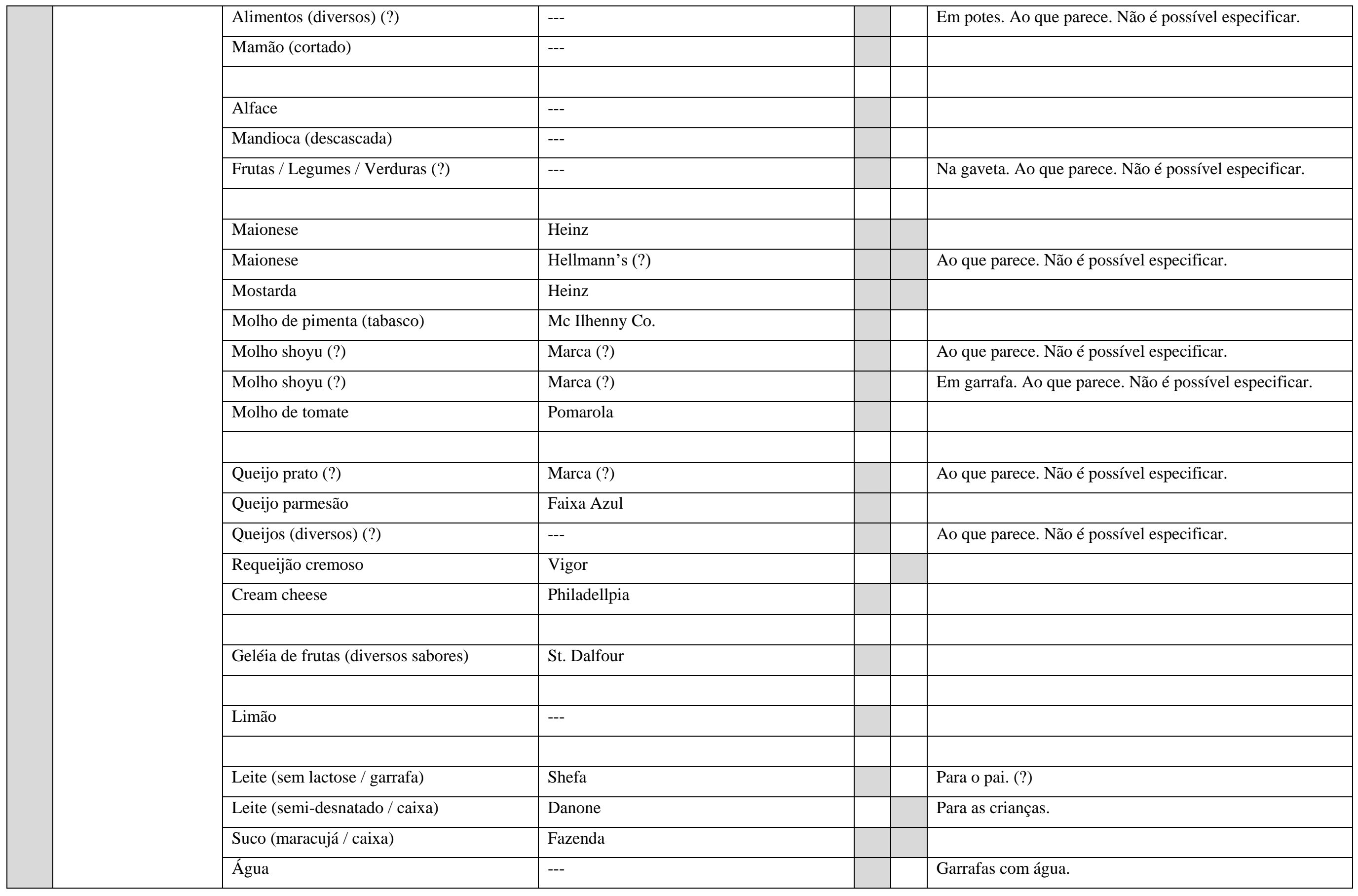




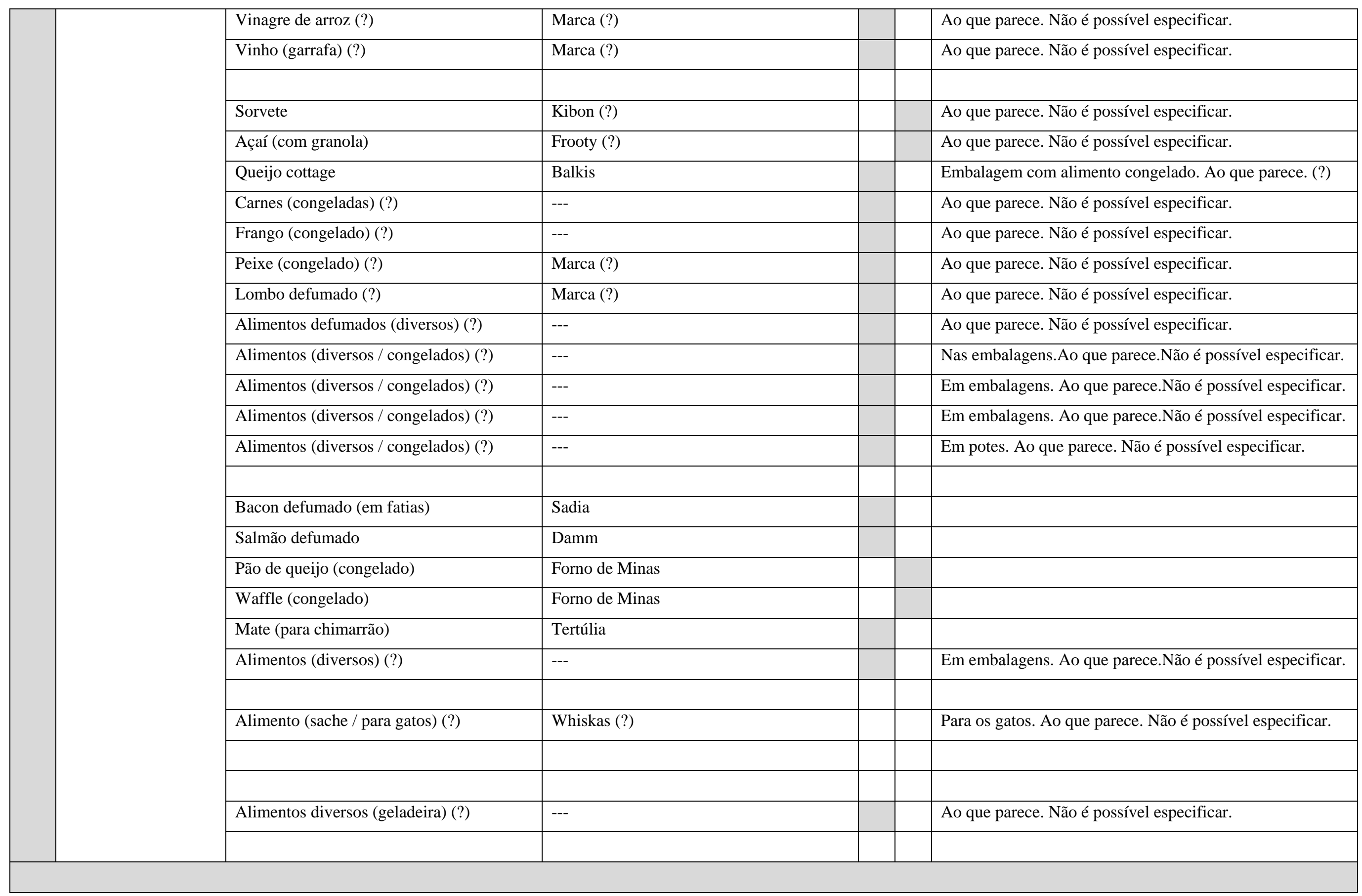




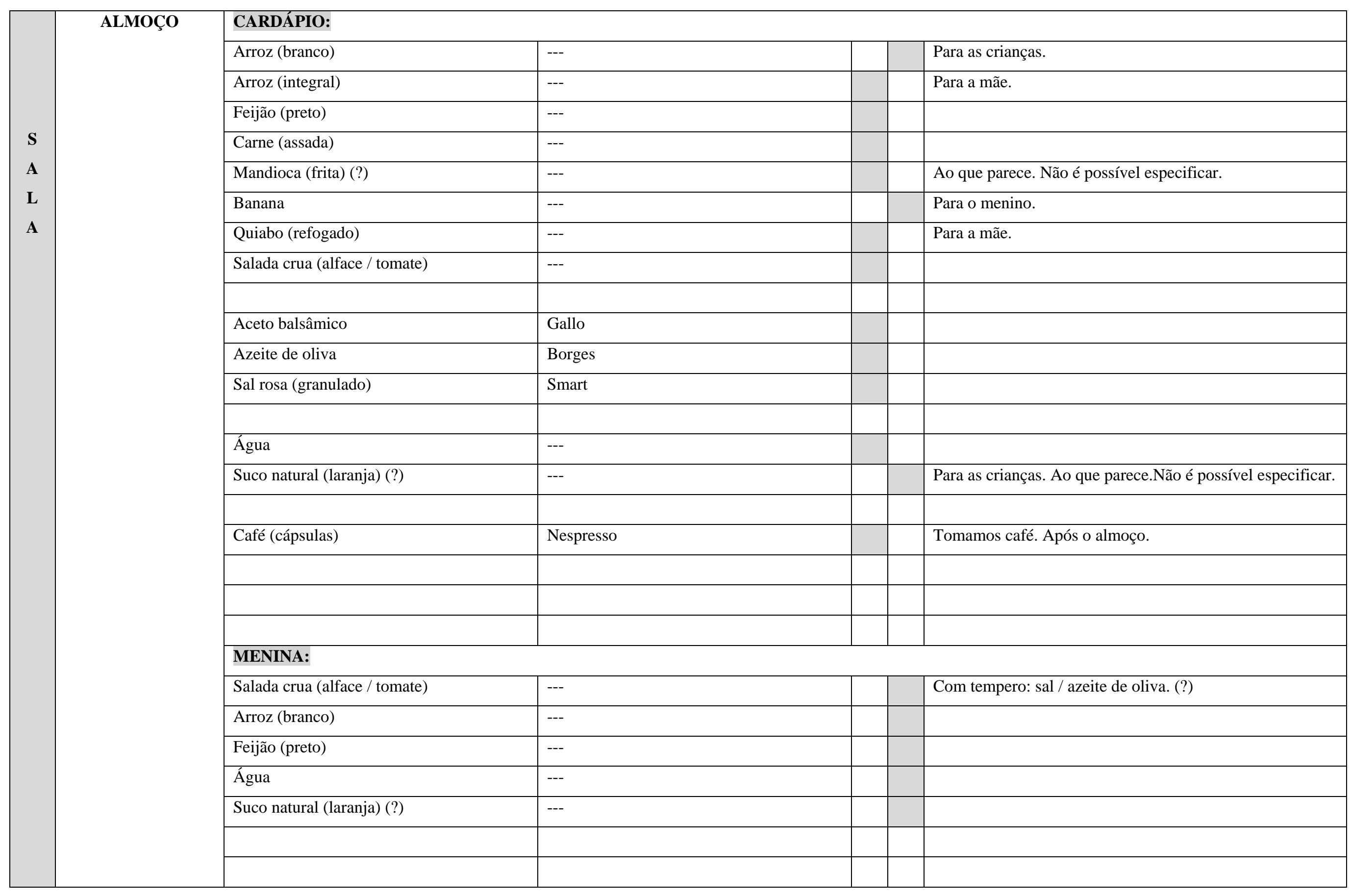




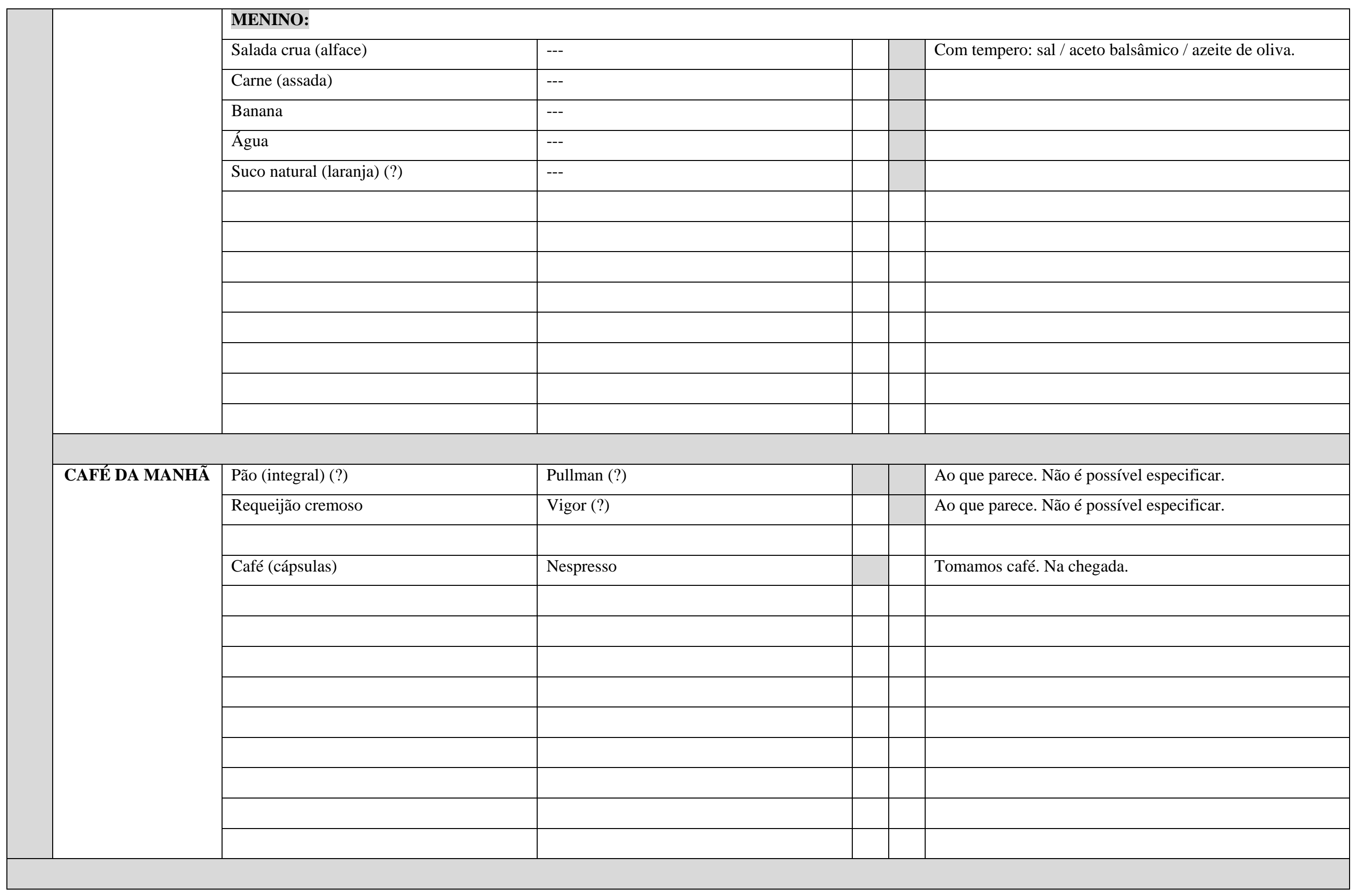




\section{SEGUNDO ENCONTRO: RITUAL DE ALIMENTAÇÃO COM AS CRIANÇAS EM CASA}

\section{MARCAS E PRODUTOS ALIMENTÍCIOS NO AMBIENTE DOMÉSTICO \\ (FOTOS / VÍDEOS / OBSERVAÇÃO)}

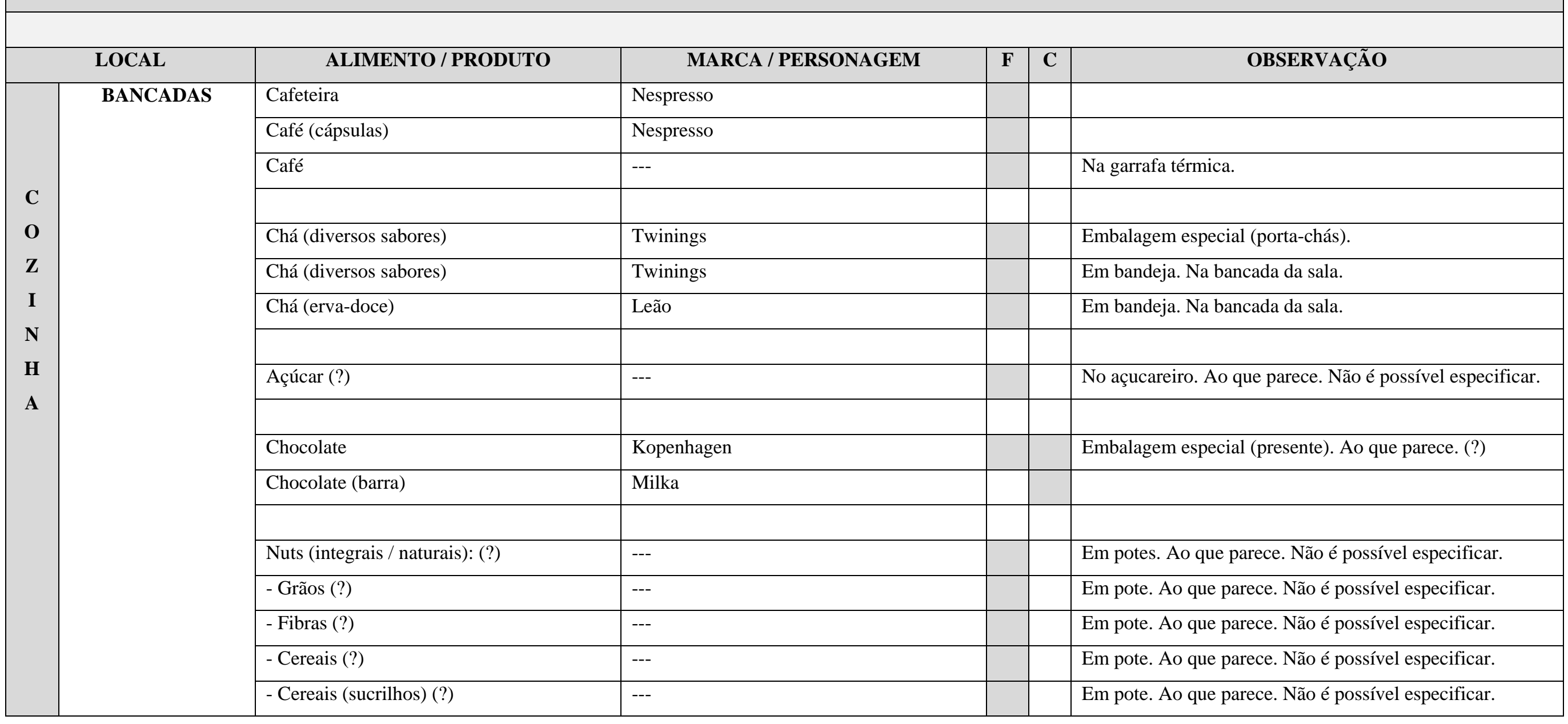




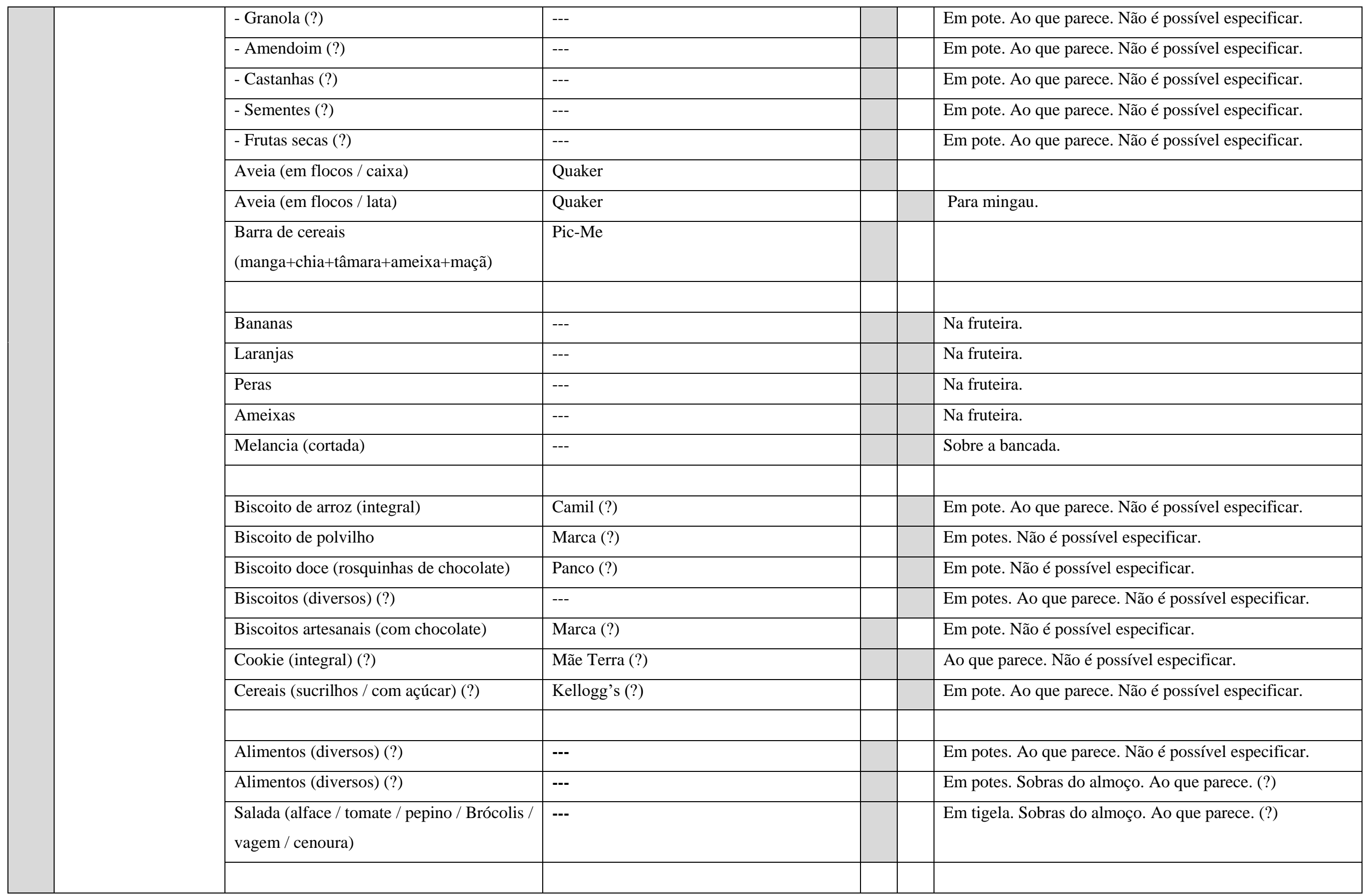




\begin{tabular}{|c|c|c|c|}
\hline & Raízes / Legumes diversos: (?) & --- & Na fruteira. Não é possível especificar todos. \\
\hline & - Batata doce & -- & Na fruteira. Abaixo da bancada. \\
\hline & - Batata & --- & $\mathrm{Na}$ fruteira. Abaixo da bancada. \\
\hline & - Inhame & --- & $\mathrm{Na}$ fruteira. Abaixo da bancada. \\
\hline & - Alho & --- & $\mathrm{Na}$ fruteira. Abaixo da bancada. \\
\hline & - Cebola & $-\cdots$ & $\mathrm{Na}$ fruteira. Abaixo da bancada. \\
\hline & Leite (sem lactose / garrafa) & Shefa & Abaixo da bancada. Para o pai. (?) \\
\hline & Leite (semi-desnatado / caixa) & Danone & Estoque. Abaixo da bancada. Para as crianças. \\
\hline & Alimentos diversos (bancadas) (?) & --- & Ao que parece. Não é possível especificar. \\
\hline ARMÁRIOS & Macarrão (espaguete) & Barilla & \\
\hline & Macarrão & Renata & Estoque. \\
\hline & Macarrão & Petybon & Estoque. \\
\hline & Macarrão instantâneo (tomate) (?) & Miojo (Turma da Mônica) (?) & Ao que parece. Não é possível especificar. \\
\hline & Arroz (branco) (?) & Camil (?) & Ao que parece. Não é possível especificar. \\
\hline & Lentilha & Yoki & \\
\hline & Trigo (para kibe) & Yoki & \\
\hline & Feijão (carioca) & Camil (?) & Ao que parece. Não é possível especificar. \\
\hline & Farinha de trigo (?) & Sol (?) & Ao que parece. Não é possível especificar. \\
\hline & Açúcar (cristal) (?) & União (?) & Ao que parece. Não é possível especificar. \\
\hline & Sal (refinado) (?) & Cisne (?) & Ao que parece. Não é possível especificar. \\
\hline & Alimentos (diversos) (?) & --- & Nas embalagens.Ao que parece.Não é possível especificar. \\
\hline & Alimentos / Mantimentos diversos: (?) & --- & Em potes. Ao que parece. Não é possível especificar. \\
\hline & - Arroz (integral) (?) & --- & Em pote. Ao que parece. Não é possível especificar. \\
\hline & - Arroz (branco) (?) & --- & Em pote. Ao que parece. Não é possível especificar. \\
\hline & - Feijão (preto) (?) & --- & Em pote. Ao que parece. Não é possível especificar. \\
\hline
\end{tabular}




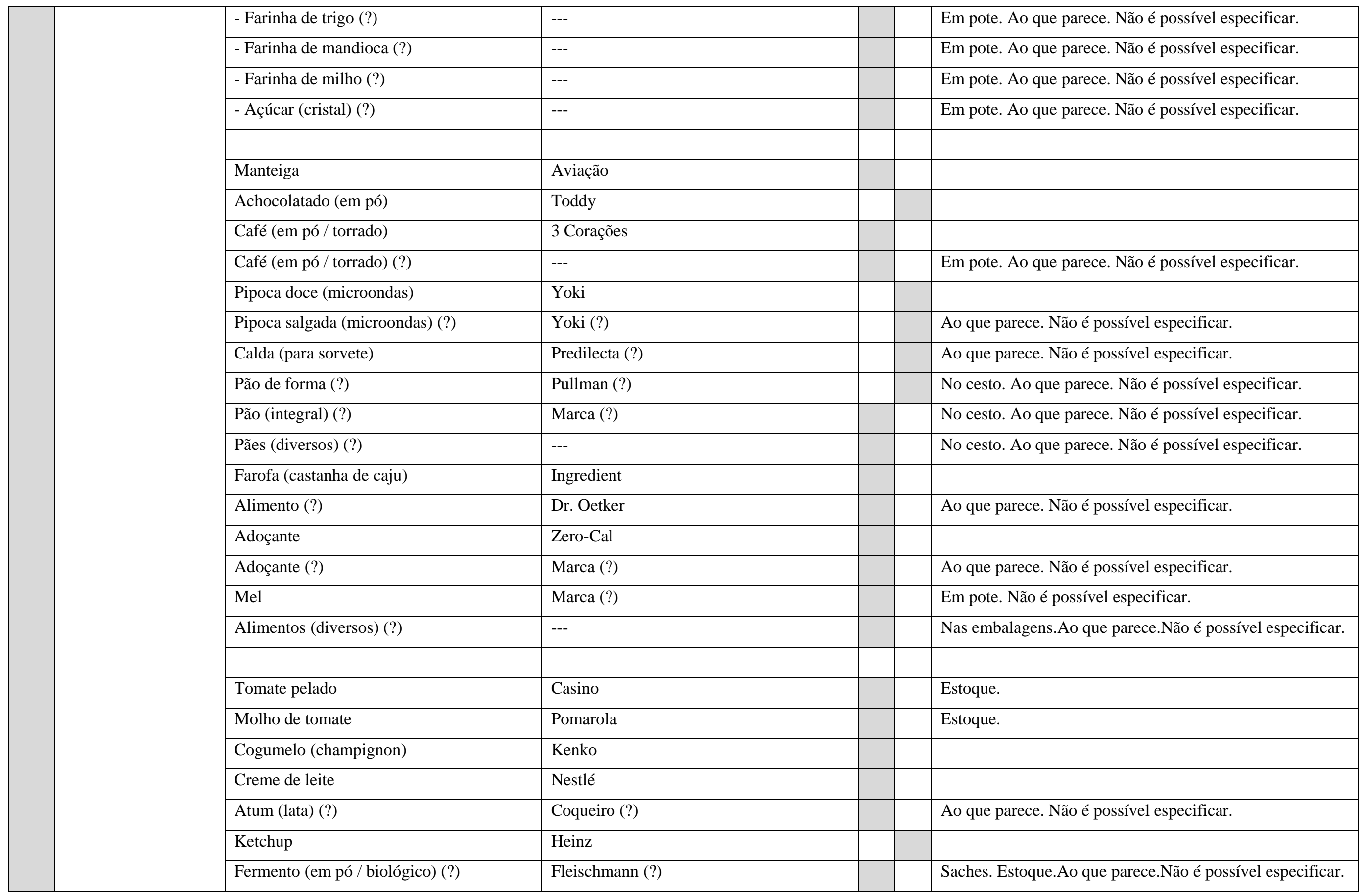




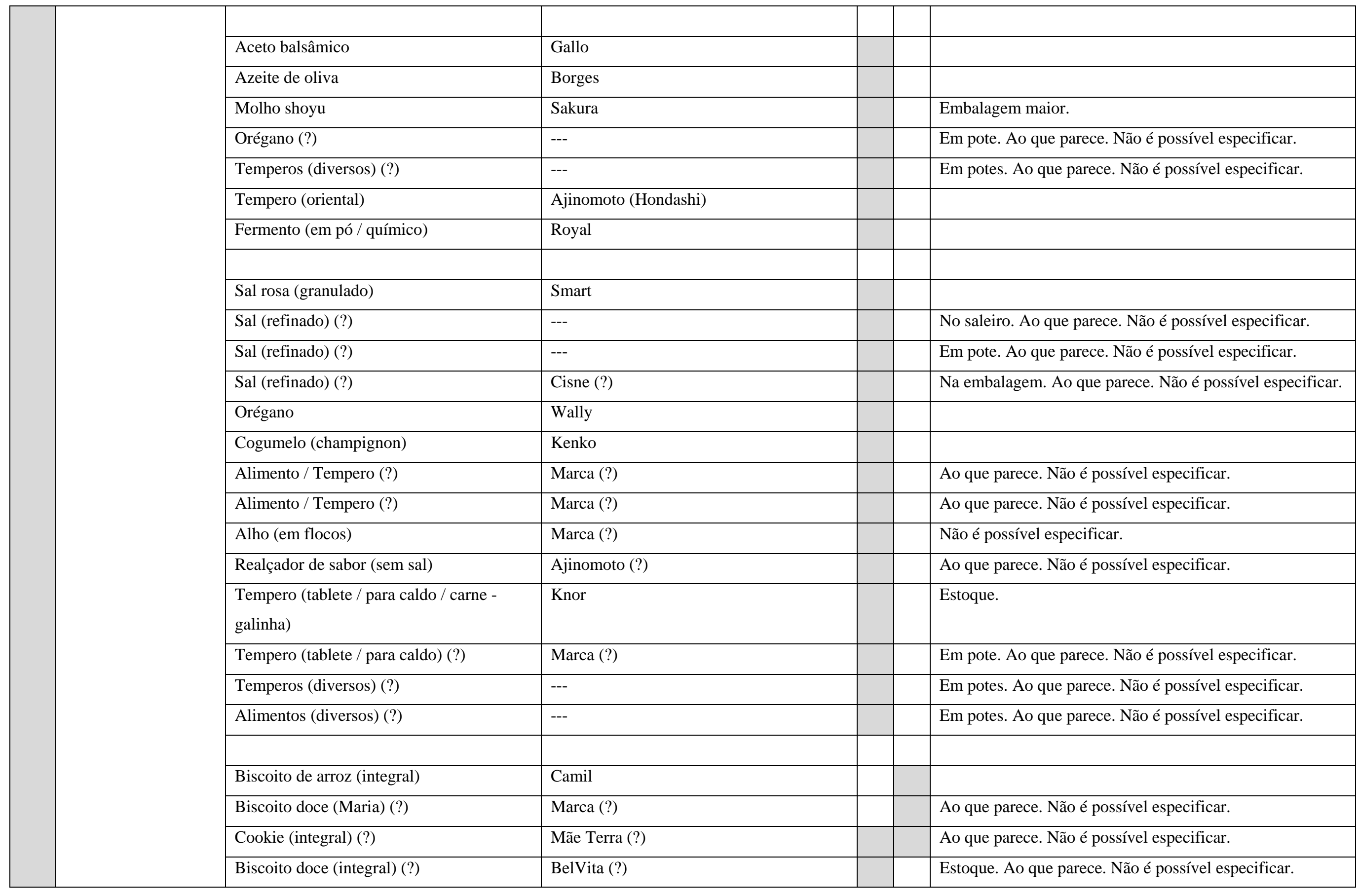




\begin{tabular}{|c|c|c|c|}
\hline & Biscoito de arroz (japonês) & Shelly Senbei & \\
\hline & Alga crocante (nori) & Lianyougang (Okazu Noi) & Estoque. Ao que parece. \\
\hline & Salgadinho (integral) & Mãe Terra (Ceboloko) & \\
\hline & Chips (batata rústica e alecrim) & Pic-Me & \\
\hline & Granola (tradicional) & Kellogg's & \\
\hline & Achocolatado (em pó) & Toddy & Estoque. Embalagem maior. \\
\hline & Alimentos (diversos) (?) & --- & Nas embalagens.Ao que parece.Não é possível especificar. \\
\hline & Batata palha (premium) (?) & Yoki & Ao que parece. Não é possível especificar. \\
\hline & Arroz para risoto (carnaroli) & Riso Inverni & \\
\hline & Amido de milho & Maizena & \\
\hline & Frutas secas (passas) & --- & Em embalagem plástica. \\
\hline & Frutas secas (diversas) & --- & Em embalagem plástica. \\
\hline & Nuts (castanhas / sementes) & --- & Em embalagem plástica. \\
\hline & Suco (maracujá - manga / caixa) & Fazenda & Estoque. \\
\hline & Alimentos (diversos) (?) & --- & Em embalagens. Ao que parece.Não é possível especificar. \\
\hline & Cereais (sucrilhos / com açúcar) & Kellogg's & Estoque. Embalagem maior. \\
\hline & Suplemento alimentar (?) & Marca (?) & Ao que parece. Não é possível especificar. \\
\hline & Temperos (diversos) & --- & Em potes (porta temperos). \\
\hline & Trufas de chocolate & Lindt & Estoque. Na bancada / armário do quarto. \\
\hline & Alimentos diversos (armários) (?) & & Ao que parece. Não é possível especificar. \\
\hline GELADEIRA & Suco (diversos sabores / caixinha) & Fazenda & Estoque. \\
\hline & Suco (diversos sabores / caixinha) & Maguary & Estoque. \\
\hline & Cerveja (long neck) & Stella Artois & Estoque. \\
\hline
\end{tabular}




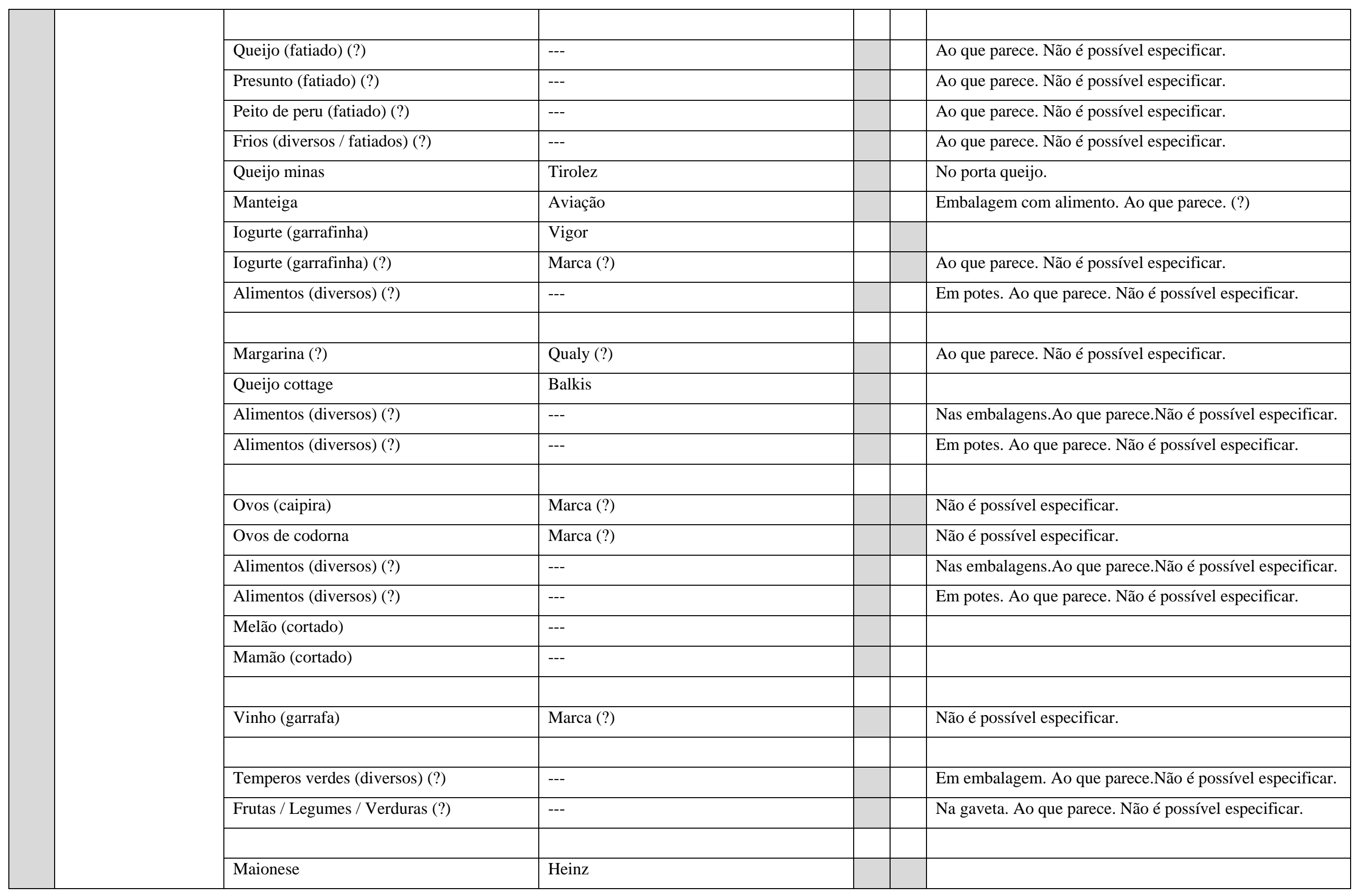




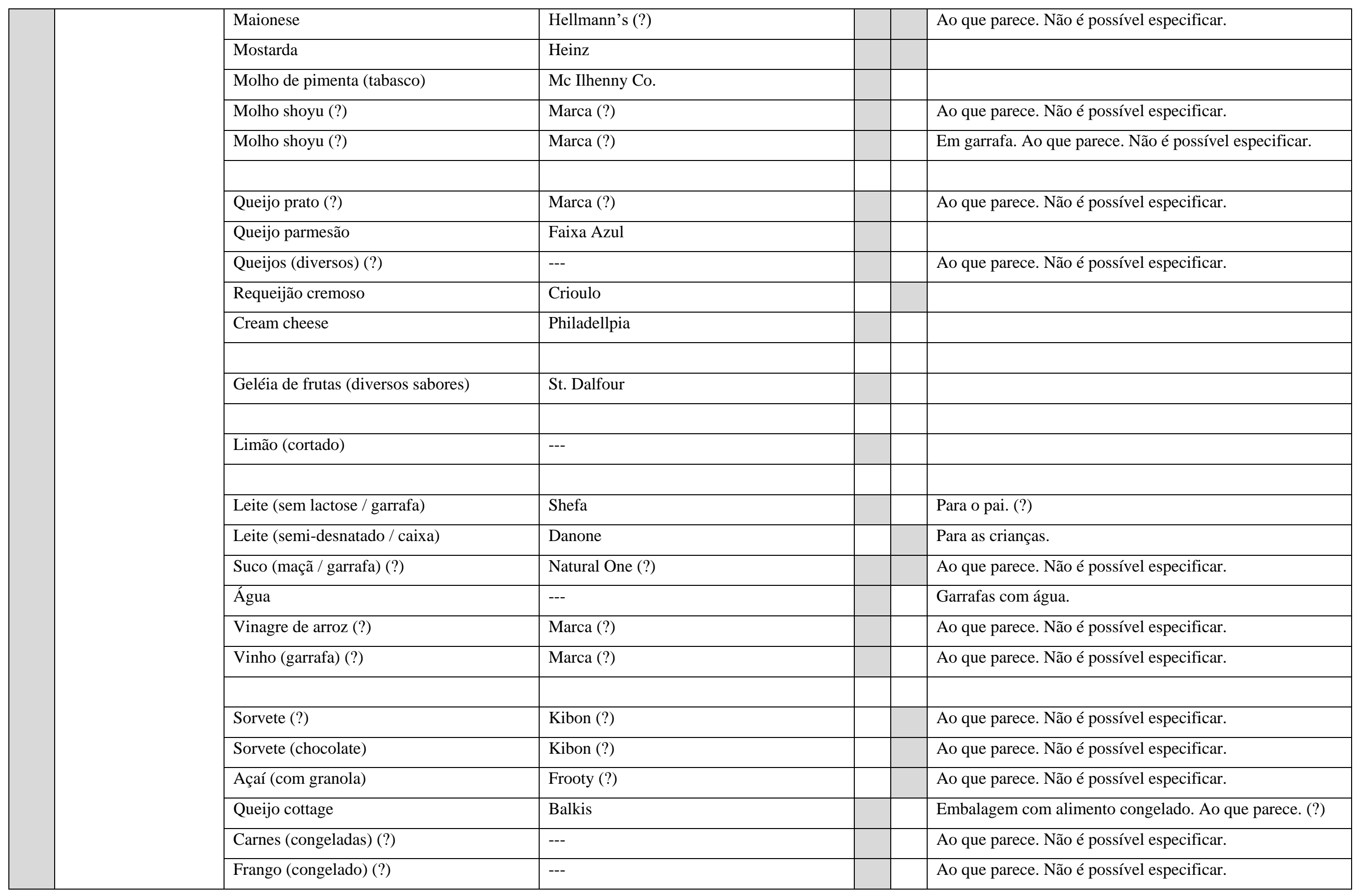




\begin{tabular}{|c|c|c|c|c|}
\hline & & Peixe (congelado) (?) & Marca (?) & Ao que parece. Não é possível especificar. \\
\hline & & Lombo defumado (?) & Marca (?) & Ao que parece. Não é possível especificar. \\
\hline & & Alimentos defumados (diversos) (?) & --- & Ao que parece. Não é possível especificar. \\
\hline & & Alimentos (diversos / congelados) (?) & --- & Nas embalagens.Ao que parece.Não é possível especificar. \\
\hline & & Alimentos (diversos / congelados) (?) & --- & Em embalagens. Ao que parece.Não é possível especificar. \\
\hline & & Alimentos (diversos / congelados) (?) & --- & Em embalagens. Ao que parece.Não é possível especificar. \\
\hline & & Alimentos (diversos / congelados) (?) & --- & Em potes. Ao que parece. Não é possível especificar. \\
\hline & & Bacon defumado (em fatias) & Sadia & \\
\hline & & Salmão defumado & Damm & \\
\hline & & Pão de queijo (congelado) & Forno de Minas & \\
\hline & & Waffle (congelado) & Forno de Minas & \\
\hline & & Mate (para chimarrão) & Tertúlia & \\
\hline & & Alimentos (diversos) (?) & --- & Em embalagens. Ao que parece.Não é possível especificar. \\
\hline & & Alimento (sache / para gatos) (?) & Whiskas (?) & Para os gatos. Ao que parece. Não é possível especificar. \\
\hline & & Alimentos diversos (geladeira) (?) & & Ao que parece. Não é possível especificar. \\
\hline & \multirow[t]{10}{*}{ ALMOÇO } & \multicolumn{3}{|l|}{ CARDÁPIO: } \\
\hline & & Arroz (branco) & --- & Para as crianças. \\
\hline & & Arroz (integral) & --- & Para a mãe. \\
\hline & & Feijão (carioca) & --- & \\
\hline & & Carne (bife acebolado) & --- & \\
\hline & & Batata doce & --- & Para a mãe. \\
\hline & & Banana & --- & Para o menino. \\
\hline & & Salada crua (alface / tomate / pepino) & --- & \\
\hline & & Salada cozida (brócolis / vagem / cenoura) & --- & \\
\hline A & & & & \\
\hline
\end{tabular}




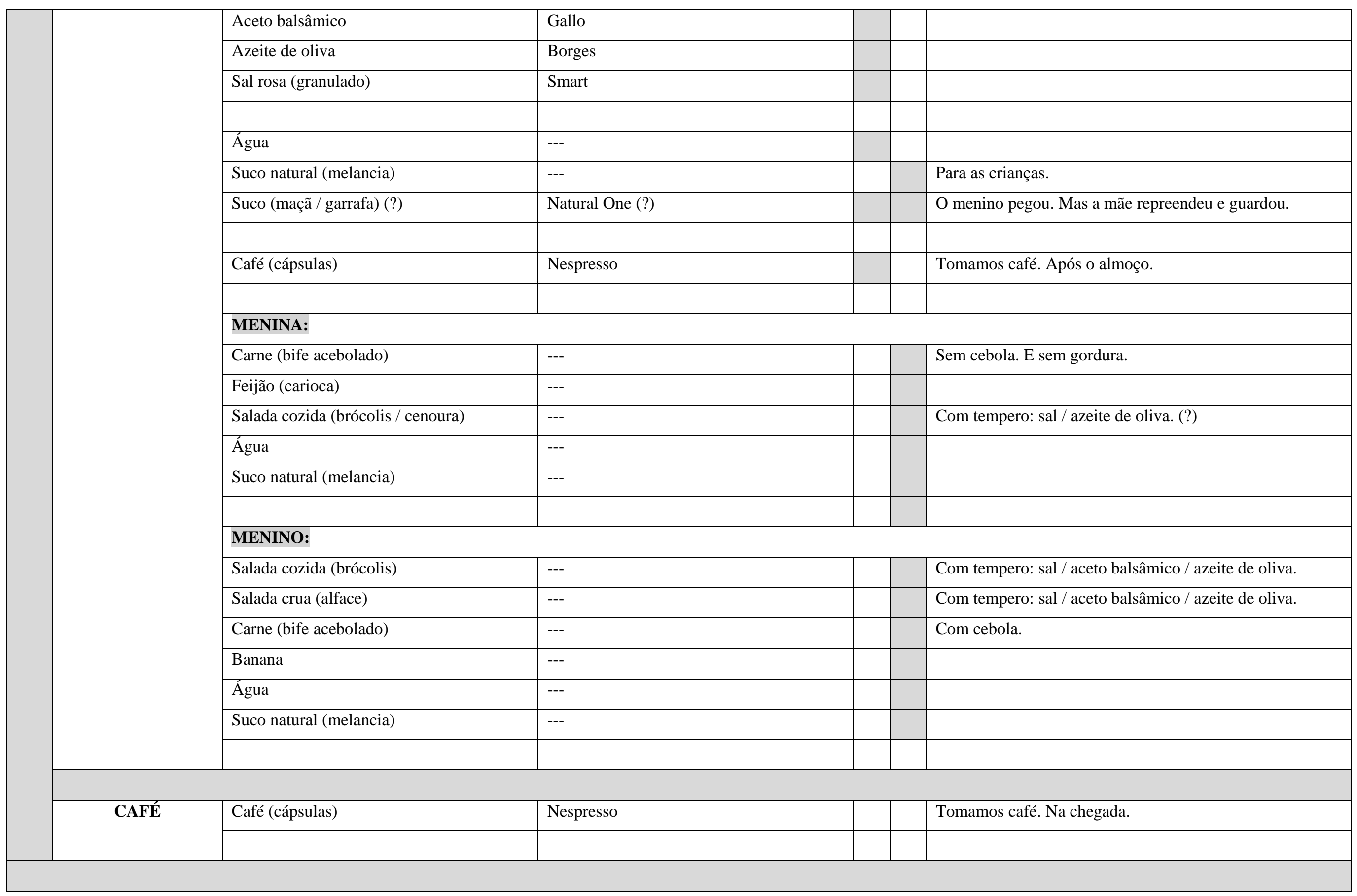




\section{TERCEIRO ENCONTRO: RITUAL DE ALIMENTAÇÃO COM AS CRIANÇAS FORA DE CASA}

MARCAS E PRODUTOS ALIMENTÍCIOS NO AMBIENTE DOMÉSTICO (FOTOS / VÍDEOS / OBSERVAÇÃO)

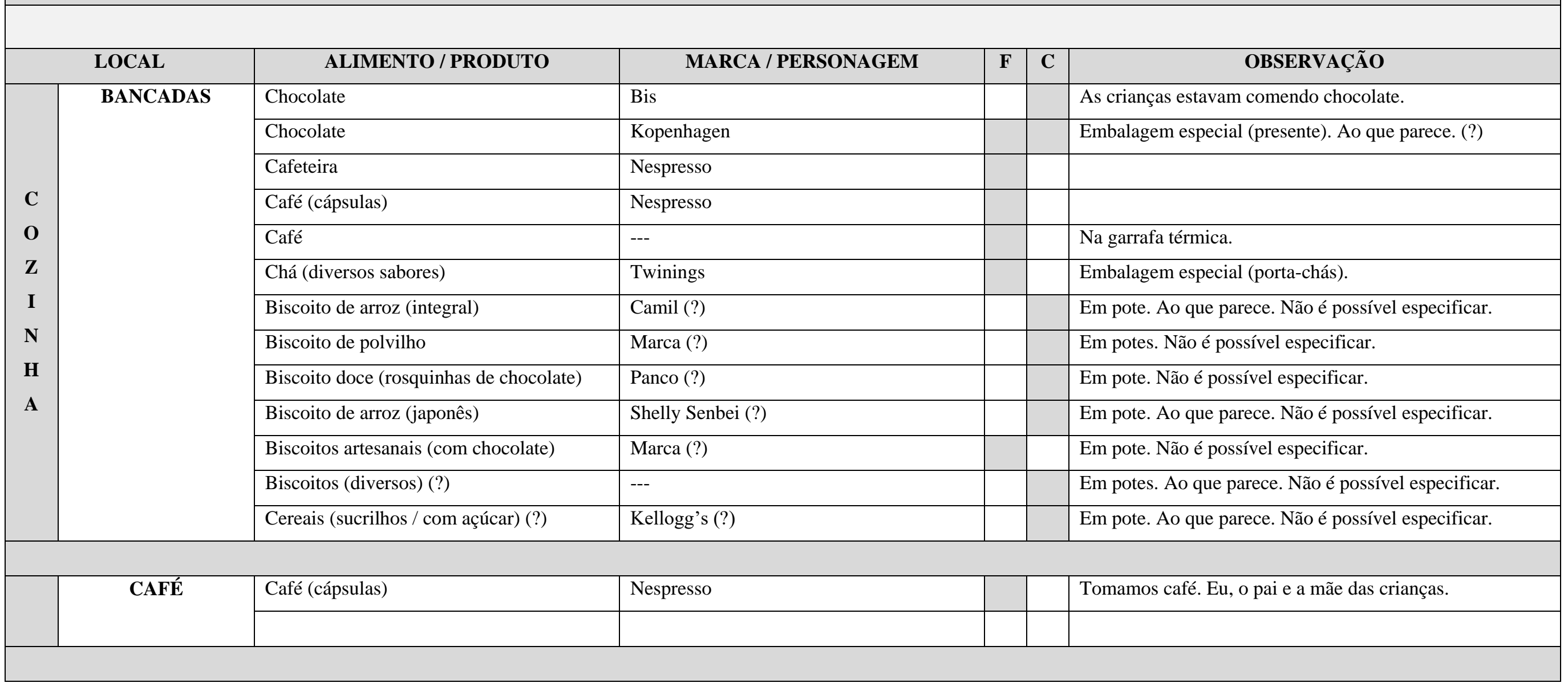




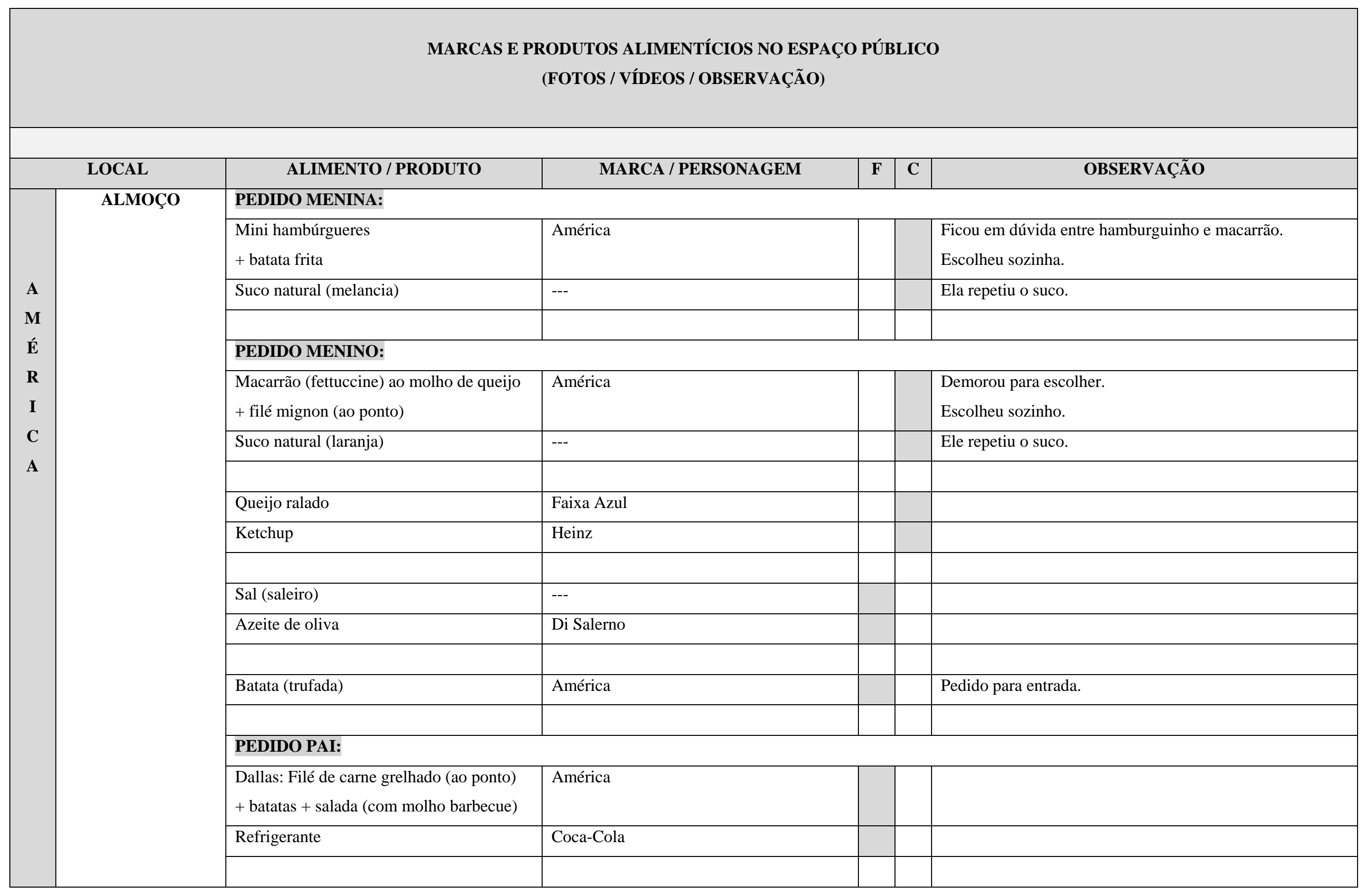




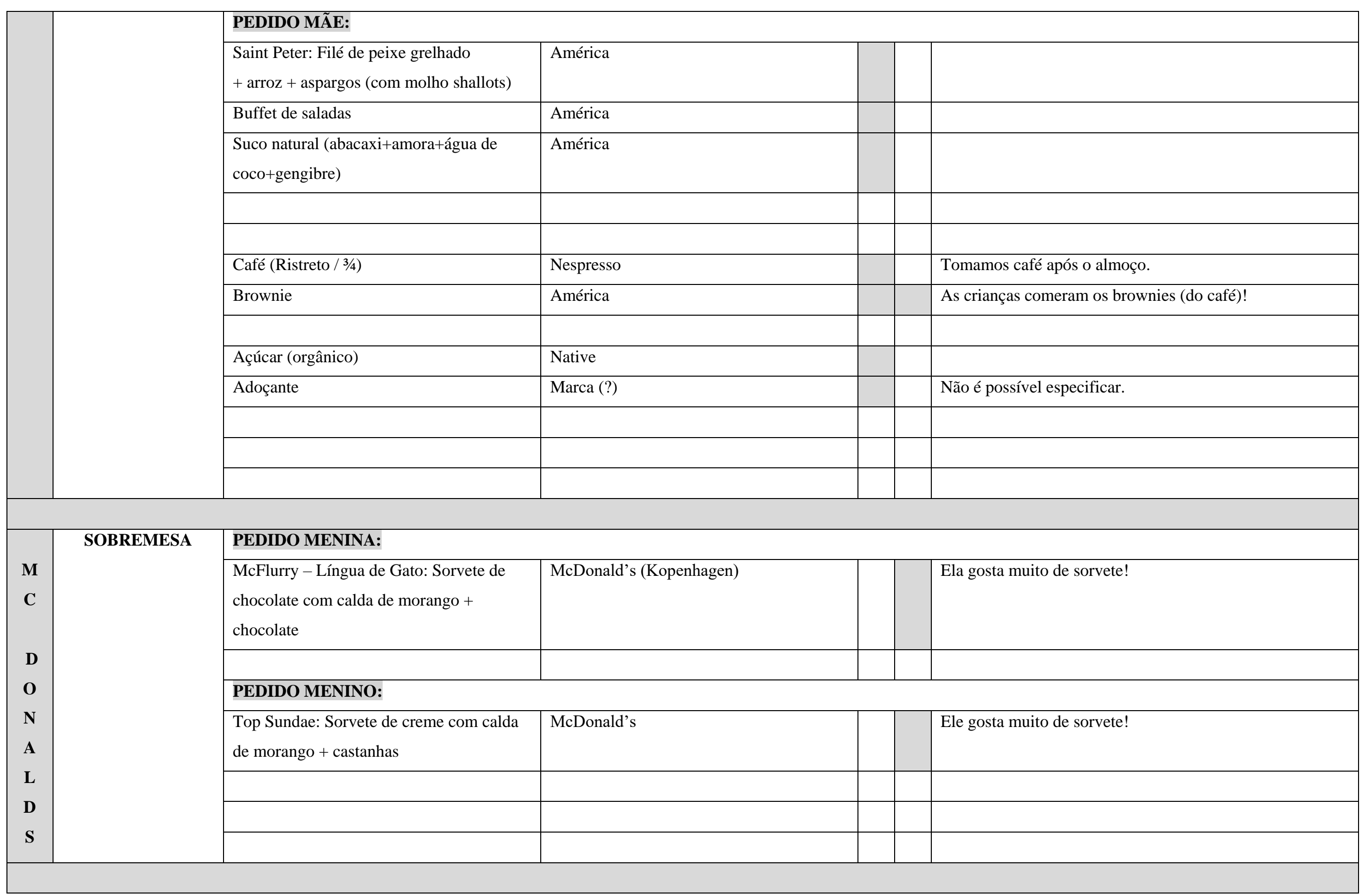




\section{R I A N Ç A S}

PRODUTOS / MARCAS / PERSONAGENS NO AMBIENTE DOMÉSTICO E ESPAÇO PÚBLICO (RELATOS / OBSERVAÇÕES / CITAÇÕES / EXPRESSIVIDADES / FOTOS / VÍDEOS / OBSERVAÇÃO)

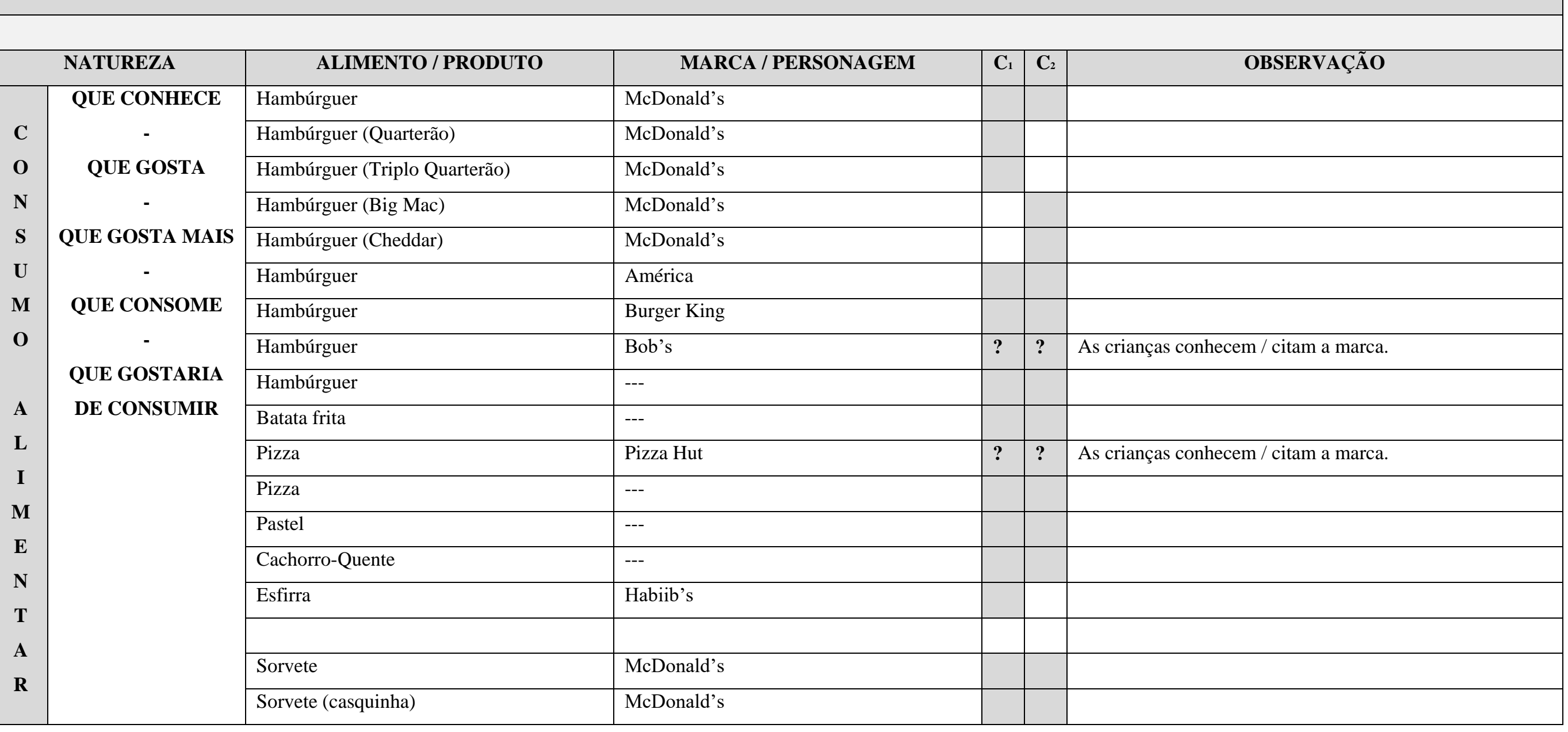




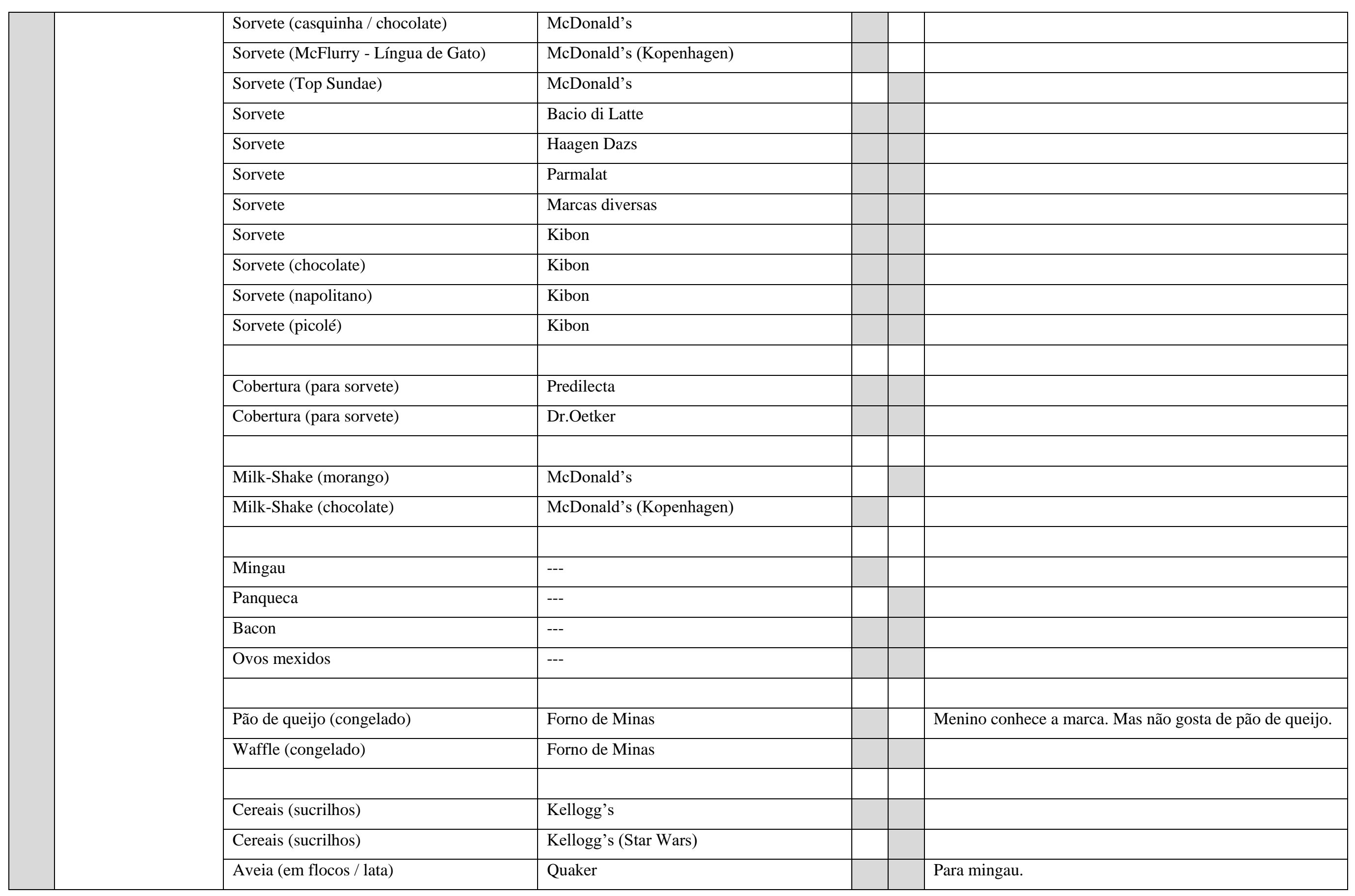




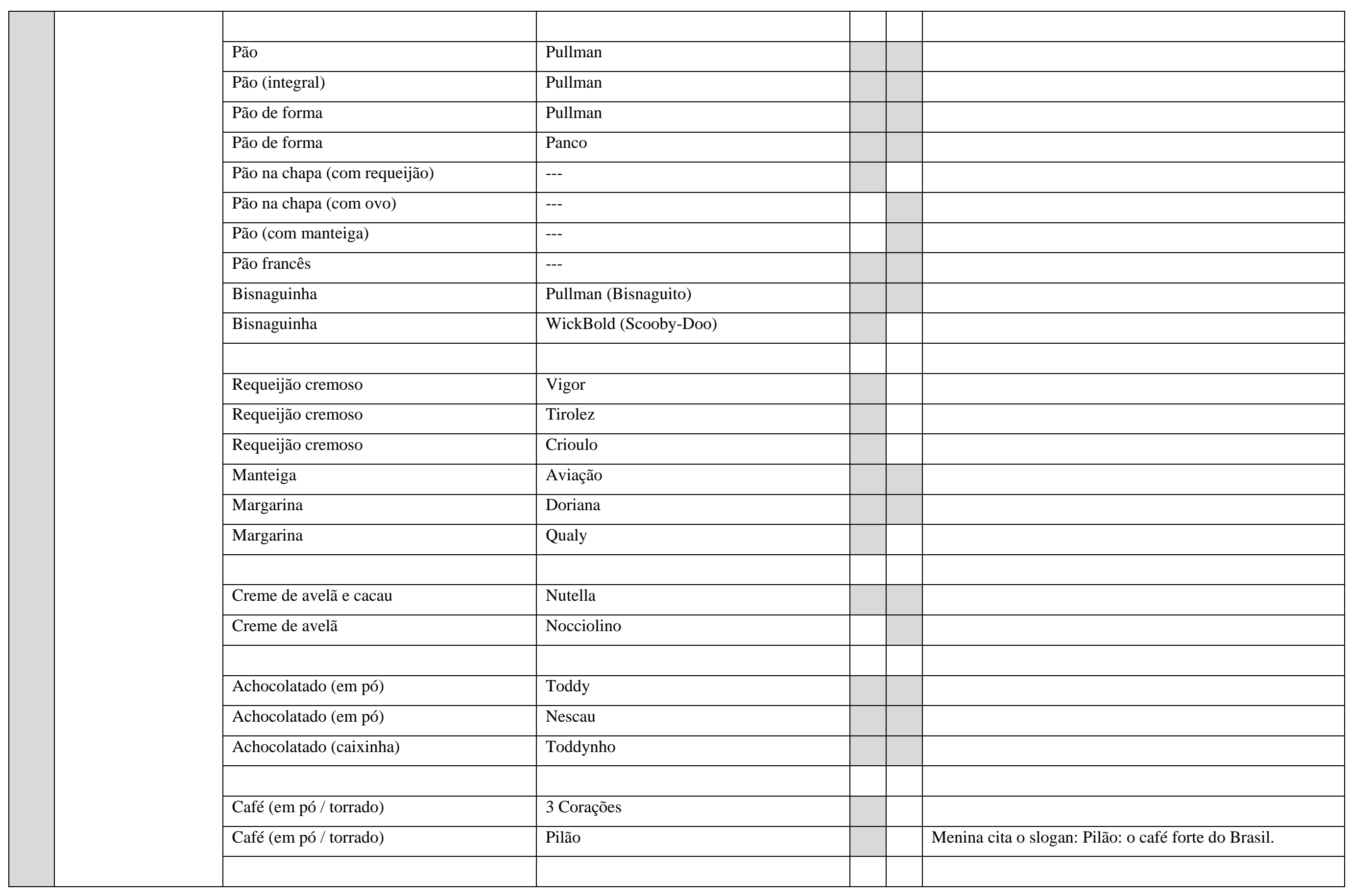




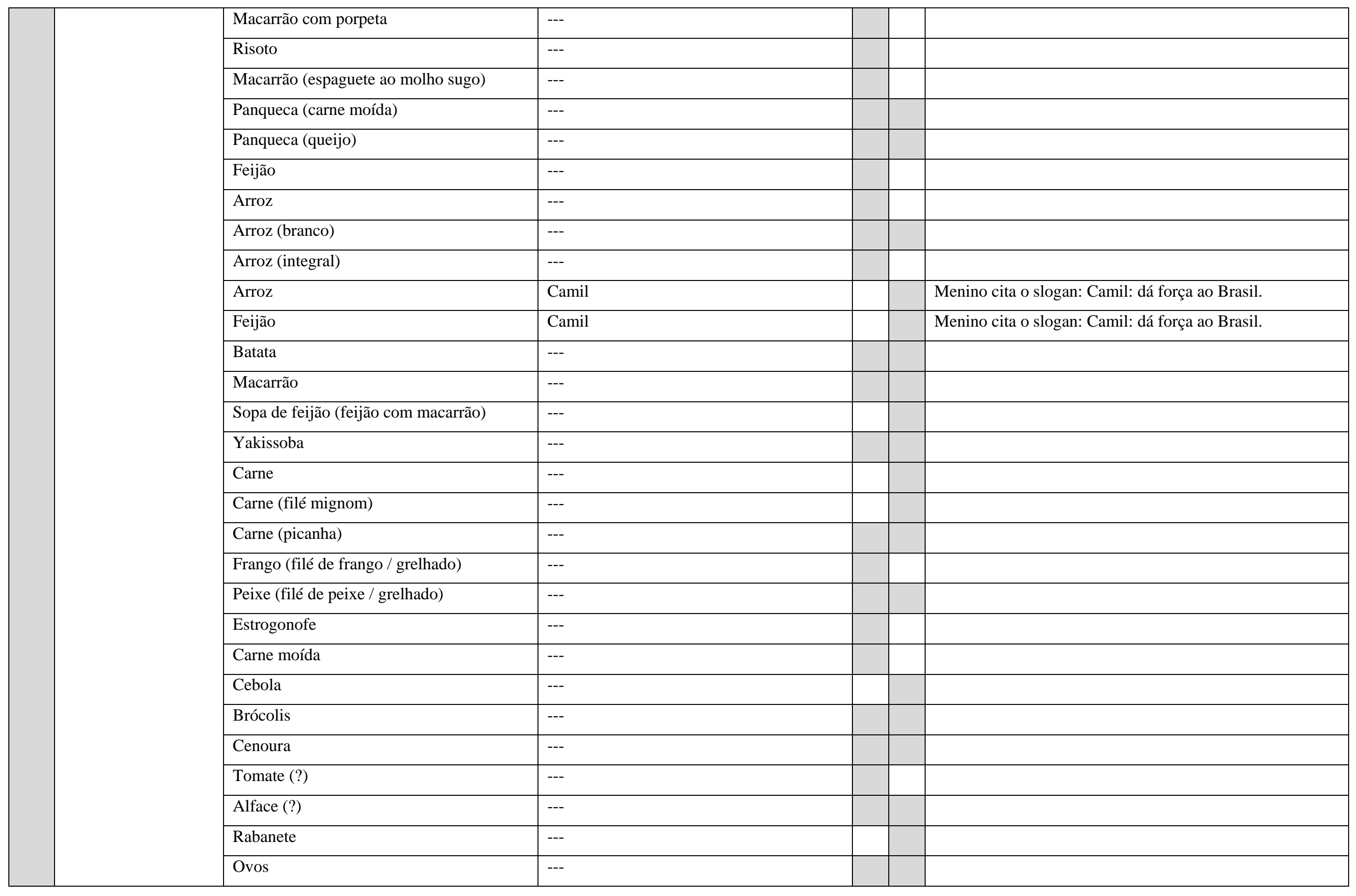




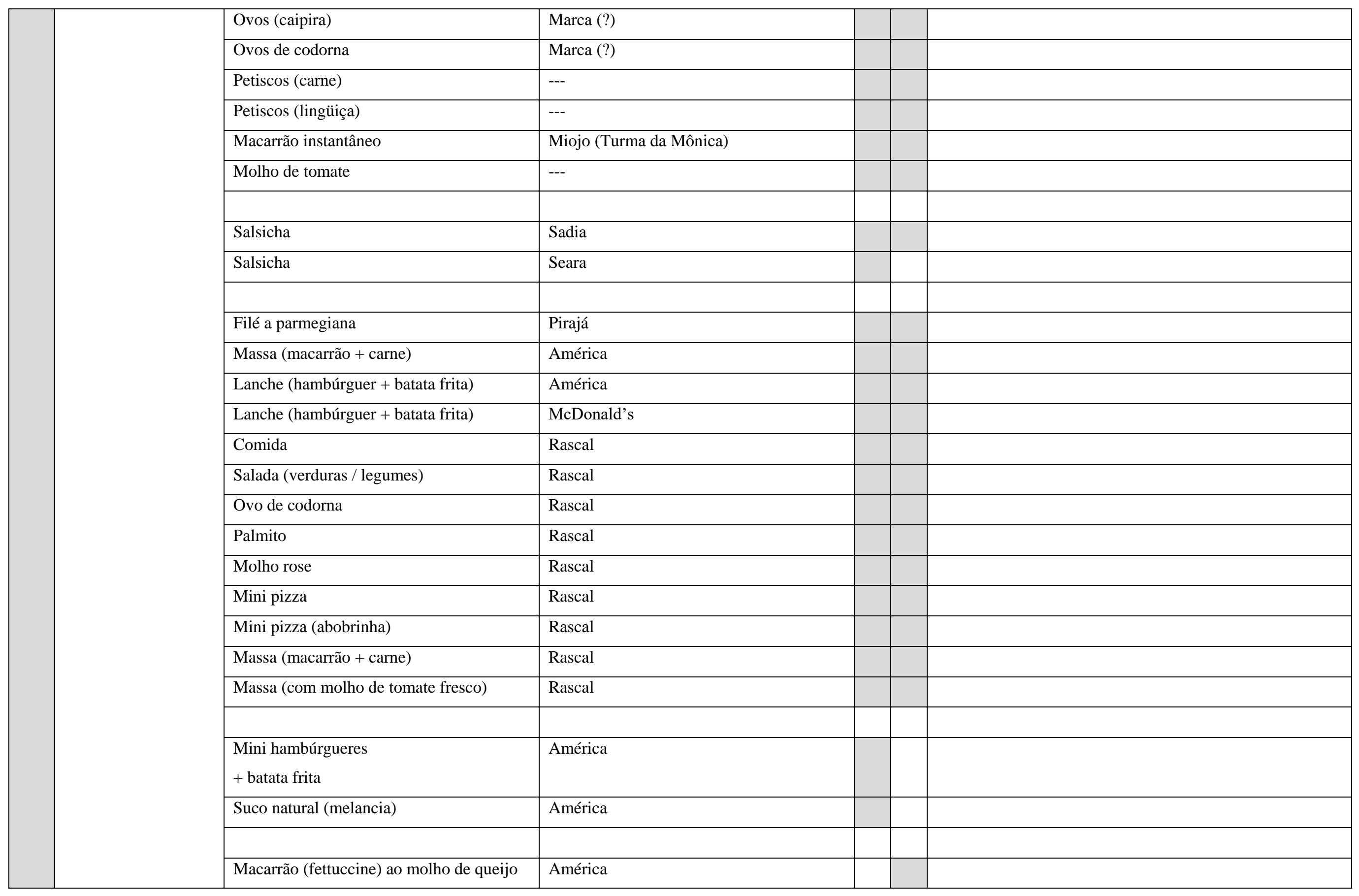




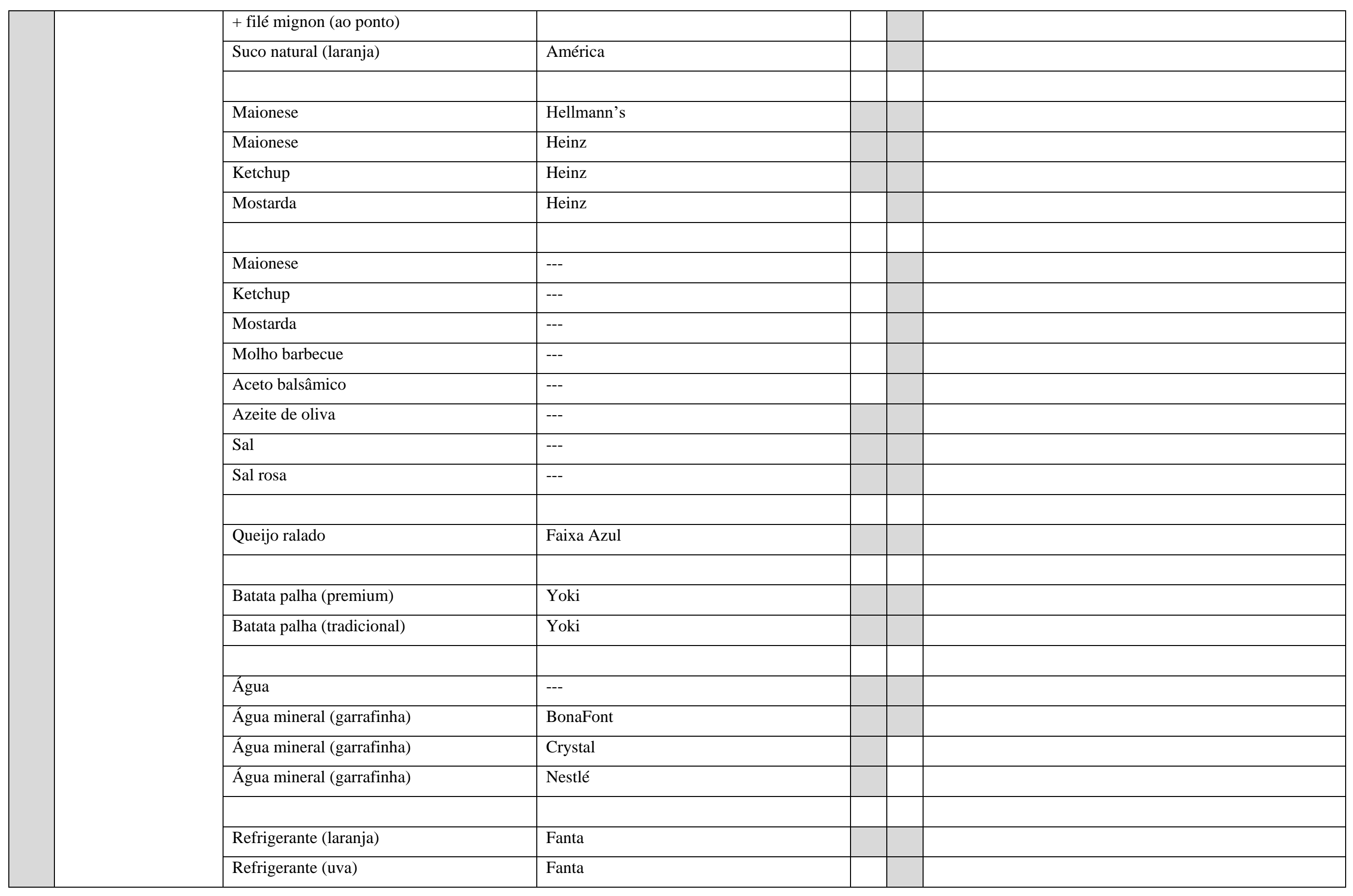




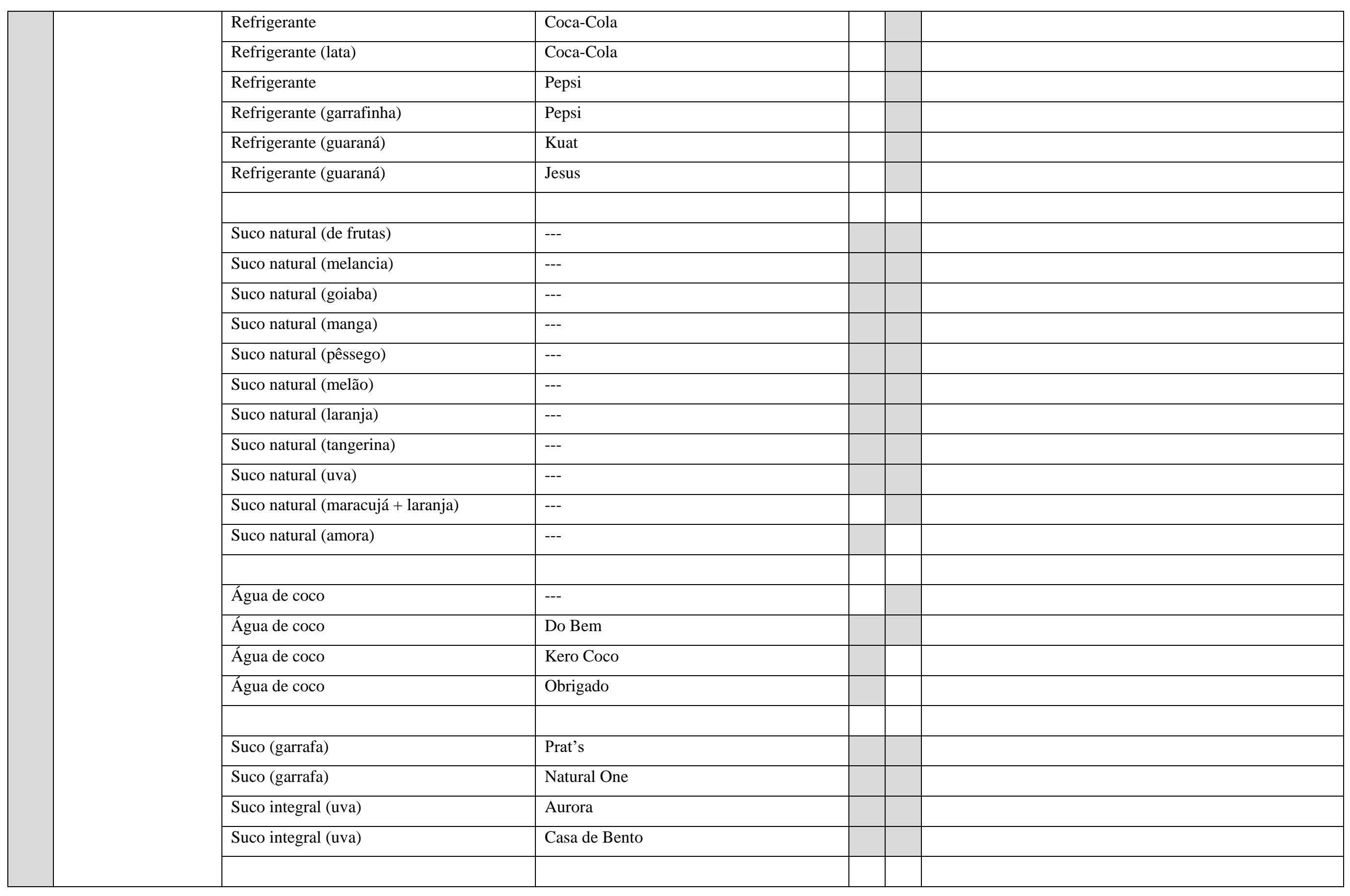




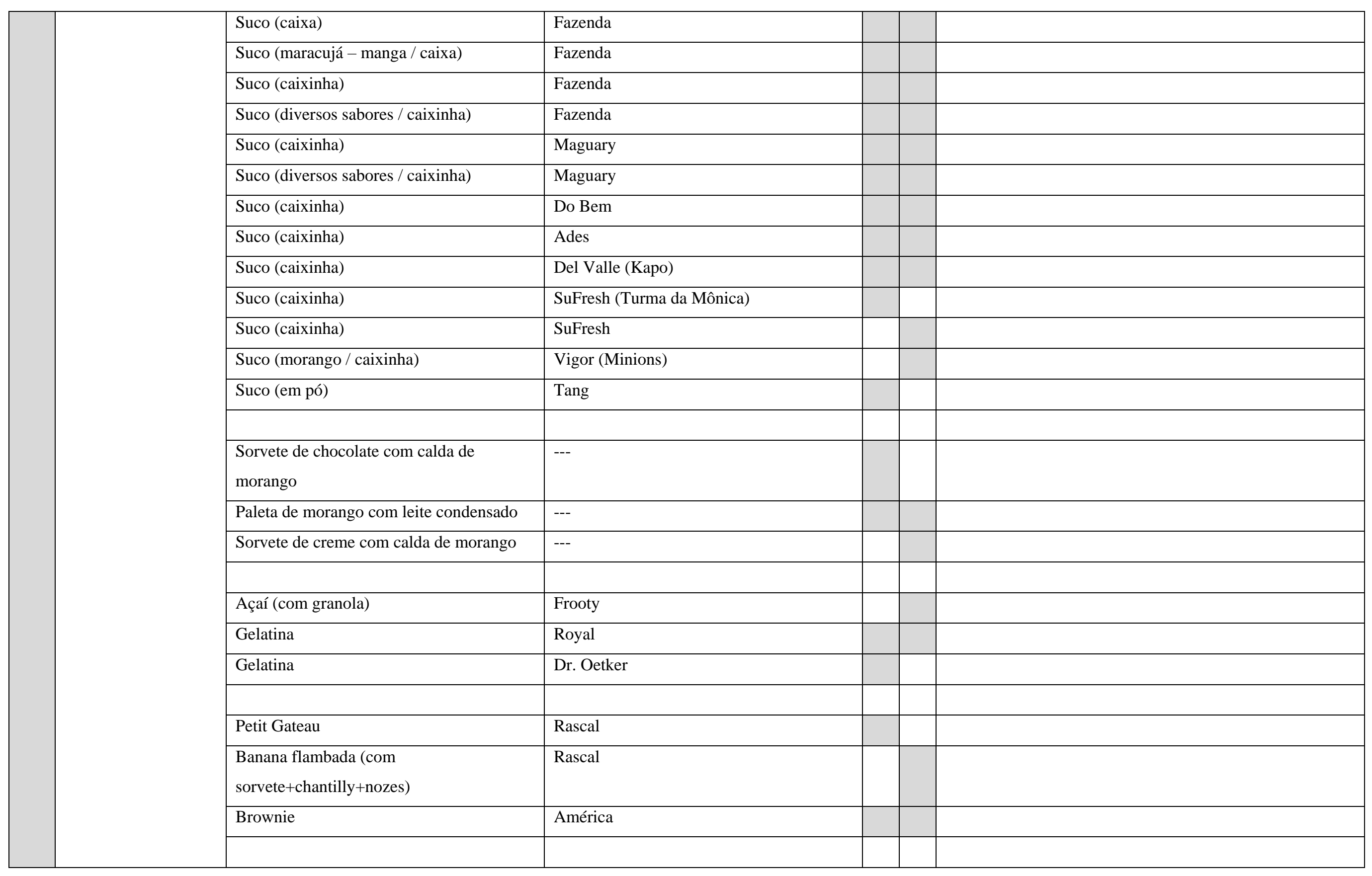




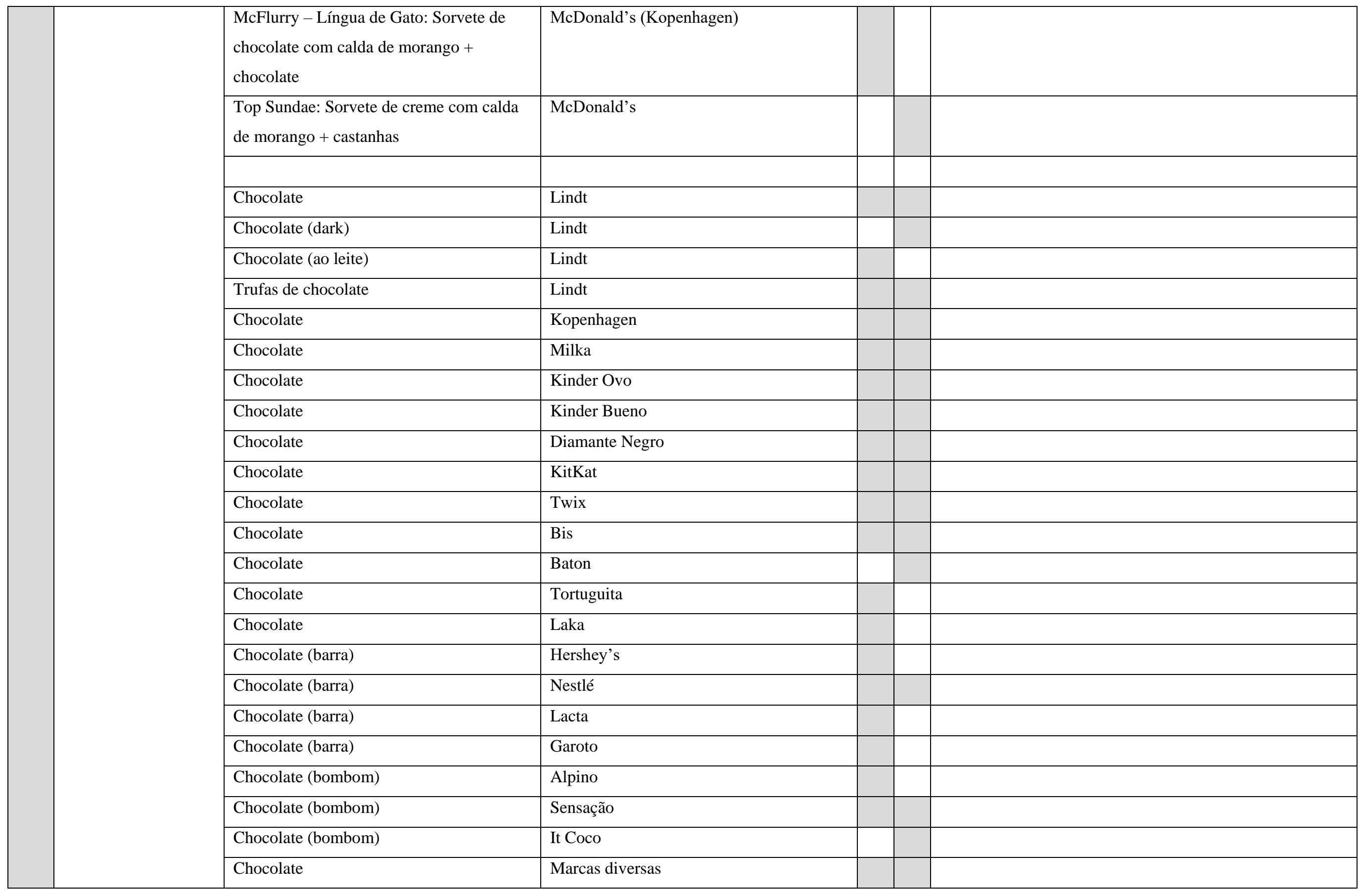




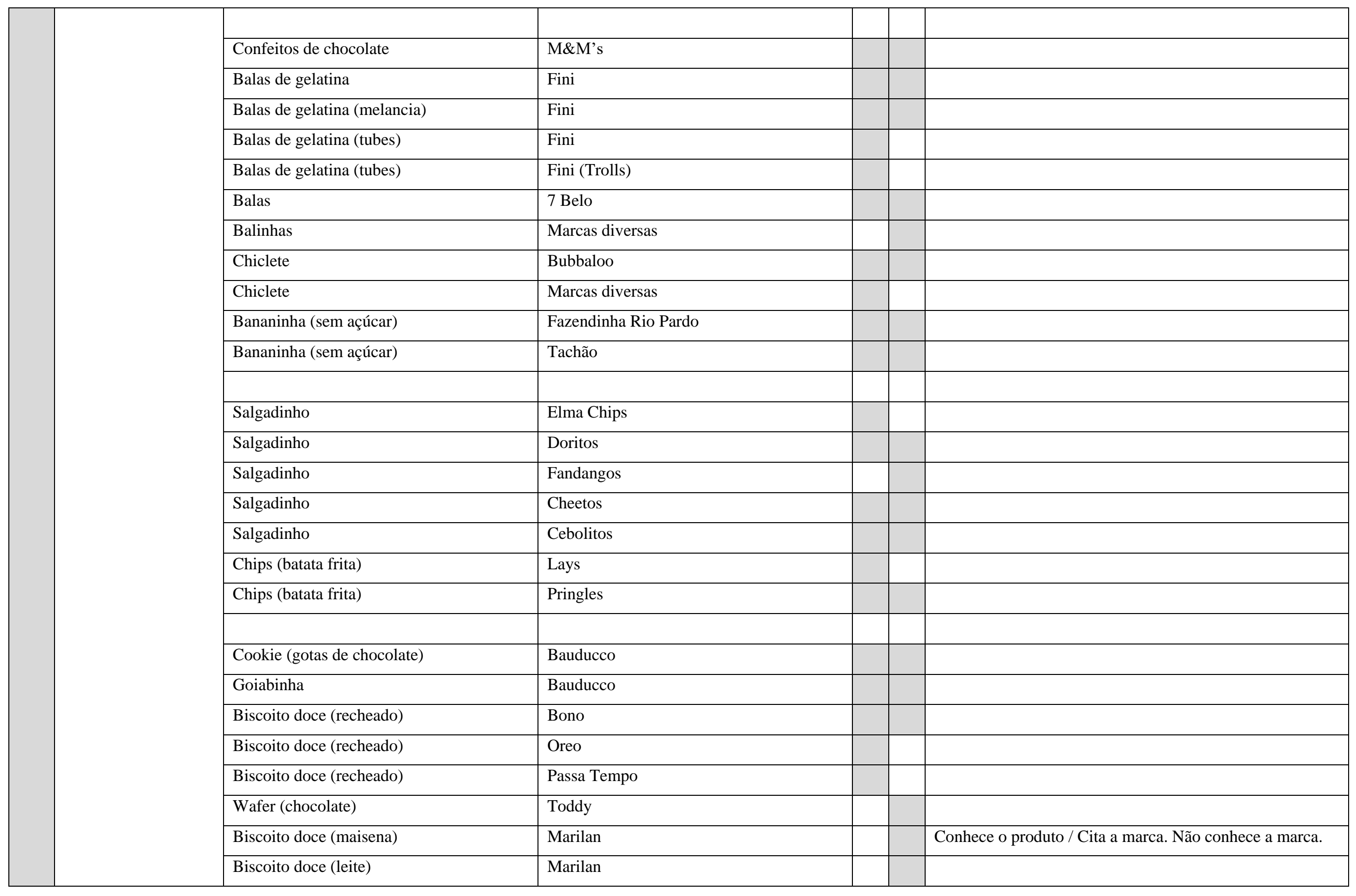




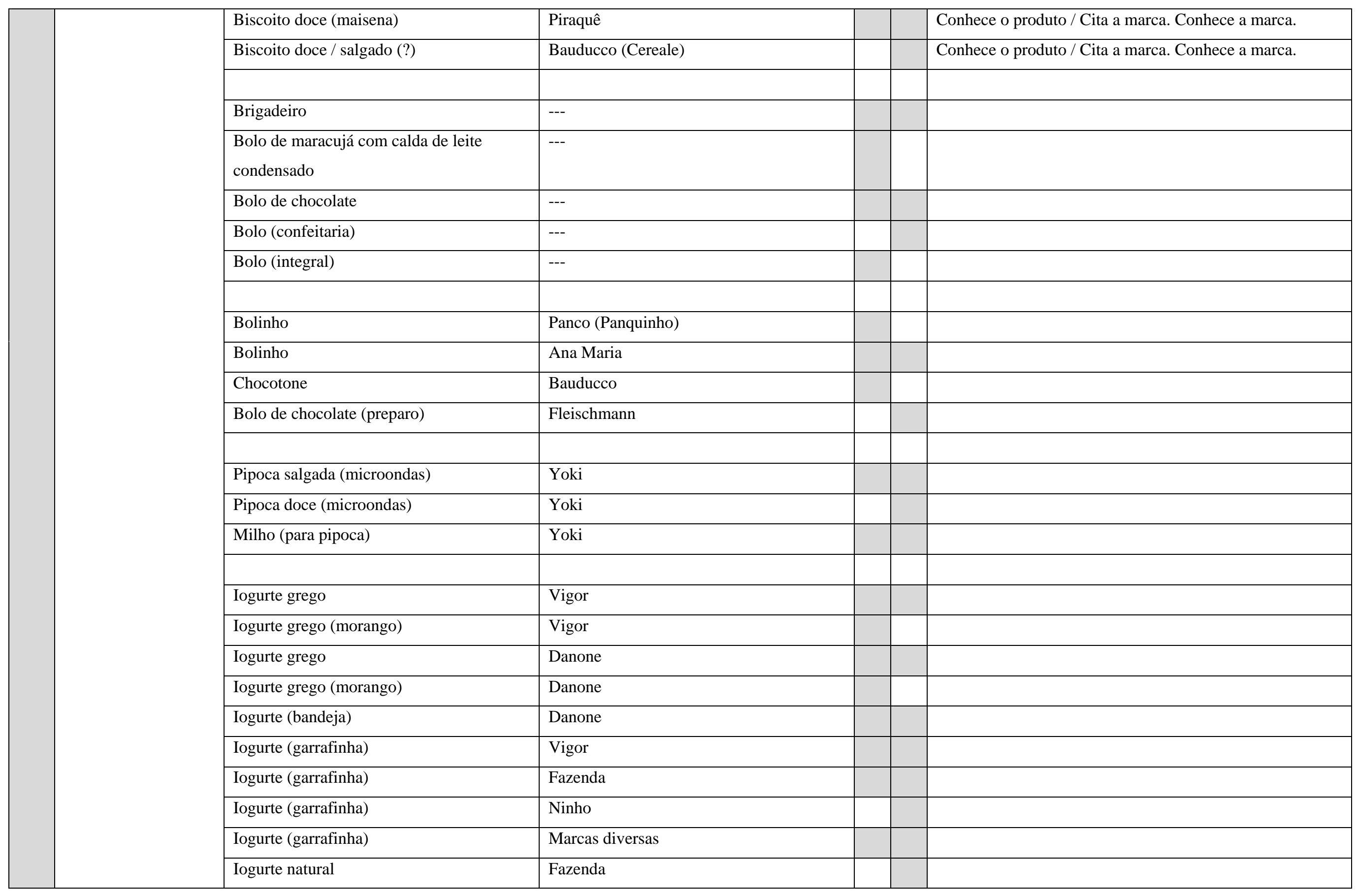




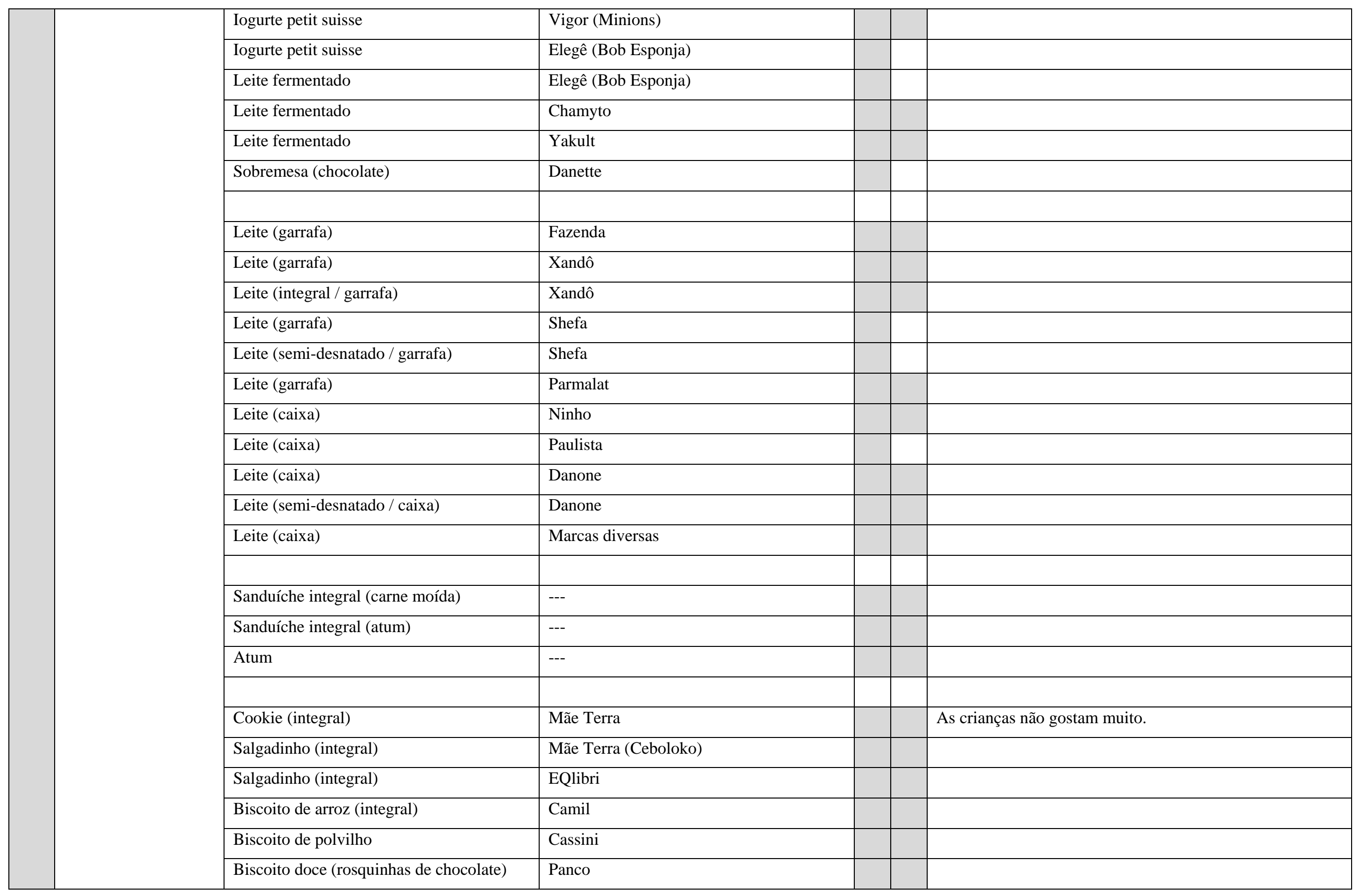




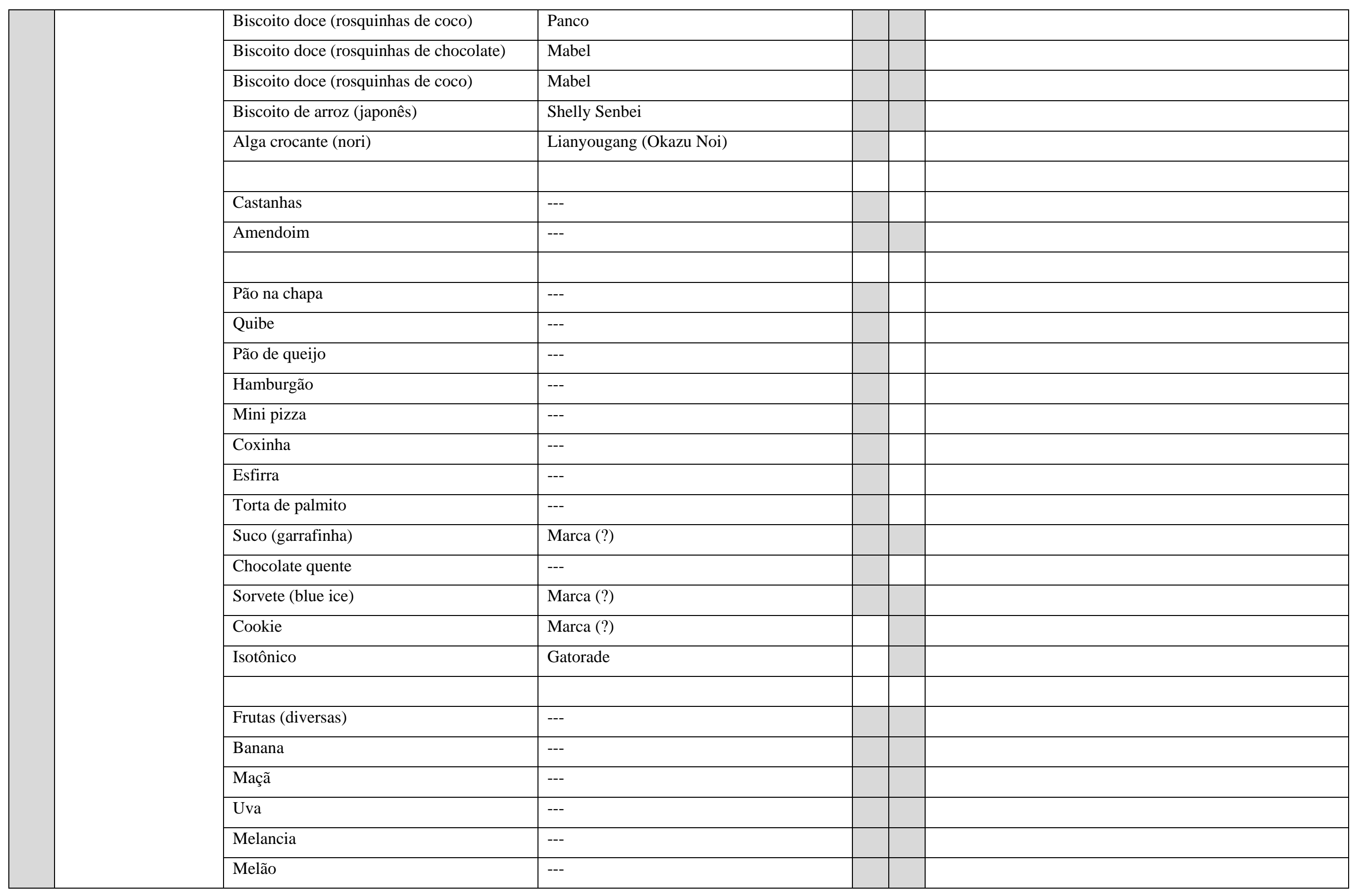




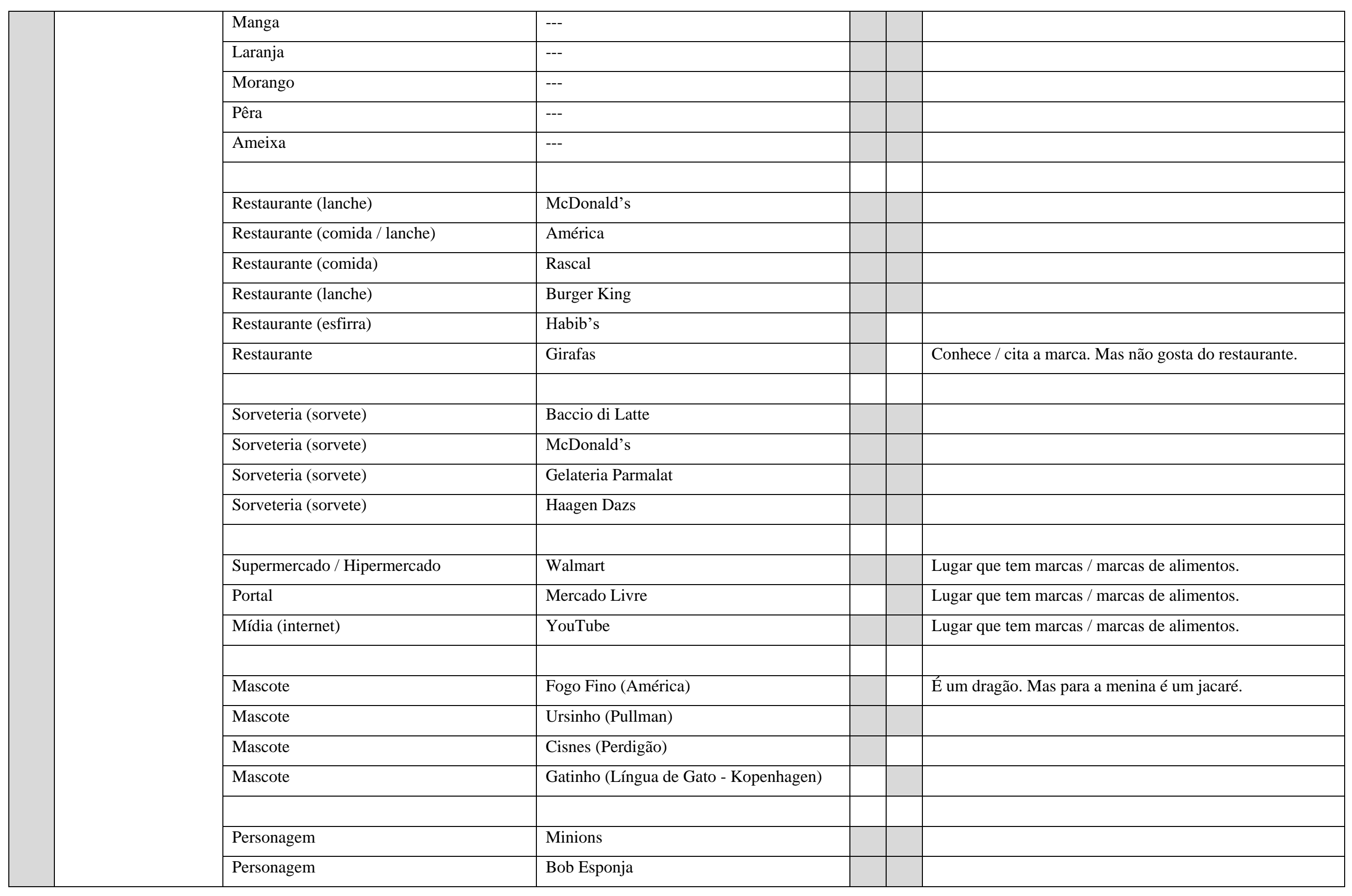




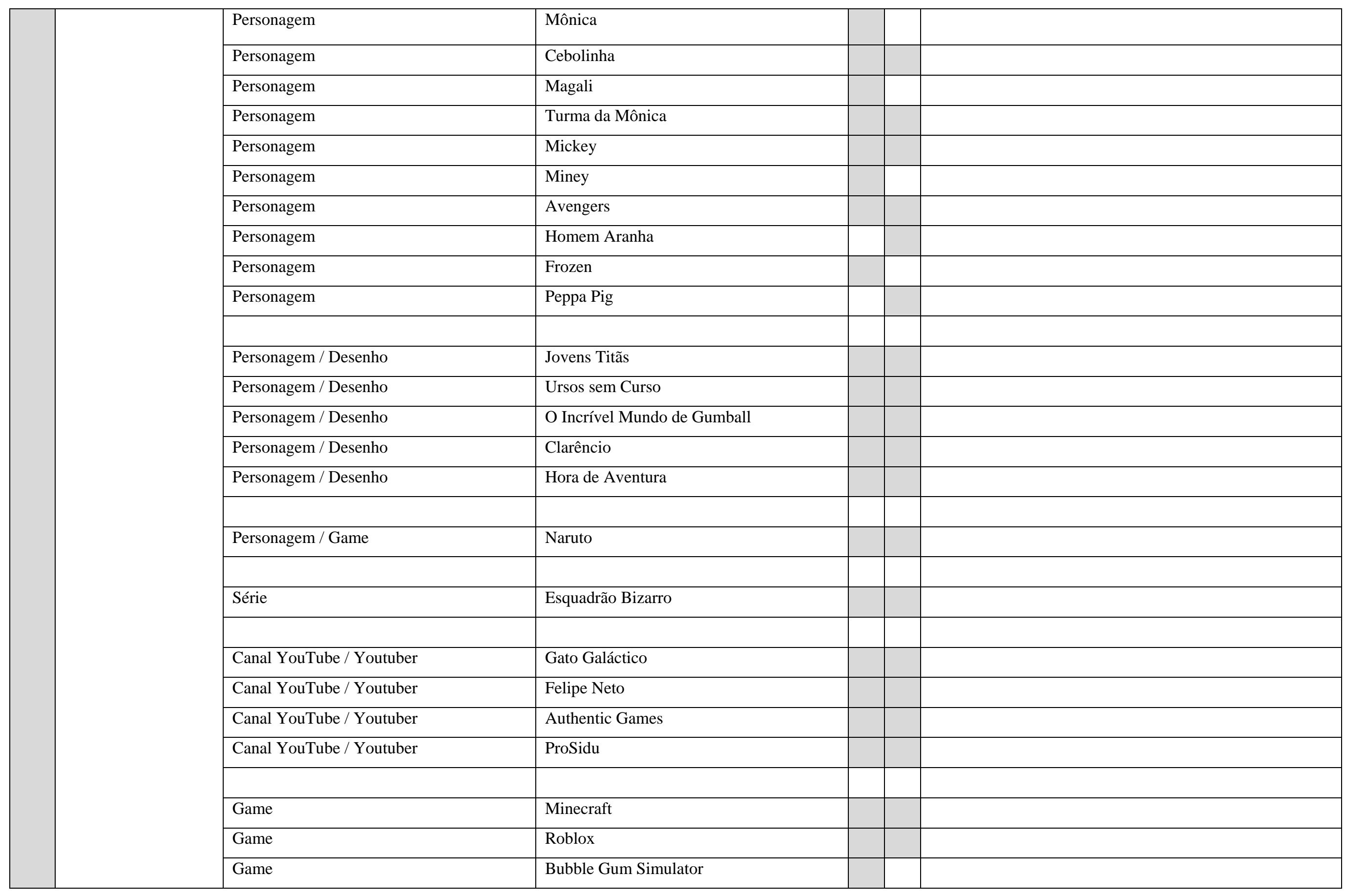




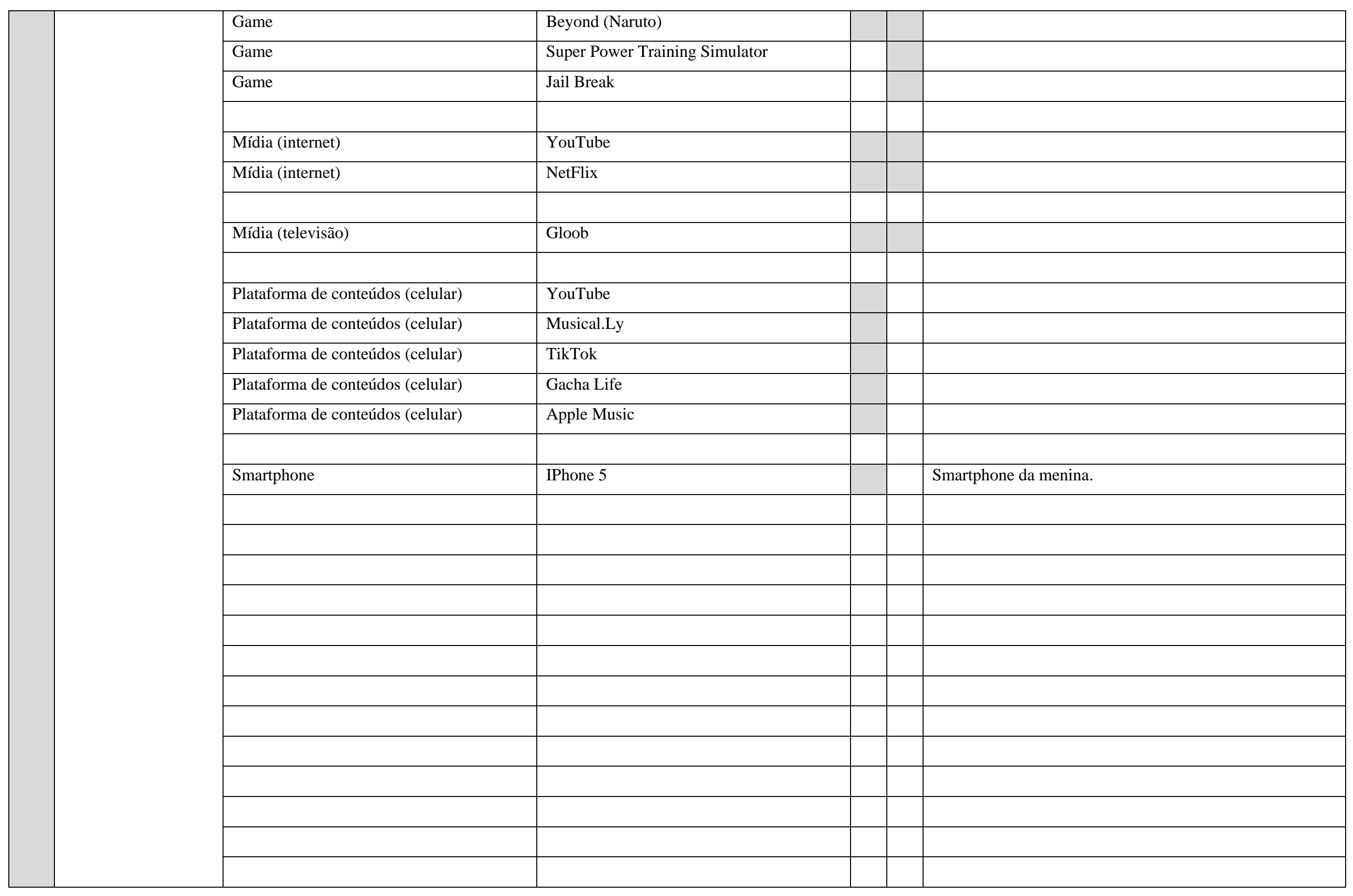




\begin{tabular}{|c|c|c|c|}
\hline \multirow{4}{*}{$\begin{array}{c}\text { QUE NÃO } \\
\text { CONHECE } \\
- \\
\text { QUE NÃO GOSTA }\end{array}$} & Carne & --- & \\
\hline & Tomate & --- & \\
\hline & Arroz & --- & \\
\hline & Feijão & --- & \\
\hline \multirow{3}{*}{$\begin{array}{c}\text { QUE NAO GOSTA } \\
\text { - } \\
\text { QUE GOSTA } \\
\text { MENOS }\end{array}$} & Macarrão & Adria & Não conhece a marca. Estranhamento. \\
\hline & & & \\
\hline & Refrigerante & --- & \\
\hline \multirow{16}{*}{$\begin{array}{c}\text { MENOS } \\
- \\
\text { QUE NÃO } \\
\text { CONSOME }\end{array}$} & Tangerina & --- & \\
\hline & & & \\
\hline & Pizza & Pizza Hut & \\
\hline & Hambúrguer & Bob's & \\
\hline & Restaurante & Giraffa's & \\
\hline & Pão de queijo & --- & \\
\hline & Cookie (integral) & Mãe Terra & As crianças não gostam muito. \\
\hline & Biscoito salgado (gergelim) & Piraquê & \\
\hline & Biscoito doce / salgado & Piraquê & \\
\hline & Biscoito doce / salgado & Marilan (?) & Não conhece a marca. Estranhamento. \\
\hline & Biscoito doce (recheado) & Trakinas & Não conhece a marca. Estranhamento. \\
\hline & Balas de gelatina & Haribo & \\
\hline & Chocolate & Hershey's (?) & Não conhece a marca. Trolagem. (?) \\
\hline & Achocolatado (caixinha) & ChocoLeco & Não conhece a marca. Estranhamento. \\
\hline & Achocolatado (caixinha) & Danone (Dori) & Não conhece o produto. Estranhamento. \\
\hline & Requeijão cremoso & Polenghi & \\
\hline
\end{tabular}




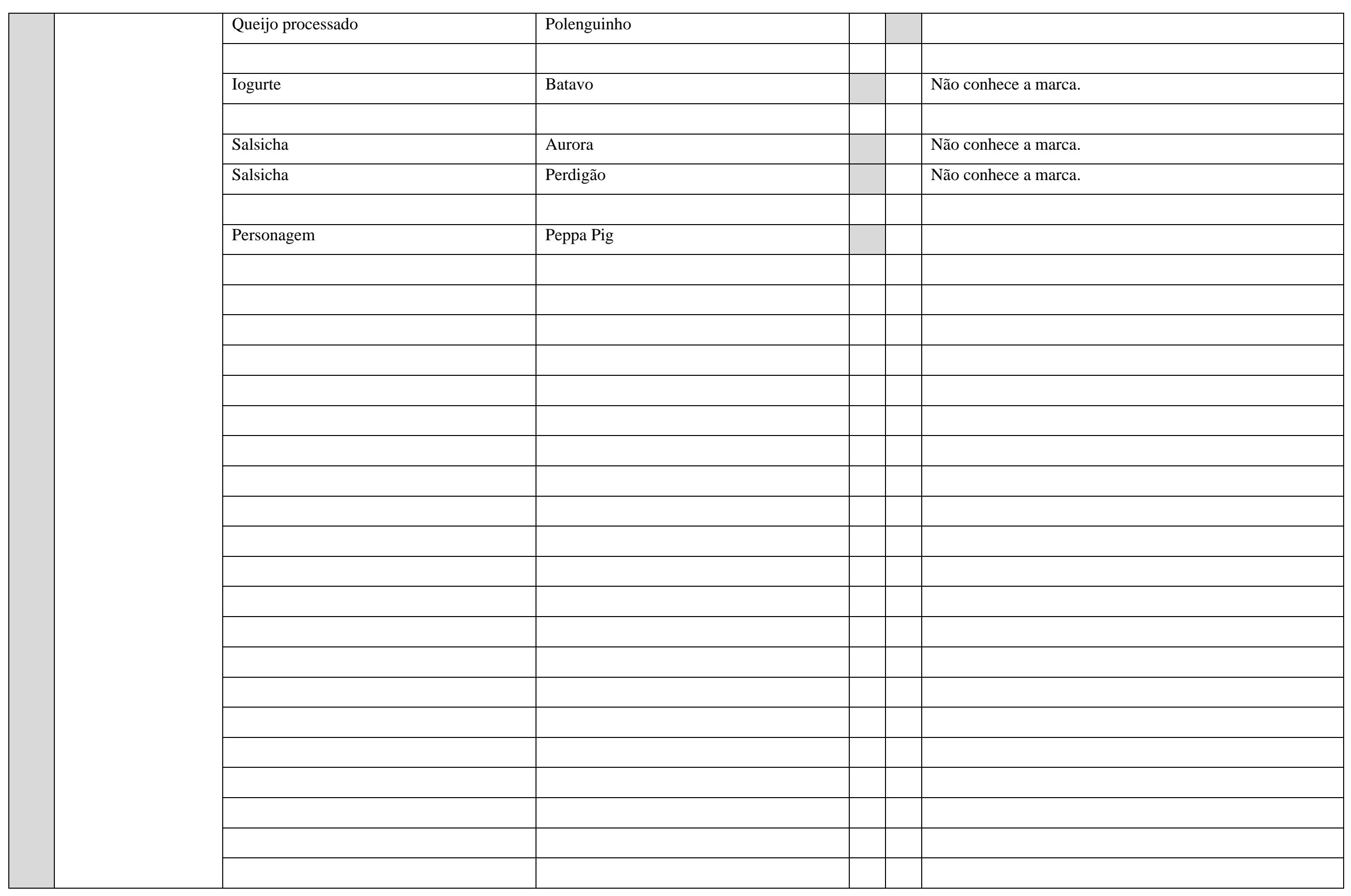




\section{QUARTO ENCONTRO: ATIVIDADE LÚDICA COM AS CRIANÇAS: BRINCADEIRA DE COMER}

PRODUTOS - MARCAS - PERSONAGENS

(RELATOS / OBSERVAÇÕES / CITAÇÕES / EXPRESSIVIDADES / FOTOS / VÍDEOS / OBSERVAÇÃ̃)

\begin{tabular}{|c|c|c|c|c|c|c|}
\hline \multicolumn{2}{|r|}{ ATIVIDADE } & ALIMENTO / PRODUTO & MARCA / PERSONAGEM & $\mathbf{F}$ & $\mathbf{C}$ & OBSERVAÇÃO \\
\hline \multirow[b]{3}{*}{$\mathbf{C}$} & \multirow[t]{16}{*}{ CAFÉ DA MANHÃ } & \multicolumn{5}{|l|}{ MENINA: } \\
\hline & & Leite (garrafa) & Shefa & & & \\
\hline & & Achocolatado (em pó) & Nescau & & & \\
\hline \multirow{3}{*}{$\begin{array}{l}\mathbf{A} \\
\mathbf{R} \\
\mathbf{D}\end{array}$} & & Pão francês & --- & & & \\
\hline & & Margarina & Doriana & & & \\
\hline & & Suco natural (uva) & $\begin{array}{ll}-- \\
\end{array}$ & & & Para ela é suco de amora. \\
\hline $\mathbf{S}$ & & Sorvete & Bacio di Latte & & & \\
\hline A & & \multicolumn{5}{|l|}{ MENINO: } \\
\hline \multirow{2}{*}{$\begin{array}{l}\mathbf{L} \\
\mathbf{I}\end{array}$} & & Leite (garrafa) & Parmalat & & & \\
\hline & & Suco (caixinha) & Ades & & & \\
\hline \multirow{2}{*}{$\begin{array}{l}\text { M } \\
\mathbf{E}\end{array}$} & & Melancia & --- & & & \\
\hline & & Banana & --- & & & \\
\hline \multirow{2}{*}{$\begin{array}{l}\mathbf{N} \\
\mathbf{T}\end{array}$} & & Sorvete & Bacio di Latte & & & \\
\hline & & Sorvete (picolé) & Kibon & & & \\
\hline \multirow{2}{*}{$\begin{array}{l}\mathbf{O} \\
\mathbf{S}\end{array}$} & & [Bisnaguinha] & [Pullman (Bisnaguito)] & & & Ele escolheu. Mas desistiu. \\
\hline & & [Pizza] & [Pizza Hut] & & & Ele escolheu. Mas desistiu. \\
\hline
\end{tabular}




\begin{tabular}{|c|c|c|c|}
\hline \multirow[t]{12}{*}{ ALMOÇO } & \multicolumn{3}{|l|}{ MENINA: } \\
\hline & Hambúrguer & McDonald's & \\
\hline & Suco natural (uva) & --- & Para ela é suco de amora. \\
\hline & Sorvete (casquinha / chocolate) & McDonald's & \\
\hline & [Brócolis] & --- & Ela escolheu. Mas desistiu. Trocou por lanche. \\
\hline & [Feijão (preto)] & --- & Ela escolheu. Mas desistiu. Trocou por lanche. \\
\hline & [Arroz (branco)] & --- & Ela escolheu. Mas desistiu. Trocou por lanche. \\
\hline & \multicolumn{3}{|l|}{ MENINO: } \\
\hline & Hambúrguer & McDonald's & \\
\hline & Refrigerante & Coca-Cola & \\
\hline & Sorvete (casquinha) & McDonald's & \\
\hline & [Refrigerante (laranja)] & [Fanta] & Ele escolheu. Mas desistiu. Trocou por Coca-Cola. \\
\hline \multirow[t]{11}{*}{ JANTAR } & \multicolumn{3}{|l|}{ MENINA: } \\
\hline & Arroz (branco) & --- & \\
\hline & Feijão (preto) & --- & \\
\hline & Morango & --- & \\
\hline & Bolo de chocolate & --- & \\
\hline & Achocolatado (caixinha) & Toddynho & \\
\hline & \multicolumn{3}{|l|}{ MENINO: } \\
\hline & Ovos & --- & \\
\hline & Banana & --- & \\
\hline & Suco natural (laranja) & --- & \\
\hline & Gelatina & Royal & \\
\hline
\end{tabular}




\begin{tabular}{|c|c|c|c|}
\hline \multirow{11}{*}{$\begin{array}{c}\text { LANCHE } \\
\text { DA ESCOLA }\end{array}$} & \multicolumn{3}{|l|}{ MENINA: } \\
\hline & Cachorro-Quente & --- & \\
\hline & Água mineral (garrafinha) & Crystal & \\
\hline & Banana & --- & \\
\hline & Iogurte grego (morango) & Danone & \\
\hline & MENINO. & & \\
\hline & \multicolumn{3}{|l|}{ MENINO: } \\
\hline & Biscoito doce (leite) & Marilan & Para ele é biscoito doce (maisena). \\
\hline & Iogurte petit suisse (morango) & Vigor (Minions) & \\
\hline & Banana & --- & \\
\hline & Suco (caixinha) & Del Valle (Kapo) & \\
\hline \multirow{15}{*}{$\begin{array}{c}\text { LANCHE } \\
\text { COM AMIGOS }\end{array}$} & \multicolumn{3}{|l|}{ MENINA: } \\
\hline & Hambúrguer & McDonald's & \\
\hline & Sorvete (casquinha / chocolate) & McDonald's & \\
\hline & Brigadeiro & --- & \\
\hline & Balas & 7 Belo & \\
\hline & Macarrão instantâneo & Miojo (Turma da Mônica) & \\
\hline & \multicolumn{3}{|l|}{ MENINO: } \\
\hline & Pão francês & --- & \\
\hline & Margarina & Doriana & \\
\hline & Achocolatado (caixinha) & Toddynho & \\
\hline & Suco natural (goiaba) & --- & \\
\hline & Brigadeiro & --- & \\
\hline & Balas & 7 Belo & \\
\hline & & & \\
\hline & & & \\
\hline
\end{tabular}




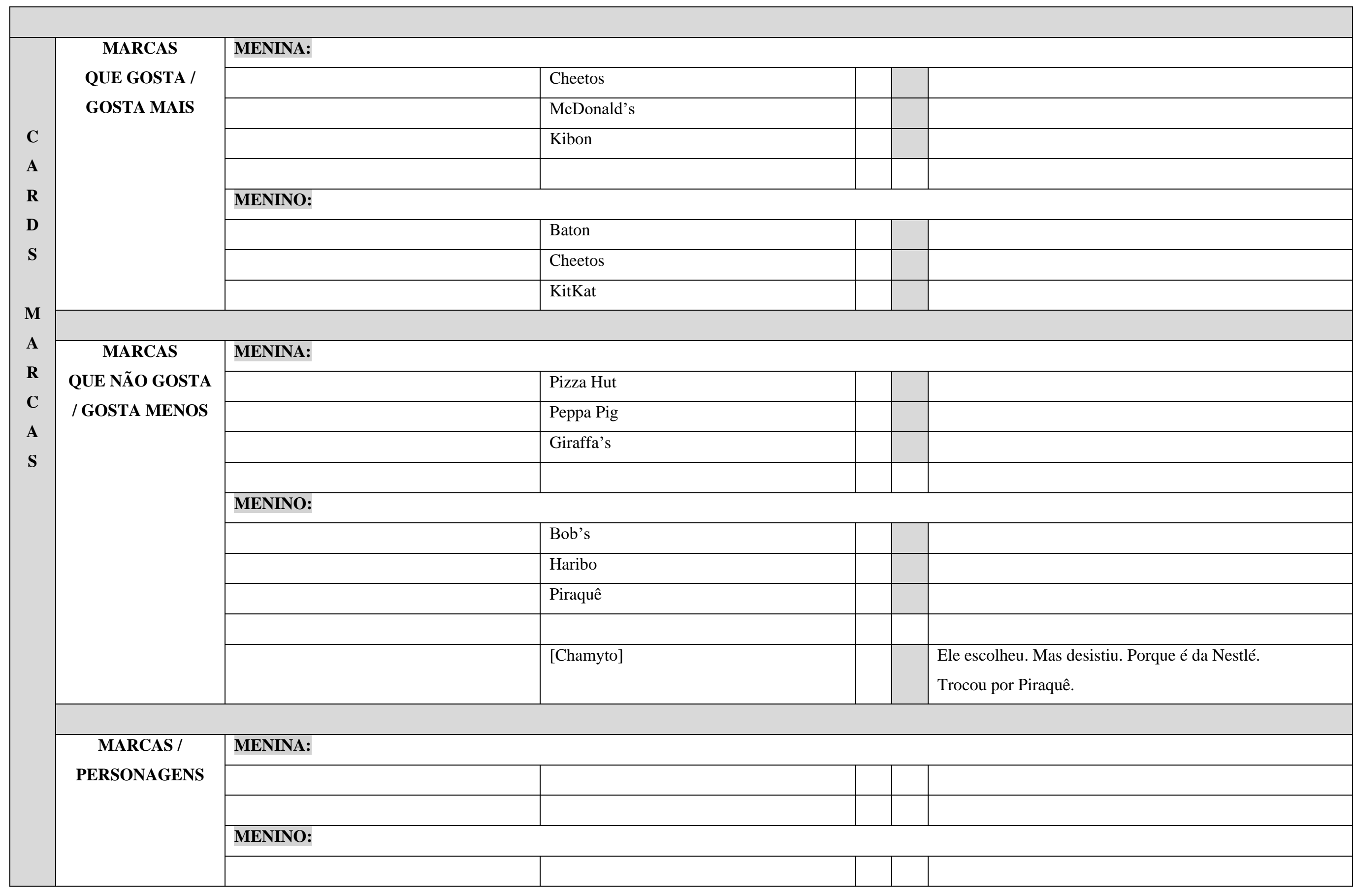




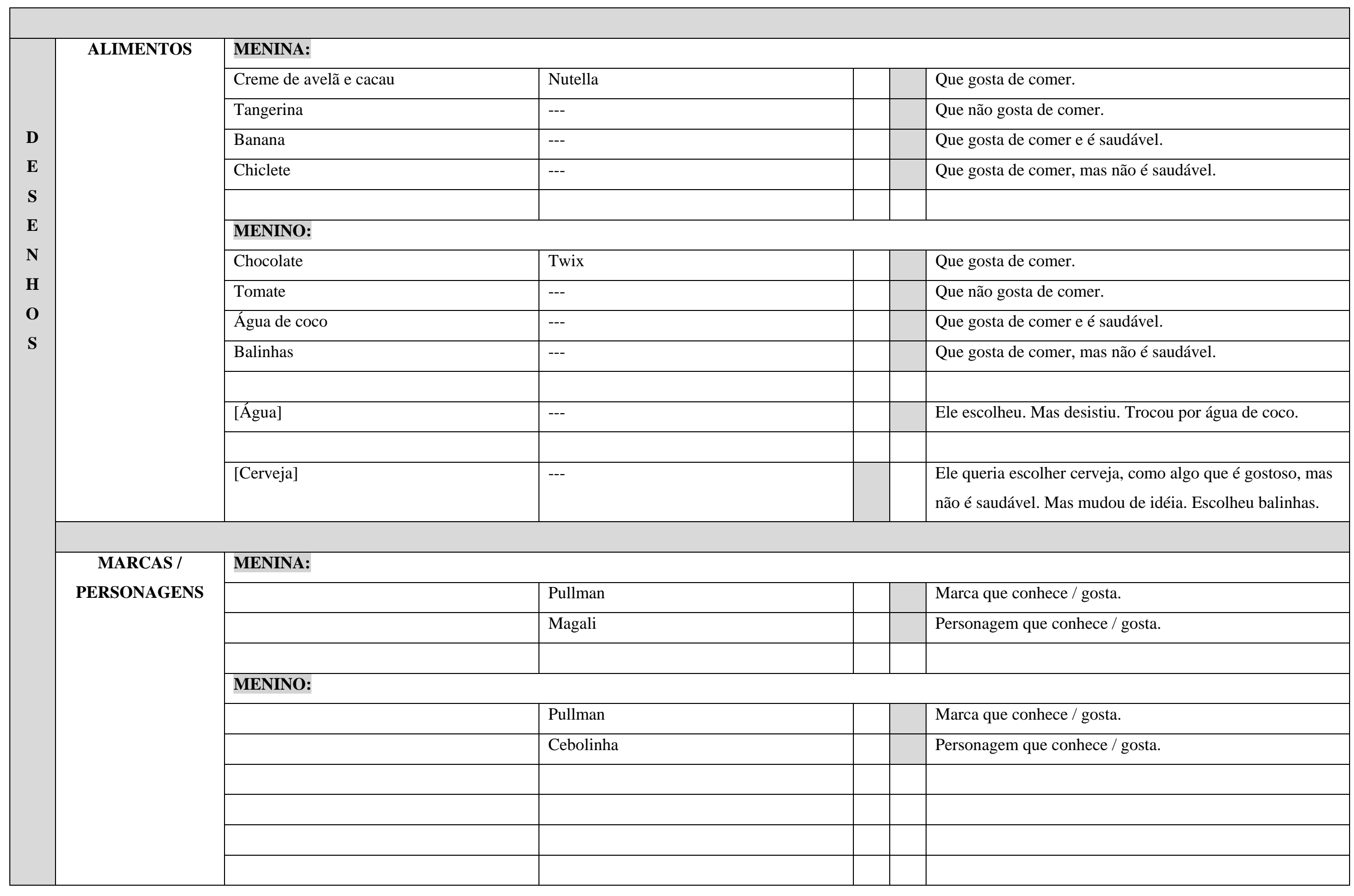




\section{QUINTO ENCONTRO: ATIVIDADE LÚDICA COM AS CRIANÇAS: BRINCADEIRA DE COMPRAR}

PRODUTOS - MARCAS - PERSONAGENS

(RELATOS / OBSERVAÇÕES / CITAÇÕES / EXPRESSIVIDADES / FOTOS / VÍDEOS / OBSERVAÇÃ̃)

\begin{tabular}{|c|c|c|c|c|c|c|}
\hline & ATIVIDADE & ALIMENTO / PRODUTO & MARCA / PERSONAGEM & $\mathbf{F}$ & $\mathbf{C}$ & OBSERVAÇÃO \\
\hline \multirow[b]{2}{*}{$\mathbf{S}$} & \multirow[t]{16}{*}{ CARRINHO } & \multicolumn{5}{|l|}{ MENINA: } \\
\hline & & Sobremesa (chocolate) & Danette & & & \\
\hline \multirow{2}{*}{$\begin{array}{c}\mathbf{I} \\
\mathbf{M}\end{array}$} & & Achocolatado (em pó) & Nescau & & & \\
\hline & & Balas de gelatina (melancia) & Fini & & & \\
\hline \multirow[t]{2}{*}{$\mathbf{U}$} & & Chips (batata frita) & Lays & & & \\
\hline & & Leite (semi-desnatado / garrafa) & Shefa & & & \\
\hline \multicolumn{6}{|l|}{ A } & \\
\hline \multirow{3}{*}{$\begin{array}{l}\text { Ç } \\
\tilde{\mathbf{A}} \\
\mathbf{O}\end{array}$} & & [Chocotone] & [Bauducco] & & & $\begin{array}{l}\text { Ela escolheu. Mas desistiu. } \\
\text { Trocou por balas de gelatina Fini. }\end{array}$ \\
\hline & & & & & & \\
\hline & & MENINO: & & & & \\
\hline \multirow[b]{2}{*}{$\mathbf{O}$} & & Suco (morango / caixinha) & Vigor (Minions) & & & \\
\hline & & Manga & --- & & & \\
\hline \multirow{2}{*}{$\begin{array}{l}\mathbf{M} \\
\mathbf{P}\end{array}$} & & Banana & --- & & & \\
\hline & & Cereais (sucrilhos) & Kellogg's (Star Wars) & & & \\
\hline \multirow{2}{*}{$\begin{array}{l}\mathbf{R} \\
\mathbf{A}\end{array}$} & & Balas de gelatina (melancia) & Fini & & & \\
\hline & & & & & & \\
\hline
\end{tabular}




\section{APRESENTAÇÃO MENINA:}

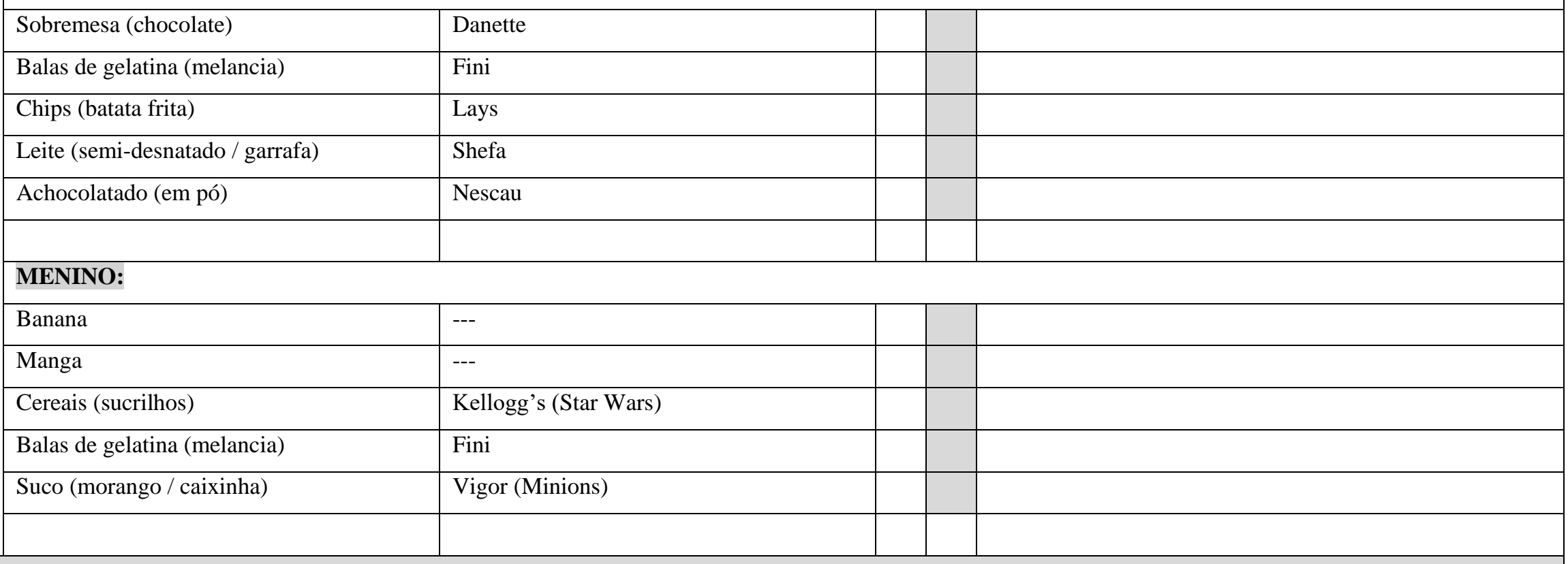

\section{QUE MAIS GOSTA MENINA:}

\begin{tabular}{|l|l|l|l|l|}
\hline MENINA: & & \\
\hline & & & & \\
\hline & & & & \\
\hline & & & & \\
\hline & & & & \\
\hline & & & & \\
\hline & & & \\
\hline & & & & \\
\hline & & & & \\
\hline & & & & \\
\hline & & & & \\
\hline
\end{tabular}




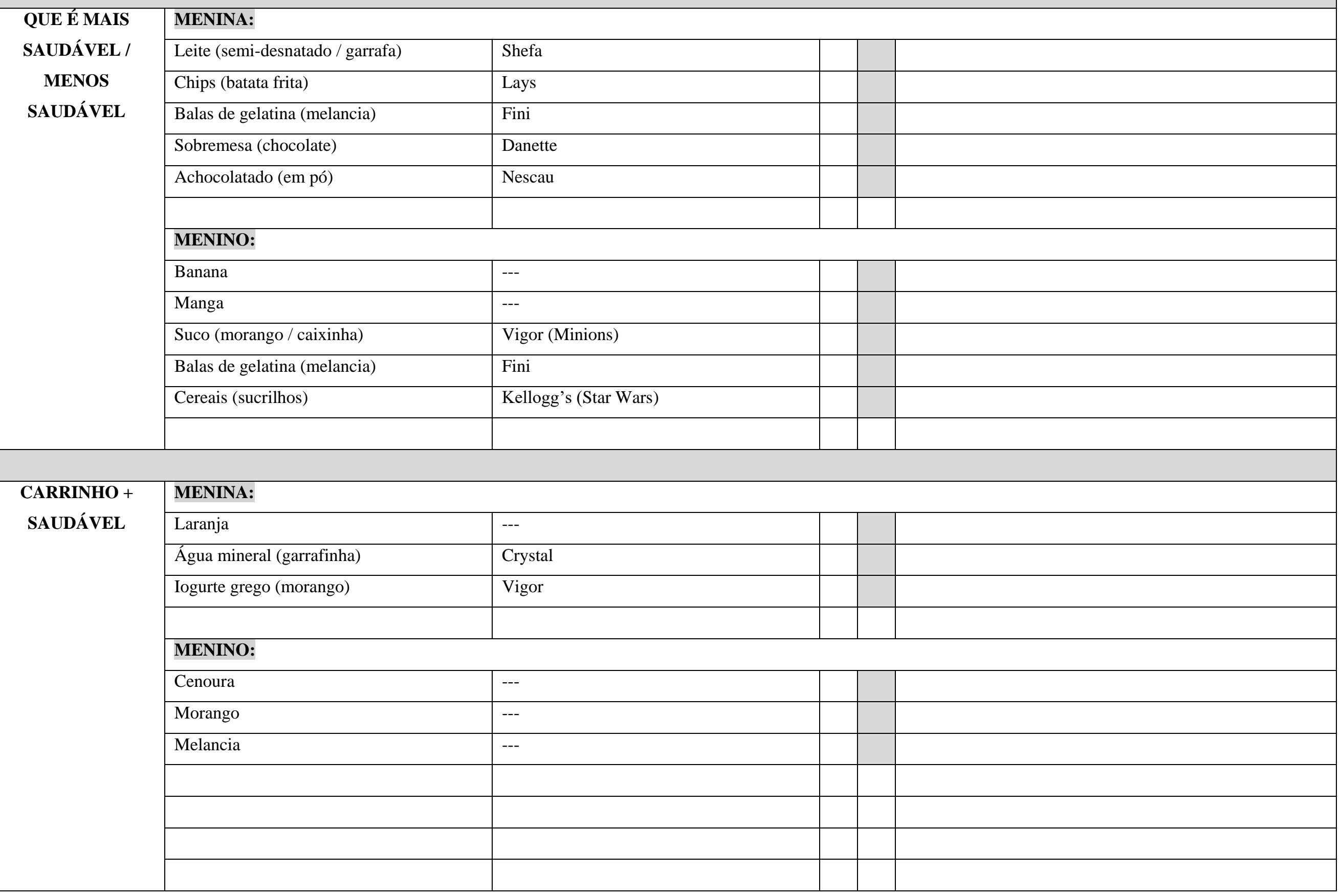




\section{PARA LEVAR}

PRA CASA

\section{MENINA:}

\begin{tabular}{|c|c|c|}
\hline Balas de gelatina (melancia) & Fini & \\
\hline Chips (batata frita) & Lays & \\
\hline Sobremesa (chocolate) & Danette & \\
\hline Leite (semi-desnatado / garrafa) & Shefa & \\
\hline [Água mineral (garrafinha)] & [Crystal] & $\begin{array}{l}\text { Ela pensou em levar a água. Mas desistiu. } \\
\text { Porque água tem em casa. }\end{array}$ \\
\hline \multicolumn{3}{|l|}{ MENINO: } \\
\hline Melancia & --- & \\
\hline Morango & --- & \\
\hline Balas de gelatina (melancia) & Fini & \\
\hline Banana & --- & \\
\hline & & \\
\hline & & \\
\hline & & \\
\hline & & \\
\hline & & \\
\hline & & \\
\hline & & \\
\hline & & \\
\hline & & \\
\hline & & \\
\hline & & \\
\hline & & \\
\hline
\end{tabular}




\section{SEXTO ENCONTRO: ATIVIDADE LÚDICA COM AS CRIANÇAS: THE KIDS: MY FOODS}

PRODUTOS - MARCAS - PERSONAGENS

(RELATOS / OBSERVAÇÕES / CITAÇÕES / EXPRESSIVIDADES / FOTOS / VÍDEOS / OBSERVAÇÃO)

ATIVIDADE MY FOODS!

\begin{tabular}{|c|c|}
\hline ALIMENTO / PRODUTO & MARCA / PERSONAGEM \\
\hline \multicolumn{2}{|l|}{ MENINA: } \\
\hline Leite (integral / garrafa) & Xandô \\
\hline Sorvete (napolitano) & Kibon (?) \\
\hline Leite fermentado & Yakult \\
\hline Waffle & Forno de Minas \\
\hline Pipoca salgada (microondas) & Yoki \\
\hline Salsicha & Sadia \\
\hline Cookie (gotas de chocolate) & Bauducco \\
\hline Bananinha (sem açúcar) & Fazendinha Rio Pardo \\
\hline Trufas de chocolate & Lindt \\
\hline & \\
\hline & \\
\hline & \\
\hline & \\
\hline & \\
\hline & \\
\hline & \\
\hline
\end{tabular}

\begin{tabular}{|l|l|l}
\hline F & C & OBSERVAÇÃO
\end{tabular}

\begin{tabular}{|l|l|l|}
\hline & & \\
\hline & & \\
\hline & & \\
\hline & & \\
\hline & & \\
\hline & & \\
\hline & & \\
\hline & & \\
\hline & & \\
\hline & & \\
\hline & & \\
\hline & & \\
\hline & & \\
\hline
\end{tabular}




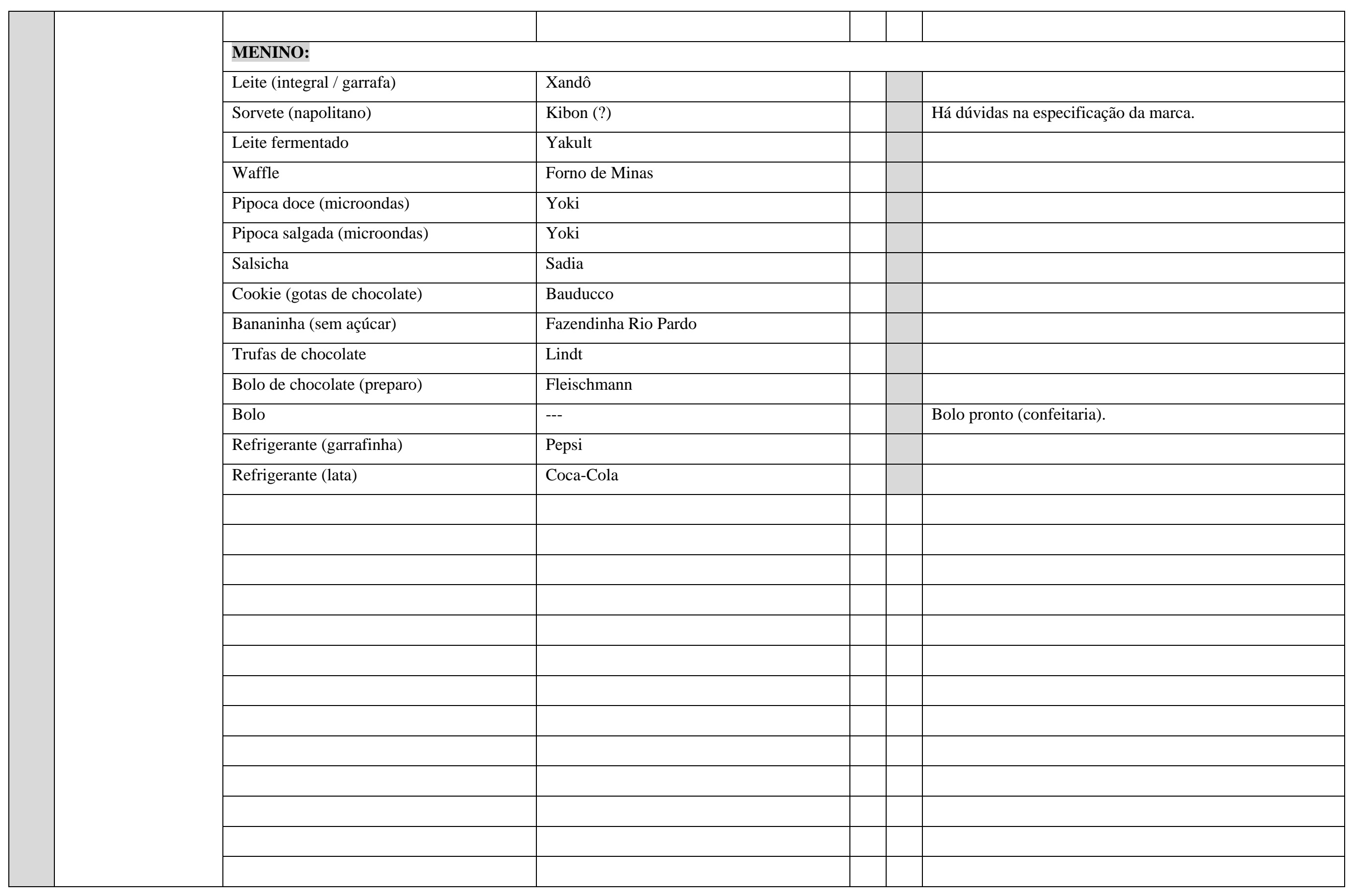




\section{Observações:}

$\mathrm{F}=$ Para a família (os pais e as crianças)

$\mathrm{C}=$ Para as crianças

$\mathrm{C} 1$ = Para a menina / Preferência da menina

$\mathrm{C} 2$ = Para o menino / Preferência do menino

Presença material $=$ Marcas e produtos alimentícios que a família $/$ as crianças consomem .

Presença simbólica = Marcas e produtos alimentícios que a família / as crianças gostariam de consumir.

(?) = Dúvidas quanto à especificação das marcas e produtos alimentícios em fotografias, vídeos ou relatos. 


\section{APÊNDICE O}

PESQUISA DE CAMPO

MARCAS E PRODUTOS NO CONTEXTO FAMILIAR

FAMÍLIA II

MARCAS E PRODUTOS: PRESENÇA MATERIAL E SIMBÓLICA 


\section{F A M Í L I A}

\section{MARCAS E PRODUTOS ALIMENTÍCIOS NO AMBIENTE DOMÉSTICO E ESPAÇO PÚBLICO (RELATOS / OBSERVAÇÕES / CITAÇÕES / EXPRESSIVIDADES)}

\begin{tabular}{|c|c|c|c|c|c|c|}
\hline \multicolumn{2}{|r|}{ NATUREZA } & ALIMENTO / PRODUTO & MARCA / PERSONAGEM & $\mathbf{F}$ & $\mathbf{C}$ & OBSERVAÇÃO \\
\hline \multirow{3}{*}{$\mathbf{C}$} & \multirow{5}{*}{$\begin{array}{c}\text { CONSUMO } \\
\text { POR MARCAS } \\
- \\
\text { DESEJO DE } \\
\text { CONSUMO POR } \\
\text { MARCAS }\end{array}$} & Bisnaguinha & Pullman & & & \\
\hline & & Bisnaguinha & WickBold & & & \\
\hline & & Bisnaguinha & Seven Boys & & & \\
\hline $\begin{array}{l}\mathbf{N} \\
\mathbf{S}\end{array}$ & & Bisnaguinha (queijo com chocolate) & Seven Boys & & & Para a menina. Ela gosta muito. \\
\hline \multirow{2}{*}{$\begin{array}{c}\mathbf{U} \\
\mathbf{M}\end{array}$} & & Bisnaguinha (Egg Esponge) & Panco & & & $\begin{array}{l}\text { Para o menino. Ele gosta muito. } \\
\text { Compra às vezes. No Carrefour é mais barato. }\end{array}$ \\
\hline & & & & & & \\
\hline \multirow[t]{2}{*}{$\mathbf{O}$} & & Pães (diversos) & Pullman & & & A mãe compra na loja de fábrica. É mais barato. \\
\hline & & Bolos (diversos) & Pullman & & & A mãe compra na loja de fábrica. É mais barato. \\
\hline $\mathbf{A}$ & & & & & & \\
\hline \multirow[b]{2}{*}{ I } & & Pão de queijo (congelado) & Estrela Mineira & & & \\
\hline & & Pão de queijo (congelado) & Duduxo & & & \\
\hline \multirow{2}{*}{$\begin{array}{l}\text { M } \\
\text { E }\end{array}$} & & Waffle (congelado) & Forno de Minas & & & \\
\hline & & & & & & \\
\hline \multirow{2}{*}{$\mathbf{N}$} & & Margarina & Doriana & & & \\
\hline & & Margarina & Claybom & & & \\
\hline \multirow{2}{*}{$\begin{array}{l}\mathbf{A} \\
\mathbf{R}\end{array}$} & & & & & & \\
\hline & & Requeijão cremoso & Danone & & & Para as crianças. Elas gostam muito. \\
\hline
\end{tabular}




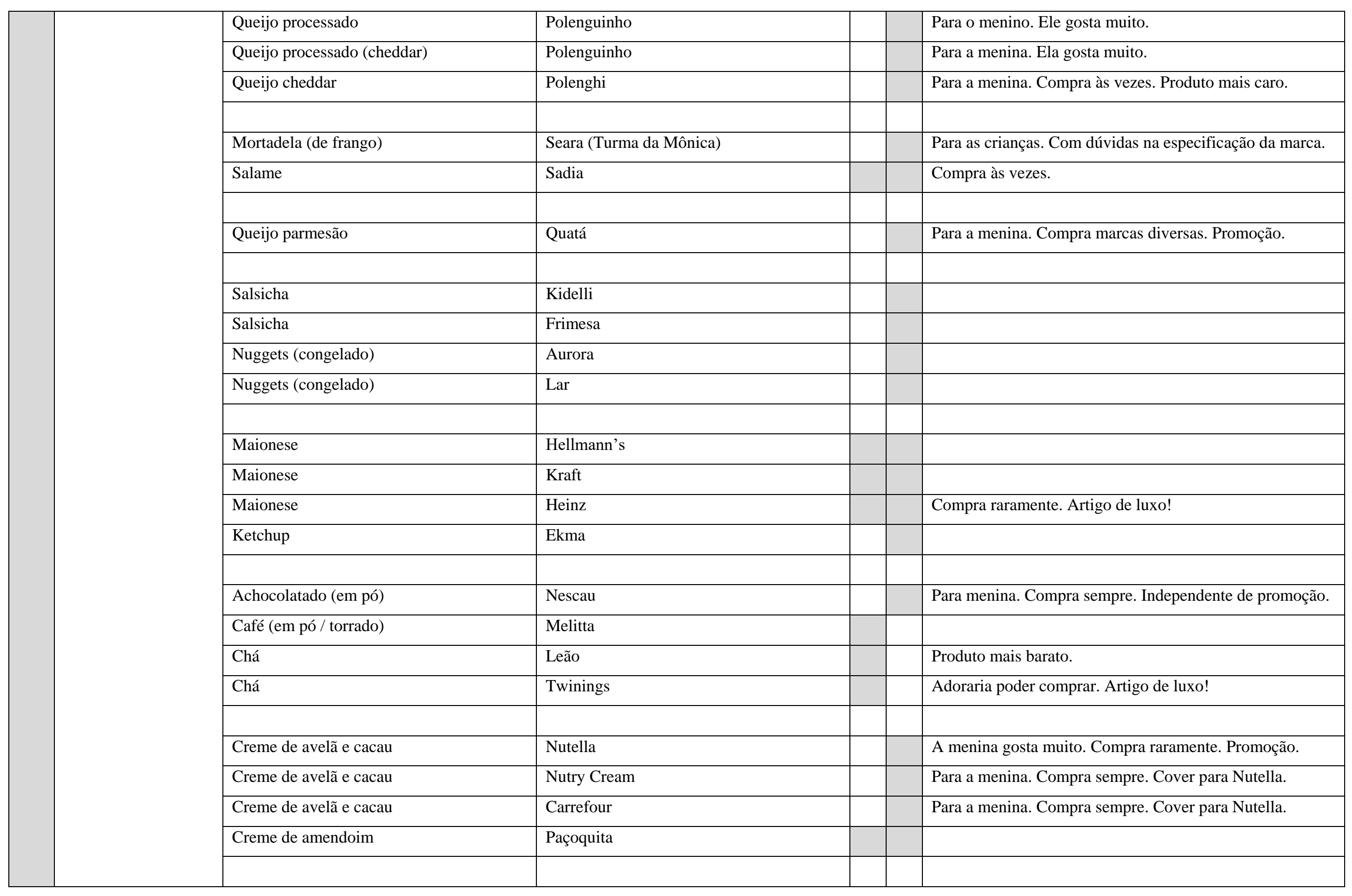




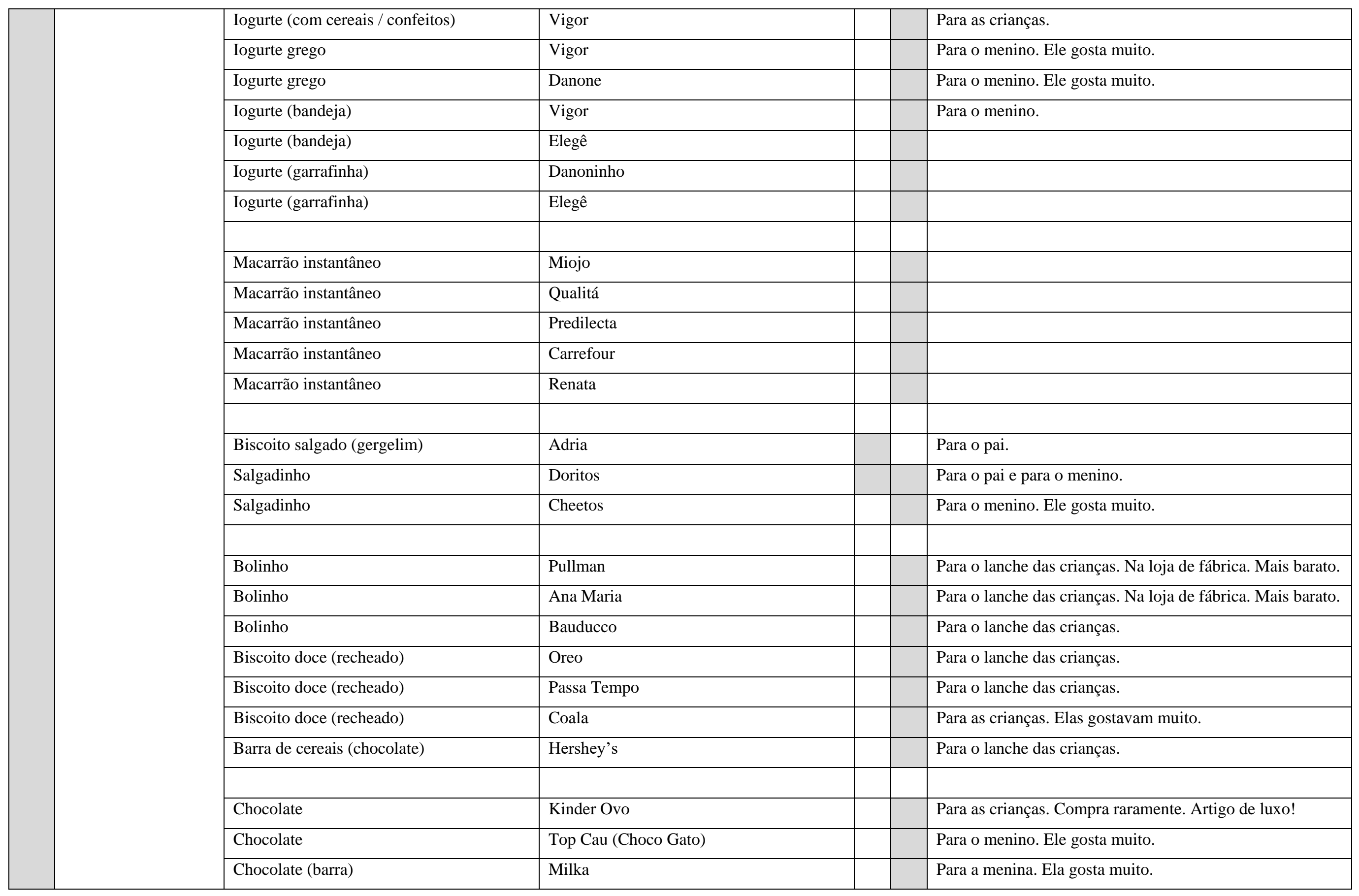




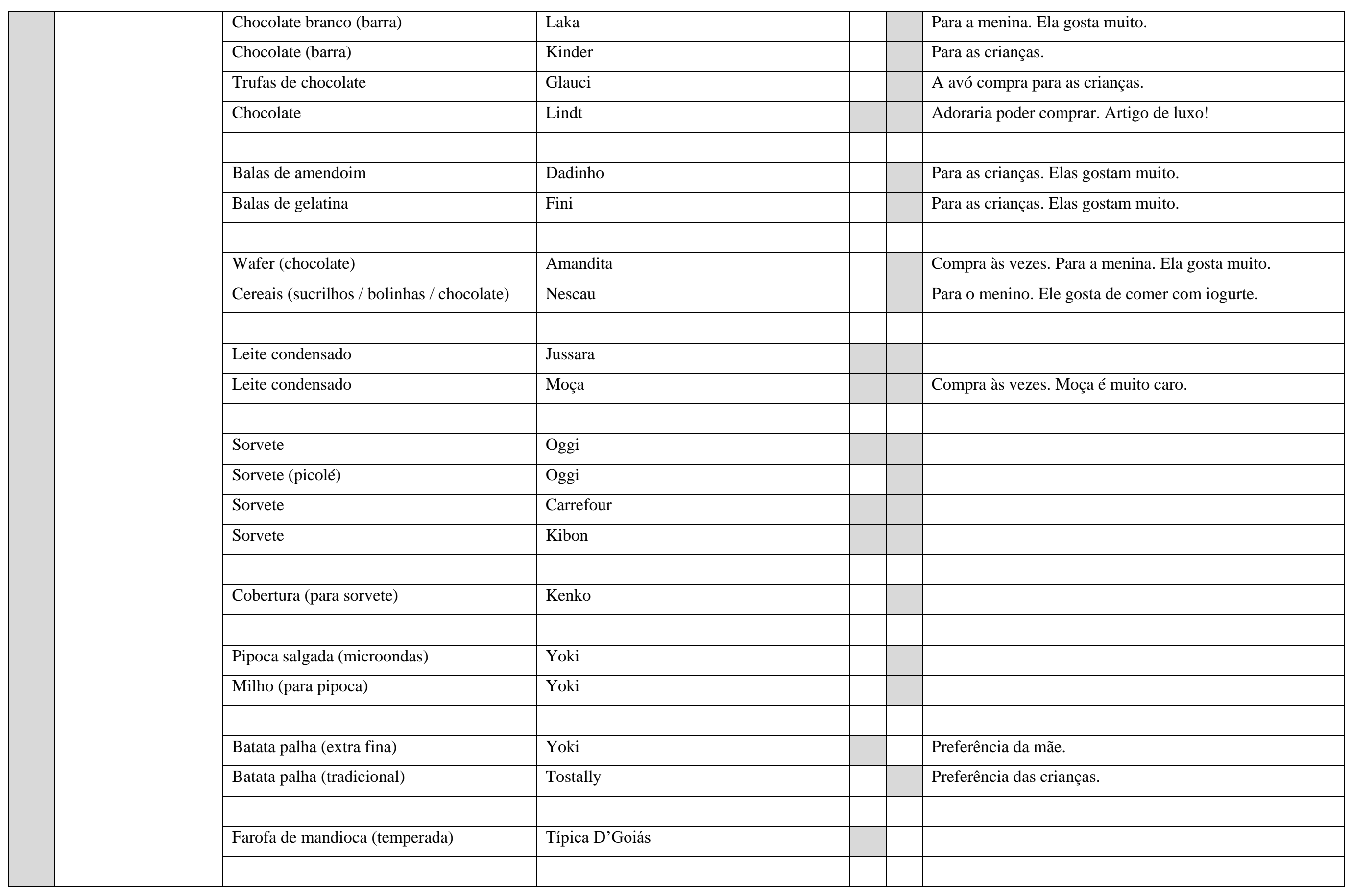




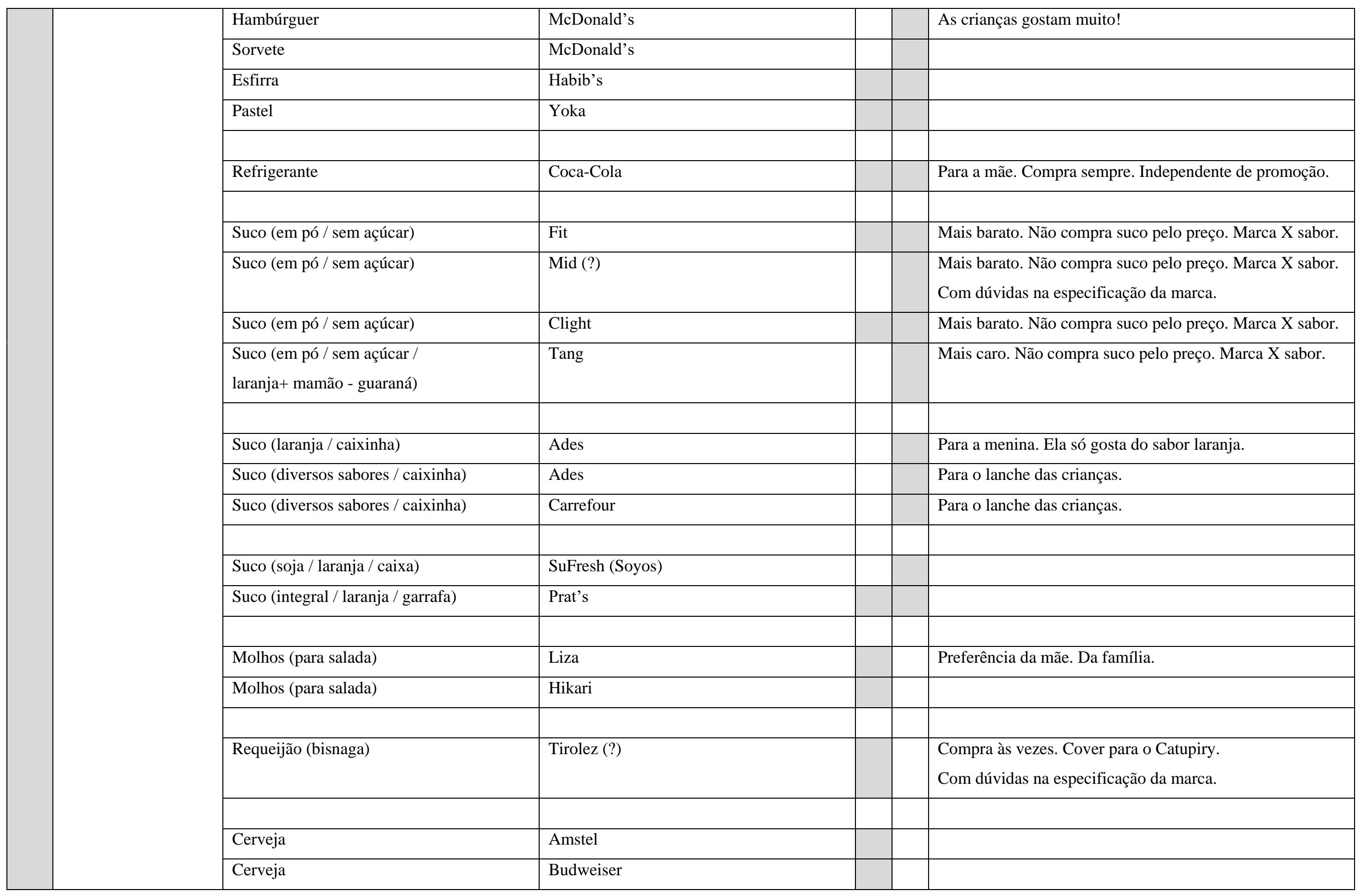




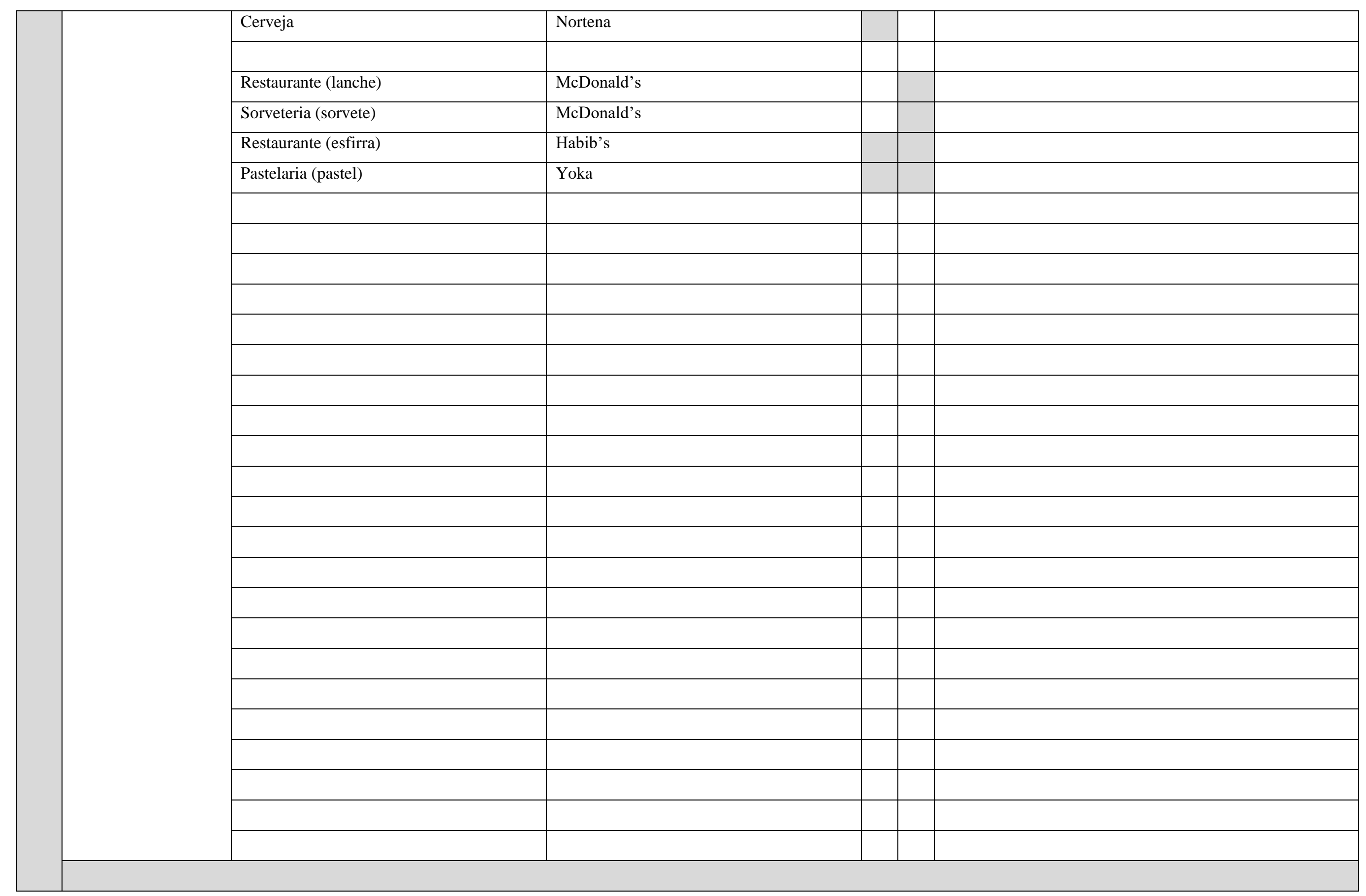




\begin{tabular}{|c|c|c|c|}
\hline \multirow{20}{*}{$\begin{array}{c}\text { CONSUMO } \\
\text { POR PRODUTOS }\end{array}$} & Arroz & Marcas diversas & Compra marcas diversas. Promoção. \\
\hline & Feijão & Marcas diversas & Compra marcas diversas. Promoção. \\
\hline & Macarrão & Marcas diversas & Compra marcas diversas. Promoção. \\
\hline & Macarrão instantâneo & Marcas diversas & Compra marcas diversas. Promoção. \\
\hline & Molho de tomate & Marcas diversas & Compra marcas diversas. Promoção. \\
\hline & Açúcar (refinado) & Marcas diversas & Compra marcas diversas. Promoção. \\
\hline & Sal (refinado) & Marcas diversas & Compra marcas diversas. Promoção. \\
\hline & Azeite de oliva & Marcas diversas & Compra marcas diversas. Promoção. \\
\hline & Molhos (para salada) & Marcas diversas & Compra marcas diversas. Promoção. \\
\hline & Leite (integral / caixa) & Marcas diversas & Compra marcas diversas. Promoção. \\
\hline & Leite (integral / sem lactose / caixa) & Marcas diversas & Para amenina. Compra marcas diversas. Promoção. \\
\hline & Margarina & Marcas diversas & Compra marcas diversas. \\
\hline & Creme de queijo & Marcas diversas & Compra marcas diversas. \\
\hline & Creme de ricota & Marcas diversas & Compra marcas diversas. \\
\hline & Queijo mussarela & Marcas diversas & \\
\hline & Queijo parmesão & Marcas diversas & $\begin{array}{l}\text { Compra às vezes. Para a menina. Ela gosta muito. } \\
\text { Compra marcas diversas. }\end{array}$ \\
\hline & Presunto & Marcas diversas & \\
\hline & Peito de peru & Marcas diversas & \\
\hline & Nuggets (congelado) & Marcas diversas & Para as crianças. Compra marcas diversas. \\
\hline & Salsicha & Marcas diversas & Para as crianças. Compra marcas diversas. \\
\hline
\end{tabular}




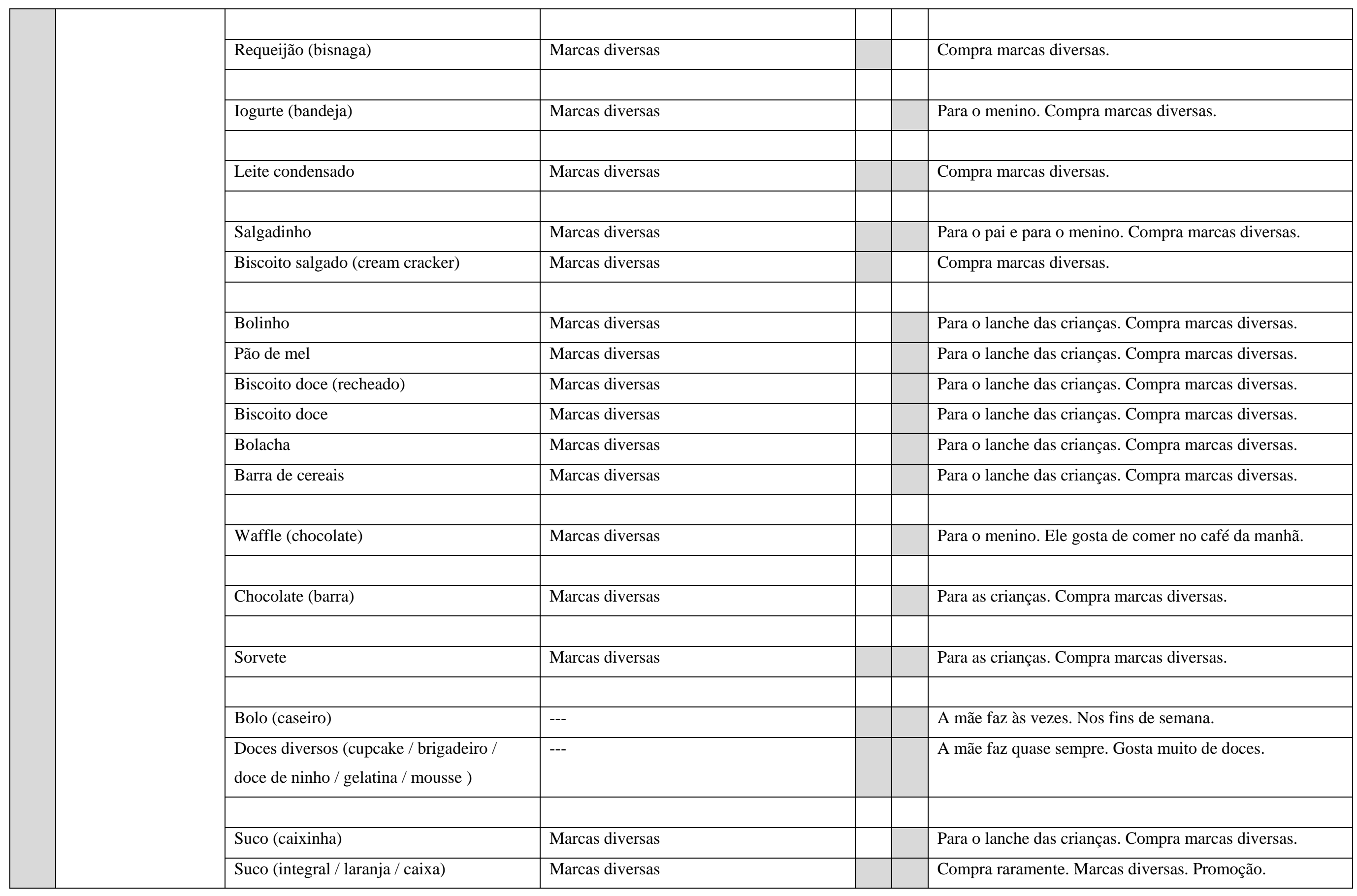




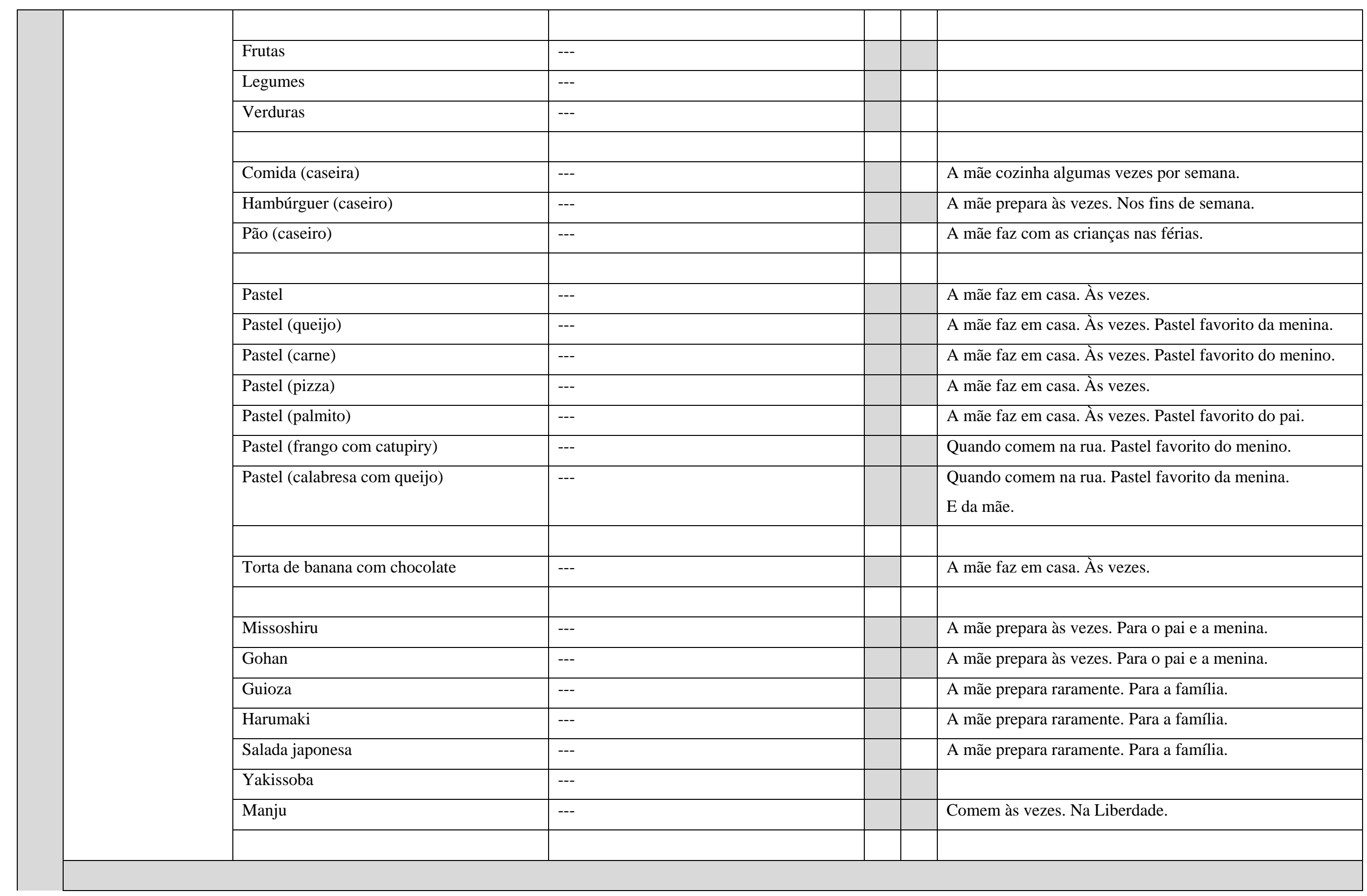




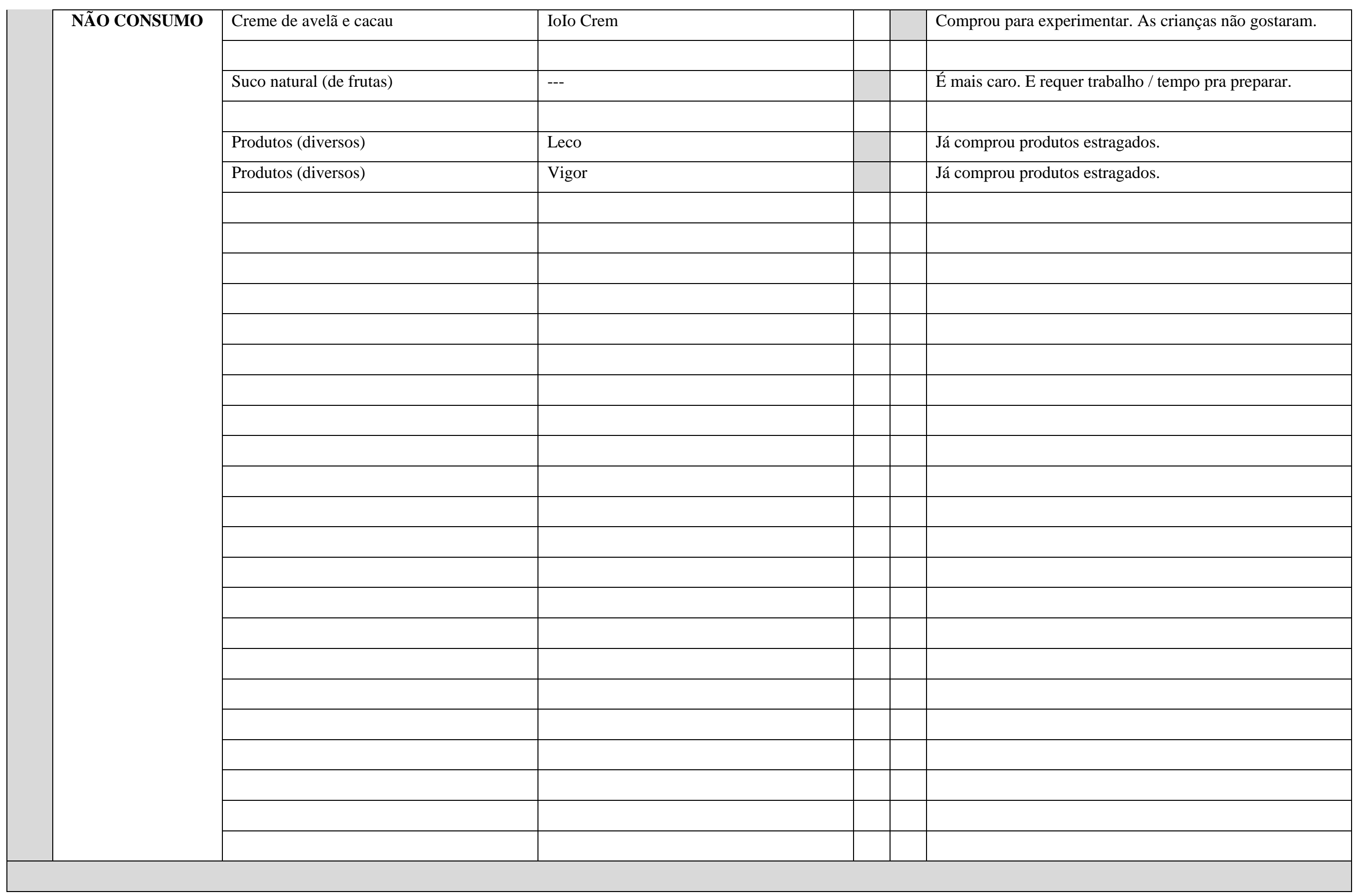


MARCAS E PRODUTOS ALIMENTÍCIOS NO ESPAÇO PÚBLICO

(RELATOS / OBSERVAÇÕES / CITAÇÕES / EXPRESSIVIDADES)

\begin{tabular}{|c|c|c|c|c|c|c|}
\hline \multicolumn{2}{|r|}{ NATUREZA } & CATEGORIA / ALIMENTO & MARCA / PERSONAGEM & $\mathbf{F}$ & $\mathbf{C}$ & OBSERVAÇÃO \\
\hline \multicolumn{7}{|c|}{ CONSUMO } \\
\hline O & MAIS & & & & & \\
\hline \multirow{2}{*}{$\begin{array}{l}\mathbf{N} \\
\mathbf{S}\end{array}$} & FREQUENTE & & & & & \\
\hline & - & & & & & \\
\hline \multirow{2}{*}{$\begin{array}{l}\mathbf{S} \\
\mathbf{U} \\
\mathbf{M}\end{array}$} & $\begin{array}{l}\text { SEMPRE / } \\
\text { OUASE SEMPRE }\end{array}$ & & & & & \\
\hline & & & & & & \\
\hline \multicolumn{7}{|l|}{$\mathbf{O}$} \\
\hline \multirow[b]{2}{*}{ A } & CONSUMO & Pizzaria (pizza) & Pizzarias diversas & & & Delivery. Ou compram na pizzaria para comer em casa. \\
\hline & MENOS & & & & & \\
\hline \multirow{2}{*}{$\begin{array}{l}\mathbf{L} \\
\mathbf{I}\end{array}$} & FREQUENTE & Restaurante (esfirra) & Habib's & & & Delivery. Ou compram no restaurante para comer em casa. \\
\hline & & & & & & \\
\hline \multirow{2}{*}{$\begin{array}{l}\text { M } \\
\mathbf{E}\end{array}$} & ÀS VEZES & Restaurante (lanche) & Lanchonetes diversas & & & Delivery. Ou compram na lanchonete para comer em casa. \\
\hline & & & & & & \\
\hline \multicolumn{7}{|l|}{$\mathbf{N}$} \\
\hline \multirow{6}{*}{$\begin{array}{l}\mathbf{A} \\
\mathbf{R}\end{array}$} & \multirow{7}{*}{$\begin{array}{c}\text { CONSUMO } \\
\text { EVENTUAL } \\
- \\
\text { RARAMENTE }\end{array}$} & Restaurante (lanche) & McDonald's & & & Raramente. Nas férias escolares das crianças. \\
\hline & & & & & & \\
\hline & & Sorveteria (sorvete) & McDonald's & & & Raramente. Nas férias escolares das crianças. \\
\hline & & & & & & \\
\hline & & Pastelaria (pastel) & Yoka & & & Raramente. Nos fins de semana. Quando vão à Liberdade. \\
\hline & & Feira (pastel) & --- & & & Raramente. Na feira. Nos fins de semana. \\
\hline & & & & & & \\
\hline
\end{tabular}




\section{PRIMEIRO ENCONTRO: CONVERSA COM A FAMÍLIA E AS CRIANÇAS}

\section{MARCAS E PRODUTOS ALIMENTÍCIOS NO AMBIENTE DOMÉSTICO}

(FOTOS / VÍDEOS / OBSERVAÇÃO)

\begin{tabular}{|c|c|c|c|c|c|c|}
\hline & LOCAL & ALIMENTO / PRODUTO & MARCA / PERSONAGEM & $\mathbf{F}$ & $\mathbf{C}$ & OBSERVAÇÃOO \\
\hline \multirow{16}{*}{$\begin{array}{c}\mathrm{C} \\
\mathrm{O} \\
\mathrm{Z} \\
\mathrm{I} \\
\mathrm{N} \\
\mathrm{H} \\
\mathrm{A}\end{array}$} & \multirow[t]{16}{*}{ LOUSA } & Bolinho (chocolate) & Ana Maria & & & Anotação para lanche da menina. \\
\hline & & Suco (laranja / caixinha) & Ades & & & Anotação para lanche da menina. \\
\hline & & Queijo processado & Polenguinho & & & Anotação para lanche da menina. \\
\hline & & Bolinho (baunilha) (?) & Bauducco & & & $\begin{array}{l}\text { Anotação para lanche do menino. } \\
\text { Não é possível especificar o sabor }\end{array}$ \\
\hline & & Suco (laranja / caixinha) & Carrefour & & & Anotação para lanche do menino. \\
\hline & & Queijo processado & Polenguinho & & & Anotação para lanche do menino. \\
\hline & & & & & & \\
\hline & & & & & & \\
\hline & & & & & & \\
\hline & & & & & & \\
\hline & & & & & & \\
\hline & & & & & & \\
\hline & & & & & & \\
\hline & & & & & & \\
\hline & & & & & & \\
\hline & & & & & & \\
\hline
\end{tabular}




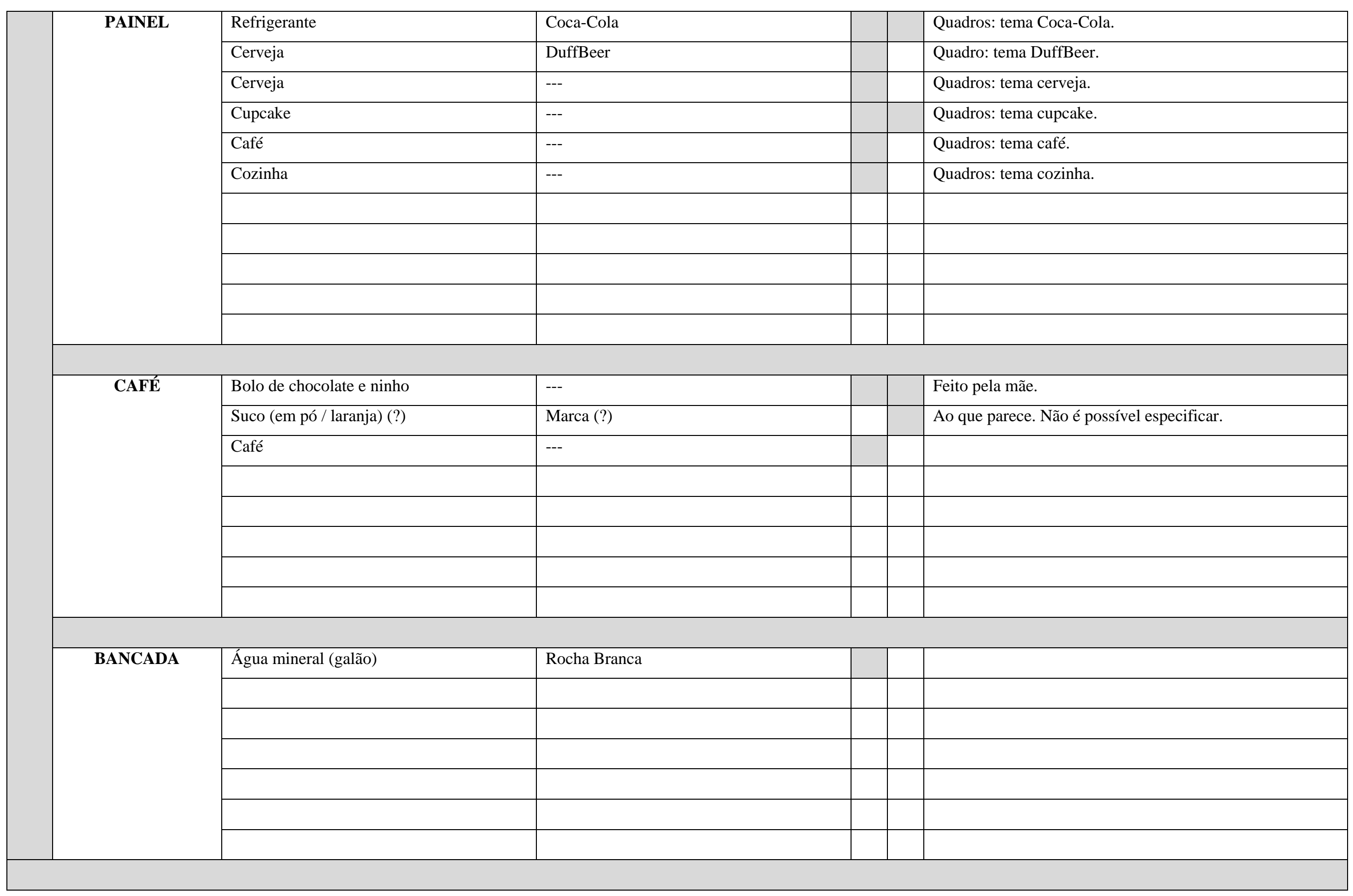




\section{SEGUNDO ENCONTRO: RITUAL DE ALIMENTAÇÃO COM AS CRIANÇAS EM CASA}

\section{MARCAS E PRODUTOS ALIMENTÍCIOS NO AMBIENTE DOMÉSTICO \\ (FOTOS / VÍDEOS / OBSERVAÇÃO)}

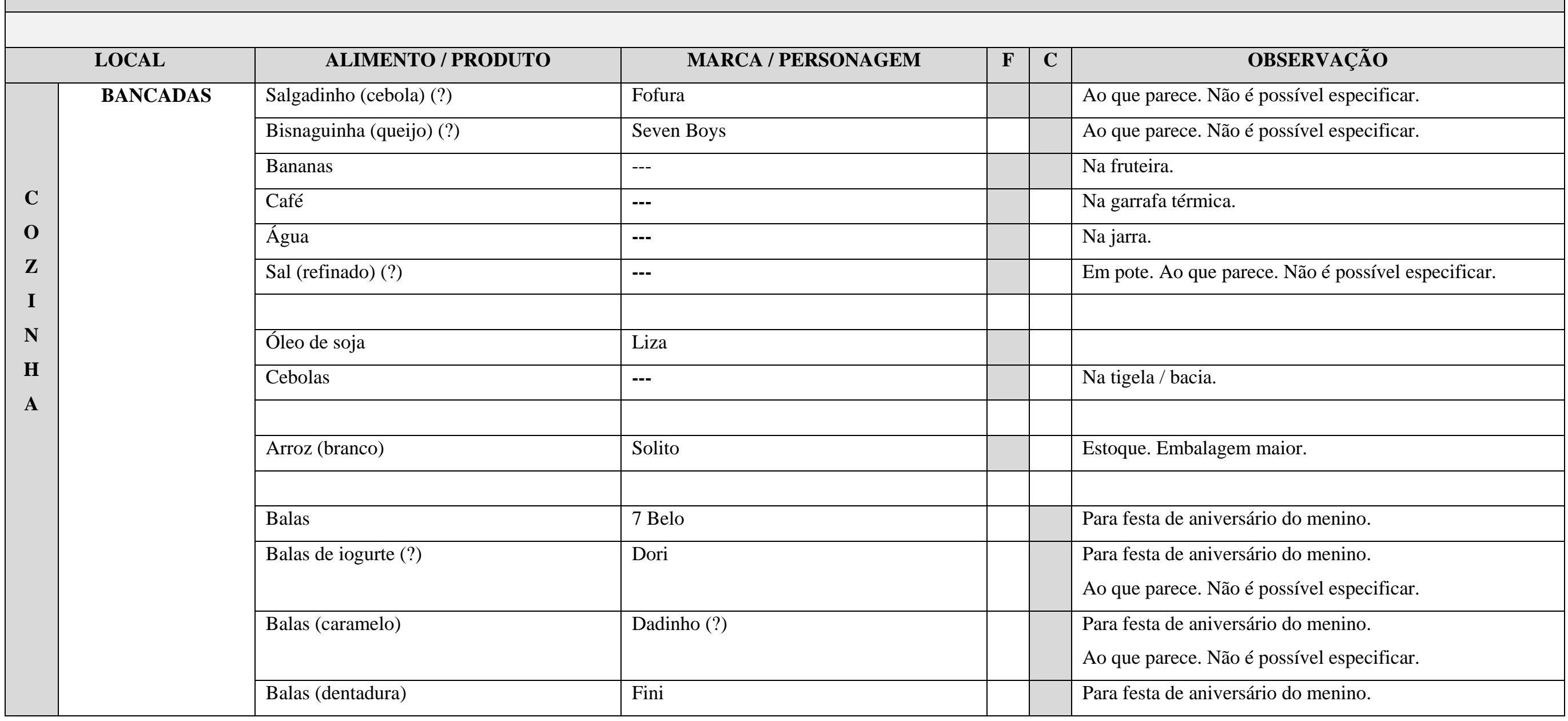




\begin{tabular}{|c|c|c|c|}
\hline & Confeitos de chocolate & Dori (?) & $\begin{array}{l}\text { Para festa de aniversário do menino. } \\
\text { Ao que parece. Não é possível especificar. }\end{array}$ \\
\hline & Água mineral (galão) & Rocha Branca & \\
\hline & Alimentos diversos (bancadas) (?) & --- & Ao que parece. Não é possível especificar. \\
\hline \multirow[t]{19}{*}{ ARMÁRIOS } & Suco (abacaxi - maçã - uva / caixinha) & Ades & Estoque. Para lanche das crianças. \\
\hline & Suco (laranja / caixinha) & Carrefour & Estoque. Para lanche das crianças. \\
\hline & Leite (integral / caixa) & Piracanjuba & Estoque. \\
\hline & Leite (integral / sem lactose / caixa) & Itambé & Estoque. Para a menina. \\
\hline & Leite (em pó) & La Sereníssima & \\
\hline & Farinha de rosca & Yoki & \\
\hline & Fubá & Sinhá & \\
\hline & Açúcar (refinado) & Caravelas & \\
\hline & Sal (refinado) & Lebre & \\
\hline & Arroz (parbolizado) & Máximo & \\
\hline & Arroz (parbolizado) & Solito & \\
\hline & Salgadinho (?) & Marca (?) & Ao que parece. Não é possível especificar. \\
\hline & Brownie (preparo) & Dr. Oetker & \\
\hline & Salgadinho & Ruffles & \\
\hline & Gotas de chocolate & Marca (?) & Não é possível especificar. \\
\hline & Café (em pó / torrado) & Melitta & \\
\hline & Batata palha (?) & Tostally (?) & Ao que parece. Não é possível especificar. \\
\hline & Chá (hortelã - camomila) (?) & Leão & Ao que parece. Não é possível especificar. \\
\hline & Achocolatado (em pó) & Nescau & Estoque. Embalagem (refil). \\
\hline
\end{tabular}




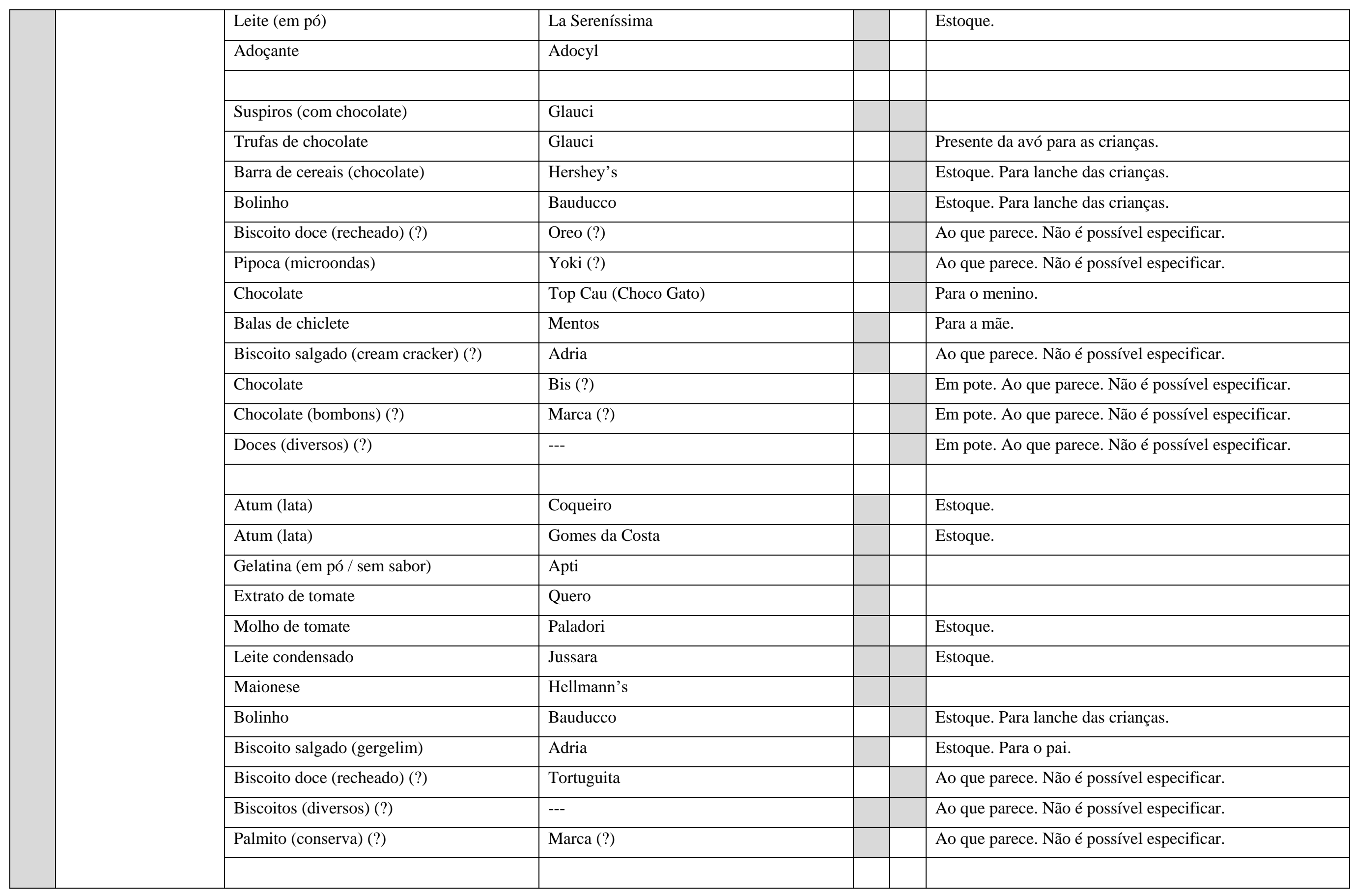




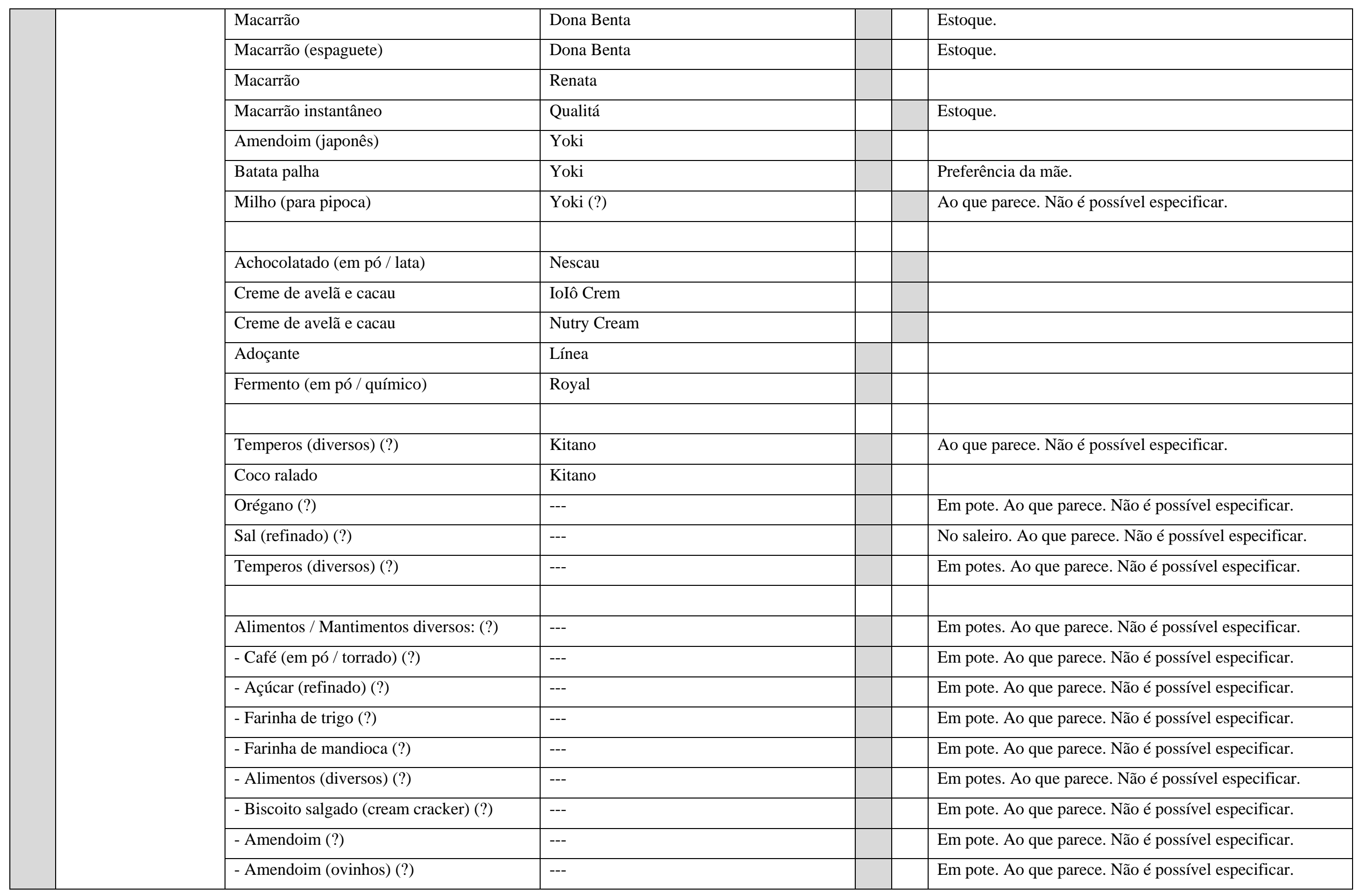




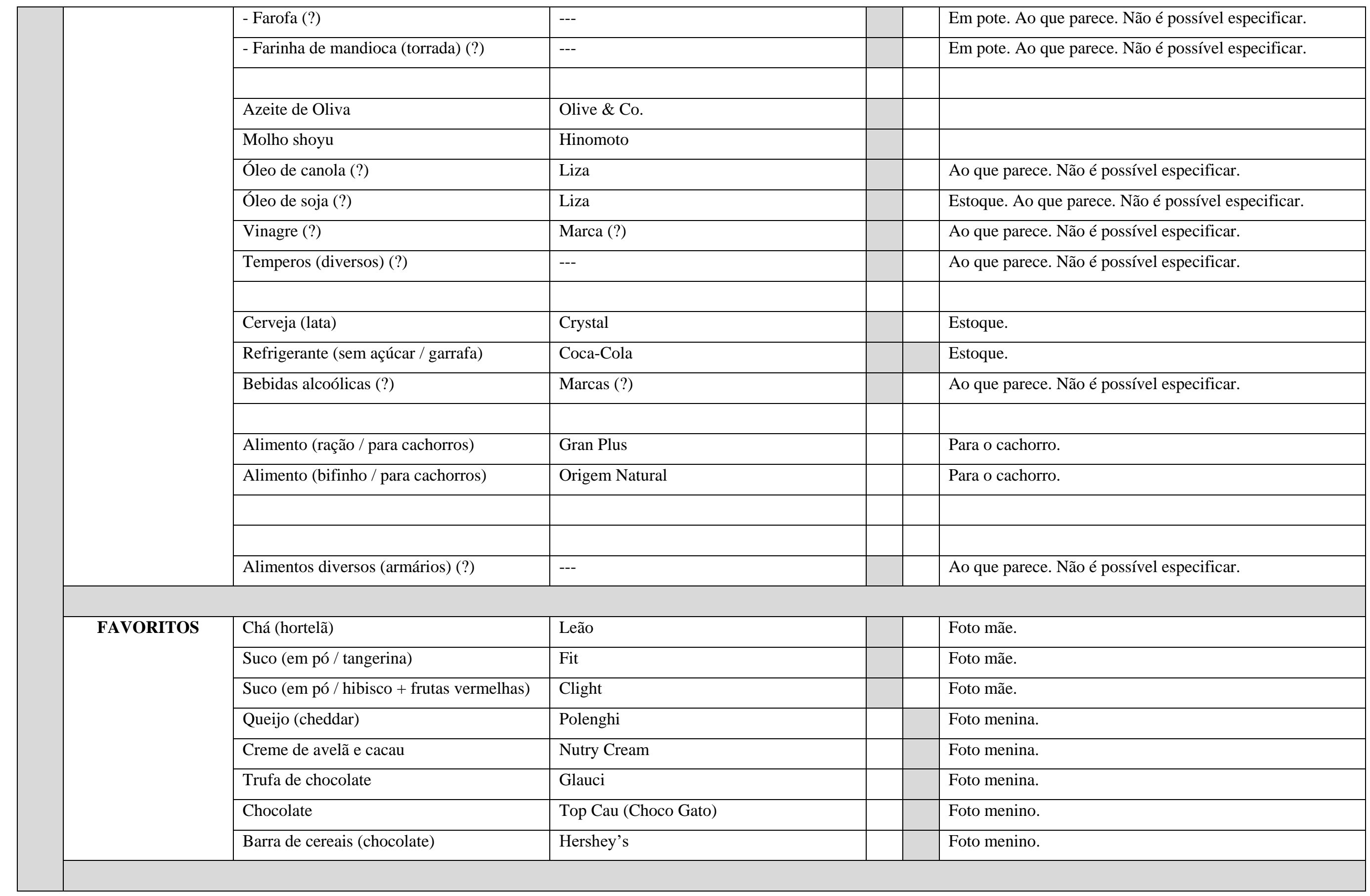




\begin{tabular}{|c|c|c|c|}
\hline \multirow[t]{25}{*}{ GELADEIRA } & Queijo processado & Polenguinho & \\
\hline & Queijo ralado & Ipanema & Estoque. \\
\hline & $\begin{array}{l}\text { Tempero (tablete / para caldo / bacon - } \\
\text { galinha) (?) }\end{array}$ & Maggi & Ao que parece. Não é possível especificar. \\
\hline & Suco (laranja - maçã - abacaxi / caixinha) & Ades & Estoque. \\
\hline & Suco (laranja / caixinha) & Carrefour & Estoque. \\
\hline & Iogurte (garrafinha) & Danoninho & Estoque. \\
\hline & Iogurte (com cereais / confeitos) & Vigor (Minions) (?) & Ao que parece. Não é possível especificar. \\
\hline & Essência de baunilha (?) & Hikari (?) & Ao que parece. Não é possível especificar. \\
\hline & Molho de pimenta (chipotle) & Cepera & \\
\hline & Pimenta de cheiro (conserva) & Kenko & \\
\hline & Tempero (oriental) (?) & Marca (?) & Ao que parece. Não é possível especificar. \\
\hline & Cerveja (lata) & Crystal & \\
\hline & Isotônico (uva) & Gatorade & \\
\hline & Ketchup (?) & Marca (?) & Ao que parece. Não é possível especificar. \\
\hline & Mostarda & Quero & \\
\hline & Maionese (?) & Kraft (?) & Ao que parece. Não é possível especificar. \\
\hline & Molhos (para salada) & Hikari & \\
\hline & Molhos (para salada) & Liza & \\
\hline & Molho barbecue & Salsaretti & \\
\hline & Molho agridoce & Kenko & \\
\hline & Molho rose (?) & Marca (?) & Ao que parece. Não é possível especificar. \\
\hline & Molho shoyu (?) & Marca (?) & Ao que parece. Não é possível especificar. \\
\hline & Tempero / Molho (?) & Marca (?) & Ao que parece. Não é possível especificar. \\
\hline & Molho de pimenta (com tahine) & Istambul & \\
\hline & & & \\
\hline
\end{tabular}




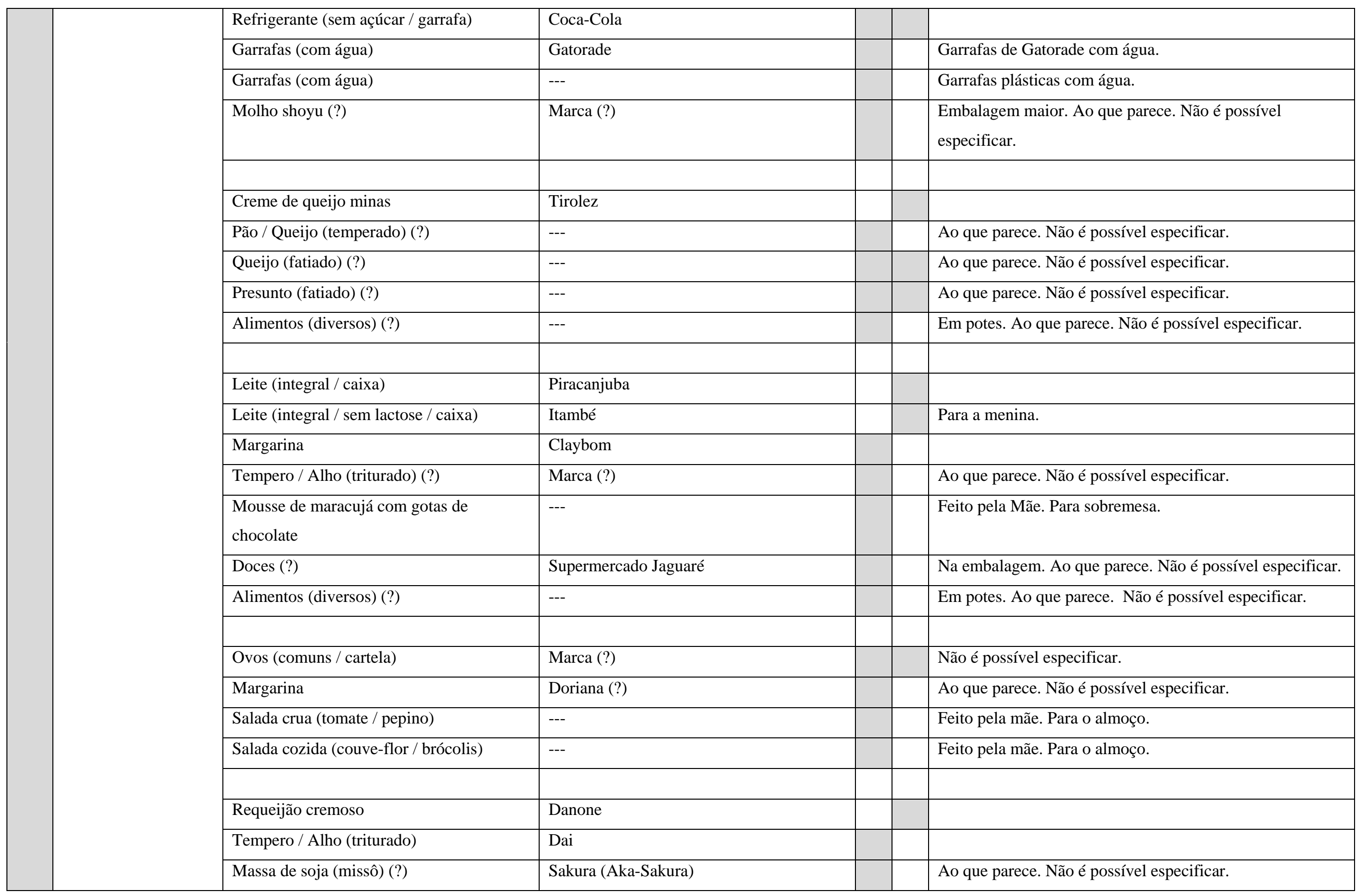




\begin{tabular}{|c|c|c|c|}
\hline & Alimentos (diversos) (?) & --- & Em potes. Ao que parece. Não é possível especificar. \\
\hline & Garrafas (com água) & --- & Garrafas plásticas com água. \\
\hline & Cenouras & --- & Em pote. \\
\hline & Frutas / legumes / verduras: (?) & --- & Na bandeja. Ao que parece. Não é possível especificar. \\
\hline & - Manga (?) & --- & Na bandeja. Ao que parece. Não é possível especificar. \\
\hline & - Tomates (?) & --- & Na bandeja. Ao que parece. Não é possível especificar. \\
\hline & - Pepinos (?) & --- & Na bandeja. Ao que parece. Não é possível especificar. \\
\hline & - Batatas (?) & --- & Na bandeja. Ao que parece. Não é possível especificar. \\
\hline & Carnes (congeladas) (?) & --- & Ao que parece. Não é possível especificar. \\
\hline & Frango (congelado) (?) & --- & Ao que parece. Não é possível especificar. \\
\hline & Salsichas (congeladas) (?) & --. & Ao que parece. Não é possível especificar. \\
\hline & Alimentos (diversos / congelados) (?) & --. & Em potes. Ao que parece. Não é possível especificar. \\
\hline & Mandioca (congelada) (?) & Bem Brasil (?) & Ao que parece. Não é possível especificar. \\
\hline & Pão de queijo (congelado) & Estrela Mineira & Ao que parece. \\
\hline & $\begin{array}{l}\text { Sorvete (picolé / uva - mamão papaia - } \\
\text { maracujá) }\end{array}$ & Oggi & \\
\hline & Alimentos diversos (geladeira) (?) & --- & Ao que parece. Não é possível especificar. \\
\hline ALMOÇO & CARDÁPIO: & & \\
\hline & Arroz (branco) & --- & Feito pela mãe. \\
\hline & Feijão (preto) & --- & Feito pela mãe. \\
\hline & Quibe ao forno (com requeijão) & --- & Feito pela mãe. \\
\hline & Salada crua (tomate / pepino) & --- & Feito pela mãe. \\
\hline & Salada cozida (couve-flor / brócolis) & --- & Feito pela mãe. \\
\hline
\end{tabular}




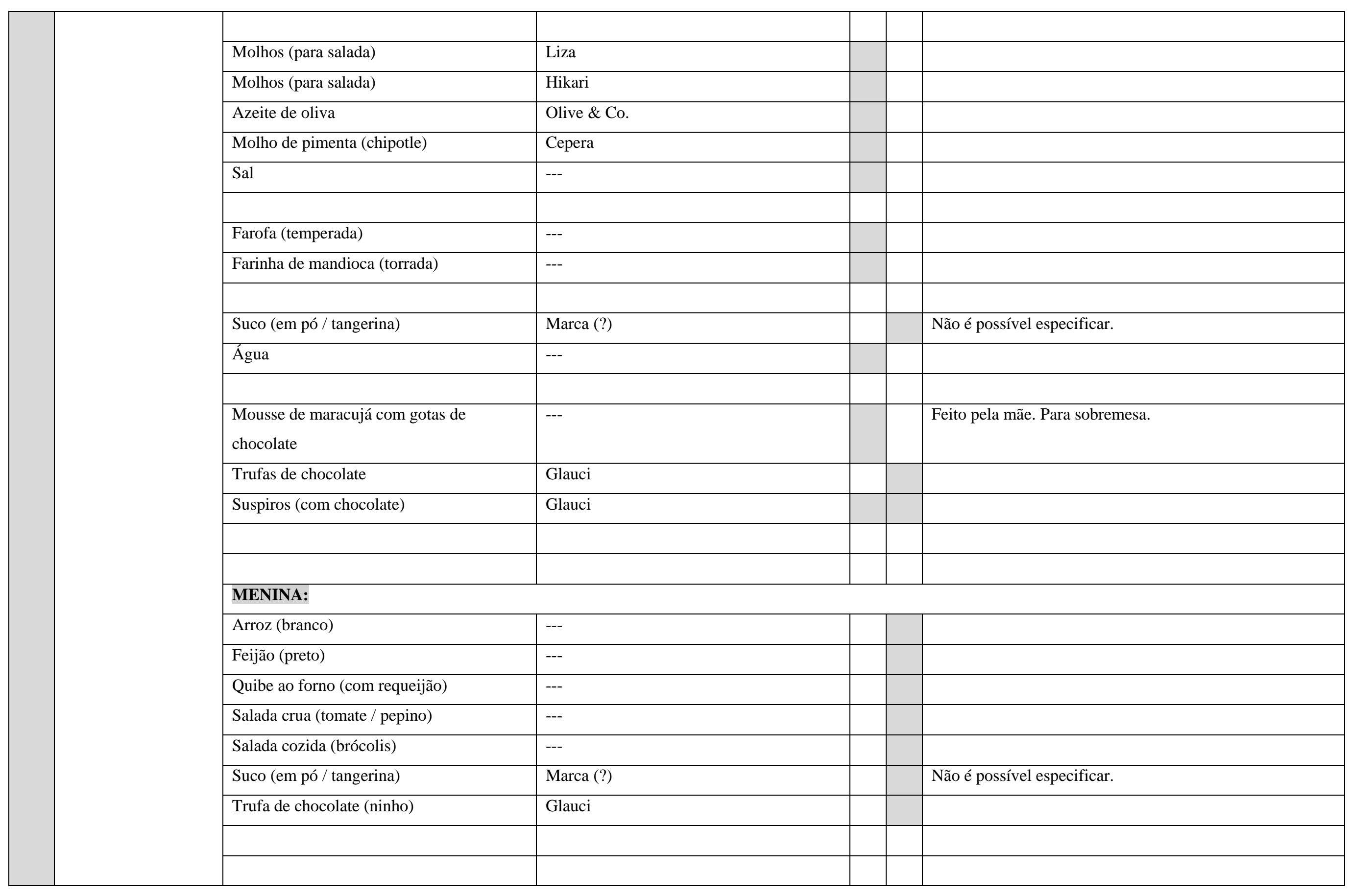




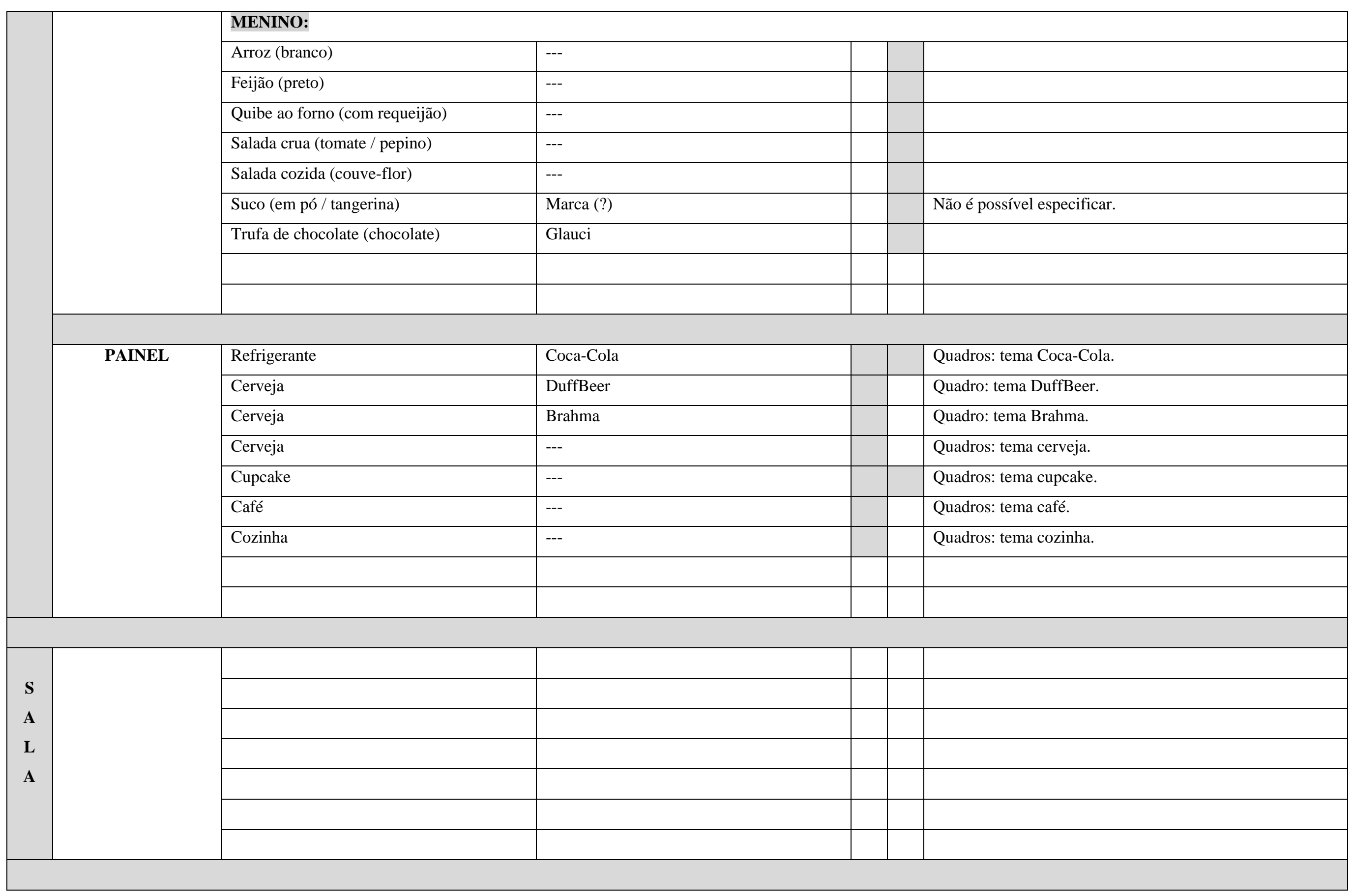


TERCEIRO ENCONTRO: RITUAL DE ALIMENTAÇÃO COM AS CRIANÇAS FORA DE CASA / LANCHE ESPECIAL COM AS CRIANÇAS EM CASA

\section{MARCAS E PRODUTOS ALIMENTÍCIOS NO AMBIENTE DOMÉSTICO}

(FOTOS / VÍDEOS / OBSERVAÇÃO)

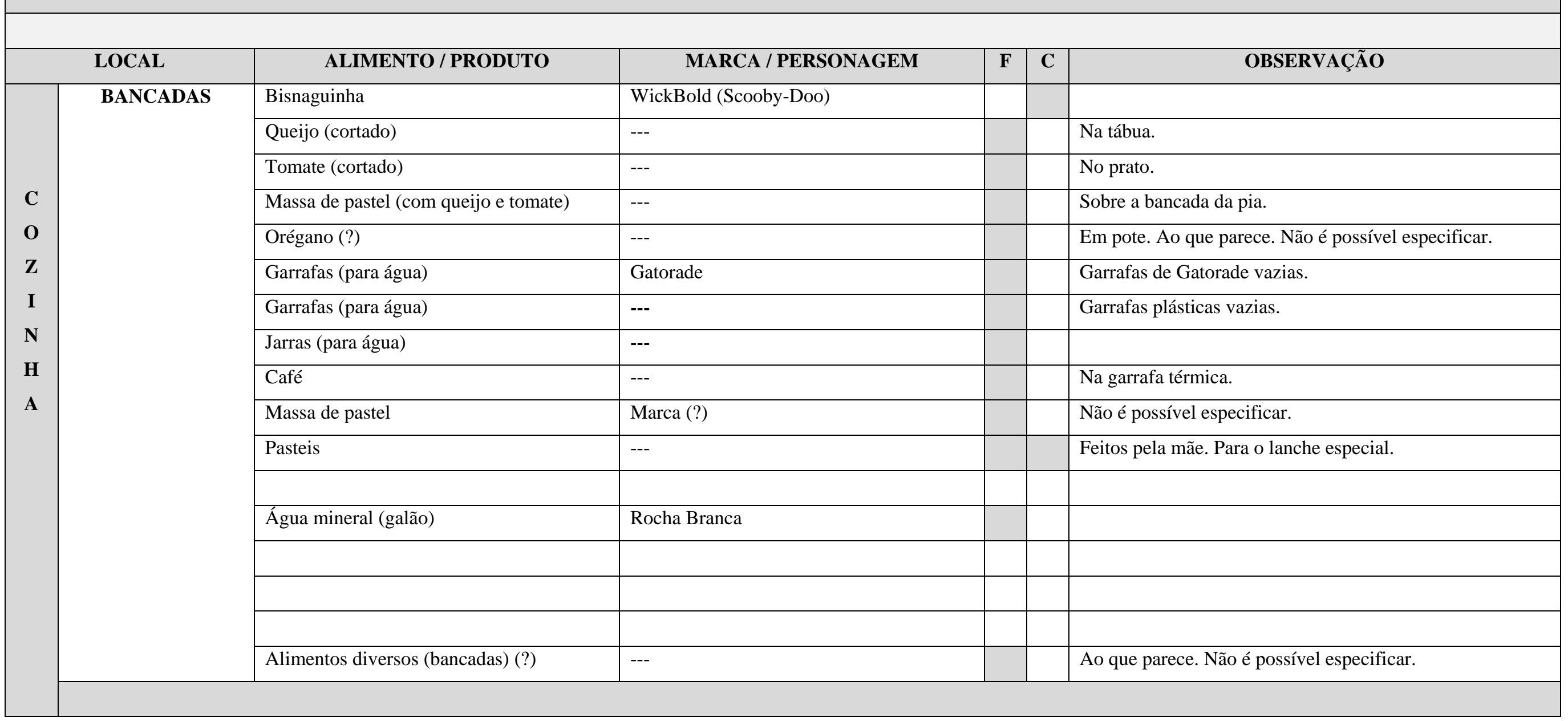




\begin{tabular}{|c|c|c|c|}
\hline \multirow[t]{26}{*}{ ARMÁRIOS } & Bolinho & Santa Edwiges & Estoque. Para lanche das crianças. \\
\hline & Brownie (preparo) (?) & Dr. Oetker & Ao que parece. Não é possível especificar. \\
\hline & Flocos de chocolate (?) & Marca (?) & Ao que parece. Não é possível especificar. \\
\hline & Chá (hortelã - camomila) (?) & Leão & Ao que parece. Não é possível especificar. \\
\hline & Balas de chiclete (?) & Mentos (?) & Para a mãe. Ao que parece. Não é possível especificar. \\
\hline & Leite (em pó) & La Sereníssima & \\
\hline & Achocolatado (em pó) & Nescau & Estoque. Embalagem (refil). \\
\hline & Aveia (em flocos) (?) & --- & Em pote. Ao que parece. Não é possível especificar. \\
\hline & Achocolatado (em pó / lata) & Nescau & \\
\hline & Creme de avelã e cacau & IoIô Crem (?) & Ao que parece. Não é possível especificar. \\
\hline & Adoçante & Línea (?) & Ao que parece. Não é possível especificar. \\
\hline & Fermento (em pó / químico) & Royal & \\
\hline & Tempero & Sazón & \\
\hline & Tempero (tablete / para caldo / picanha) & Sazón (?) & Ao que parece. Não é possível especificar. \\
\hline & Temperos (diversos) & Kitano (?) & Ao que parece. Não é possível especificar. \\
\hline & Tempero (coloral) (?) & --- & Em pote. Ao que parece. Não é possível especificar. \\
\hline & Sal (refinado) & Lebre (?) & Ao que parece. Não é possível especificar. \\
\hline & Sal (refinado) (?) & --- & Em pote. Ao que parece. Não é possível especificar. \\
\hline & Sal (refinado) (?) & --- & No saleiro. Ao que parece. Não é possível especificar. \\
\hline & Temperos (diversos) (?) & --- & Em potes. Ao que parece. Não é possível especificar. \\
\hline & Alimentos / mantimentos diversos: (?) & --- & Em potes. Ao que parece. Não é possível especificar. \\
\hline & - Café (em pó / torrado) (?) & --- & Em pote. Ao que parece. Não é possível especificar. \\
\hline & - Açúcar (refinado) (?) & --- & Em pote. Ao que parece. Não é possível especificar. \\
\hline & - Farinha de trigo (?) & --- & Em pote. Ao que parece. Não é possível especificar. \\
\hline & - Farinha de mandioca (?) & --- & Em pote. Ao que parece. Não é possível especificar. \\
\hline & - Alimentos (diversos) (?) & --- & Em potes. Ao que parece. Não é possível especificar. \\
\hline
\end{tabular}




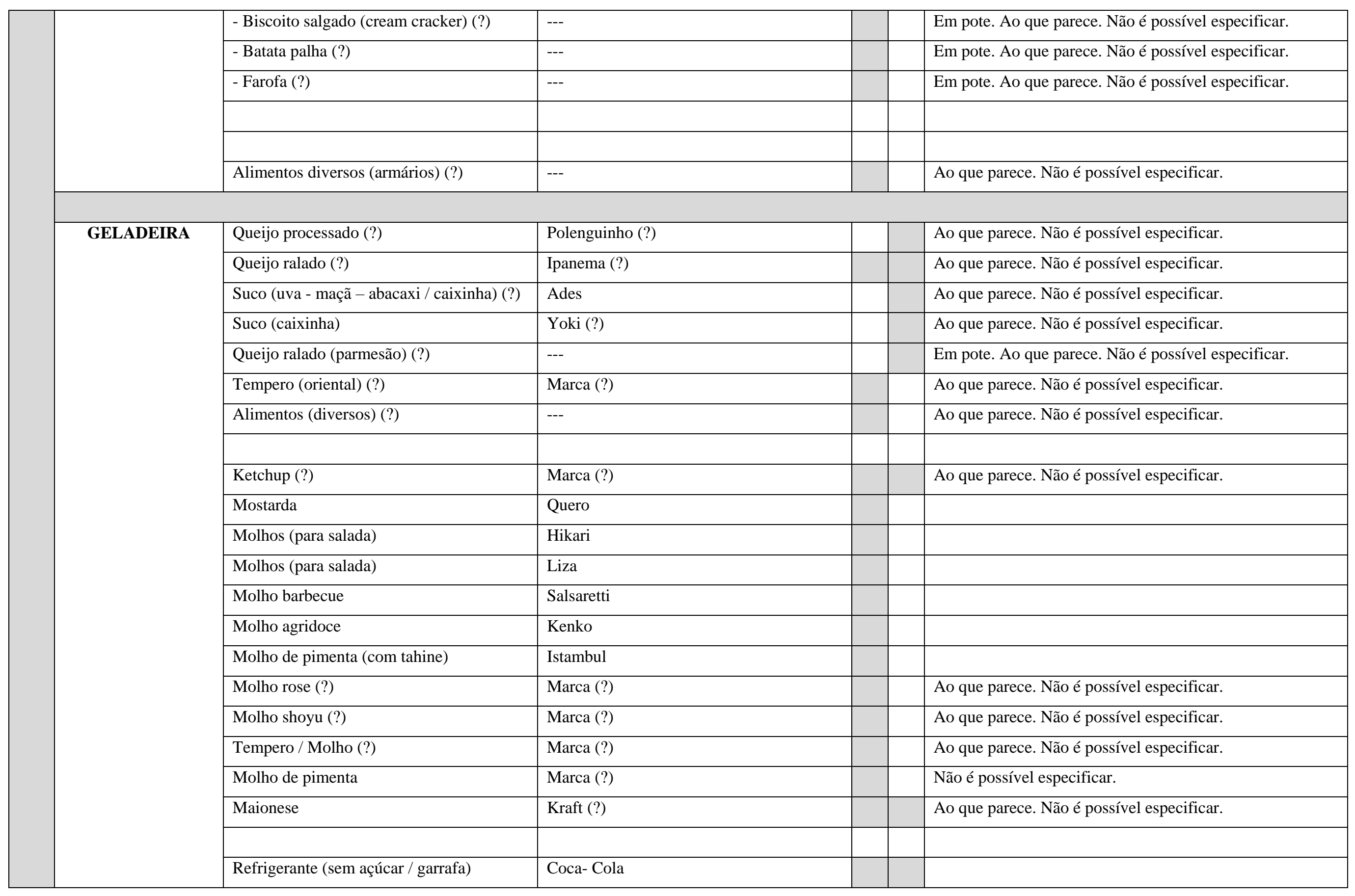




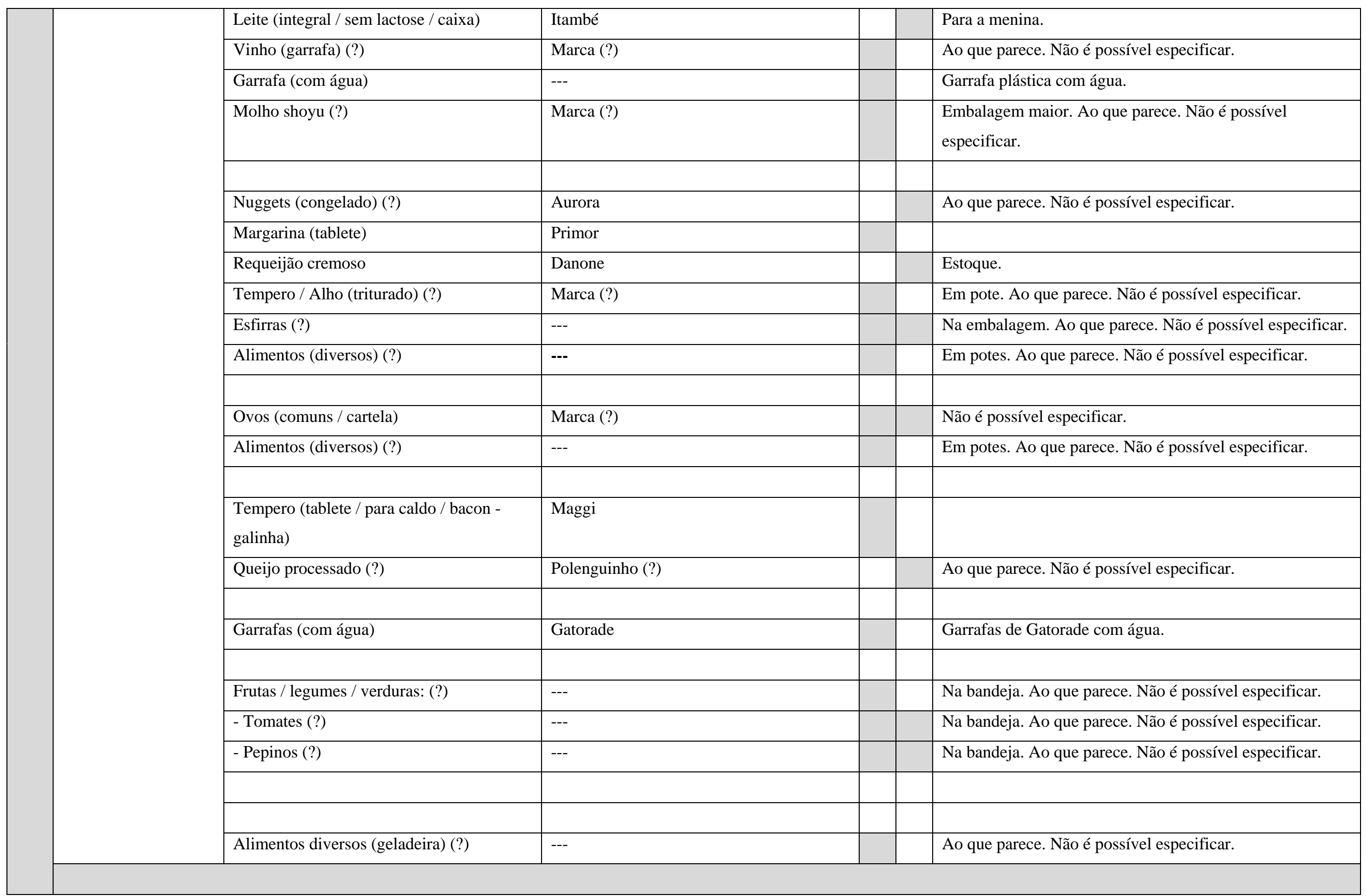




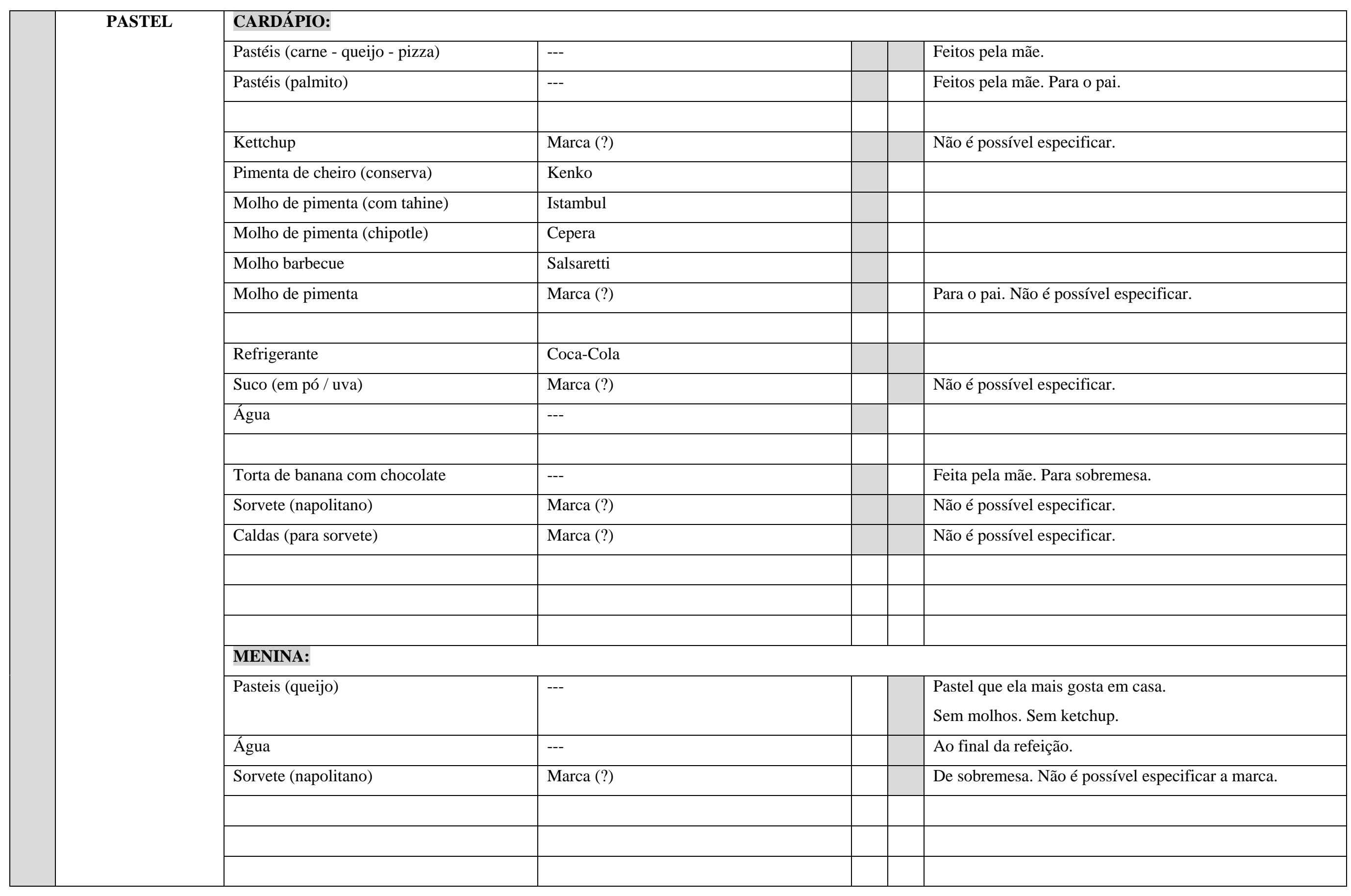




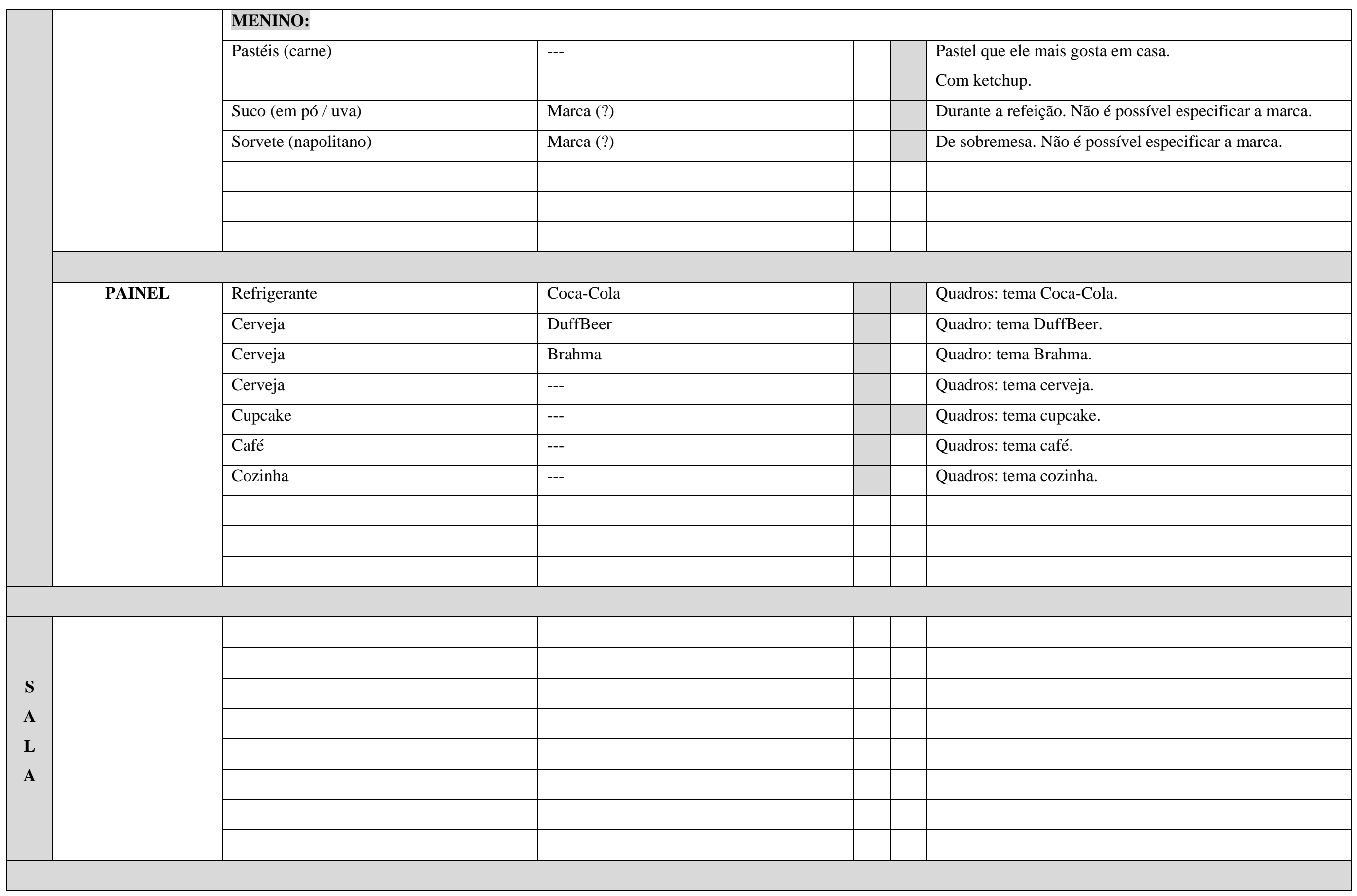




\section{R I A N Ç A S}

PRODUTOS / MARCAS / PERSONAGENS NO AMBIENTE DOMÉSTICO E ESPAÇO PÚBLICO (RELATOS / OBSERVAÇÕES / CITAÇÕES / EXPRESSIVIDADES / FOTOS / VÍDEOS / OBSERVAÇÃO)

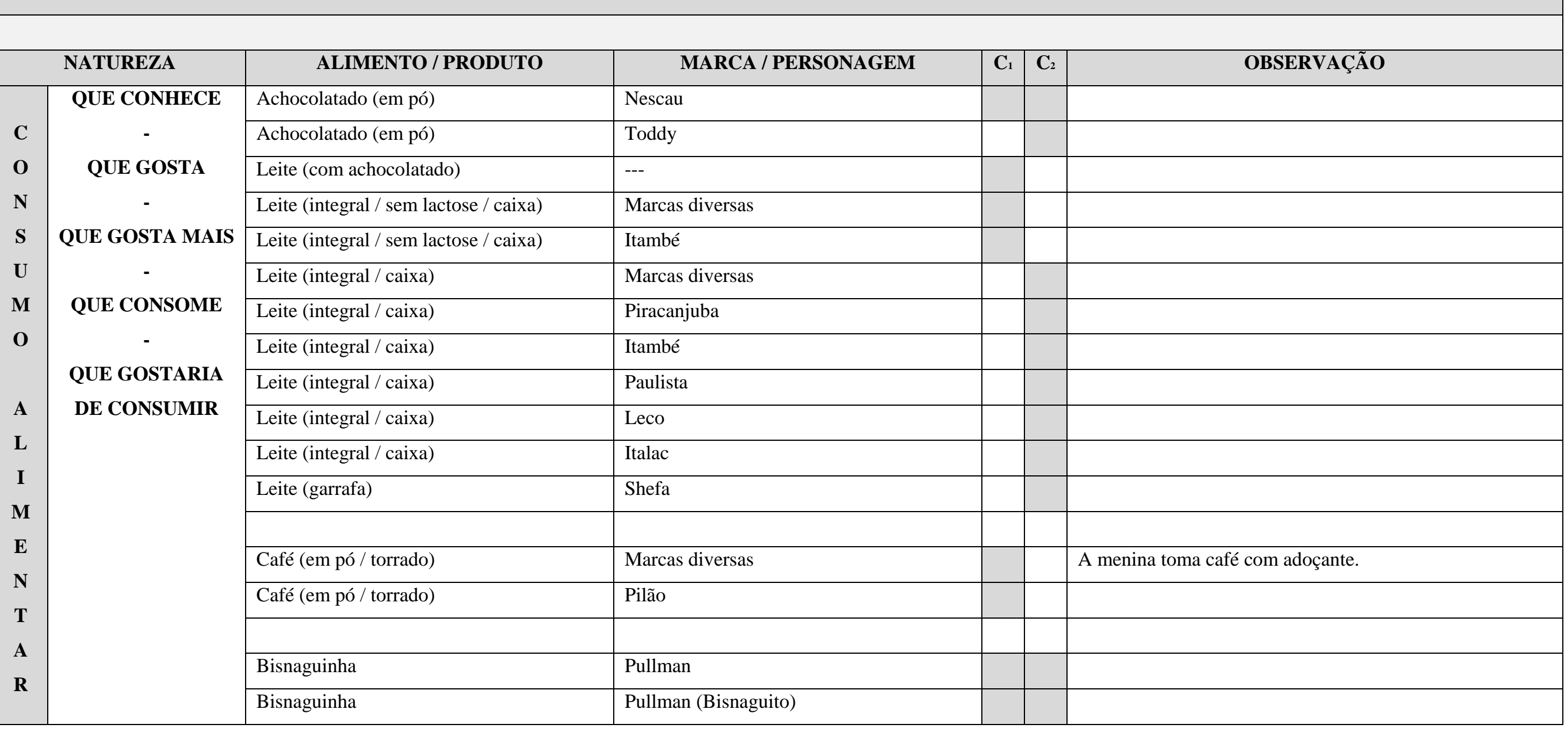




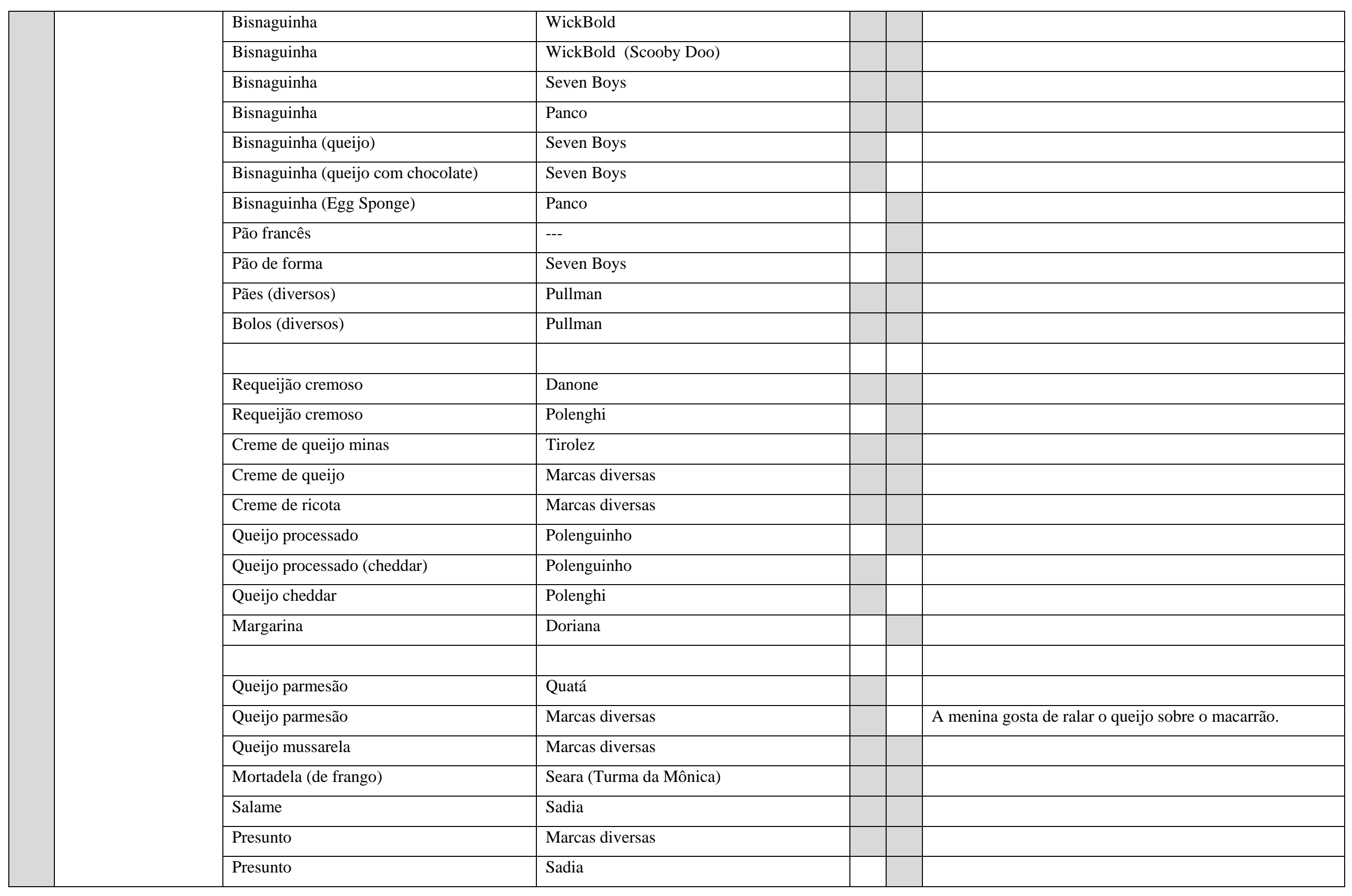




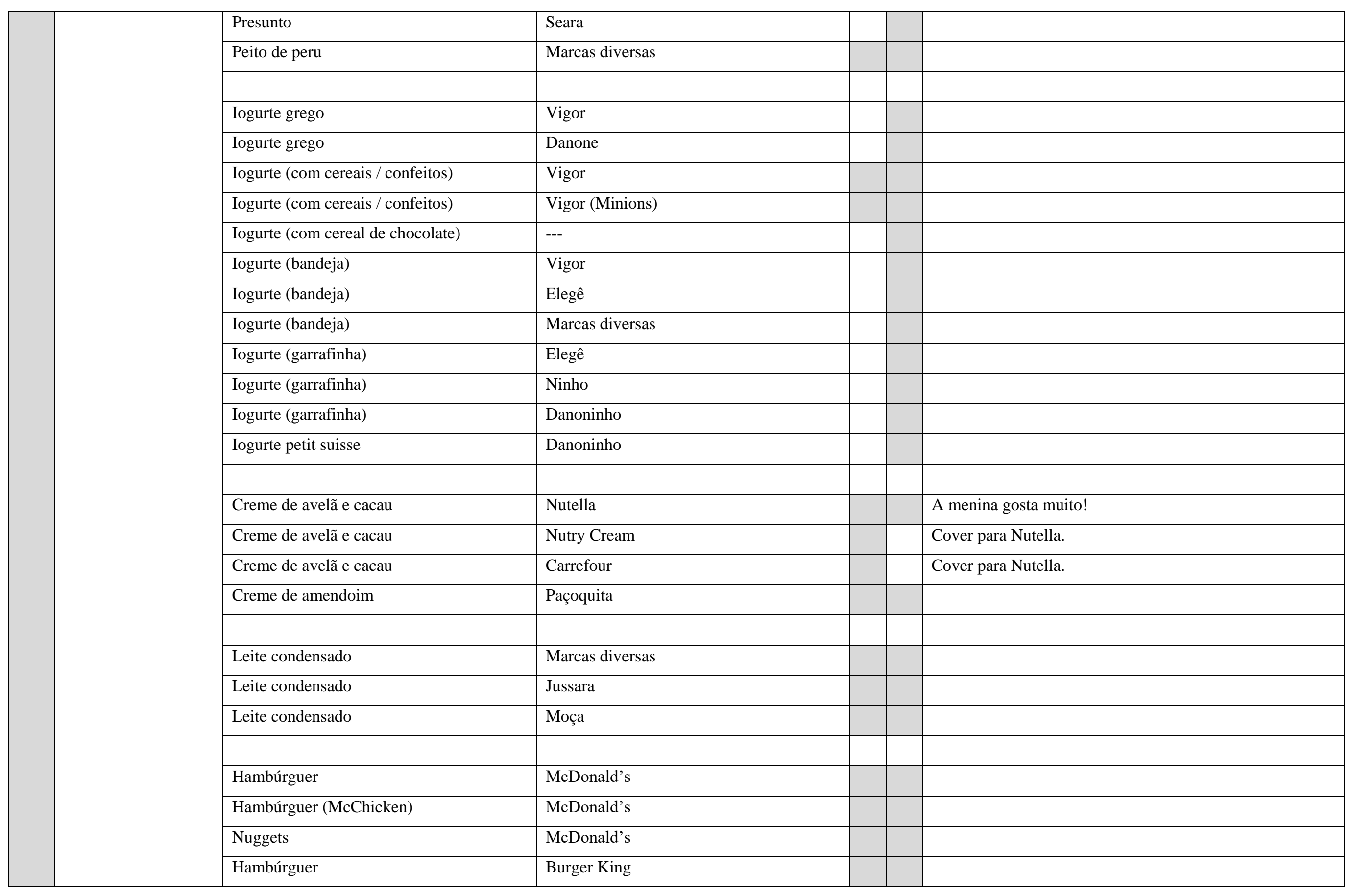




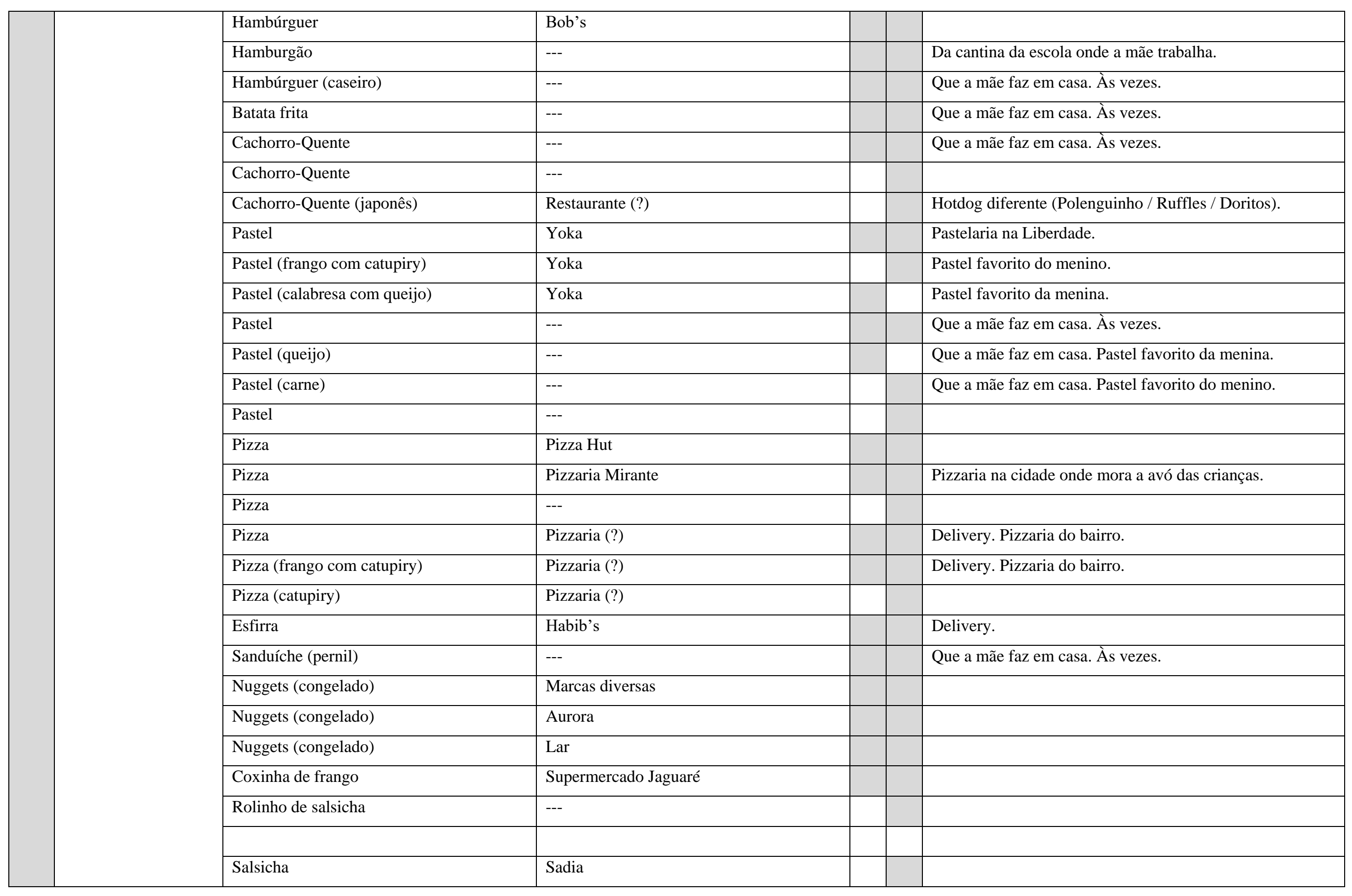




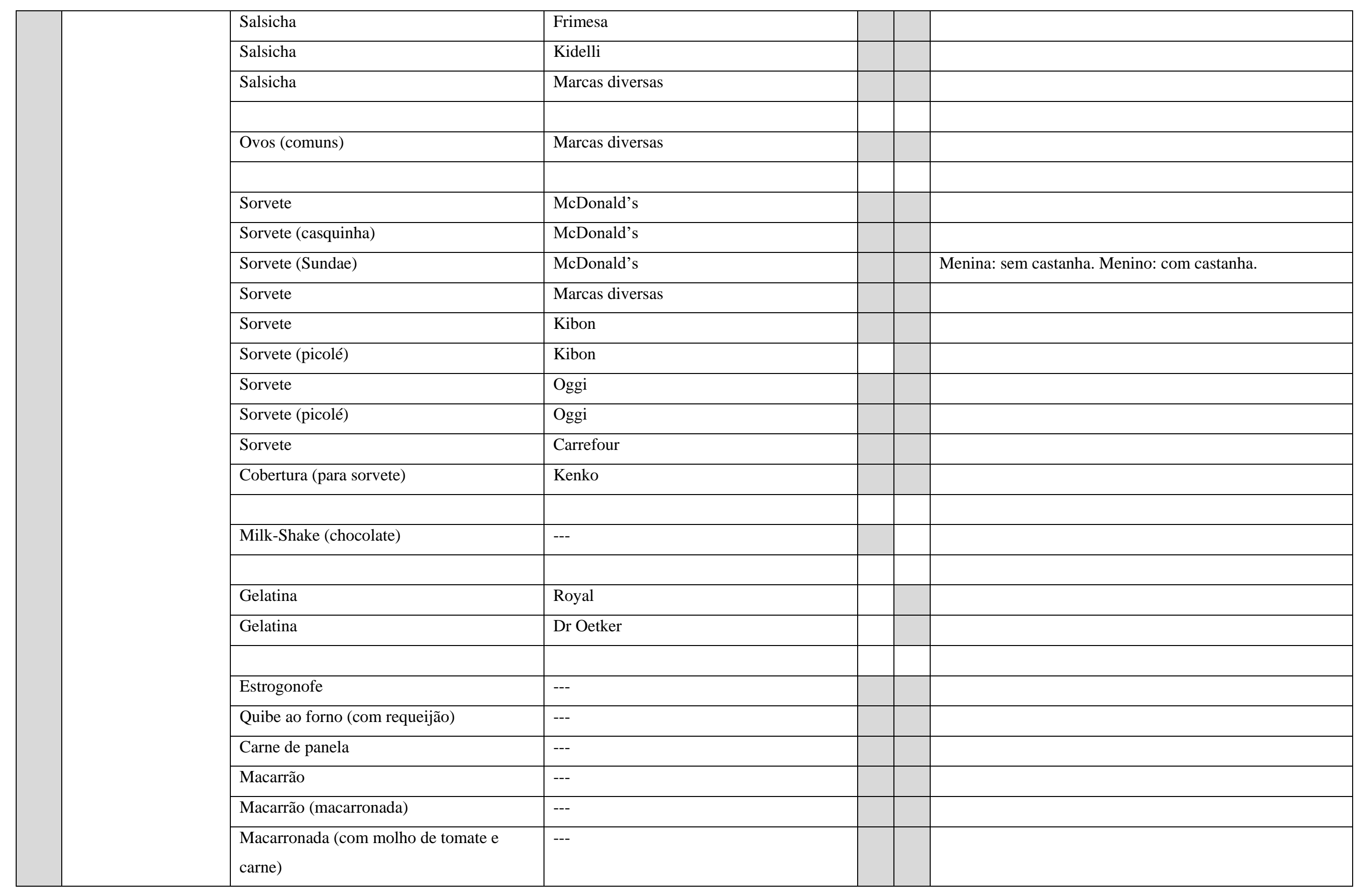




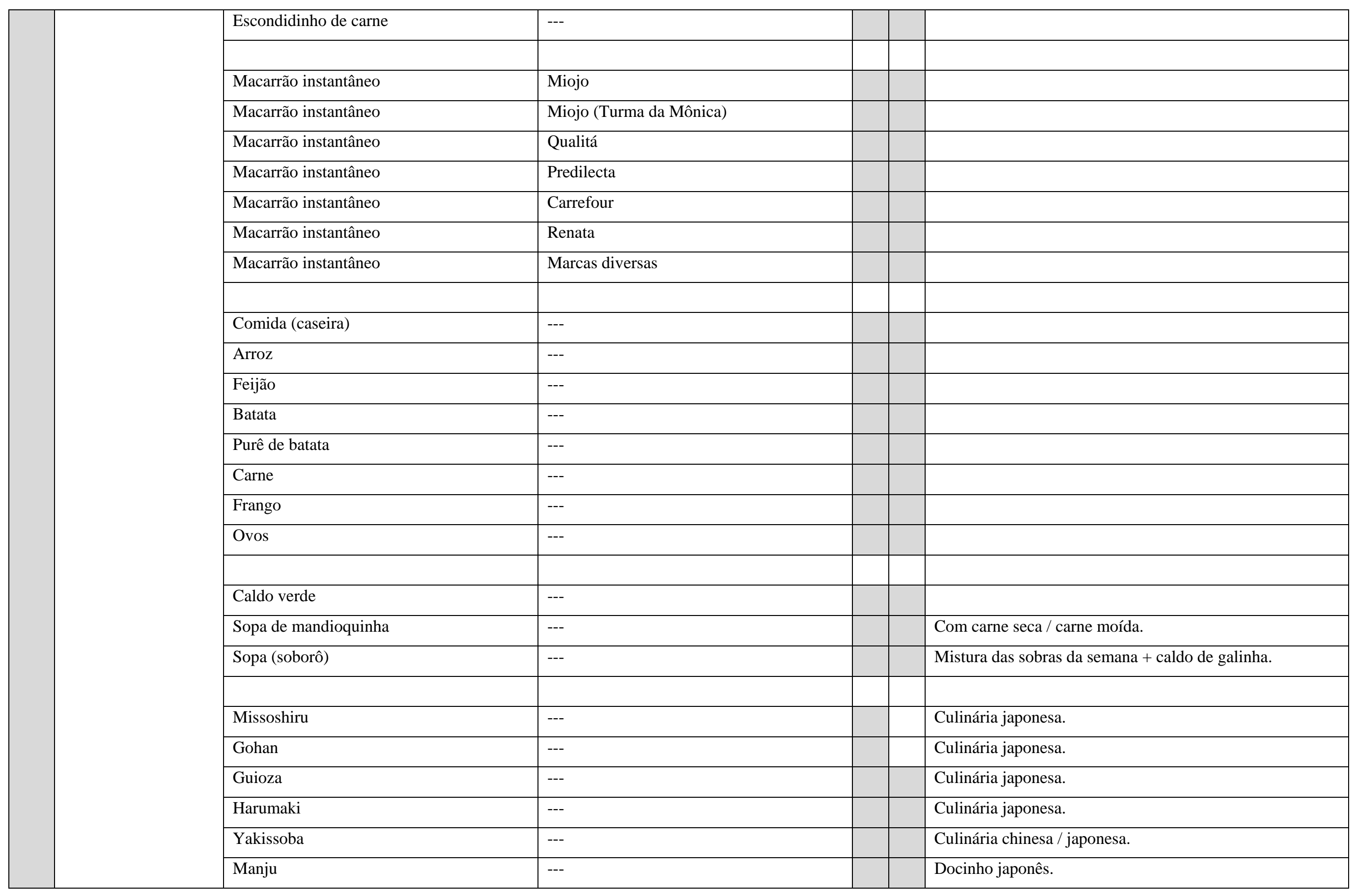




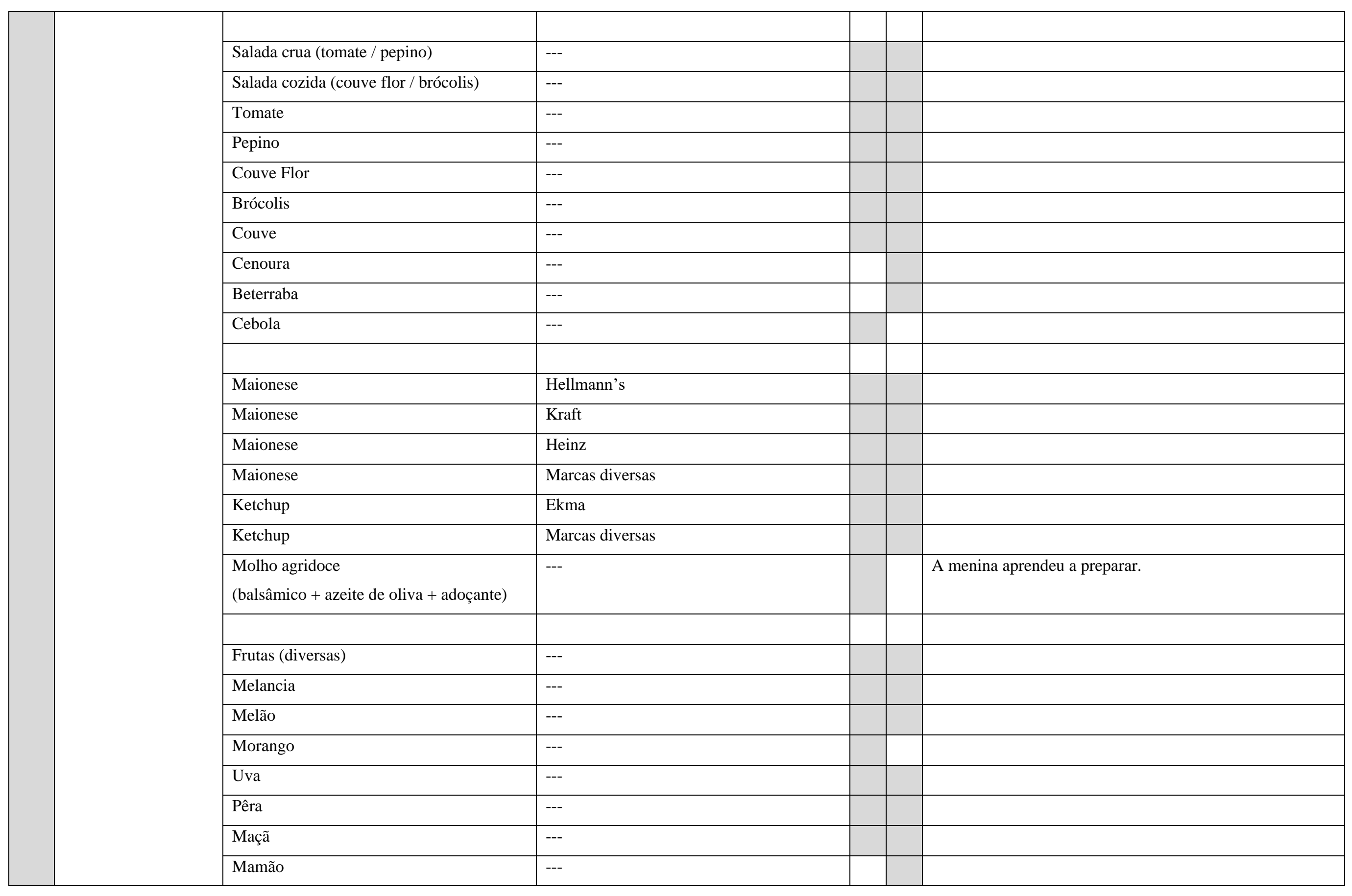




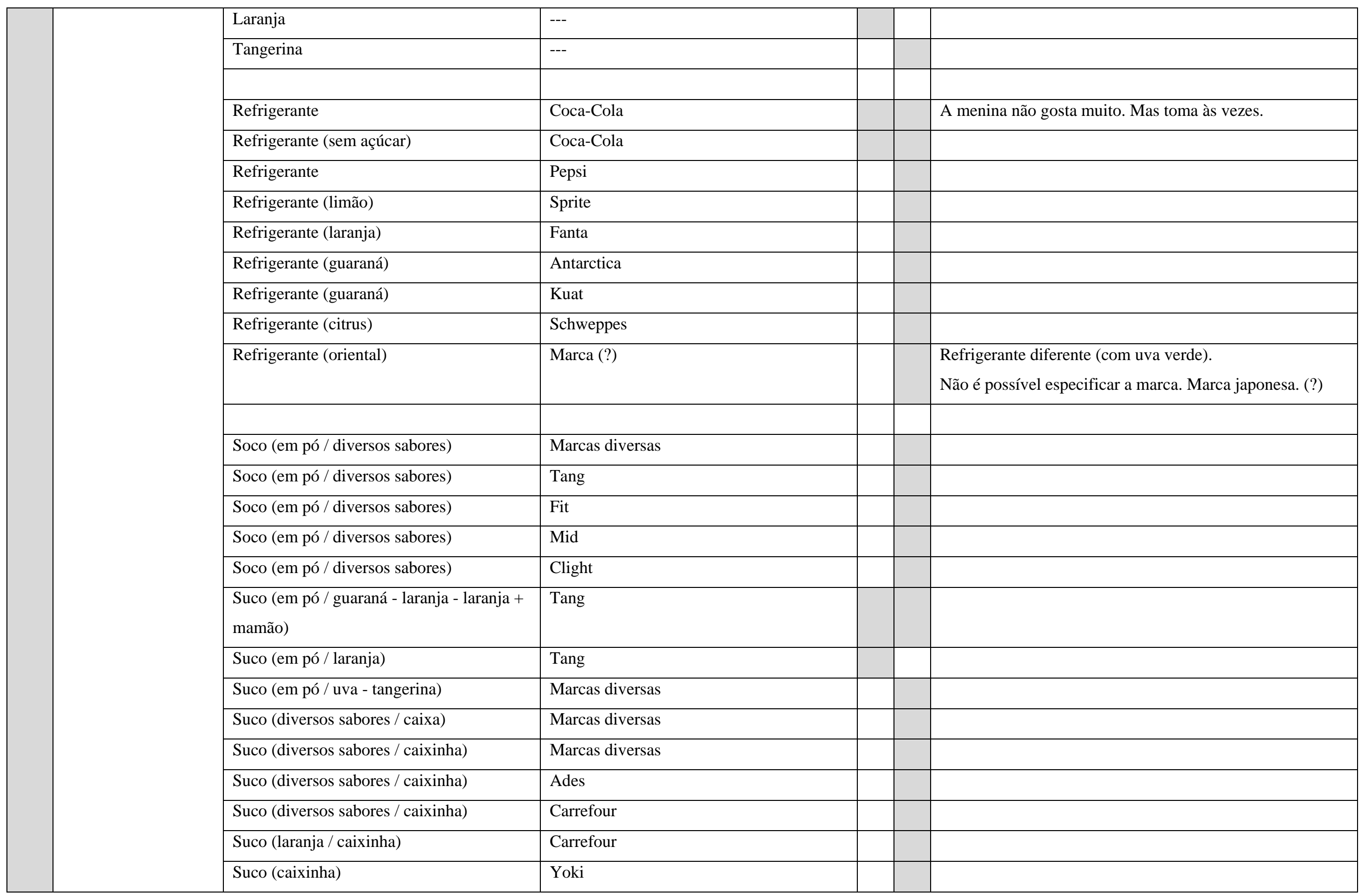




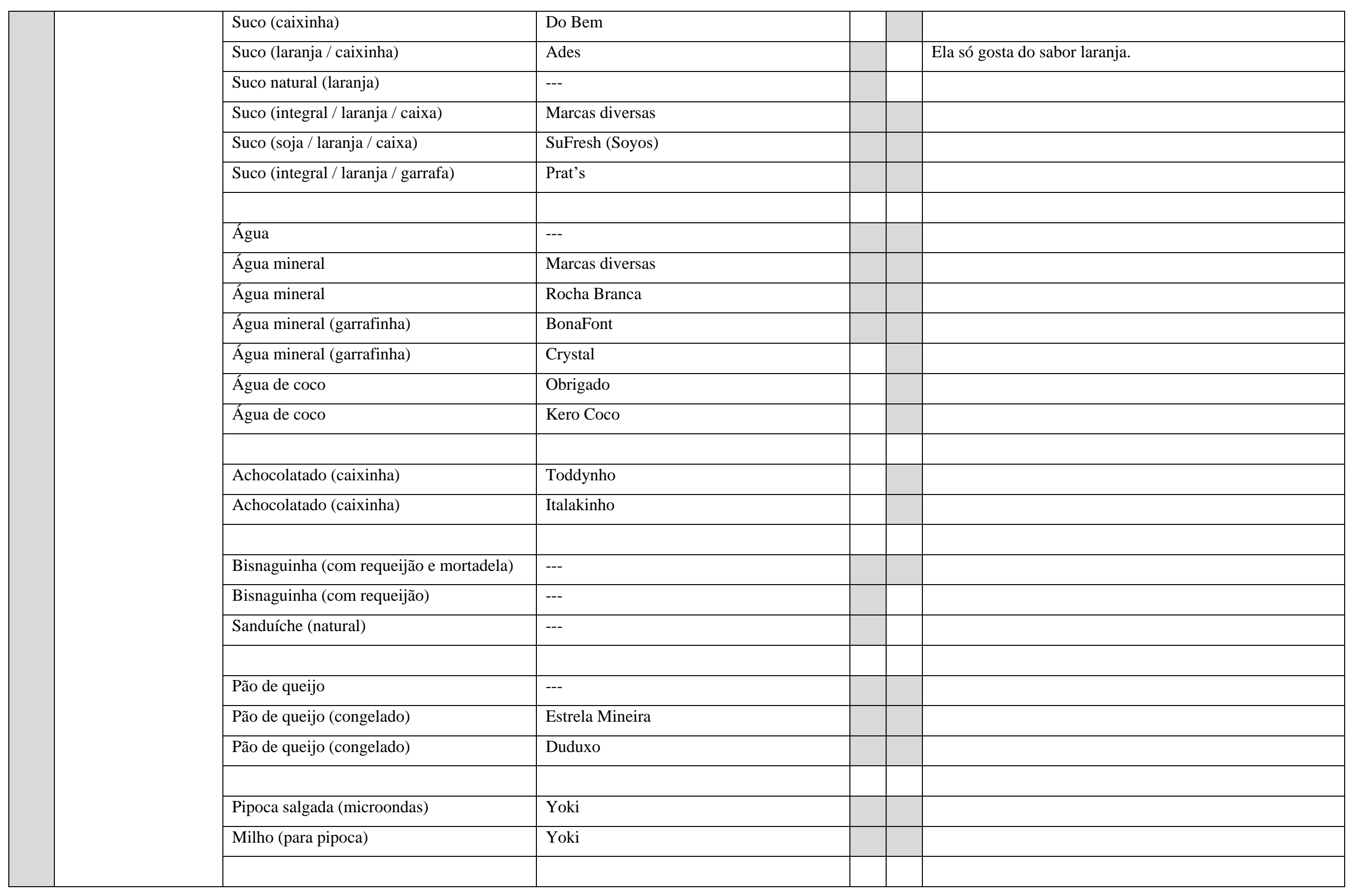




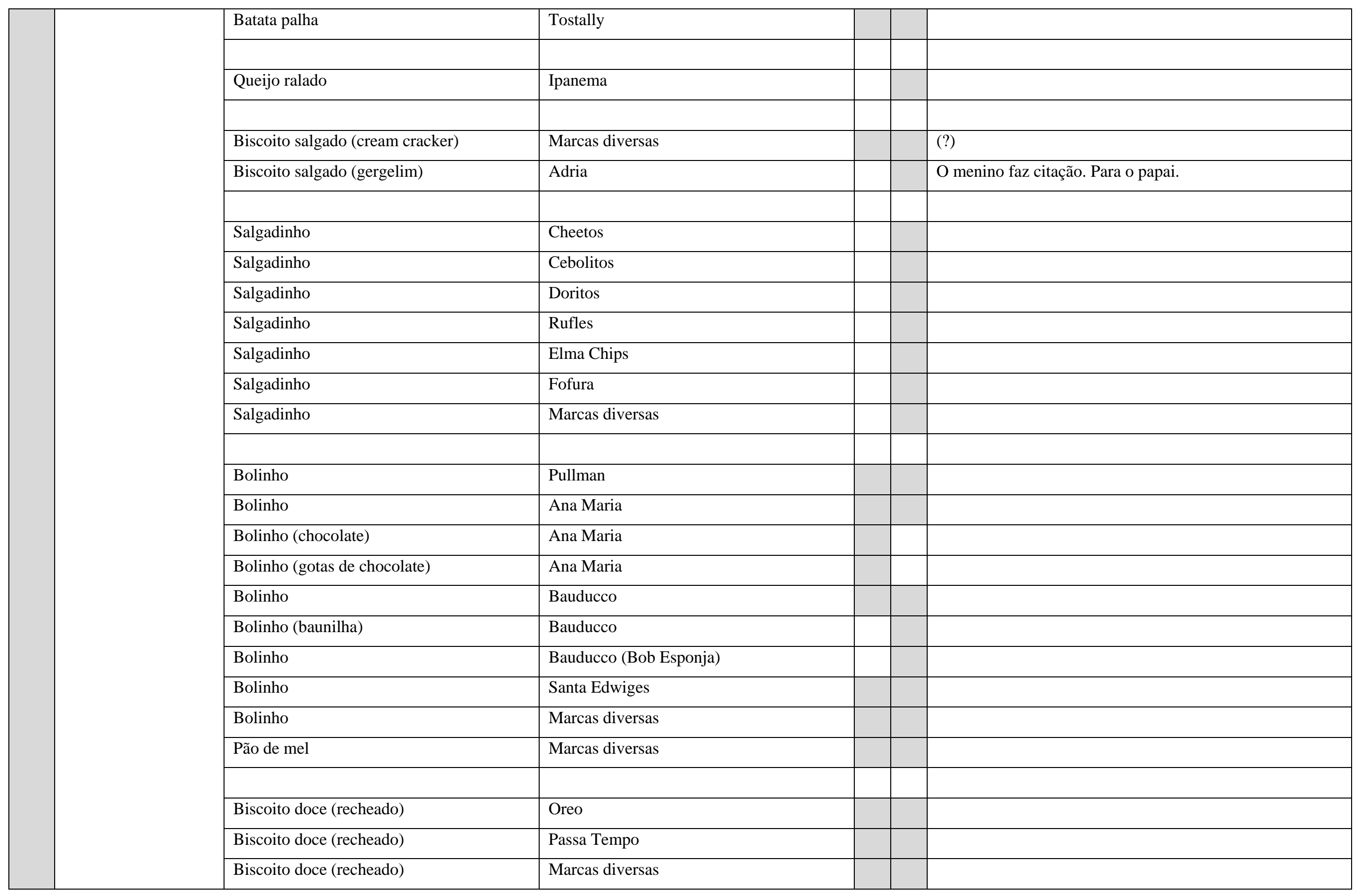




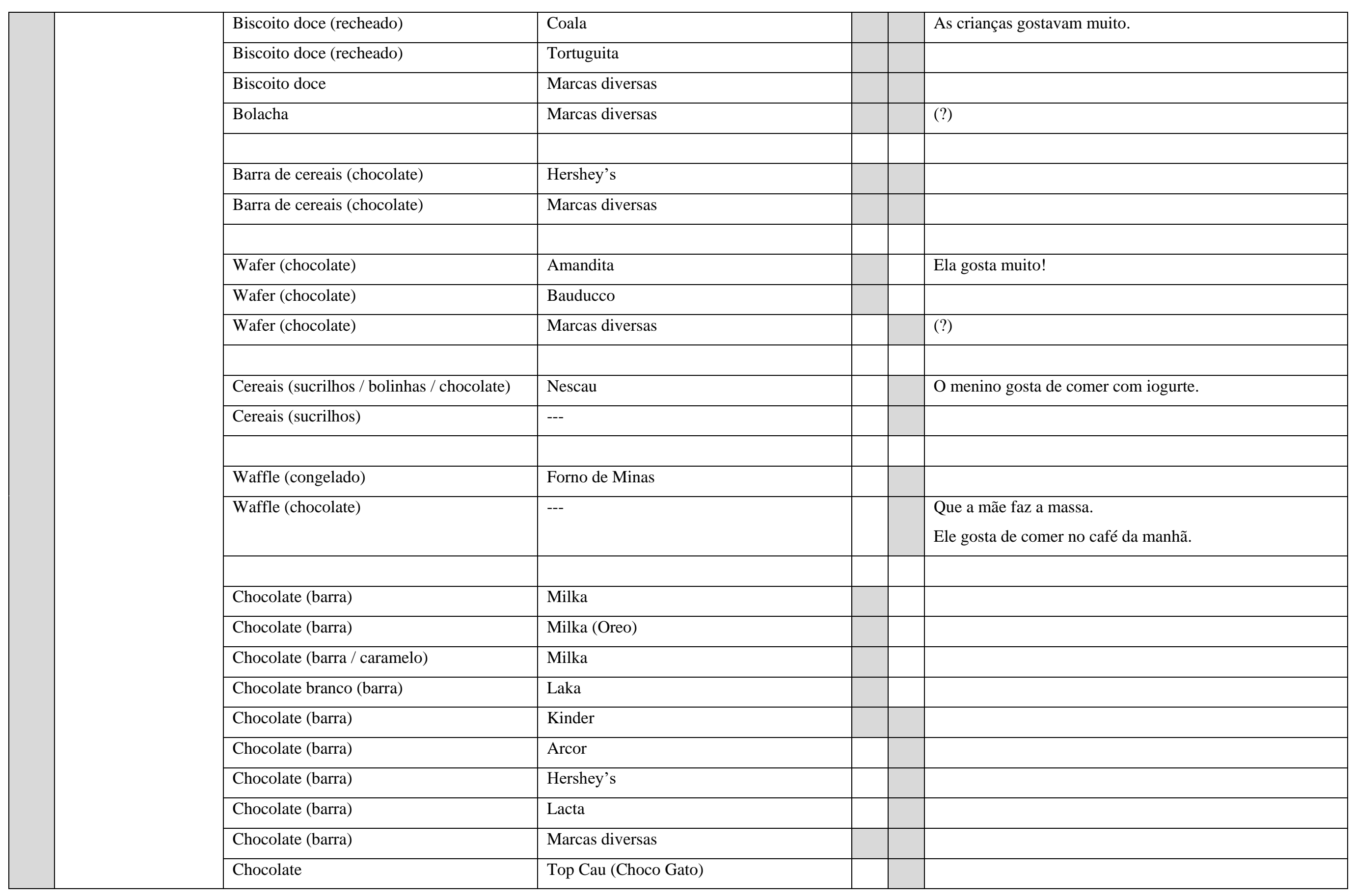




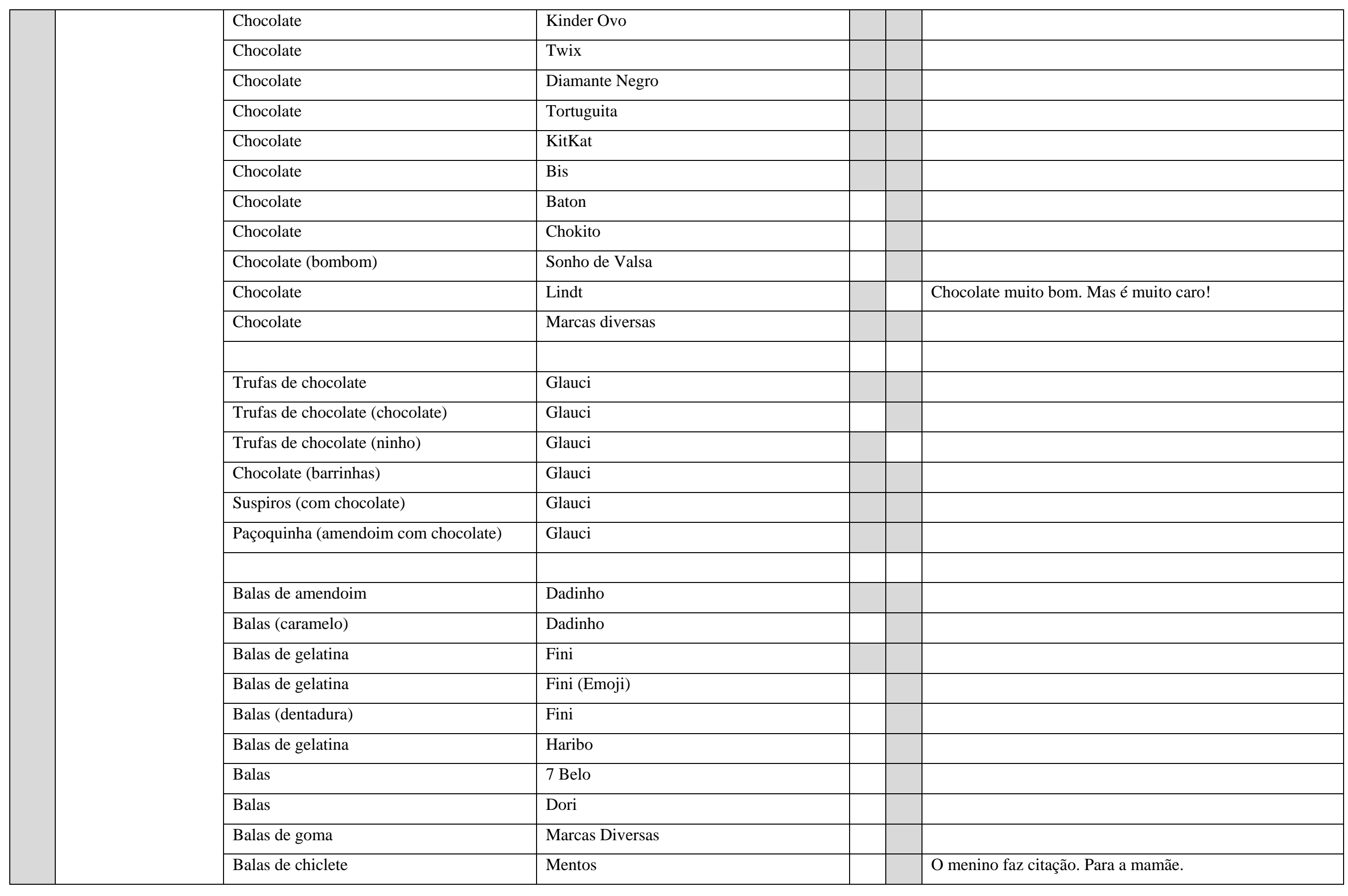




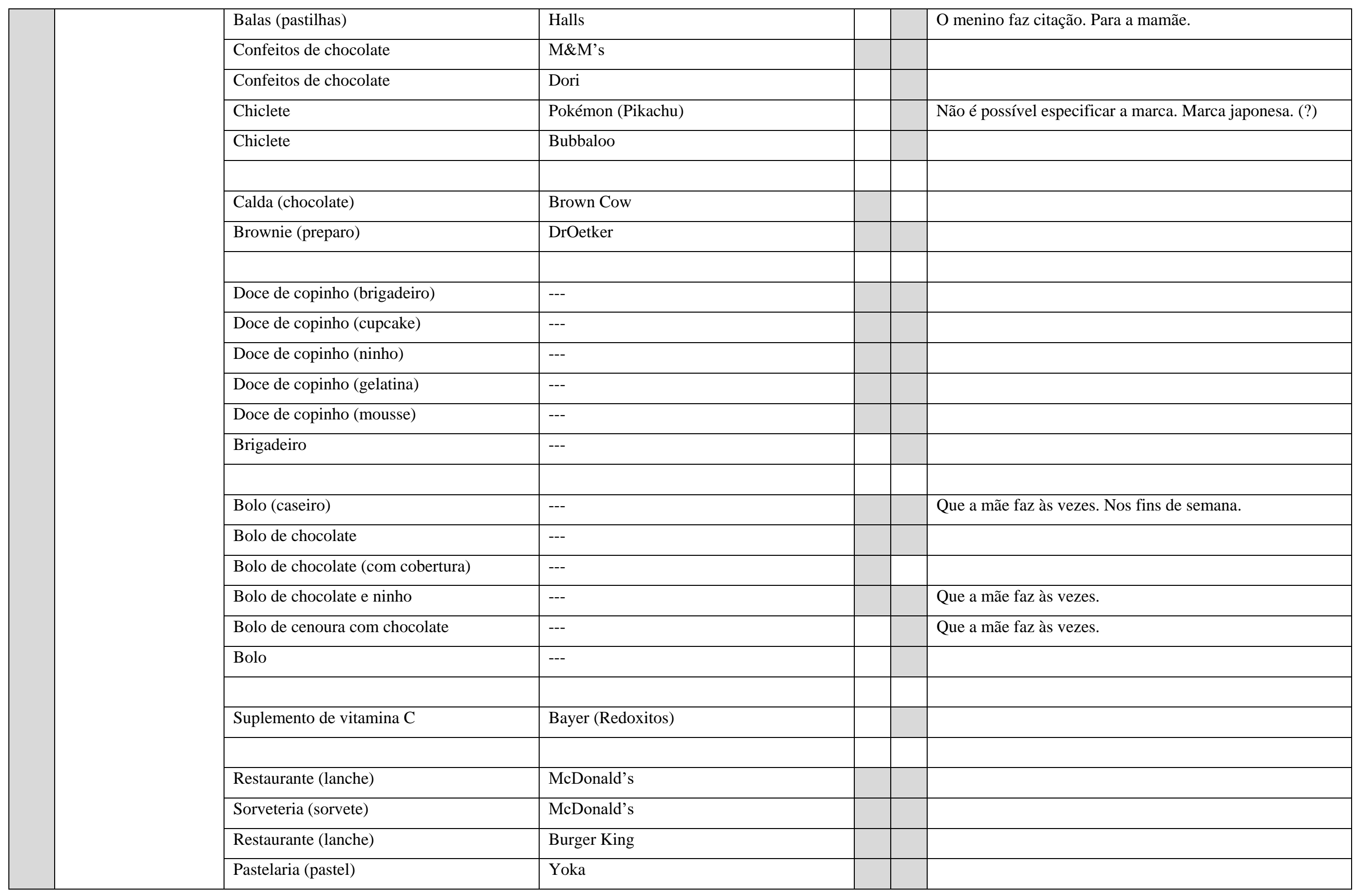




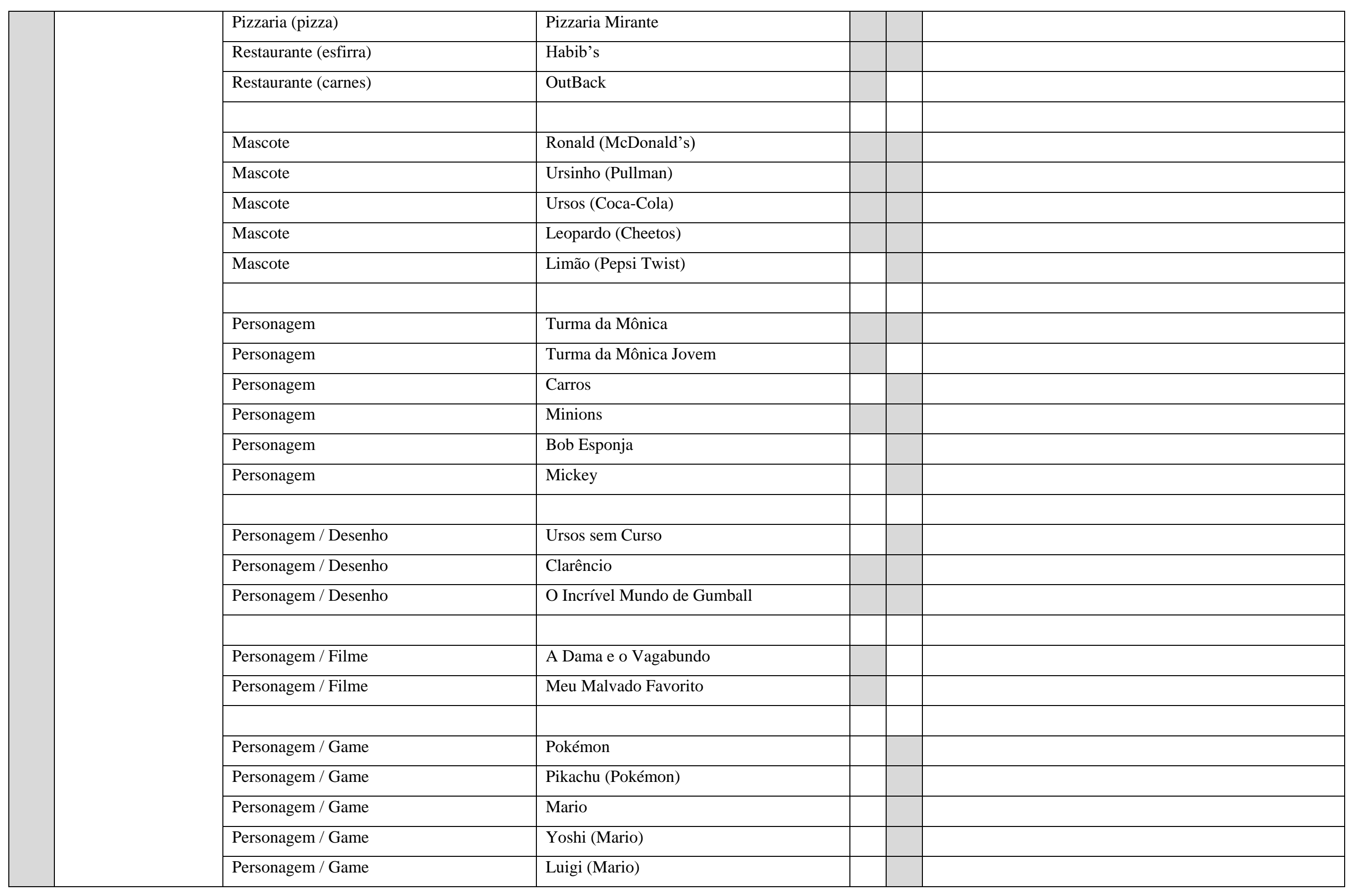




\begin{tabular}{|c|c|c|}
\hline Personagem / Game & Sonic & \\
\hline Personagem / Game & Kirby & \\
\hline Personagem / Game & Zelda & \\
\hline Série & O Mundo Sombrio de Sabrina & \\
\hline Série & One Day at a Time & \\
\hline Série & Santa Clarita Diet & \\
\hline Canal YouTube / Youtuber & Jana Taffarel & \\
\hline Canal YouTube / Youtuber & Você Sabia? & \\
\hline Instagram / Instagramer & Mari Maria & \\
\hline Canal YouTube / Instagram & Diversos & Canais sobre maquiagem / papelaria. \\
\hline Canal YouTube / Youtuber & Diversos & Canais sobre videogame. \\
\hline Game & Pokémon & \\
\hline Game & Mario & \\
\hline Game & Sonic & \\
\hline Game & Kirby & \\
\hline Game & Zelda & \\
\hline Game & The Sims 4 & \\
\hline Mídia (Internet) & YouTube & \\
\hline Mídia (Internet) & Instagram & \\
\hline Mídia (Internet) & NetFlix & \\
\hline Mídia (televisão) & Cartoon Network & \\
\hline Rede social (celular) & What'sApp & \\
\hline Rede social (celular) & Instagram & \\
\hline
\end{tabular}




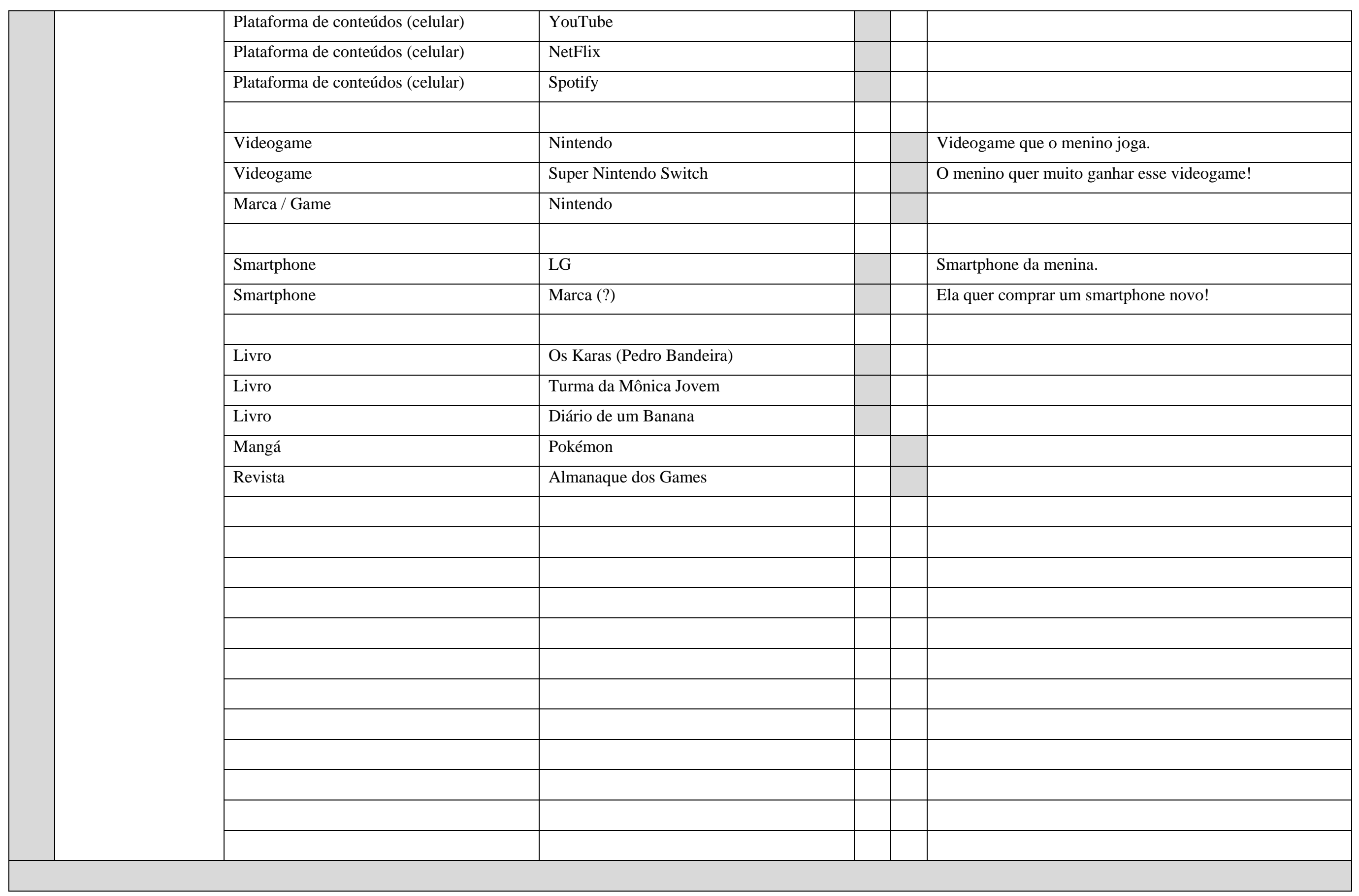




\begin{tabular}{|c|c|c|c|}
\hline QUE NÃO & Creme de avelã e cacau & IoIo Crem & As crianças experimentaram. Mas não gostaram. \\
\hline CONHECE & & & \\
\hline \multirow{3}{*}{ QUE NÃO GOSTA } & Chocolate (barra) & Garoto & \\
\hline & & & \\
\hline & Iogurte & Marcas diversas & \\
\hline \multirow{2}{*}{$\begin{array}{l}\text { QUE GOSTA } \\
\text { MENOS }\end{array}$} & Iogurte (garrafinha) & Danoninho & \\
\hline & Iogurte petit suisse & Danoninho & \\
\hline \multirow{15}{*}{$\begin{array}{l}\text { QUE NÃO } \\
\text { CONSOME }\end{array}$} & Iogurte & Elegê & Ele não conhece a marca. \\
\hline & Iogurte & Batavo & Ele não conhece a marca. \\
\hline & & & \\
\hline & Leite & Fazenda & Ele não conhece a marca. \\
\hline & Leite & Parmalat & Ele não conhece a marca. \\
\hline & Salgadinho & Marcas diversas & \\
\hline & Salgadinho & Cheetos & \\
\hline & Salgadinho (integral) & Mãe Terra & \\
\hline & Castanhas & --- & \\
\hline & Sorvete & Bacio di Latte & Ele não conhece a marca. \\
\hline & $\begin{array}{l}\text { Mousse de maracujá com gotas de } \\
\text { chocolate }\end{array}$ & --- & \\
\hline & Doce de maracujá & --- & \\
\hline & Torta de banana & --- & \\
\hline & Pastel (pizza) & --- & \\
\hline & Orégano & --- & \\
\hline & & & \\
\hline
\end{tabular}




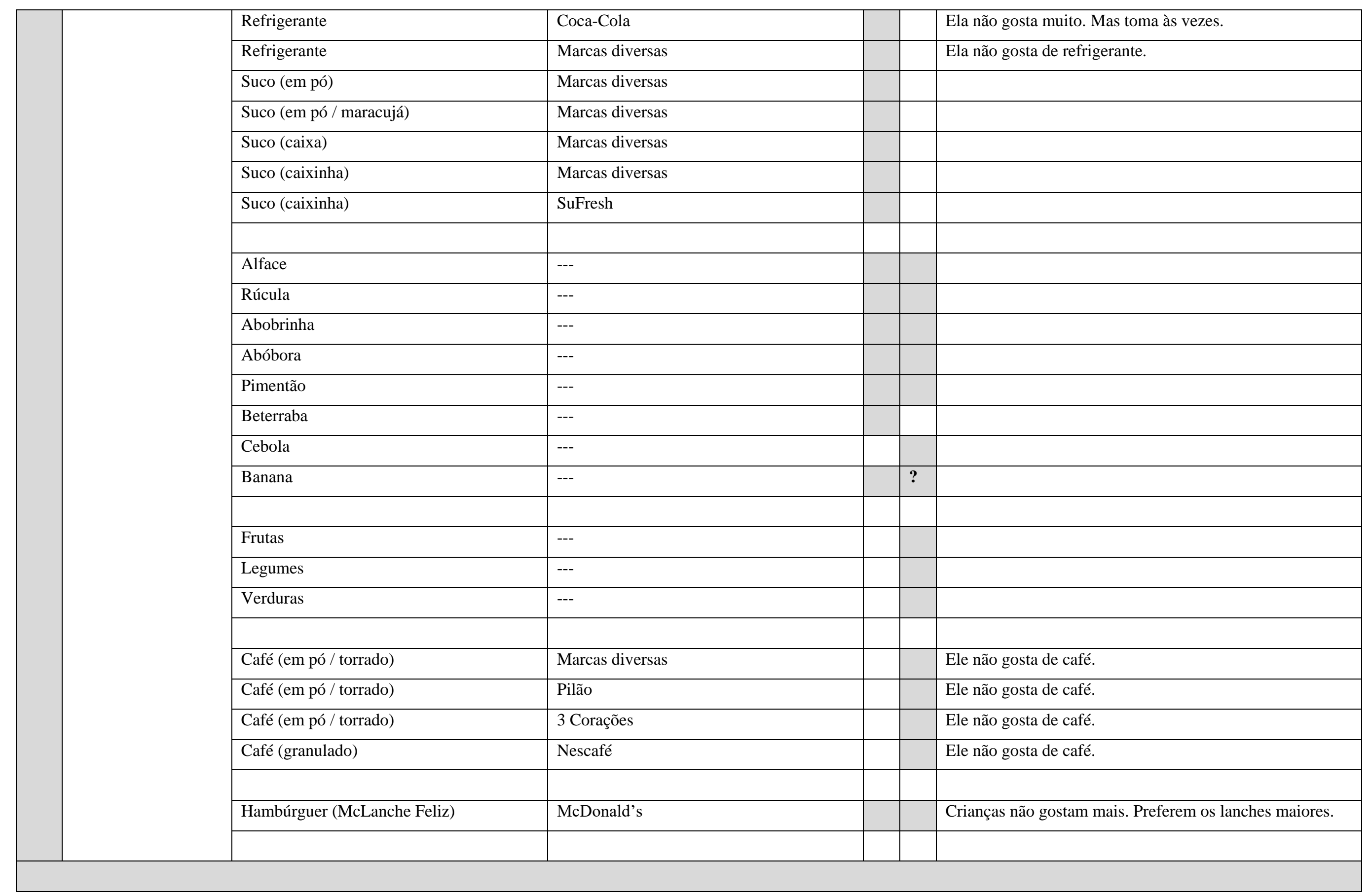




\section{QUARTO ENCONTRO: ATIVIDADE LÚDICA COM AS CRIANÇAS: BRINCADEIRA DE COMER}

PRODUTOS - MARCAS - PERSONAGENS

(RELATOS / OBSERVAÇÕES / CITAÇÕES / EXPRESSIVIDADES / FOTOS / VÍDEOS / OBSERVAÇ̃̃̃)

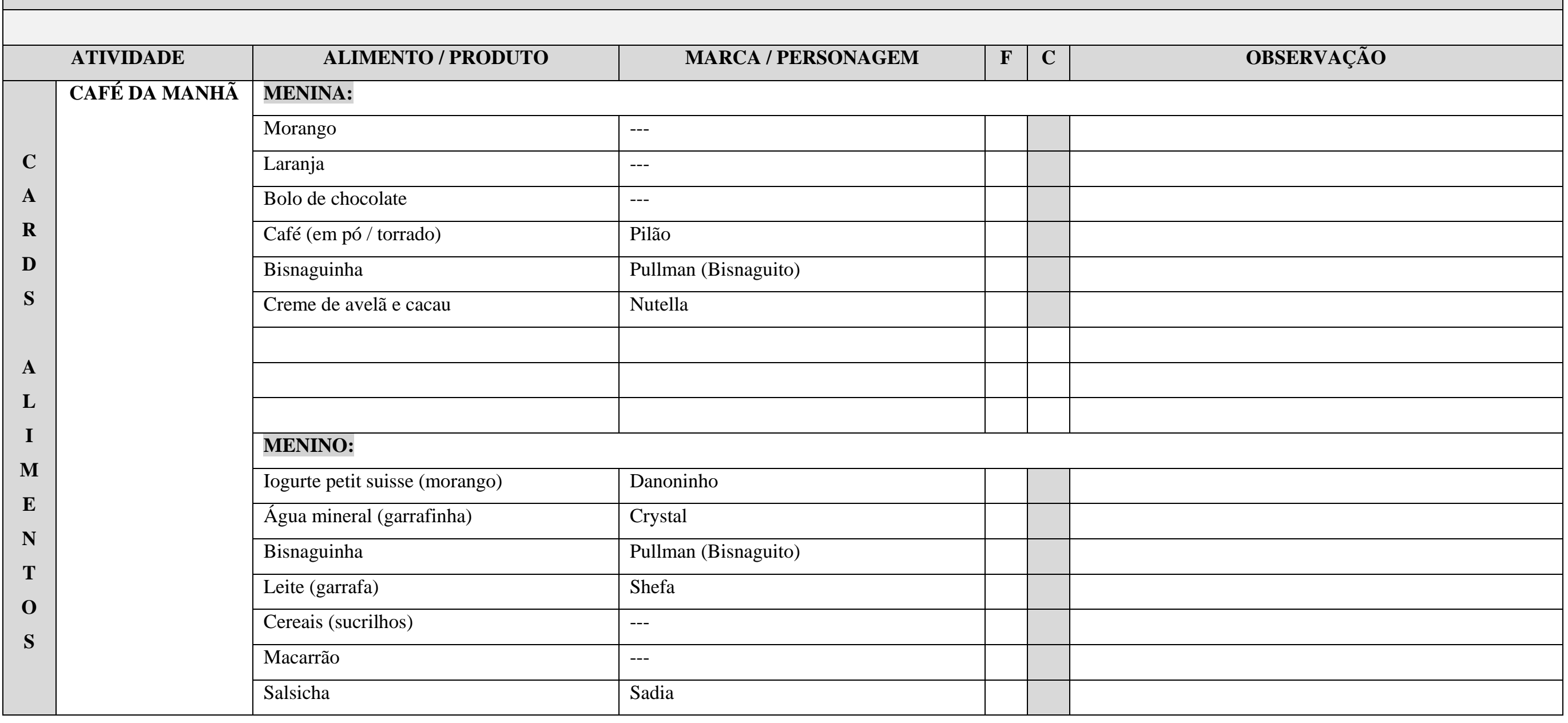




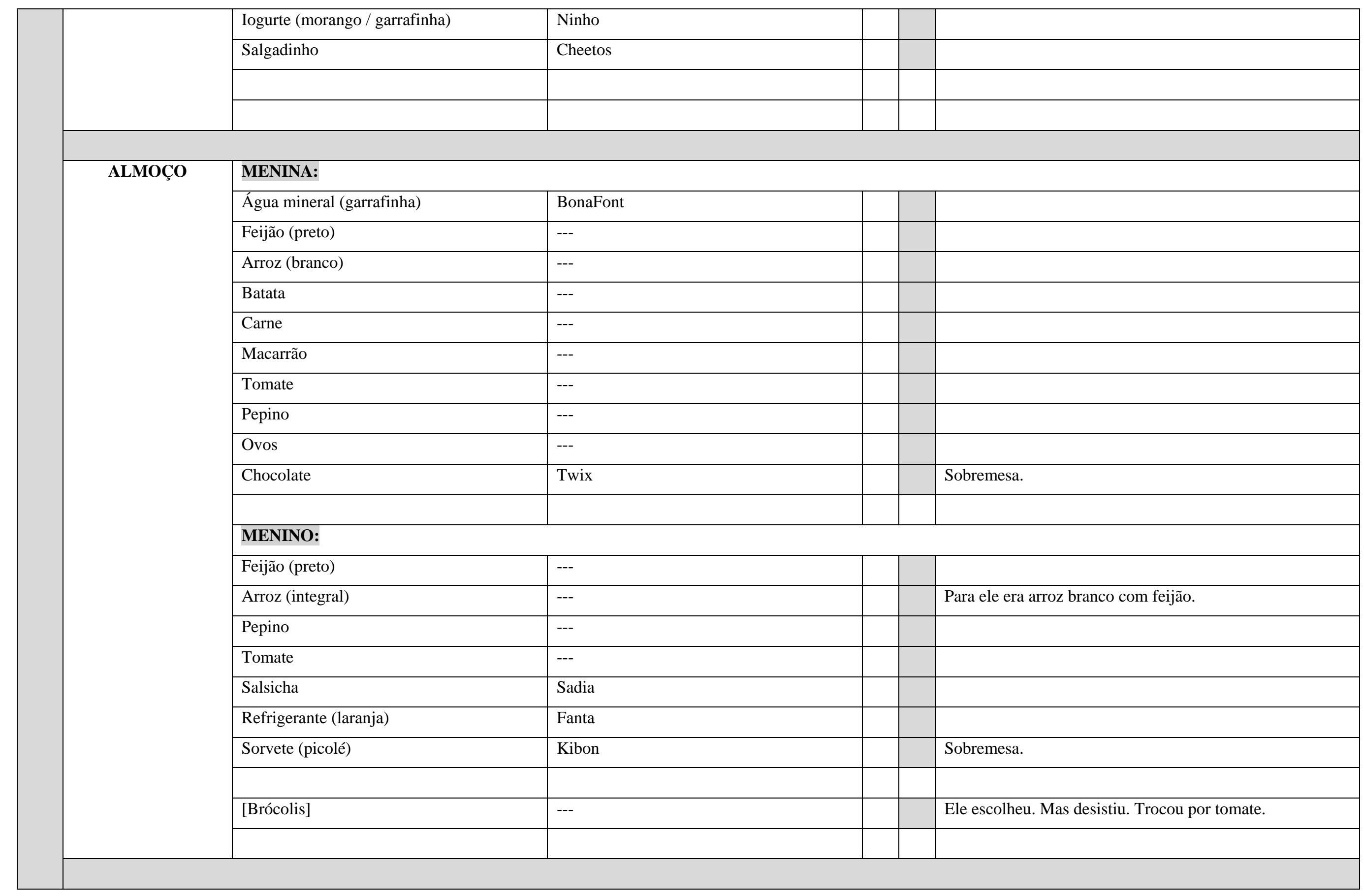




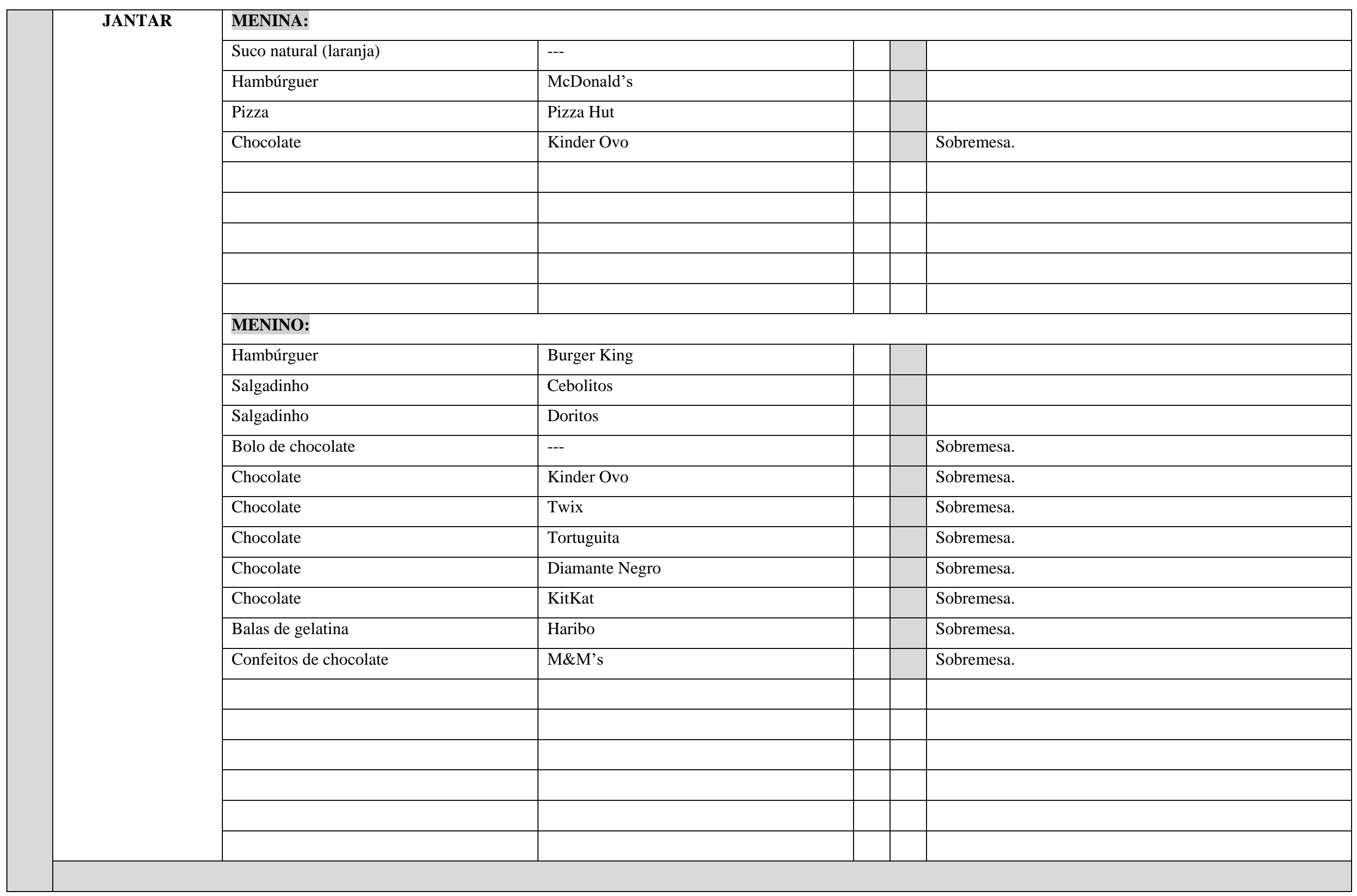




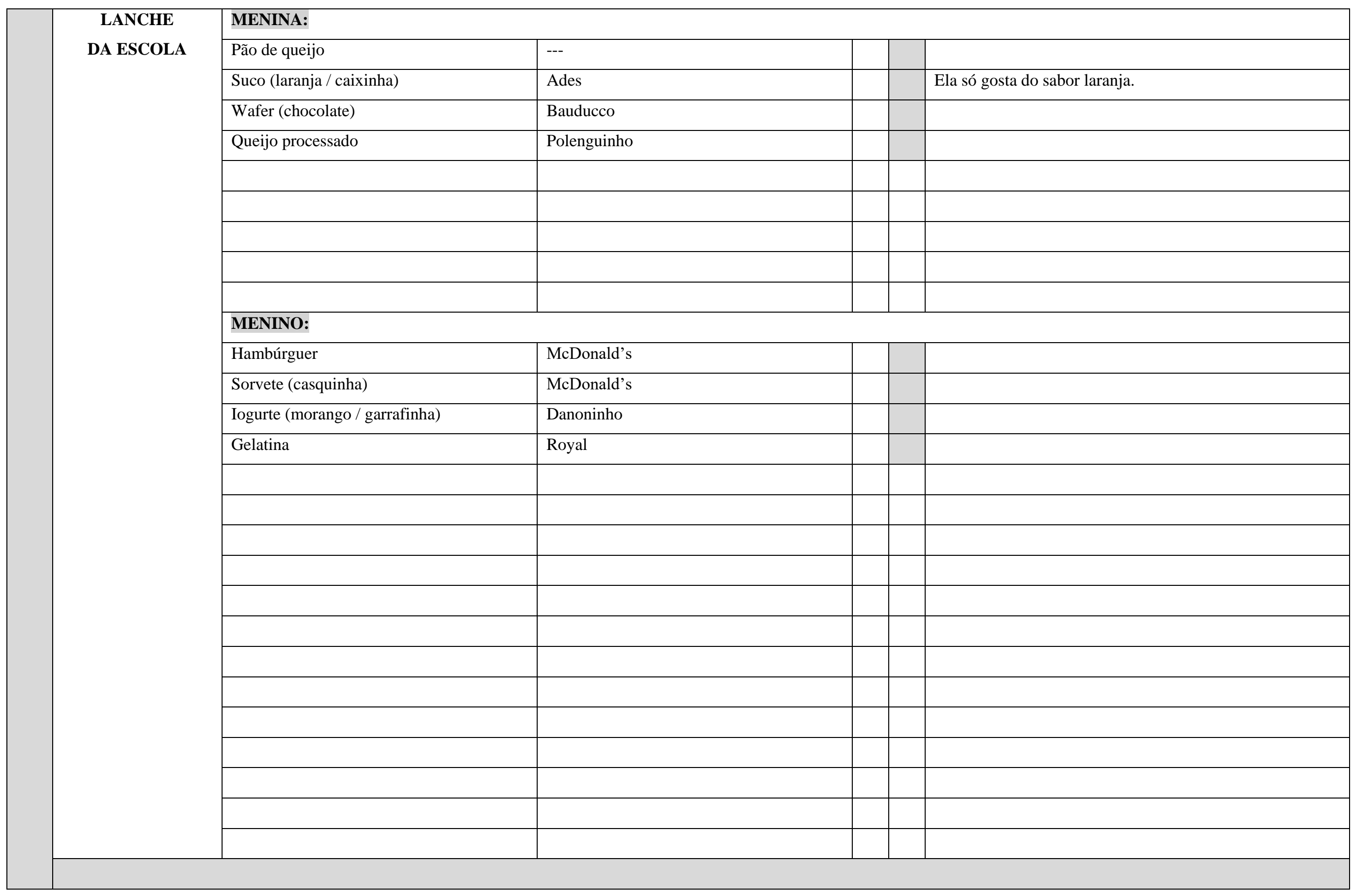




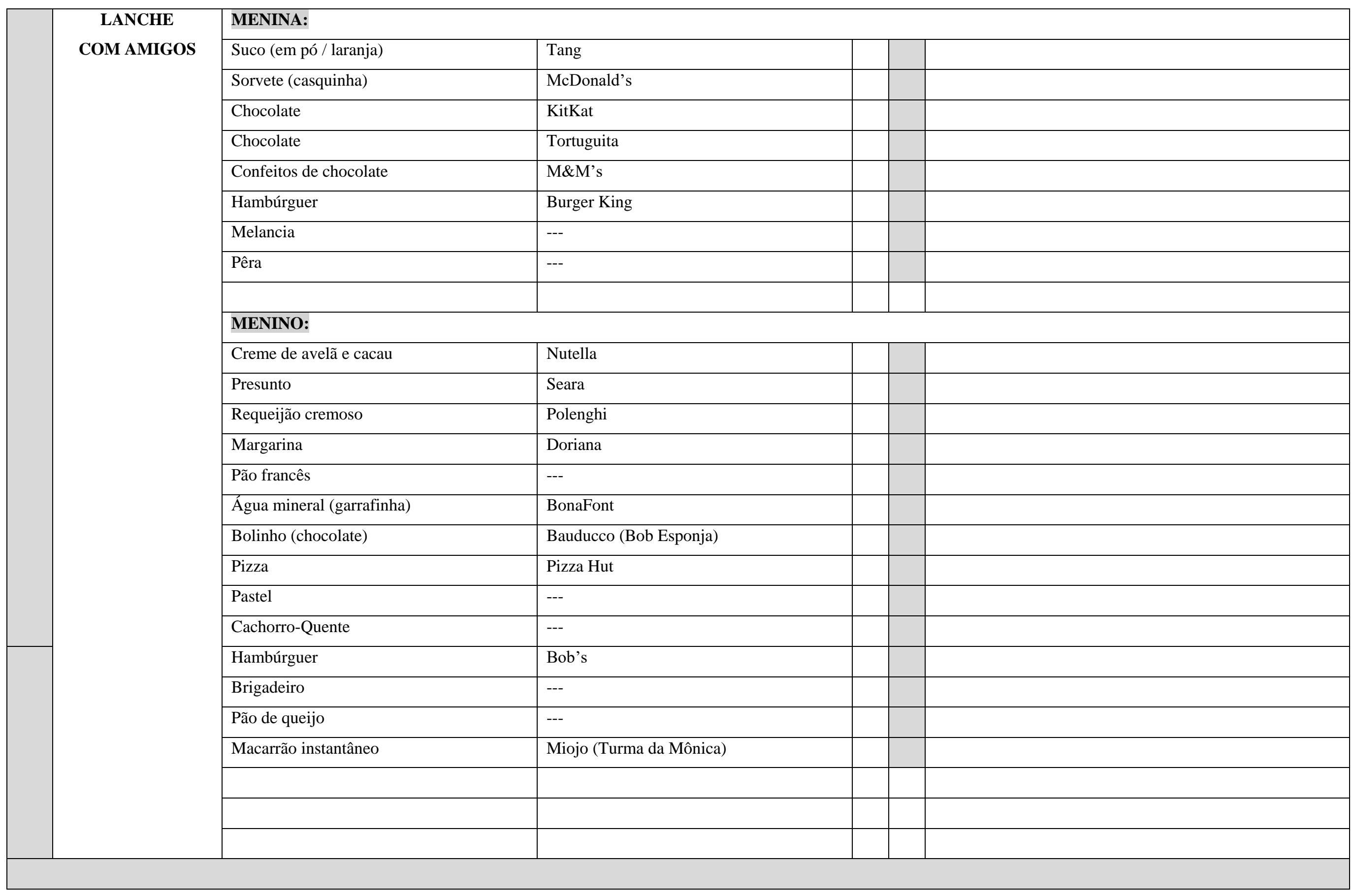




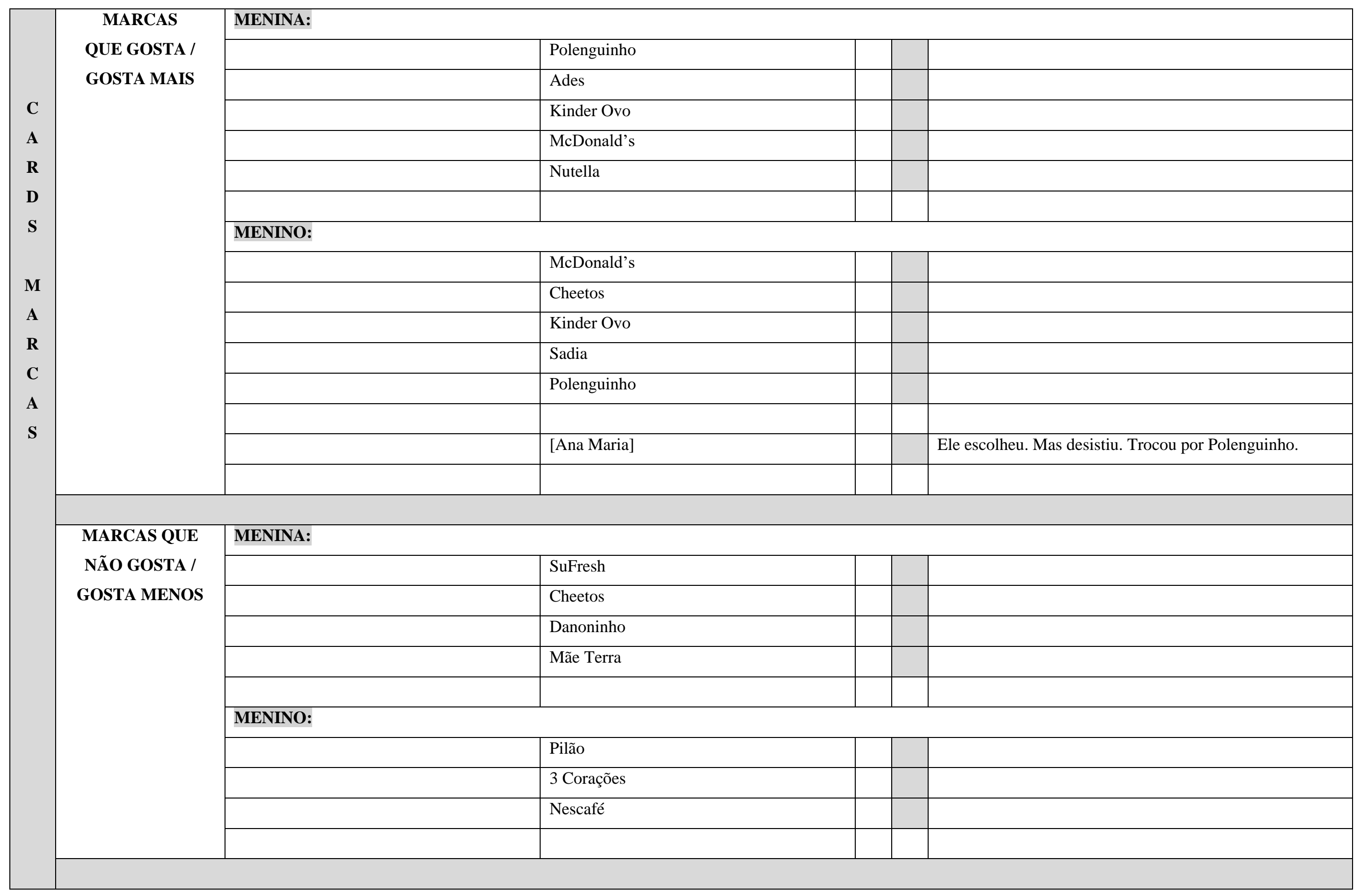




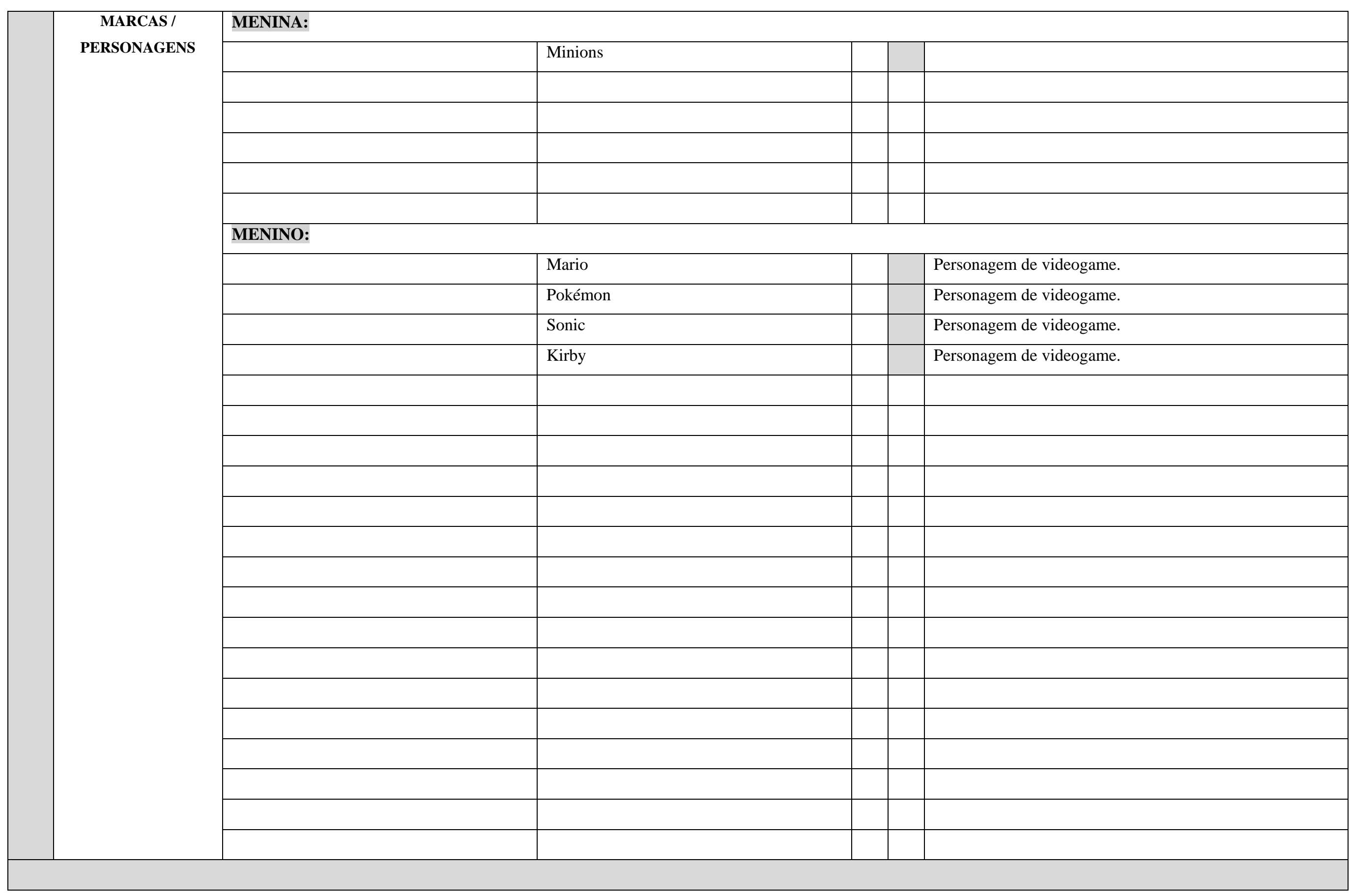




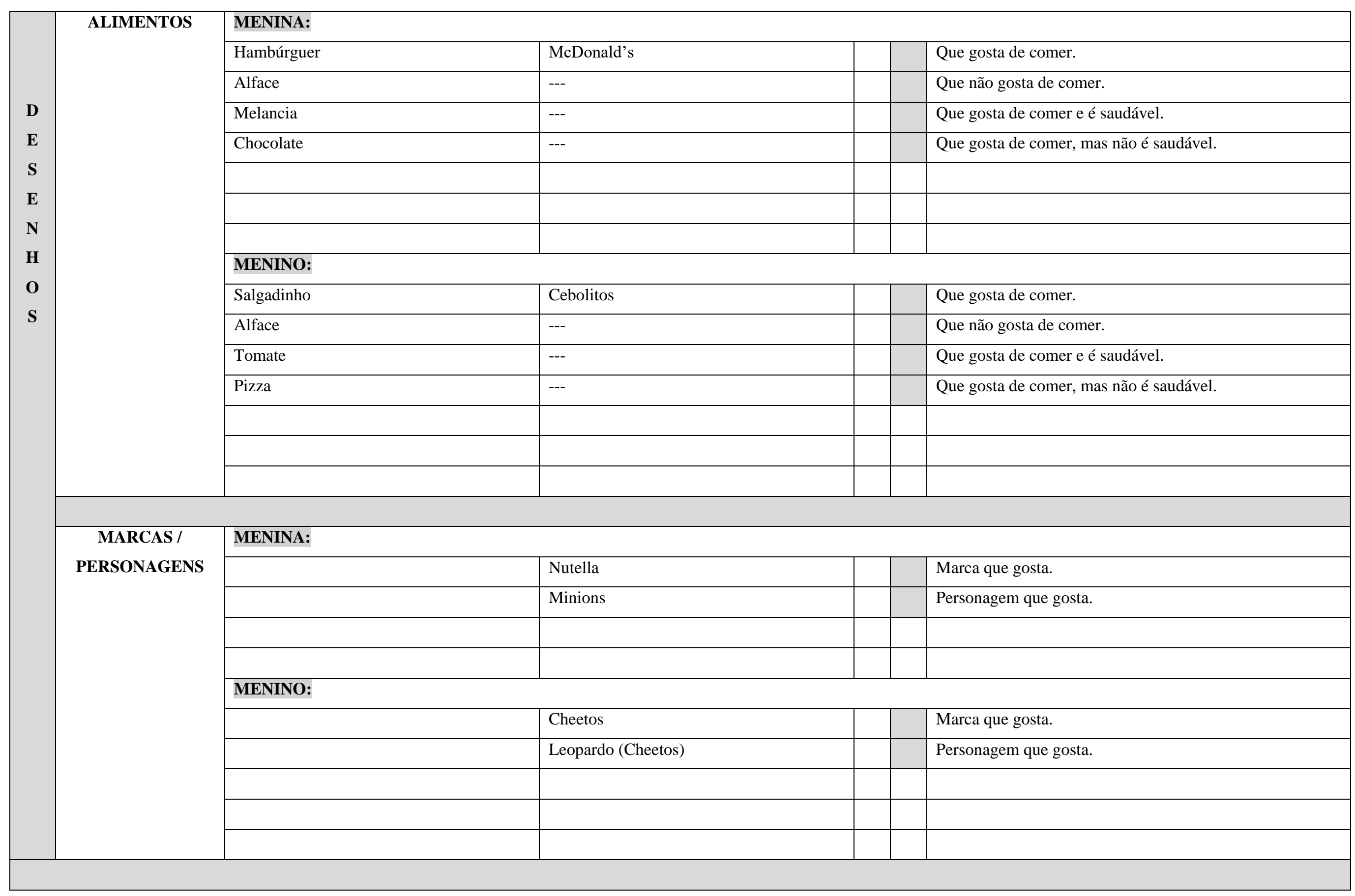




\section{QUINTO ENCONTRO: ATIVIDADE LÚDICA COM AS CRIANÇAS: BRINCADEIRA DE COMPRAR}

PRODUTOS - MARCAS - PERSONAGENS

(RELATOS / OBSERVAÇÕES / CITAÇÕES / EXPRESSIVIDADES / FOTOS / VÍDEOS / OBSERVAÇÃO)

\begin{tabular}{|c|c|c|c|c|c|c|}
\hline & ATIVIDADE & ALIMENTO / PRODUTO & MARCA / PERSONAGEM & $\mathbf{F}$ & $\mathbf{C}$ & OBSERVAÇÃO \\
\hline \multirow[b]{2}{*}{$\mathbf{S}$} & \multirow[t]{16}{*}{ CARRINHO } & \multicolumn{5}{|l|}{ MENINA: } \\
\hline & & Chocolate branco (barra) & Laka & & & \\
\hline \multirow{2}{*}{$\begin{array}{c}\mathbf{I} \\
\mathbf{M}\end{array}$} & & Chocolate (barra) & Milka (Oreo) & & & \\
\hline & & Bolinho (gotas de chocolate) & Ana Maria & & & \\
\hline \multirow[t]{2}{*}{$\mathbf{U}$} & & Suco (laranja / caixinha) & Ades & & & \\
\hline & & Chocolate & Kinder Ovo & & & \\
\hline \multicolumn{6}{|c|}{ A } & \\
\hline \multicolumn{6}{|c|}{ Ç } & \\
\hline$\tilde{\mathbf{A}}$ & & \multicolumn{5}{|l|}{ MENINO: } \\
\hline $\mathbf{O}$ & & Melancia (em cubos) & --- & & & $\begin{array}{l}\text { Ele queria pegar a fruta inteira. } \\
\text { Mas a mãe sugeriu a fruta cortada em cubos. }\end{array}$ \\
\hline \multirow[t]{2}{*}{ C } & & Refrigerante (citrus) & Schweppes & & & \\
\hline & & Balas de gelatina & Fini (Emoji) & & & \\
\hline \multirow[t]{2}{*}{ M } & & Coxinha de frango & Supermercado Jaguaré & & & \\
\hline & & Pão de forma & Seven Boys & & & \\
\hline $\mathbf{R}$ & & & & & & \\
\hline S & & & & & & \\
\hline
\end{tabular}




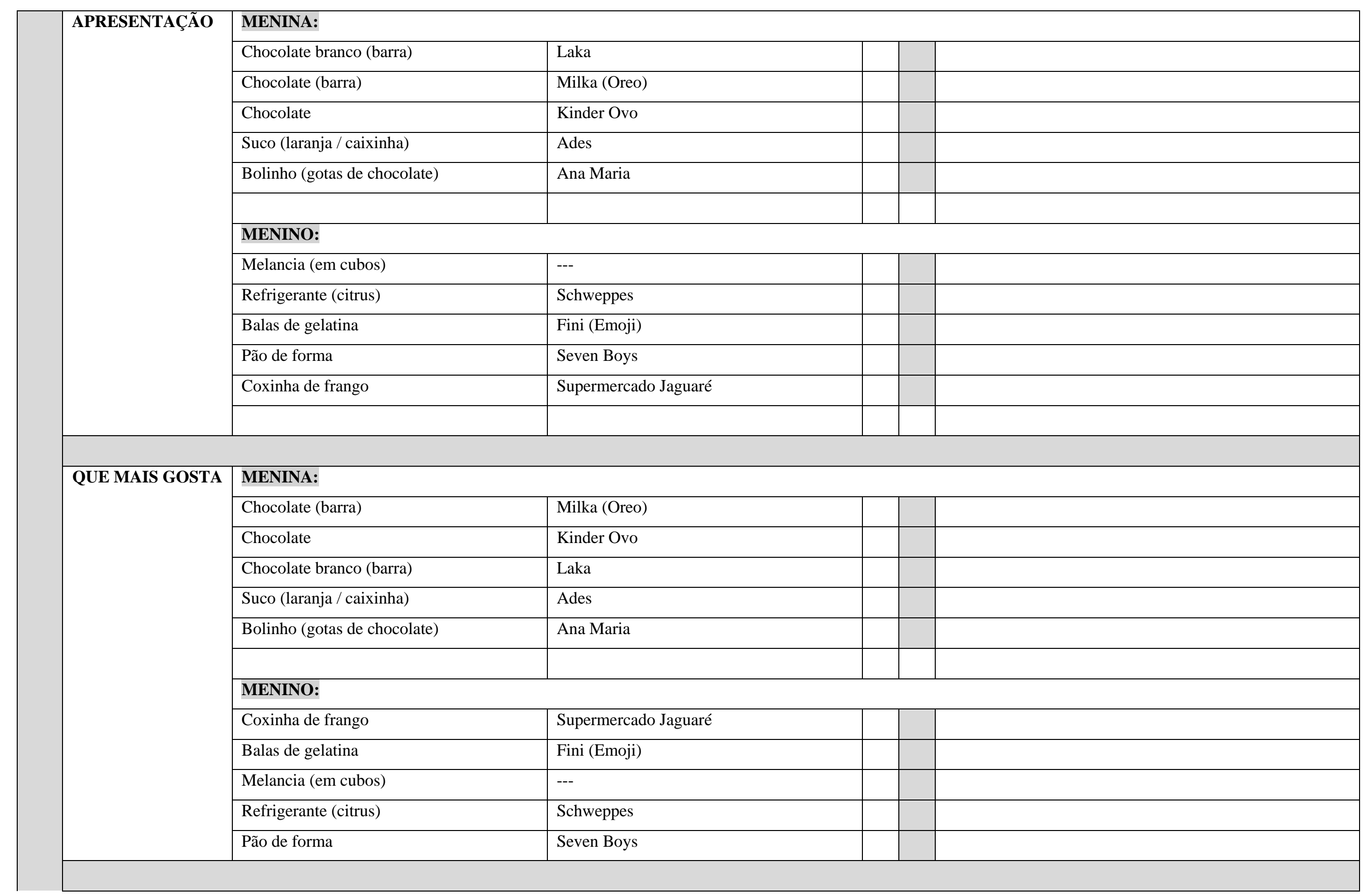




\begin{tabular}{|c|c|c|}
\hline QUE É MAIS & MENINA: & \\
\hline SAUDÁVEL / & Suco (laranja / caixinha) & Ades \\
\hline MENOS & Bolinho (gotas de chocolate) & Ana Maria \\
\hline SAUDÁVEL & Chocolate & Kinder Ovo \\
\hline & Chocolate branco (barra) & Laka \\
\hline & Chocolate (barra) & Milka (Oreo) \\
\hline & MENINO: & \\
\hline & Melancia (em cubos) & --- \\
\hline & Pão de forma & Seven Boys \\
\hline & Refrigerante (citrus) & Schweppes \\
\hline & Balas de gelatina & Fini (Emoji) \\
\hline & Coxinha de frango & Supermercado Jaguaré \\
\hline CARRINHO + & MENINA: & \\
\hline SAUDÁVEL & & \\
\hline & & \\
\hline & & \\
\hline & MENINO: & \\
\hline & & \\
\hline & & \\
\hline & & \\
\hline & & \\
\hline & & \\
\hline & & \\
\hline & & \\
\hline
\end{tabular}




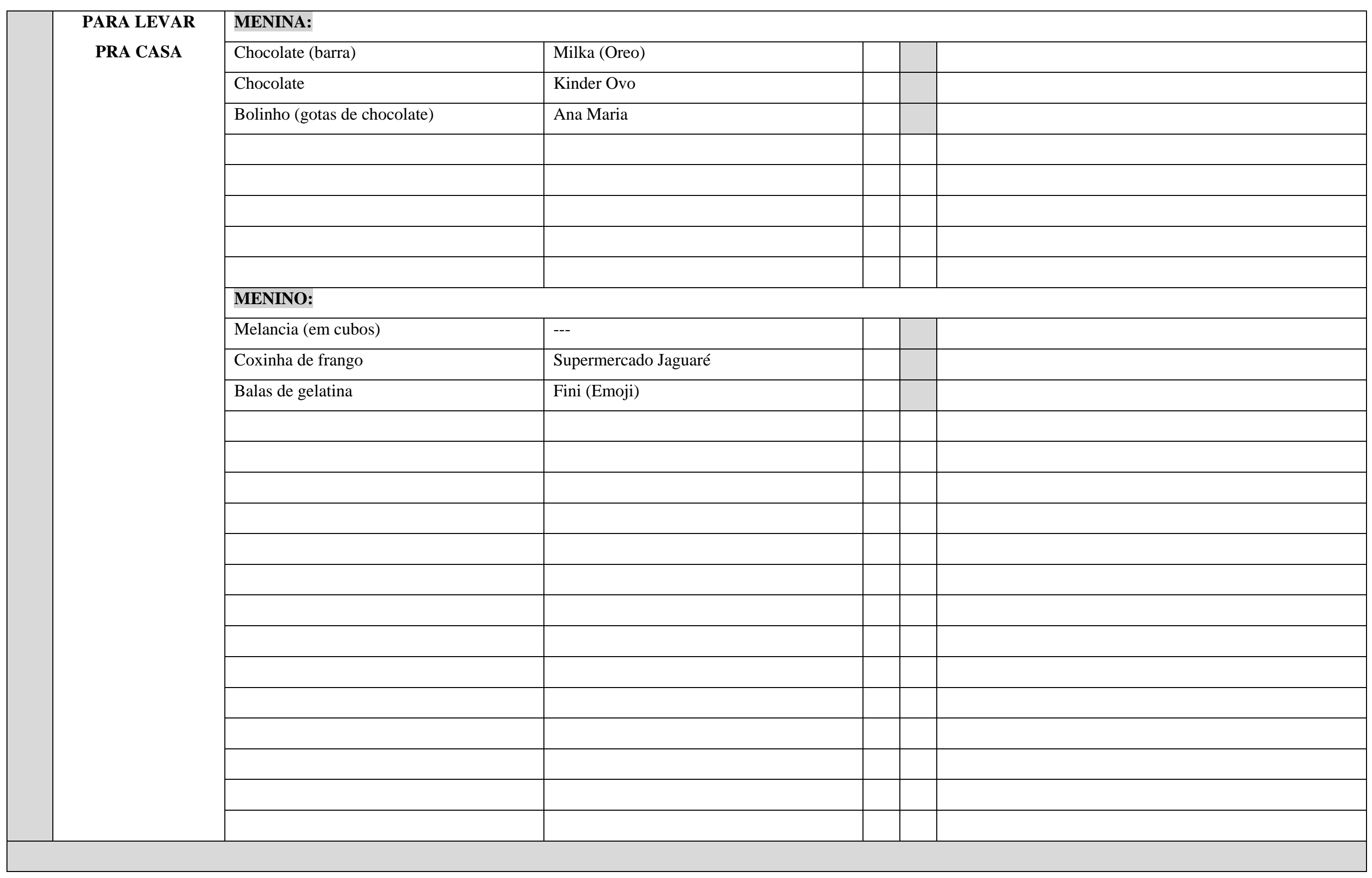




\section{SEXTO ENCONTRO: ATIVIDADE LÚDICA COM AS CRIANÇAS: THE KIDS: MY FOODS}

PRODUTOS - MARCAS - PERSONAGENS

(RELATOS / OBSERVAÇÕES / CITAÇÕES / EXPRESSIVIDADES / FOTOS / VÍDEOS / OBSERVAÇÃO)

\begin{tabular}{|c|c|c|c|c|c|c|}
\hline & ATIVIDADE & ALIMENTO / PRODUTO & MARCA / PERSONAGEM & $\mathbf{F}$ & $\mathbf{C}$ & OBSERVAÇÃO \\
\hline \multirow{5}{*}{$\begin{array}{l}\mathbf{M} \\
\mathbf{Y}\end{array}$} & \multirow[t]{16}{*}{ MY FOODS! } & \multicolumn{5}{|l|}{ MENINA: } \\
\hline & & Tomates & --- & & & \\
\hline & & Suco (laranja / caixinha) & Ades & & & \\
\hline & & Creme de avelã e cacau & Nutella & & & \\
\hline & & Wafer (chocolate) & Bauducco & & & \\
\hline \multicolumn{6}{|c|}{$\mathbf{F}$} & \\
\hline \multicolumn{6}{|c|}{$\mathbf{O}$} & \\
\hline $\mathbf{O}$ & & \multicolumn{5}{|l|}{ MENINO: } \\
\hline \multirow{8}{*}{$\mathbf{S}$} & & Tomates & --- & & & \\
\hline & & Salgadinho & Cheetos & & & \\
\hline & & Salsicha & Frimesa & & & \\
\hline & & Balas de goma & Marca (?) & & & Em potinho. Não é possível especificar a marca. \\
\hline & & Redoxitos (suplemento de vitamina C) & Bayer & & & \\
\hline & & & & & & \\
\hline & & & & & & \\
\hline & & & & & & \\
\hline
\end{tabular}




\section{Observações:}

$\mathrm{F}=$ Para a família (os pais e as crianças)

$\mathrm{C}=$ Para as crianças

$\mathrm{C} 1$ = Para a menina / Preferência da menina

C2 = Para o menino / Preferência do menino

Presença material $=$ Marcas e produtos alimentícios que a família $/$ as crianças consomem .

Presença simbólica = Marcas e produtos alimentícios que a família / as crianças gostariam de consumir .

(?) = Dúvidas quanto à especificação das marcas e produtos alimentícios em fotografias, vídeos ou relatos. 


\title{
APÊNDICE P
}

PESQUISA DE CAMPO

MARCAS E PRODUTOS NO CONTEXTO FAMILIAR

\author{
FAMÍLIA III
}

MARCAS E PRODUTOS: PRESENÇA MATERIAL E SIMBÓLICA 


\section{F A M Í L I A}

\section{MARCAS E PRODUTOS ALIMENTÍCIOS NO AMBIENTE DOMÉSTICO E ESPAÇO PÚBLICO (RELATOS / OBSERVAÇÕES / CITAÇÕES / EXPRESSIVIDADES)}

\begin{tabular}{|c|c|c|c|c|c|c|}
\hline & NATUREZA & ALIMENTO / PRODUTO & MARCA / PERSONAGEM & $\mathbf{F}$ & C & OBSERVAÇÃO \\
\hline \multirow[b]{2}{*}{ C } & \multirow{2}{*}{$\begin{array}{c}\text { CONSUMO } \\
\text { POR MARCAS }\end{array}$} & Café (em pó / torrado) & Pilão & & & \\
\hline & & Café (em pó / torrado) & Pelé & & & \\
\hline \multirow[t]{2}{*}{$\mathbf{O}$} & \multirow{4}{*}{$\begin{array}{c}- \\
\text { DESEJO DE } \\
\text { CONSUMO POR } \\
\text { MARCAS }\end{array}$} & Achocolatado (em pó) & Nescau & & & Compram sempre. Para as crianças. \\
\hline & & & & & & \\
\hline \multirow{3}{*}{$\begin{array}{c}\mathbf{U} \\
\mathbf{M}\end{array}$} & & Margarina & Qualy & & & \\
\hline & & & & & & \\
\hline & & Leite fermentado & Vigor (Minions) & & & Para as crianças. Elas gostam muito. \\
\hline \multirow[t]{2}{*}{$\mathbf{O}$} & & Leite fermentado & Elegê (Bob Esponja) & & & Para as crianças. Elas gostam muito. \\
\hline & & Iogurte petit suisse & Danoninho & & & Para a Bebê. Compram às vezes. Raramente. \\
\hline A & & Iogurte petit suisse & Chambinho & & & Para a Bebê. Compram às vezes. Raramente. \\
\hline I & & & & & & \\
\hline \multirow[b]{2}{*}{ M } & & Arroz & Camil & & & \\
\hline & & Feijão & Camil & & & \\
\hline \multirow{2}{*}{$\mathbf{E}$} & & & & & & \\
\hline & & Macarrão instantâneo & Miojo & & & \\
\hline $\begin{array}{l}\text { T } \\
\mathbf{A}\end{array}$ & & Macarrão instantâneo & Miojo (Turma da Mônica) & & & \\
\hline \multirow{2}{*}{$\mathbf{R}$} & & & & & & \\
\hline & & Lingüiça calabresa & Aurora & & & Compram às vezes. Somente com promoção. \\
\hline
\end{tabular}




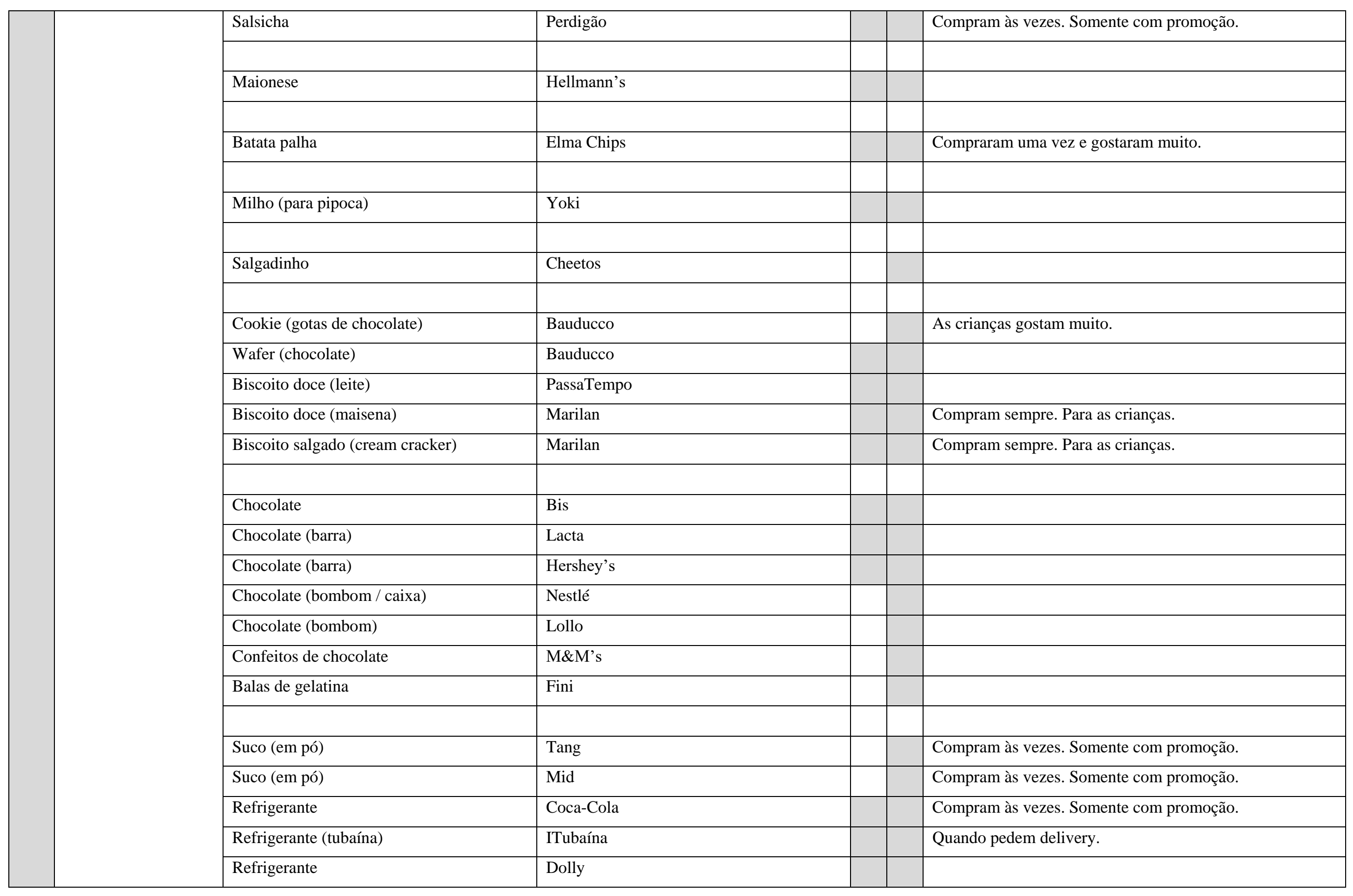




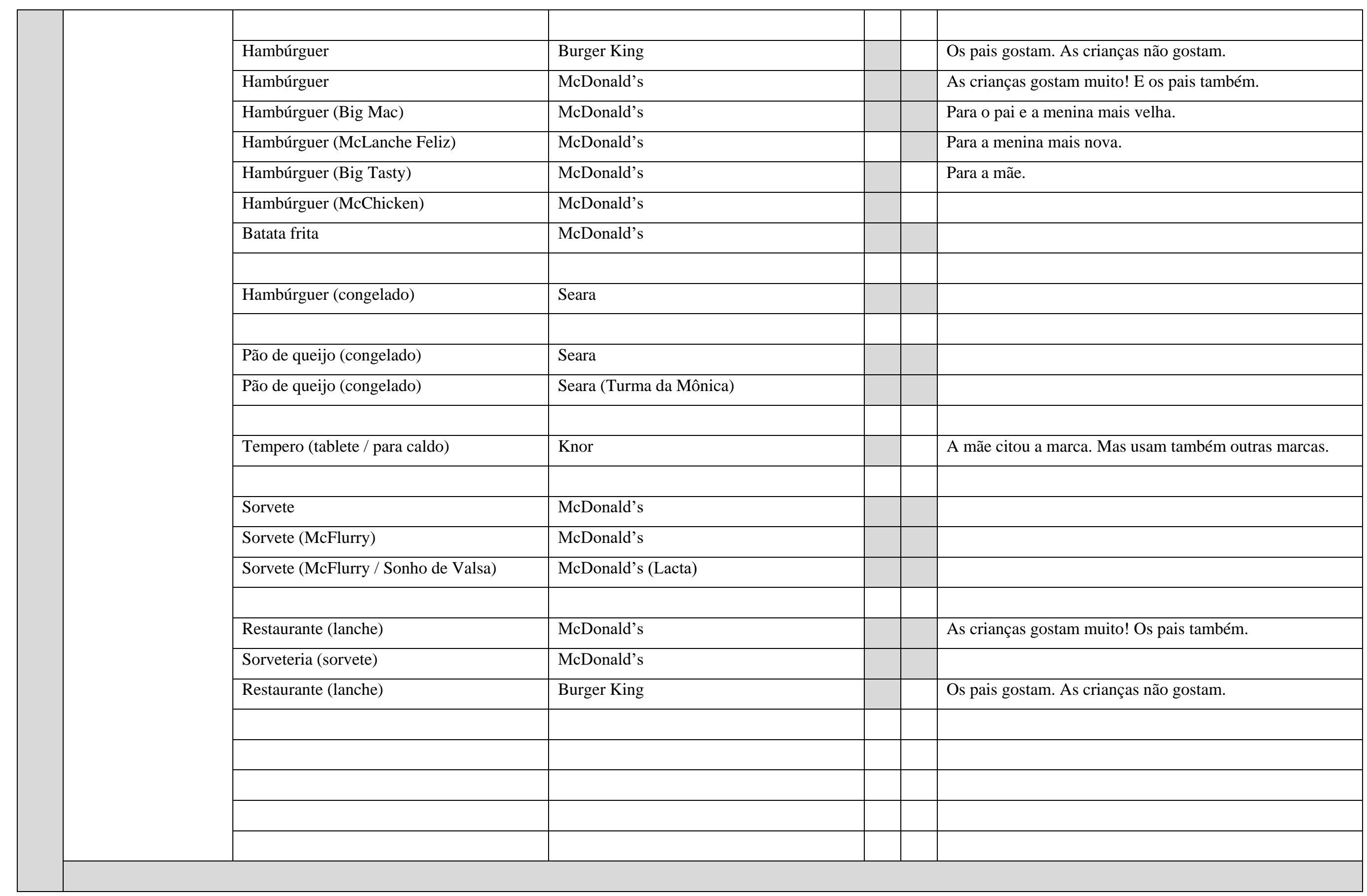




\begin{tabular}{|c|c|c|c|}
\hline \multirow{19}{*}{$\begin{array}{c}\text { CONSUMO } \\
\text { POR PRODUTOS }\end{array}$} & Leite (integral / caixa) & Marcas diversas & Compram marcas diversas. Promoção. \\
\hline & Laticínios (diversos) & Marcas diversas & Compram marcas diversas. Promoção. \\
\hline & Queijo & --- & Compram somente aos domingos. \\
\hline & Presunto & --- & Compram somente aos domingos. \\
\hline & Mortadela & --- & Compram somente aos domingos. \\
\hline & Pão francês & --- & Compram sempre. \\
\hline & Pão de queijo & --- & Compram às vezes. \\
\hline & Creme de leite & Marcas diversas & \\
\hline & Macarrão & Marcas diversas & Compram marcas diversas. Promoção. \\
\hline & Ketchup & Marcas diversas & \\
\hline & Óleo (vegetal) & Marcas diversas & Compram marcas diversas. Promoção. \\
\hline & Azeite & Marcas diversas & \\
\hline & Vinagre & Marcas diversas & \\
\hline & Sal (refinado) & Marcas diversas & \\
\hline & Açúcar (refinado) & Marcas diversas & \\
\hline & Batata palha & Marcas diversas & \\
\hline & Carne (patinho) & --- & Compram conforme as promoções. \\
\hline & Carne (alcatra) & --- & Compram conforme as promoções. \\
\hline & Frango (peito de frango) & --- & $\begin{array}{l}\text { Compram conforme as promoções. } \\
\text { Consomem mais frango de que carne. }\end{array}$ \\
\hline
\end{tabular}




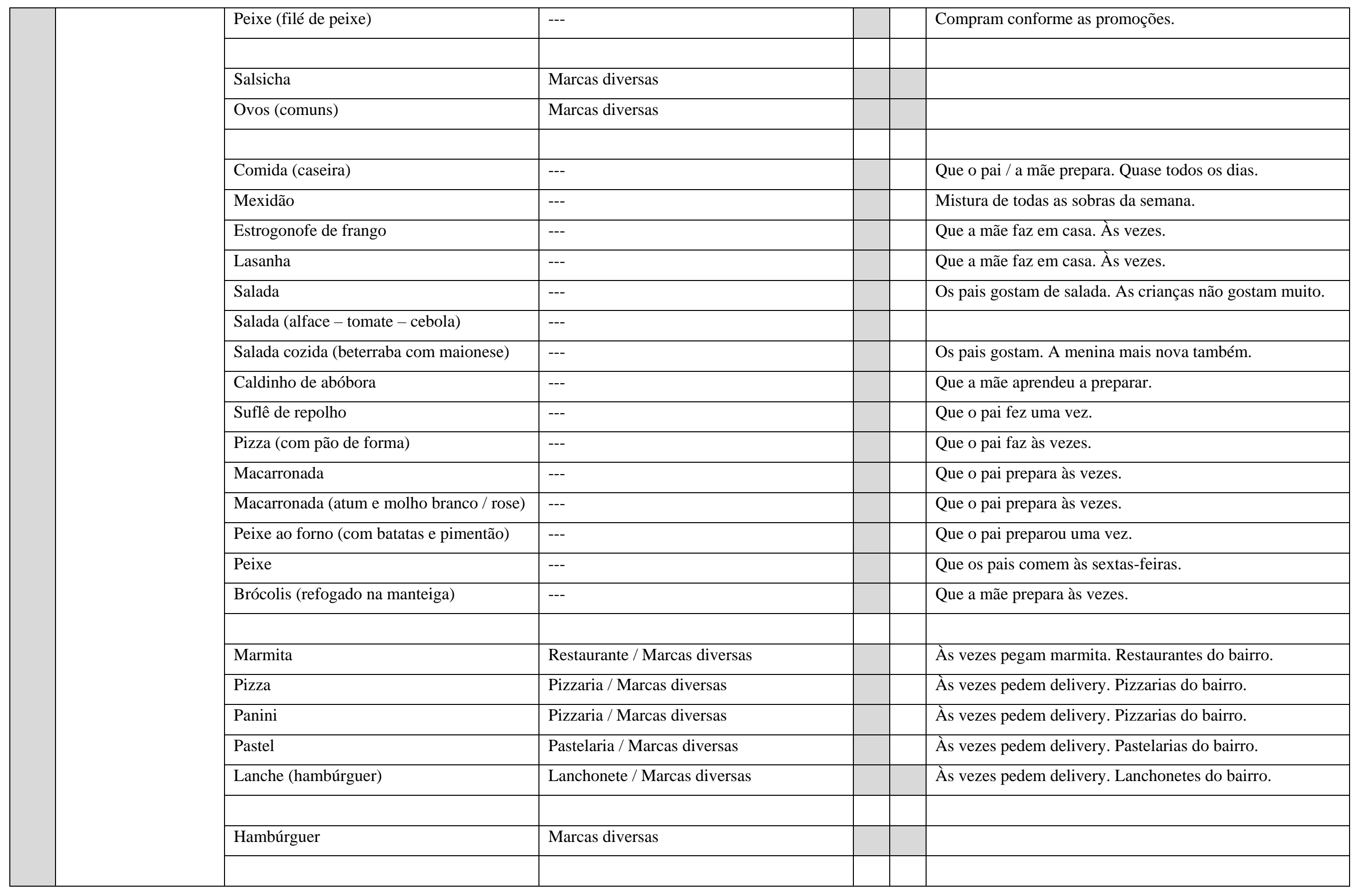




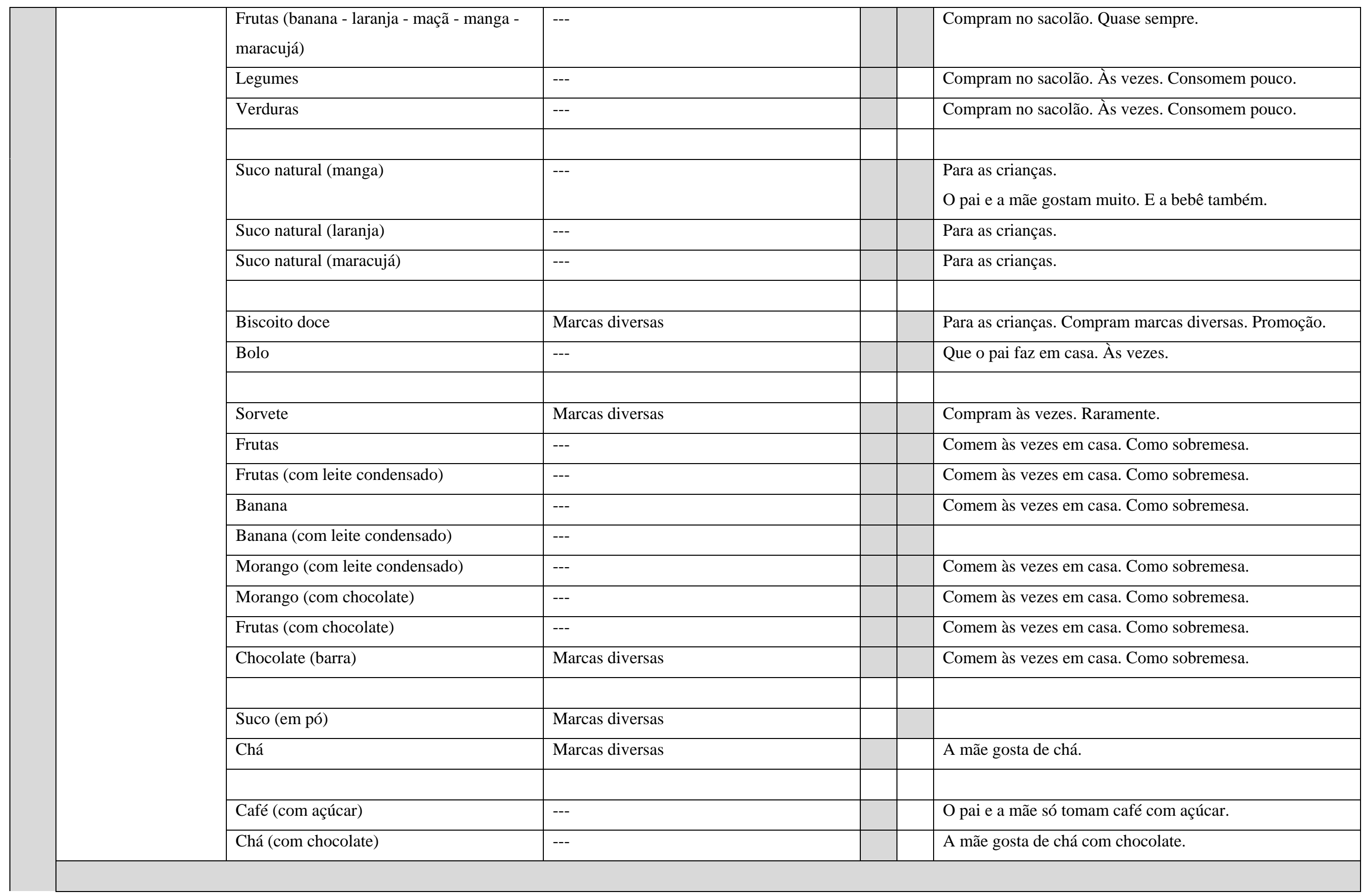




\begin{tabular}{|c|c|c|c|}
\hline \multirow[t]{24}{*}{ NÃO CONSUMO } & Biscoito doce (recheado) & Marcas diversas & Cortaram o consumo de bolacha recheada para as crianças. \\
\hline & Café (sem açúcar) & Marcas diversas & O pai e a mãe não gostam de café sem açúcar. \\
\hline & Hambúrguer & Burger King & Somente uma vez. As crianças não gostaram. \\
\hline & Restaurante (lanche) & Burger King & Somente uma vez. As crianças não gostaram. \\
\hline & & & \\
\hline & & & \\
\hline & & & \\
\hline & & & \\
\hline & & & \\
\hline & & & \\
\hline & & & \\
\hline & & & \\
\hline & & & \\
\hline & & & \\
\hline & & & \\
\hline & & & \\
\hline & & & \\
\hline & & & \\
\hline & & & \\
\hline & & & \\
\hline & & & \\
\hline & & & \\
\hline & & & \\
\hline & & & \\
\hline
\end{tabular}


MARCAS E PRODUTOS ALIMENTÍCIOS NO ESPAÇO PÚBLICO

(RELATOS / OBSERVAÇÕES / CITAÇÕES / EXPRESSIVIDADES)

\begin{tabular}{|c|c|c|c|c|c|c|}
\hline & NATUREZA & CATEGORIA / ALIMENTO & MARCA / PERSONAGEM & $\mathbf{F}$ & $\mathbf{C}$ & OBSERVAÇÃO \\
\hline \multirow{6}{*}{$\begin{array}{l}\mathbf{C} \\
\mathbf{O} \\
\mathbf{N}\end{array}$} & \multirow{8}{*}{$\begin{array}{c}\text { CONSUMO } \\
\text { MAIS } \\
\text { FREQUENTE } \\
- \\
\text { SEMPRE / } \\
\text { QUASE SEMPRE }\end{array}$} & Restaurante (lanche) & McDonald's & & & Aos domingos. Duas vezes ao mês (em média). \\
\hline & & & & & & \\
\hline & & Sorveteria (sorvete) & McDonald's & & & Aos domingos. Duas vezes ao mês (em média). \\
\hline & & & & & & \\
\hline & & Pizzaria (pizza) & Pizzarias diversas & & & \\
\hline & & & & & & \\
\hline \multirow{4}{*}{$\begin{array}{c}\mathbf{U} \\
\mathbf{M} \\
\mathbf{O}\end{array}$} & & Restaurante (lanche) & Lanchonetes diversas & & & \\
\hline & & & & & & \\
\hline & & & & & & \\
\hline & \multirow{6}{*}{$\begin{array}{c}\text { CONSUMO } \\
\text { MENOS } \\
\text { FREQUENTE } \\
- \\
\text { ÀS VEZES }\end{array}$} & & & & & \\
\hline \multirow{6}{*}{\begin{tabular}{c|c|}
$\mathbf{A}$ \\
$\mathbf{L}$ \\
$\mathbf{I}$ \\
$\mathbf{M}$ \\
$\mathbf{E}$ \\
$\mathbf{N}$
\end{tabular}} & & & & & & \\
\hline & & & & & & \\
\hline & & & & & & \\
\hline & & & & & & \\
\hline & & & & & & \\
\hline & & & & & & \\
\hline \multirow{2}{*}{$\begin{array}{l}\mathbf{N} \\
\mathbf{T}\end{array}$} & \multirow{6}{*}{$\begin{array}{c}\text { CONSUMO } \\
\text { EVENTUAL } \\
- \\
\text { RARAMENTE }\end{array}$} & Restaurante (lanche) & Burger King & & & Somente uma vez. As crianças não gostaram. \\
\hline & & & & & & \\
\hline \multirow{4}{*}{$\mathbf{R}$} & & & & & & \\
\hline & & & & & & \\
\hline & & & & & & \\
\hline & & & & & & \\
\hline
\end{tabular}




\section{PRIMEIRO ENCONTRO: CONVERSA COM A FAMÍLIA E AS CRIANÇAS}

MARCAS E PRODUTOS ALIMENTÍCIOS NO AMBIENTE DOMÉSTICO

(FOTOS / VÍDEOS / OBSERVAÇÃO)

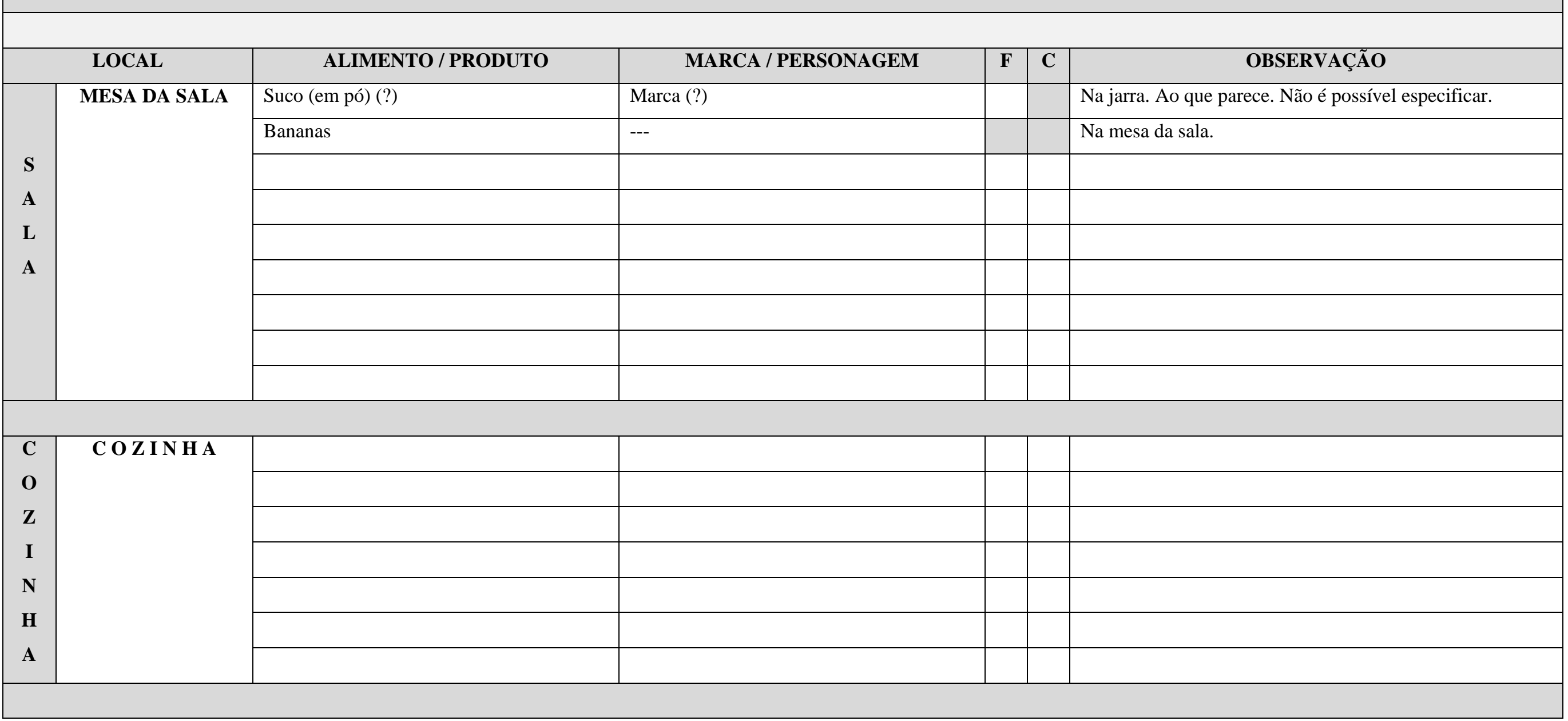




\section{SEGUNDO ENCONTRO: RITUAL DE ALIMENTAÇÃO COM AS CRIANÇAS EM CASA}

\section{MARCAS E PRODUTOS ALIMENTÍCIOS NO AMBIENTE DOMÉSTICO}

(FOTOS / VÍDEOS / OBSERVAÇÃO)

\begin{tabular}{|c|c|c|c|c|c|c|}
\hline & LOCAL & ALIMENTO / PRODUTO & MARCA / PERSONAGEM & $\mathbf{F}$ & $\mathbf{C}$ & OBSERVAÇÃO \\
\hline \multirow{15}{*}{$\begin{array}{c}\mathbf{C} \\
\mathbf{O} \\
\mathbf{Z} \\
\mathbf{I} \\
\mathbf{N} \\
\mathbf{H} \\
\mathbf{A}\end{array}$} & \multirow{15}{*}{ BANCADAS } & Suco natural (manga) & --- & & & Na jarra. Ao que parece. \\
\hline & & Água & $\begin{array}{ll}--- \\
\end{array}$ & & & Copo com água. \\
\hline & & Laranjas & --- & & & $\mathrm{Na}$ fruteira. \\
\hline & & Tangerinas & --- & & & $\mathrm{Na}$ fruteira. \\
\hline & & Bananas & --- & & & $\mathrm{Na}$ fruteira. \\
\hline & & Beterraba & --- & & & Em pote. Na bancada. \\
\hline & & Beterraba (em pedaços) & --- & & & Em pote. Na bancada. \\
\hline & & Cappuccino (tradicional / lata) & Melitta & & & \\
\hline & & Achocolatado (em pó) & Nescau (?) & & & $\begin{array}{l}\text { Para as crianças. } \\
\text { Em pote. Ao que parece. Não é possível especificar. }\end{array}$ \\
\hline & & Latas de chocolate / panetone & Garoto / Visconti / Bauducco & & & Com doces. Da festa de aniversário da menina 2. \\
\hline & & Alimento / Mantimento (?) & --- & & & Em pote. Ao que parece. Não é possível especificar. \\
\hline & & Laranjas (saco) & $\begin{array}{ll}--- \\
\end{array}$ & & & \\
\hline & & Água mineral (garrafa) & Crystal & & & \\
\hline & & Café & --- & & & Na garrafa térmica. \\
\hline & & Manga (descascada) & --- & & & No prato. Sobre a pia. \\
\hline
\end{tabular}




\begin{tabular}{|c|c|c|c|}
\hline & Água & --- & Na jarra. \\
\hline & Frango (em pedaços) & --- & Em pote. Sobre a pia. \\
\hline & Vinho (tinto / suave / garrafa) & Pérgola & Garrafa vazia. \\
\hline & Refrigerante (tubaína) & ITubaína & Garrafa vazia. Ao que parece. Não é possível especificar. \\
\hline & Alimentos diversos (bancadas) (?) & --- & Ao que parece. Não é possível especificar. \\
\hline ARMÁRIOS & Leite (integral / caixa) & Quatá & Estoque. Para as crianças. \\
\hline & Vinho (tinto / suave / garrafa) & Chalise & \\
\hline & Macarrão instantâneo (galinha caipira) & Miojo & Estoque. Para as crianças. \\
\hline & Macarrão instantâneo (carne - galinha) & Miojo (Turma da Mônica) & Estoque. Para as crianças. \\
\hline & Café (em pó / torrado) & Pilão & \\
\hline & Sal (refinado) & Cisne & \\
\hline & Chá (capim cidreira - erva doce) & Leão & \\
\hline & Chá (camomila) & Kisabor & \\
\hline & Milho verde (conserva) & Quero & \\
\hline & Sardinha (lata) & Coqueiro & Estoque. \\
\hline & Leite condensado & Piracanjuba & \\
\hline & Leite de coco & Ducoco & \\
\hline & Granulado (?) & --- & $\begin{array}{l}\text { Em embalagem plástica. } \\
\text { Ao que parece. Não é possível especificar. }\end{array}$ \\
\hline & Farofa (tradicional / temperada) & Yoki & \\
\hline & Biscoito doce (recheado) & Moça & \\
\hline & Molho de tomate & Quero & Estoque. \\
\hline & Creme de leite & Italac & \\
\hline
\end{tabular}




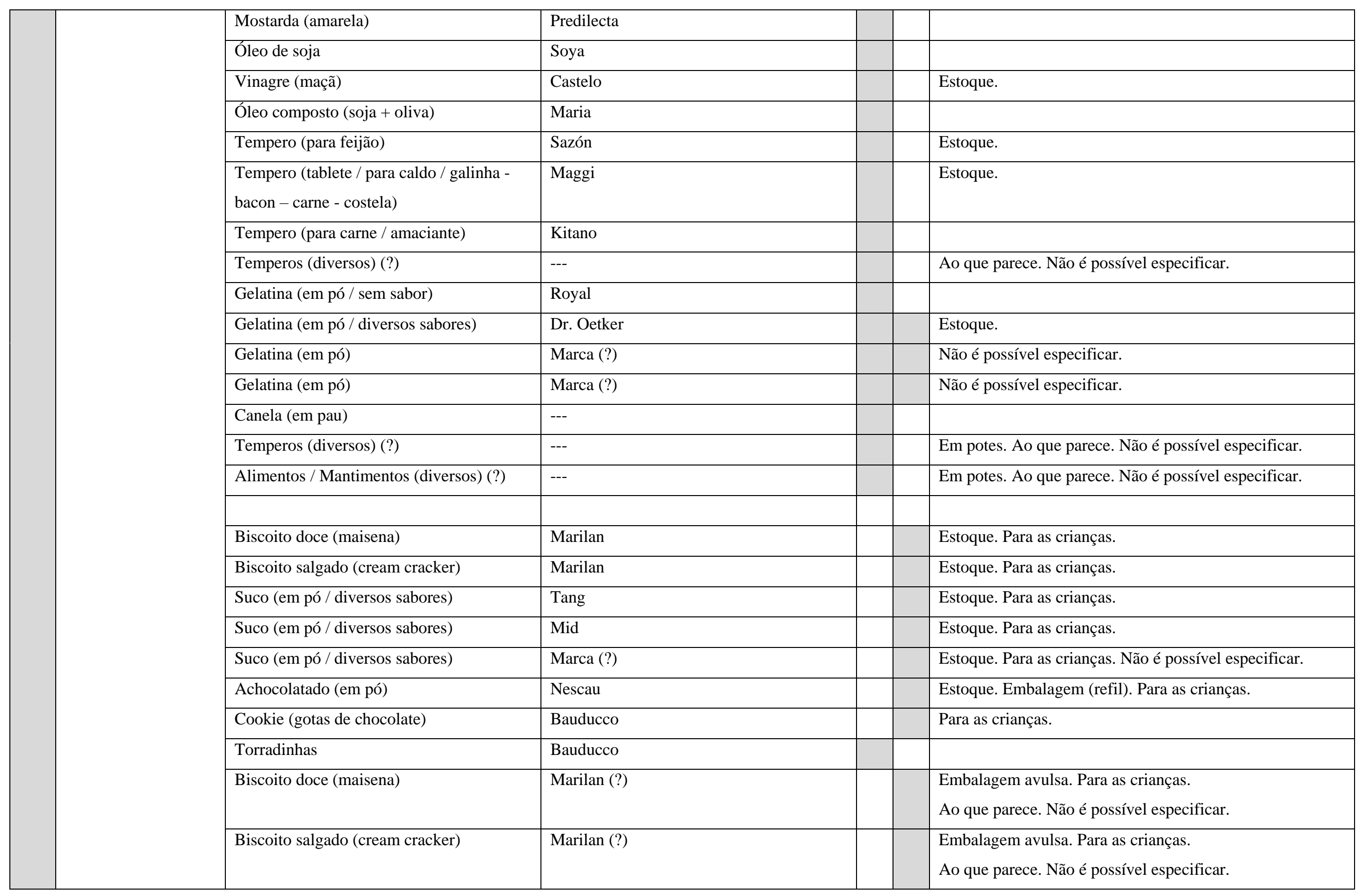




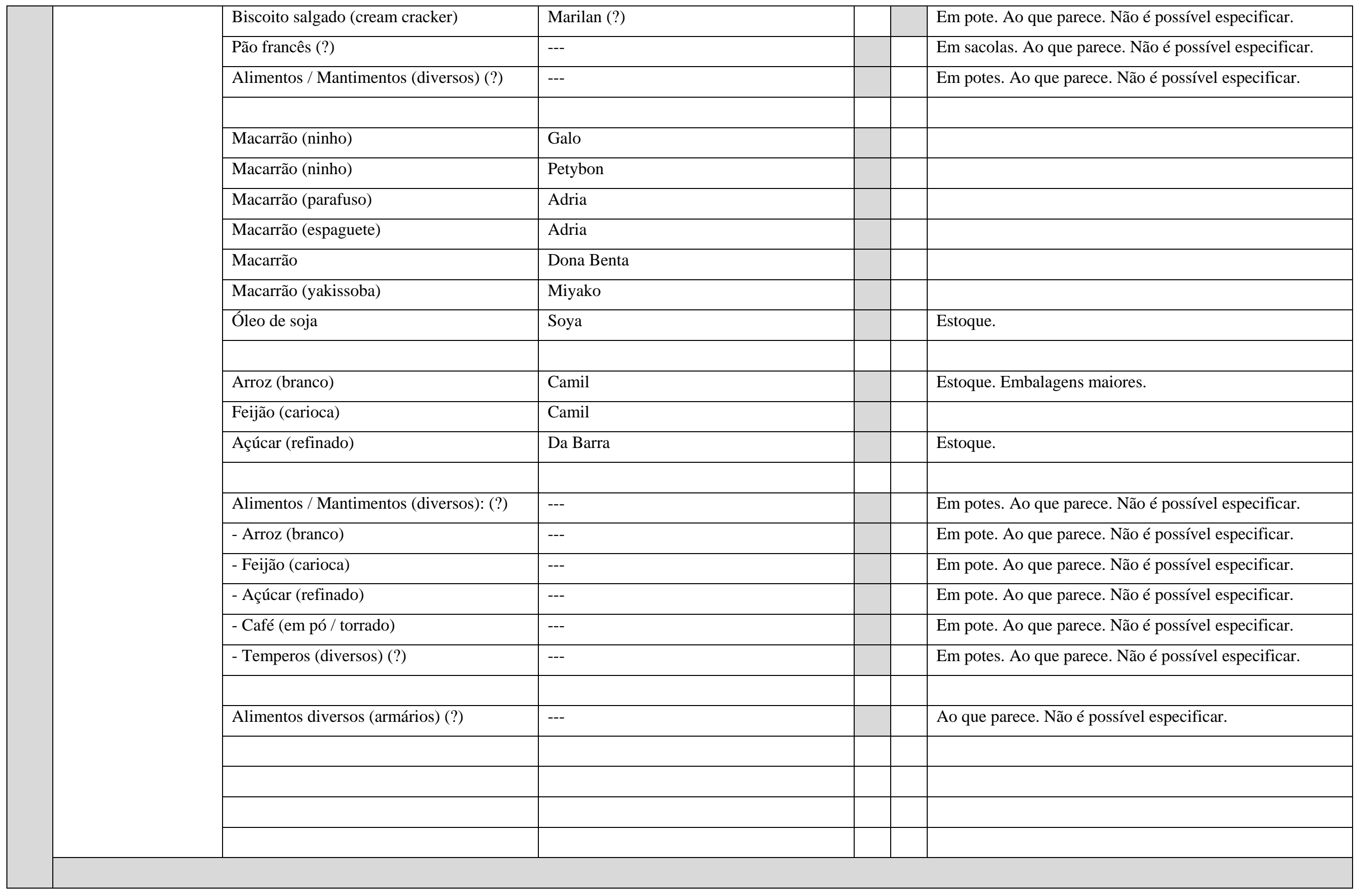




\begin{tabular}{|c|c|c|c|}
\hline \multirow[t]{25}{*}{ GELADEIRA } & Alho (picado) & Marca (?) & Não é possível especificar. \\
\hline & Doce de leite (?) & Italac (?) & Ao que parece. Não é possível especificar. \\
\hline & Margarina & Qualy & \\
\hline & Creme (chantilly) & Amélia (Chanty Mix) & \\
\hline & Leite condensado & Heloisa & \\
\hline & Lingüiça (?) & --- & $\begin{array}{l}\text { Em embalagem plástica. } \\
\text { Ao que parece. Não é possível especificar. }\end{array}$ \\
\hline & Temperos verdes (diversos) (?) & --- & Em sacola. Ao que parece. Não é possível especificar. \\
\hline & Tomates (?) & --- & Em pote. Ao que parece. Não é possível especificar. \\
\hline & Alimentos (diversos) (?) & --- & Em potes. Ao que parece. Não é possível especificar. \\
\hline & Alimentos (diversos) (?) & --- & Em panelas. Ao que parece. Não é possível especificar. \\
\hline & Frutas / Legumes / Verduras (?) & --- & Na bandeja. Ao que parece. Não é possível especificar. \\
\hline & Doce de leite (?) & Marca (?) & Ao que parece. Não é possível especificar. \\
\hline & Ovos (comuns) & Marca (?) & Não é possível especificar. \\
\hline & Ketchup & Farri & Estoque. Embalagem maior. \\
\hline & Ketchup & Kisabor & \\
\hline & Maionese & Hellmann's & \\
\hline & Molho de pimenta & Maratá & \\
\hline & Molho shoyu (?) & Marca (?) & Ao que parece. Não é possível especificar. \\
\hline & Molho barbecue (?) & Marca (?) & Ao que parece. Não é possível especificar. \\
\hline & Molho de tomate & Tarantella & \\
\hline & Fermento (em pó / químico) & Royal & \\
\hline & Solução fisiológica (?) & Marca (?) & Ao que parece. Não é possível especificar. \\
\hline & Garrafas (com água) & --- & \\
\hline & Jarras (com água) & --- & \\
\hline & Leite (integral / caixa) & Quatá & Para as crianças. \\
\hline
\end{tabular}




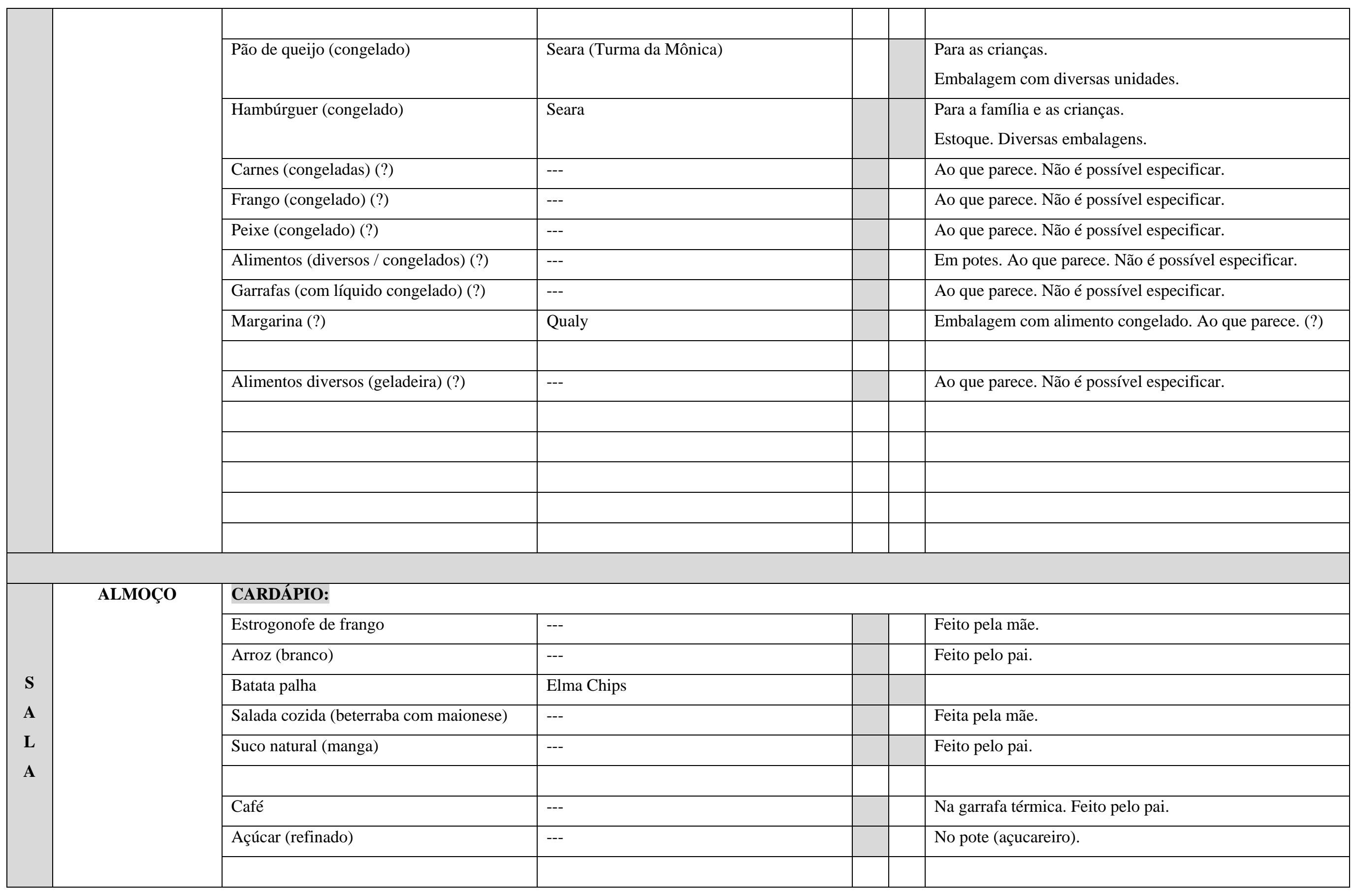




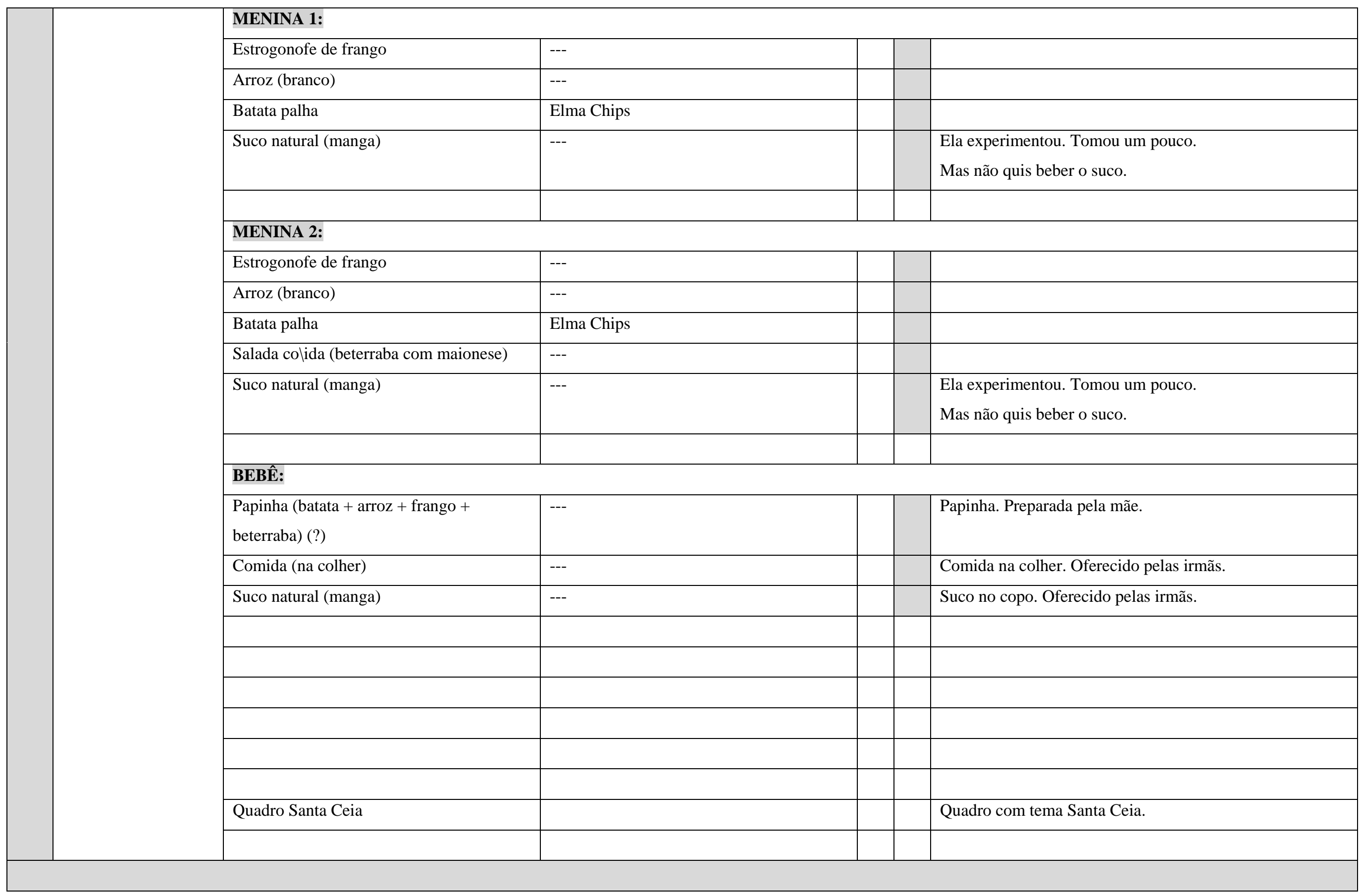




\section{TERCEIRO ENCONTRO: RITUAL DE ALIMENTAÇÃO COM AS CRIANÇAS FORA DE CASA}

\section{MARCAS E PRODUTOS ALIMENTÍCIOS NO AMBIENTE DOMÉSTICO (FOTOS / VÍDEOS / OBSERVAÇÃO)}

\begin{tabular}{|c|c|c|c|c|c|c|}
\hline & LOCAL & ALIMENTO / PRODUTO & MARCA / PERSONAGEM & $\mathbf{F}$ & $\mathbf{C}$ & OBSERVAÇÃO \\
\hline \multirow{15}{*}{$\begin{array}{c}\mathbf{C} \\
\mathbf{O} \\
\mathbf{Z} \\
\mathbf{I} \\
\mathbf{N} \\
\mathbf{H} \\
\mathbf{A}\end{array}$} & \multirow[t]{15}{*}{ BANCADAS } & Laranjas (saco) & --- & & & $\mathrm{Na}$ fruteira. \\
\hline & & Cappuccino (tradicional / lata) & Melitta & & & \\
\hline & & Achocolatado (em pó) & Nescau (?) & & & $\begin{array}{l}\text { Para as crianças. } \\
\text { Em pote Ao que parece. Não é possível especificar. }\end{array}$ \\
\hline & & Latas de chocolate / panetone & Garoto / Visconti / Bauducco & & & Com doces. Da festa de aniversário da menina 2. \\
\hline & & Alimento / Mantimento (?) & --- & & & Em pote. Ao que parece. Não é possível especificar. \\
\hline & & & & & & \\
\hline & & Suco (em pó) (?) & Marca (?) & & & Na jarra. Ao que parece. Não é possível especificar. \\
\hline & & Café & --- & & & Na garrafa térmica. \\
\hline & & Água mineral (garrafa) & Crystal & & & \\
\hline & & Água & --- & & & Garrafa plástica com água. \\
\hline & & Mamadeira & --- & & & Com resto de alimento / suco. Para a bebê. \\
\hline & & Bananas & --- & & & Em sacola. \\
\hline & & Alimento / mantimento (?) & --- & & & Em sacola. Ao que parece. Não é possível especificar. \\
\hline & & Batatas & -- & & & Na panela. Sobre o fogão. \\
\hline & & Alimentos diversos (bancadas) (?) & --- & & & Ao que parece. Não é possível especificar. \\
\hline
\end{tabular}




\begin{tabular}{|c|c|c|c|}
\hline \multirow{26}{*}{ ARMÁRIOS } & Leite (integral / caixa) & Quatá & Estoque. Para as crianças. \\
\hline & Vinho (tinto / suave / garrafa) & Chalise & \\
\hline & & & \\
\hline & Macarrão instantâneo (galinha caipira) & Miojo & Estoque. Para as crianças. \\
\hline & Macarrão instantâneo (galinha) & Miojo (Turma da Mônica) & Estoque. Para as crianças. \\
\hline & Café (em pó / torrado) & Pilão & \\
\hline & Sardinha (lata) & Coqueiro & Estoque. \\
\hline & Chá (capim cidreira - erva doce) & Leão & \\
\hline & Chá (camomila) & Kisabor & \\
\hline & Leite condensado & Piracanjuba & \\
\hline & Molho de tomate & Quero & Estoque. \\
\hline & Granulado (?) & --- & $\begin{array}{l}\text { Em embalagem plástica. } \\
\text { Ao que parece. Não é possível especificar. }\end{array}$ \\
\hline & Farofa (tradicional / temperada) & Yoki & \\
\hline & Batata palha & Yoki & \\
\hline & Óleo de soja & Soya & \\
\hline & Vinagre (maçã) & Castelo & Estoque. \\
\hline & Tempero (para feijão) & Sazón & Estoque. \\
\hline & Tempero (tablete / para caldo / galinha) & Maggi & Estoque. \\
\hline & Tempero (para carne / amaciante) (?) & Kitano (?) & Ao que parece. Não é possível especificar. \\
\hline & Temperos (diversos) (?) & --- & Ao que parece. Não é possível especificar. \\
\hline & Gelatina (em pó / sem sabor) & Royal & \\
\hline & Gelatina (em pó) & Marca (?) & Não é possível especificar. \\
\hline & Temperos (diversos) (?) & --- & Em potes. Ao que parece. Não é possível especificar. \\
\hline & Alimentos / Mantimentos (diversos) (?) & --- & Em potes. Ao que parece. Não é possível especificar. \\
\hline & Biscoito doce (maisena) & Marilan & Estoque. Para as crianças. \\
\hline & Biscoito salgado (cream cracker) & Marilan & Estoque. Para as crianças. \\
\hline
\end{tabular}




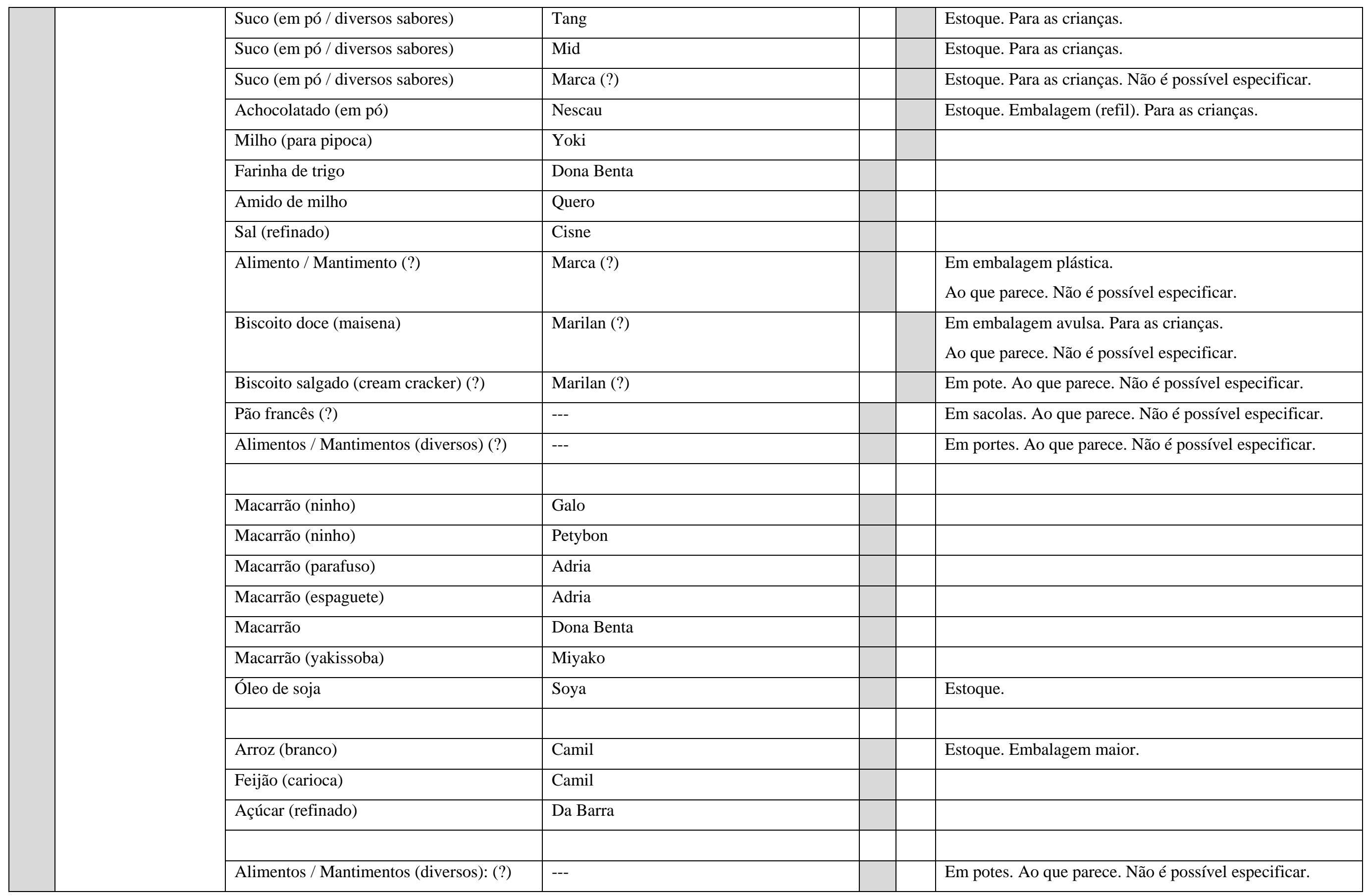




\begin{tabular}{|c|c|c|c|}
\hline & - Arroz (branco) & --- & Em pote. Ao que parece. Não é possível especificar. \\
\hline & - Feijão (carioca) & --- & Em pote. Ao que parece. Não é possível especificar. \\
\hline & - Açúcar (refinado) & --- & Em pote. Ao que parece. Não é possível especificar. \\
\hline & - Café (em pó / torrado) & --- & Em pote. Ao que parece. Não é possível especificar. \\
\hline & - Temperos (diversos) (?) & --- & Em potes. Ao que parece. Não é possível especificar. \\
\hline & Alimentos diversos (armários) (?) & --- & Ao que parece. Não é possível especificar. \\
\hline GELADEIRA & Molho de tomate & Quero & \\
\hline & Margarina & Qualy & \\
\hline & Doce de leite & Italac & \\
\hline & Creme (chantilly) & Amélia (Chanty Mix) & \\
\hline & Alimentos (diversos) (?) & --- & Em potes. Ao que parece. Não é possível especificar. \\
\hline & Alimento (?) & --- & Em panela. Ao que parece. Não é possível especificar. \\
\hline & Alimento (?) & --- & Em embalagem. Ao que parece.Não é possível especificar. \\
\hline & Frutas / Legumes / Verduras (?) & --- & Na bandeja. Ao que parece. Não é possível especificar. \\
\hline & Doce de leite (?) & Marca (?) & Ao que parece. Não é possível especificar. \\
\hline & Ovos (comuns) & Marca (?) & Não é possível especificar. \\
\hline & Ketchup & Farri & Estoque. Embalagem maior. \\
\hline & Ketchup & Kisabor & \\
\hline & Ketchup (saches) & Lanchero & \\
\hline & Mostarda (amarela) & Predilecta & \\
\hline & Molho de pimenta & Maratá & \\
\hline & Molho shoyu (?) & Marca (?) & Ao que parece. Não é possível especificar. \\
\hline & Molho barbecue (?) & Marca (?) & Ao que parece. Não é possível especificar. \\
\hline & Molho de tomate & Tarantella & \\
\hline & Fermento (em pó / químico) & Royal & \\
\hline
\end{tabular}




\begin{tabular}{|c|c|c|c|c|}
\hline & & Solução fisiológica (?) & Marca (?) & Ao que parece. Não é possível especificar. \\
\hline & & Garrafas (com água) & --- & \\
\hline & & Jarras (com água) & --- & \\
\hline & & Leite (integral / caixa) & Quatá & Para as crianças. \\
\hline & & Pão de queijo (congelado) & Seara (Turma da Mônica) & $\begin{array}{l}\text { Para as crianças. } \\
\text { Embalagem com diversas unidades. }\end{array}$ \\
\hline & & Hambúrguer (congelado) & Seara & $\begin{array}{l}\text { Para a família e as crianças. } \\
\text { Estoque. Diversas embalagens. }\end{array}$ \\
\hline & & Carnes (congeladas) (?) & --- & Ao que parece. Não é possível especificar. \\
\hline & & Frango (congelado) (?) & --- & Ao que parece. Não é possível especificar. \\
\hline & & Peixe (congelado) (?) & --- & Ao que parece. Não é possível especificar. \\
\hline & & Alimentos (diversos / congelados) (?) & --- & Em potes. Ao que parece. Não é possível especificar. \\
\hline & & Garrafas (com líquido congelado) (?) & --- & Ao que parece. Não é possível especificar. \\
\hline & & Margarina (?) & Qualy & Embalagem com alimento congelado. Ao que parece. (?) \\
\hline & & Alimento (?) & --- & $\begin{array}{l}\text { Em embalagem plástica. } \\
\text { Ao que parece. Não é possível especificar. }\end{array}$ \\
\hline & & Alimentos diversos (geladeira) (?) & --- & Ao que parece. Não é possível especificar. \\
\hline & MESA DA SALA & Garrafinha (com água) & --- & Para a bebê. \\
\hline $\mathbf{S}$ & & Pote (com alimento) & --- & Resto da papinha. Para a bebê. \\
\hline A & & & & \\
\hline $\begin{array}{l}\mathbf{L} \\
\mathbf{A}\end{array}$ & & Papinha (batata + caldo de feijão) & --- & $\begin{array}{l}\text { A bebê comeu papinha em casa. } \\
\text { Antes de saírem para o restaurante. }\end{array}$ \\
\hline & & Quadro Santa Ceia & & Quadro com tema Santa Ceia. \\
\hline
\end{tabular}




\section{MARCAS E PRODUTOS ALIMENTÍCIOS NO ESPAÇO PÚBLICO}

(FOTOS / VÍDEOS / OBSERVAÇÃO)

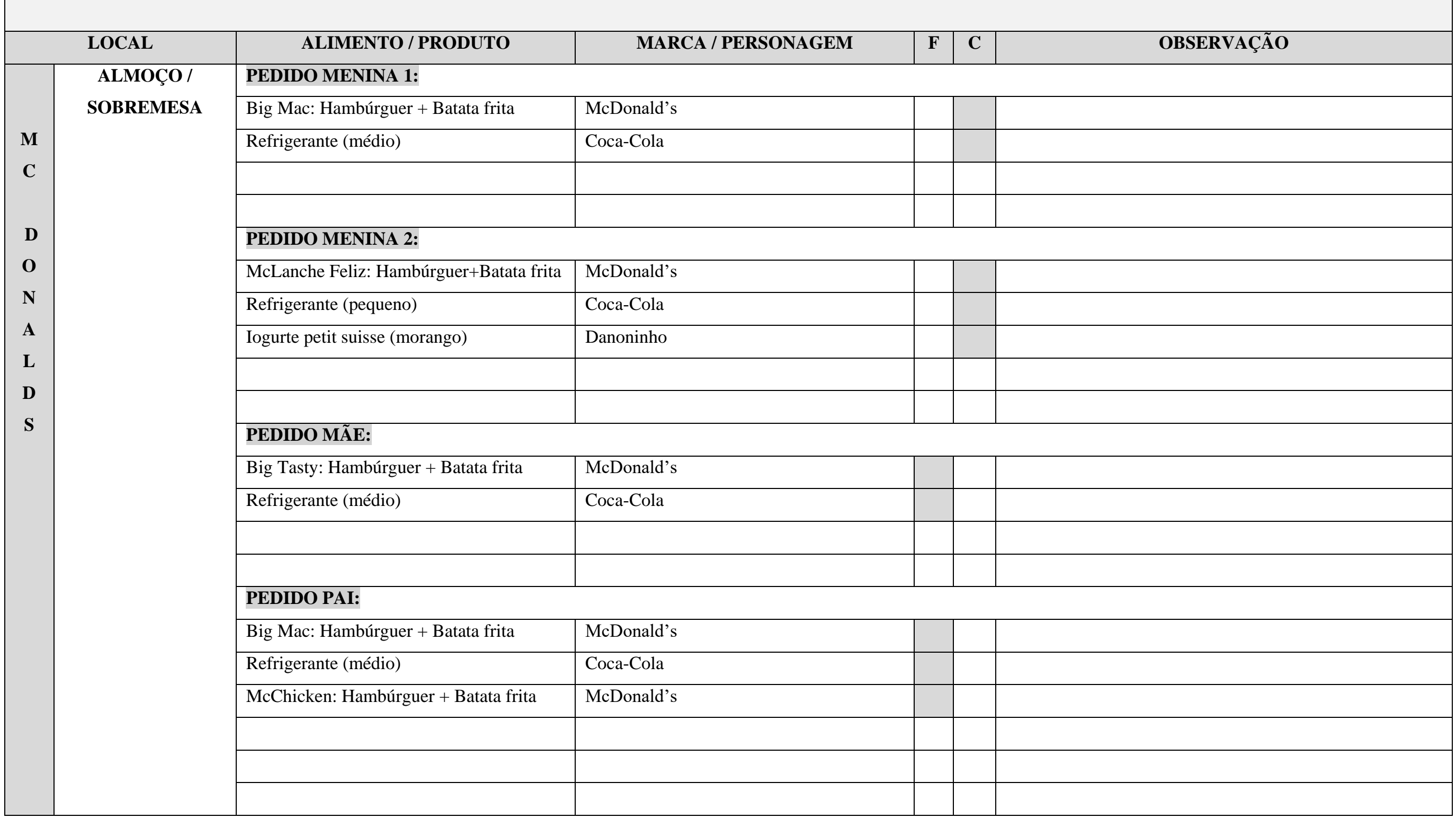




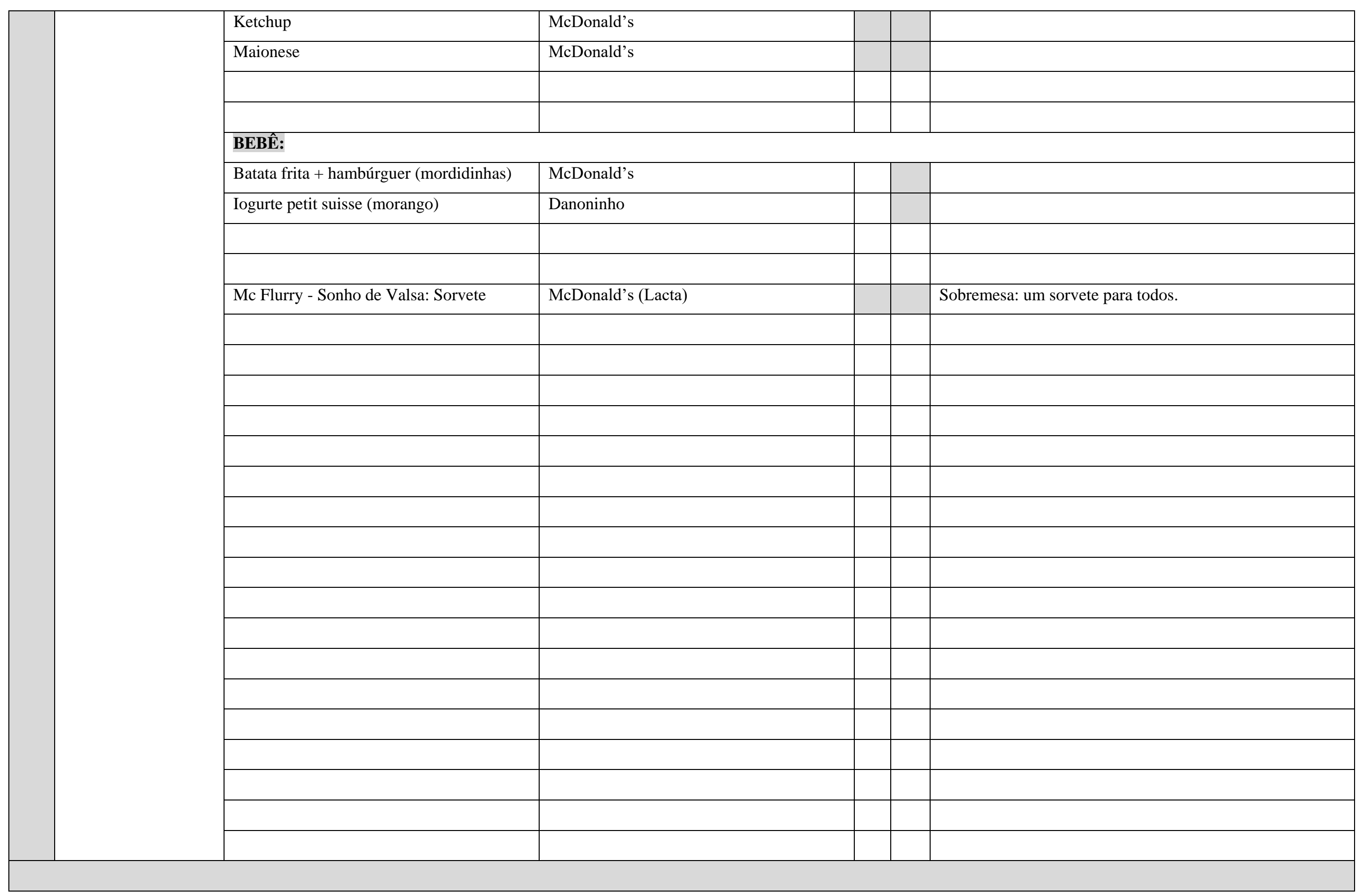




\section{R I A N Ç A S}

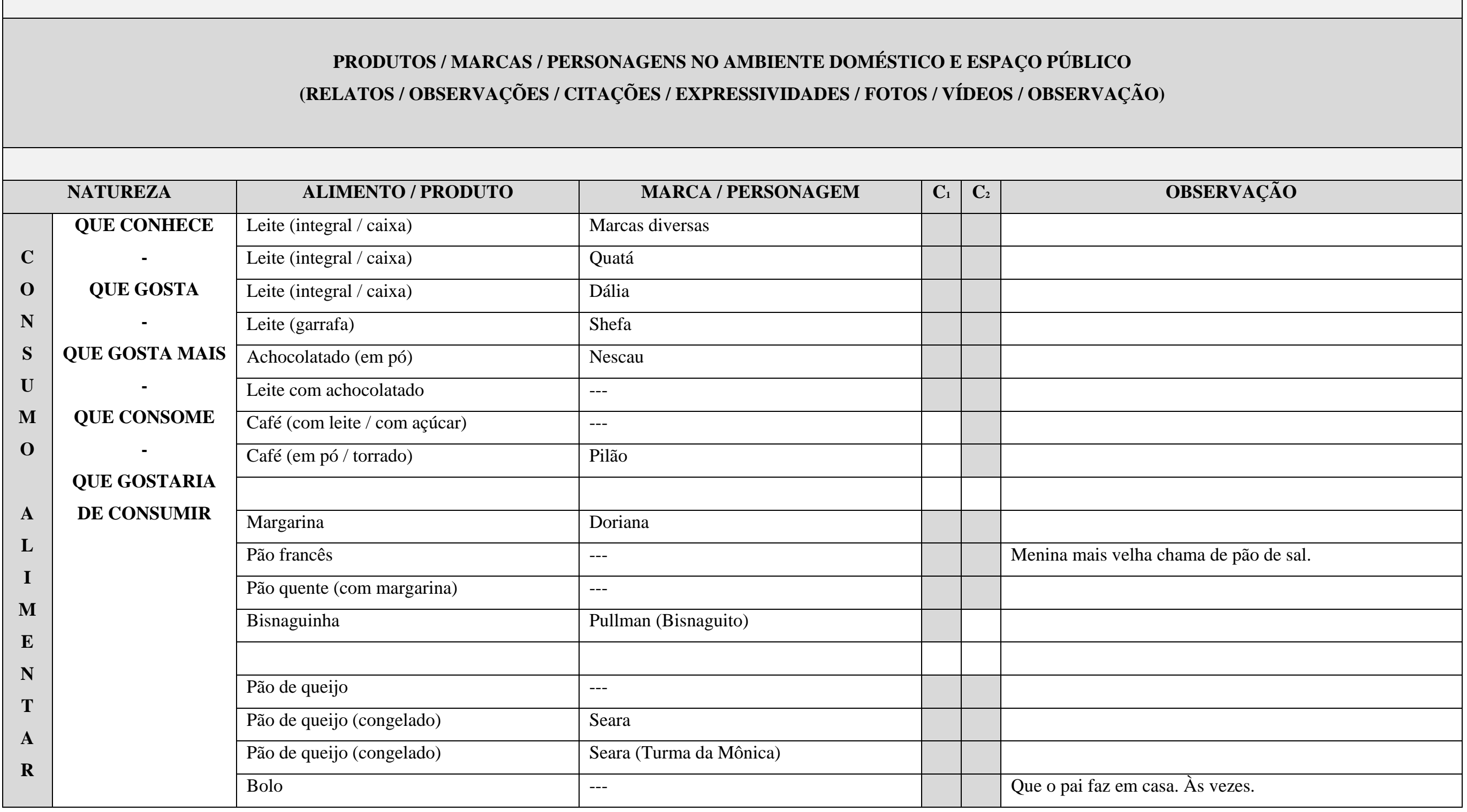




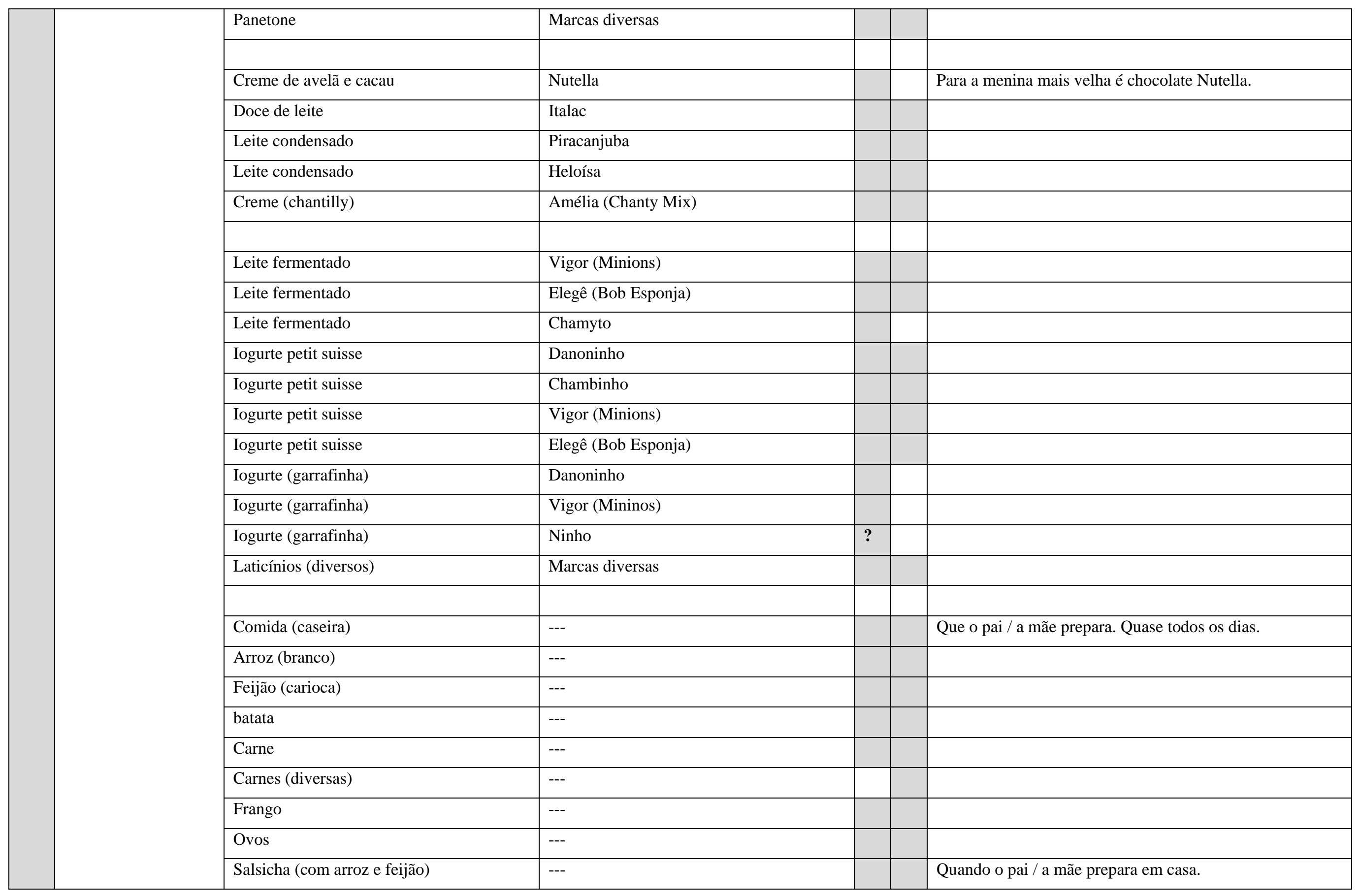




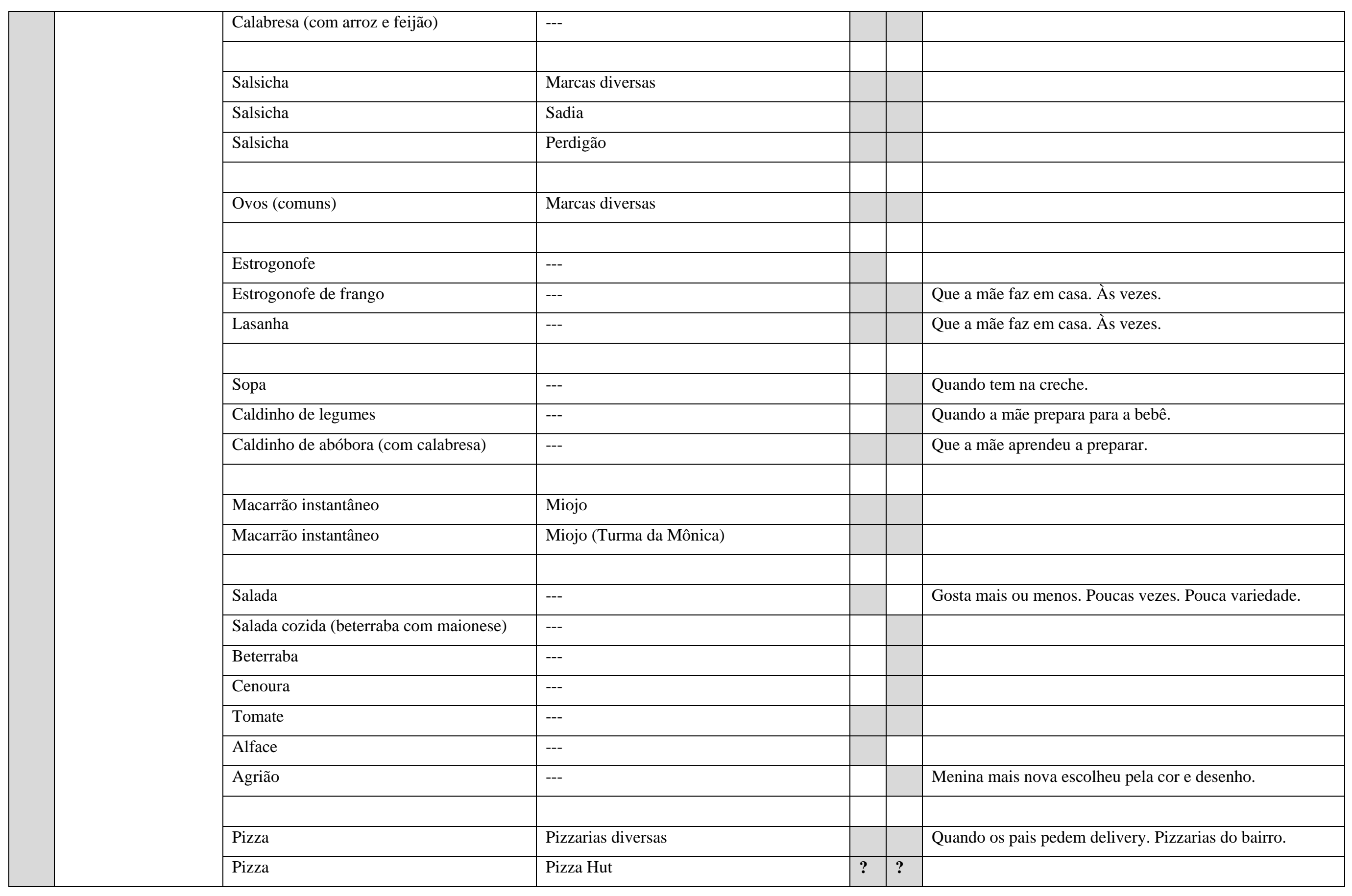




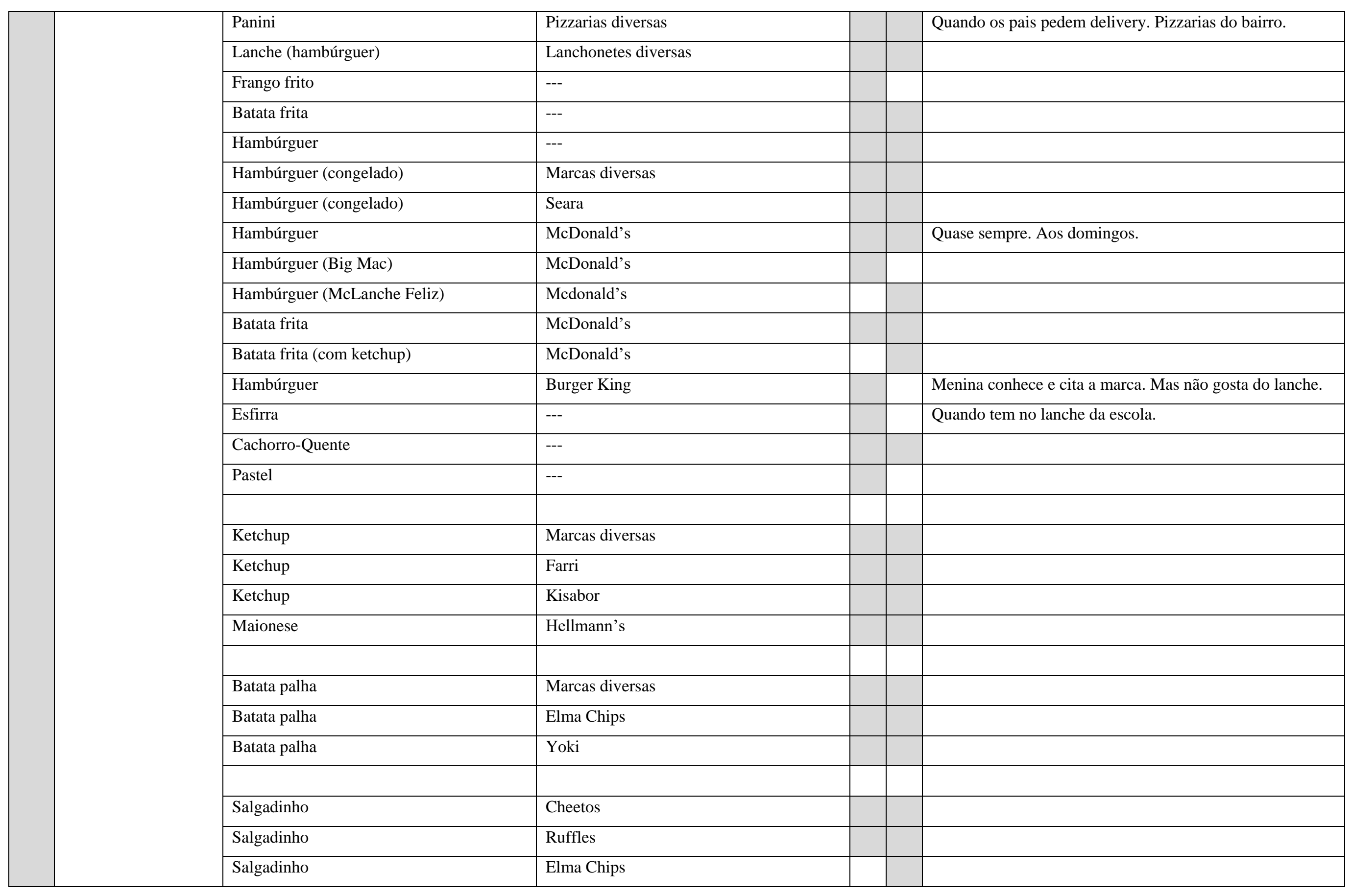




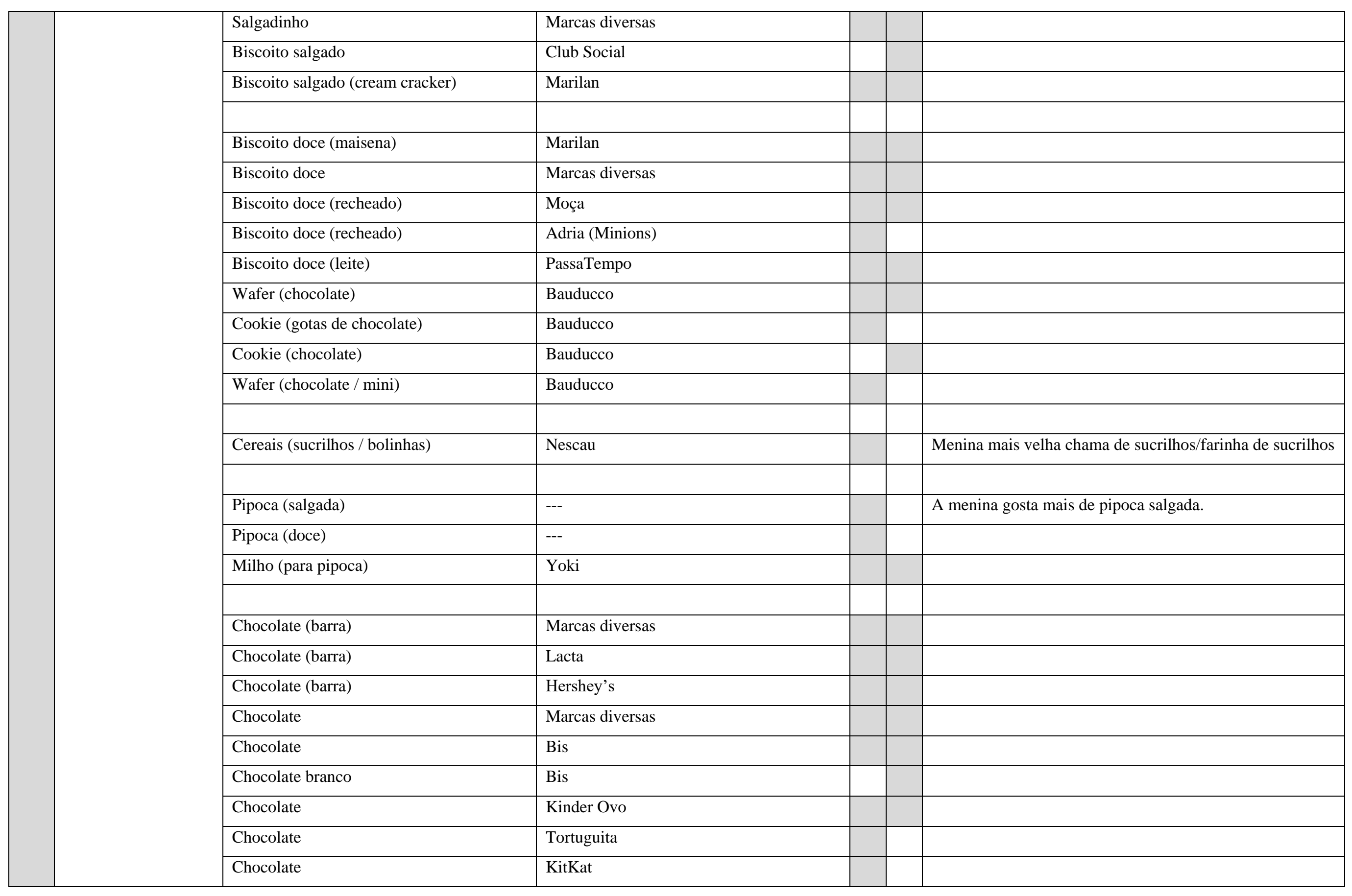




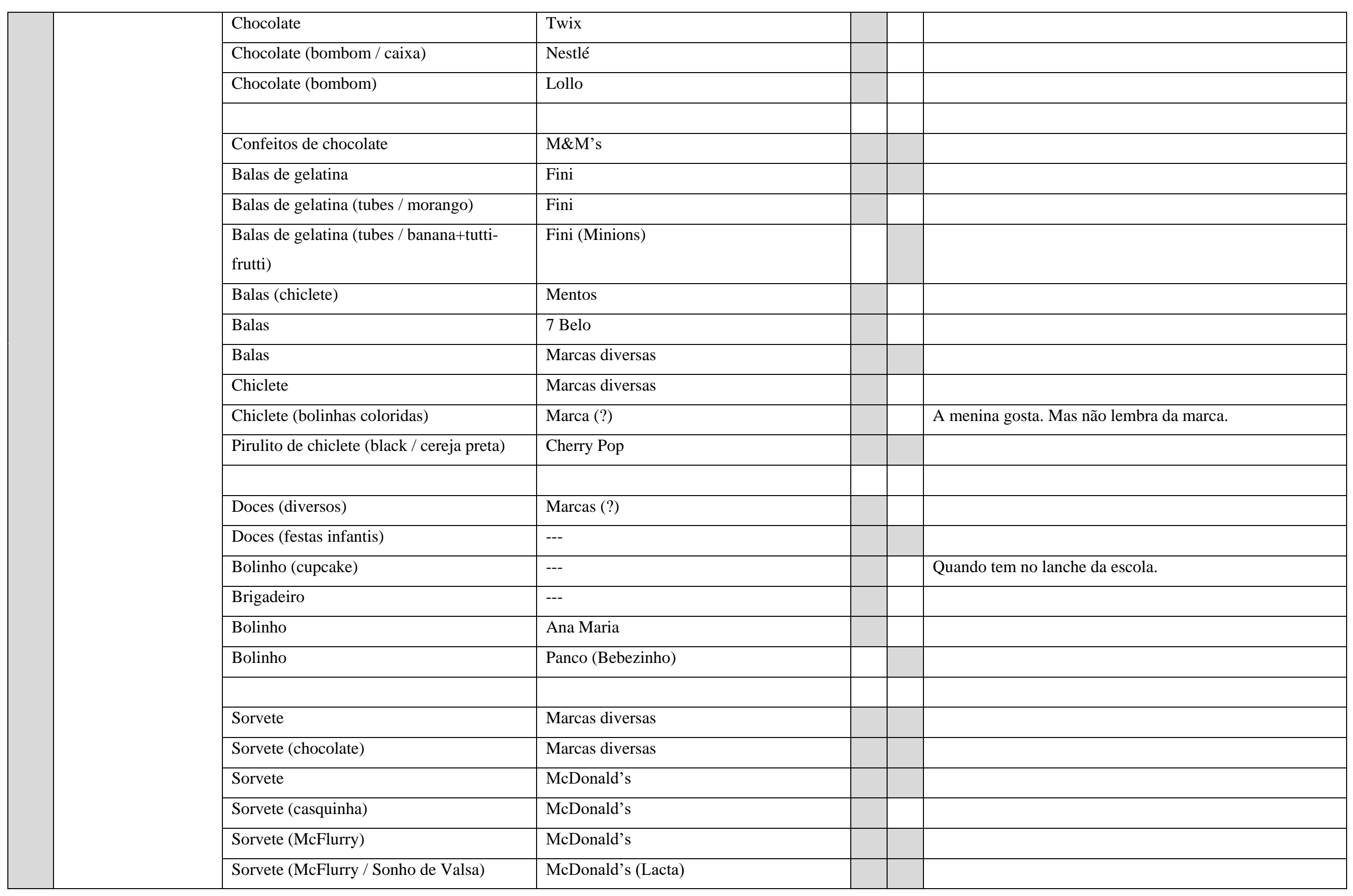




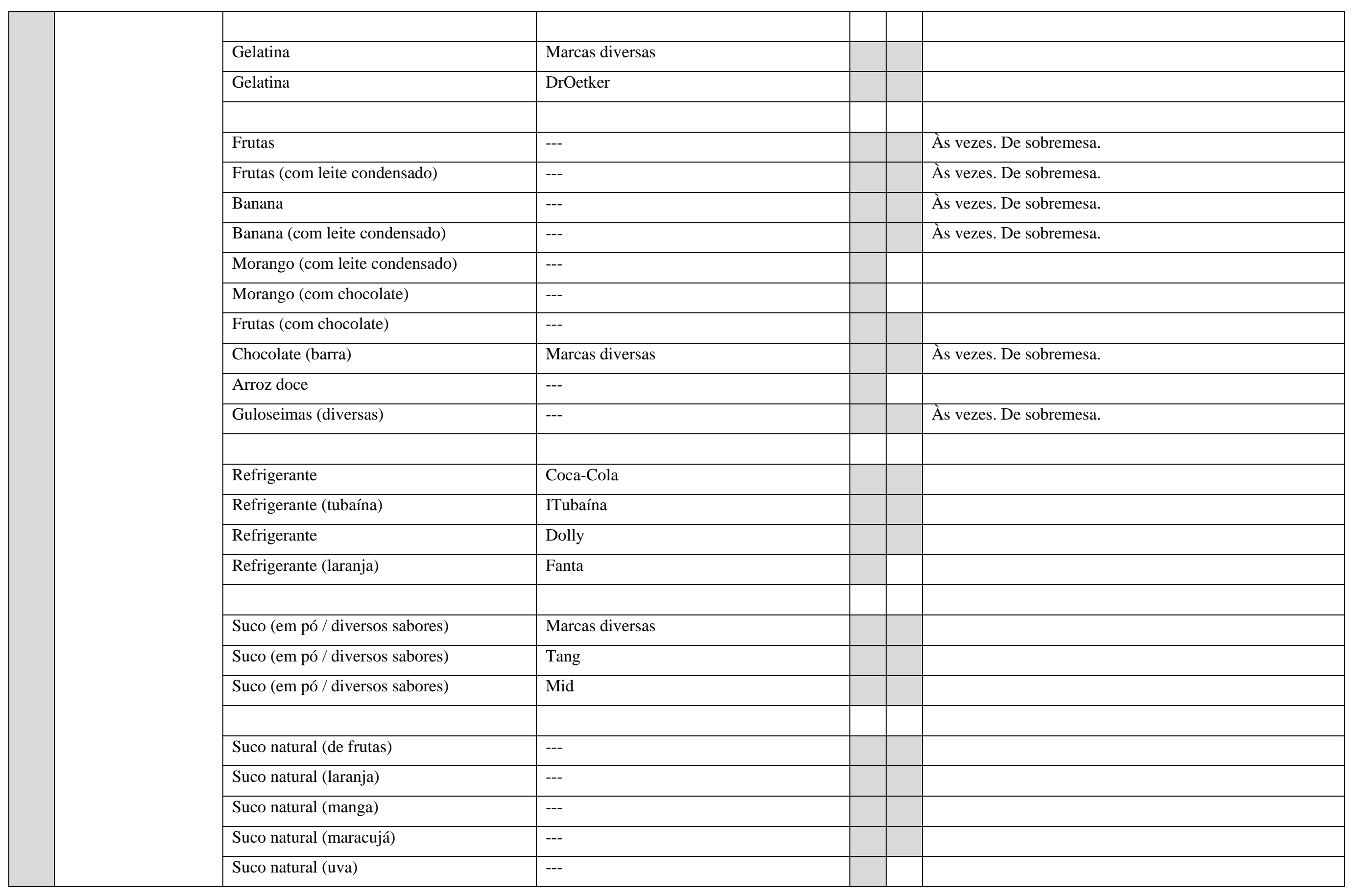




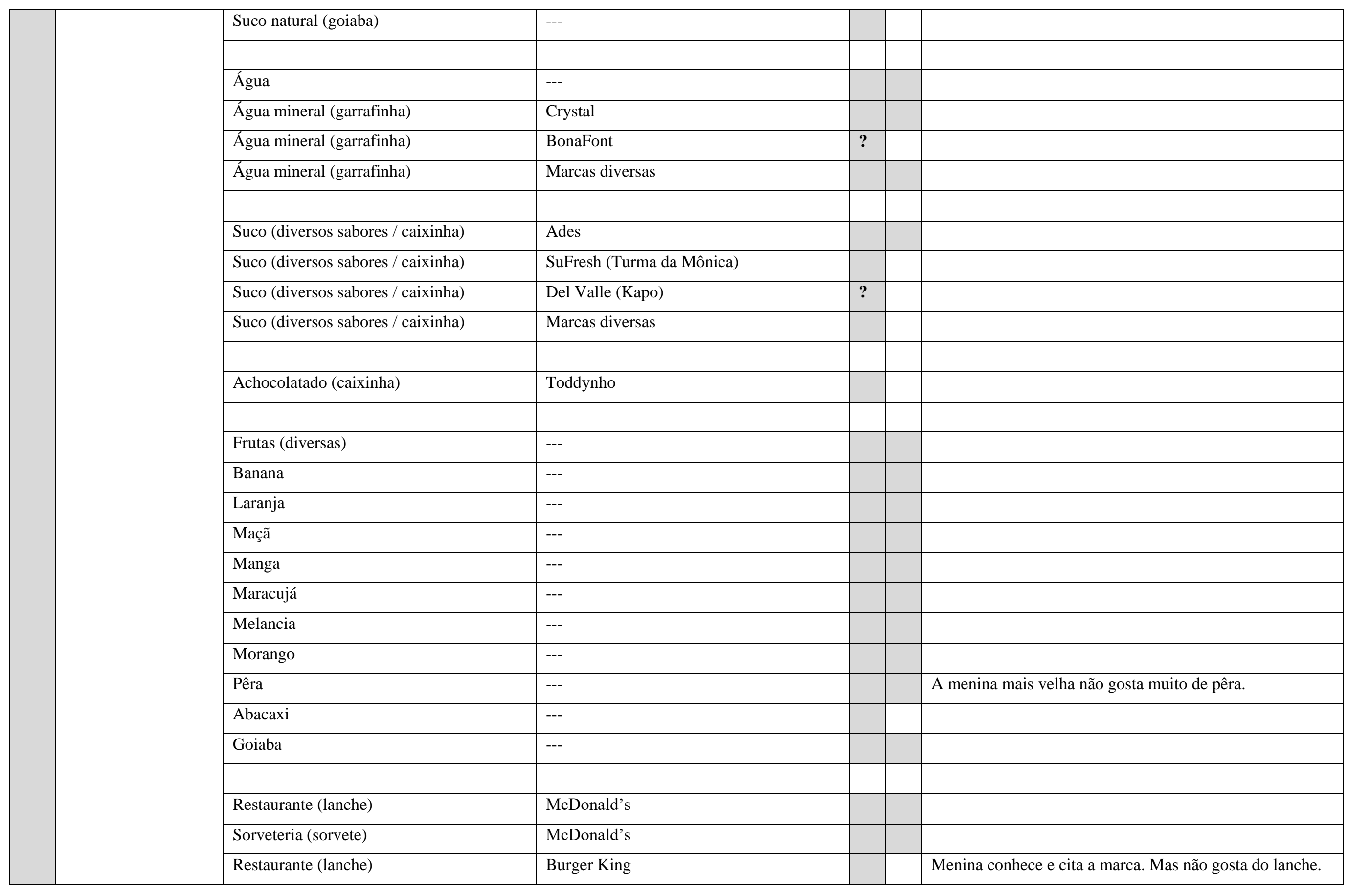




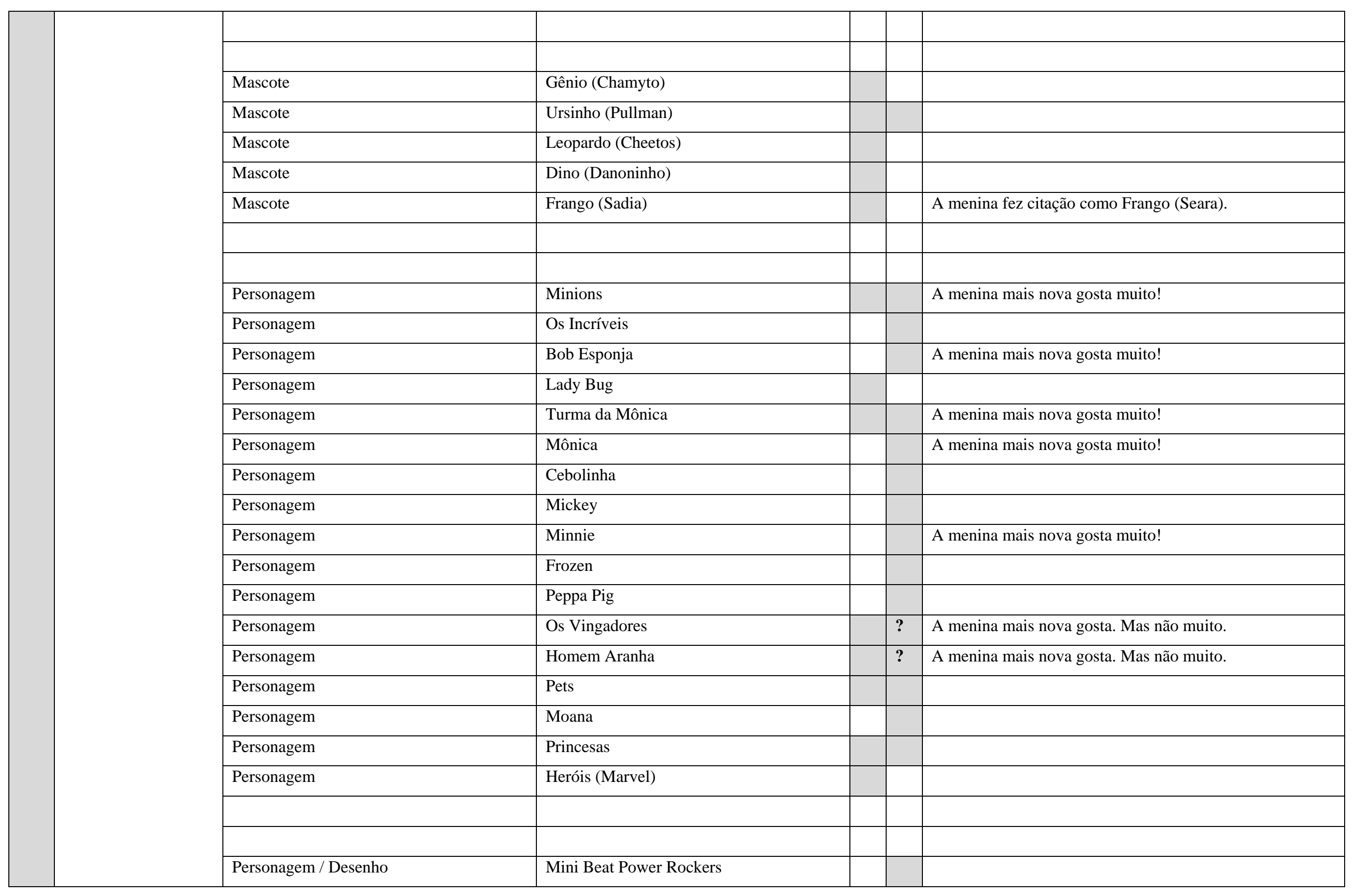




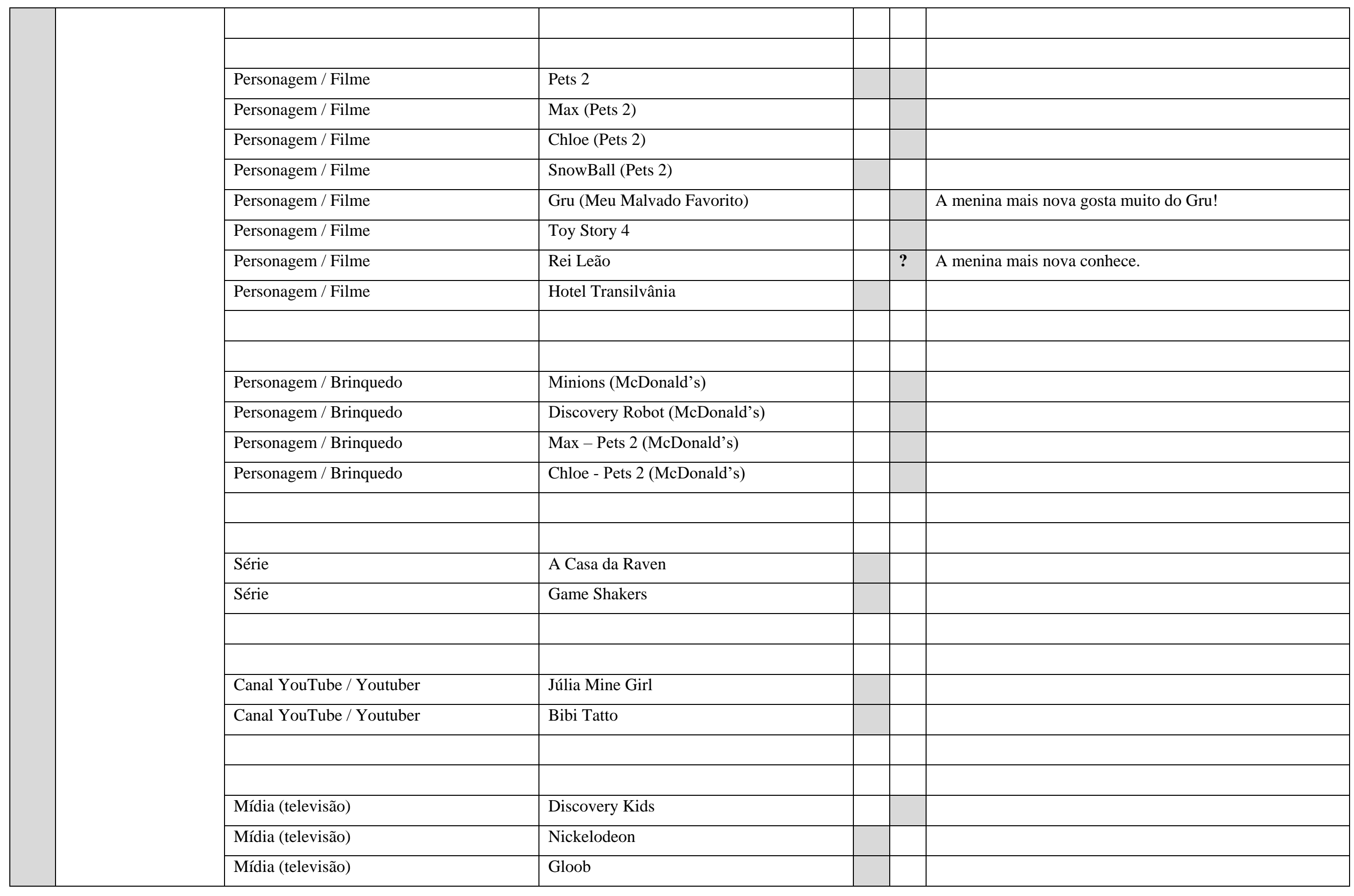




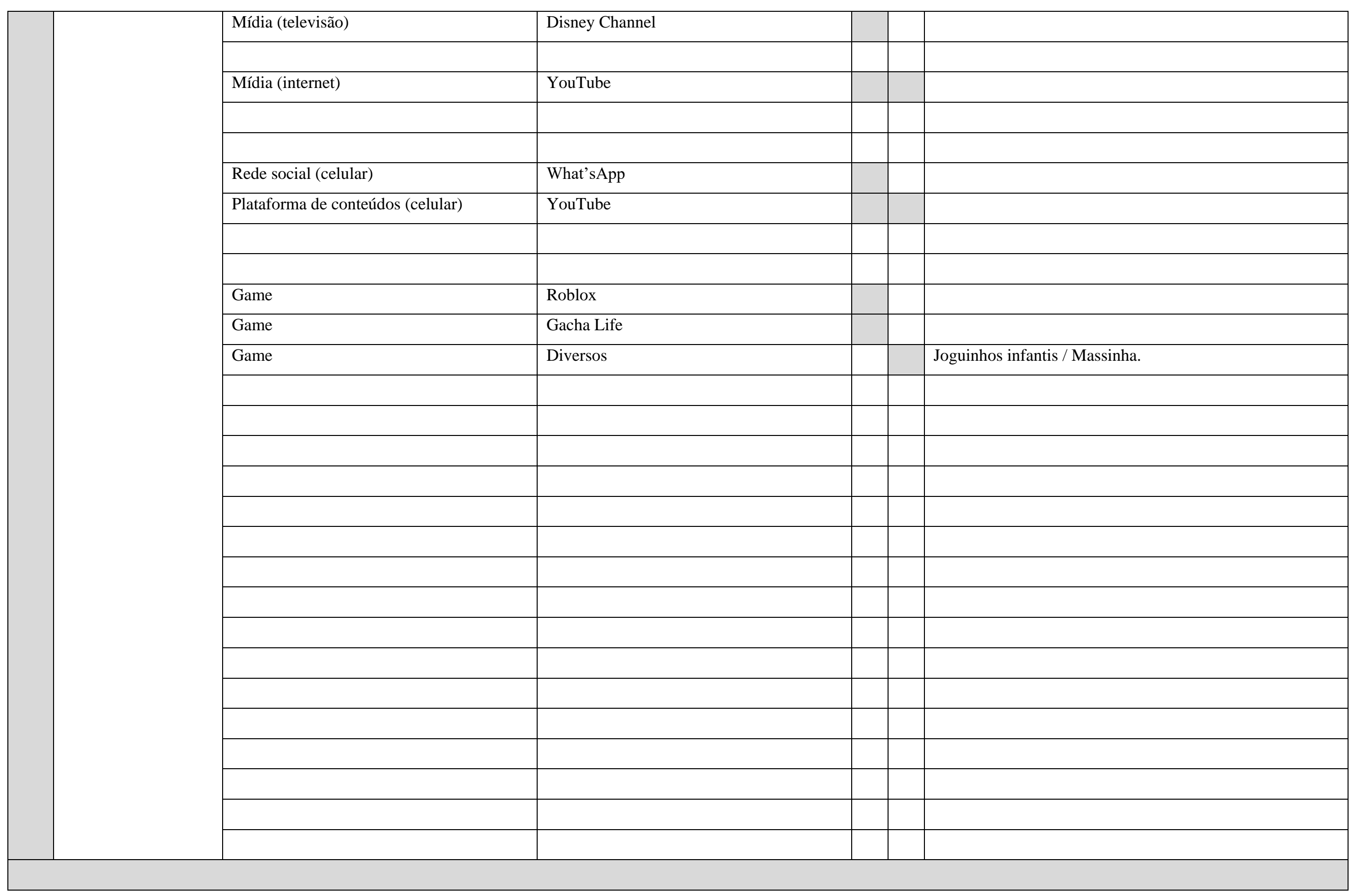




\begin{tabular}{|c|c|c|c|}
\hline QUE NÃO & Peixe (filé de peixe) & --- & Elas não gostam. E não comem. \\
\hline CONHECE & & & \\
\hline \multirow{3}{*}{ QUE NÃO GOSTA } & Hambúrguer & Burger King & Elas experimentaram. Mas não gostaram. \\
\hline & Restaurante (lanche) & Burger King & Elas experimentaram. Mas não gostaram. \\
\hline & Esfirra & Habib's & \\
\hline \multirow{2}{*}{$\begin{array}{c}\text { QUE GOSTA } \\
\text { MENOS }\end{array}$} & Restaurante (esfirra) & Habib's & \\
\hline & & & \\
\hline \multirow{17}{*}{$\begin{array}{l}\text { QUE NÃO } \\
\text { CONSOME }\end{array}$} & Picles (no hambúrguer) & --- & \\
\hline & & & \\
\hline & Queijo processado & Polenguinho & \\
\hline & Produto (?) & Italakinho & \\
\hline & Beterraba & --- & \\
\hline & Cenoura & --- & \\
\hline & Abobrinha & --- & \\
\hline & Berinjela & --- & \\
\hline & Legumes (diversos) & --- & \\
\hline & Verduras (diversas) & --- & \\
\hline & Salada & --- & \\
\hline & Alface & --- & \\
\hline & Mamão & $-\overline{---}$ & \\
\hline & Suco natural (manga) & --- & Ela gostava. Mas agora já não gosta mais tanto. \\
\hline & Suco (caixinha) & Do Bem & \\
\hline & $\begin{array}{l}\text { Pão (integral) } \\
\end{array}$ & --- & \\
\hline & Queijo branco & --- & \\
\hline
\end{tabular}




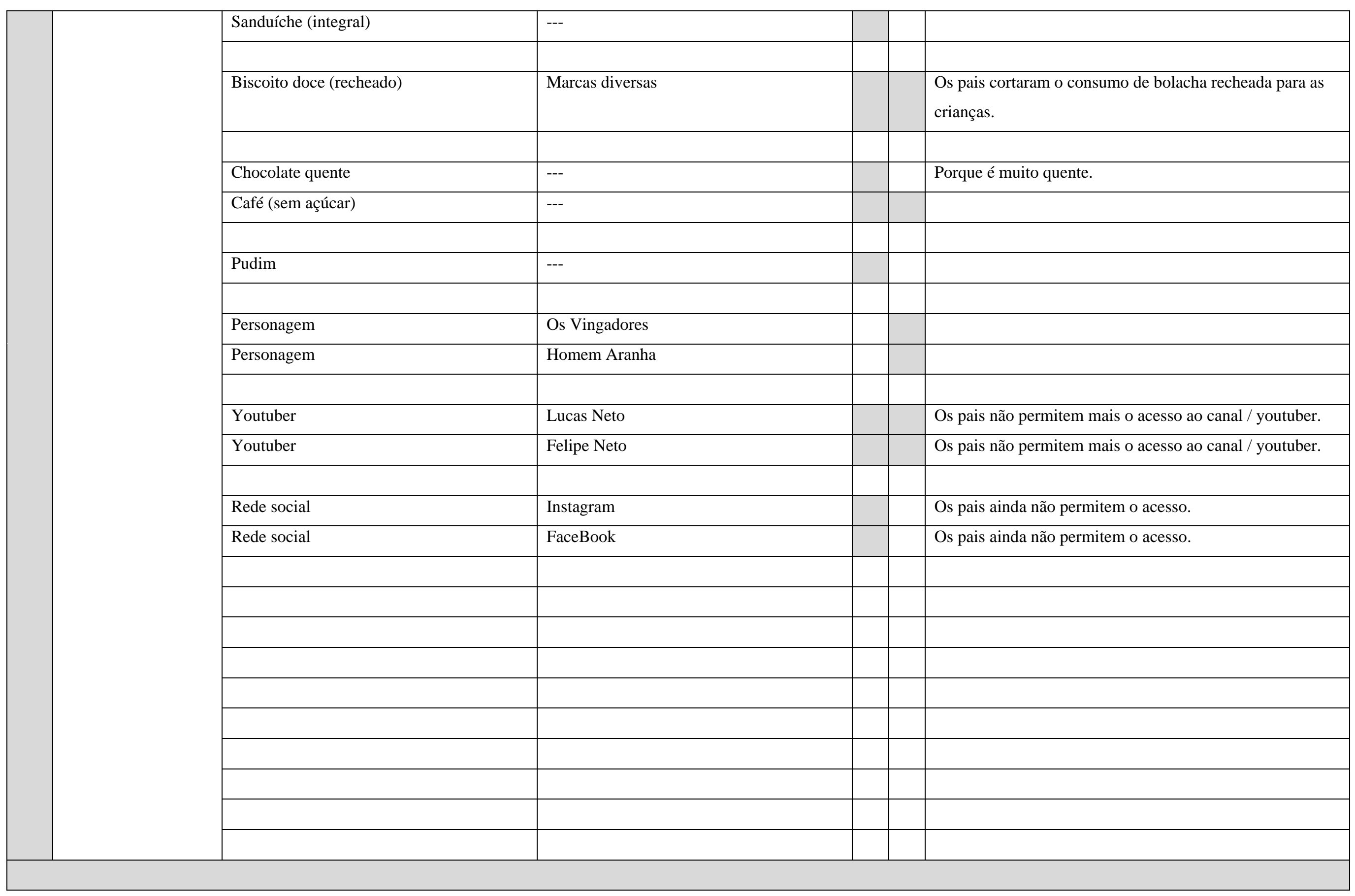


QUARTO ENCONTRO: ATIVIDADE LÚDICA COM AS CRIANÇAS: BRINCADEIRA DE COMER

PRODUTOS - MARCAS - PERSONAGENS

(RELATOS / OBSERVAÇÕES / CITAÇÕES / EXPRESSIVIDADES / FOTOS / VÍDEOS / OBSERVAÇÃO)

\begin{tabular}{|c|c|c|c|c|c|c|}
\hline & ATIVIDADE & ALIMENTO / PRODUTO & MARCA / PERSONAGEM & $\mathbf{F}$ & C & OBSERVAÇÃO \\
\hline \multirow[b]{3}{*}{$\mathbf{C}$} & \multirow[t]{17}{*}{ CAFÉ DA MANHÃ } & \multicolumn{5}{|l|}{ MENINA 1: } \\
\hline & & Margarina & Doriana & & & \\
\hline & & Pão francês & --- & & & \\
\hline \multirow{2}{*}{$\begin{array}{l}\mathbf{A} \\
\mathbf{R}\end{array}$} & & Leite (integral / garrafa) & Shefa & & & \\
\hline & & Achocolatado (em pó) & Nescau & & & \\
\hline \multirow{2}{*}{$\begin{array}{l}\text { D } \\
\text { S }\end{array}$} & & Bisnaguinha & Pullman (Bisnaguito) & & & \\
\hline & & Pão de queijo & --- & & & \\
\hline \multirow{3}{*}{$\begin{array}{l}\mathbf{L} \\
\mathbf{I}\end{array}$} & & [Margarina] & [Qualy] & & & Escolheu. Mas desistiu. Trocou por Margarina Doriana. \\
\hline & & & & & & \\
\hline & & \multicolumn{5}{|l|}{ MENINA 2: } \\
\hline \multirow{2}{*}{$\begin{array}{c}\text { M } \\
\text { E }\end{array}$} & & Leite (integral / garrafa) & Shefa & & & \\
\hline & & Margarina & Doriana & & & \\
\hline \multirow{2}{*}{$\begin{array}{l}\mathbf{N} \\
\mathbf{T}\end{array}$} & & Pão francês & --- & & & \\
\hline & & Café (em pó / torrado) & Pilão & & & \\
\hline \multirow{3}{*}{$\begin{array}{l}\mathbf{O} \\
\mathbf{S}\end{array}$} & & & & & & \\
\hline & & Cenoura & --- & & & \\
\hline & & Leite fermentado & Vigor (Minions) & & & \\
\hline
\end{tabular}




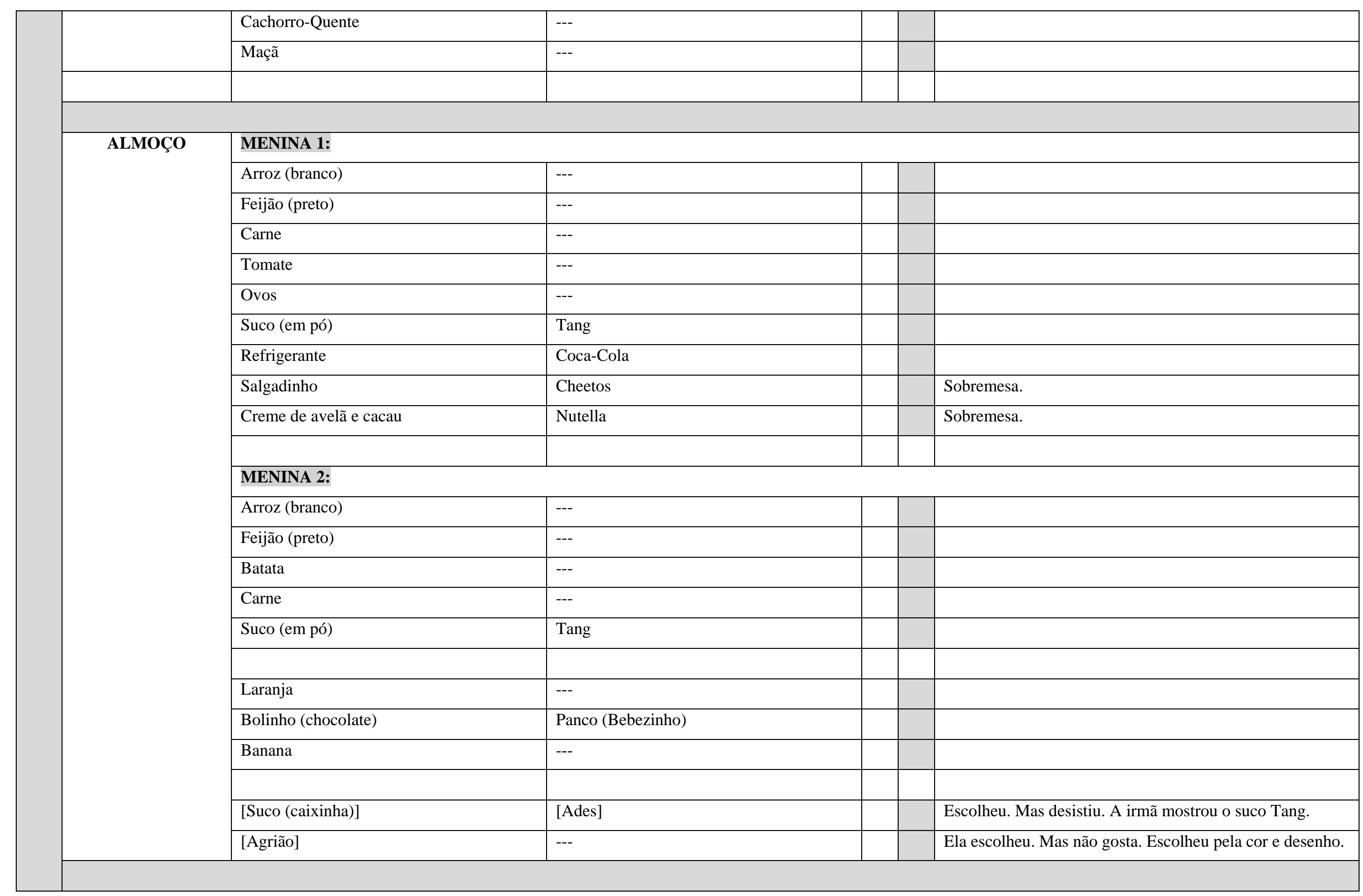




\begin{tabular}{|c|c|c|c|}
\hline \multirow[t]{24}{*}{ JANTAR } & \multicolumn{3}{|l|}{ MENINA 1: } \\
\hline & Arroz (branco) & --- & \\
\hline & Feijão (preto) & --- & \\
\hline & Carne & --- & \\
\hline & Suco (em pó) & Tang & \\
\hline & Pizza & Pizza Hut & \\
\hline & Refrigerante & Coca-Cola & Ela gosta de ITubaína também. Toda a família gosta. \\
\hline & Refrigerante (tubaína) & ITubaína & \\
\hline & Cereais (sucrilhos / bolinhas / chocolate) & Nescau & Para ela é farinha de sucrilhos. \\
\hline & Cachorro-Quente & --- & \\
\hline & Bolinho (baunilha) & Ana Maria & Sobremesa. \\
\hline & \multicolumn{3}{|l|}{ MENINA 2: } \\
\hline & Arroz (branco) & --- & \\
\hline & Feijão (preto) & --- & \\
\hline & Carne & --- & \\
\hline & Suco (em pó) & Tang & \\
\hline & Pizza & Pizza Hut & \\
\hline & Refrigerante & Coca-Cola & \\
\hline & Refrigerante (tubaína) & ITubaína & \\
\hline & Cachorro-Quente & --- & Citação do pai. \\
\hline & & & \\
\hline & & & \\
\hline & & & \\
\hline & & & \\
\hline
\end{tabular}




\begin{tabular}{|c|c|c|c|}
\hline \multirow{13}{*}{$\begin{array}{c}\text { LANCHE } \\
\text { DA ESCOLA }\end{array}$} & \multicolumn{3}{|l|}{ MENINA 1: } \\
\hline & Suco (caixinha) & Ades & No lanche da escola tem suco de diversas marcas. \\
\hline & Wafer (chocolate) & Bauducco & \\
\hline & Pera & --- & \\
\hline & Maçã & --- & \\
\hline & Pão francês & --- & No lanche da escola tem pãozinho integral. \\
\hline & Bisnaguinha & Pullman (Bisnaguito) & Sobremesa. \\
\hline & Bolinho (baunilha) & Ana Maria & Sobremesa. \\
\hline & Creme de avelã e cacau & Nutella & Sobremesa. \\
\hline & [Suco (caixinha)] & [SuFresh (Turma da Mônica)] & Estava em dúvida entre o suco (caixinha) Ades e SuFresh. \\
\hline & \multicolumn{3}{|l|}{ MENINA 2: } \\
\hline & & & \\
\hline & & & \\
\hline \multirow{10}{*}{$\begin{array}{c}\text { LANCHE } \\
\text { COM AMIGOS }\end{array}$} & \multicolumn{3}{|l|}{ MENINA 1: } \\
\hline & Salgadinho & Cheetos & \\
\hline & Confeitos de chocolate & M\&M's & \\
\hline & Refrigerante (laranja) & Fanta & \\
\hline & Hambúrguer & McDonald's & \\
\hline & Refrigerante & Coca-Cola & A menina gosta de Fanta e Coca-Cola. As amigas também. \\
\hline & \multicolumn{3}{|l|}{ MENINA 2: } \\
\hline & & & \\
\hline & & & \\
\hline & & & \\
\hline
\end{tabular}




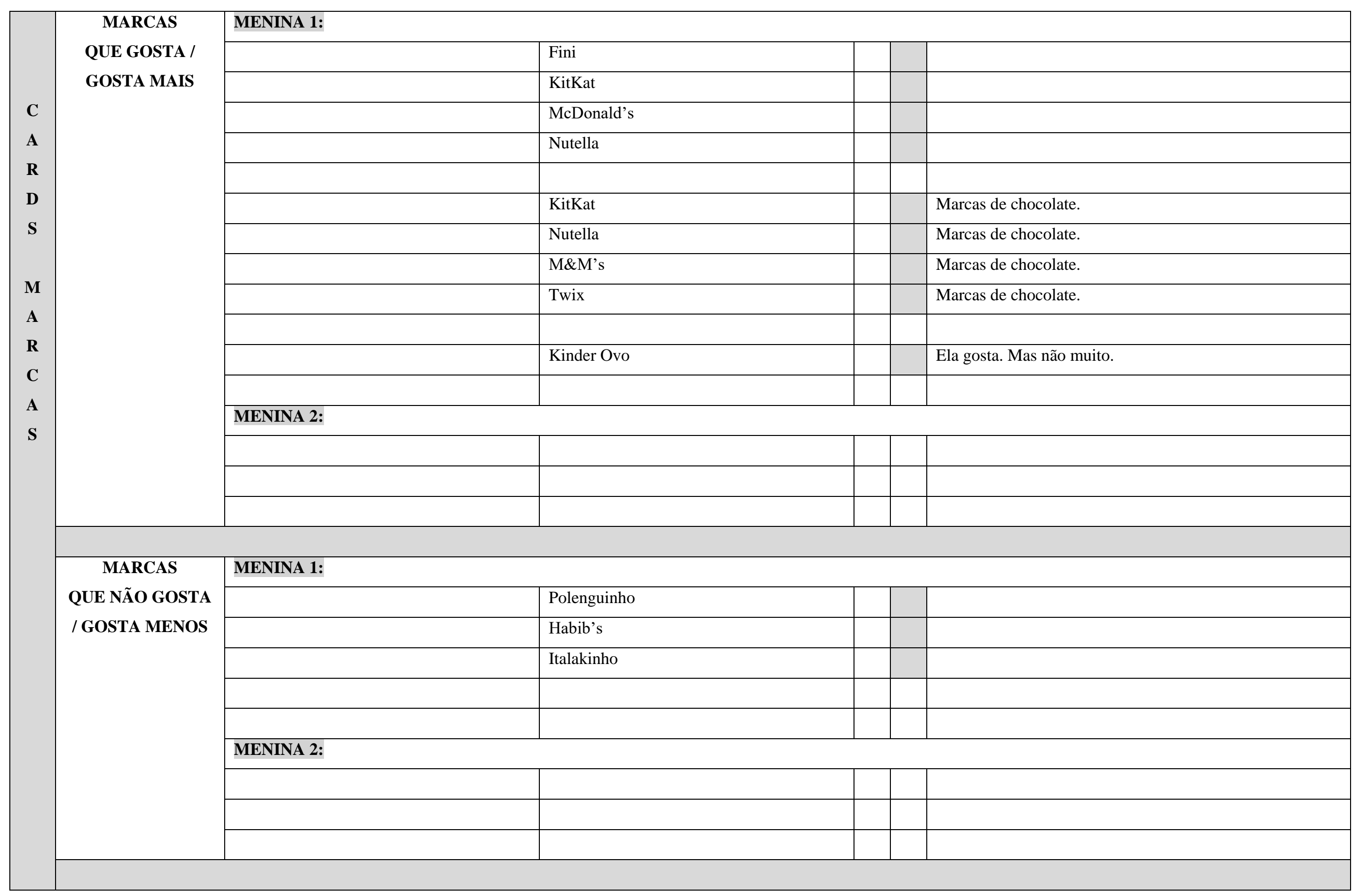




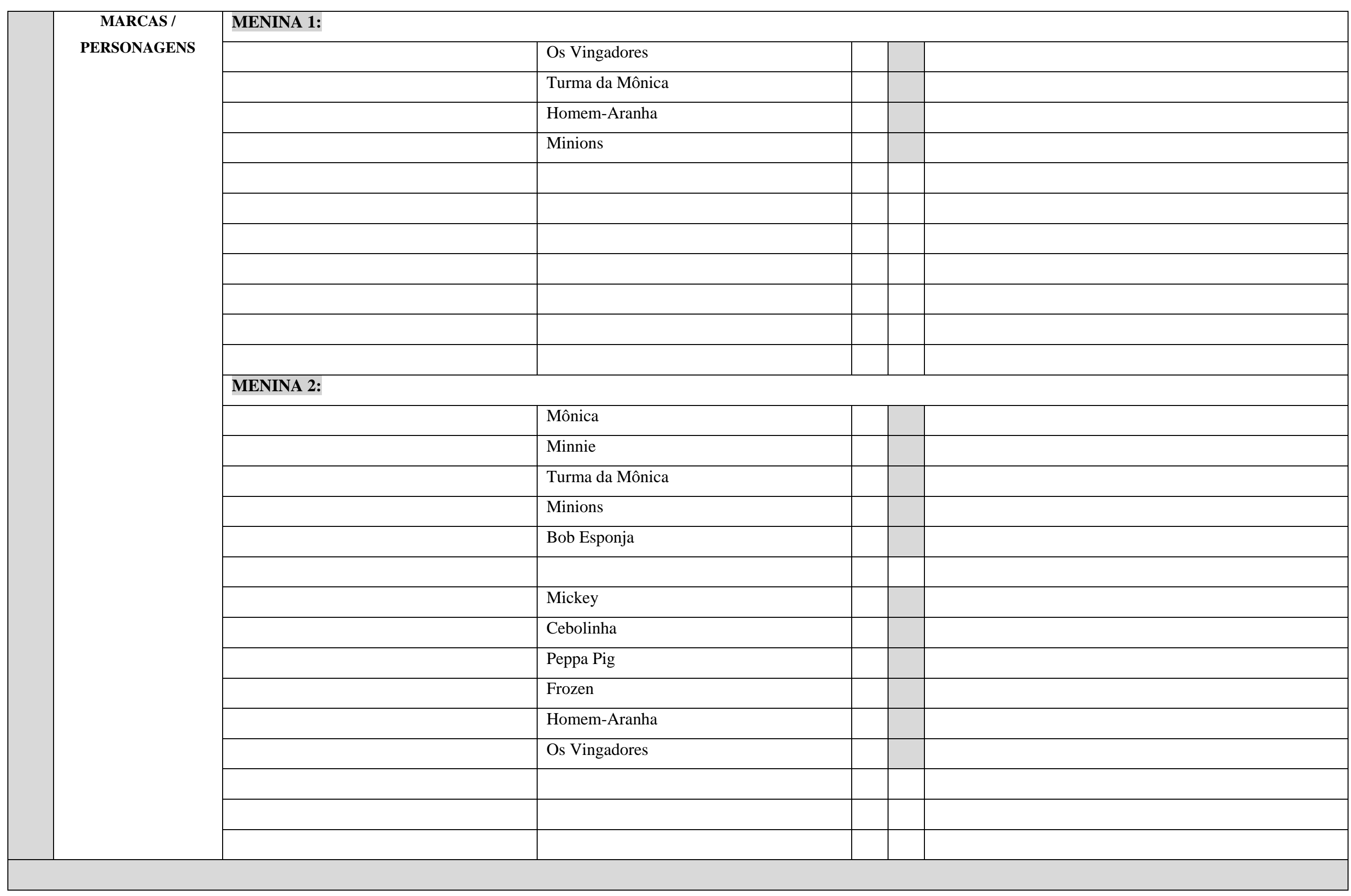




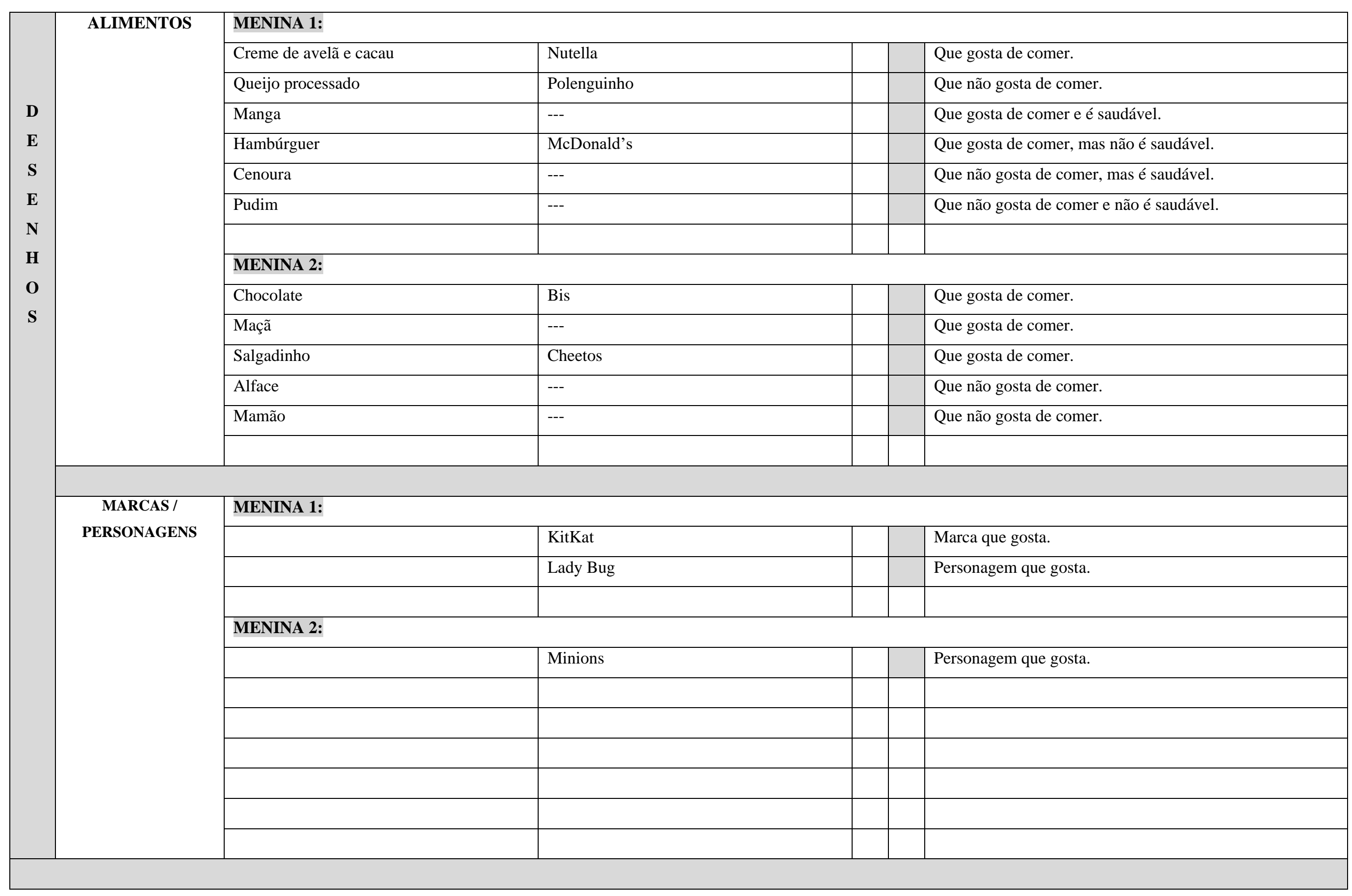




\section{QUINTO ENCONTRO: ATIVIDADE LÚDICA COM AS CRIANÇAS: BRINCADEIRA DE COMPRAR}

PRODUTOS - MARCAS - PERSONAGENS

(RELATOS / OBSERVAÇÕES / CITAÇÕES / EXPRESSIVIDADES / FOTOS / VÍDEOS / OBSERVAÇ̃̃O)

\begin{tabular}{|c|c|c|c|c|c|c|}
\hline \multirow[b]{3}{*}{$\mathbf{S}$} & ATIVIDADE & ALIMENTO / PRODUTO & MARCA / PERSONAGEM & $\mathbf{F}$ & C & OBSERVAÇÃO \\
\hline & \multirow[t]{16}{*}{ CARRINHO } & \multicolumn{5}{|l|}{ MENINA 1: } \\
\hline & & Cookie (gotas de chocolate) & Bauducco & & & \\
\hline \multirow{2}{*}{$\begin{array}{c}\mathbf{I} \\
\mathbf{M}\end{array}$} & & Chocolate & KitKat & & & \\
\hline & & Creme de avelã e cacau & Nutella & & & \\
\hline \multirow[t]{2}{*}{$\mathbf{U}$} & & Salgadinho & Ruffles & & & \\
\hline & & Balas de gelatina (tubes / morango) & Fini & & & \\
\hline A & & & & & & \\
\hline Ç & & \multicolumn{5}{|l|}{ MENINA 2: } \\
\hline \multirow{3}{*}{$\begin{array}{l}\tilde{\mathbf{A}} \\
\mathbf{O}\end{array}$} & & Cookie (chocolate) & Bauducco & & & (Choco Biscuit) \\
\hline & & Chocolate branco & Bis & & & \\
\hline & & Biscoito salgado & Club Social & & & \\
\hline \multirow[t]{2}{*}{$\mathbf{C}$} & & Salgadinho & Ruffles & & & \\
\hline & & Confeitos de chocolate & M\&M's & & & \\
\hline $\begin{array}{l}\mathbf{M} \\
\mathbf{P} \\
\mathbf{R}\end{array}$ & & $\begin{array}{l}\text { Balas de gelatina (tubes / banana+tutti- } \\
\text { frutti) }\end{array}$ & Fini (Minions) & & & \\
\hline \multicolumn{6}{|c|}{$\mathbf{A}$} & \\
\hline S & & & & & & \\
\hline
\end{tabular}




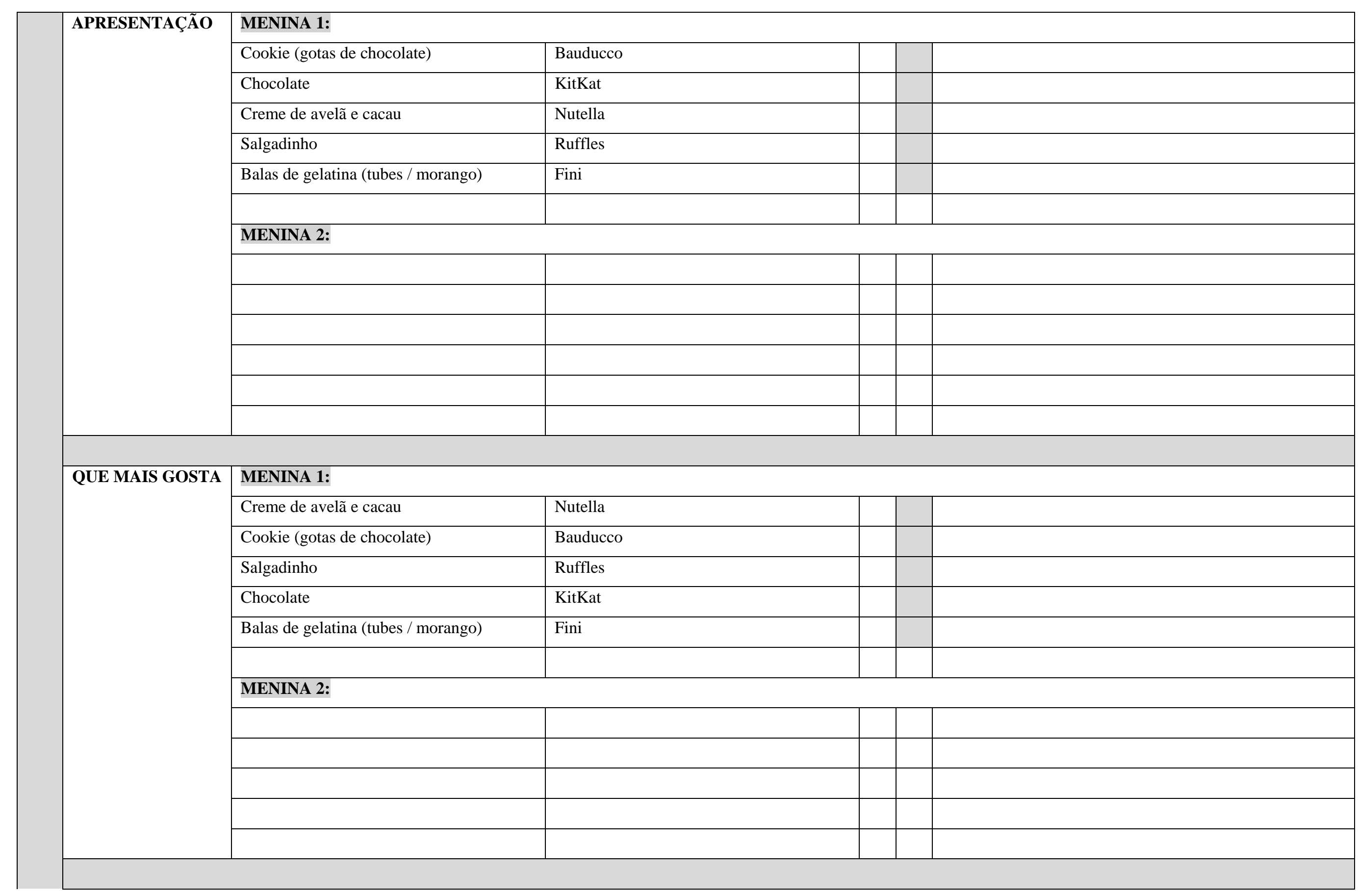




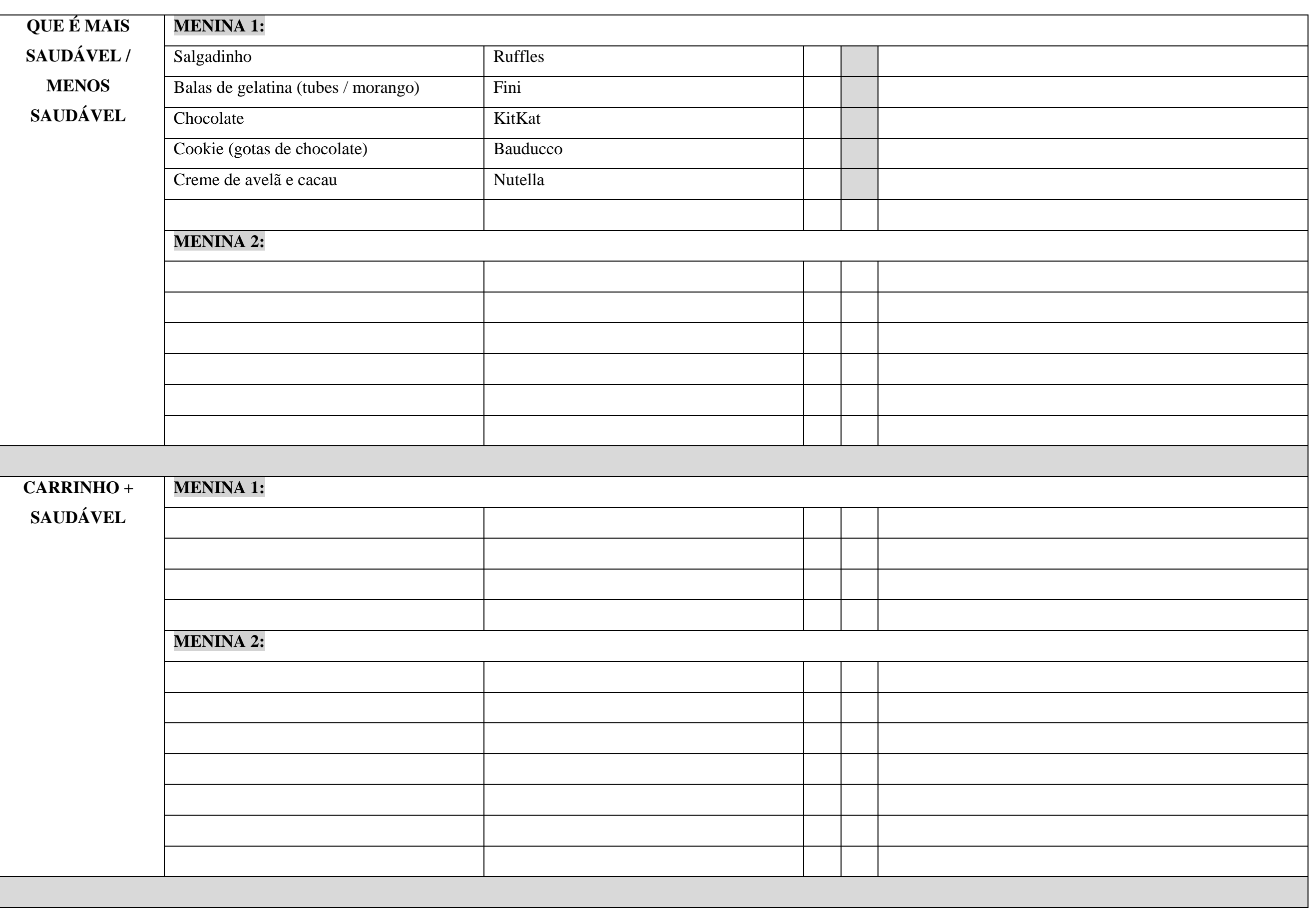




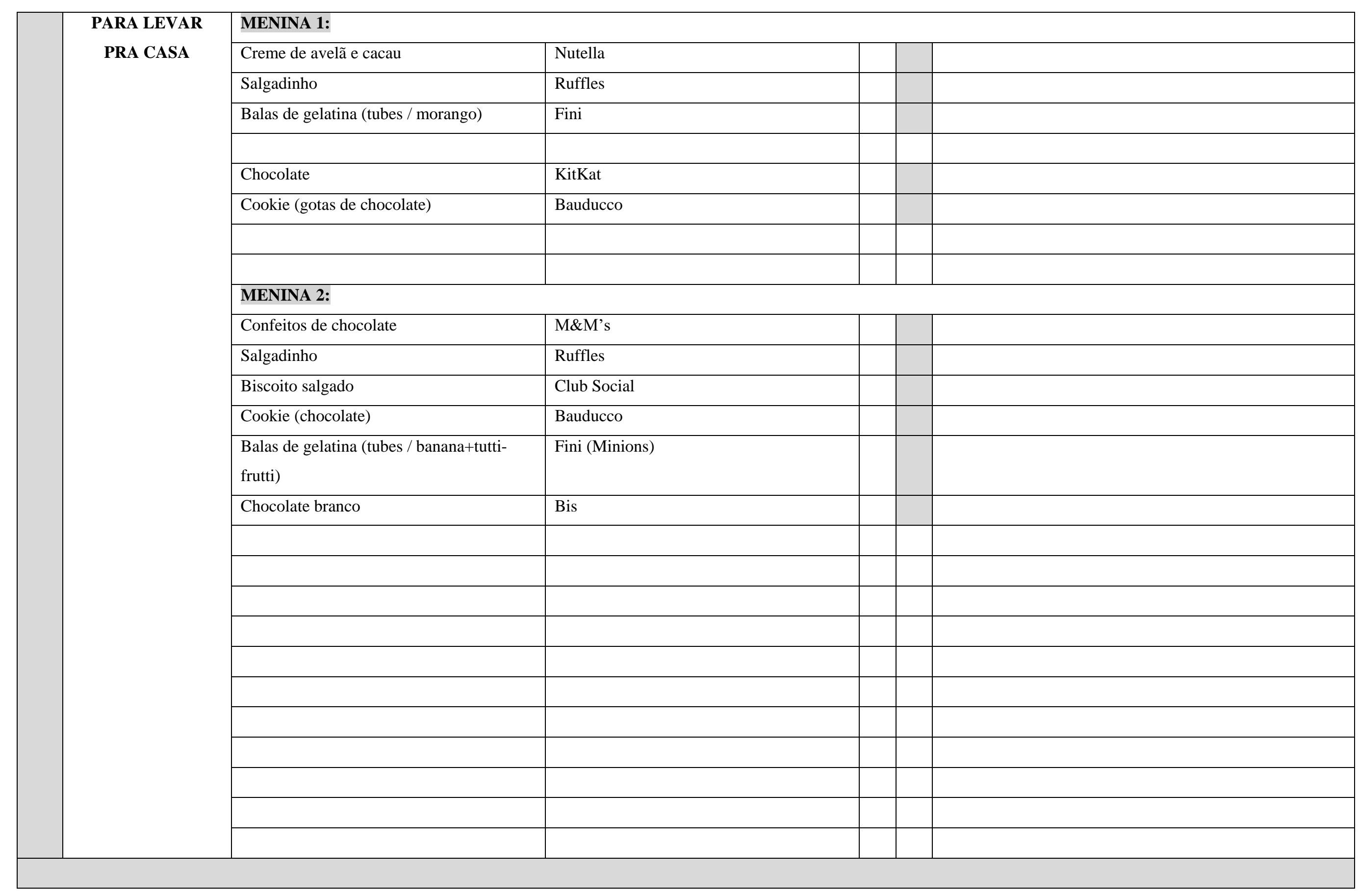


MARCAS E PRODUTOS ALIMENTÍCIOS NO AMBIENTE DOMÉSTICO

(ALMOÇO DA FAMÍLIA)

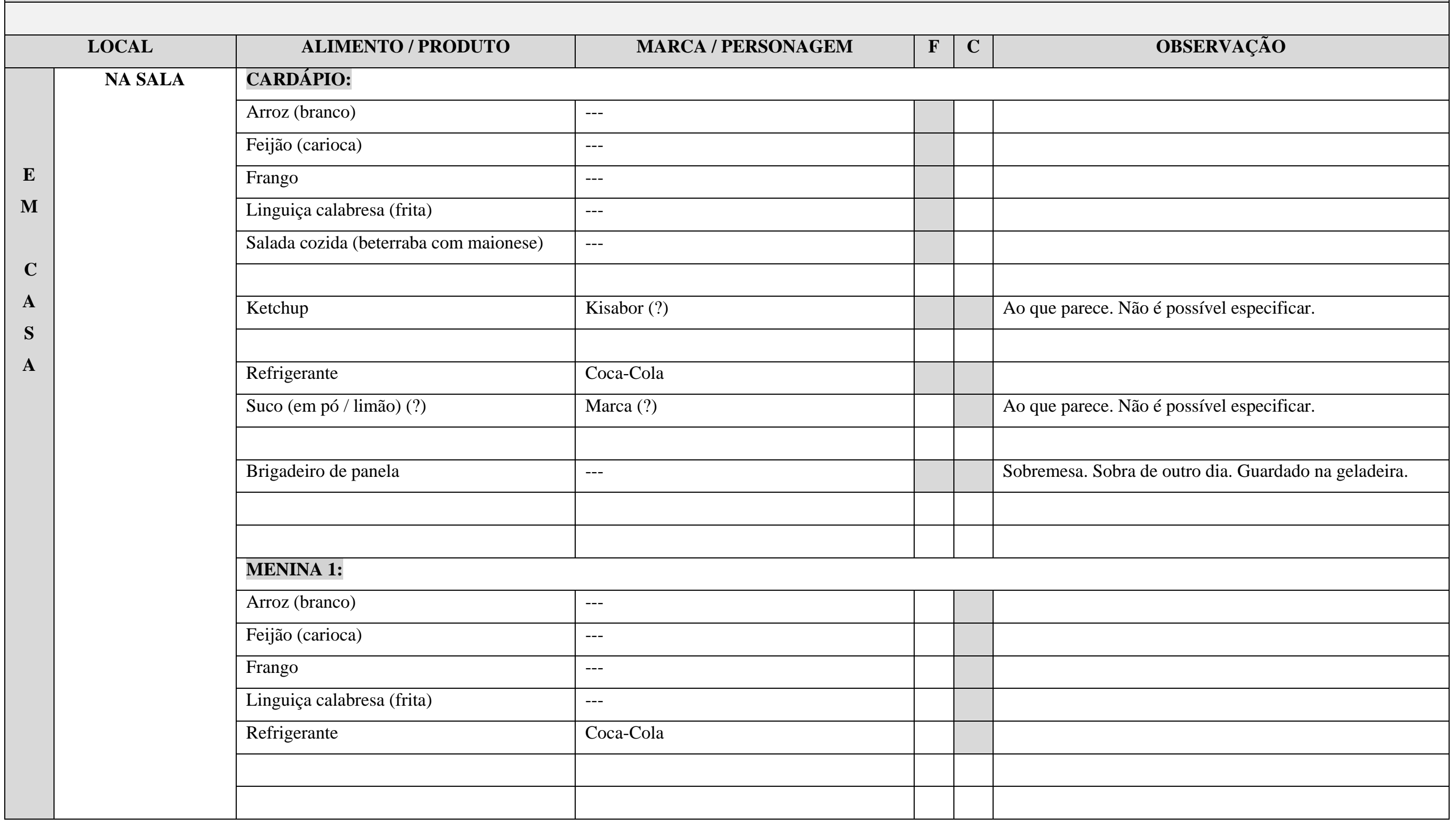




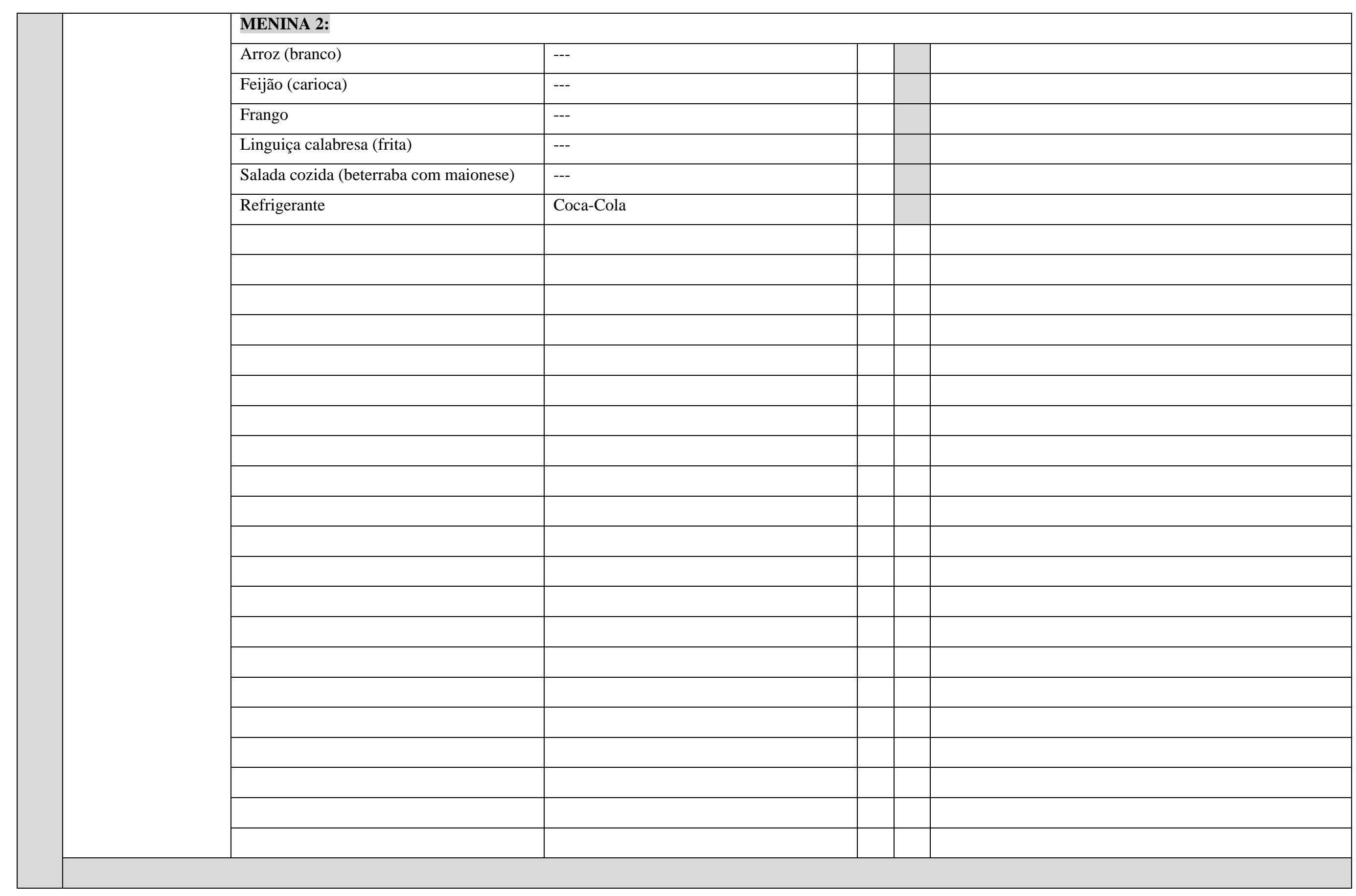




\section{SEXTO ENCONTRO: ATIVIDADE LÚDICA COM AS CRIANÇAS: THE KIDS: MY FOODS}

PRODUTOS - MARCAS - PERSONAGENS

(RELATOS / OBSERVAÇÕES / CITAÇÕES / EXPRESSIVIDADES / FOTOS / VÍDEOS / OBSERVAÇÃO)

\begin{tabular}{|c|c|c|c|c|c|c|}
\hline & ATIVIDADE & ALIMENTO / PRODUTO & MARCA / PERSONAGEM & $\mathbf{F}$ & $\mathbf{C}$ & OBSERVAÇÃO \\
\hline \multirow{6}{*}{$\mathbf{n}$} & \multirow[t]{17}{*}{ MY FOODS! } & \multicolumn{5}{|l|}{ MENINA 1: } \\
\hline & & Manga & --- & & & \\
\hline & & Banana & --- & & & \\
\hline & & Laranja & --- & & & \\
\hline & & Biscoito doce (maisena) & Marilan (?) & & & Há dúvidas na especificação da marca. \\
\hline & & Pirulito de chiclete (black / cereja preta) & Cherry Pop & & & \\
\hline \multirow[t]{3}{*}{ F } & & Creme de avelã e cacau & Nutella & & & \\
\hline & & & & & & \\
\hline & & \multicolumn{5}{|l|}{ MENINA 2: } \\
\hline \multirow{8}{*}{$\mathbf{S}$} & & Manga & --- & & & \\
\hline & & Banana & --- & & & \\
\hline & & Laranja & --- & & & \\
\hline & & Beterraba & --- & & & \\
\hline & & Biscoito doce (maisena) & Marilan (?) & & & Há dúvidas na especificação da marca. \\
\hline & & Pirulito de chiclete (black / cereja preta) & Cherry Pop & & & \\
\hline & & Pão francês & --- & & & \\
\hline & & Leite (integral / caixa) & Dália & & & \\
\hline
\end{tabular}




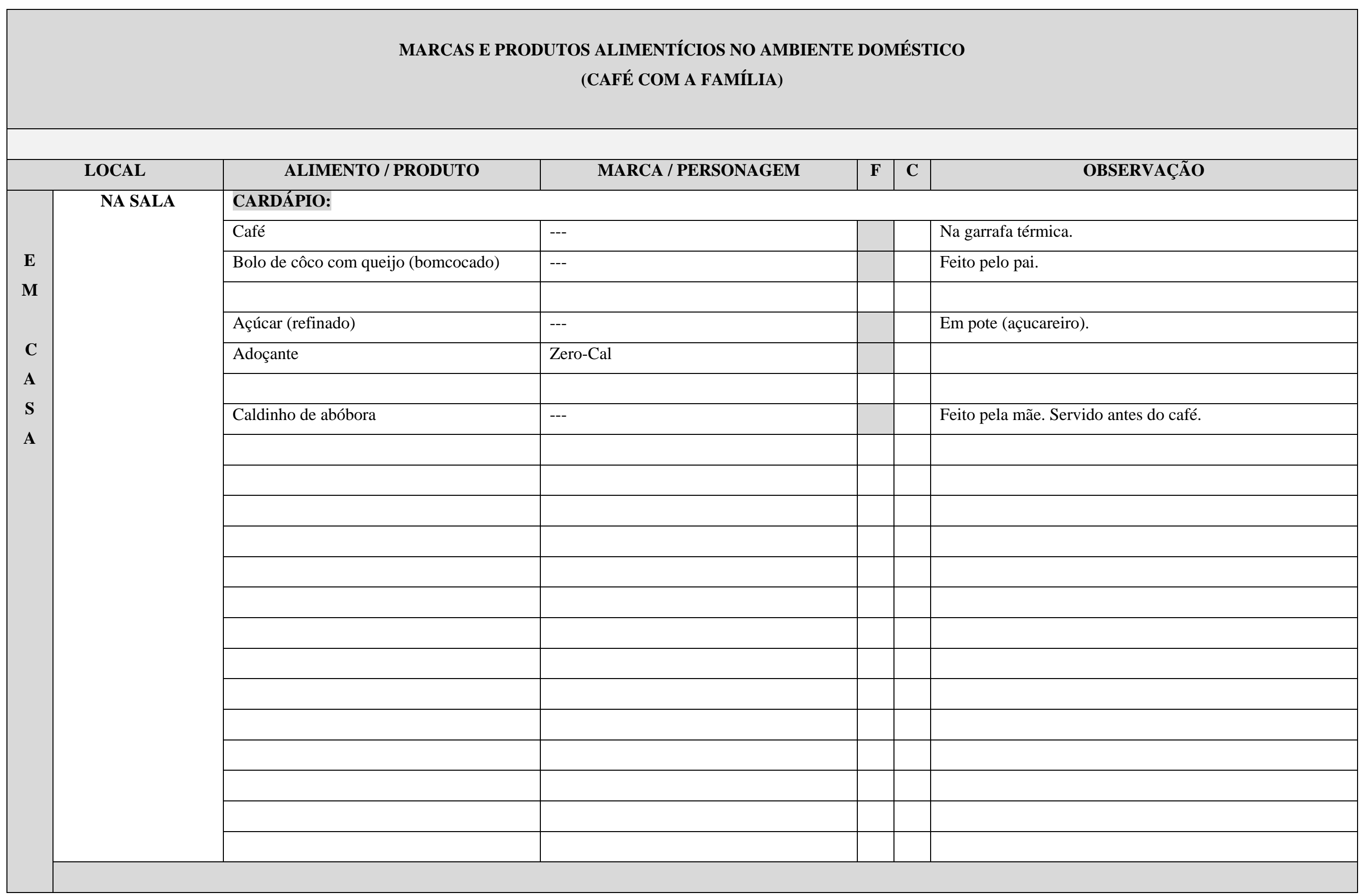




\section{Observações:}

$\mathrm{F}=$ Para a família (os pais e as crianças)

$\mathrm{C}=$ Para as crianças

$\mathrm{C} 1$ = Para a menina mais velha / Preferência da menina mais velha

C2 = Para a menina mais nova / Preferência da menina mais nova

Menina 1 = Menina mais velha

Menina 2 = Menina mais nova

Presença material $=$ Marcas e produtos alimentícios que a família $/$ as crianças consomem.

Presença simbólica = Marcas e produtos alimentícios que a família / as crianças gostariam de consumir .

(?) = Dúvidas quanto à especificação das marcas e produtos alimentícios em fotografias, vídeos ou relatos. 


\section{APÊNDICE Q}

PESQUISA DE CAMPO

MARCAS DE ALIMENTOS NO CONTEXTO FAMILIAR

\section{FAMÍLIA I}

MARCAS DE ALIMENTOS: PRESENÇA MATERIAL E SIMBÓLICA 


\section{F A M Í L I A}

MARCAS E PRODUTOS ALIMENTÍCIOS NO AMBIENTE DOMÉSTICO E ESPAÇO PÚBLICO (RELATOS / OBSERVAÇÕES / CITAÇÕES / EXPRESSIVIDADES / FOTOS / VÍDEOS / OBSERVAÇÃO)

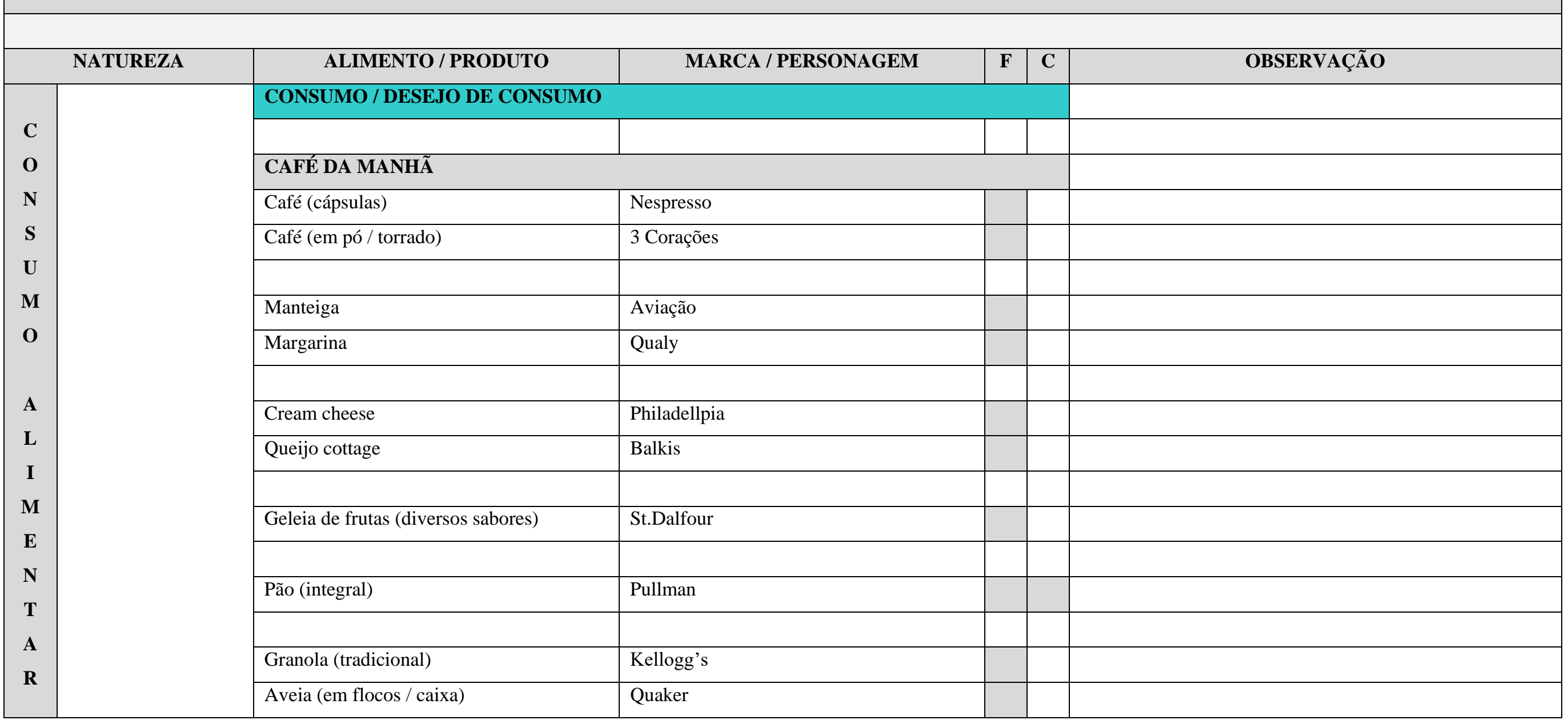




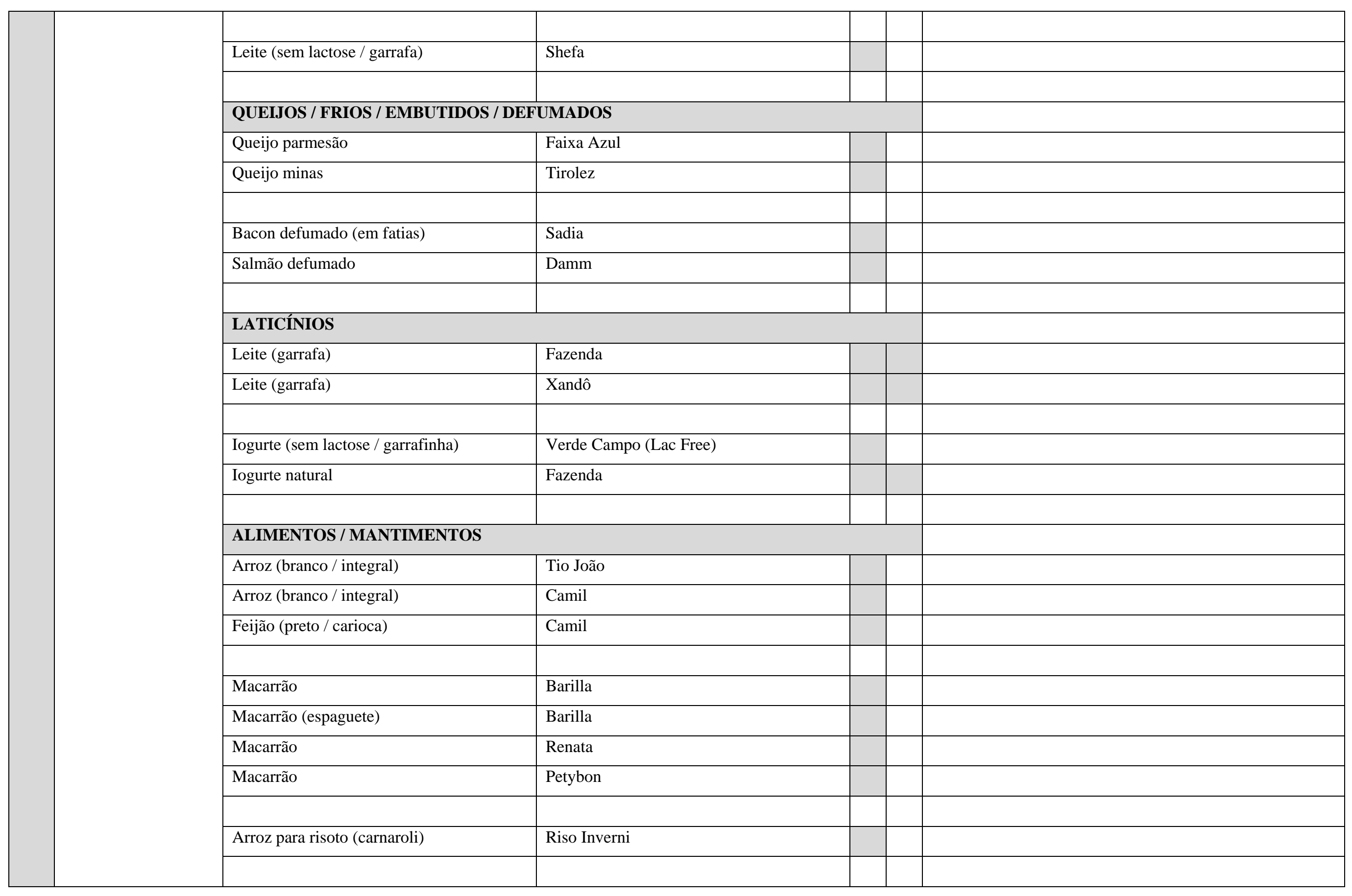




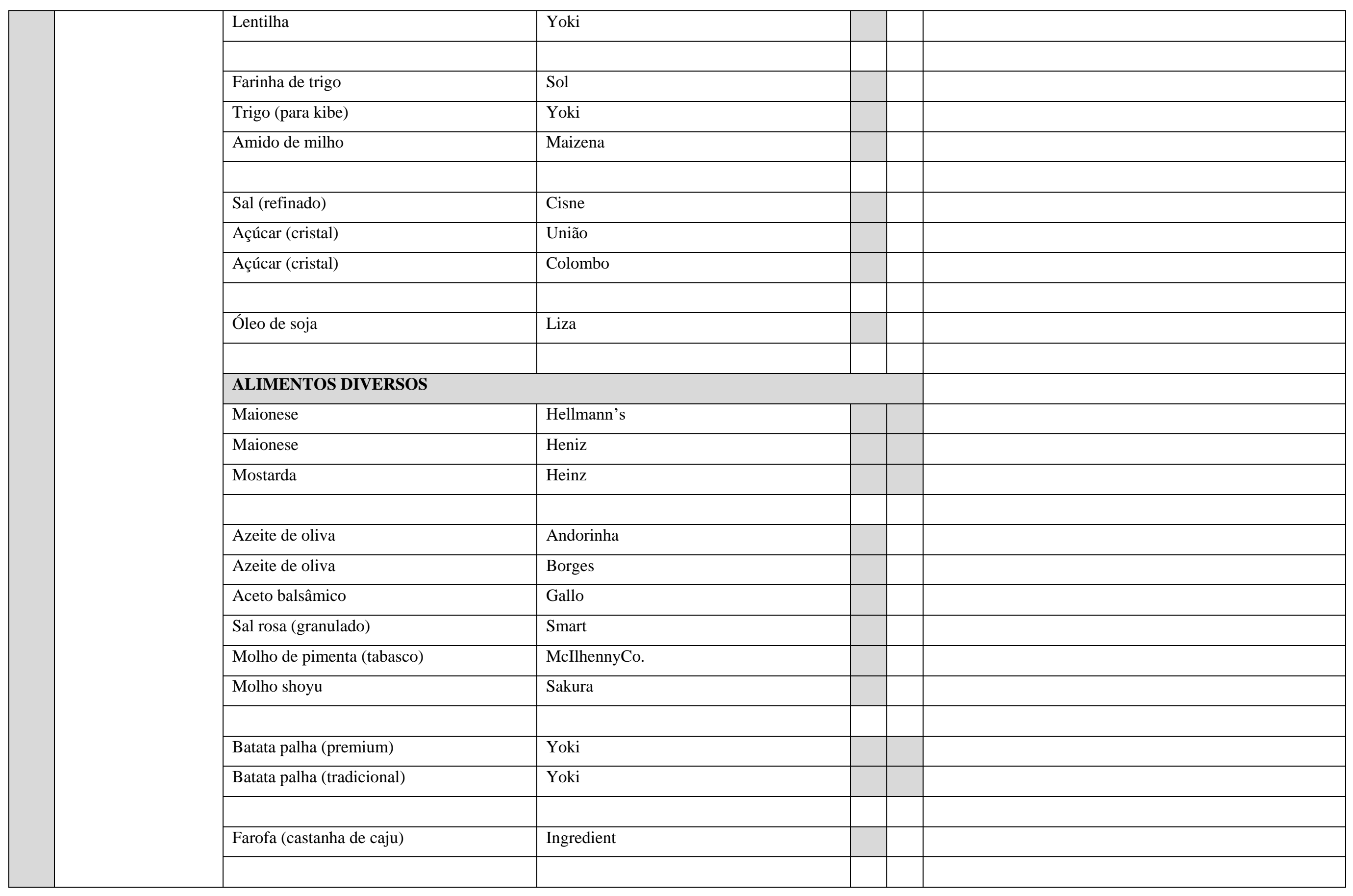




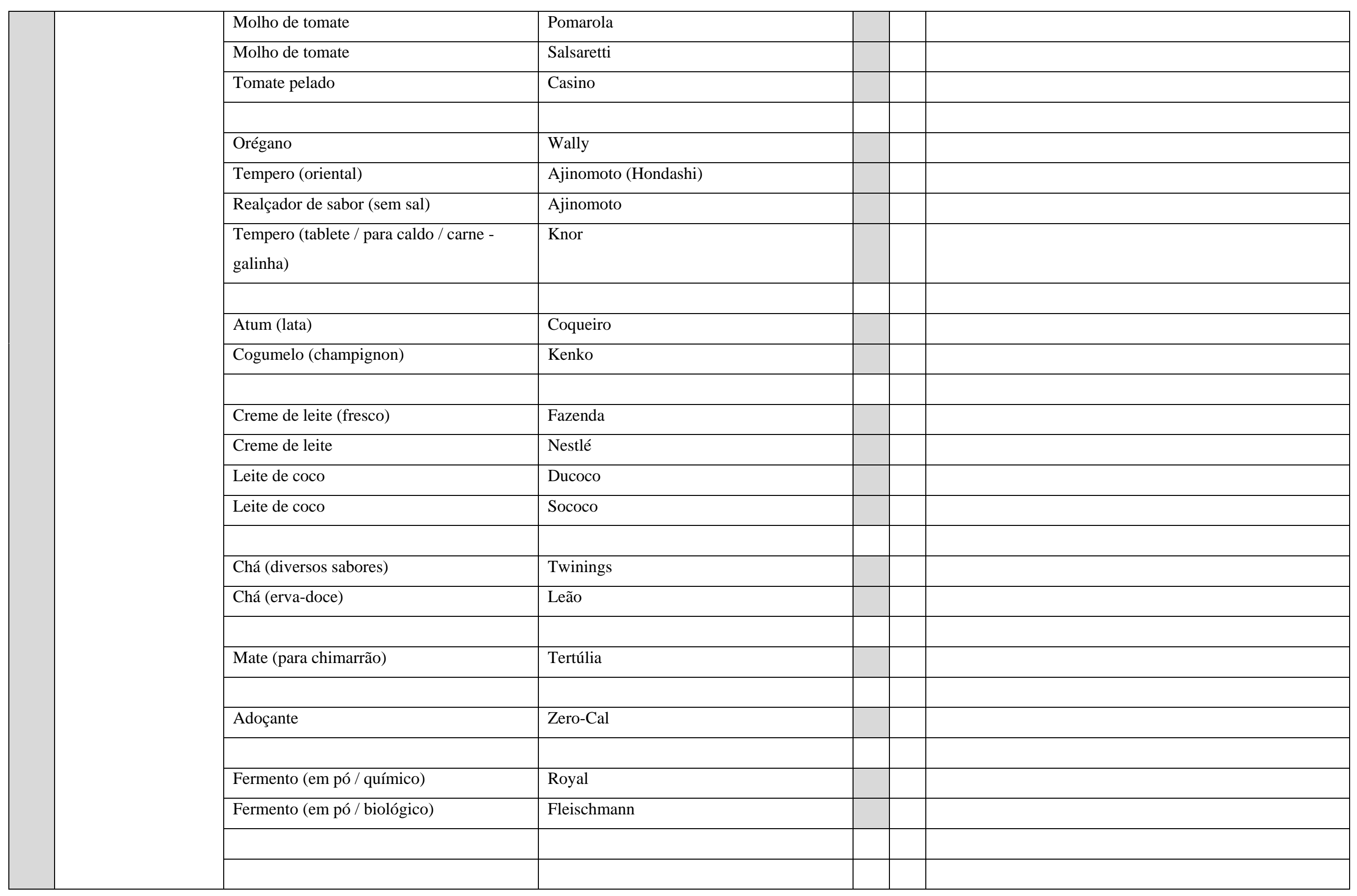




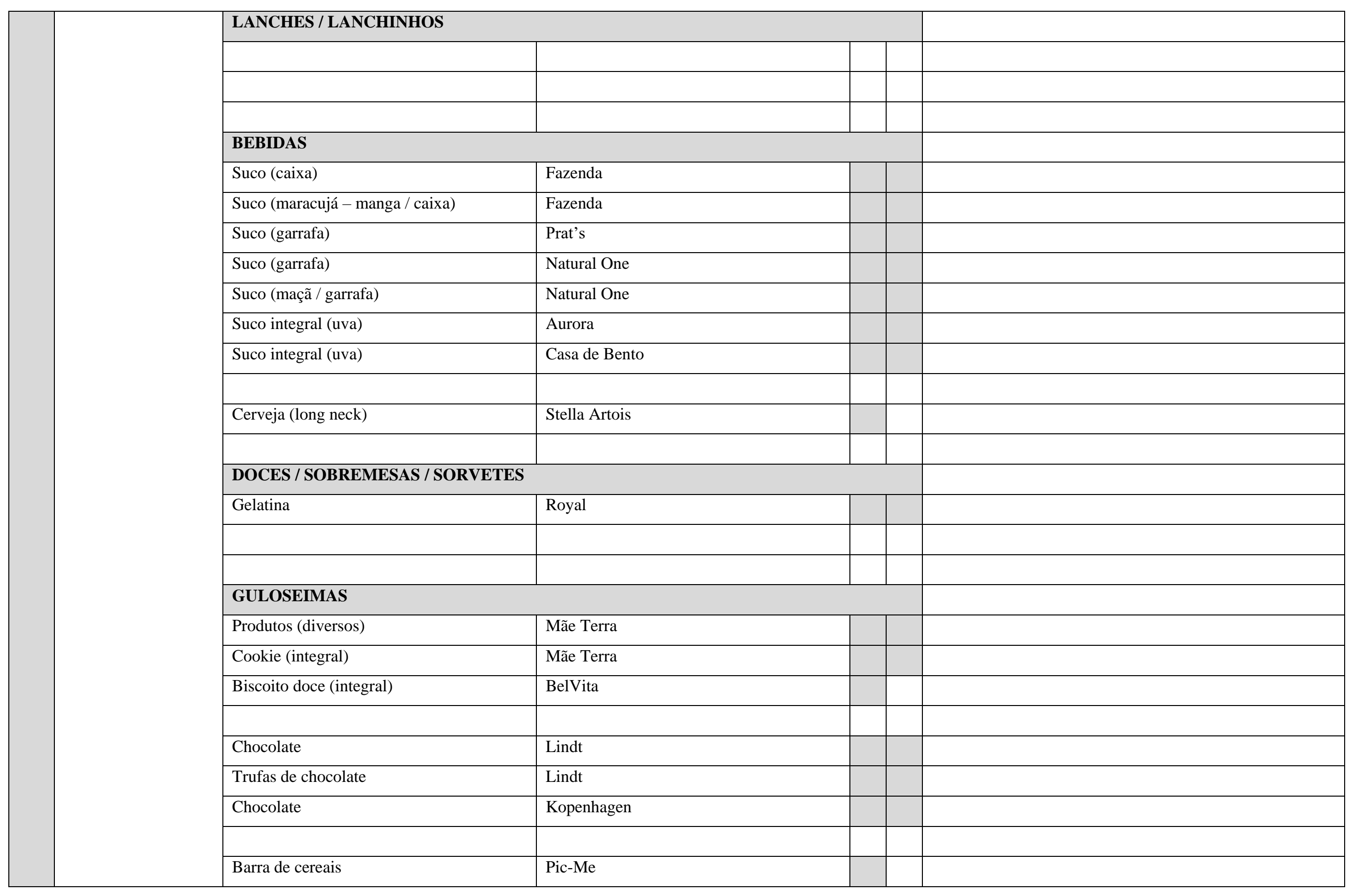




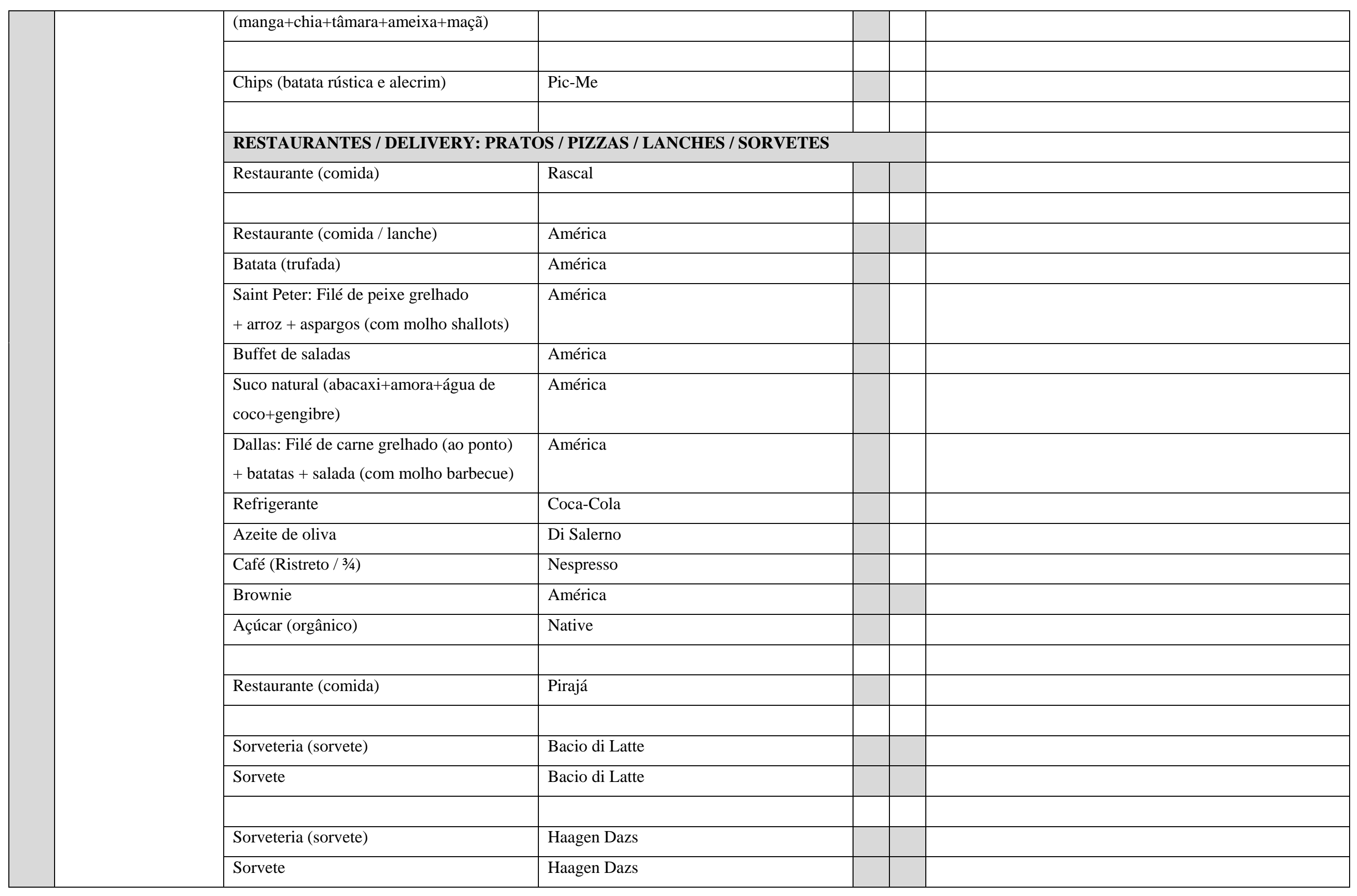




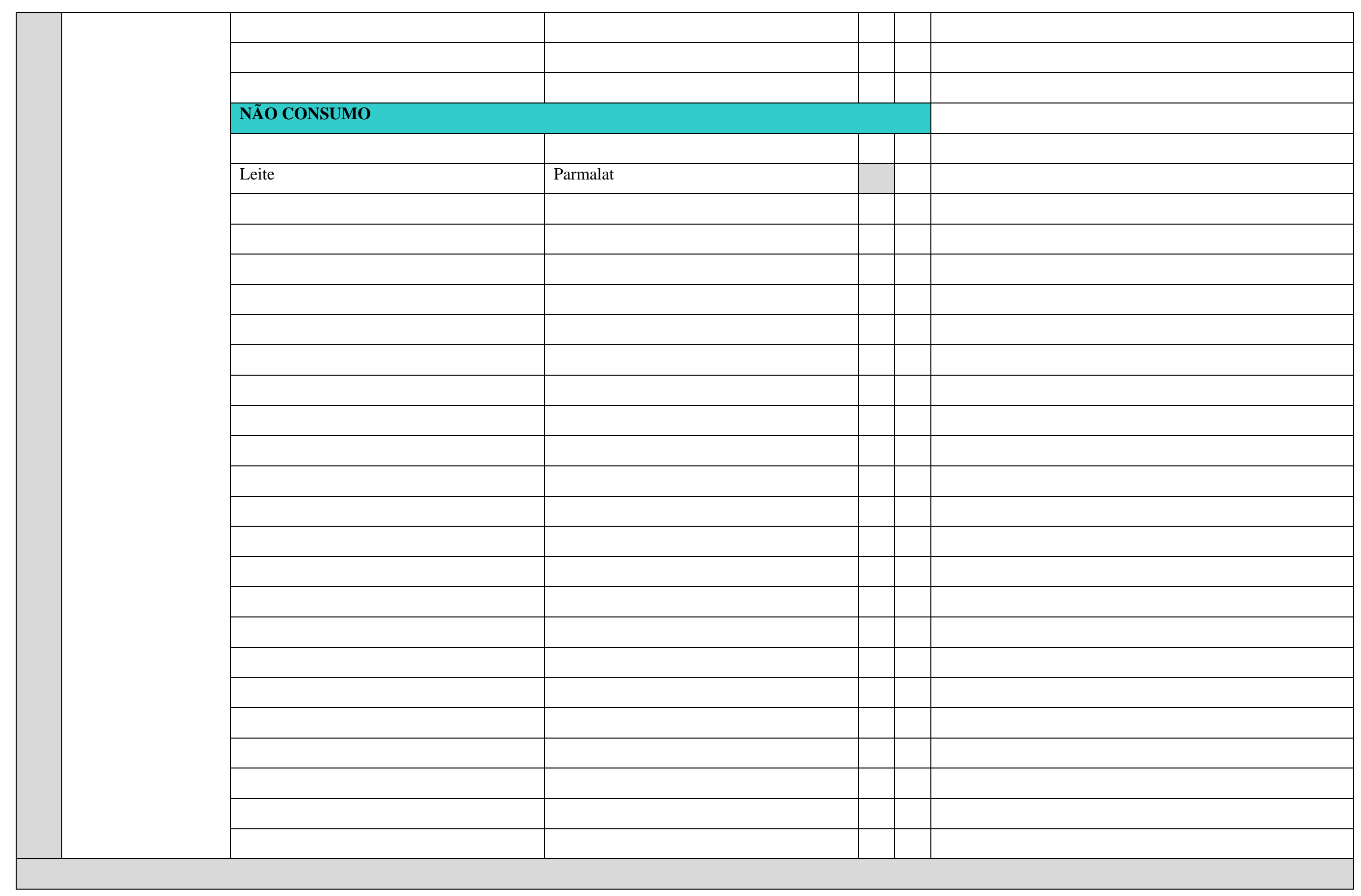




\section{R I A N Ç A S}

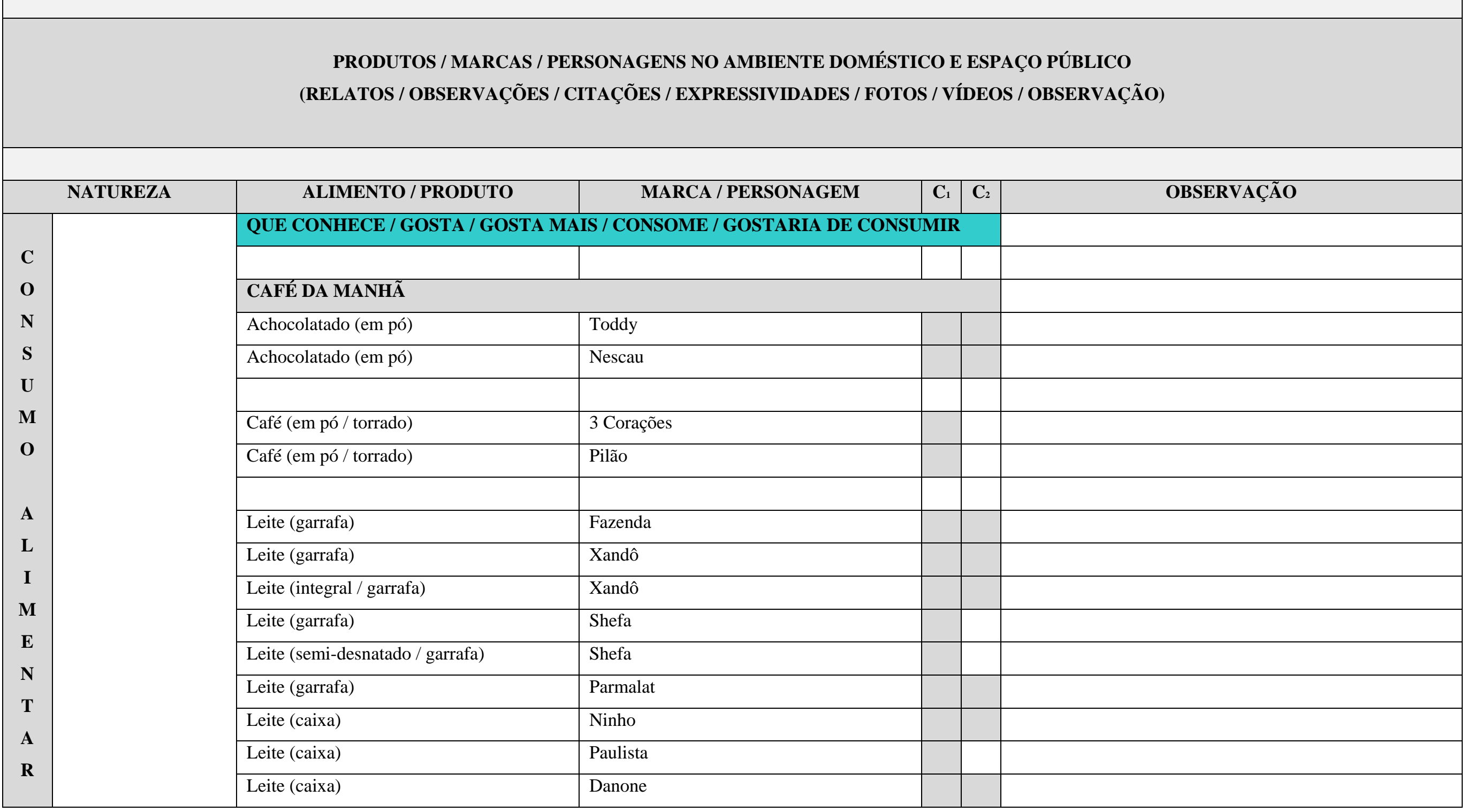




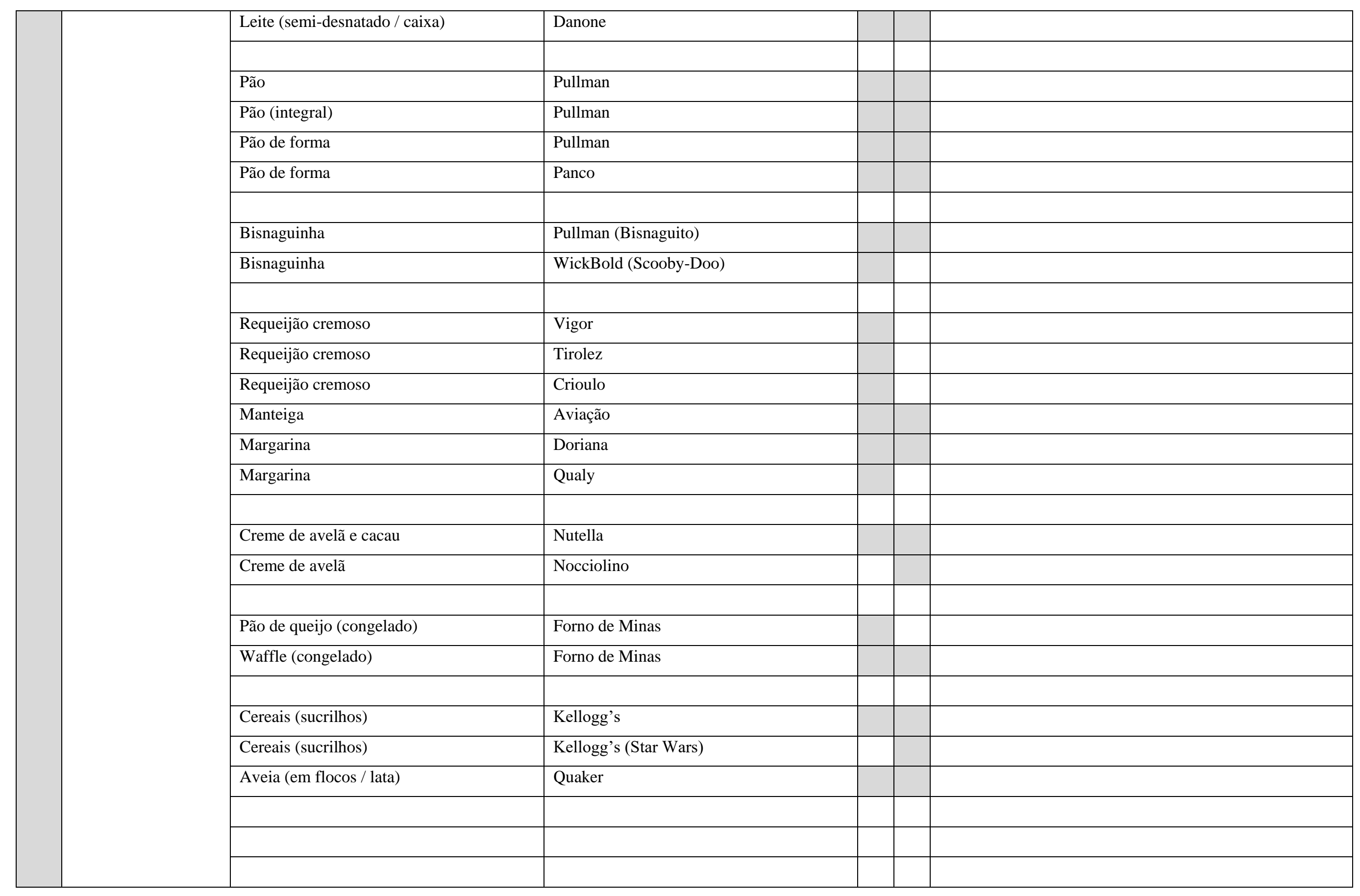




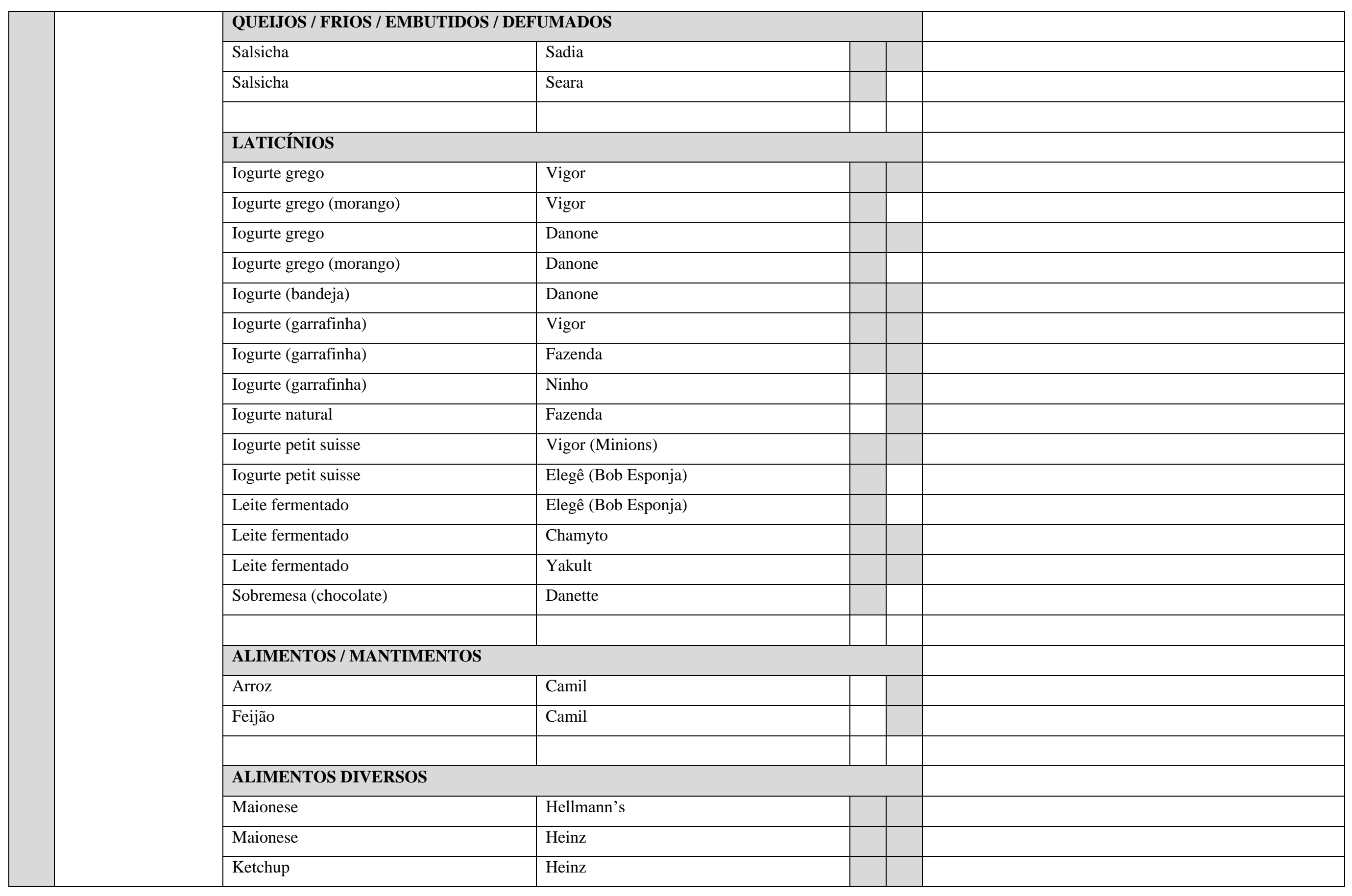




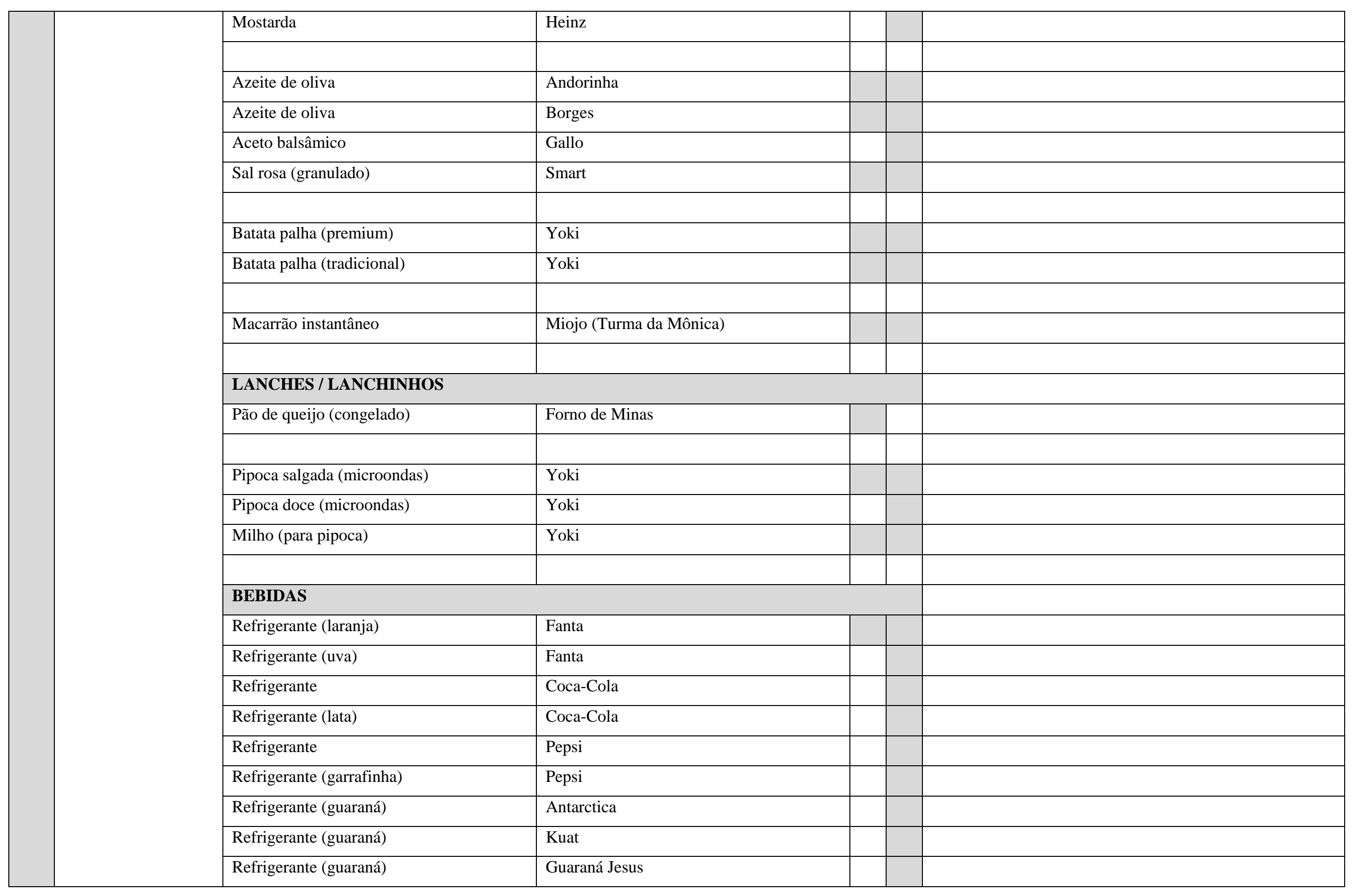




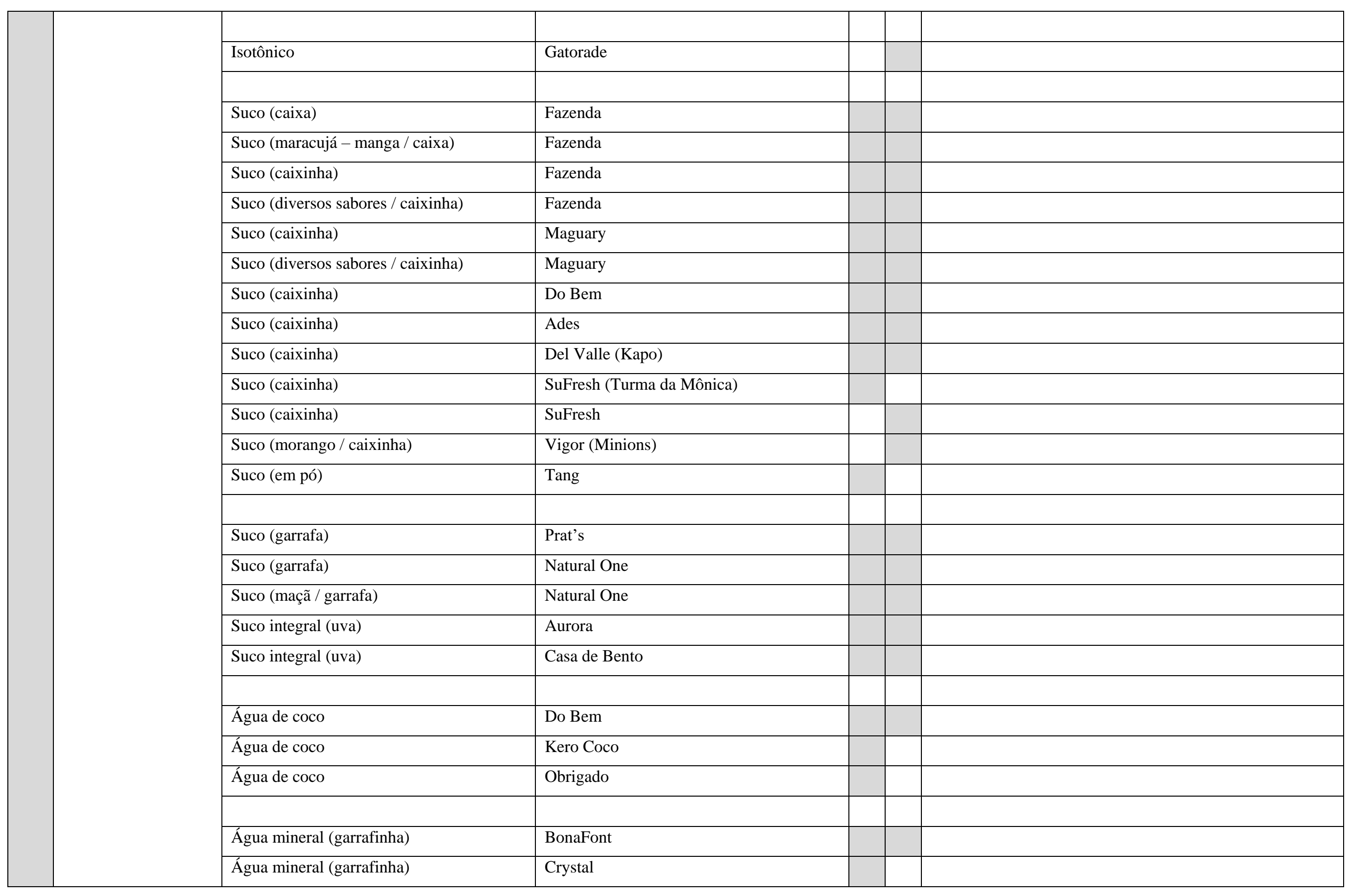




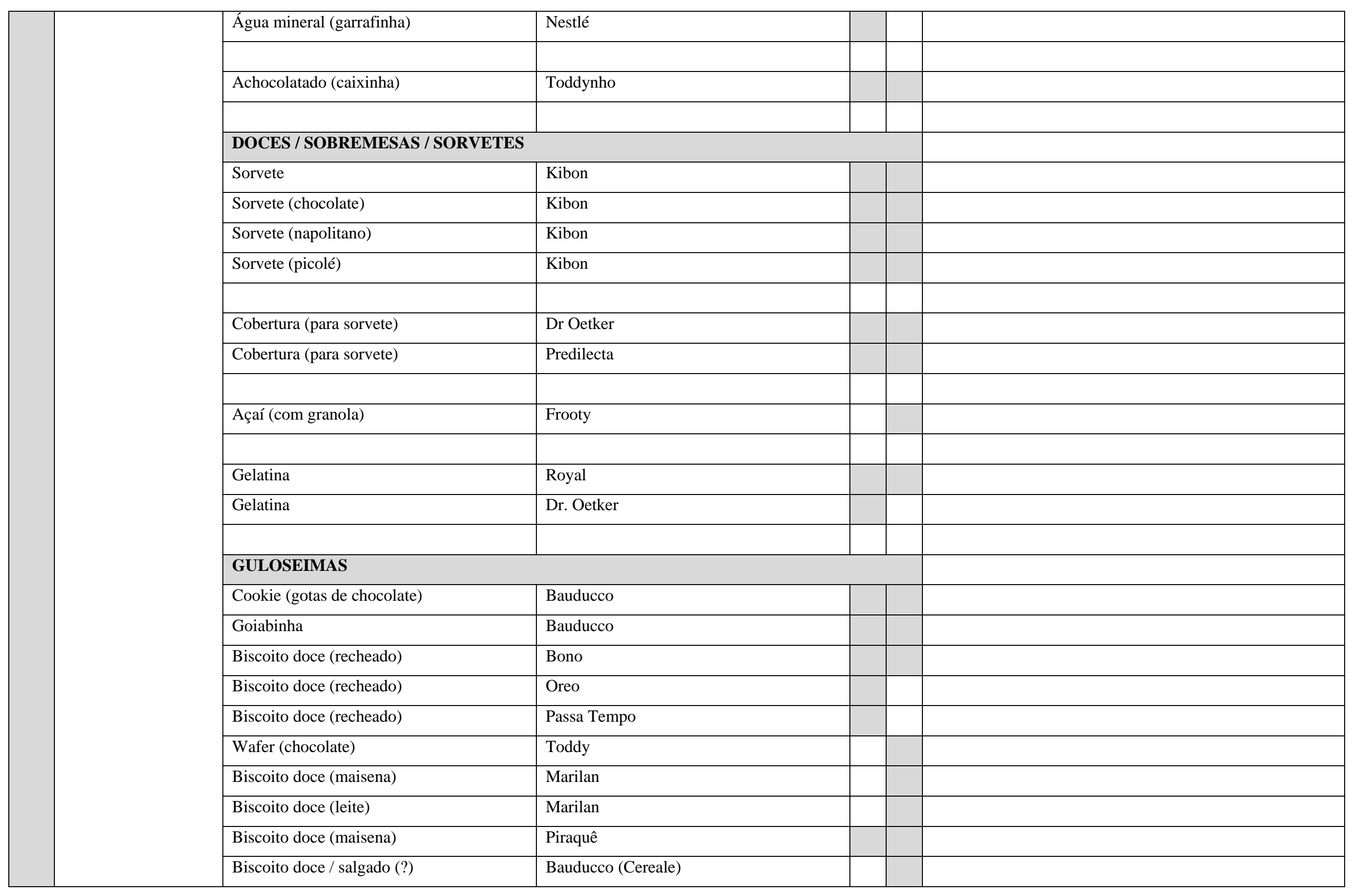




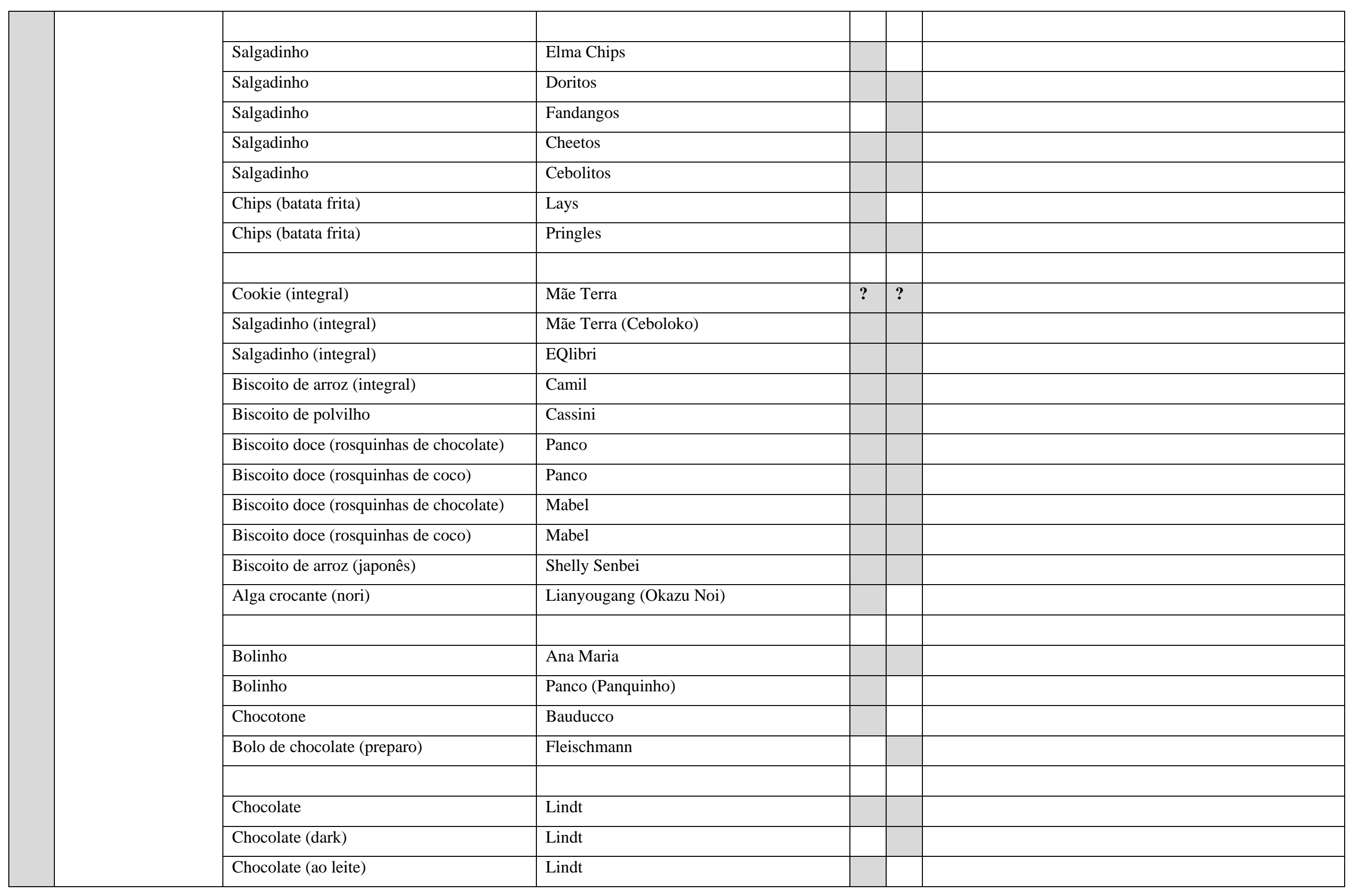




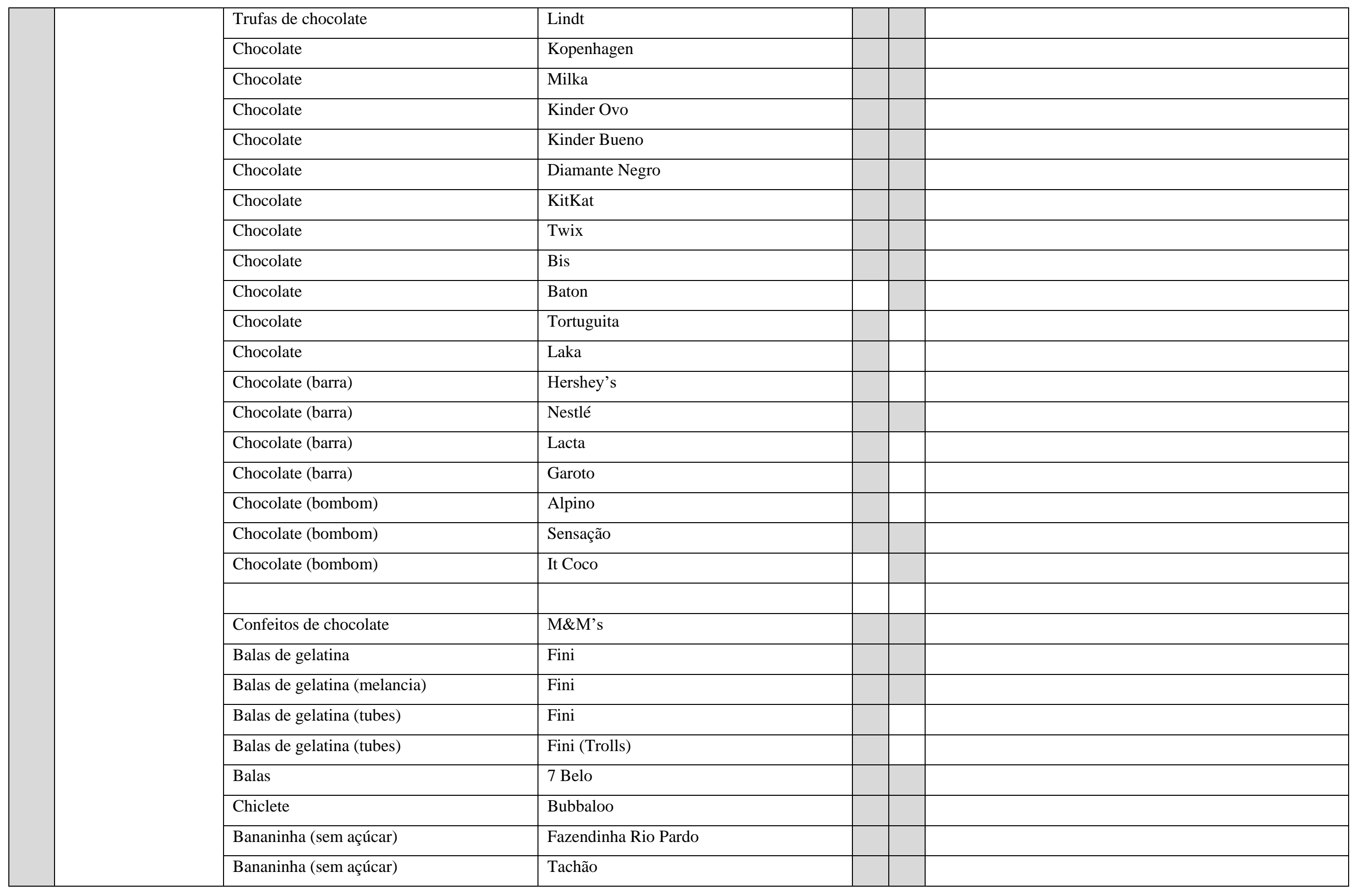




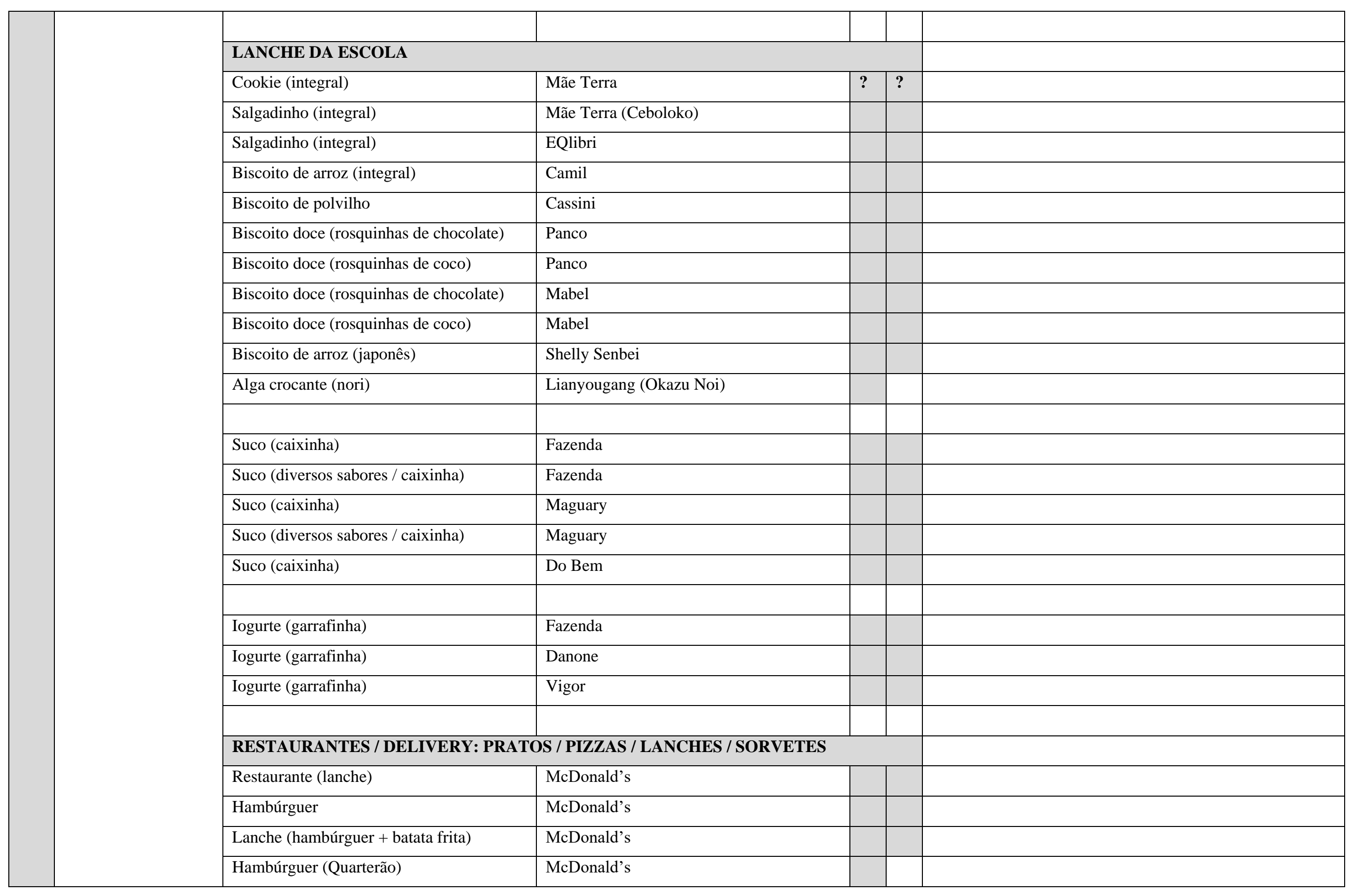




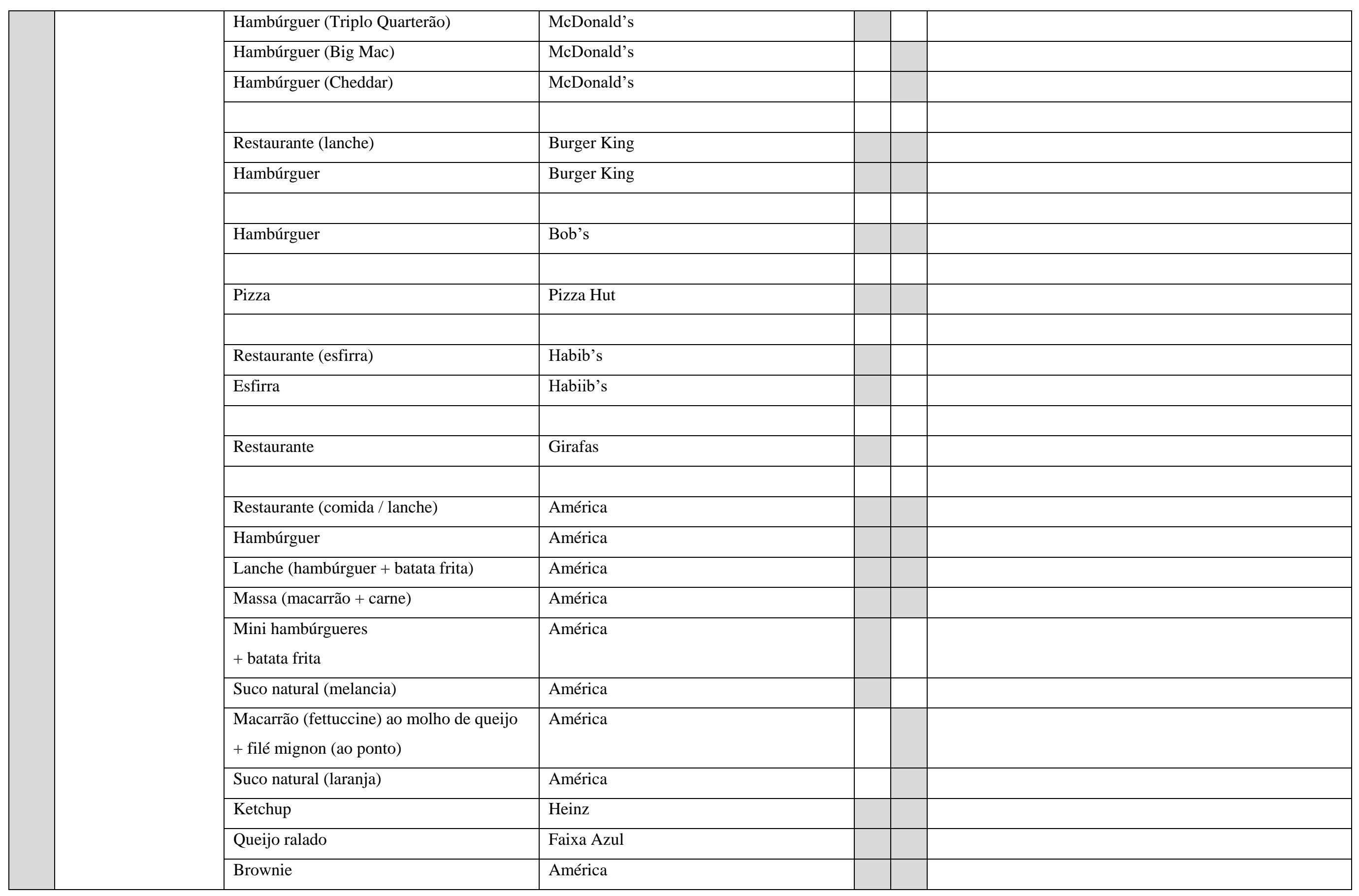




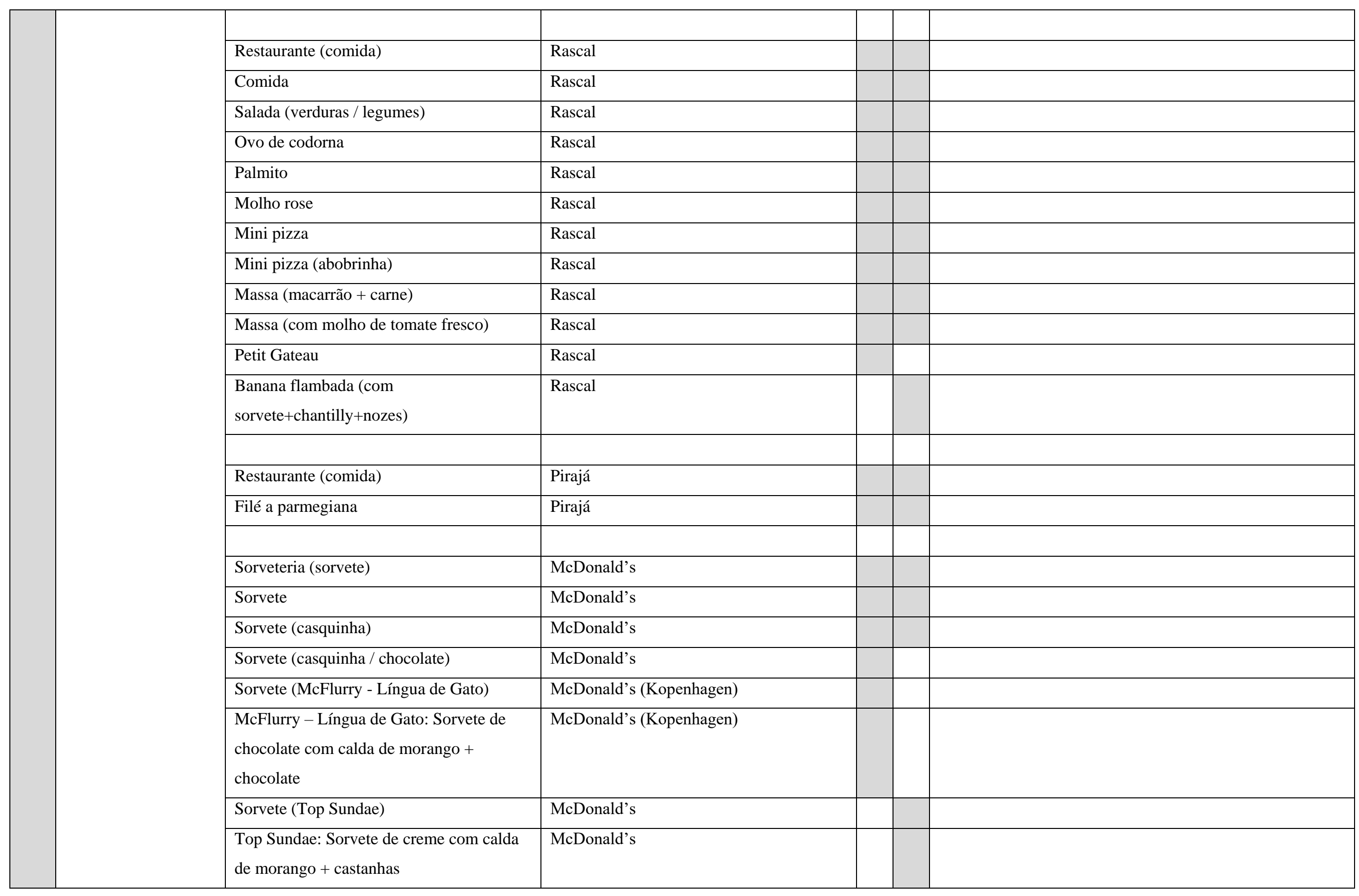




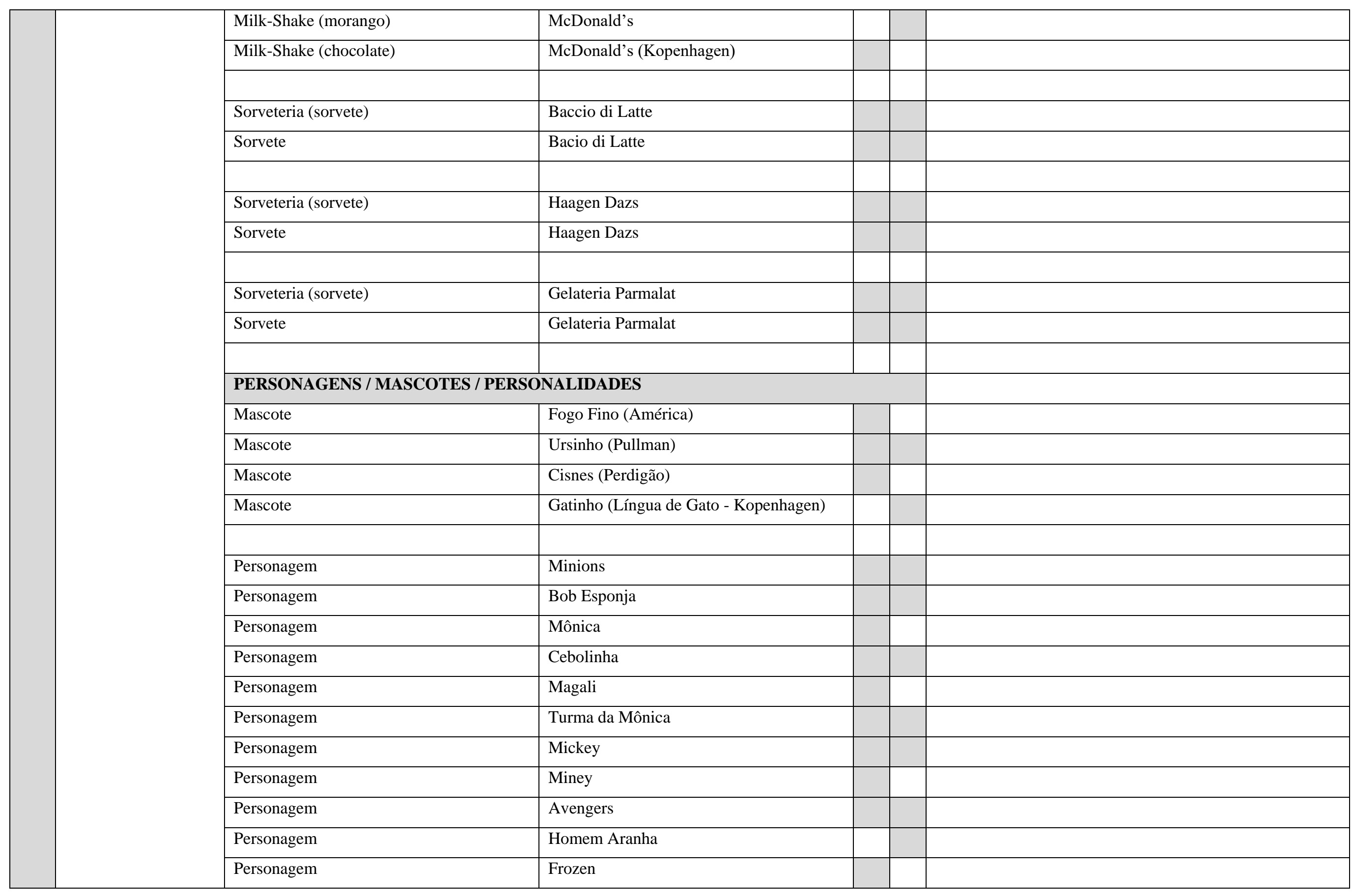




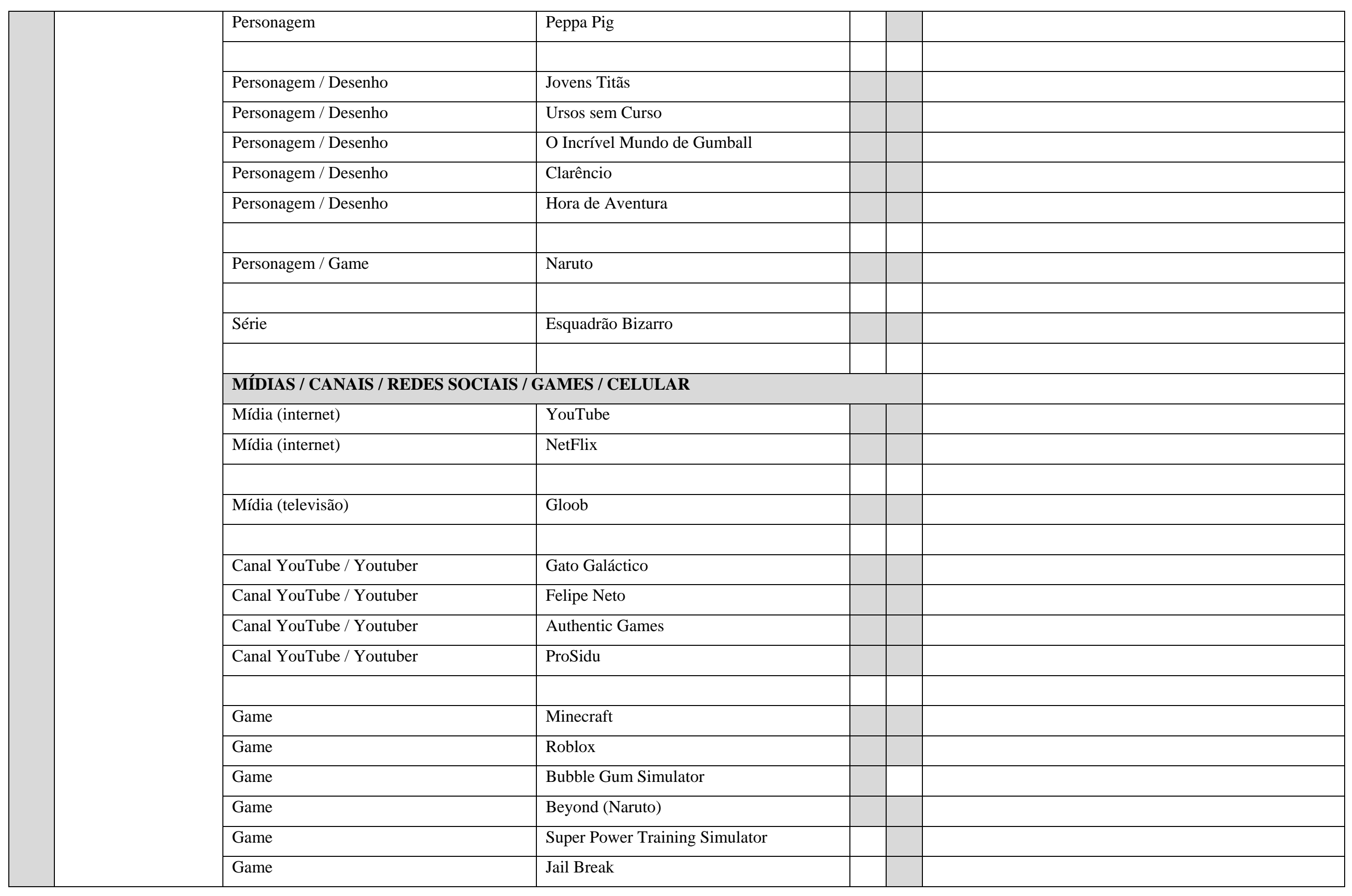




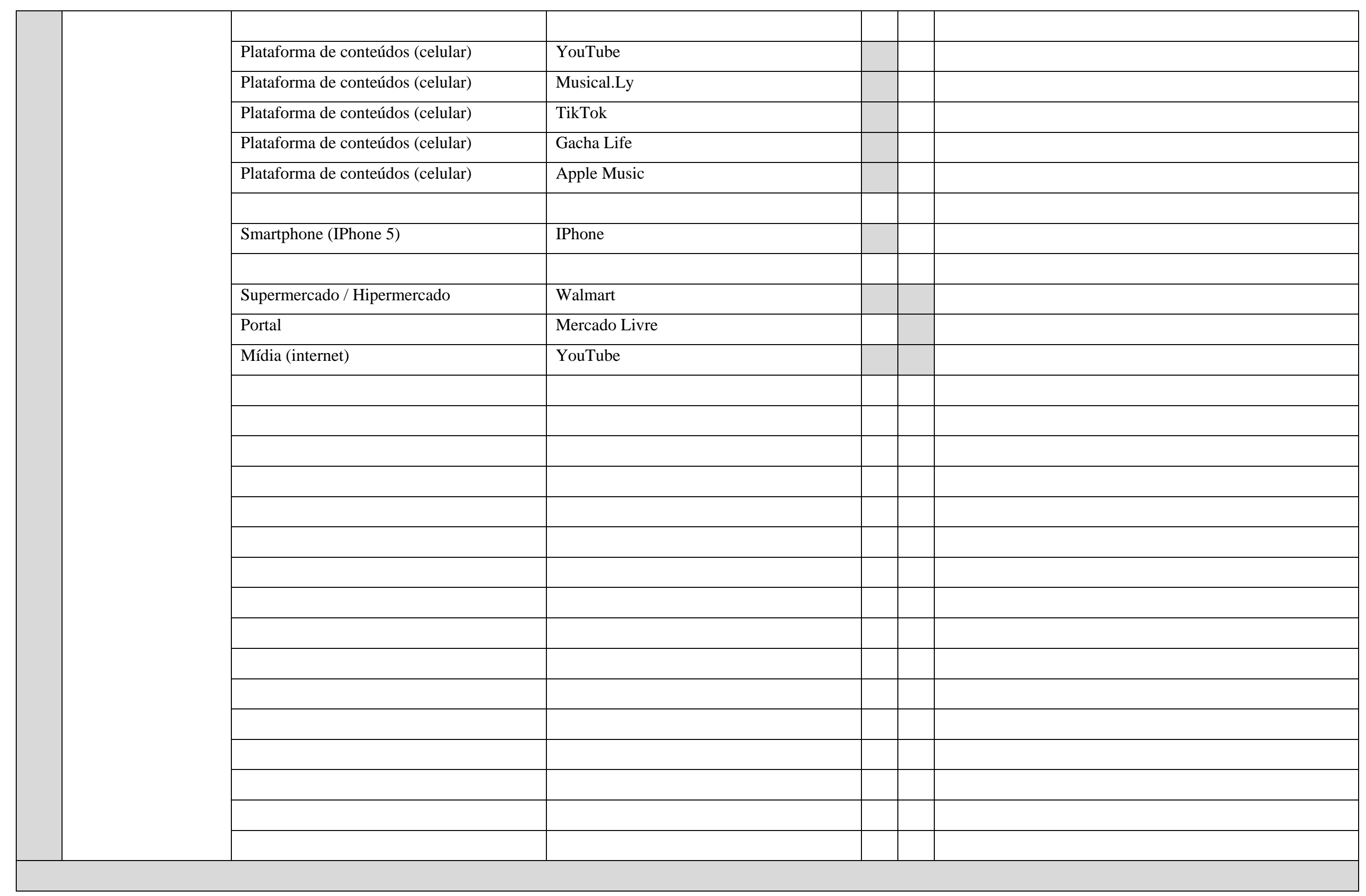




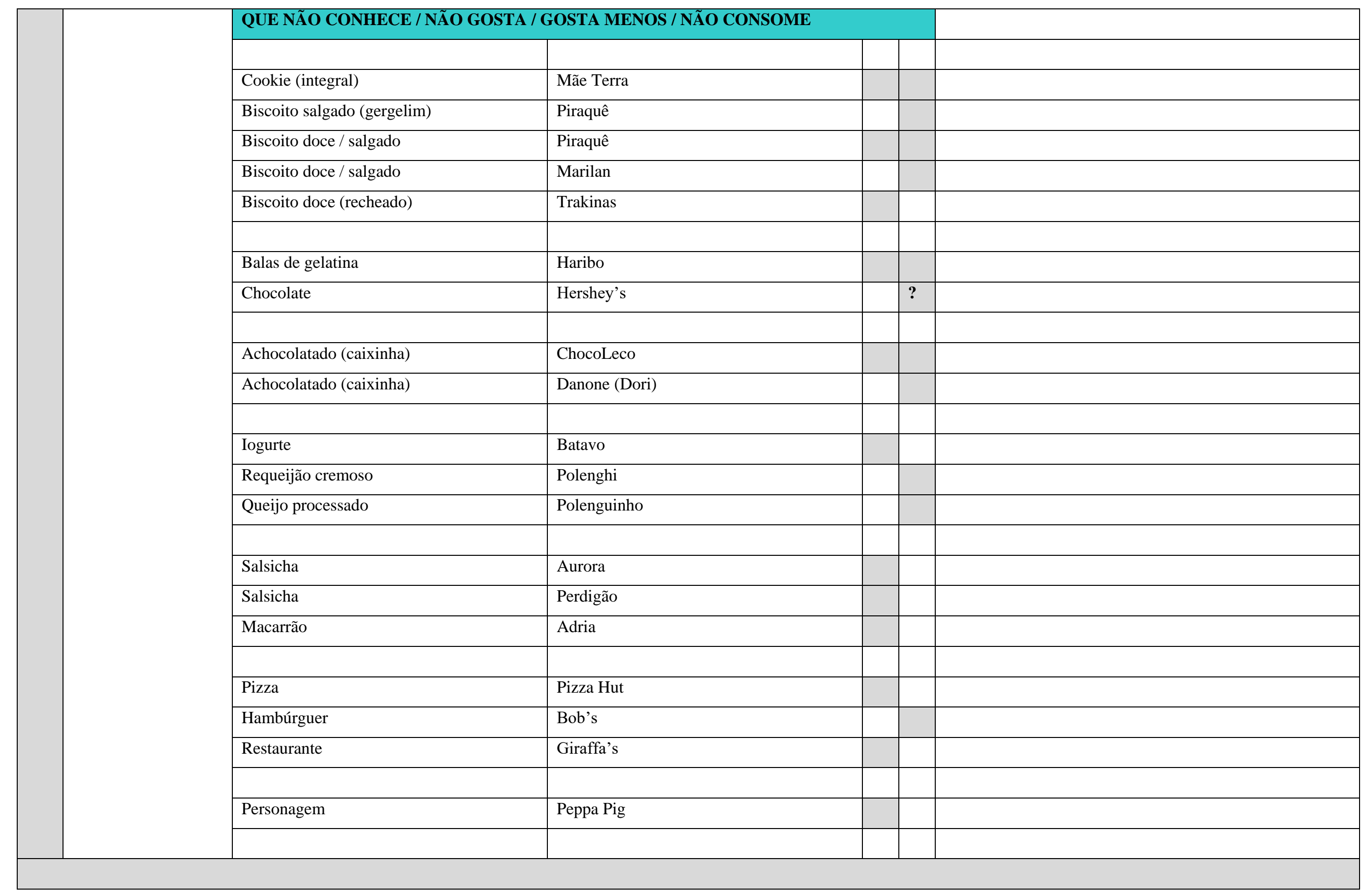


Observações:

$\mathrm{F}=$ Para a família (os pais e as crianças)

$\mathrm{C}=$ Para as crianças

$\mathrm{C} 1$ = Para a menina / Preferência da menina

$\mathrm{C} 2$ = Para o menino / Preferência do menino

Presença material $=$ Marcas e produtos alimentícios que a família $/$ as crianças consomem.

Presença simbólica = Marcas e produtos alimentícios que a família / as crianças gostariam de consumir .

(?) = Dúvidas quanto à especificação das marcas e produtos alimentícios em fotografias, vídeos ou relatos. 


\section{APÊNDICE R}

PESQUISA DE CAMPO

MARCAS DE ALIMENTOS NO CONTEXTO FAMILIAR

FAMÍLIA II

MARCAS DE ALIMENTOS: PRESENÇA MATERIAL E SIMBÓLICA 


\section{F A M Í L I A}

MARCAS E PRODUTOS ALIMENTÍCIOS NO AMBIENTE DOMÉSTICO E ESPAÇO PÚBLICO (RELATOS / OBSERVAÇÕES / CITAÇÕES / EXPRESSIVIDADES / FOTOS / VÍDEOS / OBSERVAÇÃO)

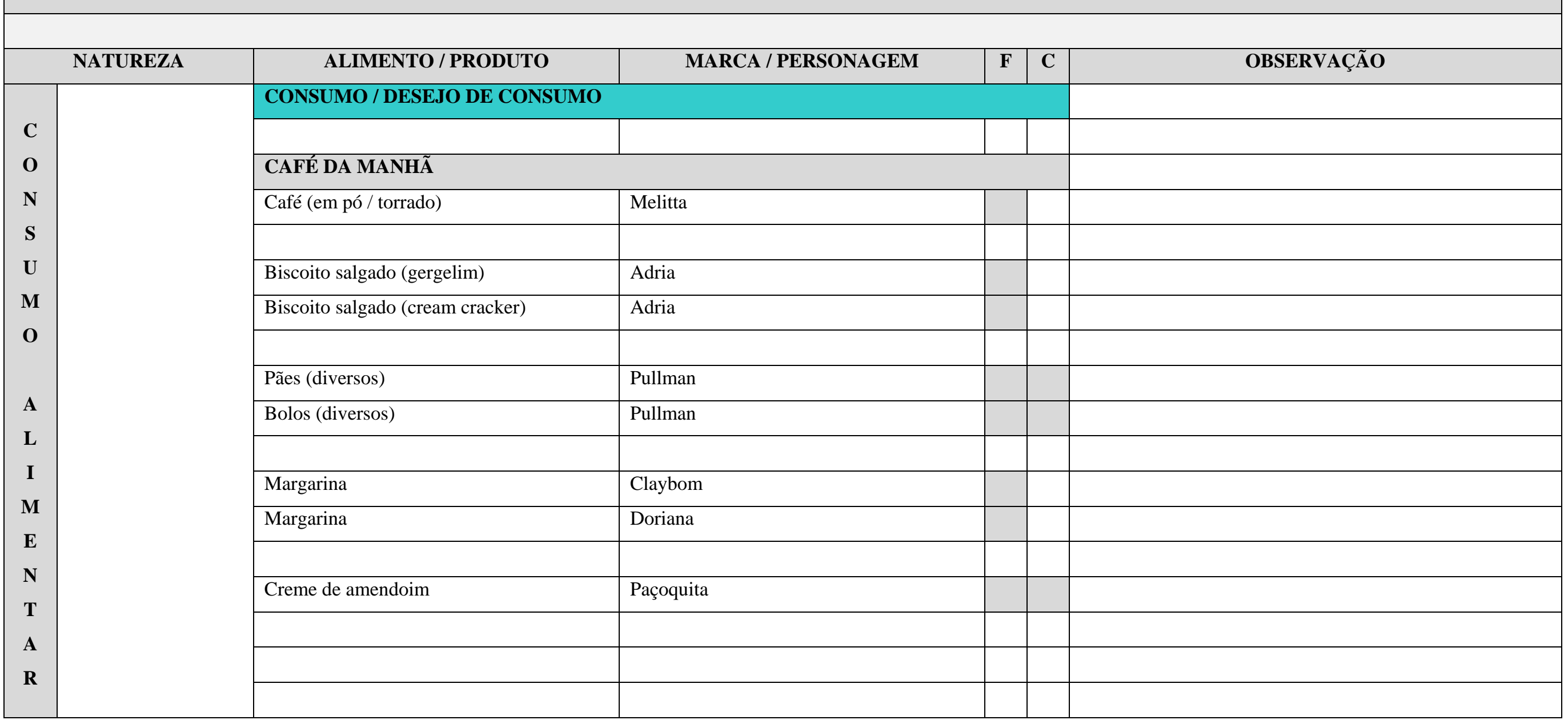




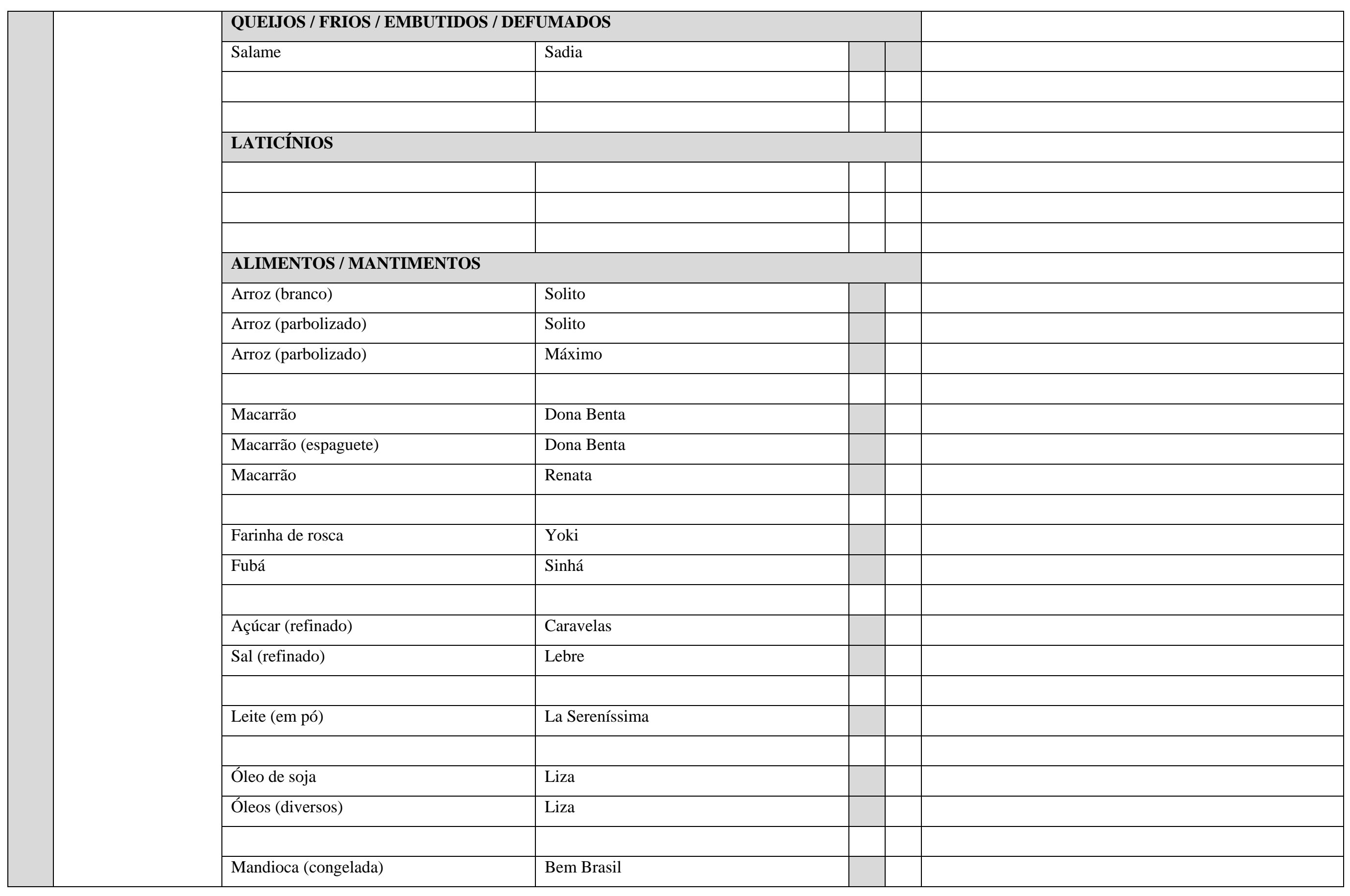




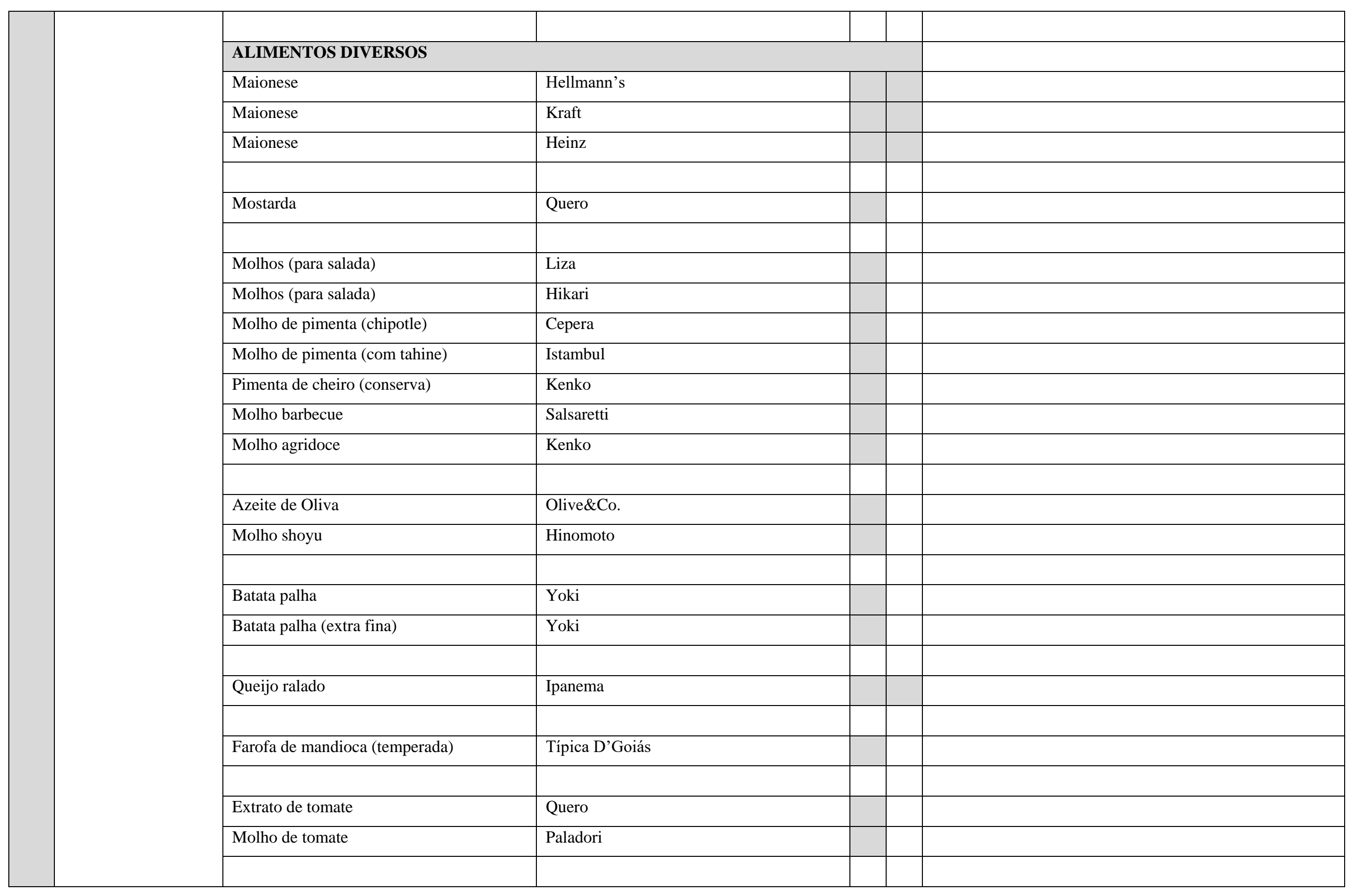




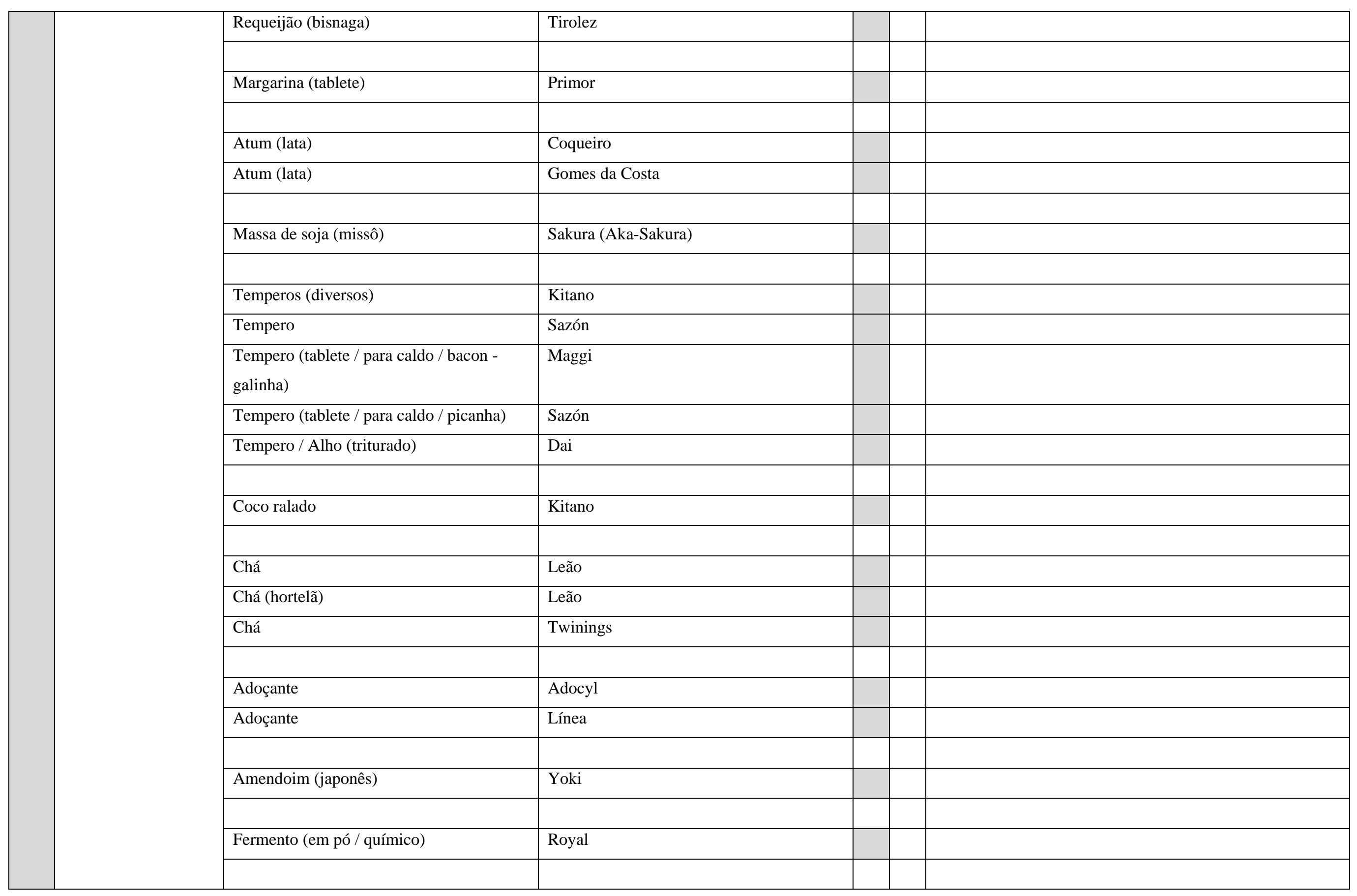




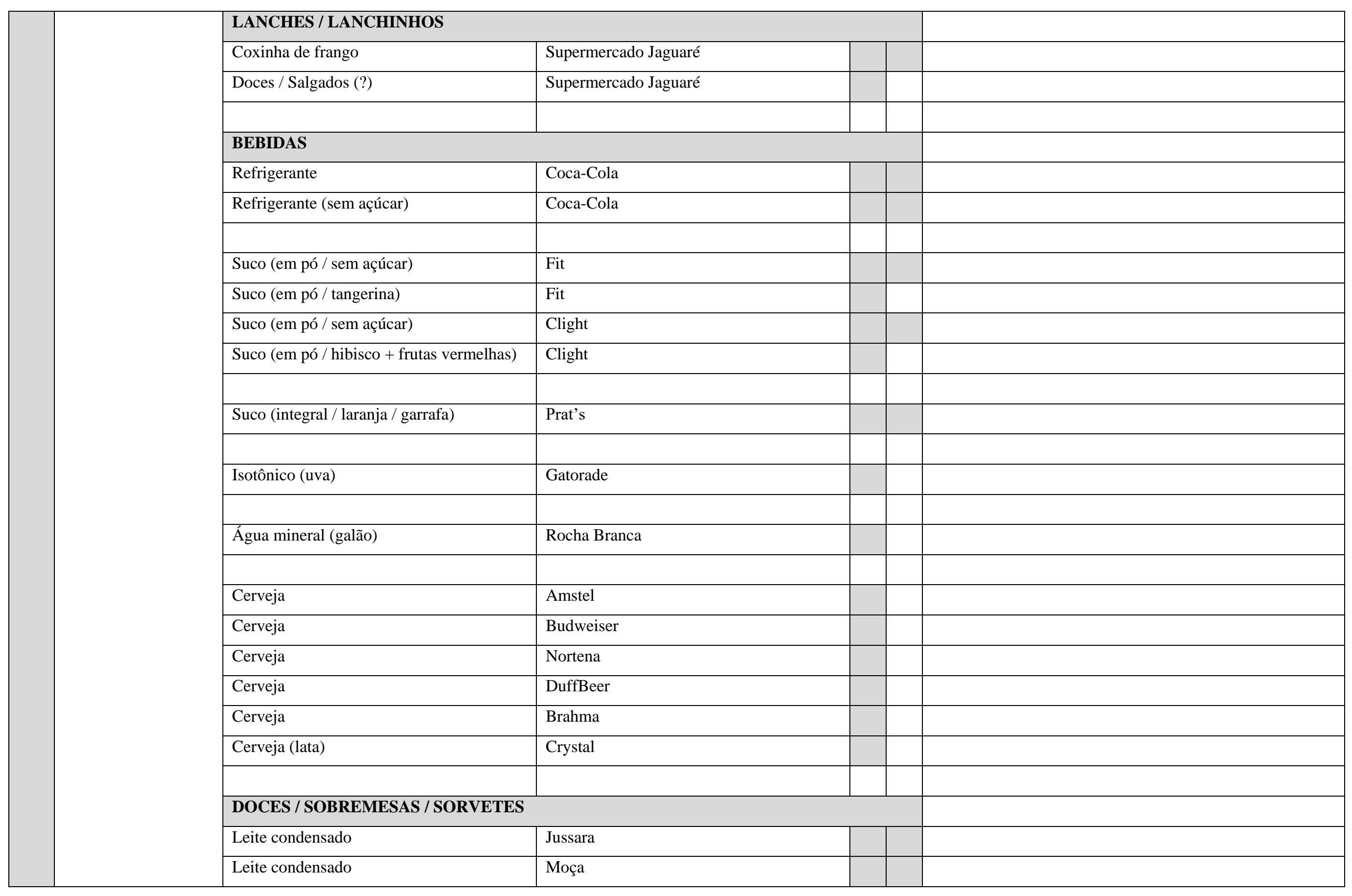




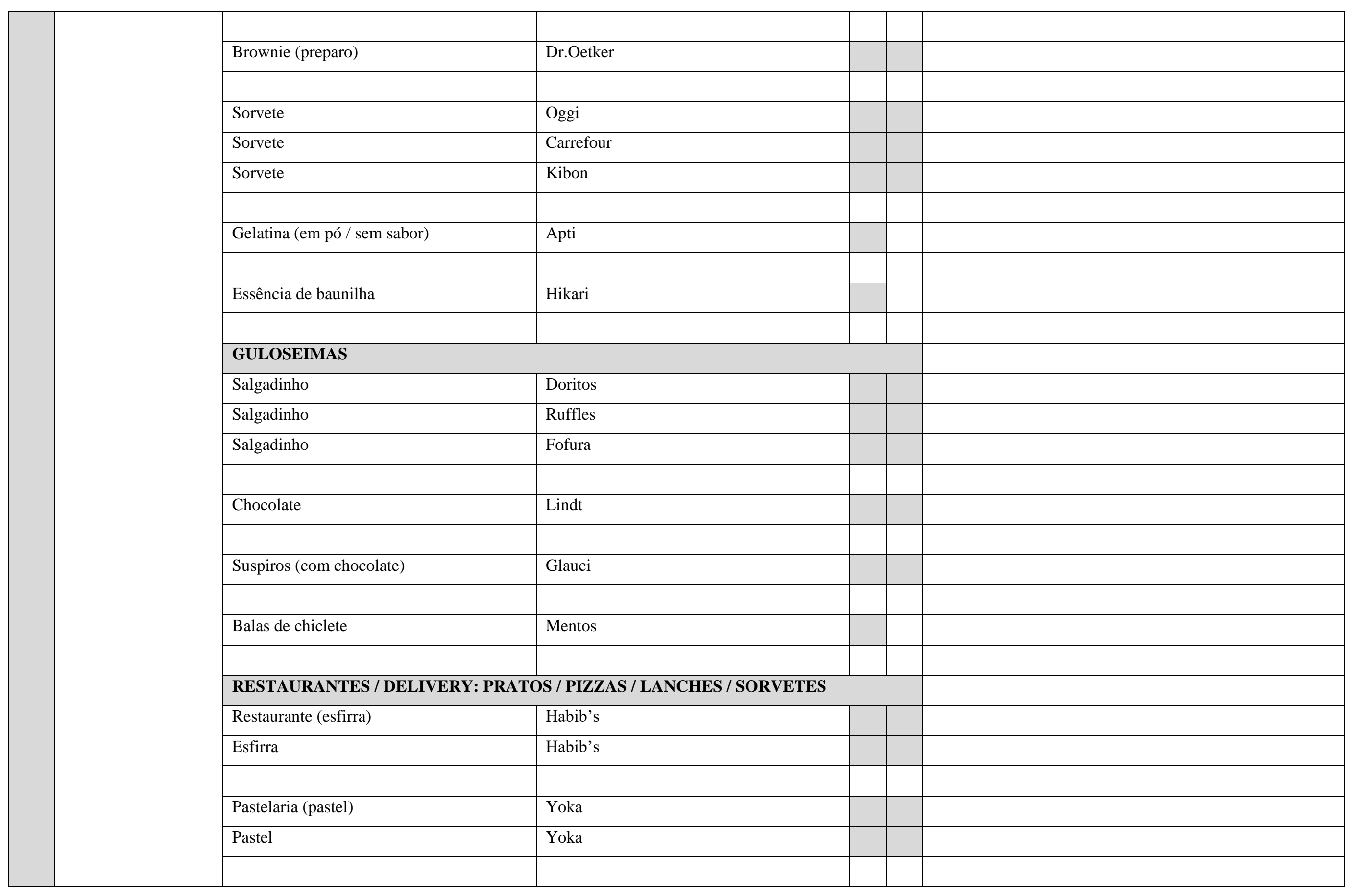




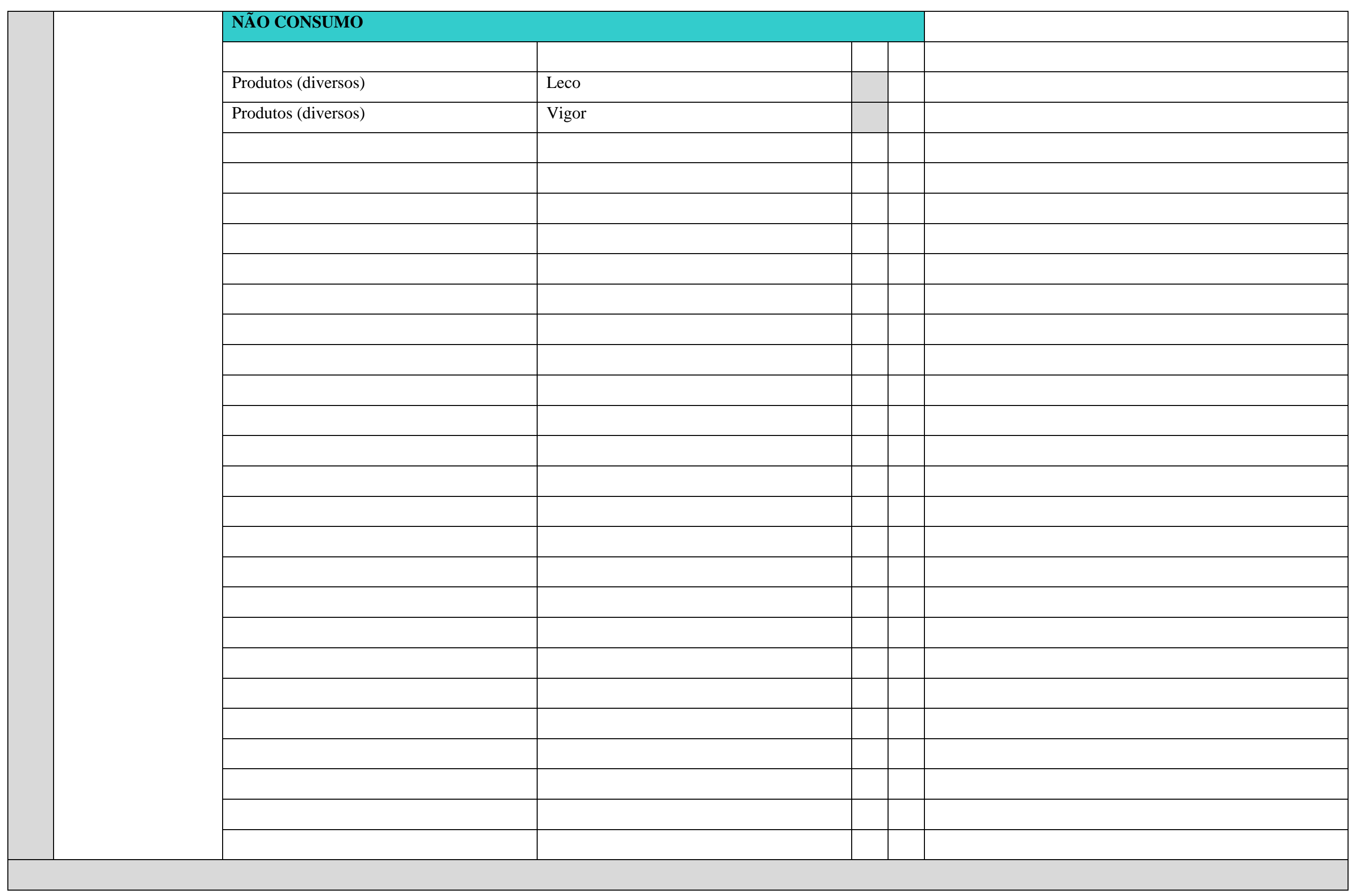




\section{R I A N Ç A S}

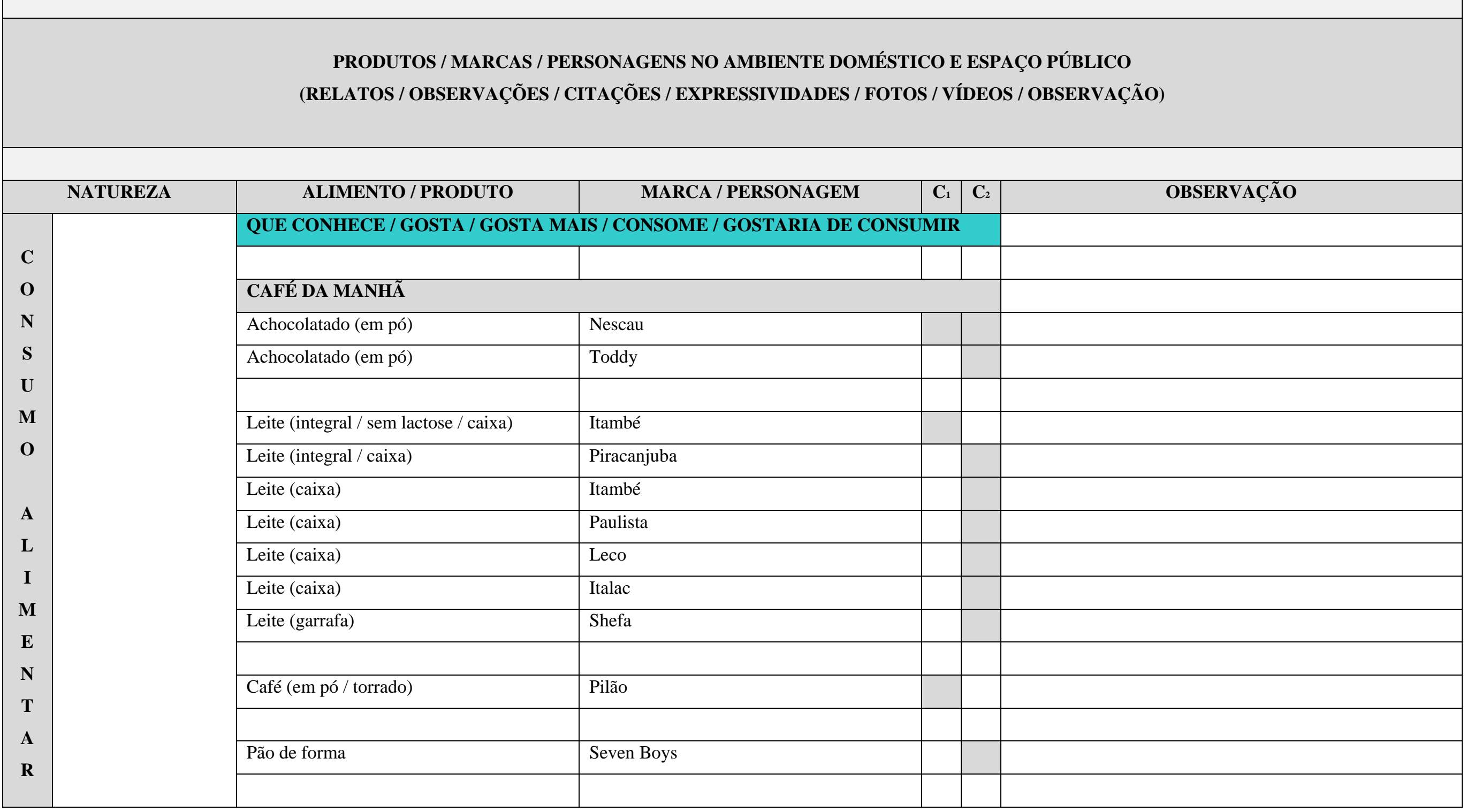




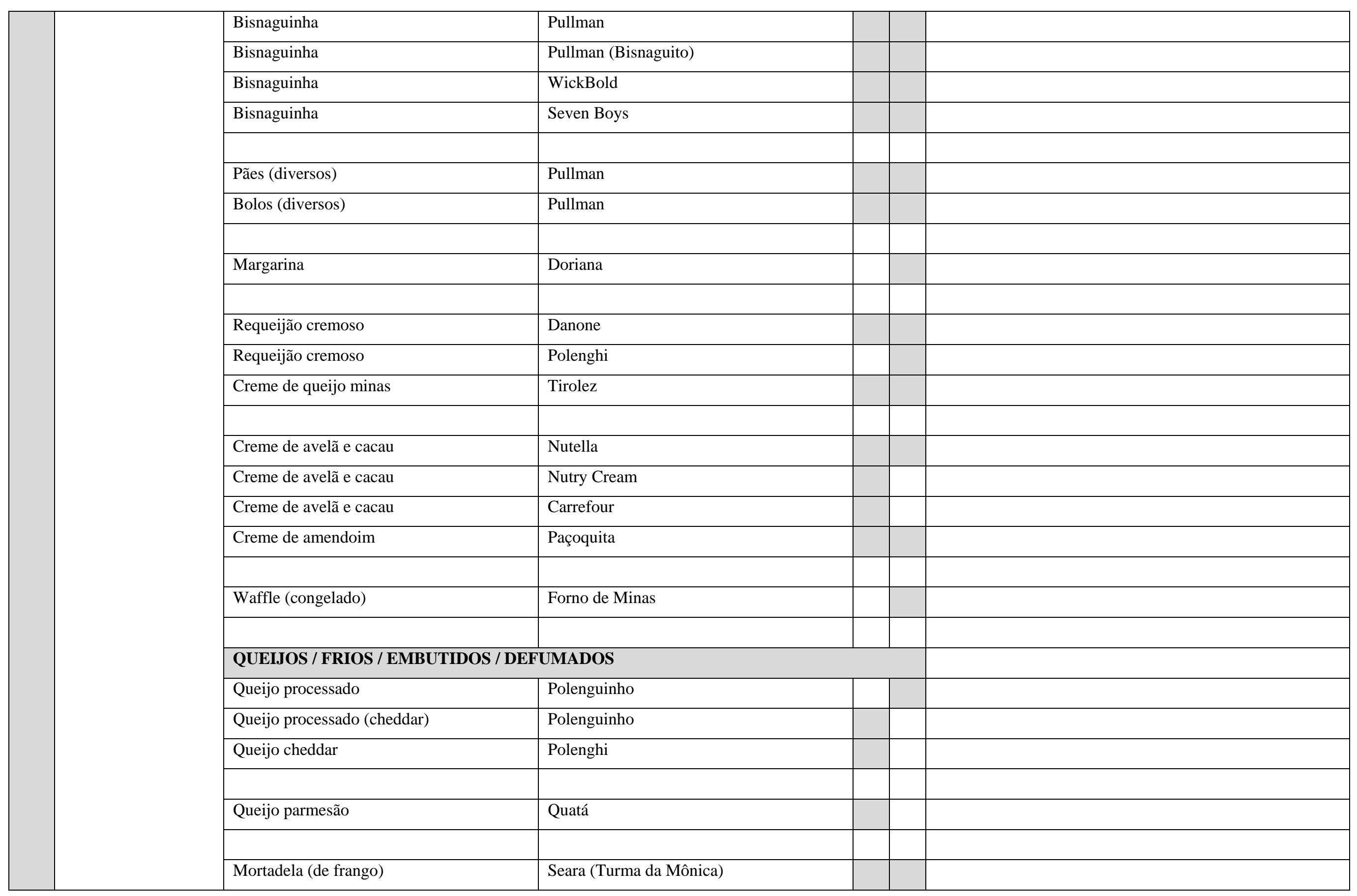




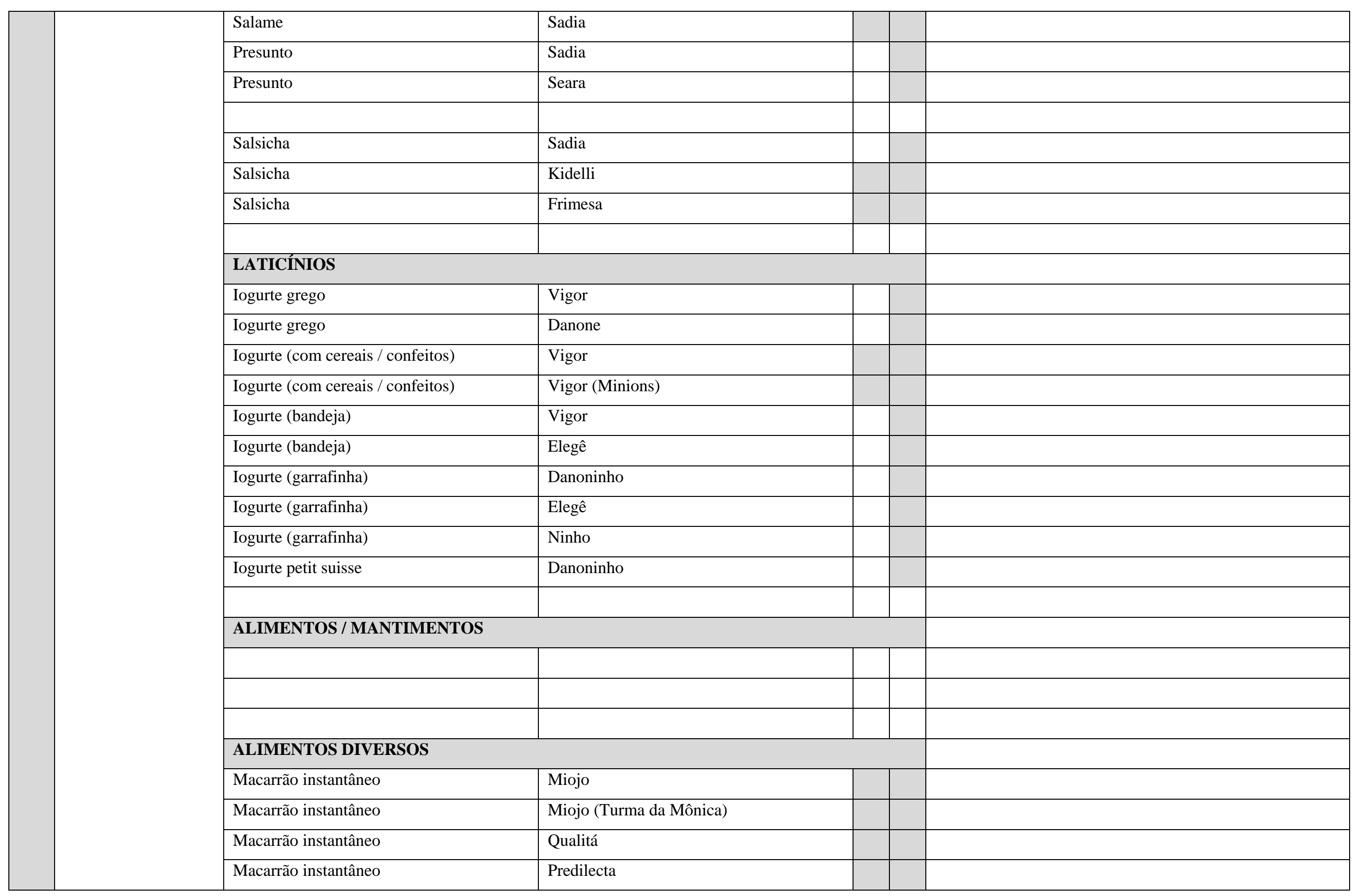




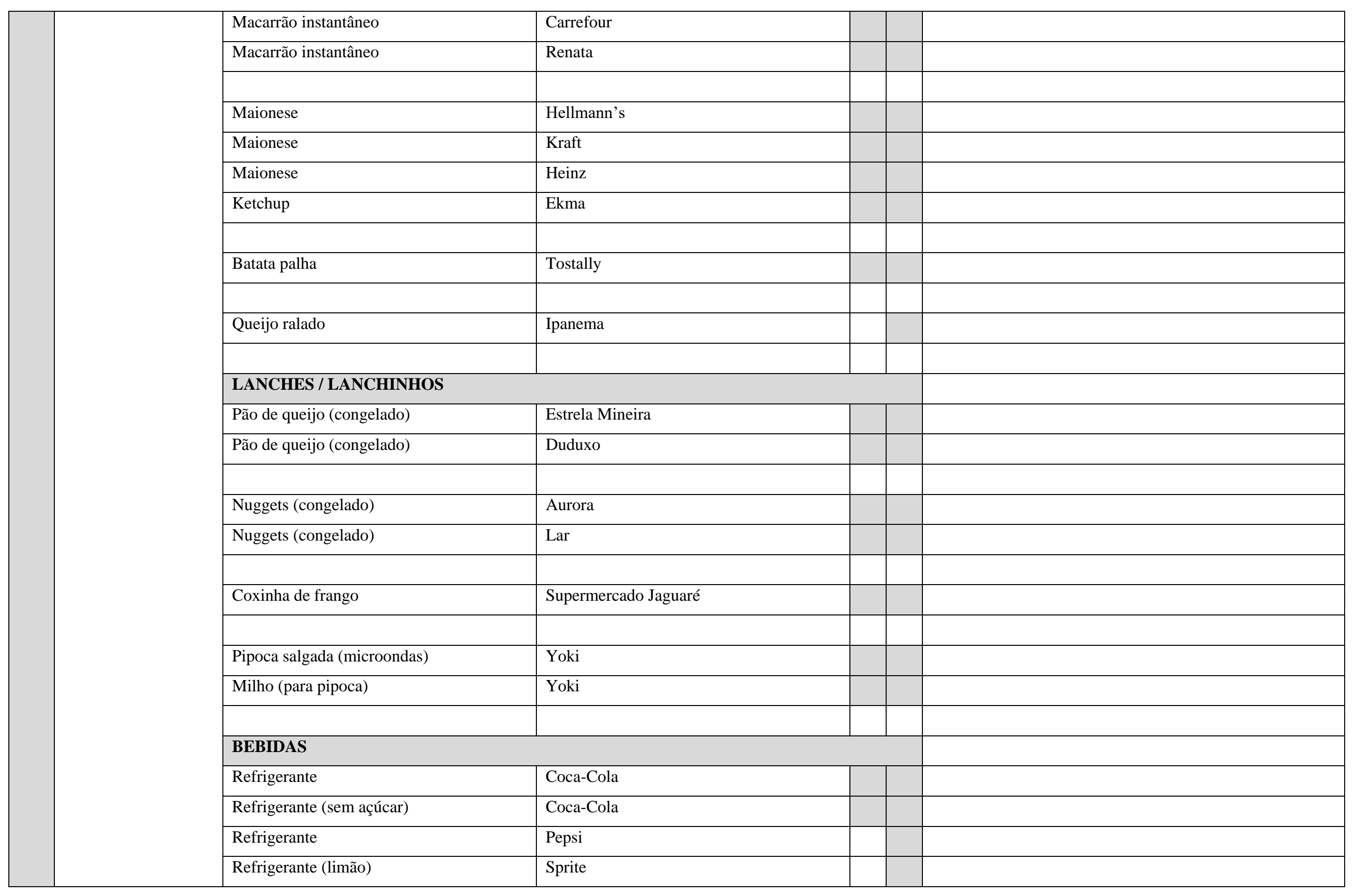




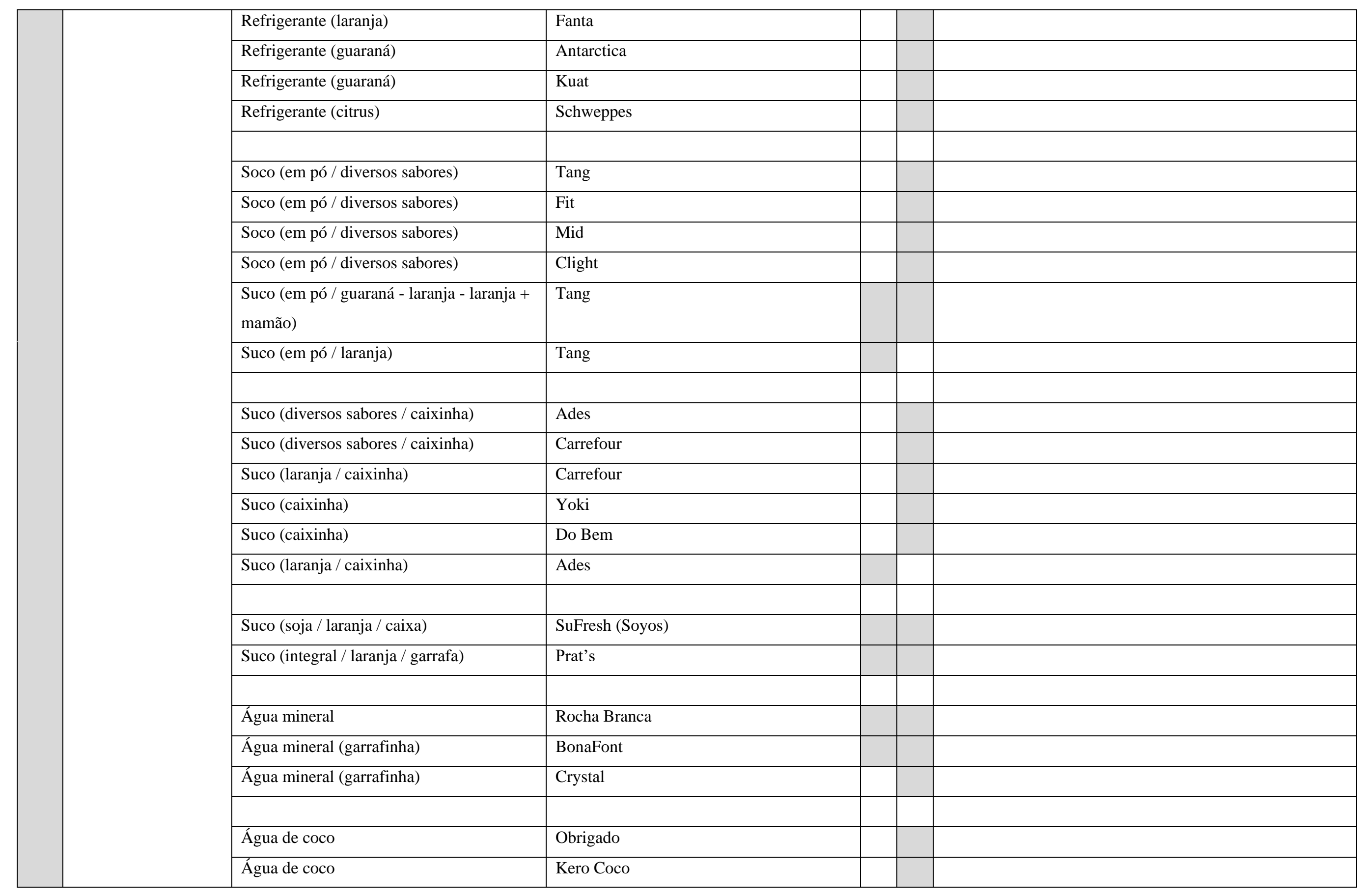




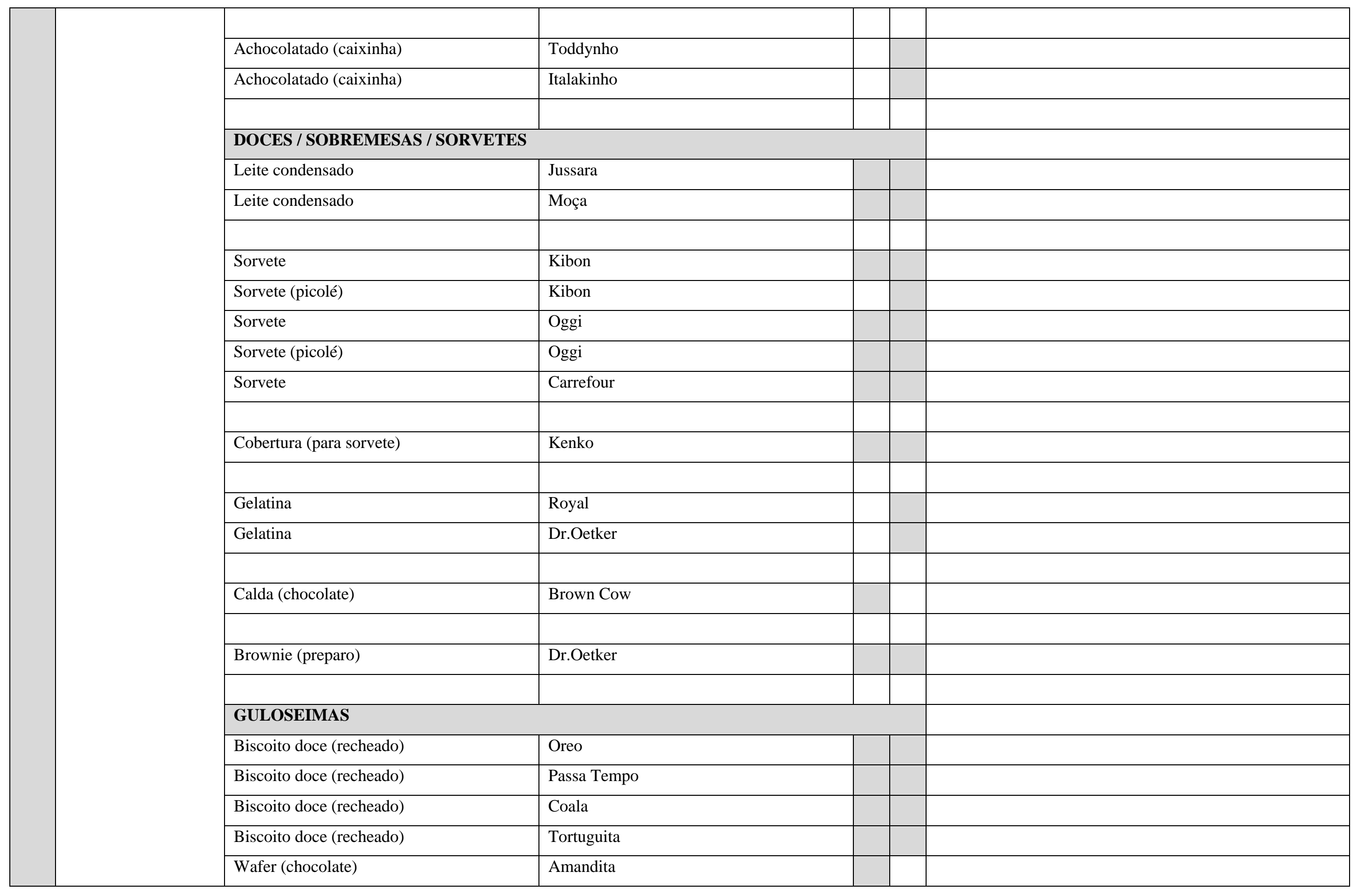




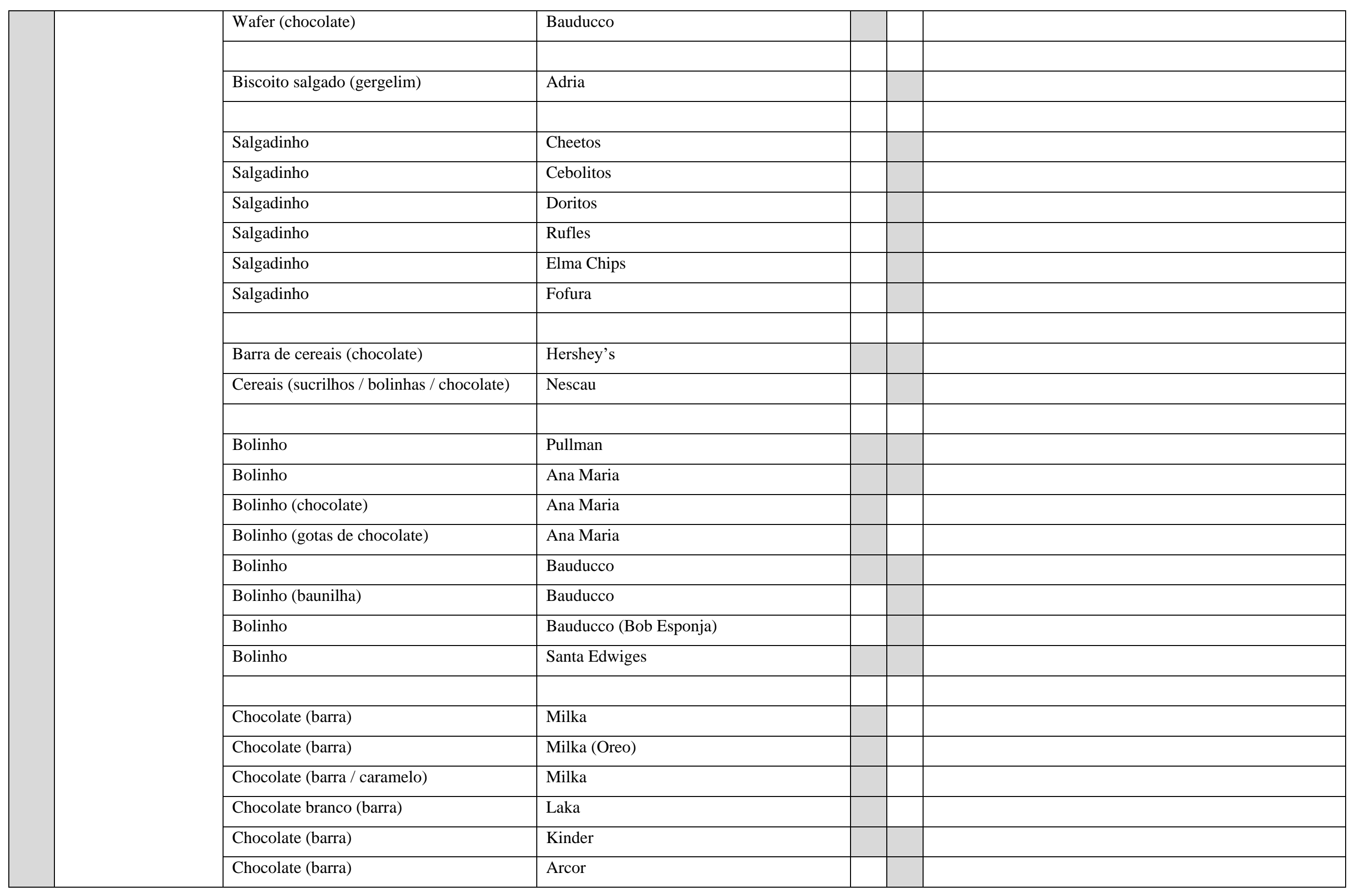




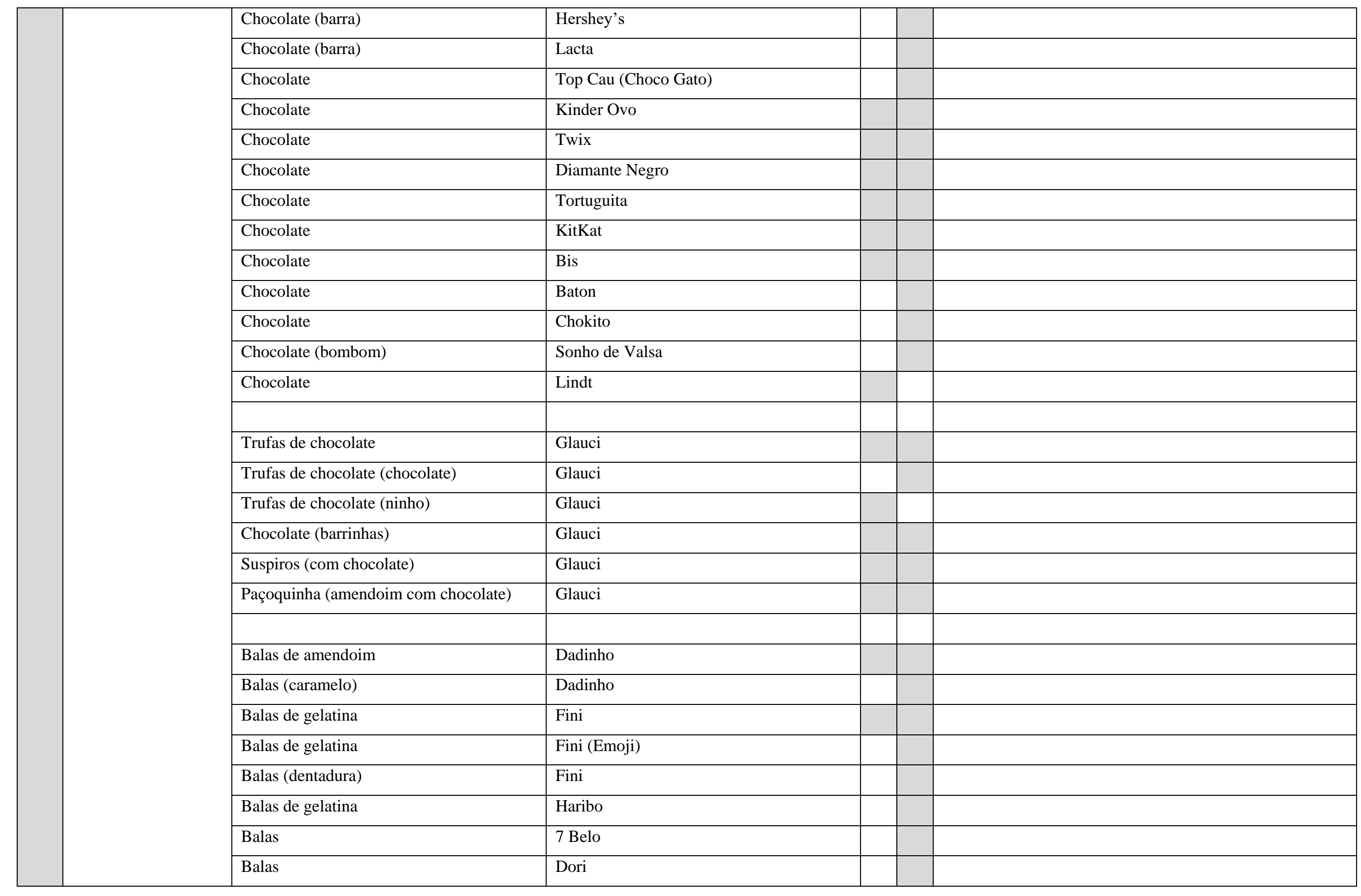




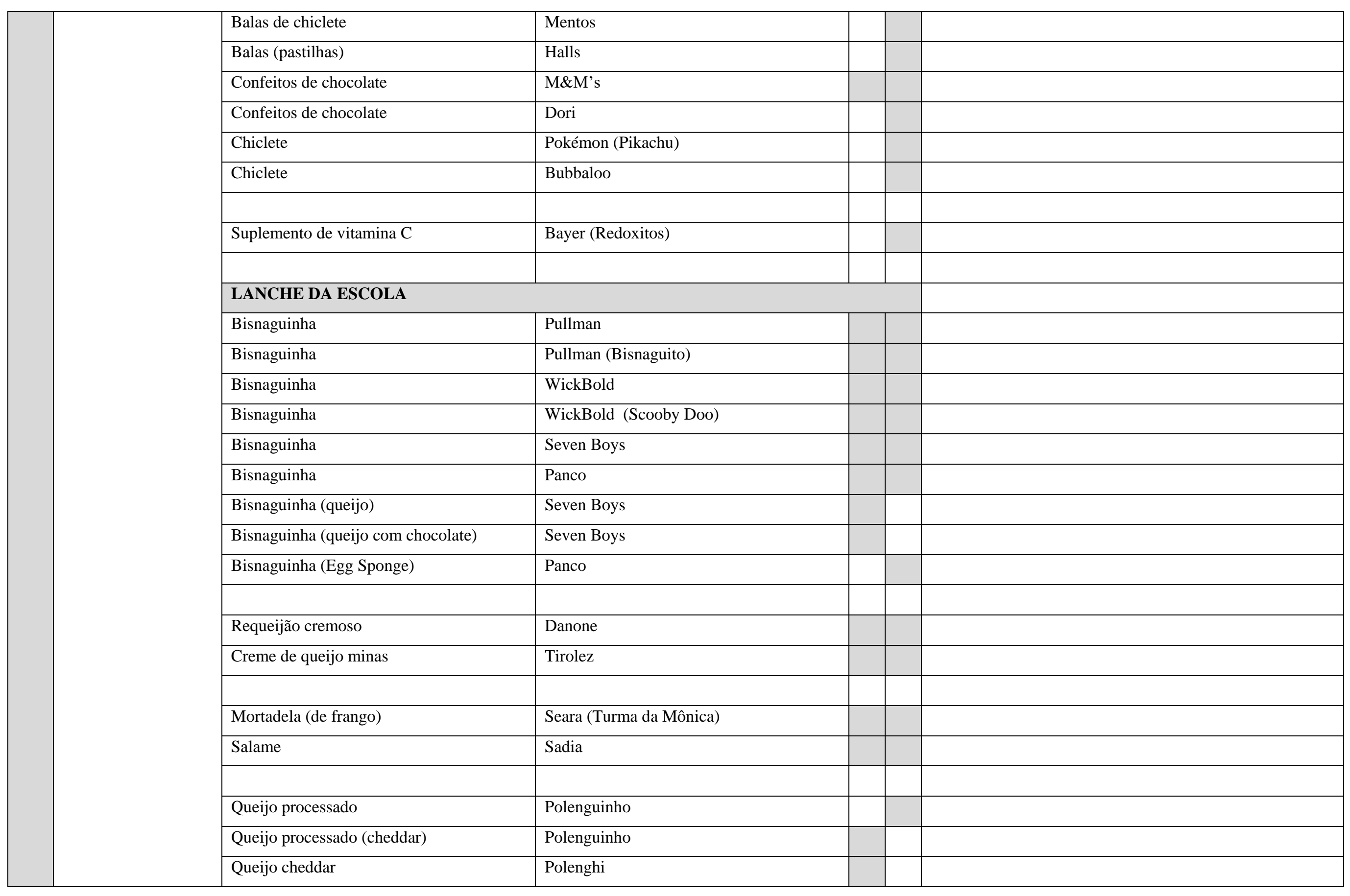




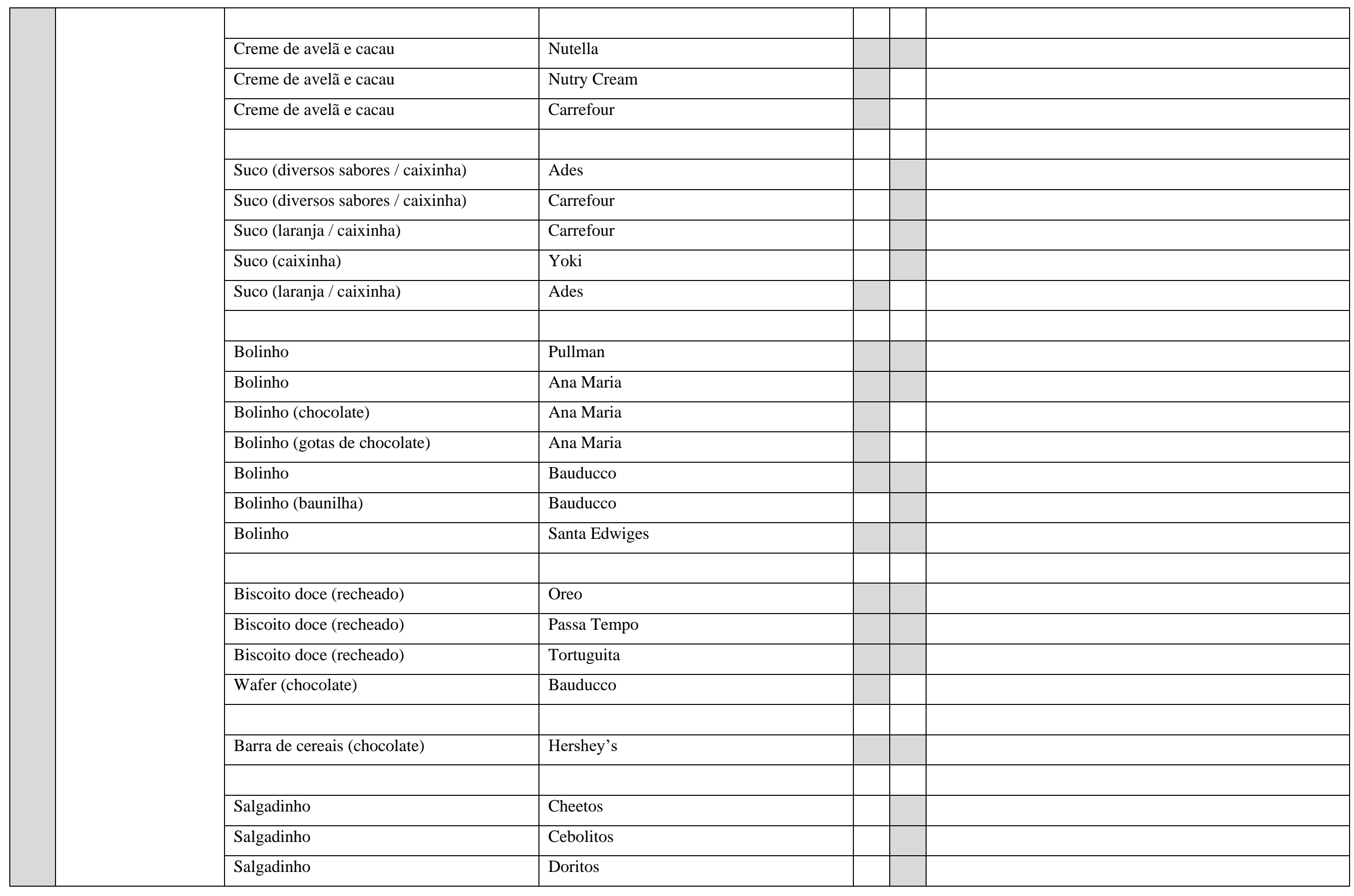




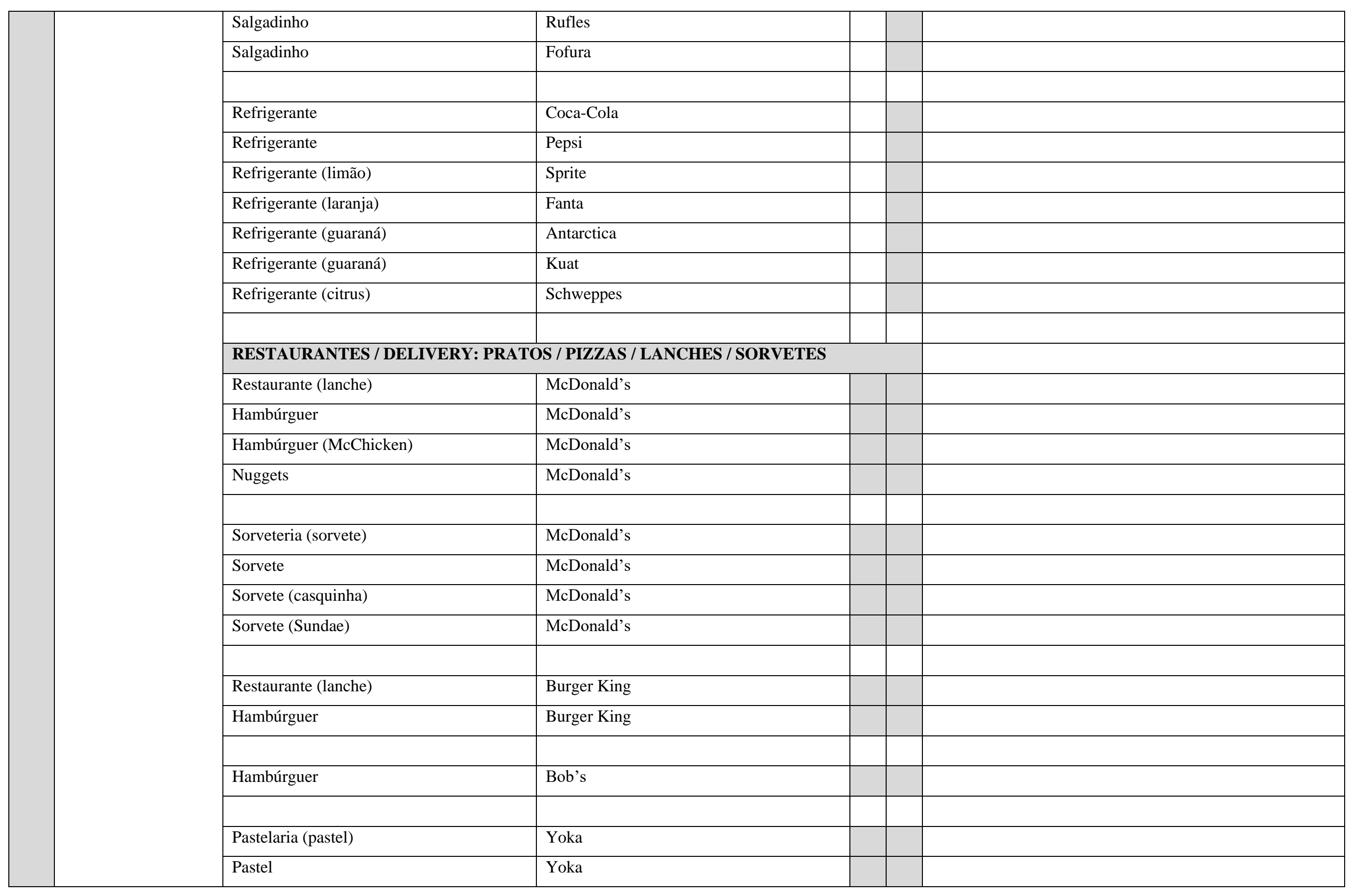




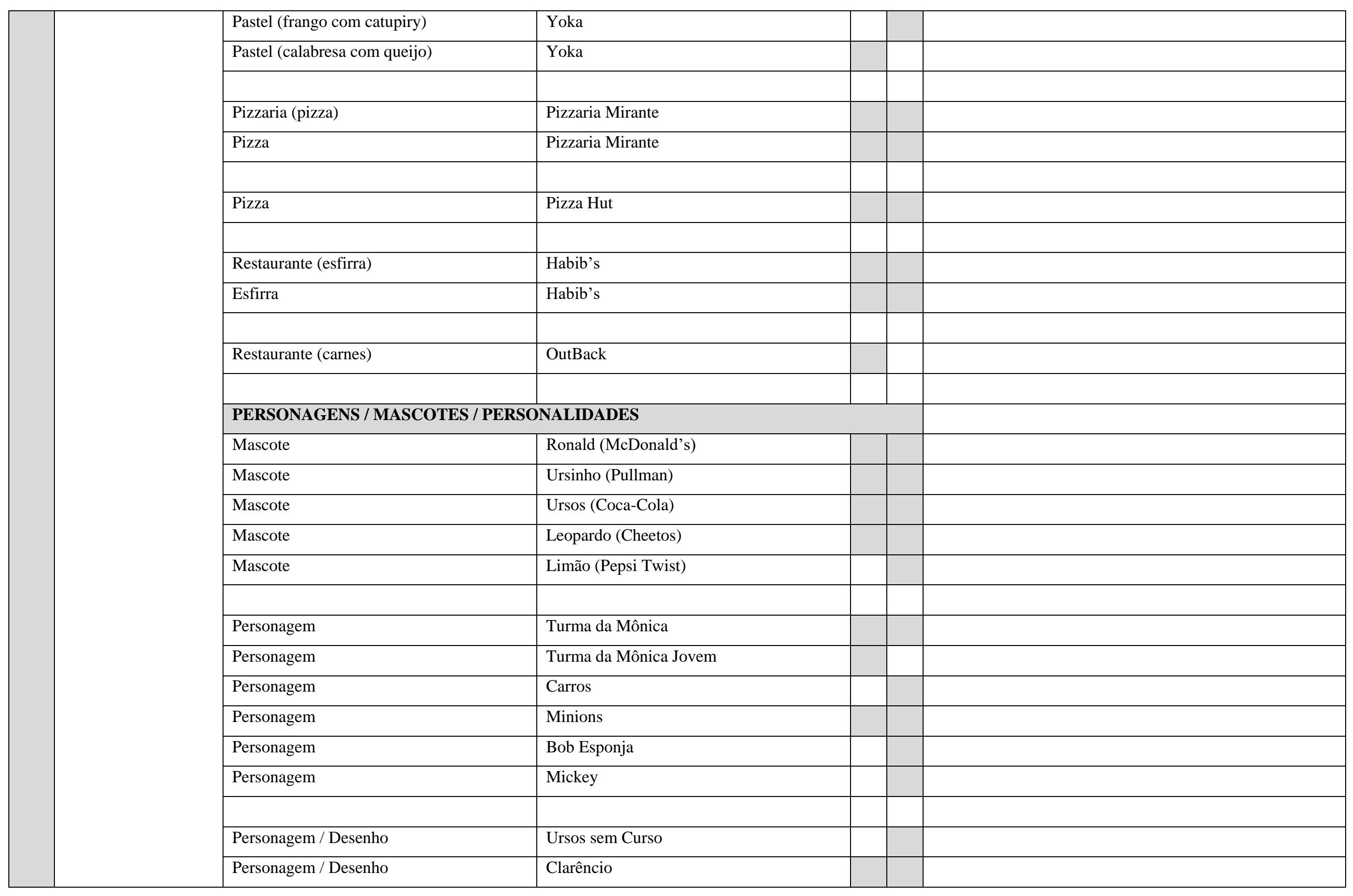




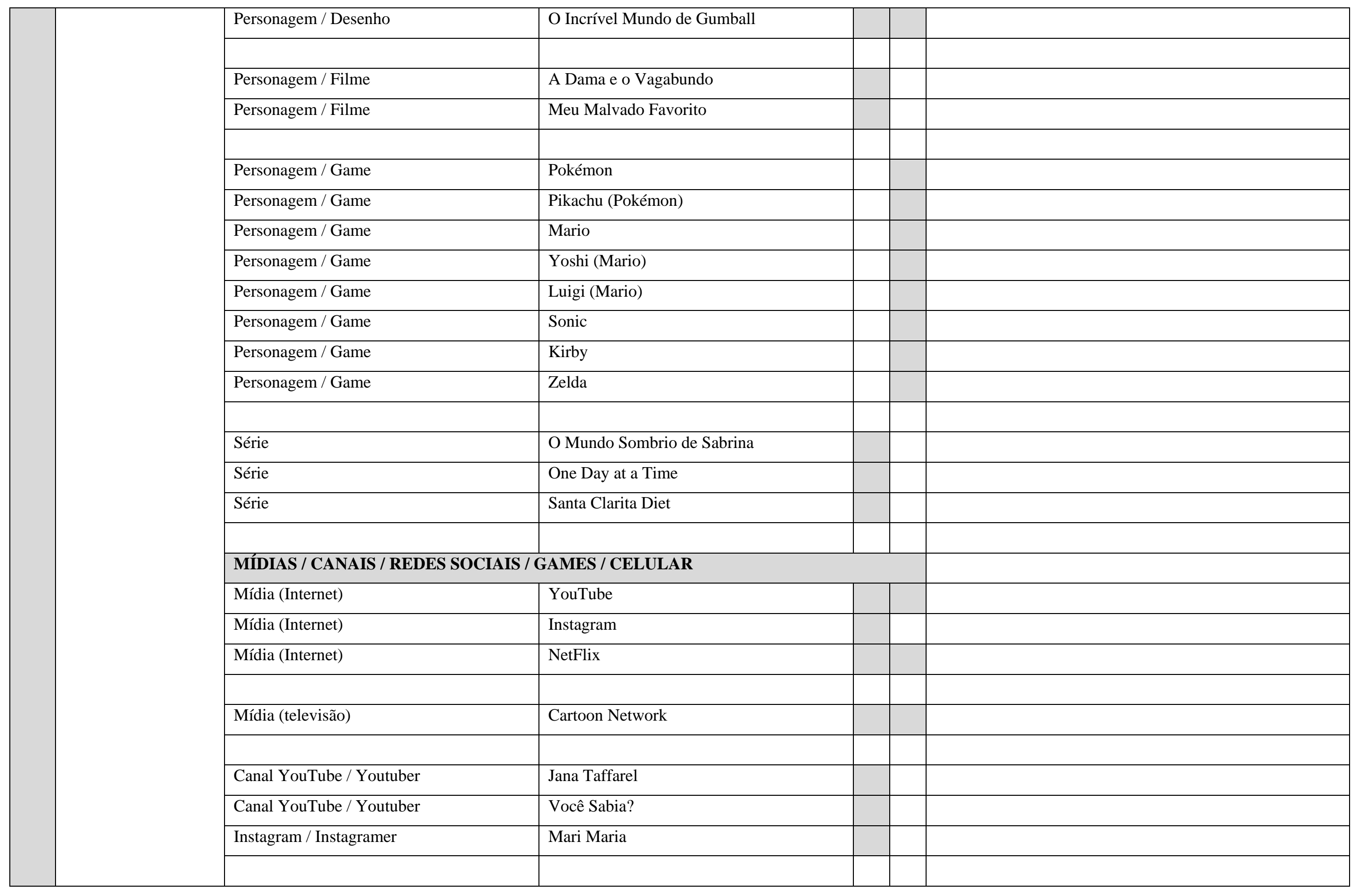




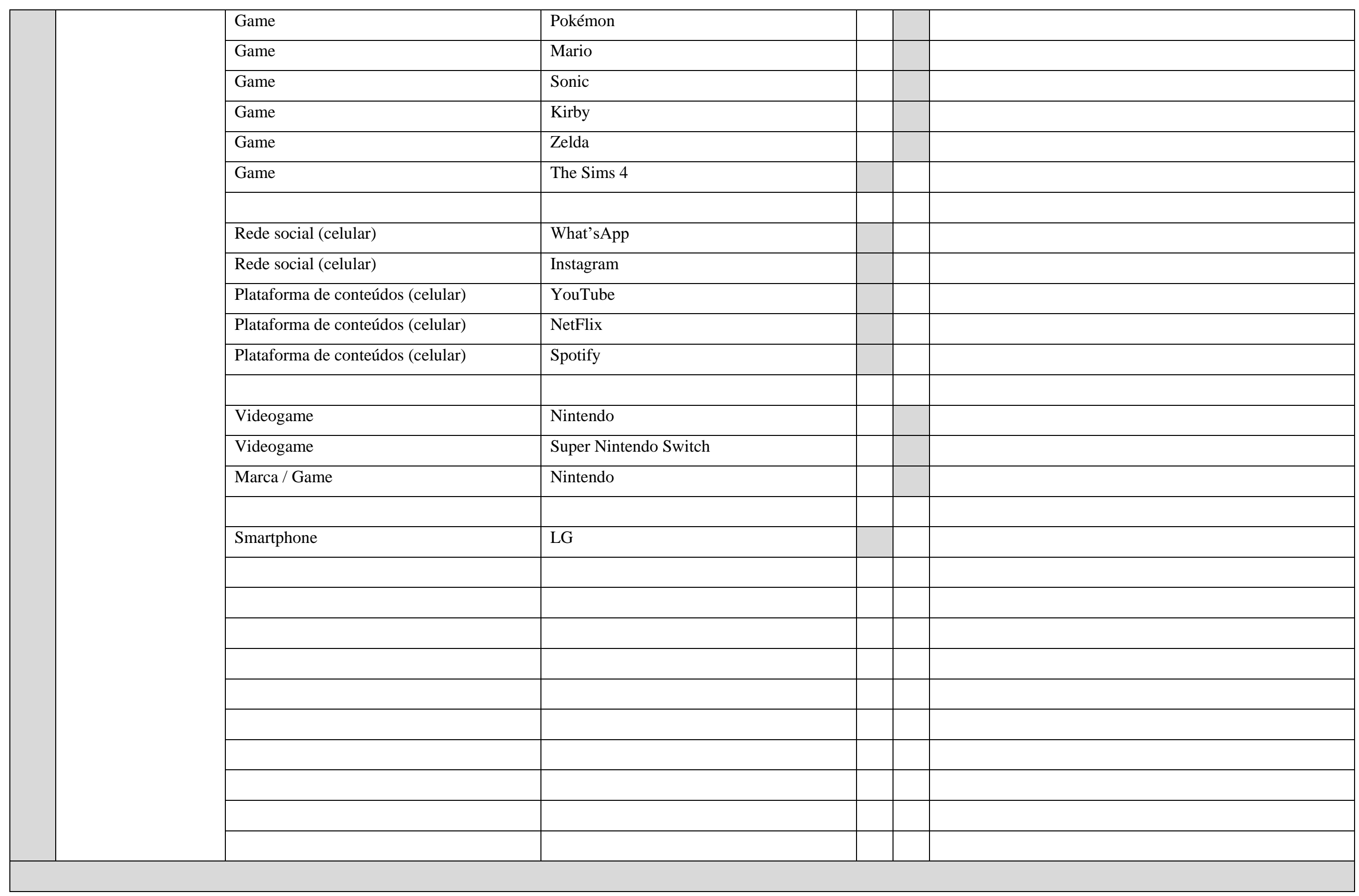




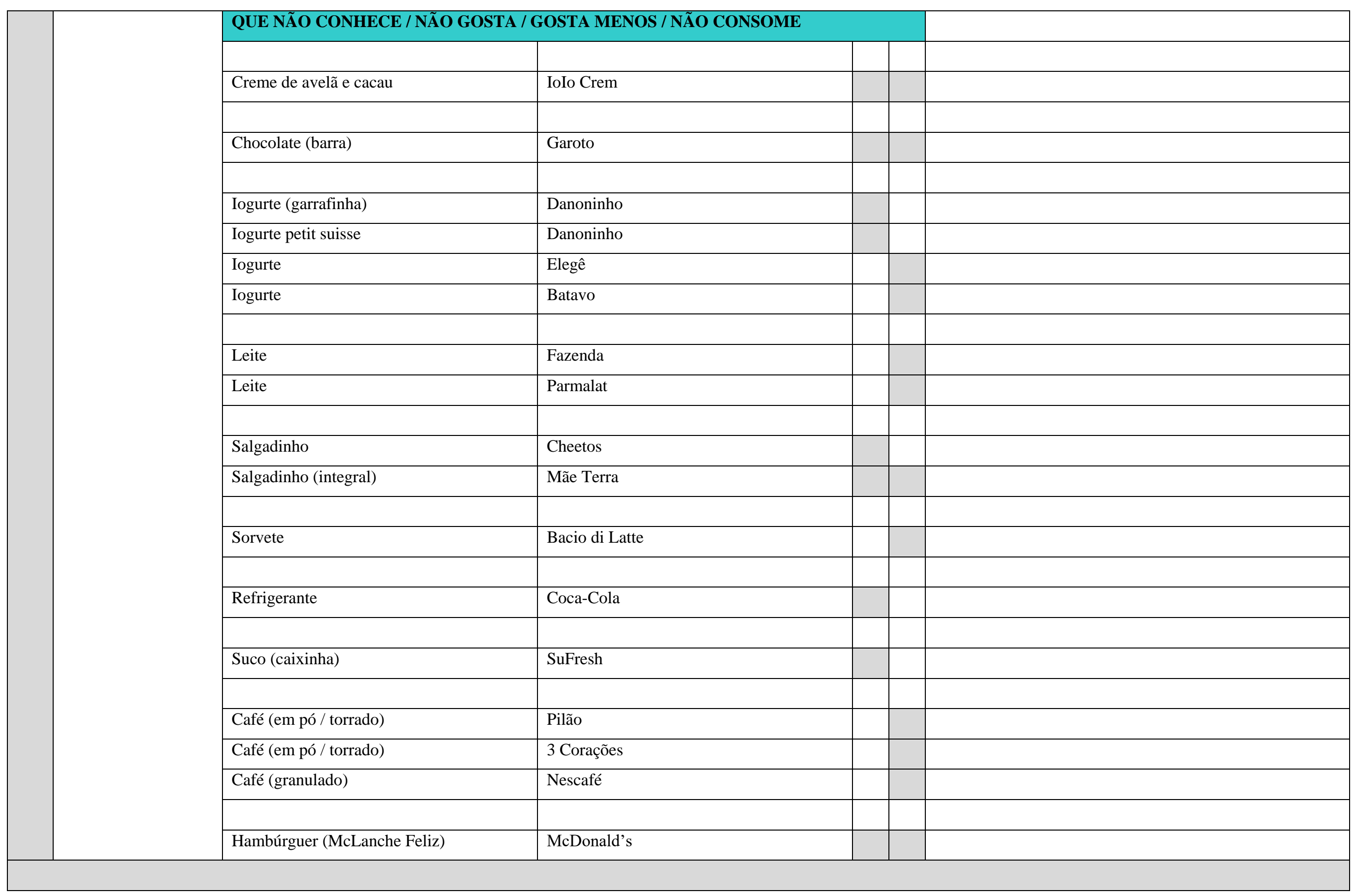


Observações:

$\mathrm{F}=$ Para a família (os pais e as crianças)

$\mathrm{C}=$ Para as crianças

$\mathrm{C} 1$ = Para a menina / Preferência da menina

$\mathrm{C} 2$ = Para o menino / Preferência do menino

Presença material $=$ Marcas e produtos alimentícios que a família $/$ as crianças consomem.

Presença simbólica = Marcas e produtos alimentícios que a família / as crianças gostariam de consumir .

(?) = Dúvidas quanto à especificação das marcas e produtos alimentícios em fotografias, vídeos ou relatos. 


\title{
APÊNDICE S
}

\author{
PESQUISA DE CAMPO
}

MARCAS DE ALIMENTOS NO CONTEXTO FAMILIAR

\author{
FAMÍLIA III
}

MARCAS DE ALIMENTOS: PRESENÇA MATERIAL E SIMBÓLICA 


\section{F A M Í L I A}

MARCAS E PRODUTOS ALIMENTÍCIOS NO AMBIENTE DOMÉSTICO E ESPAÇO PÚBLICO (RELATOS / OBSERVAÇÕES / CITAÇÕES / EXPRESSIVIDADES / FOTOS / VÍDEOS / OBSERVAÇÃO)

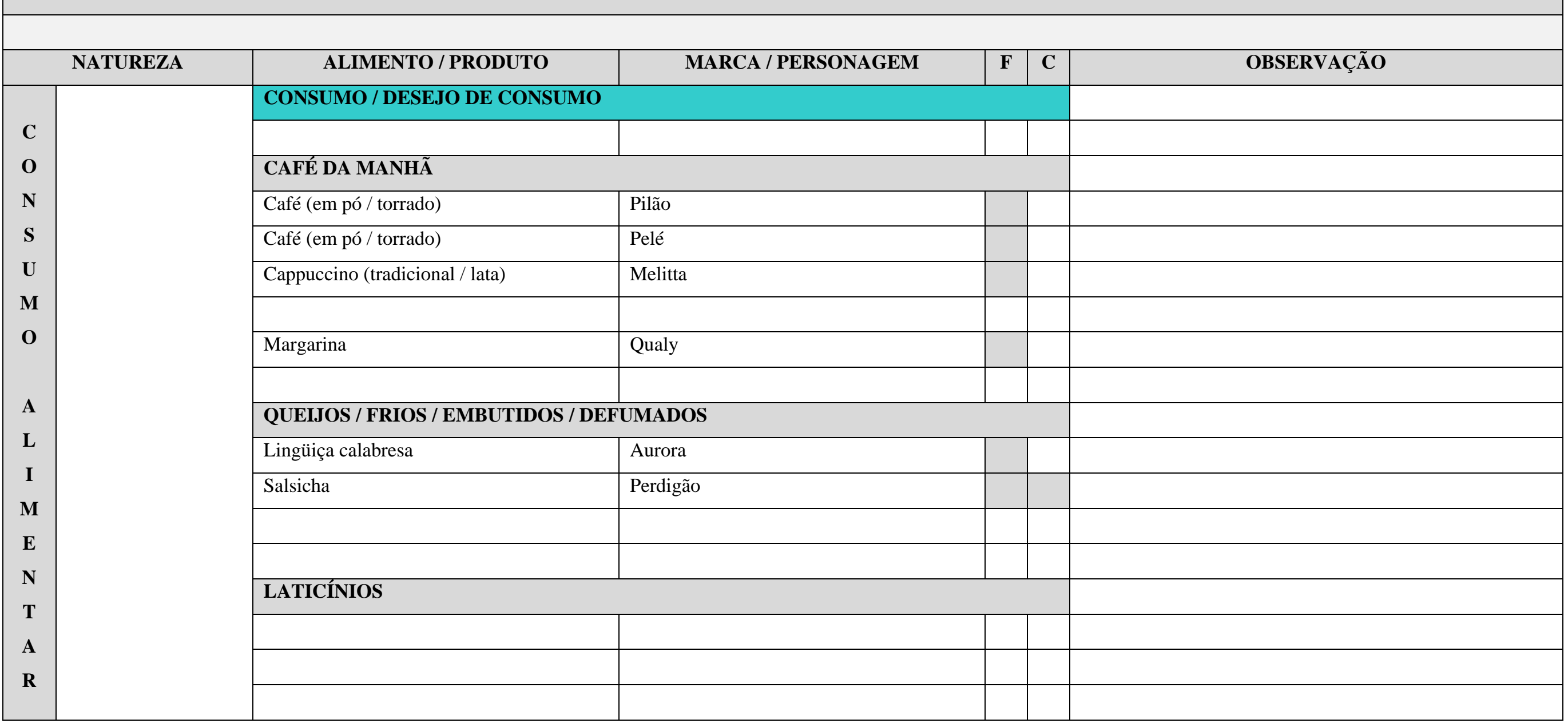




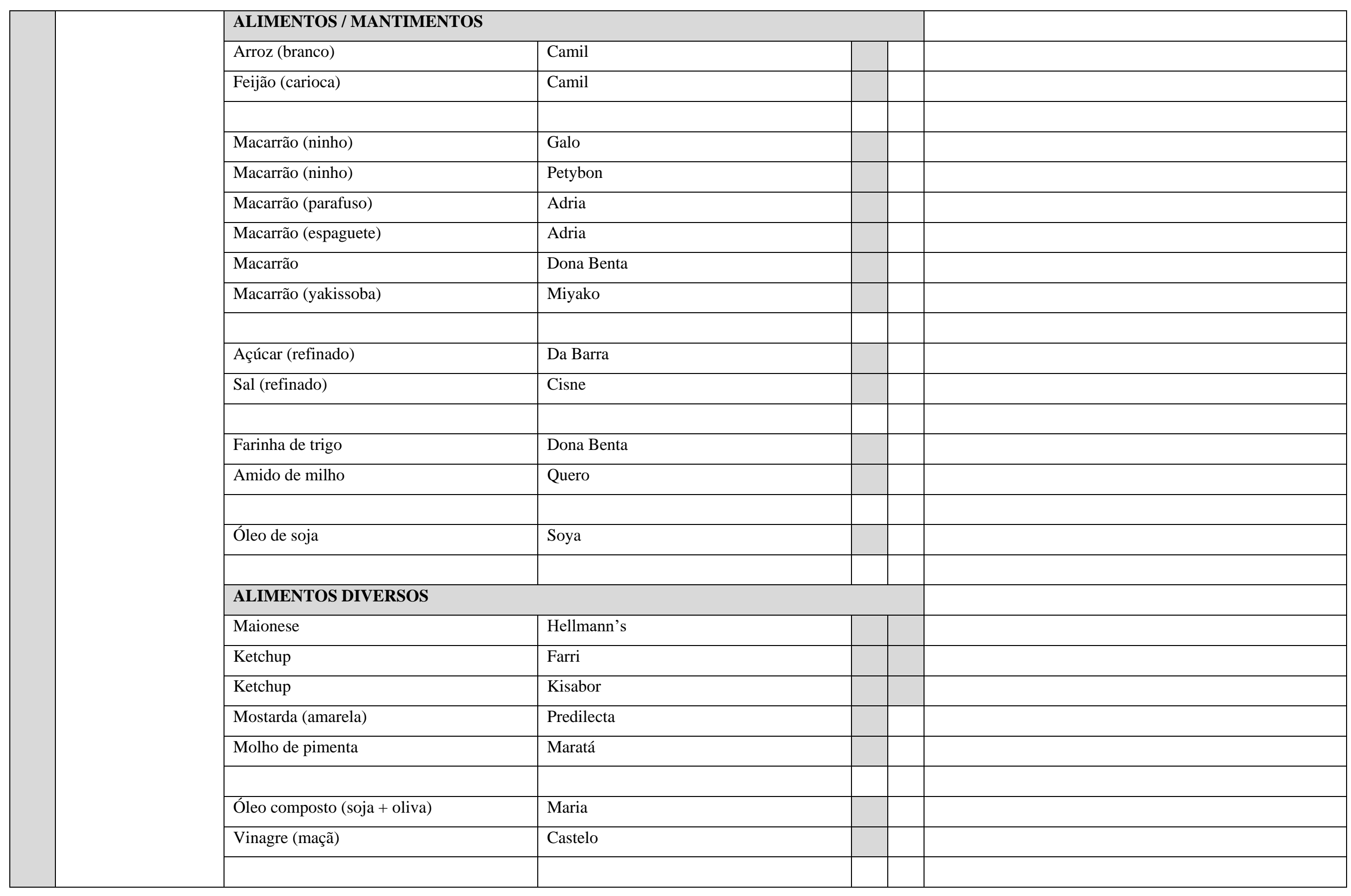




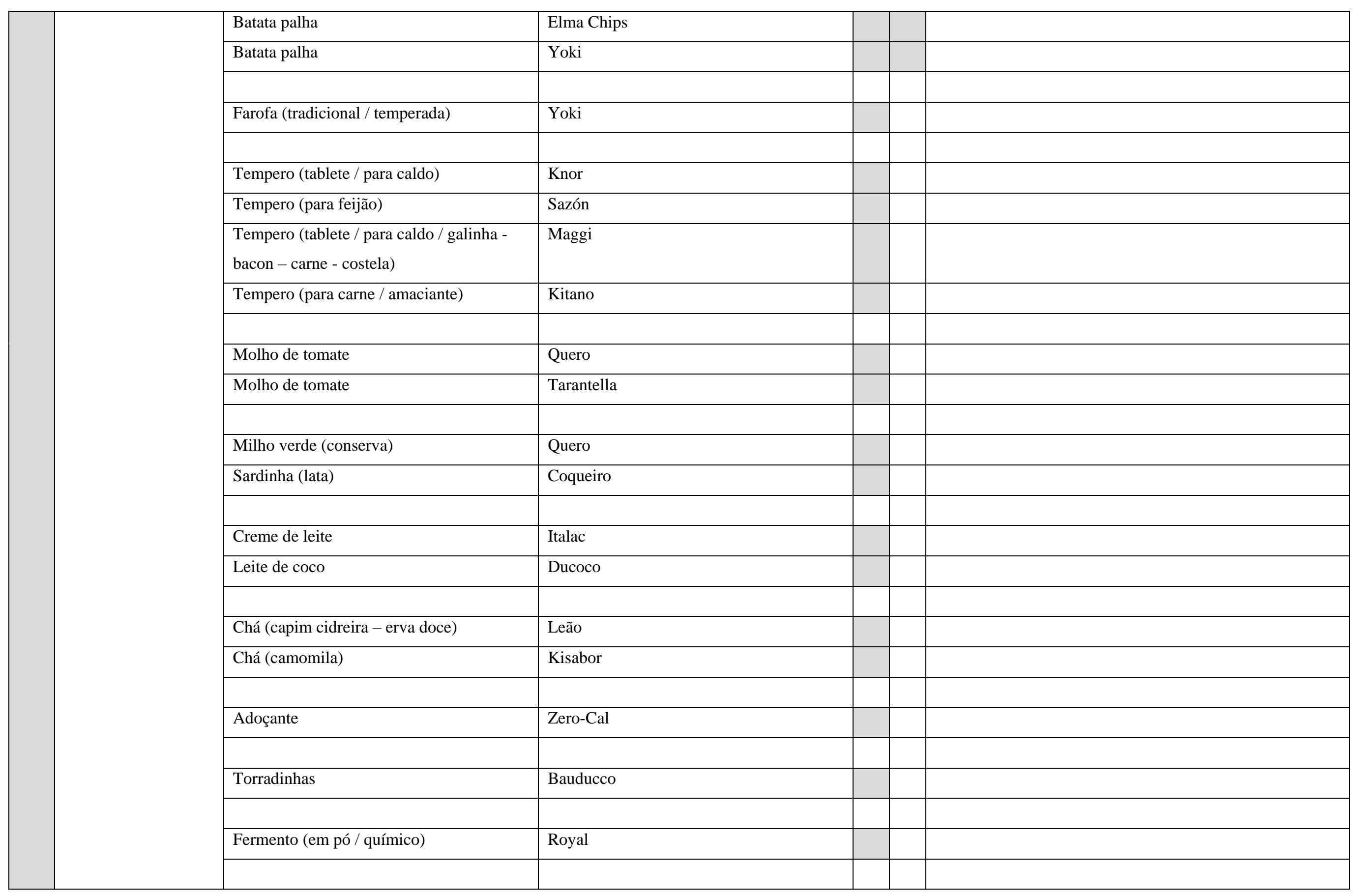




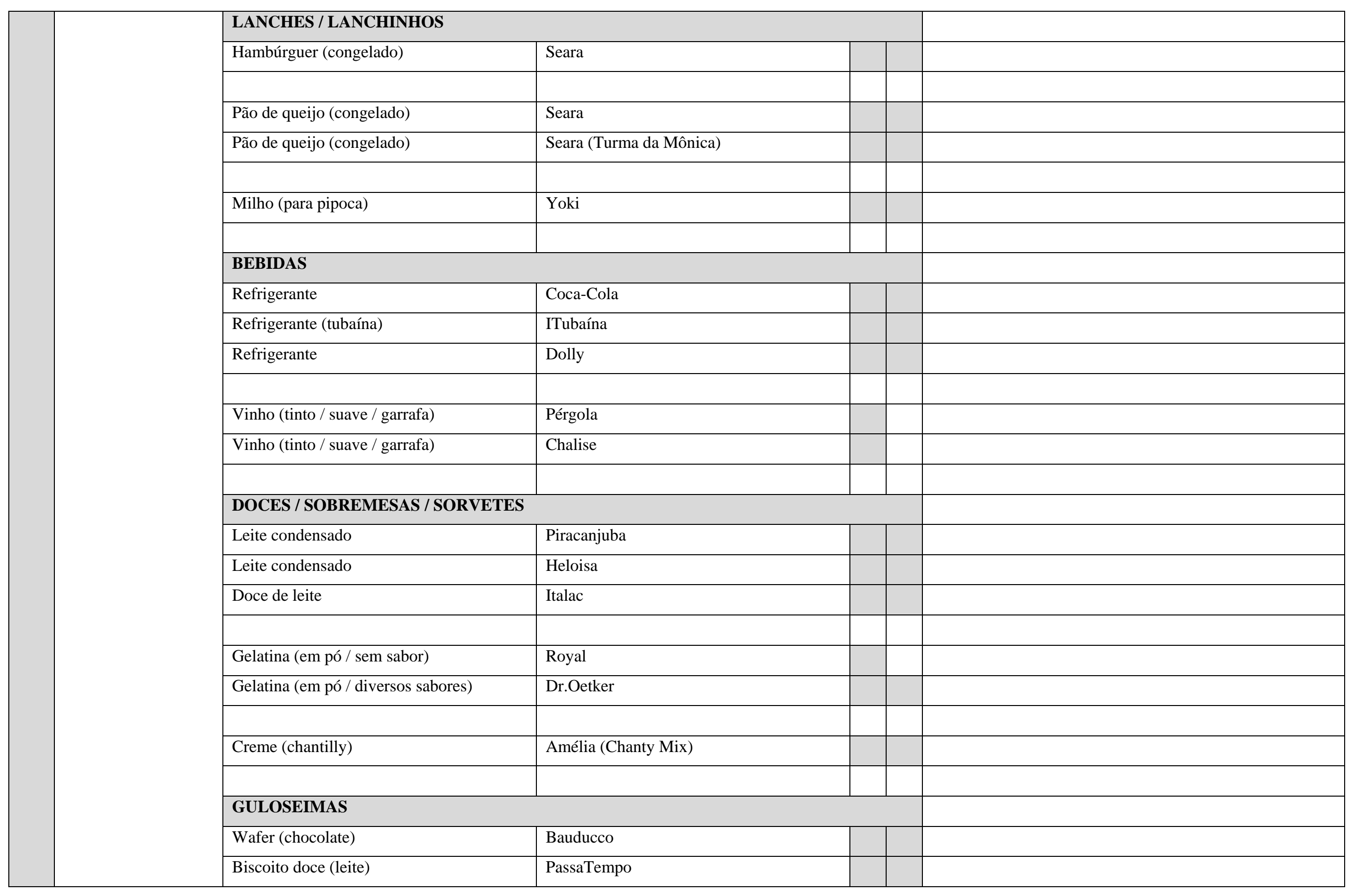




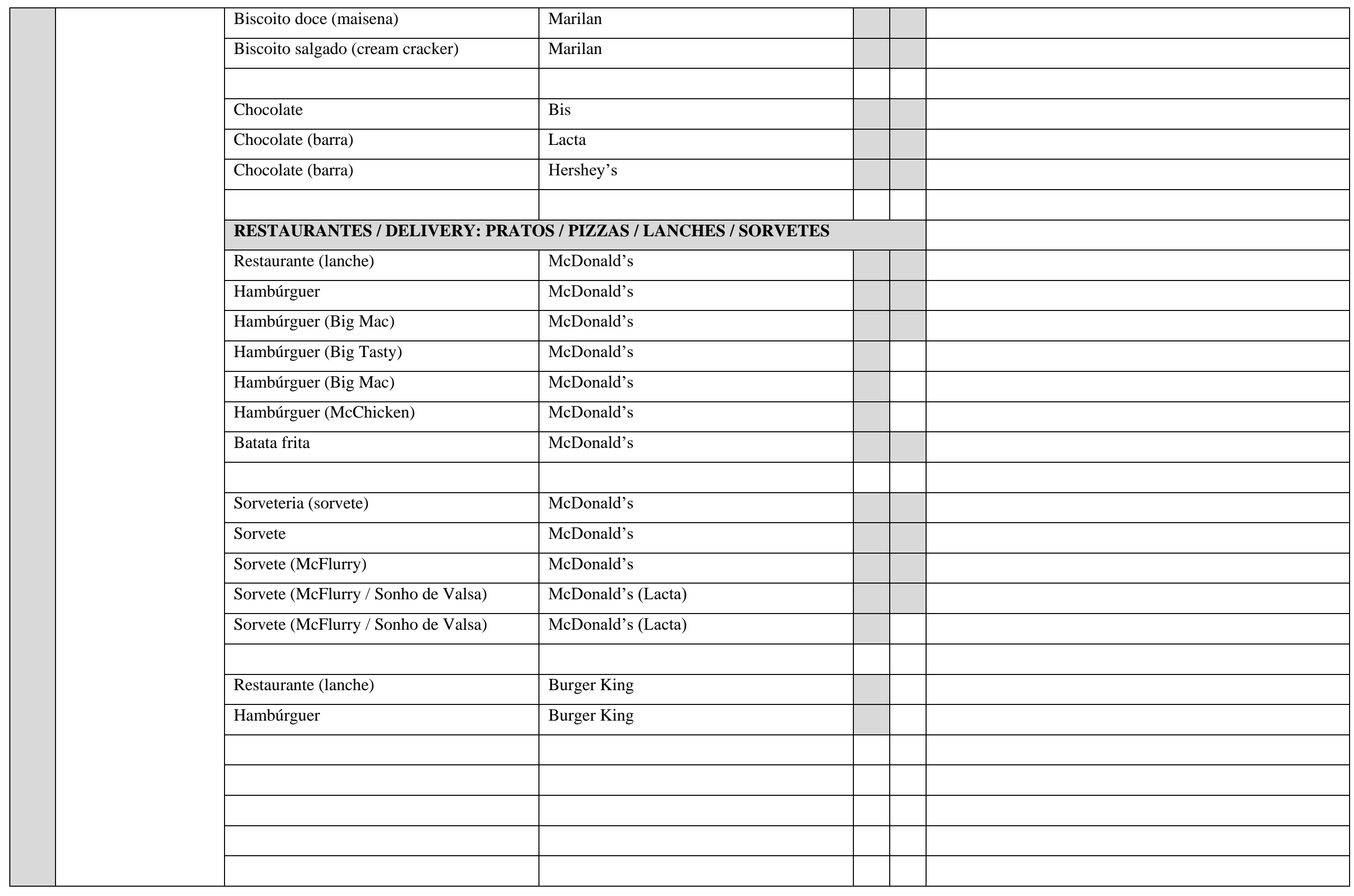




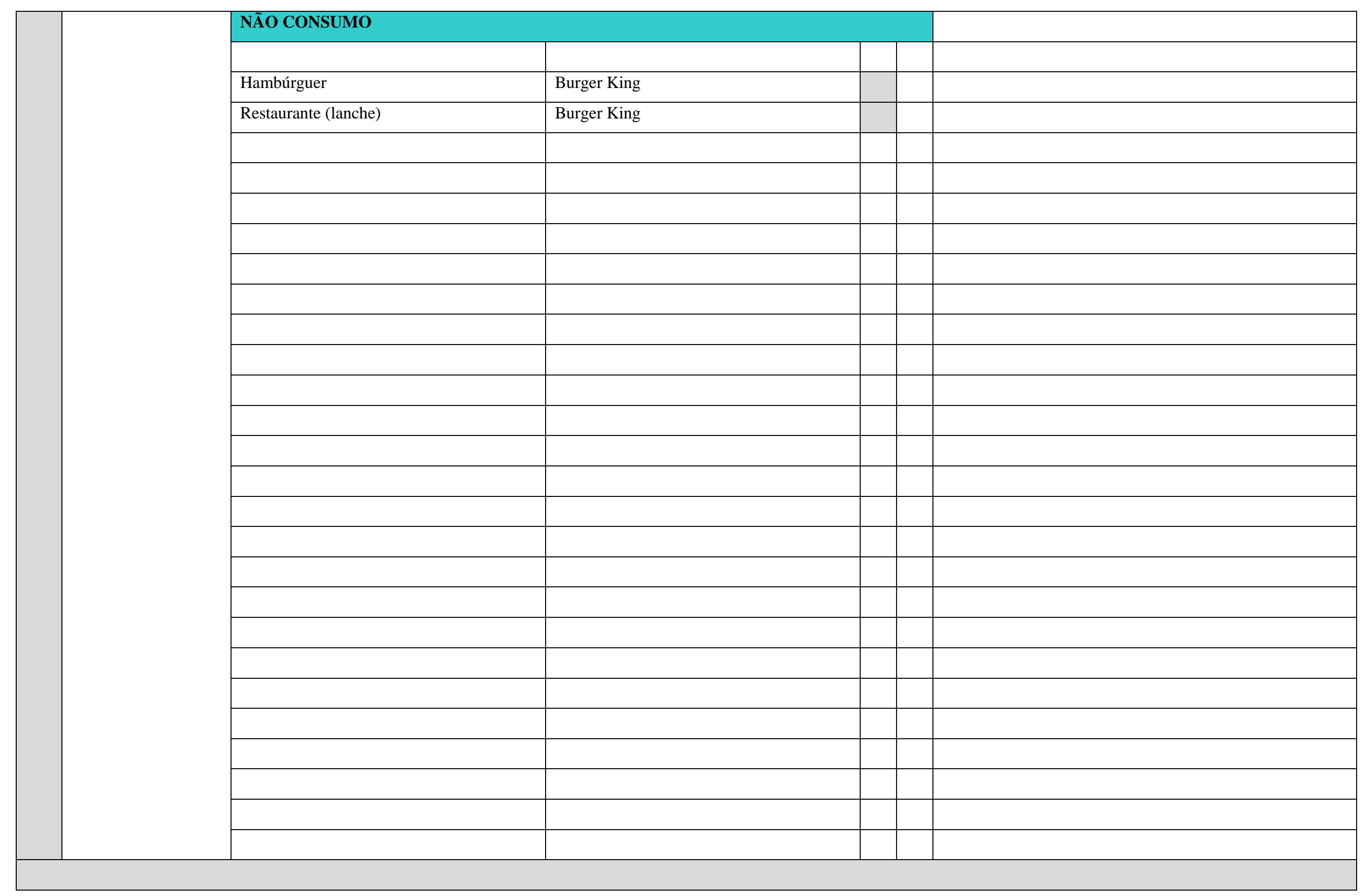




\section{R I A N Ç A S}

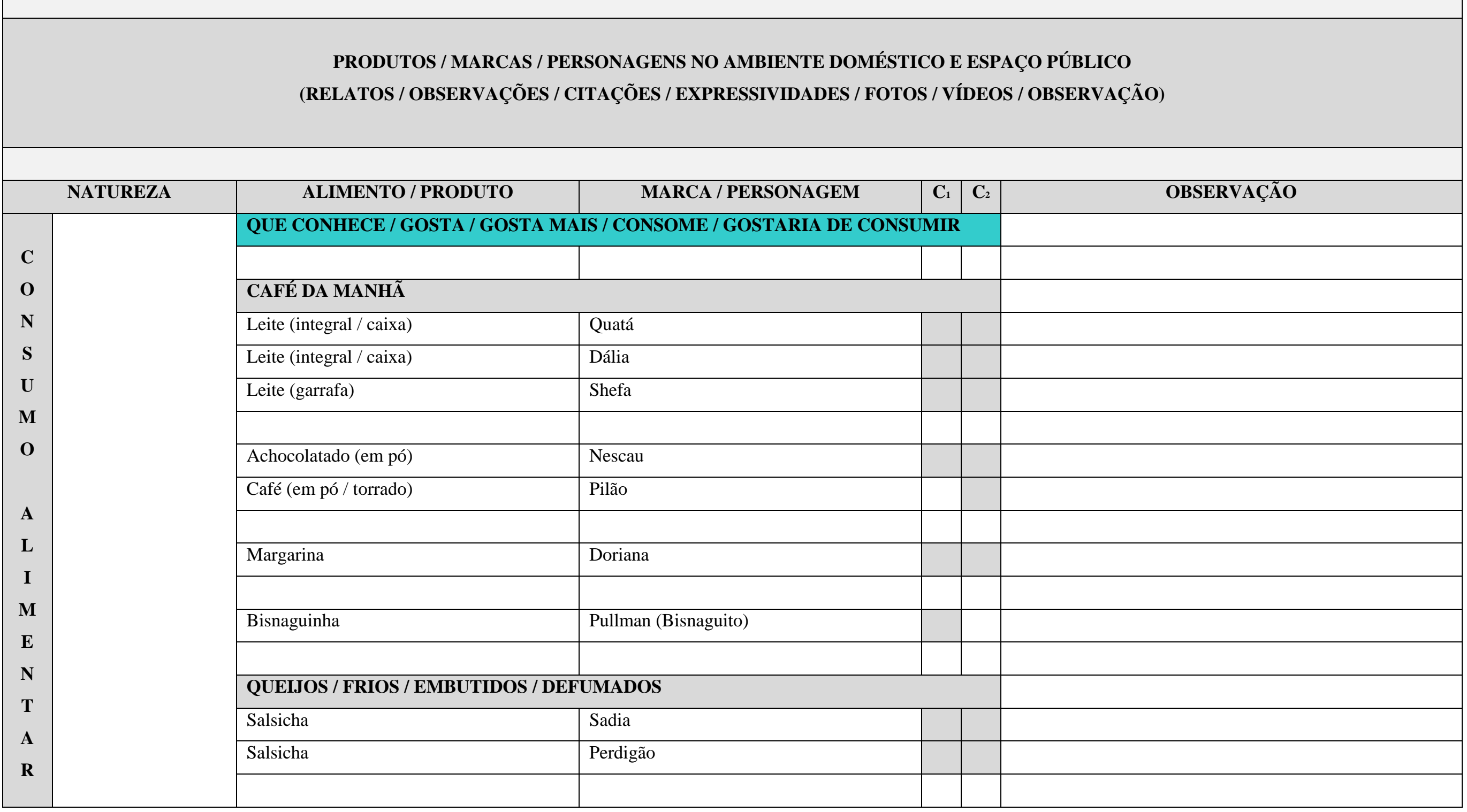




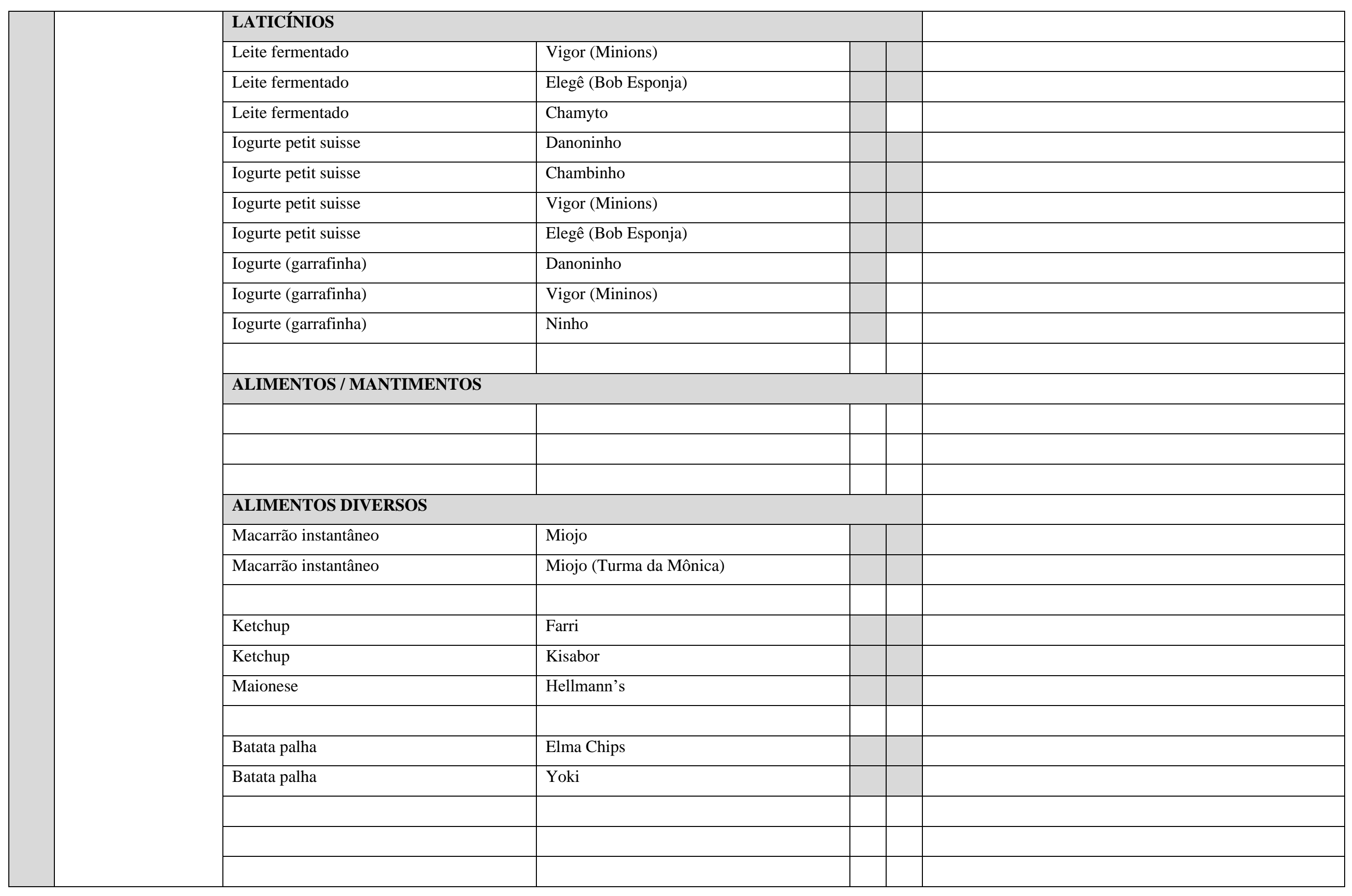




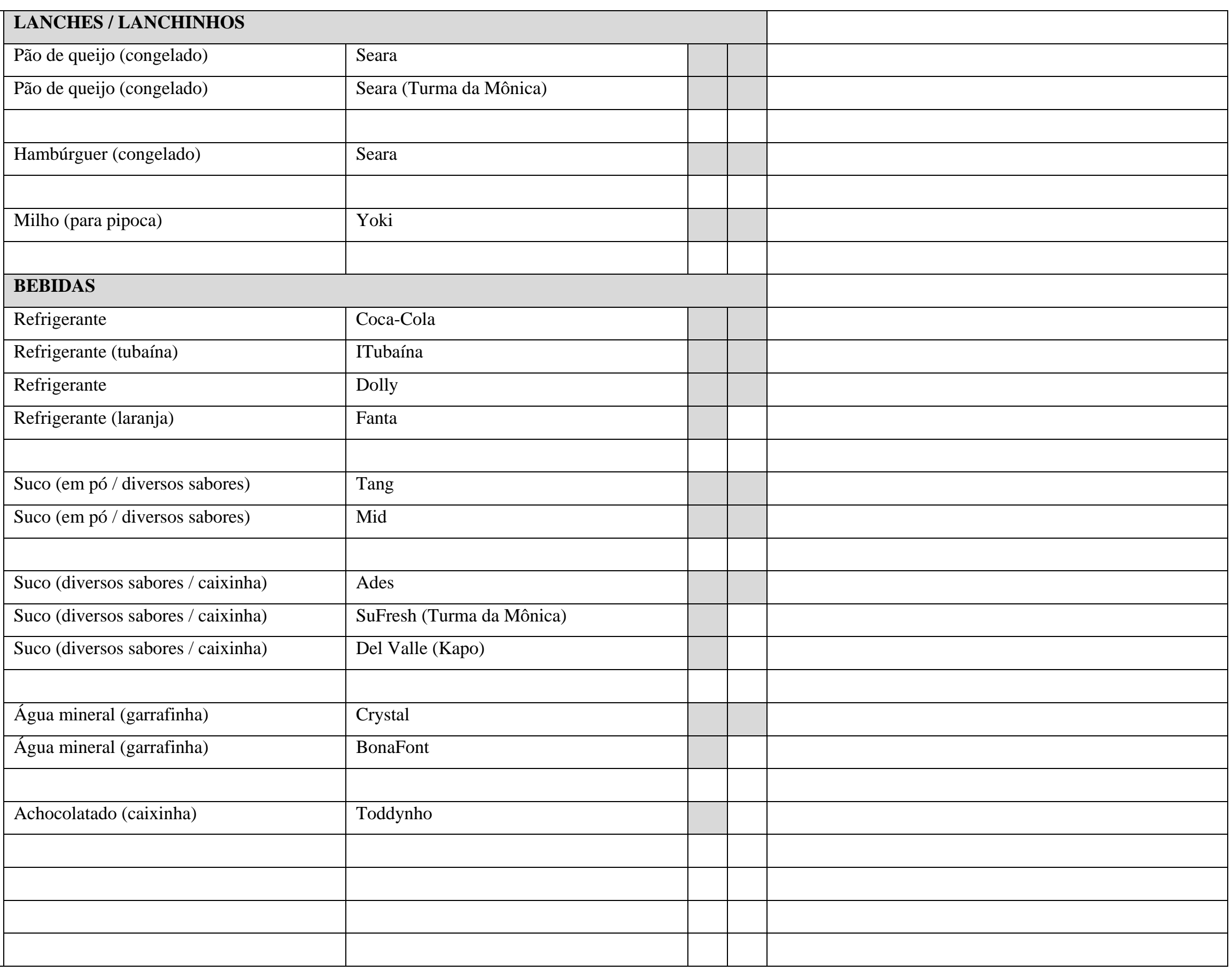




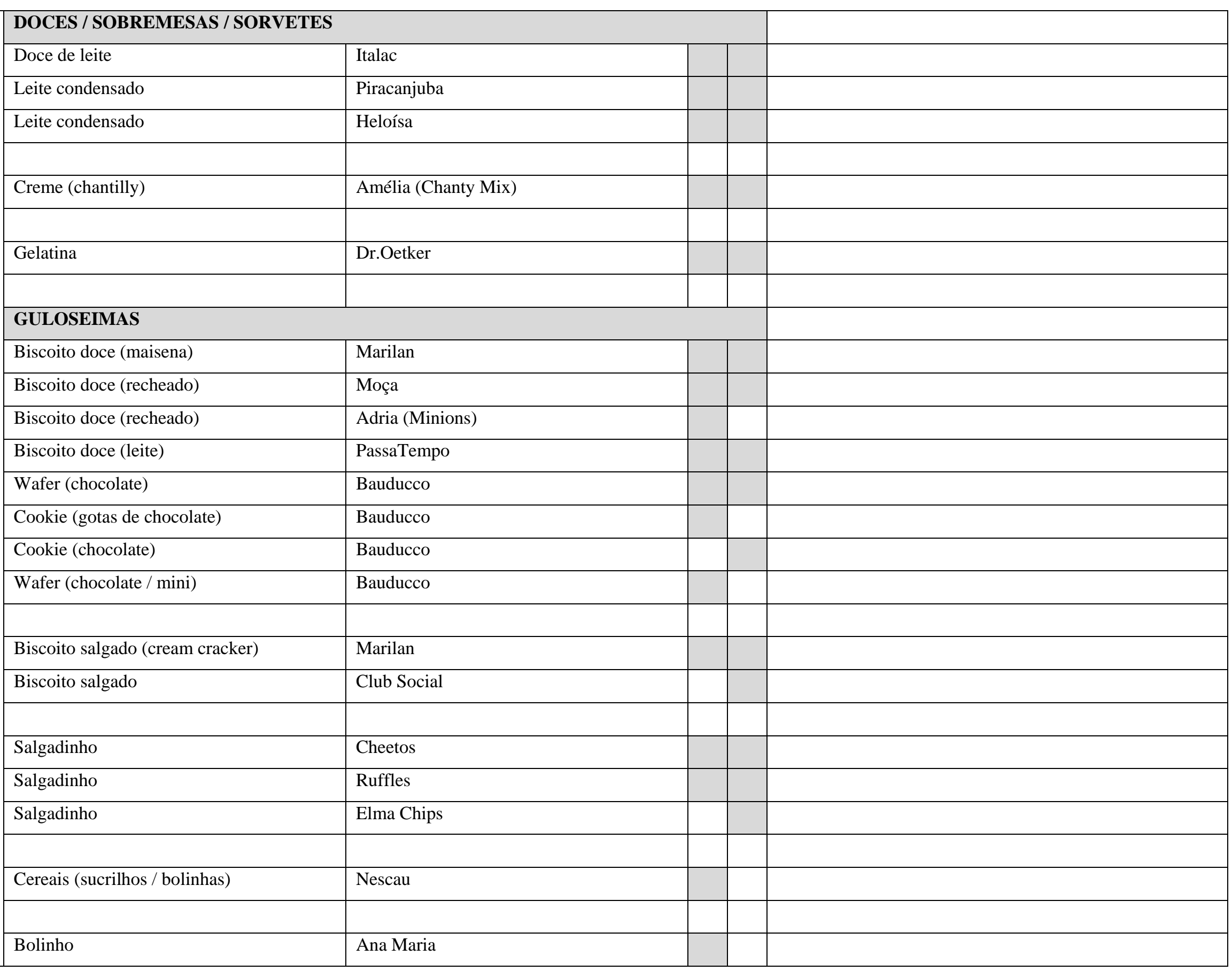




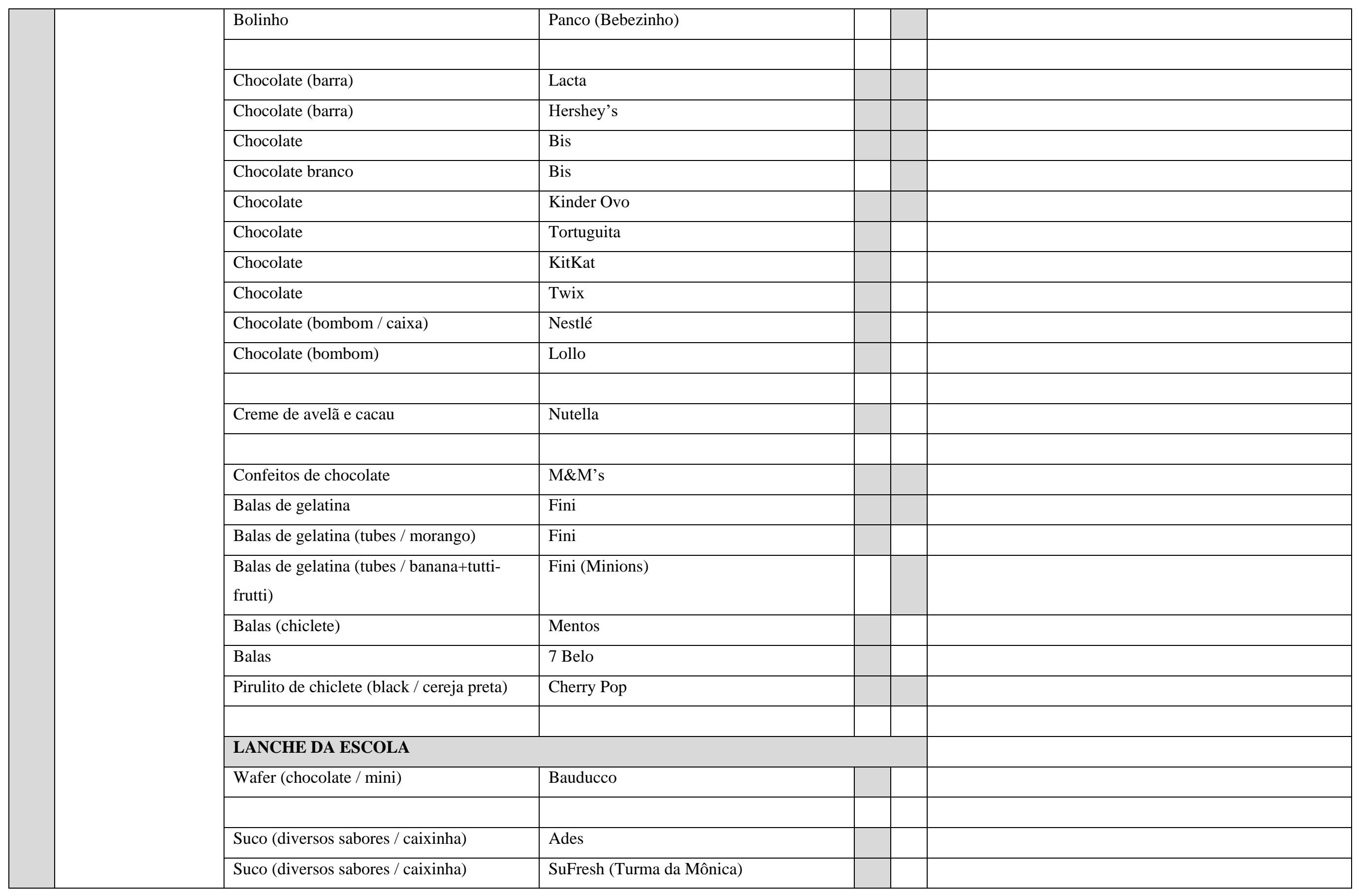




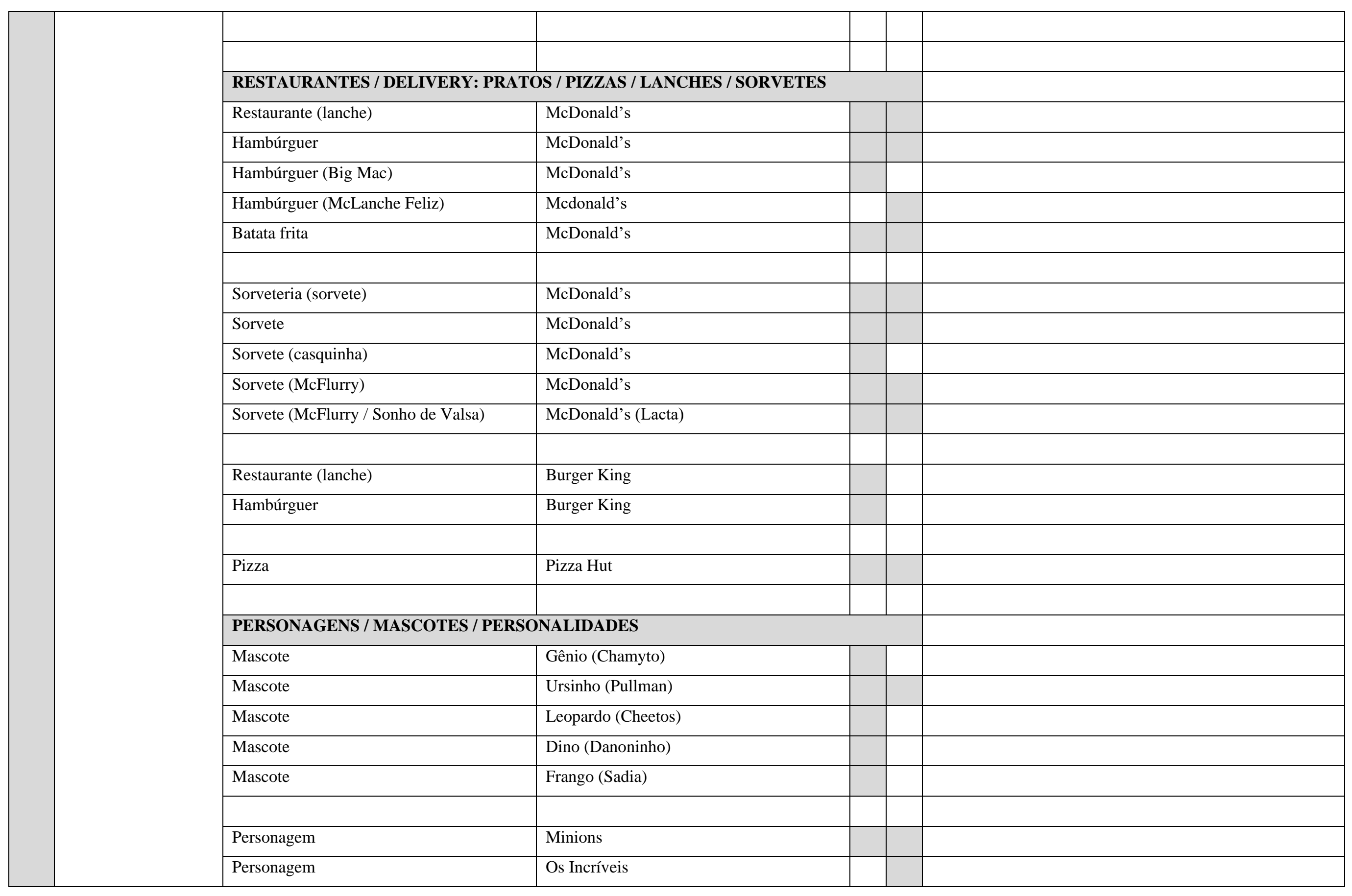




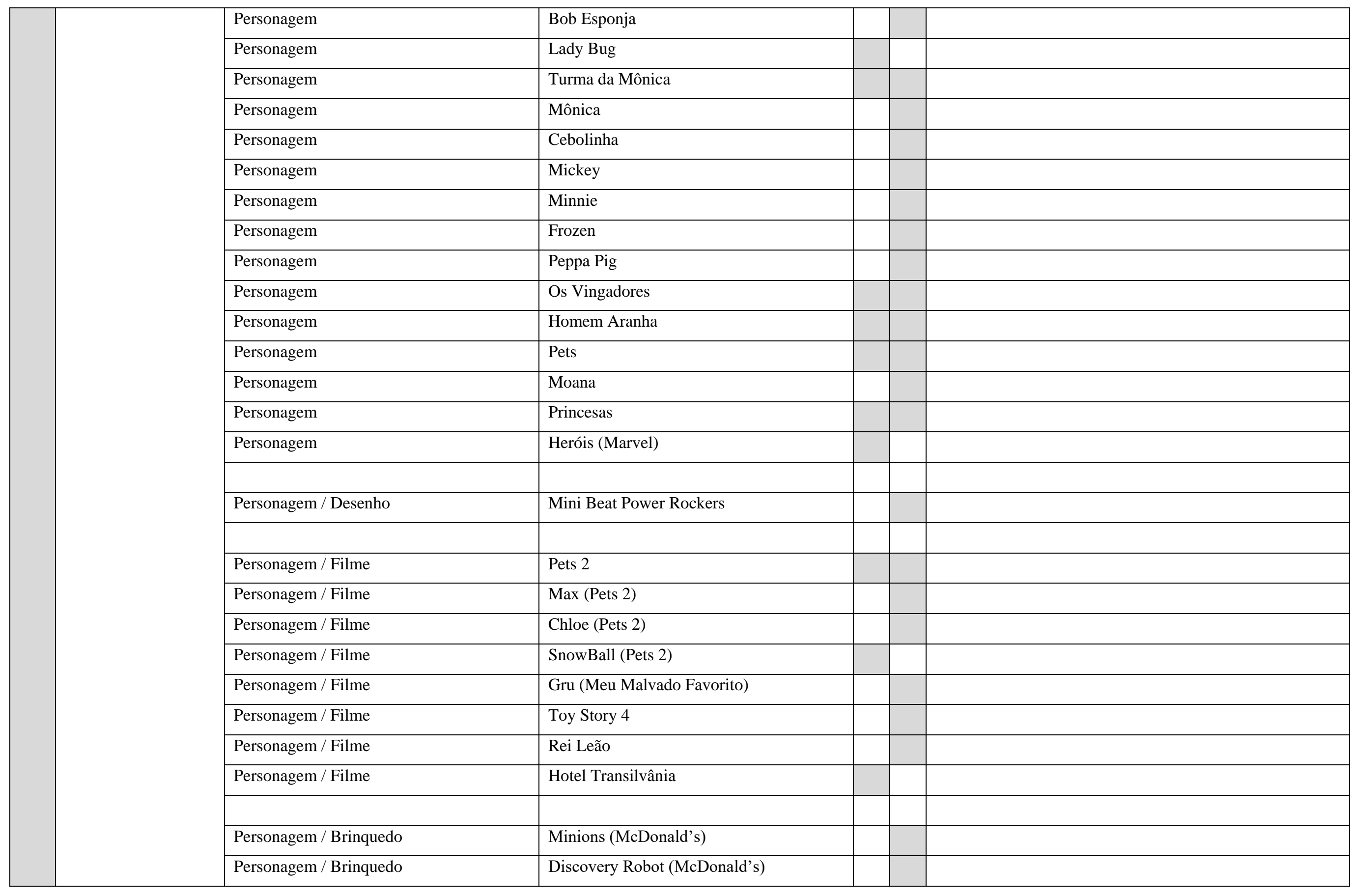




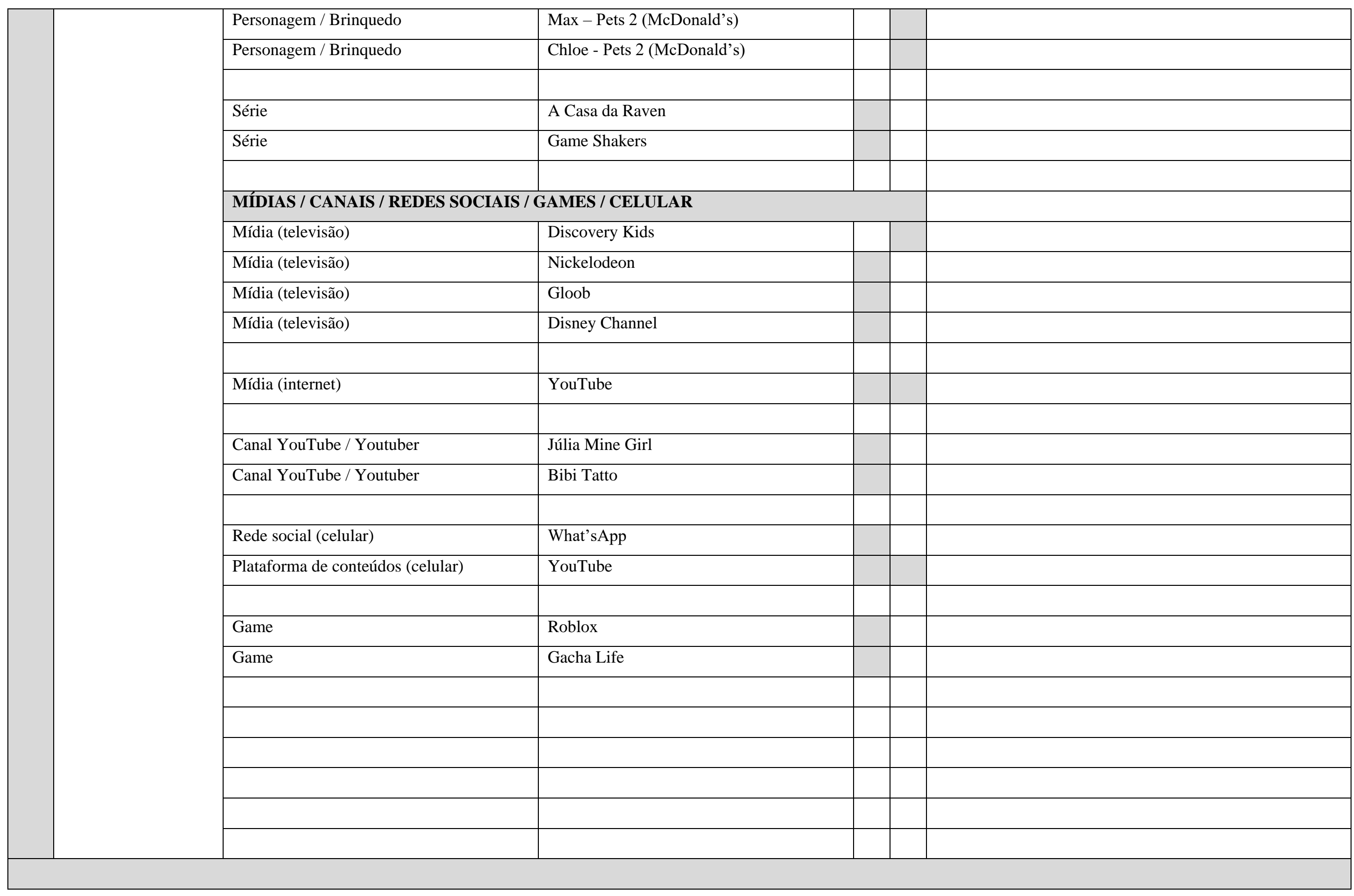




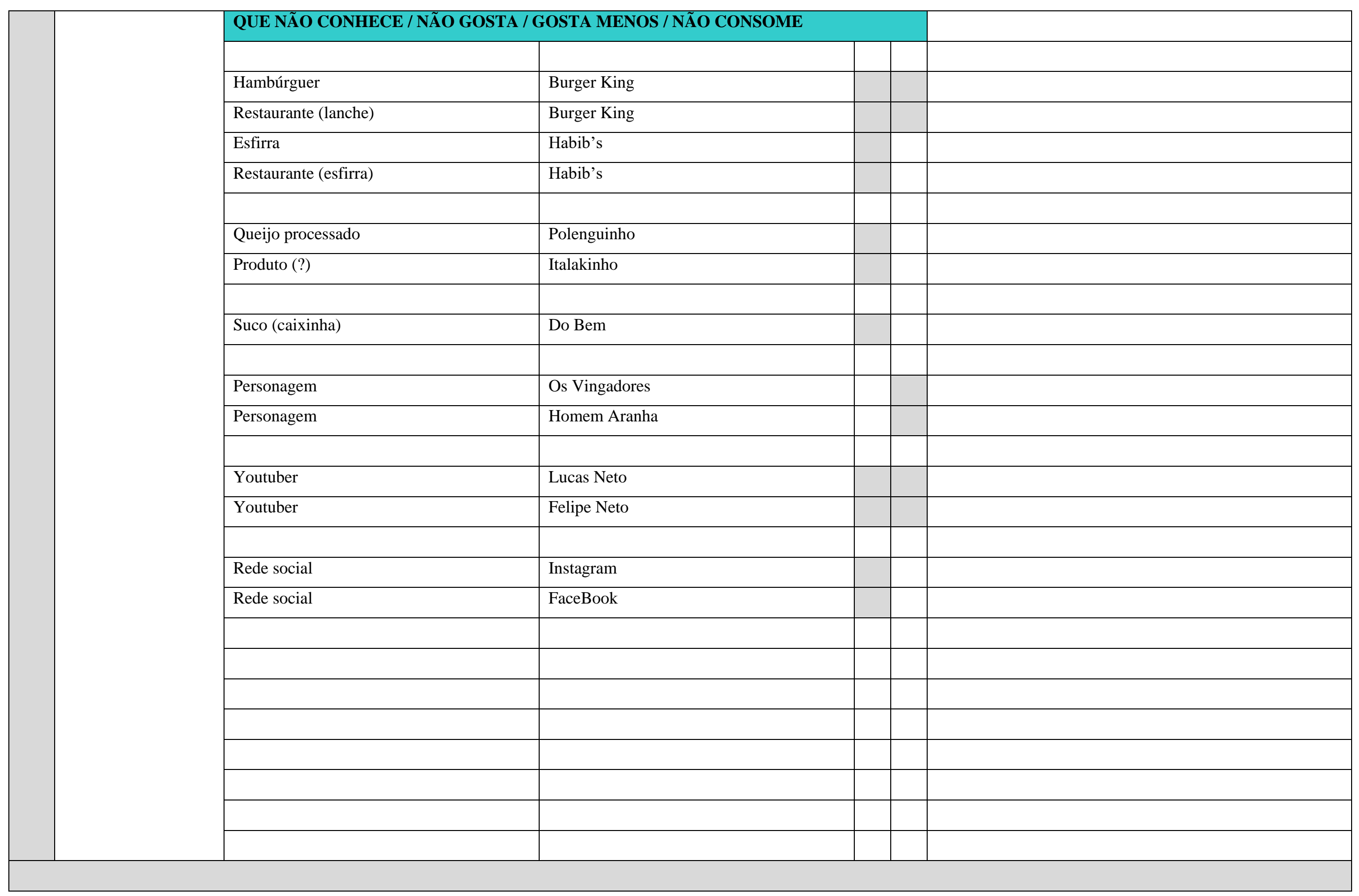


Observações:

$\mathrm{F}=$ Para a família (os pais e as crianças)

$\mathrm{C}=$ Para as crianças

$\mathrm{C} 1$ = Para a menina mais velha / Preferência da menina mais velha

$\mathrm{C} 2$ = Para a menina mais nova / Preferência da menina mais nova

Presença material $=$ Marcas e produtos alimentícios que a família $/$ as crianças consomem.

Presença simbólica = Marcas e produtos alimentícios que a família / as crianças gostariam de consumir .

(?) = Dúvidas quanto à especificação das marcas e produtos alimentícios em fotografias, vídeos ou relatos. 


\title{
APÊNDICE T
}

\section{BRINCADEIRA DE COMER}

\author{
JOGO DE CARDS ALIMENTOS \\ JOGO DE CARDS MARCAS \\ DESENHOS
}

Imagens da participação das crianças na atividade lúdica.

Imagens das composições de marcas e produtos alimentícios elaboradas pelas crianças.

Desenhos elaborados pelas crianças. 
PARTICIPAÇÃO DAS CRIANÇAS NA ATIVIDADE LÚDICA

PRIMEIRA FAMÍLIA
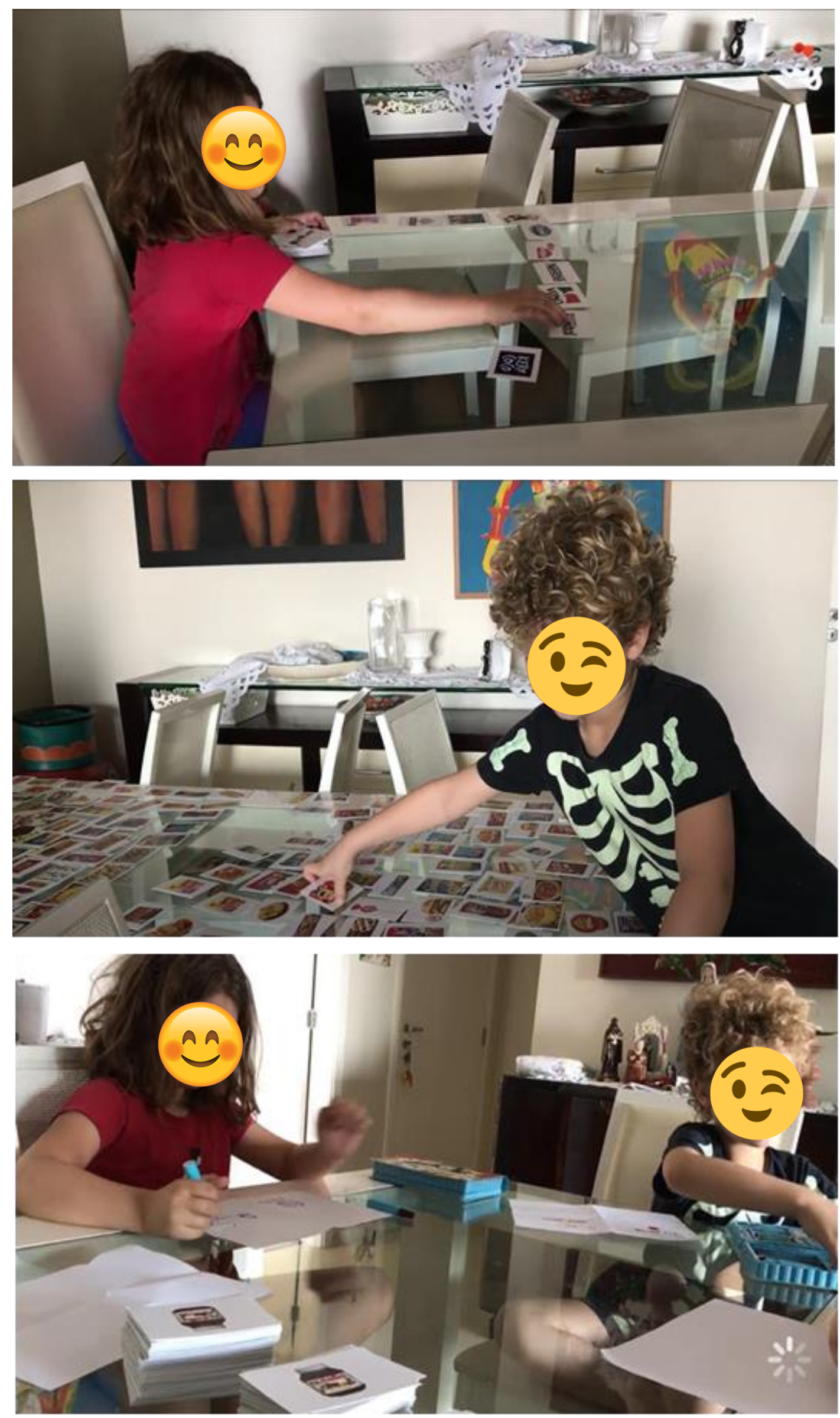
PARTICIPAÇÃO DAS CRIANÇAS NA ATIVIDADE LÚDICA

SEGUNDA FAMÍLIA
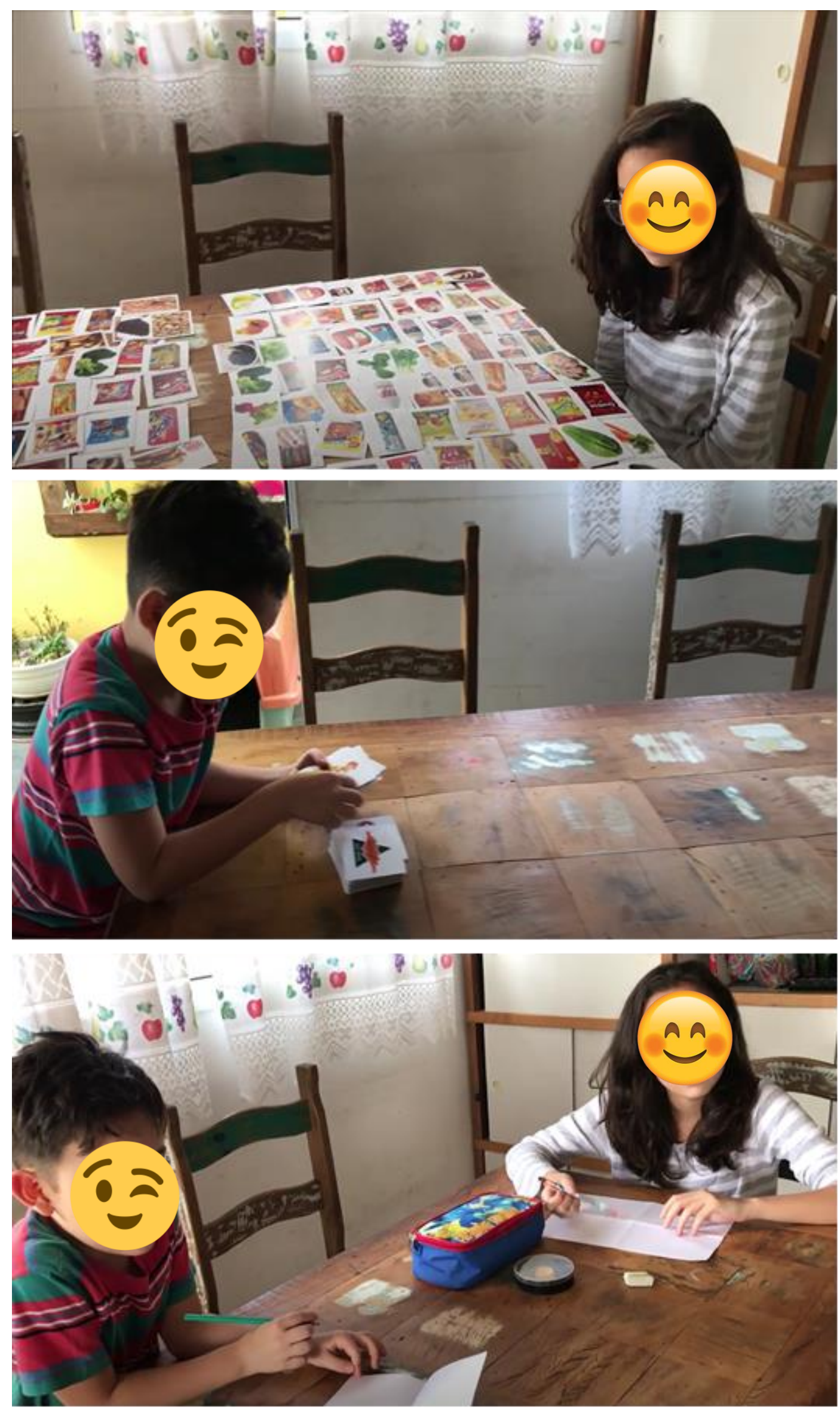
PARTICIPAÇÃO DAS CRIANÇAS NA ATIVIDADE LÚDICA

TERCEIRA FAMÍLIA
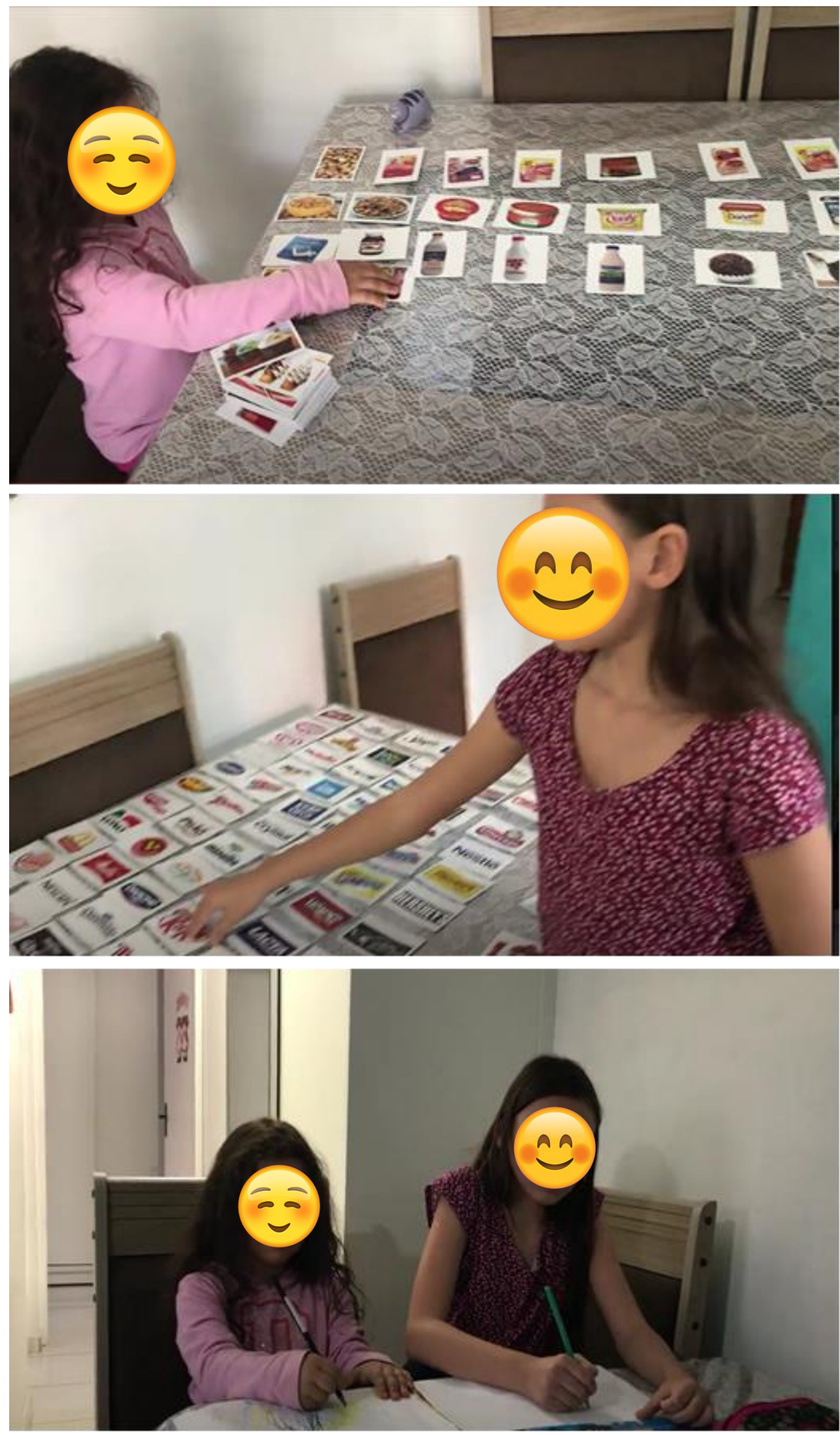
COMPOSIÇÕES ALIMENTARES

PRIMEIRA FAMÍLIA

CAFÉ DA MANHÃ

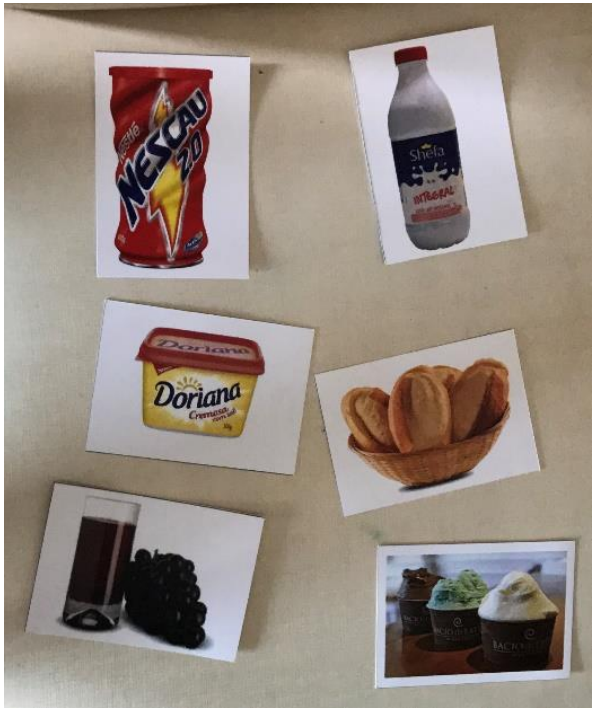

Menina

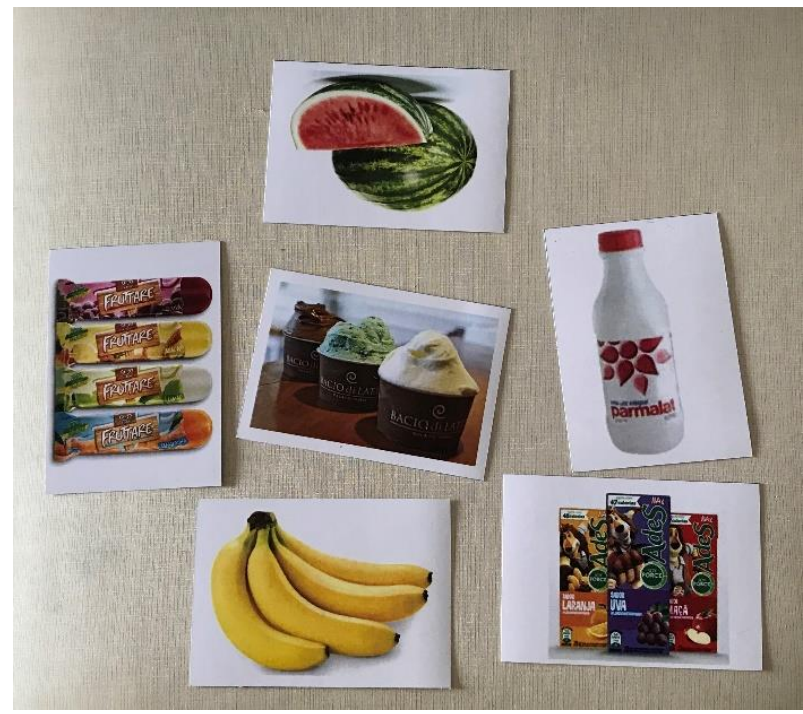

Menino

ALMOÇO

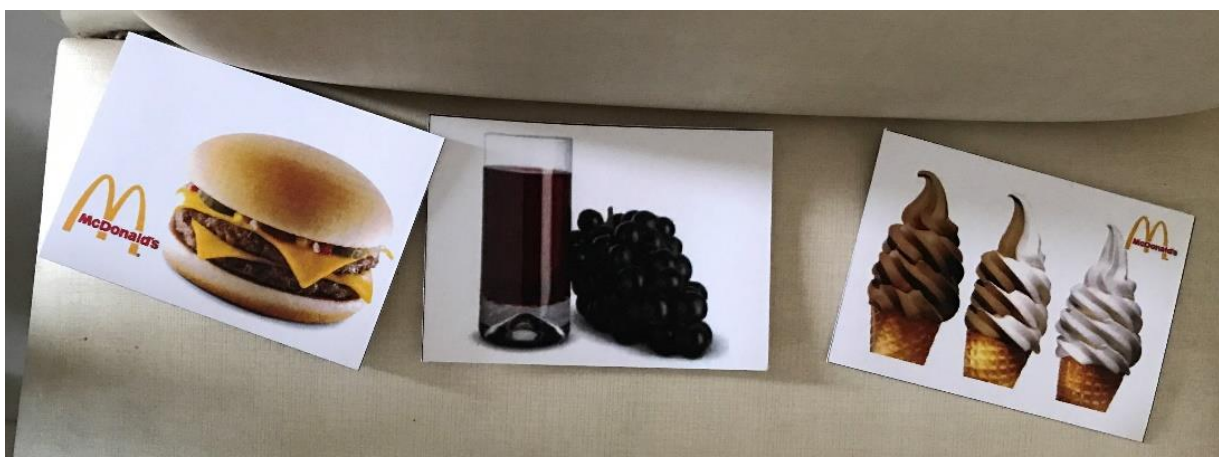

Menina

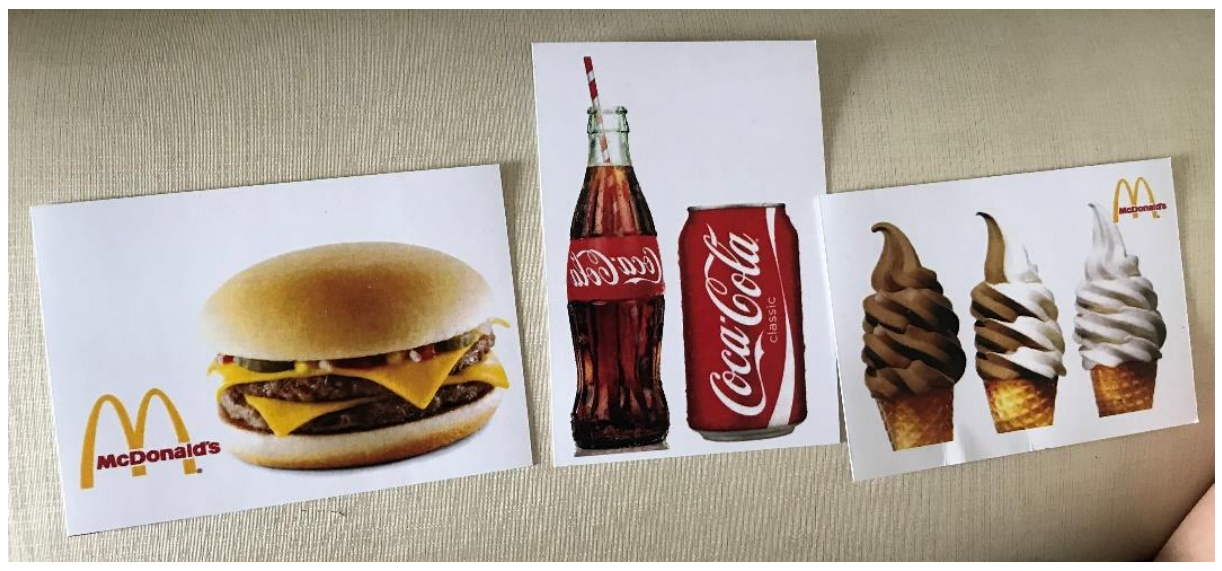

Menino 
JANTAR

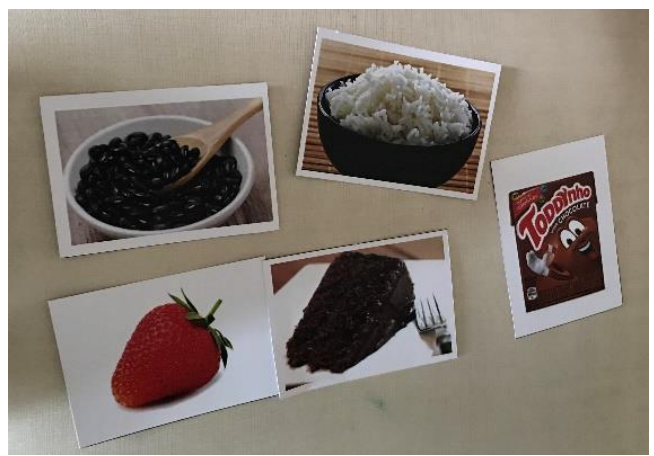

Menina

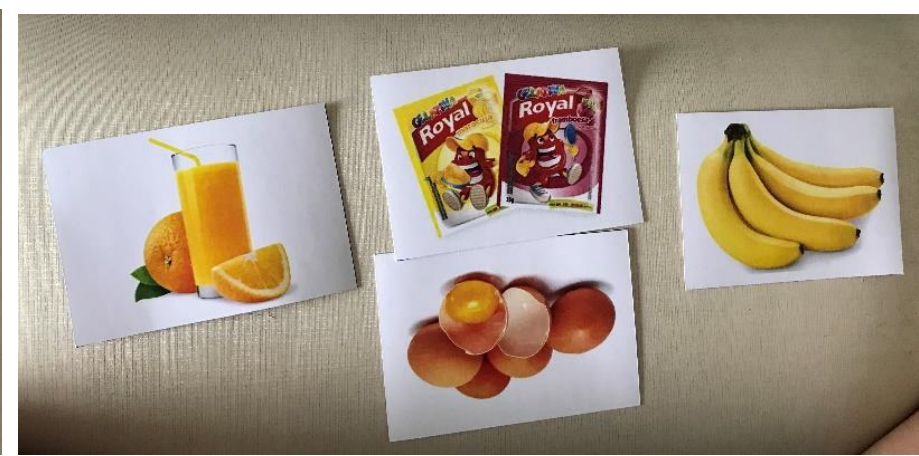

Menino

LANCHE DA ESCOLA

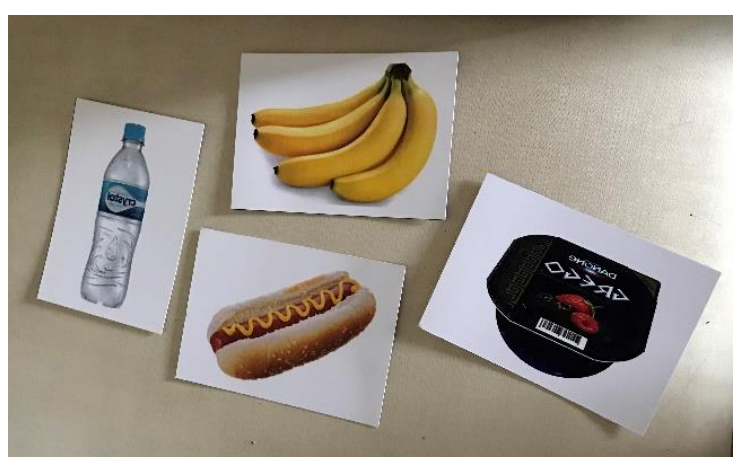

Menina

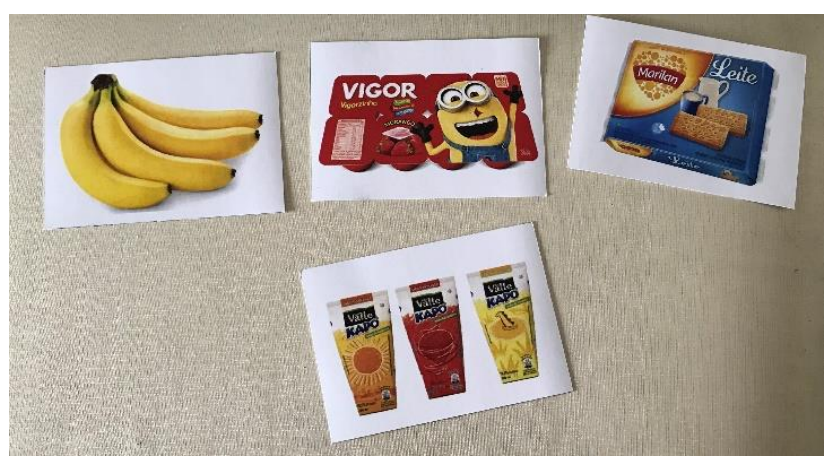

Menino

LANCHE COM AMIGOS
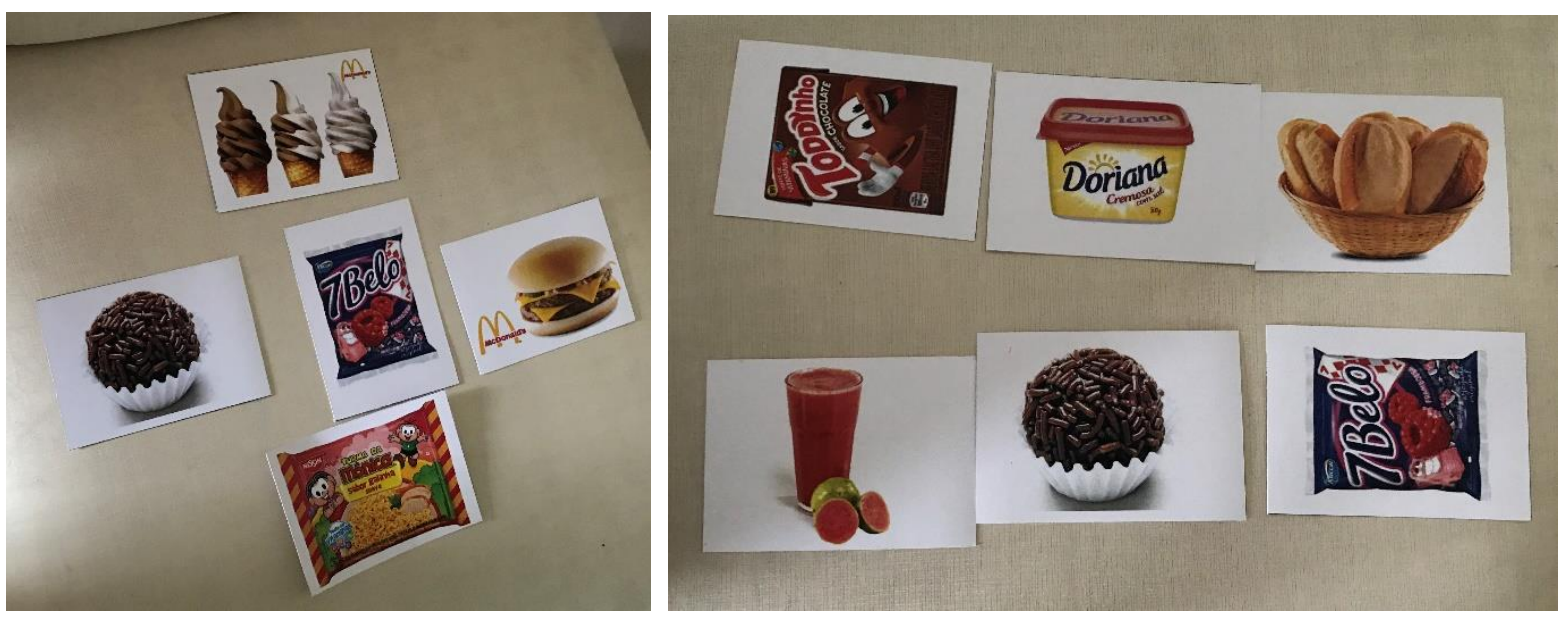

Menina

Menino 
MARCAS QUE GOSTA / NÃO GOSTA

PRIMEIRA FAMÍLIA

\section{MARCAS QUE GOSTA / GOSTA MAIS}

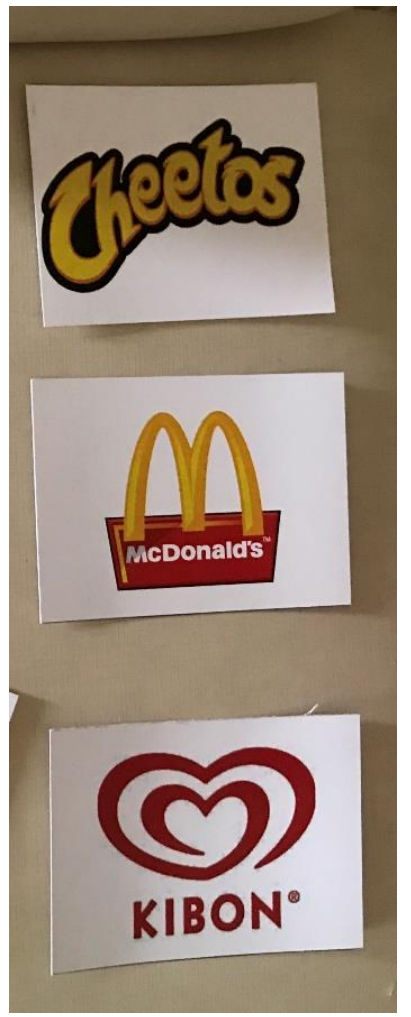

Menina

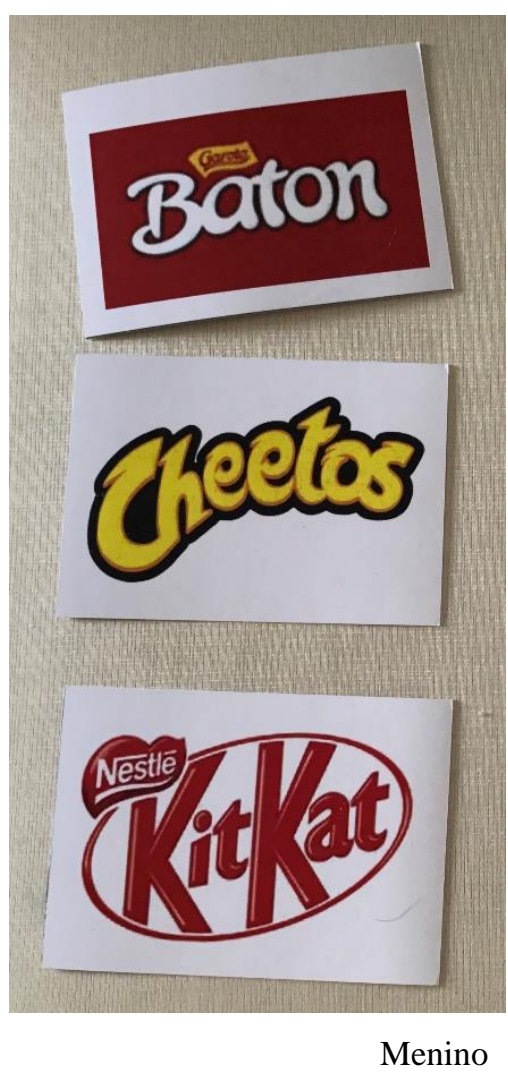

Menino

MARCAS QUE NÃO GOSTA / GOSTA MENOS
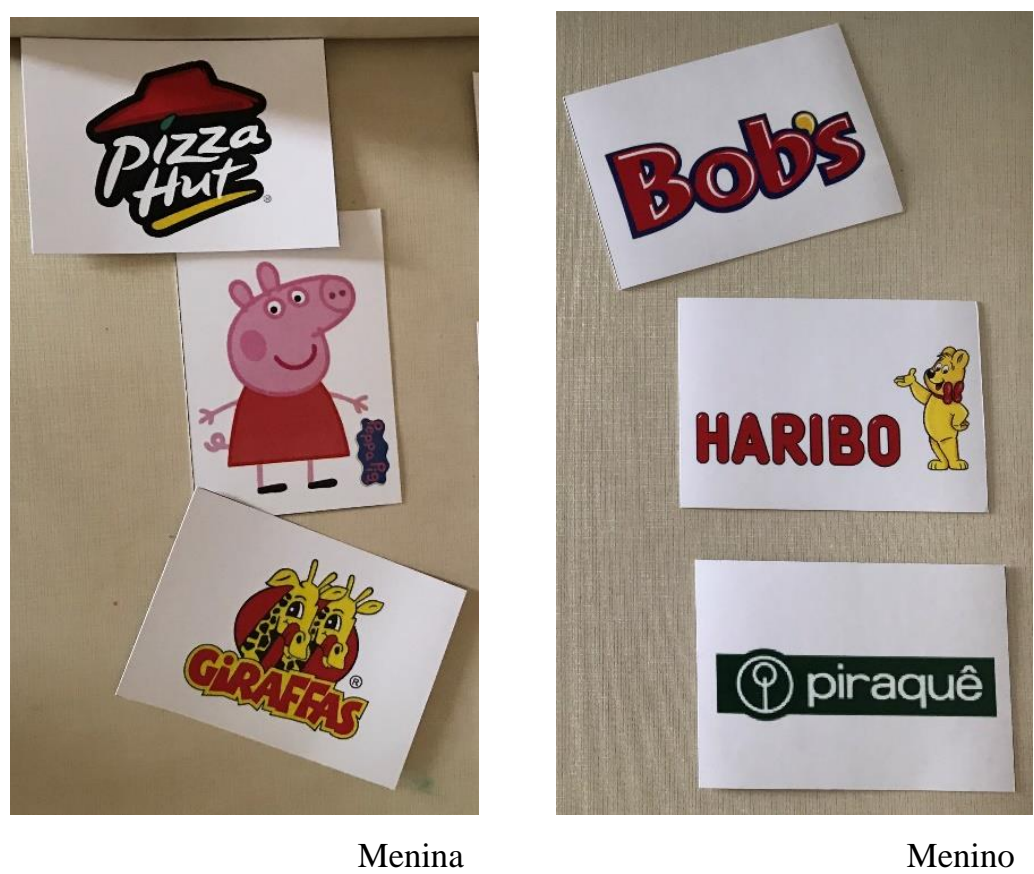
DESENHOS CONSUMO ALIMENTAR

PRIMEIRA FAMÍLIA
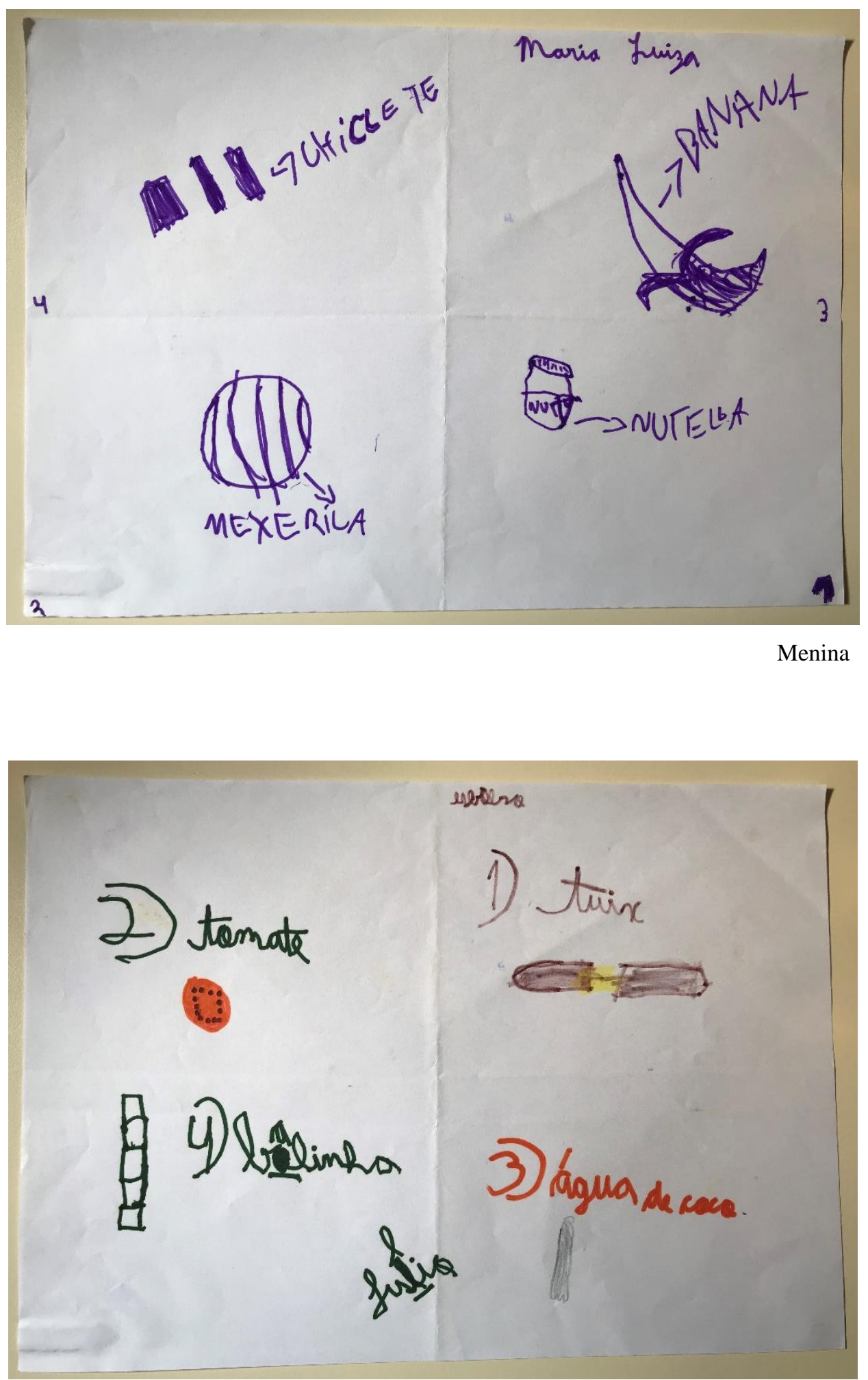

Menino 
602

DESENHOS MARCAS E PERSONAGENS

PRIMEIRA FAMÍLIA

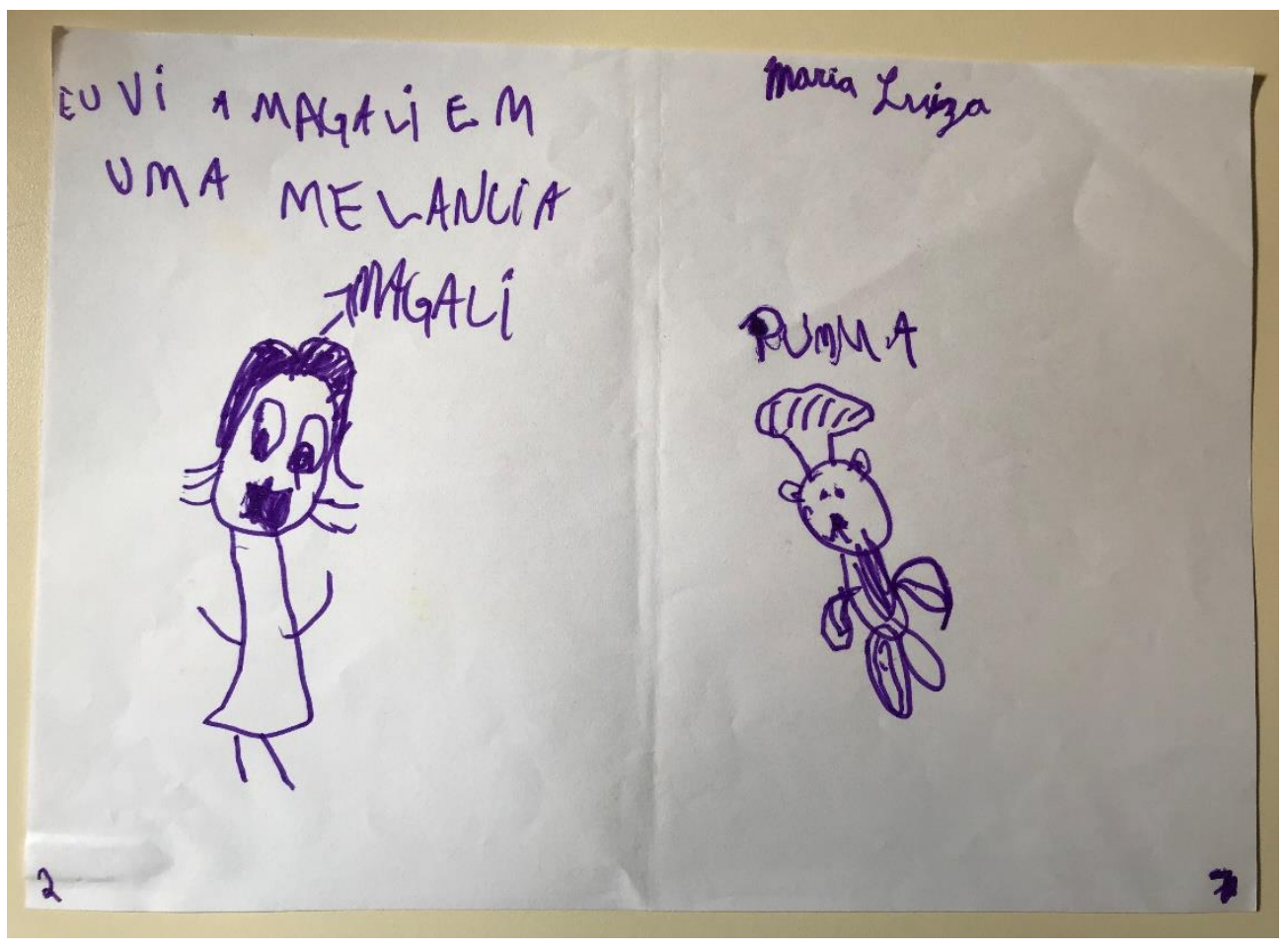

Menina

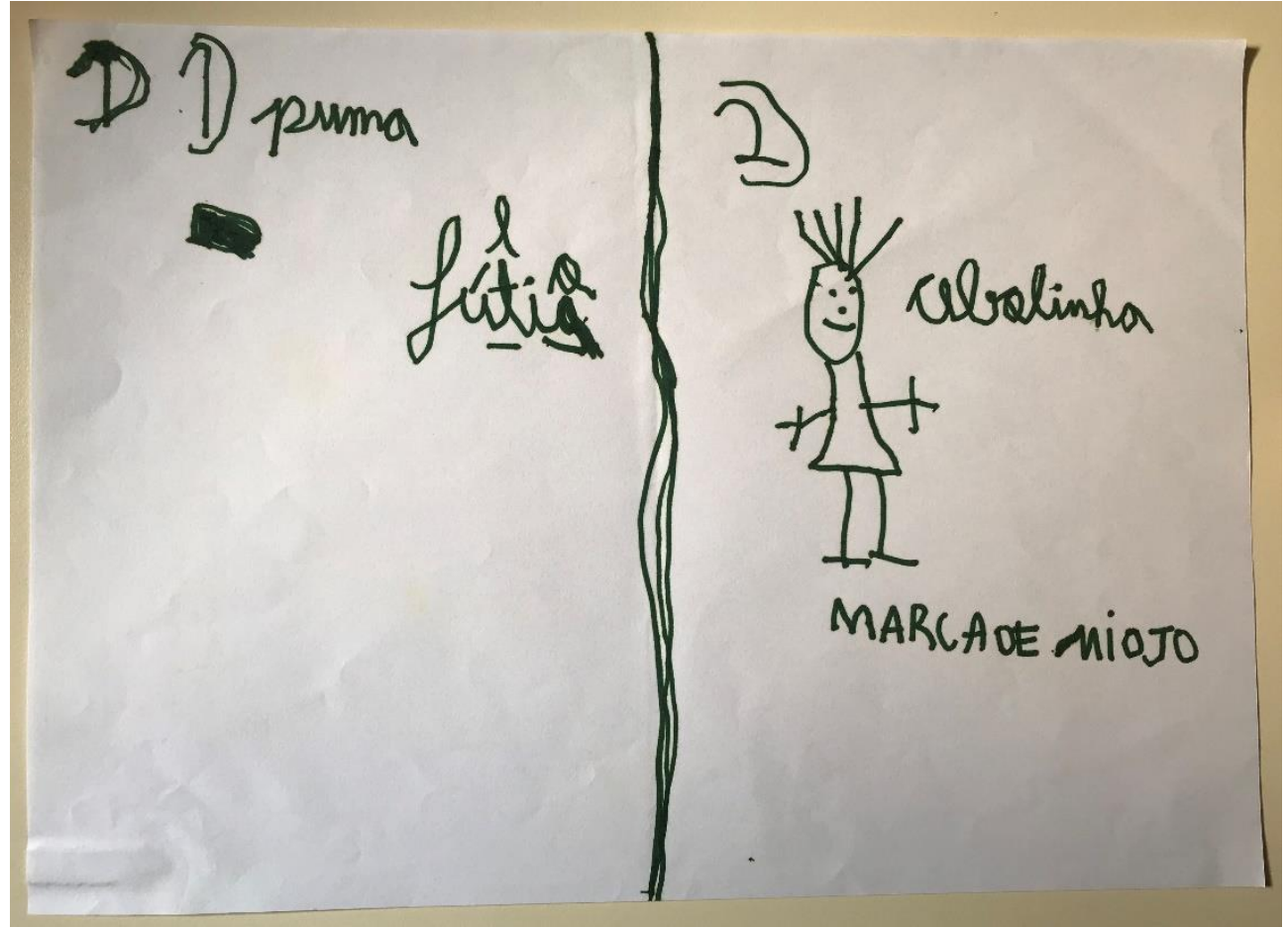

Menino 
COMPOSIÇÕES ALIMENTARES

SEGUNDA FAMÍLIA

CAFÉ DA MANHÃ

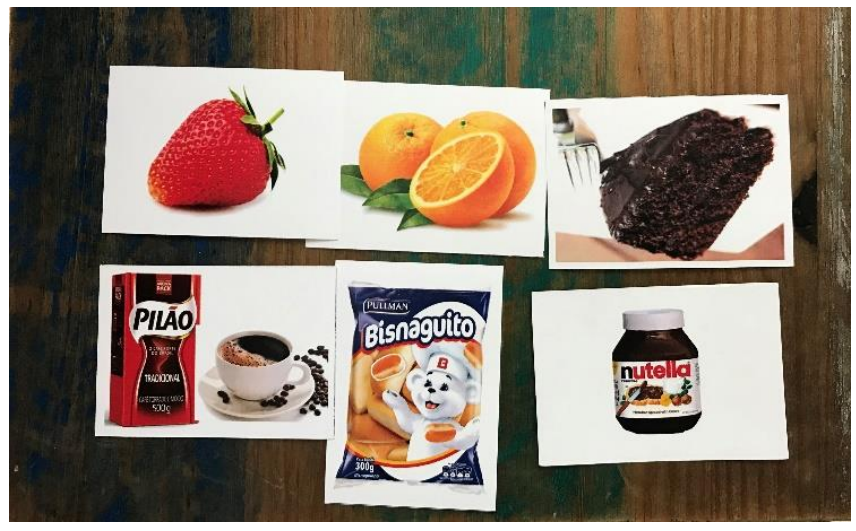

Menina

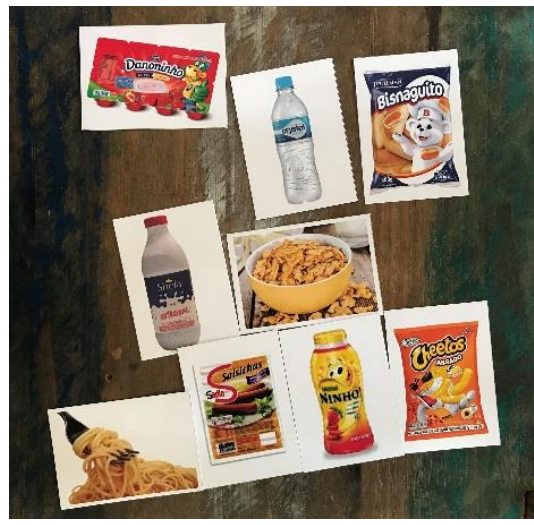

Menino

\section{ALMOÇO}

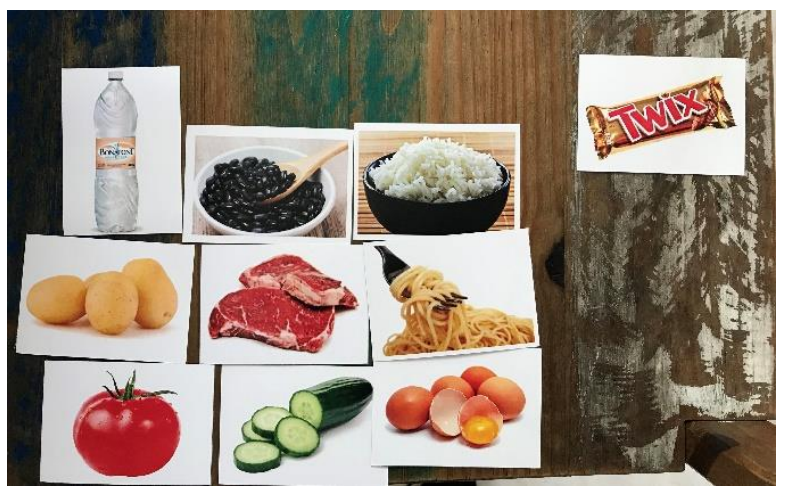

Menina

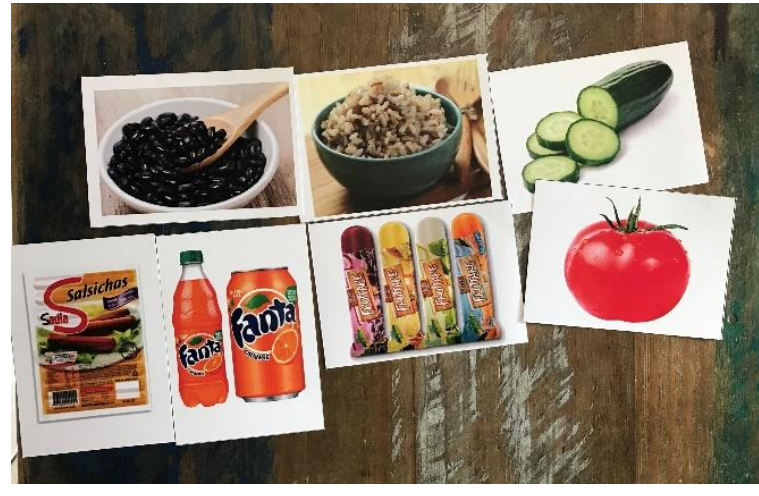

Menino

JANTAR

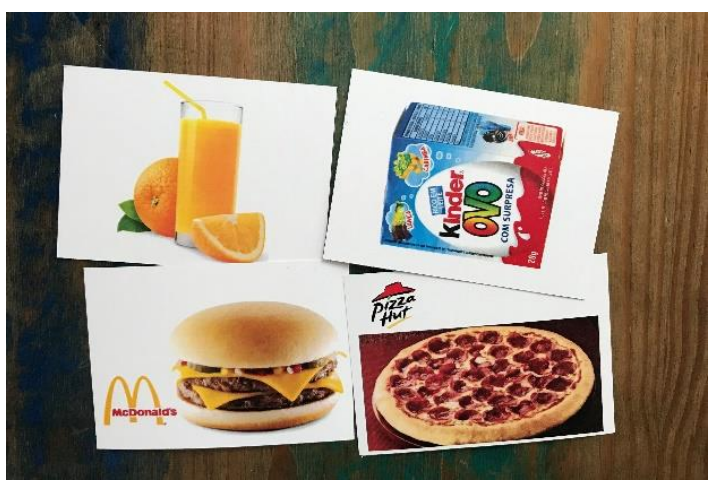

Menina

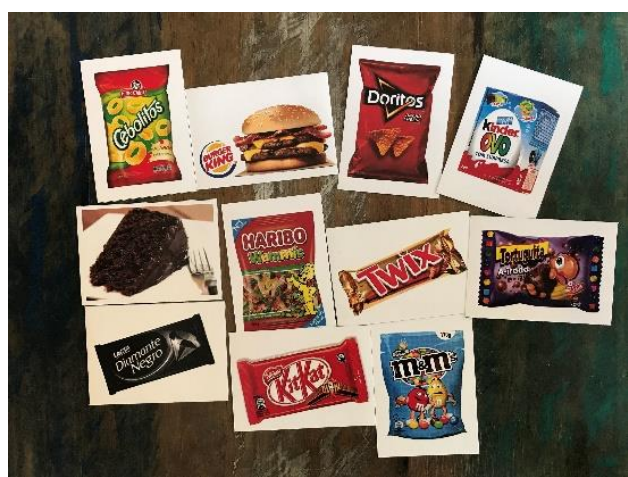

Menino 
LANCHE DA ESCOLA

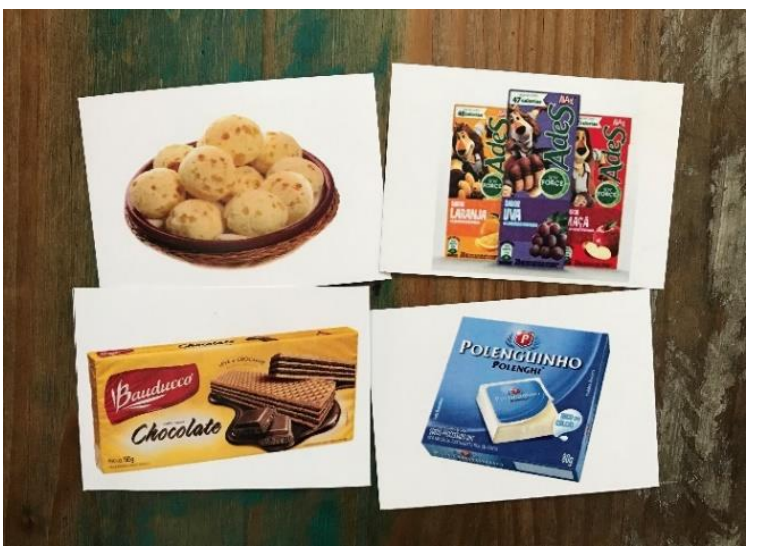

Menina

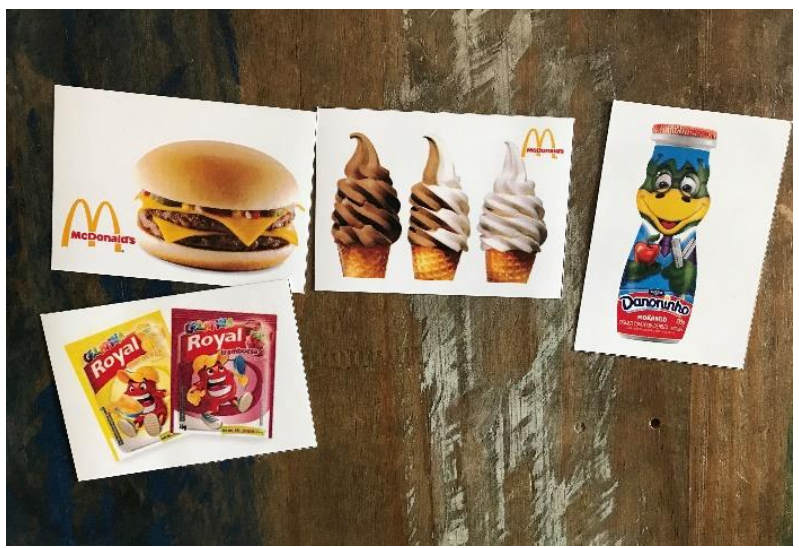

Menino

LANCHE COM AMIGOS
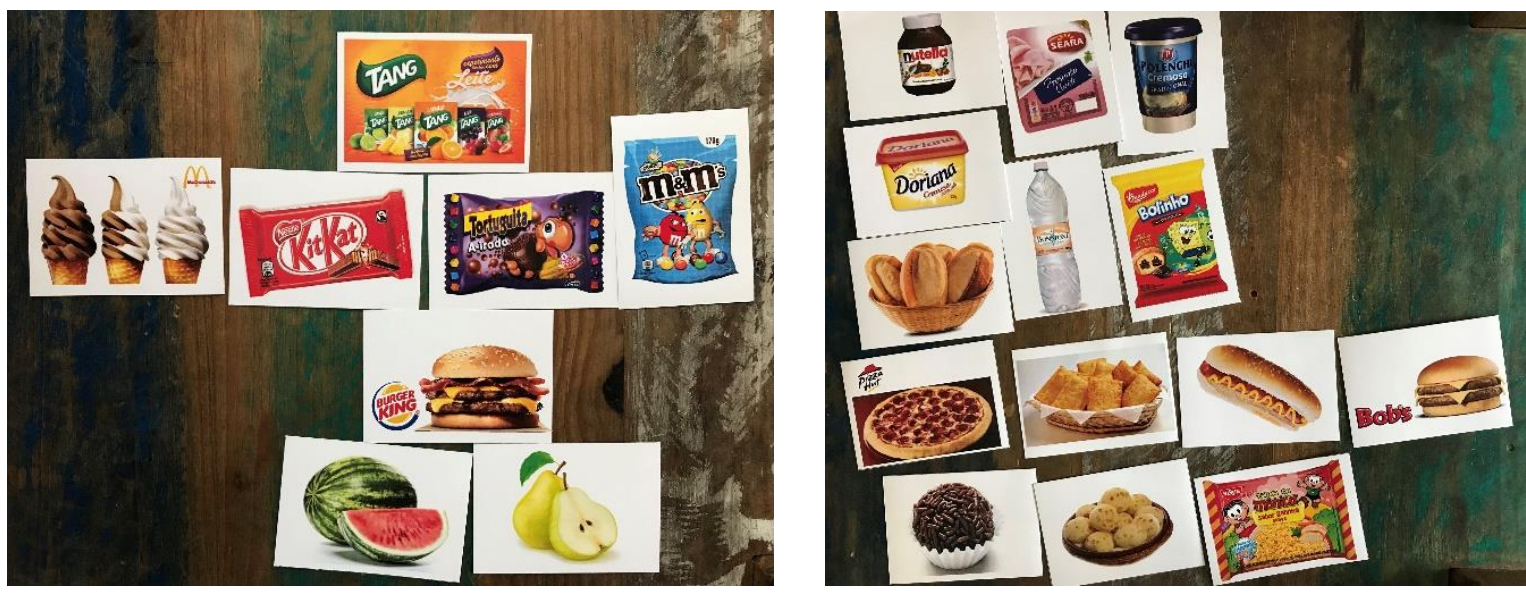

Menina

Menino 
MARCAS QUE GOSTA / NÃO GOSTA

SEGUNDA FAMÍLIA

MARCAS QUE GOSTA / GOSTA MAIS

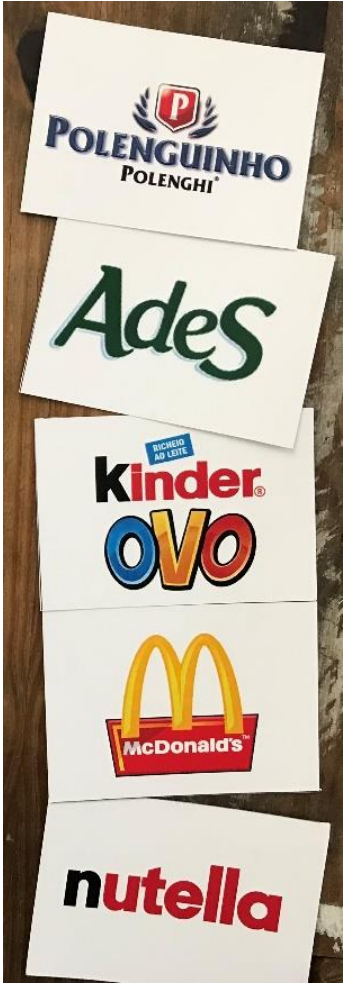

Menina

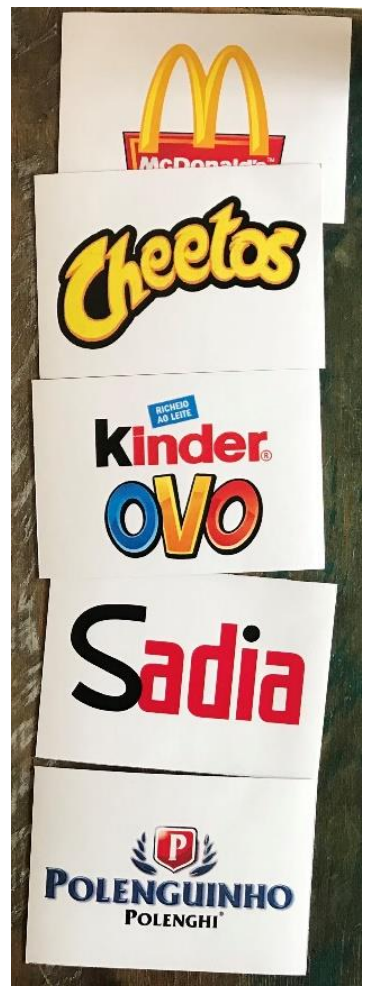

Menino

MARCAS QUE NÃO GOSTA / GOSTA MENOS

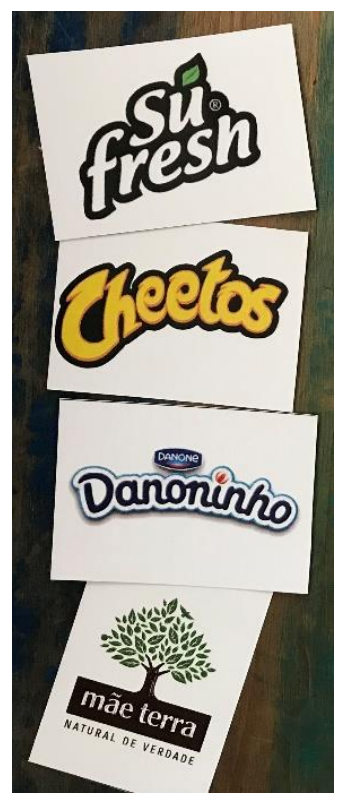

Menina

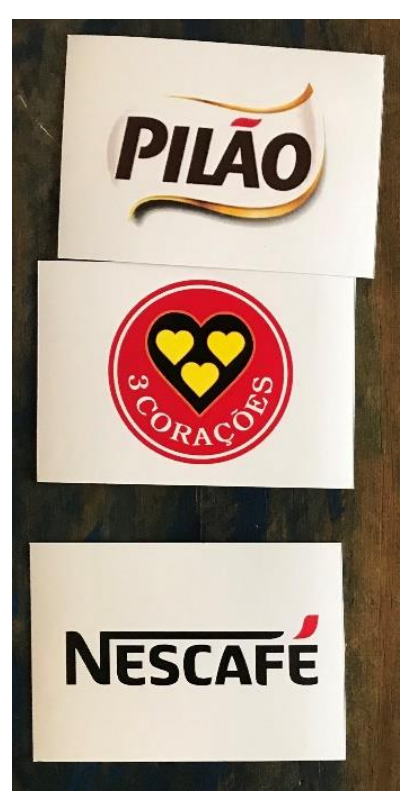

Menino 
DESENHOS CONSUMO ALIMENTAR

SEGUNDA FAMÍLIA

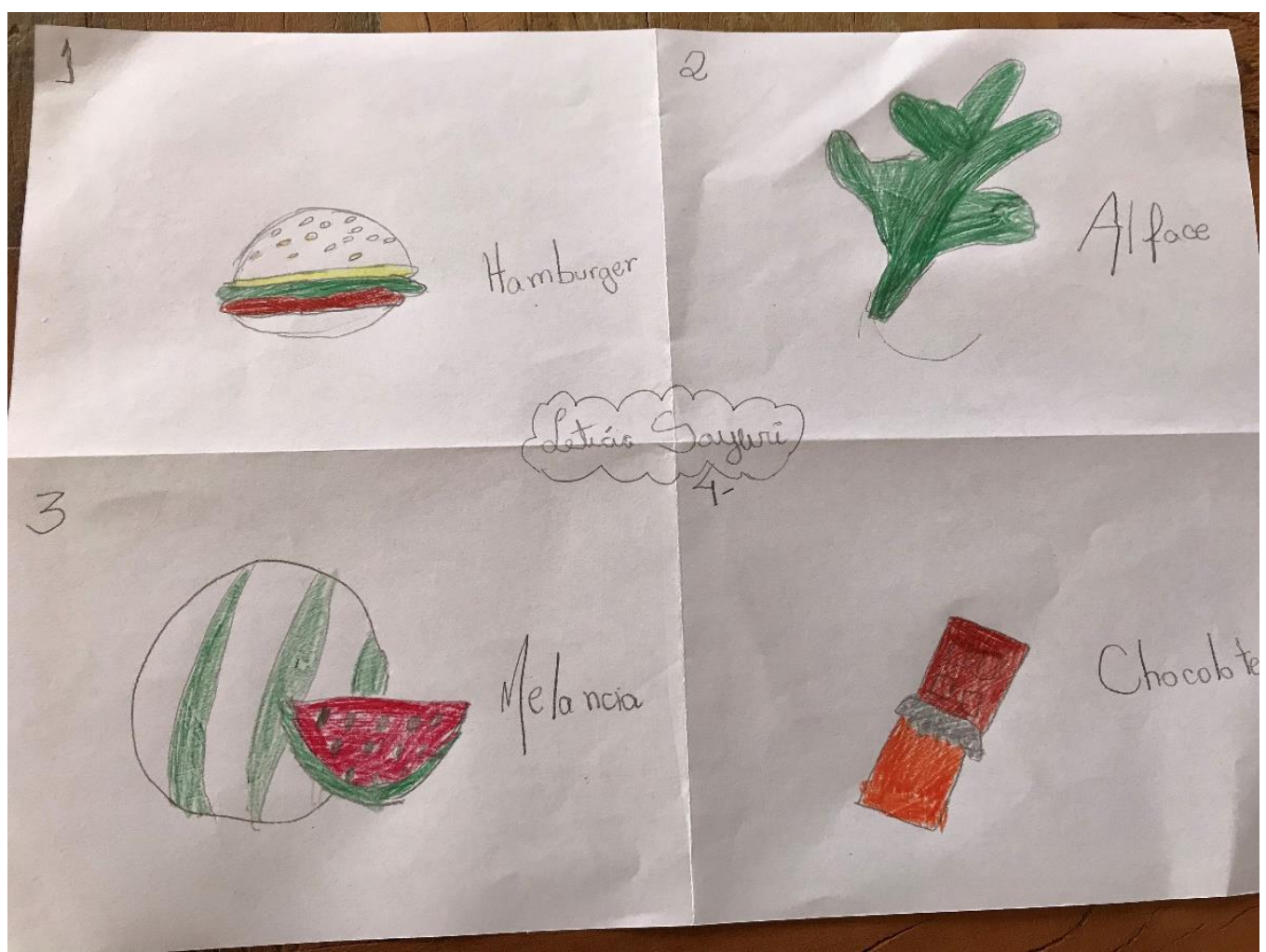

Menina

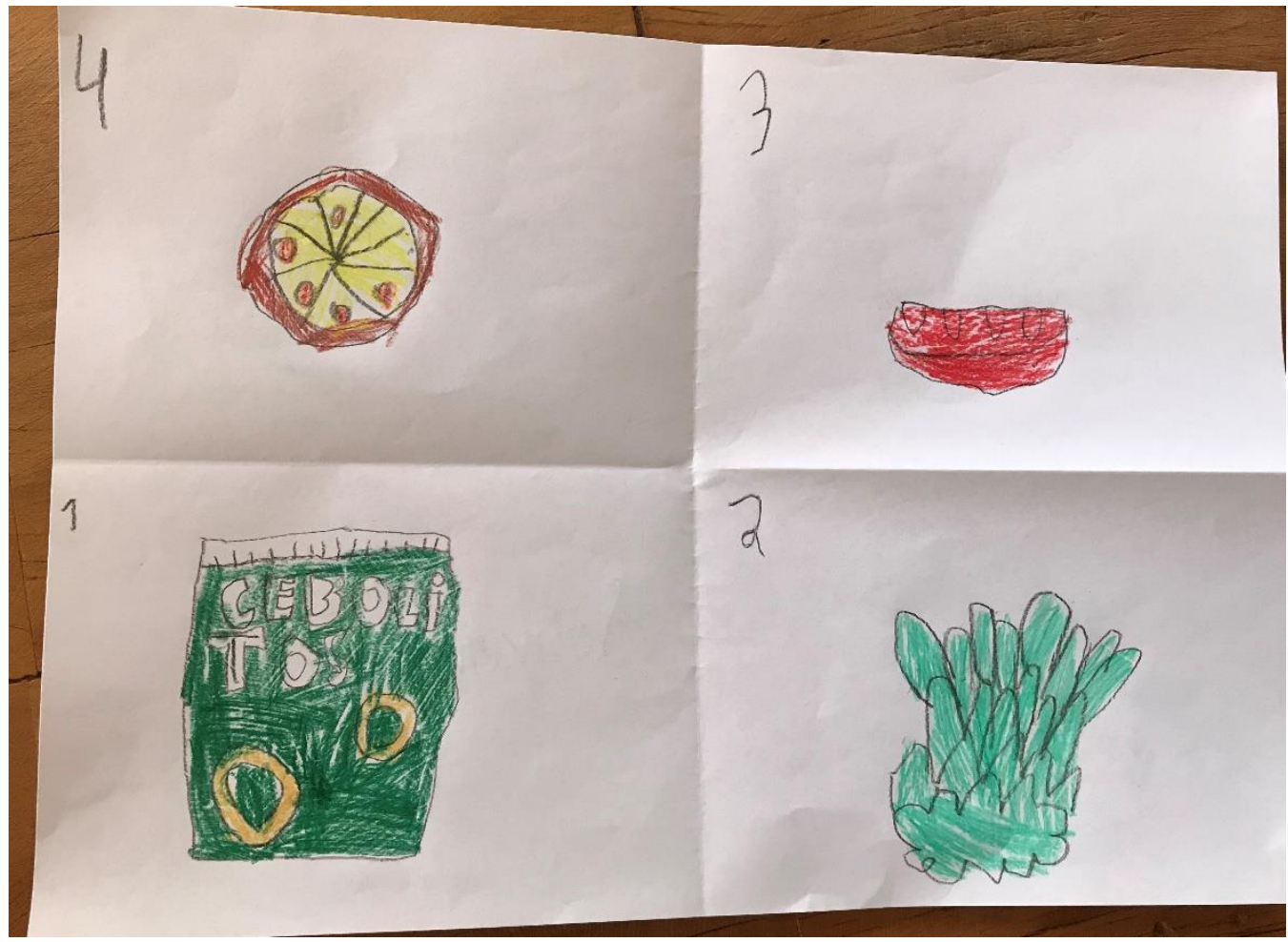


DESENHOS MARCAS E PERSONAGENS

SEGUNDA FAMÍLIA

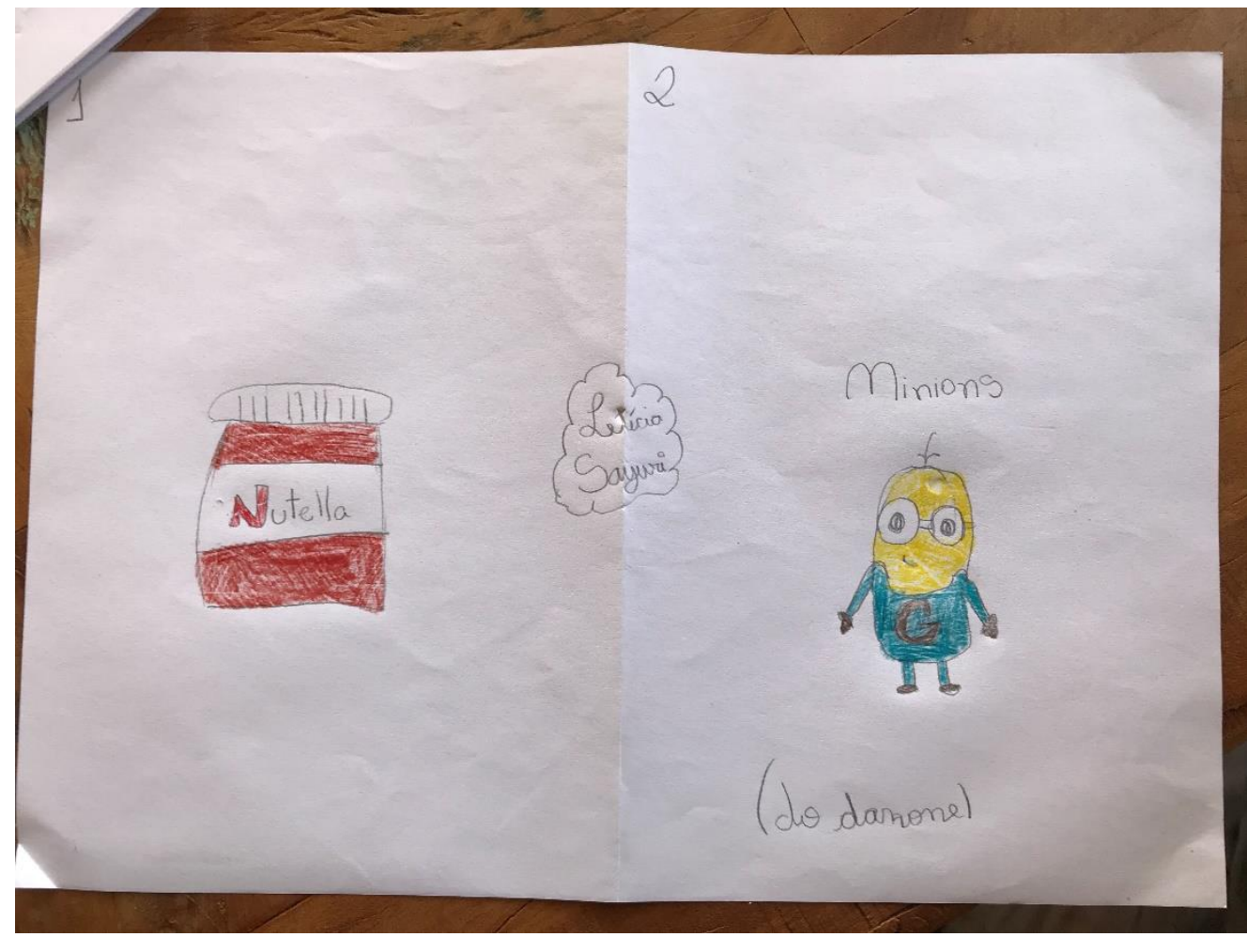

Menina

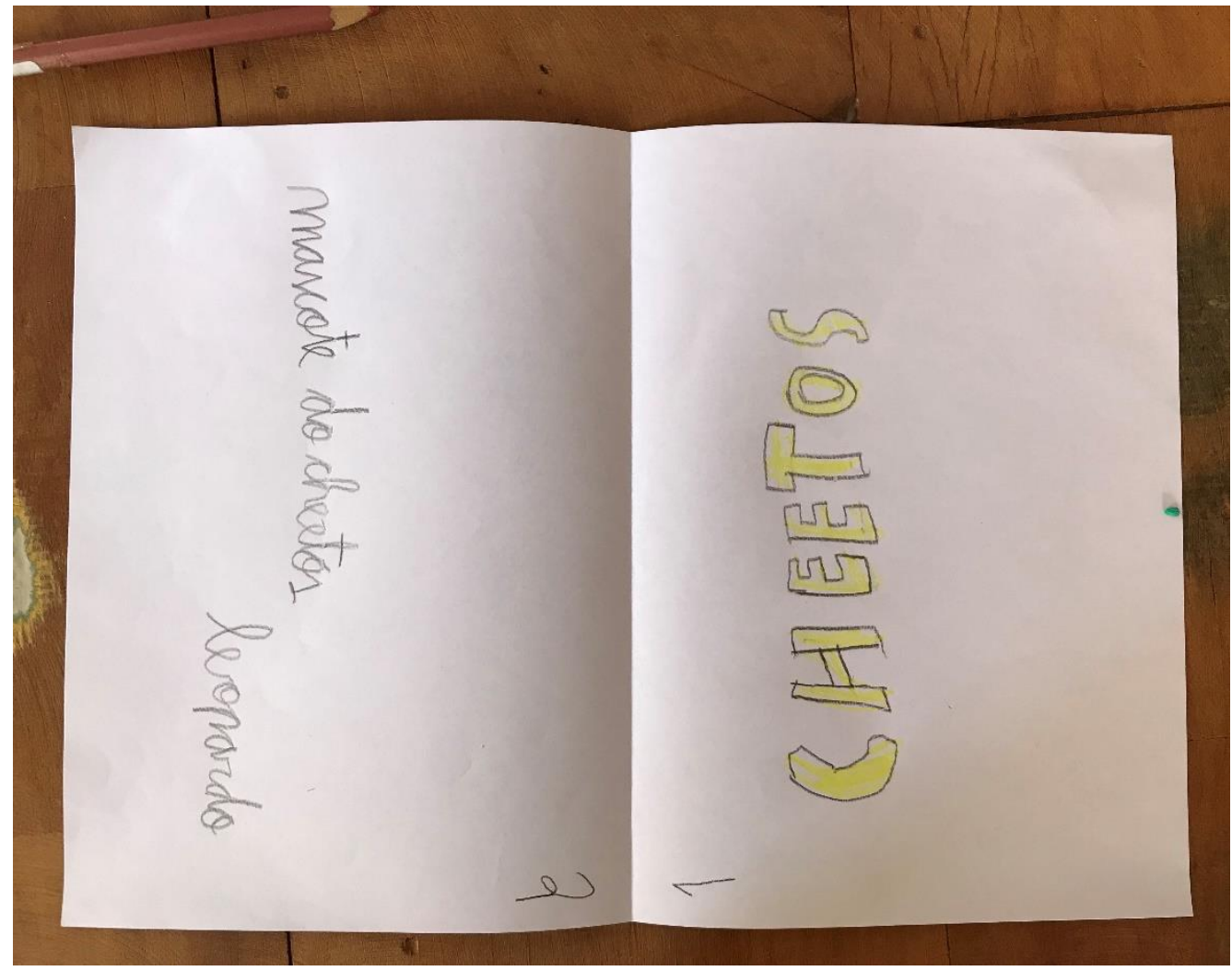


COMPOSIÇÕES ALIMENTARES

TERCEIRA FAMÍLIA

CAFÉ DA MANHÃ

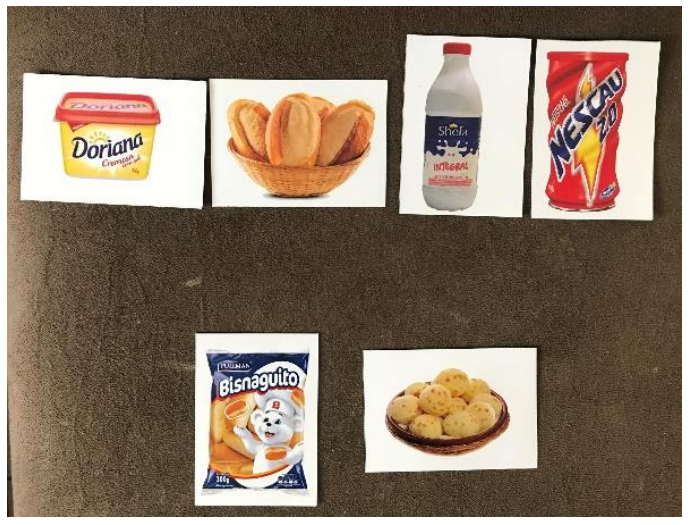

Menina mais velha

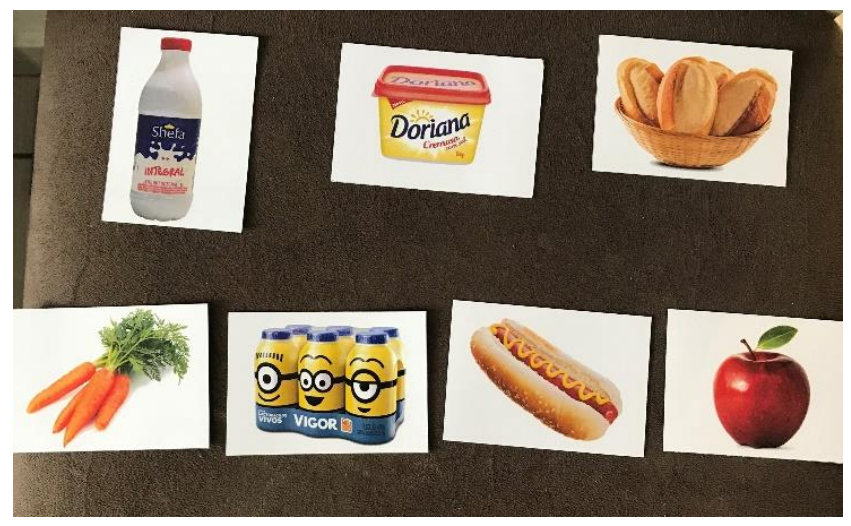

Menina mais nova

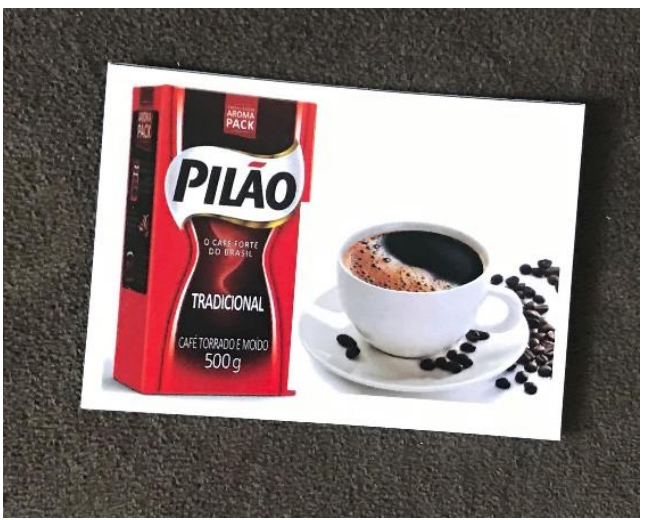

Menina mais nova
ALMOÇO

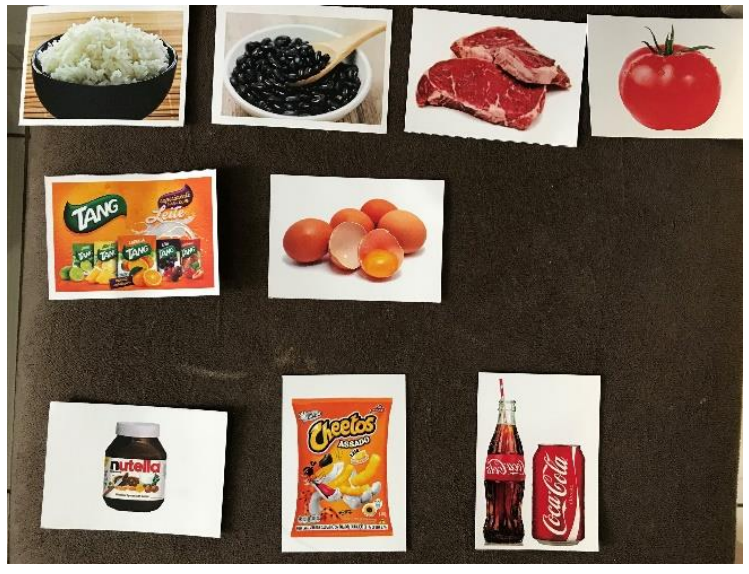

Menina mais velha

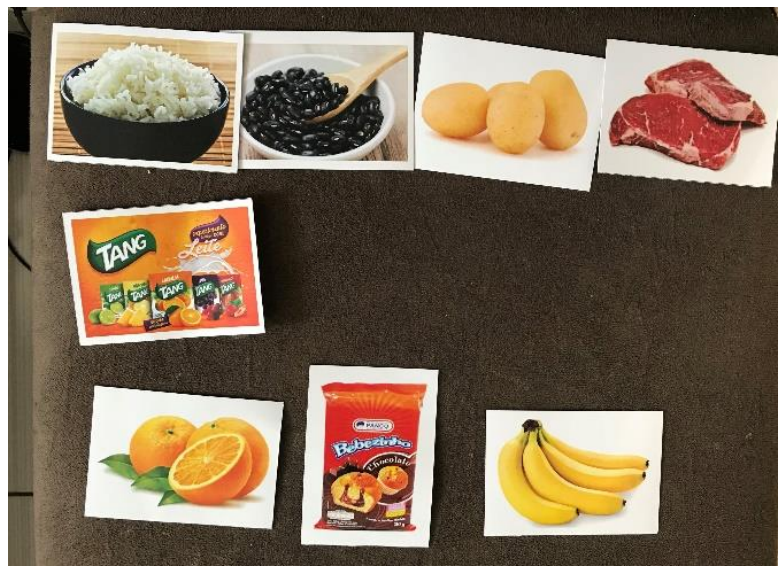

Menina mais nova 


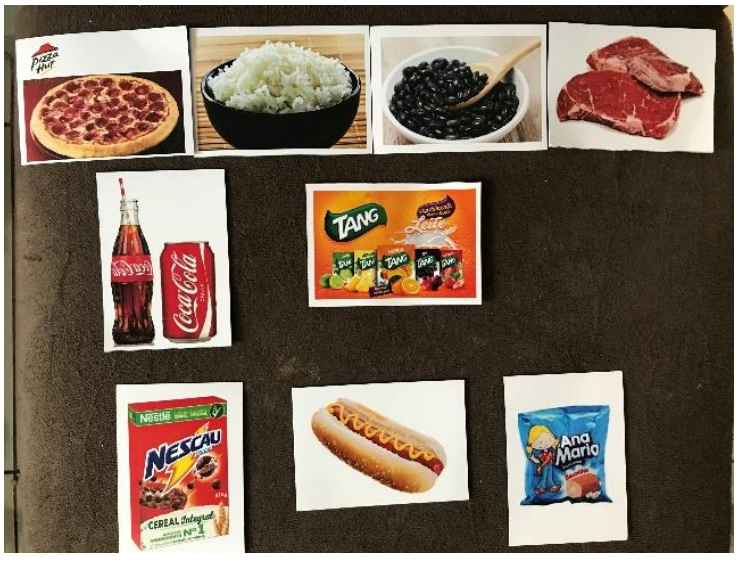

Menina mais velha

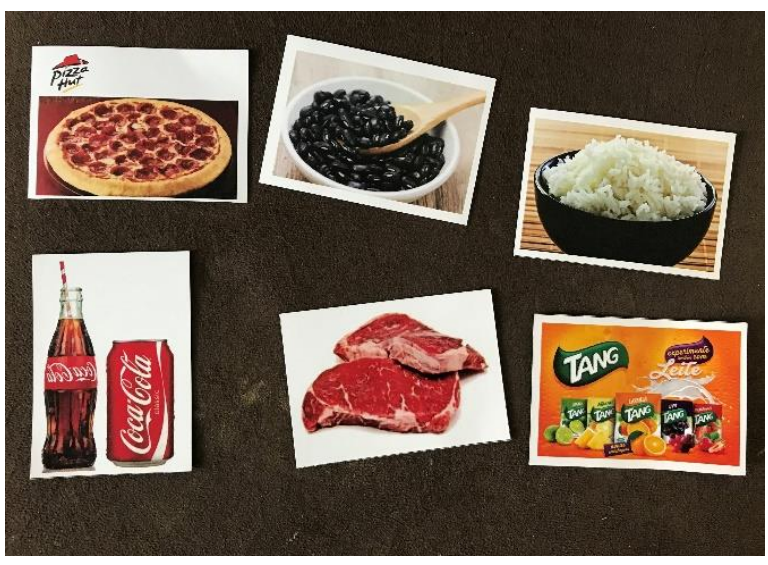

Menina mais nova

LANCHE DA ESCOLA

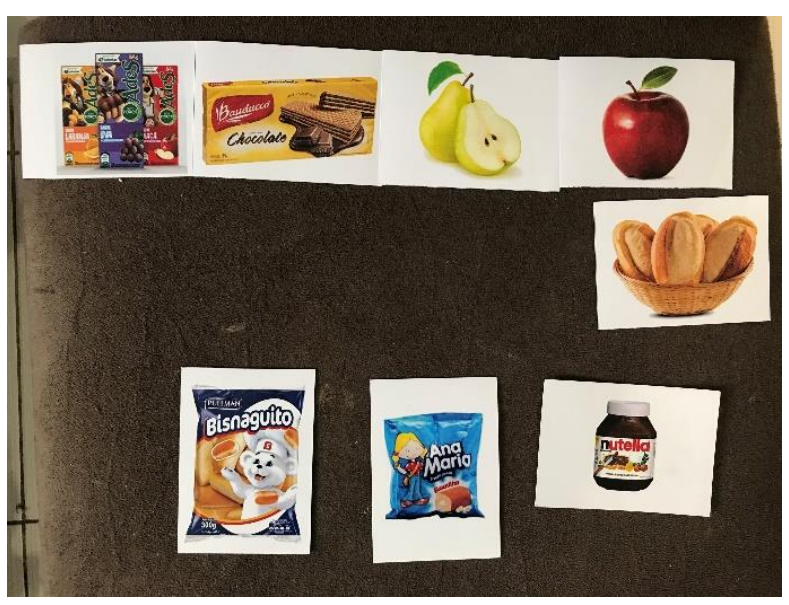

Menina mais velha

LANCHE COM AMIGOS

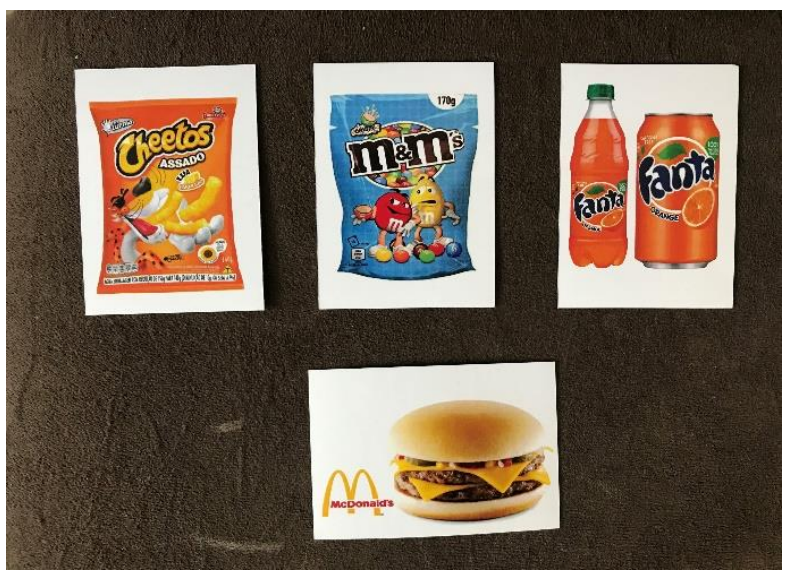

Menina mais velha 
MARCAS QUE GOSTA / NÃO GOSTA

TERCEIRA FAMÍLIA

\section{MARCAS QUE GOSTA / GOSTA MAIS}
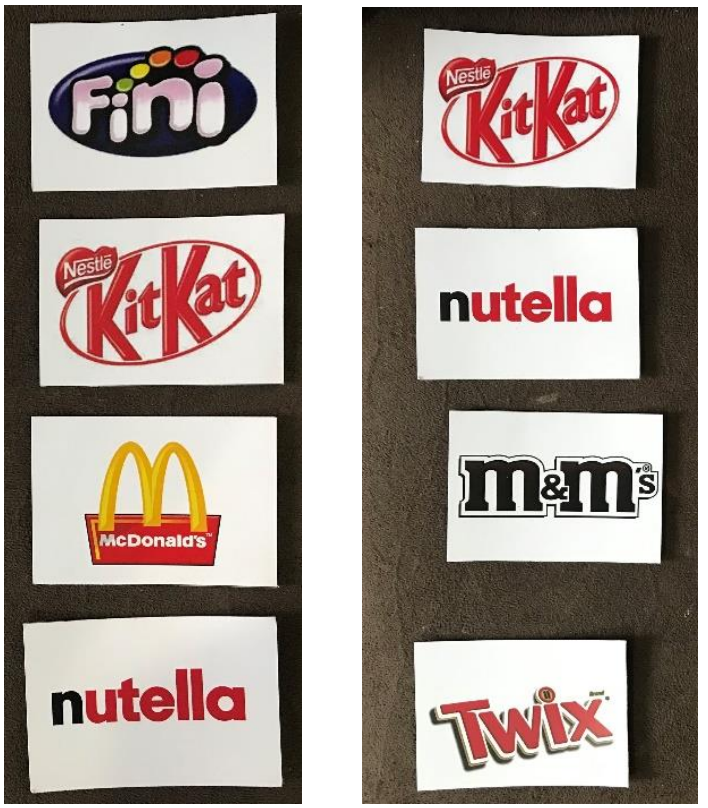

Menina mais velha

MARCAS QUE NÃO GOSTA / GOSTA MENOS

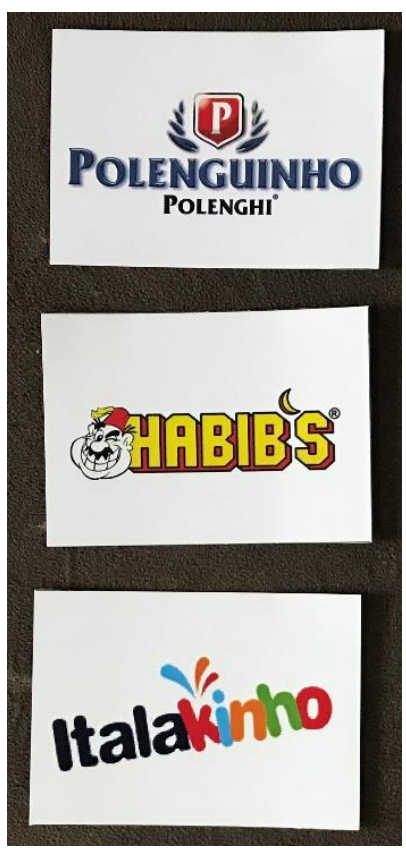

Menina mais velha 
MARCAS / PERSONAGENS

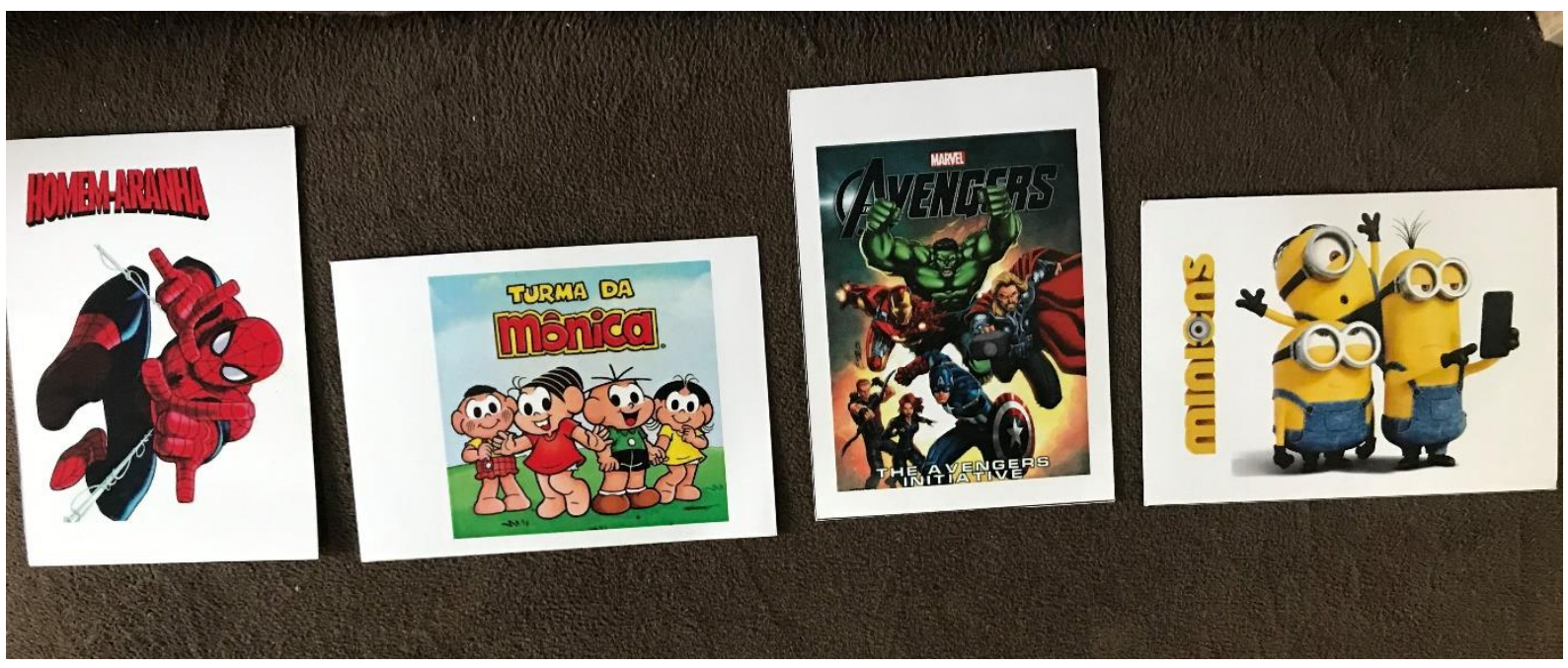

Menina mais velha

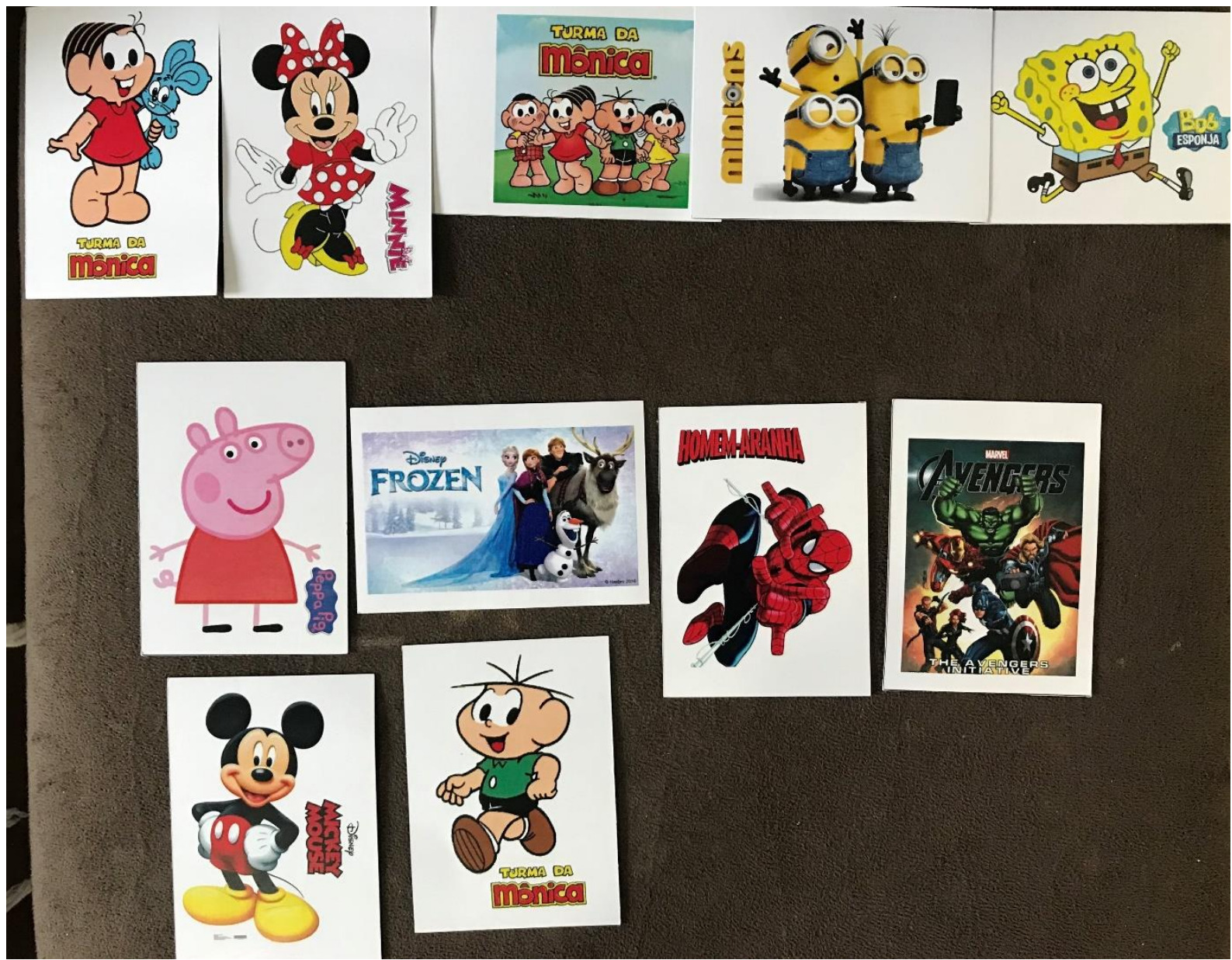

Menina mais nova 


\section{DESENHOS CONSUMO ALIMENTAR}

TERCEIRA FAMÍLIA
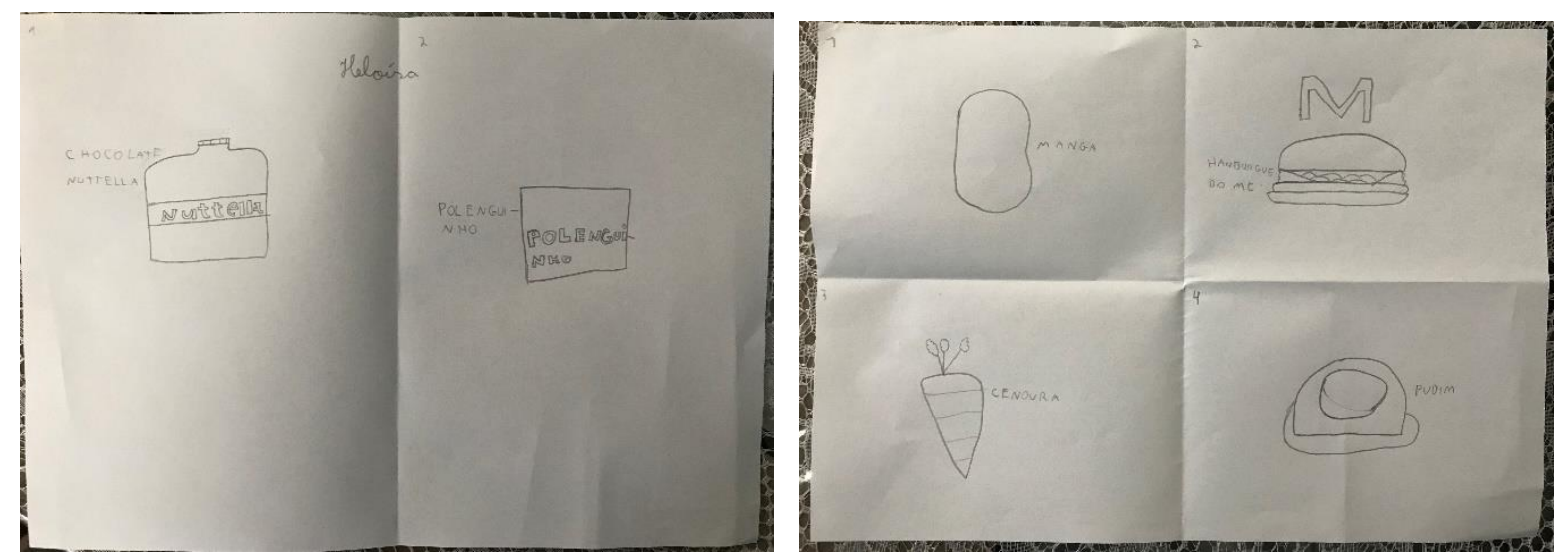

Menina mais velha

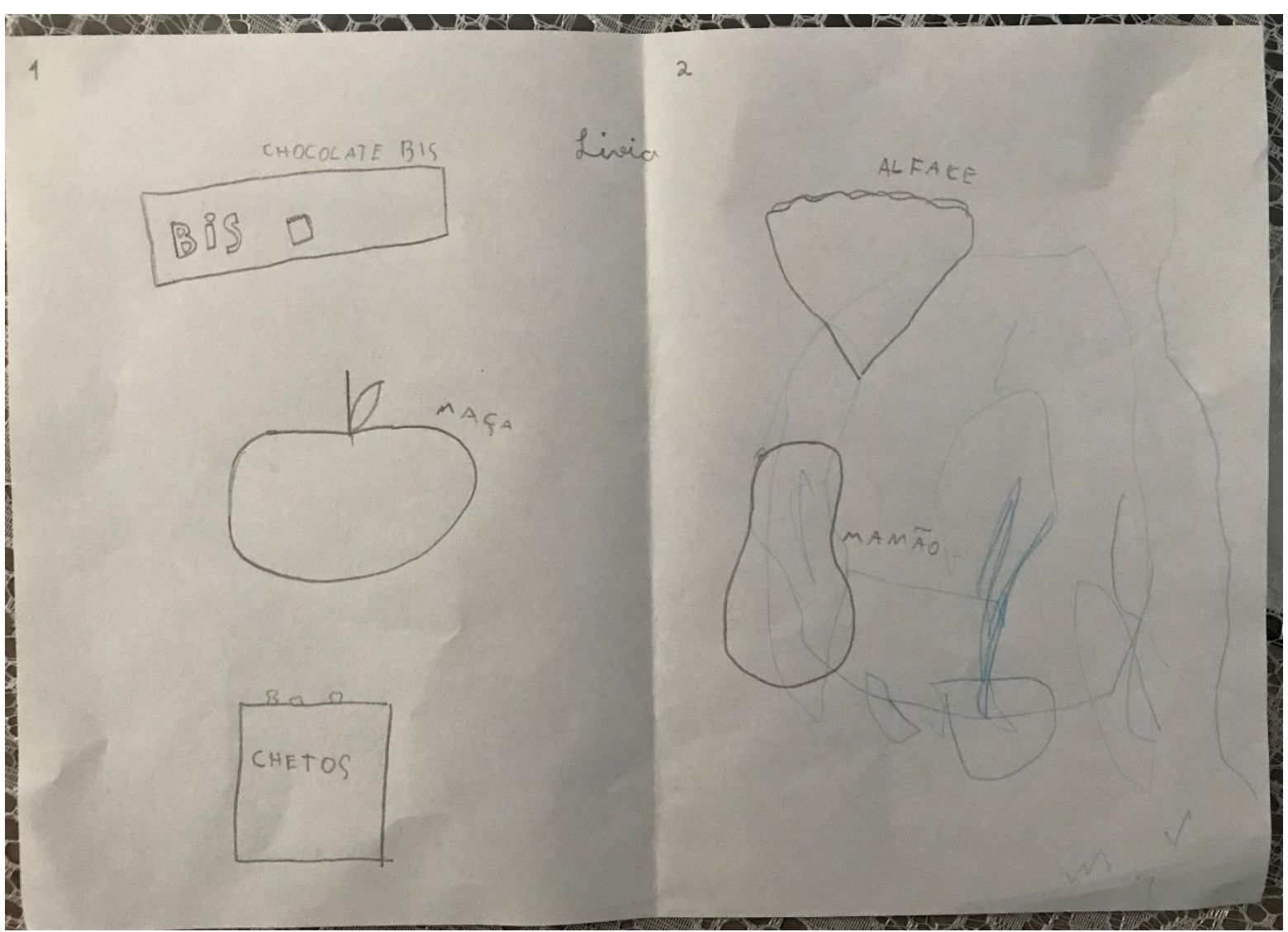

Menina mais nova 
DESENHOS MARCAS E PERSONAGENS

TERCEIRA FAMÍLIA

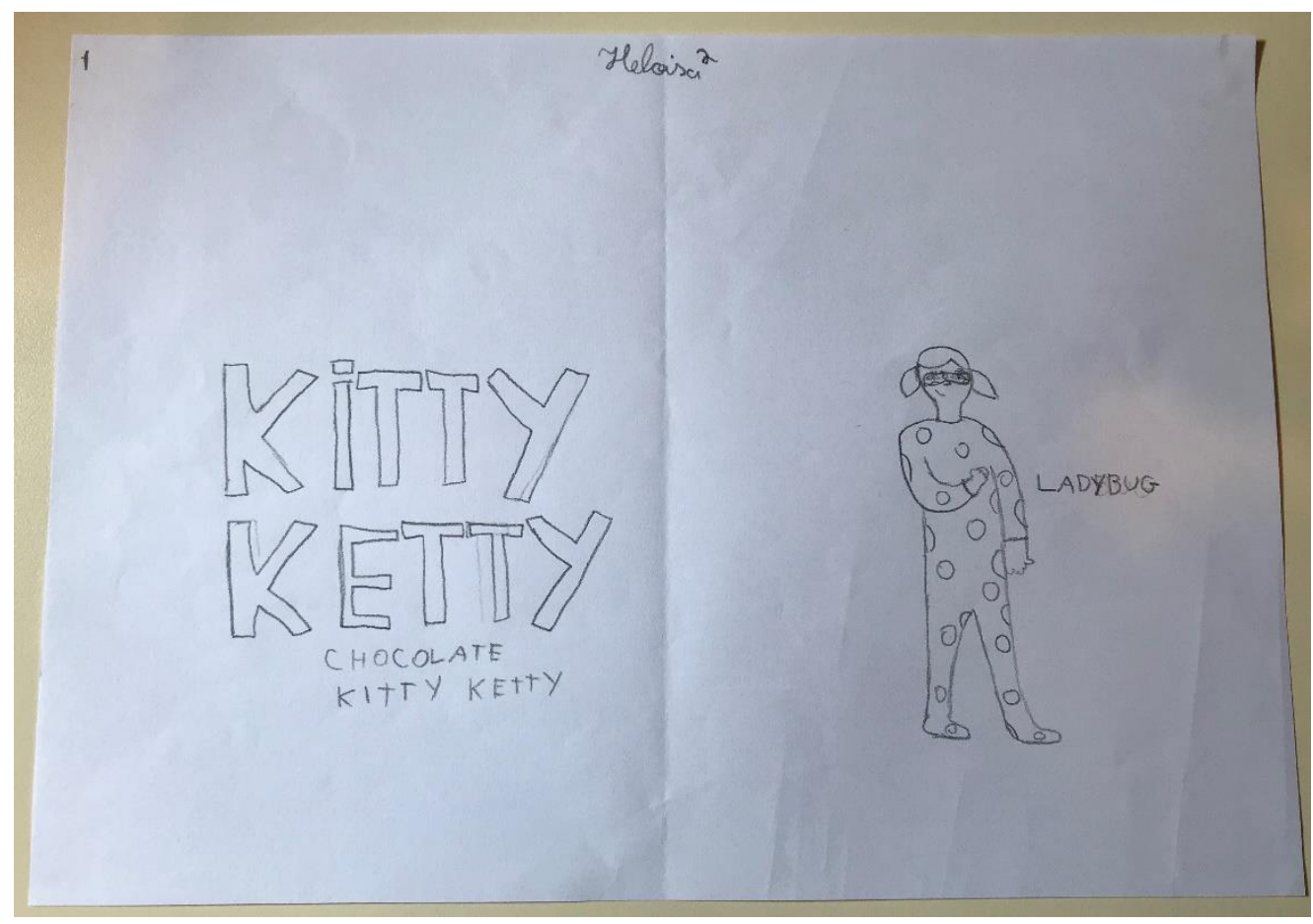

Menina mais velha

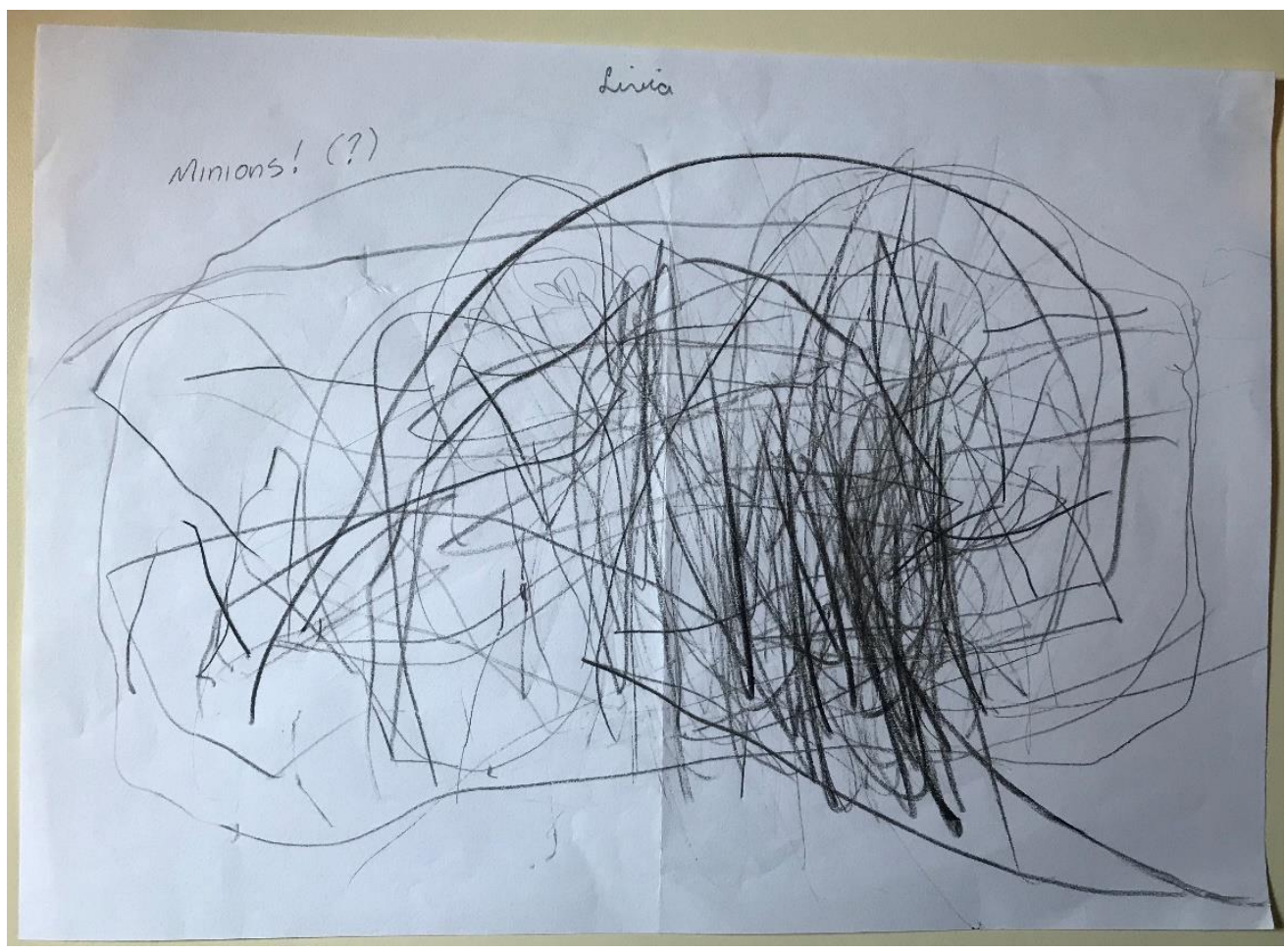

Menina mais nova 


\section{APÊNDICE U}

\section{BRINCADEIRA DE COMPRAR}

Imagens da participação das crianças na atividade lúdica.

Imagens das composições de marcas e produtos alimentícios escolhidos pelas crianças

na simulação de compras no supermercado. 
PARTICIPAÇÃO DAS CRIANÇAS NA ATIVIDADE LÚDICA

SEGUNDA FAMÍLIA
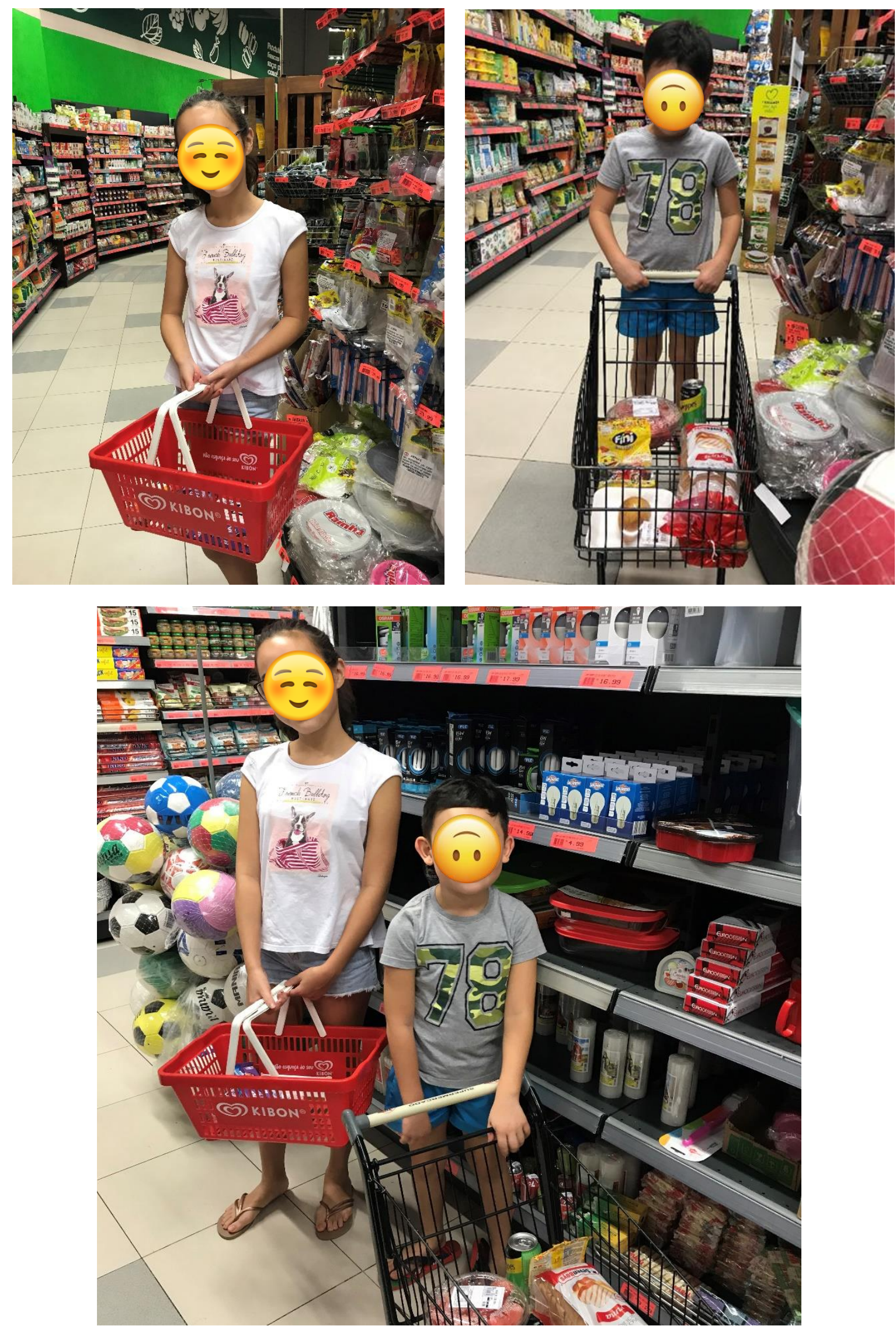
PARTICIPAÇÃO DAS CRIANÇAS NA ATIVIDADE LÚDICA

TERCEIRA FAMÍLIA
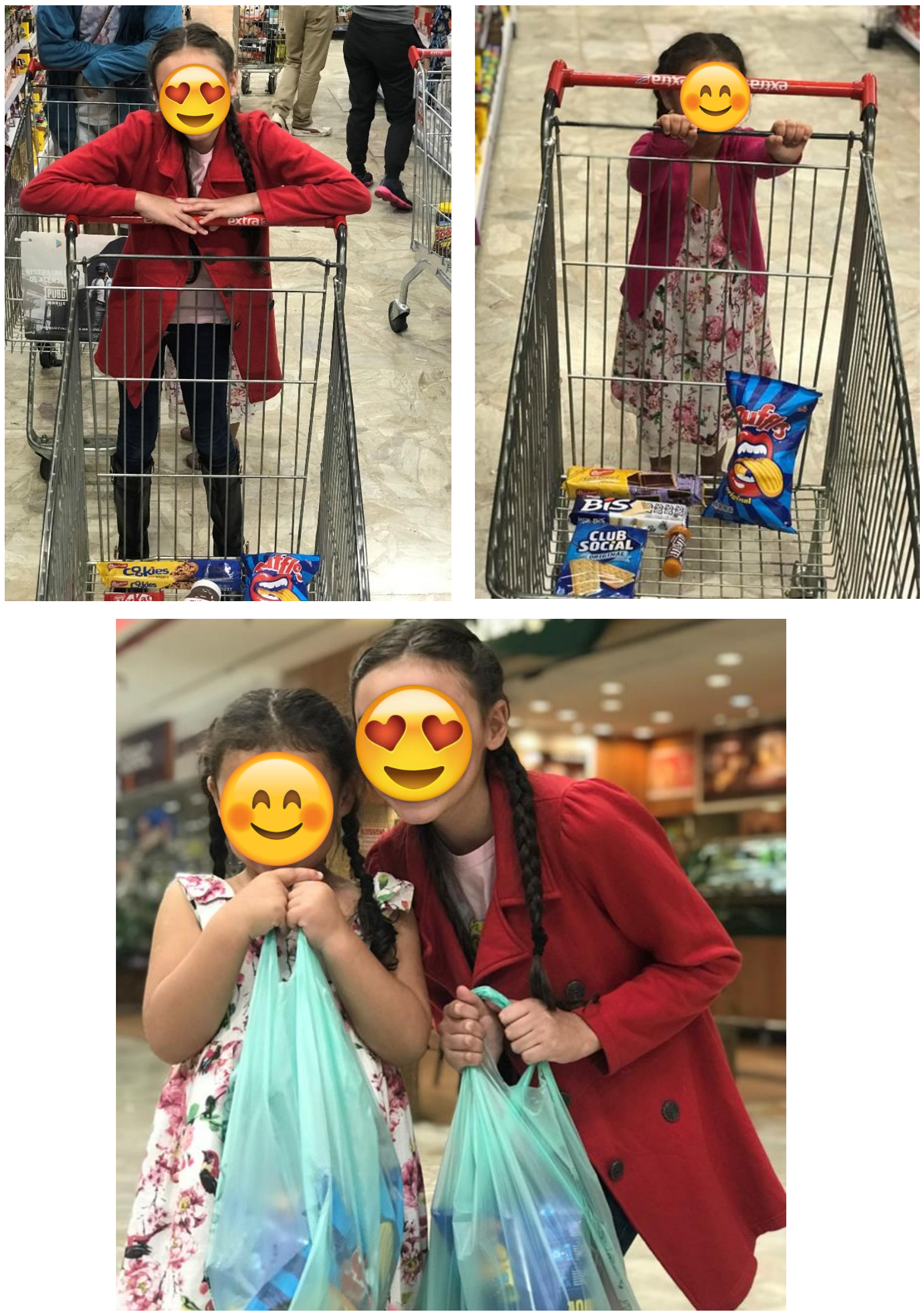
MARCAS E PRODUTOS ALIMENTÍCIOS ESCOLHIDOS PELAS CRIANÇAS NO SUPERMERCADO

PRIMEIRA FAMÍLIA
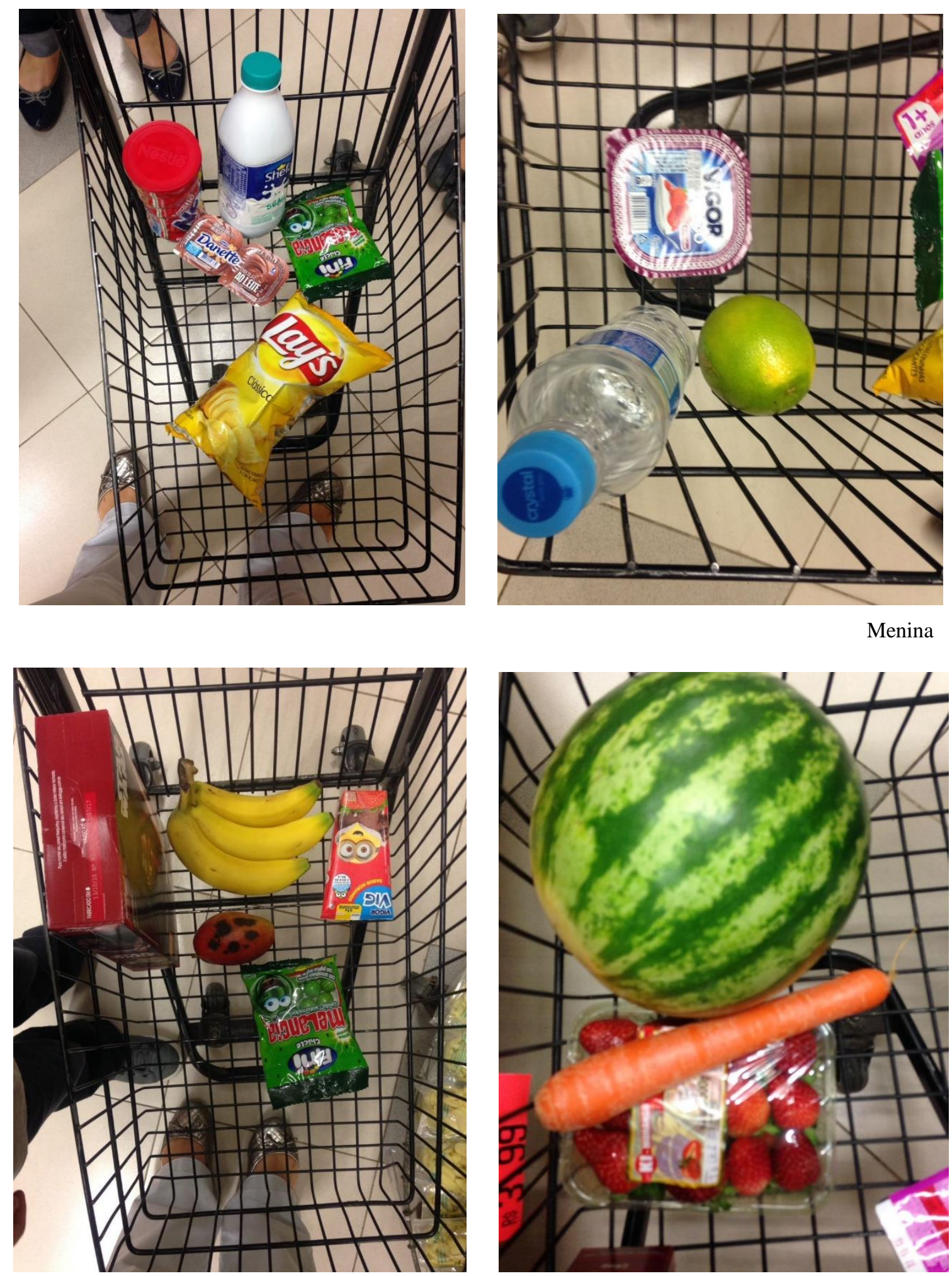

Menino 
MARCAS E PRODUTOS ALIMENTÍCIOS ESCOLHIDOS PELAS CRIANÇAS NO SUPERMERCADO SEGUNDA FAMÍLIA

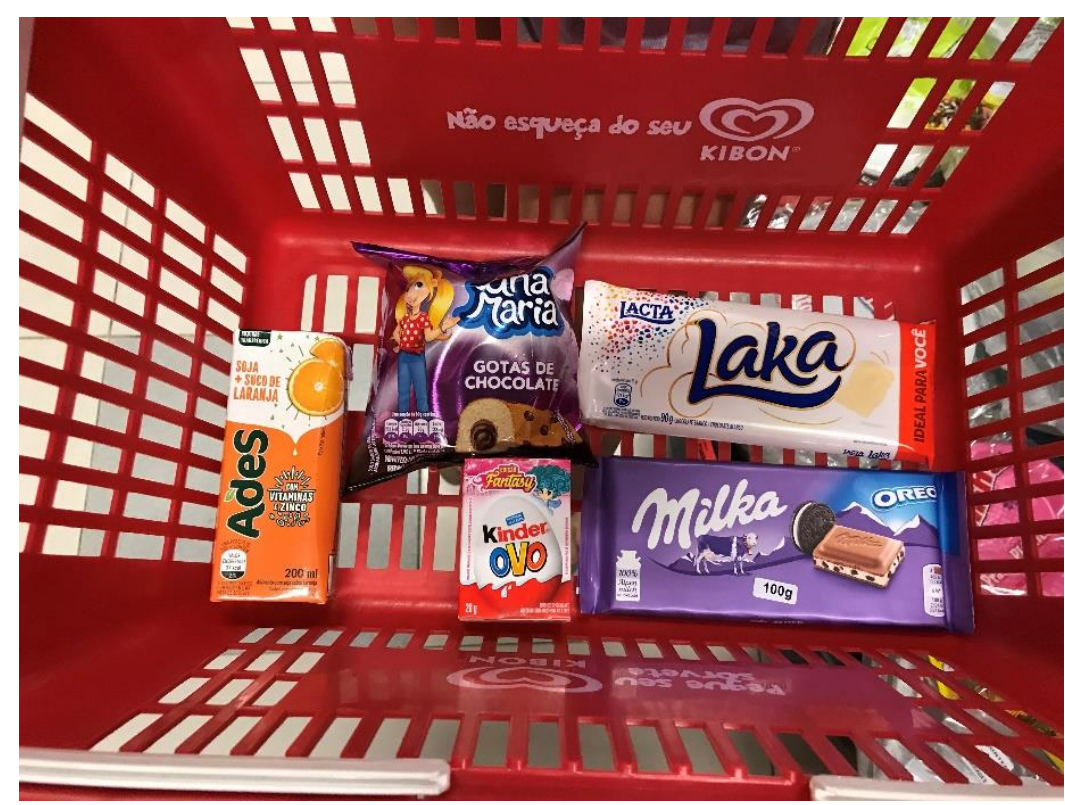

Menina

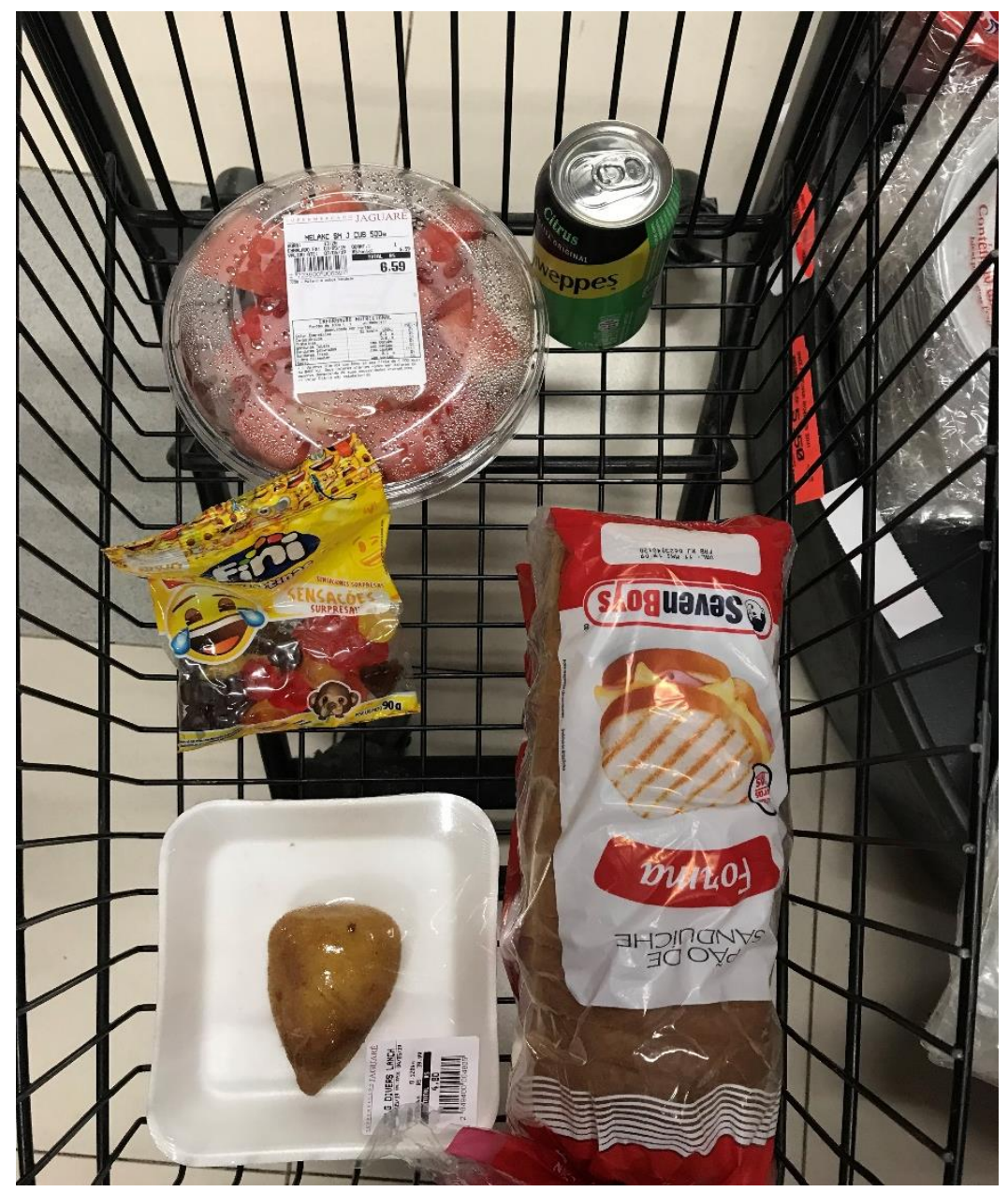

Menino 
MARCAS E PRODUTOS ALIMENTÍCIOS ESCOLHIDOS PELAS CRIANÇAS NO SUPERMERCADO TERCEIRA FAMÍLIA

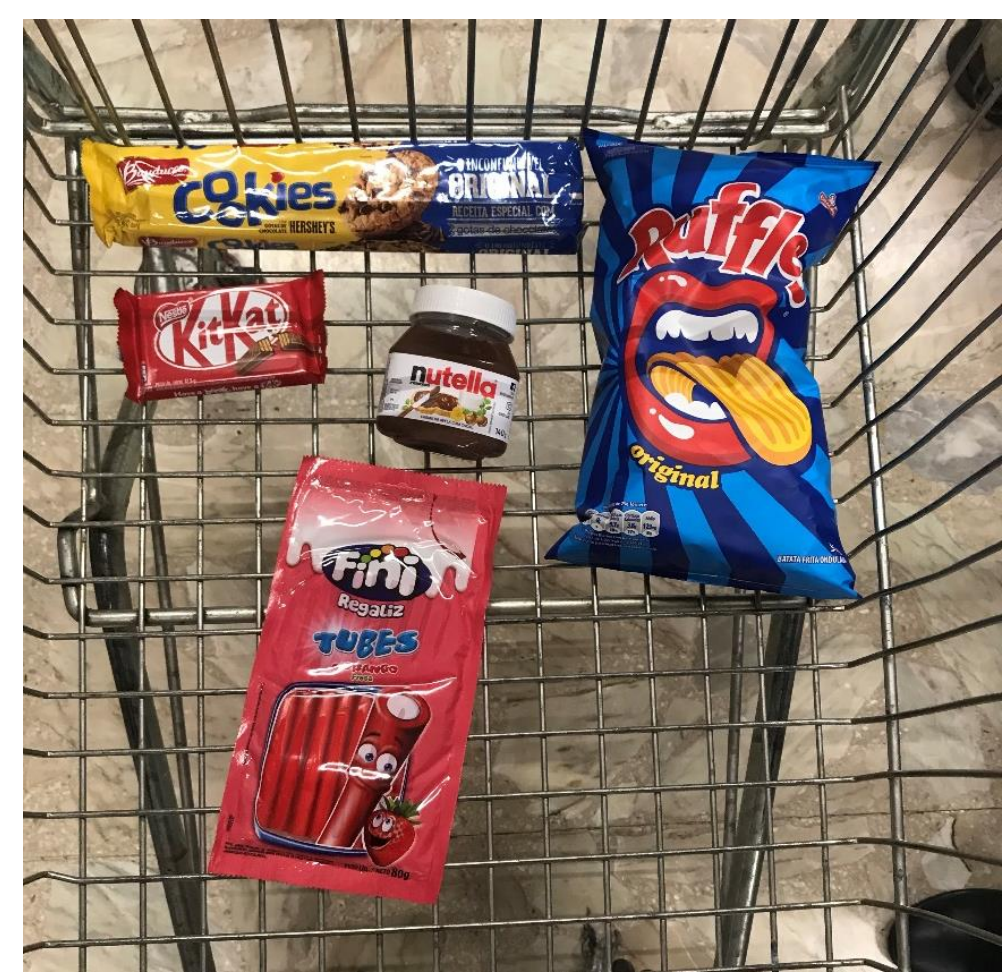

Menina mais velha

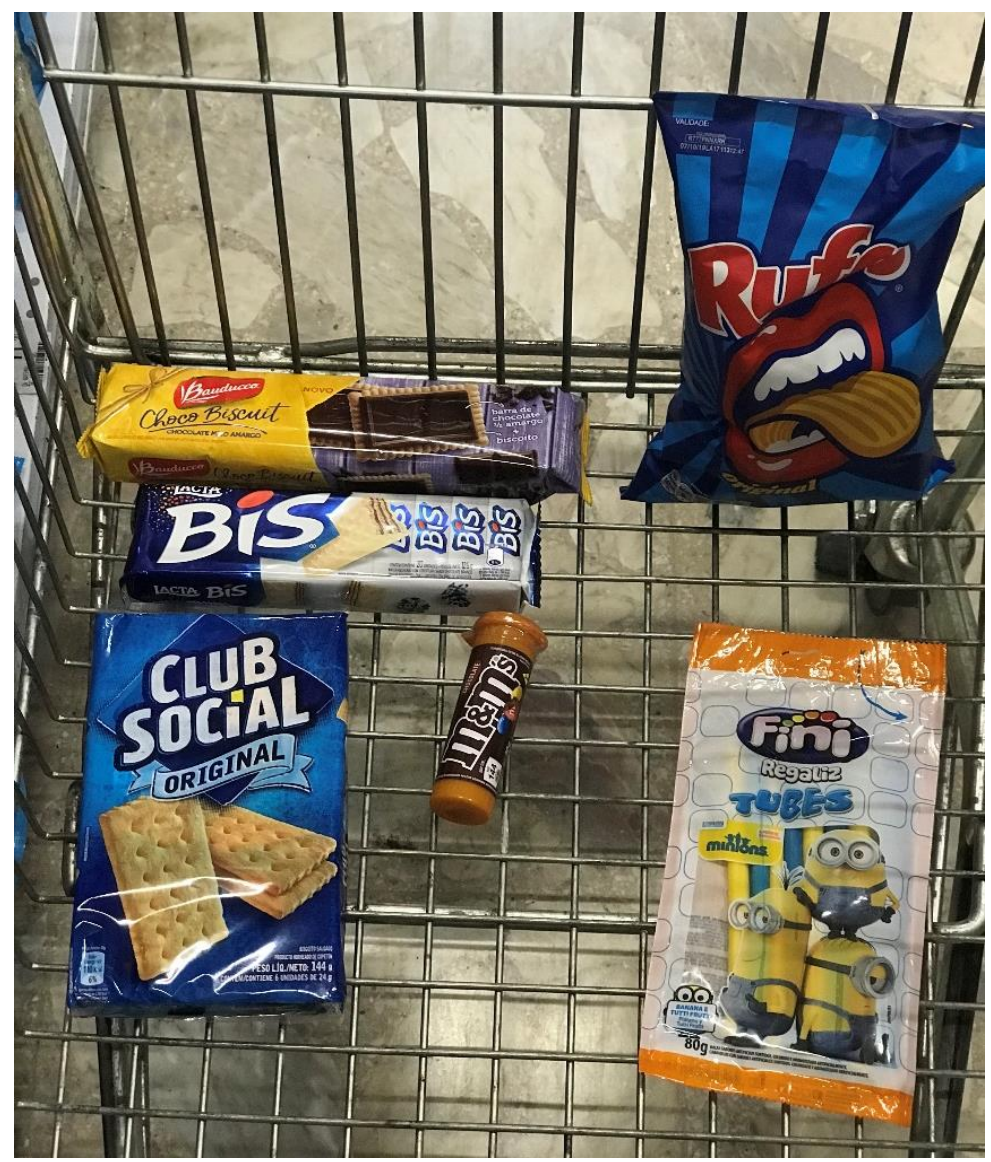

Menina mais nova 


\section{APÊNDICE V}

\section{EXPERIÊNCIA LÚDICA THE KIDS}

\section{KIDS BY KIDS}

MY FOODS

\section{MY FAMILY}

Imagens da participação das crianças na atividade lúdica.

Imagens das composições e produções elaboradas pelas crianças. 
KIDS BY KIDS: ENTREVISTA E PRODUÇÃO DE VÍDEO

PRIMEIRA FAMÍLIA
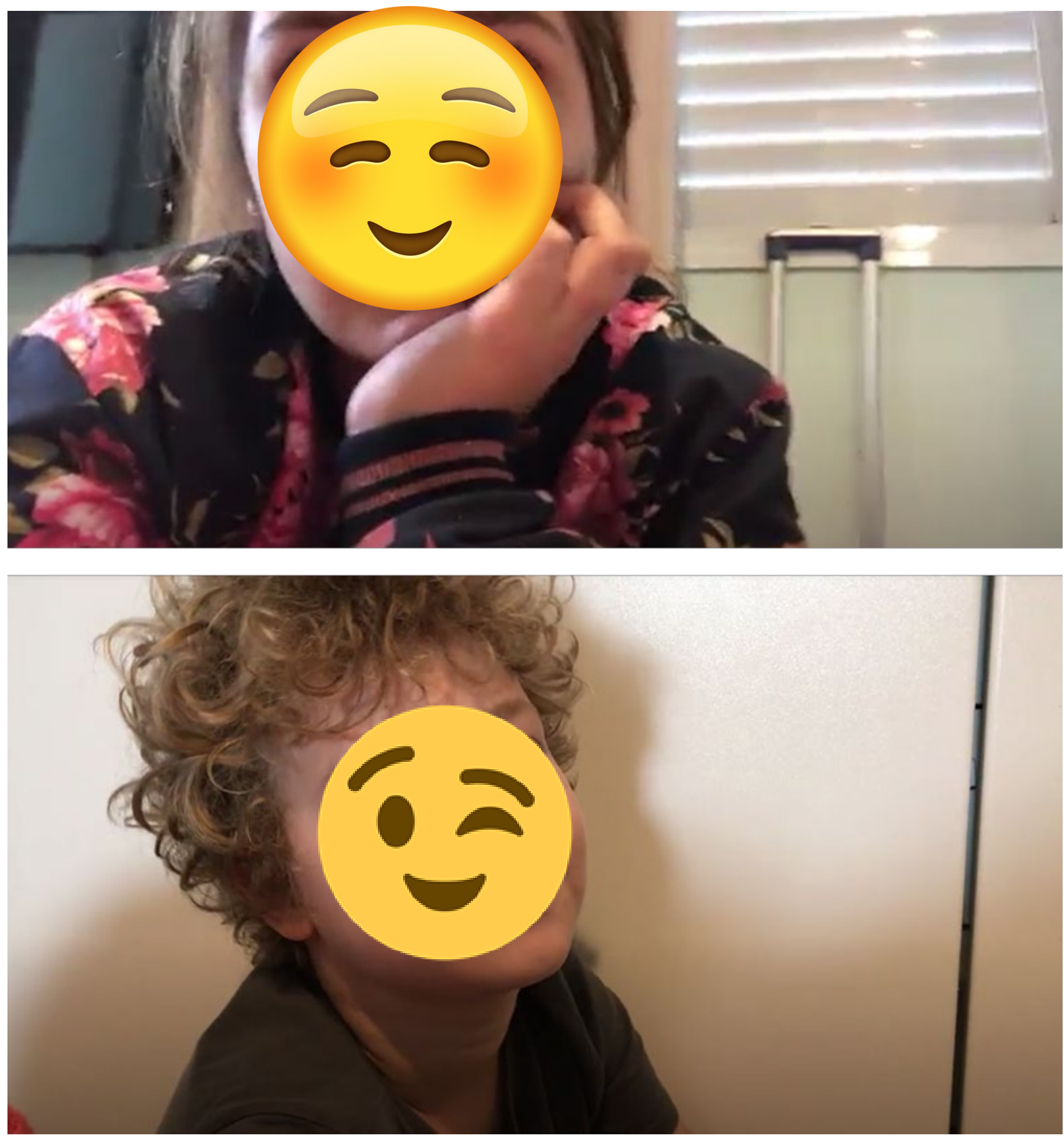
KIDS BY KIDS: ENTREVISTA E PRODUÇÃO DE VÍDEO

SEGUNDA FAMÍLIA
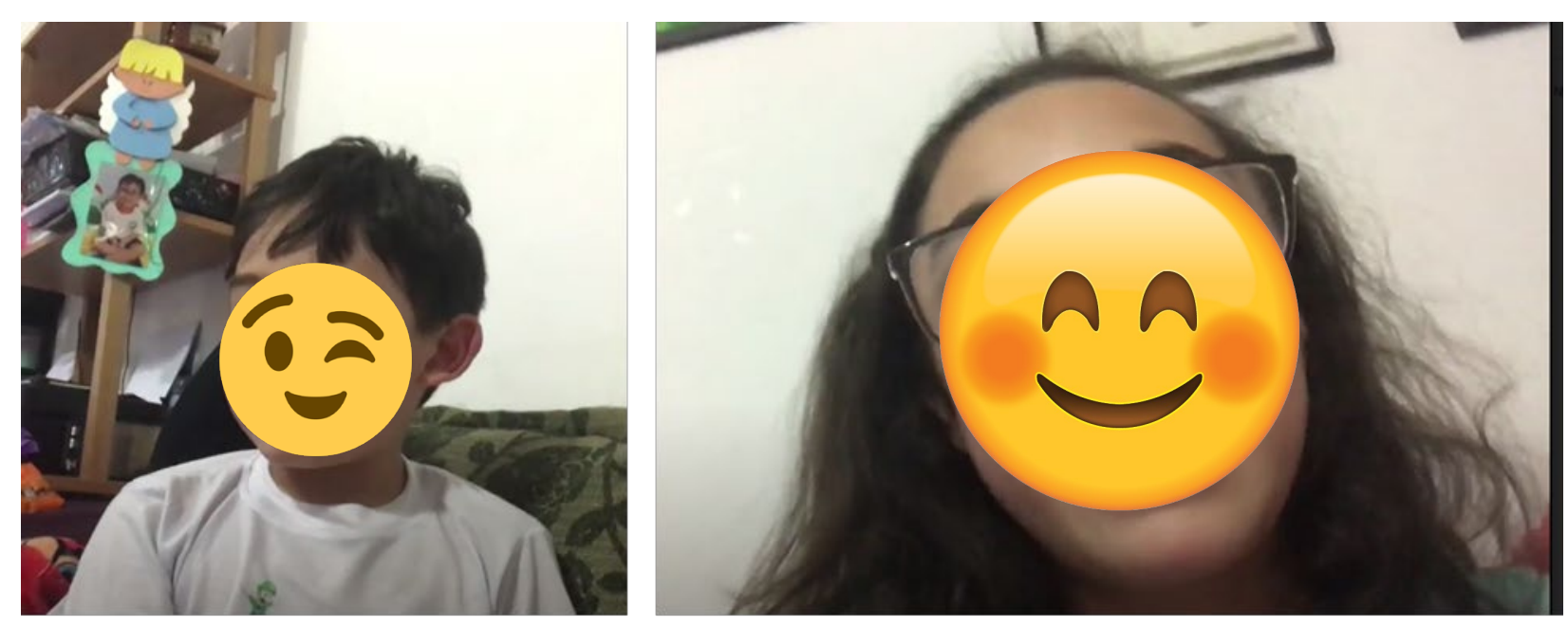

$$
\text { , }
$$

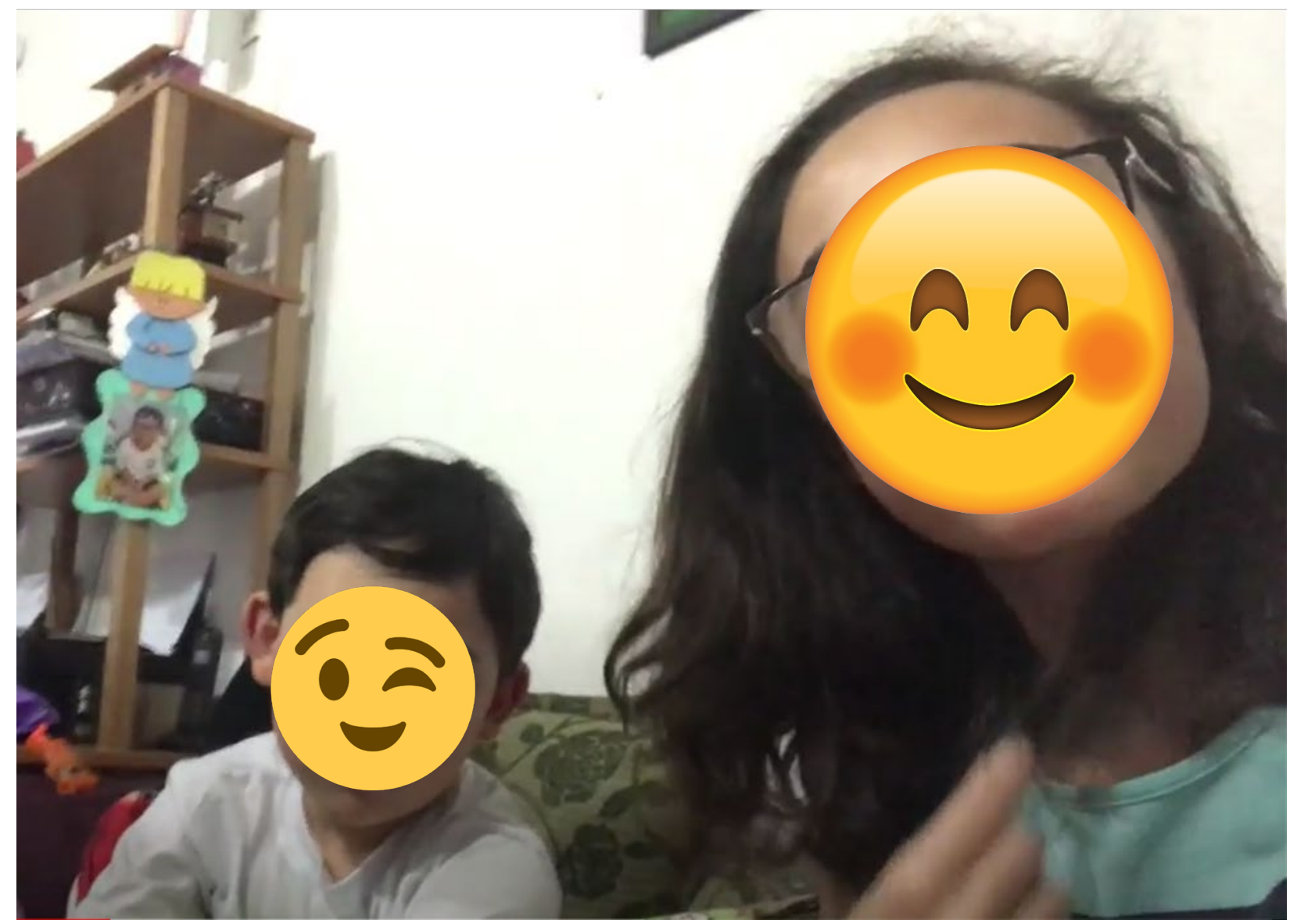


KIDS BY KIDS: ENTREVISTA E PRODUÇÃO DE VÍDEO

TERCEIRA FAMÍLIA
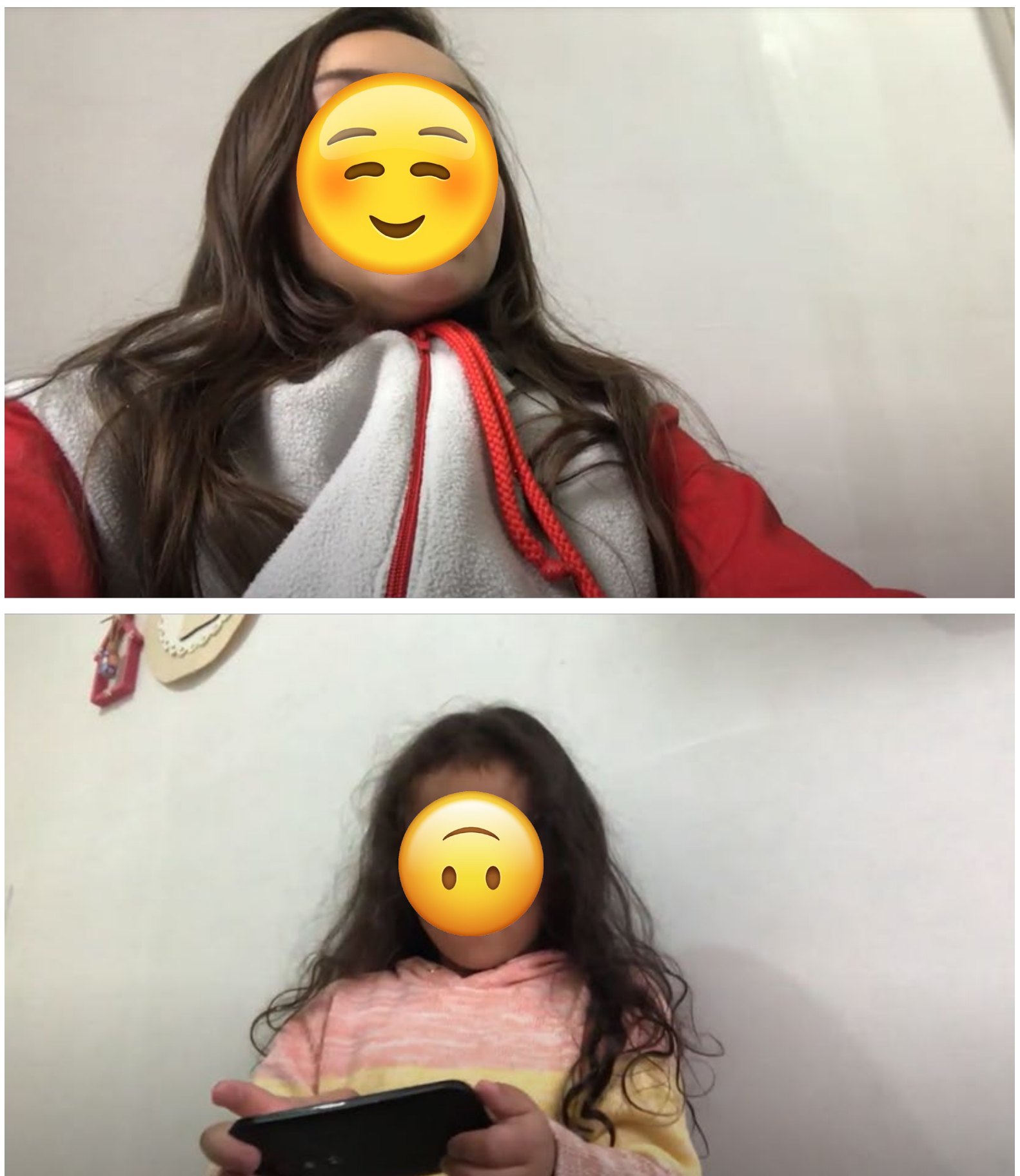
MY FOODS: PRODUÇÃO DE FOTOGRAFIA

PRIMEIRA FAMÍLIA

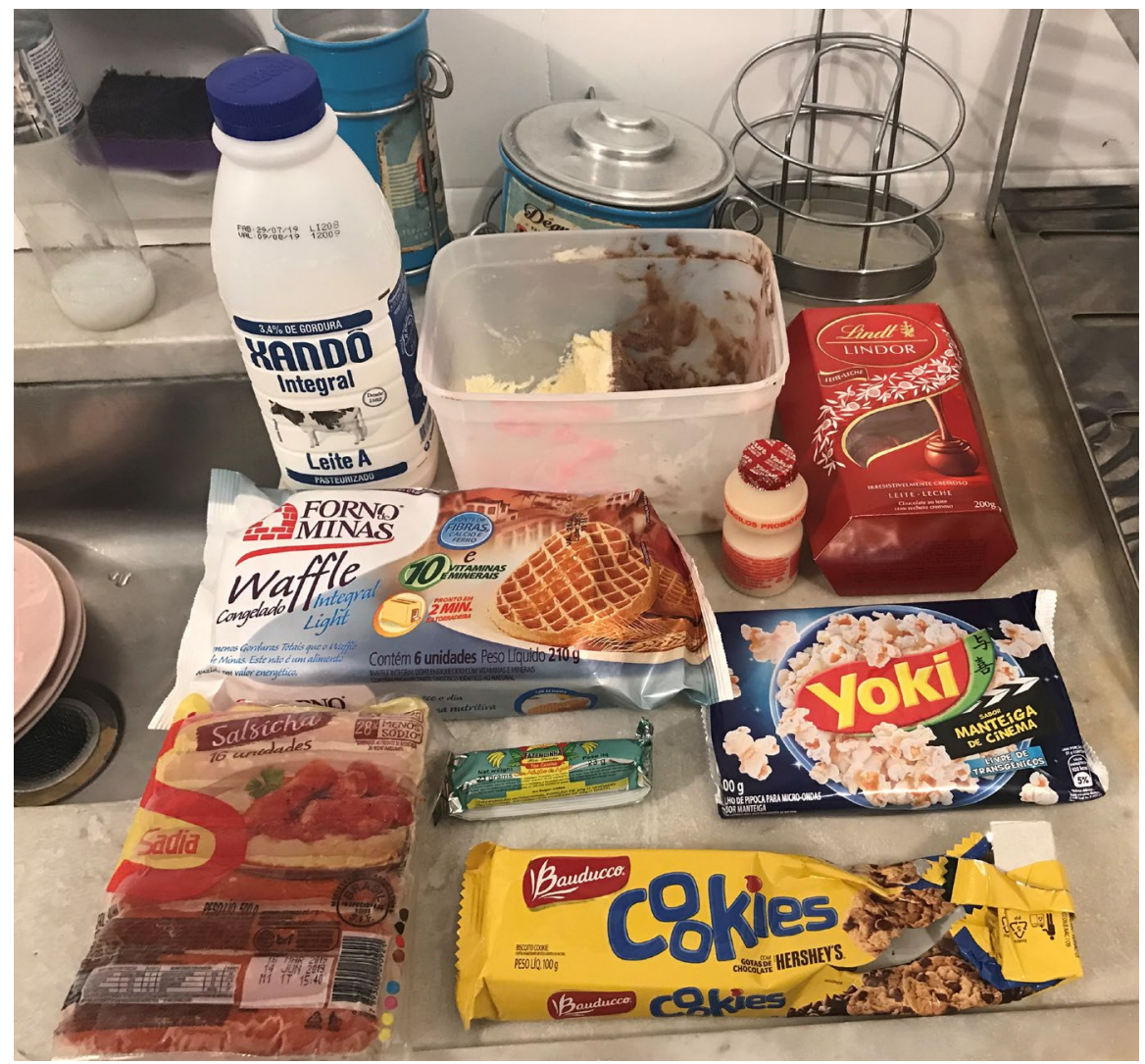

Menina

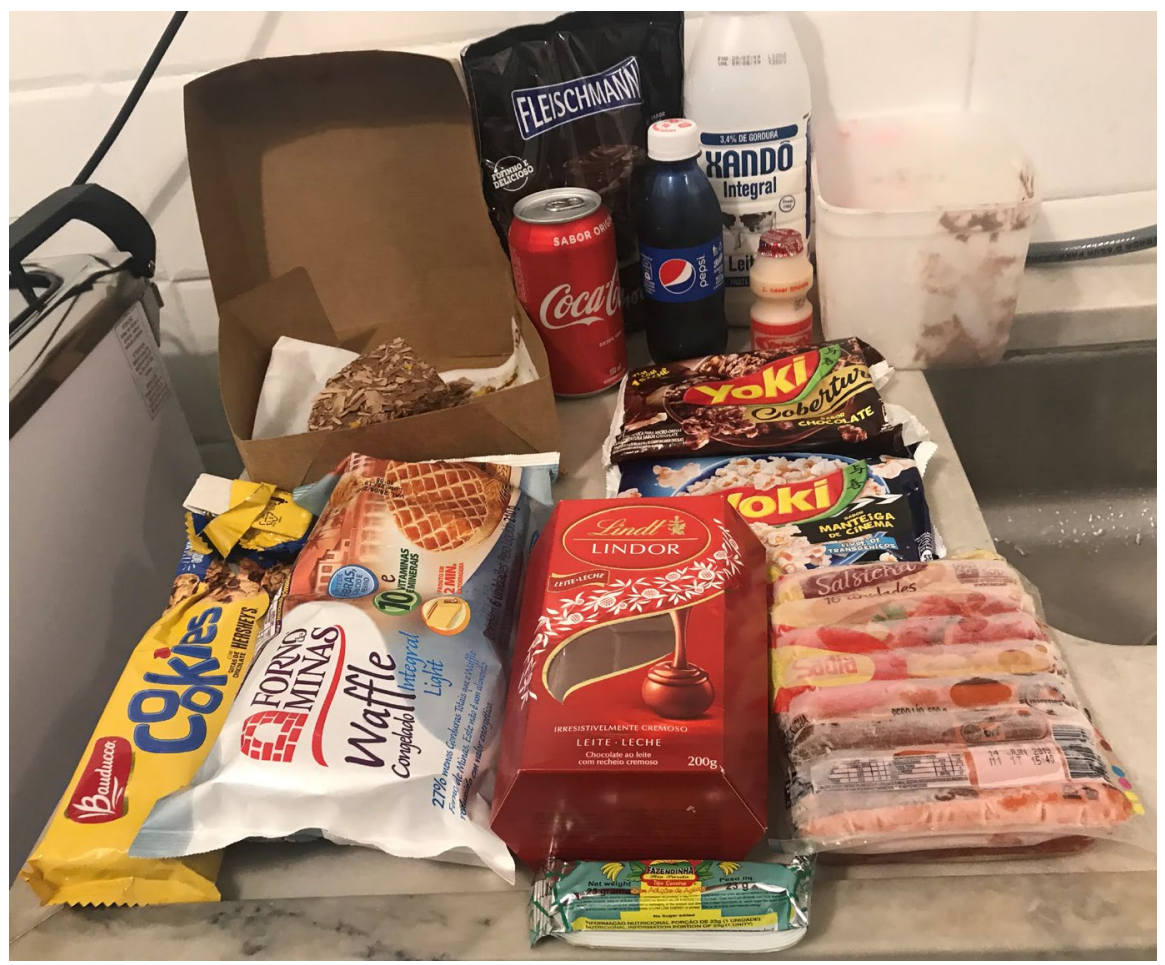

Menino 
MY FOODS: PRODUÇÃO DE FOTOGRAFIA

SEGUNDA FAMÍLIA

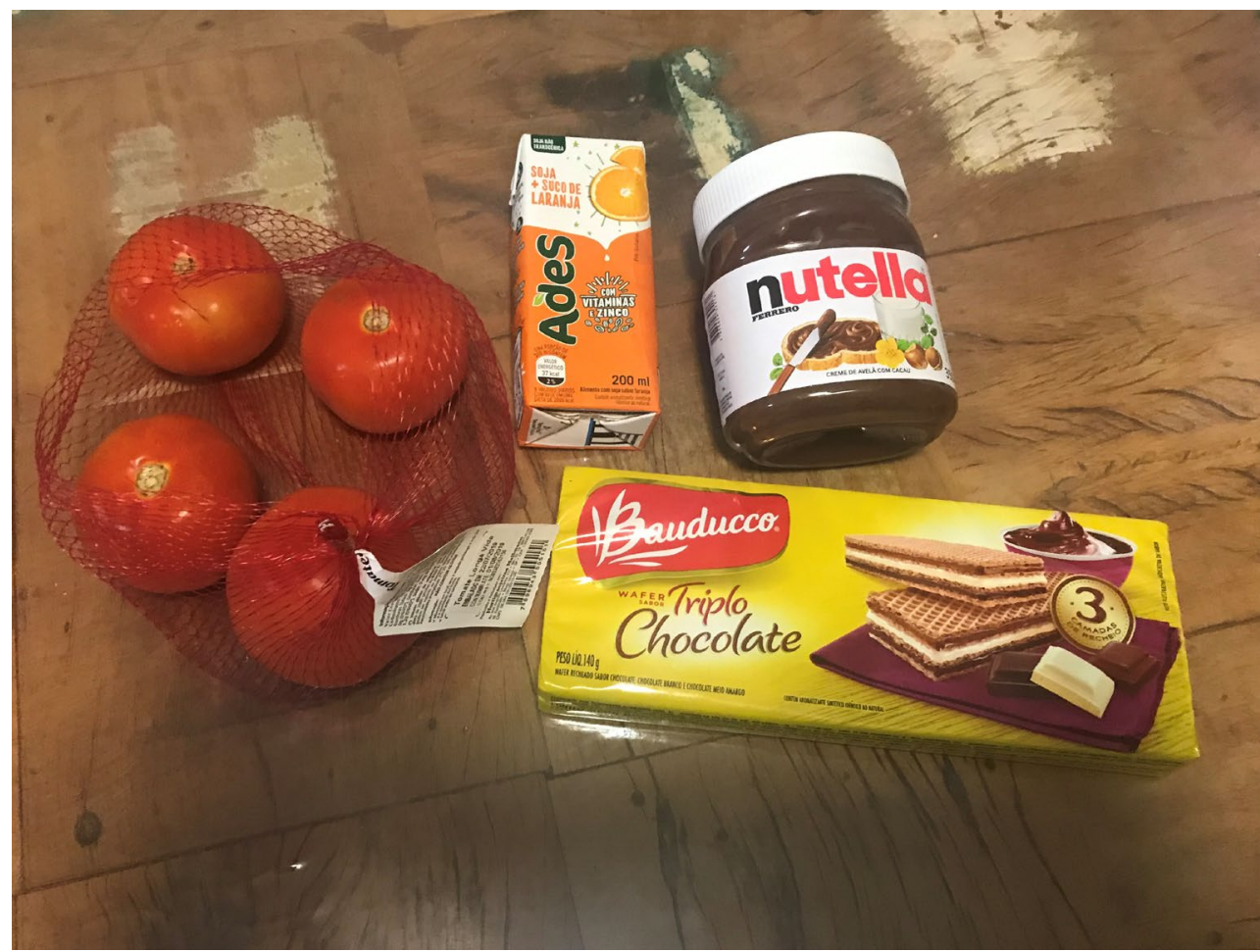

Menina

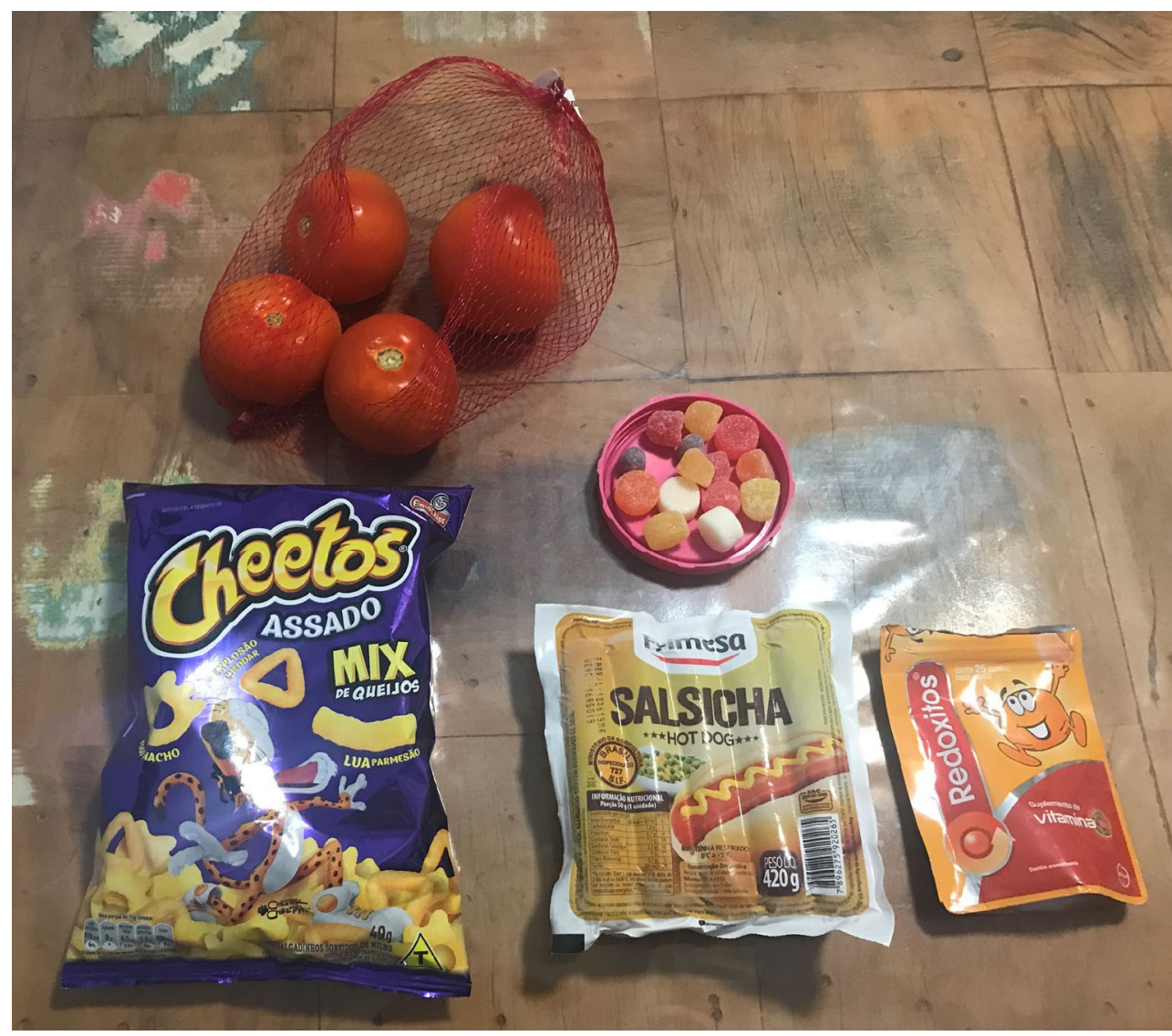

Menino 
MY FOODS: PRODUÇÃO DE FOTOGRAFIA

TERCEIRA FAMÍLIA

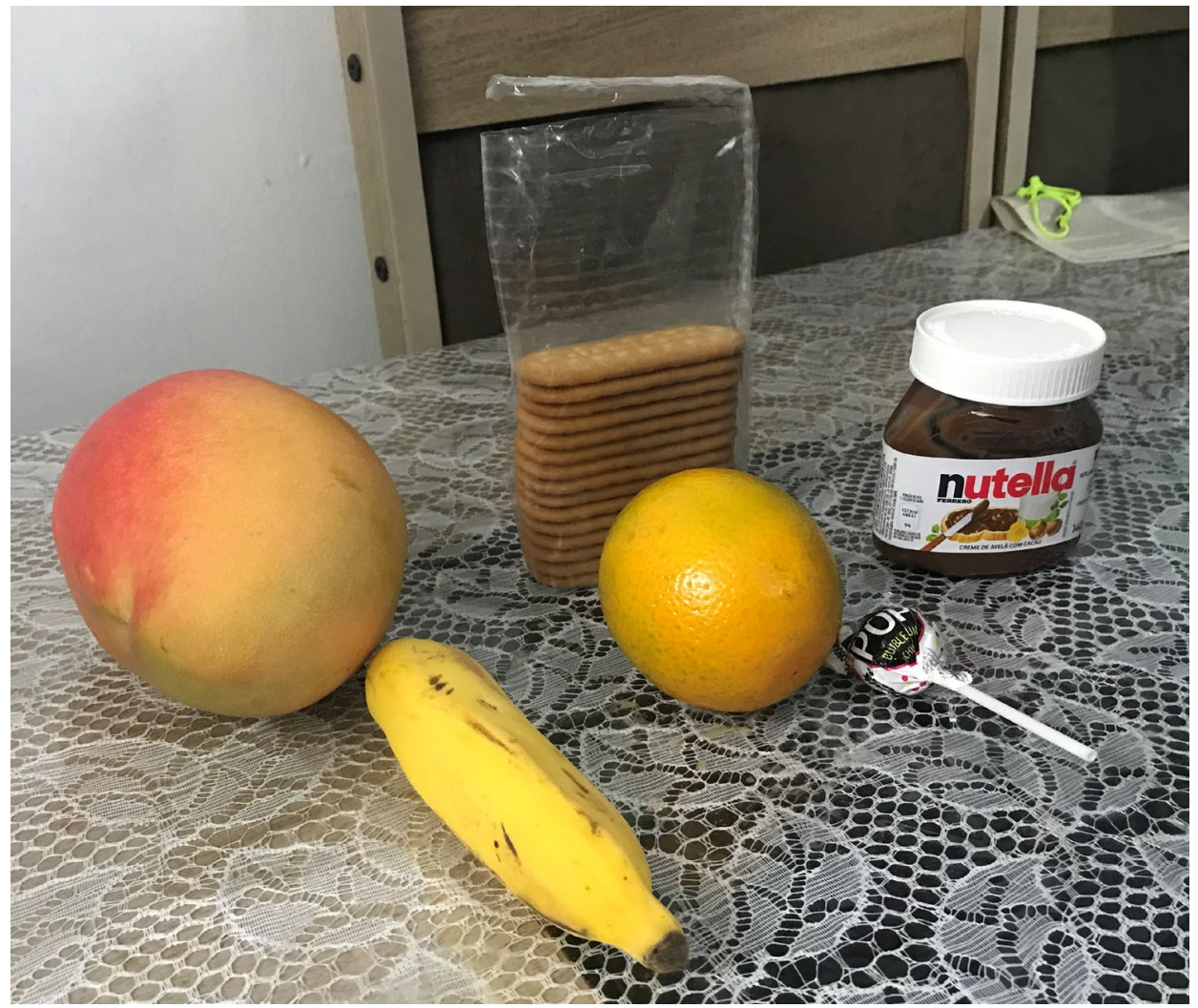

Menina mais velha

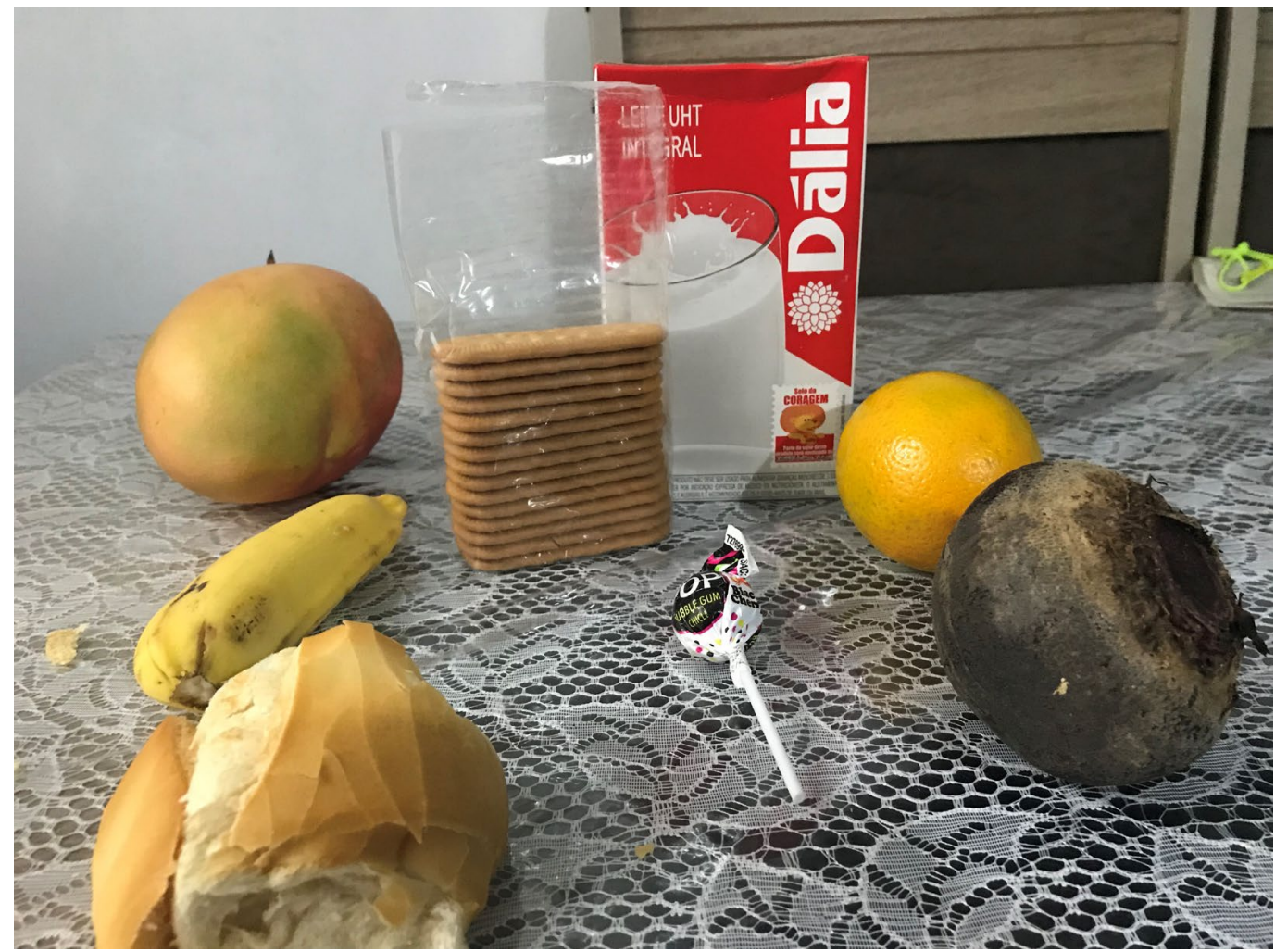

Menina mais nova 
MY FAMILY: PRODUÇÃO DE FOTOGRAFIA

PRIMEIRA FAMÍLIA
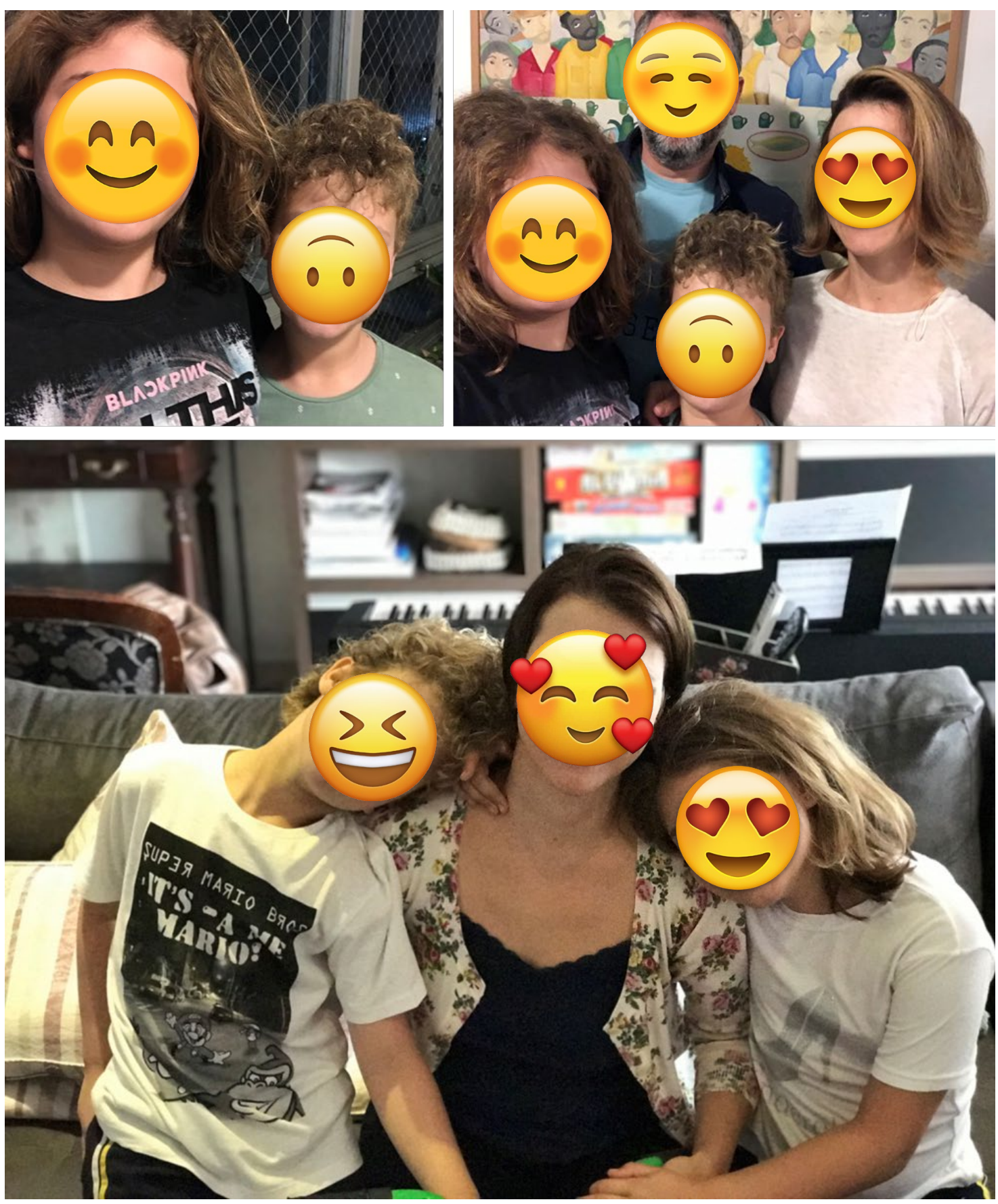
MY FAMILY: PRODUÇÃO DE FOTOGRAFIA

SEGUNDA FAMÍLIA

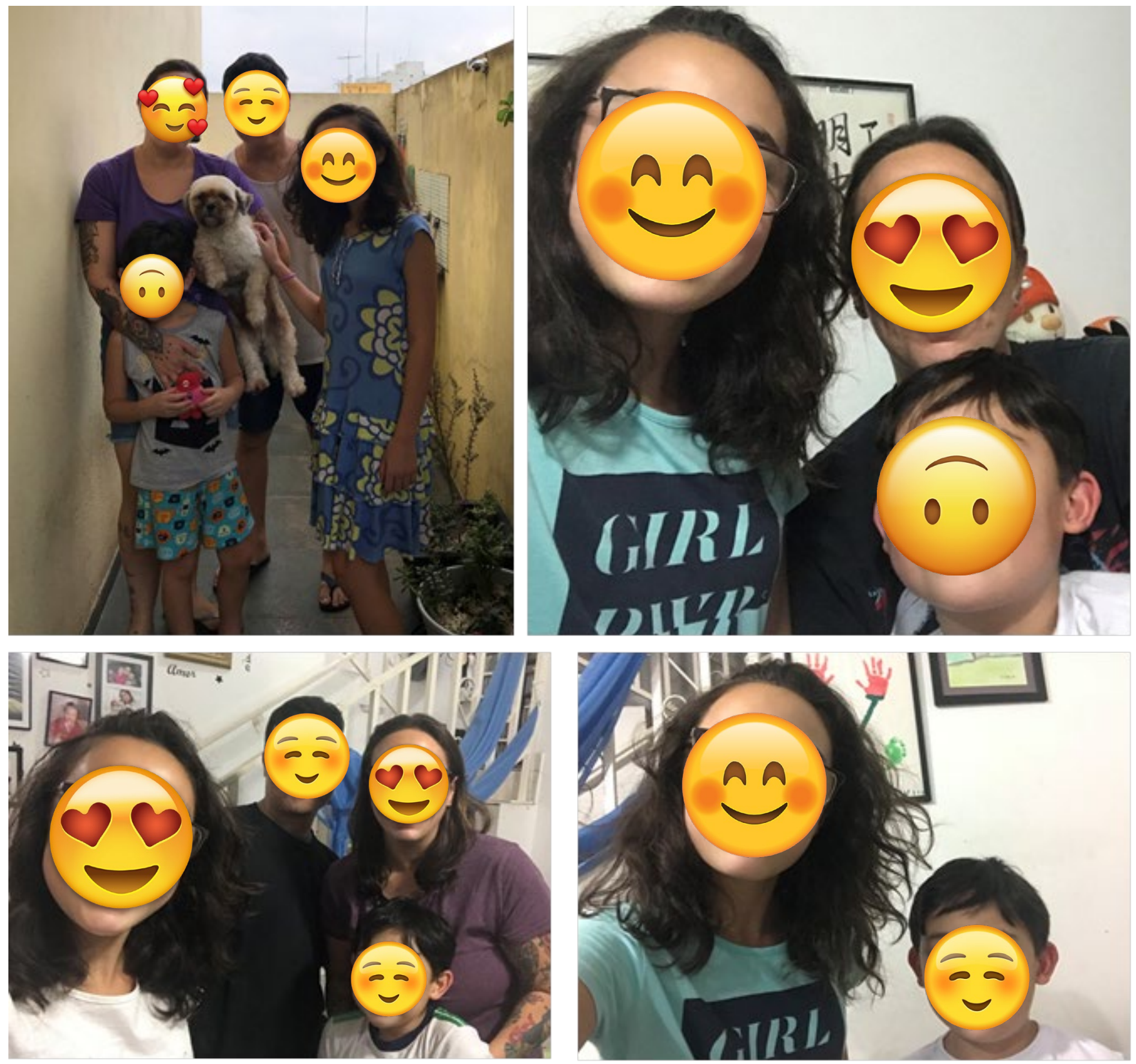


MY FAMILY: PRODUÇÃO DE FOTOGRAFIA

TERCEIRA FAMÍLIA
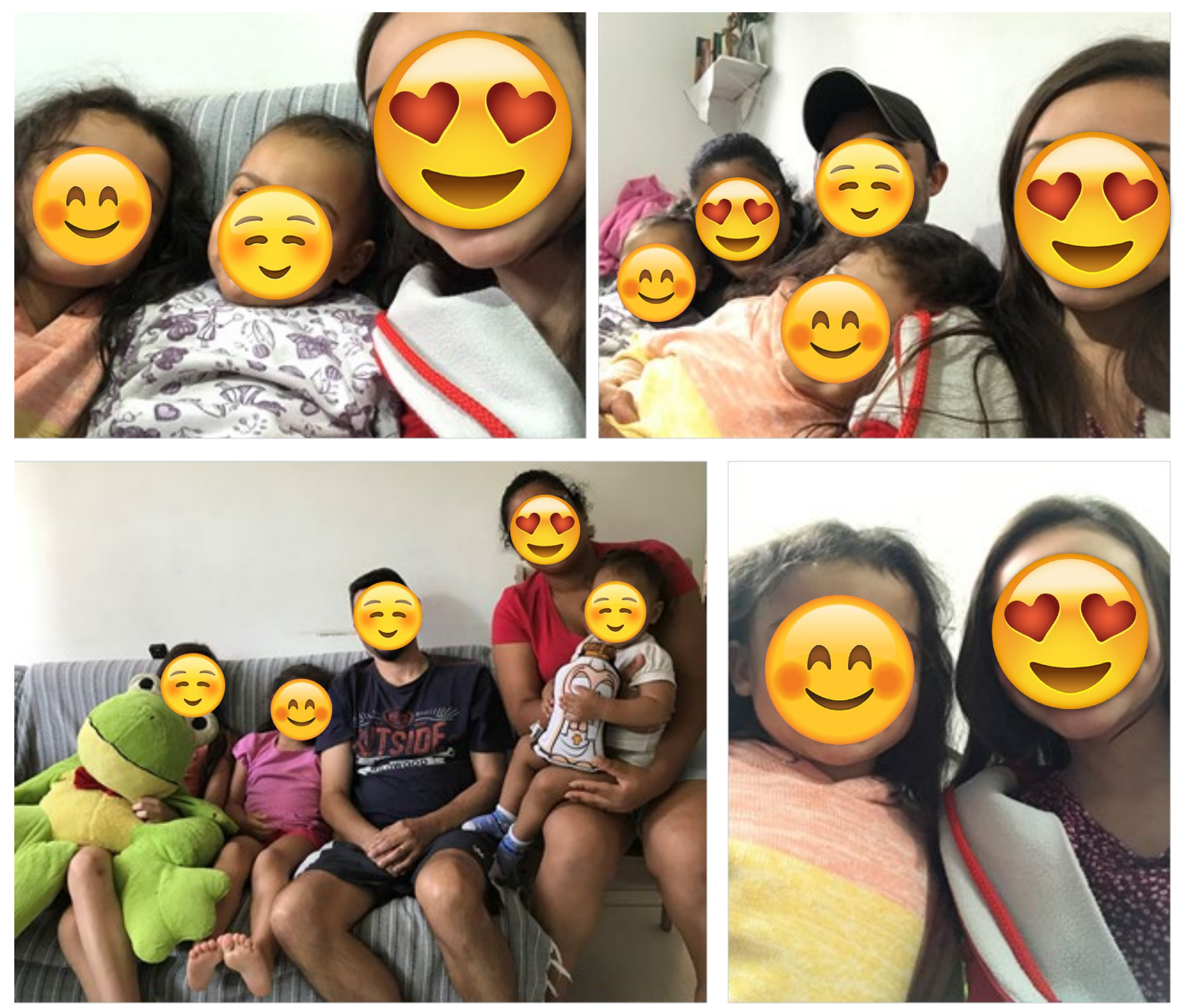